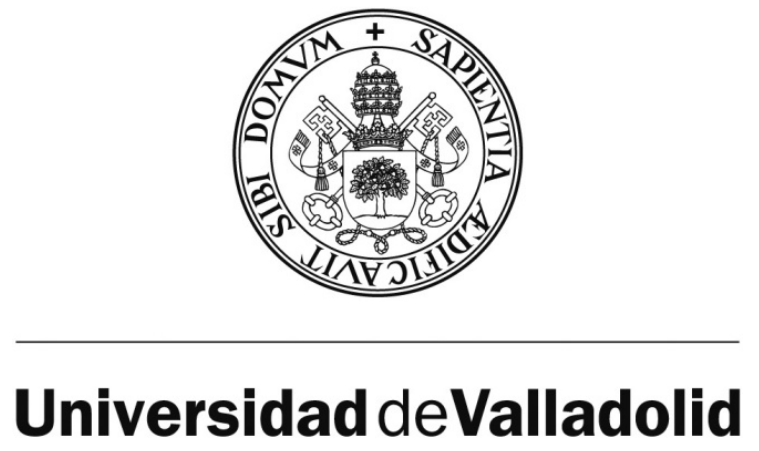

\author{
INSTITUTO UNIVERSITARIO DE \\ HISTORIA SIMANCAS
}

TESIS DOCTORAL:

\title{
Naciones de papel: \\ El conflicto entre Chile y Perú por Tacna y Arica \\ en la prensa de España (1880-1929)
}

\footnotetext{
Presentada por D. José Julián Soto Lara para optar al grado de doctor por la Universidad de Valladolid
}

\author{
Dirigida por:
}

Dra. María del Carmen Martínez Martínez 

A los españoles, chilenos y peruanos quienes, por encima de sus nacionalismos contingentes, se reconocen herederos, custodios y practicantes de una fraternidad verdaderamente trascendente: la humanidad 



\section{ÍNDICE}

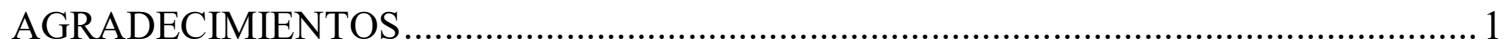

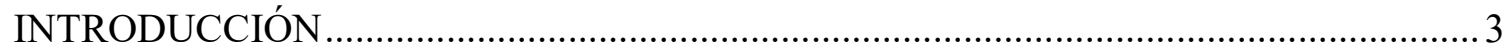

1. EL CONTEXTO HISTÓRICO DEL CONFLICTO DE TACNA Y ARICA ................... 13

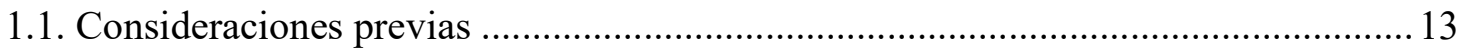

1.2. El conflicto de Tacna y Arica en la historiografía ..................................................... 18

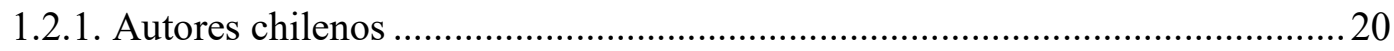

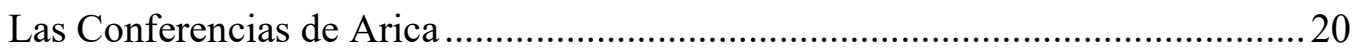

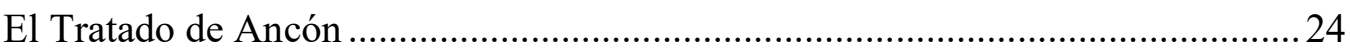

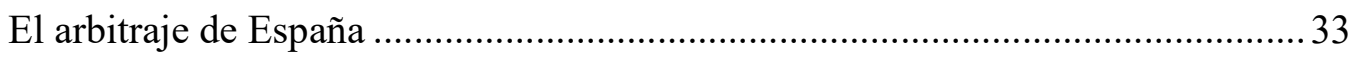

El arbitraje de los Estados Unidos y el Tratado de Lima..........................................37

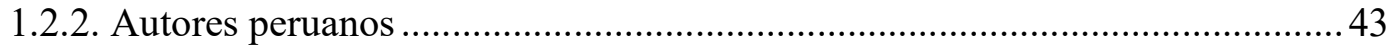

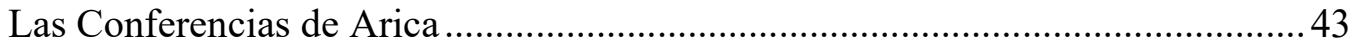

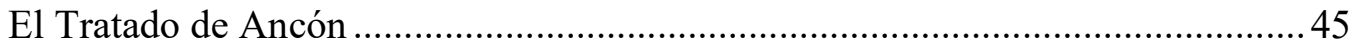

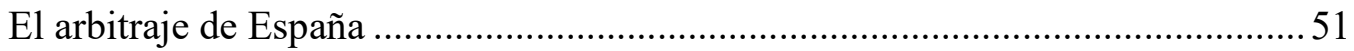

El arbitraje de los Estados Unidos y el Tratado de Lima......................................56

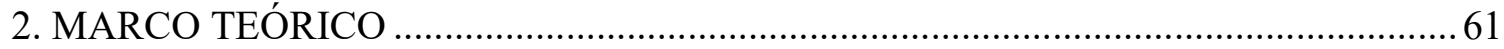

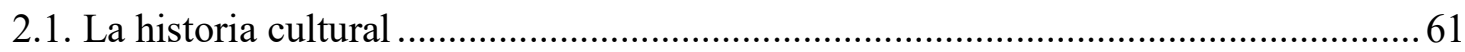

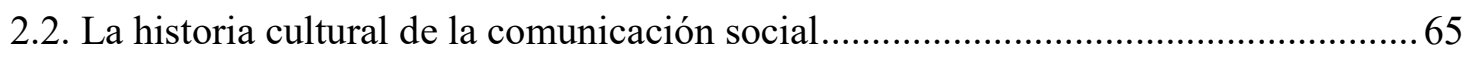

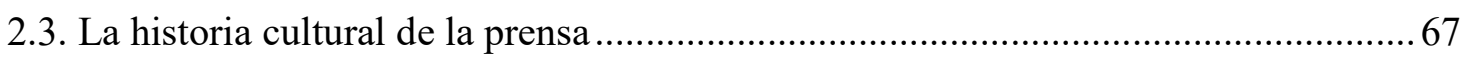

2.4. Construcción social de la realidad y prensa.......................................................... 72

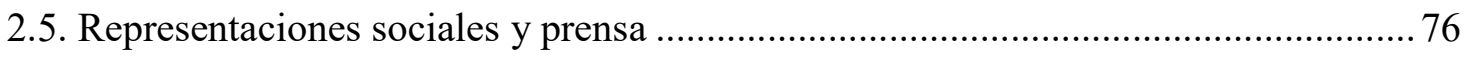

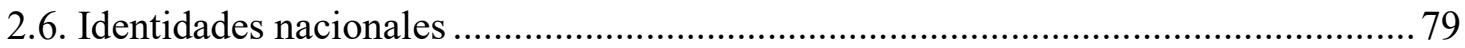

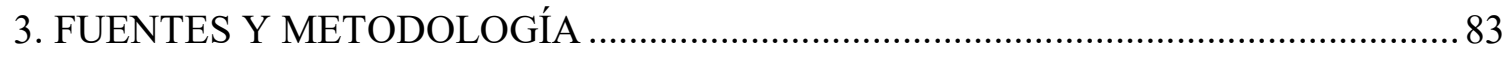

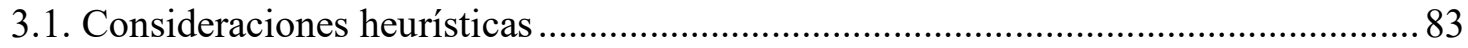

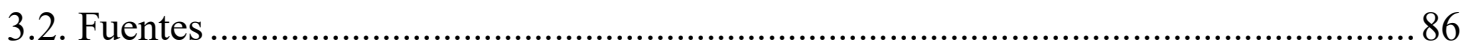

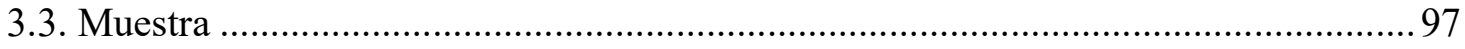

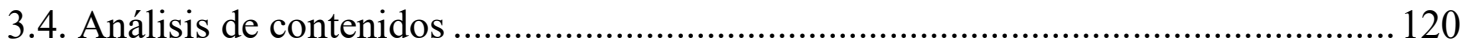

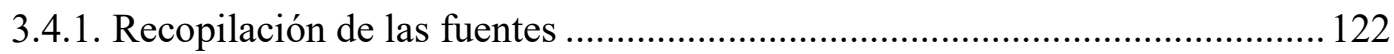

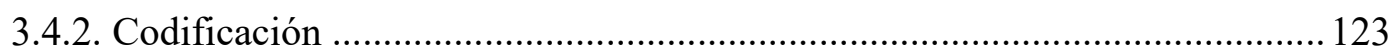

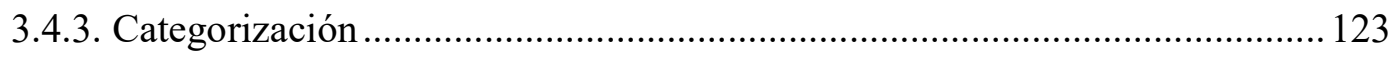




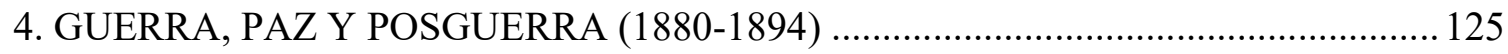

4.1. El ingreso sangriento de Tacna y Arica en la prensa .............................................. 125

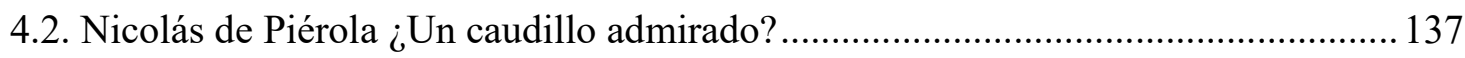

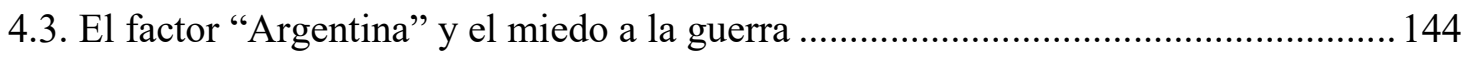

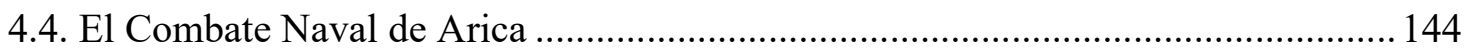

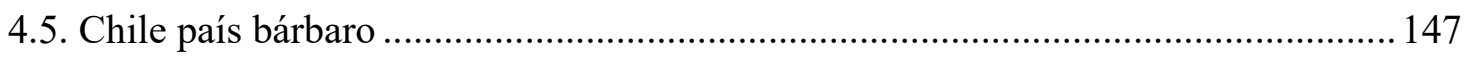

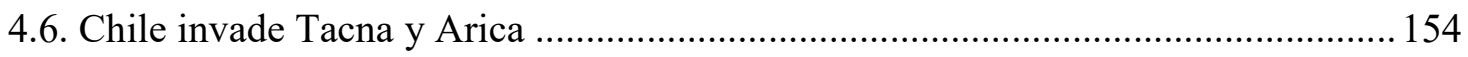

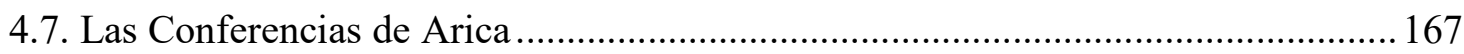

4.8. Inicio de la campaña militar chilena hacia Lima …................................................ 177

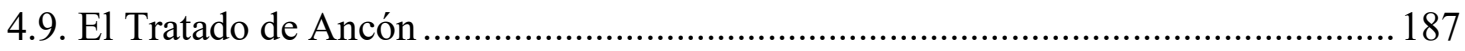

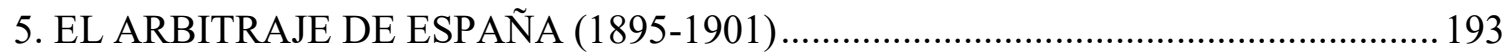

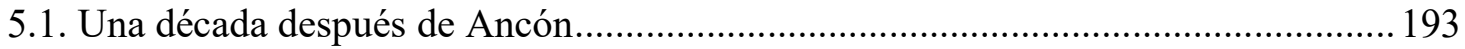

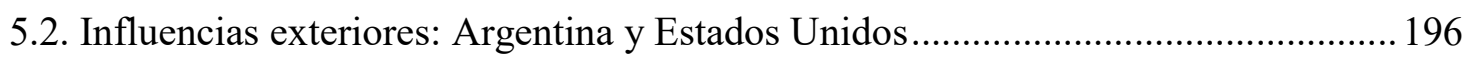

5.3. El arbitraje de España en la prensa ........................................................................ 198

5.4. Repercusiones del arbitraje español en los Estados Unidos ....................................200

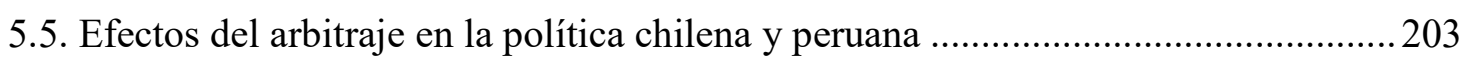

5.6. La chilenización de Tacna y Arica en los periódicos ............................................. 212

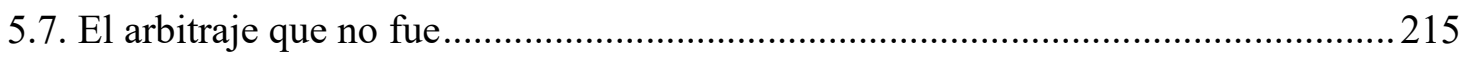

5.8. El Congreso Social-Económico Hispanoamericano y la Conferencia Panamericana

5.9. La muerte del protocolo Billinghurst-Latorre ........................................................ 221

6. TACNA Y ARICA, OPORTUNIDAD PARA LA REVITALIZACIÓN DEL

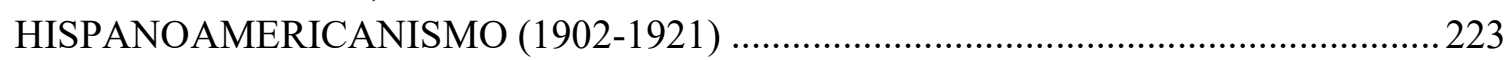

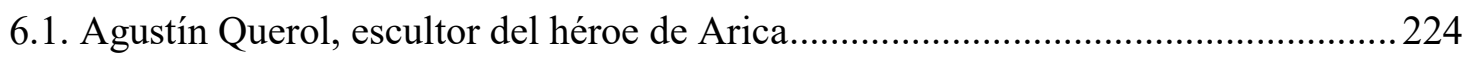

6.2. El Tratado de Paz, Amistad y Comercio entre Chile y Bolivia de 1904 ................. 234

6.3. Tacna y Arica: entre la nostalgia hispanoamericanista y el pragmatismo yanqui ... 240

6.4. Los sacerdotes católicos-peruanos expulsados de Tacna y Arica............................269

6.5. ¿Los raíles del progreso? La construcción del ferrocarril Arica-La paz en la prensa

6.6. La presidencia de Guillermo Billinghurst en Perú................................................... 291 
6.7. El problema chileno-peruano en la I Conferencia Socialista Obrera Panamericana de

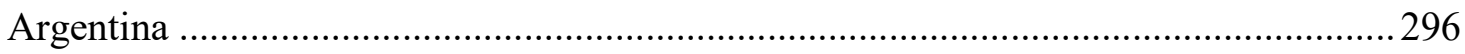

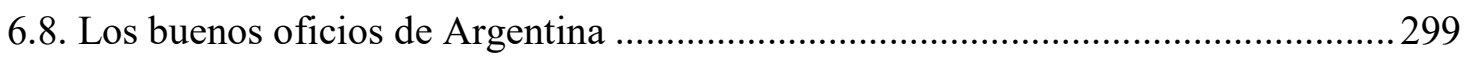

6.9. Ruptura de relaciones consulares entre Chile y Perú.............................................. 305

7. AGONÍA DEL HISPANOAMERICANISMO: EL ARBITRAJE DE LOS ESTADOS UNIDOS Y LA SOLUCIÓN DE LA CUESTIÓN DE TACNA Y ARICA (1922-1929). 337

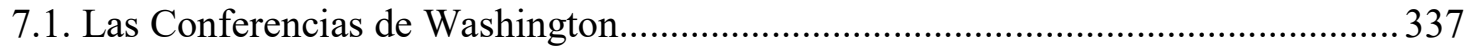

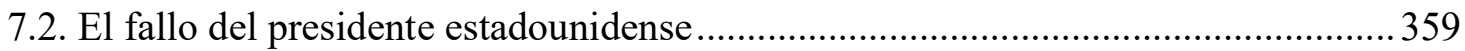

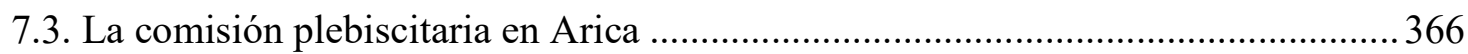

7.4. Notas de las Legaciones de Chile, Perú y Bolivia para la prensa de España............ 374

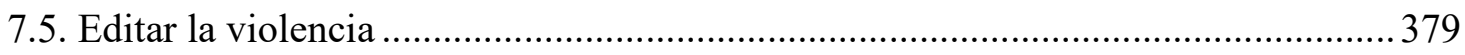

7.6. Tacna y Arica para Bolivia: La propuesta de Frank Kellogg ................................ 385

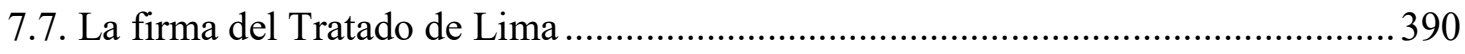

7.8. Ruegos estériles: El Nobel de la Paz para Leguía e Ibáñez .................................... 403

7.9. El Jesús del Gran Poder: Mensajero de Paz.............................................................409

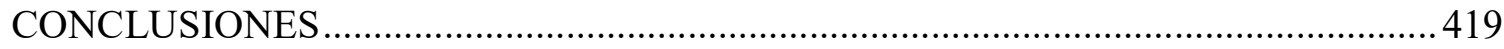

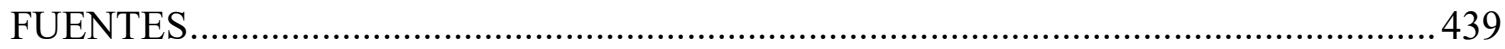

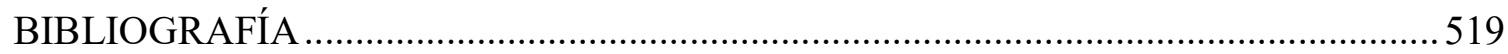

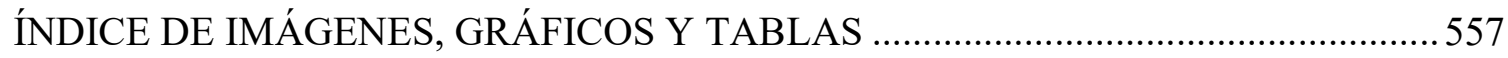





\section{AGRADECIMIENTOS}

El proceso de formación científica realizado en el máster Europa y el Mundo Atlántico: poder, cultura y sociedad (2013-2014) y el programa de doctorado del mismo nombre (2014-2016), cuyos resultados son presentados en esta tesis, fue posible gracias a la beca concedida por el Proyecto MUNDUS LINDO, programa de cooperación y movilidad en el ámbito de la Educación Superior de la Comisión Europea. Su objetivo, sintetizado en el compromiso social hacia estudiantes y académicos latinoamericanos en condiciones desfavorables y de vulnerabilidad, quizás hoy pueda ser refrendado en la persona que escribe, al concluir una parte de la perenne senda del conocimiento. En la Universidad de Valladolid, el Proyecto MUNDUS LINDO se gestiona en el Servicio de Relaciones Internacionales, actualmente coordinado por su Directora la Sra. Mar Fernández Sáinz. Para ella y el equipo humano que dinamiza la idea, vayan mis sinceros agradecimientos.

Con el mismo sentimiento, deseo expresar mi gratitud hacia la Dra. María del Carmen Martínez Martínez, eminente historiadora española del pasado americano y directora de la presente tesis. Sin su apoyo académico absoluto, su fineza en las discusiones históricas, su crítica clara y propositiva frente a las interpretaciones del aprendiz, las reflexiones que presento en este escrito, de seguro, responderían un número menor de cuestiones relevantes para el aporte en la historiografía compartida entre Europa y América. Además de historiadora, como docente comprometida, estuvo pendiente en todo momento del papel del becario chileno en la producción del saber y, tan importante en los momentos actuales, tuvo siempre -maestra- gestos indesmentibles de cordialidad, sinceridad y aliento.

Agradezco, por último, a mi madre, Edith Victoria Lara Luque, quien desde un plano emocional me muestra, una y otra vez, con acciones, palabras y silencios, lo más cercano al amor. Compañera atenta de mis primeras lecturas, por aquellos extraños tiempos del Chile que experimentaba el ocaso de una dictadura y recibía el amanecer de la democracia, respondió con cariños y sonrisas a cada pregunta por mí pronunciada. Amiga incondicional, nunca tuvo gesto alguno de cansancio y con paciencia enraizada, sospecho, en la espiritualidad de la maternidad solitaria, puso entre mis dedos bolígrafos indómitos para ensayar mis primeras letras y lápices de colores para pintar un lugar mejor donde existir. 



\section{INTRODUCCIÓN}

En esta tesis se analizan las representaciones sociales construidas por la prensa de España sobre el conflicto de Tacna y Arica acaecido entre Chile y Perú durante 1880 y 1929. Si quisiéramos establecer, desde un punto subjetivo e informal, la genealogía del problema histórico estudiado, obligatoriamente recurriríamos a las experiencias del diario vivir provistas por las relaciones interpersonales. El lector podría consentir o rechazar la idea de que vivir en un mundo globalizado que día a día vence, de la mano del capitalismo tardío, las fronteras económicas, políticas y culturales de los Estados es habitar, a la vez, un mundo donde los nacionalismos, en sus formas culturales clásicas o banales, mantienen plena vigencia.

Inmerso en él, en un diálogo cualquiera por las calles de España, emerge la curiosidad de sus habitantes por conocer algo respecto a Chile o el Perú, países que en un pasado fueron dominios territoriales de la Corona y que, por eso, tienen un lugar privilegiado en la memoria colectiva. Lejos de la península, recorriendo las comunidades del norte chileno y sur peruano, los paisanos usan un lenguaje "huérfano" para conocer a la "madre patria". A ambos lados del Atlántico, los coloquios sobre la identidad nacional de los países cuestionados utilizan una sorprendente masa de datos, estereotipos y prejuicios... El progresivo ascenso de la economía española post depresión 2008, la estabilidad económica chilena y la riqueza natural peruana, son algunos de esos lugares comunes actuales.

El origen formal de esta investigación, al contrario, parte de un interés científico. Por eso, desde la ciencia histórica, nuestro análisis "desciende" en el tiempo para intentar comprender cómo la prensa y la sociedad española de los años finales del siglo XIX e inicios del siglo XX conoció a Chile y Perú. Todos los escritores y hablantes españoles que en diferentes momentos de sus vidas pensaron y explicaron, con conocimientos empíricos o no, qué era y qué caracterizaba a ambos países americanos, hoy no están entre nosotros. Sin embargo, un conjunto relevante de sus ideas -las representaciones sociales- surgidas a causa del conflicto entre Chile y Perú por Tacna y Arica, sí. 
Para quienes están familiarizados con la historiografía puede resultar trasnochado leer, otra vez, sobre cómo las guerras libradas durante la época contemporánea provocaron conflictos nuevos entre los Estados enemigos. Cuando las causas de la guerra fueron de índole territorial, uno de esos problemas fue la delimitación de las fronteras sobre las representaciones cartográficas para saber, con rigor, donde proyectar los conceptos de nacionalidad y soberanía. Aún más, la justicia del trazado entraría en tensión con la comunidad, si alteraba de una forma radicalmente violenta su modus vivendi. El conflicto de Tacna y Arica, iniciado en 1880, es paradigmático a la hora de visualizar una pugna territorial secular que ha trascendido varias generaciones.

Ambas provincias fueron perdidas por Perú en favor de Chile durante la guerra del Pacífico (1879-1884). La legalización del país que ejercería su soberanía en ellas quedó inconclusa. El Tratado de Ancón (1883), firmado al terminar la guerra, estableció que Chile lo haría por diez años, sometiendo luego a plebiscito su adscripción nacional definitiva. Debido al espíritu oligárquico de los gobiernos de ambos países, la ciudadanía chilenoperuana fue marginada de las decisiones territoriales. Cuando, después, el Tratado de Lima (1929) entregó Tacna al Perú y Arica a Chile, se pensó que el diferendo había concluido ad infinitum. Contrariamente, la demanda realizada por Perú contra Chile en la Corte Internacional de Justicia de La Haya (2014) y la discrepancia actual sobre la soberanía de un "triángulo terrestre" en Arica confirman la pervivencia de la litis.

En España, el activismo de la prensa se apreció desde el inicio del conflicto dedicándole, en efecto, miles de noticias. Esa potencia periodística permitió interrogarnos acerca de las modalidades discursivas de esta industria española para referirse a esa disputa extranjera. Es más, la prensa enérgicamente solicitó a sus políticos intervenciones diplomáticas para resolverla. Por ejemplo, durante la guerra, exigió al gobierno más información sobre sus compatriotas avecindados en el Perú; luego, en 1901, observó cómo el arbitraje de la reina María Cristina era despreciado por Chile; publicó, posteriormente, los rumores sobre un arbitraje de Alfonso XIII y, después, criticó el desplazamiento, labrado por la Casa Blanca, del protagonismo que España "debía” tener en los asuntos americanos. 
Nuestro análisis histórico de la prensa recuerda, una vez más, el pasado compartido entre España, Chile y Perú. Es sabido que el origen de éste se remonta al siglo XVI, antecediendo la existencia republicana de los dos últimos países. Desde ahí, sin embargo, esos iniciaron sui generis lo que las ciencias sociales denominan nation-building. En esa construcción nacional y de identidades - la hispanidad, chilenidad y peruanidad- los sistemas judiciales, educativos, militares y comunicacionales, entre otros, aportaron sus aparatos y saberes. Dentro del último ámbito, las visiones de la prensa española sobre América adolecen de atención historiográfica, en comparación con la entregada a temas “endógenos". En España, salvo excepciones, ha prevalecido una mirada "introspectiva" al analizar históricamente el periodismo del ayer.

Lo afirmado anteriormente es fundamental para comprender que la prensa, en tanto medio de comunicación masivo y conductor de formas de pensamiento desde los miembros de una nación determinada hacia los "otros" es una parte sustancial en la creación y consolidación de la identidad nacional del país productor. Esa situación, significativa para nuestro modo de comprender la historiografía de la prensa ha estado, de momento, un tanto ausente en la reflexión académica, siendo necesario enfatizar que el(los) modo(s) del "ser nacional" también es(son) provocado(s) por los posicionamientos hacia naciones lejanas y no siempre fronterizas.

Las razones de esa escasez estarían relacionadas con dos aspectos metodológicos. En primer lugar, la preferencia por las fuentes de la Edad Moderna hasta comienzos del siglo XIX, inclinación que dio a luz obras claves para entender la expansión y decadencia de España en el Nuevo Mundo. Por su lado, los historiadores americanos miraron la documentación producida por la burocracia hispana con "buenos ojos" para escribir la historia fundacional de las nacientes repúblicas que, ante todo, necesitaban claridad genealógica. En segundo lugar, la desvinculación política entre España, Chile y Perú, tras alcanzar las últimas la independencia, dificultó en comparación con la época anterior, la producción de fuentes, elementos básicos para la historiografía. El estatus de la relación política no era ya entre metrópolis y dominios de ultramar, sino más bien entre Estados soberanos sin obligaciones en el mantenimiento de contactos diplomáticos. 
Nuestra investigación, consciente de la situación esbozada, no tiene por objetivo recriminar las formas de hacer historia hispanoamericana, pues es consciente de los factores ambientales que rodean al investigador. Por eso, discute, pero también propone un modelo de análisis que vincule pasados "eclipsados" y compartidos entre España, Chile y Perú en el cambio de siglo XIX al XX construyendo, alrededor de la cobertura periodística del conflicto de Tacna y Arica, un circuito explicativo donde las ganancias del saber quedan exoneradas de un monopolio historiográfico nacional. En efecto, la iluminación que se intentará sobre tres regiones sólo puede ser posible pensado, epistemológicamente, la historia desde una dimensión tridimensional y "supranacional".

¿Por qué razones la prensa española se ocupó del conflicto chileno-peruano? ¿Qué posiciones asumió hacia repúblicas que formaron parte de sus dominios americanos? ¿Manifestó filiación hacia Chile o Perú? ¿Hacia ambos? ¿Evidenció, al contrario, fobia hacia uno de los dos países? ¿Por qué? ¿Qué apreciaciones realizó de terceros países que estuvieron involucrados en la litis (Argentina, Bolivia y los Estados Unidos)? ¿Cómo construyó discursos sobre el papel que cabía a España en el conflicto? ¿Cómo describió y opinó de la diplomacia española, del arbitraje español frustrado (1901), de la pérdida de hegemonía en la "América Hispana" frente a los Estados Unidos después de 1898? ¿Cómo valoró la actuación española en la parte final del conflicto (1929)? Son algunas de las cuestiones que resolveremos en esta exploración.

La hipótesis puesta a prueba plantea que las noticias referidas al conflicto de Tacna y Arica publicadas por la prensa española durante 1880 y 1929 permitieron construir discursivamente un conjunto de representaciones sociales sobre el diferendo y, por extensión, sobre los países directa e indirectamente partícipes. En efecto, la prensa española fabricó parte de la identidad nacional chilena y peruana, pero también boliviana, estadounidense y española. Éstas, desde un plano ético, eran diferenciables a causa del desarrollo de funciones estatales opuestas en el conflicto, las que fueron informadas y opinadas por la prensa, acumulando conocimientos y cristalizando representaciones. No obstante, el dinamismo político de los países interesados en la solución del diferendo, así como la evolución de la industria periodística española, pasado el tiempo, matizaban la singularidad de la litis y las identidades nacionales. 
Por tal razón, sostendremos hipotéticamente que la prensa española construyó, en torno al problema de Tacna y Arica, la idea de su carácter amenazante para la paz americana, desestabilizando la región y distanciándola del "progreso". Vio también en éste un diferendo que evidenció la incapacidad resolutiva de los gobiernos de Chile y el Perú frente a los inconvenientes derivados del artículo tercero del Tratado de Ancón de 1883. Así, pasado el tiempo, sin desatenderlo durante medio siglo, lo calificó de antiguo, eterno y vio en él una justificación de la política exterior imperialista de los Estados Unidos hacia Hispanoamérica.

Chile fue retratado como un país bárbaro, belicoso y obstinado en dominar Tacna y Arica. Después de la guerra su identidad nacional se "desbarbarizó", valorándose el militarismo y orden que caracterizaría a su ejército y al conjunto de la nación. Los años finales del conflicto representaron en la prensa un Chile moderno, compuesto por una elite y pueblo culto, que habían concluido exitosamente el diferendo. Perú, al contrario, fue presentado como un país devastado por la guerra que, pese al heroísmo nacional en el combate, sufrió su desmembración territorial y la posterior injusticia de negociar el retorno de las "cautivas" con Chile, país transgresor del derecho internacional. El resultado de estas representaciones sobre Chile y el Perú evidencian el sentir "chilenófobo" y "peruanófilo" de la prensa.

En el caso de Bolivia la representación construida por la prensa es claramente "fóbica" y más duradera en el tiempo. Las razones de esa decisión son variadas, yendo desde el papel "vergonzoso" de su ejército en la guerra del Pacífico, pasando por fases reiteradas de anarquía gubernamental de un país con una mayoría de población indígena y, según los cánones de la modernidad, incivilizado, hasta la certeza de carecer de medios políticos y económicos para negociar con Chile la recomposición de todo el litoral perdido en la guerra. Hacia los Estados Unidos, la prensa desarrolló una actitud también fóbica, pero por razones contrarias. En esa relación había, por parte de la prensa, un conato de guerra ideológica aparte entre el hispanoamericanismo y el panamericanismo que concluyó, pese a la resistencia y crítica "poética" de España, con el triunfo del pragmatismo estadounidense que prestó, con éxito, sus “buenos oficios” al problema de Tacna y Arica. 
Para corroborar la hipótesis planteamos como objetivo general de la investigación analizar las representaciones sociales construidas y comunicadas por la prensa de España durante los años 1880 y 1929 en torno al problema entre Chile y Perú por Tacna y Arica. Esta meta supone detectar las ideas centrales y de mayor proyección del discurso periodístico español referidas a las identidades nacionales de Chile, Perú, Bolivia, Estados Unidos y España.

En directa relación se encuentran los seis objetivos específicos explicitados a continuación:

1) Seleccionar de la prensa las informaciones y opiniones realizadas frente al diferendo chileno-peruano.

2) Especificar el aporte discursivo realizado por las noticias, filtrando las relacionadas directamente con el conflicto y con las identidades nacionales de los países comprometidos.

3) Comparar las posiciones, fundamento de las representaciones sociales, de la prensa frente al procedimiento de cada uno de los países involucrados.

4) Sintetizar en cuatro fases, delimitadas por acontecimientos diplomáticos relevantes del conflicto, la evolución de las representaciones sociales construidas periodísticamente.

5) Interpretar históricamente las razones tenidas por la prensa para interesarse por la litis y por la creación de representaciones sociales definidas y divergentes hacia cada país participante del conflicto.

6) Definir las características que distinguen la singularidad del problema de Tacna y Arica y las identidades nacionales de Chile, Perú, Bolivia, Estados Unidos y España.

Nuestro estudio está organizado en siete capítulos. Posterior a la presente introducción, el primero pretende contextualizar históricamente el conflicto de Tacna y Arica. Asumiendo la dificultad de ese ejercicio abstracto por situar adecuadamente el largo 
diferendo, critica la escasa atención que ha tenido el concepto y su uso por los especialistas del pasado. Por ello prevé la conveniencia de explicar las principales características del diferendo acudiendo a dos operaciones básicas: la segmentación temática y la discriminación nacional. Reconoce que dentro del proceso de la litis hubo momentos estelares (las Conferencias de Arica, el Tratado de Ancón, el arbitraje de España, el arbitraje de los Estados Unidos y el Tratado de Lima) que dieron lugar a coyunturas diplomáticas con repercusiones en la prensa española. Esos acontecimientos favorecieron el aumento de la cobertura noticiosa, así como también la consolidación de las representaciones sociales originadas en los años de la guerra. Por su importancia, fue necesario preguntarse cómo los retrataron los autores contemporáneos y extemporáneos al conflicto, pues, como en el caso de los primeros, la pasión nacionalista unida a una concepción histórica maniquea preparó el terreno para que escritores chilenos satanizaran las "verdades" peruanas y viceversa. La constatación de esa lucha ideológica sirvió para efectuar la segunda división anunciada referida a la discriminación por la nacionalidad de los autores.

El segundo capítulo discute in extenso el concepto teórico de las representaciones sociales y las implicaciones de éste en un análisis de prensa histórica concerniente a hechos políticos de países exóticos. El término, de gran utilidad en las ciencias sociales, relativamente nuevo en su uso historiográfico produce escepticismo en nuestra disciplina (no debería ser al revés) más cercana a la inducción ofrecida por la naturaleza de sus fuentes que a la deducción provocada por la teoría social.

Por eso, el capítulo presenta la posición dialéctica asumida por esta investigación entre la teoría de las representaciones sociales y las fuentes hemerográficas estudiadas, probando en todo momento aquella, pero también mirando las noticias con los conceptos clave suministrados por ese marco. Eso no implica que la relación entre el investigador y la documentación se base en un dogmatismo teórico. Al contrario, confía cómo mediante esa conexión la teoría de las representaciones sociales puede enriquecerse al discutir cuestiones olvidadas que sólo el empirismo de la historiografía de la prensa puede aportar. Con esa intención, el hilo conductor de capítulo hace un recorrido que va angostándose desde la historia cultural, pasando por la historia cultural de la comunicación social hasta detenerse 
en una historia cultural de la prensa, caracterizada, a nuestro parecer, por asumir las premisas fundamentales del construccionismo social, anterior cronológicamente a las representaciones sociales, pero de gran importancia en su elaboración.

El tercer capítulo desarrolla la metodología aplicada sobre las noticias publicadas por la prensa española evidenciando paso a paso de qué modo se sustraen de las fuentes las representaciones sociales aludidas en el capítulo teórico. Por ello hemos diseñado una metodología bifásica. Una primera etapa consideró derivaciones del método histórico, particularmente una heurística centrada en conocer las particularidades de la prensa española. La segunda aplicó procedimientos del análisis de contenidos, distanciándonos del análisis discursivo, ocupándonos por ideas -fundamentos de las representaciones socialessocializadas por la industria periodística. Nuestro análisis tiene un carácter cualitativo, sin desechar los resultados que algunas técnicas cuantitativas ofrezcan para responder las interrogantes básicas. Como se explicará en el apartado metodológico, su espíritu es lógicoestético, no reactivo, no estructurado y "etnográfico". Allí también serán desarrolladas las fases de recopilación de la muestra, codificación, categorización y hermenéutica.

Los cuatro capítulos siguientes argumentan históricamente, es decir, revelando las evidencias documentales y explicando de forma prolija el proceso de construcción de representaciones sociales hacia el conflicto de Tacna y Arica y hacia los Estados que tomaron parte en él.

"Guerra, paz y posguerra (1880-1894)" demuestra la importancia concedida por la prensa española a la guerra del Pacífico desde su estallido en el litoral boliviano. La atención no decayó, sino más bien aumentó cuando acontecieron el combate naval de Arica, la batalla de Tacna y la batalla de Arica en 1880. Los triunfos chilenos rápidamente comenzaron a ser observados cómo fruto del barbarismo de un país belicoso. A la par, las valoraciones hacia el caudillo peruano Nicolás de Piérola, tuvieron un tono amigable. Su ferviente catolicismo, al parecer, provocó la cercanía de parte de la prensa católica española. Eran los orígenes de la "chilenofobia" y "peruanofilia" que, poco a poco, cristalizaban a la par que Chile hacía fracasar la paz discutida en las Conferencias de Arica (1880) y decidía la desintegración territorial peruana, tres años después, con el Tratado de Ancón. 
"El arbitraje de España (1895-1901)" expone los graves problemas sufridos por el supuesto incumplimiento chileno del Tratado de Ancón que impedían al Perú reincorporar las provincias de Tacna y Arica. La prensa española adujo que la responsabilidad de esa situación era de Chile -la "Prusia de América del Sur"- quien pretendía una retención forzada de la región debido a su papel geopolítico de frontera militar para los territorios salitreros de Tarapacá. Uno de los hitos más importantes de esta fase fue la firma del protocolo Billinghurst-Latorre en 1898, entre Chile y Perú, el que ofreció a la reina regente de España, María Cristina, arbitrar el conflicto.

Es enigmático el escaso interés que este hecho tuvo en la prensa. Algunas noticias, poco detalladas, referidas a su firma fueron impresas, pero casi nada sobre su impacto en la clase política española. Tal atención difirió de la importancia dada al rechazo chileno del protocolo en 1901 y a la política de chilenización elaborada desde La Moneda. Esas decisiones continuaron el proceso constitutivo de representaciones hacia Chile y el Perú en términos opuestos, donde el primero hacía gala de un nacionalismo obcecado y el segundo de un nacionalismo con voz política crítica, pero estéril en los hechos. Tacna y Arica continuaban en posesión chilena.

El capítulo seis, permite comprender los cambios ideológicos profundos de la prensa frente al tema de Tacna y Arica, relacionados con el surgimiento del interés diplomático de los Estados Unidos sobre la región. Las consecuencias presentes del desastre sufrido en 1898 contra ese país alentaron un discurso periodístico anti "yanqui", donde el diferendo Tacno-ariqueño tuvo un papel básico como detonador de representaciones adversas hacia la política exterior de los Estados Unidos en América. Considerando esa cuestión se logra entender el énfasis dado por la prensa al monumento dedicado al héroe de la batalla de Arica, Francisco Bolognesi, esculpido por el escultor Agustín Querol, pero también hacia el Tratado chileno-boliviano de 1904, la construcción del ferrocarril Arica-La Paz y las rupturas de relaciones consulares entre Chile y Perú, entre otros temas. Si bien las primeras décadas del siglo XX continuaron presentado a esos países en términos nacionalistas opuestos, se empieza a detectar un uso del lenguaje periodístico menos militante hacia el antiguo virreinato. 
El capítulo siete evidencia los discursos periodísticos españoles elaborados durante la actuación protagónica de los Estados Unidos en la litis. La comprensión detallada de esos discursos fue favorecida por la multiplicación progresiva de noticias frente al diferendo que, en el marco occidental, había cobrado gran importancia. Es por eso que desde las Conferencias de Washington de 1922, cuando La Moneda y la Casa de Pizarro deciden ceder el arbitraje al presidente Warren Harding, hasta el Tratado de Lima de 1929, la prensa consolidó las representaciones sociales sobre el conflicto y los países partícipes.

Las expresiones antichilenas o de abierta simpatía al Perú comienzan a neutralizarse, no obstante que las ideas básicas sobre esas naciones ya estaban bien asentadas, debido al trabajo dinámico que los cuerpos diplomáticos de esos países en Madrid realizaron. La solución final del diferendo, si bien no fue alcanzada por el arbitraje estadounidense, tuvo en todo momento el apoyo de la Casa Blanca. Un hispanoamericanismo agónico no criticó esos buenos oficios con la rudeza de los años anteriores, pero sí intentó demostrar la participación fundamental de la aviación española en el transporte de los documentos del tratado desde Santiago hacia Lima, así como la proposición para adjudicar el premio Nobel de la Paz a los dictadores Carlos Ibáñez del Campo y Augusto Leguía, presidentes de Chile y Perú, respectivamente.

Finalmente, las conclusiones de la investigación ratifican la importancia de la teoría de las representaciones sociales para el estudio histórico-cultural de la prensa española. Luego repasan uno a uno los objetivos específicos de la investigación intentando demostrar su consecución. Por ello, demuestra entre otras cosas, cuál fue la singularidad del conflicto de Tacna y Arica en las representaciones realizadas por los diarios y revistas sobre las que proponemos una tipología que hemos reunido en torno a siete atributos ("alógeno", "económico", de "espejo", "desestabilizador", "hermético”, “estatista” y "laberíntico”). Así mismo, sintetiza cinco representaciones difundidas en España sobre las identidades nacionales de los Estados Unidos, España, Bolivia, Perú y Chile. 


\section{EL CONTEXTO HISTÓRICO DEL CONFLICTO DE TACNA Y ARICA}

\subsection{Consideraciones previas}

La historiografía, entendida como ciencia, utiliza conceptos particulares que constituyen su lenguaje formal. Las reflexiones sobre ese lenguaje, fundamento del tesauro historiográfico, y los procedimientos prescritos por aquel, son heterogéneas. Ese estatuto científico, sin embargo, no determina la homogeneidad teórico-metodológica, es decir, la centralización del pensamiento histórico. Tal situación, más que una debilidad es una virtud que demuestra, entre otros aspectos, la vitalidad inagotable de quienes trabajan para entender el pasado. Así, el cambio permanente y la crítica hacia las tendencias conceptuales rectoras de una época se vuelven la norma.

Esa actitud, sin embargo, deja amplios espacios a las excepciones. Uno de los conceptos centrales del vocabulario historiográfico -el "contexto histórico"- se ha naturalizado, permitiendo un uso inocente y de eficiencia reducida en la "contextualización histórica" de los objetos de estudio. Las publicaciones sobre historia, en cualquiera de sus líneas de investigación consagradas (económica, política, social y cultural), olvidan, en general, explicitar qué entienden por "contexto histórico", apelando implícitamente a un entendimiento profano del lector. La apuesta es arriesgada, máxime cuando de los mismos diccionarios de la especialidad se marginan, por razones desconocidas, conceptualizaciones del vocablo aludido. Por ejemplo, los títulos Dictionnaire des Sciences Historiques ${ }^{1}$, Dizionario di Storia ${ }^{2}$, Diccionario de términos históricos y afines ${ }^{3}$, Diccionario de términos $y$ acontecimientos históricos ${ }^{4}$, Historia Universal. Diccionario de términos históricos ${ }^{5}$, Conceptos fundamentales de Historia ${ }^{6}$, prescinden de la entrada.

\footnotetext{
${ }^{1}$ Burguiere, André, Dictionnaire des Sciences Historiques, París, Presses Universitaries de France, 1986.

${ }^{2}$ Bernardi, Alberto de y Guarracino, Scipione, Dizionario di Storia, Milano, Edizioni Scolastiche Bruno Mondadori, 1993.

${ }^{3}$ ChORdÁ, Frederic, Martín, Teodoro y Rivero, Isabel, Diccionario de términos históricos y afines, Madrid, Ediciones Istmo, 1983.

${ }^{4}$ OrtegA, Julio y RIVEro, Isabel, Diccionario de términos y acontecimientos históricos, Madrid, Ediciones Globo, 2002.

${ }^{5}$ NAVARRo, Francesc (Director), Historia Universal. Diccionario de términos históricos, España, Editorial Salvat, S. L., 2004.

${ }^{6}$ SÁnCHEZ DE MADARIAGA, Elena, Conceptos fundamentales de Historia, Madrid, Alianza Editorial, 2007.
} 
La infravaloración conceptual padecida por el contexto histórico puede subsanarse, de todos modos, con el aporte de las humanidades y otras ciencias sociales. Dentro de estas últimas, la especulación filosófica de Ferrater Mora le permitió sugerir algunas ideas entorno al contexto:

El verbo latino contexere significa "tejer", "entretejer", "entrelazar". Los hilos tejidos y entrelazados forman una textura, la cual es una contextura. Se habla por ello de la contextura, así como de la textura de un material. [...] Es común hoy entender "contexto", en relación con un texto, donde el texto puede ser, y es frecuentemente, algo dicho o escrito, pero es también, o concomitantemente el sentido de lo dicho o escrito. Por extensión se entiende por "contexto" de algo una estructura dentro de la cual figura algo que sin el contexto resultaría ininteligible o menos inteligible ${ }^{7}$.

Las dificultades derivadas de la delimitación del "contexto histórico" no disminuyen, automáticamente, suscribiendo a una definición filosófica, centrada sólo en el primer término de nuestra expresión compuesta. Al mismo tiempo, deberíamos especificar qué se comprende por "lo histórico", ejercicio epistemológico que trasciende el objeto de esta investigación.

Así, de momento, interesa especificar que la historicidad del contexto estará relacionada con el fenómeno (objeto de análisis) particularmente estudiado aquí (construcción de representaciones sociales sobre la cuestión de Tacna y Arica en la prensa española). Éste, puede mirarse, por lo menos, desde dos ángulos espacio-temporales: a) el diferendo territorial de Tacna y Arica y b) la posición de la prensa española frente a ese conflicto.

Este apartado “contextual”, sin embargo, intentará -exclusivamente- definir cómo se ha entendido desde la historiografía el conflicto de Tacna y Arica. Tal decisión no excluye, durante los capítulos siguientes, comentar y criticar, cuando sea necesario, algunas referencias y conclusiones que los historiadores de la prensa han realizado respecto del papel de ese medio de comunicación en España. Lógicamente, esos estudios no consideran el problema chileno-peruano, objeto de análisis que posee un minimum de producción científica, no sólo en Europa, sino también en Sudamérica.

\footnotetext{
${ }^{7}$ FerRater Mora, José, Diccionario de Filosofia, Madrid, Alianza, 1986, p. 675.
} 
Las sugerencias conceptuales de Ferrater son valiosas. Siguiéndolas en la contextualización del problema histórico considerado en nuestro análisis, mostraremos al lector aquellos "hilos tejidos y entrelazados" que, en un plano material, son los textos que la historiografía de Chile y Perú, principalmente, dedicó al problema de Tacna y Arica. De tal modo, nuestra comprensión de ese "contexto histórico" toma distancia de las definiciones "contextuales" centradas en semas dependientes de conjuntos mayores de palabras. Dicho de otro modo, este capítulo no concibe el "contexto" en un sentido lingüístico interesado por designar "el entorno estrictamente lingüístico de un elemento sobre la cadena del discurso" ". Por el contario, al trabajar con un hecho histórico, procesual y de duración prolongada, se ha preferido explicarlo organizadamente, haciéndolo más "inteligible".

Con esa intención, los resultados del análisis interpretativo practicado sobre la bibliografía manejada se presentan en dos bloques. En efecto, el primero incluyó diversos autores chilenos y el segundo autores peruanos. La división por nacionalidad guarda relación con la importancia que tuvo el conflicto en la intelectualidad de ambos países, elites que desde las letras defendieron sus causas nacionalistas. Por lo anterior se aprecia, salvo excepciones, una narrativa histórica-patriótica donde el valor de la objetividad científica dio paso a apreciaciones emocionales hacia los países de origen de los redactores ${ }^{9}$.

\footnotetext{
${ }^{8}$ THINÈs, Georges y Lempereur, Agnès, Diccionario general de Ciencias Humanas, Madrid, Ediciones Cátedra, S. A., 1978, p. 183.

${ }^{9}$ Algunos importantes estudios de reciente aparición que no hemos incluido en esta revisión son, para el caso de autores chilenos: REPÚBLICA DE CHILE, Vocación de paz: La política exterior de Chile, Chile, Dirección Nacional de Fronteras y Límites del Estado, 2016; MORONG REYES, Germán y TÉLLEZ LUGARO, Eduardo, "De escrituras globales a proyectos locales: La historiografía nacional en el contexto de la chilenización de Tarapacá", Universum, Vol. 30, n. ${ }^{\circ}$ 2, 2015, pp. 197-217; ECKHOLT ITHURRALDE, Edgard, Chile y Perú 1994-2009: Realismo en la frontera, Santiago, Magíster en Política Exterior, IDEAACADE, Universidad de Santiago de Chile, 2012; RUBILAR LUENGO, Mauricio E., La politica exterior de Chile durante la guerra y postguerra del Pacifico (1879-1891): Las relaciones con Estados Unidos y Colombia. Diplomacia, opinión pública y poder naval. Tesis para optar al grado de doctor en Europa y el Mundo Atlántico: poder, cultura y sociedad, Valladolid, Universidad de Valladolid, 2012. [Inédita]; DÍAZ AGUAD, Alfonso y PIZARRO PIZARRO, Elías, "Tacna y Arica en tiempos del centenario", Diálogo Andino, n. ${ }^{\circ}$ 24, 2004. De autores peruanos: PEREYRA PLASENCIA, Hugo, "La negociación diplomática del Tratado de Ancón", Histórica, XXXIX.2, 2015, pp. 153-170; ROJAS, Rolando, "La guerra inacabable. Itinerario de los problemas sin resolver que dejó la Guerra del Pacífico", Revista Argumentos, n. ${ }^{\circ} 3,2013$, pp. 24-29; REPÚBLICA DEL PERÚ, Memoria del Gobierno del Perú. Controversia Marítima (Perú v. Chile). Volumen I. (Traducción no oficial), 2009. [En línea], disponible en: http://www.rree.gob.pe/noticias/Documents/Memoria\%20del\%20Gobierno\%20del\%20Per\%C3\%BA.pdf;
} 
Cada bloque analiza cuatro coyunturas históricas ocurridas durante el conflicto de Tacna y Arica: las Conferencias de Arica, el Tratado de Ancón, el arbitraje de España, el arbitraje de los Estados Unidos y el Tratado de Lima. Los tres primeros fueron construidos con bibliografía contemporánea al diferendo; por el contrario, para los dos últimos hemos recurrido a textos publicados después de 1929. De esa forma, entre otras cosas, se puede reflejar la importancia de larga duración que ha tenido la disputa territorial entre Chile y Perú, pero también algunos cambios y permanencias en las interpretaciones historiográficas que, no obstante, han permitido fabricar visiones nacionales sobre aquella.

PEASE G. Y., Franklin, Perú. Hombre e Historia. La República. III, Lima, EDUBANCO, 1993. Estudios realizados por autores de ambas nacionalidades: FERMANDOIS, Joaquín, PARODI, Daniel, ZAPATA, Antonio y GONZÁLEZ, Sergio, Generación de diálogo. Chile-Perú, Perú-Chile. Documento 2. Aspectos históricos, Lima, Equis Equis S. A., 2011; ALJOVÍN DE LOSADA, Cristóbal y CAVIERES F., EDUARDO, "Reflexiones para un análisis histórico de Chile-Perú en el siglo XIX y la Guerra del Pacífico". En CAVIERES F., Eduardo y ALJOVÍN DE LOSADA, Cristóbal (Comps.), Chile-Perú; Perú-Chile en el siglo XIX. La formación del Estado, la economía y la sociedad, Valparaíso, Ediciones Universitarias de Valparaíso, Pontificia Universidad Católica de Valparaíso, 2005, pp. 11-24. 


\section{Imagen $n .^{\circ} 1$}

LA GUERRA ENTRE CHILE, BOLIVIA Y EL PERÚ.

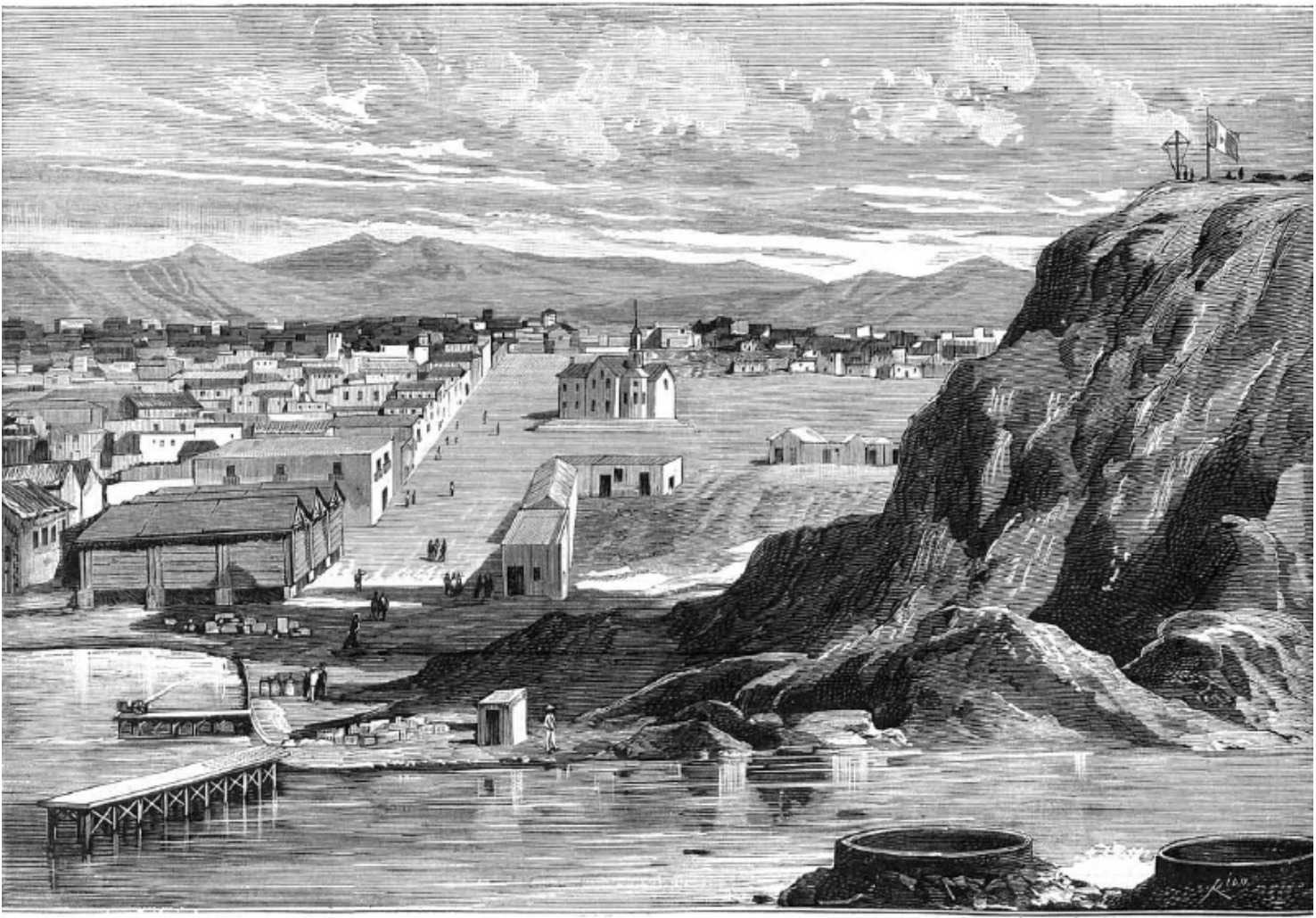

PERÚ.-vista de ARICA, PLAza rUerte sobrg la costa. - (Segun cróquis de D. Feliciano Batlle.)

Fuente: La Ilustración Española y Americana, "Perú.- Vista de Arica, Plaza fuerte sobre la costa", 15 de septiembre de 1879, n. $^{\circ} 34$, p. 156. 
1.2. El conflicto de Tacna y Arica en la historiografía

Concluidos los procesos independentistas en los dominios americanos de España, las nuevas repúblicas emprendieron la construcción de sus Estados-nacionales. Desde México, por el norte, hasta Chile, por el sur, los conflictos internos y externos no demoraron en aparecer. En los planos "nacionales", la oposición entre conservadores y liberales produjo larguísimos debates sobre las formas correctas de administrar los Estados estallando, en ocasiones, cruentas guerras civiles. En el plano internacional, la imperfecta delimitación de las fronteras que definían los límites soberanos entre las repúblicas "hermanas", desencadenó un conjunto de guerras sobre toda la geografía americana, afectando el fisco de cada una de ellas y la estabilidad macrorregional ${ }^{10}$.

Chile, Perú y Bolivia no serían la excepción. Durante 1836-1839, los dos últimos países formaron la Confederación Peruano-Boliviana derrotada por Chile en suelo peruano. Las causas, desarrollo y consecuencias de la guerra varían dependiendo de las historiografías nacionales consultadas. Una mayoría de los historiadores de esos países mantienen las visiones nacionalistas de los hechos desencadenantes del conflicto. Por ello, en esa región americana, la historia como magistra vitae fue estéril. Esos países, enfrentados bajo el mismo formato de alianza, fueron nuevamente a la guerra cuarenta años después. La Guerra del Pacífico, como se conoció mundialmente, también ha sido estudiada desde los países enfrentados con sesgos nacionalistas. Para Chile la guerra con Perú se extendió hasta 1883 y contra Bolivia un año más tarde. Los historiadores de esos países han construido una fase de historia compartida, posterior a los enfrentamientos, conocida como posguerra.

\footnotetext{
${ }^{10}$ ARAYA PINOCHET, Carlos, Historia de América en perspectiva latinoamericana, San José, EUNED, 2006, p. 147; BAUD, Michiel, "Fronteras y la construcción del Estado en América Latina". En TORRES CiSNEROS, Gustavo, VAn Dijck, Pitou, BAud, Michiel, HogenboOM, Barbara, Zoomers, Annelies, YpeiJ, Annelou y OUWENEEL, Arij, Cruzando fronteras. Reflexiones sobre la relevancia de fronteras históricas, simbólicas y casi desaparecidas en América Latina, Quito, Ediciones Abya-Yala, 2004, p. 51; PATIÑo FrANCO, José Uriel, La Iglesia en América Latina. Una mirada histórica al proceso evangelizador eclesial en el continente de la esperanza. Siglos $X V-X X$, Bogotá, Sociedad San Pablo, 2002, p. 127; ZIMmERmanN, Eduardo, "Transformaciones del Estado". En AYALA MorA, Enrique (Director) y POSADA CARBÓ, Eduardo (Coordinador), Los proyectos nacionales latinoamericanos: sus instrumentos y articulación, 1870-1930, España, Ediciones UNESCO, 2008, p. 186.
} 
Ésta, para Chile y el Perú se extendió hasta 1929, fecha del Tratado de Lima que solucionó - en teoría- el punto débil del tratado de 1883, es decir, la soberanía definitiva de Tacna y Arica. La posguerra con Bolivia finalizó en 1904, con la firma del Tratado de Paz, Comercio y Amistad, legalizando en el plano del derecho internacional la pérdida boliviana de su litoral. No obstante, somos escépticos hacia la nomenclatura de la posguerra, prefiriendo pensar un significado más genuino de aquella. En rigor, vistas los diferendos debatidos en la Corte Internacional de Justicia de La Haya entre Chile y Perú (2014) y entre Chile y Bolivia, actualmente, estamos persuadidos de la vigencia de la posguerra.

Pero ¿qué importancia tienen Tacna y Arica en todo lo señalado? Sin duda, por un lado, su situación geopolítica para Chile, Perú y Bolivia. Y, relacionada con ésta, el papel crucial en los tratados de paz y diferendos comentados. La primera situación diplomática originó el "conflicto de Tacna y Arica", que explicaremos y delimitaremos con precisión desde su origen hasta su conclusión en 1929. La cuestión de Tacna y Arica fue conocida también como "el problema de Tacna y Arica", "el problema chileno-peruano", "la cuestión chileno-peruana", "el problema de las cautivas", "la cuestión del Pacífico", "el problema del Pacífico", etc. Este problema, en líneas generales, se refiere a la disputa entre Chile y Perú por la soberanía de esa región, como consecuencia de la Guerra del Pacífico.

A nuestro juicio, la cuestión de Tacna y Arica tuvo un origen extralegal o, dicho de otra forma, anterior al Tratado de Ancón de 1883. Sin desechar su importancia, la centralidad de esa región para las relaciones entre Chile y Perú se iniciaron el 7 de junio de 1880 con el episodio militar conocido, popularmente en América, como "Asalto y Toma del Morro de Arica" o también "Batalla de Arica". Unos días antes, el 26 de mayo, las tropas chilenas habían triunfado en Tacna provocando la ruptura de la alianza militar peruano-boliviana y la retirada de este último ejército. Ese país no volvería a formar parte del conflicto armado.

Insistimos en la importancia de reconsiderar el origen del conflicto de Tacna y Arica, situándolo inmediatamente después del “Asalto". La razón: una misión diplomática estadounidense negoció con los contendientes finalizar la guerra. En esa ocasión, Chile rechazó las sugerencias del representante estadounidense y, también, las propuestas peruanas para la paz. 
El fracaso de las Conferencias de Arica, nombre con que se conocieron esas reuniones, convenció al gobierno chileno de que la solución final de la guerra estribaría sólo con la conquista de Lima. Por tal razón, desde el puerto de Arica zarpó una expedición militar hacia el centro político peruano. Se iniciaba así la "Campaña de Lima”, quizás la más desgastadora, para ambos países, en términos materiales y emocionales. El odio nacionalista parido allí se mantiene incólume hasta hoy. Los hombres públicos de Santiago habían acertado. El 20 de octubre de 1883 se firmó el Tratado de Ancón por el cual Tacna y Arica pasaron a soberanía chilena por diez años. El tratado estableció el compromiso de efectuar en esa región un plebiscito para definir comunalmente la adscripción nacional definitiva. Éste, por diversas razones relacionadas con el proceder de las cancillerías de Chile y Perú, no pudo efectuarse.

\subsubsection{Autores chilenos}

\section{Las Conferencias de Arica}

Destruido el ejército peruano-boliviano en Tacna y Arica, los diplomáticos chilenos, Eulogio Altamirano, Eusebio Lillo y José Francisco Vergara; peruanos, Antonio Arenas y Aurelio García y García; y el boliviano, Mariano Baptista, se reunieron con los ministros estadounidenses Thomas Osborn, Isaac Christiancy y Charles Adams para fijar los términos de la paz. El 22 de octubre de 1880 sesionaron a bordo de la corbeta Lackawanna $^{11}$. El Ministro de Guerra chileno, José Francisco Vergara, rechazó los buenos oficios de los Estados Unidos, sosteniendo que su país negociaría la paz directamente con sus adversarios. Para el chileno, los requisitos del diálogo serían la aceptación, por parte de Perú y Bolivia, de las condiciones propuestas por el hasta ese momento vencedor de la guerra. Vergara afirmó en las conferencias la inexistencia de motivos que obligasen al país “entregar en otras manos, por muy honradas que sean y muy seguras, la decisión de sus destinos"12. En rigor, Chile solicitó la aceptación de siete cuestiones:

\footnotetext{
${ }^{11}$ Arteaga Alemparte, posible seudónimo de algún político y escritor chileno de la década del diez del siglo pasado, aseguró que las Conferencias de Arica se desarrollaron el 27 de abril de 1880. En ARTEAGA Alemparte, El Problema del Pacífico. Artículos publicados en "O Paiz" de Río de Janeiro, sobre la cuestión de Tacna y Arica por “Arteaga Alemparte”, Santiago, Imprenta Universitaria, 1919, p. 49.

${ }^{12}$ Arteaga Alemparte, El Problema del Pacifico..., p. 42.
} 
Primera. Cesión a Chile de los territorios del Perú y Bolivia que se extienden al sur de la Quebrada de Camarones y al oeste de la línea que en la cordillera de los Andes separa al Perú y Bolivia hasta la Quebrada de la Chacarilla, y al oeste también de una línea que desde este punto se prolongaría hasta tocar en la frontera Argentina, pasando por el centro del lago de Ascotan.

Segunda. Pago a Chile por el Perú y Bolivia, solidariamente, de la suma de veinte millones de pesos, de los cuales cuatro millones serán cubiertos al contado.

Tercera. Devolución de las propiedades de que han sido despojados las empresas y ciudadanos chilenos en el Perú y Bolivia.

Cuarta. Devolución del transporte Rímac.

Quinta. Abrogación del tratado secreto celebrado entre el Perú y Bolivia el año 1873, dejando al mismo tiempo sin efecto ni valer alguno las gestiones practicadas para procurar una Confederación entre ambas naciones.

Sesta. Retención por parte de Chile de los territorios de Moquegua, Tacna y Arica, que ocupan las armas chilenas, hasta tanto se haya dado cumplimiento a las obligaciones a que se refieren las condiciones anteriores.

Séptima- Obligación de parte del Perú de no artillar el puerto de Arica cuando le sea entregado, ni en ningún tiempo, y compromiso de que en lo sucesivo será puerto exclusivamente comercial ${ }^{13}$.

Fracasadas las conferencias, el 10 de noviembre, el canciller chileno Melquiades Valderrama, explicó con un lenguaje más moderado que el pronunciado por Vergara, las razones de tal posición.

En primer lugar, señaló, que la oposición chilena frente a las propuestas de los adversarios -que, en general, solicitaban la devolución de todos los territorios perdidos en la guerra- se debía a los gastos de la movilización. El mantenimiento del ejército conllevaba exigencias económicas que aumentaban día a día. A ello se sumaban los riesgos inherentes de la guerra.

Valderrama agregaba a esos argumentos su conocimiento sobre la preparación militar que se desarrollaba en Lima y otras ciudades peruanas donde la guerra no había comenzado. Por tales hechos, defendió al gobierno chileno, sosteniendo que éste deploraba sinceramente que "las conferencias de Arica hayan sido infructuosas y hecho estéril el noble esfuerzo de la potencia mediadora, a la cual Chile agradece sinceramente su interés por el restablecimiento de la paz"14.

\footnotetext{
13 Ministerio de Relaciones Exteriores de Chile, Las Conferencias de Arica, Santiago, Imprenta Nacional, 1880, pp. 15-16.

14 Íbidem, p. 10.
} 
El resultado de las conferencias permitió al canciller declarar otros asuntos sobre Chile y sus adversarios. En su visión, si bien Perú y Bolivia habían causado la guerra, la responsabilidad directa recaía en Bolivia quien, desde hacía años, violaba los tratados solemnes suscritos por ambos Estados. En el caso del Perú, la alianza militar secreta firmada en 1873 con Bolivia, lo posicionó como país enemigo de Chile, pues La Moneda vio en el espíritu de esa alianza un sentimiento antichileno. Además, como explicó Valderrama, Chile no estaba preparado militarmente para combatir, puesto que intentaba reponerse de una severa crisis económica. El pueblo chileno, que antes de 1879 estaba ocupado en sus faenas agrícolas e industriales, empujado hacia la guerra, logró en poco tiempo vencer por mar y tierra a los aliados, viéndose ambos países imposibilitados materialmente de recuperar lo perdido. En ese momento aparecieron los buenos oficios de Washington, que Chile no dudó en aceptar. En palabras de Valderrama, su gobierno, apegado a la tradición fraternal en política internacional hacia "todas las naciones, aceptó la noble proposición de la Gran República del Norte, firmemente dispuesto a no ser obstáculo para alcanzar una paz sólida, reparadora y duradera en el porvenir" ${ }^{\prime 15}$.

Sin embargo, los petitorios del Perú y Bolivia iban en contra de la lógica de la cancillería chilena. Ese país, al ser el agredido, debía sostener una posición fuerte ante los aliados, imponiendo sus puntos de vista en los posibles acuerdos. En efecto, las compensaciones solicitadas por Chile para cubrir los gastos derivados de la guerra podían ser, por lo menos, de orden territorial o económico. Esa distinción fue comprendida por el gobierno del presidente chileno Aníbal Pinto, que resolvió inclinarse hacia la primera, conociendo el estado financiero ruinoso de los países agresores. A decir verdad, Perú y Bolivia tenían deudas externas elevadas y, por consiguiente, un nulo acceso a créditos de otras potencias europeas. En consecuencia, Chile no conferenció para defender el derecho de conquista, sino que participó sencillamente -escribió Valderrama- para lograr la paz y "la indemnización de los gastos de guerra"16. Éstas eran las exigencias justas o, como dijo Julio Pérez Canto, a quien analizaremos más adelante, las "condiciones esenciales" 17.

\footnotetext{
15 Íbidem, p. 4.

16 Íbidem, p. 6.

${ }^{17}$ PÉREZ CANTO, Julio, El conflicto después de la victoria, Recuerdo e impresiones de un ex-diplomático chileno en el Perú. La última discusión del problema de Tacna y Arica, Santiago, Edición de la empresa ZigZag, 1918, p. 68.
} 
Además, a los problemas económicos de los aliados se sumaba la inestabilidad política de sus gobiernos.

El diplomático y periodista Javier Vial Solar también se refirió a las Conferencias de Arica en un texto autobiográfico titulado Reminiscencias diplomáticas ${ }^{18}$. En la obra describió con detalles las reacciones experimentadas por los agentes aliados en el momento de recibir la minuta chilena que contenía las exigencias para la paz. Las siete peticiones, sostuvo Vial, causaron una impresión negativa en los representantes limeños y paceños quienes esperaban de Chile una posición más flexible, sobre todo, en el aspecto territorial.

Esa posición de los aliados permitió reconocer al escritor chileno un "irrealismo" poco ajustado al desempeño efectuado, hasta ese momento, en la guerra. Vial comentó que el lenguaje usado en las conferencias por Perú y Bolivia fue el propio de la época en todas sus prensas, condenando el proceder militar chileno. Las acusaciones de barbarismo se consolidaron a la par que se ocultaban los verdaderos orígenes de la guerra, que para el periodista santiaguino eran indiscutibles. Los aliados habían empujado a Chile hacia los campos de batalla. Sus políticos y militares no habían podido controlar la "imprevisora locura" de quienes olvidaron las consecuencias de la guerra. En las conferencias, la terquedad de Aurelio García y Mariano Baptista se opuso a los términos de paz ofrecidos por La Moneda, reflejando el espíritu dominante en sus gobiernos, caracterizado por "un sentimentalismo, avivado por ilusiones impropias de su situación"19.

Por otro lado, Vial defendió la oposición de la cancillería chilena frente al arbitraje estadounidense solicitado también por los plenipotenciarios aliados. Chile, dijo el santiaguino en comunión con Valderrama, no podía colocarse bajo las órdenes de un árbitro, pues como vencedor en la guerra le correspondía establecer los acuerdos de paz. En fin, con una ironía vulgar al considerar la actuación de la cancillería chilena en las conferencias, afirmó que "si por algo puede ser criticada, es tal vez por el espíritu de generosidad seguramente excesiva de que dio prueba en tal ocasión" 20.

\footnotetext{
${ }^{18}$ VIAL SOLAR, Javier, "Reminiscencias diplomáticas", La Revista Nueva, tomo II, 1900, pp. 376-390.

${ }^{19}$ VIAL SOLAR, Javier, "Reminiscencias diplomáticas”, p. 383.

20 Íbidem, p. 389.
} 
Finalizadas las Conferencias de Arica el ejército chileno inició la campaña de Lima. Los días 13 y 15 de enero de 1881 venció la resistencia peruana en las batallas de Chorrillos y Miraflores. En ese país, la dictadura de Nicolás de Piérola iniciaba su derrumbe. La guerra cambió de frente y las serranías de los Andes peruanos fueron escenario de sangrientos combates que continuarían, incluso, después de firmado el Tratado de Ancón, el 20 de octubre de 1883.

\section{El Tratado de Ancón}

Sobre el Tratado de Ancón se han escrito importantes obras que, cuantitativamente, superan a las centradas en las Conferencias de Arica. Esa producción guarda relación, sin duda, con la trascendencia diplomática del mismo. El Tratado o Pacto de Ancón, nombre con que también se conoce ese documento, finalizó la Guerra del Pacífico entre Chile y Perú, mientras que las conferencias no pasaron de ser un conjunto de reuniones estériles en ese punto.

Las consecuencias geopolíticas del tratado fueron indudables. Chile y Perú legalizaron una frontera compartida que antes de la guerra era inexistente. De los catorce artículos que, como rezó el encabezado del documento, pretendían "restablecer las relaciones de amistad entre ambos países"21, interesa el numeral tercero, que estipuló:

El territorio de las provincias de Tacna y Arica que limita, por el Norte, con el río Sama, desde su nacimiento en las cordilleras limítrofes con Bolivia hasta su desembocadura en el mar, por el Sur, con la quebrada y el río Camarones, por el Oriente, con la República de Bolivia; y por el poniente con el mar Pacífico, continuará poseído por Chile y sujeto a la legislación y autoridades chilenas durante el término de diez años, contados desde que se ratifique el presente tratado de paz. Expirado este plazo, un plebiscito decidirá en votación popular, si el territorio de las provincias referidas queda definitivamente del dominio y soberanía de Chile o si continúa siendo parte del territorio peruano. Aquel de los países a cuyo favor queden anexadas las provincias de Tacna y Arica, pagará otros diez millones de pesos, moneda chilena de plata, o soles peruanos de igual ley y peso que aquella. Un protocolo especial, se considerará como parte integrante del presente tratado, establecerá la forma en que el plebiscito debe tener lugar, y los términos y los plazos en que haya de pagarse los diez millones por el país que quede dueño de las provincias de Tacna y Arica ${ }^{22}$.

\footnotetext{
${ }^{21}$ LÓPEZ URRUTiA, Carlos, Guerra del Pacifico, Madrid, El Ciprés Editores, 2008, p. 146.

22 RepúbliCa Del Perú, Arbitraje entre el Perú y Chile: Réplica del Perú en el litigio que, emanado de la cuestión del Pacífico, se sigue ante el Presidente de los Estados Unidos de América como Árbitro, Lima, Editorial T. Scheuch, 1924, p. 5.
} 
Varios políticos explicaron las razones chilenas para firmar el tratado y anexar las provincias peruanas. Uno de ellos, Luis Barros Borgoño, comprendió que el éxito chileno en los primeros años de la guerra demostró qué Estado debía predominar en el Pacífico. Los territorios ganados al Perú y Bolivia compensaban los sacrificios realizados por Chile en una guerra provocada por los aliados. Para Barros, el "típico patriarca de polainas, guantes y bastón" 23 , los territorios conquistados eran una prenda para la tranquilidad americana y para la seguridad chilena, tesis suscrita posteriormente por La Moneda ${ }^{24}$. Pareciera, señaló, que un convencimiento similar tuvieron las autoridades peruanas suscriptoras. La larga ocupación militar chilena de Lima, así como el aniquilamiento absoluto de su ejército, obligaron al Perú pactar las condiciones de paz "que consigna el tratado de Ancón"25.

La posesión de Tacna y Arica, según el tratado, fue pensada por las autoridades chilenas con un sentido utilitario, no deseando su integración íntegra e indefinida dentro del Estado. Como la anexión de la antigua provincia peruana de Tarapacá estaba asegurada -el tratado la cedió perpetuamente a Chile- cualquier reclamo territorial boliviano no podría realizarse por puertos situados al sur de esa región, rompiendo la unidad geográfica del Estado. Por el contrario, el extremo norte del país podría, en algún momento, ofrecer Arica para concluir la mediterraneidad boliviana. En ese sentido, escribió Barros, los políticos chilenos firmantes del tratado apreciaron las futuras eventualidades fronterizas. Ellos comprendieron que si la aspiración boliviana "había de ser atendida alguna vez por Chile, tendría que serlo en la región más septentrional de la República, más al norte de la frontera que de una manera definitiva había ganado sobre el territorio del Perú"26.

El diplomático y periodista Julio Pérez Canto compartió las ideas del patricio Barros Borgoño, sobre todo en lo relativo al convencimiento experimentado por los gobernantes peruanos para finalizar la guerra. El Perú realizó la paz con Chile -aseguró- consciente de la imperiosa necesidad de reorganizar el país. Para llevar a cabo esa tarea, las autoridades sabían que la presencia militar y política chilena debía fenecer.

\footnotetext{
23 Álvarez García, Marcos, Lideres políticos del siglo XX en América Latina, Santiago, LOM Ediciones, 2007, p. 109.

24 Ministerio de Relaciones Exteriores de Chile, Las Conferencias de Washington. Antecedentes reunidos por orden del Ministro de Relaciones Exteriores, don Ernesto Barros Jarpa, Santiago, La Ilustración, 1922, p. 109.

${ }^{25}$ BARros BorgOÑo, Luis, Los tratados con Bolivia de 1895, La Paz, Imp. Moderna, 1918, p. 54.

26 Íbidem, p, 55.
} 
Toda la documentación leída y estudiada por quien fuera director de El Mercurio no hacía más que asegurar esa situación. Tan importante, en sus palabras, fue el testimonio comunicado oralmente por José Antonio Lavalle, hijo de uno de los firmantes peruanos del tratado, del mismo nombre.

El testimonio de Julio Pérez Canto es sugestivo. Parte de su carrera diplomática la desarrolló en Lima como Encargado de Negocios en 1908. Allí, como lo explicó, pudo comprender la forma de pensar a Chile en el Perú. Aun cuando en El Conflicto después de la victoria..., el autor advirtió que no contará "en detalle, y una vez más, la conocida historia de las infructuosas negociaciones hechas hasta ahora para dar cumplimiento a la cláusula del Tratado de Ancón que se refiere a la soberanía definitiva de las provincias de Tacna y Arica"27, expuso varias ideas que facilitan la comprensión de sus orígenes y consecuencias.

Por ejemplo, sobre la elaboración del artículo tercero se mostró particularmente crítico. Lo consideró “oscuro", pues no definió con precisión la "forma de cesión del territorio" ${ }^{28}$. Parte de esa culpabilidad, comentó el equilibrado Pérez Canto, la tuvo Perú, quien se opuso a la entrega definitiva de Tacna y Arica, basándose en un patriotismo que hizo obligatorio el mantenimiento de esa población peruana para no segregarla de la comunidad política mayor.

La anexión chilena de Tacna y Arica tiene, en Pérez Canto, un matiz sutil y discrepante con Barros Borgoño. Ya no sólo se deseaban mantener bajo soberanía para que, en un momento de apremio, se entregasen a Bolivia; la importancia de ambas provincias radicaba en su papel de frontera militar.

Chile pidió Tacna y Arica, aseguró Pérez Canto, porque eran ciudades perfectamente transformables en recintos militares. En Arica, la existencia de una bahía de gran extensión, así como el morro "inexpugnable", más la productividad de las tierras agrícolas del interior, eran prendas de las que Chile no podía desentenderse.

\footnotetext{
${ }^{27}$ PÉREZ CANTO, Julio, El conflicto después de la victoria..., p. 10.

${ }^{28}$ Ibidem, p. 45.
} 
En consecuencia, los políticos chilenos que elaboraron el tratado, por esas y otras razones, supusieron, dijo Pérez Canto, que Tacna y Arica fueron cedidas herméticamente a Chile. Perú, objetó esa base de discusión ${ }^{29}$. Sobre ese punto, el Encargado chileno de Negocios en Perú reprodujo los argumentos ofrecidos por Luis Aldunate Carrera, redactor del Tratado de Ancón y canciller chileno en 1883:

Creyeron los negociadores del 83 que la posesión por diez años del territorio disputado era su cesión sin el nombre. No se conoce en la historia de la diplomacia internacional un solo caso en el cual las mutaciones de la soberanía, deferidas (sic) al voto de los habitantes de una zona territorial no hayan concluido por su anexión al país poseedor. Los negociadores del 83, en la época en que se desarrollaban los sucesos, pudieron y debieron creer que, dar a Chile la posesión de los territorios del litigio, durante diez años, era darle su dominio definitivo" La declaración no puede ser más explícita, pero el Gobierno de Chile no se conformó con la estipulación convenida, sino que inició diversas gestiones encaminadas todas ellas a obtener la posesión inmediata de Tacna y $\mathrm{Arica}^{30}$.

Con un lenguaje más irritado, el político y psiquiatra Augusto Orrego Luco, cuñado de Luis Barros Borgoño, compartió gran parte de las ideas sobre el tratado ya señaladas. En las primeras páginas de su obra dedicada al diferendo estableció que el origen de la posguerra chileno-peruana se encontraba en el tratado secreto peruano-boliviano firmado en 1873. No obstante esa alianza militar, Chile venció en la guerra. La paz fue posible gracias a la conciencia chilena que comprendió la necesidad de detener la ocupación militar sobre el Perú, incapaz de ofrecer resistencia.

En ese momento, sostuvo Orrego, "Iniciamos [...] las laboriosas y largas negociaciones de la paz, con el mismo criterio de serena elevación que ha inspirado siempre nuestras relaciones exteriores" 31 .

Según Orrego Luco, Chile no impuso al Perú la paz, ni invocó el derecho supremo de las armas, aplicado desde el Tratado de Versalles de 1871. Al contrario, se alegró de la actitud del vencedor durante el fin de la guerra, porque Chile desestimó el lenguaje "prusiano" o estadounidense (contra España en 1898).

\footnotetext{
${ }^{29}$ Ibidem, p. 49.

${ }^{30}$ Ibidem, p. 75-76.

31 Orrego Luco, Augusto, La cuestión del Pacífico. Tacna y Arica, Santiago, Soc. Imprenta-Litografía Barcelona, 1919, p. 13.
} 
Consciente de que Chile fue el negociador de la paz se interrogó: “¿Y qué nación, en la historia del siglo XIX, ha puesto término a una guerra discutiendo las condiciones de paz con el vencido?"32. Para él, las cesiones territoriales del tratado eran obligatorias por los sacrificios hechos durante la guerra. Eran también las garantías para el porvenir de un país, como lo sostuvo años después el Estado, arrastrado hacia la guerra ${ }^{33}$. Por esas razones, Chile sólo pidió lo equivalente a la cobertura de los gastos de la guerra, interpretación coincidentemente realizada por Barros. La psique de Orrego se obstinaba en pensar que sólo la posesión chilena de las regiones desérticas repararía la sangre derramada por sus soldados. Allí cerraba la discusión.

Aquellos hechos eran suficientes para fundamentar la entrega íntegra de las salitreras de Tarapacá y la zona Tacno-ariqueña, obcecándose en que ambas "eran nuestra garantía y seguridad en el porvenir" ${ }^{34}$. Ese utilitarismo evidenció -como en Barros y la cesión a Bolivia o en Pérez y la militarización fronteriza- su compromiso por mantener las antiguas regiones peruanas bajo la soberanía chilena. Durante los meses previos al tratado, recordó el médico, esas opiniones fueron comunes en el país.

Orrego fue un adicto a la tesis de la cesión encubierta, efectuada por el Perú a Chile, de Tacna y Arica. En su visión, el artículo tercero fue una fórmula que cubrió con "el velo de un plebiscito la cesión real y efectiva de esos territorios" 35 . Nuevamente, el testimonio del canciller Luis Aldunate permitió afirmar el espíritu siniestro del mentado artículo, quien, según Orrego, reveló ante el congreso chileno el verdadero significado de aquel. En efecto, para Orrego el plebiscito fue solicitado por los negociadores peruanos del tratado. Esa cláusula favorecería la formación de un gobierno legítimo que no podría culparse de traición y entreguismo. De todos modos, Miguel Iglesias, caudillo peruano autor del "Grito de Montán", fue acusado de vender territorios a Chile ${ }^{36}$. En esta materia, su principal opositor fue Francisco García Calderón, quien durante su cautiverio en Chile, delata Orrego, aprobaba la cesión de Tacna y Arica.

\footnotetext{
32 Ibidem, p. 14.

33 Ministerio de Relaciones Exteriores de Chile, Las Conferencias de Washington. Antecedentes reunidos por orden del Ministro de Relaciones Exteriores, don Ernesto Barros Jarpa, Santiago, La Ilustración, 1922, p. 109.

${ }^{34}$ OrRego LuCO, Augusto, La cuestión del Pacifico..., p. 15.

35 Ibidem, p. 29.

36 Íbidem, p. 30.
} 
El periodista Arteaga Alemparte compartió, desde el anonimato, la tesis de la cesión encubierta. Escondido tras el seudónimo, el escritor chileno compiló una serie de opiniones defensoras de la soberanía chilena en Tacna y Arica publicadas en la prensa brasileña, país que desde el comienzo de la guerra favoreció discursivamente a Chile. Arteaga, consciente de esa simpatía, lo era también de la "peruanofilia" imperante en Argentina. El sentido argumentativo de Arteaga es idéntico grosso modo a los autores precedentes. Chile fue empujado a la guerra por la alianza peruano-boliviana, usuaria de la diplomacia secreta. Ello justificaba los procedimientos militares-diplomáticos que culminaron con el tratado. Éste "quiso únicamente procurar una forma de cesión simulada de Tacna y Arica, como ha ocurrido siempre en el mundo con ese género de soluciones plebiscitarias" ${ }^{37}$.

Para Arteaga, las cesiones simuladas eran válidas en la diplomacia. En el caso del tratado, su establecimiento fue humanitario, aplicándose para no lastimar la susceptibilidad del pueblo peruano y del gobierno "débil" del general Iglesias. En la mentalidad del escritor las discusiones sobre derecho que Perú deseaba entablar, décadas después del tratado, no tenían base. Además, ese documento había sido firmado con dificultades, puesto que La Moneda no encontraba "con quien firmar la paz, para concluirla de derecho"38.

Por otro lado, el ingreso de Tacna y Arica en el Estado chileno fue valorado por algunos intelectuales. El mismo Arteaga declaró que la provincia carecía de valor económico; no así estratégico, haciéndolas imprescindibles para firmar la paz. La larga ocupación chilena de Lima permitió a los líderes peruanos, varios vinculados patrióticamente con las provincias sureñas, cederlas a Chile. Arteaga aplaudió la idea patriótica de esa elite. Uno de sus miembros, Iglesias, afrontó con determinación las consecuencias de su proceder. Aun en conocimiento de esas situaciones, para nuestro autor, sólo Chile fue el artífice del tratado. Además, con una conducta ejemplar, retiró sus tropas tres días después de firmada la paz, asegurando la liberación del Perú y su posterior "unificación en la paz, auxiliada y eficazmente realizada por Chile"39.

\footnotetext{
${ }^{37}$ Arteaga Alemparte, El problema del Pacífico..., pp. 8-9.

${ }^{38}$ Ibidem, p. 65.

${ }^{39}$ Ibidem, p. 86 .
} 
La clase política chilena se convenció de la exitosa operación efectuada en Ancón. Por eso provocó gran malestar en La Moneda la declaración de nulidad del tratado efectuada por políticos y juristas peruanos en los años finales de la Primera Guerra Mundial. El periodista Ernesto Montenegro, por ejemplo, acusó el oportunismo peruano y la gestación de un complot antichileno, preguntándose: “¿Y el tratado de Ancón? Chiffon de papier, sin duda. Y los diez mil muertos y los millones perdidos por Chile por causa de una confabulación tramada contra sus intereses y contra su vida misma como nación" ${ }^{40}$.

Montenegro sugirió respetar el tratado. Su propuesta se oficializó durante la posguerra mundial. En rigor, ese cumplimiento respondía a las grandes aspiraciones de las naciones deseosas por aportar, desde la moral, al acerbo común de la humanidad. Sin embargo, en el caso peruano esa moralidad no existía. Su percepción hacia el Perú era totalmente negativa, viendo muy difícil concluir, de una vez, la disputa surgida en Ancón. El espíritu "peruanófobo" del ensayista expresó:

Un pueblo débil, un pueblo moralmente débil, es el peor vecino que puede tocarle en suerte a una nación pacífica y próspera. Y si ese pueblo habita un vasto territorio, un suelo rico y productivo, mientras que el otro posee apenas una lonja de tierra de riquezas naturales sólo explotables a fuerza de trabajo y energías, es fácil suponer que la incomprensión, los recelos, la envidia, de una parte y el espíritu de empresa del lado opuesto, lleguen tarde o temprano al conflicto y tropiecen por muchos años en el camino de la reconciliación ${ }^{41}$.

Sintetizando las opiniones chilenas relacionadas con el tratado se aprecia que: a) Chile fue arrastrado a la guerra contra Perú y Bolivia, quienes desde 1873 convinieron una alianza militar, b) El desgaste heroico del ejército chileno durante la guerra obligó a indemnizaciones territoriales a Perú y Bolivia, y c) El artículo tercero del tratado fue, en verdad, una cesión territorial encubierta de Tacna y Arica.

Esos razonamientos sentimentales y jurídicos fueron el quid de la posición asumida por la cancillería chilena encabezada por Ernesto Barros Jarpa en 1921, durante la presidencia de Arturo Alessandri, al reanudarse las conversaciones con el Perú de Augusto Leguía para solucionar la litis. Barros Jarpa expuso, basándose en documentación diplomática, las causas de la guerra y los orígenes dificultosos y consecuencias del tratado.

\footnotetext{
${ }^{40}$ Montenegro, Ernesto, La cuestión chileno-peruana, Santiago, La Penitenciaría, 1919, p. 21.

${ }^{41}$ Ibidem, p. 109.
} 
Como para los anteriores autores, para Barros Jarpa la guerra fue injusta. Chile fue atacado por una alianza consciente de la inestabilidad económica de su víctima; ganó la guerra. Tacna y Arica, comentó, fueron solicitados al Perú por las circunstancias, pues en "el límite de estas provincias encontraba Chile la única garantía estratégica y económica para la defensa del salitre de la provincia de Tarapacá y para la provisión agrícola de esas zonas áridas y estériles" ${ }^{42}$.

Barros Jarpa usó una retórica piadosa. Intentó demostrar que las peticiones chilenas en Ancón fueron las mínimas que podían hacerse al enemigo, pues Chile estuvo en condiciones de imponer fácilmente su voluntad a un Perú despedazado por cruentas luchas internas. Los negociadores chilenos, en palabras del canciller, pudiendo imponer “condiciones de paz más rigurosas, $[. .$.$] no lo hicieron" { }^{43}$. Es más, en ese momento crítico para Perú, Chile sólo exigió la cesión de Tacna y Arica, revistiéndola, con lenguaje diplomático, de una formalidad plebiscitaria y el pago de los millones de pesos.

Barros aseguró que en 1883 esas ciudades no importaban al Perú. Sus desprendimientos del Estado no rompían la unidad territorial, pues no formaban parte de la geografía peruana. En Lima se consideraban dominios remotos; el gobierno descuidaba su progreso. De esa forma el ministro deseaba convencer a sus lectores que la cesión encubierta había sido real. Por ello, con dureza, escribió: "Muchos otros argumentos podría agregar para demostrar en la forma más irredarguible, que la cláusula tercera del Tratado de Ancón importa lisa y llanamente la venta de los territorios a que ella se refiere"44.

A la par, en Barros Jarpa se observa la intención de fortalecer la imagen chilena en el exterior. Su gobierno, explicó, basado en un americanismo fraternal, silenció la circunstancia en que el Perú "cedió" Tacna y Arica, siendo esa la "verdadera interpretación histórica" ${ }^{45}$. Tal forma de entender la litis fue compartida por otros dos importantes políticos chilenos contemporáneos de Barros Jarpa.

\footnotetext{
42 BARros JARPA, Ernesto, Hacia la solución. Apuntaciones al margen de la negociación chileno-peruana de 1921, Santiago, Imprenta Universitaria, 1922, p. 14.

${ }^{43}$ Ibidem, p. 46.

${ }^{44}$ Ibidem, p. 15.

${ }^{45}$ Idem.
} 
Por un lado Gonzalo Bulnes, historiador oligarca empeñado en reforzar la idea de que la posición del Estado -sus poderes públicos y el pueblo, "desde el más humilde ciudadano hasta la más alta corporación del Estado"46 - era unívoca. Por otro, el senador de Malleco, Guillermo Rivera, quien aseguraba que el plebiscito fue sólo "un eufemismo encaminado a establecer en definitiva el dominio de Chile sobre Tacna y Arica" ${ }^{97}$.

Sobre esa unanimidad revisaremos sólo los casos emblemáticos que derrumban esta idea tan defendida por la clase política chilena: Agustín Ross y Carlos Vicuña. El primero, convencido de que en Chile inventaba toda clase de argumentos para afirmar que el artículo tercero implicó una cesión disimulada. Ross aseguraba que la culpabilidad en la demora y el fracaso plebiscitario era chilena. En el momento de escribir su crítica a la diplomacia chilena habían transcurrido veinticinco años, por lo que preguntó: "¿Por qué? En conciencia podemos afirmar que no se ha realizado porque Chile lo ha estorbado, oponiendo todo género de dificultades y de expedientes dilatorios" ${ }^{48}$. Sin embargo, el proceder chileno consistía en culpabilizar al Perú quien utilizaba la misma estrategia. El fundamento de Ross era su nacionalismo ferviente que haría prevalecer el espíritu justiciero de Chile. Su propuesta, además, guardaba equidad hacia el Perú, ya que cediendo Tacna y Arica a Bolivia, aquel país nada perdería. Bolivia satisfaría sus aspiraciones territoriales y Chile se quitaría esa "brasa de fuego"49 de las manos. El anciano patricio sabía que Chile y Perú contaban con más de cien puertos no faltándoles, por eso, ni uno más. Ambos gobiernos debían desapegarse de Tacna y Arica. Chile - decía- caprichosamente continúa poseyéndolas aunque sus derechos sean problemáticos y Perú:

quiere recuperar la posesión de ellos por amor propio herido y por la remotísima esperanza de recuperar Tarapacá. [...] Mientras tanto, Bolivia, de quien por el orden natural de las cosas y por la geografía, deberían formar parte esos territorios, carece de ellos y se encuentra en situación deprimida. Se necesita una actitud más razonable de parte de Chile [...], pues regularizando definitivamente los deslindes de los tres Estados vecinos quedaríamos en paz y libres de complicaciones, renunciando sólo a derechos precarios y eventuales $[\ldots]^{50}$.

\footnotetext{
46 Íbidem, p. 27.

47 Íbidem, p. 34.

${ }^{48}$ Ross, Agustín, Tacna y Arica: la solución del problema mediante su transferencia a Bolivia, La Paz, Imp. Moderna, 1918, p. 7.

${ }^{49}$ Ibidem, p. 44.

${ }^{50}$ Ibidem, pp. 41-42.
} 
Razonamientos similares efectuó Carlos Vicuña, profesor de Estado destituido de sus labores por sus críticas a la diplomacia chilena, quien se cuestionó: “¿Puede un profesor de Estado plantear soluciones de un conflicto, contrarias a una ley, como lo es el Tratado de Ancón?"51. Vicuña, por esa y otras preguntas, fue acusado de anarquista. Aseguraba que Tacna y Arica estaban en poder chileno por las irregularidades derivadas del tratado. Sobre esas presas de guerra, Chile impuso un "régimen oprobioso de tiranía con el candoroso anhelo de chilenizar esas provincias por la fuerza" ${ }^{52}$. Es más, el profesor aseguró que Tacna y Arica eran peruanas por historia, geografía y tradiciones, desafiando, quizás, la posición oficial personificada en Barros Jarpa. Las ciudades “cautivas” le pertenecían no sólo por eso sino también por el Tratado de Ancón. La justicia ordenaba -concluía- que Chile devolviera Tacna y Arica al Perú, su verdadero dueño.

\section{El arbitraje de España}

Diez años después de Ancón el plebiscito no se realizó. Los autores chilenos, en su mayoría, aseveraron que el Perú se desentendió del compromiso. Arteaga Alemparte escribió la declaración de un agente peruano quien aseguró al diplomático chileno Máximo Lira la carencia de fondos para cubrir la indemnización acordada en el tratado ${ }^{53}$. Orrego Luco, el psiquiatra y político, dio fe que desde 1893 Chile propuso metodologías plebiscitarias, encontrando siempre una oposición peruana esperanzada de que "algún incidente inesperado pudiera colocarnos en condiciones que le fueran favorables" ${ }^{\text {. }}$. De todos modos, los datos sobre las razones del incumplimiento son herméticos y contradictorios dificultando establecer tesis sólidas. Pérez Canto, por ejemplo, aseguró que Eugenio Larrabure y Unanue, canciller e historiador peruano, inició en agosto de 1892 la redacción de un protocolo de bases plebiscitarias ${ }^{55}$, afirmación corroborada por el historiador tacneño Carlos Wiesse ${ }^{56}$.

\footnotetext{
51 VicuñA, Carlos, La libertad de opinar y el problema de Tacna y Arica, Santiago, Imprenta, Litografía y Encuadernación Selecta, 1921, p. 48.

52 Ibidem, p. 140.

53 Arteaga Alemparte, El problema..., pp. 8-9.

${ }^{54}$ OrRego LuCO, Augusto, La cuestión del Pacífico..., p. 31.

${ }^{55}$ PÉrez CANTO, Julio, El conflicto después de la victoria..., p. 76.

${ }^{56}$ Wiesse, Carlos, El asunto de Tacna y Arica, Lima, Emp. Tip. Lártiga, 1917, p. 32.
} 
Aquel enigma diplomático antecede al interesante papel que cupo a España en la resolución del conflicto. La nueva fase mantuvo, según autores chilenos, una superioridad ética de este país respecto al procedimiento legalista del Perú. Pérez Canto, en El Conflicto después de la victoria..., al escribir sobre el protocolo Billinghurst-Latorre -nombre del pacto que delegó el arbitraje en España- señaló que Chile envió al Perú una misión diplomática reservada, encabezada por el ministro de la Corte Suprema, Máximo Flores. Perú, en respuesta, envió a Santiago un equipo diplomático a cargo del vicepresidente Guillermo Billinghurst, resultando de esas conferencias un "desgraciadísimo convenio"57 firmado el 16 de abril de 1898. Omitió en la obra los hechos que permitieron evaluar negativamente la participación hispana; quizás ésta, con la correspondiente cesión de soberanía chilena en la litis, fue la razón principal del acedo.

España, acorde al protocolo, decidiría la calidad de los votantes, el tipo de voto, es decir, su carácter público o secreto, y la proposición de la presidencia en el plebiscito. Otro aspecto de las conversaciones fue el monetario. Interesaba valorar los territorios disputados y los plazos de pago. Si el plebiscito favorecía al Perú, reincorporaría Tacna y Arica antes de los quince días, pagando "un millón en el plazo de diez días; otro millón un año después, y dos millones al fin de cada uno de los cuatro años siguientes" ${ }^{58}$.

Pérez Canto reservó las razones de los diputados chilenos, quienes desaprobaron el protocolo en 1901. El paso del tiempo, desde 1898 hasta ese año, impidió el entendimiento de los litigantes. Al contrario, explicó las tácticas del plenipotenciario peruano en Chile, Cesáreo Chacaltana, responsable del "rompimiento"59 diplomático. En términos semejantes, Barros Jarpa reconoció las responsabilidades compartidas en los fracasos diplomáticos, o, eso se desprende de Las Conferencias de Washington... donde defendió la inimputabilidad chilena por la frustración plebiscitaria. Al respecto, reflexionó, si dos

\footnotetext{
${ }^{57}$ PÉREZ CANTO, Julio, El conflicto después de la victoria ..., p. 83.

${ }^{58}$ Idem.

${ }^{59}$ Idem.
} 
naciones no acuerdan un contrato ninguna de ellas es responsable, "así lo ha estimado el Perú cuando, después de 1894 ha negociado con Chile sobre bases plebiscitarias"60.

Tales ideas fueron profundizadas en una obra hermana de la citada, donde explicó que el arbitraje español naufragó debido a las dificultades para determinar los fundamentos de la votación. Al parecer, Barros Jarpa deseaba demostrar que el protocolo no fijó las bases plebiscitarias, limitándose a "concertar un arbitraje de la Reina de España, que no llegó a ser sancionado, para que fijara las condiciones en que debía celebrarse la consulta plebiscitaria"61. La aclaración precedente fue clave en Hacia la solución..., porque durante su redacción las cancillerías aún discutían quienes podrían o no votar. Ese y otros aspectos, como el secreto del sufragio ${ }^{62}$ y el arbitraje español, fueron atacados por Alberto Salomón Osorio, en ese momento canciller peruano, crítico de una diplomacia chilena violadora de los tratados de 1883 y 1898. Por ello, el abogado defendió la inejecutabilidad del último, pues "derivaba" 63 del vulnerado Tratado de Ancón.

Pérez Canto y Barros Jarpa formaron parte de dos generaciones herederas de una chilenidad ortodoxa, basadas en el rechazo de las propuestas peruanas que colocaran en riesgo la administración chilena de Tacna y Arica. Ese discurso se adoptó en una parte considerable de la sociedad. Sin embargo, hubo pensadores disidentes que apelaron al americanismo y a la fraternidad chileno-peruana. A diferencia del grupo conservador, tuvo un eco imperceptible en la diplomacia y pueblo chileno.

Una vez más Carlos Vicuña expresó por qué meditar sobre la gravedad del diferendo era deber moral. Pensaba que sólo el ejercicio filosófico ayudaría a elaborar soluciones pacíficas, justicieras y trascendentes, incluso bajo "amenazas" 64 , aludiendo con ello a su exoneración del magisterio, después de criticar la acción del gobierno chileno en Tacna y Arica. Sintetizó parte de su posición con estas palabras:

\footnotetext{
60 Ministerio De Relaciones ExTERIORES DE CHILE, Las Conferencias de Washington: antecedentes reunidos por orden del Ministro de Relaciones Exteriores, don Ernesto Barros Jarpa, Chile, Imprenta Lit. y Enc. La Ilustración, 1922, p. 18.

${ }^{61}$ BARRos JARPA, Ernesto. Hacia la solución: apuntaciones al margen de la negociación chileno-peruana de 1921, Chile, Imprenta Universitaria, 1922, p. 140.

${ }^{62}$ United States. President (1923-1929: CoOlidge), Tacna-Arica: fallo arbitral, Chile, Imprenta Chile, $1925, \mathrm{~s} / \mathrm{p}$.

${ }^{63}$ BARros JARPA, Ernesto, Hacia la solución..., p. 140.

${ }^{64}$ Revista Claridad, 1921, Vol. I, n. ${ }^{\text {33, s/p. }}$
} 
El problema de Tacna y Arica no estriba ciertamente ni en que Chile se quede con esas provincias, ni tampoco en que las devuelva al Perú: plantear en el terreno meramente político esta cuestión carece de verdad, porque el problema es más alto y trascendental. Consiste él esencialmente en que cese el entredicho de Chile y el Perú, vuelva entre ambos la amistad, nacida de la paz moral, y desaparezca el síntoma perturbador de la armonía de nuestro continente. Consecuencia de ello será el cambio de la política agresiva, la disminución de los armamentos, el desarrollo del comercio y la vuelta al predominio de los conceptos morales, hoy día abandonados por la necesidad de cohonestar nuestra política. Me parece una solución conveniente la devolución de esas provincias al Perú, porque ésta es la única manera de llegar a aquella paz y amistad, ya que el Perú no renunciará ni por dinero ni por la fuerza a sus sentimientos, que son respetables y justos. No quiero invocar precedentes ni ejemplos de mi actitud, pero si hacer una sencilla consideración: Chile desde hace treinta años está tratando de resolver este problema mediante una cierta política, no exenta de incoherencia, que los simples particulares ni siquiera conocemos, y el problema ha envejecido sin que la solución satisfaga. En tales condiciones, cuando va en ello la paz de América, la prosperidad de Chile y la sangre de nuestros propios hijos, ¿no será lícito, a lo menos, buscar una nueva solución, en reemplazo de la vieja, inadecuada? ${ }^{65}$.

El prolífico Vicuña, en misiva enviada al canciller Ernesto Barros Jarpa el 23 de agosto de 1921, se refirió a las palabras empleadas por éste en el parlamento chileno hacia su persona. La intervención del diplomático había girado en torno a la inconveniencia de que los profesores opinasen sobre problemas políticos y discreparan, públicamente, con la política exterior. El maestro consideró monstruosa esa prescripción afirmando su libertad incorruptible en esa materia. La tiranía consiste -expresó a su "amigo" Ernesto"esencialmente en la persecución a las opiniones, persecución hoy día ridícula, porque el Gobierno ni siquiera tiene los medios para ejercitarla"66. Ante estos hechos, Miguel de Unamuno, desde España, felicitó al preceptor por su "noble patriotismo humano"67.

Galvarino Gallardo Nieto, en una opinión afín con carácter más bien de "doxa", cuestionó la prolongación indefinida de la litis entre Chile y Perú. El periodista explicó que el conflicto impedía acordar entre los Estados políticas que favorecieran a los millones de habitantes de ambas naciones. En sus palabras: “¿Interesa más a la prosperidad material, al desenvolvimiento intelectual, a la civilización en una sola palabra, de estas dos repúblicas el alejamiento de las soluciones pacíficas?"68.

\footnotetext{
${ }^{65}$ Vicuña, Carlos, La libertad de opinar y el problema de Tacna y Arica, Chile, Imprenta Selecta, 1921, pp. 46-47.

${ }^{66}$ El Mercurio, “Carlos Vicuña Fuentes”, 16 de agosto de 1931, p. 5.

${ }^{67}$ Unamuno, Miguel de, Epistolario inédito 2, 1915-1936, Madrid, Espasa Calpe, 1991, p. 104.

${ }^{68}$ ViCUÑA, Carlos, La libertad de opinar..., p. 147.
} 
El juicio histórico del abogado era ilusionante. Si bien acusaba graves desaciertos de todos los gobiernos chilenos y sus cancillerías en el diferendo; mantenía la esperanza en una utópica armonía americana. Citando a Gonzalo Bulnes, historiador que comentó la fijeza de la cancillería peruana, criticó la política exterior chilena, la cual, desde Ancón hasta 1920, era "ninguna, y quien se atreva a sostener lo contrario puede estar absolutamente cierto de incurrir en un grueso error" 69 .

Después de firmado el Tratado de Ancón, escribió Gallardo, nadie dudó en la efectividad del plebiscito. Pero, un año antes del protocolo Billinghurst-Latorre, la situación cambió. Hizo fortuna la tesis chilena de ceder Tacna y Arica a Bolivia. Para aumentar la incertidumbre, el año 1900, con España como mediadora se levantó otro escenario diplomático ${ }^{70}$. Lo anterior hizo reflexionar a Gallardo sobre si “¿Hay o no razón para decir con honrada franqueza que jamás hemos tenido una política definida, estable en este problema?"71.

La importancia de este dúo disidente, acusado en ocasiones de antipatriota, radicó en la denuncia pública de la vulneración chilena al tratado. Se desconoce que autores peruanos plantearan soluciones similares mutatis mutandis a Vicuña y Gallardo.

\section{El arbitraje de los Estados Unidos y el Tratado de Lima}

El descalabro del arbitraje español profundizó la enemistad entre La Moneda y la Casa de Pizarro. Dos décadas después, los traspiés de las negociaciones continuaban evidenciando la esterilidad del diálogo diplomático. La situación, no obstante, cambió definitivamente cuando, en Chile, el gobierno de Arturo Alessandri decidió concluir el problema de Tacna y Arica, a esas alturas antiguo y desgastante.

\footnotetext{
${ }^{69}$ ViCUÑA, Carlos, La libertad de opinar..., pp. 148-149.

${ }^{70} \mathrm{La}$ acusación de carecer de una posición unívoca para el problema de Tacna y Arica también fue efectuada por la cancillería peruana en una obra de los años veinte. Allí se relató cómo "Chile sostuvo audazmente la teoría de que el Tratado de Ancón había cedido completamente las provincias en el artículo III; que ese Tratado no dispone lo que claramente dice; y que la disposición sobre el plebiscito era un simple disfraz o panacea para las sensibilidades del Perú" Ver: REPÚBLICA DE PERÚ. Arbitraje entre el Perú y Chile: réplica del Perú en el litigio que, emanado de la Cuestión del Pacífico, se sigue ante el presidente de los Estados Unidos de América como árbitro, Perú, Editorial T. Scheuch, 1924. p. 106.

${ }^{71}$ ViCUÑA, Carlos, La libertad de opinar..., p. 150.
} 
La obra, posiblemente más importante, que describe y organiza esa última etapa del conflicto fue escrita por Juan José Fernández Valdés, diplomático e historiador chileno. Un examen minucioso del Archivo Histórico del Ministerio de Relaciones Exteriores de Chile y del National Archives of the United States, entre otros, le permitió exponer un cuadro pormenorizado de la nueva fase aquí estudiada ${ }^{72}$.

Según Fernández, cuando Alessandri asumió la presidencia el 23 de diciembre de 1920, creyó oportuno acercarse a los Estados Unidos para resolver el diferendo de Tacna y Arica. El Perú, con Augusto Leguía en la presidencia, mantenía desde los años de la Guerra del Pacífico una relación estrecha con el país del norte. Si bien éste deseaba que Washington arbitrara el conflicto, el presidente Warren Harding condicionaba su participación a una decisión unánime de los interesados. A la vez, rechazaba, inspirado en la doctrina Monroe, la participación de cualquier Estado europeo en cuestiones de política americana.

Alessandri, explicó Fernández, confió a Ernesto Barros Jarpa el Ministerio de Relaciones Exteriores, quien inició sus funciones el 17 de agosto de 1921 con una enérgica "ofensiva diplomática"73. Como parte de esa, el joven, pero habilidoso canciller ${ }^{74}$, sugirió al Perú, mediante comunicaciones cablegráficas, realizar el plebiscito pactado en Ancón. La situación no era sencilla. En más de una ocasión pareció que la "ofensiva" fracasaba debido a las respuestas "destempladas" de Alberto Salomón, canciller peruano, seguro de que su gobierno deseaba "que se resuelvan arbitralmente las infracciones cometidas por Chile del Tratado que impuso por medio de la fuerza $[\ldots]^{p 75}$.

Estos intercambios cablegráficos, respaldados por la diplomacia estadounidense, restablecieron el diálogo entre La Moneda y la Casa de Pizarro y, en opinión de Fernández, demostraron el éxito de la política exterior de Alessandri y Barros Jarpa. En efecto, estas conversaciones, centradas en Tacna y Arica, desestimaban la idea peruana sobre la

\footnotetext{
72 Todo este apartado, salvo excepciones citadas debidamente, se construyó con las interpretaciones y datos aparecidos en su libro Chile y Perú. Historia de sus relaciones diplomáticas entre 1879 y 1929.

${ }^{73}$ FernándeZ VAldÉs, Juan José, Chile y Perú. Historia de sus relaciones diplomáticas entre 1879 y 1929 , Santiago, RIL editores, 2004, p. 362.

${ }^{74}$ Lagos Carmona, Guillermo, Historia de las Fronteras de Chile. Los tratados de límites con Perú, Santiago, Editorial Andrés Bello, 1981, p. 49.

${ }^{75}$ FernÁNDEZ VALDÉs, Juan José, Chile y Perú..., p. 369.
} 
caducidad del tratado y, con ello, sus pretensiones por recuperar Tarapacá. Cabe mencionar, por otro lado, que Bolivia, enterada de estas gestiones, solicitó su participación al Secretario de Estado Charles Hughes, aunque no fue aceptada, argumentándose que se discutirían sólo temáticas bilaterales pendientes entre Chile y Perú.

Ambos países acreditaron cuerpos diplomáticos en Washington para discutir una fórmula resolutiva del diferendo. Las reuniones se conocieron como las Conferencias de Washington. Arturo Alessandri nombró a Carlos Aldunate y Luis Izquierdo para la representación de Chile; Augusto Leguía a Hernán Velarde y Melitón Porras, por parte del Perú. Las conferencias, iniciadas el 15 de mayo de 1922, convinieron el 17 de julio solicitar al presidente Harding su acción arbitral ${ }^{76}$. El protocolo y un acta complementaria del arbitraje señalaron:

Artículo $1^{\circ}$ Queda constancia de que las únicas dificultades derivadas del Tratado de Paz sobre las cuales los dos países no se han puesto de acuerdo son las cuestiones que emanan de las estipulaciones no cumplidas del artículo tercero de dicho Tratado.

Artículo $2^{\circ}$ Las dificultades a que se refiere el artículo anterior serán sometidas al arbitraje del Presidente de los Estados Unidos de América, quien las resolverá sin ulterior recurso con audiencia de las partes y en vista de las alegaciones y probanzas que estas presenten. Los plazos y procedimientos serán determinados por el Árbitro.

Artículo $3^{\circ}$ El presente protocolo será sometido a la aprobación de los respectivos Gobiernos y las ratificaciones serán canjeadas en Washington por intermedio de los representantes de Chile y del Perú dentro del plazo máximo de tres meses [...].

A fin de precisar el alcance del arbitraje estipulado en el artículo segundo del Protocolo -leemos en el documento-, se acordó:

Primero. Está comprendida en el arbitraje la siguiente cuestión promovida por el Perú en la reunión celebrada por la Conferencia el 27 de mayo último. Con el objeto de determinar la manera como debe darse cumplimiento a lo estipulado en el artículo tercero del Tratado de Ancón, se somete a arbitraje si procede o no, en las circunstancias actuales, la realización del plebiscito.

El Gobierno de Chile puede oponer, por su parte ante el Árbitro, todas las alegaciones que crea convenientes a su defensa.

Segundo. En caso de que se declare la procedencia del plebiscito, el Árbitro queda facultado para determinar sus condiciones.

Tercero. Si el Árbitro decidiera la improcedencia del plebiscito, ambas partes, a requerimiento de cualquiera de ellas, discutirán acerca de la situación creada por este fallo.

\footnotetext{
76 Íbidem, p. 390.
} 
Es entendido, en el interés de la paz y del buen orden que, en este caso, y mientras esté pendiente un acuerdo acerca de la disposición del territorio, no se perturbará la organización administrativa de las provincias.

Cuarto. En caso de que no se pusieren de acuerdo, los dos Gobiernos solicitarán, para este efecto, los buenos oficios del Gobierno de los Estados Unidos.

Quinto. Están igualmente comprendidas en el arbitraje las reclamaciones pendientes sobre Tarata y Chilcaya, según lo determine la suerte definitiva del territorio a que se refiere el artículo tercero de dicho Tratado.

Esta Acta forma parte integrante del Protocolo de su referencia. $[\ldots]^{77}$.

Ambos documentos, discutidos en el congreso chileno, enfrentaron a "alessandristas" con opositores del gobierno. Fueron rechazados fundamentalmente, porque el título primero del acta complementaria cedía a Estados Unidos la decisión sobre la procedencia o no del plebiscito. El ministerio de Barros Jarpa cayó, sucediéndole Samuel Claro Lastarria, quien persuadió a la oposición para aceptar un arbitraje que, según esa, colocaba a Chile en similitud con "las razas semi civilizadas"78.

Las discusiones parlamentarias continuaron. El canciller ejerció desde el 29 de agosto hasta el 16 de octubre de 1922 cuando le sucedió Carlos Aldunate quien tuvo mayor éxito en sus gestiones: el protocolo fue aprobado por ambas cámaras antes de finalizar ese año. El presidente estadounidense -escribió Fernández- aceptó el cargo de árbitro el 29 de enero de 1923 y en marzo se fijaron los plazos para la presentación de las defensas y los alegatos de cada república.

El equipo jurídico de Chile lo encabezó Ernesto Barros Jarpa y Carlos Aldunate; el peruano, Melitón Porras y Solón Polo. Ambos cuerpos de especialistas fueron asesorados por los juristas estadounidenses Robert Lansing, Lester H. Woolsey, Edwin Borchard, J. S. Cavero, Joseph E. Davies, Wade H. Ellis y Hoke Smith"79. En síntesis, Chile abogó por efectuar la votación; Perú defendió la tesis que hacía impracticable el plebiscito dictaminado en Ancón debido a la chilenización sufrida por Tacna y Arica. Los equipos diplomáticos de esos países expusieron "honradamente" sus tesis jurídicas en un expediente de casi seis mil páginas ${ }^{80}$.

\footnotetext{
77 Íbidem, pp. 391-392. (Las cursivas son nuestras).

78 Íbidem, p. 407.

79 Íbidem, pp. 412-414.

${ }^{80}$ Lagos CARMOnA, Guillermo, Historia de las Fronteras de Chile..., p. 53.
} 
El fallo del árbitro fue publicado el 4 de marzo de 1925. Allí, Warren Harding sostuvo que debía realizarse el plebiscito de Tacna y Arica, delegando la planificación del acto electoral a una comisión plebiscitaria presidida por un miembro estadounidense, uno chileno y otro peruano. Los comisionados debían designarse antes de cumplirse los cuatro meses de expedición del laudo. Posteriormente, dentro de los seis meses siguientes, la comisión debía comenzar sus trabajos en Arica.

Una vez instalada, la violencia nacionalista entre chilenos y peruanos en Tacna y Arica hizo que tanto el presidente de la comisión, general John Pershing, como su sucesor, William Lassiter, declararan impracticable la votación por falta de "atmósfera". Los delegados de Chile y Perú, Agustín Edwards y Manuel de Freyre, fracasaron en sus intentos por coordinar el plebiscito.

Una vez más el arbitraje de una potencia extranjera no logró su propósito. Chile puso fin al trabajo conjunto con los Estados Unidos y el Perú el 18 de junio de 1926; meses antes, desde el 17 de febrero, Chile y Perú aceptaron los buenos oficios de los Estados Unidos atraídos "en salvar su prestigio internacional como amigables componedores" Las cancillerías de los países interesados comenzaban la búsqueda de nuevas alternativas. La Casa Blanca, por medio de su Secretario de Estado, Frank Kellogg, argumentó que la cesión de Tacna y Arica a Bolivia resolvería las cuestiones limítrofes para beneficio de los litigantes y de la paz americana. Esta propuesta, impopular en los pueblos chileno y peruano, fue rechazada por La Moneda y la Casa de Pizarro. En el Perú, "la indignación popular no es para descrita (sic). Se prefería [...] entregar Tacna y Arica a Chile que a Bolivia" $"$.

El régimen político chileno había cambiado. En septiembre de 1924 un golpe de estado había concluido con el gobierno de Alessandri. Luego, con la dictadura de Carlos Ibáñez del Campo el incipiente presidencialismo chileno quedaba sepultado. El nuevo gobernante deseaba constituir una "patria nueva", asesorado por un grupo de profesionales jóvenes. Las relaciones exteriores fueron confiadas al treintañero Conrado Ríos Gallardo, criado en Arica y quien rápidamente elaboró una política de acción para solucionar el

\footnotetext{
${ }^{81}$ BARros, Mario, Historia diplomática de Chile (1541-1938), Barcelona, Ediciones Ariel, p. 707.

${ }^{82}$ Idem.
} 
diferendo con el Perú. Fernández señaló que la propuesta de Gallardo consideraba tres alternativas: la continuación del arbitraje estadounidense; la nacionalización definitiva de Tacna y Arica; y, por último, dar inicio a un diálogo directo con la cancillería peruana ${ }^{83}$. Entre todas, triunfó la última.

Fernández introdujo el azar en la solución definitiva del problema de Tacna y Arica. Comentó cómo, con ocasión de la VI Conferencia Internacional Panamericana celebrada en La Habana, el representante chileno, Alejandro Lira y su delegación, compartieron barco con sus pares peruanos. En la isla, el representante estadounidense y subsecretario de Asuntos Latinoamericanos, Francis White, celebró reuniones informales con los ministros de Chile y Perú. En ellas comenzaría a gestarse la idea de suprimir la alternativa plebiscitaria, recurriendo a la partición territorial. En el mapa, la provincia de Tacna debería entregarse al Perú y la de Arica a Chile.

En efecto, Chile y Perú restablecieron relaciones diplomáticas apoyados en todo momento por la Secretaría de Estado de los Estados Unidos. Consecuentemente, a comienzo de octubre de 1928, presentó sus credenciales en La Moneda el peruano César Elguera; en Lima lo hizo Emiliano Figueroa. Mientras que en Santiago el pueblo chileno recibió con calidez y entusiasmo al embajador peruano, en Lima "Un pueblo silencioso, retraído, hosco, presenció el paso de las carrozas. Ni un aplauso" 84 . En la antigua capital virreinal, los primeros diálogos entre Leguía y Figueroa trataron sobre la petición peruana de anexión de Tacna y Arica, cediendo a Chile sólo una franja sureña de la desértica región.

A la par de esa propuesta, afirmó Fernández, Leguía elaboraba una fórmula tendiente a crear el protectorado de Tacna y Arica, que estaría a cargo de Chile, Perú y los Estados Unidos. Otras discusiones entabladas entre estos dos políticos evaluaron la pertinencia de crear, cedida hipotéticamente Arica a Chile, un puerto peruano en esa ciudad y, por otro lado, el compromiso de que "ninguno de los dos contratantes, sin previo acuerdo entre ellos, podría conceder a un tercero el territorio o una parte de aquel al que se referiría dicho instrumento jurídico" 85 .

\footnotetext{
${ }^{83}$ FERnÁndez VALdÉs, Juan José, Chile y Perú..., p. 522.

${ }^{84}$ BARros, Mario, Historia diplomática de Chile..., p. 710.

${ }^{85}$ Fernández VALdÉs, Juan José, Chile y Perú..., p. 522.
} 
Finalmente, el 3 de junio de 1929 fue suscrito el Tratado de Lima, por el que Perú incorporaba a su soberanía Tacna y Chile a Arica, resolviendo el diferendo surgido en el Tratado de Ancón de 1883, tal cual lo establecieron los artículos primero y segundo, que aquí citamos, de un total de trece:

Artículo primero. Queda definitivamente resuelta la controversia originada por el artículo tercero del Tratado de Paz y Amistad de veinte de octubre de 1883, que era la única dificultad pendiente entre los Gobiernos signatarios.

Artículo segundo. El territorio de Tacna y Arica será dividido en dos partes, Tacna para el Perú y Arica para Chile. La línea divisoria entre dichas dos partes, y, en consecuencia, la frontera entre los territorios de Chile y el Perú, partirá de un punto de la costa que se denominará "Concordia", distante diez kilómetros al norte del puente del río Lluta, para seguir hacia el oriente paralela a la vía de la Sección chilena del ferrocarril de Arica a $\mathrm{La}$ Paz y distante diez kilómetros de ella, con las inflexiones necesarias para utilizar, en la demarcación, los accidentes geográficos cercanos que permitan dejar en territorio chileno las azufreras del Tacora y sus dependencias, pasando luego por el centro de la Laguna Blanca, en forma que una de sus partes quede en Chile y la otra en el Perú $[\ldots]^{86}$.

\subsubsection{Autores peruanos}

\section{Las Conferencias de Arica}

El diplomático y periodista Pedro José Calderón, Secretario de Estado en el Ministerio de Relaciones Internacionales y Culto durante las Conferencias de Arica, publicó una circular diplomática donde sintetizó el parecer de su gobierno. En ella analizó uno por uno los ofrecimientos chilenos para lograr la paz, asegurando que el desmembramiento territorial peruano y boliviano comportaba una decisión vejatoria hacia ambas naciones, pues comprometía sus soberanías. Aseguró que Chile provocó la guerra, haciéndolo de un modo cobarde, sin previo aviso y "resucitando una barbarie que la

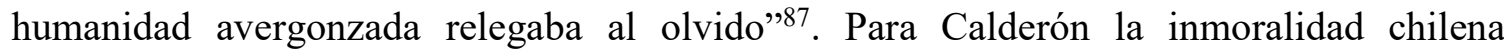
explicaba la petición segunda, relativa al pago de indemnizaciones de guerra que debían beneficiar a los aliados y no a Chile. La inferioridad moral de ese país, no obstante, lo conducía a solicitar cobros millonarios que Perú y Bolivia no estaban dispuestos a pagar.

\footnotetext{
86 Íbidem, p. 606.

87 CALderón, Pedro José, "Nueva circular del gobierno peruano sobre las Conferencias de Arica". En Editorial ANDrÉs Bello, Boletín de la Guerra del Pacífico, 1879-1881, Santiago, Editorial Andrés Bello, 1979, pp. 888-889.
} 
En definitiva, el proceder de Chile durante las conferencias se situó fuera del derecho internacional.

Para el Secretario de Estado, la tercera petición del equipo jurídico chileno no tenía cabida (devolución de las propiedades chilenas confiscadas en Perú y Bolivia). El Perú, en todo momento, se había mantenido respetuoso con las propiedades de los empresarios chilenos debido a la "hidalguía natural" de sus autoridades. La ausencia de ese valor en las autoridades chilenas, le permitió al político peruano criticar sus propuestas relacionadas con la retención temporal de Moquegua, Tacna y Arica y la prohibición de artillar este último puerto. La respuesta impetuosa del limeño a la cancillería chilena fue resumida del siguiente modo: "nosotros, el mundo y principalmente la América, juzgará definitivamente de ellas; y su fallo, dictado por la justicia, será el principio del orden moral, que Chile ha desquiciado en esta guerra fratricida con afrenta de la civilización y de la humanidad ${ }^{88}$.

Frente a la escasez de trabajos de autores peruanos sobre las Conferencias de Arica su alianza con Bolivia permite recuperar el punto de vista de su socio plasmado en la obra Conferencias diplomáticas de Arica, publicada en La Paz en 1880. Allí, los representantes bolivianos, Mariano Baptista y Juan Carrillo, prologan los documentos oficiales de las conferencias en un sentido, como es esperable, opuesto a las opiniones del chileno Valderrama, elogiando "la actitud elevada con que los Excmos. Plenipotenciarios del Perú han llevado su delicada y difícil tarea, llevando a ella el valioso concurso de una razón previsora y práctica" ${ }^{\prime 9}$.

Baptista y Carrillo se desequilibran en el momento de analizar la guerra y sus consecuencias. No es sorprendente; aquella estaba en curso. En efecto, sólo logran comprender y valorar la vocación de paz del gobierno boliviano, considerándola elevada y sincera. Ellos, aseguraron, deseaban la paz, pero una paz que honrase a los aliados y a los intereses sudamericanos. Para eso, las propuestas chilenas de las conferencias debían modificarse totalmente, pues cerraban, de antemano, toda discusión. De hecho, como lo

\footnotetext{
${ }^{88}$ Idem.

${ }^{89}$ RePÚBliCA DE Bolivia, Conferencias diplomáticas de Arica entre los plenipotenciarios de Bolivia, Chile y el Perú con motivo de la mediación de Estados Unidos, La Paz, Imprenta de la Unión Americana, 1880, p. 3.
} 
explicaron, las conferencias en Arica sirvieron sólo para dar cuenta de que la paz entre los beligerantes era imposible.

La responsabilidad absoluta recayó en Chile por su rechazo hacia todas las indicaciones pacifistas de Bolivia. Los diplomáticos del Palacio Quemado se lamentaban, además, de que ni siquiera los buenos oficios de los Estados Unidos fueron suficientes para modificar la posición de sus pares chilenos:

Nada fue bastante a alterar la invariable resolución mantenida por los Excmos. Plenipotenciarios chilenos sobre la apropiación definitiva de todo el Litoral boliviano, y del peruano hasta Camarones, como base sine qua non de cualquier arreglo [...]. Nuestros esfuerzos han sido infructuosos para restablecer una paz honrosa y segura ente las tres Repúblicas. El arbitraje, solución la más digna en las contiendas de los pueblos civilizados, ha sido rechazada. La América decidirá de qué parte se halla la justicia ${ }^{90}$.

El trabajo de Baptista y Carrillo mereció el elogio del canciller boliviano quien concluyó que durante las Conferencias de Arica la posición de los diplomáticos aliados se elevó sobre las exigencias momentáneas, pensando una paz duradera. Esa resolución guardó relación con la intención boliviana de no perturbar el camino hacia el progreso que debía experimentar América. Chile, por el contrario, con sus pretensiones territoriales legitimaba el derecho de conquista sobre la costa boliviana y el desierto salitroso peruano, desconociendo "las tendencias humanitarias y civilizatorias de nuestro tiempo"

\section{El Tratado de Ancón}

Casi una decena de libros publicados en el Perú sobre el tratado comparten un marcado sentimiento "chilenófobo". Las apreciaciones constitutivas de esa pasión están relacionadas con la culpabilidad chilena en el desencadenamiento de la guerra; la barbaridad de su ejército; la inmoralidad extremadamente ambiciosa del país al momento de pactar la paz en Ancón; y la violación permanente del tratado no sometiendo a plebiscito Tacna y Arica, como prescribía el documento diplomático.

\footnotetext{
90 Idem.

${ }^{91}$ RepúbliCA de Bolivia, Conferencias diplomáticas de Arica ..., p. 37.
} 
Todos esos libros, a la vez, fueron escritos en la última fase de la Primera Guerra Mundial, momento en que el Perú, según la diplomacia chilena, pensó que sus reivindicaciones territoriales podían realizarse.

Augusto Orrego Luco, con un sesgo mal intencionado, escribió al respecto: "Era natural que en el Perú, hermosa tierra de imaginaciones tropicales, todo se viera a través del prisma de esas nuevas ilusiones" pequeño litigio con nosotros con la gran causa de la Francia; que Arica y Tacna aparecieran como sinónimos de la Alsacia y la Lorena"93.

El abogado e indigenista Manuel Yarlequé recopiló en 1917, en un libro escueto ${ }^{94}$, cinco artículos referidos al Tratado de Ancón. En todos ellos, la idea fundamental no admitía discusiones: Chile, hacía treinta y cuatro años que violaba el tratado, sin intenciones de efectuar el plebiscito establecido. Para Yarlequé, sin embargo, el fin de la Primera Guerra Mundial debía cambiar la política exterior de ese país. Por su lado, el Perú se esperanzaba en que el ejemplo europeo concientizase a Chile para devolver Tacna y Arica al ver "que el final de la guerra mundial, trae la reivindicación de los territorios conquistados, doquiera que haya actuado la conquista" ${ }^{95}$.

Cuando escribió el cataquense, se vivía, según su impresión, una contienda mundial. La lucha se desarrollaba entre la justicia y la libertad, por un lado, y el imperialismo y la conquista, por el otro. El máximo representante de las dos últimas actitudes, contrarias al derecho internacional, era Prusia, seguida por todas las naciones donde el predominio de la fuerza erosionaba las soberanías territoriales. Vista esa situación, esas naciones eran adversarias de la humanidad, siendo "por consiguiente, enemiga de la humanidad, Chile, que por la conquista nos arrebató y se niega a restituir nuestros territorios meridionales"96. El entusiasmo nacionalista de Yarlequé posibilitó algunas contradicciones en las primeras páginas de su obra. Temía, además de la actitud señalada anteriormente, que Chile buscase una fórmula para solucionar el diferendo y legalizar, definitivamente, la posesión de

\footnotetext{
${ }^{92}$ ORRego LuCO, Augusto, La cuestión del Pacífico ..., p. 34.

93 Idem.

${ }^{94}$ YARLeQUÉ, Manuel, Artículos internacionales sobre Tarapacá, Tacna y Arica, Lima, Imp. y Librería de San Pedro, 1917.

95 Íbidem, p. 3.

${ }^{96}$ Íbidem, p. 8. (Las cursivas son nuestras).
} 
Tarapacá. Para él, con esa estrategia deseaba convencer al mundo de la renuncia peruana a la recuperación de esa región. Por eso, aprovechando su manuscrito, alertó al pueblo peruano del posible plan de La Moneda.

La resistencia que "heroicamente" realizaban los peruanos en Tacna y Arica no podía recibir, por parte de la Casa de Pizarro, las manifestaciones de desidia, al parecer, conocidas por Yarlequé. Los gestos más honorables de la peruanidad se habían realizado durante las últimas décadas de la chilenización, cuando el gobierno chileno intentó por medios legales extraer las costumbres republicanas peruanas. Yarlequé explicó el recuento de esa nacionalización inmoral así: "Quiso el conquistado anonadar y expulsar a los peruanos de Tacna y Arica por medio del servicio militar, de la persecución de nuestros hermanos, la supresión de periódicos, clausura de colegios y Clubs y expulsión de los curas ${ }^{97}$. Esas medidas tenían por objetivo la desaparición del electorado peruano para una supuesta época plebiscitaria. A ellas sumó el armamentismo chileno, efectuado con fondos provenientes de la explotación salitrera. Idénticas acusaciones contra la chilenización realizaron el historiador peruano Pedro Dávalos y Lissón ${ }^{98}$ y la cancillería de ese país ${ }^{99}$.

Para Yarlequé el tratado fue impuesto por Chile y, posteriormente, violado por el mismo país, puntualmente al retener por más de diez años Tacna y Arica. Así, al "presente no es obligatorio el plebiscito para el Perú, porque anulado el tratado por la acción del mismo conquistador, no es válida ninguna de sus cláusulas"100. El comportamiento jurídico de Chile había permitido, tácitamente, la devolución al Perú de los títulos jurídicos y de dominio sobre Tacna, Arica y Tarapacá. Tal situación otorgaba al Perú el derecho de percibir monetariamente las indemnizaciones de todos los perjuicios producidos tras veintitrés años de posesión legal. Un suspicaz Yarlequé se preguntaba, si Chile violó el tratado “¿acaso seremos tan ingenuos para celebrar otros tratados que correrían la misma suerte?"101.

\footnotetext{
97 Íbidem, p. 4.

${ }^{98}$ DÁvalos y Lissón, Pedro, Tacna y Tarapacá peruanos. Artículos publicados en "El Comercio" de Lima, en el mes de diciembre de 1918, [s. d.], [s. d.], 1918.

${ }^{99}$ Ministerio de Relaciones EXTERIORES Del Perú, Circulares diplomáticas, Lima, Imp. Americana, 1919.

${ }^{100}$ YARLEQUÉ, Manuel, Artículos internacionales..., p. 18.

101 Íbidem, p. 19.
} 
El testimonio del mencionado Dávalos y Lissón tiene una importancia particular. Sus impresiones del tratado se fundaban en la experiencia. Él vivió la época de su firma. Como comentó, su generación era, en parte, privilegiada, ya que asistió a la desmembración del país, pero también lo haría a la reconstitución territorial. Ese era el anhelo del novelista que observaba desde Lima la modificación del mapa europeo en 1918.

Tal certeza le permitió afirmar al antiguo combatiente de Miraflores ${ }^{102}$ : "Nos encontramos en la misma situación en que están los franceses que presenciaron la caída de 1870 y que por el triunfo de la Libertad y el Derecho y de la Justicia recuperan Alsacia y Lorena"103. En otras palabras, la analogía histórica fue retratada por Isaac Alzamora, quien aseguraba que el triunfo aliado en la Primera Guerra Mundial contra el imperio de la fuerza y la conquista loada por Chile "repercutió instantáneamente sobre Tacna y Arica, donde la presión de la fuerza se quiso llevar a los últimos límites, para llegar a una solución definitiva antes de que la justicia internacional sea un hecho en el mundo"104.

En su escrito patriotero, Dávalos y Lissón, rápidamente dejaba de lado la templanza que exigían los conceptos de libertad, derecho y justicia. Al comprender, tal y como Yarlequé, que el Tratado de Ancón había caducado por el incumplimiento chileno, exhortaba a sus lectores no temer a los ejércitos chilenos. Apeló, desde su tribuna, al efecto aglutinante de la valentía nacionalista. Estamos convencidos, afirmó, "que cualquier día nos vuelven a invadir; sin embargo, estamos resueltos a todos los sacrificios, a todos los desastres, antes que dar por concluida la conquista de Tacna y Tarapacá"105.

En su relato también se pueden encontrar alusiones contrarias a la política de los Estados Unidos durante los años de la Guerra del Pacífico. Crítico duro de los sucesores de James Garfield y James Blaine, vio en ellos a los patrocinadores del barbarismo chileno en Lima. Para el orgullo peruano, no obstante, esa época reflejó la gran entereza del país. Sus soldados, con la capital dominada por Patricio Lynch, continuaron la lucha desde las serranías y resistieron hasta 1883.

\footnotetext{
${ }^{102}$ MC EvoY, Carmen, La utopía republicana. Ideales y realidades en la formación de la cultura política peruana (1871-1919), Lima, Pontificia Universidad Católica del Perú, 1997, p. 249.

${ }^{103}$ DÁvalos y Lissón, Pedro, Tacna y Tarapacá peruanos..., p. 6.

${ }_{104}$ Alzamora, Isaac, La cuestión peruano-chilena, París, Petite collection américaine, 1919, p. 23.

${ }^{105}$ DÁvalos Y Lissón, Pedro, Tacna y Tarapacá peruanos..., p. 7.
} 
Lamentablemente, se desprende de la opinión de Dávalos y Lissón, el presidente Iglesias violó la Constitución del Perú y el sentimiento nacional, firmando el tratado.

Frente al mandatario desarrolló una opinión ambivalente. El profanador de la "Constitución del Estado y el sentimiento nacional"106 fue, al mismo tiempo, un sincero "hombre de honor [...] valiente"107 que consintió la desmembración territorial creyendo que con la firma del tratado hacía un mal menor al país. Quienes lo conocieron, dijo incluyéndose, "en esos días de desaliento, de sangre, de incendios, de vergüenza, de ministros americanos al servicio de Chile, de hambre, de miseria, de plagio y flagelo en las plazuelas públicas de Lima no disculpamos su falta; pero sí la atenuamos"108. Chile, comentó en el mismo sentido otro diplomático peruano, carecía de medios para continuar dominando el Perú, quien comprendió que debía recobrar, de cualquier modo, su libertad ${ }^{109}$.

Como anunciamos, la cancillería del Perú oficializó las ideas de la imposición del tratado y su incumplimiento por parte de Chile. Además, lo culpó de la guerra, opinión compartida por varios defensores de la causa peruana ${ }^{110}$. Chile, leemos en Circulares diplomáticas había hecho en 1879 una guerra expoliadora y de conquista contra dos países hermanos -Perú y Bolivia- "víctimas del mismo plan de agresión"111.

El Ministerio de Relaciones Exteriores agregó a su acusación la retención indebida de Tacna, Arica y Tarata. Reconocía, de todos modos, que el tratado dio títulos de legalidad para que Chile ocupase las dos primeras por diez años; no así lo situado fuera de esos límites. Por eso la cancillería señaló: “con esa tendencia al despojo y al abuso que ha caracterizado siempre la actitud de Chile en todo lo referente al cumplimiento del tratado de Ancón, retuvo sin razón [...] una parte del distrito de Tarata" ${ }^{112}$.

\footnotetext{
106 Íbidem, p. 17.

107 Íbidem, p. 37.

108 Íbidem, p. 38.

${ }^{109}$ AlZAMORA, Isaac, La cuestión peruano-chilena..., p. 22.

${ }^{110}$ Idem; RePÚBliCA DEL Perú, Arbitraje entre el Perú y Chile. Réplica del Perú en el litigio que, emanado de la cuestión del Pacifico, se sigue ante el Presidente de los Estados Unidos de América como Árbitro, Washington D. C., [s. d.], 1924, p. 22.

${ }^{111}$ Ministerio DE RElaciones EXTERIORES DEL PERÚ, Circulares diplomáticas...

112 Íbidem, p. 51.
} 
En otro texto publicado dos años después insistió en responsabilizar a Chile de la guerra. La verdadera razón de ésta habían sido las riquezas peruanas codiciadas por el país del sur, y no al revés, pues Chile carecía de todo patrimonio. En él también se criticó la opinión chilena sobre la anarquía peruana previa a la firma del tratado. Aquella razón era la “eterna muletilla con que los chilenos, aprovechándose de nuestras contiendas políticas, tratan de desprestigiarnos, de hacernos perder las simpatías de América y la consideración del mundo"113.

En ese ejemplar se adjuntaron las declaraciones del canciller chileno Luis Aldunate, artífice del tratado, quien valoró la decisión peruana de concluir la guerra. Allí expresó que la extensión del conflicto se debió, principalmente, a la negación peruana de aceptar la desmembración territorial. No obstante, después de legalizarla, toda la responsabilidad por solucionar el diferendo fue chilena. Sin márgenes para las dudas, se preguntó: "Si han pasado los diez años y Chile no ha desocupado el territorio, como lo dispone el tratado ¿De quién será la culpa? La respuesta es obvia"114.

Una tercera publicación oficial argumentó consistentemente la ilegitimidad del "cautiverio". Pasados los diez años, aseguró, el dominio chileno en esas provincias expiró, tal como lo establecía el tratado. Ese país estaba aprovechándose erróneamente de una situación posterior, porque sin plebiscito la presencia chilena allí estaba fuera del derecho. Por ello, el procedimiento correcto hubiese sido "entregar la posesión al Perú el 28 de marzo de 1894, al expirar la posesión temporal [...] Al haberlo hecho así, el Perú habría llevado a cabo el plebiscito" 115 .

Por último, el tratado fue valorado por Ismael Portal, historiador y excombatiente de la guerra quien deseaba dar a conocer al mundo el sufrimiento peruano. Su objetivo, en última instancia, era derribar la propaganda chilena que afirmaba la legalidad de la ocupación de Tacna y Arica.

113 RepúbliCa del Perú, En la Cámara de Diputados. El Ministro de Relaciones Exteriores Dr. Alberto Salomón refuta al canciller chileno Sr. Barros Jarpa, Lima, Imp. Torres Aguirre, 1921, p. 17.

114 RePÚbliCA Del Perú, En la Cámara de Diputados..., p. 25.

115 RePúBliCA DEL Perú, Arbitraje entre el Perú y Chile. Réplica del Perú en el litigio que, emanado de la cuestión del Pacífico, se sigue ante el Presidente de los Estados Unidos de América como Árbitro, Washington D. C., [s. d.], 1924, p. 22. 
Para eso, Portal interrogaba a sus lectores en los siguientes términos: “¿Se ha opuesto acaso el Perú al cumplimiento de ésta ni de ninguna otra de las cláusulas del inicuo tratado que suscribió, bajo la presión de la fuerza?"116.

El tratado, en Portal, se comparó con un "espantoso cataclismo" que arriesgó la libertad en América. Después de firmarlo, Chile impidió de todas las formas posibles la celebración del plebiscito. El mundo -sin ofrecer mayores argumentos en este puntoparecía creer en que el Perú se oponía y esquivaba el arreglo. Para contradecir tal afirmación citó las opiniones de dos políticos chilenos, los senadores Yáñez y Ross, críticos del papel de la cancillería chilena en la litis.

\section{El arbitraje de España}

El planteamiento central de los autores peruanos evaluadores del protocolo de 1898 fue autocomplaciente. Aquel propuso, en todo momento, una cancillería peruana activa en la conducción de las negociaciones para resolver el diferendo y, por el contrario, una cancillería chilena obstaculizadora y enemiga de todo acuerdo limítrofe.

Enrique Castro y Oyanguren, periodista y diplomático, es fiel exponente de esa posición. Planteó que dos años antes de la suscripción protocolar, la diplomacia peruana indujo a la chilena a cumplir el tratado. Esa gestión hizo que Chile considerara un arbitraje español que fallara los aspectos fundamentales de la votación ${ }^{117}$. Castro y Oyanguren, además, enalteció la figura de Guillermo Billinghurst, quien "logró en pocos días de la diplomacia chilena lo que en vano habíase intentado en mucho tiempo"118. El vigor de esa cancillería también fue establecido por el diplomático, jurista e historiador Alberto Ulloa Sotomayor.

\footnotetext{
${ }^{116}$ Portal, Ismael, Chile ante el árbitro. Su conducta desde 1820, Lima, Librería e Imprenta OIL, 1924.

117 Para consultar otras obras que traten sobre la importancia española en la elección de los votantes ver: BARreto, José María, El problema peruano-chileno (1883-1911), Perú, Imprenta Americana, 1919, p. 106; BArreto, José María, Sin réplica. Cartas diplomáticas, Bolivia, Imprenta Velarde, 1919, p. 45; WIESSE, Carlos, Resumen de historia del Perú, Perú, Librería francesa científica Galland, 1908, p. 267; REPÚBLICA DEL PERÚ, Arbitraje entre el Perú y Chile: réplica del Perú en el litigio que, emanado de la Cuestión del Pacífico, se sigue ante el presidente de los Estados Unidos de América como árbitro, Perú, Editorial T. Scheuch, 1924, p. 185.

118 Castro y Oyanguren, Enrique, Entre el Perú y Chile: la cuestión de Tacna y Arica. Páginas de divulgación histórica, Perú, Imprenta del Estado, 1919, p. 35.
} 
Según él, en las negociaciones preliminares del protocolo, Chile insistió en fragmentar la provincia de Tacna y Arica en tres zonas, efectuando el plebiscito sólo en una. Las otras pasarían "a propiedad soberana de uno y otro país, respectivamente. Pero ante la negativa peruana, las negociaciones tomaron su verdadero camino" ${ }^{119}$.

Para ambos diplomáticos peruanos el fracaso del protocolo guardó relación, en parte, con el papel jugado por un tercer país, ajeno a las negociaciones entre Chile y Perú. Argentina, que tenía graves problemas fronterizos con Chile, ingresó en la escena amenazando desatar la guerra en el extremo suramericano produciendo una "tensión prebélica" ${ }^{20}$. En esos momentos, según Castro y Oyanguren, las intenciones de La Moneda fueron prácticas. Sus diplomáticos negociaron estratégicamente el protocolo con el objetivo de distraer al Perú e impedir su alianza militar con Argentina, a la que también, hipotéticamente, se uniría Bolivia. Esa triple alianza, inédita en la historia militar de esos países, hubiese significado la derrota chilena segura, país que, atacado por tres frentes, no podría haber desarrollado su capacidad defensiva.

Diluida la amenaza bélica, el papel de Argentina cambió. El autor peruano lo expresó así: "la atmósfera internacional se serena, el peligro de guerra con la Argentina se desvanece, los ejércitos enfundan sus cañones, y la situación y los compromisos se transforman"121. Idéntico argumento fue elaborado por Carlos Téllez, sosteniendo que al firmarse el protocolo, la relación chileno-argentina amenazaba con una guerra inminente. La posibilidad de una alianza peruano-argentina permitió la afabilidad chilena hacia el Perú aceptando "el arbitraje que antes había rechazado"122.

Raúl Porras Barrenechea también se adhirió a esa interpretación. El historiador peruano aseguró que Chile firmó el protocolo urgido por las circunstancias internacionales.

\footnotetext{
${ }^{119}$ UlLOA, Alberto. El fallo arbitral del Presidente de Estados Unidos de América en la cuestión de Tacna y Arica, Perú, Seminario y Cía., 1925, p. 21.

120 TABANERA GARCÍA, Nuria, "Una crisis nacional en la distancia. El 98 español visto desde Argentina". En Saz Campos, Ismael, y Archilés i Cardona, Ferran, Estudios sobre nacionalismo y nación en la España Contemporánea, Zaragoza, Prensa Universitarias de Zaragoza, 2011, p. 120.

${ }^{121}$ Castro y Oyanguren, Enrique. Entre el Perú y Chile..., p. 36.

122 TÉllez, Carlos, La cuestión de Tacna y Arica, Perú, Editorial Cervantes, 1925, p. 213.
} 
En concreto, al finalizar 1898, La Moneda acordó arbitrar la cuestión limítrofe chileno-argentina, alejando el peligro ${ }^{123}$. A modo de anécdota, relató el acercamiento entre los presidentes de Chile y Argentina en el Estrecho de Magallanes en febrero de 1899, donde el último susurró al primero que "se encogería de hombros ante todo lo que hiciera Chile para liquidar sus cuestiones derivadas de la guerra del 79"124.

El mantenimiento del engaño hecho por Chile al Perú en la promesa plebiscitaria, permitió al peruano enjuiciarlo en términos duros. La honradez y la fe pública, señaló, quedaron "extramuros" en Chile. A la vez, recordó la frase célebre del canciller alemán Bethmann Hollweg sobre cómo un tratado puede, de un momento a otro, transformarse en un simple pedazo de papel. Citó, también, a Manuel Candamo, presidente peruano entre 1903 y 1904, quien lamentó, en su momento, que sólo los acontecimientos obligaron a Chile a firmar el protocolo.

Al variar la situación creada por Argentina, Castro y Oyanguren sostuvo que Chile transformó su estrategia. El protocolo “quedó empolvándose en los archivos de la Cámara de Diputados, y a los requerimientos del Perú contestaba la diplomacia de Santiago con dilaciones, esperas y evasivas"125. En ese país interesó demostrar la obstaculización chilena hacia la paz, popularizándose la publicación del acuerdo de los diputados, no sólo en la prensa, sino también en documentos oficiales reunidos por el Ministerio de Relaciones Exteriores. La parte central del acuerdo decía:

Teniendo presente las diversas observaciones formuladas en el debate y en especial la conveniencia de que sean resuelto directamente por los Gobiernos de Chile y del Perú, los puntos que el protocolo de 16 de abril de 1898 entregan a la resolución de un árbitro, la Cámara acuerda que se envíen los antecedentes al Ejecutivo a fin de que inicie nuevas gestiones diplomáticas, para dar cumplimiento a la cláusula $3^{\text {a }}$ del Tratado de Ancón ${ }^{126}$.

\footnotetext{
123 Porras BarrenecheA, Raúl, Historia de los límites del Perú: texto dictado a los alumnos del Colegio Anglo-Peruano de Lima, conforme al programa oficial, Perú, Librería francesa científica y casa editorial E. Rosay, F. y E. Rosay, 1930, p. 127.

${ }^{124}$ Porras BARRENEChEA, Raúl, Historia de los límites del Perú..., p. 128.

${ }^{125}$ CASTRo y Oyanguren, Enrique, Entre el Perú y Chile..., p. 36.

${ }^{126}$ RePÚBLICA DE PERÚ, Arbitraje entre el Perú y Chile: réplica ..., p. 184. Otra alusión a este párrafo de gran interés diplomático entre las relaciones de Chile y Perú en: Ministerio DE RELACIONES EXTERIORES DEL PERÚ, Exposición documentada sobre el estado actual del problema del Pacífico, Perú, Imprenta Torres Aguirre, 1921, p. 75. Una obra peruana que explicó las razones de la demora de la Cámara de diputados chilena para aprobar el protocolo, sin relacionar su decisión con un mero capricho político fue escrita por Carlos Téllez. El autor asumió que el factor Argentina fue fundamental y que luego de pasado el temor a la
} 
La visión peruana sobre el protocolo consolidó las ideas sobre el oportunismo de La Moneda. De hecho, el mismo argumento fue presentado por la cancillería peruana en los años veinte del siglo pasado cuando, por entonces, el arbitraje plebiscitario era coordinado por los Estados Unidos. En la réplica al arbitraje entre Perú y Chile, leemos:

En 1898, cuando Chile estuvo en dificultades con la República Argentina y al borde de la guerra, se negoció en Santiago el protocolo Billinghurst-Latorre, que dispuso la realización de un plebiscito y que la Reina de España resolviera por arbitraje las condiciones de los votantes. Chile pareció deseoso de arreglar su controversia con el Perú; pero tan pronto como pasó la crisis con la Argentina, cambió su actitud y promovió discusiones en detalle, extremando sus exigencias, tales como la de que el Perú se comprometiera a no explotar los yacimientos salitreros que se descubrieran y pudieran perjudicar el monopolio que Chile tiene sobre el salitre. El Perú continuó, sin embargo, urgiendo la aprobación del protocolo durante las sesiones del Congreso chileno de 1898-99 [...] Durante las sesiones del Congreso chileno, en 1901, el Perú continuó sus esfuerzos en ese sentido. Al fin, en 1901, el Congreso de Chile devolvió el protocolo al Ejecutivo sin aprobarlo ${ }^{127}$.

A juicio de los diplomáticos peruanos, la oscura posición chilena dificultó el arreglo. En el Perú se asentó la idea de la antiética chilena, propagada por escritores, periodistas y políticos. Para ellos, la irresponsabilidad y la inmoralidad, en materia diplomática, frustraban el entendimiento. Parecía que para este último país el Tratado de Ancón perdía validez cada día, porque no percibía de parte de Chile una voluntad para efectuarlo.

Perú se convenció de que con o sin arbitraje el plebiscito no se efectuaría, pues Chile entorpecía todo arreglo. Ismael Portal, miembro del Instituto Histórico del Perú y miembro de la Sociedad Americana de Derecho Internacional de Washington, escribió, al respecto, una virulenta obra antichilena condenando la conducta de La Moneda en sus relaciones diplomáticas con el Perú ${ }^{128}$.

guerra se abrió una nueva fase que él denominó de "dilación". Manuel Francisco Benavides, Encargado de Negocios del Perú, envió una nota al Ministro de Relaciones Exteriores de Chile solicitando la aprobación o desaprobación del protocolo. El 24 de diciembre de 1898 el canciller chileno respondió sobre "lo difícil que era que la Cámara de diputados se ocupara del asunto, dado el hecho de que estaba en sesiones extraordinarias, y de tener que ocuparse preferentemente de la ley de presupuesto y otras de carácter constitucional”. En: TÉLLEZ, Carlos, La cuestión ..., p. 213.

${ }^{127}$ REPÚBLICA DE PERÚ, Arbitraje entre el Perú y Chile: réplica..., p. 105.

128 PORTAL, Ismael, Chile ante el árbitro... 
En la introducción aludió la enérgica posición peruana para solucionar el diferendo. Allí lanzó el primer dardo contra Chile, país habituado a "no respetar sus más sagradas obligaciones internacionales"129. Portal creía que el arbitraje, en jurisprudencia internacional, era "sagrado". Al ser un acto ejercido con nobleza por una tercera potencia España-, se debía respetar, pues escudaba la justicia, impidiendo la guerra. En la terna diplomática para el arbitraje integrada por Chile, Perú y España, reflexionó Portal, existía una aberración que impedía su organización. Esa anomalía era ejercida por los países con "sed de dominio y de conquista, porque es un freno que los sujeta a sus perversos planes" ${ }^{130}$. La alusión a Chile era evidente, los juicios de valor rotundos.

Esa desconfianza hacia la diplomacia chilena permitió a Portal pensar en cómo admitiría Chile un arbitraje. El fracaso del protocolo clarificaba que sabía utilizar estrategias evasivas de las responsabilidades contraídas en el plano del derecho internacional. Por eso, con ironía, recordó el acuerdo de 1898, el que solicitando la cooperación de la reina María Cristina sólo mortificó "a la augusta señora"131.

En otra publicación oficial se reiteró la imagen de una diplomacia chilena inmoral. En ella el objetivo político era publicar una propaganda negativa hacia Chile dando cuenta de su resistencia constante a todo arreglo del diferendo, violando los tratados suscritos. Circulares diplomáticas afirmó que Chile incumplía el tratado que impuso por las armas ${ }^{132}$.

Alberto Salomón, varias veces canciller peruano entre 1920 y 1925, continuó la campaña de desprestigio hacia Chile, sentando a su cancillería sobre el banquillo de los acusados por su volubilidad. Según Salomón, el único esfuerzo realizado por Chile fue obstruir los arreglos fronterizos, dudando de la honestidad de los negociadores chilenos. Recordaba, de la siguiente manera, los avatares del protocolo Billinghurst-Latorre:

Chile se esforzó siempre por impedir que el plebiscito se realizara. Solo en una ocasión de su historia diplomática ha parecido dispuesto a negociar las bases del plebiscito: en 1898, cuando se firmó el protocolo Billinghurst-Latorre. Y, como saben los señores representantes, inmediatamente que desapareció la circunstancia que le diera origen, o sea la tirantez de relaciones con la República Argentina; tan luego que se realizó la conferencia

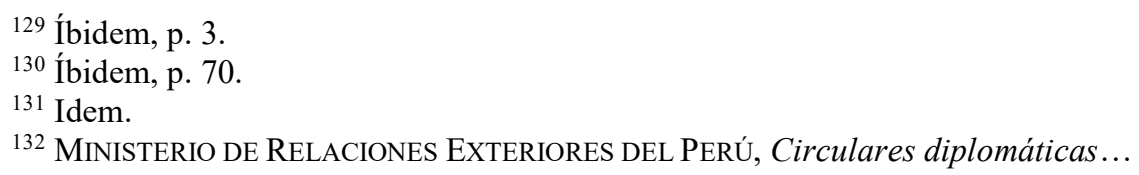


de Magallanes entre los presidentes Errázuriz y Roca, y cesó esa tirantes, declararon los chilenos, sin ningún pudor, que ya no tenía por qué llevarlo a cabo, que no irían al plebiscito porque las condiciones habían cambiado ${ }^{133}$.

El discurso del vigor peruano en las negociaciones para solucionar el problema fronterizo con ayuda española es reiterativo. Porras, aludiendo al buen momento internacional previo a 1898, recordó cómo a Billinghurst le fue fácil negociar el arbitraje español. El protocolo, sostuvo el escritor, esperanzó al gobierno peruano y al pueblo tacnoariqueño, donde se "creyó en la próxima realización del plebiscito, el que, en esa fecha, hubiera sido abrumadoramente favorable al Perú"134.

\section{El arbitraje de los Estados Unidos y el Tratado de Lima}

Jorge Basadre Grohmann, historiador nacido en Tacna, explicó en su monumental Historia de la República del Perú 1822-1933, el impacto que la chilenización tuvo en Tacna y Arica con anterioridad al periodo del arbitraje de los Estados Unidos. Desde comienzos del siglo XX, aseguró, el Estado chileno adoptó un conjunto de medidas que permitieran chilenizar a la población de las provincias en litigio. El objetivo era el triunfo en el plebiscito que el Tratado de Ancón estipuló en 1883. Para ello, comenzó por la infancia. Más de treinta escuelas fueron clausuradas por orden del gobierno acusándolas de enseñar conocimientos exclusivamente referidos a la historia y la geografía peruana.

En relación a lo anterior, Basadre apuntó una larga lista de cambios introducidos por Chile en Tacna y Arica, entre los que cabe mencionar la instalación de la Corte de Apelaciones en Tacna; el establecimiento de una plana mayor del ejército en esa ciudad; la alta inversión económica destinada a erigir edificios de gobierno; la aplicación de sistemas para la obtención de agua potable y otras obras públicas, y, por último, la "fundación de un diario para la propaganda chilena" ${ }^{\prime 135}$.

\footnotetext{
${ }^{133}$ Ministerio de Relaciones Exteriores del Perú, En la Cámara de Diputados ..., pp. 26-27.

${ }^{134}$ Porras Barrenechea, Raúl, Historia de los límites del Perú..., p. 126.

135 BASADRE, Jorge, Historia de la República del Perú 1822-1833, tomo XII, Lima, Editorial Universitaria, 1969, p. 11.
} 
Hacia finales de 1909, señaló el tacneño, las autoridades chilenas aplicaron mano dura con los trabajadores portuarios peruanos, quienes debieron abandonar sus faenas. A los aduaneros de ese país se les canceló la licencia para comercializar productos. Consecuentemente, los pobladores peruanos fueron hostilizados con la intención de que emigrasen. Al igual que las escuelas, todas las iglesias que funcionaban en la frontera fueron clausuradas. Los religiosos encargados del servicio espiritual en Tacna y Arica “eran, en verdad, poderosos agentes en la preservación, difusión y ahondamiento del sentimiento patriótico"136, papel elogiado por el historiador.

Durante noviembre y diciembre de 1918, otra vez, fueron expulsados masivamente de Tarapacá, Tacna y Arica ciudadanos peruanos. El argumento dado por la cancillería chilena a la peruana, explicó Basadre, se basó en la crisis salitrera producida por la guerra mundial. Estas cuestiones sociales, políticas y económicas, tuvieron como consecuencia la ruptura de las relaciones consulares produciendo "notorio daño para las relaciones comerciales que habían subsistido a pesar de las anteriores divergencias diplomáticas"137.

En julio de 1919, Augusto Leguía se convirtió en presidente provisorio del Perú. Basadre comentó que transformó, audazmente, la litis en un arma electoral. Eso favoreció que, a fines de ese año, la Asamblea Nacional declarase caducado el Tratado de Ancón, idea ilusa, romántica e impracticable, en palabras del historiador. En esa situación la cancillería chilena inició su "ofensiva diplomática”. Basadre señaló que ésta, liderada por el presidente Arturo Alessandri y su canciller, Ernesto Barros Jarpa, señaló el abandono de la política chilena antiarbitraje que se había sostenido desde la Guerra del Pacífico.

En ese entendimiento, Chile y Perú buscaron en los Estados Unidos el mediador que pusiera fin al largo diferendo por Tacna y Arica. Basadre aseguró -sin citar documentación diplomática ni de otro tipo- que Washington, con discreción, solicitó al gobierno limeño abandonar la idea de la nulidad del tratado, pues eso colocaba al país en un estado de guerra que no estaba preparado para afrontar.

\footnotetext{
136 Íbidem, p. 91.

137 Íbidem, p. 421.
} 
Las Conferencias de Washington "fueron discutidas secretamente"138. Mientras el Perú proponía la devolución inmediata de Tacna y Arica, Chile planteó cuatro formas diferentes para celebrar el plebiscito. El nulo acuerdo en estas materias produjo la sensación de que la única manera de resolver el conflicto sería mediante el arbitraje del presidente Harding quien decidiría si procedía o no el plebiscito. En el Perú el debate se volvió nacional. Muchos temieron que la improcedencia plebiscitaria fuese comprendida por Chile como la "consagración definitiva de su soberanía sobre Tacna y Arica puesto que esa solución sería el desahucio de la única forma o manera de devolver al Perú las provincias que entregó en el tratado de Ancón"139.

Basadre comentó que el laudo publicado el 4 de marzo de 1925 legalizando el plebiscito favoreció a Chile, pues su triunfo en las votaciones era altamente probable ${ }^{140}$. El presidente Leguía, siguiendo su táctica inicial, intentó la movilización de la opinión pública peruana hacia el tema plebiscitario, desviando la atención de los conflictos políticos internos.

Una vez establecida la comisión plebiscitaria en Arica, los episodios de violencia nacionalista, sobre todo de chilenos contra peruanos, en la interpretación del historiador tacneño, perjudicaron la ejecución del plebiscito. El 9 de julio de 1926, el representante estadounidense en la zona del conflicto, general William Lassiter, decidió la cancelación del plebiscito debido a las condiciones desfavorables que impedían su correcta realización. Esos hechos demostraron que "la tesis sostenida por el Perú ante el árbitro había obtenido un triunfo póstumo. El plebiscito no llegó a efectuarse"141.

Por las razones anteriores, escribió Basadre, la historia del Perú debe contemplar un espacio de gratitud a los generales estadounidenses y sus delegados quienes trabajaron con espíritu de justicia y objetividad. Su actuación diplomática señala "un episodio en la dura

\footnotetext{
${ }^{138}$ BASADRE, Jorge, Historia de la República del Perú 1822-1833, tomo XIII, Lima, Editorial Universitaria, 1968, p. 107.

139 Íbidem, p. 109.

140 Íbidem, p. 144.

${ }^{141}$ Íbidem, p. 152.
} 
lucha por el Derecho en América y en el empeño de defender y tonificar los valores morales, constantemente acallados y zaheridos en la vida cotidiana"142.

Antes del Tratado de Lima de 1929 las relaciones diplomáticas chileno-peruanas mostraron una genuina mejoría. Ocho meses de arduo trabajo duraron las negociaciones entre el presidente peruano Augusto Leguía y el ministro chileno Emiliano Figueroa Larraín. Aquel había realizado una serie de propuestas que iban desde la entrega de Tacna y Arica al Perú hasta la neutralización de la última ciudad con apoyo de otros países sudamericanos (Venezuela y Uruguay).

El presidente de los Estados Unidos, Herbert Hoover, prestó sus buenos oficios en la recta final de las negociaciones entre Leguía y Larraín. El documento, que con anterioridad citamos in extenso, selló después de medio siglo un pacto de amistad entre los antiguos rivales de guerra ${ }^{143}$. Basadre elogia por ello la actitud chilena en los siguientes términos:

El Gobierno de Chile después de 1926 o en los años siguientes bien pudo no hacer nada o plantear fórmulas imposibles y dejar que el tiempo terminara de consolidar el estado posesorio sobre el territorio en disputa. Con ello hubiera puesto en práctica el punto de vista del Presidente Ramón Barros Luco que hacia 1910 decía: "Nosotros no tenemos ningún problema con el Perú; el problema es para ellos que no tienen Tacna y Arica". Ni el Presidente Ibáñez ni su canciller Conrado Ríos Gallardo escogieron esa política. Buscaron con previsión y valor moral la rehabilitación de Chile, el eclipse del problema con beneplácito de los dos litigantes, la fórmula transaccional, la amistad peruano-chilena. Para ello sacrificaron Tacna y un poco de dinero y así perdieron una zona considerada, sin importancia estratégica [...] sin gran valor económico y donde el sentimiento peruano no había podido ser desarraigado; y cubrieron con un título jurídico la chilenización de Arica, puesto importante no sólo para los dos países sino también en relación con Bolivia y que, además de su significado estratégico, poseía un valor sentimental acrecentado por el morro $^{144}$.

\footnotetext{
142 Íbidem, p. 156.

${ }^{143}$ Una visión crítica hacia el Tratado de Lima tuvo el historiador peruano José de la Riva-Agüero. Sobre la paz de 1929 escribió: "Entiéndase bien mi pensamiento: censuro ese tratado por la defectuosísima frontera que nos señala, indefendible militar y aduaneramente con nuestras solas fuerzas; me lamento de las muchas oportunidades antes de él desperdiciadas para más libres soluciones; pero estoy muy lejos de desear su desahucio ni su revisión, que significarían la última calamidad y la peor locura". En: RIVA-AGÜERO, José de la, Estudios de historia peruana. La emancipación y la república. VII, Lima, Pontificia Universidad Católica del Perú, 1971, p. 332.

144 Íbidem, pp. 172-173.
} 



\section{MARCO TEÓRICO}

En la actualidad, la historiografía sobre el papel de la prensa española durante los años que duró el conflicto entre Chile y Perú por Tacna y Arica es inexistente. Ese desierto, referido a un aspecto específico del pasado compartido entre España, Chile, Perú, Bolivia y Estados Unidos puede ser valorado, por lo menos, de dos formas opuestas. En primer lugar, puede ser entendido negativamente, porque la ausencia de estudios clásicos o visiones novedosas imposibilitaría la elaboración crítica de un marco teórico donde compartir o debatir tales escritos. En segundo lugar, puede ser entendido positivamente, pues abriendo una línea de investigación novel y creativa, el historiador puede pasar directamente al análisis de las fuentes, sin detenerse en el ejercicio comprensivo de lo dicho por otros especialistas.

Ninguna de las dos posturas, desde nuestro punto de vista, es superior a la otra. La valoración de la situación es relativa y dependerá, en última instancia, de las decisiones teóricas del historiador por posicionarse, para explicar su perspectiva de análisis, dentro de alguna de las líneas de investigación consagradas por la reflexión y la práctica del oficio. Entre éstas, no hay duda, que la oferta está más bien acotada -historia política, historia económica, historia social, historia cultural, etc.-, pero la decisión, en gran medida, estará influenciada por las interrogantes iniciales de la investigación, así como por las fuentes seleccionadas para ensayar algunas respuestas empíricas a esas cuestiones.

\subsection{La historia cultural}

En relación con esta última afirmación, la evaluación de ambas situaciones evidencia los beneficios de mirar el pasado desde las premisas básicas y las reflexiones profundas de la historia cultural. Estamos convencidos de que poco ayuda a la comprensión de aquel aludir a una historia sin referente temático (político, social, cultural), por muy general que sea. Frente a las acusaciones, unas más fundadas que otras, entabladas contra la historia cultural, pensamos que esa línea no detiene, retrasa ni confunde la comprensión del pasado. Es más, como se sabe, lo que se juega en esa discusión es la antigua controversia entre el rol histórico de las estructuras y el rol de los agentes históricos. 
Tales posiciones, herederas de épocas diferentes en la reflexión de lo social, el estructuralismo funcionalista, por un lado y el retorno al sujeto por el otro, han colisionado en la práctica no vislumbrándose por ningún lado un acercamiento sincero. En efecto, esta tensión ha permitido que el estructuralismo no haya dominado completamente en el campo científico de la historia, pues ha tenido que debatir con intelectuales defensores, según ellos, de la libertad humana y "el carácter imprevisible de los acontecimientos"145.

Como suele suceder con estos debates, la victoria de uno u otro bando es finita. En la práctica, los investigadores y sus aprendices cultivan los más diversos aspectos de la historia enriqueciendo, sin duda, el acervo cultural occidental. De todos modos, es difícil negar una "subsunción estructural"146 fraguada por los historiadores socioculturales, quienes atribuyen al sujeto un papel activo en la transformación y configuración de la práctica social tomándolo "como punto de partida de la indagación histórica"147. Sólo en los últimos cuatro años se han publicado trabajos espléndidos relacionados con la perspectiva cultural aplicada a la historia ${ }^{148}$.

En el campo de la historia cultural, comprendemos cómo el impacto del "giro cultural" de los años setenta favoreció, posteriormente, la realización de interesantes investigaciones histórico-culturalistas. La historia cultural surgía del "naufragio de la historia serial y marxista" 149 . Inventariarlas y comentarlas sobrepasa los límites de este capítulo. Una buena síntesis fue ofrecida por Antonio Viñao quien comentó: "raro es el mes en que no aparece, con esa rúbrica, algún nuevo libro o artículo"150.

\footnotetext{
${ }^{145}$ Bourdé, Guy y MARTin, Hervé, Las escuelas históricas, Madrid, Akal S. A., 2004, p. 211.

${ }^{146}$ CABRERA, Miguel, Historia, lenguaje y teoría de la sociedad, España, Ediciones Cátedra, 2001, p. 34.

${ }^{147}$ Idem.

${ }^{148}$ LÓPEZ, Javier, Breve historia cultural de los nacionalismos europeos, Madrid, Catarata, 2013; CAMPO TEJEDOR, Alberto del, Historia cultural del flamenco: el barbero y la guitarra, Córdoba, Almuzara, 2013; WERNER, Florian, La materia oscura: historia cultural de la mierda, Barcelona, Tusquets, 2013; HuERTAS, Rafael, Historia cultural de la psiquiatría, Madrid, Catarata, 2012; Moscoso, Javier, Historia cultural del dolor, Madrid, Taurus, 2011.

149 AURELl, Jaume, La escritura de la memoria. De los positivismo a los postmodernismos, Valencia, Universitat de València, 2005, p. 182.

150 VIÑAO, Antonio, "Historia de la educación e historia cultural: posibilidades, problemas, cuestiones". Revista de Educación, n. ${ }^{\circ}$ 306, 1995, p. 245.
} 
Luego, Peter Burke intentó responder varias cuestiones concernientes al quehacer historiográfico de ese ámbito en dos trabajos ya clásicos, ¿Qué es historia cultural $^{151}$ ? y Formas de historia cultural ${ }^{152}$, y en España, los historiadores Justo Cerna y Anaclet Pons en La historia cultural. Autores, obras, lugares ${ }^{153}$, realizaron un recuento de los numerosos trabajos que unificaron las dimensiones histórico-antropológicas, a la par de definir los temas centrales y sus metodologías de análisis.

Más tarde, en Francia, el historiador Marcel Detienne, en el capítulo Histoire/anthropologie $e^{154}$ apeló al reconocimiento mutuo que deberían realizar historiadores y antropólogos para abordar en conjunto el pasado, puesto que comparten el interés por las sociedades humanas y, en última instancia, ambos apelan a la retórica en la construcción de sus relatos. Esa conexión ineludible entre cultura y lenguaje, tendría que ver con el origen de la historia cultural pues, en tanto confluencia epistémica, tal relación permitiría el surgimiento de aquella, la que enfatiza en "el capital simbólico más que en el capital material y, finalmente más en el código lingüístico que en el contenido mismo de lo transmitido" 155 .

En concreto, la historia cultural puede entenderse como una respuesta científica a la historia historizante ocupada, como es sabido, por los "grandes hechos" de los Estados y sus "héroes". La historia cultural, sin obviar esos conocimientos, demuestra gran inquietud por resolver problemas históricos vinculados con las formas de pensamiento de las culturas que se desarrollan en las sociedades estudiadas. Las ideas colectivas, su formación y principales características, sus orígenes y sus cambios en el tiempo son objetivos centrales de esta disciplina.

${ }^{151}$ BURKe, Peter, ¿Qué es historia cultural?, Barcelona, Paidós, 2005.

152 BURKe, Peter, Formas de historia cultural, Madrid, Alianza Editorial, 2006.

${ }^{153}$ SERnA, Justo y Pons, Anaclet, La historia cultural. Autores, obras, lugares. Madrid, Ediciones Akal S. A., 2005.

${ }^{154}$ DetienNe, Marcel, L'identité nationale, une énigme, París, Éditions Gallimard, 2010.

155 Moreno, Francisco, "Prólogo. Historia, sociedad y lengua". En Rebeca Barriga y Pedro Martín (Dir.). Historia sociolingüística de México. Volumen I, México D. F. El Colegio de México, Centro de Estudios

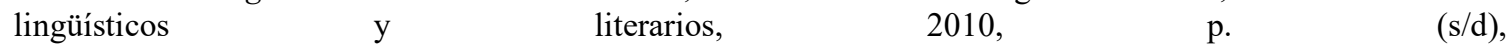
$<$ https://books.google.es/books?id=wXJdCQAAQBAJ\&printsec $=$ frontcover\&dq=historia + sociolinguistica $+\mathrm{d}$ $\mathrm{e}+\mathrm{M} \% \mathrm{C3} \%$ A9xico\&hl=es\&sa=X\&ved=0ahUKEwiH0tb979HKAhXCuRQKHdxYCIIQ6AEIJTAB\#v=onepa ge\&q\&f=false $>$ [consultado el: $15 / 09 / 2014]$. 
El mismo Peter Burke explicó que el punto de partida de la historia cultural se puede entender como "una reacción contra enfoques previos del pasado que omitían algo a la par escurridizo e importante" ${ }^{156}$. Tales aspectos de los modos de pensar, nada fáciles de tomar, estarían en la base de las ocupaciones intelectuales de los historiadores culturales. El enfoque sobre lo simbólico en la cultura y los ensayos interpretativos serían dos pasos ineludibles para los cultores de esta disciplina.

Por lo que se refiere al aspecto interpretativo, pocas dudas quedan respecto a tal acto reflexivo en la escritura y la explicación histórica. No es necesario asumir una militancia tenue o agresiva en las filas de la historia cultural. Sin embargo, respecto al concepto de cultura, la sola afirmación obliga a introducirse en un largo y vigente debate dentro de la historia cultural y de la antropología cultural. Ejemplos de esos esfuerzos por explicar con palabras la abstracción de la cultura se pueden rastrear en los innumerables libros y artículos científicos esforzados por lograrlo. Las definiciones ya clásicas formuladas por Edward Tylor, Franz Boas, Bronislaw Malinowski, Clyde Kluckhohn o Claude LeviStrauss, han sido una y otra vez compendiadas por estudios posteriores. Las bibliotecas y los depósitos digitales de artículos científicos así lo demuestran ${ }^{157}$.

Ese panorama conceptual invita a la selección, pues solo ajustando los lentes del "microscopio" teórico social el análisis de los datos puede resultar satisfactorio. Escogiendo, a la vez, se puede comprender con mayor precisión la trama de significados que en el seno de la sociedad estudiada permanecieron y cambiaron en un continuum incesante. Considerando esa situación, nuestra investigación parte de la conceptualización geertziana de los "signos" textuales producidos por la prensa, en tanto medio de comunicación social.

\footnotetext{
${ }^{156}$ BURKe, Peter, ¿Qué es...?, p. 13.

${ }^{157}$ AIME, Marco, Cultura, Buenos Aires, Adriana Hidalgo editora, 2015; BARRERA LunA, Raúl, "El concepto de cultura, definiciones, debates y usos sociales". Revista de Claseshistoria, febrero de 2013, p. (s/d), disponible en: http://www.claseshistoria.com/revista/index.html; GÜELL, Pedro, "¿Qué se dice cuándo se dice cultura? Notas sobre el nombre de un problema", Revista de Sociología, n. . 22, 2008, pp. 37-64; MoRAGAS, Miquel de, Interpretar la comunicación. Estudios sobre medios en América y Europa, Barcelona, Gedisa S. A., 2011; NANDY, Achis, Imágenes del Estado. Cultura, violencia y desarrollo, México, FCE, 2011; ITROIZ, Josefina, TRUPA, Noelia y VACCA, Laura Celina, "Discutiendo el concepto de cultura". Acta académica de la VI Jornadas de Sociología de la Universidad Nacional de la Plata, disponible en: http://www.aacademica.org/000-027/749.pdf; VERA NORIEGA, José Ángel, RoDRÍGUEZ CARVAJAL, Claudia Karina y GRUBITS, Sonia, "La psicología social y el concepto de cultura", Psicología \& Sociedade, volumen 21, n. $^{\circ} 1,2009$.
} 
En consecuencia, no iremos tras de leyes científicas. El análisis cultural e histórico es interpretativo de las significaciones, buscando, en efecto, "la explicación, interpretando expresiones sociales [...] enigmáticas en su superficie" ${ }^{158}$. Esas expresiones socio-textuales conformaron dentro y fuera de la prensa parte del sentido común, sistema de pensamiento constituido "históricamente y [...] sujeto a pautas de juicio definidas históricamente"159.

La relación entre prensa y sentido común es rígida, "Los medios dependen de él. Lo reproducen, apelan a él, pero también lo explotan y lo representan erróneamente"160. Su actuación es significativa en el ámbito mundano donde "Filtran y modelan las realidades cotidianas a través de sus representaciones singulares y múltiples"161. Valga comentar aquí que con posterioridad a los aportes de Geertz para comprender la cultura, otros estudiosos han propuesta conceptos asociados "cada vez más con conceptos tales como movimiento y transformación por lo que va asumiendo progresivamente una imagen más dinámica, menos cerrada y en continuo desarrollo"162.

\subsection{La historia cultural de la comunicación social}

Centrándonos en los problemas principales de esta investigación y cómo afrontarlos, nos situaremos desde una perspectiva científica más delimitada aún, pero surgida desde la historia cultural. Nos referimos a la historia cultural de la comunicación social (HCCS). El uso, ahora, del concepto comunicación nos remite a ésta en tanto acción y con ello se logra retomar el énfasis en la producción y el quehacer del "sujeto". La comunicación, dentro de la historia cultural de la comunicación, es considerada como una "acción significativa que tiene como finalidad que otro comprenda lo que significa esa acción y que sea efectivamente comprendida" 163 .

\footnotetext{
${ }^{158}$ GEERTZ, Clifford, La interpretación de las culturas, Barcelona, Editorial Gedisa, S. A., 1997, p. 27.

${ }^{159}$ GEERTZ, Clifford, Conocimiento local. Ensayo sobre la interpretación de las culturas, Barcelona, Paidós, S. A., 1994, p. 96.

${ }^{160}$ Silverstone, Roger, ¿Por qué estudiar los medios? Buenos Aires, Talleres gráficos EFE, 2004, p. 21.

${ }^{161}$ Idem.

162 AIME, Marco, Cultura, p. 28.

${ }^{163}$ RomÁn, Mercedes, “Aspectos metodológicos de la historia de la comunicación”, Latina. Revista Latina de comunicación social, n. ${ }^{\circ}$ 43, 2001, <http://www.ull.es/publicaciones/latina/2001/latina43julio/38roman.htm> [consultado el: 12/07/2015].
} 
La comunicación así entendida poseería cinco características fundamentales: es humana, social, referencial, una realidad compleja y, por último, ocurre en el tiempo presente. El énfasis de esta última afirmación no debe ser excluida del plano epistemológico en la presente investigación. Por el contrario, reflexionar en torno al tiempo presente en un estudio histórico como éste puede facilitar la explicitación del por qué, dónde y cómo surgen las preguntas fundamentales realizadas a las fuentes históricas seleccionadas.

Todas estas últimas cuestiones provienen, por decirlo de algún modo, del tiempo presente. Ésta y otras novedades reflexivas previas a la escritura de la historia, como la centralidad de lo imaginario en la investigación, ha sido criticada con buenos argumentos por algunos historiadores españoles. Una buena síntesis fue redactada por el profesor Yanes en la introducción de su Metodología de la historia social en Canarias ${ }^{164}$. Allí aludió a la "piedra angular" de la nueva historia - una adjetivación aplicada indiscriminadamente al grueso de las corrientes innovadoras $-^{165}$ comentando:

[...] para esta nueva historia, los individuos aprehenden y conceptualizan la realidad social en la que están inmersos en función del patrón de significados, llamado discurso o metanarrativa, que está vigente en el contexto, con lo cual rechaza que los condicionantes socioeconómicos determinen de manera unívoca la conducta de las personas y explica la diversidad de respuestas que una misma realidad social ha generado en el tiempo y el espacio $^{166}$.

Menos combativa es la postura defendida por el historiador Juan Gracia Cárcamo. Éste, seguidor de la historia cultural de los setenta, prefiere hoy denominarla "historia sociocultural”, dando cuenta así de su gran desconfianza en lo que bautizó con el nombre de "determinismo culturalista". Según el historiador vizcaíno, este tipo de error teóricometodológico vendría dado por un enfoque exclusivista sobre los textos, sus discursos y representaciones ${ }^{167}$.

\footnotetext{
${ }^{164}$ YANES, Julio, Metodología de la historia de la comunicación social en Canarias. La prensa y las fuentes hemerográficas, Tenerife, Ediciones de baile de Sol, 2005.

165 Íbidem, p. 27.

166 Íbidem, p. 27-28.

${ }^{167}$ GRACIA, Juan, "Historia de la comunicación: perspectivas metodológicas y teórico historiográficas desde la historia cultural", Historia Contemporánea, n. ${ }^{\text {4 } 45, ~ 2013, ~ p p . ~ 639-688 . ~}$
} 
No obstante esas dos apreciaciones, como se puede comprender ahora, historiacultura-comunicación poseen una estrecha relación que permite comprender los modos del pensamiento y maneras de representar la realidad de las sociedades analizadas. Son, como lo sugirió Ramón Zallo, interrelaciones que son decisivas en la forma en que se despliega el sistema mundo ${ }^{168}$. Nosotros, desde la historia, intentaremos comprender una facción de ese sistema mundo desde la producción periodística española entre 1880 y 1929 sobre la cuestión de Tacna y Arica como un evento de comunicación y cultural que implica, entre otras cosas:

[...] un proceso relacional entre los individuos que participan en su producción y ejecución [favoreciendo] relaciones estructuradas simples y complejas. La forma simple se genera cuando los contenidos culturales son transmitidos directamente de un individuo a otro. Las formas complejas suponen multiplicidad de mensajes y maneras diversas de interacción, desde un individuo a un grupo hasta de grupos comunicándose con otros grupos. Así, comunicarse es literalmente, el modo como las culturas funcionan, se construyen y se transforman. [...] la comunicación es el puente que enlaza la vivencia del individuo con la de su grupo de pertenencia y, cuando es necesario, con individuos de otros grupos. Esta vivencia es también de tipo mental, ya que el pensamiento y la comunicación con otros se desarrollan como un diálogo interno del individuo consigo mismo. De allí que podemos concluir que el propio pensamiento es el resultado de los procesos comunicacionales entre los individuos de una sociedad que forman parte de una cultura misma ${ }^{169}$.

2.3. La historia cultural de la prensa

¿Cómo "pensó" la prensa española el proceso para solucionar el problema de Tacna y Arica? Hemos, conscientemente, entrecomillado primer verbo pues aquí nos interesa el pensamiento periodístico, pero también la praxis que condujo a escribir esos pensamientos. Interesa dentro de la historia cultural de la comunicación social las relaciones entre el pensar y el decir, entre los discursos y las prácticas. El ámbito mental, como afirmó Amodio en el texto citado anteriormente, guarda relación con los procesos de comunicación entre los individuos de una sociedad que forman una cultura. Por ello nos interesa fijar bien cuál es el medio por dónde transcurre la comunicación y donde se depositan los mensajes escritos.

\footnotetext{
168 ZALlo, Ramón, Estructuras de la comunicación y cultura. Políticas para la era digital, Barcelona, Editorial Gedisa S. A., 2011, p. 42.

${ }^{169}$ AMODIO, Emanuele, Cultura, comunicación, lenguaje, Caracas, IESALC UNESCO, 2010, p. 25.
} 
Como se desprende del título de esta investigación tal medio es la prensa escrita. Sólo explicitado eso, estamos en situación de ubicar correctamente el área de la historia en la que se enmarca el trabajo y que hemos denominado, sin más acotaciones, Historia Cultural de la Prensa. En efecto, para pensar en una historia cultural de la prensa representando aspectos político-diplomáticos de América conviene comprender y asumir axiomáticamente que la prensa, en tanto creador influyente de opiniones, es un actor que juega dos papeles centrales en la sociedad: uno social y otro político.

En el primer caso, esa situación fue remarcada por Héctor Borrat, quien consideró a la prensa como un actor social que discute con otros actores, que como en nuestro caso, están "especializados en la producción y comunicación pública de relatos y comentarios acerca de los conflictos existentes entre actores de ese y de otros sistemas políticos"170. Lo último ocurre debido a la posición específica de la prensa que está enmarcada, como lo asegura Kircher, en un universo de relaciones de fuerzas objetivas compitiendo con las demás publicaciones y definiendo su posición dentro de ese campo. Así, en tanto actor social "no sólo se convierte en un mediador entre la sociedad civil y el estado, sino que construye representaciones de poder en la sociedad en cuyo interior opera" ${ }^{171}$.

La prensa, diarios y revistas publicadas en la España de fines del siglo XIX y comienzos del XX, son fuentes históricas valiosas que permiten conocer el pensamiento político de esa época sobre una cuestión "extranjera". Interesa constatar su poder "creativo" para inducir a la imaginación de problemas políticos distantes, mediante la técnica de la escritura periodística, favoreciendo la formación de estereotipos y, a veces, prejuicios de orden nacional. Tal actitud, encuentra su fundamento en las características dinámicas de las sociedades que no reciben con completa sumisión los saberes e informaciones de otras, foráneas, lejanas o cercanas. Por el contrario, como ha explicado Marco Aime, "la mayoría de las veces las metabolizan, las reelaboran y las hacen propias; y, llegadas a esa instancia ya son algo nuevo, algo que es de ellos"172.

\footnotetext{
${ }^{170}$ BorRAT, Héctor, "El periódico. Actor del sistema político”, Anàlisi, n. ${ }^{\circ}$ 12, 1989, pp. 67-80.

${ }^{171}$ KIRCHER, Mirta, "La prensa escrita. Actor social y político, espacio de producción cultural y fuente de información histórica”, Revista de Historia, n. ${ }^{\circ}$ 19, 2005, p. 116.

172 AIME, Marco, Cultura, p. 71.
} 
Es fundamental explicar aquí que la historia cultural de la prensa toma, en parte, distancia de la historia de la prensa. Si bien ambas comparten indudablemente el interés por las fuentes hemerográficas, la última disciplina desconfía, en gran medida, de las conceptualizaciones teóricas que la primera discute y define antes de comenzar sus análisis e interpretaciones. Lo anterior no quiere decir que sus estudios queden invalidados por los historiadores culturales de la prensa, pues, sin duda, las grandes obras que se han realizado en nombre de la historia de la prensa son camino obligado para los investigadores de la historia cultural de ésta. Una crítica a la historia de la prensa en su versión tradicional, sin ser un culturalista, la esbozó Pizarroso hace más de veinte años al afirmar que tales obras:

[...] no van más allá de la enunciación y de la catalogación, presentándosenos como descripciones más o menos sistematizadas de las distintas publicaciones con biografías o anecdotarios de los hombres que les dieron vida, o bien como más o menos completas catalogaciones de periódicos o de periodistas ${ }^{173}$.

De todas formas, una característica de la historia cultural de la prensa es que interroga a sus fuentes no sólo para argumentar o contradecir hipótesis de trabajo histórico, sino que las ubica en el centro de la investigación histórica, siendo problemas primarios para resolver su constitución heurística ${ }^{174}$, es decir, los orígenes de la fuente de prensa, el lugar y contexto, la retórica usada en sus escritos, los grupos económicos o de poder político que la sostienen, si enfatiza opiniones o las disfraza de informaciones (sin reflexionar sobre la intención de ofrecer al público éstas y no aquellas).

La prensa, para la historia cultural de ésta, adquiere centralidad en las sociedades contemporáneas, donde el acceso masivo a los discursos desplegados sobre papel por parte de millones de personas puede crear formas de pensamientos y puede incitar determinados tipos de prácticas sociales. La prensa no sería un espejo que refleja la realidad tal como es, sino que sería un foco y "su enfoque puede estar orientado por grupos con especial interés en un tema"175.

\footnotetext{
${ }^{173}$ Pizarroso, Alejandro, Historia de la prensa, Madrid, Centro de Estudios Ramón Areces, 1994, p. 3.

174 Soto LARA, José Julián, "La prensa española como fuente histórica para el problema de Tacna y Arica (1880-1901): heurística y método”, TRIM Tordesillas Revista de Investigación Multidisciplinar, n. ${ }^{\circ}$ 7, 2014, pp. 25-42.

${ }^{175}$ MoRAGAS, Miquel de, Interpretar la comunicación..., p. 109.
} 
Por otro lado, en peso productivo, no cabe duda que la historia cultural de la prensa va detrás de la historia clásica de la prensa. Por el contrario, si se quisiera comparar a aquella con la ya comentada historia cultural de la comunicación, la situación evidencia cambios. Ésta, con sus temas, materialidad de sus objetos, soportes y consumidores "están presentes en numerosos autores europeos, que se preguntan en cómo se forman y se transmiten [esas] producciones humanas"176. O como lo sugirió Arcangeli: "la historia de las formas de comunicación ha sido en todas partes el terreno preferido de esta manera de hacer historia [refiriéndose a la historia cultural]".

Por esas razones, la situación de la "historia cultural de la prensa" desafía al historiador, planteando grandes dudas acerca de la ponderación de las consecuencias sociales de las lecturas de los diarios y revistas cuando -lamentablemente- no se cuenta con documentos que expliciten tal situación. Es esta una de las grandes diferencias con la "historia cultural de la lectura" que ha tenido un impulso notable de la mano de Roger Chartier y que constituye un "sector puntero en la nueva historia cultural"177.

Nuestra investigación profundiza, parafraseando a Jean Claude Abric, en la visión funcional del mundo o, en palabras de Sandra Araya, en los sistemas cognitivos, no avanzando hacia la dimensión actitudinal de los lectores influenciados por los escritos. De esa forma, nos distanciamos de la "historia de la lectura", que considera vital la relación entre el "mundo del texto" y el "mundo del lector"178. Esa relación texto-lector favorece la elaboración de cuestiones fundamentales, por ejemplo, ¿Cómo los textos impresos, son utilizados por los lectores? y “Cómo, gracias a la mediación de esta lectura [...], construyen estos individuos una representación de ellos mismos, una comprensión de lo social, una interpretación de su relación con el mundo natural y con lo sagrado? ${ }^{179}$.

\footnotetext{
${ }^{176}$ PONS, Anaclet y SERNA, Justo, "Variaciones sobre la historia cultural en España". En Philip Poirrier, $L a$ historia cultural ¿Un giro historiográfico mundial?, Valencia, Publicaciones de la Universitat de Valencia, 2012, pp. 187-199.

177 BURKe, Peter, "Historia cultural de las prácticas intelectuales". En FERNÁNDEZ SEBASTIÁN, Javier, CAPellán de Miguel, Gonzalo, Conceptos politicos, tiempo e historia. Nuevos enfoques en historia conceptual, Madrid, McGraw-Hill Interamericana de España, 2013, p. 131.

178 CAVAllo, Guglielmo y CHARTIER, Roger, Historia de la lectura en el mundo occidental, Madrid, Taurus, 2001.

179 CHARTIER, Roger, El mundo como representación. Estudios sobre historia cultural, Barcelona, Gedisa, 1999, p. I. Otra reflexión acerca de la relación texto-lector en: DARNTON, Robert, "Historia de la lectura". En Peter Burke (Ed.), Formas de hacer historia, Madrid, Alianza Editorial, 1993, pp. 177-208,
} 
Otra esquematización dialéctica que intenta relacionar a los productores de discurso con sus consumidores es la ofrecida por Patrick Charaudeau, quien sostiene que existe un "mundo por comentar", tomado por quien transmite determinadas informaciones, transformándolo así en el "mundo comentado"180. En nuestro análisis de la prensa española, el mundo del lector y el mundo comentado no son investigados y conscientemente nos hemos distanciado de éstos. El argumento de esta separación lo justificó Edward Berenson, quien al reflexionar sobre esa situación explicó que cuando los discursos son apremiantes existen varias posibilidades de que sus consumidores los hagan suyos, sin embargo poco sabemos sobre, "la manera en que las personas van a valorar las informaciones que han recibido o, concretamente, cómo estas informaciones van a influir en sus comportamientos" ${ }^{\prime 181}$.

En nuestro caso, "el mundo del texto" está compuesto por los diarios y revistas recopiladas, así como por los perfiles que intentaron dibujar sobre los países en conflicto. Esa prensa, actuando bajo los principios de la veracidad, informó de problemas contemporáneos, algunos de los cuales estuvieron directamente relacionados con España (situación de la colonia española en el Perú durante la Guerra del Pacífico, aceptación de la reina regente María Cristina para arbitrar el conflicto de Tacna y Arica, espectacularidad de los vuelos del Jesús del Gran Poder y transporte del tratado de 1929), pero distantes espacialmente dificultando el estatus de esa condición.

De todos modos, esa lejanía no impidió entregar factualidad, en términos de Potter, al relato noticioso que, probablemente, se consumió como realidad objetiva. De lo anterior es válido considerar de modo latente dos interrogantes para el estudio “¿Cómo se produce una descripción para que se considere factual?”182, y “¿Cómo se hace parecer sólida, neutral e independiente del hablante, un mero reflejo de algún aspecto del mundo?"183.

\footnotetext{
${ }^{180}$ CHARADEAU, Patrick, El discurso de la información. La construcción del espejo social, Barcelona, Gedisa Editores, 2007, p. 118.

${ }^{181}$ BERENSON, Edward, "La historia cultural americana. La historia cultural de Francia vista desde América". En Philip Poirrier, La historia cultural ¿Un giro historiográfico mundial?, Valencia, Publicacions de la Universitat de Valencia, 2012, p. 77.

${ }_{182}$ POTTER, Jonathan, La representación de la realidad: discurso, retórica y construcción social, Barcelona: PAIDÓS, 1998, p. 13.

${ }^{183}$ Idem.
} 
2.4. Construcción social de la realidad y prensa

El poder constructivo de la prensa española y su papel creador de imágenes en torno a la cuestión chileno-peruana por Tacna y Arica y, por extensión, sobre América, nos permite comprender cómo las palabras escritas en aquella, permitieron, usando una expresión consolidada por la reflexión y la investigación social, “construir la realidad". De esta situación surge la cuestión fundamental en el planteamiento teórico que hemos venido estableciendo desde la historia cultural, para delimitar cómo miraremos las fuentes histórico-hemerográficas. Esta se puede sintetizar en la relación existente entre el estudio de las representaciones sociales, como sistemas socio-cognitivos, y la "construcción social de la realidad", favorecidas por ellas.

La mediación de ese proceso estaría, sin duda, guiada por la prensa histórica española que funcionaría como un "artefacto cultural" que permite y facilita la imaginación y sofisticación o empobrecimiento de los significados con que se mira la "realidad", entendiendo el carácter construido y no ontológico de esta última. Tal afirmación hace comprensible el hecho de que la producción de noticias con sus mensajes y, como lo han sugerido algunos investigadores, sólo con sus titulares ${ }^{184}$, permita "construir una nueva realidad, al punto de que podemos hablar de una realidad inventada, de una realidad desde donde se crean metáforas y grandes relatos sobre la sociedad y el mundo" ${ }^{185}$. La mediación de la prensa, como dijimos, ocurre porque fabrica representaciones sociales de poder en el seno social que la enmarca, haciendo imposible no pensar su estudio atendiendo a las "producciones simbólicas, o más bien, [...] los discursos en tanto representaciones simbólicas"186.

\footnotetext{
${ }^{184}$ BERNAL RodRígueZ, Manuel, "La construcción social de la realidad en los titulares de prensa (Los sucesos de Casa Viejas de 1933 en ABC)". En Herrero Aguado, Carmen, Israel Garzón, Estrella, Espejo Cala, Carmen, Bernal Rodríguez, Manuel, García Gordillo, María del Mar, GonzÁlez Galiana, Rafael, MÉndez GaRCía De PAREDES, Elena, Andalucía como ámbito de interés periodístico, Sevilla, Padilla Libros editores \& libreros, 1998, pp. 71-93; SÁNCHEZ GARCíA, Francisco José, Pragmática de los titulares políticos. Las estrategias implícitas de persuasión ideológica, Madrid, Visor Libros S. L., 2010.

185 APARICI, Roberto, "La construcción de la realidad". En APARICI, Roberto (Coord.), La construcción de la realidad en los medios de comunicación, Madrid, Universidad Nacional de Educación a Distancia, 2010, p. 15.

${ }^{186}$ KIRCHER, Mirta, “La prensa escrita. Actor social y político...”, p. 117.
} 
La prensa analizada, en tanto actor sociopolítico, por medio de la utilización del lenguaje escrito, tiene la capacidad de crear realidades nuevas o mediante la reproducción constante aumentar la densidad de las ya existentes. Esta modalidad "performativa"187 adquiere su consistencia debido a la "objetivación". En el estudio clásico de Berger y Luckmann se explica cómo la producción humana de signos es un caso específico de “objetivación”, al tener ésta una intencionalidad explícita de significados subjetivos. De tal modo que "los sistemas de signos son objetivaciones en el sentido de que son accesibles objetivamente más allá de la expresión de intenciones subjetivas «aquí y ahora»"188. Esa situación hace que el lenguaje sea fundamental para la comprensión de la cotidianidad y de realidades lejanas permitiendo la objetivación de experiencias variadas [...]"189.

Además, el lenguaje trasciende el tiempo presente y el espacio donde se enuncia, es decir, "puedo dialogar con él sobre individuos y colectividades con los que de momento no estamos en interacción «cara a cara» [...] Como resultado de estas trascendencias, el lenguaje es capaz de «hacer presente» una diversidad de objetos que se hayan ausentes [...] Más sencillamente, en cualquier momento puede actualizarse todo el mundo a través del lenguaje" ${ }^{190}$. Ese poder para hacer presente situaciones alejadas de los centros de producción del discurso periodístico, como Madrid o Barcelona por nombrar algunos, permite imaginar las representaciones sociales dispuestas en las hojas de papel que de otro modo resultarían inexistentes.

\footnotetext{
187 Este concepto no tiene una traducción al castellano. La palabra es tomada de su forma en inglés performative la que sugiere la "realización" de los hechos enunciados. Entrecomillamos la última expresión, porque es una adecuación de la palabra "realizativa" que tampoco existe en castellano y sería una traducción de lo que Austin denominó perfomatory. Como lo explicó en un pie de página: "En otras ocasiones usé la palabra «realizatoria» («performatory»), pero ahora prefiero «realizativa» porque es menos fea, más manejable, y porque su formación es más tradicional. En: Austin, J. L., Cómo hacer cosas con palabras, Santiago, Escuela de Filosofía Universidad ARCIS, Edición electrónica de www.philosophia.cl, 2009, p. 6. Lo que interesa considerar aquí es cómo los estudios de Austin demostraron otra dimensión del lenguaje aparte de las ya sabidas lógica, semántica y representativa- denominada "performativa" que estaría "unida a la fuerza ilocucionaria del acto mismo de decir algo". En: HeRRERo CECILIA, Juan, Teorías de pragmática, de lingüística textual y de análisis del discurso, Cuenca: Ediciones de la Universidad de Castilla-La Mancha, 2006, p. 51. Lo "ilocucionario", palabra inexistente también en el castellano nos remite a lo ilocutivo, es decir, aquello "considerado en función de la intención del hablante al emitirlo [...]". En: $<$ http://dle.rae.es/?id=Kz0Vifv $>$ [consultado el: 30/01/2016].

188 Berger, Peter y LuCKMAnN, Thomas, La construcción social de la realidad, Buenos Aires, Talleres Gráficos Color EFE, 2003, p. 52.

189 Íbidem, p. 55.

190 Íbidem, p. 56.
} 
Al lograr la vitalidad de aquellas, no caben dudas que las noticias textuales estudiadas aquí conectan diferentes partes de la "realidad" en la cotidianidad uniendo territorios, dialogando con "individuos y colectividades con los que de momento no estamos en interacción cara a cara"191. Todas estas situaciones imaginarias se vuelven posibles por el lenguaje compartido que define el mundo que rodea, clasifica y describe esa realidad, dando "voz a nuestra fantasía"192 y vitalizando "proyecciones que van más allá del hecho vivido" 193 . Esa realidad social fabricada y representada por la prensa puede ser, según Abric, tomada grupalmente y "reconstruida en el sistema cognitivo, integrada en su sistema de valores, que depende de su historia y el contexto social e ideológico" ${ }^{194}$. Como la percepción del mundo se realiza sobre una red de estereotipos variable de una cultura a otra, interesa también considerar el papel de la prensa española en la difusión de información o "desinformación"195.

Peter Burke, se ha encargado de fortalecer los vínculos entre la historia y las "representaciones sociales" y de profundizar en cómo el lenguaje constituye una forma de hacer por ser "una fuerza activa dentro de la sociedad"196. Esa cualidad podría equipararse con el papel productor y transmisor sígnico realizado por la prensa española en su calidad de "semióforo"197. Su análisis histórico permite considerar los "intereses, los valores, las representaciones y las creencias que reflejan la forma en que se concibe el mundo"198.

\footnotetext{
191 Íbidem, p. 54.

192 AIME, Marco, Cultura, p. 29.

${ }^{193}$ Idem.

${ }^{194}$ ABRIC, Jean-Claude, Prácticas sociales y representaciones, México, Ediciones Coyoacán, 2001, p. 12.

195 BuRKe, Peter, Historia social del conocimiento. De la Enciclopedia a la Wikipedia, volumen II, Barcelona, Paidós orígenes, 2012, p. 122.

${ }^{196}$ BuRKe, Peter, Funciones sociales del lenguaje a través de la historia, Madrid, Alianza Editorial, 1996, p. 38; BuRKe, Peter, ¿Qué es historia cultural?..., p. 85.

${ }^{197}$ Los semióforos son "objetos reconocidos en una sociedad dada como portadores de significados y por lo tanto fabricados o expuestos con el fin de dirigirse a la mirada, bien de manera exclusiva, bien conservando una función utilitaria", por ejemplo, "escritos de todo tipo, manuscritos e impresos". Para analizarlos, Pomian explicó: los semióforos se pueden estudiar y comparar desde dos aspectos: el material y el significante. En el primer caso, se tratan como producciones naturales o cosas. Sólo en el segundo caso se tiene en cuenta su especificidad. Pero los significados son transmitidos mediante imágenes y textos; es el tratamiento de una cosa para convertirla en imagen, exponiéndola a la mirada e impidiendo que se utilice, lo que transforma esta cosa en semióforo". En: PomiAn, K. Sobre la historia, Madrid, Cátedra, 1999, pp. 110-111. Una interpretación de este concepto resumió: "un objeto visible cargado de significación, algo que el libro plasmaría con total claridad”. En: SERNA, Justo y PONS, Anaclet, La historia cultural. Autores, obras y lugares, Madrid, Ediciones Akal S. A., 2005, p. 213.

198 GARCía GonZÁlez, Gloria M., Anotaciones para una reflexión sobre la historia de la prensa y de la comunicación en España, Studia Zamorensia n. ${ }^{\circ}$ 2, 1995, p. 192.
} 
El mismo Burke afirmaría, tiempo después, "Nuestras mentes no reflejan la realidad de manera directa. Percibimos el mundo sólo a través de una red de convenciones, esquemas y estereotipos, red que varía de una cultura a otra"199. Esos reflejos indirectos permitirían a los grupos sociales dotar de sentido las pautas de conducta de los demás, pero también "entender la realidad mediante su propio sistema de referencias"200.

La importancia de las "representaciones sociales" para la historia cultural es manifiesta. No es extraño entonces que el número de obras basadas en ese campo teórico muestre elevada producción. Además, un foco puntual de ese interés se sitúa sobre el estudio de los "otros", como las praxis políticas de las repúblicas involucradas en el diferendo. Sobre éstas se desarrollaron "modos estereotipados de percibir y describir [esa] cultura desconocida"201. Esos modos de comprensión, visibilizados por la escritura transmitieron valores y creencias "entre pueblos lejanos y generaciones separadas"202. En fin, sólo con la producción incesante de ese "otro" se construye el "nosotros", pues la identidad nacional, así como los diversos tipos de identidades culturales, es una abstracción relacional, es decir, "No hay identidad sin alteridad: somos lo que los otros no son"203.

En el extremo, los organismos sociales ocupados en la producción y la transmisión sígnica podrían representar la realidad "falsificando" totalmente la historia. Esto ocurriría cuando el mundo que es presentado en las noticias "no tiene la más mínima relación con la realidad, ya que la verdad sobre cada asunto queda enterrada bajo montañas de mentiras" 204 . En efecto, los diarios podrían ser las herramientas usadas para legitimar una visión sobre el conflicto chileno-peruano y, por extensión, América. De tal modo se facilitaría el conocimiento de una porción del continente mediante un acto de "magia social" consistente en producir la existencia de lo nombrado ${ }^{205}$.

\footnotetext{
199 BURKe, Peter, "Obertura: la nueva historia, su pasado y su futuro". En BuRKE, Peter, Formas de hacer Historia, Madrid, Alianza Editorial, 1996, p. 18.

${ }^{200}$ ABRIC, Jean-Claude, Prácticas sociales..., p. 13.

${ }^{201}$ BURKE, Peter, ¿Qué es historia cultural?..., p. 85.

202 HeRnÁNDEZ SANDOICA, Elena, Tendencias historiográficas actuales. Escribir historia hoy, Madrid, Akal, 2004, pp. 329-330.

${ }^{203}$ AIME, Marco, Cultura, pp. 105-106.

${ }^{204}$ ChOMSKY, Noam y RAMOnet, Ignacio, Cómo nos venden la moto, Barcelona, Icaria, 2010, p. 27.

${ }^{205}$ BOURDIEU, Pierre, ¿Qué significa hablar?, Madrid, Akal D. L., 1985, p. 90.
} 
Partimos aquí de la base que la prensa es un actor social con voz autorizada para declamar "verdades" de temas conflictivos, como, por ejemplo, una guerra y las consecuencias de ésta. De todos modos, no estamos en condiciones de sustentar con documentación histórica la intención -explícita- de construir representaciones sociales positivas o negativas culturalmente hacia Chile, Perú, Bolivia o Estados Unidos a propósito de la cuestión tacno-ariqueña. Tal situación, como veremos, no inhabilitará sus elaboraciones.

De todos modos, siempre es conveniente para el enriquecimiento de los análisis históricos de prensa sospechar de los medios utilizados. Esta "metodología de la sospecha" fue comentada por Melvin De Fleur y Sandra Ball-Rokeach después de estudiar a Walter Lippmann. Los investigadores escribieron: "la cuestión más importante de Lippmann era que las representaciones de la prensa eran a menudo espurias en el sentido que confundía o creaban imágenes en nuestras cabezas, distorsionadas o incluso completamente falsas sobre el mundo exterior" 206 .

\subsection{Representaciones sociales y prensa}

Las "representaciones sociales" han sido definidas por varios autores siguiendo la tradición inaugurada por Serge Moscovici, quien las entendió como "una modalidad particular del conocimiento, cuya función es la elaboración de los comportamientos y la comunicación entre individuos"207. Su propuesta no estuvo exenta de críticas ${ }^{208}$. También pueden entenderse como conocimientos organizados que hacen comprensible la realidad físico-social, integrando el sujeto al grupo liberándolo de "los poderes de su imaginación" 209 o, como lo aseguró en su otoño el rumano, de su “invisibilidad"210.

\footnotetext{
${ }^{206}$ De FleUr, Melvin y BALl-RoKeACH, Sandra, Teorías de la comunicación de masas, Barcelona, Ediciones Paidós Ibérica, S. A. 1993, p. 336.

${ }^{207}$ Cegarra, José, "Fundamentos teórico epistemológicos de los imaginarios sociales". Cinta de Moebio. Revista de epistemología de ciencias sociales, n. $^{\circ} 43,2012$, p. 3.

208 CASTORINA, José y BARREIRO, Alicia, "Las representaciones sociales y su horizonte ideológico: Una relación problemática”, Boletín de psicología, n. ${ }^{\circ} 86,2006$.

${ }^{209}$ CEgARRA, José, Fundamentos..., p. 3.

210 Moscovici, Serge, "Prefacio". En Ángel Arruda y María del Alba (Coords.), Espacios imaginarios y representaciones sociales. Aportes desde Latinoamérica, Barcelona, Anthropos, 2007, p. 10.
} 
Aún cuando el origen científico de esa teoría esté vinculado a la psicología social, el uso extendido a otras áreas de las ciencias sociales es evidente, por lo menos en las últimas tres décadas. Las "representaciones sociales" nos permiten comprender cómo la sociedad llega a pensar sobre uno o varios temas fundamentales para su existencia y mantenimiento; quiénes favorecen la visibilidad de ese tipo de temas, así como la invisibilidad de otros; mediante qué tipos de canales de comunicación se logra la transmisión de los conocimientos que permiten tales pensamientos, etc. Tales consideraciones nos sitúan en el centro del debate sobre la creación sistemática de representaciones sociales por el poder de la cultura escritural, pues logra definir temas de relevancia social, adjudicando valores identificables para sociedades "extranjeras" o grupos intra-sociales.

Asumiendo la complejidad por asir las "representaciones sociales" de un modo concreto y definitivo, puesto que además poseen cierto dinamismo en la sociedad donde circulan, exponemos algunas ideas que guiarán nuestra comprensión de éstas. Los siguientes conceptos se sugiere utilizarlos en un sentido operativo, puesto que no es el objetivo de esta investigación ofrecer un nuevo enfoque de la teoría de las representaciones sociales, puesto que para esto deberíamos cruzar de disciplina hacia la psicología social o la sociología, por mencionar sólo algunas. Conviene, por el contrario, afirmar con rigor metodológico y fidelidad a los textos de las fuentes, que la constitución y solidificación de representaciones sociales elaborada por la prensa española desentrañará "lo implícito y lo explícito a partir de las evidencias [...] sin llegar al delirio interpretativo"211. Entenderemos por "representaciones sociales" las cinco propuestas que siguen:

a) “[...] programas de percepción, construcciones con estatus de teoría ingenua, que sirven de guía para la acción e instrumento de lectura de la realidad; sistemas de significaciones que permiten interpretar el curso de los acontecimientos y las relaciones sociales; que expresan la relación que los individuos y los grupos mantienen con el mundo y los otros, que son forjadas en la interacción y el contacto con los discursos que circulan en el espacio público; que están inscritas en el lenguaje y las prácticas; y que funcionan como un lenguaje en razón de su función simbólica y de los marcos que proporcionan para codificar y categorizar lo que compone el universo de la vida",212.

\footnotetext{
211 CORVALÁn, Facundo, "50 años de representaciones sociales y psicología: campo Psy, bifurcaciones y desafíos”, ECOS Estudos contemporaneos da subjetividade, n. ${ }^{\circ} 1,2013$, p. 125.

212 Jodelet, Denis y GuERrero, Alfredo, Develando la cultura. Estudios en representaciones sociales. México, Universidad Nacional Autónoma de México, 2000, p. 10.
} 
b) "Una visión funcional del mundo que permite al individuo o al grupo conferir sentido a las conductas y entender la realidad mediante su propio sistema de referencias" ${ }^{\text {"213. }}$.

c) [...] sistemas cognitivos en los que es posible reconocer la presencia de estereotipos, opiniones, valores y normas que suelen tener una orientación actitudinal positiva o negativa" 214 .

d) El fenómeno de las representaciones sociales se ubica en la interfase de lo psicológico y lo social, de lo simbólico y de lo real, concurriendo a la construcción social de la realidad [que enfatiza] sobre la construcción del conocimiento en la vida cotidiana, por lo que podríamos decir que su teoría es una suerte de epistemología del sentido común [...] Así mismo, al estudiarlas, nos proponemos conocer, por un lado, lo que piensa la gente y cómo llega a pensar así, y por otro lado, la manera en que los individuos conjuntamente construyen su realidad y, al hacerlo, se construyen a sí mismos [...] El lenguaje juega un papel de fundamental importancia en la transmisión, comunicación y permanente reconstrucción de símbolos y significados [puesto que] permiten la comunicación al proveer un código para el intercambio social y un código para nombrar y clasificar los diversos aspectos del mundo y de la historia individual y grupal [...]. Se arraigan en la cultura, entendida como una construcción social, es decir, como patrones estructurados de significados sucesivamente legitimados por las diversas formas de relaciones y prácticas sociales" 215 .

e) El primer aspecto que caracteriza a las representaciones sociales es como una «imagen»: a) estructurada, b) cognitiva, afectiva, evaluativa y operativa, c) metafórica o icónica de $d$ ) los fenómenos socialmente relevantes" ${ }^{\text {"216 }}$.

En rigor, esta investigación tiene como finalidad establecer las ideas generales y específicas que el problema de Tacna y Arica creó en la prensa española. Esta situación, compleja, por variadas razones, entre ellas la lejanía del conflicto, la relación e interés más sentimental que de acción política, no impidió construir representaciones sociales sobre el conflicto. Pero esa complejidad no se detuvo allí. Como lo hemos sugerido, la prensa al trazar las líneas gruesas del conflicto y bosquejar un modelo identificable, fue generando a la par otros tipos de representaciones sociales que entenderemos como subsidiarias de la primera. Esas representaciones sociales son apéndices de la principal, pero, no cabe duda, que facilitan la comprensión de la primera. Tales representaciones secundarias se refieren a un problema fundamental, el de las identidades nacionales, pues el problema de Tacna y Arica tenía su centro de energía en una cuestión de índole nacional.

\footnotetext{
213 ABRIC, Jean-Claude, Prácticas sociales y representaciones. México, Ediciones Coyoacán, 2001, p. 13.

214 ARAYA, Sandra, "Las representaciones sociales: ejes teóricos para su discusión”, Cuadernos de ciencias sociales, n. ${ }^{\circ} 127,2002$, p. 11.

215 BANChS, María, AgUdo, Álvaro y AstorgA, Lislie, "Imaginarios, representaciones y memoria social”. En ARrudA, Ángela y DE AlBA, Martha, Espacios imaginarios y representaciones sociales. Aportes desde Latinoamérica, Barcelona, Anthropos Editorial, 2007, pp. 62-64.

216 WAGNER, Wolfgang y HAYES, Nicky, El discurso de lo cotidiano y el sentido común. La teoría de las representaciones sociales, Barcelona, Anthropos Editorial, 2011, p. 69.
} 
La prensa, al referirse a la cuestión de Tacna y Arica, hablaba obligatoriamente de Chile y Perú, los actores principales de la "tragedia", pero también de Bolivia-quien deseó una salida al océano Pacífico desde inicios del siglo XX por Arica- al pensar ese territorio como el puente histórico que unía desde la época española las tierras altas de Potosí con el mar. Por último, las referencias sobre los Estados Unidos por sus insistentes sugerencias de prestar "buenos oficios" diplomáticos en la resolución del litis y las relacionadas con la política exterior de España en la disputa nos permiten pensar, por plantearlo metafóricamente, en un caleidoscopio donde el tubo sería el largo proceso de definición de la frontera y los espejos, los países involucrados.

\subsection{Identidades nacionales}

Finalmente resta definir qué entenderemos por nacionalismo, pues ese concepto compone absolutamente la identidad nacional de los países estudiados. Ernest Gellner, desde la filosofía, explicó que el nacionalismo es "un principio político que sostiene que debe haber congruencia entre la unidad nacional y política”217. Esa situación era más constatable en la España del cambio de siglo que en Chile, Perú y Bolivia, donde la litis tensionaba tal principio. Para referirnos a las identidades nacionales de esos países usaremos los términos coloquiales de "chilenidad", "peruanidad" y "bolivianidad". Cuando hablemos de la identidad nacional de España usaremos "hispanidad". En el caso de los Estados Unidos de Norteamérica evitaremos el equívoco "americanidad" de uso europeo, recurriendo sólo cuando sea necesario al término cacofónico "estadounidensidad".

Como ha sido tradicional, un grupo importante de investigaciones referidas a las "representaciones sociales" de la identidad nacional de los países aquí considerados tienen como objeto de estudio comprender el proceso interno de construcción nacional, es decir, cómo dentro de sus propias fronteras estatales se ha conformado lo nacional. En el caso chileno esas obras han detectado cómo se ha pensado y manifestado la "chilenidad" en las clases dominantes de la sociedad, expandiendo posteriormente esa sentimentalidad nacional hacia las clases populares y cómo éstas han imaginado la nación rearticulando algunos saberes nacionalistas sin grandes matices.

${ }^{217}$ GELlNER, Ernest, Naciones y nacionalismo, España, Alianza Editorial, 2001, p. 13. 
Esta perspectiva "sociohistórica-introspectiva", como la hemos denominado, puede ser enriquecida con aproximaciones situadas, como la nuestra, sobre las "representaciones sociales” externas de los países. ¿Cómo se ve desde España, Chile, Perú o Bolivia? Puede ser una pregunta que circule actualmente por foros económicos para conocer en qué países invertir con menos dificultades bajo un contexto neoliberal. Para nosotros, por el contrario, es interesante preguntarnos, desde la historia, cómo se imaginó en la prensa de España el problema de las fronteras aludido y qué rasgos se adjudicaron a los países envueltos en aquel. Este no es un estudio de historia económica, como hemos explicado con anterioridad.

Anthony Smith refiere la importancia de la guerra en la creación de la comunidad nacional y propone "recordar cómo las comunidades étnicas y nacionales han reforzado su sentimiento de identidad colectiva, mediante la movilización de hombres, enemistades sostenidas y amenazas de guerra" 218 . Lo anterior incita a pensar en "cómo los recuerdos y mitos surgidos a partir de batallas contribuyeron a crear una sensación de unidad étnica o nacional"219. Así, la "religión de la historia" es concebida por Smith como una herramienta de poder estatal con el fin de intentar labrarse un futuro a imagen y semejanza del pasado, pero "no de cualquier pasado, por supuesto, sólo del auténtico pasado, el pasado genuino de un pueblo en su tierra natal" 220 .

Ese pasado, en el caso español, entendía los vínculos históricos con los dominios ultramarinos americanos y con los sangrientos episodios bélicos que conducirían hacia la emancipación de los antiguos territorios de la Corona. De ahí que la prensa sintiera una atención especial por el conflicto de límites entre Chile y Perú, pues ambos, durante la época aludida, formaron parte de su Estado-Nación. El nacionalismo, según Smith, es elaborado canónicamente en grupos de poder selectos de la sociedad donde se desarrolla. Estos grupos pueden ser considerados como una intelligentsia liderada por intelectuales que configuran, consumen y ofrecen la mitología nacionalista elaborada. Tal sería el caso de la prensa española aquí estudiada quien mediante sus reflexiones y publicaciones cotidianas proveyó a la sociedad nacional lectora de informaciones relativas a territorios americanos.

\footnotetext{
${ }^{218}$ SMITH, Anthony, Nacionalismo y modernidad, España, Istmo, 2000, p. 153.

${ }^{219}$ Idem.

${ }^{220}$ SMITH, Anthony, Nacionalismo..., p. 207.
} 
Por eso también es importante recalcar el entendimiento de la prensa española como un "artefacto cultural", en tanto mecanismo constructor de nacionalidad. Sin sumergirnos en el debate antiguo sobre su rol como cuarto poder del Estado, creemos que es legítimo entender la prensa española, en general, como una herramienta intelectual a disposición de una elite. Es importante, además, considerar que un artefacto cultural, luego de su creación y circulación por la sociedad tiene la potencialidad de transformarse en "modular", es decir, tener capacidad de ser trasplantado a diversos espacios y, con esto, a diversas gentes con "grados variables de autoconciencia, a una gran diversidad de terrenos sociales, de mezclarse con una diversidad correspondiente amplia de constelaciones políticas e ideológicas" 221 .

Por otro lado, habrá pocas dudas habrán respecto del error cometido al considerar la importancia exclusiva del nacionalismo para la política. Al contrario, como lo ha demostrado Smith, el nacionalismo, lejos de estar limitado al mundo de la política, es a la vez cultural e intelectual. Ambas características explican el papel del nacionalismo en la estructuración de "nuestros puntos de vista globales y nuestros sistemas simbólicos"222. La creación de esas visiones y simbologías ha estado tradicionalmente a cargo de grupos intelectuales de gran influencia dentro de los límites del Estado quienes dedican su potencial intelectual "a descubrir y representar las identidades e imágenes de sus respectivas naciones" 223 . Pero también, habría que agregar, de aquellas naciones vecinas y lejanas con las cuales se compartían vínculos históricos, religiosos y lingüísticos, como de hecho fue la relación entre los países involucrados en el conflicto de Tacna y Arica. Las constataciones anteriores hicieron reflexionar a Smith en los siguientes términos:

Todo esto sugiere que es necesario prestar mucha atención al papel que desempeñan los elementos simbólicos del lenguaje y en la ideología y la moral del nacionalismo, así como los aspectos rituales y emocionales del discurso y la acción de la nación. No basta con poner en relación un discurso nacional(ista) concreto con unos grupos sociales o unos actores políticos determinados [...]. El nacionalismo tiene sus propias reglas, ritmos y recuerdos, que modelan los intereses de sus seguidores $[\ldots]^{224}$.

\footnotetext{
221 ANDERSON, Benedict, Comunidades imaginadas. Reflexiones sobre el origen y la difusión del nacionalismo, México, FCE, 1993, p. 21.

${ }^{222}$ SMITH, Anthony D., Nacionalismo. Teoría, ideología, historia, Madrid, Alianza Editorial, 2001, p. 14.

223 Íbidem, p. 15.

${ }^{224}$ Idem.
} 
Los aportes realizados por la prensa española a la promoción de la hispanidad se evidencian en la estandarización de la alteridad. Los "otros", como dijimos, fueron los Estados partícipes del diferendo, sobre quienes la prensa construyó representaciones que transformaron (o no) la percepción de la comunidad lectora. La prensa, sea estatal o privada, intenta homogeneizar las ideologías, realizando "propaganda deliberada"225, en nuestro caso analizado, de carácter nacional. Ese medio, puntualmente, facilita su técnica moderna e industrializada para socializar, por vía de la representación, la "clase de comunidad imaginada que es la nación"226. Tal diseminación de representaciones simbólicas, en síntesis, apoyan la construcción de la nación ${ }^{227}$, pues sus significados se aprenden gracias a la proyección realizada desde la imprenta a la sociedad.

\footnotetext{
${ }^{225}$ HoBSBAwM, Eric, Naciones y nacionalismos desde 1780, Barcelona, Crítica, 1998, p. 151.

${ }^{226}$ ANDERSON, Benedict, Comunidades imaginadas..., p. 47.

${ }^{227}$ SMITH, Anthony, “¿Gastronomía o geología? El rol del nacionalismo en la reconstrucción de las naciones”. En Fernández Bravo, Álvaro (Comp.), La invención de la nación. Lectura de la identidad de Herder a Homi Bhabha, Buenos Aires, Manantial, 2000, p. 190.
} 


\section{FUENTES Y METODOLOGÍA}

\subsection{Consideraciones heurísticas}

La heurística tiene un lugar central en la historia desde la época de su institucionalización como ciencia. A Leopold Von Ranke, historiador alemán, se debe la introducción del concepto Heuristik en la disciplina, relacionándola a documentos "escritos", los únicos que permitirían comprender las acciones de los sujetos históricos. El prusiano "definió la historia como una disciplina heurística asignándole como finalidad primera la búsqueda de la objetividad"228.

En ese contexto científico caracterizado por la objetividad de las investigaciones históricas, Charles Langlois y Charles Seignobos en 1898 dedicaron el primer capítulo de su Introducción a los estudios históricos a la heurística. La entendieron, en líneas generales, como la búsqueda documental. Enfatizando la importancia de las fuentes para la historia, señalaron cómo sin ellas se corría el riesgo de que periodos históricos se volviesen enigmáticos. Para evitarlo, se debe "averiguar si contamos con documentos, y en caso afirmativo, con cuántos y dónde se encuentran"229.

A pesar del tiempo transcurrido desde la primera edición de Introducción..., tiene plena vigencia el juicio respecto a la gran cantidad de documentos disponibles para los historiadores, lo que debiera repercutir, idealmente, en una elección y análisis adecuado. La heurística -escribieron a finales del siglo XIX- "resulta hoy mucho más fácil que en otras épocas" ${ }^{230}$. Si bien son conocidas las críticas contra la historiografía positivista y sus cultores, es innegable que la relevancia asignada a las fuentes, en tanto soporte material de su escritura, es deudora de esa tradición científica. Tal constatación ha permitido asegurar que el positivismo historiográfico eliminó "la fantasía de la narrativa histórica"231, debilitando "decisivamente las adhesiones metafísicas"232.

\footnotetext{
${ }^{228}$ Burguière, André, Diccionario Akal de ciencias históricas, Madrid, Ediciones Akal, S. A., 1991, p. 581.

229 Langlois, Charles-V. y SeIGnobos, Charles, Introducción a los estudios históricos. En SEVILLANO CALERO, Francisco, Salamanca, Universidad de Alicante, 2003, p. 59.

230 Íbidem, p. 60.

${ }^{231}$ MORAL RuÍz, Joaquín del, Historia y ciencias humanas. Sobre metodología y didáctica, Madrid, Huerga y Fierro Editores, S. L., 1999.

232 Íbidem, p. 37.
} 
La historiografía posterior instaló en la comunidad científica la certeza de que la crítica de las fuentes o "técnica de la investigación histórica"233 y la heurística como técnica ${ }^{234}$ o "manejo escrupuloso de las fuentes"235, obligaban al historiador detallar qué fuentes validaban sus interpretaciones ${ }^{236}$, además de preguntarse por las características primarias y secundarias de aquellas (lugar de producción e importancia de su publicación en la sociedad estudiada). En relación con lo anterior, La heurística también ha sido entendida como "método heurístico"237, prescribiendo localizar, clasificar y comparar fuentes. La inicial debería encontrarse en todo trabajo histórico-científico ${ }^{238}$. Por eso, Barona afirmó: "la primera tarea que se debe plantear es la heurística o de localización de fuentes"239, las cuales podrían ser primarias o secundarias.

Nuestra investigación comprueba la hipótesis utilizando fuentes primarias, sin descuidar las secundarias, que revelan el estado de la cuestión ${ }^{240}$ y ayudan a plantear preguntas relevantes en la investigación. Heurística sería saber preguntar, buscar, localizar y describir documentos, una labor "estratégica que nos enfrenta a uno de los aspectos más instrumentales de esta disciplina: el acceso a las fuentes"241. Romo puntualizará: "la heurística consiste en interrogarse por qué materiales y de qué especie nos permitirán perseguir los hilos que se entrelazan en la pregunta que nos formulamos" 242 .

\footnotetext{
${ }^{233}$ OSSIO SANJINÉS, Luís, Introducción a la teoría de la historia, La Paz, Librería Editorial Juventud, 1981, p. 57.

${ }^{234}$ PRIORA, Juan Carlos, "La arqueología como ciencia que confiere veracidad a un documento histórico". En GALleti, Amelia, Hablemos de historia. Cuestiones teóricas y metodológicas de la historia, Paraná, Editorial de Entre Ríos, 2006, p. 83.

${ }^{235}$ MORAL Ruíz, Joaquín del, Historia y ciencias humanas. Sobre metodología y didáctica, Madrid, Huerga y Fierro Editores, S. L., 1999, p. 37.

${ }^{236}$ VELASCO GÓMEZ, Ambrosio, "Introducción: perspectivas y horizontes de la heurística en las ciencias y las humanidades". En Velasco GóMEZ, Ambrosio (Coord.), El concepto de heurística en las ciencias y las humanidades, México, Siglo XXI Editores, 2000, p. 9.

237 Quintero L., Gilberto R., "Los fundamentos de la historia como disciplina científica". En LÓPEZ BohóRquez, Alí Enrique (Coordinador), En búsqueda de la historia. Memorias de las Iras Jornadas de Investigación de Escuela de Historia. Homenaje al Dr. Eduardo Arcila Farías, Venezuela, Consejo de Publicaciones de la Universidad de los Andes, 1998, p. 61.

${ }^{238}$ Barona, Josep Lluís, Ciencia e Historia, Debates y tendencias en la historiografia de la ciencia, Godella, Seminari d'Estudis sobre la Ciència, 1994, p. 69.

${ }^{239}$ Idem.

${ }^{240}$ Idem.

241 ARIAS SERRANO, Laura, Las fuentes de la historia del arte en la época contemporánea, Barcelona, Ediciones del Serbal, 2012.

${ }^{242}$ Romo FeITO, Fernando, “Escucho con mis ojos a los muertos”. La odisea de la interpretación literaria, Madrid, Consejo Superior de Investigaciones Científicas. Instituto de Lengua, Literatura, Antropología, 2008, p. 196.
} 
A nuestro juicio, la dispersión conceptual de la heurística provoca una reflexión epistemológica doble sobre la historia. La primera, de carácter peligroso, supondría que el nexo entre la formulación de interrogantes y las fuentes estaría dado por la existencia de esas, debilitando, en efecto, la creatividad del historiador. Lo cierto es que en ocasiones la relación interrogantes-fuentes no siempre es visible, existiendo interrogantes históricas de corte intercontinental como la planteada en esta investigación.

La segunda, de carácter creativo, pero de ningún modo superior a la anterior, motiva al historiador a "descubrir" fuentes que respondan a determinados problemas, a condición de que "las fuentes de conocimientos de los hechos [...] puedan reducirse a la palabra escrita" ${ }^{243}$. En la situación de las fuentes hemerográficas españolas, más que la reducción de los conocimientos a la palabra, interesa ampliar la comprensión de los significados de esas dentro de un contexto histórico.

La heurística, debido a su polisemia y anfibología, necesita situarse con exactitud dentro del marco de la historiografía y, a la vez, delimitar qué tipo de fuentes se localizan para interpretar. Como se sabe, las fuentes de la historia, a diferencia de lo pensado en el pasado, pueden ser escritas o no. Nuestro estudio se centra en las escritas y particularmente en las producidas por la prensa española referida al problema de Tacna y Arica. En concreto, por sus implicancias técnicas y reflexivas adherimos a la definición de heurística citada a continuación in extenso:

[...] la heurística consiste en el estudio del descubrimiento y la invención; mejor aún, de la invención y del descubrimiento debidos a la reflexión y no al azar. En consecuencia, todos los factores y elementos extrarracionales o irracionales que juegan un papel en la invención y el descubrimiento deben quedar por fuera de la heurística. [...] El problema grueso al que al mismo tiempo responde la heurística y que lo constituye consiste, por tanto, en cómo renovar el pensamiento, esto es, cómo modificar las estructuras mentales adquiridas y obtener ideas nuevas [...] Pues bien, de manera puntual: cómo modificar las estructuras mentales y renovar el pensamiento constituye, sin lugar a dudas, el principal problema científico, filosófico y político del mundo del siglo XXI $[\ldots]^{244}$.

\footnotetext{
${ }^{243}$ Matute, Álvaro, Heurística e historia, México, Centro de Investigaciones Interdisciplinarias en Ciencias y Humanidades, 1999, p. 149.

${ }^{244}$ MALDONADO, Carlos Eduardo, "Heurística y producción de conocimiento nuevo en la perspectiva CTS". En HeRnÁndez GARCÍA, Iliana (Compiladora), Estética, ciencia y tecnología. Creaciones electrónicas y numéricas, Colombia, Editorial Pontificia Universidad Javeriana, 2005, pp. 101-107.
} 
En otras ocasiones discutimos aspectos heurísticos referidos a la prensa española durante la cuestión Tacno-ariqueña en una temporalidad menor a la tratada aquí ${ }^{245}$. Al ampliarla, la fuente mantiene su valía y potencial para la historia cultural de la prensa. Esas aptitudes no requieren una defensa a priori, ya realizada con claridad por Tuñón de Lara ${ }^{246}$ y Rivas ${ }^{247}$, en España y Chile, respectivamente. Si bien otros especialistas se han referido a esa condición, la prensa localizada para esta investigación exige, de todos modos, una serie de consideraciones.

\subsection{Fuentes}

En primer lugar, la búsqueda de noticias relacionadas con la cuestión fronteriza se realizó a partir de los fondos de la Hemeroteca Digital de la Biblioteca Nacional de España. El motor de búsqueda con el que cuenta el investigador nos permitió identificar las noticias relacionadas con Tacna y Arica y puso en evidencia que las registros sobre "Chile" y "Perú" no siempre guardaban relación con nuestro objeto de estudio. De hecho, las publicaciones relacionadas con Chile y Perú durante el período 1880-1929 eran 8024 y 5566, respectivamente. En segundo lugar, es importante comprender la producción de noticias de un conflicto internacional o extranjero, visto desde España. Las narrativas diferentes entre noticias "nacionales" y las que contaban lo sucedido allende las fronteras, es evidente.

\footnotetext{
245 SOTO LARA, José Julián, "La prensa española como fuente histórica para el problema de Tacna y Arica (1880-1901): heurística y método", Tordesillas Revista de Investigación Multidisciplinar, n. ${ }^{\circ}$ 7, 2014, pp. 2542; SоTo LARA, José Julián, "El arbitraje de España de 1898 en la cuestión de Tacna y Arica: estado del arte y perspectivas heurísticas, Realidades y perspectivas de jóvenes investigadores. Nuevas fronteras de investigación. Actas Coloquios EChF, n. ${ }^{\circ}$ 7, París, Ediciones EChF, 2015, pp. 145-172.

${ }^{246} \mathrm{La}$ prensa puede ser una fuente de información sobre cuestiones precisas o "una fuente para expresar corrientes de opinión, actitudes políticas e ideológicas; también una fuente que recoge la mentalidad de una época [...] En fin, la prensa es en sí misma objeto de una historia; en este último caso el periódico es objeto y fuente a la vez". Ver: RAMOS SANTANA, Alberto, "La vida cotidiana en el Cádiz de las Cortes. El recurso a la prensa como fuente para su estudio". En CANTOS CASENAVE, Marieta, DurÁn LóPEZ, Fernando, ROMERO FERRERO, Alberto (Eds.), La Guerra de pluma. Estudios sobre la prensa de Cádiz en el tiempo de las cortes (1810-1814). Tomo III. Sociedad, consumo y vida cotidiana, España, Universidad de Cádiz-Servicio de Publicaciones, 2008, p. 48.

247 RIVAS, Fernando, "La prensa escrita como documento histórico: cuidado, prevenciones y consideraciones", En SANTANDER Molina, Pedro (Editor), Analizando los medios y la comunicación. Teoría y métodos, Chile, Pontificia Universidad Católica de Valparaíso, 2009, pp. 51-64.
} 
Por ejemplo, las producciones periodísticas españolas respecto de la Guerra hispano-estadounidense distaban de las publicadas sobre la cuestión por la prensa chilena. Lo mismo sucedió con las noticias sobre la Guerra del Pacífico entre Chile, Perú y Bolivia al revisar diarios de esos países y, también de España. En esas distorsiones, el contexto de producción "nacional" y, en efecto, las identidades nacionales en conflicto, determinan diferencias en la transmisión, recepción e interpretación de las noticias. Su "naturaleza", sería involuntaria e inevitable, formando, "parte esencial de la actividad periodística" 248 . En ese oficio, los contenidos proposicionales expresados en actos de "referencia" y "predicación" diferirían en los casos nacionales e internacionales, puntualmente en la caracterización de lo referido por el hecho de compartir o no valores y normas sociales. Eso llevaría, en situaciones nacionales, a hacer un uso mayor de actos "perlocutivos" que buscarían, entre otras cosas, persuadir a los lectores ${ }^{249}$.

En tercer lugar, las distancias geográficas entre los acontecimientos publicados por la prensa y los profesionales, es decir, los operarios "intérpretes" de agencias americanas, por un lado, y las imprentas españolas, por otro, determinan la existencia de ruidos que podrían, eventualmente, dificultar la veracidad de los originales. El "ruido psicológico" producido por "pensamientos distractores" se podría presentar en cualquier punto de la relación planteada. Es, en palabras de Schiffman y Kanuk, una barrera a la comunicación $^{250}$.

El problema de la distancia guarda relación con los avances o retrocesos de una industria de la prensa que no satisfacía la necesidad de información de acontecimientos americanos. No siendo objetivo de esta investigación los cambios tecnológicos, consideramos que el seguimiento durante medio siglo de un conflicto del Nuevo Mundo, podría dar algunas luces al respecto, por lo menos al fijarnos en el aumento evidente del número de noticias.

\footnotetext{
${ }^{248}$ Boni, Federico, Teoría de los medios de comunicación, Barcelona, Universitat Autònoma de Barcelona. Servei de Publicacions; Castelló de la Plana, Publicaciones de la Universitat Jaume I; Barcelona, Universitat Pompeu Fabra; València, Publicacions de la Universitat de València, 2008, p. 109.

249 AKMAJIAN, Adrian, DEMERS, Richard A. y ARNISH, Robert M., Lingüística: una introducción al lenguaje y la comunicación, Madrid, Alianza Editorial S. A., 1987, p. 316.

250 Schiffman, Leon G. y KANUK, Leslie Lazar, Comportamiento del consumidor, México, Pearson Educación, 2005, p. 302.
} 
La distancia geográfica no fue sólo un problema kilométrico. Al margen de ese, se encuentra la permanencia de ideas anticuadas correspondientes mínimamente a las "realidades" que describían. En España, las existentes sobre Chile o Perú a finales del siglo XIX y comienzos del XX, se fundamentaban en representaciones sociales de la época virreinal que apuntaban en el caso chileno a su lejanía y "condición isleña" ${ }^{251}$-desierto de Atacama al norte, Patagonia y Tierra del Fuego al sur, Océano Pacífico al oeste y los Andes al este- y que grosso modo era habitado por sujetos guerreros.

Esa última situación puede considerarse uno de los imaginarios sobre Chile más poderoso, de alguna manera, conservado hasta la actualidad, con valoraciones menos arcaicas alusivas a la valentía, gallardía y coraje de sus "hombres". Un marcador importante de la imagen de Chile en España fue, sin duda, su participación en la Exposición Iberoamericana de Sevilla en $1929^{252}$. Weber, quien se ha preguntado por la raíz histórica de ese imaginario, escribió: “Acaso ningún otros pueblo nativo de América desarrolló una capacidad militar para mantener la independencia de forma tan rápida y eficaz como los pueblos de habla araucana del centro-sur de Chile"253. Este autor reflexionó sobre el impacto de la guerra de Arauco en las relaciones hispano-indígenas. Explicó cómo La Araucana de Ercilla vulgarizó ideas del espíritu guerrero indígena en España ya que, al leerse en toda Europa, "propagó por el continente la reputación de los araucanos como un pueblo indomable" 254 .

Ya en 1880, debido al problema de la distancia y el conocimiento deficiente de los países "no civilizados", la Revista Contemporánea en su sección dedicada al extranjero, criticó la despreocupación de la prensa hacia la política de aquellos. Opinó en los siguientes términos:

\footnotetext{
${ }^{251}$ Barros Van Buren, Mario, Historia diplomática de Chile. 1541-1938, Santiago, Editorial Andrés Bello, 1990, p. 373; CARDEmil Herrara, Alberto, El camino de la utopía. Alessandri, Frei, Allende. Pensamiento y obra, Santiago, Editorial Andrés Bello, 1997, p. 272; STUVEN, Ana María, Chile disperso. El país en fragmentos, Santiago, Editorial Cuarto Propio, 2007, pp. 47-50; FUnDACIÓN ASTUR, Ciclo de conferencias. Pensando el futuro, Ediciones Trilce, Montevideo, 2012, p. 149.

252 DÜMMER SCHEEL, Sylvia, Sin tropicalismos ni exageraciones. La construcción de la imagen de Chile para la exposición Iberoamericana de Sevilla en 1929, Santiago, RIL Editores, 2012.

${ }^{253}$ WeBER, David, Bárbaros. Los españoles y sus salvajes en la era de la Ilustración, Barcelona, Editorial Crítica, 2007, p. 88.

${ }^{254}$ Idem.
} 
La prensa española, por desgracia, deja un gran vacío en este punto, que necesita y debe llenarse. La política interior de los pueblos no civilizados llama poco la atención de Europa. Como la ignorancia es inseparable de la debilidad, naturalmente, no se abrigan grandes temores acerca de la mejor o peor administración o la más o menos defectuosa organización de dichos pueblos. Si se piensa en ellos, no es por respeto a su civilización, ni consideración a su fuerza, sino sólo por averiguar qué potencia civilizada a de conquistarlos o explotarlos. Esto es triste, pero de todo punto exacto. La parte no civilizada de la humanidad recibe y recibirá sin cesar terribles humillaciones. Este mal no desaparece ni desaparecerá, mientras no desaparezca la ignorancia que es su causa ${ }^{255}$.

Un cuarto aspecto a comentar es el tiempo asociado a la distancia porque, tratándose de noticias, uno de los principales ideales periodísticos en esa forma de reflejar el mundo es la velocidad. Históricamente, el tráfico comercial tuvo un papel destacado en la difusión de noticias y también en el aumento en la velocidad de la comunicación. Su perfeccionamiento fue básico para aumentar la eficiencia de la prensa. En el siglo XVI el comercio fluido entre España y América había favorecido la producción de "hojas de noticias" y "hojas económicas en forma de avisos"256.

Bauer ha dicho: "El tráfico es lo originario, el periódico es su beneficiario. Y si este alaba la actualidad como su fin supremo, lo cierto es que sólo pudo conseguirla gracias a los logros colosales de la técnica" ${ }^{257}$. El historiador alemán acentuó la relatividad de lo actual, debiendo considerar "que el influjo recíproco entre el ritmo más rápido o más lento de la vida y los progresos técnicos, repercute [...] en la manera de concebir lo que es actual o no" ${ }^{258}$. Relacionado con eso, en la Europa de fin de siècle, el menor tiempo transcurrido entre los hechos y su publicación en la prensa, se consideraba un logro del ideal de la inmediatez informativa. Ésta no debía alterar la calidad analítica y la extensión de la noticia; en la práctica, las semanas o el mes de atraso, desfasaban los contenidos pudiendo desprestigiar empresas creyentes en la "verdad" de lo publicado, llegando en ocasiones a "lances de honor" 259 por la defensa de la honra en juego.

\footnotetext{
${ }^{255}$ Revista Contemporánea, "Revista extranjera", enero-febrero 1880, tomo XXV, p. 88.

256 Soriano Llobera, Juan M., Prensa económica ¿Ángel o demonio? De la democracia a la actualidad, Huelva, Servicio de publicaciones Fundación para la Investigación Juan Manuel Flores Jimeno, 2012, p. 39.

${ }^{257}$ BAUER, Wilhelm, La opinión pública y sus bases históricas, Santander, Publicaciones de la Universidad de Cantabria, 2009, p. 349.

${ }^{258}$ Íbidem, p. 350.

${ }^{259}$ SÁIZ, María Dolores, "La prensa madrileña en torno a 1898", Historia y Comunicación Social, n. ${ }^{\circ} 3,1998$, p. 198.
} 
La creencia en la "verdad", denominada por Miceli y otros "ortodoxia tradicional", se desarrolló en los orígenes del periodismo moderno, donde "la labor informativa debería basarse en los hechos de la realidad y mantenerse equidistante de los conflictos sociales"260. Desde entonces "la noticia fue equiparada al hecho"261.

En la España de fines del siglo XIX el retraso de los periódicos resentía "los intereses del comercio de la población importante"262. En 1921, la situación de la prensa aún se prestaba a críticas del siguiente tono: "la vida comercial española, desde una punta a otra del sistema o lo que sea, está enlazada en la complejidad de la vida total de la nación, [...] estamos atrasados en prensa, en teorías y sistemas administrativos"263. Sólo a partir de 1929 algunos logros de la aviación española permitirían transportar prensa por vía aérea alcanzando niveles modernos más aceptables ${ }^{264}$.

En el desarrollo de la investigación, la extracción de fuentes se hizo de diarios y revistas publicadas en España entre 1880 y 1929. Ambos años se relacionan más con hitos propios del conflicto que con coyunturas de la historia española, tales como el comienzo del "turnismo"265, en un extremo y el golpe de Estado fracasado de José Sánchez Guerra contra Primo de Rivera en 1929, en el otro.

El título de nuestro trabajo, Naciones de papel: El conflicto entre Chile y Perú por Tacna y Arica en la prensa de España (1880-1929), requiere de una confesión con objeto de evadir los riesgos de las generalizaciones lingüísticas que, en gran parte, critica este trabajo. A decir verdad, al expresar "en la prensa de España" no deseamos persuadir al lector a creer que analizamos la totalidad de la prensa española, por dos razones obvias, también necesarias de explicar. En primer lugar, la Hemeroteca Digital de la Biblioteca Nacional de España si bien reúne un porcentaje elevado de periódicos del pasado, la muestra no es completa.

\footnotetext{
${ }^{260}$ EsPeChe, Carlos Ernesto, "Periodismo objetivo o subjetivo, una falsa dicotomía", Congreso de Periodismo y medios de comunicación, 2012, p. 4.

${ }^{261}$ Idem.

${ }^{262}$ La Discusión, [s. t.], 17 de diciembre de 1858, p. 2.

${ }^{263}$ España, "El crédito comercial y lo demás", 5 de febrero de 1921, n. ${ }^{\circ} 301$, p. 4.

${ }^{264}$ Revista Ilustrada de Banca, Ferrocarriles, Industrias y Seguros, "El servicio de comunicaciones aéreas, adjudicado", 10 de enero de 1929, n. $^{\circ} 1$, p. 6.

265 Granados Loureda, Juan Antonio, Breve historia de los Borbones españoles, España, Ediciones Nowtilus, S. L., 2010, p. 182.
} 
En segundo lugar, la prensa analizada no es en estricto rigor de toda España, sino más bien, por razones relacionadas con su conservación en la Biblioteca Nacional, de la publicada principalmente en Madrid y Barcelona ${ }^{266}$. Esa hegemonía industrial que cupo a ambas ciudades fue, en parte, explicada por Saiz: "Madrid y Barcelona fueron los dos principales centros publicísticos; la prensa editada en Madrid era en realidad prensa de difusión nacional, porque muchos de los grandes diarios vendían parte de su tirada en provincias" 267.

\section{Gráfico n..$^{\circ} 1$}

\section{Lugares de publicación de la prensa}

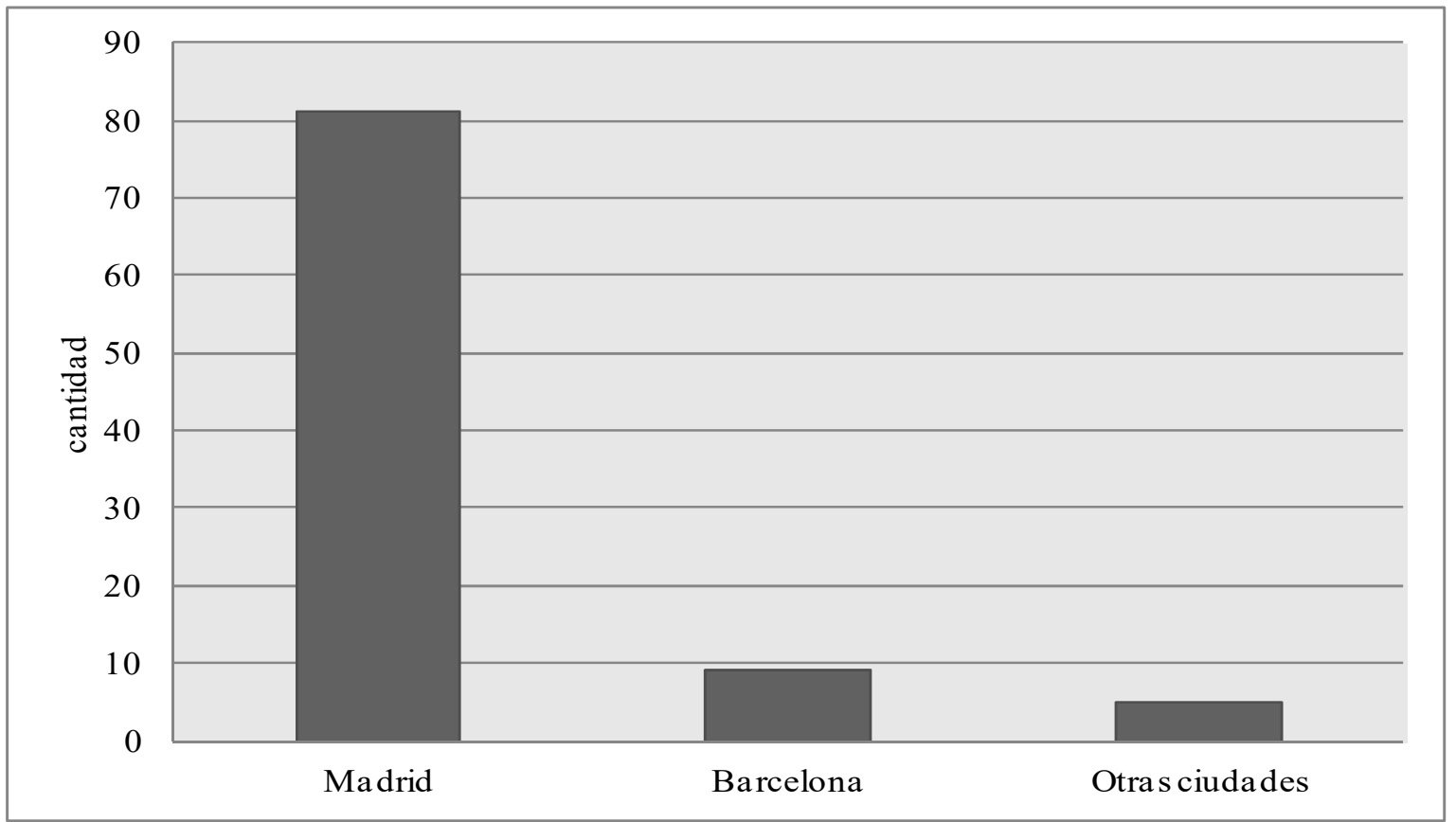

Fuente: Elaboración propia a partir de las fuentes hemerográficas analizadas.

Otras ciudades: Salamanca, Málaga, Las Palmas.

${ }^{266}$ El Norte de Castilla, diario de Valladolid, publicó un escaso número de noticias relacionadas con el problema entre Chile y Perú. Por esa razón lo hemos excluido de la muestra. Por otro lado, según la información facilitada por la Jefatura del Servicio de Gestión de Colecciones de Prensa Seriada de la Biblioteca Nacional de España, la prensa regional fue depositada en los fondos de esa institución en 1941, dificultando la recopilación de noticias entre 1880-1929. Más adelante, en el gráfíco n. ${ }^{\circ} 6$ se visualiza la producción de las prensas de Madrid, Barcelona y otras ciudades (Salamanca, Málaga, Las Palmas y Valencia) respecto al problema chileno-peruano.

${ }^{267}$ SAIZ, María Dolores, "La prensa madrileña en torno a 1898”, Historia y Comunicación Social, n. ${ }^{\circ}$ 3, 1998, p. 197. 
La muestra reunida y en la que se basa nuestro análisis asciende a 2379 noticias o, técnicamente, unidades de análisis de base no gramatical (UABNG). Durante la investigación también las denominaremos unidades redaccionales (UR), concepto que incluye "noticias, crónicas, reportajes, entrevistas, artículos, críticas, comentarios y opiniones de los columnistas"268.

La distribución anual de las UABNG durante el periodo considerado es variable (gráfico n. ${ }^{\circ}$ 2). Así, después de un número superior a las cien en 1880 , fecha del "Asalto y Toma del Morro" de Arica durante la Guerra del Pacífico, las noticias disminuyen para remontar después de una década con la Guerra Civil chilena de 1891, donde se enfrentaron "presidencialistas" con "parlamentaristas".

\section{Gráfico n. ${ }^{\circ} 2$}

Número de noticias sobre Tacna y Arica (1880-1929)

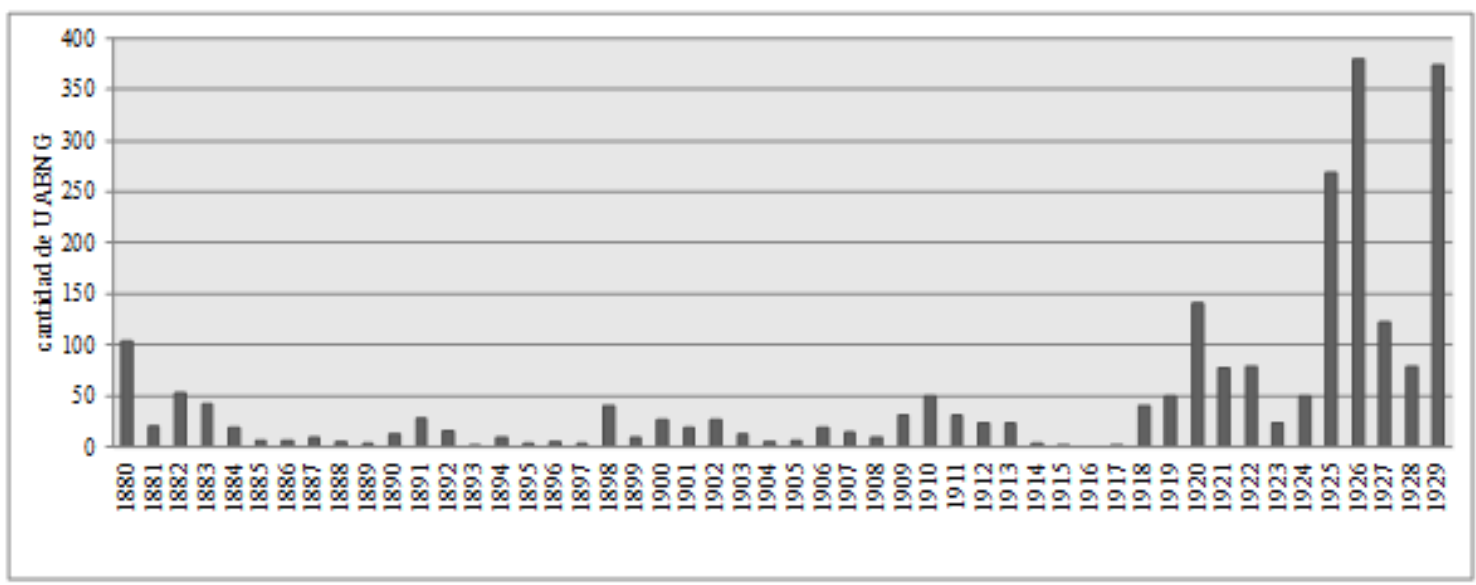

Fuente: Elaboración propia a partir de las fuentes hemerográficas analizadas.

En ese conflicto, el capitalismo inglés entabló alianza con el parlamento chileno, ambos enemigos del nacionalismo económico del presidente José Manuel Balmaceda. Ello hizo que enfrentados se interesaran por Tacna y Arica, ciudades protectoras del salitre tarapaqueño, según las visiones de importantes políticos chilenos de la época.

\footnotetext{
${ }^{268}$ Moreno, Amparo, RovetTo, Florencia y Buitrago, Alfonso, ¿De quién hablan las noticias? Guía para humanizar la información, Barcelona, Icaria editorial S. A., 2007, p. 39.
} 
Balmaceda había concedido importancia a la frontera, preocupándose por los problemas diplomáticos irresolutos, entre ellos "el futuro de Tacna y Arica y la cuestión del tratado de paz definitivo con Bolivia"269. Por eso, elaboró una política militar con objeto de “consolidar la hegemonía de Chile en el Pacífico Sur y conjurar las apetencias territoriales de Estados vecinos" ${ }^{270}$. No obstante, su suicidio, ocurrido el 19 de septiembre de 1891, marcó la derrota del proteccionismo y la legalidad del saqueo inglés del subsuelo del Atacama. La guerra fue conocida en España. Al comenzar las desavenencias entre el parlamento y Balmaceda, un escritor de una revista madrileña, vaticinó: “Chile será bien pronto víctima de la guerra civil que la conducirá de una manera inevitable a la ruina económica y financiera" 271 .

Después de 1891 el número de noticias zigzaguea entre valores altos y bajos evidenciando un aumento hacia 1898 a raíz del protocolo Billinghurst-Latorre, acuerdo entre Perú y Chile para solicitar la coordinación del plebiscito de Tacna y Arica a la reina María Cristina. El protocolo fue desestimado por Chile en 1901, prescindiendo de los buenos oficios españoles. Sería la última vez que Chile, Perú y España negociarían un arbitraje u otro mecanismo diplomático que estabilizara la frontera. A nuestro juicio, marca el inicio de una fase donde el monroísmo blinda de cualquier intención foránea la litis puntualmente europea- mediadora entre Chile y Perú. Para España esta derrota ideológica halla razones en su posición global, pues "no sólo era un país de segundo orden, [...] sino, que, además, se encontraba internacionalmente aislado por la incuria de su diplomacia y por la falta de una política exterior bien definida y cultivada" 272 .

Estudios posteriores demuestran que la inhabilidad diplomática española en Perú y Chile, no fue tan grotesca como se desprende de la cita anterior ${ }^{273}$. De todos modos, se debe considerar el impacto moral que significó para España su derrota ante los Estados Unidos en 1898. Allí, la prensa fue determinante en la guerra; en España "se encontraba a años luz

\footnotetext{
${ }^{269}$ NúÑEZ P., Jorge, 1891. Crónica de la Guerra Civil, Santiago, LOM Ediciones, 2003, p. 115.

${ }^{270}$ Idem.

${ }^{271}$ Revista de España, "Crónica exterior”, enero y febrero de 1891, tomo CXXXII, p. 637.

272 SOLAR, David, "Una guerra por encima de las posibilidades españolas", Historia y comunicación social, n. ${ }^{\circ} 3,1998$, p. 248.

${ }^{273}$ MARTínEZ RiAZA, Ascensión, "Por daños y perjuicios: reclamaciones de españoles en el Perú, siglos XIX y XX”, Anuario de Estudios Americanos, n. ${ }^{\circ} 66$, enero-junio, 2009; EsTRADA TURRO, Baldomero, Desarrollo empresarial urbano e inmigración europea: españoles en Valparaíso (1880-1940), Memoria para optar al grado de Doctor, Facultad de Geografía e Historia, Universidad Complutense de Madrid, 2012.
} 
de la gran Prensa europea y americana"274. Sólo el fracaso arbitral estadounidense en Tacna y Arica de 1926 hará rumorear a la prensa de ambos países la posible participación arbitral del rey Alfonso XIII. Hasta ahora -publicó un diario español- "ningún despacho de las naciones litigantes ha comprobado la noticia"275.

Las fluctuaciones en el número de noticias continúa después de 1901; a diferencia de la etapa anterior, su aumento alcanza cifras máximas durante 1910-1913. Ese incremento se relaciona con las conmemoraciones del centenario republicano chileno en 1910 y con los nuevos conflictos que tuvo con Perú por la soberanía de Tacna y Arica, siendo puntualmente la expulsión de los curas peruanos el más atractivo para la prensa hispana. Con relación a la primera coyuntura, las celebraciones realizadas en Chile ensalzando a la nación estuvieron marcadas por la tragedia -la muerte del presidente Pedro Montt- y por la paradoja en la identidad del país que mostraba al mundo una "modernidad" europeísta escondiendo, a la vez, los aspectos "tradicionales". En medio de esa tensión se construía el ferrocarril de Arica a La Paz, obra en la que Montt había puesto gran interés. El ambiente de progreso hizo pensar a la clase política que él encabezaba el intento de solución del problema de la frontera norte. En suma, todas estas situaciones explican el aumento de noticias en el último cuarto del siglo XIX.

En relación a la segunda coyuntura, la importancia otorgada por la prensa a la expulsión de sacerdotes peruanos liderados por Vitaliano Berroa -ultranacionalista y discípulo de Duhamel, teólogo defensor de la causa francesa en Alsacia y Lorena ${ }^{276}$ - se funda en el interés en conflictos católicos ocurridos en otros puntos del planeta. Es probable que esa inclinación se haya incrementado por la misión supletoria realizada por carmelitas españoles en las iglesias de Tacna y Arica. Cabe señalar que un número importante de prensa revisada es específicamente de corte católico.

\footnotetext{
274 Arroyo Cabello, María, "La prensa murciana en el desastre del 98”, Historia y Comunicación Social, n. ${ }^{\circ} 3,1998$, p. 15.

${ }^{275}$ La Correspondencia Militar, “¿El arbitraje de Tacna y Arica será ofrecido al Rey de España?”, 8 de julio de 1926, p. 6.

${ }^{276}$ GUEVARA TORRES, José Guillermo, Tacna: la chilenización imposible. Visión del proceso de chilenización de Tacna y Arica (1880-1929), 2012, p. 21, <http://myslide.es/documents/tacna-la-chilenizacionimposible.html> [consultado el: 20/03/2014].
} 
De todos modos, el aumento explicado debe relativizarse, puesto que en el tramo 1914-1917 hubo momentos de total silencio, como ocurrió en 1916, donde no hemos localizado ninguna noticia. Como lo planteó Requeijo y otros, parafraseando a Pizarroso sobre el impacto de la Gran Guerra en la prensa española, aquella fue "el primer conflicto de la Historia en el que la retaguardia pasa a jugar un papel tan importante o más que el del frente"277. Para ellos, la propaganda se encauzó hacia los pueblos para concienciarlos. En tanto arma, la prensa fue fundamental en la victoria final de la Triple Entente. Schulze, usando una expresión idéntica, aseguró que durante la conflagración los medios tuvieron “por primera vez en la Historia, un papel importante en el desarrollo de una guerra"278.

El descenso abrupto de noticias relativas a Tacna y Arica durante la guerra europea no es extraño. Los enfrentamientos militares de la guerra y las relaciones de las cancillerías europeas se privilegiaron en la prensa española por razones comprensivas, como la cercanía geográfica y el interés "natural" fundado en una identidad europea compartida. La prensa incrementó el número de noticias que día a día dieron cuenta de los enfrentamientos entre las alianzas militares. Ya no se dispuso en los diarios de espacios grandes para nimiedades referidas a los amoríos del actor estadounidense Lionel Lawrence, "casado once veces y divorciado otras tantas" 279 , por nombrar uno de cientos de ejemplos. Al respecto, Nouschi se refirió a la crisis política de 1914, que arrastraría hacia el "abismo" a Europa. Mientras se incubaba la crisis y las cancillerías se afanaban -escribió- la prensa "se apasiona por... los sucesos" 280 .

Fuera de Europa, en Tacna y Arica, la inestabilidad soberanista de esos años se templó, disminuyendo los miedos hacia los irredentismos belicosos. Entre 1912 y 1914 la frontera norte no había sufrido episodios graves de violencia nacionalista ${ }^{281}$. No obstante, la base espiritual de esa moderación era el nacionalismo, motor de las relaciones diplomáticas

\footnotetext{
${ }^{277}$ Requeijo Rey, Paula, SAnz GonzÁlez, Carlos y Valle, Carlos del, "Propaganda norteamericana en la Primera Guerra Mundial: simplificación y deformación a través del cartel”, Historia y comunicación social, vol. 18, 2013, p. 32.

278 SCHUlZE SCHNEIDER, Ingrid, "Los medios de comunicación en la Gran Guerra, Todo por la Patria", Historia y comunicación social, vol. 18, 2013, p. 15.

${ }^{279}$ La Correspondencia de España, "Cosas Yanquis", 9 de febrero de 1914, p. 3.

${ }^{280}$ NousCHI, Marc, Historia del siglo XX. Todos los mundos. El mundo, Madrid, Ediciones Cátedra, S. A., 1996, p. 55. El autor se refiere irónicamente al asesinato del periodista francés Calmette a manos de madame Caillaux.

281 GonZÁlez MiRAndA, Sergio, El dios cautivo: Las ligas patrióticas en la chilenización compulsiva de Tarapacá (1910-1922), Santiago, LOM Ediciones, 2004, p. 64.
} 
chileno-peruanas. Durante la primera década del siglo ese nacionalismo se afirmó con vigor. Renouvin escribiría: "los litigios fronterizos siguen enfrentando a estos hermanos de lengua [...] Perú y Chile luchan por la posesión de la región de Tacna y Arica" ${ }^{282}$. La mesura nacionalista en el plano local y el descenso de noticias en España, en el plano general (véase gráfico n. ${ }^{\circ}$ 2), sería sólo la calma antecesora de la tormenta.

Durante los últimos doce años del litigio se localiza el número más elevado de noticias del periodo examinado. No obstante, un acercamiento fino distingue tres fases con un factor común: los buenos oficios de Washington. La primera, desde 1918 hasta 1922, caracterizada por el pacifismo de Woodrow Wilson y su emplazamiento a las cancillerías chilena y peruana para finalizar la cuestión fronteriza, así como por las "Conferencias de Washington" donde los diplomáticos de Chile, Perú y Estados Unidos acordaron efectuar el plebiscito incumplido desde 1894.

La segunda, desde 1923 hasta 1926. Las noticias aumentan debido al establecimiento de la Alta Comisión Plebiscitaria en Arica, organismo encargado de planificar el plebiscito, encabezada por el general estadounidense John Pershing. Los conflictos entre los diplomáticos comisionados y la violencia nacionalista desatada en la sociedad fronteriza produjeron la publicación de centenares de noticias en España. El descontrol de la situación provocó el cese de las funciones de la Comisión. Estados Unidos había fracasado en su mediación.

La tercera fase, entre 1927-1929, está marcada por la finalización del conflicto el 3 de junio de 1929 con el Tratado de Lima, pero además por un acontecimiento simbólico para la hispanidad. Los documentos del tratado fueron transportados desde Santiago a Lima por los aviadores españoles Ignacio Jiménez y Francisco Iglesias en el avión Jesús del Gran Poder, aprovechando "una gira de buena voluntad por los países hispanoamericanos"283. El vuelo significó para España el triunfo de la aviación nacional y la certeza, más imaginaria que real, de un papel fundamental en la conclusión del litigio.

\footnotetext{
282 ReNOUVIN, Pierre, La crisis europea y la I ${ }^{a}$ Guerra Mundial (1904-1918), Madrid, Ediciones Akal S. A., 1990, p. 61.

${ }^{283}$ BASADRE, Jorge, Historia de la República del Perú, 1822-1933, tomo XIII, sexto periodo, el oncenio y sus consecuencias inmediatas, Lima, Editorial Universitaria, 1968, p. 278.
} 
En una visión de conjunto, la publicación de noticias dibuja un gráfico temporal en el que se advierten altibajos, reflejo de un interés periodístico variable hacia la lid. Las puntas más altas fueron favorecidas por acontecimientos directamente relacionados con Tacna y Arica y, por el contrario, las bajas por sucesos indirectamente vinculados. Esos, de repercusiones considerables para España, determinaron la producción noticiosa de la frontera.

\subsection{Muestra}

La importancia de observar qué fuentes hemerográficas ofrece la producción histórica de prensa española es fundamental para realizar nuestra investigación. La selección de éstas constituye el denominado "universo de análisis"284 el cual, en escasas oportunidades puede abarcarse por completo. En nuestro caso, al contrario, optamos por seleccionar todas las noticias localizadas, desechando la idea de analizar sólo un "conjunto limitado del universo a investigar" ${ }^{285}$. Esa decisión posibilitó que nuestra muestra sea, con mayor razón, "una representación razonable ajustada al «estado de la cuestión» de la totalidad del universo" $" 286$.

El número de títulos de revista utilizados asciende a 67 (tabla $n .^{\circ}$ 1) y los diarios revisados a 26 (tabla . $^{\circ}$ 2). El peso cuantitativo del primer grupo frente al segundo (gráfico n. ${ }^{\circ}$ 3) está relacionado con la periodicidad de publicación, pues mientras los diarios lo hacen, como su nombre indica, diariamente, las revistas tienen una periodicidad que va desde la semana, la quincena, el mes y hasta el año, caso de los anuarios. La incidencia de esa periodicidad en la muestra analizada queda demostrada en el gráfico $n .^{\circ} 4$ donde se aprecia la presencia mayoritaria de noticias extraídas de diarios que casi cuadriplican las extraídas de revistas.

\footnotetext{
${ }^{284}$ PÉREZ SERRANO, Gloria, Investigación cualitativa. Retos e investigaciones. II Técnicas y análisis de datos, Madrid, Editorial La Muralla S. A., 1994, p. 176.

${ }^{285}$ Castro Nogueira, Luis, Castro Nogueira, Miguel Ángel y Morales NaVArro, Julián, Metodología de las ciencias sociales. Una introducción crítica, Madrid, Tecnos, 2008, p. 33.

${ }^{286}$ GonzÁlez Río, María José, Metodología de la investigación social. Técnicas de recolección de datos, Alicante, Editorial AguAClARA, 1997, p. 42.
} 
Tabla n. ${ }^{\circ} 1$

\begin{tabular}{|c|c|c|c|}
\hline \multicolumn{4}{|c|}{ Títulos de las publicaciones y periodicidad } \\
\hline 1. ¡Adelante! & Semanal & 34. La Emigración Española & Quincenal \\
\hline 2. Actualidades & Semanal & 35. La Esfera & Semanal \\
\hline 3. Aérea & Mensual & 36. La España Moderna & Mensual \\
\hline 4. Almanaque Bailly-Bailliere & Anual & 37. La Fiesta Brava & Semanal \\
\hline 5. Alrededor del Mundo & Semanal & 38. La Gaceta Literaria & Quincenal \\
\hline 6. Anuario de Comercio, de la & Anual & 39. La Ilustración & Semanal \\
\hline Industria, de la Magistratura & & 40. La Ilustración Artística & Semanal \\
\hline 7. Archivo Diplomático de & Semanal & 42. La Ilustración Católica & Semanario \\
\hline $\begin{array}{ll} & \text { España } \\
\text { 8. } & \text { Archivo Diplomático }\end{array}$ & & $\begin{array}{l}\text { 43. La Ilustración Española } \\
\text { v Americana }\end{array}$ & Semanal \\
\hline $\begin{array}{l}\text { 8. Archivo Diplomatico } \\
\text { Consular de España }\end{array}$ & semanal & 44. La Americana Ilustración & Mensual \\
\hline $\begin{array}{l}\text { 9. Archivo Diplomático-político } \\
\text { de España }\end{array}$ & Semanal & $\begin{array}{l}\text { Financiera } \\
\text { 45. La Ilustración Ibérica }\end{array}$ & Semanal \\
\hline 10. Arquitectura y Construcción & Mensual & 46. La Ilustración Militar & Quincenal \\
\hline 11. Buen Humor & Semanal & 47. La Lectura & Mensual \\
\hline 12. Cervantes & Mensual & 48. La Lectura Dominical & Semanal \\
\hline 13. Cosmópolis & Mensual & 49. La Nación Militar & Semanal \\
\hline 14. El Álbum Ibero Americano & Semanal & 50. La Unión Ilustrada & Semanal \\
\hline 15. El Año Político & Anuario & 51. Las Dominicales del & Semanal \\
\hline 16. El Arte de el Teatro & Quincenal & Libre Pensamiento & \\
\hline $\begin{array}{l}\text { 17. El Estudiante } \\
\text { 18. El Mentidero }\end{array}$ & $\begin{array}{l}\text { Semanal } \\
\text { Semanal }\end{array}$ & $\begin{array}{l}\text { 52. Madrid Cientifico } \\
\text { 53. Muchas Gracias }\end{array}$ & $\begin{array}{l}\text { Decenal } \\
\text { Semanal }\end{array}$ \\
\hline 19. El Mundo de los Niños & Decenal & 54. Mundo Gráfico & Semanal \\
\hline 20. El Mundo Ilustrado & Quincenal & 55. Nuestro Tiempo & Mensual \\
\hline 21. El Mundo Naval Ilustrado & Quincenal & 56. Nuevo Mundo & Semanal \\
\hline 22. El Nuevo Régimen & Semanal & 57. Oro de Ley & Semanal \\
\hline 23. España & Semanal & 58. Panorama & Quincenal \\
\hline 24. España y América & Quincenal & 59. Por esos Mundos & Semanal \\
\hline 25. Faro & Semanal & 60. Revista Contemporánea & Mensual \\
\hline $\begin{array}{l}\text { 26. Gaceta de los Caminos de } \\
\text { Hierro }\end{array}$ & Semanal & $\begin{array}{l}\text { 61. Revista de Archivos, } \\
\text { Bibliotecas y Museos }\end{array}$ & $\begin{array}{l}\text { Sin } \\
\text { información }\end{array}$ \\
\hline 27. Guía Oficial de España & An & 62. Revista de España & Quincenal \\
\hline $\begin{array}{l}\text { 28. Gutiérrez } \\
\text { 29. Hojas Selectas }\end{array}$ & $\begin{array}{l}\text { Semanal } \\
\text { Mensual }\end{array}$ & $\begin{array}{l}\text { 63. Revista de Geografia } \\
\text { Comercial }\end{array}$ & Quincenal \\
\hline $\begin{array}{l}\text { 30. Ilustración Católica de } \\
\text { España }\end{array}$ & Quincenal & $\begin{array}{l}\text { 64. Revista } \\
\text { Internacional }\end{array}$ & Semanal \\
\hline $\begin{array}{l}\text { 31. Industria e Invenciones } \\
\text { 32. La América }\end{array}$ & $\begin{array}{l}\text { Semanal } \\
\text { Ouincenal }\end{array}$ & $\begin{array}{l}\text { 65. Revista Iberoamericana } \\
\text { de Ciencias Eclesiásticas }\end{array}$ & Mensual \\
\hline 33. La Ciudad Lineal & Quincenal & $\begin{array}{l}\text { 66. Revista Ilustrada de } \\
\text { Banca, Ferrocarriles, } \\
\text { Industria y Seguros } \\
\text { 67. Vida Marítima }\end{array}$ & Decenal \\
\hline
\end{tabular}

Fuente: Elaboración propia a partir de información de la Hemeroteca Digital de la Biblioteca Nacional de España. 
Tabla n. ${ }^{\circ} 2$

\begin{tabular}{|l|}
\hline \multicolumn{1}{|c|}{ Título de los diarios } \\
\hline 1. Diario Oficial de Avisos de Madrid \\
2. El Correo Militar \\
3. El Día \\
4. El Día (sucesor del anterior) \\
5. El Globo \\
6. El Heraldo Militar \\
7. El Heraldo de Madrid \\
8. El Imparcial \\
9. El Liberal \\
10. El País \\
11. El Siglo futuro \\
12. El Sol \\
13. La Acción \\
14. La Correspondencia de España \\
15. La Correspondencia Militar \\
16. La Dinastía \\
17. La Discusión \\
18. La Época \\
19. La Iberia \\
20. La Libertad \\
21. La Monarquía \\
22. La Nación \\
23. La República \\
24. La Unión \\
25. La Unión Católica \\
26. La Voz \\
\hline
\end{tabular}

Fuente: Elaboración propia a partir de Hemeroteca Digital de la Biblioteca Nacional de España (www.bne.es).

\section{Gráfico n. ${ }^{\circ} 3$}

Tipo de publicaciones: revistas y diarios

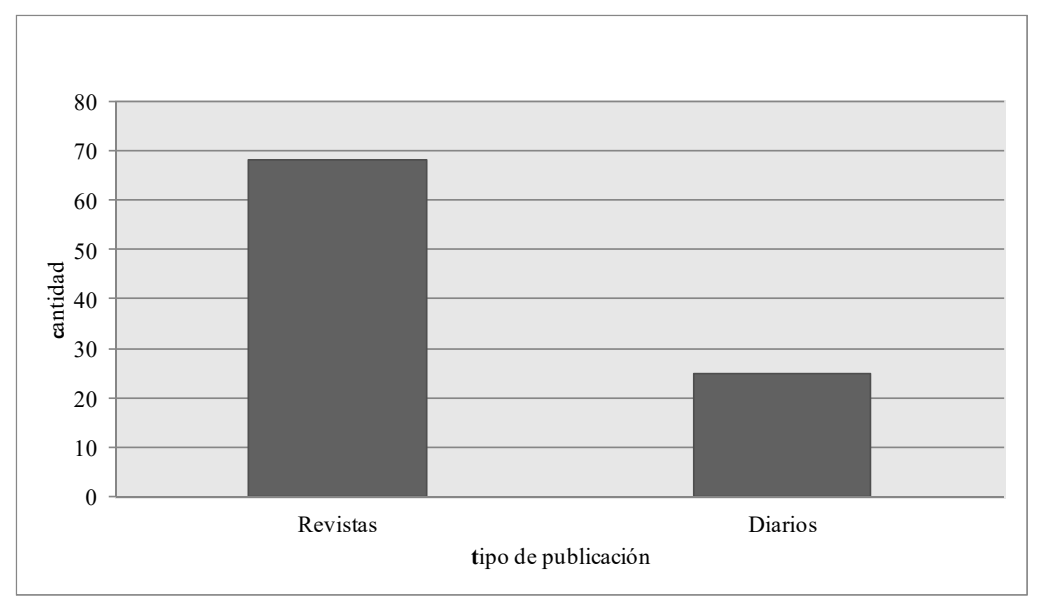

Fuente: Elaboración propia a partir de Hemeroteca Digital de la Biblioteca Nacional de España (www.bne.es). 


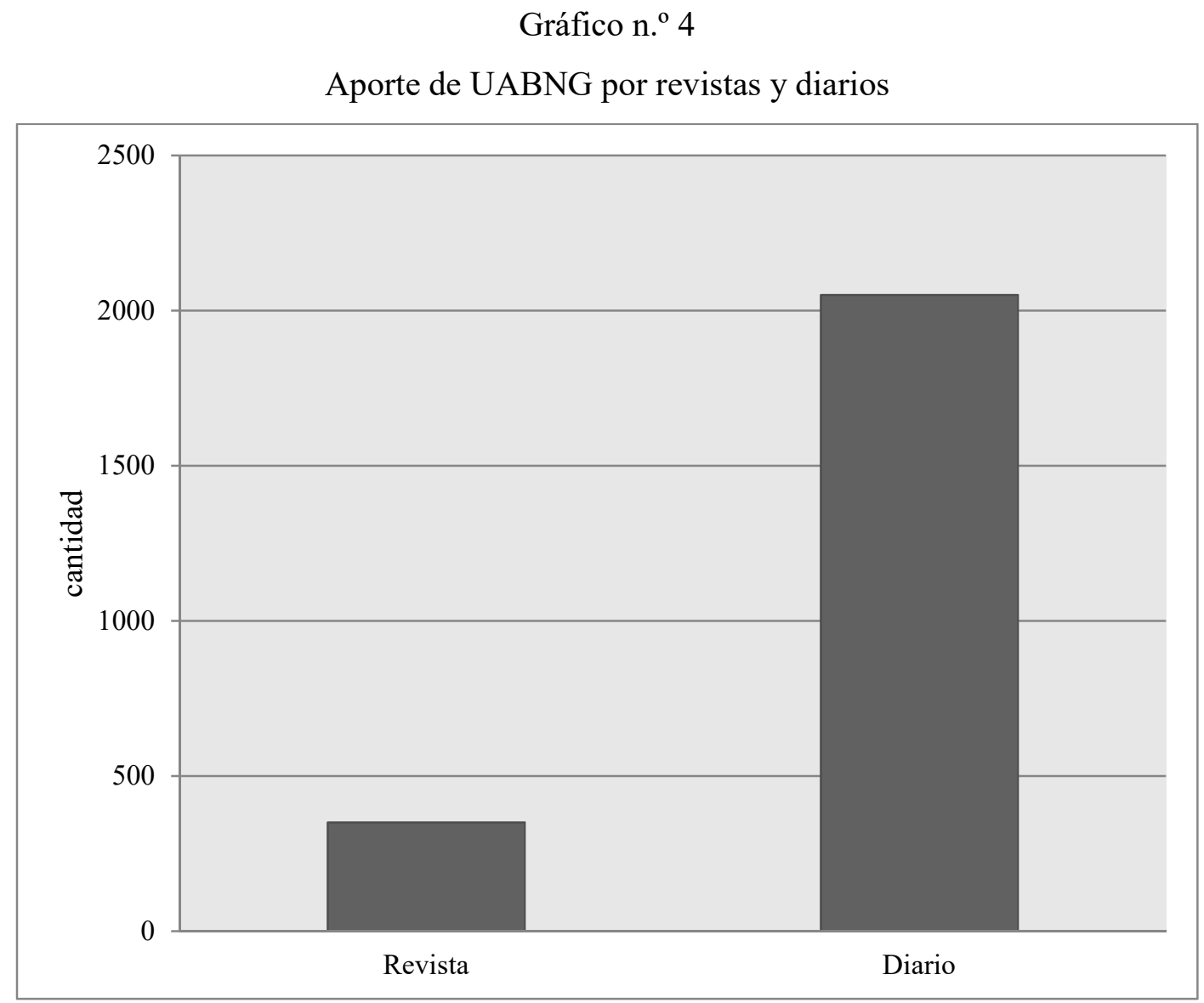

Fuente: Elaboración propia a partir de la información facilitada sobre los títulos consultados en la Hemeroteca Digital de la Biblioteca Nacional de España (www.bne.es).

Las ideologías -entendiéndolas básicamente como las "creencias fundamentales de un grupo y de sus miembros" 287 - u orientaciones políticas de las publicaciones revisadas son detalladas en el gráfico n. ${ }^{\circ}$ 5. Su integración tiene como objetivo dar a conocer algunas ideologías presentes en España durante 1880 y 1929. Como advertirá el lector, si bien para un número elevado de publicaciones carecemos de información, otros títulos tienen una clara orientación liberal, católica, militar, republicana, monárquica y conservadora, por mencionar algunas. En la representación gráfica hemos excluido aquellas publicaciones que, por su contenido, se clasificarían como costumbristas, taurinas, humorísticas, científicas, artísticas, racionalistas, feministas, etc.

${ }^{287}$ VAN DiJK, Teun, Ideología y discurso. Una introducción multidisciplinaria, Barcelona, Editorial Ariel S. A., $2^{\mathrm{a}}$ edición, 2008, p. 14. 
Es importante detectar y analizar las ideologías que subyacen en la prensa para comprender, si lo amerita, relaciones fácticas entre éstas y la cuestión chileno-peruana. Una mirada a priori sobre las fuentes sugiere que la prensa, en general, tomó una posición homogénea frente al conflicto en el plano moral. Asegurar que esa situación se debió a la distancia entre los intelectuales españoles que publicaban y la región sería equívoco, porque, como veremos, hubo momentos de gran producción noticiosa con alto contenido emocional.

\section{Gráfico n. ${ }^{\circ} 5$}

Orientación de las publicaciones

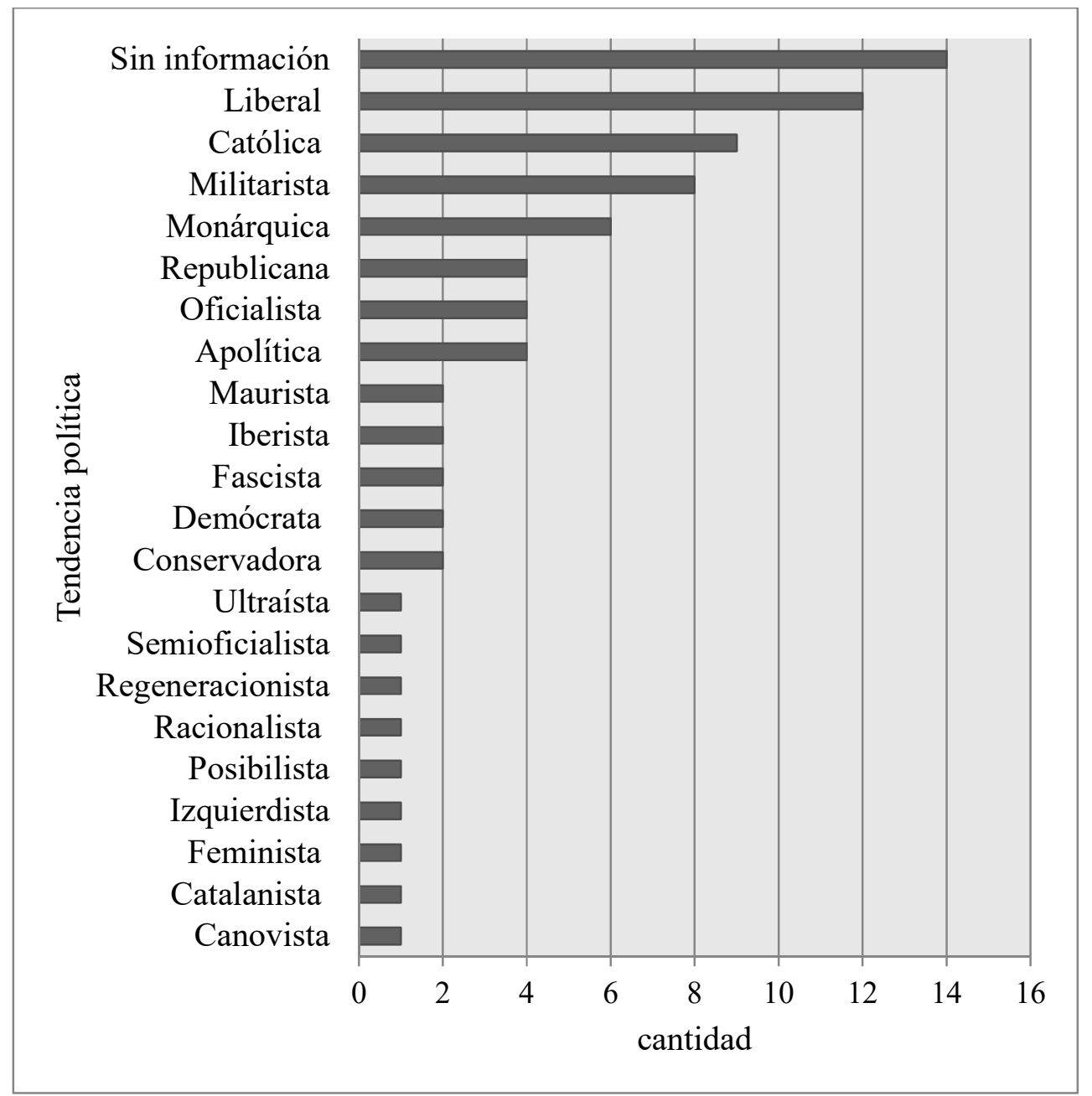

Fuente: Elaboración propia a partir de información ofrecida en Hemeroteca Digital Hispánica de la BNE (www.bne.es) 
De momento, es preferible pensar que el problema chileno-peruano no modificó las diferencias que liberales, conservadores o republicanos tuvieron en el plano político nacional. Los sucesos endógenos fueron material para una prensa activista que sirvió de plataforma a ideas políticas. Por ello, debe considerarse una situación comentada por un estudio relacional entre el poder político y la prensa que afirmó, con datos mínimos hallados en otra investigación ${ }^{288}$, cómo en el siglo XIX cada político español dirigía un periódico o más ${ }^{289}$. En un entorno periodístico de libre expresión, "todos los partidos, todas las fracciones políticas, todas las disidencias, todas las personalidades, tienen su órgano" 290 .

Tuñón de Lara prescribió al historiador de la prensa considerar que, más allá de los géneros del texto, la prensa es ideología ${ }^{291}$. Van Dijk, por su parte, aseguró que probablemente no exista otro discurso más penetrante y social que el periodístico. Ello obliga a analizar rigurosamente "los temas y el estilo de las noticias para comprender cómo se ejerce el poder político [...] y cómo se comunican e inculcan las ideologías"292. Lull, por último, planteó la relación entre ideología y medios de comunicación que convendría considerar al estudiar las representaciones sociales de Tacna y Arica en la prensa española:

La palabra ideología [...] se refiere con más frecuencia a la relación en gran escala que se da entre la información y el poder social en contextos político-económicos. En este sentido, aquellos que poseen el poder político y económico en la sociedad defienden, a través de una cantidad de canales, formas de pensamiento seleccionadas. La creciente manipulación de la información y la imaginería públicas construye una poderosa ideología dominante que ayuda a sustentar los intereses materiales y culturales de sus creadores. Su poder o su dominación procede directamente de la capacidad que tienen para articular públicamente sus sistemas de ideas preferidos. Por consiguiente, la ideología tiene fuerza cuando puede ser representada y comunicada ${ }^{293}$.

\footnotetext{
288 PÉREZ ROLDÁN, Carmen, "La prensa republicana madrileña durante el siglo XIX: La Igualdad y El Combate como ejemplos de periódicos republicanos", Historia y Comunicación Social, n. o 4, 1999, pp. 317 339.

${ }^{289}$ CAL, Rosa, "Las presiones del poder sobre los medios de comunicación social”, Historia y comunicación social, vol. 7, 2002, p. 14; RUIZ, Nicolás, "La prensa nacionalista en Vizcaya durante la Restauración: el espejo de una comunidad en construcción”, El Argonauta español, n. ${ }^{\circ}$ 5, 2008, pp. 1-14.

${ }^{290}$ SeOAne, María Cruz, Historia del periodismo en España, 2. El siglo XIX, Madrid, Alianza Editorial, 1996, p. 254.

${ }^{291}$ Alía MiRAndA, Francisco, Técnicas de investigación para historiadores, Madrid, Editorial Síntesis, 2005, p. 327-328.

${ }^{292}$ VAn DiJK, Teun, Discurso y poder, Barcelona, Editorial Gedisa S. A., 2009, p. 99.

${ }^{293}$ Lull, James, Medios, comunicación, cultura. Aproximación global, Buenos Aires, Amorrortu Editores, 2007, p. 20.
} 
El número de noticias o unidades de análisis localizados en cada título de los considerados es variable (gráfico $n .^{\circ}$ ). Por razones de pertinencia numérica y distorsión visual, en la representación gráfica se han considerado las publicaciones que aportaron diez unidades de análisis o más. Un grupo considerable de la prensa contribuyó con alrededor de cincuenta unidades al estudio. Solamente El Sol superó las 300, seguido por La Época, El Imparcial, La Voz, La Correspondencia Militar y El Heraldo, con más de 150 noticias. Incluimos la relación completa de todos los títulos utilizados en el apartado de "Fuentes históricas".

Es importante visibilizar esta situación, porque antes de tratar científicamente los documentos analizando sus contenidos, el historiador puede verse influido, durante la hermenéutica, por las visiones publicadas de los sucesos de Tacna y Arica.

Ese peligro puede concretarse si se considera el contexto socio-intelectual del historiador ${ }^{294}$, pues éste influye "en las operaciones que hace un historiador al interpretar sus fuentes" 295 . O, como al comentar las reflexiones de Paul Ricouer ${ }^{296}$ ha enfatizado Gandarillas: "Esperamos de la historia una cierta objetividad [...] es objetivo lo que el pensamiento metódico ha elaborado, ordenado, comprendido y lo que de este modo puede hacer comprender [...] esperamos del historiador cierta calidad de subjetividad"297.

Ésta debiese caracterizarse por su adecuación a la objetividad conveniente para la historia, es decir, una "subjetividad implicada, implicada por la objetividad esperada [...] Bajo el título de subjetividad esperamos algo más grave que la buena subjetividad del historiador; esperamos que la historia sea una historia de hombres [..."”298.

\footnotetext{
${ }^{294}$ RAMíREZ, Mario Teodoro, De la razón a la praxis. Vias hermenéuticas, Morelia, Siglo XXI Editores, 2003, p. 126; SÁNCHEZ GÓMEZ, Gonzalo, "El acto social de investigar". En TORRES CARRILlO, Alfonso y JiMÉNEZ BECERRA, Absalón, (Compiladores), La práctica investigativa en ciencias sociales, Bogotá, Universidad Nacional Pedagógica, 2006, pp. 154-158.

${ }^{295}$ MENDIOLA, Alfonso y ZERMEÑO, Guillermo, "Hacia una metodología del discurso histórico". En GALINDO CÁCERES, Luis Jesús (Coordinador), Técnicas de investigación en sociedad, cultura y comunicación, México, Addison Wesley Longman, 1998, p. 194.

${ }^{296}$ RiCOUER, Paul, Historia y Verdad, Madrid, Encuentro, 1990.

${ }^{297}$ GANDARILla SALGADO, José Guadalupe, Globalización, totalidad e historia. Ensayos de interpretación crítica, Buenos Aires, Ediciones Herramienta, 2003, p. 49.

${ }^{298}$ Idem.
} 


\section{Gráfico n. ${ }^{\circ} 6$}

Número de noticias por publicación

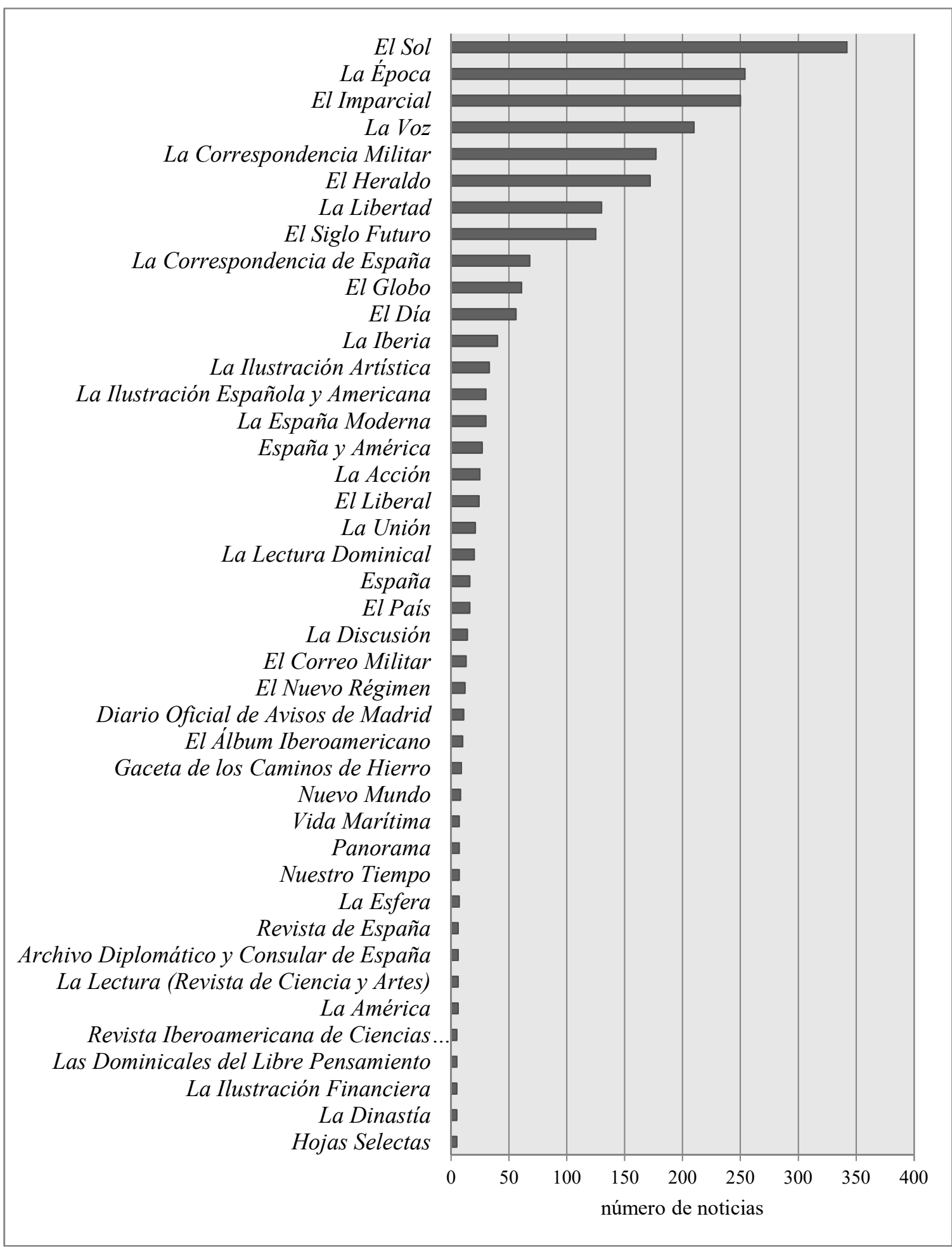

Fuente: Elaboración propia a partir de las fuentes hemerográficas analizadas. 
Mirada desde España, la cuestión chileno-peruana requirió de una tecnología comunicacional que relativizara su ubicación remota. La ausencia de reporteros, que puede considerarse signo de la infravaloración del litigio para la industria periodística o reflejo de la precariedad de capitales, hizo inevitable el telégrafo y la compra de noticias a agencias de prensa que miraban la realidad con "los ojos teñidos por los colores de las banderas"299 de sus naciones. Los convenios entre las empresas de prensa y las agencias transformaron a las noticias en bienes económicos, adquiriendo un valor específico en el mercado. En efecto, se convirtieron "en una mercancía de consumo masivo" ${ }^{300}$. Todas esas operaciones técnicas -explicó Boned para el caso español- se realizaron en un contexto de modernización ralentizada ${ }^{301}$.

Esa situación trabó "el normal desarrollo de los medios"302, según lo planteó una historiadora de la prensa quien, lamentablemente, no profundizó en lo que entendía por "normal" en el plano productivo y mediático. Comparada con la prensa de otros países europeos, la española se encontraba en un atraso, a "años luz"303. Esa opinión, fue contradicha por otra historiadora, quien vio en la prensa hispana de fines del siglo XIX una industria "consolidada" y "moderna" ${ }^{304}$. Sáiz, defensora de ese status, enfatizó cómo en torno a 1898 la mejora en las infraestructuras que sostenían la prensa -ferrocarriles, telegrafía y telefonía- era indesmentible. Delgado, en una interpretación similar, señaló cómo comenzando el siglo XX se fortaleció el modelo maquetado a fines del siglo XIX, es decir, "el periódico de empresa por una parte y el de opinión por otra" ${ }^{305}$ permitiendo incrementar el porcentaje de lectores y, en efecto, el "asentamiento del modelo y de lo que le rodea, agencias de noticias, desarrollo del telégrafo y del teléfono"306.

\footnotetext{
${ }^{299}$ SoHR, Raúl, Historia y poder de la prensa, Santiago, Editorial Andrés Bello, 1998, p. 29.

${ }^{300}$ Idem.

${ }^{301}$ BONED CÓLERA, Ana, "La vertiente popular de El Resumen y su inserción en la prensa de masas", Historia y Comunicación Social, n. ${ }^{\circ}$ 2, 1997.

302 Idem.

303 Arroyo Cabello, María, "La prensa murciana en el desastre del 98”, Historia y Comunicación Social, n. ${ }^{\text {o } 3,1998, ~ p . ~} 15$.

${ }^{304}$ SAIZ, María Dolores, "La prensa madrileña en torno a 1898”, Historia y Comunicación Social, n. ${ }^{\circ}$ 3, 1998, p. 200.

305 Delgado IdARretA, José Miguel, "La prensa: fuente historiográfica". En InSTITUTO DE EstUdios Riojanos (Editores), Investigación humanística y científica en La Rioja. Homenaje a Julio Luis Fernández Sevilla y Mayela Balmaseda Aróspide, La Rioja, Instituto de Estudios riojanos, 2000, p. 251.

${ }^{306}$ Idem.
} 
La participación de agencias en la producción de noticias sobre Tacna y Arica en la prensa española es relevante. Una cantidad importante patentizó su agencia proveedora (gráfico n. ${ }^{\circ}$ 7), destacando: Americana, Associated Press, Fabra, Febus, Interviews y

\section{Wanderers.}

\section{Gráfico n. ${ }^{\circ} 7$}

Agencias de prensa

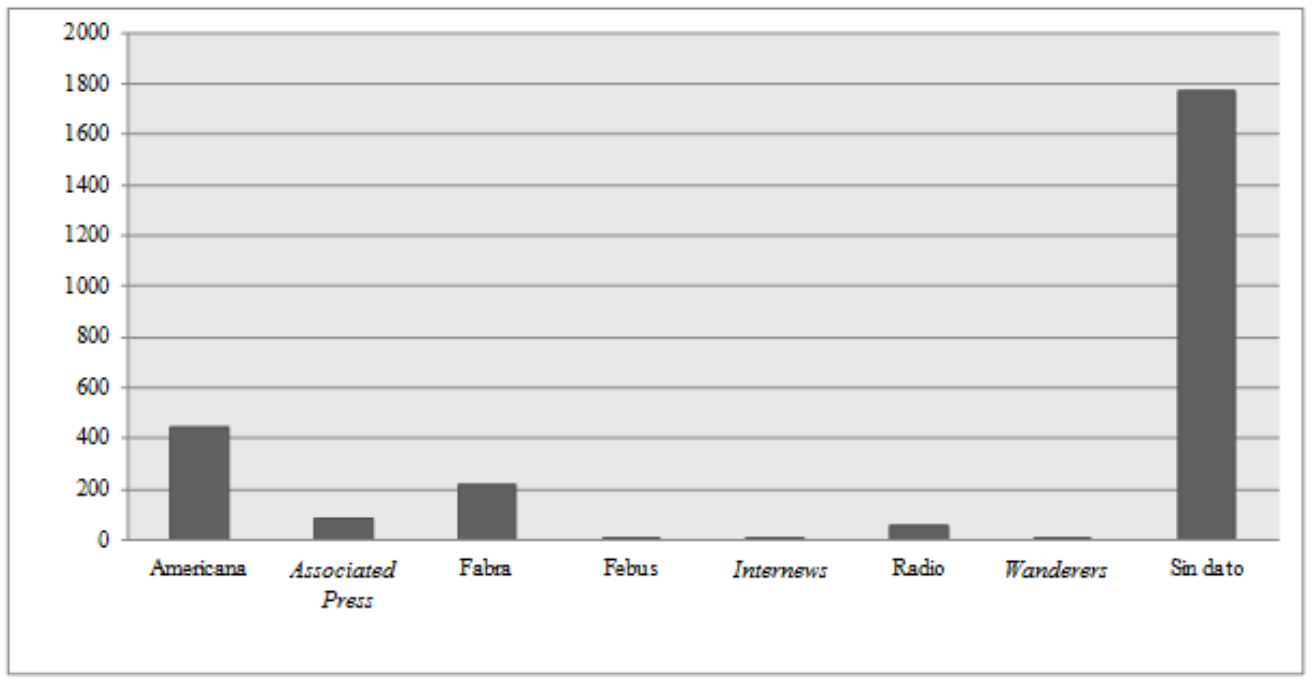

Fuente: Elaboración propia a partir de las fuentes hemerográficas analizadas. Nota: Sin ser una agencia, la radio comenzó a utilizarse por la prensa española para informar de Tacna y Arica durante los años 20 del siglo pasado. Demuestra, sin duda, los cambios tecnológicos que la industria periodística comenzaba a experimentar. Las consecuencias, sin duda, se relacionaron con la velocidad en la transmisión de noticias desde países extranjeros.

Como se observa en el gráfico, la Americana, propiedad del periodista brasileño Oscar de Carvalho Azevedo, fue la principal proveedora de noticias entre América y España, seguida de la Associated Press, fundada hacia 1846 en Nueva York ${ }^{307}$. En ese negocio, la guerra ideológica entre hispanoamericanismo y panamericanismo -por una posición hegemónica de España y Estados Unidos, respectivamente, en América- no pareció importar a los empresarios del periodismo español. Sobre el propietario de la agencia Americana una revista española comentó:

\footnotetext{
307 Salvo Raúl Sohr, quien asegura que la fecha de fundación de la Associated Press fue en 1846, otras publicaciones sitúan ese hito del periodismo mundial en 1848. Ver: GARGUREVICH, Juan, A golpe de titular: CIA y periodismo en América Latina, Praga, Videopress, 1981, p. 30; SAlinas, Raquel, Agencias transnacionales de información y el Tercer Mundo, Ecuador, Quito Times, 1984, p. 34; LóPEZ VALLE, Diana, ZAMORANo Silva, Osvaldo, Periodismo libre en patrias libres, Checoslovaquia, Federación Latinoamericana de Periodistas, 1985 , p. 54
} 
Se encuentra en Madrid el notable e ilustrado periodista americano Oscar de Carvalho Azevedo, que lleva más de veinte años dedicado a la labor de dignificar la prensa y a estrechar las relaciones hispanoamericanas, trabajando sin descanso en todos los periódicos de importancia de Río de Janeiro. Con su actividad prodigiosa fundó en el Brasil la Agencia Americana, con sucursales en Buenos Aires, Montevideo y Santiago de Chile, y durante la guerra las montó en París, Londres y Lisboa. Desde hace tiempo mantiene importante servicio telegráfico con los principales periódicos de Madrid, en primer término, para difundir, cuantas noticias puedan interesar al fomento de nuestras relaciones con América. Cuenta en la actualidad con más de doscientos periódicos abonados al servicio de su Agencia. [...] El Sr. Carvalho Azevedo obsequió en el Hotel Ritz al Cuerpo Diplomático acreditado en Madrid y a los representantes de la prensa madrileña; también asistió el periodista chileno D. José Manuel Raposo. ${ }^{308}$

Pese a lo señalado, respecto a la procedencia de las noticias, tal como se advierte en el gráfico n. $^{\circ}$ 7, en la mayoría no se identifican agencias. Esto es importante señalarlo, pues sugiere cómo un bloque de las noticias forjadoras de representaciones sociales sobre Tacna y Arica no tuvo una agencia determinada, y en última instancia un autor, delegando esa responsabilidad en el diario o revista circulante. De eso se desprende una particularidad de la prensa como fuente: un "artefacto cultural" mediador, pero a la vez con una "función autónoma en la producción y reproducción de las estructuras sociales del poder”309.

En otras palabras, si la mayor cantidad de noticias analizadas no tienen agencias responsables, pero se sabe, por el estilo de redacción, que no corresponden a corresponsalías, cabe preguntarse, ¿de dónde provienen las ideas en torno a Tacna y Arica?, ¿quiénes y cómo se enteran de los sucesos de esa región? A decir verdad, las respuestas a esas interrogantes son enigmas que permiten considerar la existencia de productores "fantasmales" de representaciones sociales. De todos modos, el problema de las agencias innominadas podría resolverse sumándose a los planteamientos de Lull, quien influido por la idea gramsciana de "hegemonía ideológica", aseguró que las ideologías comunicadas por los medios pueden reafirmarse y fortalecerse "por obra de un sistema eficazmente entretejido de agencias distribuidoras de información y de prácticas sociales que se dan por sentadas y terminan impregnando todos los aspectos de la realidad social y cultural" 310 .

\footnotetext{
${ }^{308}$ La Ilustración Española y Americana, "Las relaciones entre España y América", n. ${ }^{3} 33$, 8 de septiembre de 1919 , p. 525.

${ }^{309}$ VAN DiJK, Teun, Discurso y poder, Barcelona, Editorial Gedisa S. A., 2009, pp. 95-96.

${ }^{310}$ Lull, James, Medios, comunicación, cultura. Aproximación global, Buenos Aires, Amorrortu Editores, 2007, p. 52.
} 
Tabla n. ${ }^{\circ} 3$

Autores de noticias referidas a la cuestión de Tacna y Arica

\begin{tabular}{|c|c|c|c|}
\hline Nombre & Nacionalidad & Nombre & Nacionalidad \\
\hline 1. Albistur, Luis & - & 54. Graell Alabern, Guillermo & Española \\
\hline 2. Aldunate, Luis & Chilena & 55. Gutiérrez Rave, José & Española \\
\hline 3. Alessandri, Arturo & Chilena & 56. Heliófilo (s) & \\
\hline 4. Altamira, Rafael & Española & 57. Hernández, [¿?] & - \\
\hline 5. Altolaguirre, Ángel de & Española & 58. Herrera, Ricardo & - \\
\hline 6. Anaya Ruiz, Francisco & Española & 59. Huidobro, Alamiro & Chilena \\
\hline 7. Andrenio (s) & & 60. Irarrázaval, Leónidas & Chilena \\
\hline 8. Araquistáin, Luis & Española & 61. Jacobo Fitz-James Stuart y & Española \\
\hline 9. Asquerino, Eusebio & Española & Falcó (duque de Alba) & \\
\hline 10. Ugarte, Manuel & Argentina & 62. José Peynado, Francisco & Dominicano \\
\hline 11. Ballesteros Álava, Pío & Española & 63. Kas (s) & - \\
\hline 12. Barcia Trelles, Camilo & Española & 64. Laffite, Alfredo de & Española \\
\hline 13. Barros Jarpa, Ernesto & Chilena & 65. Leguía, Eduardo & Peruana \\
\hline 14. Basadre, Modesto & Peruana & 66. León Pérez, Isaac & \\
\hline 15. Bauer, Ignacio & Española & 67. Lorza, Ezequiel & Española \\
\hline 16. Becker, Gerónimo & Española & 68. Madueño, Mariano & Peruana \\
\hline 17. Bedoya Lerzundi, Manuel & Peruana & 69. Martínez de Velasco, E. & Española \\
\hline 18. Beltrán Rózpide, Ricardo & Española & 70. Martínez del Peral, José & Española \\
\hline 19. Bereber, Juan & - & 71. Martínez Velez, Pedro & Española \\
\hline 20. Blasco, Ricard & Española & 72. Matte, Jorge & Chilena \\
\hline 21. Burgos y Seguí, C. de & Española & 73. Maúrtua, Víctor Manuel & Peruana \\
\hline 22. Cabal, Constantino & Española & 74. Melossi Hutchinson, A. & Chilena \\
\hline 23. Cabrinety, Manuel & Española & 75. Menechella (s) & - \\
\hline 24. Camín, Alfonso & Española & 76. Mínimo (s) & - \\
\hline 25. Canel, Eva & Española & 77. Monjas, Ángel & Española \\
\hline 26. Carner i Puigoriol, José & Española & 78. Montserrat y Archs, Juan & Española \\
\hline 27. Carrancá y Trujillo, Raúl & Mexicana & 79. Muñoz Rodríguez, Fidel & Chilena \\
\hline 28. Castelar, Emilio & Española & 80. Olariaga Pujana, Luis & Española \\
\hline 29. De Tormes & - & 81. Ortúzar Bulnes, Adolfo & Chilena \\
\hline 30. Debans, Camilo & Francés & 82. Padre Rossello & - \\
\hline 31. Dermeval Lessa (s) & - & 83. Palma, Angélica & Peruana \\
\hline 32. Diez de Medina, Fernando & Boliviana & 84. Palma, Ricardo & Peruana \\
\hline 33. Doctor Mengano (s) & - & 85. Pan, Ismael del & Española \\
\hline 34. Domínguez Rodiño, E. & Española & 86. Paula Flaquer, Francisco de & Española \\
\hline 35. Dubois, Antonio & Española & 87. Pérez Caballero, Juan & Española \\
\hline 36. Dupuy de Lome, Enrique & Española & 88. Pérez de Guzmán, Juan & Española \\
\hline 37. Edwards Bello, Joaquín & Chilena & 89. Petit Lecaros, Benigno & Peruana \\
\hline 38. Elguera, César & Peruana & 90. Piacentini, Jorge & Argentina \\
\hline 39. Paulet Mostajo, Pedro E. & Peruana & 91. Plá Espí, Ricardo & Española \\
\hline 40. Espina, Antonio & Española & 92. Renovales (s) & - \\
\hline 41. Espinosa, D. & Española & 93. Révesz, Andrés & Húngara \\
\hline 42. Falcón Garfias, César & Peruana & 94. Risquet, Fernando & Española \\
\hline 43. Fernández Bremón, José & Española & 95. Rittwagen, Guillermo & Española \\
\hline $\begin{array}{l}\text { 44. Fernández Pesquero, } \\
\text { Javier }\end{array}$ & Española & $\begin{array}{l}\text { 96. Rodríguez Mendoza, Emilio } \\
\text { 97. Saissy (s) }\end{array}$ & $\begin{array}{l}\text { Chilena } \\
-\end{array}$ \\
\hline 45. Fillol, Gil & Española & 98. Sanamor (s) & - \\
\hline 46. Francos Rodríguez, José & Española & 99. Santiago y Carrión, E. de & Española \\
\hline 47. Galera y Romero, Andrés & Española & 100. Sarrablo y Palacio, Alfonso & Española \\
\hline 48. Gandásegui, Remigio & Española & 101. Sassone, Felipe & Peruana \\
\hline 49. García Pérez, A. & - & 102. Tito Liviano (s) & - \\
\hline 50. García, Arturo & Española & 103. Vera, Vicente & Española \\
\hline 51. Gay y Forner, Vicente & Española & 104. Vidal, Fabián & Española \\
\hline $\begin{array}{l}\text { 52. Gómez de Baquero, } \\
\text { Eduardo }\end{array}$ & Española & $\begin{array}{l}\text { 105. Vighi Fernández, Francisco } \\
\text { 106. Zulueta R., Jaime de }\end{array}$ & $\begin{array}{l}\text { Española } \\
\text { Española }\end{array}$ \\
\hline 53. Góngora, Alonso de (s) & Española & 107. Zulueta y Escolano, Luis de & Española \\
\hline
\end{tabular}

Fuente: Elaboración propia a partir de las fuentes hemerográficas analizadas. (s): seudónimo. 
En otro aspecto, la larga duración -no en sentido braudeliano- de la posguerra chileno-peruana permitió opinar a escritores de nacionalidades heterogéneas (tabla $n .^{\circ} 3$ ). En ellos constatamos posiciones políticas argumentadas sobre la litis y, por extensión, a los procedimientos que Chile y Perú, principalmente, desarrollaban para finiquitarla. La participación de escritores fue notable, bordeando los cien. Si bien la mayoría fueron españoles, por ejemplo, Fabián Vidal, Ricardo Beltrán Rózpide y Remigio Gandásegui, también hubo extranjeros como Arturo Alessandri Palma y Emilio Rodríguez Mendoza, políticos chilenos; Eduardo Leguía y César Elguera, políticos peruanos, entre otros. La prolongación del problema y las dificultades diplomáticas acrecentadas año tras años ofrecieron a los publicistas un repertorio variado de acontecimientos sobre los que opinar.

Como es previsible, las diferencias de las noticias en lo relativo a sus fuentes de origen -agencias, desconocidas, firmadas por escritores- nos acercan al problema de los tipos de publicaciones. Es conocida la discusión de los especialistas en torno a las categorías de las noticias, distinguiendo por lo menos dos: las "informativas" y las de “opinión”. Las primeras guardarían relación con textos más “objetivos”; las segundas tendrían una base más "subjetiva" o "interpretativa”. Esta configuración dualista es antigua y tiene una densidad de bibliografía que hace imposible discutirla en este estudio.

Sin entrar en ese debate, por comprender que una noticia "informativa" siempre "opina" (considerando a la prensa como actor sociopolítico dentro de la comunidad donde se produce) y que una "opinión" publicada siempre "informa" datos; y que, en consecuencia, toda noticia publicada desde su elaboración hasta su lectura por los receptores, posee subjetividad, compartimos los planteamientos teóricos de Paniagua que superan la antítesis al introducir en la creación de noticias de prensa el factor procesual o dinámico $\mathrm{y}$, además, relacional entre informaciones y opiniones. Así, además, se comprende su afirmación sobre la inexistencia de los géneros, por lo menos, como habitáculos que contienen textos, pues aquellos serían "sólo postes orientadores [...] Lo que existe en realidad son los textos mismos con un contenido de información e interpretación que evoluciona según pasa el tiempo"311.

\footnotetext{
311 Paniagua Santamaría, Pedro, Información e interpretación en periodismo. Hacia una nueva teoría de los géneros, Barcelona, Carrera Edició, 2009, p. 10.
} 
Por su parte, Jorque elaboró una tipología del texto informativo ${ }^{312}$ incluyendo las nociones clásicas de informaciones y opiniones, donde se sobreentiende que, como en Paniagua, superó la polarización entre "informaciones" y "opiniones". La tipología comprende tres niveles, a saber: a) Textos informativos de relieve: Noticia, noticiacomentario, entrevista; b) Textos informativos de detalle: Reportaje, crítica, crónica y c) Textos de acumulación: Columna de opinión, editorial, columna de análisis. Consecuentemente, las noticias utilizadas en esta investigación también pueden clasificarse por su carácter "informativo" o de "opinión" -palabras empleadas sólo utilitariamente-, homologando, por un lado, los textos de relieve con las unidades donde predomina la información y, por otro, los textos de detalle con los de opinión (gráfico n. ${ }^{\circ}$ 8). Traducido a dígitos, el número de noticias con información bordea los 1400 casos, por encima de las noticias de opinión que superan los 800 .

\section{Gráfico n. ${ }^{\circ} 8$}

Texto de relieve (información) y texto de detalle (opinión)

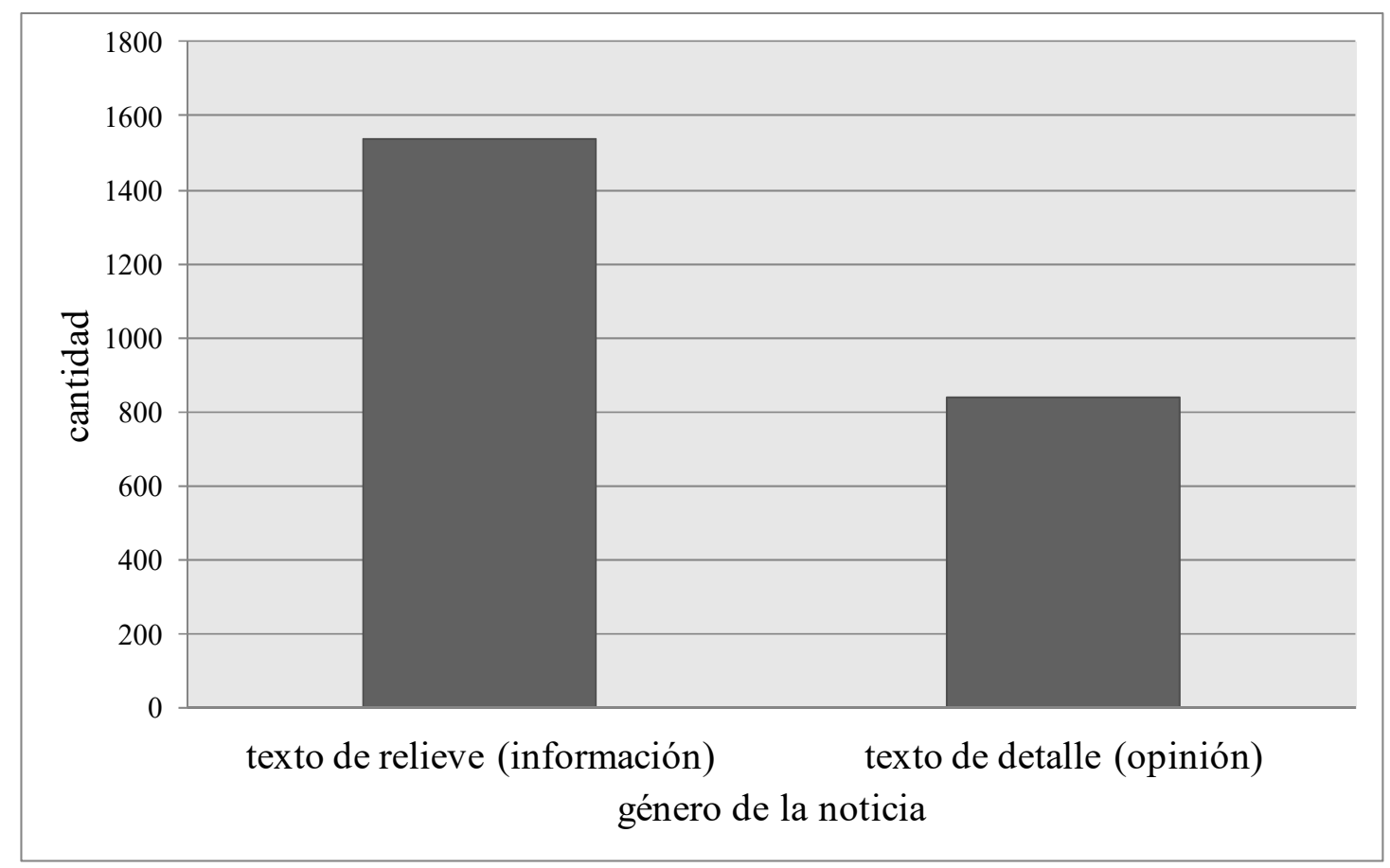

Fuente: Elaboración propia en base a fuentes hemerográficas analizadas.

\footnotetext{
312 Alía Miranda, Francisco, Técnicas de investigación para historiadores, Madrid, Editorial Síntesis, 2005, p. 336.
} 
Desconocemos investigaciones en el área de la historia cultural de la prensa que evalúen la efectividad de uno $\mathrm{u}$ otro tipo de texto periodístico en la constitución de representaciones sociales. No obstante, en esta investigación es imprescindible considerar la importancia de la inserción aleatoria de noticias informativas o de opinión. Como hemos expresado en el apartado teórico, al enfocarnos exclusivamente en el texto y no en los lectores, desconocemos el impacto social de leer una nota de relieve o de detalle.

Lo comentado tiene importancia especial en la comprensión de la construcción de representaciones, pues para elaborarlas eficazmente en prensa se requiere de simpleza y reduccionismo analítico de los hechos. Un acercamiento a su "relieve" permitiría publicar generalizaciones y lugares comunes de la relación entre Chile y Perú. En los textos de "detalle", la "crítica" como subgénero explicaría las narrativas utilizadas por los escritores identificados. En aquella "se atiende de forma preeminente a los factores semánticos e ideológicos del discurso informativo" 313 .

En otro ámbito, es necesario detectar la nacionalidad exacta de las publicaciones periodísticas que utilizó la prensa española para referirse a la cuestión de Tacna y Arica. Saber con precisión el país de producción de las noticias utilizadas por las editoriales hispanas explica, en gran parte, las tendencias de adhesión o rechazo hacia el papel de Chile y Perú durante el conflicto. Con esa intención se elaboraron dos tablas que detallan los principales países de América y Europa -incluyendo el nombre de todos los diarios posicionados frente a la litis- de quienes se benefició el periodismo español (tabla n. ${ }^{\circ} 4 \mathrm{y}$ n. ${ }^{\circ}$ 5). Puntualmente, en los casos de la prensa chilena y peruana -medios que trataron de "generar una «opinión pública favorable»" ${ }^{14}$ durante el origen del conflicto- consultada por las industrias periodísticas españolas aparece un indicador que abarca una cantidad desconocida e innominada de diarios agrupados como "prensa chilena en general", "prensa limeña en general" y "prensa peruana en general" (tabla n. ${ }^{\circ}$ ). Considerar ese hecho permite pensar, hipotéticamente, qué importancia dieron los diarios españoles consultados al pluralismo ideológico existente dentro de un Estado, como al proceso selectivo de sus

\footnotetext{
313 Idem.

314 MARTínEZ RiAZA, Ascensión, "Estado y territorio en Iberoamérica. Conflictos interregionales. Un modelo analítico: la Guerra del Pacífico, 1879-1883”, Revista Complutense de Historia de América, n. ${ }^{\circ}$ 20, 1994, p. 186.
} 
fuentes. Al parecer, esos diarios fueron representados idealmente como órganos extremadamente homogéneos desde un punto de vista nacional frente al conflicto territorial.

\section{Tabla n. ${ }^{\circ} 4$}

Publicaciones americanas utilizadas como fuentes de información por la prensa española.

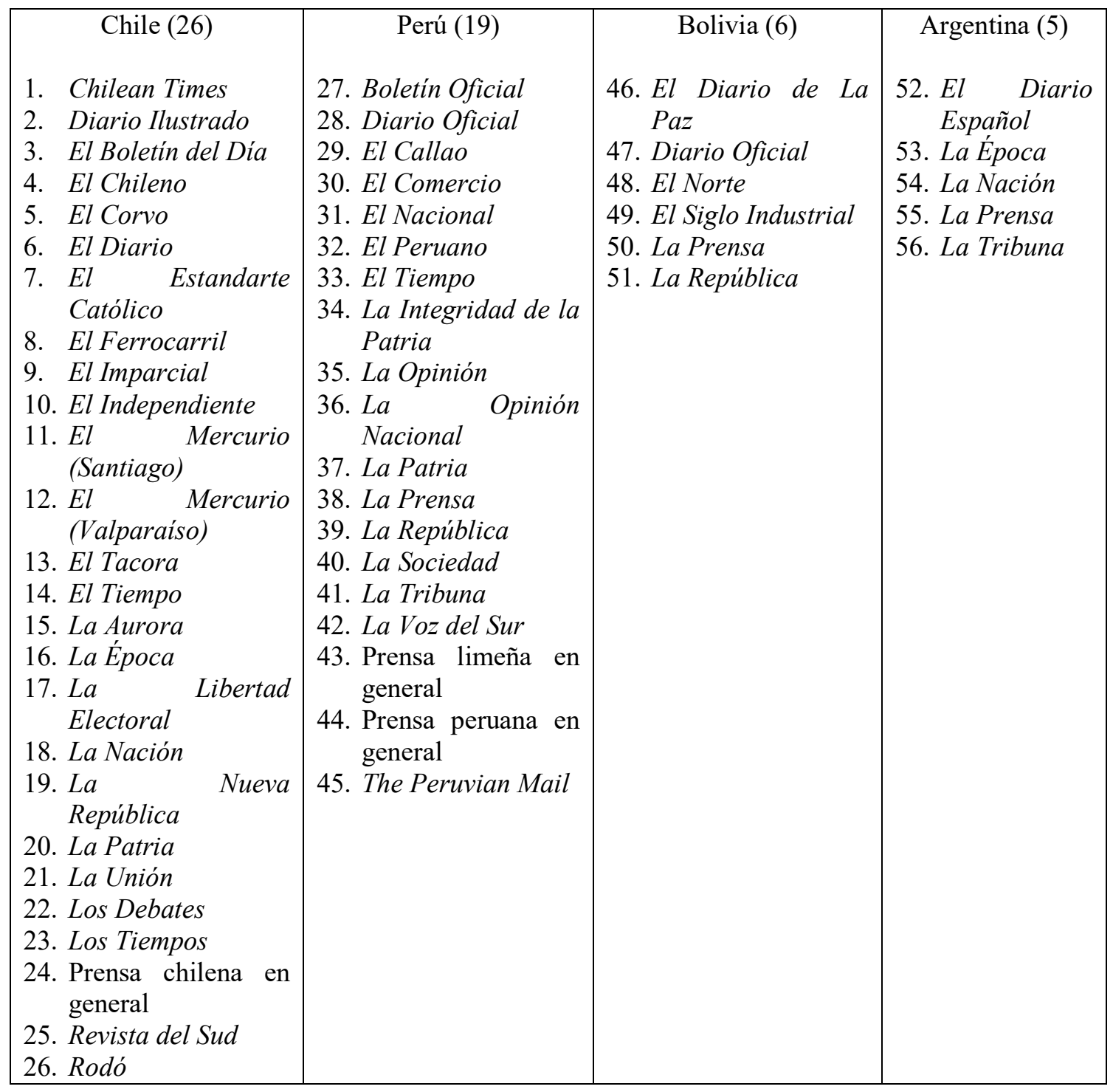

Fuente: Elaboración propia en base a fuentes hemerográficas analizadas. Nota: Las publicaciones correspondientes a los números 24,43 y 44 no son en estricto rigor nombres de prensa, sino más bien la forma genérica de prensa, en el mismo orden, chilena, limeña y peruana. La incluimos por su gran presencia como fuente de las unidades de análisis por nosotros utilizadas ${ }^{315}$.

\footnotetext{
${ }^{315}$ La tabla no incluye las prensas de Colombia, Cuba, Ecuador, El Salvador y Uruguay referidas a la cuestión de Tacna y Arica debido a su representatividad mínima. En el primer caso sólo hay una referencia a la "prensa colombiana"; en el segundo, al Diario Español y a la "prensa cubana"; en el tercero, a La Nación; en el cuarto, a El Día; por último, sólo dos referencias a los diarios uruguayos Diario del Plata y La Colonia Española.
} 
Tabla n..$^{\circ} 5$

Publicaciones extranjeras utilizadas como fuentes por la prensa española

\begin{tabular}{|c|c|c|c|}
\hline $\begin{array}{l}\text { EE.UU. (14) } \\
\text { 1. Chicago Tribune } \\
\text { 2. Echo } \\
\text { 3. El Correo } \\
\text { 4. El Progreso } \\
\text { 5. La Raza Latina } \\
\text { 6. Las Novedades } \\
\text { 7. Panama Star and } \\
\text { Herald } \\
\text { 8. Prensa } \\
\text { neoyorquina en } \\
\text { general } \\
\text { 9. Star and Herald } \\
\text { 10. The Herald } \\
\text { 11. The New York } \\
\text { Herald } \\
\text { 12. The New York } \\
\text { World } \\
\text { 13. The (New York) } \\
\text { Times } \\
\text { 14. The World }\end{array}$ & $\begin{array}{l}\text { Inglaterra (7) } \\
\text { 15. Daily Chronicle } \\
\text { 16. Daily Mail } \\
\text { 17. Daily News } \\
\text { 18. Saint James } \\
\text { Gazette } \\
\text { 19. Standard } \\
\text { 20. The South } \\
\text { American Journal } \\
\text { 21. The Times }\end{array}$ & $\begin{array}{l}\text { Francia (6) } \\
\text { 22. Le Figaro } \\
\text { 23. La Gaceta } \\
\text { Internacional } \\
\text { 24. Le Matin } \\
\text { 25. Le Memorial } \\
\text { Diplomatique } \\
\text { 26. Le Petit Parisien } \\
\text { 27. Le siècle XIX }\end{array}$ & $\begin{array}{l}\text { Italia (4) } \\
\text { 28. El Observatorio } \\
\text { Romano } \\
\text { 29. Il Diritto } \\
\text { 30. Italia Militar } \\
\text { 31. La Tribuna }\end{array}$ \\
\hline
\end{tabular}

Fuente: Elaboración propia en base a fuentes hemerográficas analizadas.

Es coincidente la primacía de Chile y Perú, países directamente interesados en Tacna y Arica. En los casos de Bolivia y Argentina, la razón estribó en que ambos países limitaban con los anteriores. Todos se interesaron en la litis y sus noticias fueron consideradas en España como expresión de visiones cercanas al problema. En Bolivia se elaboraron noticias sobre Arica, pues una vez perdida la salida al mar, sus políticos construyeron un discurso reivindicativo, donde Arica debía ser el puerto boliviano. Además, anexándosela -aseguraban sus ideólogos-pacificaría el odio chileno-peruano.

La presencia argentina se debe a otras razones. Ese país tuvo un papel central en la gestación del protocolo Billinghurst-Latorre de 1898. Según la historiografía peruana, Chile interesadamente lo firmó debido a tensiones limítrofes y diplomáticas con Argentina. Su objetivo era librarse de una guerra eventual en dos frentes. Los historiadores limeños han subrayado que el desentendimiento chileno hacia el acuerdo, una vez tranquilizadas las pulsiones armadas con Argentina, demostraron la inmoralidad y bajeza de aquel país. 
Para los cuatro países existió un periódico privilegiado por la prensa española (gráfico n. ${ }^{\circ}$ 9). Estos "informantes clave", portadores de conocimientos especializados, parafraseando a McKernan ${ }^{316}$, permitieron extraer informaciones para la publicación posterior. En el caso chileno, El Mercurio tuvo primacía, seguido por La Patria y La Nación, todos con una línea editorial nacionalista, no sólo a juzgar por el nombre de sus títulos, como en los dos últimos casos, sino también por sus ideólogos. Un buen ejemplo de estos fue Agustín Edwards McClure, fundador y propietario de El Mercurio desde 1900, Ministro Plenipotenciario de Chile en Inglaterra en 1910, Presidente de la Asamblea General de la Sociedad de las Naciones los años 1922-1923 y representante chileno frente a la Comisión Plebiscitaria de Tacna y Arica en 1925, entre otros cargos de relevancia nacional e internacional.

\section{Gráfico n. ${ }^{\circ} 9$}

Publicaciones de Chile, Perú, Bolivia y Argentina más utilizadas.

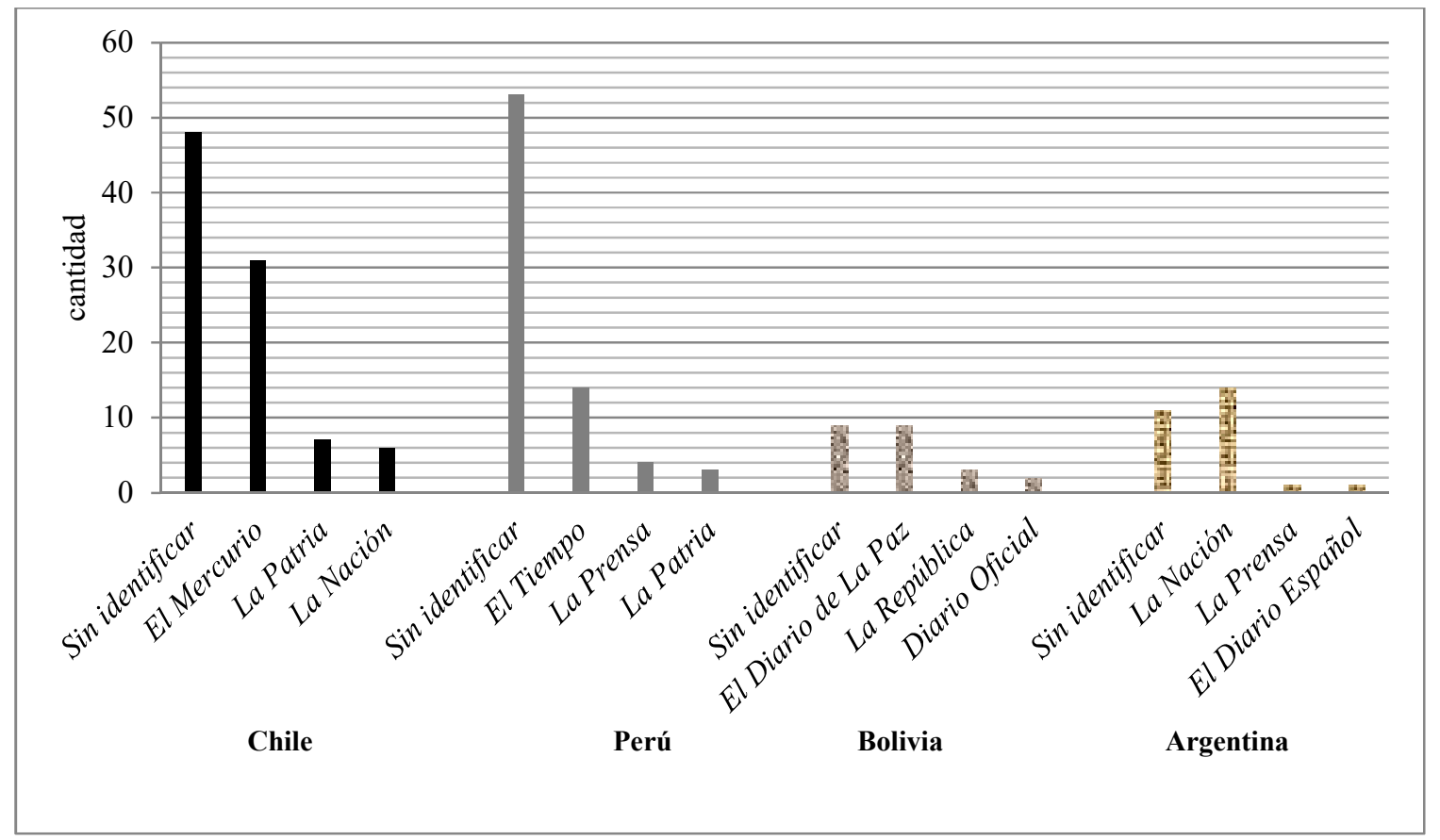

Fuente: Elaboración propia en base a fuentes hemerográficas analizadas.

\footnotetext{
${ }^{316}$ MCKERNAN, James, Investigación-acción y currículum. Métodos y recursos para profesionales reflexivos, Madrid, Ediciones Morata S. L, 2001, p. 152.
} 
Entre los 57 diarios hispanoamericanos, El Mercurio fue el más citado en España, seguido de lejos por El Tiempo de Perú y La Nación de Argentina (tabla n. ${ }^{\circ}$ 4). Un dato notable es la inclusión del pasquín ultranacionalista chileno-ariqueño El Corvo, aparecido los años plebiscitarios de 1925-1926, enmarcado entre las publicaciones patrióticas, esporádicas y chismosas ${ }^{317}$. A excepción de aquel, la prensa española no usó ninguna publicación ariqueña. Los diarios y revistas de esas ciudades se preocuparon por las dimensiones sociales y culturales del litigio $\mathrm{y}$, como se puede prever, reflejaron otros ángulos del conflicto menos conocidos en España.

Es importante consignar cómo los periódicos usados y no identificados son mayoritarios en los casos de Chile, Perú y Bolivia, los países más comprometidos en la cuestión, por sus vínculos territoriales, mientras que la excepción fue la prensa argentina. Eso se suma al problema de la producción de representaciones sociales "fantasmas", ya comentado en el caso de las noticias sin agencias.

En efecto, en el momento de publicar noticias de la frontera, la prensa introdujo en cientos de ocasiones las expresiones "leemos en la prensa chilena", "los diarios peruanos comentan", "los periódicos bolivianos publican", etc., todas locuciones generales homogeneizadoras del mercado periodístico americano.

La prensa española también consultó prensas de países con una industria periodística más desarrollada, como Estados Unidos, Inglaterra y Francia (gráfico n. ${ }^{\circ} 10$ ). A diferencia de su abastecimiento con publicaciones hispanoamericanas, el número de diarios y revistas descendió de 57 hasta 31. El declive de publicaciones proveedoras podría tener relación con su identificación, pues ahora constatamos un descenso brusco del grupo "sin identificar". A excepción de Estados Unidos, la prensa inglesa, francesa e italiana, tienen presencias importantes con sus diarios The Times, Le Matin y Il Diritto, respectivamente.

\footnotetext{
${ }^{317}$ DíAZ AguAD, Alfonso, "La violencia del discurso. La problemática política y social de Tacna y Arica a través de la prensa local, 1918-1926”. En DíAZ ARAYA, Alberto, RuZ ZAGAL, Rodrigo y GALDAMES RosAS, Luis (Compiladores), Tiempos violentos. Fragmentos de historia social en Arica, Arica, Ediciones Universidad de Tarapacá, 2014, p. 75.
} 


\section{Gráfico n. ${ }^{\circ} 10$}

Publicaciones extranjeras más utilizadas por la prensa

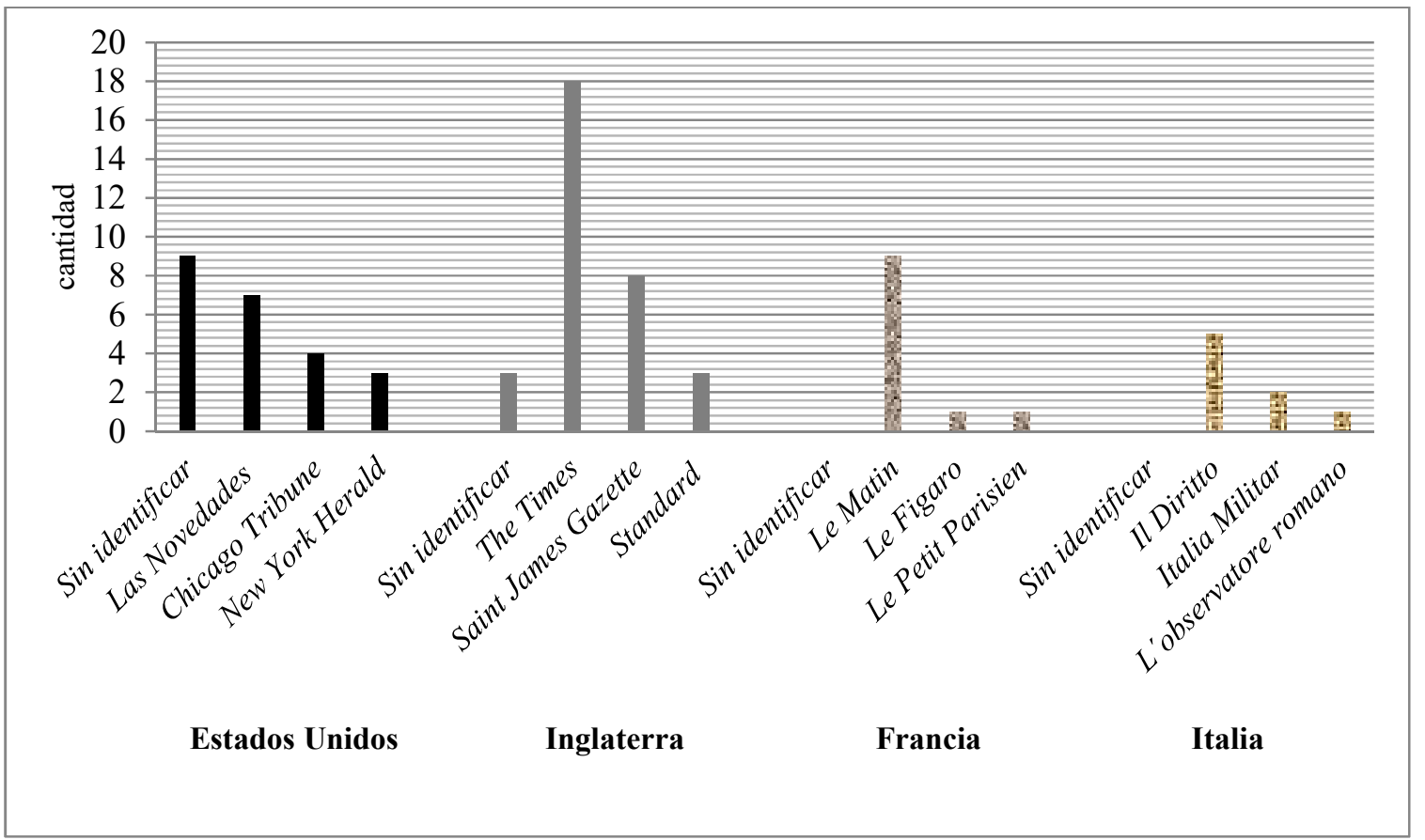

Fuente: Elaboración propia en base a fuentes hemerográficas analizadas.

Una investigación profunda sobre las fuentes usadas por la prensa española -sean americanas o europeas- debiese plantear preguntas del siguiente orden: ¿por qué la empresa española de noticias reconocía en esos países un potencial informativo?, ¿qué tipo de filiaciones ideológicas entre la prensa española y la de aquellos países aprobaba la compra o el préstamo noticioso?, ¿de qué formas se realizaban las traducciones idiomáticas en los diarios españoles? En última instancia, la heurística practicada sobre fuentes hemerográficas españolas debiera efectuarse también con la prensa americana y europea identificada. No cabe duda que, en definitiva, la cercanía a los productores variados de representaciones sociales de la frontera esclarecería los orígenes de los rasgos principales de aquellas. Así, por su importancia en el ámbito mundial, interesaría el caso del The Times inglés, acentuado por algunas investigaciones debido a su peso en la "opinión pública"318.

\footnotetext{
318 LÓPEZ LitA, Rafael, FERnÁNDEZ BELTRÁn, Francisco y DURÁn MAÑÉs, Ángeles (eds.), La prensa local y la prensa gratuita, Castelló de la Plana, Publicacions de la Universitat Jaume I, 2002, p. 185; VILLARES, Ramón y BAHAMONDE, Ángel, El mundo contemporáneo del siglo XIX al XX, [edición digital].
} 
La parte final del análisis heurístico concierne a los aspectos territoriales o de localización de las noticias de Tacna y Arica. Este conflicto deshilvanó el tejido social de la frontera en un aspecto local, pero también produjo tensiones diplomáticas en una escala global. Sus repercusiones variaron territorialmente, desde el sitio mismo hacia otros lugares alejados, como las capitales de los países implicados o, aún más lejos, en países europeos, como lo demostró el interés de sus prensas. Explicando la situación con una metáfora sísmica, los terremotos socio-políticos acontecidos en el epicentro Tacno-ariqueño expandieron ondas destructivas alcanzando distancias heterogéneas. Una lista de las ciudades damnificadas se ofrece en la tabla n. ${ }^{\circ} 6$. El casi medio centenar de lugares donde circuló la tragedia diplomática entre Chile y Perú, demuestra el interés suscitado en occidente. Por el contrario, una cifra elevada de noticias no especificó su procedencia (gráfico n. ${ }^{\circ} 11$ ). De todas formas, como era previsible, Chile y Perú tuvieron posiciones de avanzada, debido a que la solución de la litis, por lo menos en teoría, correspondía efectuarla a esos países.

\section{Tabla n. ${ }^{\circ} 6$}

Ciudades de referencia usadas por la prensa para informar del conflicto

\begin{tabular}{|l|l|}
\hline 1. Antofagasta & 25. Managua \\
2. Arica & 26. México D. F. \\
3. Balboa & 27. Montevideo \\
4. Barcelona & 28. Nauen \\
5. Berlín & 29. Nueva York \\
6. Biarcliff Manon & 30. Oruro \\
7. Bogotá & 31. Panamá \\
8. Buenos Aires & 32. París \\
9. Burdeos & 33. Pernambuco \\
10. Cádiz & 34. Quito \\
11. Callao & 35. Río de Janeiro \\
12. Caracas & 36. Roma \\
13. Friedrichshafen & 37. San Sebastián \\
14. Ginebra & 38. Santiago \\
15. Guayaquil & 39. Sao Paulo \\
16. La Habana & 40. Sevilla \\
17. La Paz & 41. Sídney \\
18. Lima & 42. Valparaíso \\
19. Limoges & 43. Viena \\
20. Lisboa & 44. Vigo \\
21. Londres & 45. Viña del Mar \\
22. Lugares no explicitados & 46 . Washington \\
23. Lyon & 47. Wisconsin \\
24. Madrid & \\
\hline
\end{tabular}

Fuente: Elaboración propia en base a fuentes hemerográficas analizadas. 
En la práctica, el intervencionismo estadounidense y sus intereses por consolidar el monroísmo en la región posibilitaron los buenos oficios del país del norte y con eso la producción noticiosa sobre Tacna y Arica. Principalmente los diarios estadounidense New York Times y Washington Post debatieron y opinaron con vehemencia respecto a la política fronteriza chilena. Ambas publicaciones "desempeñaron un rol activo durante la preparación del plebiscito de Tacna y Arica, asumiendo una posición contraria a los intereses chilenos, a fin de salvaguardar el prestigio e influencia internacional de Estados Unidos"319. Estas situaciones, en parte, permiten comprender la posición terciaria de ese país como centro productor de noticias.

Otra consideración. La frontera fue imaginada y construida como una región conflictiva, plasmación machacona de la prensa santiaguina, limeña y paceña. Las noticias que publicaron tuvieron eco en las imprentas matritenses y tuvieron en ocasiones anormales referencias territoriales a Arica (gráfico n. ${ }^{\circ} 12$ ). Su observación permite pensar cómo las representaciones sociales fabricadas utilizaron como material de referencia noticias sin precisar su procedencia, mecanografiadas en las metrópolis de Chile, Perú y Bolivia que ignoraban el movimiento socio-político de la limes chileno-peruana y, por último, introducidas sin mayor elaboración en aquella. El centralismo periodístico propio de esos países iba de la mano con el centralismo político. Centralizar la prensa tenía como objetivo, sin duda, la construcción de una "opinión pública" -en sentido acrítico- alineada con los intereses de las elites nacionales. Las periferias regionales de los países andinos estudiados disponían de una infraestructura básica para imprimir sus medios de comunicación. En Arica, por ejemplo, la competencia de prensas con dueños de nacionalidad chilena, por un lado, y peruana, por otra, finalizó dramáticamente el 18 de julio de 1911, cuando pandillas de ultranacionalistas chilenos destruyeron las máquinas del Morro de Arica. En conclusión, sospechamos con algo de certeza que las representaciones circulantes en la prensa española fueron superposiciones de representaciones nacionales. Ese proceso, visto desde América, se constituyó con el siguiente orden: Tacna o Arica (local), Santiago o Lima (nacional), Madrid o Barcelona (internacional).

\footnotetext{
${ }^{319}$ LLANOS SIERRA, Nelson, El reino chileno del terror: la prensa estadounidense y la controversia de Tacna y Arica, 1925-1926, Estudios hemisféricos y polares, vol. 2, n. ${ }^{\circ} 2,2011$, p. 45.
} 


\section{Gráfico n. ${ }^{\circ} 11$}

Procedencia de las noticias de referencia por países para informar de la litis

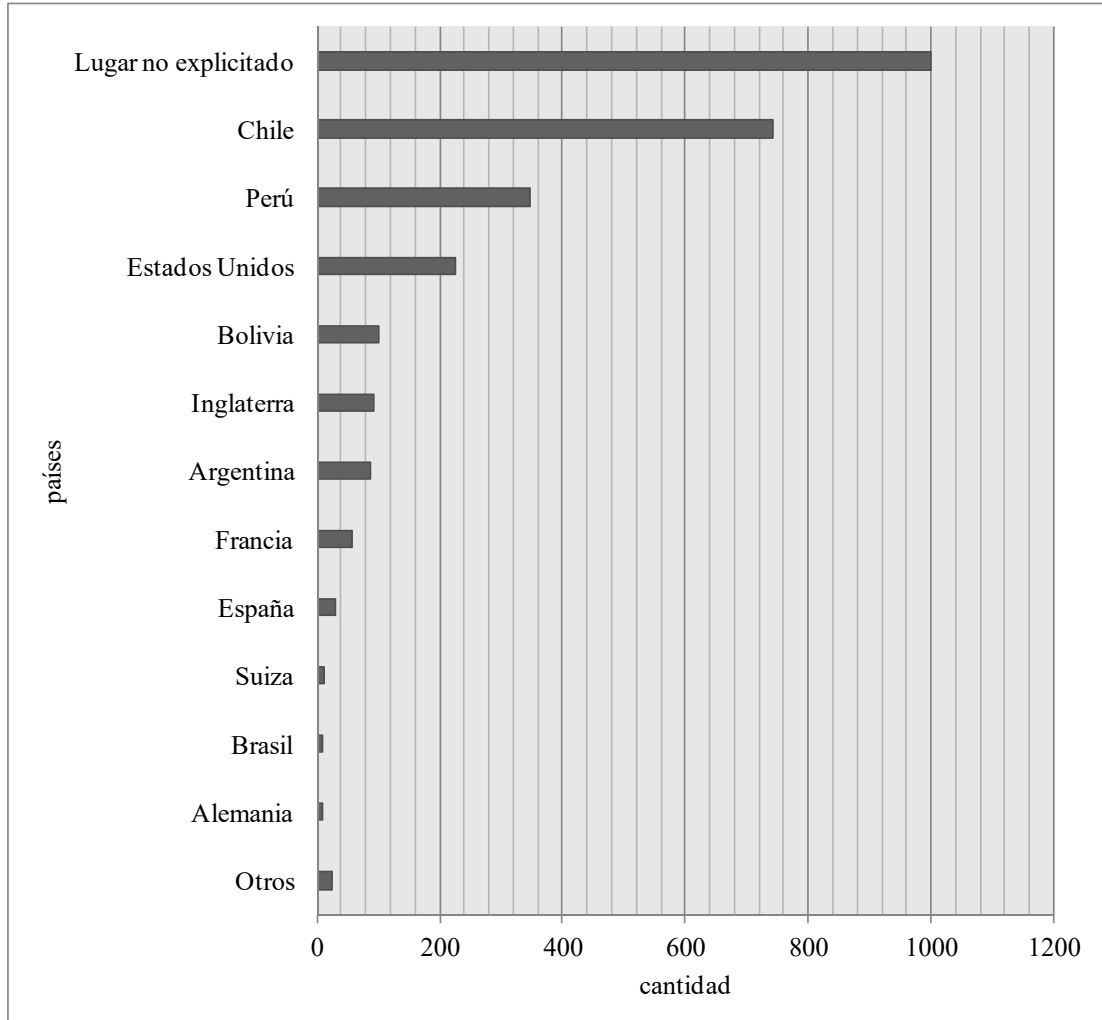

Fuente: Elaboración propia en base a fuentes hemerográficas analizadas.

Nota: La variable "otros" incluye: Panamá, Uruguay, Cuba, Australia, Italia, México, Ecuador, Venezuela, Austria, Nicaragua, Portugal, Colombia.

\section{Gráfico n. ${ }^{\circ} 12$}

Utilización de Arica en la prensa para referirse al conflicto

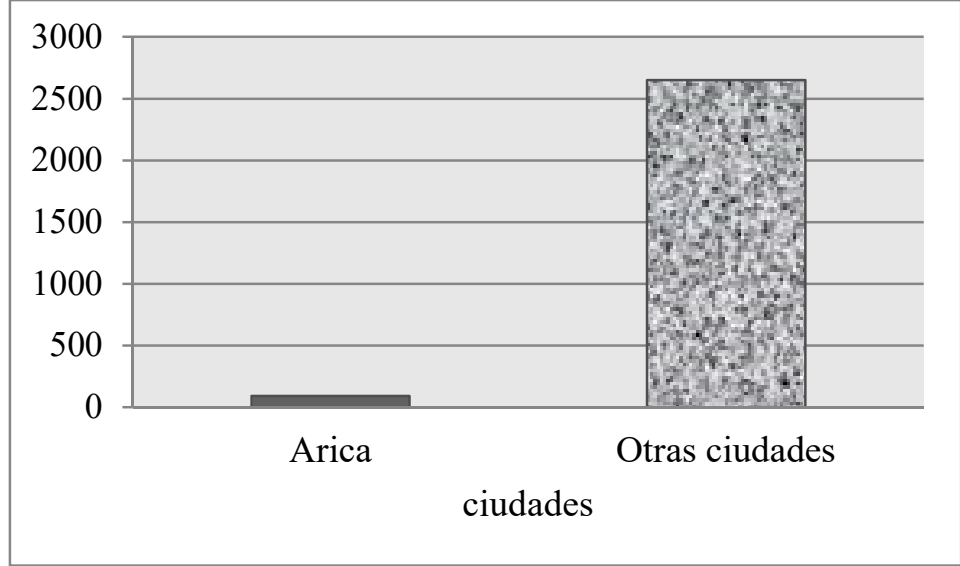

Fuente: Elaboración propia en base a fuentes hemerográficas analizadas. Otras ciudades: las señaladas en la tabla n. ${ }^{\circ} 6$. 


\subsection{Análisis de contenidos}

El método que hemos elaborado para la presente investigación es bifásico. En primer lugar, se usarán los principios fundamentales de la metodología histórica con el objeto de conocer en profundidad las fuentes que sustentan el estudio. En segundo lugar, se realizará un análisis de contenidos. Este procedimiento requiere una serie de aclaraciones, puesto que desde su origen hasta hoy se ha visto enriquecido por la profundización teórica en torno a los problemas sociales investigados y por el uso de ordenadores para la sistematización de los datos. No es la intención de este apartado, por interesante que sea, realizar una historia del análisis de contenido, a la cual otros autores ya han referido ${ }^{320}$.

Por el contrario, en este capítulo interesa explicitar que el análisis de contenido aquí planteado no se adhiere a la noción maniquea que entiende los procedimientos cualitativos como formas totalmente opuestas a los procedimientos cuantitativos. Las posibilidades ofertadas por la estadística para la comprensión del pasado, no es motivo importante de debate disciplinar. Así lo han demostrado obras canónicas en ese campo ${ }^{321}$. Si bien esas corrientes metodológicas poseen grados de especificidad y especialización indudables, este estudio analiza los datos históricos beneficiándose de ambas. La superación de esa antinomia científica fue subrayada hace décadas por Reichardt y otros investigadores ${ }^{322}$. No obstante, como se observará, el peso del análisis cualitativo será mayor que el del cuantitativo, debido a los intereses teóricos desde donde planteamos las interrogantes centradas en la construcción social de representaciones surgidas a raíz del problema de Tacna y Arica en la prensa española.

\footnotetext{
320 Alonso, Sonia, Volkens, Andrés y Gómez, Braulio, Análisis de contenidos de texto políticos. Un enfoque cuantitativo, Madrid, Centro de Investigaciones Sociológicas, 2012; BARDIN, Laurence, Análisis de contenido, Madrid, Akal S. A., 2002; PÉREZ SERRANO, Gloria, Investigación cualitativa. Retos e interrogantes..., pp. 133-136; KRIPPENDORFF, Klaus, Metodología de análisis de contenido. Teoría y práctica, Barcelona, Ediciones Paidós, 1990.

321 Chaunu, Pierre, Historia cuantitativa, historia serial, México, Fondo de Cultura Económica, 1987; Floud, Roderick, Métodos cuantitativos para historiadores, España, Alianza Editorial, 1979; LANDES, David, LinZ, Juan, Tilly, Louise, TiLly, Charles y otros, Las dimensiones del pasado. Estudios de historia cuantitativa, España, Alianza Editorial, 1974.

322 ReICHARDT, Charles y COOK, Thomas, "Hacia una superación del enfrentamiento entre los métodos cuantitativos y cualitativos". En COOK, T. D. y REICHARDT, Ch. S., Métodos cualitativos y cuantitativos en investigación evaluativa, Madrid, Ediciones Morata, S. L., 2005, pp. 25-58; ÁLVAREZ, Juan, "Investigación cuantitativa/investigación cualitativa ¿Una falsa disyuntiva?”. En CoOK, T. D. y REICHARDT, Ch. S., Métodos cualitativos y cuantitativos en investigación evaluativa, Madrid, Ediciones Morata, S. L., 2005, pp. 9-24.
} 
Tal afirmación requiere mayor precisión, puesto que la decisión de no tomar partido por el aspecto cuantitativo o cualitativo y, a la vez, afirmar el predominio del enfoque cualitativo implica tres cuestiones.

De partida, la aproximación analítica decidida parar estudiar la prensa es lógicaestética. Este concepto fue explicado por Raymond Colle quien distinguió otros dos tipos de análisis de contenido: el lógico y el lógico-semántico. Nuestra apropiación del carácter lógico-estético se debe a la atención puesta en los "procedimientos de expresión utilizados por el emisor, buscando características (de estilo, vocabulario, efectos estéticos y retóricos

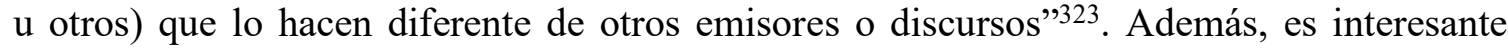
considerar que para Colle, prescindir de los "componentes semánticos" imposibilitaría hablar de análisis de contenido. Esta primera cuestión enfatiza que el discurso periodístico sobre el diferendo será investigado sólo en los textos publicados que conforman la muestra y no en los receptores de tales escritos. Esta última cuestión fue comentada en el capítulo precedente al notar la diferencia entre el "mundo del texto" y el "mundo del lector".

Una segunda consideración surge al concebir nuestro análisis de contenido como un análisis "no reactivo" y "no estructurado". Estas situaciones se desprenden de los datos que se desean analizar para argumentar las preguntas de investigación. Klaus Heinemann se refirió en un reciente estudio a algunas ventajas de los análisis de contenidos, mencionando entre otras, el hecho de ser un "procedimiento de medición no reactivo" y, en lo relativo a las fuentes, por trabajar con "material no estructurado"324. El primer aspecto está vinculado con la influencia que puede tener el recolector de los datos sobre los emisores de esos datos. En nuestro caso estamos frente a un procedimiento no reactivo, porque el objeto de análisis -la prensa histórica- no cambia o se altera luego del estudio. Por su lado, cuando nos referimos a material no estructurado queremos dar a entender que las noticias analizadas no están sistemáticamente dispuestas para aplicar las técnicas de investigación, sino por el contrario, el historiador manipula y estructura el material de base según los objetivos de la investigación.

323 Colle, Raymond, El análisis de contenido de las comunicaciones. 2. Técnicas de análisis, Tenerife, Sociedad Latina de Comunicación Social, 2011, p. 7.

324 HeInEmAnN, Klaus, Introducción a la metodología de la investigación empírica, Barcelona, Editorial Paidotribo, 2003, p. 148 . 
En tercer lugar y por último, practicaremos en las noticias referidas a la frontera chileno-peruana un análisis de contenido de carácter "etnográfico". Esta variante en el análisis de contenidos hace posible comprender los textos de prensa como "artefactos culturales" con sentido dentro de la sociedad española del pasado importándonos por eso las "palabras, significados y temas" 325 así como las relaciones teóricas que se puedan sostener o refutar en el proceso de comprensión de los significados latentes ${ }^{326}$.

Estas intenciones han hecho posible que el acercamiento a ese pasado sea desde la historia cultural, la cual centra sus intereses en las identidades culturales, dentro de las que se encuentra un tipo específico de identidad -la nacional- que aquí investigamos y, además, de los modos de pensamiento o "representaciones sociales", como es correcto afirmarlo en el lenguaje de las ciencias sociales. En esta investigación entendemos que los contenidos de las noticias no son "simplemente el significado de las palabras, ni una simple suma de los mismos" 327 , más bien, las palabras debiesen ser entendidas "como agrupamientos verbales en relación con otras y dentro de un conjunto". Esos conjuntos constituyen “representaciones sociales" de la realidad externa a la prensa a la cual se refiere de un modo determinado.

Dicho lo anterior, se debe enfatizar que analizar los contenidos de la prensa histórica española comprende cuatro etapas obligatorias. Cada una de éstas sigue a la otra, por lo que es necesario remarcar aquí el sentido lineal o en cadena de su aplicación. La secuencia seguida ha sido: recopilación de las fuentes, codificación, categorización y hermenéutica.

\subsubsection{Recopilación de las fuentes}

Las fuentes analizadas son, en su totalidad, noticias de la prensa española referidas al problema de Tacna y Arica producidas entre 1880 y 1929. Las referencias se extrajeron de los títulos que ofrece la Hemeroteca Digital de la Biblioteca Nacional de España ${ }^{328}$. La muestra reunida se eleva a 2379 unidades de análisis. Cada noticia es entendida de dos

\footnotetext{
${ }^{325}$ CEA, María, Fundamentos y aplicaciones en metodología cuantitativa, España, Síntesis, 2012, p. 174.

326 Íbidem.

327 FELIZ, Tiberio, "Análisis de contenido de la comunicación asíncrona en la formación universitaria", Revista de Educación, n. ${ }^{\circ}$ 358, mayo-agosto 2012, <http://www.revistaeducacion.mec.es/doi/358_079.pdf > [consultado el: 05/12/2014].

${ }^{328}$ Ver Hemeroteca Digital de la Biblioteca Nacional de España en: http://hemerotecadigital.bne.es/index.vm
} 
maneras: como unidad de análisis de base no gramatical y como unidad de análisis de base lexical. Esto, en el primer caso, quiere decir que el contenido de la noticia está dado por la extracción de la idea central de ésta. Es decir, se realiza el resumen de la noticia surgiendo de aquel una idea general. Cuando consideramos las palabras o el léxico de la noticia valoramos aquella como una unidad de análisis de base lexical, puesto que nuestro interés se centra en las palabras que aparecen de manera explícita en el texto de la noticia. La intención de identificar una misma unidad de análisis de dos maneras que pudiesen parecer contradictorias se realiza con el objetivo de acceder a los datos que contienen y al conocimiento que ofrecen desde sus vértices cuantitativas y cualitativas, sintetizadas en un enfoque mixto de investigación.

\subsubsection{Codificación}

Las noticias de la prensa española, una vez conceptualizadas como unidades de análisis de base para revisar su contenido, son enumeradas correlativamente desde la más temprana hasta la más reciente, es decir desde 1880 hasta 1929. La adjudicación de un dígito a cada una guarda relación con la individualización de la noticia a efectos de su análisis en profundidad. Además, la asignación de números sirve para la creación de una plantilla de datos que facilita la ordenación, la gestión y el análisis de información que distinguirá aspectos que configuren las temáticas predilectas de la prensa para referirse al problema de Tacna y Arica.

\subsubsection{Categorización}

En directa relación con lo anterior, las categorías son construcciones que aglomeran por afinidad una cantidad mensurable de unidades de análisis. Las categorías permiten visualizar núcleos o temas de preferencia de la prensa. En esta investigación las categorías que se han establecido son: descripciones del conflicto fronterizo; proceder político de Chile; proceder político de Perú; proceder político de Bolivia; participación diplomática de los Estados Unidos; participación diplomática de España. 


\subsubsection{Hermenéutica}

Es la interpretación de los datos históricos analizados. Permite responder y explicar científicamente a las interrogantes iniciales de la investigación. Además, la interpretación de los datos permite validar o contradecir la hipótesis formulada en ella. El modelo argumentativo que se seguirá en esta investigación se dividirá en capítulos y en subcapítulos siguiendo un desarrollo cronológico.

En efecto, esta división se realizará en cuatro apartados que consideran los sucesos acaecidos en los siguientes periodos: 1880-1894; 1895-1901; 1902-1922; 1922-1929. Las coyunturas históricas escogidas como fechas límites de cada tramo son, en el mismo orden: la Guerra del Pacífico y fin del plazo legal para realizar el plebiscito de Tacna y Arica; el inicio de la "ilegalidad" del Tratado de Ancón según la perspectiva peruana y los años de los buenos oficios de España para la solución del conflicto; el fracaso de los buenos oficios españoles y etapa previa a los buenos oficios de los Estados Unidos; las Conferencias de Washington e inicio de los buenos oficios de los Estados Unidos y la firma del Tratado de Lima de 1929 que zanjó diplomáticamente el problema de Tacna y Arica. 


\section{GUERRA, PAZ Y POSGUERRA (1880-1894)}

La importancia otorgada por los diarios y revistas de España a la Guerra del Pacífico fue indudable. Desde su inicio, el 14 de febrero de 1879 con el desembarco chileno en Antofagasta, las informaciones y las opiniones ocuparon una parte importante de los principales medios de comunicación. Cuando el teatro de la guerra se trasladó hacia el norte, las ciudades de Tacna y Arica comienzan su tímida aparición en la prensa, que cambiaría drásticamente cuando los ejércitos de los países en armas se enfrenten en las batallas de Tacna y Arica, el 26 de mayo y 7 de junio de 1880, respectivamente. Las victorias chilenas en ambas batallas obedecieron, según la prensa, al barbarismo e implacable militarismo chileno. Esas derrotas provocaron la caída del gobierno peruano que rápidamente fue asumido por el caudillo Nicolás de Piérola, quien despertó gran admiración en parte de la prensa católica de la península. Esos y otros acontecimientos formarían las bases del proceso de cristalización de una "chilenofobia" y una "peruanofilia" en la prensa estudiada ${ }^{329}$.

\subsection{El ingreso sangriento de Tacna y Arica en la prensa}

En el contexto de la Guerra del Pacífico, el "Asalto y Toma del Morro de Arica" (7 de junio de 1880) fue fundamental en el surgimiento del problema por la soberanía de Tacna y Arica. Casi dos semanas antes, Tacna, ubicada 56 kilómetros al norte de Arica, había caído también en manos de las tropas chilenas (26 de agosto de 1880). Desde entonces y hasta 1929, Chile y Perú no encontrarían soluciones adecuadas para resolver el conflicto regional. La entrada ensangrentada de Tacna y Arica se volvió más evidente aún, porque durante varias décadas antes del conflicto, eran mencionadas, sobre todo Arica, sólo para publicitar las grandes rutas oceánicas de los navíos comerciales europeos.

\footnotetext{
329 "Guerra, Paz y Posguerra" y "El arbitraje de España” fueron estudiados anteriormente en nuestro Trabajo Fin de Máster Visiones de la prensa española en torno al problema de Tacna y Arica: Desde la Guerra del Pacífico hasta el arbitraje de España (1880-1901) del programa Europa y el Mundo Atlántico: poder, cultura y sociedad.
} 
Los movimientos militares alrededor de Arica habían empezado meses atrás. La ciudad se encontraba bloqueada o, según otra expresión desacertada, tomada ${ }^{330}$ desde noviembre de 1879. Un diario predijo, con infortunio, la destrucción de ésta en febrero ${ }^{331}$, situación relacionada con la llegada a la plaza de 13000 efectivos peruano-bolivianos desde Tarapacá, donde habían sido derrotados por el ejército chileno ${ }^{332}$. El Globo comentó esos desplazamientos, el aumento de la tropa chilena con 4000 hombres y también los debates argentinos posteriores a las derrotadas aliadas para restablecer la paz.

Otra publicación aumentó esas informaciones, refiriéndose a la retirada de los aliados del extremo sur peruano. Éstos "han evacuat completament Tarapaca y han arribat á Arica" ${ }^{333}$. El mismo periódico catalán informaba del bloqueo de Arica y del intercambio de prisioneros entre los bandos en pugna: “diuhen que'ls aliats evacuaren á Varapaca (sic), l'esquadra xilena bloqueja a Arica y s'efectuá un cambi de presoners xilens y aliats"334.

Para la historiografía nacionalista peruana de la posguerra uno de los hechos más emblemáticos durante el bloqueo fueron las acciones "heroicas" de las naves que intentaron romper el sitio de Arica. Una de las obras más representativas de esa corriente, Historia de la Guerra de América entre Chile, Perú y Bolivia, describió los hechos sin renunciar a pronunciarse en todo momento a favor del proceder peruano. La Unión, al mando del comandante Manuel Villavicencio, había salido desde El Callao hacia Arica por orden del dictador Nicolás de Piérola. El objetivo de la travesía según el autor era "Forzar el bloqueo de Arica, que vigilaba rigurosamente el blindado Huáscar"335 lo que "no era nada fácil"336. Sin embargo, "el intrépido comandante de la Unión denodado hasta la temeridad, por la necesidad e importancia del asunto, pasa rápidamente entre dos buques chilenos, y se introduce en la bahía de Arica al alba del 19 de marzo"337.

\footnotetext{
${ }^{330}$ La Opinión, "Partes telegráficos", 19 de enero de 1880, p. 3.

${ }^{331}$ El Bien Público, "América del Sur", 17 de marzo de 1880, p. 2.

332 La Mañana, "Noticias", 21 de enero de 1880, p. 3; Diari Catalá, "Telégramas de la prempsa extranjera", 19 de enero de 1880, p. 4; El Bien Público, "Telegramas particulares", 20 de enero de 1880, p. 2.

${ }^{333}$ Diari Catalá, "Telégramas de la prempsa extranjera”, 19 de enero de 1880, p. 4.

${ }^{334}$ Diari Catalá, "Telégramas de la prempsa extranjera", 18 de enero de 1880, p. 8.

335 Caivano, Thomas, Historia de la Guerra de América entre Chile, Perú y Bolivia, Iquique, Librería Italiana Baghetti Hermanos, 1904, pp. 367-368.

336 Idem.

${ }^{337}$ Idem.
} 


\section{Imagen $n^{\circ} 2$}

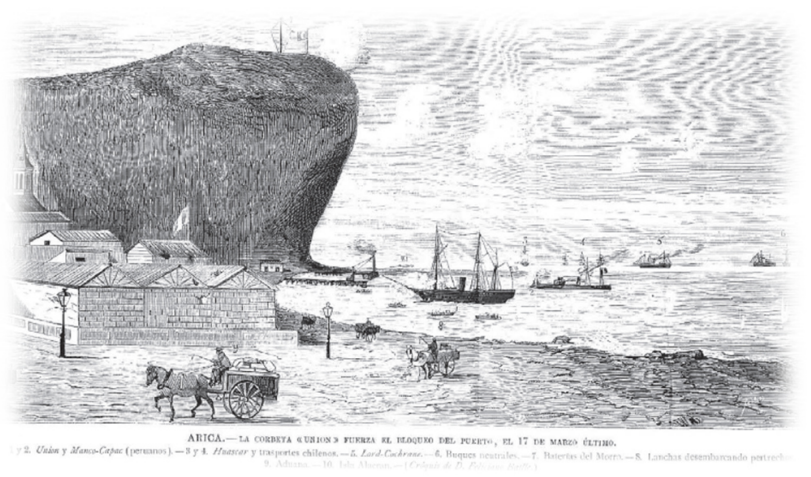

Fuente: La Ilustración Española y Americana, "La corbeta «Unión» fuerza el bloqueo del puerto, el 17 de marzo último", n. ${ }^{\circ} 22,15$ de junio de 1880, p. 381.

En España, los periódicos versaron en torno al bloqueo. La Unión -escribiría una publicación basada en correspondencia peruanófila- en atrevida y heroica empresa ${ }^{338}$ eludiría a las naves chilenas logrando desembarcar su cargamento de "armas y municiones para los peruanos bloqueados en Arica"339. La pluma présaga de algunas publicaciones deseó la finalización de la guerra antes de las batallas de Tacna y Arica; la paz, "deseada de todas veras" 340 , por el contrario, se alejaba. Ambas ciudades ingresarían sangrientamente en las páginas de la prensa española.

El bloqueo desabasteció a los ariqueños de los bienes de consumo que los vapores peruanos y extranjeros transportaban desde Lima y otros puertos del mundo. Los acorazados chilenos encargados de esa misión se bautizaron Blanco Encalada y El Loa ${ }^{341}$, en honor del primer presidente de la república y del río que cruzaba el desierto de Atacama, respectivamente. Las misiones realizadas por esas naves habían posibilitado que, poco a poco, Chile se posicionase como dueño del Pacífico Sur. Gracias al bloqueo, a comienzos de 1880 , Chile conquistaba todo el litoral sur peruano, agregándolo al chileno ${ }^{342}$. Esa expansión territorial traería crecimiento económico y un reposicionamiento, a nivel sudamericano, como potencia marítima detrás del Brasil.

\footnotetext{
${ }^{338}$ El Bien Público, "Carta del Perú", 2 de junio de 1880, p. 2.

${ }^{339}$ El Bien Público, "La Guerra del Pacífico", 22 de abril de 1880, p. 3.

340 Íbidem, p. 1.

${ }^{341}$ El Imparcial, "Sección de noticias", 19 de enero de 1880, p. 1; La Discusión, "Noticias", 22 de enero de 1880 , p. 2.

${ }^{342}$ La Ilustración Española y Americana, "La Guerra del Pacifico", n. ${ }^{\circ} 1,8$ de enero de 1880, p. 10.
} 
El bloqueo chileno cortó la cablegrafía entre Lima y Tacna y Arica. Su interrupción fue uno de los objetivos de la marina para impedir la coordinación de los aliados. Una carta escrita en Lima hacia enero, comentando esa situación, se publicó en España un mes y medio después. Allí se explicó el estado de las transmisiones, entre otros temas, lamentando la incomunicación "con los puertos del sur; pues los chilenos han cortado el cable en varios puntos, y la única prueba que tenemos es la entrada de los vapores-correos, por orden de los buques enemigos" ${ }^{343}$.

La prensa situó geográficamente a los lectores. Si bien era conocido el enlace histórico entre América y España, fundamento del conocimiento geográfico, las publicaciones consideraron necesario detallar el teatro de operaciones. A diferencia de Perú y Bolivia, el escenario chileno no se consideró porque la guerra no se hizo en ese suelo. Así, La Ilustración Española y Americana intentó subsanar las dificultades provocadas por la ignorancia territorial. Aquella se centró en los recursos naturales, razón de la "lamentable guerra" 344 . La estrategia discursiva "imaginaria", explicó las complicaciones de los europeos para comprender los lugares de la guerra. Ellos y "los que procedemos de las pintorescas vertientes de los Pirineos o de los Alpes, difícilmente nos formamos idea de un país sin agua y de lo que ésta representa" 345.

La América paradisiaca de vegetación tupida poseía también desiertos áridos e infernales. Allí, las pampas yermas del litoral boliviano y el extremo sur peruano contrastaban con el Pacífico imponente y refrigerante. El "paraíso terrenal", la creencia más cristiana de Colón ${ }^{346}$, no incluyó el desierto de Atacama. Con un espíritu poético similar al del Almirante, La Ilustración ... describió su volcanismo: "sus entrañas vomitan fuego por la boca de los volcanes del Arequipa y Pichu-Pichu [...] crecen todos los años capas de sal que forman carreras de colinas"347. El salitre dinamiza "el extraordinario movimiento comercial de Iquique con ocasión de cualquiera guerra europea o americana" ${ }^{" 348}$.

\footnotetext{
${ }^{343}$ El Bien Público, [s. t.], 6 de marzo de 1880, p. 2.

${ }^{344}$ La Ilustración Española y Americana, "La Guerra del Pacifico", n. ${ }^{\circ} 1,8$ de enero de 1880, p. 10.

${ }^{345}$ Idem.

346 TODOROv, Tzvetan, La conquista de América. El problema del otro, México D. F., Siglo XXI Editores, p. 25.

${ }^{347}$ La Ilustración Española y Americana, "La Guerra del Pacifico", n. ${ }^{\circ} 1,8$ de enero de 1880, p. 10.

${ }^{348}$ Idem.
} 
En fechas anteriores a las batallas de Tacna y Arica se dieron también a conocer en la prensa algunas características climatológicas del territorio. El contexto bélico de tales informaciones había sido la desastrosa campaña de Tarapacá para el ejército aliado por lo que las referencias meteorológicas se entrecruzaban con las militares. Ciertos periódicos comentaron el cese temporal de la guerra en los siguientes términos: "Después de la batalla y toma de Tarapacá y de las escaramuzas habidas en el desierto de Atacama, entre los grados 22 y 23 , no ha habido encuentro alguno notable entre los beligerantes" ${ }^{\text {"349. Para las }}$ publicaciones la estrategia chilena era dejar pasar los meses "más calurosos del año, antes de renovar las hostilidades en [...] Arica, evitando [...] el riesgo de las enfermedades endémicas que podrían aparecer en el ejército maniobrando en comarcas poco salubres ${ }^{350}$.

Las descripciones naturalistas de Bolivia difirieron de la aridez del sur peruano. Aquellas, por el contrario, se identificaron con la montaña y el altiplano, agregando indisolublemente las dificultades que tendría ese país para recuperar las arenas del Pacífico. El artículo "El camino de Bolivia hacia el Atlántico" comentó largamente ese problema. Las ideas generales afirmaban que bastaba mirar una cartografía para comprender qué era Bolivia: un país situado en el corazón de Sudamérica. El centro estaba formado por la meseta andina, cuya cadena principal lo separaba por el oeste del desierto atacameño, rico en minerales, salitre y guano. En la dilatada costa -continuaba la descripción-Bolivia tenía el puerto de Cobija y algunas caletas donde se cargaba minerales y salitre, "que son hoy día conocidas en Europa por los hechos de la actual guerra del Pacífico"351. Ese artículo comentaba la posesión chilena de todo ese litoral. Hacia 1880, fecha de su publicación, el vínculo de Bolivia con el mar se rompió, porque "además de ser probable que pierda la costa que posee en ese Océano, [...] no se contenta comerciando con el mundo, tan sólo por los puertos peruanos de Arica, Mollendo e Iquique" ${ }^{352}$.

\footnotetext{
${ }^{349}$ El Imparcial, "Carta del Pacífico", 10 de febrero de 1880, p. 2.

${ }^{350}$ Idem. Otras referencias a la "insalubridad" del clima en: La Ilustración Española y Americana, "Crónica Americana", n. ${ }^{\circ}$ 24, 30 de junio de 1880, p. 427.

${ }^{351}$ Boletín de la Sociedad Geográfica de Madrid, "El camino de Bolivia al Atlántico", tomo IX, septiembre de 1880, p. 173.

352 Idem.
} 
Imagen $n^{\circ} 3$

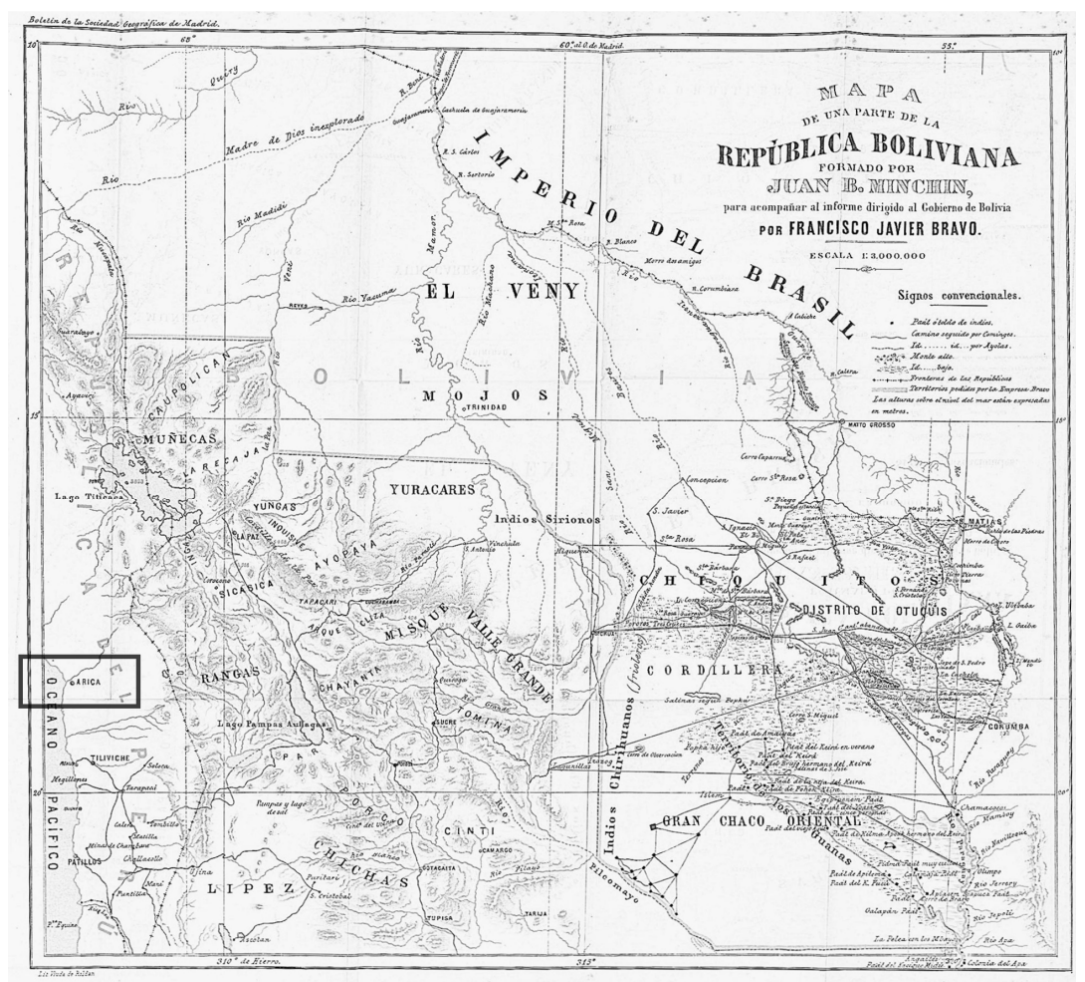

Fuente: Boletín de la Sociedad Geográfica de Madrid, "Mapa de una parte de la República boliviana", tomo IX, octubre de 1880, p. 149. (El resaltado es nuestro).

Dejando de lado, de momento, las representaciones geográficas y considerando la política de los países en armas, uno de los hechos más importantes ocurrido antes de las batallas de Tacna y Arica fue la destitución del presidente boliviano Hilarión Daza (28 de diciembre de 1879) mientras se encontraba en la última ciudad. Los problemas en la conducción militar comenzaron, a decir verdad, con anterioridad. Tras la derrota en Tarapacá, su ejército en total desobediencia se retiró hacia Tacna; la organización de los aliados no mejoraría allí. Los diarios publicaron que las tropas bolivianas habían sido expulsadas de Tacna por el general Lizardo Montero después de la caída de Daza. Luego se sabría que esa información era errónea, pues los sobrevivientes de Tarapacá se encontraban "acampados cerca de aquella ciudad"353. De todos modos "no se espera mucho de sus servicios" $" 354$.

\footnotetext{
${ }^{353}$ El Bien Público, [s. t.], 6 de marzo de 1880, p. 2.

${ }^{354}$ Idem.
} 
En España se publicaron las razones de la huída aliada de Tarapacá con informaciones obtenidas en Valparaíso llegadas, a la vez, desde Lisboa. El texto aclaraba la anarquía entre los subalternos de Daza. El origen chileno de la noticia permite comprender la retórica usada para explicar la descoordinación militar peruano-boliviana. Las tropas bolivianas -leemos allí- mandadas por "el presidente en persona, hallándose faltas de agua, regresaron a Tacna abandonando a su comandante, que, acompañado únicamente de dos ayudantes, se volvía también a Tacna" ${ }^{355}$.

El argumento "acuático" del fracaso tarapaqueño con el tiempo dio paso a otros relatos más elaborados. De todas formas es importante considerar las raíces nacionalistas de esa publicación. Como sabemos, gran parte de las guerras contemporáneas, no siendo esta la excepción, se dirimieron en las imprentas. Sólo considerando ese aspecto es posible cuestionar la veracidad del supuesto saqueo de las tropas bolivianas en Tacna y Arica. La mentira periodística aseveró que de aquella ciudad "habían marchado 200 familias por temor a los bolivianos" 356 .

Telegramas recibidos en España daban cuenta de que el ejército chileno había aprisionado a Daza $^{357}$. Durante su estancia en Arica, el general se enteró del golpe de estado efectuado por militares respaldados en movimientos populares disconformes con la conducción de la guerra ${ }^{358}$. El ejército boliviano, escribió un diario español basándose en el diario limeño El Peruano, acantonado en Tacna, desconoció la autoridad de Daza el 28 de diciembre último, proclamando como general al coronel Eliodoro Camacho. El cambio de mando se había realizado "pacíficamente" 359 . Otro diario, apoyado en La Raza Latina de Nueva York, comentó el gran desprestigio de Daza en Bolivia. Su política, juzgada de funesta por el periódico, le permitió afirmar que el militar se había ocupado más de “«politiquilla» doméstica que de hacer la guerra a Chile"360. Por fortuna, terminaba la nota, desaparecía de escena quedando tiempo para reparar el daño ocasionado.

\footnotetext{
${ }^{355}$ El Bien Público, "Chile y Perú", 3 de enero de 1880, p. 1.

${ }^{356}$ Idem.

${ }^{357}$ El Amigo, "Revista de los principales sucesos de la semana", 6 de junio de 1880, p. 3.

${ }^{358}$ El Comercio, [s. t.], 20 de febrero de 1880, p. 1.

${ }^{359}$ El Bien Público, “América del Sur", 17 de marzo de 1880, p. 2.

${ }^{360}$ Idem; La Iberia, “América del Sur”, 11 de marzo de 1880, p. 2.
} 
Bastaron días para que la prensa publicara telegramas recibidos en París firmados por la Legación de Chile anunciando la destitución de Hilarión Daza. En su reemplazo, para el mando de las tropas, quedaría el general Narciso Campero. En La Paz, los diarios informaron que se había producido un motín apoyando a Daza (14 de enero de 1880), detenido con la muerte del "rebelde", Fabián Luna. En la ocasión fueron heridos el coronel López, enemigo de Daza, “y varios oficiales y soldados. Muertos también hubo algunos. Parte de la tropa apoyó el movimiento"361.

La situación sociopolítica boliviana auguraba un mal término en la guerra. Es necesario comprender la pobreza generalizada y el desánimo reinante de la población después de todas las derrotas militares. La pérdida del litoral produjo efectos similares. Dos notas aparecidas en la prensa dan cuenta de la delicada situación boliviana desde visiones opuestas, siendo el tono de la primera más pesimista que el de la segunda. La miseria es cada día mayor -dice la primera- pues nadie trabajaba por miedo a ser alistado en el ejército aliado o en el de los diversos caudillos que desean el poder. Los indios "que es allí el hombre de trabajo, es a la vez el instrumento de que se valen los caudillos para imponerse a la nación. Ellos son los que suministran la principal entrada del Tesoro nacional, y son también la carne de cañón"362.

Una sensación contraria trasmite la noticia que informó sobre la caída de Daza. Pareciera que el objetivo del escrito tiene un interés "apaciguador" de la anomia aliada, pues refuerza la idea de que la deposición del líder boliviano por una comisión popular había sido inocua para Bolivia y Perú. La noticia aseguraba que el desplome de Daza no había afectado "de ninguna manera la alianza existente entre el Perú y Bolivia. Por el contrario, las declaraciones que se han hecho revelan que es un sentimiento y una aspiración unánime en el pueblo boliviano estrechar aún más los vínculos que lo unen al Perú, y marchar junto con él, sobre el enemigo común de ambas repúblicas ${ }^{363}$.

\footnotetext{
${ }^{361}$ La Iberia, "Chile”, 18 de abril de 1880, p. 2; El Católico, “América del Sur”, 21 de abril de 1880, p. 3.

${ }^{362}$ La Iberia, "América del Sur", 18 de abril de 1880, p. 2; El Católico, “América del Sur", 21 de abril de 1880, p. 3.

${ }^{363}$ El Bien Público, “América del Sur”, 17 de marzo de 1880, p. 2.
} 
Desde ese momento y durante un tiempo la tormenta política de Bolivia no amainaría. La prensa hispana bautizó de pueblo indómito ${ }^{364}$ y frívolo ${ }^{365}$ a su población. La elaboración de estereotipos de lo boliviano continuaría durante la posguerra. Los medios, artífices de esas ideas, se preguntaban ¿Qué importancia se da a Bolivia en Europa? Deseando, a renglón seguido, que no sea cierto el temor de que la prensa, el Gobierno y la opinión general, "sólo sepan de Bolivia que allí estaba el Potosí [...] pero que no produce riqueza, porque se trabaja mal [...]"366.

Las estadísticas publicadas permitían comprender el tránsito histórico enrevesado de la economía boliviana. Las cifras del tesoro fiscal (desde el 14 de febrero hasta el 31 de diciembre de 1879), desglosadas en los ochos indicadores incluidos en la tabla n. ${ }^{\circ}$, demuestran la bancarrota del país. En ese periodo se invirtió 1563926,17 bolivianos nombre de la moneda del país andino- "en la manutención de los ejércitos de Daza y Campero" 367 , equivalente a un porcentaje superior al 50\% del erario público. La década anterior no fue mejor. Los años setenta significaron para su economía la llegada de inversiones extranjeras pero sólo la Compañía de Salitres y Ferrocarriles de Antofagasta, dirigida por capitales ingleses y chilenos, proporcionó en 1878 ganancias “valoradas en 28 millones de pesos, casi catorce veces la renta nacional boliviana" 368 .

Tabla n. $^{\circ} 7$

Tesoro fiscal boliviano hacia 1879

\begin{tabular}{|l|r|}
\hline & \multicolumn{1}{|c|}{ Bolivianos } \\
\hline 1. Segundo semestre de la contribución indígena & 791248,70 \\
\hline 2. Diezmos y primicias (pagados casi en su totalidad por los indígenas) & 252016,00 \\
\hline 3. Contribución a la coca & 250000,00 \\
\hline 4. Pastos del interior & 380000,00 \\
\hline 5. Empréstito forzoso, lo realizado & 500000,00 \\
\hline 6. Empréstito en el Banco Nacional & 600000,00 \\
\hline 7. Salitre del Joco (mensualidades salvadas) & 50000,00 \\
\hline 8. Aduanas del Sur & 60000,00 \\
\hline TOTAL & 2783264,70 \\
\hline
\end{tabular}

Fuente: Elaboración propia basada en: El Católico, “América del Sur”, 21 de abril de 1880, p. 3.

\footnotetext{
${ }^{364}$ El Siglo Futuro, “América”, 2 de octubre de 1880, p. 3.

${ }^{365}$ Idem.

${ }^{366}$ Boletín de la Sociedad Geográfica de Madrid, "El camino de Bolivia al Atlántico", tomo IX, septiembre de 1880, p. 174.

${ }^{367}$ El Católico, “América del Sur", 21 de abril de 1880, p. 3.

${ }^{368}$ DunKerley, James, Orígenes del poder militar. Bolivia 1879-1935, La Paz, Plural Editores, 2006, p. 33.
} 


\section{Imágenes $n .^{\circ} 4$ y 5}
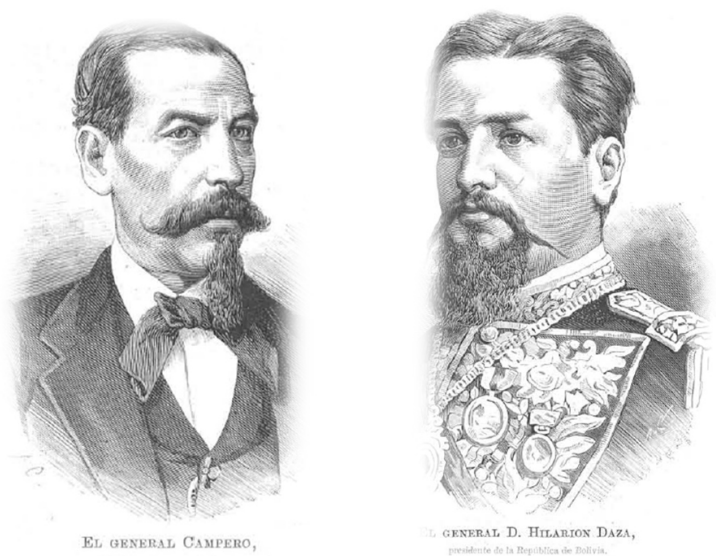

Fuente: La Ilustración Española y Americana, "El general Campero" y "El general D. Hilarión Daza", 15 de julio de 1879, n. ${ }^{\circ} 26$, p. 28.

Una suerte similar tuvo Perú en el plano político, pero también en el ámbito socioeconómico. Martínez Riaza, refiriéndose a esta época, escribió: "Fueron años de quiebra social y económica agravada por la crisis política sostenida por las distintas facciones en conflicto"369. Las actitudes del presidente peruano ejemplifican, sin duda, tal condición. Mariano Ignacio Prado había decidido instalarse en Arica para obtener una perspectiva mejor de la guerra. Sabía que la recepción de las informaciones en Lima era deficiente lo que, probablemente, llevaría a decisiones equivocadas. Sin embargo, con posterioridad a las derrotas aliadas, el 18 de diciembre de 1879 decidió embarcarse hacia Europa. El objetivo del viaje fue la compra de armamento que ayudase a contrarrestar la previsible derrota peruana en la guerra ${ }^{370}$.

El presidente Prado sería noticia en España. Desde Nueva York se informó del embarque clandestino de Prado usando identificación falsa en El Callao. Un sector político peruano evaluó esa aventura como un acto de cobardía y abandono. La deserción propició

\footnotetext{
${ }^{369}$ MARTínez RiAZA, Ascensión, «A pesar del gobierno». Españoles en el Perú, 1879-1939, Madrid, Consejo Superior de Investigaciones Científicas. Instituto de Historia, 2006, p. 88. Otro interesante estudio de la autora en: MARTínEZ RiAZA, Ascensión, "Las relaciones entre el Perú y España 1880-1930”. En UnESCO, Estado de los estudios histórico-sociales sobre el Perú a finales del siglo XX, Lima, Lima UnESCO-Universidad de Lima-Fondo de Cultura Económica, 1998, pp. 439-466.

${ }^{370}$ El proceder del presidente Prado continúa siendo un hecho que causa debates en la historiografía peruana. Una obra relativamente nueva y con documentación inédita, a decir de su autor, en: GARCÍA BELAÚNDE, Víctor Andrés, El expediente Prado, Lima, Universidad San Martín de Porres, 2014.
} 
el advenimiento de Nicolás de Piérola, quien mediante un golpe de estado instauró una nueva dictadura.

El Globo y La Mañana ${ }^{371}$, al respecto, publicaron escritos del historiador francés Jean Joseph François Poujolat. Las noticias de América del Sur confirman lo que hasta ahora hemos dicho -reflexionó el autor de Historia de Jerusalén- la "caída del presidente Prado en el Perú, su viaje a Europa, la elevación del dictador Piérola, la revolución que ha estallado en La Paz, [...] y la huida del presidente Hilarión Daza" ${ }^{372}$. Poujolat agregó a la catástrofe militar sufrida por los aliados una opinión en desarrollo a ambos lados del Atlántico: la alianza peruano-boliviana sólo existía nominalmente. Era probable que Bolivia, para conseguir una salida al mar, se uniese ahora con Chile.

El temor a la traición boliviana se hizo real antes de la batalla de Tacna. Con anterioridad a ésta ya se escribía sobre el carácter funesto de la alianza ${ }^{373}$. A la vez, su ausencia de mando produjo miedo en esos países, lo que se conocería en otros lugares del mundo. En España, por ejemplo, se informó que en Pisagua, puerto defendido por ochocientos bolivianos y ciento veinte peruanos, los segundos habían luchado con más tesón que los primeros. Al finalizar el encuentro, parte del ejército boliviano se retiraría hacia La Paz. La Iberia, en su estilo, comentó que cuando el presidente Daza desde Arica pretendió ayudar a los aliados, habían salido de esta última ciudad tres mil bolivianos, pero “a las dos jornadas se negaron los batallones a continuar avanzando, bajo el inútil pretexto de que no habían encontrado los víveres distribuidos en las etapas convenientes" 374 .

Por otro lado, la prensa publicó informaciones relacionadas con la participación de españoles avecindados en la zona de guerra. El caso del gallego Eduardo Llanos es sugestivo. Comerciante y cónsul español en Iquique, realizó allí la inhumación del capitán de la corbeta chilena Esmeralda, Arturo Prat. En las expresiones de El Imparcial, sin la espontánea injerencia del caballero español, los chilenos no hubieran sabido nunca donde reposaban las cenizas de "su héroe favorito" ${ }^{375}$. A consecuencia de la conducta de Llanos,

\footnotetext{
${ }^{371}$ La Mañana, "Noticias", 14 de enero de 1880, p. 3.

${ }^{372}$ El Globo, "Revista Extranjera", 19 de enero de 1880, p. 2.

${ }^{373}$ El Siglo Futuro, “América del Sud", 3 de abril de 1880, p. 2.

${ }^{374}$ La Iberia, "América del Sur, 29 de enero de 1880, p. 2.

${ }^{375}$ El Imparcial, "Carta del Pacífico", 10 de febrero de 1880, p. 2.
} 
Chile aprobó un proyecto de ley tendiente a premiarlo con una distinción estatal. El artículo n. ${ }^{\circ} 7$ del documento premió a Llanos con una medalla de oro con la siguiente inscripción: "La República de Chile en homenaje de agradecimiento al Sr. D. Eduardo Llanos", y en el reverso el escudo chileno con la fecha del combate y de la presente ley.

La prensa se ocupó, además, de las protestas realizadas en Santiago por agentes comerciales y diplomáticos europeos perjudicados por el conflicto. Fueron los casos de los comerciantes ingleses, italianos, franceses, alemanes y españoles, quienes experimentaron grandes pérdidas económicas en el transcurso de la guerra ${ }^{376}$. Algunas informaciones que circularon en España provenientes de Nueva York, obtenidas de los tripulantes del vapor Alaska, anclado por un tiempo en Arica, anunciaron las protestas de varios cónsules extranjeros hacia el proceder militar chileno.

La causa principal de las quejas eran los bombardeos realizados por la escuadra sobre los pueblos cercanos a Mollendo, con la intención de inutilizar la línea férrea que conectaba la ciudad con otras del sur. El Bien Público comentó la respuesta del encargado chileno de los cañoneos: "Al recibir una enérgica protesta de los cónsules extranjeros residentes en el puerto, contra conducta tan bárbara, [...] replicó que el ferrocarril era propiedad del [...] Perú y que su deseo era inutilizarlo si era posible" 377 . Se desprende de la nota que el problema visto por los cónsules eran la imprudencia militar y la deshumanización de la guerra. Los bombardeos del sur peruano se hacían "sin reflexionar al mismo tiempo que las vidas de muchos inofensivos combatientes quedaban expuestas por tan inútiles medidas" ${ }^{\prime 378}$.

Las protestas de los diplomáticos europeos no se escucharon con tanta fuerza en Perú. Era obvio. Las ciudades conquistadas por Chile tenían numerosos comerciantes del viejo continente que guardaban cierta solidaridad con el Perú. Muchos de ellos en ese país habían establecido sus empresas y desarrollado su vida. En el antiguo virreinato, pese a todo, continuaba la dificultosa implementación de la dictadura pierolista.

\footnotetext{
${ }^{376}$ La Ilustración Española y Americana, "Crónica Americana”, n. ${ }^{\circ}$ 24, 30 de junio de 1880, p. 427.

${ }^{377}$ El Bien Público, "América del Sur”, 3 de abril de 1880, p. 2.

${ }^{378}$ Idem.
} 
4.2. Nicolás de Piérola ¿Un caudillo admirado?

Es atractiva la predilección de parte de la prensa española hacia el dictador peruano Nicolás de Piérola. Cuesta trabajo disipar las dudas de por qué tanta admiración por su persona. En los periódicos españoles, ocasionalmente, se tomaron reportajes de diarios argentinos y cartas peruanas elogiando la figura del militar. El Siglo Futuro escribió a su favor en varias ocasiones; por el contrario, El Bien Público, en la pluma de Orestes Araujo, cumplía la misión de la crítica mordaz.

La primera visión ideó la imagen de un distinguido hombre de letras, jurisconsulto notable, dueño de un carácter impetuoso, economista habilidoso, estratega, organizador y dotado de una gran inteligencia. En fin, se trataba de un hombre de principios y convicciones "basadas en el estudio de los hombres y de las cosas" 379 . Piérola no estaba "dispuesto a vacilaciones de ningún género, y una vez trazado el plan que se proponga seguir, marcha adelante con la fe del creyente" ${ }^{380}$. El vigor del dictador, después de los fracasos de Tacna y Arica, lo convenció de reorganizar la administración interior de Perú, renovando todos los ayuntamientos del país y fijando el valor del sol (moneda peruana). La exclusión ciudadana en las decisiones político-militares marcó una parte de la dictadura. La otra estuvo caracterizada por la mentira. Una vez en el poder, el caudillo envío una circular a las legaciones diplomáticas fuera de Perú asegurando "no ser efectivo el bloqueo de los chilenos" 381 .

El catolicismo del dictador peruano, patrocinador de negocios "eclesiásticos"382, fue un símbolo de garantía para la prensa católica española que confesaba, sin ambages, su admiración ${ }^{383}$. Mientras disfrazara la dictadura con un halo de providencialismo no habría reproches para el arequipeño.

Un artículo del Echo, diario inglés usado por uno español, se refirió a la faceta religiosa del dictador. Ese documento, enviado a Vincenzo Pecci, nombre profano de León XIII, podría acercarnos a las razones de la admiración que El Siglo... sintió hacia él. Allí se

\footnotetext{
${ }^{379}$ El Siglo Futuro, “América”, 23 de febrero de 1880, p. 3.

${ }^{380}$ Idem.

${ }^{381}$ El Bien Público, [s. t.], 6 de marzo de 1880, p. 2.

382 El Siglo Futuro, "América del Sur", 28 de junio de 1880, p. 2.

${ }^{383}$ El Siglo Futuro, “América del Sud”, 3 de abril de 1880, p. 2.
} 
resumieron los objetivos autoimpuestos por Piérola al tomar el rumbo político de su país. Titulado don Nicolo de Piérola, nuevo Dictador del Perú, al anunciar al papa su elevación al poder supremo, después de hacer ardientes protestas de adhesión y de amor filial al Padre Santo, explicaba: "que desde que subió al poder sólo tiene tres pensamientos: $1^{\circ}$ Acabar con los chilenos. $2^{\circ}$ Regenerar las instituciones del país, y $3^{\circ}$ Consolidar, respetar y favorecer los derechos del catolicismo" 384 .

Otra publicación de El Siglo... elogió la adscripción de la dictadura al Vaticano. Han transcurrido cinco meses desde que el señor Piérola fue aclamado y en ese tiempo decía la nota- "no se ha desmentido su actividad; su celo por la Religión y por la patria ha trazado huellas que señalará la historia con honrosa mención"385. La cita es valiosa porque considera positivamente el ardoroso catolicismo del caudillo y, a la vez, permite entender la visión de la historia manejada por los piadosos redactores del diario. Es probable que una especie de providencialismo histórico les hiciese pensar en la univocidad entre el "ser" creyente y la beatificación de los procedimientos mundanos del dictador. Aquel reunía en sí "muchas de las cualidades de un católico «modelo» del siglo XIX"386.

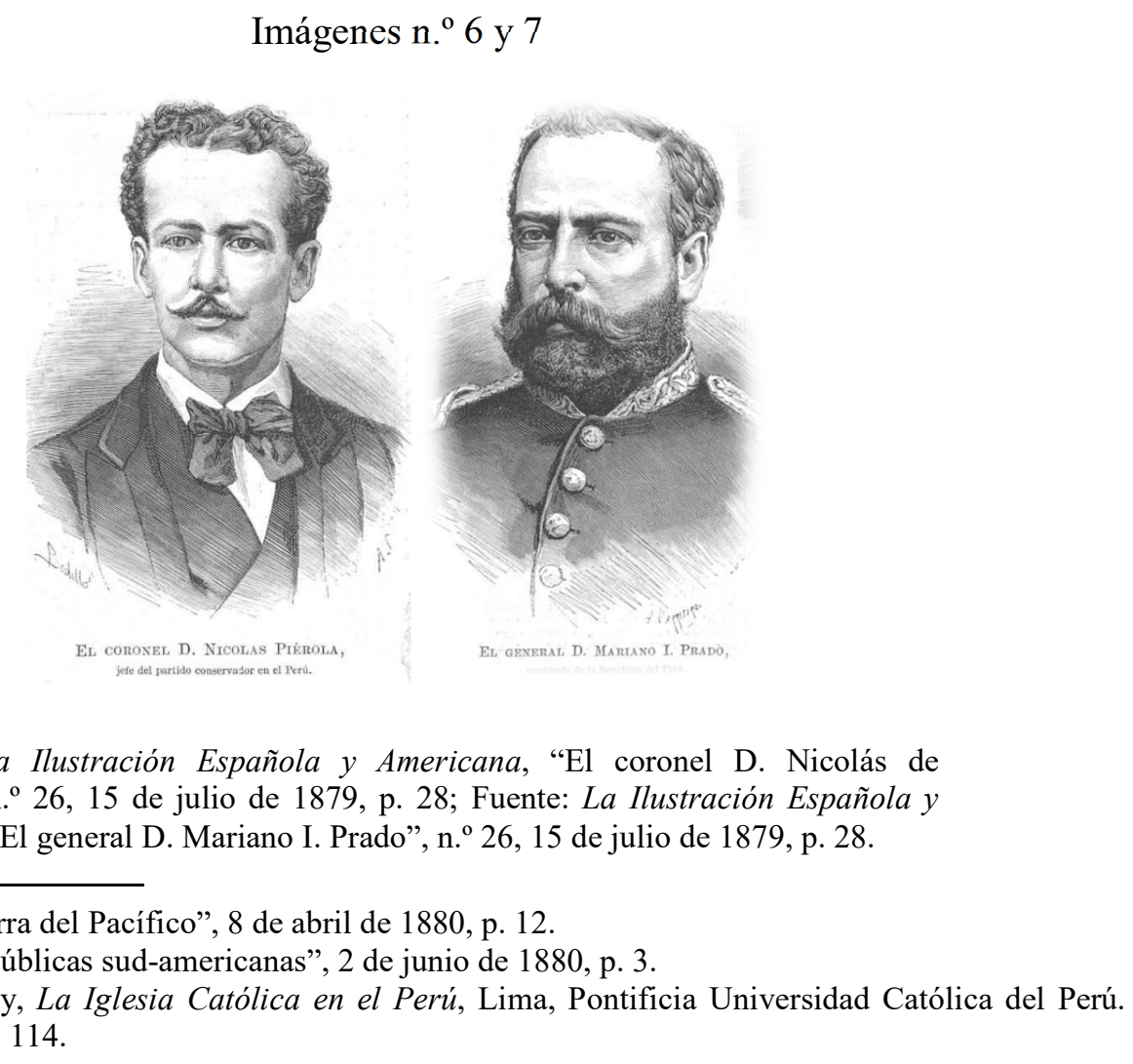

Fuente: La Ilustración Española y Americana, "El coronel D. Nicolás de Piérola", n. ${ }^{\circ}$ 26, 15 de julio de 1879, p. 28; Fuente: La Ilustración Española y América, "El general D. Mariano I. Prado", n. ${ }^{\circ} 26,15$ de julio de 1879, p. 28.

\footnotetext{
${ }^{384}$ La América, "La Guerra del Pacífico", 8 de abril de 1880, p. 12.

${ }^{385}$ El Siglo Futuro, "Repúblicas sud-americanas", 2 de junio de 1880, p. 3.

${ }^{386}$ Klaiber S. J., Jeffrey, La Iglesia Católica en el Perú, Lima, Pontificia Universidad Católica del Perú. Fondo Editorial, 1996, p. 114.
} 
La admiración fanática hacia la dictadura no podía seguir enmascarándose: "no es posible que nos despojemos enteramente de ilusiones cuando se trata de la suerte del doctor Piérola, para quien nuestras simpatías son hoy más vivas que nunca"387. La propensión del diario guardaba un disimulado antichilenismo. La nota concluía explicando su vinculación hacia Piérola, caudillo por "quien sentimos verdadero interés al verle invocar a Dios en las grandes tribulaciones que otros atrajeron sobre su país, al verle refugiarse en su fe cristiana para salvar al país que se propuso regenerar ${ }^{388}$.

El enaltecimiento de la figura de Piérola debía realizarse opacando a su antecesor, el "infeliz"389 general Prado. Mientras el dictador continuaba con tesón preparando los elementos militares que permitiesen tomar la ofensiva en la guerra, a causa de los malos manejos de Prado, las ofensivas chilenas en la costa atacaban, como lo enfatizaban los diarios, las caletas peruanas de pescadores indefensos ${ }^{390}$.

La habilidad estratégica de Piérola se fundamentaba en su actuación como "revolucionario" en el pasado. En 1874 y 1876, había encabezado revoluciones políticas contra los presidentes Manuel Pardo y Mariano Ignacio Prado. En ambas demostró "bastante habilidad en el modo de manejar a su gente"391, siendo un "infatigable conspirador, tan conocido ya de los lectores de La Ilustración" ${ }^{\text {392 }}$. El Siglo..., a propósito de un decreto de Piérola contra los comisionados peruanos Francisco Rosas y J. M. Goyeneche, por fraude al fisco, celebró la gran energía desplegada por el dictador ${ }^{393}$ y alabó sus dotes de "entendimiento, corazón y carácter"394.

Piérola gozó en España de "buena prensa". Su imagen se reforzó con noticias referidas a actos filantrópicos realizados en Lima para apoyar a las víctimas de las inundaciones murcianas de octubre de 1879. Conocidos en Lima los hechos de la riada de Santa Teresa, la comunidad española junto con los vecinos nativos más acaudalados, organizaron funciones en el Teatro Politeama a beneficio de los afectados. Un despacho

\footnotetext{
${ }^{387}$ El Siglo Futuro, "Repúblicas sud-americanas", 2 de junio de 1880, p. 3.

${ }^{388}$ Idem.

${ }^{389}$ La Iberia, “América del Sur", 11 de marzo de 1880, p. 2.

${ }^{390}$ Idem.

${ }^{391}$ La Época, [s. t.], 12 de abril de 1880, p. 1.

${ }^{392}$ La Ilustración Española y Americana, "Sucesos de América", n. ${ }^{\circ}$ 27, 8 de mayo de 1880, p. 291.

${ }^{393}$ La Época, [s. t.], 12 de abril de 1880, p. 1.

${ }^{394}$ El Siglo Futuro, "Repúblicas sud-americanas", 2 de junio de 1880, p. 3.
} 
limeño introducido en una publicación española se refería a la participación excepcional del "gobernante" en esos actos, en medio de sus laboriosas tareas patrióticas. La carta fundamentó la participación del dictador sosteniendo: “Tratábase de España y el señor Piérola no podía ser indiferente" 395 . Durante todas las fiestas, continuaba Omega, seudónimo del escritor, "los peruanos manifestaron que fraternizan íntimamente con España"396.

El antiapologista de Piérola, por antonomasia, fue Orestes Araujo. Su oposición al paladín peruano fue inmediata. En una de las primeras crónicas de la guerra enviadas desde Uruguay mostró gran malestar por las decisiones del caudillo. El Perú bajo sus órdenes escribió- ha continuado perdiendo ciudades y pueblos sin grandes luchas, ruidos y batallas. Lo único sorprendente, manifestaba, al parecer languidecido frente al cese de enfrentamientos militares, había sido el combate naval de Arica y la "parodia"397 del bombardeo de El Callao, una "farsa [...] más digna de teatro automático que de conquistadores" 398 .

Araujo condenó la declaración oficial de la dictadura que calificó de "indignos y cobardes a varios militares, incluso al expresidente Prado, que a causa de una revolución

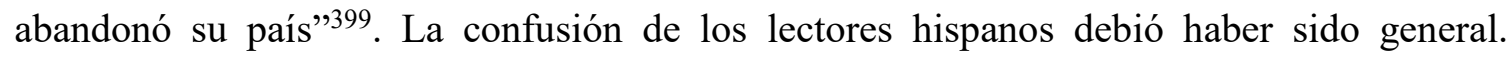
Meses antes, un despacho chileno aseguró que Prado, comprendiendo la situación peruana desastrosa, habíase embarcado "clandestinamente para los Estados Unidos, diciendo que iba a comprar buques de guerra, llevándose dos millones de duros; pero los peruanos saben que no verán ni los barcos ni el dinero" ${ }^{400}$. Araujo reprobó también la autodenominación de Piérola, en medio de la guerra, de Protector de la raza indígena en el Perú.

La ambivalencia periodística provocada por Piérola se explicaría, en el caso de sus defensores, por la urgencia de un "orden político" para el Perú en guerra. Por el contrario, las opiniones de Araujo, se comprenden como notas críticas al desenvolvimiento interior del dictador. Araujo eludió referirse a decisiones y acciones contra Chile. Esta situación

\footnotetext{
${ }^{395}$ El Bien Público, "Carta del Perú", 2 de junio de 1880, p. 2.

${ }^{396}$ Idem.

${ }^{397}$ El Bien Público, "Cartas Sud Americanas”, 12 de julio de 1880, p. 1.

${ }^{398}$ Idem.

${ }^{399}$ El Bien Público, “Cartas Sud Americanas”, 21 de agosto de 1880, p. 1.

${ }^{400}$ El Comercio, [s. t.], 20 de febrero de 1880, p. 1.
} 
quedaría demostrada una vez más con la Constitución del Perú redactada durante la dictadura, documento también conocido como Estatuto Provisorio, que duraría "un año y 9 días"401. Aquel texto le confirió la facultad de nombrar sucesores en el mando de la nación (El parlamento peruano anuló en 1886 todos los actos del gobierno pierolista) ${ }^{402}$.

Comunicando con pesar lo anterior, Araujo transmitía al director de El Bien Público: "Ya puede V. comprender, señor director, que cuando un pueblo soporta estas humillaciones, hasta pierde el sentimiento de su propia independencia"403. Piérola se había transformado, continuaba Araujo mezclando pareceres antichilenos, dejando de ser el patriota sacrificado de antes que actuaba "en aras de su patria; el ánimo de sus connacionales se ha enervado y toda la América del Sur observa con sentimiento como Chile va a avanzando en su soberbia [...] y en su afán de conquista"404.

Apenas sabida por el español la toma del poder por el peruano sus escritos publicados en el Bien Público se esforzaron por desacreditarlo. Esa publicación, normalmente compuesta de cuatro páginas, ocupó en su edición del 12 de abril de 1880 una página y media para socializar sus visiones sobre el caudillo arequipeño. Araujo se mostró en un primer momento escéptico ante las actuaciones del "nuevo personaje" como lo denominó, quien "ha aparecido en la escena política de la república peruana, no se sabe si para salvar a su pueblo del borde del abismo o para precipitarlo más rápidamente en él”405.

La desconfianza que embargaba a Araujo es probable que guarde relación con su antichilenismo. De ser cierta tal predilección entre los países en guerra, la llegada al poder de un nuevo personaje no podría ser vista con satisfacción para quien deseaba el establecimiento en Perú de una organización político-militar que estuviese a la altura de la situación y así vencer a Chile. Además, el culto y refinado historiador español, debió sentir recelo por el dictador, otro más, en la breve historia republicana de Perú, que decía conocer bien. Esta última razón lo llevaría a situar a Piérola en el mismo nivel que otros políticos de

\footnotetext{
${ }^{401}$ RoBles MendOZA, Román, Legislación peruana sobre comunidades campesinas, Lima, Fondo Editorial de la Facultad de Ciencias Sociales Universidad Nacional Mayor de San Marcos, 2002, p. 47.

402 MirkinE-GuEtZÉviTCH, Boris, Derecho constitucional internacional, Madrid, Editorial Reus S. A., 2009, p. 189.

${ }^{403}$ El Bien Público, “Cartas Sud Americanas”, 21 de agosto de 1880, p. 1.

${ }^{404}$ Idem.

${ }^{405}$ El Bien Público, "Cartas Sud Americanas", 12 de abril de 1880, p. 1.
} 
dudosa ética en la vida pública, entre ellos, los presidentes, José Balta y Montero, Tomás Gutiérrez, Manuel Pardo y Lavalle -todos asesinados en Lima, el primero en el cuartel de San Francisco, el segundo colgado en la Catedral y posteriormente quemado en la Plaza Mayor $^{406}$ y el último en las puertas del Senado-, Juan Antonio Pezet y Mariano Ignacio Prado.

La serie extendida de acontecimientos sospechosos en la administración del Estado que cupo a cada uno de ellos permitió a Araujo realizar juicios sobre Piérola. Sin duda, una suerte de espíritu mágico poseyó al escritor quien instaló las falencias de aquellos en el nuevo agitador. Así, el oportunismo del iracundo dictador quedó plasmado en una de las oraciones del escrito que nucleó la crítica. Sobre la forma en que "El Califa"407 se hizo con el poder durante el solsticio de diciembre de 1879 Araujo escribió: "aprovechándose de la ausencia del Presidente legal del Perú [...] con un golpe de mano rápido, violento, preconcebido [...] se ha hecho árbitro de los destinos de su propio pueblo" 408 .

De todos modos, hay que reconocer en Araujo una vocación historiadora: la inquietud por saber los orígenes del caudillo. Del mismo modo que lo redactó posteriormente con ironía un historiador francés - los orígenes de un objeto de estudio representaran para la "tribu" de los historiadores un "ídolo"- Araujo se preguntó ¿quién es Piérola? La respuesta la dividía en dos partes. La primera dedicada al padre, llamado también Nicolás y el segundo al personaje. El primero, aseguraba Araujo, había ocupado cargos de importancia en la Audiencia de Sevilla hacia 1814; había sido diputado en Cortes en el bienio 1820-1822; obtenido una cátedra en la Universidad Central de Madrid en 1823 y, entre otras cosas, había sido Ministro de Estado en Perú en 1853.

Del "Califa", por otro lado, se sabía que había nacido en 1830 educándose en el Seminario Santa Teresa. Su inteligencia y buenos modales lo habían hecho resaltar entre sus compañeros llegando a ser profesor de filosofía en el Seminario de Lima. Su labor periodística posterior lo condujo a la fundación del importante diario El Tiempo. El ingreso en política quedaría de manifiesto con la ocupación de la Secretaría de Estado de Comercio

\footnotetext{
406 SANOJA HeRnÁNDEZ, Jesús, Diccionario de terrorismo, Caracas, Editorial SEC S. A., 2002, pp. 74-76.

${ }^{407}$ Quiroz, Alfonso W., Corrupt Circles. A History of unbound graft in Peru, Washington D. C., The Johns Hopkins University Press, 2008, p. 506.

${ }^{408}$ El Bien Público, "Cartas Sud Americanas", 12 de abril de 1880, p. 1.
} 
y Hacienda en 1869, donde, en palabras de Araujo, "enalteció el nombre de su país algún tanto quebrantado en el extranjero por los desaciertos de pasados gobiernos" ${ }^{409}$. Sin embargo, su apego a las leyes cambiaría en 1877 cuando se sublevó al gobierno peruano debido, se desprende del artículo, a "su carácter inquieto y turbulento" 410 .

Todas las situaciones descritas configuraban la conclusión de Araujo para explicar la actualidad del gobierno pierolista. Con aquellas, se entendía, por ejemplo, la dictadura y su espíritu creativo de un conjunto de leyes favorables a la continuidad de Nicolás de Piérola en el poder, tales como el nombramiento de magistrados y funcionarios del poder judicial, que debían pasar ineludiblemente por la autorización del caudillo. Por otro lado, la dureza demostrada en su trato con la oposición tenía raíces en el pasado. La pena de muerte a un grupo de cincuenta sublevados contra él demostró la implacabilidad del caudillo. En el contexto de la guerra con Chile un diario peruano usado por Araujo escribió: "no creemos que sea medio adecuado para vencer a los chilenos el fusilar a los peruanos"411. En efecto, el control de la prensa se hizo perentorio para la dictadura y frente a una protesta del gremio de periodistas limeños estableció su encarcelamiento.

La duración de la dictadura se hacía insospechable para Araujo. Los movimientos de la guerra se concentraban en el sur peruano. Tacna y Arica comenzaban a ser bombardeadas por la escuadra chilena y la pérdida total de Tarapacá mantenía en la incertidumbre a los líderes peruanos. El historiador "peruanófilo" no se refería a la situación de la clase política chilena, más bien concentraba su atención en los hechos políticos de Perú. Al parecer, preveía un momento de estabilización de la caótica Lima de comienzos de 1880. En ello tendrían un papel fundamental, según su interpretación de los hechos, las mujeres. En sus palabras: "Piérola goza de generales simpatías entre el sexo bello de la República y ya pueden suponer nuestros lectores la influencia que la mujer ejerce en el hogar doméstico, sobre todo aquí, en la América del Sur"412.

\footnotetext{
409 Íbidem, p. 2.

${ }^{410}$ Idem.

411 Íbidem, p. 1.

${ }^{412}$ El Bien Público, "Cartas Sud Americanas", 12 de abril de 1880, p. 1.
} 
4.3. El factor "Argentina" y el miedo a la guerra

Por otro lado, fue relevante el papel adquirido por Argentina en el curso de la guerra. Su situación fronteriza con Chile, la delimitación inconclusa del territorio en la zona sur de ambos países, sus antiguas conversaciones con Perú para acordar una alianza militar, etc. la colocaron "bajo sospecha" por parte de Chile. De esta realidad se percató la prensa hispana informando la existencia de un "factor" nuevo en la guerra.

La amenaza de la guerra con Argentina fue una imagen recurrente desde 1880 hasta 1898 cuando, probablemente, empujó a la negociación del protocolo Billinghurst-Latorre entre Perú y Chile. Al respecto, un diario matritense publicó: "Dicen que los chilenos están preparando un ejército para la nueva guerra, y que los argentinos han comprado dos blindados de primera clase al Gobierno italiano"413. Si bien esa publicación reconocía la escasez de noticias recibidas desde Chile "creía” tener razones para esperar la ruptura con Argentina, puesto que ambos países realizaban grandes preparativos militares.

Puntualmente, en el caso argentino, se habló de un enrolamiento militar de 50000 hombres y del pago de enganches para formar parte de la tropa. Los rumores de guerra continuaron en vísperas de la expedición chilena a Lima, lo que llevó a una publicación hispanoamericanista a desear la fugacidad de esos comentarios para la paz americana ${ }^{414}$.

\subsection{El Combate Naval de Arica}

Mientras Nicolás de Piérola y el pueblo peruano organizaban la guerra desde Lima se mantuvo el bloqueo chileno de Arica, estrategia que no estuvo exenta de problemas para ambos países. En el caso peruano, el miedo se agudizó desde fines de 1879 hasta el Asalto y Toma del Morro ${ }^{415}$. La población, cercada desde el mar por la marina chilena, poco a poco, sintió el desabastecimiento de los productos de primera necesidad.

\footnotetext{
${ }^{413}$ La Iberia, "América del Sur", 25 de febrero de 1880, p. 2.

${ }^{414}$ La Ilustración Española y Americana, "Don Manuel Baquedano”, n. ${ }^{\circ}$ 55, 8 de diciembre de 1880, p. 338.

${ }^{415}$ Las ideas básicas sobre las visiones de la prensa española en la batalla de Arica en: SoTo LARA, José Julián, "La campaña de Tacna y Arica en la prensa española", Tordesillas Revista de Investigación Multidisciplinar, n. ${ }^{\circ}$, pp. 55-73, 2015.
} 
Las familias de Tacna y Arica, explicaba un reportaje proveniente de Uruguay, habían comenzado a emigrar hacia la ciudad sureña de Iquique en previsión de los próximos sucesos militares y acosados también "por la escasez de elementos de vida"416. Según la información impresa en España, el puerto peruano de Arica había sido bombardeado por el acorazado chileno Huáscar incendiando una parte de la ciudad defendida por más de mil hombres ${ }^{417}$.

\section{Imagen $n .^{\circ} 8$}

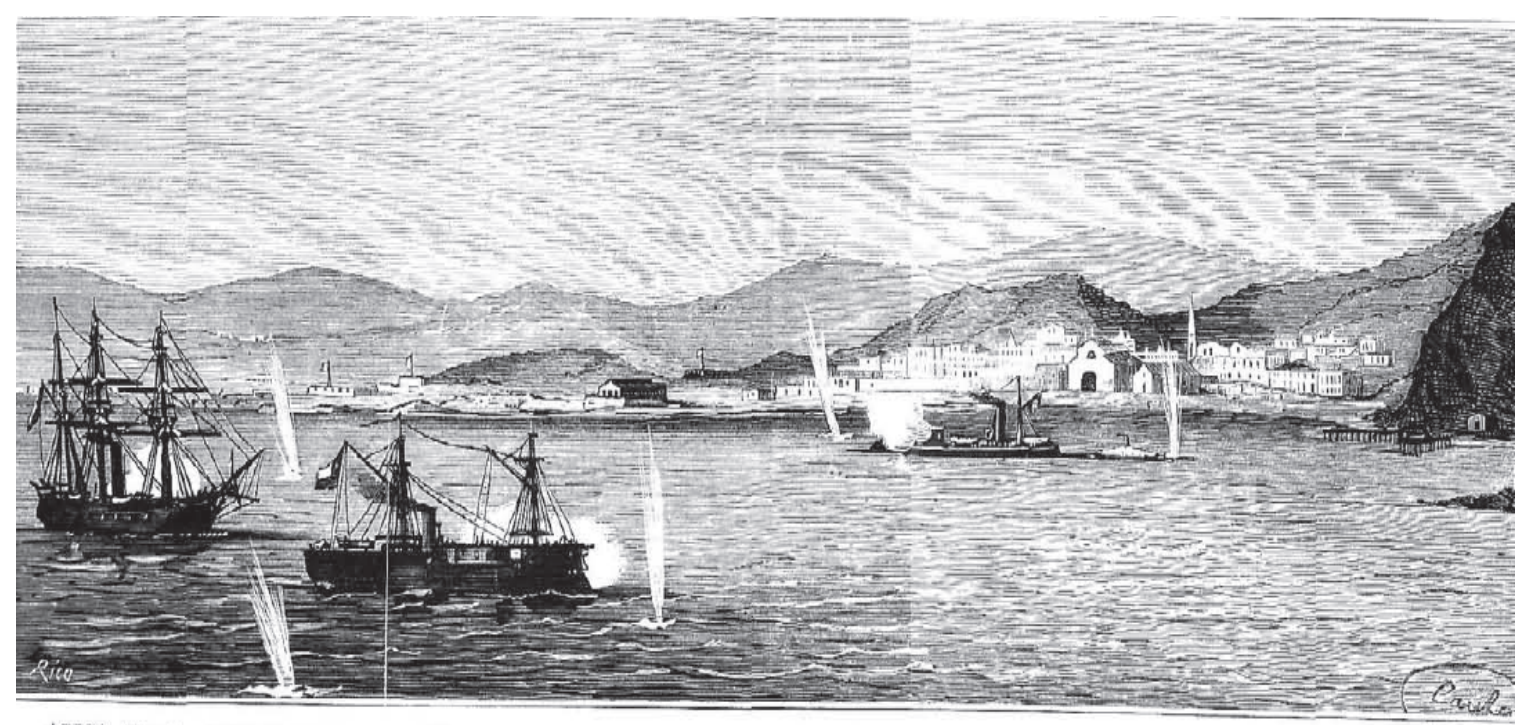

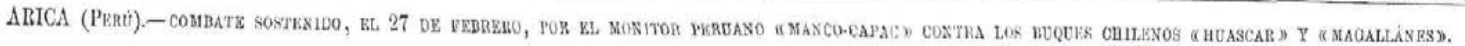

Fuente: La Ilustración Española y Americana, “Arica (Perú). Combate sostenido el 27 de febrero, por el monitor peruano «Manco Capac» contra los buques chilenos «Huáscar»y «Magallanes»", n. ${ }^{\circ} 22,15$ de junio de 1880 , p. 381.

En Chile se publicó la noticia de la muerte de Manuel Thompson, "valiente capitán"418 del Huáscar, acorazado peruano capturado por Chile en el combate de Angamos, meses antes. La información fue reproducida por periódicos españoles ${ }^{419}$ e

\footnotetext{
${ }^{416}$ El Bien Público, "Cartas Sud Americanas", 12 de julio de 1880, p. 1.

${ }^{417}$ La Época, "Prensa extranjera", 4 de abril de 1880, p. 3; Diario de Córdoba, "América", 18 de mayo de 1880 , p. 1.

${ }^{418}$ La Ilustración Española y Americana, "Sucesos de América", 8 de mayo de 1880, p. 291.

${ }^{419}$ El Siglo Futuro, "América del Sur", 9 de marzo de 1880, p. 3; El Globo, "Noticias generales", 10 de marzo de 1880, p. 3; El Imparcial, "Sección de noticias", 11 de marzo de 1880, p. 3; El Globo, "Perú", 27 de marzo de 1880, p. 3; El Siglo Futuro, "América del Sud", 3 de abril de 1880, p. 2; El Liberal, "Extranjero", 5 de abril de 1880, p. 1; La Ilustración Española y Americana, "Perú", n. ${ }^{\text {o }} 13,8$ de abril de 1880, p. 222; El Comercio, "Gacetillas", 13 de marzo de 1880, p. 3; El Áncora, "Sección extranjera", 21 de abril de 1880, p. 3; El Amigo, "Revista de los principales sucesos de la semana", 14 de marzo de 1880, p. 3; El Comercio, "Revista extranjera de El Comercio", 4 de abril de 1880, p. 1.
} 
ingleses, como el Pall Mall Gazette. Desde allí, una carta enviada por Eduardo Asquerino al diario La América, enfatizó que el bombardeo de Arica se realizó por diversión estratégica bien concebida y audazmente ejecutada, pues mientras se realizaba esto, "una poderosa escuadra chilena ocupaba el puerto de Ilo y un ejército de 14000 invasores penetraba en el país"420.

La Unión y El Bien Público, sospechando de sus fuentes de información por proceder de Chile, describieron la muerte de Thompson con detalle. Una bala en su estómago, la caída de su corazón por un lado y la cabeza, los brazos y las piernas por otro, fueron partes de la secuencia fatal que lo situó en el panteón de los héroes. Los restos del marino que había combatido contra España a mediados de la década de los sesenta "fueron colocados en un barril para ser trasladados a Chile" ${ }^{421}$. Otro diario, usando ahora fuentes peruanas, escribía: "Las últimas noticias [...] dice que los chilenos bombardean Arica con cañones Armstrong de a 150, y que los defendían de un ataque por medio de torpedos" ${ }^{422}$.

\section{Imagen n. ${ }^{\circ} 9$}

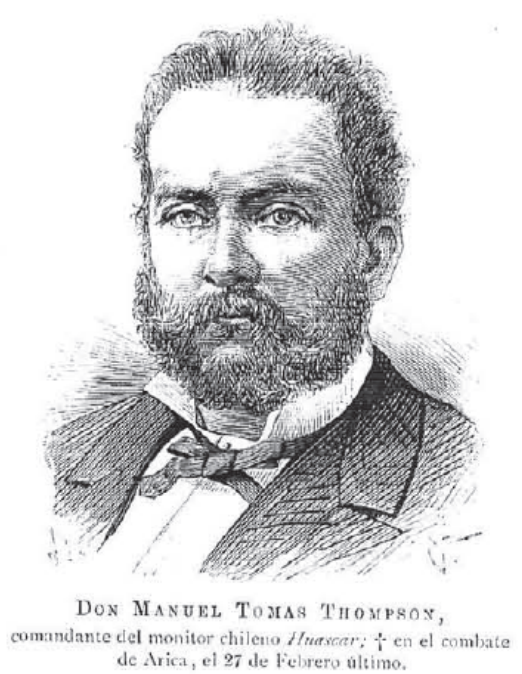

Fuente: La Ilustración Española y Americana, "Don Manuel Thompson, comandante del monitor chileno Huáscar", n. ${ }^{\circ} 22,15$ de junio de 1880, p. 379.

\footnotetext{
${ }^{420}$ La América, "La Guerra del Pacífico", 8 de abril de 1880, p. 12.

${ }^{421}$ El Bien Público, "Cartas Sud Americanas", 12 de julio de 1880, p. 1.

${ }^{422}$ El Áncora, "Sección extranjera", 21 de abril de 1880, p. 3.
} 
Una reseña de los momentos más tensos del bloqueo de Arica fue construida en base a partes oficiales chilenos que La Ilustración Española y Americana disponía. En esa, elogiaron en una biografía a Manuel Thompson, recordando su participación en la guerra contra España de 1865. Incluía su retrato y concluía llamando la atención sobre la valentía mostrada por los chilenos y peruanos. La revista reconocía que "pocas guerras modernas han sido tan abundantes en hechos valerosos y en patrióticos sacrificios como ésta, que tanto deploramos"423. Con razón, un historiador de la marina chilena ha opinado que la muerte de Thomson fue inútil, pues su fama no necesitaba de su heroica muerte. La prueba de aquello "es que la acción de Arica es poco conocida entre los chilenos" 424.

\subsection{Chile país bárbaro}

Chile planificó los movimientos futuros de la guerra durante el bloqueo de Arica. En Santiago la prensa rápidamente adoptó un discurso belicista proclive a emprender una campaña militar hacia Lima ${ }^{425}$. En el campo periodístico así lo percibieron algunos diarios españoles, basados en correspondencia llegada desde Lima, acusando a la prensa chilena de contribuir "a sostener la exacerbación de las pasiones y el carácter odioso"426.

Las victorias navales y militares en la costa boliviana y en el sur peruano habían robustecido la identidad guerrera chilena. En un primer momento este cambio no motivó la realización de análisis profundos en la prensa española. El primer diario que trató esta situación, La Iberia, anexó el artículo titulado “¿A Arica o a Lima? A ambos a la vez”" ${ }^{27}$, de un conocido diario chileno, donde se decía con aires "prusianos": "Arica sigue siendo para nosotros -y dispénsenos la Francia la comparación- el Belfort del Perú y Lima, ¡Perdónenos Dios! el París de esa nación decrépita y envilecida"428.

\footnotetext{
${ }^{423}$ La Ilustración Española y Americana, "Guerra del Pacífico", n. ${ }^{\text {2 } 2, ~} 15$ de junio de 1880, p. 379.

${ }^{424}$ LÓPez Urrutia, Carlos, Historia de la Marina de Chile, Santiago, Editorial Andrés Bello, 1968, p. 398.

${ }^{425}$ El Áncora, "Sección Extranjera", 5 de julio de 1880, p. 3.

${ }^{426}$ El Siglo Futuro, "América del Sud", 3 de abril de 1880, p. 2; El Timón, "Guerra chileno-peruana”, 29 de octubre de 1880, p. 3. Al respecto, una historiadora peruana ha escrito: "La prensa chilena contribuyó con su arsenal retórico a la legitimación ideológica de la ocupación del territorio enemigo". En: McEvoY, Carmen, "Civilización, masculinidad y superioridad racial: Una aproximación al discurso republicano chileno durante la Guerra del Pacífico (1879-1884)", Revista de Sociología e Política, vol. 20, n. ${ }^{\circ}$ 42, 2012, p. 78.

${ }^{427}$ La Iberia, “América del sur", 12 de marzo de 1880, p. 2.

${ }^{428}$ Idem.
} 
La analogía histórica que tanta aceptación alcanzó durante el medio siglo de duración del conflicto bélico-diplomático y que comparaba a Chile con Alemania y al Perú con Francia, concluía sus deseos de la siguiente forma: "Necesitamos ir a Lima [...] para derribar allí con el impulso e irresistible empuje de nuestras victoriosas bayonetas el pedestal de cieno y barro sobre el que se alzaba el [...] orgullo peruano" ${ }^{29}$.

“¿A Arica o Lima?...” incluía otros pensamientos chilenos referidos al porqué el Estado decidió tomar Tacna y Arica. Una de las razones simbólicas, según el redactor, era probar a América y Perú el poderío militar chileno. Esa fuerza marcial era capaz de aniquilar peruanos por el "empuje del soldado chileno y su irresistible coraje"430. La guerra desatada, sin duda, llevaba a sus defensores chilenos a buscar los argumentos finales de las masacres, muchas veces, en sujetos irresponsables, puntualmente el pueblo ajeno a la decisiones de las elites dirigentes. Tales visiones hicieron puntualizar al misterioso ideólogo chileno que Arica era para Chile "un triunfo guerrero, costoso si se quiere, pero indispensable: Lima será un triunfo exigido, más que por el Ejército chileno, por las temerarias y locas provocaciones de la prensa, hombres públicos y pueblo del Perú" ${ }^{431}$.

No cabe duda que el belicismo chileno se tornó desagradable para la prensa. Con ese ánimo se escribió en varias ocasiones sobre la barbaridad y vandalismo de la guerra llevada por Chile, país apodado como la Alemania Sudamericana ${ }^{432}$. Al respecto un historiador español que disfrutaba con la comparación sentenció: "Tal es la actualidad de esta guerra, hecha sin premeditación, y en la cual los aliados representan idéntico papel que el de la nación francesa cuando midió sus armas con la prevenida y cauta Alemania"433. Ya antes los medios criticaron los ataques chilenos a poblados peruanos indefensos sin emplear “armas nobles y medios legítimos para lograr éxito en la guerra y triunfo en los combates" $" 434$.

\footnotetext{
${ }^{429}$ Idem.

${ }^{430}$ Idem.

${ }^{431}$ La Iberia, "América del sur”, 12 de marzo de 1880, p. 2. Otras referencias sobre la decisión del gobierno de Chile por atacar Lima en: La Ilustración Española y Americana, "Crónica Americana”, n. ' 24, 30 de junio 1880, p. 427.

${ }^{432}$ El Liberal, "Chile y España", 9 de septiembre de 1882, p. 1.

${ }^{433}$ El Bien Público, "Cartas Sud Americanas", 21 de agosto de 1880, p. 1.

${ }^{434}$ La Unión, "Correo de Ultramar", 1 de julio de 1880, p. 1; El Bien Público, "Cartas Sud Americanas", 12 de julio de 1880 , p. 1.
} 
La prensa, para sumar argumentos a la barbarie chilena, filtró documentos oficiales de ese país que pusieron al descubierto las tácticas para apaciguar a Perú y llevarlo a la rendición. En aquellos, Chile apelaba a la destrucción del Perú haciéndoles "sentir la dureza y la crueldad de la guerra en su mayor amplitud" ${ }^{35}$. Por aquel entonces Chile estaba al tanto de la organización de grupos guerrilleros en el Perú, a quienes se les debía informar que "estamos dispuestos a reprimir esos excesos con la mayor severidad posible [...] a quien se sorprenda con las armas en la mano será inmediatamente pasado por las armas" ${ }^{\$ 36}$. Esas consideraciones formaban parte de la correspondencia intercambiada entre el Jefe de las fuerzas chilenas en Pisagua y el Ministro chileno de Guerra y Marina.

Lo importante aquí es que publicitando esa agresividad chilena surgió una corriente de opinión solidaria con el sufrimiento peruano bajo "los términos en que la guerra comienza a hacerse" ${ }^{437}$. De modo que se continuó insertando comunicados chilenos que pronosticaban el advenimiento de una "guerra tremenda". En esos términos, por ejemplo, un diario hispano hizo alusión al plan chileno de bombardear Arica "hasta destruirlo" 438 , hecho que no ocurrió.

Por un tiempo la ciudad se utilizó como campo de prueba para las cañoneras adquiridas por la marina chilena. Ante esa situación, sumada a los temblores destructivos de los años 1868 y 1877, Arica fue considerada como uno de los pueblos más castigados del mundo, antes por "los terremotos, y ahora por el azote de una guerra repugnante, inhumana, bárbara"439. Tal vez la "barbarización" de la guerra guardó relación con su propia "excepcionalidad", pues en ella Chile incorporó nuevos territorios equivalentes a más de siete grados de latitud, complicando el dominio efectivo de los mismos ${ }^{440}$.

En Lima se redactaron cientos de noticias censurando el proceder chileno en la guerra. Lo interesante de éstas, para nosotros, es que luego fueron publicadas en España, lo que sirvió para fortalecer la oposición a Chile en el extranjero. No obstante, la prensa limeña antichilena tenía sus días contados.

\footnotetext{
${ }^{435}$ El Siglo Futuro, “América del Sud”, 3 de abril de 1880, p. 2.

${ }^{436}$ Idem.

${ }^{437}$ Idem.

${ }^{438}$ La Iberia, “América del Sur”, 18 de abril de 1880, p. 2.

${ }^{439}$ El Siglo Futuro, "Guerra del Pacífico", 11 de junio de 1880, p. 2.

${ }^{440}$ La Ilustración Española y Americana, "Crónica Americana", n. ${ }^{\circ}$ 24, 30 de junio de 1880, p. 427.
} 
Cuando el ejército chileno ocupó Lima se prohibió toda prensa contraria al país conquistador. De todas formas, la opinión y el juicio hacia Chile, condensada en la siguiente cita textual, marcarían la imagen construida que aún se constata en la sociedad peruana. En palabras resumidas, Chile fue un país deshonroso, ambicioso, codicioso, ladrón, etc. el que a juzgar por sus victorias demostró que "no pocas veces la fortuna favorece a quien menos se lo merece" ${ }^{441}$. Parte del artículo dijo lo siguiente:

La guerra que Chile nos hace no es guerra de honor, ni de recuperación de su propiedad; no: la guerra que Chile nos hace es guerra de destrucción, es guerra alimentada por la ambición y soberbia más refinadas, es guerra de explotación y de comercio. Así y sólo así se explica el por qué todo lo irrespeta y avasalla Chile; el por qué no tiene reparo ni con las alarmas de la América; el por qué, a la manera del salteador, no duerme, sino que vela sobre la presa para apoderarse de ella al menor descuido; el por qué establece bloqueos de burla, invade traidoramente, extrae pasajeros escudados por bandera neutral, bombardea ciudades indefensas, se apropia de riquezas ajenas, sin que nada le importe, ni sea parte a detenerle la propia dignidad, el respeto al derecho de gente y la cultura y civilización cristianas ${ }^{442}$.

A esta opinión antichilena que circuló por España una nota excepcional fue el análisis de la situación redactado por una de las revistas más importantes ${ }^{443}$. En esta se informó acerca de los buenos precios que el cobre chileno estaba alcanzando en los mercados europeos, así como las excelentes cosechas agrícolas. Todo lo anterior en el marco, según la publicación aludida, de la "honradez del gobierno chileno y en general de todos los empleados de su administración [los que] contribuyen eficazmente al buen orden y a los progresos, lentos, pero constantes, de aquel país". 444

En esta suerte de apología marginal de Chile se establecían comparaciones ya no con Alemania sino con Inglaterra. Dos pruebas convincentes de ese parangón eran, en primer lugar, la Constitución, y en segundo lugar, la legalidad. Por último, la nota invitaba al establecimiento de relaciones diplomáticas entre Chile y España, olvidando "prejuicios añejos e injustificados"445. La firma del tratado que debía sellar esas conversaciones se demoraría un tiempo, no obstante la apertura de un nuevo espacio comercial entre ambos países suscitó en España nuevas vetas de trabajo para varios armadores y astilleros.

\footnotetext{
${ }^{441}$ La Unión, "Correo de Ultramar", 1 de julio de 1880, p.1.

${ }^{442}$ El Siglo Futuro, "América del Sud", 3 de abril de 1880, p. 2.

${ }^{443}$ La Ilustración Española y Americana, "Sucesos de América", n. ${ }^{2}$ 27, 8 de mayo de 1880, p. 292.

${ }^{444}$ Idem.

${ }^{445}$ Idem.
} 
A finales de abril de 1880 continuaba el bloqueo de Arica. Hacia el sur de la ciudad los territorios estaban ocupados por el ejército chileno y hacia el norte el desembarco de tropas se había realizado sin contratiempos. Los cambios políticos en Bolivia reavivaron la esperanza de que bajo el mando del General Narciso Campero llegase a Arica una tropa superior a los ocho mil hombres. Así, los aliados ofrecerían al ejército chileno una resistencia que bordearía los veinticuatro mil hombres, puesto que en Arica se contaba con una fuerza de quince mil peruanos.

En resumidas cuentas, de ocurrir el choque entre chilenos y peruanos, los primeros contarían con dieciocho mil hombres, una cifra bastante inferior a la de los aliados. A eso había que sumar el debilitamiento de las tropas chilenas que, según un diario hispano, “están desmoralizadas a causa del hambre y la sed que están sufriendo hace seis meses" Además, las condiciones ambientales favorecieron la aparición de dolencias acompañadas de fiebre "con grande (sic) intensidad en el campamento chileno, llenando los hospitales de enfermos" ${ }^{\prime 47}$.

En esa época el ejército chileno se entregó a la tarea de reafirmar su invasión y dominación en Tarapacá, zona rica en salitre y guano. Con eso, la economía del país tenía un futuro halagüeño. Paulatinamente, Arica generó menor cantidad de noticias, pero una interrogante cobró gran relevancia en el desarrollo de la guerra: ¿El Ejército chileno atacaría Lima para, una vez vencida la capital peruana, solicitar la paz? o ¿primero atacaría a Arica?

Uno de los medios importantes para definir el barbarismo chileno fue la correspondencia peruana publicada en España. Otro tanto hizo el testimonio de diplomáticos peruanos en el extranjero. El caso de Eugenio Larrabure y Unánue merece atención, porque desempeñó funciones en el Ministerio de Relaciones Exteriores al comenzar la guerra, y luego formó parte de la Legación peruana en España encabezada por José Joaquín de Osma. Atento al desarrollo de los acontecimientos militares se vio en la obligación de dar algunas explicaciones más detalladas y rectificar otras, según lo explicó en carta publicada en El Timón hacia el 29 de octubre de 1880.

\footnotetext{
${ }^{446}$ El Liberal, "Extranjero", 30 de abril de 1880, p. 1.

${ }^{447}$ Idem.
} 
No analizaremos las estrategias retóricas usadas por Larrabure para crear en los lectores españoles un sentimiento negativo hacia Chile y positivo hacia su país. La articulación de su argumento se comprende si definimos las dos áreas comentadas por el emisario. La primera, referida al modo chileno de guerrear y la segunda a la violación del derecho de gentes. Los métodos de la escuadra y el ejército chileno fueron criticados en todo momento por sus adversarios. Las consecuencias sociales de la guerra empujaron hacia el odio a sus artífices. Larrabure no fue la excepción. Le dolían los bombardeos de pueblos indefensos "florecientes" de comercio e industria. Los chilenos habían causado la ruina "de numerosos extranjeros, entre ellos muchos españoles que habían formado fortuna a fuerza de trabajos y fatigas" 448 .

Por entonces, Inglaterra había sido uno de las primeras potencias críticas del proceder militar chileno. Los representantes británicos en Perú "ha rebut órdre d'unirse á las reclamacions del representants francés é italiá, contra tots los actes en que's falti als usos de la guerra observats en las nacions civilisadass" ${ }^{449}$. Los procedimientos del almirantazgo chileno habían molestado al cuerpo diplomático extranjero en Perú pues había minimizado los tiempos para que las "naves neutrales" 450 carguen productos comerciales. Eran los chilenos, continuaba Larrabure, quienes bombardeaban trenes con pasajeros, produciendo muerte y desolación. A diferencia de El Callao, artillado para resistir los fuegos chilenos, Chancay, Chorrillos y Ancón sufrían las embestidas por diversión chilena.

La cobardía demostrada por Chile durante el año que había durado la guerra tenía un fundamento histórico en la lectura que el diplomático hacía de los hechos. Coincidentemente, la raíz de esa actitud procaz, venía desde los tiempos de la guerra entre Chile-Perú-Bolivia y España durante los años sesenta. Para mostrar sus pruebas Larrabure comentaba los sucesos que permitieron incluir en la escuadra chilena a la Covadonga: “declarada la guerra por Chile a España en aquella época, la corbeta chilena Esmeralda, al divisar la goleta española, en las aguas de Papudo, izó bandera inglesa, pidiendo socorro con urgencia" ${ }^{451}$.

\footnotetext{
${ }^{448}$ El Timón, "Guerra chileno-peruana", 29 de octubre de 1880, p. 2.

${ }^{449}$ Diari Catalá, "Extracte de telegramas de la prempsa local", 17 de julio de 1880, p. 8.

${ }^{450}$ El Bien Público, "Carta del Perú", 2 de junio de 1880, p. 2.

${ }^{451}$ El Timón, "Guerra chileno-peruana", 29 de octubre de 1880, p. 2.
} 
La traición chilena fue relatada por el diplomático peruano de la siguiente manera: "El generoso comandante de la Covadonga hizo forzar la máquina para ir en auxilio del barco que juzgaba inglés; pero cuando se acercaba a éste, recibió una inesperable y terrible

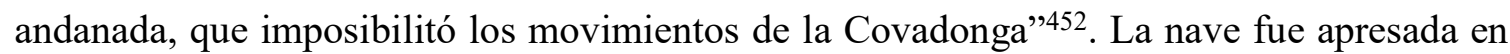
el acto por el almirante Williams Rebolledo, uno de los líderes de la escuadra chilena durante la Guerra del Pacífico. Esas razones, es decir, la vigencia casi total de los guerreros del 65 fundamentaría lo que el peruano comprendió como injustificable "odio al Perú y a España"453.

Sobre el segundo aspecto, según el análisis de Larrabure, Chile estaba manteniendo una posición extrajurídica al no atenerse a las normas vigentes regulatorias de la guerra. Las normas que regían el comportamiento de los ejércitos, expiando muchos comportamientos en virtud del amor a las banderas, estaban incluidas en el Derecho de Gentes. El bombardeo de poblados peruanos, comentado anteriormente, se encontraba condenado por los principales tratadistas de ese derecho ${ }^{454}$. No obstante, el Larrabure historiador lapidaba la conducta diplomática chilena de ayer y hoy: "Las leyes de guerra y los preceptos del derecho internacional son mirados, y lo fueron siempre, con el mayor desprecio por Chile" 455 .

Dejaremos aquí las adulteraciones históricas de Larrabure quien acusó a Chile de declarar la guerra a Perú en abril de 1879, sin mencionar exprofeso -a efectos de no debilitar su argumentación-, la alianza militar pactada entre su país y Bolivia en 1873 y, por último, la declaración de guerra de Bolivia a Chile el 1 de marzo de 1879. El Encargado de Negocios de Perú en España ${ }^{456}$ durante 1881 tuvo una participación importantísima en la discusión del Tratado de Ancón en 1883 y, diez años después, en 1894, durante los intentos frustrados por ejecutar el plebiscito en Tacna y Arica.

\footnotetext{
452 Idem.

453 Idem.

${ }^{454}$ Idem.

${ }^{455}$ Idem.

456 Escagedo Salmón, Mateo, Solares montañeses: viejos linajes de la provincia de Santander, vol. 8, Santander, Wilsen Editorial, 1991, p. 186.
} 


\subsection{Chile invade Tacna y Arica}

Los meses de mayo y junio de 1880 fueron trascendentales para la Guerra del Pacífico. En los hechos, el cerco que la marina chilena extendió sobre la costa peruana y los bombardeos encarnizados de poblados allí asentados dieron paso a los movimientos terrestres del ejército. En ese tiempo, la guerra en Chile se popularizó. Las victorias de Tarapacá y el dominio teórico del Pacífico Sur, sumado al trabajo nacionalista de la prensa, legitimó los métodos militares que se usarían en las batallas de Tacna y Arica, conocidas en las historiografías de los países involucrados, en el mismo orden, como la "Batalla del Alto de la Alianza" y el "Asalto y Toma del Morro de Arica".

Antes de abrirse los fuegos, una revista española se preguntó: “¿Intentarán los chilenos un golpe atrevido, abandonando los alrededores de Arica, y desembarcando fuerzas cerca del Callao y avanzando hacia Lima?"457. De ser positiva la respuesta, continuó la publicación con escepticismo hacia la eficacia militar aliada, los soldados peruanos "¿podrían hacer frente a un ejército que se ha batido varias veces, con poderosa artillería, de que el Perú no dispone, avezado a las vicisitudes de la campaña en un país malsano?" 458 . La revista no se aventuraba a sugerir respuestas. Era el silencio previo que antecede la catástrofe.

El 31 de mayo aparecieron en la prensa noticias referidas a la victoria chilena en Tacna y el posterior avance de su ejército hacia Arica. España conoció, mediante sus periódicos, el parte oficial firmado por el general Manuel Baquedano dando cuenta de la resistencia aliada tenaz que, sin embargo, no había logrado frenar a "nuestros valientes soldados" ${ }^{459}$ en Tacna. En ese documento relataba la dispersión de los soldados peruanos y bolivianos con posterioridad a la derrota. Finalizaba su correspondencia escribiendo al Ministro de Guerra: "Congratulo a usted y al país por esta victoria, golpe muy severo para el enemigo, y que no podrá fácilmente reparar, mientras que para Chile es la consolidación del trabajo encomendado a su ejército" 460 .

\footnotetext{
${ }^{457}$ La Ilustración Española y Americana, "Sucesos de América", n. ${ }^{\circ}$ 27, 8 de mayo de 1880, p. 292.

${ }^{458}$ Idem.

${ }^{459}$ El Bien Público, "La Batalla de Tacna”, 17 de julio de 1880, p. 1.

${ }^{460}$ Idem.
} 


\section{Imagen n. ${ }^{\circ} 10$}

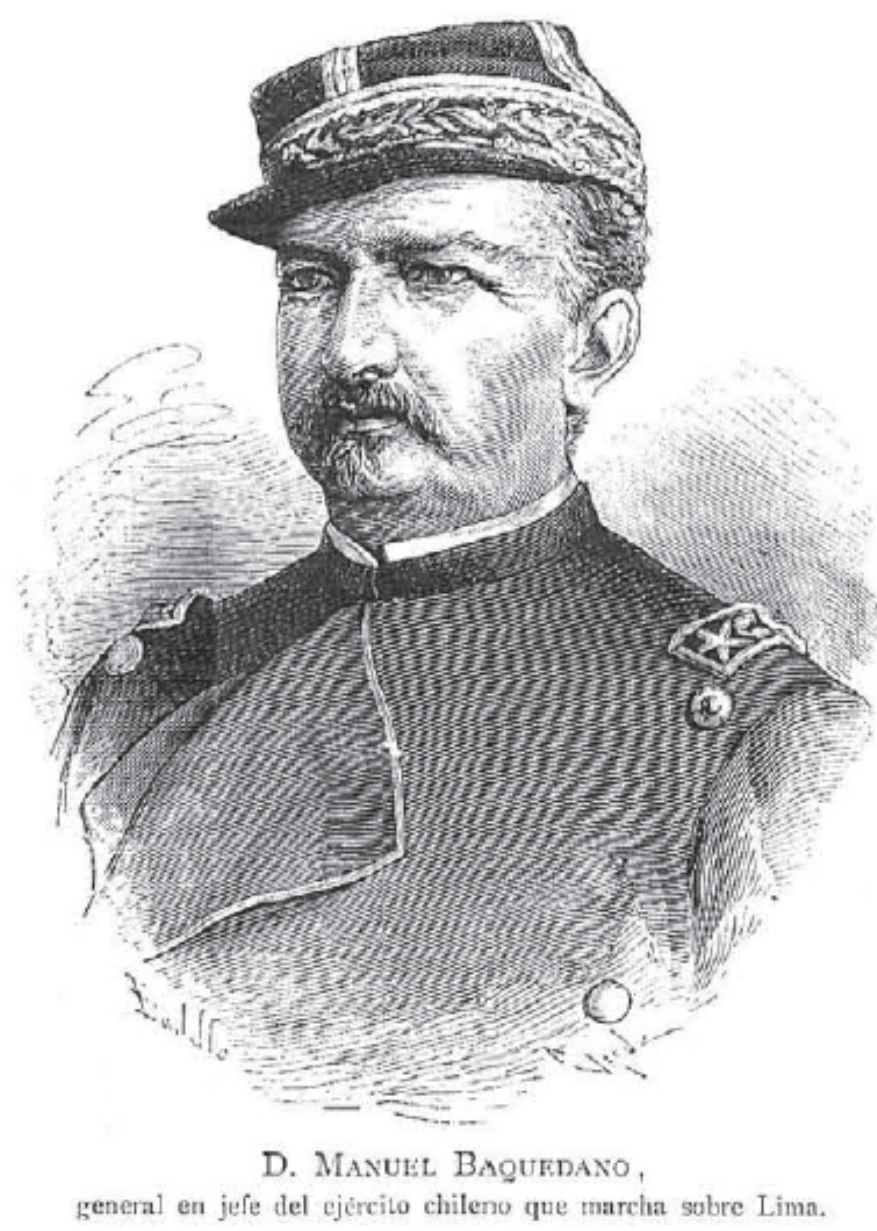

Fuente: La Ilustración Española y Americana, "D. Manuel Baquedano, general en jefe del ejército chileno que marcha sobre Lima", n. ${ }^{\circ} 45,8$ de diciembre de 1880, p. 338.

Días después se publicaron notas extensas detallando lo sucedido en esa ciudad. Una comentó, por ejemplo, el horario de inicio y fin del enfrentamiento, el armamento utilizado por los ejércitos y una lista de fallecidos, "quizás la más larga que se encuentre en los anales de ambos países" ${ }^{461}$. Alineado con el Perú, las opiniones de Orestes Araujo se refirieron al poder armamentístico chileno, como las baterías Krupp, determinantes en el triunfo que tanto lo atormentaba. En Tacna, por ejemplo, las tropas del ejército peruanoboliviano fueron vencidas por los chilenos, pero "no humilladas" 462.

\footnotetext{
${ }^{461}$ La Época, "Noticias de la Guerra Chileno-Peruana", 22 de julio de 1880, p. 1.
}

${ }^{462}$ El Bien Público, "Cartas Sud Americanas", 22 de julio de 1880, p. 1. 
Araujo, en posesión de documentación oficial chilena relativa a Tacna, la interpretaba a contrapelo. Basado en el parte de Baquedano -un militar recto y representante perfecto de una "visión caballeresca y rancia sobre la ética de los que luchan" 463 - aseguró que los aliados se batieron "bizarramente" 464 . No ocultando la felicidad que le causaron las bajas chilenas agregaba, respecto al sanguinario encuentro de Tacna, la espectacularidad de que daban pruebas "las numerosas bajas que han experimentado los chilenos" ${ }^{465}$. Ningún juicio de valor, como a los que acostumbró a sus lectores para referirse a Chile, hizo de los soldados peruanos que asesinaron al negociador chileno con las tropas aliadas en Tacna. Sólo escribió, bordeando la justificación, que tales hechos fueron causados, como lo escribirían los cónsules extranjeros en Lima, por soldados ebrios.

En Araujo la esperanza del triunfo aliado menguaba. Mientras que en su correspondencia inicialmente no existen referencias explícitas hacia el Estado y ejército chileno, en la posterior a la derrota aliada de Tacna sí. Un ejército más numeroso y la obediencia militar a los superiores, inexistentes en los peruanos, fueron las razones más usadas. A eso se sumaba el crédito comercial chileno ilimitado en Europa para la compra de armamento.

En otro aspecto, las analogías del erudito una vez más pretendieron hacer comprensible en España lo ocurrido en Sudamérica. Antes de la conquista chilena de Arica comentó: "Sólo, pues un Waterloo podría cambiar la faz de tan triste cuadro. De no ocurrir [...] lo seguro es que destrozado el Perú materialmente, sin tiempo, sin dinero y sin hombres para reponerse, se haga una paz que lo deje aniquilado por largo tiempo" ${ }^{466}$. Los vaticinios de Araujo se confirmaron con el tiempo. Continuando sus comparaciones, nivelaba al Perú con la Francia de Thiers, haciendo una llamada al país andino para aprovechar esa lección. Sólo así "despierta el patriotismo y se levanta más potente que nunca, corrigiendo los grandes defectos que afectan a la sociedad peruana" 467 .

\footnotetext{
${ }^{463}$ Villalobos, Sergio, Chile y Perú..., p. 163.

${ }^{464}$ El Bien Público, "Cartas Sud Americanas", 22 de julio de 1880, p. 1.

${ }^{465}$ Idem.

466 Idem.

${ }^{467}$ Idem.
} 
La prensa española informó de la preparación en Arica de una resistencia peruana "a todo trance" y de la toma de prisioneros por los chilenos quienes, además, se habían apoderado de varios cañones de guerra ${ }^{468}$. En relación a aquello, en Tacna había caído prisionero el presidente boliviano, General Narciso Campero, tildado por una publicación de demagogo y poseedor de una gran "ampulosidad y palabrería" ${ }^{469}$. Su proceder políticomilitar ha permitido que parte de la historiografía chilena valore su compromiso "nacional" para continuar la guerra contra Chile en conocimiento de la situación adversa de su país ${ }^{470}$. En España, esa situación reforzó la interpretación de una Bolivia debilitada que, aliada a Perú, ayudaba poco a la causa militar común.

Al respecto, un diario señaló, "si como se asegura, el presidente de Bolivia es prisionero hoy del ejército de Chile, perderá el Perú por completo hasta el débil e inseguro apoyo de sus aliados; porque será inevitable una revolución en La Paz"471. La misma publicación aseveró la ejecución de cuatro militares en Potosí que "probablemente abrirán un nuevo periodo de sangre, de los que tan comunes son en aquella república"472. Días después, la supuesta prisión de Campero se pondría en entredicho con informaciones de la Italia Militar que negaban esos hechos ${ }^{473}$.

Araujo tuvo una posición marginal en la bolivianofobia de la prensa. Más influido por sus deseos que por los sucesos militares analizó la realidad boliviana con ingenua esperanza. Según él, Bolivia contaba con un ejército equipado. A sus hombres o hijos, como les llamaba, "no les falta ánimo para el combate, carecen de armas y [...], en las batallas, los indefensos más han servido de blanco al fuego de la poderosa artillería chilena que de ayuda a los peruanos" 474 .

\footnotetext{
${ }^{468}$ La Época, "Despachos telegráficos", 31 de mayo de 1880, p. 1; El Siglo Futuro, "Telegramas", 31 de mayo de 1880, p. 3; El Liberal, "Telegramas", 31 de mayo de 1880, p. 3; El Globo, "Telegramas de la Agencia Fabra", 31 de mayo de 1880, p. 3; El Imparcial, "Despachos telegráficos", 31 de mayo de 1880, p. 1; La Unión, "Correo extranjero", 3 de junio de 1880, p. 1; La Crónica Meridional, "Noticias generales", 3 de junio de 1880, p. 3; Diario de Córdoba, "Estranjeras (sic)", 2 de junio de 1880, p. 2; El Comercio, "Correo de anoche", 2 de junio de 1880, p. 2; El Áncora, "Partes Telegráficos", 3 de junio de 1880, p. 3.

${ }^{469}$ El Siglo Futuro, “América del Sur", 28 de junio de 1880, p.2.

${ }^{470}$ CONCHA, José Miguel, Iniciativas chilenas para una alianza estratégica con Bolivia (1879-1899), La Paz, Plural Editores, 2011, p. 66.

${ }^{471}$ El Siglo Futuro, "Repúblicas sud-americanas", 2 de junio de 1880, p. 3.

${ }^{472}$ El Siglo Futuro, “América del Sur”, 28 de junio de 1880, p.2.

${ }^{473}$ El Siglo Futuro, "La Guerra en el Pacífico", 9 de agosto de 1880, p. 2.

${ }^{474}$ El Bien Público, "Cartas Sud Americanas", 21 de agosto de 1880, p. 1.
} 
Una consecuencia política de la batalla de Tacna fue el quiebre aliado y la retirada de los bolivianos hacia la cordillera. Perú, que ingresó en la guerra apoyando a Bolivia, quedó abandonado y con el ejército chileno merodeando sus costas y planificando atacar a Arica o Lima, idea "disparatada que no merece la honra comentarse" ${ }^{475}$. Un diario catalán, por su parte, mencionó la toma de Tacna y otros detalles que anticipaban el curso de la guerra: "Los xilens s'han apoderat de Tafna després de renyida lluyta, apoderantse de vuit canons y fent molst presoners. Las tropas xilenas se dirigeixen sobre Arica" ${ }^{476}$.

La noticia de la batalla de Arica tardó una semana en llegar a España ${ }^{477}$. Los primeros informantes fueron El Globo, El Imparcial y el Diari Catalá, quienes utilizaron como fuente diarios estadounidenses. Lo central del mensaje era que los chilenos asaltaron Arica, aprisionando a la guarnición peruana y echando a pique al Manco Capac. El Diari... publicó: “Las últimas noticias rebudas aseguran que'ls peruans han soferi una derrota grave en Arica, habent caigut la ciutat en poder dels xilenos"478. Y, al día siguiente, escribió: "Telégramas del Pacifich diuhen que los xilenos han prés Arica per asalt, fent presonera á tota la guarnició. La corbeta peruana Mancocapac ha anat á pico" ${ }^{479}$.

Si se confiaba en esas publicaciones el curso de la guerra era totalmente desfavorable para el Perú. El país sufría una nueva derrota continuando su desmembración territorial. El matiz chileno, en los diarios españoles, era evidente cuando las notas periodísticas provenían de Valparaíso. En esas noticias se enfatizaban las considerables pérdidas aliadas, a la par de que "Nuestro ejército victorioso continúa su movimiento ofensivo" $" 480$.

${ }^{475}$ El Bien Público, “América del Sur”, 17 de marzo de 1880, p. 2.

${ }^{476}$ Diari Catalá, "Extracte de telegramas de la prempsa local”, 1 de junio de 1880, p. 8.

477 El Globo, "Telegramas de la Agencia Fabra", 15 de junio de 1880, p. 3; El Imparcial, "Despachos telegráficos", 11 de junio de 1880, p. 3; La Discusión, "Despachos telegráficos", 11 de junio de 1880, p. 2; El Liberal, "El telégrafo", 11 de junio de 1880, p. 3; Diario Oficial de avisos de Madrid, "Despachos telegráficos", 11 de junio de 1880, p. 3; La Iberia, "Despachos telegráficos de la Agencia Fabra", 15 de junio de 1880, p. 1; La Época, "Despachos telegráficos", 15 de junio de 1880, p. 5; La Unión, "Telegramas de la Agencia Fabra", 15 de junio de 1880, p. 1; El Siglo Futuro, "Telegramas de la Agencia Fabra", 15 de junio de 1880, p. 3; El Amigo, "Revista de los principales sucesos de la semana", 13 de junio de 1880, p. 4; El Graduador, "Despachos telegráficos", 18 de junio de 1880, p. 2.

478 Diari Catalá, "Guerra entre Xile y Perú", 14 de junio de 1880, p. 4.

${ }^{479}$ Diari Catalá, “Telégramas particulars”, 15 de junio de 1880, p. 8.

${ }^{480}$ La Época, "Despachos telegráficos", 12 de junio de 1880, p. 3; El Siglo Futuro, "Telegramas Agencia Fabra", 12 de junio de 1880, p. 3; El Imparcial, "Agencia Fabra", 13 de junio de 1880, p. 3; La Discusión, 
El atraso en la circulación de los detalles ocurridos en Arica revela su situación periférica en relación a los centros peruano y chileno donde, en cantidad, se producía información sobre la guerra. Así, después de un mes, se publicaron los pormenores de la batalla de Arica aportando datos no elaborados por las interpretaciones historiográficas nacionalistas que harían los historiadores. Después de la victoria dirigieron los chilenos sus operaciones contra la plaza de Arica -escribió un diario-, que fue tomada el 7 de junio por asalto. En previsión de la acción, escribió El Siglo, “algunas obras de la plaza estaban minadas, pero una de ellas fue asaltada por error, cuando los defensores estaban en ella y los enemigos lejos; y la posición de las demás fue revelada por un prisionero" ${ }^{\text {481. Este }}$ último hecho sería motivo de disputas en el Perú, donde la acusación popular de traición a la patria cayó sobre el ingeniero peruano Teodoro Elmore. La fatalidad la heredaría su hijo, el escritor Edwin Elmore, asesinado por el poeta José Santos Chocano, a causa de enemistades e injurias recíprocas relacionadas con los sucesos de 1880. El parte firmado por Baquedano entregó interesantes detalles bien conocidos en la historiografía chilena ${ }^{482}$ que corresponden a la visión oficial ${ }^{483}$. El diario que tomó ese documento tenía una posición marcadamente properuana, por lo que antes de adjuntar en su órgano los sucesos del Morro publicó un discurso emotivo que Nicolás de Piérola dio a su país luego de enterarse de las derrotas de Tacna y Arica.

\footnotetext{
"Despachos telegráficos", 13 de junio de 1880, p.2; El Liberal, "El Telégrafo", 13 de junio de 1880, p. 4; El Bien Público, "Telegramas particulares", 15 de junio de 1880, p. 3.

${ }^{481}$ El Siglo Futuro, "Guerra del Pacífico", 16 de junio de 1880, p. 2.

482 TOMA DE ARICA. Arica, Junio 7 de 1880. Señor Ministro de la Guerra: El día 3 del presente mes me puse en marcha para este puerto, con el objeto de destruir la última fuerza enemiga que se mantenía en pie de resistencia en estos departamentos. Después de estudiadas las posiciones del enemigo y colocar convenientemente nuestras fuerzas, envié el 5 por la mañana un parlamento al jefe de la plaza intimándole rendición en vista de la inutilidad de su resistencia. La resolución del coronel Bolognesi fue negativa, y en vista de ella rompí las hostilidades con nuestra artillería. Ayer la escuadra bombardeó la plaza por espacio de tres horas. Adoptadas las últimas disposiciones resolví atacar hoy en la madrugada las fortificaciones de esta plaza. Efectivamente, los fuegos se rompieron al aclarar, y después de poco más de una hora de reñido combate, la ciudad estaba en nuestro poder. El enemigo hizo volar con minas preparadas de antemano algunas fortificaciones. Solamente en el Morro quedaron algunos cañones útiles. El Manco Capac abrió sus válvulas y se fue a pique, entregándose su capital y tripulación prisionera a bordo del Itata. Todo el honor de la jornada corresponde a los regimientos $3^{\circ}$ y $4^{\circ}$ de línea, que se batieron con extraordinario arrojo, y el Lautaro, que no encontró gran resistencia en el punto que atacó. El ataque fue dirigido por el coronel D. Pedro Lagos. Las pérdidas del enemigo son grandes, y las nuestras ascienden a poco más de 300, no alcanzando a cien los muertos. La victoria ha sido completa y por ella felicito al país y al supremo gobierno. Manuel Baquedano. En: El Siglo Futuro, "La Guerra en el Pacífico", 19 de agosto de 1880, p. 3.

483 Otra descripción chilena del Asalto y Toma del Morro de Arica en: La Iberia, "Extranjero", 18 de febrero de 1881 , p. 3.
} 
La visión de los vencidos en esa región fue asumida por Araujo. Las opiniones del menorquín son abiertamente "chilenofóbicas", defendiendo la guerra como relación entre estados, al tiempo de criminalizar las acciones militares chilenas. La valoración desigual de los bandos facilita la comparación constante y simplista entre los "buenos" aliados y los "malos" chilenos. Para crear la última idea se vale de comentarios circulantes en Perú y Bolivia alusivos a los asesinatos y abusos hacia la población europea. Además, decía el historiador, los más débiles de Arica -mujeres, ancianos y niños-, no se habían librado de los ataques de los militares chilenos.

En opinión enviada a España, publicada el 21 de agosto de 1880, Araujo mutó desde el periodista riguroso al prestidigitador orgulloso. Comenzaba su escrito alabándose del siguiente tenor: "Mis profecías se han cumplido en todas sus partes" 484 . La magia de su pensamiento le permitió visibilizar que desde Tacna las tropas chilenas se dirigirían hacia Arica. Aunque los aliados "se sostuvieron bizarramente" 485 haciendo volar minas cargadas de antemano en el campo enemigo, el autor no mencionaba la condición poco noble de esa arma, pero, por el contrario, remarcaba la resistencia peruana. Seducido por sus predicciones terminaba su nota con la humildad del sabio: "preveo un rápido desenlace, a causa del estado de abatimiento en que se hallan los aliados, y más aún los peruanos" ${ }^{486}$.

En un artículo posterior, Araujo saturó la primera página del diario con sus imprecaciones antichilenas protegidas por su noción de verdad. Leemos, "A medida que el tiempo transcurre van poniéndose en transparencia los asuntos del Pacífico y surge la verdad de los últimos acontecimientos" ${ }^{\prime 48}$. Si bien no hay pruebas de su presencia en el escenario bélico, de sus afirmaciones bien podría deducirse lo contrario. Tacna y Arica se encuentran llenas de escombros y desoladas, apuntó, complementando para el caso de la segunda ciudad: "al cruzar por frente a ella, acude a la imaginación del viajero el recuerdo de los crímenes cometidos por los chilenos en esta guerra brutal, salvaje, exterminadora" ${ }^{\$ 88}$.

\footnotetext{
${ }^{484}$ El Bien Público, "Cartas Sud-Americanas”, 21 de agosto de 1880, p. 1.

485 Idem.

${ }^{486}$ Idem.

${ }^{487}$ El Bien Público, “Cartas Sud Americanas”, 14 de octubre de 1880, p. 1.

${ }^{488}$ Idem.
} 
La clasificación binaria de los combatientes ensayada por Araujo estuvo definida por el humanitarismo demostrado con posterioridad de las batallas. De tal modo, mientras que los peruanos y bolivianos se mostraron "nobles con los vencidos, clementes con los prisioneros" ${ }^{489}$, los chilenos despiadados. Después del combate de Tacna, por ejemplo, "pasaron a cuchillo toda la guarnición de esta plaza [...] También en Arica pasaron a cuchillo los chilenos a toda clase de extranjeros de toda nacionalidad"490. Un número considerable de muertos, según el historiador, fueron españoles e italianos. La hecatombe, en palabras de Araujo, se puede sintetizar así:

Los chilenos arrasaron Arica después de incendiar el pueblo y haber entrado a saco y degüello. De dos mil aliados que defendían esta plaza solo habrán escapado con vida unos doscientos. El ejército chileno compuesto en su inmensa mayoría de "rotos" (descamisados) ha cometido en Tacna y Arica toda clase de fechorías, no respetando ni el honor de las más tiernas niñas de la sociedad peruana ${ }^{491}$.

Para Chile, la importancia de conquistar Arica en el transcurso de la guerra fue indudable por tres razones. En primer lugar, con el dominio chileno, Bolivia y Perú podían dar por perdidos extensos territorios, lo cual enclaustraba en el altiplano a Bolivia y arrebataba las riquezas salitreras al Perú. La retención de Arica permitía a Chile constituir un área de límite y protección fronteriza para sus nuevas adquisiciones. Es por eso que los sucesos de junio fueron tergiversados, sobre todo, por informantes peruanos.

De lo anterior estuvo al tanto la prensa española que puso en duda las informaciones procedentes de Lima u otras ciudades donde había agentes peruanos que comunicaban los sucesos. Un buen ejemplo fue la información que hizo circular el Cónsul General del Perú en Panamá. Un diario español, basándose en esa fuente, publicó que después de tres horas de "encarnizado combate, los chilenos consiguieron ocupar Tacna, quedando 8.000 hombres fuera de combate por ambas partes. Añade que los ejércitos aliados peruanos y bolivianos acudieron en seguida en auxilio de Tacna"492. La incorrección de los datos fabricaba la patraña histórica de la toma de Tacna. El Cónsul remataba su engaño sosteniendo que cuando llegaron -refiriéndose a los aliados- "la ciudad estaba ya en poder

\footnotetext{
489 Idem.

${ }^{490}$ Idem.

${ }^{491}$ Idem.

${ }^{492}$ El Siglo Futuro, "Guerra del Pacífico", 16 de junio de 1880, p. 3.
} 
enemigo. En vista de esto, resolvieron poner sitio a la plaza, consiguiendo cercar por completo a los chilenos ${ }^{493}$.

Tal manipulación de los hechos fue criticada por La Ilustración Española y Americana. Sabiendo que los pormenores transmitidos por telégrafo eran escasos y contradictorios, debido a la interrupción telegráfica entre Santiago y Buenos Aires, desmintió las declaraciones del cónsul peruano. Éste, entre otras cosas, afirmó que la población tacneña cayó en poder de Chile después de tres días de "encarnizada lucha, quedando ocho mil hombres de entrambas partes fuera de combate, muerto el coronel boliviano Camacho, y mil chilenos en poder del general Montero, habiendo sido destrozado por Leiva Montero el ejército de los últimos" ${ }^{494}$. La Ilustración... afirmó que "lo postrero no es cierto", porque de serlo no explicaba el movimiento del ejército chileno hacia Arica, el segundo puerto más importante del Perú ${ }^{495}$.

En segundo lugar, Arica tenía para Chile gran importancia geopolítica, porque podría utilizarse como moneda de cambio en tratados limítrofes con Bolivia. El puerto de Arica hasta el 7 de junio fue "emporio del comercio del sur del Perú, y salida natural de Bolivia" ${ }^{496}$. Es sensato establecer que en esa época no era explícita la política chilena de negar a Bolivia una salida al mar. Su mediterraneidad no formó parte del discurso gobernante chileno, más bien existió la voluntad contraria, es decir, entregar algún puerto en los territorios ganados al Perú. Por lo menos, esa posición aparece en un diario español que utilizó fuentes chilenas declarando ser opinión general en Chile que después de “asegurar el gobierno [...] la posesión de los distritos mineros pertenecientes a Bolivia [...] procurará concluir la paz [...] mediante la cesión de los distritos peruanos comprendidos entre Arica y Arequipa" ${ }^{497}$. En tercer lugar, la batalla de Arica fue trascendental en el desarrollo de la historia común entre Chile y Perú. Inmediatamente después de aquella se discutieron alternativas para finalizar la guerra. De haber entablado las bases para la paz, desde un plano político realista, no se hubiese producido el desgaste económico y moral en los años en que ambos países continuaron las hostilidades.

\footnotetext{
${ }^{493}$ Idem.

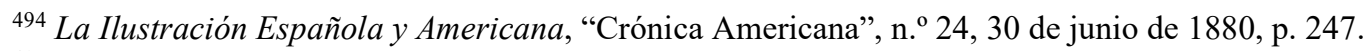

495 Idem.

496 Idem.

${ }^{497}$ El Siglo Futuro, "Guerra del Pacífico", 16 de junio de 1880, p. 3.
} 
La prensa chilena formó una opinión pública dispuesta a continuar la guerra. Diarios populares como El Independiente y La Patria publicaron eventuales tratados de paz que aniquilaban aún más la posición aliada ${ }^{498}$. La prensa hispana vio en ellos "deformidad" y "presuntuosa locura" ${ }^{499}$. Esa prensa instaló un escenario de incertidumbre donde se alejaba la paz. Lo que si se sabía, como en la mayoría de las guerras, era que Chile, en su calidad de vencedor, tendría la autoridad para imponer los puntos fundamentales del arreglo. Sin embargo, lo que hacía poco probable el fin de la guerra era la posición que habían asumido los aliados después de las derrotas de Tacna y Arica.

Ambos países declararon que rechazarían la paz prolongando la guerra "cueste lo que cueste" 500 . Esa actitud produjo decenas de nuevas batallas por toda la geografía peruana que aún no había caído bajo dominio chileno, con la finalidad de que los aliados pidiesen la paz. Según la prensa, Chile no cedería sus conquistas desde Arica hacia el sur. Tal situación hizo pensar en las siguientes cuestiones: ¿Puede Bolivia suscribir a la pérdida completa de su litoral, con los abundantes recursos que le proporcionaba? ¿Firmará jamás el Perú una paz en condiciones tan onerosas como la renuncia de sus grandes depósitos de guano y nitrato $?^{501}$.

\footnotetext{
${ }^{498}$ El Siglo Futuro, “América del Sur", 28 de junio de 1880, p. 2.

${ }^{499}$ El proyectado tratado de paz decía: “Artículo $1^{\circ}$ El Perú y Bolivia reconocen la soberanía de Chile sobre el territorio conquistado por sus armas y que actualmente ocupan, desde el deslinde Norte de la provincia de Moquegua. Chile se compromete a ceder a Bolivia, en virtud de un pacto especial, el territorio que antes formaban las provincias de Moquegua, Tacna y Arica, bajo las condiciones que entre Chile y Bolivia se estipularen. Artículo $2^{\circ}$ El Perú entregará a Chile los dos monitores Manco Capac y Atahualpa, toda la artillería del Callao y arrasará las fortificaciones del Callao. Artículo $3^{\circ}$ El Perú pagará a Chile todos los gastos de guerra, según las cuentas que pase la contaduría mayor, etc. Pagará, además, la cantidad de 2.500.000 pesos como exacción de guerra, para ser repartidos a prorrata de sus sueldos entre los militares de mar y tierra que componen el ejército de Chile. Artículo $4^{\circ}$ No habiendo impuesto contribuciones de guerra el Ejército de Chile a los pueblos o municipios a medida que los ocupaba, ni exigidoles (sic) de ningún súbdito particular del Perú ni de Bolivia, estos países devolverán a sus dueños las naves con su cargamento de propiedad particular que hubieren apresado, o en su lugar el valor correspondiente a juicio de árbitros; devolverán también a sus dueños las propiedades particulares de chilenos que hubieran secuestrado, abonándolos los perjuicios sufridos. En caso de discordia, toda cuestión de reclamo será resuelta por jueces árbitros, que deberán fallar en el plazo perentorio de un mes. Artículo $5^{\circ}$ Chile se compromete a pagar la mitad de la deuda exterior del Perú que haya estado en manos de extranjeros antes de la declaración de guerra, al tipo que en esa época tenía en la Bolsa de Londres. Artículo $6^{\circ}$ Hasta el cumplimiento de los artículos $2^{\circ}, 3^{\circ}$ y $4^{\circ}$ de este tratado, Chile mantendrá en la plaza del Callao una guarnición de 6.000 hombres y una parte de su escuadra, cuyas fuerzas serán estipendiadas por el Perú”. En: El Siglo Futuro, “América del Sur”, 28 de junio de 1880, p. 2.

${ }^{500}$ La Ilustración Española y Americana, "Crónica Americana", n. ${ }^{\circ} 24,30$ de junio de 1880, p. 430; La América, "La Paz en el Pacífico", 28 de julio de 1880, p. 12.

${ }^{501}$ La Ilustración Española y Americana, "Crónica Americana", 30 de junio de 1880, p. 430.
} 
Un segmento de la prensa española creyó que el advenimiento de la paz, bajo los términos chilenos, era inminente. Se redactó cómo en los países en guerra habían circulado opiniones referidas a la paz deshonrosa para el Perú postulada por Chile. Se proponía el ingreso en esa discusión, mediante los buenos oficios, de países americanos y europeos, alimentando la confusión en torno a la conclusión de la guerra. Sin embargo, nada de lo anterior tenía una fuente fidedigna. Algunos diarios propusieron que, debido al agotamiento de las fuerzas militares de los países beligerantes, había llegado el momento de finalizar la guerra. Todos, de algún modo, erraron sus pronósticos. Sin duda, la noticia de que un nuevo proyecto de confederación se estaba pactando entre Perú y Bolivia, inyectó mayor entusiasmo en el espíritu guerrero chileno que puso en su horizonte la conquista de Lima.

El 16 de junio, publicó La Unión, Piérola puso en conocimiento del Consejo de Estado los protocolos de las negociaciones para realizar la Confederación PeruanoBoliviana $^{502}$; otros diarios informaron que días antes se había firmado esa unión ${ }^{503}$. Este fue uno de los argumentos chilenos para proyectar su campaña hacia Lima que, no obstante las victorias militares chilenas en Tarapacá, Tacna y Arica, continuó considerándose como una "fantasía militar" 504 , sin sustento técnico e inejecutable si "un resto de sentido común quedara en los militares chilenos" 505 . Por su parte, otras publicaciones insertaban noticias limeñas favorables a la guerra. Los chilenos, catalogados de modo peyorativo en el Perú como "rotos", ignoraban, dijo el diario aludido, que ese país estaba anímicamente fortalecido mientras Chile continuaba ebrio con "sus baratos triunfos" 506.

Las crónicas de Araujo relacionadas con las consecuencias de la Batalla de Arica nuevamente tuvieron espacio en la prensa española. Desde la fecha del combate hasta la de la firma de la crónica transcurrieron más de cuarenta días. A su vez, la publicación del texto en El Bien Público se demoraría un mes. Es interesante la relación de tiempos entre los acontecimientos y su publicación, porque permite reflexionar en torno a las dificultades de la prensa para obtener relatos densos y no sólo telegramas que privilegiaban, como se sabe, la rapidez y síntesis de los mensajes.

\footnotetext{
${ }^{502}$ La Unión, "Noticias de América", 6 de septiembre de 1880, p. 2.

${ }^{503}$ El Siglo Futuro, “América”, 2 de octubre de 1880, p. 3.

504 Idem.

505 Idem.

506 Idem
} 
Si bien el Araujo intelectual no ha sido exhaustivamente investigado ${ }^{507}$, su pensamiento histórico permite interrogarse sobre su oposición al militarismo chileno. Interesa remarcar esa cuestión, pues en él detectamos incoherencias frente a la guerra. Como se ha propuesto ${ }^{508}$, la "heroicidad" con que catalogó el militarismo de la alianza entre Uruguay, Brasil y Argentina contra Paraguay durante la guerra de la Triple Alianza (1864-1870) se enmarca dentro de la historiografía "patria" uruguaya. Se debe reconocer que el matiz existente entre las estrategias militares de la Triple Alianza y las de Chile es difícil establecer siendo, por ahora, más importante comprender los fundamentos de su favoritismo peruano-boliviano. Ese sentir se relaciona, desde un punto de vista general, con la violación de las normativas vigentes a fines del siglo XIX sobre las prácticas de la guerra, es decir, la creencia en la existencia de guerras civilizadas y otras bárbaras. Esa normativa se nutría no sólo de la costumbre, sino también de la Convención de Ginebra $(1864)^{509}$, la Convención de San Petersburgo $(1868)^{510}$, la Declaración de Bruselas $(1874)^{511}$ y el Manual de Leyes y Costumbres de Guerra de Oxford $(1880)^{512}$.

\footnotetext{
507 Algunas publicaciones referidas a Araujo en: JULIÀ I SEgUí, Gabriel, Un menorquín para Uruguay: Orestes Araujo, Sicoa, Ciutadella de Menorca, 1993; Colom CaÑellas, Antoni J., Alzina Seguí, Pere, "La historia de 1'educació a Menorca. Análisi bibliográfica", Educació y Cultura. Revista Mallorquina de Pedagogía, n. ${ }^{\circ}$ 18, 2005, pp. 7-22; S.U.H.E., "Breve reseña de la creación de la SUHE (Sociedad Uruguaya de Historia de la Educación)", Historia de la Educación. Anuario, vol. 11, 2010, < http://www.scielo.org.ar/scielo.php?script=sci_arttext\&pid=S2313-92772010000100022> [consultado el: 25/12/2015]; BONSIGNORE CARO, Federico, Attlántida. Historia, imágenes y personalidades, a cien años de su creación, Montevideo, Trilce, 2011, p. 24; SANSÓN CORBO, Tomás David, "La contribución de intelectuales extranjeros en la configuración de la historiografía uruguaya", Revista Expedições. Teoría de História \& Historiografia, vol. 5, n. ${ }^{\circ}$ 1, 2014, p. 59; PIERROTTI, Nelson, "La educación colonial en Montevideo y la banda oriental ¿Quién enseñaba, cómo y para qué? (1726-1814)", Estudios Históricos, n. ${ }^{\circ} 14,2015$, < http://www.estudioshistoricos.org/14/eh1403.pdf> [consultado el: 25/12/2015]; PESCE, Fernando, Sentidos políticos, finalidades formativas y enfoques disciplinares en la Geografia como materia escolar en la Enseñanza Secundaria uruguaya. (1935-1963), Tesis doctoral, pp. 77-84, < http://repositorio.flacsoandes.edu.ec/bitstream/10469/6660/2/TFLACSO-2014LFPG.pdf> [consultado el: 25/12/2015].

508 REALI, María Laura, "El conflicto regional visto desde Uruguay y la construcción de un relato revisionista". En CRESPO, Horacio, PALACIO, Juan Manuel y PALACIOS, Guillermo (Coordinadores), La guerra del Paraguay. Historiografias. Representaciones. Contextos, México, El Colegio de México, 2013, edición electrónica sin número de página.

${ }^{509}$ ABRISKETA, Joana, "El derecho a la asistencia humanitaria: fundamentación y límites", Los desafios de la acción humanitaria: Un balance. En: ROBERTS, Adam, ABRISKETA, Joana, ETXEBERRíA, Xavier, ReY, Francisco, Sogge, David, Raisin, Joanne, Ramsbotham, Alexander, AguirRe, Mariano, MÉdicos siN FRONTERAS, Barcelona, Icaria Editorial S. A., 1999, pp. 77-78.

510 GARCía-SAYÁn, Diego, Vidas paralelas. Región andina, desafios y respuestas, Bogotá, Tercer Mundo Editores, 1999, p. 72.

511 RoBLEs MUÑOZ, Cristóbal, 1898: Diplomacia y opinión, Madrid, Consejo Superior de Investigaciones Científicas, 1991, p. 170.
} 
Desde lo particular, las muertes en la colonia española de Arica a comienzos de junio podrían ser los motivos del antichilenismo expresado. El "antichilenismo" del incombustible Araujo señaló, a mediados de 1880, que después de las batallas de Tacna y Arica ningún hecho notable "en los anales de la Guerra del Pacífico" 513 había tenido lugar. Por esa razón, la brevedad de su carta se remitía a describir, sin mayores valoraciones, el proyecto de creación de los Estados Unidos Peruano-Bolivianos. El 16 de junio de 1880, Piérola puso en conocimiento del Consejo de Estado peruano los protocolos para acometes la unificación administrativa. La presidencia del nuevo estado recaería en el presidente peruano y la vicepresidencia en el boliviano. Supuestamente, la asamblea constituyente se reuniría en Arequipa el 9 de diciembre de 1881.

\section{Imagen $n .^{\circ} 11$}

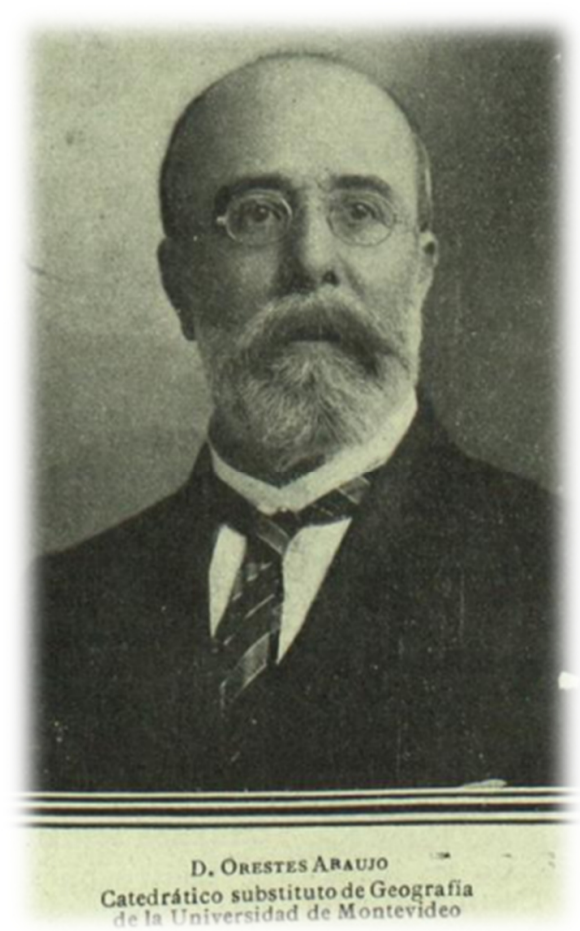

Fuente: Mercurio, “D. Orestes Araujo", 6 de febrero de 1913, n. ${ }^{\circ}$ 169, p. 61.

\footnotetext{
512 ETCHEBERRY, Alfredo, Conceptos generales y bosquejo histórico del Derecho Penal Internacional, 2006, p. $\quad 3, \quad<$ https://webcache.googleusercontent.com/search?q=cache:mlCu WtBBLgJ:https://www.ucursos.cl/derecho/2012/1/D125C0729/6/material_docente/bajar\%3Fid_material\%3D419022+\&cd=1\&hl=es\& $\mathrm{ct}=\mathrm{clnk} \& \mathrm{gl}=\mathrm{es}>$ [consultado el: $25 / 12 / 2015$ ].

${ }^{513}$ El Bien Público, "Cartas Sud Americanas", 9 de septiembre de 1880, p. 1.
} 
Toda la correspondencia escrita por Araujo en Montevideo -ciudad donde ocupó diversos cargos en el gobierno uruguayo- y enviada a la prensa española, puede entenderse en palabras de Guha ${ }^{514}$, como fragmentos de un "discurso primario". Éste posee un carácter oficial y suele ser producido por "burócratas, soldados, agentes y otros, directamente empleados por el gobierno" 515 , pero también por "aquellos que no pertenecían al sector oficial pero estaban simbióticamente relacionados con el [...]"516, como actuó Araujo con sus mimos constantes hacia la actuación peruana y boliviana en la guerra. Desconocemos algún tipo de vínculo directo con esos países, así como la existencia en su biografía de momentos traumáticos con Chile o alguno de sus ciudadanos.

Siguiendo con Guha, no podrían clasificarse los escritos de Araujo dentro de los "discursos secundarios" ni "terciarios", porque sus ideas son más bien "historiografía en estado bruto" $" 517$ características de los primarios. Los rasgos principales de los discursos secundarios se relacionan con la intención transformadora de ciertos acontecimientos en historia; y, en el caso de los discursos terciarios, la diferencia de años transcurrida entre acontecimientos y escritura de la historia, fundamentalmente, en tercera persona ${ }^{518}$.

\subsection{Las Conferencias de Arica}

Durante la Campaña chilena de Tacna y Arica la prensa, en general, retrató un Chile ambicioso e invasor, cuando no bárbaro, construyéndose una imagen exterior permanente en el tiempo. Por tal razón es interesante notar, aunque sea una entelequia, cómo la firma de la paz, en esta época, habría lavado la apreciación internacional de Chile. Como se sabe, bajo los buenos oficios de los Estados Unidos, en octubre de 1880, se negoció finalizar la guerra en Arica. Con anterioridad, el puerto peruano de Islay se había barajado como lugar de reunión de los países enfrentados ${ }^{519}$. Las historiografías de Chile y Perú han llamado a esas reuniones diplomáticas "Conferencias de Arica", efectuadas a bordo del buque de guerra estadounidense Lackawanna.

\footnotetext{
${ }^{514}$ GUHA, Ranahit, Las voces de la historia y otros estudios subalternos, Barcelona, Crítica, 2002.

515 Íbidem, p. 46.

516 Idem.

517 Íbidem, p. 50.

518 Íbidem, p. 75.

${ }^{519}$ El Bien Público, “América del Sur”, 29 de noviembre de 1880, p. 2.
} 
En España la prensa informó sobre las "negociaciones de paz en Arica, entre Chile y el Perú, con la intervención de los Estados Unidos"520. Algunos diarios celebraron la noticia, mientras otros la reprodujeron sin realizar juicios hacia la paz o la guerra. De todos modos, con anterioridad y de una manera excepcional se publicó una resolución del Gabinete chileno que "parecía" terminar la guerra con la derrota peruana en Arica ${ }^{521}$. Ese acontecimiento, con la victoria chilena, selló la campaña militar y, pese a las intenciones de algunos políticos y de la parte más belicosa del pueblo, la paz se sintió cercana. En los hechos, la idea de que Chile necesitaba la paz más que el Perú se hizo fuerte. Las noticias provenientes de aquel país compartidas con la llegada del vapor Amazonas explicaban: "No quiere decir que carezca Chile de recursos para prolongar la guerra indefinidamente, pero sí que con esto se arruinaría y que de ello está convencido. El Perú está arruinado y no podría estarlo más por mucho que durara la guerra" ${ }^{922}$.

El 3 de octubre de 1880, desde El Callao salieron rumbo a Arica el transporte de guerra peruano Chalaco -comprado en 1864 a la Pacific Steam Navigation Company el cual "disponía de dos cañones de cuarenta libras cada uno"523 - y el Lackawanna. La comisión diplomática del Perú estuvo conformaba por Antonio Arenas, Aurelio García y García y los ayudantes Barcárcel, Garland y Navarro. Del lado boliviano los señores Terrazas, Flores y Jaime. En el caso chileno, confesaba la prensa con incertidumbre, los señores Santamaría, Huneus e Irarrázaval ${ }^{524}$. Las comisiones de trabajo fueron presididas por los ministros estadounidenses en Chile y el Perú, Mr. Thomas Osborne y Mr. Isaac Christiancy, respectivamente 525 .

\footnotetext{
${ }^{520}$ El Siglo Futuro, "Telegramas", 12 de octubre de 1880, p. 3; El Imparcial, "Agencia Fabra", 12 de octubre de 1880, p. 2; El Liberal, "El Telégrafo", 12 de octubre de 1880, p. 3; La Iberia, "Despachos telegráficos de la Agencia Fabra", 12 de octubre de 1880, p. 2; La Época, "Despachos telegráficos", 12 de octubre de 1880, p. 3; La Época, "Prensa extranjera", 14 de octubre de 1880, p. 3; La Unión, "Correo extranjero", 15 de octubre de 1880, p. 1.

${ }^{521}$ El Áncora, "Sección Extranjera", 5 de julio de 1880, p. 3.

${ }^{522}$ El Bien Público, "América del Sur", 29 de noviembre de 1880, p. 2.

${ }^{523}$ CAMPo Rodríguez, Juan del, Batallas legendarias del Perú y del mundo: episodios y anécdotas, Lima, Fondo Editorial Fundación Academia Diplomática del Perú, 2002, p. 161.

${ }^{524}$ Una alineación diferente de los cuerpos diplomáticos de Chile y Bolivia consignó a los siguientes representantes: Eulogio Altamirano, Eusebio Lillo y José Francisco Vergara (Chile); Mariano Baptista (Bolivia). En: El Comercio, "Cómo se gobiernan las repúblicas", 30 de diciembre de 1880, p. 1.

${ }^{525}$ La Iberia, "América del Sur", 21 de noviembre de 1880, p. 2; El Bien Público, "América del Sur”, 29 de noviembre de 1880 , p. 2.
} 
El Siglo Futuro mantuvo su matiz bolivianófobo durante la época de elaboración de la paz en Arica. Bolivia, en su profunda corrupción, bajeza y humillación secular -publicóse prestaría a todo, “como podría ser, justificándose así lo que hemos asentado más de una vez, a saber: que la alianza del Perú con la república de los Melgarejos, Dazas y otros

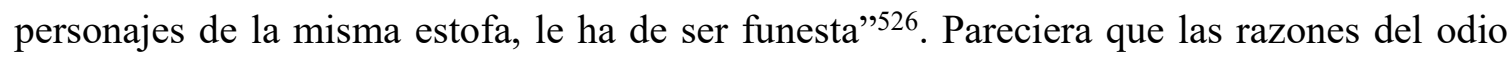
manifestado en El Siglo... hacia Bolivia se sitúan en la responsabilidad que le atribuía en el estallido de la guerra. Para el diario dirigido por Cándido Nocedal, Bolivia había arrastrado al Perú a "una guerra estúpida dentro de los intereses de la política elevada, que bien pudo plantearse en beneficio del Perú y de Chile, y de la civilización en general de la parte Sur de América" 527.

Las condiciones exigidas por Chile a Perú y Bolivia para firmar la paz fueron las siguientes:

1. $\quad$ Cesión a Chile de los territorios del Perú y Bolivia que se extienden al sur de la quebrada de Camarones y al oeste de la línea que en la cordillera de los Andes separa al Perú y Bolivia hasta la quebrada de la Chacarilla, y al oeste también de una línea que desde este punto se prolongaría hasta tocar con la frontera argentina, pasando por el centro del lago de Ascotan.

2. $\quad$ Pago a Chile por el Perú y Bolivia solidariamente de la suma de 20 millones de pesos, de los cuales cuatro millones serán entregados al contado.

3. ${ }^{\circ} \quad$ Devolución de las propiedades de que han sido despojados las empresas y ciudadanos chilenos en el Perú y Bolivia.

4. ${ }^{\circ} \quad$ Devolución del transporte Rímac.

5. ${ }^{\circ} \quad$ Abrogación del tratado secreto celebrado entre el Perú y Bolivia el año 1873, dejando al mismo tiempo sin efecto ni valor alguno las gestiones practicadas para procurar una confederación entre ambas naciones.

6. ${ }^{\circ} \quad$ Retención por parte de Chile de los territorios de Moquegua, Tacna y Arica que ocupan las armas chilenas hasta tanto se haya dado cumplimiento a las obligaciones a que se refieren las condiciones anteriores.

7. $\quad$ Obligación por parte del Perú de no artillar el puerto de Arica cuando le sea entregado, ni en ningún tiempo, y compromiso de que en lo sucesivo será puerto exclusivamente comercial ${ }^{528}$.

\footnotetext{
${ }^{526}$ El Siglo Futuro, "América del Sur”, 28 de junio de 1880, p. 2.

527 Idem.

${ }^{528}$ La Época, [s. t.], 27 de diciembre de 1880, p. 1; La Iberia, "América del Sur", 27 de diciembre de 1880, p. 2; La Discusión, "Chile", 28 de diciembre de 1880, p. 2; El Liberal, "Extranjero", 10 de enero de 1881, p. 1 .
} 
Las Conferencias de Arica fueron un fracaso para la paz, pero una victoria para Chile. Sumaba así otro argumento para sus avances militares. En rigor, la única forma de que la paz no estuviese organizada con la influencia de otras potencias, léase EE.UU., era llegar a Lima y negociar. Así ocurriría en Ancón, próximo a Lima, en 1883. Para convencerse de la posición chilena contraria a la paz -escribía un diario- bastaba "leer las dos primeras líneas de la minuta en que constaban las bases chilenas puestas al debate" ${ }^{529}$. Chile decía a los aliados en ese documento, continuaba ese diario irónicamente, con franqueza verdaderamente republicana que "exigía la aprobación de aquellas condiciones para llegar al resultado de obtener la paz; y en seguida, en la condición primera, consagraba el derecho de conquista pretendiendo anexionarse el terreno ocupado por la fuerza de las armas" $" 530$.

El Siglo... escribió días antes del revés de las conferencias haciendo gala, otra vez, de su "bolivianofobia". Además de mencionar los problemas de la organización militar reclutadora de soldados, remarcó el hecho de que ya no figuraba "para nada el nombre de Bolivia en la contienda del Perú con Chile [...] todo hace creer en el fracaso de las ilusiones del dictador del Perú". Como hemos visto, el defensor obcecado de la dictadura católica, defendió a Piérola quien "por su desventura y la del país que rige, no comprendió antes ni ha comprendido luego que la alianza con Bolivia le era funesta, que esa república debe desaparecer de cualquier modo" ${ }^{\prime 531}$.

El fracaso de las Conferencias de Arica tuvo otras repercusiones en la prensa española. La influencia ideológica y económica estadounidense en América Latina venía intentándose, a lo menos desde el plano retórico, desde los años de la Doctrina Monroe, varias veces recordada por la prensa, pues era más bien "una declaración de esperanzas futuras que un plan de actuación inmediato" ${ }^{532}$. Por su parte, el hispanismo inflexible de la prensa, así como el sentimiento de vínculos culturales compartidos con América, hacían desconfiar del interés mostrado por Washington en Tacna y Arica.

\footnotetext{
${ }^{529}$ El Comercio, "Cómo se gobiernan las repúblicas”, 30 de diciembre de 1880, p. 1.

${ }^{530}$ Idem.

${ }^{531}$ El Siglo Futuro, "El Perú", 9 de noviembre de 1880, p. 3.

532 SÁNCHEZ GÓMEZ, Julio, Hermana mayor o enemiga. Latinoamérica frente a Estados Unidos en el cambio de siglo (1898-1906). En EstebAn DE VeGA, Mariano, Luis MARTín, Francisco de, Morales Moya, Antonio, Jirones de Hispanidad: España, Cuba, Puerto Rico y Filipinas en la perspectiva de dos cambios de siglo, Salamanca, Universidad de Salamanca, 2004, p. 174.
} 
De todas formas, en algún momento, al diario mallorquín le pareció razonable aceptar la propuesta aliada del arbitraje estadounidense rechazada por Chile "pensando republicanamente que el árbitro de las bayonetas era más razonable, sobre todo cuando éstas eran vencedoras" ${ } 533$. Ese diario previó con temor la extensión del militarismo chileno el cual debía detenerse por estrategias "menos amistosas" y “eficaces” de los EE.UU.

Lo que continuaba en el reportaje cristalizaba un eurocentrismo duro que infravaloraba la política americana. Expresiones como "Continuará la guerra con todos sus horrores, se destrozarán mutuamente aquellas repúblicas hermanas, donde hay menos libertad que en las monarquías europeas"; "la miseria que no tardará en enseñorearse por completo de aquellas feraces comarcas"; "Todo esto sucede en aquellas repúblicas, a pesar de que la unidad de raza, de costumbre y de religión forma un lazo imposible de desatar, pues de otra suerte la guerra sería el estado normal de esa región", son retazos de una apreciación más política-emocional que sociológico-racional ${ }^{534}$. Ese eurocentrismo también fue detectado hacia otros países influenciados por España ${ }^{535}$.

El fracaso de las conferencias detonó en este autor anónimo especulaciones importantes sobre la civilización y la barbarie, tópico manido dentro del cuadro de la modernidad decimonónica. Pueblos como Chile, Perú y Bolivia, que apelaron a la guerra para solucionar disputas territoriales y desacuerdos legales, por ser ese el medio más humanitario, son pueblos que "no han llegado al grado de civilización que se necesita para poder blasonar de cultura en 1880, mientas los pueblos más belicosos y más potentes dan diarias muestras de moderación"536. Análisis posteriores de la sociedad hispana demostrarían con argumentos serios su situación de atraso en el panorama europeo. Sólo Madrid y Barcelona mostrarían aspectos eminentemente modernos, siendo en palabras de Ortega y Gasset "auténticas «islas de modernidad»"

\footnotetext{
${ }^{533}$ El Comercio, "Cómo se gobiernan las repúblicas”, 30 de diciembre de 1880, p. 1.

534 Todas las cursivas del párrafo son nuestras.

535 InAREJOS MuÑOZ, Juan Antonio, "La prensa decimonónica en Filipinas: de la censura a soporte revolucionario". En BÜRKI, Yvette y PARTZSCH, Henriette (Coords.), Redes de comunicación: Estudios sobre la prensa en el mundo hispanohablante, Berlín, Frank \& Timme GmbH Verlag für wissenschaftlich Literatur, 2016, p. 207.

${ }_{536}$ El Comercio, "Cómo se gobiernan las repúblicas", 30 de diciembre de 1880, p. 1.

${ }^{537}$ FUSI, Juan Pablo, Historia mínima de España, Madrid, Turner Publicaciones S. L., 2012, p. 198.
} 
El Comercio no explicó la historia diplomática compartida por las repúblicas analizadas. Poseído por un europeísmo desatinado, comparó las repúblicas feraces con "dos naciones tan fuertes como España y Francia"538, para demostrar cómo solucionaron el conflicto de Andorra. El diario aludió a la consagración de los derechos y privilegios particulares de ese país efectuada por el general Prim ${ }^{539}$. Sobre el trabajo conjunto de esos países, la experiencia de la revolución de Andorra de 1881, le daría la razón ${ }^{540}$.

Los pueblos civilizados, continuaba, sólo debían concebir la guerra necesaria, definida por la dificultad de eludirla con honorabilidad, es decir, después de hacer "todos los esfuerzos que la dignidad consciente". El apologista de la guerra "racional" condenó la evasión chilena de los buenos oficios estadounidenses asegurando: "En honor a la verdad, digamos [...] que Bolivia y el Perú se han mostrado más propicios a la paz que Chile [...] Pero [...] sobre lo que no cabe duda es respecto a la enseñanza que de esta guerra resultará para los vencidos"541. La moraleja ofrecida por el redactor demostró "que no es en las instituciones republicanas donde están vinculadas la cultura y la felicidad de los pueblos ${ }^{542}$.

En ese contexto, el desorden de la vida pública de las repúblicas sudamericanas, la demagogia política y otros excesos de sus dictaduras no les permitiría nunca rivalizar con los Estados Unidos. La publicación, en parte, no erraba. Agregaba que la doctrina Monroe "no es un arma americana y a favor de todo aquel continente, sino pura y exclusivamente al servicio de la gran potencia del norte"543. Más enfático sobre la supuesta ayuda desinteresada estadounidense fue El Siglo Futuro. Reacio a la influencia de esa potencia en América, no le extrañó el fracaso de los propósitos conciliadores de la diplomacia de Washington. La caída de las Conferencias de Arica obedecía, en su interpretación, a que Estados Unidos tenía con los países negociadores de la paz intereses de especulación ${ }^{544}$.

\footnotetext{
${ }^{538}$ El Comercio, "Cómo se gobiernan las repúblicas", 30 de diciembre de 1880, p. 2.

${ }^{539}$ MARín GonZÁlez, Gelu, Atlas de Europa. La Europa de las lenguas, la Europa de las naciones, Madrid, Ediciones Istmo S. A., 2000, p. 64.

${ }^{540}$ GiRAl QuintanA, Eugenio, La radiodifusión en Andorra. Política, economía y espacio comunicacional en un pais dependiente, Barcelona, Universitat de Barcelona, 1988, p. 30, < http://www.tesisenred.net/bitstream/handle/10803/22682/01.EGQ_1de10.pdf?sequence=1> [consultado el: $25 / 12 / 2015]$.

${ }^{541}$ El Comercio, "Cómo se gobiernan las repúblicas”, 30 de diciembre de 1880, p. 2.

542 Idem.

${ }^{543}$ La Ilustración Española y Americana, "Sucesos de América", n. 27, 8 de mayo de 1880, p. 293.

${ }^{544}$ El Siglo Futuro, "Repúblicas del Pacífico", 26 de octubre de 1880, p. 3.
} 
De todos modos, ese diario no veía formas para disminuir la injerencia estadounidense y posicionar la española dentro del ámbito político sudamericano. Así fue como criticó la acción de Emilio Castelar y Cristino Martos (imagen **), quienes pretendían restablecer la fraternidad perdida con las antiguas colonias de la metrópoli. El problema, como satirizó el diario, era que "nuestra flamante diplomacia en el Perú ni aún conocida es más que en el presupuesto general de gastos, puesto que ni para favorecer a las personas e intereses españoles en Pisagua, Arica, Mejillones y otros puntos de la costa ha servido, cuando menos para interponer su influjo pacificador" ${ }^{545}$.

\section{Imágenes n. ${ }^{\circ} 12,13$ y 14}
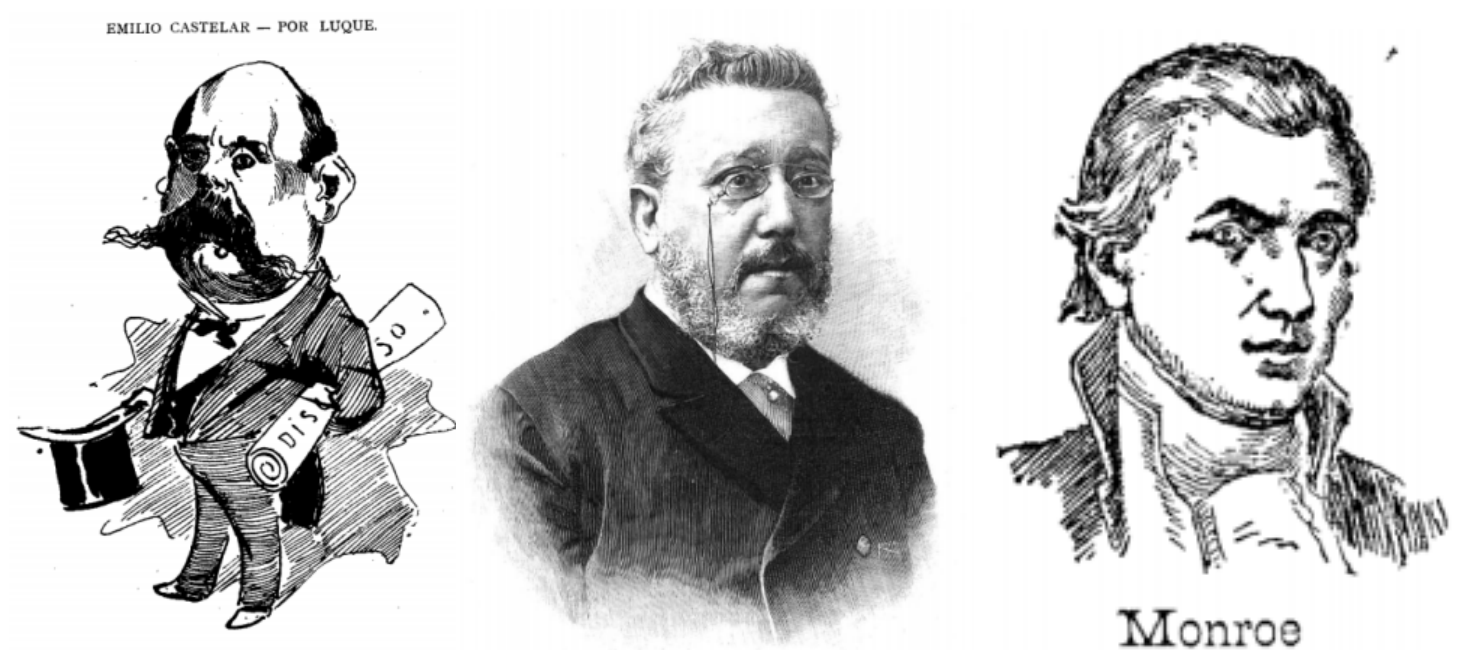

Fuentes: Madrid Cómico, "Emilio Castelar", 2 de mayo de 1880, n. ${ }^{\circ} 18$, p. 1; La Ilustración Española y Americana, "Excmo. Señor D. Cristino Martos", n. ${ }^{\circ}$ 5, 8 de febrero de 1893, p. 1; Los Lunes de El Imparcial, “¡Oh qué gran país!”, 9 de marzo de 1896, p. 1.

En fecha posterior, ese diario publicó los hechos que habían rodeado a las conferencias y que, de alguna forma, suscitaron su ruina, señalando tres. La negación de Piérola de entregar Tarapacá a Chile; el apresamiento del vapor Isluga, usado para transportar armamentos, en las cercanías del puerto peruano de Paita; y, por último, la destrucción de la línea férrea que unía ese puerto con Huaca y la posterior petición de contribuciones de guerra a esa municipalidad. Ante su negativa, el ejército chileno destruyó varias propiedades del Estado peruano.

\footnotetext{
${ }^{545}$ Idem.
} 
Mientras los representantes diplomáticos de Francia, Inglaterra e Italia habían tomado medidas para la protección de sus ciudadanos en caso de una invasión chilena, los agentes diplomáticos españoles demostraron negligencia en esa cuestión. Esos países, a diferencia de España, intentaron cooperar en "la búsqueda de una solución pacífica al conflicto" $" 546$. El Siglo... inició una estrategia alarmista donde el miedo sería el canal para exigir a las autoridades políticas más información proveniente del frente de guerra. Tal petición se relacionaba, a su vez, con su conocimiento sobre la presencia de una colonia española numerosa en el Perú.

Allí, instigaba el diario, los diplomáticos deberían proporcionar información por respeto al tesoro español, "no dejándonos entregados a los recortes de periódicos que llegan a Madrid con treinta o cuarenta días de fecha" ${ }^{547}$; tal deseo era "pedir peras al olmo" Con ese ánimo escribía las molestias sufridas por no poder responder a los españoles que, día a día, preguntaban por la suerte de hijos, hermanos y parientes, algunos saqueados y asesinados en Lima ${ }^{549}$.

Intentando alertar a los políticos españoles sobre la situación, se publicó una nota a los encargados de las relaciones diplomáticas con América. La misma finalizó planteando las siguientes cuestiones: "Y bien: interrogamos, si posible fuera, a quien corresponde: ¿No tiene otra obligación el gobierno de España que la de desear la paz entre Chile y el Perú?”550. A las que sumaba: “¿Carece el representante español en Lima de las debidas instrucciones para asociarse a los de otras potencias, [...] a fin de proteger a los extranjeros?" 551 . Personalizando, por último, la situación: "Y los Sres. Martos, Castelar o tutti quanti de los amigos ardientes de los intereses españoles en América ¿qué dicen?" 552.

La escasez de noticias del Perú y el eco que tuvo en la prensa aumentaría. Si bien en Tacna y Arica residían españoles, hacia 1880 su número era incomparable con los asentados en Lima. Saber de ellos se volvió prioritario para una prensa consciente de "la

\footnotetext{
546 NovaK TAlaVera, Fabián, Las relaciones entre el Perú y Francia (1827-2004), Lima, Fondo Editorial de la Pontificia Universidad Católica del Perú, 2005, p. 126.

${ }^{547}$ El Siglo Futuro, "El Perú", 9 de noviembre de 1880, p. 3.

548 Idem.

${ }^{549}$ Idem.

${ }^{550}$ El Siglo Futuro, "Repúblicas del Pacífico", 4 de noviembre de 1880, p. 2.

${ }^{551}$ Idem.

552 Idem.
} 
ignorancia en que vivimos y la inquietud que aqueja a las familias cuyos miembros están en Perú" ${ }^{53}$ o, como lo explicó un diario catalán aludiendo a un sentimiento hispano compartido, dada la numerosa colonia española y particularmente catalana que puebla aquellas regiones -decía- "no sería per deinés preguntar á nostre Gobern si considera suficientment protegíts los interessos de nostres súbdits, ja que en aquells paissos no sol pedarse per excés d'escrupulositat en respectar lo pabello de nostra patria" ${ }^{554}$.

Varios diarios españoles utilizaban notas periodísticas publicadas en diarios peruanos lo que explica, en parte, la censura de las acciones chilenas. En pocas ocasiones se detuvieron a analizarlas, pues la intención era informar "objetivamente" lo sucedido al otro lado del Atlántico. Por ejemplo, el 19 de noviembre de 1880 circuló en España un artículo de La Patria que hacía una apología de la altivez moral peruana y un reconocimiento de la perfidia chilena. Los periodistas españoles fueron encandilados por la pluma peruana y en un espacio redactaron "si Chile entra al debate tiene que hacer la apoteosis del crimen para defender sus atentados; si no acepta la discusión reagrava su responsabilidad [...] dejando al Perú ampliamente escudado por la justicia y el derecho" 555 .

A la nota anterior se adjuntó el titular “¡A las armas!”, con la intención de que los lectores se "puedan formar juicio de lo que allí sucede" 556 . " A las armas!” era claro y enfático. Aseguraba que mientras Chile había propuesto las bases de la paz y nombrado a sus embajadores para discutir el proyecto tenía urdida una práctica alevosa contra el Perú. La tónica de su actitud había sido "tirar el poncho para distraer a la víctima y darle la puñalada por la espalda" ${ }^{557}$. Chile, para el Perú, era el enemigo enmascarado, el Caín de América, el beligerante de intrigas, de ardides, de engaños y de traiciones. En conclusión, los chilenos son, decía el escritor peruano, los cartagineses del Pacífico, pues la fe chilena era la fe púnica. La comparación histórica erraba en lo relacionado con la ausencia de “espíritu patriótico" 558 cartaginés, hecho difícil de probar en el caso chileno.

\footnotetext{
${ }^{553}$ El Siglo Futuro, "República peruana", 15 de diciembre de 1880, p. 3.

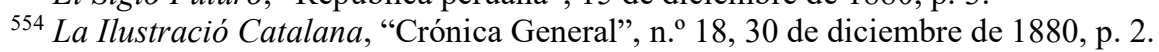

${ }^{555}$ La Iberia, “América del Sur", 19 de noviembre de 1880, p. 2.

${ }^{556}$ Idem.

557 Idem.

558 YÉPEZ CASTILlo, Aureo, Roma, Caracas, Universidad Católica Andrés Bello, 1995, p. 99.
} 
Otra noticia de un diario limeño impresa en España a comienzos de diciembre alertaba a Chile para considerar lo delirante de sus ensueños de conquista que conllevarían el castigo internacional por violar los principios del derecho y la justicia. Además responsabilizaba a Chile de la guerra, catalogada como un escándalo mundial, por desmembrar al Perú y Bolivia rompiendo el equilibrio de las naciones sudamericanas ${ }^{559}$.

Todas esas actitudes se comprendían mejor atendiendo la identidad chilena ${ }^{560}$. Según la nota anexada por la prensa española, Chile tenía instituciones, hábitos e instintos rebeldes y reacios a las prescripciones del derecho. Era un país que representaba para América una amenaza y un peligro para su prosperidad. El artículo finalizaba con una certeza: Chile era un país incivilizado. Lo primero que ese país necesitaba era el impulso irresistible de una civilización, de una idea, de algo que fuese capaz de nacer, crecer y extenderse -comenzaba el pasquín- pero, por el contrario, "Chile es la negación de todo eso: Chile es un pueblo torpe, un pueblo rudo, un pueblo que hace ya el camino de bajada, y en su huella no se divisa luz alguna [...]"561. Chile, para el autor de los improperios, era una "falsificación de todo lo real que aparenta, tiene buques, pero no tiene marinos: tiene material de guerra, pero no tiene material humano; tiene rifles y cañones, pero no tiene soldados $^{562}$.

En la prensa española se publicó una circular de la Secretaría de Relaciones Exteriores y Culto para las Legaciones del Perú en el exterior ${ }^{563}$. Allí se culpaba del fracaso de la paz a las "absurdas" pretensiones chilenas, país arrastrado por las más innobles y degradantes pasiones. En la visión oficial del Perú, la tenacidad chilena para designar a Arica como lugar de las conferencias se relacionaba con la pretensión de irritar el patriotismo peruano al hallarse tal puerto bajo la presión de las armas. En esa nota también se criticó el rechazo de Chile al arbitraje estadounidense que, según el documento, había sido propuesto por el Perú.

\footnotetext{
${ }^{559}$ La Iberia, "América del Sur", 2 de diciembre de 1880. p. 2.

${ }^{560}$ Entre las escasas notas que se publicaron en España sobre la idiosincrasia chilena vistas por autores chilenos sugerimos leer "Cómo somos y como nos juzgan" publicada en Chile por La Patria de Valparaíso. En: La Iberia, "América del Sur", 2 de diciembre de 1880, p. 2.

561 Idem.

562 Idem.

${ }^{563}$ La Iberia, “América del Sur”, 27 de diciembre de 1880, p. 2.
} 
Tal como la información anterior, hubo otras que se enmarcaron dentro de una campaña de desprestigio chileno en el exterior. En esta ocasión se trató de una carta enviada por el Ministro de Negocios Extranjeros de Bolivia, Juan Carrillo, al Ministro de Estados Unidos en ese país, Charles Adams, que fue publicada a comienzos de diciembre en España.

Carrillo hacía referencia a los actos de devastación consumados por Chile en el norte peruano contra la propiedad privada, un ultraje a la civilización y al derecho de las naciones. El político boliviano acusaba a Chile de practicar una guerra destructora que debía ser juzgada en duros términos por los demás estados americanos. Por último, comunicaba al agente estadounidense la urgencia de llamar la atención de la diplomacia chilena en el sentido de que todas las acciones de guerra comentadas se realizaban durante los preparativos de las conversaciones para la paz.

\subsection{Inicio de la campaña militar chilena hacia Lima}

En noviembre de 1880, tras el fracaso de las Conferencias de Arica, la expedición chilena a Lima era una realidad. Por entonces, la prensa española citó variadas notas periodísticas emitidas en Chile ${ }^{564}$ en las que se clarificaba que la única alternativa para concluir la guerra era atacar la capital peruana. Diarios de Chile como El Mercurio, El Independiente, Los Tiempos, entre otros, asumieron un papel movilizador y proclive a la guerra.

De su lectura, la prensa española concluía que el pueblo chileno estaba embriagado con sangre y excitado por el saqueo de los pueblos peruanos. Al parecer, las dudas que generaba en el gobierno chileno una expedición a Lima alimentaron en su prensa una campaña enérgica, empujando al país hacia la antigua capital virreinal. A modo de ejemplo, una de aquellas dijo: "Era tiempo ya de saber, de decidir, de resolver, si por fin se va o no a Lima; o en otros términos, si se ha engañado al país laborioso, trabajador [...], diciéndole que se iba a terminar con un golpe decisivo y final la guerra actual" 565 .

\footnotetext{
${ }^{564}$ La Ilustración Española y Americana, "Don Manuel Baquedano", n. ${ }^{\circ} 45,8$ de diciembre de 1880, p. 338.

${ }^{565}$ El Siglo Futuro, "El Perú", 9 de noviembre de 1880, p. 3.
} 
Una vez más la pluma de Araujo no escatimó usar la emotividad para juzgar el proceder chileno. Como la mayoría de los detractores de su militarismo, vio imposible una campaña chilena hacia Lima. Las distancias geográficas, así como los recursos económicos que el Estado debía utilizar hacían improbable, para Araujo y otros escritores, la ocupación limeña. Los hechos les demostrarían todo lo contrario; ellos se mantendrían redactando anatemas altisonantes contra ese país.

Envalentonados los chilenos -escribió el español- con esta serie ininterrumpida de triunfos, "intentan ahora llevar sus armas invencibles hasta la capital (sic) de la antigua monarquía de los Incas ${ }^{566}$. Al parecer, sabía que la planificación de esa empresa se había realizado en reuniones secretas del Alto Mando militar donde, además, se "hizo presente también que este plan ofrecía la no despreciable ventaja de una doble economía de sangre y dinero, y se agregó que sería el único medio de impedir la eternización de la campaña" ${ }^{567}$.

La campaña servía para demostrar el odio desarrollado por Chile hacia Perú y Bolivia. El Araujo historiador, en una faceta más cercana al publicista nacionalista, aportaba los argumentos necesarios para que en España se imaginase un Chile brutalizado por las victorias militares. Con la vivacidad que los tonos exclamatorios permiten y rematando su texto con analogías históricas, Araujo escribió:

La actitud de Chile demuestra bien claramente su encono contra Perú y Bolivia, y más lo demuestra aun el grito que se oye del uno al otro extremo del primero de estos países. La prensa toda inserta en sus columnas frases como éstas: “¡A Lima luego, para dictar allí la sentencia de muerte del Perú!”, “¡A Lima, pero llevando en nuestras manos, además del fusil del guerrero, el látigo del vengador!”, “¡A Lima, para pasear nuestras plantas sobre un tapiz de cabezas y cervices inclinadas y sumisas como de un esclavo ante la presencia de su señor!”, “¡A Lima, sí; pero mientras tanto, a Ancón, a Chorrillos, a todos los puertos y costas del Perú", "El Perú ha sido infiel a la lealtad y a la justicia: el Perú debe ser destruido. Chile así lo ha jurado y lo será". [...] Pero a estos soberbios chilenos, orgullosos y petulantes como ningún otro pueblo del mundo, no se les ocurre la idea de que tales vueltas pudiera dar la loca fortuna que en vez de entrar triunfantes en Lima no fuese Lima la tumba de sus glorias y de su ejército, como lo fue España para el invencible Napoleón el grande ${ }^{568}$.

\footnotetext{
${ }^{566}$ El Bien Público, "Cartas Sud Americanas", 14 de octubre de 1880, p. 1.

567 Idem.

568 Idem.
} 
El 14 de noviembre de 1880 salió desde Arica una expedición hacia Lima compuesta por setenta barcos. Los datos circulantes por España mencionaban un ejército de 30000 hombres, 2000 caballos y 100 cañones, formando cuatro divisiones. Perú, por su parte, armó a todos los hombres válidos, doblando a las fuerzas chilenas ${ }^{569}$. Parte de la prensa vio en esa diferencia, así como en las dificultades del transporte de víveres y municiones al Perú, la perdición de Chile ${ }^{570}$.

\section{Imagen n. ${ }^{\circ} 15$}

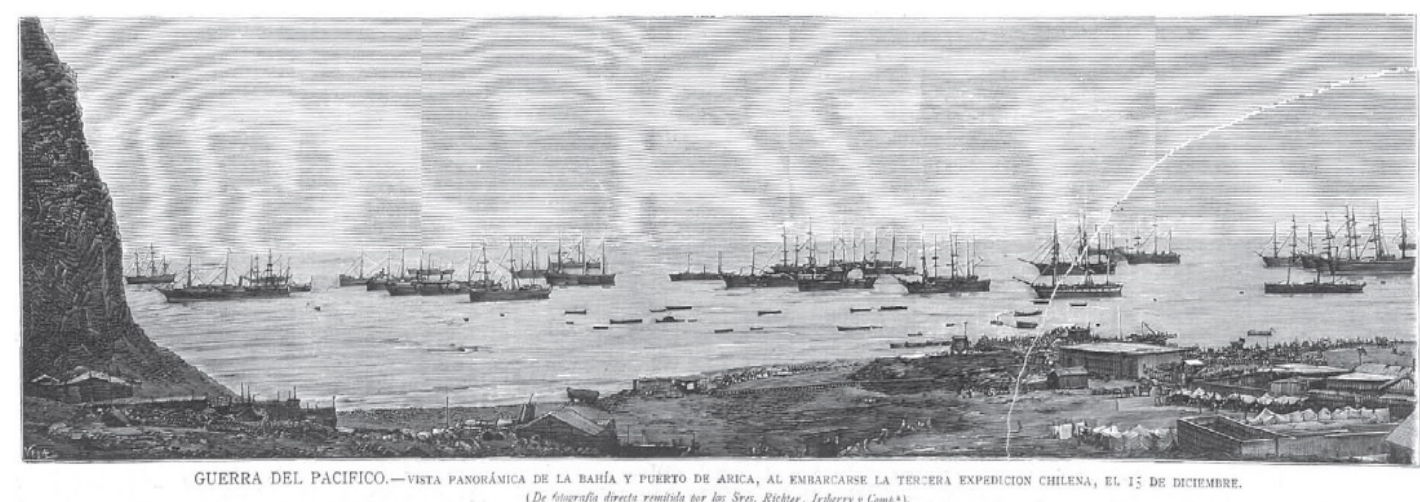

Fuente: La Ilustración Española y Americana, "Vista panorámica de la bahía y puerto de Arica al embarcarse la tercera expedición chilena el 15 de diciembre", el 15 de diciembre", n. ${ }^{\circ} 8,28$ de febrero de 1881. p. 124.

Es necesario desconfiar de esos números. Su inexactitud se observa, por ejemplo, en las cifras de las fuerzas chilenas entregadas por La Opinión quien publicó cómo el 6 de noviembre salieron de Arica 2500 chilenos con 500 caballos y 100 cañones $^{571}$. El Comercio, El Constitucional y La Crónica Meridional, entre otros, consignaron 25000 , 5000 y $100^{572}$. Por último, El Comercio de Cádiz aseguró que los guarismos eran del orden de 25000,500 y $100^{573}$. En la raíz de esas incoherencias estaban las dificultades para seguir

\footnotetext{
${ }^{569}$ La Época, [s. t.], 16 de noviembre de 1880, p. 3; La Ilustración Católica, "Chile", n. ${ }^{\circ} 19,21$ de noviembre de 1880, p. 152; La Época, "Despachos telegráficos", 1 de diciembre de 1880, p. 2; La Iberia, "América del Sur", 2 de diciembre de 1880, p. 2; El Áncora, "Sección Extranjera", 19 de noviembre de 1880, p. 3.

${ }^{570}$ El Siglo Futuro, "Guerra del Pacífico", 1 de diciembre de 1880, p. 3.

571 La Opinión, "Correo", 2 de diciembre de 1880, p. 3; Diario de Córdoba, "Estranjeras (sic)", 3 de diciembre de 1880, p. 2; El Áncora, "Partes Telegráficos", 2 de diciembre de 1880, p. 4.

572 El Comercio, "Partes telegráficos", 3 de diciembre de 1880, p. 3; El Constitucional, "Despachos telegráficos", 3 de diciembre de 1880, p. 3; El Graduador, "Despachos telegráficos", 3 de diciembre de 1880, p. 2; La Crónica Meridional, "Telegramas", 5 de diciembre de 1880, p. 2.

${ }^{573}$ El Comercio, "Correo de anoche", 3 de diciembre de 1880, p. 2.
} 
el avance de las operaciones militares guiándose "por boletines contradictorios, en los que cada cual se atribuye la victoria" ${ }^{274}$.

La certeza de la información publicada en España acerca de la fecha de inicio de la expedición también fue baja. Luego de un mes de concretarse la salida desde Arica hacia Lima continuaba la controversia sobre aquella. Informaciones recogidas principalmente de diarios italianos y algunas correspondencias oficiales chilenas señalaban el 6, el 15 y el 25 de noviembre 575 . Una publicación de finales de febrero de 1881 , cuando ya se había concretado la toma de Lima, daba fechas fidedignas de las tres expediciones chilenas que salieron de Arica: la del 15 y 29 de noviembre, y la del 15 de diciembre.

Otra fuente hemerográfica copiosa uso varias páginas evaluando a los tres ejércitos, donde Chile ocupaba el primer lugar en moral y recursos materiales ${ }^{576}$. Sus soldados eran prototipo del genio indio "de pura raza de la América del Sur, ya por su aspecto y carácter, ya por su valor y espíritu salvaje innatos, teniendo por esto cierta remota analogía con el turco del ejército francés" 577 .

\section{Imágenes $n .^{\circ} 16$ y 17}
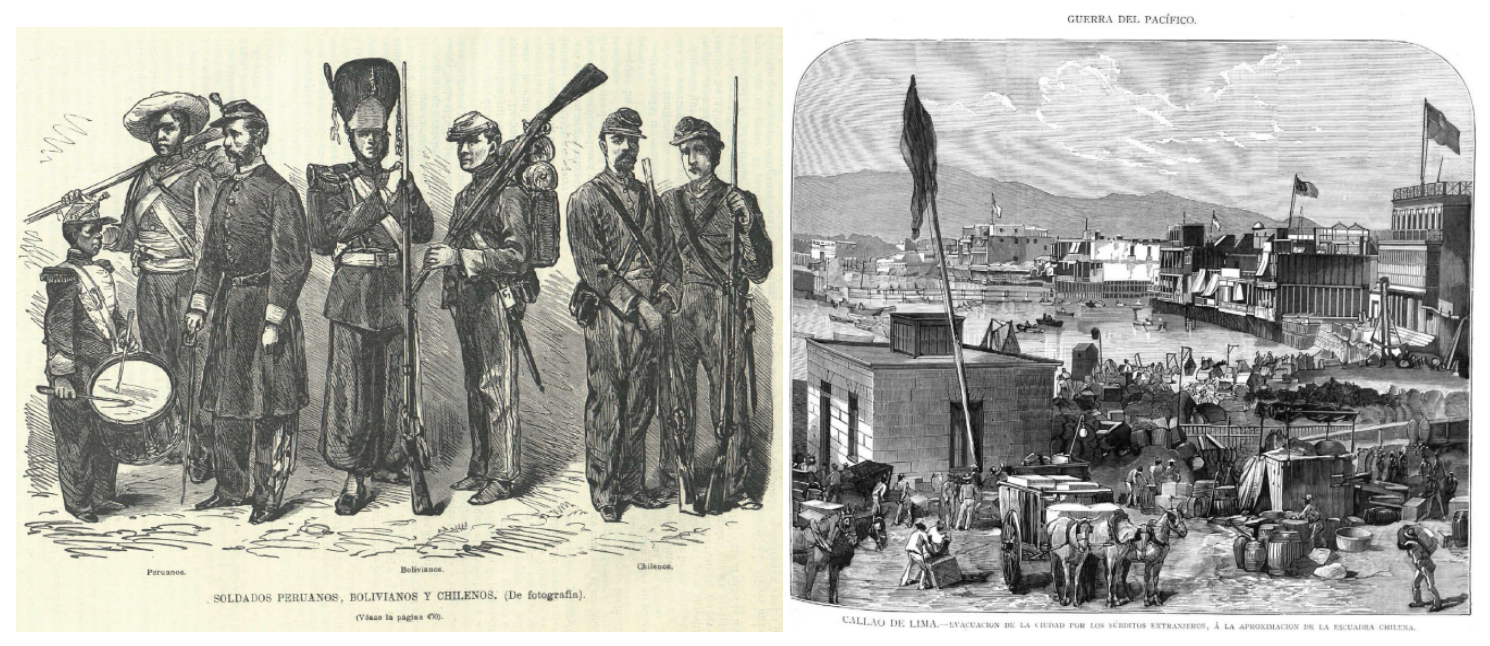

Fuentes: El Mundo Ilustrado, "Soldados peruanos, bolivianos y chilenos", n. ${ }^{\circ} 39,1880$, p. 464; La Ilustración Española y Americana, "Callao de Lima. Evacuación de la ciudad por los súbditos extranjeros, a la aproximación de la escuadra chilena”, n. ${ }^{\circ}$ 4, 30 de enero de 1881, p. 57.

${ }^{574}$ El Bien Público, "Chile y Perú", 3 de enero de 1880, p. 2.

${ }^{575}$ El Siglo Futuro, “América del Sud", 15 de diciembre de 1880, p. 3.

${ }^{576}$ El Mundo Ilustrado, "Las fuerzas terrestres y marítimas de Chile, Perú y Bolivia en la guerra actual”, n. ${ }^{\circ} 39$, año 1880 , p. 470.

${ }^{577}$ Idem. 
El ejército peruano, por el contrario, era inferior en todos los aspectos. Carecía del instinto guerrero de los "araucanos", de instrucción y de espíritu emprendedor. El peruano "no posee ninguno de los elementos físicos y morales cuyo conjunto fijan y determinan el espíritu de un ejército; en vano se buscará en sus filas la obediencia y el entusiasmo" ${ }^{578}$. El ejército de Bolivia, por último, contaba en tiempos de paz con sólo 1500 a 2000 hombres carentes "completamente de espíritu militar, ya a causa de la completa falta de instrucción, ya porque los diplomas de oficial son venales, es decir, pueden comprarse" ${ }^{279}$.

Una vez más Araujo construyó la efigie de la peruanidad viril, pero ahora durante la cotidianidad limeña previa a la invasión. Con su "nacionalismo literario" 580 personificó a Lima, haciendo pensar al lector que los limeños estaban "en pie de guerra". Interesa subrayar su valoración del nacionalismo como ideología permisiva de asesinatos sin la criminalización de esos sino, por el contrario, venerando a los mártires. El intelectual preguntó desde su bureau: ¿Quién no concurre a la cita augusta hecha en nombre de la patria? y agregaba cómo Lima había contemplado desde la lejanía el sacrificio de los peruanos, levantándose con grandiosidad y esperando la venganza de la soberbia chilena.

El día a día de Lima, complementaban otros diarios, sufría grandes cambios. El cierre obligatorio del comercio a las 15:00 horas, para instruir militarmente al pueblo y el sonido de las campanas catedralicias para reunir a todos los peruanos sin distinguir "edad, posición social, ni color" ${ }^{\prime 51}$, fueron sólo dos ejemplos. El objetivo: manejar eficazmente el rifle contra los chilenos. A cargo del general Concha, leemos en la carta, Lima se militarizó. Por todos lados aparecieron cañones y elementos de guerra. Las montañas que rodeaban Lima fueron artilladas. El cerro San Cristóbal, "que ocupa en Lima la misma posición que en Barcelona el castillo de Montjuich" ${ }^{282}$, estaba en su totalidad artillado y por las calles y plazas "sólo circulan jefes, oficiales y soldados; la única conversación es la guerra, los armamentos y la resistencia hasta morir" 583 .

\footnotetext{
${ }^{578}$ Idem.

${ }^{579}$ Idem.

580 PereirA-Muro, Género, Nación y Literatura. Emilia Pardo Bazán en la literatura gallega y española, Estados Unidos, Purdue University Press, 2013, p. 24.

${ }^{581}$ El Timón, "Guerra chileno-peruana", 29 de octubre de 1880, p. 2.

582 Idem.

${ }^{583}$ Idem.
} 
Araujo para fabricar sus relatos se apoyaba en fuentes primarias. Y, con intención, a veces, caía en anacronismos. En una de sus notas aseguró, citando a un compañero de profesión, cómo la "capital de los reyes, dice un escritor que hállase (sic) en la actualidad en Lima, ha respondido al llamamiento del jefe supremo que la declara en pie de defensa militar, corriendo a alistarse en el brillante ejército" ${ }^{584}$. Ese cuerpo militar no existía por lo que debía constituirse en menos de un mes con cincuenta mil hombres aptos, valientes y “ebrios de gloria y de venganza [...] Niños, adolescentes, jóvenes, hasta los ancianos, los capitalistas, [...] los hombres de letras, los artesanos, los industriales, las universidades, los colegios" $" 585$.

La veleidad de Araujo hacia la figura de Piérola no sorprende. De ser un acérrimo opositor a la dictadura y, por medio de la escritura periodística, transformarse en su antiapologista, ahora admiraba las medidas del gobierno peruano por "prontas y enérgicas" 586 . La prensa, por su lado, para crear un ambiente favorable a la guerra contra Chile y, según lo explicado por Araujo, establecía analogías con la historia española. Los diarios -escribió- utilizan "el ejemplo de la inmortal Zaragoza y del pueblo español que supo sacudir el yugo del corso afortunado" ${ }^{587}$. Y concluía:

¿Por qué el Perú no puede imitarnos, ya que es sangre de nuestra sangre y lleva consigo el sello del espíritu caballeresco y la heroica constancia heredados de nuestros padres? Si España se emancipa de Napoleón; los argentinos repelen con la fuerza las pretensiones de la Gran Bretaña, y Méjico derrumba un imperio odioso; ¿será posible que al Perú le falte ese amor fanático por la independencia, que es el rasgo característico de la raza latina? ${ }^{588}$.

Otras cartas publicadas esos días en España daban a entender que el Perú mantenía la esperanza de la victoria. En la introducción de una daba cuenta del sangriento curso de la guerra, así como del éxito que acompañaba al ejército chileno. Éste, ocupando todo el sur peruano, amenazaba con seriedad a Lima. Los métodos militares chilenos, decía esa correspondencia, deshonraban al pueblo y gobierno del país. El "pie de los muros de Lima" 589 sería el sitio de la revancha. El sufrimiento y la resignación patriótica peruana por

\footnotetext{
${ }^{584}$ El Bien Público, "Cartas Sud Americanas", 14 de octubre de 1880, p. 1.

${ }^{585}$ Idem.

586 Idem.

${ }^{587}$ Idem.

${ }^{588}$ El Bien Público, "Cartas Sud Americanas", 14 de octubre de 1880, p. 1.

${ }^{589}$ El Timón, "Guerra chileno-peruana", 29 de octubre de 1880, p. 2.
} 
los desastres y reveses del ejército -concluía- habían retemplando al pueblo aprestándose sus hombres para defender Lima. Se confiaba, por último, que "en el caso probable de ser Lima atacada, será defendida por todos, y con una tenacidad y heroísmo igual a los ilustres defensores de la inmortal Gerona y de la heroica Zaragoza"590.

La prensa se centró en narrar hechos de guerra sucedidos cerca de Lima. A la vez, continuó utilizando como fuente de sus noticias las publicadas en diarios peruanos que acusaban a Chile de hacer la guerra de exterminio "por el solo deseo de hacer mal"591. Así, la imagen chilena en España pulió aún más su carácter marcial. Otras publicaciones se mostraron menos parciales, lo que no significaba eludir sus puntos de vista. Un diario defendió su derecho a opinar del siguiente modo: "nosotros tenemos más derecho a hablar así, cuanto que en la guerra del Pacífico nos opusimos con todas nuestras fuerzas, primero a que se declarara, y después a que se mantuviera" 592.

El inicio de 1881 fue trágico para las aspiraciones peruanas en la guerra. El 13 de enero se libró la batalla de Chorrillos, el 16 la de Miraflores y el 17 se ocupó Lima. El telégrafo había dado cuenta de esas actividades a los periódicos españoles. Una publicación, por ejemplo, comentó la rendición de El Callao, los combates sangrientos de Miraflores y de Chorrillos, la toma de Lima, y el propósito peruano de refugiarse en los Andes, para oponer a Chile una resistencia pasiva ${ }^{593}$. Otra, referida a las estrategias de Baquedano, señaló que con éstas el militar había provocado la dispersión peruana tomando “fácilmente" Lima ${ }^{594}$. Ahí, días antes se había realizado la evacuación de familias europeas en embarcaciones con banderas de sus países. Luego de la caída de Lima y ante la evidencia de la superioridad militar chilena, otra vez, se comentó en los diarios españoles el advenimiento de la paz ${ }^{595}$.

\footnotetext{
${ }^{590}$ Idem.

${ }^{591}$ La Iberia, "América del Sur", 14 de enero de 1881, p. 2.

${ }^{592}$ La Ilustración Española y Americana, "Revista Americana", n. . 4, 30 de enero de 1881, p. 63.

${ }^{593}$ Idem.

${ }^{594}$ La Ilustración Española y Americana, "Guerra del Pacífico", n. ${ }^{\circ}$ 15, 22 de abril de 1881, p. 251.

${ }^{595}$ La Iberia, "América”, 12 de febrero de 1881, p. 2; La Ilustración Española y Americana, "Guerra del Pacífico", 28 de febrero de 1881, p. 123.
} 

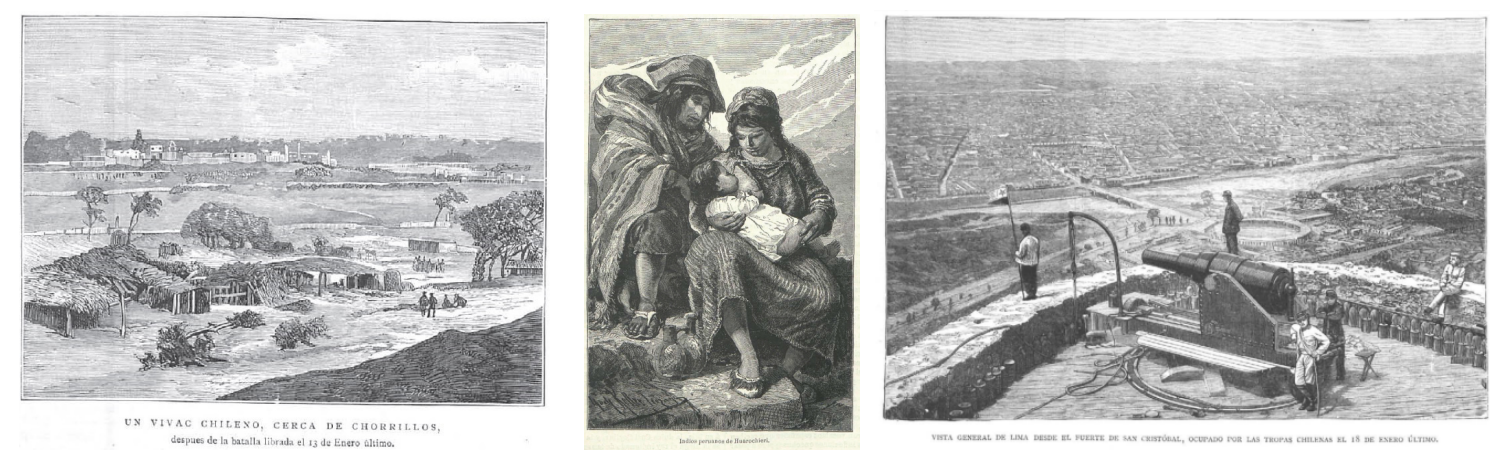

Fuentes: La Ilustración Española y Americana, "Un vivac chileno cerca de Chorrillos, después de la batalla librada el 13 de enero último", n. ${ }^{\circ}$ 15, 22 de abril de 1881, p. 264; El Mundo Ilustrado, "Indios peruanos de Huarochirí", año 1883, n. ${ }^{\circ}$ 147, p. 76; La Ilustración Española y Americana, "Vista general de Lima desde el Fuerte de San Cristóbal, ocupado por las tropas chilenas el 18 de enero último", n. ${ }^{\circ} 16,30$ de abril de 1881, p. 276.

El posible ofrecimiento de buenos oficios ingleses generó recelos en la prensa. Como en el caso de las Conferencias de Arica y la participación estadounidense, ahora se sospechó de las verdaderas intenciones inglesas, potencia carente de bases navales en el Pacífico Sur. Ese interés y la cesión de alguna isla peruana que, supuestamente, Chile haría a Inglaterra, permitía a un periódico afirmar que con un nuevo motivo "se llamará a Chile la Inglaterra de Sudamérica"596. Inglaterra, para parte de la prensa, necesita mantener su hegemonía mundial que cedía frente al imperialismo estadounidense.

Tras la ocupación de Lima se perdió la esperanza chilena de finalizar la guerra en un plazo próximo. La razón estribó en el traslado del escenario bélico hacia la sierra poblada principalmente de indígenas. Nicolás de Piérola y Lizardo Montero, publicó un diario, apoyados por fuerzas respetables en el Cuzco y Cajamarca, resolvieron continuar la guerra con Chile hasta agotar el último recurso ${ }^{597}$. Algunos diarios, al tanto de que la paz se alejaba, se lamentaron de que las noticias peruanas fuesen "nada tranquilizadoras" 598 . Ante el inminente dominio chileno estallaron resistencias por doquier y, a ratos, los conflictos armados surgieron entre peruanos ${ }^{599}$.

\footnotetext{
${ }^{596}$ El Pabellón Nacional, "Inglaterra", 5 de febrero de 1881, p. 3.

${ }^{597}$ El Imparcial, "Noticias de Sud-América", 14 de junio de 1881, p. 3.

${ }^{598}$ La Iberia, "América", 26 de agosto de 1881, p. 2.

${ }^{599}$ Idem; La Iberia, "Paz con honra", 23 de septiembre de 1881, p. 2; La Iberia, "América", 20 de octubre de 1881, p. 3.
} 
El caos sembrado en la sociedad peruana por la guerra se constató en la clase dirigente peruana. Ésta se dividió profundamente ante la presencia militar chilena en Lima. Nicolás de Piérola se retiró a las serranías para combatir desde las alturas y la presidencia provisional del país la asumió Francisco García Calderón, desde el 12 de marzo hasta el 6 de noviembre de 1881. A fines de septiembre de ese año su mandato había influido negativamente en las conversaciones de paz con el plenipotenciario chileno Manuel Godoy. Sin embargo, para octubre esa situación cambió y, según informó un diario, García Calderón estaba convenciendo a los chilenos de que convendría desocupar Lima y permitírsele "establecerse en el palacio" ${ }^{600}$.

La petición del presidente peruano naufragó. Consciente de la desorganización creada por la guerra, sugería negociar la paz con la mediación de Inglaterra, Francia, Italia y Brasil ${ }^{601}$. Ninguna de esas peticiones triunfó. Es más, García Calderón fue apresado por Chile y enviado a una prisión en el sur del país. La justificación de ese acto penal la realizaría Patricio Lynch, apodado en Chile "el último virrey del Perú", quien sostuvo que la resolución de García Calderón a no ceder territorio peruano y no aceptar las condiciones de paz chilenas, comunicadas en las Conferencias de Arica, bastaban para su detención.

En la Memoria del contraalmirante Lynch, publicada en La Iberia, el chileno señaló que su decisión de encarcelar a García Calderón fue tomada porque "en los primeros días de septiembre tuve conocimiento pleno de que continuaba [...] burlándose de mis disposiciones" ${ }^{\circ 02}$. Por eso, desde el 15 de noviembre de 1881 la presidencia del Perú la asumió el militar Lizardo Montero ${ }^{603}$; las tropas de otro general, Avelino Cáceres, no reconocían la legalidad de aquel. Llegado un momento, el Perú tuvo más de tres cabezas visibles ansiosas del poder supremo lo que hizo preguntarse a un diario: “¿quién de los tres o cinco presidentes ha de nombrar delegados para tratar con Chile? ¿A cuál de ellos ha de dirigirse esta república, en la confianza de la legalidad [...]?" ${ }^{604}$.

\footnotetext{
${ }^{600}$ La Iberia, "América”, 20 de octubre de 1881, p. 3.

${ }^{601}$ El Imparcial, "La América del Sur", 22 de octubre de 1881, p. 2.

${ }^{602}$ La Iberia, “América”, 21 de octubre de 1882, p. 2.

${ }^{603}$ Una completa biografía del presidente interino del Perú Lizardo Montero que enfatizó sus aspectos políticos y militares en: La Ilustración Española y Americana, "El contraalmirante Lizardo Montero", n. ${ }^{\circ} 32$, 30 de agosto de 1882 , p. 3.

${ }^{604}$ El Siglo Futuro, "La Guerra del Pacífico", 31 de enero de 1883, p. 2.
} 


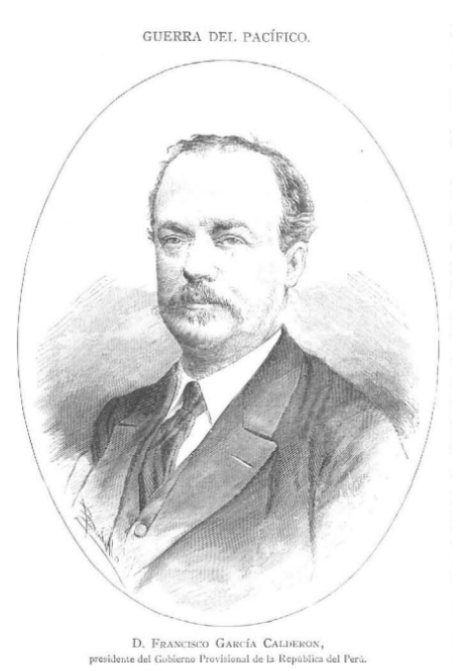

Fuente: La Ilustración Española y Americana, "D. Francisco García Calderón", n. ${ }^{\circ} 16,30$ de abril de 1881, p. 276.

En el plano social, las verdaderas víctimas de la guerra eran los habitantes de pueblos indefensos y saqueados "por los dispersos peruanos antes de abandonarlos, y por los soldados chilenos al entrar en ellos, aunque sin resistencia" ${ }^{605}$. Al respecto, una carta peruana publicada en España concluía con una anotación lamentable. Aludía que en el Perú reinaba el miedo más entre paisanos que al invasor chileno. En esa turbulencia algunos españoles perdieron sus vidas. Por ejemplo, el español Juan Huerta, asesinado por la tropa peruana al oponer resistencia en $\mathrm{Ica}^{606}$.

Otros, con mejor suerte, como un grupo de comerciantes españoles, franceses e italianos se organizaron contra los cobros de patentes industriales que Chile realizaba en Lima $^{607}$. Sobre eso, una noticia peruana usada por La Iberia, resumió la situación política del país en pocas palabras: "Estamos en completa anarquía, gracias a las oficiosidades de Mr. Hurlbut" ${ }^{\prime 08}$. Este último, agente diplomático estadounidense sucesor de Christiancy desde 1881. Una parte de la correspondencia limeña llegada a España afirmaba el inicio de una fase caótica en la ciudad intentando - paradójicamente y con desesperación- demostrar que el orden, la valentía y la peruanidad se impondrían ante la expedición militar chilena.

${ }^{605}$ La Época, "Cartas peruanas", 13 de abril de 1882, p. 4.

${ }^{606}$ Idem.

${ }^{607}$ La Iberia, "América", 19 de mayo de 1882, p. 2.

${ }^{608}$ Idem. 


\subsection{El Tratado de Ancón}

Un año antes de firmar la paz, el Secretario de Estado de EE.UU., Frelinghuysen, informó sobre la aceptación chilena de sus buenos oficios para conferenciar con el Perú ${ }^{609}$. Las condiciones de paz impuestas por Chile, según el diario que publicó esa noticia, eran la cesión de Tarapacá y una indemnización de 20 millones de dólares a pagar en dieciséis años. De no abonar el dinero en ese plazo, Arica sería cedida perpetuamente a Chile. Si Perú rechazaba esa condición, Chile "renunciaría a todo nuevo ofrecimiento de intervención amistosa por parte de los Estados Unidos"610.

En España, la paz chilena se consideró “terrible”, lamentando la prensa la situación peruana $^{611}$. La cesión de Tarapacá, punto central del acuerdo, suponía perder la zona de mayor riqueza para su economía. En el caso de Arica, la proposición chilena de comprarla equivalía, para la peruanidad, una burla insoportable. En efecto, el Perú se negó "rotundamente" a aceptar una armisticio que exigía "la posesión definitiva de Arapacá (sic) y la venta de Arica" ${ }^{612}$.

A fin de cuentas, Chile era el responsable de continuar la guerra puesto que sus exigencias retardaban "el día de la paz, que tanto anhelamos" ${ }^{613}$. Otra noticia culpó a Chile de querer conseguir siempre la satisfacción de todas sus exigencias ${ }^{614}$. En fin, para Chile la guerra le estaba granjeando en el exterior la fama de un país invasor, calculador, impositivo, ladrón y rapaz. Demorando la paz, escribió un diario, domina al Perú a su antojo e impone su ley en todas partes, saqueando a menudo a los capitalistas peruanos ${ }^{615}$.

\footnotetext{
${ }^{609}$ El Siglo Futuro, "Estados Unidos", 1 de febrero de 1882, p. 3.

${ }^{610}$ Idem; El Día, "América Española", 15 de febrero de 1882, p. 2; La Iberia, "Correo de América", 16 de febrero de 1882, p. 2; El Siglo Futuro, "América del Sur", 16 de febrero de 1882, p. 3; La América, "La América Latina", n. ${ }^{\circ}$ 7, 8 de abril de 1882, p. 6.

${ }^{611}$ La América, "La América Latina", n. ${ }^{\circ} 7,8$ de abril de 1882, p. 6.

${ }^{612}$ El Siglo Futuro, "Telegramas Agencia Fabra", 19 de mayo de 1882, p. 3; La Unión, "Boletín Telegráfico", 19 de mayo de 1882, p. 4; La Época, "Nuestros telegramas", 19 de mayo de 1882, p. 2; La Discusión, [s. t.], 20 de mayo de 1882, p. 3; La Correspondencia de España, "Despachos telegráficos", 20 de mayo de 1882, p. 1; La Iberia, "Telegramas de la Agencia Fabra", 20 de mayo de 1882, p. 3; Diario Oficial de avisos de Madrid, "Despachos telegráficos", 20 de mayo de 1882, p. 2; El Globo, "Telegramas", 20 de mayo de 1882, p. 2; El Liberal, "El Telégrafo", 20 de mayo de 1882, p. 2.

${ }^{613}$ La América, "La isla de Cuba y las repúblicas hispano-americanas", n. ${ }^{\circ} 14,28$ de julio de 1882 p. 6.

${ }^{614}$ Revista de España, "Crónica política”, n. ${ }^{\circ}$ 89, noviembre-diciembre de 1882, p. 287.

${ }^{615}$ El Correo Militar, "Repúblicas del Pacífico", 14 de marzo de 1882, p. 2.
} 
En relación a Bolivia, Chile permitió el transporte de mercancías por Arica mediante el pago de derechos moderados de importación y exportación ${ }^{616}$. Esa medida económica prologó la existencia de una cláusula por la cual Chile permitió una salida al mar del comercio boliviano por Arica en 1884. En La Paz circulaban rumores, como confesó la prensa, sobre la ruptura de la alianza, pues Bolivia estaría dispuesta a recibir Arica a cambio de la pérdida de su litoral ${ }^{617}$.

En esas circunstancias y luego de haber ocupado militarmente varios puertos bolivianos y sur-peruanos, Chile aumentó considerablemente los ingresos de su hacienda. Al terminar 1881 "Las aduanas del Callao, Arica, Iquique, Tocopilla, Mejillones y Antofagasta han producido al vencedor $8.470 .578,12$ pesos" ${ }^{\prime \prime 18}$. Las contribuciones de guerra, ventas de guano, los bienes tomados al enemigo, los salitres de Tarapacá, etc. continuaba- "3.611.629,42 pesos, los empréstitos y la emisión de papel moneda, 30.000.000; la acuñación de moneda feble, 1.419.112,65.- Total, 45.501.284 pesos"619.

Es posible que una vez evaluadas las ganancias económicas obtenidas tras la ocupación de los territorios peruanos y bolivianos, Chile se esforzara por asentar allí firmemente su dominio. Con tal intención, el gobierno chileno decretó que los productos procedentes de los sitios antes nombrados fuesen considerados como mercancías chilenas y se cobrasen las contribuciones impuestas en ese país. A eso se sumó, en el plano legal, la expedición de una serie de decretos para establecer la organización de la justicia en Arica, Tacna e Iquique. En el ámbito legislativo el parlamento chileno estaba próximo a presentar un proyecto de ley que señalase dichas regiones como territorio nacional. Tales acciones realizadas por el Estado chileno permitieron juzgar a un escritor español que, de hecho, se comenzaba a mirar esos territorios como "cosa propia" 620 .

\footnotetext{
${ }^{616}$ El Siglo Futuro, "Telegramas de la Agencia Fabra", 14 de febrero de 1882, p. 4; La Época, "Nuestros Telegramas", 14 de febrero de 1882, p. 3; La Unión, "Telegramas", 14 de febrero de 1882, p. 3; El Día, "Telegramas Agencia Fabra", 14 de febrero de 1882, p. 2; La Correspondencia de España, "Despachos telegráficos", 15 de febrero de 1882, p. 1; La Discusión, "Noticias generales", 15 de febrero de 1882, p. 3; La Iberia, "Telegramas de la Agencia Fabra", 15 de febrero de 1882, p. 2; El Globo, "Extranjero", 15 de febrero de 1882, p. 2.

${ }^{617}$ La Época, "Cartas peruanas", 13 de abril de 1882, p. 4.

${ }^{618}$ El Día, “América Española”, 23 de febrero de 1882, p. 1.

${ }^{619}$ Idem.

${ }^{620}$ La Iberia, "América", 19 de mayo 1882, p. 2; El Día, "América Española”, 18 de junio de 1882, p. 1; El Imparcial, "Sección de noticias", 7 de julio de 1882, p. 2; El Día, "América Española”, 25 de agosto de 1882,
} 
Mientras se negociaba la paz entre Chile y Perú, el primero selló con España un Tratado de Paz y Amistad. Ambas naciones, "hija y madre", como publicó un diario español $^{621}$, concluían las gestiones diplomáticas para iniciar una nueva etapa en sus relaciones. Según la costumbre, un buque chileno visitaría algunos puertos españoles y, desde ese país, con dirección a Valparaíso iría la fragata Navas de Tolosa con la misma intención. La embarcación española arribó a mediados de marzo de 1883 y saludó al puerto chileno en señal de la reanudación de las relaciones. Un diario español comentó con agrado que, luego de dieciocho años de ruptura diplomática entre Chile y España, el 12 de junio "se firmó el tratado de paz y amistad entre las dos naciones" ${ }^{622}$. Alfredo Laffite, periodista de El Liberal, enfatizó que la paz se había firmado con un país montado "a la moderna" quienes de seguro se regocijarán de volver a ser "nuestros más íntimos amigos”623.

Entre el 8 de noviembre y el 3 de diciembre de 1882 toda la información periodística circulante por España sobre la paz chileno-peruana fue confusa. Sólo se distinguen noticias relacionadas con el fracaso de la paz y otras referidas a su concertación. En lo relativo a las primeras se aludió al nuevo fracaso diplomático estadounidense, pese a "los estímulos de su inmensa ambición"

A decir verdad, las razones del fracaso se encontraban en una divergencia entre Chile y Perú por la demarcación fronteriza. Desde el punto de vista peruano, Tacna y Arica no debían incorporarse a Chile, mientras que Tarapacá si ${ }^{625}$. La paz sólo era rumor. Los diarios españoles utilizaban noticias neoyorquinas informando todo lo contrario a lo anterior, sosteniendo que se había "convenido la paz entre Chile y el Perú, bajo la base de la cesión a Chile de Tacna y Arica" ${ }^{26}$.

p. 2; El Día, “América Española”, 24 de noviembre de 1882, p. 2; La Iberia, [s. t.], 3 de diciembre de 1882, p. 3 .

621 El Liberal, "Chile y España", 9 de septiembre de 1882, p. 1; El Correo Militar, "Repúblicas del Pacífico",14 de marzo de 1883, p. 2.

${ }^{622}$ El Globo, "Noticias generales", 18 de junio de 1883, p. 2.

${ }^{623}$ El Liberal, "Chile y España", 9 de septiembre de 1882, p. 1.

${ }^{624}$ El Siglo Futuro, "La Guerra del Pacífico", 31 de enero de 1883, p. 2

${ }^{625}$ El Imparcial, "Sección de noticias", 8 de noviembre de 1882, p. 3; El Día, "América Española", 24 de noviembre de 1882, 2; La Iberia, "América", 2 de diciembre de 1882, p. 1; La Discusión, "Extranjero", 3 de diciembre de 1882, p. 2.

${ }^{626}$ La Época, "Nuestros telegramas", 13 de noviembre de 1882, p. 3; El Imparcial, "Sección de noticias", 13 de noviembre de 1882, p. 1; El Liberal, "El telégrafo", 13 de noviembre de 1882, p. 1; La Correspondencia de España, "Despachos telegráficos", 13 de noviembre de 1882, p. 3; El Globo, "De la Agencia", 13 de 
Como se comprende, la situación geopolítica de Arica fue fundamental en la guerra y en la paz. Si en un primer momento su conquista determinó los movimientos militares, en las Conferencias de Arica, Chile, al desestimar la paz, exigió el dominio absoluto de ese territorio a los Estados Unidos. Otra alternativa fue la petición de cesión por quince años al Perú para que luego un arbitraje decidiera su futuro ${ }^{627}$ idea que pronto se diluyó. En Chile la posibilidad de que terceros países decidieran sobre su soberanía desagradaba. Marginado Estados Unidos de las negociaciones, Arica fue vista como "moneda de cambio". De tal modo, se concibió como un puerto para entregar a Bolivia ${ }^{628} \mathrm{y}$, finalmente, como un territorio neutral, independiente, protegido por Chile, Perú y Bolivia.

Todas esas alternativas fracasaron. Tacna y Arica quedaron bajo dominio chileno por diez años, debiéndose luego realizar un plebiscito solicitando la aceptación o rechazo de la soberanía chilena. Según nuestras fuentes, hacia la primera quincena de mayo la noticia circuló masivamente con un error fundamental: se dijo que la paz fue "firmada", cuando sólo se habían resuelto los puntos fundamentales del tratado. La publicación decía que según dicho tratado "el Perú cede Tacna y Arica a Chile por diez años. Después de este plazo, un plebiscito decidirá sobre la suerte de dichos territorios. Para dicho plebiscito serán convocados los habitantes de los mismos" $" 629$. A propósito de esa estipulación de la paz un diario recordó el artículo n. ${ }^{\circ} 5$ del Tratado de Praga, según el cual las poblaciones de Schleswig debían ser consultadas por Prusia para resolver su destino. Ese diario temió que Chile tampoco quisiera desprenderse de Tacna y Arica pasados los diez años ${ }^{630}$.

noviembre de 1882, p. 2; La Iberia, "De la Agencia Fabra", 13 de noviembre de 1882, p. 2; La Unión, "Boletín telegráfico", 13 de noviembre de 1882, p. 4; Diario Oficial de Avisos de Madrid, "Despachos telegráficos", 13 de noviembre de 1882, p. 3.

${ }^{627}$ La Iberia, "América", 2 de diciembre de 1882, p.1; La Discusión, "Extranjero", 3 de diciembre de 1882, p. 2.

${ }^{628}$ El Correo Militar, "Última hora”, 10 de enero de 1883, p. 2; El Día, "Telegrama Agencia Fabra”, 10 de enero de 1883, p. 1; Diario Oficial de avisos de Madrid, "Despachos telegráficos", 11 de enero de 1883, p. 3; El Globo, "Telegramas", 11 de enero de 1883, p. 3; La Unión, "Boletín telegráficos", 10 de enero de 1883, p. 4; El Siglo Futuro, "Telegramas", 10 de enero de 1883, p. 3; La Iberia, "Telegramas de la Agencia Fabra", 11 de enero de 1883, p. 2; La Discusión, "Despachos telegráficos", 11 de enero de 1883, p. 2; El Correo Militar, "La cuestión del Pacífico", 12 de febrero de 1883, p. 2; El Día, "Noticias varias", 3 de abril de 1883, p. 1; La Discusión, "Extranjero", 3 de abril de 1883, p. 2.

${ }^{629}$ El Día, "Telegramas (Agencia Fabra)", 16 de mayo de 1883, p. 1; La Época, [s. t.], 16 de mayo de 1883, p. 3; El Siglo Futuro, "Telegramas", 16 de mayo de 1883, 3; La Iberia, "Telegramas", 17 de mayo de 1883, p. 2; El Correo Militar, "Del extranjero", 17 de mayo de 1883, p. 2; El Imparcial, "Sección de noticias", 22 de mayo de 1883, p. 3; Archivo Diplomático de España, n. ${ }^{\circ}$ 38, 21 de enero de 1884, p. 22.

${ }^{630}$ El Imparcial, "Sección de noticias", 22 de mayo de 1883, p. 3. 
La corrección de los hechos tardaría unos días. La prensa anunció las "condiciones principales" del tratado de paz entre Chile y Perú. En primer lugar, escribió, Tarapacá pasará a perpetuo dominio de la República de Chile; el Perú pagará a Chile la suma de diez millones de pesos y, por último, Chile conservará durante algún tiempo Tacna y Arica ${ }^{631}$. Las pérdidas territoriales peruanas permitieron la publicación de un artículo extenso bautizando a ese país como "La Polonia de América"632.

El Tratado de Ancón, luego de acaloradas discusiones en el Congreso de Chile, se firmó el 20 de octubre de 1883. Las noticias de la prensa chilena, desconfiando de la política peruana, fueron usadas en los periódicos españoles. Se pensaba que el tratado podría desconocerse por los caudillos que resistían la ocupación militar. Lo anterior generaba una opinión favorable al apoyo material que Chile debía ofrecer al presidente peruano, con el objeto de dominar a los militares "rebeldes", como Andrés Avelino Cáceres, por ejemplo ${ }^{633}$.

A lo anterior se sumó que, dos meses antes de firmar el tratado, Lizardo Montero, el antiguo presidente peruano, y el general boliviano Narciso Campero planeaban la reivindicación de Tacna y Arica para Bolivia ${ }^{634}$. De todos modos, como se había conversado entre los negociadores de la paz, el 23 de octubre "desocuparon a Lima y el Callao las tropas chilenas en medio del orden más completo, y se han retirado a los

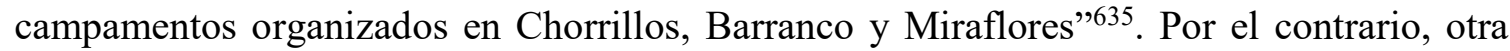
publicación acusó a los chilenos de que al retirarse de la capital "se llevaron cuantos objetos habían podido arrancar de los edificios y monumentos públicos, aunque han prometido devolverlos" 636 .

\footnotetext{
${ }^{631}$ El Día, 27 de mayo de 1883, p. 1; El Imparcial, 28 de mayo de 1883, p. 1; El Correo Militar, 28 de mayo de 1883, p. 3; Diario Oficial de Avisos de Madrid, "Noticias extranjeras", 28 de mayo de 1883, p. 3; La Correspondencia de España, "Despachos telegráficos", 28 de mayo de 1883, p. 1; El Liberal, "Extranjero", 28 de mayo de 1883, p. 1; El Globo, "Telegramas", 28 de mayo de 1883, p. 2; La Discusión, "Extranjero", 29 de mayo de 1883 , p. 2.

${ }^{632}$ El Día, "La Polonia de América", 21 de diciembre de 1883, p. 1.

${ }^{633}$ La Unión, "Chile y el Perú", 25 de junio de 1883, p. 2; El Día, "América Española", 11 de febrero de 1884, p. 1; La Discusión, "Extranjero", 12 de febrero de 1884, p. 2.

${ }^{634}$ La Unión, "La paz entre Chile y Perú", 4 de agosto de 1883, p. 2.

${ }^{635}$ La Unión, "La paz entre Chile y Perú", 8 de diciembre de 1883, p. 2.

${ }^{636}$ Archivo Diplomático-político de España, "Noticias del Pacífico", n. o 35, 29 de diciembre de 1883, p. 562. La llamada de atención en cursiva es nuestra.
} 


\section{Imagen $n .^{\circ} 22$}

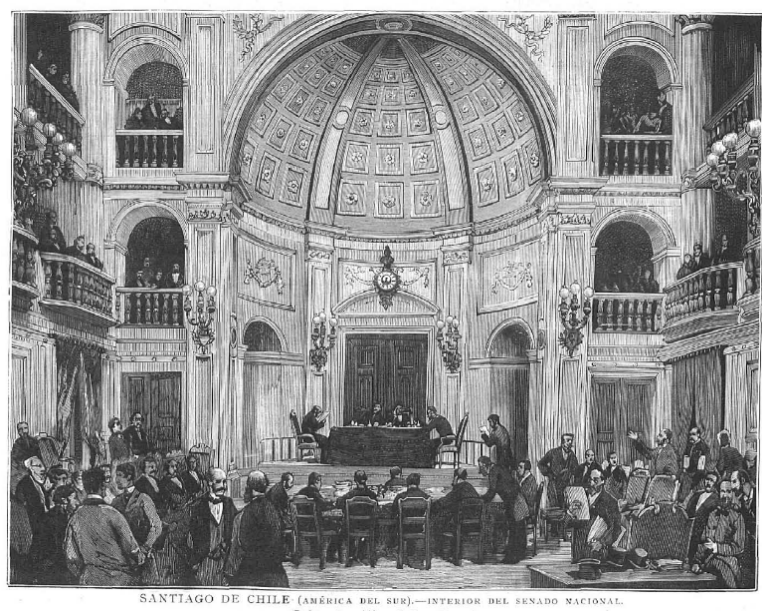

Fuente: La Ilustración Española y Americana, "Santiago de Chile. Interior del Senado Nacional", 8 de julio de 1883, n. ${ }^{\circ} 25$, p. 4.

La firma del tratado requería la ratificación del congreso peruano para alcanzar la paz. Entre tanto, dada la convulsión política del país, cualquier cosa podía alterar lo pactado. Es sabido que las bases del acuerdo no eran muy conocidas en Chile ni en el Perú. De todos modos, en España la paz fue bien recibida. "En América se nos da al fin el espectáculo de dos pueblos hermanos, pactando tregua en sus encarnizados rencores" ${ }^{637}$, publicó un diario.

Por su lado, los rumores que vincularon al presidente peruano Iglesias con el pago chileno anticipado de dinero por Tacna y Arica ${ }^{638}$, así como el desconocimiento del tratado que hicieron algunos países europeos con intereses económicos en la zonas salitreras ${ }^{639}$ no impidieron que el 11 de marzo de 1884 Perú aceptara los términos propuestos por Chile. Desde este país llegó información a España sobre cómo se había recibido la finalización de la guerra: "CHILE.- La ratificación del tratado de paz con el Perú ha sido celebrada, en las principales poblaciones de Chile con salvas de artillería y otras demostraciones oficiales de regocijo" 640 .

\footnotetext{
${ }^{637}$ Revista Contemporánea de Madrid, "Revista extranjera", n. ${ }^{\circ}$ 48, noviembre de 1883, p. 377.

${ }^{638}$ La Discusión, "Extranjero", 5 de enero de 1884, p. 2; El Día, "América Española", 11 de febrero de 1884, p. 1; La Discusión, "Extranjero", 12 de febrero de 1884, p. 2.

${ }^{639}$ El Siglo Futuro, "Revista extranjera", 5 de abril de 1884, p. 3; La América, "Europa y el Tratado de Paz chileno peruano", n. ${ }^{\circ} 7,15$ de abril de 1884, p. 5.

${ }^{640}$ La Iberia, "Chile", 5 de junio de 1884, p. 2.
} 


\section{EL ARBITRAJE DE ESPAÑA (1895-1901)}

Este segundo periodo examina la gravedad adquirida por el diferendo a causa del incumplimiento del Tratado de Ancón. Los problemas internos de Chile y Perú impidieron que el plebiscito se realizara en 1894, asomándose en el horizonte el arbitraje español pactado en el protocolo Billinghurst-Latorre de 1898. Desestimado por Chile, quien además inició la "chilenización" de Tacna y Arica, produjo nuevos discursos que reforzaron las representaciones sociales de Chile y Perú iniciadas en el periodo anterior.

\subsection{Una década después de Ancón}

Al concluir la Guerra del Pacífico, las condiciones chilenas dificultaron alcanzar la paz. Perú y Bolivia terminaron la guerra en medio de grandes crisis políticas y económicas que encontraron una justificación desde sus pueblos en el afán conquistador de Chile. Algunos grupos políticos de los países vencidos miraron el derrumbe con autocrítica; la visión oficial consignó al país del sur como culpable de todos sus males. En ese ambiente de tensión la apertura del problema de Tacna y Arica, a consecuencia del artículo tercero del tratado, condensó en un hecho material los odios nacionalistas y creó un campo de choque de fuerzas donde desde 1883 se midieron los nacionalismos de Chile y Perú.

Las ciudades que el Perú cedió por un plazo de diez años a Chile formaban parte de su extremo sur y representaban un baluarte para el sentimiento nacional. En Tacna, el 20 de junio de 1811, Francisco Antonio Zela y José Rosa de Ara expresaron "el primer grito de Independencia del Perú" ${ }^{641}$. En Arica, el desarrollo económico poscolonial, al amparo del Estado peruano, le permitió adquirir una "importancia estratégica a nivel comercial" 642 . Arica, en la década del ochenta del siglo XIX, era considerada como "el centro de importación más afamado que los Estados Unidos, Inglaterra, Francia, Alemania e Italia tienen para su comercio con el interior de toda la región y con Bolivia”643.

\footnotetext{
${ }^{641}$ ViCuña MaCKenNA, Benjamín, La revolución de la Independencia del Perú. Desde 1809 a 1819, Lima, Imprenta del Comercio por J. M. Monterola, 1860, p. 184.

${ }^{642}$ Díaz Araya, Alberto; Ruz Zagal, Rodrigo; Galdames Rosas, Luis y TaPia Tosetti, Alejandro, "El Arica peruano de ayer. Siglo XIX", Revista Atenea n. ${ }^{\circ}$ 505, 2012, pp. 159-184.

${ }^{643}$ La Ilustración Española y Americana, "Por ambos mundos", n. ${ }^{\circ}$ 40, 30 de octubre de 1892, p. 299.
} 
Como se puede comprender, ambas provincias constituían para el Perú "dos grandes fuentes de riquezas" ${ }^{\prime 644}$. Esas razones pusieron en el centro del debate el destino de Tacna y Arica una vez llegado el año 1894, cuando debía realizarse el plebiscito. Es por eso que "la representación diplomática del Perú en Santiago de Chile, por orden de su gobierno, desde agosto de 1892 solicitó del chileno se comenzasen a negociar las bases para que el plebiscito se pudiera celebrar en la época determinada por el pacto común"645.

Ese mismo año, una publicación oficial de España llamó la atención respecto al ingreso del problema de Tacna y Arica en una fase poco agradable ${ }^{646}$. Comprendía que había escasas posibilidades de que el conflicto se resolviese con prontitud, en el marco de la paz y de manera satisfactoria. Sus líneas hacían eco de una petición chilena de prórroga del plebiscito, no obstante, el Perú cada día demostraba mayor ansia de recobrar sus territorios perdidos.

Por el lado del Perú, un freno a sus intenciones serían sus "perturbaciones interiores" que, en el campo diplomático, habían entorpecido todos los progresos ${ }^{647}$. En tal ambiente enrarecido se formularon en la prensa las siguientes preguntas: ¿Accederá Chile a los deseos del Perú, o les pondrá reparos y obstáculos? Y en este último caso ¿se resignará éste con su suerte, o pondrá en juego, todos sus recursos sin detenerse ni aun ante la guerra a trueque de rescatar sus dos provincias? ${ }^{648}$

Ante el eventual fracaso plebiscitario, circuló en España un documento rescatado del diario tacneño El Tacora, fundado en 1883 por Roberto Freyre, que impulsaba desde sus líneas la celebración del plebiscito acordado ${ }^{649}$. En esa nota se dirigió el diplomático peruano Bendeana al chileno Anselmo Blanlot-Holley con el objetivo de estipular las siguientes cuestiones:

\footnotetext{
${ }^{644}$ Las Dominicales del Libre Pensamiento, "Perú", n. ${ }^{549,} 17$ de marzo de 1893, p. 4.

${ }^{645}$ La España Moderna, "Revista Hispanoamericana", n. ${ }^{\circ}$ 139, 1 de julio de 1900, p. 126.

${ }^{646}$ Archivo Diplomático y Consular de España, "Cuestiones Internacionales: Tacna y Arica”, n. ${ }^{\circ}$ 421, 16 de septiembre de 1892 , p. 1681.

${ }^{647}$ La España Moderna, "Revista Hispanoamericana", n. ${ }^{\circ} 139,1$ de julio de 1900, p. 126.

${ }^{648}$ Archivo Diplomático y Consular de España, "Cuestiones Internacionales: Tacna y Arica”, n. ${ }^{\circ} 421,16$ de septiembre de 1892, p. 1682.

${ }^{649}$ GARgureVich, Juan, Prensa, radio y TV. Historia crítica, Lima, Editorial Horizonte, 1987, p. 154.
} 
1. $\quad$ El Perú no aceptaría la prórroga del plazo estipulado en el Tratado de Ancón, para la verificación del plebiscito que debe solucionar la cuestión de Tacna y Arica.

2. $\quad$ El Gobierno y el pueblo peruanos no consideran como una dificultad insalvable, dado el caso que el plebiscito les favoreciera, del pago a Chile de 10 millones de pesos fuertes.

3. ${ }^{\circ} \quad$ La aspiración suprema del pueblo peruano es la revancha y el rescate de Tacna y Arica $^{650}$.

El último punto amenazó con una nueva guerra chileno-peruana ${ }^{651}$, hecho reprochado por la publicación hispana y pacifista, que propuso solucionar los diferendos como debían hacerlo los "hermanos". La postura se fundamentó en que nada era tan desastroso como la guerra, debiendo evitarla usando los buenos oficios de "las otras naciones de nuestra raza enclavadas en el continente sudamericano" ${ }^{652}$. Ese “intervencionismo pacifista" fue apoyado por otros periódicos. La idea era progresar materialmente e impedir que la guerra detenga una marcha ya ralentizada. Bajo esa premisa humanitaria la intervención de los pueblos amigos debía evitar la guerra en obsequio a la paz y al progreso de las naciones ${ }^{653}$. Por último, es interesante constatar como con anterioridad a la propuesta de arbitraje la prensa mencionó la chilenización de Tacna y Arica, proceso iniciado después del fracaso del protocolo. Desde 1892 La Moneda se encontraba trabajando en la "chilenización" y "los residentes chilenos y sus allegados que habían acudido en gran número, en estos diez años" ${ }^{654}$. Esto fue visto como una "tiranía militar" que debía finalizar, pues sólo daba miserias y gastos que no faltaban ${ }^{655}$. Finalmente, una revista laica sugirió la paz eterna para el Perú como condición obligatoria en la recuperación de su fama y puesto en la familia americana ${ }^{656}$.

\footnotetext{
${ }^{650}$ Por el contrario, hubo publicaciones seguras que de triunfar el Perú, no podría pagar la cifra que el tratado estipulaba. Eso se relacionaba con su Hacienda profundamente resentida sin condiciones de "hacer el considerable desembolso que la restitución exige". Ver: La Ilustración Española y Americana, "Por ambos mundos", n. . 40, 30 de octubre de 1892, pp. 299-302. La Nación Militar aseguraba que al momento de vencer el plazo de ocupación chilena la inestabilidad política peruana y pobreza "no le permitieron cumplir el tratado estipulado". Ver: La Nación Militar, "Los militares de América", 8 de abril de 1900, pp. 538-539.

651 Para revisar otras predicciones periodísticas sobre una futura guerra entre Chile y Perú ante el incumplimiento del Tratado de Ancón ver: La Ilustración Española y Americana, "Por ambos mundos", n. ${ }^{\text { }}$ 40, 30 de octubre de 1892, pp. 299-302.

${ }^{652}$ Archivo Diplomático y Consular de España, "Cuestiones Internacionales: Tacna y Arica”, n. ${ }^{\circ} 421,16$ de septiembre de 1892, p. 1682.

${ }^{653}$ La Ilustración Española y Americana, "Por ambos mundos", n. o 40, 30 de octubre de 1892, pp. $299-302$.

${ }^{654}$ Idem.

${ }^{655}$ La Ilustración Española y Americana, "Por ambos mundos", n. ${ }^{\circ}$ 40, 30 de octubre de 1892, p. 299.

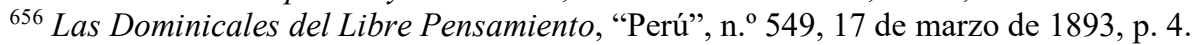




\subsection{Influencias exteriores: Argentina y Estados Unidos}

El papel de Argentina fue relevante en la tensión chileno-peruana de posguerra. En cierta manera, al igual que los demás implicados, tenía "una carga espiritual" que lo hacía proclive a la guerra, como explicó una noticia. Esa "calentura congénita de la sangre, que perturba a menudo la serenidad de la razón" ${ }^{657}$ daba pie a contemplar la posibilidad una segunda Guerra del Pacífico ${ }^{658}$. Chile y Argentina se sentían poderosos, lo que conducía a un sentimiento celoso recíproco y así, aunque vivían con aparente cortesía se odiaban cordialmente $^{659}$. El miedo a una nueva guerra condujo a la prensa a informar sobre las tropas, la preparación militar de los países y otros temas afines. Al concluir 1892 la situación militar de Perú, Bolivia y Argentina se describía de la siguiente forma: "El Perú añadiría a sus 4500 hombres de pie de paz, 6500 de la Escuela Militar y de la Guardia Cívica, y luego hasta 42000 de la Guardia Nacional"660. En el caso de Bolivia, "en cuatro o seis meses, prepararía de 16 a 20000 hombres. La Argentina dispone de su ejército permanente de 12000 y podría llegar a reunir 100 ó 150000 de la Guardia Nacional, además de su escuadra" ${ }^{661}$.

El Álbum Iberoamericano resaltó la cautela y previsión de Argentina que había desarrollado una política armamentística. Su gobierno había adquirido gran cantidad de fusiles Maüser para dotar al ejército de material moderno de guerra. De alguna forma, el pacifismo reflejado en otras publicaciones aquí se torcía, apoyado en el Derecho Internacional que permitía "apercibirse a la defensa cuando las naciones vecinas hacen alarde de querer preponderar sobre otras naciones" ${ }^{\prime 62}$. Las posibilidades de una guerra entre Chile y Argentina hacia 1896 mantenían plena vigencia ${ }^{663}$.

\footnotetext{
${ }^{657}$ La Ilustración Española y Americana, "Por ambos mundos", n. ${ }^{\circ}$ 40, 30 de octubre de 1892, p. 299.

${ }^{658}$ En Chile y en Argentina, hacia finales del siglo XIX, la formación de ejércitos profesionales fue concebida como uno de los requisitos de ingreso en la "modernidad". En ese sentido, el armamentismo obsesivo y la actualización de los saberes militares se traducían como signos inequívocos de mayor civilidad. En ambos países se adaptó el modelo prusiano y, como lo sostiene Lemogodeuc, el armamentismo permitió a Europa extender sus áreas de influencias económicas. Ver: LEMOGODEUC, Jean-Marie, América Hispánica en el siglo XX: identidades, culturas y sociedades, Caracas, Universidad Católica Andrés Bello, 2002, p. 123.

${ }^{659}$ La Ilustración Española y Americana, "Por ambos mundos", n. ${ }^{\circ}$ 40, 30 de octubre de 1892, p. 299.

${ }^{660}$ Idem.

661 Íbidem, p. 300.

${ }^{662}$ El Álbum Iberoamericano, "Crónica española y americana”, n. ${ }^{\circ}$ 24, 30 de junio de 1895, p. 278.

${ }^{663}$ Revista de Geografía Comercial, “América", n. ${ }^{\circ} 153$ y 154, 1 de mayo de 1896, p. 343.
} 
En ese escenario beligerante, las influencias de los Estados Unidos eran importantes. Por eso se estableció desde los reportajes españoles que, en caso de guerra, ese país se opondría a Chile a cambio de dominar el puerto peruano de Chimbote. Esa intención yankee se encuadraba en una guerra subterránea que a propósito del problema de Tacna y Arica se luchó entre imprentas de España y Estados Unidos. Al respecto, escribió un español: "Mala, detestable es la guerra entre pueblos hermanos; pero mucho peor es la injerencia de otros que quieran convertirse en primos, y que, con excusa de prestar un apoyo temporal, se agarran por eterno algún pedazo de la patria" ${ }^{664}$.

El plebiscito debía efectuarse en 1894 terminando la ocupación chilena; nada de eso ocurrió. En abril apareció en la prensa una nota enviada por Chile y Perú a los Estados Unidos conviniendo ambos estados el aplazamiento del plebiscito para octubre ${ }^{665}$.

La muerte del presidente peruano, el militar tarapaqueño Remigio Morales Bermúdez, ocurrida el 1 de abril de 1894, justificó el cese de los preparativos del plebiscito que estaban discutiéndose. En el parlamento chileno se leyó una nota dando cuenta del aplazamiento del plebiscito argumentándolo con el fallecimiento de Morales. Además, el mensaje dejaba constancia del aumento de la inmigración chilena en los territorios de Tacna y Arica666. El Nuevo Régimen comentaba los trabajos de los "Gobiernos chileno y peruano en preparar el plebiscito que ha de decidir la suerte de las provincias de Tacna y Arica, ayer pertenecientes al Perú y hoy bajo el dominio de Chile"667. La simpleza con que argumentaba el incumplimiento del tratado hizo afirmar al diario que no había sido posible a ambos países por dos razones, al "Gobierno de Santiago, por las revueltas políticas y el reciente encumbramiento de los liberales; al de Lima, por la muerte del Presidente Morales Bermúdez, que, como saben nuestros lectores, ha producido honda división en los partidos" $" 668$.

\footnotetext{
${ }^{664}$ La Ilustración Española y Americana, "Por ambos mundos", n. ${ }^{\circ}$ 40, 30 de octubre de 1892, p. 299.

${ }^{665}$ El Siglo Futuro, "Extranjero", 25 de abril de 1894, p. 3.

${ }^{666}$ La Correspondencia de España, "De la Agencia Fabra", 3 de junio de 1894, p. 2; El Día, "Chile", 2 de mayo de 1894, p. 2; El Nuevo Régimen, "Extranjero", 19 de mayo de 1894, p. 3; La Iberia, "Santiago de Chile", 2 de junio de 1894, p. 1; La Unión Católica, "Por telégrafo", 2 de junio de 1894, p. 2; El Siglo Futuro, "Telegrama", 2 de junio de 1894, p. 3; El Nuevo Régimen, "Chile", 9 de junio de 1894, p. 4.

${ }^{667}$ El Nuevo Régimen, "Chile", 19 de mayo de 1894, p. 3.

${ }^{668}$ Idem.
} 
El conflicto interno que generó la muerte de Morales Bermúdez se prolongó hasta entrado 1895. Clericalismo y militarismo fueron acusados como las dos plagas que azotaban al Perú desde $1821^{669}$. Una vez más la sucesión en el poder político peruano nublaba el horizonte internacional para la solución del problema de Tacna y Arica. La caída consecutiva de Justiniano Borgoño, Andrés Avelino Cáceres y Manuel Candamo Iriarte encontró solución en la persona de Nicolás de Piérola, quien asumiría el mando supremo de la nación el 8 de septiembre de 1895, entregándolo el mismo día cuatro años después.

En su presidencia, Chile, al margen del tratado, ofreció la suma de quince millones de pesos por las provincias de Tacna y Arica ${ }^{670}$. A la par, en el mensaje presidencial de apertura del Congreso chileno de 1896, la máxima autoridad preveía la pronta solución "de las dificultades pendientes con el Perú respecto a los territorios de Tacna y Arica"671. En el caso de la apertura del Congreso peruano, la situación fue idéntica. El mensaje presidencial en aquella ocasión hizo "constar que el Perú podrá recuperar en breve a Tacna y Arica sin impuestos adicionales" 672 .

\subsection{El arbitraje de España en la prensa}

Antes del ingreso español en la escena diplomática se rumoreó que Chile había resuelto el diferendo devolviendo íntegramente las provincias al Perú ${ }^{673}$. La fuente del rumor provino de Valparaíso. Meses después, el 1 de mayo de 1898, apareció en la prensa el arbitraje de España en el conflicto. La información breve, titulada "arbitraje por España" señaló que "En Santiago de Chile (Perú) (sic) han decidido someter a un plebiscito la propiedad de las provincias de Ragna (sic) y Arica, y pedir a la Reina de España decida las condiciones del plebiscito. (Fabra)"674.

\footnotetext{
${ }^{669}$ Las Dominicales del Libre Pensamiento, "La Guerra del Perú", n. ${ }^{\circ} 663,26$ de abril de 1895, p. 4.

${ }^{670}$ Revista de Geografía Comercial, "América”, n. ${ }^{\circ} 153$ y 154, 1 de mayo de 1896, p. 7.

${ }^{671}$ La Época, "Apertura del Congreso chileno", 2 de junio de 1896, p. 3; El País, "Congreso de Chile", 3 de junio de 1896, p. 3; La Correspondencia de España, "Telegramas”, 3 de junio de 1896, p. 3.

${ }^{672}$ El País, "Mensaje presidencial", 14 de agosto de 1897, p. 2; El Siglo Futuro, "Mensaje presidencial", 14 de agosto de 1897, p. 3; La Unión Católica, "Mensaje presidencial", 14 de agosto de 1897, p. 3.

${ }^{673}$ El Nuevo Régimen, "Chile", 12 de febrero de 1898, p. 2.

${ }^{674}$ El Imparcial, "Arbitraje por España", 1 de mayo de 1898, p. 3; El Globo, "Un plebiscito", 1 de mayo de 1898, p. 3; El Día, "Un plebiscito", 1 de mayo de 1898, p. 1; Ilustración Católica de España, "Historia al día", n. 9, 15 de mayo de 1898, p. 14; La Opinión, "Crónica”, 6 de junio de 1898, p. 2.
} 


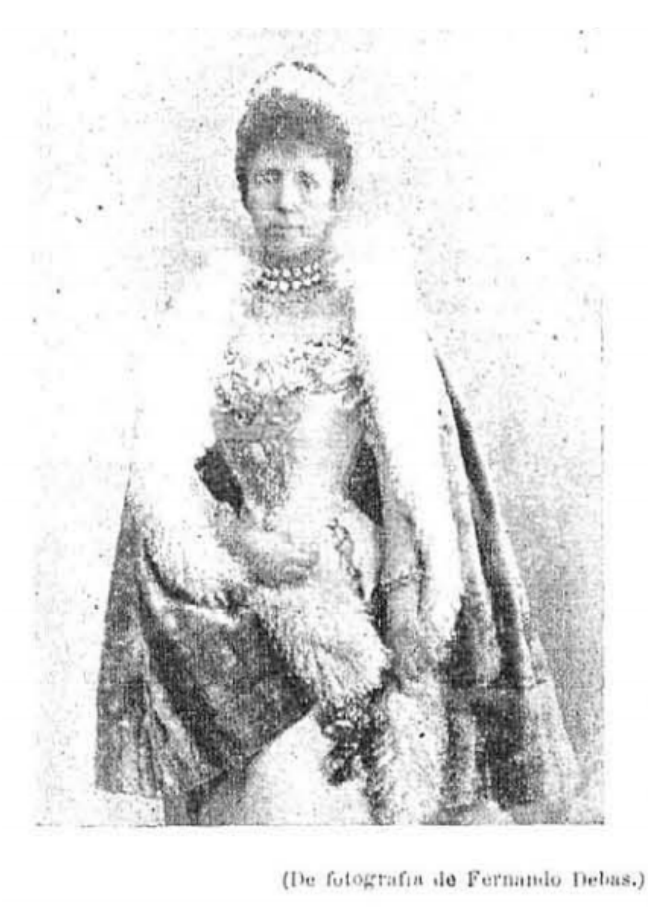

\section{S. M. LA REINA REGGENTE DE ESPANA}

Fuente: La Época, “S. M. la Reina Regente de España”, 25 de diciembre de 1896, p. 2.

Con mayor profundidad el Diario Oficial de Avisos informó que el Congreso peruano había comenzado a discutir el protocolo Billinghurst-Latorre para resolver la cuestión de Tacna y Arica. La noticia explicaba que, en virtud de lo establecido en él, se debería realizar en la región un plebiscito presidido por tres delegados de cada país. El objetivo del mecanismo electoral resolvería si ambas provincias continuaban siendo chilenas o volverían a ser peruanas. La importancia del árbitro español radicaba en el papel concedido. En rigor, el artículo n. ${ }^{\circ} 1$ del protocolo Billinghurst-Latorre, en sus apartados primero y segundo otorgaba a España la decisión respecto a quienes tenían derecho a participar en la votación plebiscitaria, determinando los requisitos de nacionalidad, sexo, edad, estado civil, residencia y cualquiera otro que debían reunir los votantes y, también, si el voto debía ser público o secreto ${ }^{675}$.

\footnotetext{
${ }^{675}$ La Época, "El taller de noticias falsas", 4 de julio de 1898, p. 2; El Imparcial, "Chile y el Perú. Arbitraje de la reina Regente de España", 8 de julio de 1898, p. 2; La Época, "El arbitraje de España sobre Tacna y Arica", 4 de octubre de 1898, p. 1; El Nuevo Régimen, "Chile y el Perú", 13 de mayo de 1899, p. 1.
} 
El país favorecido por los votos de los electores - concluía la nota- tomaría posesión “inmediatamente de las referidas provincias, y pagará al otro los 19 millones acordados en el Tratado de Ancón. Esta deuda quedará garantizada por los rendimientos de la Aduana de Arica" ${ }^{" 676}$. Al parecer, la certidumbre en la realización del plebiscito durante los días posteriores a la aceptación del gobierno español era indudable. El embajador español en Santiago, Salvador López Guijarro, había comunicado que "en término de cuarenta días habrá de procederse a las operaciones de su ejecución"677.

\subsection{Repercusiones del arbitraje español en los Estados Unidos}

La elección realizada por Chile y Perú para confiar a España el arbitraje así como su pronta aceptación generó un resentimiento en los afanes de influencia y dominación política estadounidense. Algunos diarios españoles acusaron a la prensa de ese país de ser un "taller de noticias falsas contra España en América" ${ }^{678}$, en los momentos en que no cejaban en su propósito de arrojarlos de la soberanía de todo el territorio americano. Se refirieron a la prensa estadounidense en términos despectivos por auspiciar publicaciones dañinas y desapegadas a la verdad en contra de las instituciones españolas para boicotear el arbitraje en la cuestión de Tacna y Arica ${ }^{679}$.

En el mismo sentido, se acusó a Inglaterra de poner en circulación noticias que hablaban de un estallido revolucionario en Madrid en el que murieron Segismundo Moret y el General Martínez Campos. En aquella revuelta, Mateo Sagasta se habría refugiado en la Embajada inglesa. Esos hechos fueron comentados en Santiago y Lima en donde algunos periódicos pidieron que se nombrase a un nuevo árbitro. Sin embargo, "los ministros de los dos gobiernos, peruano y chileno, no se dejaron influir por la marejada que levantó la falsa noticia, que, como es natural, a los dos o tres días quedó desmentida" ${ }^{680}$.

\footnotetext{
${ }^{676}$ Diario Oficial de Avisos de Madrid, "Extranjero", 21 de junio de 1898, p. 1.

${ }^{677}$ La Correspondencia de España, "Ecos del día", 17 de septiembre de 1898, p. 2.

${ }^{678}$ La Época, "El taller de noticias falsas", 4 de julio de 1898, p. 2; El Siglo Futuro, "Arbitraje de España entre Chile y Perú", 5 de julio de 1898, p. 1.

${ }^{679}$ La Época, "El Ministro de España en la Argentina", 22 de agosto de 1898, p. 4.

${ }^{680}$ La Época, "El taller de noticias falsas", 4 de julio de 1898, p. 2.
} 


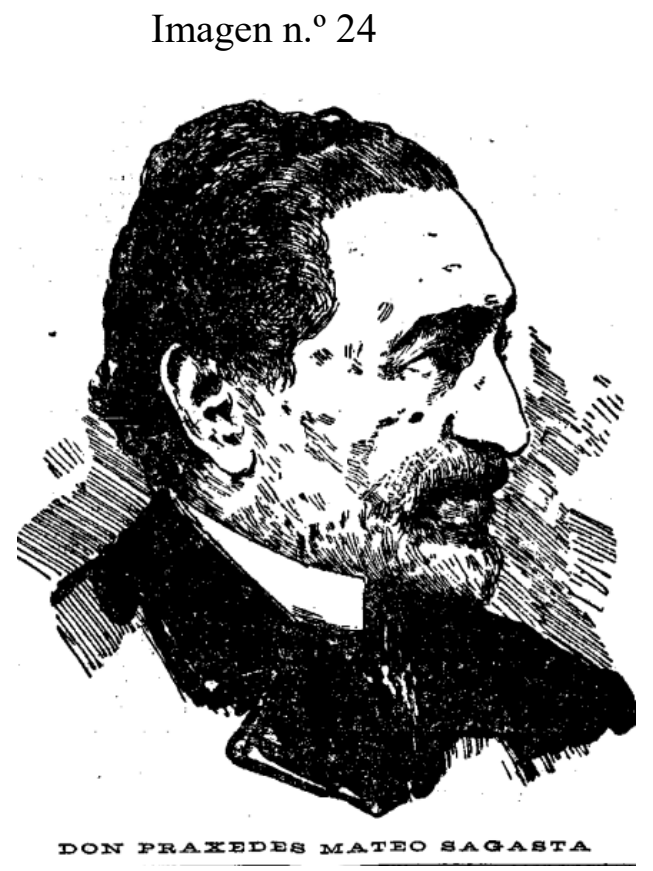

Fuente: Heraldo de Madrid, "Las Cortes actuales (Mateo Sagasta)", 11 de junio de 1901, p. 2.

La actitud contraria al arbitraje español de los Estados Unidos e Inglaterra tenía por objetivo "dejar en desaire la elección puesta para un papel tan delicado en el Gobierno de S. M. la Reina Regente" ${ }^{981}$. La mentira periodística asumida por los anglosajones tenía una vieja data, pero había sido incrementada en la coyuntura bélica de 1898 .

Estados Unidos -escribió un hombre de prensa- se siente avaro de "nuestras" posesiones coloniales en América, en Asia y en las islas del Mar Boreal, informando, por vía de los telégrafos, que las instituciones fundamentales de España se hallaban en inminente peligro de desaparecer. Unos años antes, en 1881, cuando para definir cuestiones similares a las de Tacna y Arica, los gobiernos de Colombia y Costa Rica solicitaron los buenos oficios del Rey de los Belgas, Leopoldo, y del Rey de España Alfonso XII "El Pacificador", Estados Unidos realizó su mejor labor obstructiva en las mediaciones. En 1900, cuando el arbitraje español se mostraba imposible por diversas razones, no faltó la publicación española que vio en esa caída la participación una "mano oculta de poderosa influencia" ${ }^{682}$.

${ }^{681}$ La Época, "El arbitraje de España sobre Tacna y Arica", 2 de septiembre de 1898, p. 1.
682 La España Moderna "Revista Hispanoamericana", n ${ }^{\circ} 139,1$ de julio de 1900, p. 126. 
El delirio de la prensa causado por la actitud de los Estados Unidos e Inglaterra hizo sospechar la existencia de "pacto secreto" entre esos países para aniquilar toda presencia española en América. El problema tuvo una justificación de índole racial. En ese panorama, pugnaban las "razas" sajona y latina, por lo que no era ingenuo preguntarse -escribía un diario- si no deberían unirse los latinos para detener esa situación ${ }^{683}$.

La respuesta española a los ataques periodísticos estadounidenses se sostuvo en el hispanoamericanismo. El reconocimiento mutuo entre España y América, de fuertes lazos comunes, permitía actos de confianza como la designación arbitral. El problema de Tacna y Arica y la firma del protocolo era un ejemplo concreto de cómo se continuaba mirando a la "madre patria" para resolver conflictos entre sus hijos ${ }^{684}$.

El peso de una historia común no podía borrarse como lo pretendían los Estados Unidos. Juan Pérez de Guzmán y Gallo, historiador español, evidenció su pacifismo hispanoamericanista haciendo público su "amor a aquellas repúblicas disgregadas del seno de España [lo que] nos mueve a desear ardientemente que la paz no se interrumpa entre ellas”685. Por eso también la prensa se caracterizó por reafirmar su influencia política, oponiendo resistencia al interés estadounidense en la región. De algún modo había que mantener y aprovechar, en el plano económico, "los vínculos históricos, [...] étnicos, [...] de la sangre" ${ }^{" 686}$. La prensa apelaba a la comunidad americana a que tomase conciencia de que la única amenaza a su soberanía provenía desde Estados Unidos ${ }^{687}$ y se esforzó por mantener el relato "civilizador" de España en América. Una de las páginas que sacralizaba las relaciones entre España y las comunidades precolombinas entendió que España hizo América. El cristianismo era el motor "civilizador", los conquistadores artífices de la "renovación social", la escolástica el pensamiento que conducía a la "civilización intelectual”, los magistrados observadores de la disciplina gubernamental y de la justicia, etc. ${ }^{688}$.

\footnotetext{
${ }^{683}$ El Nuevo Régimen, "Las alianzas", 17 de noviembre de 1900, p. 1.

${ }^{684}$ La Época, "Carta del Perú", 23 de septiembre de 1898, p. 2.

${ }^{685}$ La Epoca, "Chile y la Argentina", 9 de septiembre de 1898, p. 1.

${ }^{686}$ La España Moderna, "Revista Hispanoamericana", n. ${ }^{\circ} 139,1$ de julio de 1900, p. 126.

${ }^{687}$ La España Moderna, "Revista Hispanoamericana", n. ${ }^{\circ} 132,1$ de diciembre de 1899, p. 191.

${ }^{688}$ La Época, "El arbitraje de España sobre Tacna y Arica", 2 de septiembre de 1898, p. 1.
} 
5.5. Efectos del arbitraje en la política chilena y peruana

En ese conjunto de ideas, se condenaría desde la prensa con vocación hispanoamericanista toda referencia a Estados Unidos como mediador del problema entre Chile y Perú. Si bien desde la imprenta era dificultoso intervenir directamente en la elite chileno-peruana que miraba con agrado los buenos oficios estadounidenses, excluyendo, a la par, a los europeos en el problema, los periódicos no darían por olvidada la batalla ideológica. La pérdida de Cuba, Puerto Rico y Filipinas, todas relacionadas con el imperialismo estadounidense reforzaban la actitud en contra del país del norte.

Para la época del cambio de siglo, en Perú se escucharon cada vez más fuerte dos planteamientos cívicos respecto al futuro de Tacna y Arica, siendo uno colectivo y otro más bien personal. El primero suscitó interés en la prensa española que se refirió, en noticia aparecida el 31 de diciembre de 1898, a los movimientos revolucionarios contrarios al apoyo que el Congreso extraordinario había mostrado al protocolo. El estado de anomia causado por el próximo plebiscito repercutió en la suspensión de garantías constitucionales "para prevenir y conjurar las tentativas iniciadas contra las instituciones" 689.

Un político peruano, Alejandro Garland, que aspiraba a un cargo diplomático en Washington, publicó un folleto titulado El problema de Tacna y Arica ${ }^{690}$ en el cual, luego de hacer un análisis a la luz del derecho internacional, sugirió que Perú se pusiese bajo la protección inmediata de los Estados Unidos “ofreciéndole por precio de esta protección todo linaje de privilegios políticos y comerciales, sino hasta islas y territorios para sus estaciones navales y sus depósitos de carbón y comercio en las fronteras de Chile"691. Garland fue acusado en la prensa española de ser un folletinista aprovechador. La burla a su propuesta internacional le hizo ganar el apodo de "Míster", por utilizar el problema de Tacna y Arica para favorecer la política estadounidense encabezada por James Blaine, Secretario de Estado, encaminada a buscar la aproximación del Perú con la potencia del norte.

\footnotetext{
${ }^{689}$ La Correspondencia, "Del extranjero", 31 de diciembre de 1898, p. 1.

${ }^{690}$ Garland, Alejandro, El problema de Tacna y Arica. Confidencial, Lima, Imprenta La Industria, 1900.

${ }^{691}$ La España Moderna, "Revista Hispanoamericana", n. ${ }^{\circ}$ 139, 1 de julio de 1900, p. 126; El Nuevo Régimen, "Tacna y Arica", 13 de octubre de 1900, p. 1; La Época, "Las repúblicas territoriales en las repúblicas sudamericanas", 14 de octubre de 1900, p. 2.
} 
En función de eso una publicación preguntó ¿Es esta sólo una actitud de defensa contra Chile en la cuestión de Tacna y Arica? ¿No hay términos posibles de un arreglo de este asunto en una inteligencia común entre los Gobiernos de Chile, Perú, Argentina y Bolivia? ¿Qué significa esta apelación a la intervención de los Estados Unidos? Las respuestas eran concretas. Si Perú aceptaba esa intervención abjuraría de su origen y abdicaría de su independencia, pues "los poderosos nunca intervienen sin cobrar harto caro el precio de su intervención" ${ }^{692}$. El afán peruano en conseguir apoyo yankee continuó, al tiempo que se acercó a otras repúblicas. La intención era rescatar Tacna y Arica finalizando la ocupación ilegal de Chile, el "pequeño coloso naval del extremo austral del Pacífico"693.

El apoyo de esa última idea se reafirmó en la prensa que ordenó: "Desistan [...] de intervenciones extrañas y no den injerencias en sus negocios íntimos a rivales poderosos" ${ }^{\prime 64}$. Nos interesa plantear las preguntas que referidas a lo anterior circularon en España constatando la agitada diplomacia sudamericana. ¿No tenemos al Perú -publicóbuscando contra Chile, las alianzas de la Argentina, de Bolivia, del Paraguay, del Brasil, en el largo litigio de sus provincias cautivas y "no teniendo gran confianza en arrastrar a estos aliados [...] negocia la alianza con los Estados Unidos [...] para llevarle a intervenir?" ${ }^{995}$.

¿Qué aspectos vieron los diplomáticos chilenos y peruanos para requerir de los servicios de España en el problema de Tacna y Arica? La respuesta no está cerrada y la literatura revisada no le ha dado mayor importancia. La lectura de las fuentes de prensa nos permite pensar que la labor pulcra del plenipotenciario español en Lima, Julio Arellano, habría influido en que se pensase en los buenos oficios de España. Un diario sostuvo que "tal vez a este prestigio y a esta influencia fuera debida la designación de S.M. la Reina Regenta para el alto arbitraje sobre los territorios de Tacna y Arica, en que los gobiernos de Chile y Perú están empeñados"696.

\footnotetext{
${ }^{692}$ La España Moderna, "Revista Hispanoamericana", n. ${ }^{\circ}$ 139, 1 de julio de 1900, p. 126.

${ }^{693}$ La España Moderna, "Revista Hispanoamericana", n. ${ }^{\circ} 140,1$ de agosto de 1900, p. 147; El Nuevo Régimen, "Tacna y Arica", 13 de octubre de 1900, p. 1.

${ }^{694}$ La Época, "El problema del Pacífico en la América del Sur", 9 de octubre de 1900, p. 3; El Nuevo Régimen, "Tacna y Arica", 13 de octubre de 1900, p. 1; El Álbum Iberoamericano, "Chile, Perú y Bolivia", 30 de noviembre de 1900, p. 518.

${ }^{695}$ La España Moderna, "Revista Hispanoamericana", n. ${ }^{\circ}$ 140, 1 de agosto de 1900, p. 147.

${ }^{696}$ La Época, "El Ministro de España en la Argentina", 22 de agosto de 1898, p. 4.
} 
Por otro lado, existió la posibilidad de que el presidente de Chile, Federico Errázuriz Echaurren y el vicepresidente del Perú, Guillermo Billinghurst, hayan pensado en la regencia de María Cristina aprovechando el restablecimiento de las relaciones internacionales con la antigua metrópoli. Otro indicador relevante fue la concesión de la condecoración de la Gran Cruz de Isabel la Católica al presidente chileno, el 9 de abril de 1897.

El hecho de que el surgimiento de la idea ocurriese en Chile se sustenta además en que allí, luego de una reunión entre los políticos mencionados, se citase al Ministro de España en Chile, Salvador López Guijarro, quien, a pesar de su agitada vida privada, tenía en Santiago grandes simpatías ${ }^{697}$. López Guijarro, quien en 1895 había asumido el cargo de representar a la reina María Cristina en Chile ${ }^{698}$, había gestionado con ese país un tratado de extradición, beneficios de indemnizaciones para súbditos españoles durante la guerra del Pacífico y la guerra civil de 1891 y, por último, había prestado "grandes servicios en contra de la solapada propaganda filibustera en contra de los Sres. Hortos y Agüero y otros, cuyo resultado fue anularla completamente" ${ }^{\circ 99}$.

En contra de lo que se podría pensar, el arbitraje español acordado el 16 de abril de 1898 no detuvo el temor a la guerra. Por el contrario, el armamentismo en Chile y Perú continuó, como fue la tónica, después de la Guerra del Pacífico. Su firma pareció destinada al fracaso, pues sólo nueve días después el Congreso estadounidense declaró la guerra a España colocando en el centro del debate político y periodístico español a la isla de Cuba. De todos modos, el Ministro de España en Lima, Julio Arellano, anunció en esa capital el 6 de agosto que el gobierno de María Cristina había aceptado "con gusto ser árbitro entre el Perú y Chile en la cuestión del plebiscito sobre Tacna y Arica"700.

\footnotetext{
${ }^{697}$ La Época, "El arbitraje de España entre Chile y Perú", 23 de agosto de 1898, p. 3; El Globo, "El arbitraje de España entre Chile y Perú", 24 de agosto de 1898, p. 3.

${ }^{698}$ ESTRADA TURRA, Baldomero, "La historia infausta de la inmigración española en Chile a través de los conflictos comerciales y políticos", Revista Historia, n. ${ }^{\circ}$ 35, Chile, 2002, $<$ http://revistahistoria.uc.cl/estudios/1865/> [consultado el: 25/12/1925].

${ }^{699}$ El Eco de Santiago, "De todas partes", 27 de agosto de 1898, p. 4.

${ }^{700}$ La Época, "Notas de última hora", 30 de agosto de 1898, p. 3; El Imparcial, "La cuestión chileno peruana", 31 de agosto de 1898, p. 1. La Época, "El arbitraje de España sobre Tacna y Arica", 2 de septiembre de 1898, p. 1.
} 
De todos modos el arbitraje español en la cuestión de Tacna y Arica quedó relegado a un segundo plano en la prensa española. Un periodista se arriesgó a comentar la posibilidad de que el problema cubano se resolviese utilizando un arbitraje como el acordado por Chile y Perú en la cuestión de Tacna y Arica ${ }^{701}$. En el hemisferio sur, el Perú de Nicolás de Piérola declaró inmediatamente la neutralidad de su país en el conflicto entre Estados Unidos y España. Esa actitud fue continuada por Chile, lo que permitió asegurar a un diario madrileño que los lazos de la sangre, del culto, de la lengua, de la historia y de las costumbres, habían mantenido en ambos países los "vínculos de mutuo afecto entre la gran familia española de los dos mundos"702.

En el senado peruano el protocolo para el arbitraje de España se aprobó por 34 votos a favor frente a 9 y en la Cámara de Diputados el resultado a favor fue de 81 frente a 18 . Los votos en contra argumentaron que algunas insinuaciones apoyadas por la prensa estadounidense en lo tocante a la fragilidad del sistema político español eran reales. Por ejemplo, el Partido Constitucional del Perú se preguntaba qué sucedería con el plebiscito si "la versatilidad de los acontecimientos humanos hacía desaparecer la Regencia de España"703, el Partido Unión Nacional temía que la Corona española no ofreciera garantías. El órgano de prensa más importante del país, El Comercio, sin ningún respeto, como prologó un diario español, publicó:

A nuestro juicio ese arreglo es aceptable. Dijimos desde que se conocieron sus principales estipulaciones, y en ello insistimos ahora, que parecía un error haber designado al Gobierno de la Reina de España como árbitro de las cuestiones que el protocolo deja planteadas y no resueltas.

En efecto, cuando ese documento se firmó, la guerra entre España y los Estados Unidos era un hecho; y aparte de las consideraciones de que es posible que la contienda dé por resultado la desaparición del Gobierno de la Reina y aún del régimen que este encarna en España, es incuestionable que, por lo menos, ese Gobierno no se encontrará durante mucho tiempo en condiciones de dedicar su atención a asuntos de la naturaleza del que le sometemos; lo cual pueda dar por resultado que si, por complacer al Perú y Chile, lo hace en plazo en breve, su fallo no sea tan acertado como nuestros derechos evidentes lo exigen para quedar ampliamente satisfechos ${ }^{704}$.

\footnotetext{
${ }^{701}$ La Época, "Las negociaciones sobre la paz", 22 de julio de 1898, p. 1; El País, "Negociaciones de paz", 23 de julio de 1898, p. 2; El Liberal, "Las negociaciones sobre la paz", 29 de julio de 1898, p. 1.

${ }^{702}$ La Época, "Tratado de paz y amistad con el Perú", 30 de julio de 1898, p. 2; La Dinastía, "Tratado de paz y amistad con el Perú", 2 de agosto de 1898, p. 1.

${ }^{703}$ La Época, "El arbitraje de España sobre Tacna y Arica", 2 de septiembre de 1898, p. 1.

${ }^{704}$ Idem. (Las cursivas aparecen en el original).
} 
Es probable que los acontecimientos en el Atlántico norte hicieran dudar al Perú sobre la realización del plebiscito. De todos modos, mientras confiaban en Chile los rumores de guerra contra Argentina lo distraían de su compromiso con Perú. Sobre este último país comenzaron a publicarse cifras relativas a su solvencia económica para realizar, de ser necesario, el pago por Tacna y Arica que ascendía a "un millón de duros"705. En relación con ello, Piérola, en su mensaje de 1898, dijo que el producto del monopolio de la sal había elevado a 734000 soles las ganancias del Estado, lo que permitiría pagar inmediatamente a Chile por Tacna y Arica. Por el contrario, una revista crítica de esa solvencia opinó que el Perú no exigió el cumplimiento de lo pactado, “debido a la escasez de recursos con que cuenta actualmente, pues [...] atraviesa una crisis económica"706.

Antes de finalizar este año clave, en Perú y España persistía la creencia en el plebiscito. En un plazo no lejano -difundió una revista- debe modificarse la geografía sudamericana. A ello se sumaba la confianza de que Tacna y Arica volverían al seno de su patria histórica ${ }^{707}$. Nicolás de Piérola, por su parte, en la apertura de la legislatura ordinaria leyó un mensaje donde explicó que en el problema de Tacna y Arica solo se esperaba el voto de los diputados chilenos "para entrar en inmediata ejecución"708.

Una de las escasas fuentes españolas que se alineó con Chile afirmaba lo contrario. Manuel Cabrinety y Guteras deseaba, claramente, que Tacna y Arica quedasen en posesión de Chile, puesto que a su amparo habían florecido y desarrollado el comercio y la industria "más que todo el tiempo que permanecieron unidas a su primitiva patria"709. Cabrinety había sido nombrado Director de la Escuela de Pilotos de Chile, por lo que no era extraño su discurso sobre la modernidad. Mientras Chile representaba el empuje de la civilización, Perú era un sinónimo de atraso y ausencia de progreso. Esas visiones rivalizaron en el plano de las ideas marcando, al separarse Tacna y Arica, el tránsito histórico de ambas ciudades durante el siglo XX.

\footnotetext{
${ }^{705}$ La Época, "Perú y Chile", 31 de julio de 1898, p. 3; El Siglo Futuro, "Telegramas de la Agencia Fabra", 31 de julio de 1898, p. 2; El Día, "Pago de una indemnización", 31 de julio de 1898, p. 3; El Globo, "El arbitraje de España entre Chile y el Perú", 1 de agosto de 1898, p. 2; Heraldo de Zamora, "Telegramas del extranjero", 1 de agosto de 1898, p. 2.

${ }^{706}$ El Mundo Naval Ilustrado, "Tacna y Arica", n. ' 33, 1 de septiembre de 1898, p. 18.

${ }^{707}$ Idem.

${ }^{708}$ La Época, "Carta del Perú", 23 de septiembre de 1898, p. 2.

${ }^{709}$ El Mundo Naval Ilustrado, "Tacna y Arica", n. ${ }^{\circ} 33,1$ de septiembre de 1898, p. 18.
} 
Para fines de 1898 la situación diplomática se tensó. En España se acusó a la política exterior chilena y peruana de ineficacia, mientras persistía la valoración positiva hacia el árbitro español. Pese a la guerra con los Estados Unidos, España mantenía un vivo interés en el problema de Tacna y Arica por tres razones fundamentales. En primer lugar, por estar en el área de influencia del hispanoamericanismo; luego por albergar ambos países una numerosa colonia española y, en tercer lugar, por mantener relaciones políticas y comerciales.

Como se explicó, el poder legislativo peruano había aprobado con rapidez el arbitraje, pero en Chile la situación se dilató. Mientras el senado aceptó, la Cámara de diputados evidenció una demora que en el Perú se consideró injustificada ${ }^{710}$. Las razones de esa demora, según la prensa española, se debían a la amenaza "real" de guerra entre Chile y Argentina. En aquella situación, los diputados chilenos consideraron oportuno quitarle urgencia a la discusión para:

1. ${ }^{\circ},[\ldots]$ obligar a la Cámara a permanecer reunida todo el mes de Septiembre en expectación de lo que pueda ocurrir en el conflicto pendiente entre Chile y la Argentina; 2. ${ }^{\circ}$, para no prestar esa prenda al Perú, hasta ver si las hostilidades se rompen con la Argentina, y la actitud que el Perú toma en pro o en contra de algunos de los dos beligerantes; $3 .^{\circ}$, para no conceder al Perú en esta cuestión, y a Bolivia en otro protocolo también de fronteras, ventajas sobre los territorios que disfrutan, antes de medir el éxito del grave problema pendiente del otro lado de la cordillera ${ }^{711}$.

La oposición de la Cámara de diputados de Chile a la aprobación del protocolo estuvo a punto de provocar una "crisis ministerial"712. En España, su actitud hizo que en el Consejo de Ministros de la Regencia de 3 de octubre de 1898 se designara para el estudio del plebiscito a José Fernández Jiménez, anterior subsecretario de Estado. El gobierno español esperará "los datos necesarios para el exacto conocimiento de la cuestión" "713. Esos datos nunca cruzarían el Atlántico.

\footnotetext{
${ }^{710}$ El Día, "De ayer a hoy", 17 de septiembre de 1898, p. 1; El Imparcial, "Un arbitraje de España", 20 de septiembre de 1898, p. 3; La Época, "Un arbitraje de España", 20 de septiembre de 1898, p. 1.

${ }^{711}$ La Época, "Arbitraje de España entre el Perú y Chile”, 20 de septiembre de 1898, p. 1.

${ }^{712}$ La Época, "Noticias de Chile", 27 de septiembre de 1898, p. 3.

${ }^{713}$ La Época, "El arbitraje de España sobre Tacna y Arica", 4 de octubre de 1898, p. 1; La España Moderna, "Revista Hispanoamericana", n. ${ }^{\circ}$ 139, 1 de julio de 1900, p. 126.
} 
El problema de Tacna y Arica generó discusiones en extremo violentas. El apasionamiento de los políticos en este tema y la presión ejercida desde las fronteras vecinas hicieron que el lenguaje retórico diera paso a palabras altisonantes. Por eso, las sesiones de los diputados se realizaron a puerta cerrada. De todas formas en España se publicó, como una anécdota, la irritabilidad de algunos políticos chilenos. El caso de los diputados Ibáñez y Pinto en la sesión del 3 de agosto de 1898 fue descrita de la siguiente forma: “[...] habiendo este último acusado al primero de estar obstruyendo la aprobación, y provocando una contestación brusca de Ibáñez, que Pinto Agüero calificó de insolente, salieron de la Cámara desafiados, y aún se concertó entre padrinos el duelo a pistola"714.

Otra razón que ayuda a comprender la posición de los diputados chilenos se relaciona con la demografía de Tacna y Arica. En una sesión de la Cámara, el reconocido diputado ultranacionalista, Abraham Konig, entregó cifras sobre la población chilena y peruana existente en las provincias del norte. De realizarse el plebiscito, el resultado favorecería al Perú, si es que todos sus ciudadanos votaban por esa nación y no se presentaba alguna "anomalía". Los datos no estaban actualizados, pero podrían servir como reflejo de la población hacia 1898. Ésta ascendía a 24500 habitantes, de los que 3294 gozaban de derecho de voto $^{715}$. En la siguiente tabla se incluyen datos del año 1907 concernientes a la nacionalidad de los extranjeros residentes en Tacna y Arica. Los españoles residentes en la zona de conflicto superaban los setenta.

Tabla $n^{\circ} 8$

Nacionalidad de los habitantes de Tacna y Arica en 1907

\begin{tabular}{|l|r|}
\hline \multicolumn{1}{|c|}{ Nacionalidad } & Habitantes con derecho a voto \\
\hline Perú & 2142 \\
\hline Chile & 402 \\
\hline Bolivia & 350 \\
\hline Otras nacionalidades & 400 \\
\hline Total & 3294 \\
\hline
\end{tabular}

Fuente: Elaboración propia basada en: La Época, "El arbitraje de España sobre Tacna y Arica”, 4 de octubre de 1898, p. 1.

\footnotetext{
${ }^{714}$ La Época, "El arbitraje de España sobre Tacna y Arica", 4 de octubre de 1898, p. 1.

715 Idem.
} 
Tabla n. ${ }^{\circ} 9$

Nacionalidad de los extranjeros con distinción del sexo

\begin{tabular}{|l|r|r|r|l|r|r|r|}
\hline \multirow{2}{*}{ Nacionalidad } & \multicolumn{3}{|c|}{} & \multirow{2}{*}{ Nacionalidad } & \multicolumn{3}{|c|}{} \\
\cline { 2 - 8 } & $\mathrm{V}$ & $\mathrm{M}$ & Total & & $\mathrm{V}$ & $\mathrm{M}$ & Total \\
\hline Alemania & 24 & 8 & 32 & España & 45 & 33 & 78 \\
\hline Argentina & 17 & 8 & 25 & Estados Unidos & 2 & 0 & 2 \\
\hline Austria-Hungría & 6 & 2 & 8 & Francia & 10 & 9 & 19 \\
\hline Bolivia & 1038 & 683 & 1721 & Gran Bretaña & 13 & 18 & 31 \\
\hline Brasil & 1 & 0 & 1 & Italia & 169 & 61 & 230 \\
\hline Colombia & 2 & 1 & 3 & Portugal & 1 & 0 & 1 \\
\hline China & 48 & 0 & 48 & Suiza & 3 & 2 & 5 \\
\hline Dinamarca & 0 & 1 & 1 & Turquía & 1 & 0 & 1 \\
\hline Ecuador & 4 & 2 & 6 & Total & 1384 & 828 & 2212 \\
\hline
\end{tabular}

Fuente: RePÚBliCA DE CHILE, Memoria presentada al Supremo Gobierno por la Comisión Central del Censo, Santiago, Oficina Central de Estadística, Sociedad Imp. y Lit. Universo, 1908, p. 11. (Donde V: varón y M: mujer).

En el Perú la situación no era mejor. Una revista laica de España dio a conocer un discurso del ensayista y anarquista peruano Manuel González Prada en el que hacía un llamamiento a la guerra contra Chile. Proponía a su pueblo asumir una posición clara en los momentos en que Argentina amenazaba los territorios del extremo sur de Chile. Así mismo, apoyaba una triple alianza entre su país y Bolivia-Argentina, porque la neutralidad podía ser mirada como una manifestación hostil a sus vecinos diplomáticamente más cercanos. González no temía establecer lazos otra vez con Bolivia, aun cuando los recuerdos de esa unión fueran tristes. La alianza de peruanos y bolivianos en 1879, dijo, recuerda la fraternidad de Sancho y don Quijote, "pues en las desventuradas aventuras de la guerra ellos salvaban el cuerpo y nosotros recibíamos los palos" ${ }^{716}$. Refiriéndose al protocolo de Tacna y Arica, lo criticó por considerarlo una artimaña más de Chile para "arrullar" al Perú con ternura y promesas de amistad. Y previó lo que sucedería:

¡Qué, si hoy mismo, amenazado por una guerra exterior, quizá en vísperas de una espantosa contienda civil, arruinando en su crédito con enormes deudas fiscales, casi a la orilla del abismo, cuando debería obligarnos con su lealtad y su buena fe, se burla de nosotros con un insidioso protocolo, donde, lejos de concedernos esperanzas de reivindicar Tacna y Arica, nos envuelve en una interminable serie de cuestiones para desorientarnos...! $!^{717}$.

\footnotetext{
${ }^{716}$ Las Dominicales del Libre Pensamiento, "Flagelación en el Perú", n. ${ }^{\circ}$ 355, 24 de noviembre de 1898, p. 2. ${ }^{717}$ Idem.
} 
En España, parte de la prensa que siguió el problema de Tacna y Arica, hizo suya la interpretación de González Prada que compartía un grupo de políticos peruanos. Se acusó a Chile de dilatar la solución de las provincias cautivas aprovechando "el minuto de tregua y la esperanza de reconciliación con la Argentina"718. Así, en 1899 los cimientos del plebiscito comenzaban a tambalearse. La estrategia política de Chile no fue más que una "triquiñuela de habilidad dudosa para dejar dilatado y embarazado el asunto"719.

Según esa visión, Chile buscó al Perú como aliado en caso de guerra con Argentina, encuadrado en su política "cartaginesa". Con ínfulas de "conquistador" destruía el protocolo mostrando su desinterés en efectuar el plebiscito ${ }^{720}$. El Nuevo Régimen imputó a Chile no haber devuelto Tacna y Arica una vez vencido el plazo de ocupación y de suscitar problemas sobre quienes debían votar en el plebiscito. A lo anterior se sumaba el hecho de que "ni aún después de habérsela decidido por un arbitraje, se aviene a restituirlas ni a inquirir el voto de los que habitan"721. La solución del diferendo quedaba en Chile por ser ese el país que debía encauzar su compromiso de $1898^{722}$.

De modo opuesto a la mayor parte de la muestra de prensa, poseemos escasos documentos críticos con su gobierno. Uno de ellos comentó la extrañeza que le causó el que Chile y Perú escogiesen por árbitro a un gobierno que "jamás ha pensado en ningún plebiscito, ni jamás ha tenido la más remota idea de resolver por él ninguna de las muchas cuestiones que lo aconsejaban y aun lo imponían"723. Por otro lado, La España Moderna, que en la mayoría de sus escritos atacó los procedimientos diplomáticos chilenos, en algunas publicaciones futuras equilibraría su visión. Así se desprende al leer un párrafo referido a la designación de la Reina Regente de España como árbitro. En él se explicó que ni Chile ni Perú estaban en una situación económica favorable para realizar el pago por Tacna y Arica. Ambos países no se habían "preparado en este terreno a la última consagración del litis" ${ }^{\text {724. }}$.

\footnotetext{
${ }^{718}$ La España Moderna, "Revista Hispanoamericana”, n. ${ }^{\circ}$ 139, julio de 1900, p. 126.

${ }^{719}$ La España Moderna, "Revista Hispanoamericana", n. ${ }^{\circ}$ 121, enero de 1899, p. 132.

${ }^{720}$ Idem.

${ }^{721}$ El Nuevo Régimen, "Tacna y Arica”, 13 de octubre de 1900, p. 1.

${ }^{722}$ La España Moderna, "Revista Hispanoamericana", n. ${ }^{\circ} 131,1$ de noviembre de 1899, p. 157.

${ }^{723}$ El Nuevo Régimen, "Chile y el Perú", 13 de mayo de 1899, p. 1.

${ }^{724}$ La España Moderna, "Revista Hispanoamericana", n. ${ }^{\circ}$ 143, noviembre de 1900, p. 169.
} 
5.6. La chilenización de Tacna y Arica en los periódicos

¿Qué grado de responsabilidad tuvo el Perú en el fracaso del plebiscito? Es una pregunta relevante, puesto que de la lectura de las fuentes se desprende sólo una actitud incompetente del gobierno chileno. Es cierto que la actitud de los diputados impidió el arbitraje, pero eso debió repercutir en las presiones que la diplomacia peruana pudo haber realizado. En ese sentido, La España Moderna dijo: "al Perú le es imputable la responsabilidad de no haber procedido con mayor diligencia" 725 .

La última esperanza de que España tuviese un cometido meritorio en el diferendo dependía del sucesor de Piérola quien, si bien estabilizó al Perú ${ }^{726}$, no impidió los problemas provocados por esa sucesión que impidieron al negociador del protocolo, Guillermo Billinghurst, tomar el poder. Billinghurst, disidente del pierolismo, imprimió "su influjo personal ahora a los elementos de su elección, y mañana a la política de su

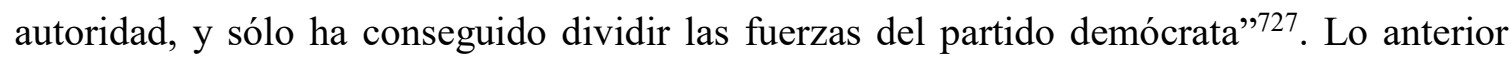
llevaría a que Piérola claudicase en su espaldarazo al vicepresidente entregando su apoyo al representante de la unión demócrata-civilista, Eduardo López de Romaña. Así, la llegada a la presidencia peruana del negociador del protocolo se suspendía hasta 1912.

El paso del siglo XIX al XX atestiguó la ruptura de las frágiles vigas que sostenían el protocolo y el arbitraje de España. Chile comenzaba de manera abrupta una política de chilenización de Tacna y Arica, con el objetivo de construir una conciencia de chilenidad proclive a que, cuando la diplomacia se pusiese de acuerdo en acometer con seriedad el plebiscito, la comunidad peruana le diera su voto ${ }^{728}$. Perú, por su parte, había caído una vez más en el juego de la crisis política. El gobierno de López de Romaña encarceló a sus opositores, entre los que figuraron el senador Dyer, el médico Flórez, los diputados Valora, Augusto Leguía y Martínez, este último líder de la Unión Nacional en el Congreso.

\footnotetext{
${ }^{725}$ La España Moderna, "Revista Hispanoamericana", n. ${ }^{\circ}$ 139, julio de 1900, p. 126.

${ }^{726}$ La España Moderna, "Revista Hispanoamericana", n. ${ }^{\circ}$ 121, enero de 1899, p. 163.

${ }^{727}$ La España Moderna, "Revista Hispanoamericana", n. ${ }^{\circ} 123$, marzo de 1899, p. 199.

${ }^{728}$ Otras ideas básicas sobre las representaciones periodísticas escritas por la prensa española respecto a la chilenización fueron abordadas en: SOTO LARA, José Julián, "El conflicto de Tacna y Arica entre Chile y Perú: La visión de la prensa española (1880-1929)”. En HERnÁNDEZ RodRíGUEZ, Paula, HeRnÁNDEZ SÁnchez, Gustavo, JuAnes Cortés, Antonio, Píriz GonzÁlez, Carlos, PovedA Arias, Pablo, RodríGuez ESCOBAR, Moisés, Las violencias y la historia. Colección temas y perspectivas de la historia, n. ${ }^{\circ}$, Salamanca, Ergar Ediciones Antema, 2016, pp. 145-165.
} 


\section{Imagen $n .^{\circ} 25$}

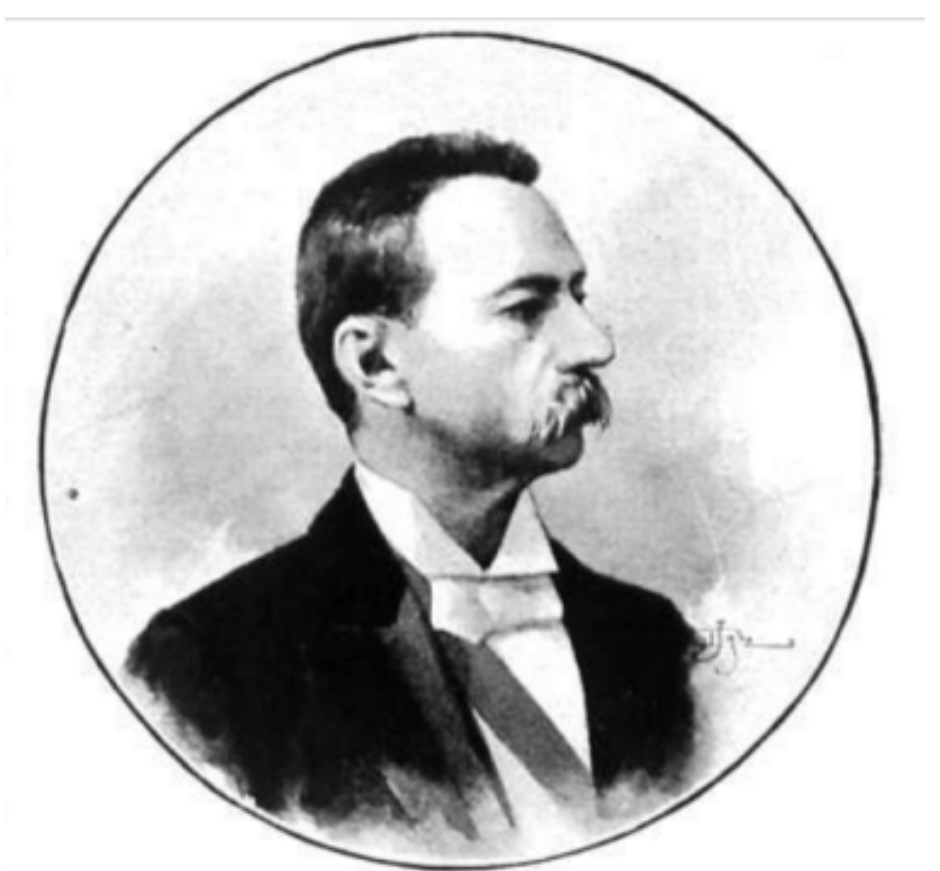

\section{Excmo. Sr. D. Eduardo L. de Romaña Presidente de la República del Perú}

Fuente: Hojas Selectas, "Excmo. Sr. D. Eduardo L. de Romaña”, Madrid-Barcelona, Biblioteca Salvat, 1902, p. 535.

Esas situaciones hicieron diagnosticar a un órgano informativo español la "enfermedad endémica" que incurablemente afectaba al Perú. Uno de sus periodistas advirtió cómo mientras los caudillos antes nombrados mantenían la incertidumbre, "Chile procurando chilenizar los territorios cautivos de Tacna y Arica, hace fundar en ellos

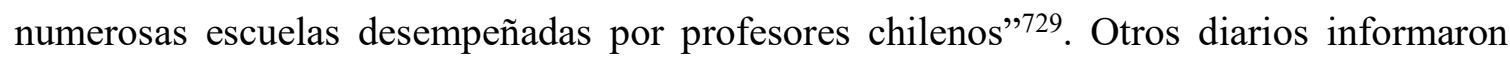
cómo Chile, fracasado el arbitraje, quiso terminar el problema fronterizo con una decisión unilateral. Así, como rezaba en su escudo nacional, "Por la razón o la fuerza", se empeñó en "chilenizarlos completamente para poder obtener en caso necesario un plebiscito favorable" ${ }^{730}$. Burlándose del arbitraje, incumpliendo lo convenido, continuó la transformación administrativa de Tacna y Arica demostrando su indudable propósito anexionista.

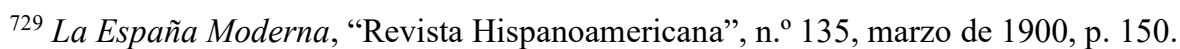

${ }^{730}$ La Nación Militar, "Los militares de América”, 8 de abril de 1900, p. 539.
} 
En efecto, en Tacna se estableció un Tribunal Superior, se cerraron las escuelas peruanas y se prohibió celebrar "el aniversario de la independencia del Perú, que es la nación a que de derecho pertenece" ${ }^{" 731}$. El objetivo era la conquista sentimental, para convertir la "peruanidad" en "chilenidad”. El proceso usó violencia simbólica, entendida en un diario como "apelaciones violentas", para chilenizar las "memorias"732 aunque de momento cubrió "la administración pública [y] el régimen de la enseñanza"733.

La chilenización fue enjuiciada en el exterior. El antichilenismo enarbolado por un diario bonaerense fue copiado por una revista hispana, dejando constancia de que el viejo plan de la chilenización se realizaba rechazando otras soluciones ${ }^{734}$. Ésta declarada en 1900, pero efectuada desde la ocupación, demostró que Chile incumplía su compromiso, pues al tomar la provincia prometió que "durante los diez años de esta hipoteca, nada se movería en Tacna y Arica por las autoridades chilenas, y se respetaría siempre el sentimiento nacional"735. Otro diario subrayó la retención indebida de Tacna y Arica ${ }^{736}$.

El Estado chileno colonizó las "cautivas". El mecanismo de "enganche" de esos pobladores se realizó concediendo "pasaje gratis a bordo del transporte de guerra Casma, a cuantos ciudadanos deseen ir a poblar dicha provincia"737. También se militarizó la región, asentando un contingente militar importante y destinando fondos estatales para fortificarla. Por ejemplo, la comisión Körner envió 30000 rifles Mannlicher adquiridos en Alemania. Arica se consideró como la centinela de la frontera y del salitre tarapaqueño. Por tal razón pasó de puerto comercial a "ciudad militar"738. De todos modos, algunos diarios ya enfatizaban el hecho de que esa zona se estaba chilenizando cada día más ${ }^{739}$.

\footnotetext{
${ }^{731}$ El Nuevo Régimen, "Tacna y Arica”, 13 de octubre de 1900, p. 1; La Época, "Las cuestiones territoriales en las repúblicas sudamericanas", 15 de octubre de 1900, p. 1; La Ilustración Artística, "Revista HispanoAmericana", n. ${ }^{\circ} 1$ 020, 15 de julio de 1901, p. 2.

${ }^{732} \mathrm{CID}$, Gabriel, "De guerras, ritos y conquistas: Conmemoraciones bélicas y nacionalismo chileno en el "norte grande", 1879-1910". En CAVIERES FIGUEROA, Eduardo y CHAUPIS TORRES, José, La guerra del Pacífico en perspectiva histórica. Reflexiones y proyecciones en pasado y presente, Arica, Universidad de Tarapacá, 2015, p. 186.

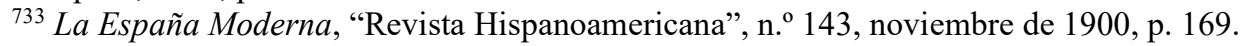

${ }^{734}$ La Nación Militar, "Ecos militares de América”, 3 de junio de 1900, p. 600.

${ }^{735}$ La España Moderna, "Revista Hispanoamericana", n. ${ }^{\circ}$ 139, julio de 1900, p. 126.

${ }^{736}$ El Liberal, “Argentinos y chilenos”, 30 de diciembre de 1901, p. 1.

${ }^{737}$ La Nación Militar, "Ecos militares de América", 15 de julio de 1900, p. 3.

${ }^{738}$ El Correo Militar, "El país chileno", 14 de diciembre de 1900, p. 2.

${ }^{739}$ La España Moderna, "Revista Hispanoamericana", n. ${ }^{\circ} 153$, septiembre de 1901, p. 159.
} 
Una síntesis de las medidas para chilenizar Tacna y Arica fueron escritas del siguiente modo:

Entretanto lleva a cabo la chilenización de Tacna y Arica, donde ha reforzado su ejército de ocupación y suprimido las Escuelas peruanas, sometiendo la organización eclesiástica de las mismas, antes dependientes de los obispos peruanos, a la silla episcopal de Chile. Todas esas medidas revelan la firme voluntad de transformar la ocupación de ambas provincias en anexión definitiva, sin ejecutar la cláusula del plebiscito establecido por el tratado de Ancón, que puso fin a la guerra con el Perú ${ }^{740}$.

En el mismo tono una revista de comienzos de 1901 dedicó un extenso reportaje a la chilenización de Tacna y Arica el que trataba de:

[...] las medidas tomadas por el gobierno chileno para lograr este fin, trasladando a Tacna la Corte o Tribunal de Iquique y conversión de aquella ciudad en cabeza de una zona militar. Búscase con esto la manera de convencer a los habitantes de aquellos territorios, de que su prosperidad y bienestar esté más bien vinculados a la soberanía de Chile sobre estas provincias que a la del Perú, para que decidan por aquella ${ }^{741}$.

\subsection{El arbitraje que no fue}

Las cenizas del protocolo Billinghurst-Latorre hicieron rebrotar con mayor intensidad los odios de Perú hacia Chile ${ }^{742}$. La guerra con el Perú, que se había mantenido en los últimos años en una fase de latencia, resurgió. Este ciclo en las relaciones chilenoperuanas fue detectado por la prensa que comentó la entrada en un nuevo periodo de actividad, donde era inminente una desavenencia al calor de ánimos nacionalistas enconados ${ }^{743}$. Mientras el Perú continuó la agonía de solicitar un arreglo, "Chile no quiere devolver los dos mencionados territorios" $" 744$ y por más que se esforzaba en solucionar "aparentemente" de modo pacífico el conflicto compraba apresuradamente armamento en Alemania.

\footnotetext{
${ }^{740}$ La Época, "Las cuestiones territoriales en las repúblicas sudamericanas", 14 de octubre de 1900, p. 2.

${ }^{741}$ La España Moderna, "Chilenización de Tacna y Arica”, n. ${ }^{\circ}$ 147, marzo de 1901, p. 148.

${ }^{742}$ Las ideas fundamentales acerca de las representaciones periodísticas realizadas por la prensa española sobre el fracaso del arbitraje español fueron abordadas en otro estudio histórico nuestro. Ver: SOTO LARA, José Julián, "La guerra y posguerra del Pacífico en la prensa de España: Desde las Conferencias de Arica hasta el arbitraje de la Reina María Cristina (1880-1901)". En GIMÉNEZ CHORNET, Vicent y COLOMER Viadel, Antonio, I Congreso Internacional América-Europa, Europa-América, Valencia, Editorial Universitat Politècnica de Valéncia, 2015, pp. 249-270.

${ }^{743}$ La Época, "España en América", 24 de agosto de 1900, p. 3.

${ }^{744}$ El Álbum Iberoamericano, "Crónica española y americana", n. ${ }^{\circ}$ 21, 7 de junio de 1900, p. 242; La Nación Militar, "Ecos militares de América", 15 de julio de 1900, p. 3.
} 
Algunos de los elementos de guerra encargados a Körner fueron 395 cañones de último modelo, 175000 fusiles Maüser, 27575 revólveres, 29000 lanzas, 125000 sables de caballería, 85 millones de cartuchos Maüser, 55000 de obuses, entre otras $\operatorname{cosas}^{745}$. A esto se debía sumar la preparación de un Ejército de 200000 hombres, un número que para el área Sudamericana estaba fuera de poder ser igualado ${ }^{746}$. A decir de una revista española, el armamentismo chileno tenía que ver con "los ímpetus belicosos" del país ${ }^{747}$.

El fracaso del arbitraje español tuvo como consecuencia que la prosperidad sudamericana dependiese de la solución que adoptasen los gobiernos de Santiago y Lima. Sus representantes diplomáticos, junto a los de Argentina, Brasil y Bolivia, con motivo de la festividad del apóstol Santiago celebraron en la capital de Chile una suntuosa fiesta político-religiosa liderada por el arzobispo Mariano Casanova, en donde las fricciones internacionales parecían comenzar a diluirse. Por momentos el fantasma de la guerra desaparecía, pero no tardaba en retornar. En mayo de 1901 otra vez se temió una guerra entre Chile y Perú. En calidad de enemigos perpetuos y a causa del problema de Tacna y Arica “Chile y Perú se preparan para la guerra” anunció El Álbum Iberoamericano ${ }^{748}$.

\subsection{El Congreso Social-Económico Hispanoamericano y la Conferencia Panamericana}

Dos eventos de la diplomacia internacional debatieron el problema de Tacna y Arica: el Congreso Social y Económico Hispano-Americano celebrado en Madrid en 1900 y a la II Conferencia Panamericana reunida en México en 1901-1902. Mientras la importancia del primero radica en la contribución realizada por la intelectualidad española sobre el tema americano ${ }^{749}$, la del segundo evidenció la gran hostilidad sentida por las repúblicas americanas hacia la política exterior de los Estados Unidos ${ }^{750}$.

\footnotetext{
${ }^{745}$ La Época, "Las cuestiones territoriales en las repúblicas sudamericanas", 15 de octubre de 1900, p. 1; La Ilustración Artística, "Revista Hispano-Americana", n. ${ }^{\circ} 1$ 020, 15 de julio de 1901, p. 2.

${ }^{746}$ La Época, "Las cuestiones territoriales en las repúblicas sudamericanas", 14 de octubre de 1900, p. 2.

${ }^{747}$ El Álbum Iberoamericano, "Excmo. Sr. D. Federico Errázuriz, Presidente de la República de Chile”, n. ${ }^{\circ} 15$, 22 de abril de 1901, p. 179.

${ }^{748}$ El Álbum Iberoamericano, "Chile y Perú", n. ${ }^{\circ} 18,14$ de mayo de 1901. p. 2.

749 ZulETA, Ignacio, La polémica modernista: el modernismo de mar a mar, 1898-1907, Bogotá, Instituto Caro y Cuervo, 1988.

750 Bobbio, Norberto, MATteucci, Nicola y PASQuino, Gianfranco, Diccionario de Política, México, Siglo XXI Editores, 2005, p. 1119.
} 
El congreso, normado por el Real Decreto de 16 de abril de 1900, trataría "los más trascendentales problemas que interesan a España a Portugal y a las repúblicas americanas de nuestro mismo origen"751. Fue ideado por la Unión Ibero Americana -institución que "tan valiosos servicios ha prestado a la causa de la confraternidad entre los pueblos español, portugueses y americo-latinos" ${ }^{752}$ - recibiendo el patrocinio del gobierno español. La presidencia se confió a Faustino Rodríguez San Pedro y tanto la reunión como los preparativos merecieron en la prensa la inserción de grabados y fotografías alusivas.

\section{Imágenes n. ${ }^{\circ} 26,27$ y 28}
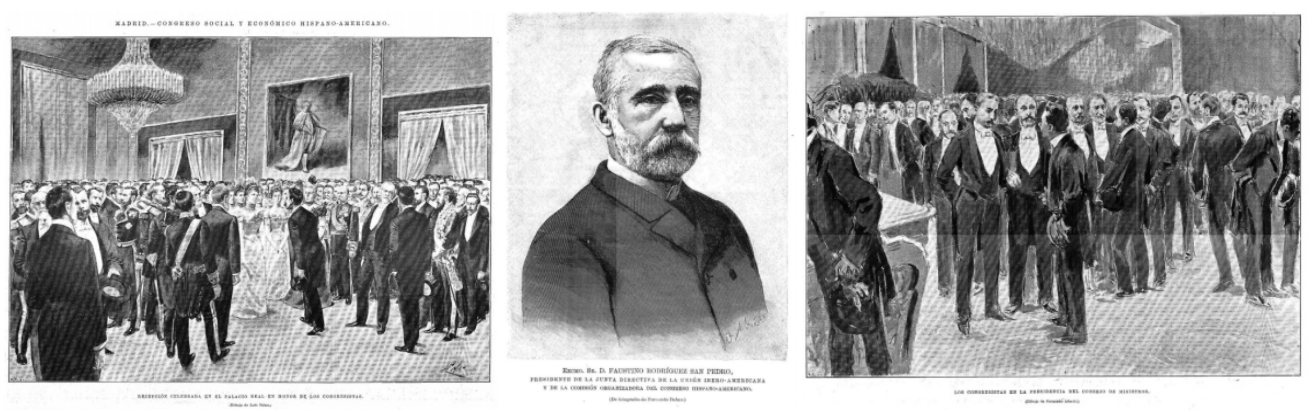

Fuentes: La Ilustración Española y Americana, "Recepción celebrada en el Palacio Real en honor de los congresistas", n. ${ }^{\circ}$ 43, 22 de noviembre de 1900, p. 300; La Ilustración Española y Americana, "Preparación para la celebración del Congreso Hispano-Americano", n. ${ }^{\circ}$ 39, 22 de octubre de 1900, p. 234; La Ilustración Española y Americana, "Los congresistas en la presidencia del Consejo de Ministros", n. ${ }^{\circ}$ 43, 22 de noviembre de 1900, p. 301.

Antes de efectuarse la reunión se temió que los acuerdos proclives a arbitrajes carecieran de solidez para su ejecución. La idea era crear Tribunales Permanentes de Arbitraje para los casos existentes o surgidos con posterioridad entre los estados. El evidente fracaso del protocolo Billinghurst-Latorre tenía eco en las misiones diplomáticas presentes, restando credibilidad a la fórmula ${ }^{753}$. Si bien el objetivo del Congreso fue estrechar los vínculos "entre pueblos de una misma lengua y una misma sangre, y preparar a lo sumo futuras resoluciones diplomáticas"754, la influencia española en esa materia iría en declive durante el siglo XX.

\footnotetext{
${ }^{751}$ La Ilustración Artística, "Congreso Social y Económico Hispano-Americano", n. ${ }^{\circ} 963,11$ de junio de 1900, p. 392.

${ }^{752}$ Idem.

${ }^{753}$ La España Moderna, "Revista hispanoamericana", n. ${ }^{\circ}$ 140, agosto de 1900, p. 147.

${ }^{754}$ El Nuevo Régimen, “Las Alianzas”, 17 de noviembre de 1900, p. 1.
} 
De todos modos, la prensa continuó comentando noticias relacionadas con Tacna y Arica para recalcar su postura antiyanqui. A la luz de un informe aparecido en el The New York Herald sobre el tema, una revista dijo que ese escrito era reflejo del espíritu desvanecido de "Yanquilandia", opuesta a toda tendencia hispanoamericanista. Según la nota, Estados Unidos deseaba absorber por etapas a América y por eso desconfiaba de los Estados que se "desnudan de ella, entregándose inermes a las contingencias del porvenir ${ }^{755}$.

En la II Conferencia Panamericana, celebrada el 22 de octubre de 1901 el problema de Tacna y Arica también estuvo en el centro del debate diplomático. La organización de las conferencias tenía como objetivo profundizar, según la política de Blaine, la influencia política de los Estados Unidos en los países de habla hispana. De modo anecdótico, en esos días circularon rumores sobre la pretensión de México de arbitrar en buena forma lo que no había podido ser concluido por la Regencia de María Cristina.

De todas maneras, en las conferencias de México se quiso establecer el principio jurídico internacional del arbitraje obligatorio con efectos "retroactivos" para dirimir todos los conflictos domésticos entre los Estados de Sudamérica. Eso pondría a Chile en una situación diplomática arriesgada que el país no se permitiría transitar. Bajo ese marco, la decisión de los territorios de Tacna y Arica pasaría así de las manos españolas a, lo más probable, las de los Estados Unidos, líderes indiscutibles de las conferencias.

Por esa razón, la actuación de los diplomáticos chilenos en ese punto fue clara: no discutiría ninguna medida de carácter retroactivo. Esa actitud obró aún más en la imagen de "mal vecino" que, desde la Guerra del Pacífico, Chile se estaba creando en la medida que Perú, Bolivia y Argentina veían de buena forma la instancia arbitral. La impresión que causó la actitud chilena en una revista española fue negativa. A fin de cuentas, lo que Chile estaba demostrando era que no permitiría la intervención de terceras potencias en el problema con Perú, pues eso pondría en riesgo su libertad de acción necesaria para conservar por medio de las armas la región de Tacna y Arica ${ }^{756}$. Un diario español, a propósito, se interrogó:

\footnotetext{
${ }^{755}$ La España Moderna, "Revista Hispanoamericana", n. ${ }^{\circ}$ 144, 1 de diciembre de 1900, p. 157.

${ }^{756}$ La Ilustración Artística, "Revista Hispanoamericana", n. ${ }^{\circ} 1$ 020, 15 de julio de 1901, p. 2; La Época, "El próximo Congreso Panamericano", 29 de septiembre de 1901, p. 1.
} 
Ya la designación de Méjico para celebrar la Conferencia, que fue una habilidad de Mr. Hay, produjo mal efecto en América, porque se comprendió la intención que a que aquel guiaba, y la actitud de Chile en el congreso hispano-americano de Madrid permitió comprender que ahora, como en 1889 , fracasaría toda tentativa en favor del arbitraje.

¿Cómo había de aceptar la república chilena el arbitraje, tal como lo consigna el art. $2^{\circ}$ del Tratado de Washington de 1890, esto es, obligatorio para todas las controversias relativas a los privilegios diplomáticos o consulares, a las fronteras, territorios o indemnizaciones, al derecho de navegación, y a la validez, interpretación y violación de tratados? ¿Cómo él había de aceptar esto cuando tiene pendiente la cuestión referente al cumplimiento del tratado de Ancón y a los territorios de Tacna y Arica? ${ }^{757}$.

La posibilidad de solucionar el diferendo desprendiéndose de España y, según lo discutido en México, recurriendo a países sudamericanos amparados por los Estados Unidos desagradó a algunos diarios españoles. La reorganización del Consejo Internacional de las Repúblicas Americanas, como punto trascendental de las conferencias, no era vista de modo positivo por España. Asentada en Washington hizo pensar a un periodista que la institución era una dependencia más del Ministerio de Negocios Extranjeros de la Casa Blanca $^{758}$. En el fondo, el problema que preveían los diarios españoles se relacionaba con las concesiones de soberanía hacia los Estados Unidos y la mengua de la independencia de las repúblicas hispanoamericanas.

La posición chilena para preservar Tacna y Arica amenazó con derrumbar la instancia panamericana. El encargado chileno, en vez de dirigir sus reclamaciones en lo relativo al arbitraje "retroactivo" al secretario mexicano Ignacio Mariscal, lo hizo a John Hay, secretario de Estado de los Estados Unidos. Este último, en el interés de que ningún país se ausentase de las conferencias, realizó algunas modificaciones a las estipulaciones del arbitraje y envió a su par mexicano las reformulaciones. Este no quiso recibir por conducto del Ministerio de Washington las explicaciones de Chile y amenazó con la renuncia de su país si Estados Unidos continuaba con su postura intervencionista. Comenzaba así la agonía del panamericanismo como nueva solución al antiguo problema de Tacna y Arica. El panamericanismo, como ideología, no era más que "un guisado que, si llegara a hacerse, se convertiría en merienda de yanquis" ${ }^{\text {"759. }}$.

\footnotetext{
${ }^{757}$ La Época, "Relaciones Hispano-Americanas", 3 de julio de 1901, p.1.

${ }^{758}$ La Época, "El próximo Congreso Panamericano", 29 de septiembre de 1901, p. 1.

${ }^{759}$ El Heraldo, "Desde México", 16 de diciembre de 1901, p. 2.
} 
En efecto, un cable proveniente de Londres informó a El Heraldo que el Congreso Panamericano había forjado un nivel de expectativas irracionales las cuales, de seguro, comprometerían el éxito de su implementación. Un ejemplo de esas expectativas se había colocado en el problema del arbitraje. En contra de las intenciones del Perú, la Comisión Preparatoria de Washington se encargó de dejar claro que la figura "retroactiva" no se utilizaría para la solución de problemas entre repúblicas americanas. Esa estipulación creó la atmósfera necesaria para que el discurso del diplomático peruano fuese emocionante, como lo dijo un diario español, dejando "en situación difícil a los diplomáticos, sobre todo al referirse a Tacna y Arica"760.

En Chile, el Ministro del Interior, Aníbal Zañartu, en el acto de apertura del Parlamento dio lectura a las líneas de actuación política que seguiría el país en el tema de fronteras con Perú. En esa ocasión definió la postura que tendría la cancillería en México. Será -dijo- un motivo de especial satisfacción contribuir con su concurso a la aceptación del arbitraje en general aplicado a las cuestiones que puedan presentarse en lo futuro, sin más excepciones que las que afectan a la soberanía y la dignidad ${ }^{761}$.

\section{Imagen n. ${ }^{\circ} 29$}

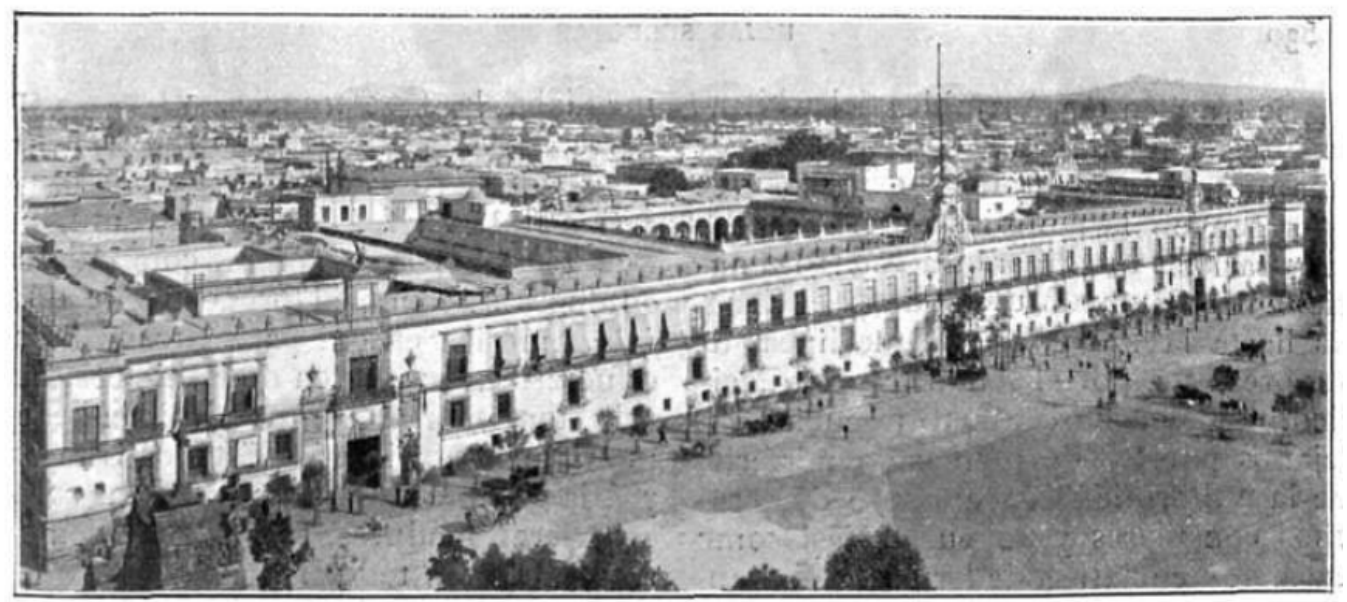

Palacio Nacional de México,

donde Celebró sus sesiones la Conferencia Internacional Americana

Fuente: Hojas Selectas, "La Conferencia internacional americana de México", año primero, Madrid-Barcelona, 1902, p. 34.

\footnotetext{
${ }^{760}$ El Heraldo, "El Congreso Panamericano", 7 de noviembre de 1901, p. 1.

${ }^{761}$ Revista Iberoamericana de Ciencias Eclesiásticas, "Chile", tomo II, 1901, p. 233.
} 
5.9. La muerte del protocolo Billinghurst-Latorre

El año de la muerte del protocolo Billinghurst-Latorre (1901) coincidiría con la fecha de defunción del presidente chileno Federico Errázuriz, bajo cuyo mandato se negoció el arbitraje de España en la cuestión de Tacna y Arica. Ese año, la discusión acalorada de 1898 se había atenuado al extremo de desaparecer la alternativa plebiscitaria.

Con motivo de su muerte los diarios españoles elogiaron su personalidad política. Se aplaudió su visión y estrategia militar dentro del contexto continental. Él había dotado a las fuerzas armadas chilenas de elementos ofensivos en los momentos que la situación de la América meridional así lo exigía ${ }^{762}$. Esa política armamentista, según esa publicación, no le impidió consagrar sus mejores esfuerzos para mantener la paz. Errázuriz fue quien ensayó una solución amistosa con Argentina por los territorios de la Patagonia. Con Perú, como hemos visto, por el problema de Tacna y Arica. A Errázuriz, además, lo había distinguido su afecto por España, actitud que lo hizo merecedor de la Gran Cruz de Isabel la Católica.

Tales virtudes permitieron que un juicio benévolo de la prensa española, no dejando notas amargas para el futuro, como, por el contrario, sucedería en el Perú. La razón de esa predisposición periodística tuvo relación con el fracaso del protocolo y con la insistencia “débil” realizada por Errázuriz y su ministro Latorre en la Cámara de Diputados, órgano político opositor al arbitraje. Solo unos meses antes, esa Cámara había decidido "desestimar" el protocolo Billinghurst-Latorre eliminando la participación de España en cualquier acto plebiscitario que pudiese celebrarse. El Proyecto de Acuerdo presentado en la Comisión de esa Cámara decía:

Teniendo presentes las diversas observaciones formuladas en el debate y en especial la conveniencia de que sean resueltos directamente por los gobiernos de Chile y el Perú los puntos que el Protocolo de 16 de Abril de 1898 entrega a la resolución de un árbitro, la Cámara acuerda que se envíen los antecedentes al Ejecutivo, a fin de que inicie nuevas gestiones diplomáticas para dar cumplimiento a la cláusula $3^{\mathrm{a}}$ del Tratado de Ancón. Santiago, 14 de enero de 1901. - Miguel Cruchaga, Francisco A. Pinto, Manuel Salinas y Guillermo Pinto Agüero ${ }^{763}$.

\footnotetext{
${ }^{762}$ La Correspondencia, "El Presidente Errázuriz", 18 de julio de 1901, p. 3.

${ }^{763}$ Bello Codecido, Emilio, Anotaciones para la historia de las negociaciones diplomáticas con el Perú y Bolivia (1900-1904), Chile, Imprenta La Ilustración, 1919, p. 28.
} 
Imágenes n. ${ }^{\circ} 30,31,32,33$ y 34
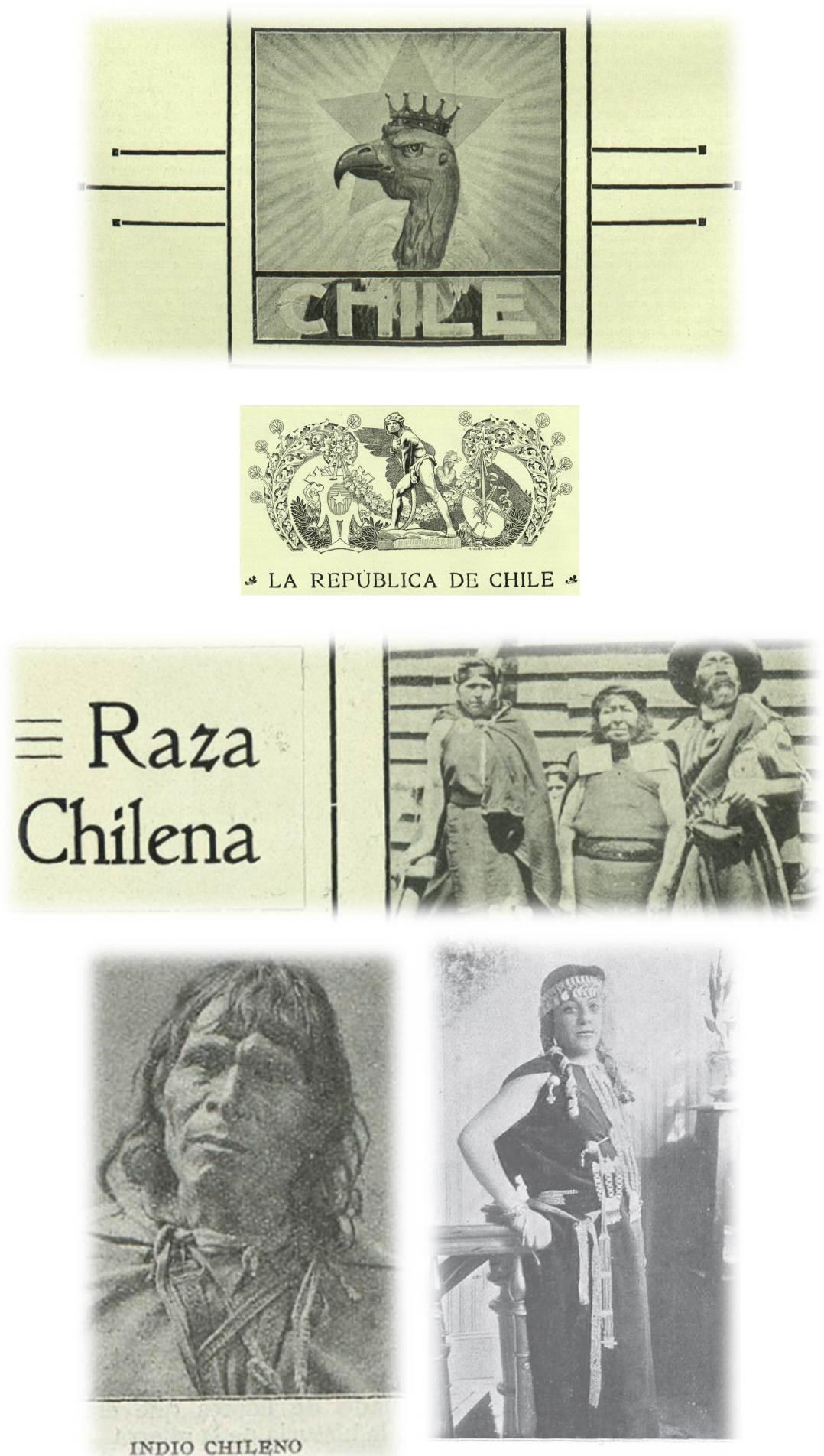

Fuente: Mercurio, "La República de Chile", 7 de marzo de 1912, n. ${ }^{\circ}$ 145, p. 67; Idem; Mercurio, "Raza chilena", 20 de octubre de 1910, n 109, p. 392; Mi Revista, "Indio chileno", octubre de 1917, ${ }^{\circ}$ 79, p. 261; Hojas Selectas, "Mujer indígena araucana", n 121, 1912, p. 856. 


\section{TACNA Y ARICA, OPORTUNIDAD PARA LA REVITALIZACIÓN DEL HISPANOAMERICANISMO (1902-1921)}

El paso del siglo XIX al XX coincidió con una serie de cambios ideológicos en la prensa española interasada en América y particularmente en las relaciones entre Chile y Perú. Es probable que el incumplimiento del Tratado de Ancón y el estrepitoso final del protocolo Billinghurst-Latorre, pese a la deficiente cobertura informativa, haya generado en esta fase un interés renovado por explicar un diferendo que se alargaba en el tiempo. La prensa tomó conciencia, en el despunte del siglo XX, de que las influencias políticas de España en América no alcanzaban la importancia que sus intelectuales y hombres de Estado anhelaban. Concomitantemente, la política exterior de los Estados Unidos, el rival victorioso de 1898, por el contrario, evidenció una capacidad de planificación exterior mayor resultante en su imperialismo hacia el resto de América. Como se sabe, el nuevo respiro de la Doctrina Monroe desplazaba a Europa y, por consiguiente, a España de cualquier forma de intervención en América. Ese y otros motivos fueron suficientes para que la prensa atacara las pretensiones de hegemonía yanqui y criticara, para el caso que nos importa, sus intenciones de solucionar el conflicto de Tacna y Arica. La presente etapa, por último, interesa analizarla, ya que la construcción de representaciones sobre los países litigantes, si bien mantuvo las ideas básicas del pasado, fue matizándose hacia prejuicios menos burdos producto de un número creciente de opiniones e informaciones.

Imagen n..$^{\circ} 35$

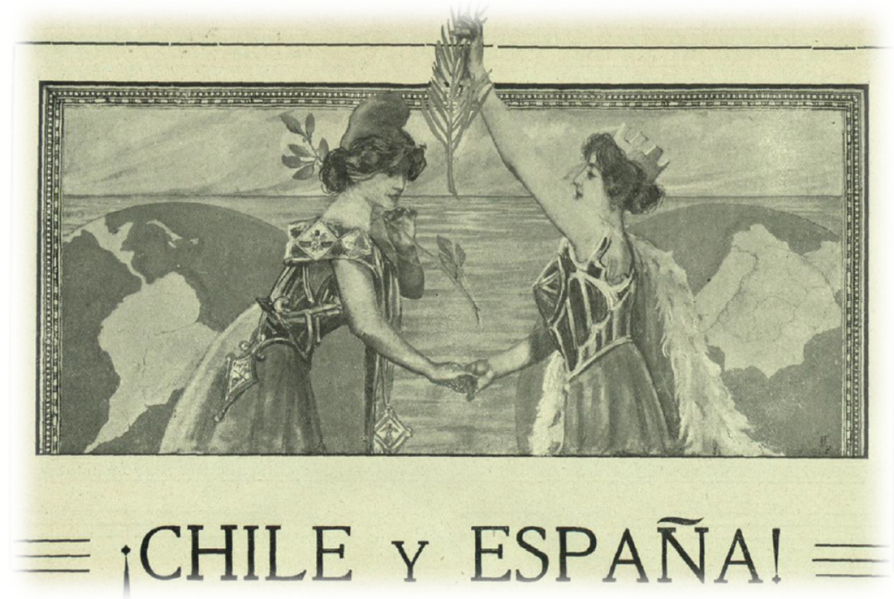

Fuente: Mercurio, "Chile y España", 20 de octubre de 1910, n. ${ }^{\circ} 109$, p. 418. 
Concluida la participación diplomática de España en el problema de Tacna y Arica, el interés periodístico por la faceta política de éste derivó hacia lo artístico. Puntualmente, las noticias relacionadas con la frontera chileno-peruana versaron en torno al premio, un "ruidoso triunfo"764 y "verdaderamente extraordinario"765 otorgado en Perú al escultor Agustín Querol ${ }^{766}$, "El genio", como se le apodó. La Municipalidad de Lima había convocado un concurso para que una amplia muestra de escultores, entre trescientos y cuatrocientos $^{767}$, presentasen los bosquejos de lo que sería una estatua en honor al coronel peruano Francisco Bolognesi, héroe -según la historiografía de Perú y Chile- de la batalla de Arica. La obra ganadora representaba a Bolognesi "moribundo, pistola en mano y a punto de caer" 768 razón por la que fue retirada de su emplazamiento inicial, en el centro limeño, a mediados del siglo XX.

\footnotetext{
${ }^{764}$ Mercurio, "El monumento a Bolognesi", 1 de septiembre de 1904, n. ${ }^{\circ} 34$, año IV, p. 212.

${ }^{765}$ La Correspondencia de España, "Un triunfo de Querol", 11 de abril de 1902, p. 2.

${ }^{766}$ Para un estudio acabado y contemporáneo a Querol ver: GIL, Rodolfo, Agustín Querol, Madrid, Saenz de Jubera, 1910. Otros detalles de la biografía de Agustín Querol y del proceso de construcción del monumento a Bolognesi en: Bernales Ballesteros, Jorge, Estabridis CÁrdenas, Ricardo, Gisbert, Teresa, Mesa, José de, LÁmbarri Bracesco, Jesús, TORD, Luis Enrique, CASTRILlón, Alfonso, Escultura en el Perú, Lima, Banco de Crédito del Perú, 1999; OrRego, Juan Luis, Lima 1. El corazón de la ciudad, Lima, Santillana S. A. 2013; VARgas Ugarte, Rubén, Historia General del Perú, Barcelona, Carlos Milla Batres, 1984; VILlegas TORRES, Fernando, El Perú a través de la pintura y crítica de Teófilo Castillo (1857-1922): nacionalismo, modernización y nostalgia en la Lima del 900, Lima, ANR, 2006; VILLEGAS TORRES, Fernando, "Vínculos artísticos entre España y Perú (1892-1929): Elementos para la construcción del imaginario peruano", Memoria presentada para optar al grado de Doctor, Madrid, Universidad Complutense de Madrid, Facultad de Geografía e Historia, Departamento de Historia del Arte III, 2013; BASADRE, Jorge, Historia de la república del Perú, Lima, Tall. Graf. P. L. Villanueva, 1968; LÓPEZ MARTínEZ, Héctor, El siglo XX en el Perú a través de El Comercio, Lima, Editorial El Comercio, 1994.

${ }^{767}$ Revista de archivos, bibliotecas y museos, "Variedades", 1 de abril de 1902, n. 4 y 5, año IV, p. 409; Las dominicales del libre pensamiento, "El Coronel Bolognesi”, 18 de abril de 1902, p. 1; La Ilustración española y americana, "Monumento a Bolognesi", 30 de junio de 1902, n. ${ }^{\circ} 24$, p. 399.

${ }^{768}$ GUTIÉRREZ VIÑUALES, Rodrigo, "Monumentos conmemorativos de escultores españoles en Iberoamérica (1897-1926)". En CABAÑAS BRAVO, Miguel (Coord.), El arte español fuera de España, España, CYAN, Proyectos y Producciones editoriales, S. A., 2003, p. 357. Resulta interesante comprender los usos políticos de los monumentos en los países occidentales. En el caso concreto del Perú, la desaparición de la obra de Querol se relacionó con el mensaje "derrotista" del coronel Bolognesi. Aunque, como lo había afirmado a comienzos del siglo XX el Delegado Militar del gobierno peruano en Europa, coronel Tolmos a Agustín Querol en su paso por el taller de este último: "Esto es admirable: no puedo contemplarlo sin gran emoción. He sido capitán a las órdenes de ese hombre... No puede darse nada más parecido, más real y al mismo tiempo más artístico". En: La Época, "En el estudio de Querol", 26 de enero de 1903, p. 1; La Correspondencia de España, "En el estudio de Querol", 1 de febrero de 1903, p. 2; El Liberal, "El monumento a Bolognesi", 26 de enero de 1903, p. 3; El Imparcial, "Una obra de Querol", 26 de enero de 1903, p. 3 .
} 
Es posible que la concesión del premio a Agustín Querol para realizar una estatua del coronel peruano haya favorecido la exageración de su conducta en el campo de batalla por parte de la prensa remarcando los valores "sagrados" de quien dio su vida por Perú. De todos modos, esa situación dio pie para que el nombre de Arica circulara por los diarios peninsulares que, desde un comienzo, anunciaron la convocatoria del concurso para ejecutar "un monumento que debe conmemorar la defensa de la plaza de Arica y el heroico sacrificio del Coronel Francisco Bolognesi y de sus compañeros en junio de 1880"769; escribiendo sobre el monumento que, "en la capital del Perú se levantará para honrar en mármoles la figura del coronel Bolognesi, el héroe de la gloriosa epopeya de Arica"770 o felicitando al querido amigo que "en reñidísimo concurso ha logrado el primer premio por su proyecto de monumento conmemorativo de la gloriosa defensa de la plaza de Arica y el heroico sacrificio del coronel don Francisco Bolognesi [...] en junio de 1880"771.

Una estrategia periodística, usada con el fin de argumentar el heroísmo del actor principal de la obra de Querol, fue la utilización del relato de un subalterno de Bolognesi, el coronel peruano Mariano José Madueño, quien había trabajado con él en la sección de Estadística Militar fundada por el presidente peruano Manuel Pardo. Además, Madueño en carta dirigida al Director de Las Dominicales del Libre Pensamiento, Fernando Lozano, usuario del seudónimo Demófilo, explicó que su objetivo era arrojar claridad a los lectores españoles sobre el memorable hecho de armas que Querol convertiría en escultura. Le importaba compartir la forma en que el artista había concebido el diseño, pues trataba de uno de los dramas y hazañas militares más notables de la pasada centuria. Madueño había recorrido el Morro de Arica y recolectado impresiones de los hechos entre los años 18851886. Merece la pena transcribir su proyecto iconográfico:

\footnotetext{
769 Arquitectura y Construcción, Bellas Artes, Decoración, Industria, Arte Moderno, Revista Mensual, “Concursos", enero de 1902, año VI, n. ${ }^{\circ} 114$, p. 16; La Correspondencia de España, "Un triunfo de Querol", 11 de abril de 1902 , p. 2.

${ }^{770}$ El Heraldo, "El monumento a Bolognesi", 12 de diciembre de 1902, p. 3.

${ }^{771}$ La Ilustración Artística, "Monumento a Bolognesi", 19 de mayo de 1902, n. ${ }^{\circ}$ 1064, p. 338. Otras referencias al heroísmo del militar peruano en: El Heraldo, "En el estudio de Querol", 13 de mayo de 1904, p. 1; La Época, "En el estudio de Querol", 26 de enero de 1903, p. 1; La Correspondencia de España, "En el estudio de Querol", 1 de febrero de 1903, p. 2; El Liberal, "El monumento a Bolognesi”, 26 de enero de 1903, p. 3; El Imparcial, "Una obra de Querol”, 26 de enero de 1903, p. 3; La Lectura, "Querol, por José R. Melida”, mayo de 1902, año II, p. 78.
} 
[...] Pienso que debía dibujarse el pedestal y basamento de Bolognesi, haciendo una imagen del Morro en mármol y bronce. A sus costados, por el frente de la estatua de Bolognesi, el episodio del Consejo de guerra con el parlamentario chileno Salvo [...]. En el otro frente, el opuesto, Bolognesi respondiendo y despidiendo a Salvo con la frase "Quemaremos el último cartucho". Detrás de él todos sus jefes agrupados y como observándole. En el frente tercero, a la izquierda de Bolognesi, el cuadro de la batalla general, según el croquis (adjunto), con Bolognesi en la cumbre, al pie del pabellón nacional, flameando, cerca de la garita de madera, abarcando y dirigiendo desde esa altura todo el campo de la lucha de mar y tierra. El frente cuarto, a la derecha de Bolognesi, el último episodio: la línea peruana, rota y deshecha por la abrumadora superioridad en el número y elementos de los atacantes, muertos y heridos por doquier, baterías voladas, edificios del puerto incendiados y ardiendo, metrallas y bombas de los cañones de tierra y de los buques reventando. Por los costados del Morro, subiendo hacia la cumbre, las columnas enemigas; una, la más próxima, apuntando y descargando sus rifles sobre Bolognesi y sus ocho o nueve ayudantes personales, cayendo muertos al propio tiempo que disparaban su último tiro [...]. Luego éste, bien destacado, cayendo acribillado de balazos, al pie del pabellón, abrazado al asta de la bandera con el brazo izquierdo y con el derecho disparando el último cartucho de su revólver sobre la columna, que a pocos pasos le abrazó con su descarga. Más allá, sobre el borde del Morro, hacia el mar, ya desprendido sobre el abismo, un jinete con su caballo precipitándose sobre las escarpadas orillas del Océano Pacífico. Fue el coronel Alfonso Ugarte que, no habiendo podido caer por el plomo, furioso y desesperado, antes que caer prisionero, buscó la muerte arrojándose, caballo y todo, sobre el abismo. [...] El cuadro cuarto debe también ostentar la bahía con un monitor viejo o batería flotante peruana hundiéndose, por determinación de sus propios tripulantes [...]. Sobre el gran pedestal (forma de morro) debe venir la gran estatua de Bolognesi, sola, con el asta y el pabellón peruano a la espalda de la estatua, en la cual, ya como mortalmente herido, debe aparecer Bolognesi abrazando con su mano izquierda el asta del pabellón y con su mano derecha quemando con su revólver el último cartucho... Tal sería, en mármol y bronce, la concepción completa de ese gran poema militar, de esa verdadera Ilíada Americana en la cual fue Aquiles el denodado coronel Bolognesi ${ }^{772}$.

Con el detalle de la descripción y las valoraciones de los acontecimientos se sugería a los lectores sólo una interpretación de la batalla. Así, la visión peruana y no la chilena era conocida en España. El autor ratificó el heroísmo de Bolognesi y su tropa, desplazando el papel del soldado chileno que solicitó la rendición de Arica. Reforzó, además, las diferencias numéricas entre los ejércitos, idea que ayudaba a comprender el desenlace del conflicto por razones cuantitativas. Por último, no son extrañas las referencias europeas del militar peruano viendo en Bolognesi al Aquiles de Arica, comparándolo con militares del “estilo de Delaray, Botha y otros del Transvaal, tan heroicos en el combate como generosos y humanos en la victoria"773.

\footnotetext{
772 Las Dominicales del Libre Pensamiento, "El Coronel Bolognesi”, 18 de abril de 1902, p. 1.

773 Idem.
} 
La prensa entregó información útil para quienes querían enviar a Lima sus propuestas de escultura. De hecho, la Secretaría de Estado de España facilitó La Liga Nacional, publicación limeña que incluyó las bases y un retrato del coronel peruano ${ }^{774}$. También demostró admiración por el vetusto coronel. La lectura de la prensa permite constatar la fascinación hacia quien dio la vida por su bandera. Sólo por citar un ejemplo aparecido en un diario matritense de 1908: "Francisco Bolognesi, el gran Bolognesi, inmortalizado en el Morro de Arica [...] [fue uno de los héroes] que aún en las sombras de la muerte esplenden luz sobre el Perú heroico, cansado de producir grandes guerreros, grandes e insignes patriotas" 775 .

Es altamente probable que la glorificación de este tipo "heroísmo" sea publicada con apasionamiento para que esa conducta fuese modeladora en diferentes contextos nacionales. En ese sentido, poco importaba la derrota militar peruana, pues ésta de manera indefectible creaba a los santos varones de los Estados. O, como lo expresó el redactor de ese diario: "La campaña del Pacífico en 1879, fue un desastre para el Perú; pero un desastre lleno de gloria, que aún hay gloria en la derrota cuando se muere dignamente"776.

Como es entendible, la glorificación de un alto mando del ejército -cuando fallece en condiciones de gran dificultad, por ejemplo, en la conquista chilena de Arica- permite la admiración de grandes comunidades nacionales. El nacionalismo se ve así nutrido y justificado. En ocasiones, como sucedió con la muerte de Bolognesi, no están del todo claras las circunstancias de su muerte. En Perú, el héroe es reconocido por su determinación de "quemar hasta el último cartucho" en la confrontación con los chilenos, pero, en este último país, circula con mucha energía la idea de que la muerte del coronel fue una autoinmolación desde la altura del morro hacia el acantilado que conecta ese promontorio con el océano Pacífico. Se comenta, lejos de los fundamentos históricos, que tomó desde la cima del peñón la bandera peruana para que no fuese capturada por los invasores chilenos. Las historiografías de los países implicados en la guerra han sido enfáticas en señalar que el suicida fue el mayor Alfonso Ugarte.

\footnotetext{
${ }^{774}$ El Heraldo, "Noticias generales", 11 de enero de 1902, p. 6.

${ }^{775}$ El Día, "La guerra entre Chile y Perú", 17 de noviembre de 1908, p. 2.

${ }^{776}$ Idem.
} 


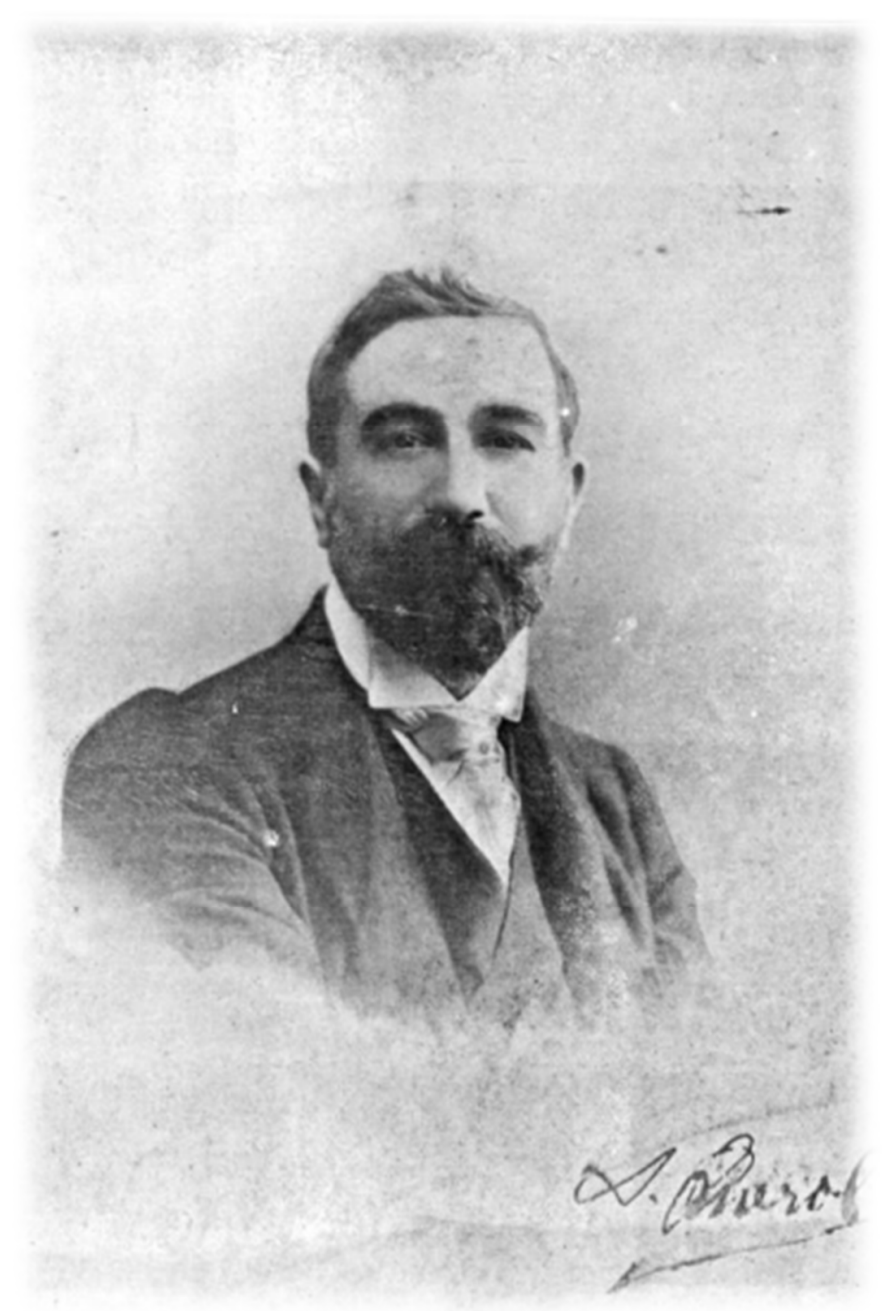

Fuente: Actualidades, “Agustín Querol”, 11 de mayo de 1902, n. ${ }^{\circ}$ 19, p. 9.

La reproducción del error histórico se puede detectar en publicaciones españolas posteriores al 7 de junio de 1880, fecha de la batalla, tales como la aparecida en España y América, asegurando que con la obra de Querol se honraba la memoria de Bolognesi, quien “combatió heroicamente en la guerra del Perú con Chile y que al fin dio una prueba de patriotismo pagano, pues derrotado, puso término a sus días arrojándose al mar, caballero en su corcel, desde un acantilado de Arica"777.

\footnotetext{
${ }^{777}$ España y América, "Nuestros grabados", 1 de enero de 1906, p. 80.
} 
Otras revistas mejor informadas comentaron la decisión de Ugarte. La narración de los periodistas destacó la tragedia: “es espantoso el episodio de Ugarte, que viéndose perdido, lanza hacia un precipicio su caballo y con él se despeña sobre los abismos rugientes del mar [...]"778 o comentó la lograda escena del artista al representar a Ugarte “despeñándose con su caballo por escarpado cantil, cuya base azotan furiosas las olas del mar, son en todo dignas del talento de Querol"779.

La construcción del relato, claro está, echa mano a palabras cargadas de emoción, como en el caso anterior, refiriéndose a la furia marina. La costa sur ariqueña, muy por el contrario, se caracteriza por su carencia de grandes oleajes, lo que se relaciona con la forma del suelo marino y otros detalles oceanográficos que no cabe comentar aquí. Más importantes, sin duda, son las erratas que se advierten en la datación de la batalla de Arica. Algunos diarios se refieren al acto heroico de Bolognesi en 1879, cuando, en verdad, su paso al martirologio de los héroes peruanos sucedió un año después.

Por otro lado, el impacto social que tuvo en España el triunfo de Agustín Querol no fue menor. La prensa dio cobertura a las celebraciones coordinadas por el periodista Justo Zamora, Martínez Sierra y González Pola que se ofrecieron al artista catalán. A comienzos de julio de 1902, por ejemplo, en los Jardines del Buen Retiro en Madrid se festejó su "ruidoso triunfo en la capital del Perú"780. Para esa ocasión, se reunió parte importante de la elite artística y política española. Representando a esta última, estuvo el señor Requejo, Subsecretario del ministerio de instrucción pública; Gascón, diputado por Tortosa; Ortega Munilla, director del diario El Imparcial; don Emilio Sala, marqués de Tovar y don Rafael Calzada, conde de Vilana, Morayta, Belmás y el conde de San Simón, entre otros. Se leyeron, escribió un diario, variados telegramas y cartas de apoyo y admiración para el artista, quien culminaría su obra el 25 de enero de $1904^{781}$.

Es interesante captar cómo la sensibilidad del poeta Salvador Rueda compuso un soneto, publicado en algunos diarios, titulado La piedra a Querol:

\footnotetext{
${ }^{778}$ Mercurio, "El monumento a Bolognesi", 1 de septiembre de 1904, n. ${ }^{\text {34 }}$, año IV, p. 212. Otra referencia sobre el final de Ugarte en: La Época, "En el estudio de Querol", 26 de enero de 1903, p. 1.

${ }^{779}$ La Época, "En el estudio de Querol”, 26 de enero de 1903, p. 1.

${ }^{780}$ El Heraldo, "Conmemorando un triunfo", 3 de julio de 1902, p. 2.

${ }^{781}$ Almanaque Bailly Bailliere, "El año artístico y literario (1903)", 1904, s/d, p. 233.
} 
La piedra está vestida de blancura

igual que una divina desposada,

y el escultor la envuelve en su mirada

con pecho estremecido de ternura.

Desciende Dios en forma de luz pura del taller por la cúpula sagrada, y da su bendición inmaculada

al gran artista y a la piedra dura.

Casto el cincel, la esposa fecundiza

y sus blancas entrañas diviniza

con nuevos seres de almas misteriosas.

Y nacen a la luz reyes severos,

héroes y vates, santos y guerreros,

con nuevos seres de almas misteriosas,

musas y Apolos, vírgenes y diosas ${ }^{782}$

La poesía del malagueño, sin duda, guardaba relación con el diseño del monumento.

$\mathrm{Su}$ descripción detallada fue publicada por un semanario barcelonés en los siguientes términos:

El proyecto premiado [...] consta de un plinto general escalonado, sobre el cual se alza una masa mural acolumnada cuadrilonga, envuelta por numerosísimas figuras agrupadas artísticamente y destacadas desde la línea inferior hacia el pedestal, yéndose a perder en relieve en las del monumento, entrelazadas artísticamente y cubriéndose casi por completo, se ven las figuras de la Fama y de la Gloria, y en las cuatro caras inferiores del friso, ocupando los respectivos centros del pedestal, se destacan en artísticos medallones orlados de guirnaldas los retratos de los compañeros de Bolognesi. Rematan la composición que envuelve el capitel las cariátides de Minerva, Hércules, Marte y Lar, que representan la Sabiduría, la Fuerza, el Valor y la Patria. Sobre la base del pedestal se levanta en noble actitud la estatua del Perú y en el primer tercio de la escalinata se ven los atributos guerreros. La cara inferior presenta en su parte más baja la estatua de la Historia, inspirada por un genio, en bajo relieve, y más abajo una matrona que personifica la Guerra. El monumento en su conjunto es grandioso y de bellísimas líneas, y en todos sus detalles responde admirablemente al pensamiento que en la obra preside, y para que se comprenda su importancia bastará decir que para la ejecución del mismo se destina la cantidad de 18.000 libras esterlinas ${ }^{783}$.

\footnotetext{
${ }^{782}$ El Heraldo, "Conmemorando un triunfo", 3 de julio de 1902, p. 2.

${ }^{783}$ La Ilustración Artística, "Monumento a Bolognesi", 19 de mayo de 1902, n. ${ }^{\circ}$ 1064, p. 338. Otras descripciones detalladas de la obra de arte en: Mercurio, "El monumento a Bolognesi", 1 de septiembre de 1904, n. ${ }^{\circ}$ 34, año IV, p. 212; El Heraldo, "En el estudio de Querol", 13 de mayo de 1904, p. 1; La Lectura, "Querol, por José R. Melida", mayo de 1902, año II, n. ${ }^{\circ}$ 17, p. 78; La Ilustración española y americana, "Monumento a Bolognesi", 30 de junio de 1902, n. ${ }^{\circ}$ 24, p. 399.
} 
La victoria del artista español llevó a la prensa a incurrir en una de las estrategias facilitadoras de la imaginación más recurrentes. En efecto, al tratarse de un concurso limeño, ganado por un artista español, relacionado con las formas de hacer la guerra en un territorio específico, Arica, la prensa se refirió, en variadas ocasiones, al "triunfo de Querol en América"784. Ese triunfo se entendió como una parte del proceso de reposicionamiento de España en América, siendo Agustín Querol el artista que "había glorificado el arte español en América y había reconquistado el respeto y la admiración de los americanos por los artistas españoles"785, todas muy provechosas para "nuestro arte patrio"786.

Bajo esa misma interpretación, la prensa española entendió la planificación de la inauguración del monumento, prevista para el 4 de agosto de 1902, pero que finalmente se retrasaría un par de años. Un diario matritense explicó que la obra de Querol "proporciona el medio de aunar sentimientos históricos de raza"787 y otro, publicado por esos meses, sostuvo que el "triunfo alcanzado por tan notable maestro es motivo de orgullo para España, que de manera tan digna aumenta las simpatías entre ambas naciones"788. La intención de esas opiniones era remarcar que este tipo de acercamientos entre España y América era el camino del porvenir ${ }^{789}$.

Probablemente, señalar ese camino guardaba relación con la conciencia hispana de una suerte de olvido, en América, de los vínculos culturales -en el más amplio sentido de esa palabra- que los unían y que para comienzos del siglo pasado eran difíciles de constatar. Esta reflexión se desprende de la valoración realizada por la prensa sobre el intelecto español, en el pasado y presente, favorable a España, "madre patria" que "no podrá ser olvidada por América" 790 y a lo cual "contribuyen poderosamente nuestros artistas"791.

\footnotetext{
${ }^{784}$ El Heraldo, "Conmemorando un triunfo", 3 de julio de 1902, p. 2.

${ }^{785}$ Idem.

${ }^{786}$ La Correspondencia de España, “Agustín Querol”, 11 de junio de 1902, p. 1.

${ }^{787}$ El Heraldo, "El monumento a Bolognesi”, 12 de diciembre de 1902, p. 3.

${ }^{788}$ El Imparcial, "Los triunfos de Querol", 10 de junio de 1902, p. 1.

${ }^{789}$ El Imparcial, "Los españoles en América", 11 de abril de 1902, p. 2.

${ }^{790}$ La Correspondencia Militar, “Agustín Querol”, 11 de abril de 1902, p. 2.

${ }^{791}$ Idem.
} 
En líneas generales, esa situación había sido remarcada por unos de los invitados a la cena de honor, quien enfatizó "la importancia del triunfo que se celebraba, en lo que tiene de lazo de unión entre España y las repúblicas de Sud-América [...]"792. El espíritu hispano poseyó al artista, quien no dudó en declarar que el triunfo no era suyo, sino más bien del alma española que había hablado a través de él. Esta situación se hizo evidente en otro de sus comentarios, ya terminada la ceremonia, camino a su taller, "Ahora, fortalecido con este testimonio de simpatía, que tanto agradezco, vuelvo a mi estudio a reñir nuevas batallas, a conseguir si la suerte me ayuda nuevos laureles con que ceñir la frente de nuestra amada patria" $" 793$.

El hispanismo del artista, sin duda, se reforzaba con la venia periodística que sintió un triunfo personal en una escala nacional. Un buen ejemplo de ello son las palabras compartidas por un diario que vio positivamente la difusión del arte español por América. Esa era una manera de restablecer lazos políticos y emocionales, cortados a comienzos del siglo XIX.

El proyecto de nuestro compatriota - dijo El Heraldo- fue juzgado desde luego como triunfo para España y como motivo de orgullo para cuantos ansiamos que nuestras glorias "se difundan en aquellas apartadas regiones, unidas a nuestra patria por los vínculos del cariño y del Arte"794. Terminaba esa publicación lastimándose de que faltasen pocos días para que la obra del genio abandonara para siempre España. Sólo un consuelo aplacaba esa emoción: la estatua de Bolognesi "entre los americanos, contribuirá a que perdure la fama de nuestras glorias y de nuestras grandezas"795. En ese sentido, El Imparcial opinaba que el conocimiento de la obra en Perú sería un nuevo triunfo para el artista y, tan importante como lo anterior, "un motivo más de que el nombre de España sea pronunciado en aquella república con el entusiasmo y el cariño de que los peruanos nos han dado más de una muestra" ${ }^{\text {796. }}$

\footnotetext{
${ }^{792}$ El Heraldo, "Conmemorando un triunfo", 3 de julio de 1902, p. 2.

${ }^{793}$ Idem.

${ }^{794}$ El Heraldo, "En el estudio de Querol", 13 de mayo de 1904, p. 1.

${ }^{795}$ El Heraldo, "En el estudio de Querol", 13 de mayo de 1904, p. 1.

${ }^{796}$ El Imparcial, "Una obra de Querol", 26 de enero de 1903, p. 3.
} 
Al otro lado del Atlántico, la prensa limeña consagró artículos elocuentes referidos al entusiasmo popular por la victoria de Querol. El parlamento del país le hizo llegar al artista su "clamoroso aplauso"797, por la obra que era la "perfecta realización de los ensueños de todo un pueblo"798. El Imparcial reunió varias noticias de diarios peruanos para publicar, posteriormente, que la opinión pública de ese país valoró profundamente el enaltecimiento de la "gallarda figura del heroico caudillo de Arica"799. La grandiosidad de la misma, apuntaba el Mercurio, suscitó la admiración general. Esto conllevaba la viva expectación que se evidenciaba con un sinnúmero de demandas de los croquis y las fotografías de la obra. En consecuencia, los diarios más importantes de España y el extranjero solicitaban esas informaciones.

\section{Imagen n. ${ }^{\circ} 37$}
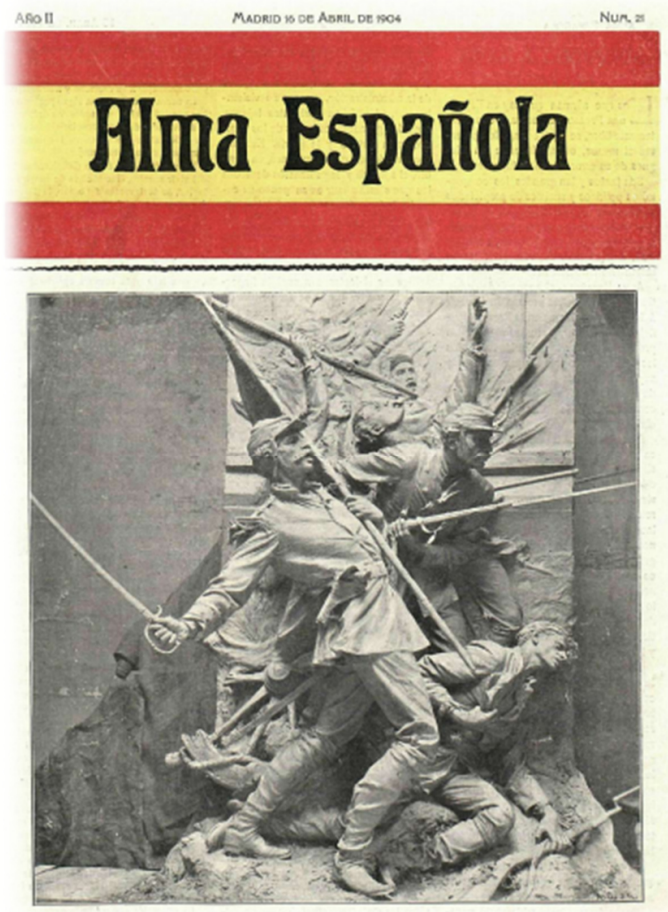

Fuente: La Ilustración Artística, "Agustín Querol.- Monumento a Bolognesi”,16 de abril de 1904, n. ${ }^{\circ} 1064$, p. 332.

\footnotetext{
${ }^{797}$ El Heraldo, "Querol en América", 9 de junio de 1902, p. 1.

${ }^{798}$ Idem.

799 El Imparcial, "Los triunfos de Querol”, 10 de junio de 1902, p. 1; La Correspondencia de España, “Agustín Querol”, 11 de junio de 1902, p. 1.
} 
El triunfo de Querol en Perú, país "cuyo nombre va amorosamente ligado al de España en las loanzas al artista" ${ }^{\circ 00}$, serviría como trampolín para que otros países americanos deseasen entablar negocios con el artista español ${ }^{801}$. De hecho, afirmó un periódico, "son ya varias las Repúblicas americanas de donde ha recibido nuestro eminente compatriota encargos en cantidad no escasa, y se anuncian ya dos o tres monumentos cuya ejecución piensan encomendarle algunos de aquellos países" ${ }^{\$ 02}$.

Parte de esta ebullición americana por el arte español fue explicada en la prensa con un sello romántico que generalizó, sin dudas, el aprecio por el arte europeo. Los americanos -reflexionó un escritor- son eternos enamorados de nuestras leyendas, de nuestros poetas y nuestros pintores. Continuó la noticia, “[...] la suerte quiso que un alma española, el alma ardiente y genial de Querol, haya tenido el supremo acierto de rimar en el bronce y en el mármol el poema que canta con acentos vigorosos y pujantes la sublime epopeya de los héroes peruanos" $" 803$.

\subsection{El Tratado de Paz, Amistad y Comercio entre Chile y Bolivia de 1904}

Para las relaciones internacionales entre Chile y Bolivia la firma del tratado de 1904 representó el fin de la tregua acordada en 1884 que establecía el retorno a las hostilidades bélicas siempre y cuando se avisara esa intención con la anticipación de un año, por lo menos. El fin de la guerra hizo posible que el 20 de octubre de 1904 se firmara el Tratado de Paz, Amistad y Comercio que estipuló, en sus puntos más importantes, la incorporación soberana de la antigua provincia litoral boliviana dentro de los márgenes del estado chileno y, en compensación por ésta, la construcción del ferrocarril desde Arica hasta La Paz con capitales chilenos.

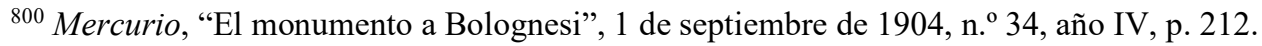

801 Ya en 1900 había esculpido la "Carta Magna y las cuatro regiones argentinas" destinada para la ornamentación de Buenos Aires. En 1908 entregó a Paraná, ciudad también de Argentina, el "Monumento al general Justo José de Urquiza". México pudo admirar el estilo del catalán en 1911. Una revista mexicana de la época publicó: "Han llegado a las obras del Teatro Nacional de México los dos magníficos Pegasos, obras del malogrado escultor español Agustín Querol, representando uno la música y otro la poesía”. En: MoYSSÉN, Xavier, La crítica de arte en México, 1896-1921, Estudios y documentos I (1896-1913), Tomo I, México, Universidad Nacional Autónoma de México. Instituto de Investigaciones Estéticas, 1999, p. 549.

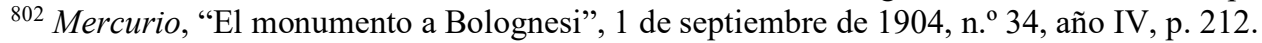

${ }^{803}$ El Heraldo, "En el estudio de Querol", 13 de mayo de 1904, p. 1.
} 
La centralidad que tuvo Arica en este tratado y con esta el problema de la frontera chileno-peruana no fue indiferente para la prensa española que en fechas anteriores al tratado previó la cesión de la provincia litoral boliviana al estado chileno "a cambio de alguna indemnización" ${ }^{804}$, como lo dio a conocer el filósofo y geógrafo español Ricardo Beltrán Rózpide ${ }^{805}$.

Algunas revistas se refirieron al tratado valorando el pacifismo de los suscriptores. Vida Marítima, comentó lo favorable que había sido octubre para los pueblos de "raza española". Chile y Bolivia, profundizó, después de un cuarto de siglo de enemistad establecen la soberanía chilena sobre Antofagasta comprometiéndose en construir un ferrocarril ${ }^{806}$. Esto último permitió asegurar a la revista que, tras firmar el tratado, Chile sería la nación más favorecida con el comercio exterior boliviano. Por lo mismo, el tratado “es un nuevo éxito de la política chilena, no por más pacífica que antes, menos hábil”807.

La Ilustración Artística, por su parte, concordaba con Vida Marítima en el juego estratégico manejado por Chile quien, una vez finalizada las disputas territoriales con Argentina, pudo concentrar sus energías diplomáticas en el caso boliviano. Las dificultades de las diplomacias sudamericanas para cubrir con éxito varios frentes de conflicto dio pie para que aquella revista afirmara que una vez aprobados "los convenios o pactos que garantizan, por ahora, las buenas relaciones entre la República Argentina y Chile, la atención de los políticos sudamericanos se fija preferentemente en la llamada cuestión del Pacífico" $" 808$.

\footnotetext{
${ }^{804}$ Ilustración Artística, "Revista Hispano Americana", 1 de septiembre de 1902, n. ${ }^{\circ}$ 1079, p. 570.

${ }^{805}$ Este intelectual español dedicó al problema de Tacna y Arica más de una reflexión. En uno de sus libros comentó: "Tacna y Arica continúan en el mismo estado, y nada nuevo puede consignarse, como no sea la opinión de un estadista chileno, el Sr. Walker Martínez, ex-Ministro y Jefe del partido conservador, para quien las tales provincias no valen la pena de que dos pueblos discutan acerca de su soberanía en ellas. La posesión ha de ser onerosa para la República a la que definitivamente se adjudiquen; su valor económico es escaso, y aún han perdido más en estos últimos años, porque casi todo el tráfico entre la costa del Pacífico y Bolivia ha de hacerse por los ferrocarriles de Mollendo-Puno, vía peruana, al Norte de Tacna, y AntofagastaOruro, vía chilena, muy al sur de Arica. Sin embargo, a fines de 1903 se dijo que el gobierno chileno estaba decidido a resolver la cuestión anexionando definitivamente a la República los citados territorios. No hay que consignar el mal efecto que esos rumores causaban en el Perú”. En: BELTRÁN RÓZPIDE, Ricardo, Los pueblos hispanoamericanos en el siglo XX, Madrid, Imprenta de Administración Militar, 1904, pp. 254-255.

${ }^{806}$ Vida Marítima, "Revista hispano-americana", 30 de octubre de 1904, año III, n. ${ }^{\text {102, p. } 1}$

${ }^{807}$ Idem.

${ }^{808}$ Ilustración Artística, "Revista Hispano Americana”, 1 de septiembre de 1902, n. ${ }^{\circ}$ 1079, p. 570.
} 
La administración chilena sobre los territorios conquistados al finalizar la guerra fue concebida en esta prensa como la culpable de la inestabilidad fronteriza sudamericana. Por ejemplo, en una de sus publicaciones, recordó algunos momentos en que "el difícil problema pareció que estaba a punto de resolverse" 809 tales como el arbitraje de España de 1898.

Si bien no es inequívoca una actitud de la prensa que responsabilice únicamente a Chile de ese fracaso, las afirmaciones de la Ilustración Artística podrían hacer pensar lo contrario. Al referirse a las "dificultades de última hora" para lograr la paz, se nombraron publicaciones geográficas chilenas que establecían en Sama el límite norte del país. Ese hecho llevaba trazas de naturalizarse, violando los acuerdos anteriores. Similarmente, aunque Bolivia y Perú confiaban en la mediación de Argentina para solucionar diferendos, con ello Chile hubiese "lastimado, seguramente, el amor propio nacional"810. Opinión semejante se publicó con motivo de los preparativos del tratado chileno-boliviano. Chile "se había anexionado las provincias marítimas bolivianas de Cobija y Atacama, al mismo tiempo que ocupaba las provincias de Tarapacá, Arica y Tacna, pertenecientes al Perú, aliado de Bolivia"811. De esas apreciaciones se desprendió la idea de que Chile otra vez había vencido, pues tenía la potestad de "conceder determinadas facilidades comerciales para compensar la pérdida del litoral experimentada por dicha República"\$12.

Cada uno de los matices lingüísticos utilizados con relación a Chile construyó, poco a poco, su representación social en España como un país que recurría a la violencia y la imposición en sus relaciones internacionales. La naturalización de esas conductas permitió a una publicación seria, que en rigor no debía realizar valoraciones, sostener que Chile había iniciado la Guerra del Pacífico valiéndose de pretextos relacionados con el cobro de impuestos a los quintales de "guano (nitro)" 813 exportados desde el puerto de Antofagasta.

\footnotetext{
${ }^{809}$ Idem.

${ }^{810}$ Ilustración Artística, "Revista Hispano Americana", 1 de septiembre de 1902, n. ${ }^{\circ} 1079$, p. 570.

${ }^{811}$ La Dinastía, "Las diferencias entre Chile y Bolivia", 22 de mayo de 1903, p. 3; La Época, "Las diferencias entre Chile y Bolivia", 22 de mayo de 1903, p, 3.

${ }^{812}$ Idem.

813 Almanaque Bailly-Bailliere, "Historia General de la América del Sur. Bolivia", 1908, Madrid, Casa Editorial Bailly-Bailliere, p. 296.
} 
Sin detenernos en el error del almanaque sobre el recurso natural gravado con impuestos, pues, a decir verdad, se trató de salitre y no de guano, Chile fue acusado de acechar a Bolivia para en "un momento oportuno [...] apoderarse del territorio" 814 e invadir "sin declaración de guerra Bolivia, rechazando la mediación de Perú, al que declaró la guerra antes que se declarase el casus foederis" ${ }^{815}$. Unos días después de la firma del tratado, en España se publicó que: "Bolivia y Chile han convenido definitivo tratado de paz. Los territorios del litoral del Pacífico ocupados por la segunda de dichas Repúblicas quedan ya bajo su soberanía" $" 16$.

En cambio, continuó la noticia, Bolivia recibirá unos cuantos millones de pesos, y Chile se compromete a construir el ferrocarril de Arica a La Paz. Ésta y otras vías férreas proyectadas darán a Bolivia salida hacia el Pacífico. Si hubiera dificultades para el cumplimiento del tratado, Guillermo II, emperador de Alemania, actuaría como árbitro. Ocioso sería decir, finalizaba la nota, que "hay muchos bolivianos que consideran este tratado como un acto de expoliación que realiza Chile con el consentimiento del actual gobierno de Bolivia"817.

Al transcurrir el tiempo, otras revistas españolas se centraron en la dimensión social del tratado y en cómo no había sido bien recibido en la población boliviana. Por ejemplo, La Ilustración Artística, comentó el encuentro "telefónico" entre los presidentes de Bolivia, Ismael Montes, sucesor de José Manuel Pando, y el presidente de Chile, Germán Riesco. Los avances en los medios de comunicación habían permitido que una línea telefónica conectara Arica con La Paz, "atravesando desiertos y montañas" ${ }^{818}$, como escribió la revista. En ese reportaje se subrayó la impopularidad del tratado chileno-boliviano en el último país en los siguientes términos: "no todos los bolivianos participan de la satisfacción que el tal tratado ha producido en el Presidente y su gobierno y en los adictos a él" ${ }^{\prime 19}$.

\footnotetext{
${ }^{814}$ Almanaque Bailly-Bailliere, "Historia General de la América del Sur. Bolivia", 1908, Madrid, Casa Editorial Bailly-Bailliere, p. 296.

${ }^{815}$ Idem.

${ }^{816}$ La Ilustración Artística, "Revista Hispanoamericana", 21 de noviembre de 1904, año XXIII, n. ${ }^{\circ} 1195$, p. 762.

${ }^{817}$ Idem.

818 Idem.

${ }^{819}$ La Ilustración Artística, "Revista Hispanoamericana", 1 de mayo de 1905, n. ${ }^{\circ}$ 1218, p. 282.
} 
Allí, los opositores al tratado conformaron una visión negativa hacia el presidente, acusándolo de traición a la patria por ceder territorios a Chile. Como lo explicó Loreto Correa, la construcción de ferrocarriles era uno de los caminos para "exportar los productos bolivianos y [...] lograr el desarrollo que convertiría a Bolivia en una especie de Suiza americana" 820 . Otras noticias se refirieron al tratado celebrado por Chile y Bolivia errando en el país de pertenencia de Tacna y Arica. El Álbum Iberoamericano, por ejemplo, aseguró que acababa de celebrarse un tratado entre Bolivia y Chile, perdiendo el primer país una salida al mar, obligándose Chile, por eso, "a construir un ferrocarril entre La Paz y el puerto de Arica. Al terminarse esta línea Bolivia quedará distante de la costa sólo doce horas en vez de noventa y seis, cobrando gran importancia sus (sic) provincias de Tacna y Arica ${ }^{821}$. En fecha posterior, esta revista publicó en la sección "Crónica española y americana" las repercusiones que, en parte de la clase política chilena, suscitó el tratado. Si bien no era la opinión general en Chile, alguna prensa de la época se solidarizó con la mediterraneidad boliviana: "los periódicos del Perú como los de Chile ocupanse del tratado chilenoboliviano, y algunos de ellos, hasta los mismos chilenos, lo condenan aconsejando al Gobierno que restituya al Perú las provincias de Tacna y Arica"822. El argumento de esa restitución guardaba relación con el hecho de que su nacionalidad, según el Tratado de Ancón "no se halla todavía definida. Al abogar por esa restitución cree la prensa ser acto de estricta justicia y un medio para que cese la tirantez entre dos pueblos hermanos, entrando en relaciones de recíproca $\operatorname{amistad}^{823}$.

Como hemos señalado, si bien la definición de la soberanía definitiva de Tacna y Arica era una cuestión bilateral entre Chile y Perú, la posición de Bolivia siempre fue un factor presente en el momento de tomar decisiones limítrofes. O, dicho de otra forma, cada discusión entre las cancillerías de Chile y Perú por Tacna y Arica no podía marginar completamente a Bolivia, pues ésta pensó seriamente que esa zona podía cedérsele como método "purificador" de la intoxicada diplomacia chileno-peruana. Por lo anterior, la importancia geopolítica de Tacna y Arica las situó en el foco del deseo de esos tres países.

\footnotetext{
${ }^{820}$ CORREA, Loreto, "Del poder a los tratados: desarrollo y ferrocarriles en Bolivia, 1870-1904". Historia, Vol. 46, n. ${ }^{\circ}$ 2, 2013, <http://www.scielo.cl/scielo.php?pid=S0717-71942013000200001\&script=sci_arttext $>$ [consultado el: 05/07/2014].

${ }^{821}$ El Álbum Iberoamericano, "Crónica europea y americana”, 22 de enero de 1905, n. 3, p. 26.

${ }^{822}$ El Álbum Iberoamericano, "Crónica española y americana", 30 de abril de 1905, n. ${ }^{\circ}$ 16, p. 182.

${ }^{823}$ Idem.
} 
Así, en el momento de la publicación del tratado, Perú no quedó indiferente, pues no aceptó que Chile prometiera construir un ferrocarril en Arica haciendo un acto de soberanía “ilegal”. La prensa advirtió que esa construcción se encuadraba en la política marcada para “chilenizar dicha provincia" 824 , previendo su dominio ${ }^{825}$. Perú, escribió la misma revista, no tolerando la situación, protestó contra el decreto chileno que fijó límites entre Pisagua y el Departamento de Arica. La sutileza hacia el Perú se constata con aseveraciones que elogian el militarismo y el progreso de ese país: "Perú no cesa en su obra de regeneración y engrandecimiento, y cuida muy especialmente de aumentar sus fuerzas militares y de establecer vías de comunicación" $" 26$.

Una explicación elocuente sobre la responsabilidad chilena en los fracasos plebiscitarios hizo la Ilustración Artística, quien acusó a Chile por el ejercicio ilegal de soberanía. El Perú protestó contra el convenio chileno-boliviano -explicó la revistaapelando a sus derechos en Tacna y Arica, porque la construcción del ferrocarril era “ejercer actos de soberanía, que Chile no tiene, puesto que la nacionalidad de aquellos territorios depende de lo que resuelva el [...] plebiscito [...] Y ese plebiscito no se ha llevado a cabo por culpa de Chile" 827.

Después de 1904, decaen las noticias sobre Tacna y Arica y su relación con el tratado. Aparecerían algunas notas dispares sobre acuerdos posteriores que debían marcar el territorio por donde atravesaría el ferrocarril y su posible neutralización ${ }^{828}$, otras sobre el incesante afán anexionista de Chile pretendiendo "que el tendido de esta línea férrea pase por Collalmane para que los terrenos pertenecientes a esta comarca boliviana pasen a la soberanía de aquel país" ${ }^{829}$ y, por último, de los buenos deseos del presidente boliviano para impulsar el desarrollo económico de su país a instancias del tendido ferroviario ${ }^{830}$.

\footnotetext{
${ }^{824}$ La Ilustración Artística, "Revista Hispanoamericana", 21 de noviembre de 1904, n. ${ }^{\circ}$ 1195, año XXIII, p. 762.

${ }^{825}$ La Ilustración Artística, "Revista Hispanoamericana", 1 de mayo de 1905, n. ${ }^{\circ} 1218$, p. 282.

${ }^{826}$ La Ilustración Artística, "Revista Hispanoamericana", 21 de noviembre de 1904, n. ${ }^{\circ}$ 1195, año XXIII, p. 762.

${ }^{827}$ La Ilustración Artística, "Revista Hispanoamericana", 1 de mayo de 1905, n. ${ }^{\circ} 1218$, p. 282.

${ }^{828}$ El Heraldo, "Chile", 19 de febrero de 1906, p. 1.

${ }^{829}$ La Correspondencia Militar, “América”, 13 de septiembre de 1906, p. 2.

${ }^{830}$ El Día, "Bolivia", 2 de abril de 1909, p. 2.
} 
6.3. Tacna y Arica: entre la nostalgia hispanoamericanista y el pragmatismo yanqui

Las repercusiones del segundo Congreso Panamericano celebrado en la ciudad de México los años 1901-1902, donde Chile se consideró "predestinado para ser la gran potencia de América del Sur" ${ }^{\prime 31}$, no cesaron en la prensa española. Rubén Darío, el poeta y diplomático nicaragüense conocido como el "príncipe de las letras castellanas", uno de los representantes más importantes del modernismo y, por entonces, escritor de la revista Hojas Selectas, se refirió a una de ellas. En concreto, felicitaba la actitud del presidente ecuatoriano, el liberal Leónidas Plaza Gutiérrez de Caviedes, quien defendió frente a Theodor Roosevelt, presidente de los Estados Unidos, una posición favorable a los arbitrajes como mecanismo jurídico para resolver problemas entre países hispanoamericanos.

El papel de los arbitrajes se había acordado en el Congreso de La Haya, donde se estableció que la convención del arbitraje se debía concertar por disidencias ya existentes o por disidencias eventuales. Los Estados Unidos, por el contrario, preferían la modalidad de los "buenos oficios". Esta última situación permitió al poeta referirse al presidente Roosevelt como el "jefe de la gran república imperialista y peligrosa" ${ }^{832}$, pero también a la particular posición chilena. Este país se marginó de las instancias arbitrales, sosteniendo que esa posición se relacionaba con que "estima dañoso tal principio para sus intereses en la pendiente cuestión de Tacna y Arica" ${ }^{833}$. En ese artículo, sin acusar directamente las formas de hacer política exterior de Chile, llamó a la reflexión a algunos presidentes americanos que, en sus palabras, "entronizando un despotismo primitivo, provocan a la continua agitaciones y revueltas que son la ruina de los estados, y los cuales, en juegos de cancillería, tienen como la mira la política desleal y la conquista" ${ }^{934}$.

\footnotetext{
831 CAStro PeÑA, Yeni, El mito Roosevelt para América Latina (1901-1909), Quito, Universidad Andina Simón Bolívar, Abya Yala, Corporación Editora Nacional, 2007, p. 84.

${ }^{832}$ Hojas selectas, “Excelentísimo Sr. General Leónidas Plaza G.”, enero de 1902, p. 898.

${ }^{833}$ Idem.

${ }^{834}$ Idem.
} 
La crítica política del nicaragüense frente al presidente Roosevelt y las formas del “imperialismo" 835 que comenzaban a hacerse palpables sobre América Latina no quedó plasmada en textos de politología. A su modo, el "poeta y profeta de la raza hispánica" 836 legó al futuro la oda $A$ Roosevelt. En este poema sintetizó la idea central de la pugna ideológica entre España y Estados Unidos por la hegemonía ideológica que ambos desearon sobre América Latina. $\mathrm{O}$, como un estudioso de su prosa ha señalado, A Roosevelt "es uno de los poemas más representativos de Cantos de vida y esperanza, resumen fundamental del contenido de la obra -la política, la protesta social, la conciencia de Hispanoamérica, la religión, el amor hacia España [...] la desconfianza hacia los Estados Unidos" ${ }^{937}$. Por su interés, reproducimos un fragmento de la oda:

Es con voz de la Biblia, o verso de Walt Whitman, que habría de llegar hasta ti, Cazador, primitivo y moderno, sencillo y complicado, con un algo de Washington y cuatro de Nemrod. Eres los Estados Unidos, eres el futuro invasor de la América ingenua que tiene sangre indígena, que aún reza Jesucristo y aún habla español. [...]

Crees que la vida es incendio, que el progreso es erupción, que en donde pones la bala el porvenir pones.

No.

Los Estados Unidos son potentes y grandes. Cuando ellos se estremecen hay un hondo temblor que pasa por las vértebras enormes de los Andes. Si clamáis, se oye como el rugir de un león. Ya Hugo a Grant lo dijo: Las estrellas son vuestras. (Apenas brilla, alzándose, el argentino sol y la estrella chilena se levanta...) Sois ricos.

\footnotetext{
${ }^{835}$ HENKEL, Andrea, "Rubén Darío y la cultura norteamericana: A Roosevelt", Seminario El Mediterráneo en la poesía del Modernismo y del 27', Universität zu Köln Fachbereich Romanistik Wintersemester 2009/2010, $<\mathrm{http}$ ://lateinamerika.phil-fak.uni-

koeln.de/fileadmin/sites/aspla/bilder/ip_2010/Andrea_Henkel_RubenDario_pdf> [consultado el: 05/02/2015].

836 SANZANA INSUNZA, Isaac, "Consideraciones sobre el cosmopolitismo en Rubén Darío", Revista Borradores, Vol. X-XI, año 2009-2010, Universidad Nacional de Río Cuarto, p. 1.

${ }^{837}$ ARANGO, Manuel Antonio, “Aspectos sociales en tres poemas de Cantos de vida y esperanza, de Rubén Darío: «Salutación del optimista», «Los cisnes», n. ${ }^{\circ}$ 1, y «A Roosevelt»", Anales de Literatura Hispanoamericana, Vol. 6, 1977, p. 287.
} 
Juntáis al culto de Hércules el culto de Mammón; y alumbrando el camino de la fácil conquista; la libertad levanta su antorcha en Nueva-York.

Mas la América nuestra, que tenía poetas desde los viejos tiempos de Netzahualcoyotl, que ha guardado la huella de los pies del gran Baco que el alfabeto pánico en un tiempo aprendió; que consultó los astros, que conoció la Atlántida cuyo nombre nos llega resonando en Platón, que desde los remotos momentos de su vida vive de luz, de fuego, de perfume, de amor, la América grande de Moctezuma, del Inca, la América fragante de Cristóbal Colón, la América católica, la América española, la América en que dijo el noble Guatemoc: "Yo no estoy en un lecho de rosas"; esa América que tiembla de huracanes y que vive de amor, hombres de ojos sajones y alma bárbara, vive. Y sueña. Y ama, y vibra, y es la hija del Sol. Tened cuidado. ¡Vive la América española! Hay mil cachorros sueltos del león español. Se necesitará, Roosevelt, ser, por Dios mismo, El Riflero terrible y el fuerte Cazador, para poder tenernos en vuestras férreas garras. Y, pues contáis con todo, falta una cosa: ¡Dios! $!^{838}$

En otro aspecto, frente al avance político y económico de los Estados Unidos en los antiguos territorios españoles, la posición de Rubén Darío, como hemos visto, no fue exclusiva, ni mucho menos marginal. Su acentuada defensa de los vínculos culturales entre España y los países de allende el Atlántico reafirmaron las constataciones de algunos estudios recientes ${ }^{839}$. Ello queda de manifiesto tanto en su exaltación de lo hispanoamericano, como en el rechazo y la denuncia de quien lo amenaza, esto es, los Estados Unidos y Europa, que a menudo eran vistos como sujetos colonizadores.

\footnotetext{
${ }^{838}$ RUBÉn DARÍo, Antología poética, Madrid: Editorial EDAF, S. L., 1998, pp. 144-146.

839 Rodríguez Murillo, Marco Antonio, "Modernismo y sociedad en la obra poética de Rubén Darío", Temas antropológicos, Revista cientifica de investigaciones regionales, Vol. 35, n. ${ }^{\circ}$ 1, 2012-2013, Universidad Autónoma de Yucatán, pp. 81-107; ACEREDA, Alberto, "La hispanidad amenazada: Rubén Darío y la guerra del 98”, Bolingual Review/La revista bilingüe, vol. 25, n. ${ }^{\circ}$ 1, pp. 99-110; MC CALLISTER, Rick, "Esquizofrenia e imperialismo en Rubén Darío", Revista Cátedra, n. ${ }^{\circ} 14$, julio-diciembre 2010, Universidad de Managua; TunNERMANn BerHeIM, Carlos, "El pensamiento político de Rubén Darío", UPOLI CIELAC, Documento de trabajo, n. ${ }^{\circ}$ 3, Disponible en: http://biblioteca.clacso.edu.ar/Nicaragua/cielacupoli/20100709040155/C4.pdf
} 


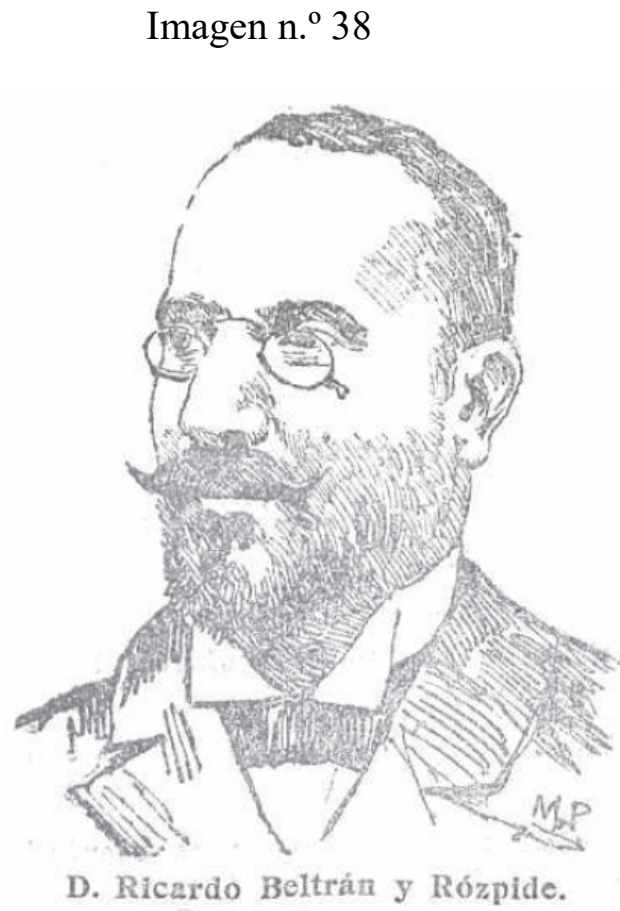

Fuente: El Globo, “D. Ricardo Beltrán y Rózpide”, 1 de junio de 1903, p. 1.

En España, el profesor Ricardo Beltrán Rózpide publicó periódicamente artículos sobre esta cuestión. Como antes, mantuvo su "peruanofilia" y recriminó, por otro lado, la actitud yanqui. Lo primero se notó durante el supuesto armamentismo peruano de comienzos de siglo que, según él, causaba recelos entre los países vecinos.

Perú había enviado fondos, para adquirir acorazados, a Europa y Estados Unidos, negocio que incluía el envío de oficiales para su perfeccionamiento. Beltrán Rózpide se hizo eco de las declaraciones de la diplomacia peruana quien afirmó "que tales armamentos no obedecen a propósitos belicosos [siendo] pueril hablar de preparativos de guerra porque el ejército y la marina del Perú cuenten algunas baterías más y algunas unidades nuevas" ${ }^{\circledR 40}$. Por el contrario, continuaba la nota, la diplomacia peruana tenía "la mira puesta en Tacna y Arica y en el cumplimiento del Tratado de Ancón; mas no con intento de provocar a Chile, sino para ponerse en condiciones de pagarle la indemnización convenida si el plebiscito fuese favorable a la devolución de esas provincias" ${ }^{841}$.

\footnotetext{
${ }^{840}$ La Ilustración Artística, "Revista hispanoamericana", año XXV, 14 de mayo de 1906, n. ${ }^{\circ}$ 1272, p. 314.

${ }^{841}$ Idem.
} 
Verídicas o no las declaraciones peruanas, lo cierto es que poco a poco comenzaron a surgir ideas sobre la creación de un nuevo Estado en los territorios ocupados por Tacna y Arica. La gestación de un nuevo país en la triple frontera chileno-peruano-boliviana nunca se realizaría, siendo un anhelo poco popular en Chile y Perú que surgiría, por lo menos, durante los próximos treinta años. Según la Ilustración artística, la República del Pacífico, como debería llamarse Tacna y Arica una vez convertido en país, era una idea estadounidense. La nota detallada decía:

Atribuyese la idea a los yanquis, pues dicen que con dinero de ellos se trata de ganar adeptos y promover un movimiento insurreccional que tenga por consecuencia la creación de esa República, amparada o protegía más o menos paladinamente por el gobierno de Washington. La empresa nos parece bastante aventurada ${ }^{842}$.

La posición de Beltrán Rózpide era contraria al proceder estadounidense, ahora, con el caso de Tacna y Arica. Esta afirmación se puede sostener, por lo menos, entendiendo la valoración del movimiento emancipador (?), inexistente, por razones desconocidas, en la bibliografía chilena y peruana que aborda el problema de límites. Para el periodista español, se desprende del texto, ese movimiento estaba organizado por un grupo insurrecto contra la autoridad del momento; además, de crearse la república, esta gozaría de la protección "paladina", es decir, clara y patente, de los Estados Unidos; siendo aquellas situaciones motivos para desconfiar de esa empresa "bastante aventurada".

Otras noticias que circularon entonces se refirieron al potencial surgimiento del nuevo país, no obstante, la incorrección de las informaciones adjudicó a Tacna y Arica rasgos no válidos, pero que, al igual que el reporte anterior, achacaba al presidente estadounidense la responsabilidad del conflicto. Los informes llegados a El Heraldo desde Chile daban a conocer en España lo alarmado que estaba aquel gobierno por los rumores que circulaban por diversos países sudamericanos relativos a "una posible intentona para declararse independientes Tacna y Arica, la parte más rica de Chile, conquistada a Bolivia y Perú" $\$ 43$.

\footnotetext{
842 Idem.

${ }^{843}$ El Heraldo, "Chile", 2 de marzo de 1906, p. 1.
} 
Tales rumores, como señalamos, fueron atribuidos a "la injerencia solapada de Roosevelt, con el fin de provocar otro conflicto como el de Panamá, que ha desmembrado el territorio de Colombia" ${ }^{444}$. En concreto, los errores reproducidos por el diario, al no explicitar la fuente, se vuelven difíciles de adjudicar a un tercero quien aseguró, primero, que Tacna y Arica eran los territorios más ricos de Chile, cuando, a juzgar por los recursos naturales existentes y las redes comerciales occidentales, tal zona era Tarapacá y, segundo, la conquista de Tacna y Arica afectó sólo a Perú, pues Bolivia no ejercía soberanía alguna sobre aquellas con anterioridad a 1879.

En general, la situación fronteriza entre los Estados americanos y, en particular, la cuestión de Tacna y Arica, se debatieron en otro foro internacional de interés parar la prensa. El 21 de junio de 1906 se celebró en Río de Janeiro el III Congreso Panamericano. Participaron en él, exceptuando Venezuela y República Dominicana, todos los países. El objetivo de la reunión era:

[...] propender a la cordialidad internacional entre todos los pueblos del continente americano y a la realización de todo aquello que asegure y estimule el progreso, la civilización y el imperio de la justicia y de la libertad en toda América. [...] Los países latinos de América han visto con zozobra muchos de los actos recientes de la política internacional norte-americana; esos países, celosos de su independencia y su soberanía, no están dispuestos a aceptar la tutela paternal en más de una ocasión proclamada por míster Roosevelt. En las frecuentes ocasiones en que ese magistrado se ha ocupado de la doctrina Monroe, ha insistido en acentuar el alcance de esa doctrina como él la entiende. Según él, la doctrina Monroe protege á las naciones americanas de toda tentativa extraña de conquista ó de colonización. Si eso fuese todo, acaso nada hubiera que observar, pero Mr. Roosevelt ha agregado que si alguna nación americana llegara á caer en el desgobierno y en la anarquía, se hará necesaria la intervención de una nación civilizada para restablecer la normalidad, y que esa nación no podrá ser sino los Estados Unidos. Como ellos mismos serán jueces de lo que constituya desgobierno y anarquía, las posibilidades de su acción adquieren un carácter ominoso para la independencia de los países americanos. La doctrina Monroe declara el continente americano intangible á toda conquista ó colonización europea. Así la integridad de las naciones americanas está protegida contra todo esfuerzo europeo. El representante de Bolivia, con una perspicacia que le honra, pidió que la soberanía de las naciones americanas estuviera también garantizada contra las tentativas de otras naciones americanas. [...] América latina no olvida sus vínculos tradicionales con la vieja Europa, de la que ha recibido población, capitales, cultura y religión. Toca á esa vieja Europa no descuidarse en esta lucha de intereses con adversario tan formidable y tan hábil, y á los pueblos latinoamericanos les toca estudiar con ánimo sereno lo que mejor convenga a sus intereses históricos y permanentes ${ }^{845}$.

\footnotetext{
${ }^{844}$ Idem.

${ }^{845}$ Hojas selectas, “Crónica internacional”, 1906, (sin ningún dato de la edición), pp. 931-933.
} 
Los juicios de la prensa también se dirigieron hacia Elihu Root, Secretario de Guerra y de Estado de los Estados Unidos. Su comportamiento en Río de Janeiro -dijo El Liberal- tuvo la gravedad y tranquilidad propia de un yanqui. El diplomático demostró gran curiosidad en todas las sesiones del Congreso, permitiéndole informar detalladamente de la situación del "gran negocio de la preponderancia americana en América Latina" ${ }^{846}$ al presidente Roosevelt. Ese diario fantaseaba con los diálogos sostenidos entre ambos, comentando que aunque los propósitos de dominio político y económico absoluto no se habían evidenciado, "no han perdido los yankees el gran terreno conquistado en los Congresos anteriores" $" 847$.

Para la prensa, este triunfo se explicaba por el conocimiento que los diplomáticos estadounidenses tenían de los países americanos o, como escribió El Liberal, conocimiento de la "vidriosa susceptibilidad" de esos pueblos. Estados Unidos procuraba "disfrazar sus

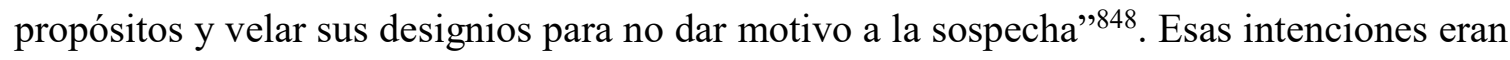
netamente económicas, teniendo como objetivo desarrollar las relaciones comerciales entre el país del norte y Latinoamérica, anhelo "deseado tan ardientemente por los Estados Unidos" $" 849$ y que, contrario a los intereses españoles, "no podrá hacerse sino en perjuicio de los productores europeos" $" 850$.

La acusación más grave realizada por los diarios contra la diplomacia estadounidense se relacionó con el peso de los asuntos económicos en las reuniones, en perjuicio, de los temas políticos. Uno de los más interesantes era la situación de Tacna y Arica la que, a juzgar por la prensa, había sido desatendida por los Estados Unidos. En estas cuestiones económicas ha hecho hincapié la Gran República -señaló un periódico-, no así "en otras cuestiones, como, por ejemplo, en la famosa de Tacna y Arica, antiguos territorios de Perú, que Chile, en la Guerra del Pacífico, ocupó provisionalmente, negándose a restituirlos con manifiesta burla del Tratado de Ancón de $1883^{851}$.

\footnotetext{
${ }^{846}$ El Liberal, "Después del Congreso", 4 de septiembre de 1906, p. 1.

${ }^{847}$ Idem.

${ }^{848}$ Idem.

${ }^{849}$ Idem.

${ }^{850}$ Idem.

${ }^{851}$ Idem.
} 
La resistencia chilena al arbitraje contrariaba el interés mayoritario de los países americanos, quienes lo tildaron de "mal vecino". Reuniones como las de Río de Janeiro, en donde se discutían los beneficios arbitrales, y en donde la negación chilena demostraba firmeza, permitió la cristalización de esa idea. En rigor, esa junta buscaba "la adhesión americana al principio del arbitraje" ${ }^{\text {"52, }}$, aspirando "a que todos los conflictos puedan ser resueltos por este principio reconocido y acatado por todas las naciones" ${ }^{\text {853. }}$.

A Perú, el conflicto de Tacna y Arica, y otros diferendos, lo volvían defensor convencido del arbitraje. José María Álvarez, escritor de La Lectura entendió la fe peruana en esa doctrina. Comprendía que esa concepción jurídica se debía a la inexistencia de otro país más agobiado por conflictos internacionales. De esos, el más importante era el sostenido con Chile. Una noticia con acento "chilenófobo", señalaba las disputas limítrofes entre Perú-Bolivia, Perú-Ecuador, Perú-Brasil y especialmente con Chile, que desde "el atropello jurídico de Tacna y Arica dejó sembrados el odio y el rencor entre dos pueblos hermanos" 854 , impidiendo "la confraternidad y confederación de pueblos que debían estar unidos según el principio de las modernas nacionalidades" ${ }^{955}$.

Álvarez juzgó las propuestas peruanas para solucionar este último problema, acusando a la cancillería de "entreguismo" al imperialismo estadounidense. Los fundamentos de esa opinión eran las manifestaciones de la diplomacia peruana hacia Root, “el gran asesino del derecho público americano". Álvarez alertaba sobre los peligrosos que esta política internacional conllevaría a esa república, la cual "no marcha expedita y desembarazada en los múltiples, varios y pavorosos problemas que se ciernen sobre el horizonte de la patria" ${ }^{856}$. En conclusión, las palabras del escritor eran una forma de castigo al Perú por no conservar la soberanía nacional con los honores esperados de los hombres públicos, actitud que amenazaba con "destruir el edificio y afear la esbeltez arquitectónica del gran santuario de la integridad territorial" 857 .

${ }^{852}$ UgALDE, Luis, El Gomecismo y la politica panamericana de Estados Unidos, Caracas, Universidad Católica Andrés Bello, 2005, p. 25.

${ }^{853}$ Idem.

${ }^{854}$ La Lectura, “El Perú contemporáneo”, enero de 1907, n. ${ }^{\text {o } 73, ~ p . ~} 186$.

${ }^{855}$ Idem.

856 Íbidem, p. 187.

${ }^{857}$ Idem. 
De asumir esa idea -la responsabilidad compartida por Estados Unidos y Perú en la destrucción paulatina de la soberanía republicana en América-deberíamos comprender a Tacna y Arica como un momento diplomático fundamental y posibilitador del “intervencionismo" de la Casa Blanca. Esas intervenciones eran acordes con una política exterior centrada en afirmar su predominio marítimo en el Pacífico sur. En la práctica, el proyecto de expansión territorial enmarcó también las negociaciones, anunciadas por la prensa, con Ecuador ${ }^{858}$ y Panamá, países con quienes se intentaría respectivamente la compra de las islas Galápagos y la construcción de fortificaciones en el canal de Panamá.

Las anteriores negociaciones estaban más avanzadas que las conversaciones entre los Estados Unidos y el Perú con el objeto de obtener el primer país del segundo "un puesto

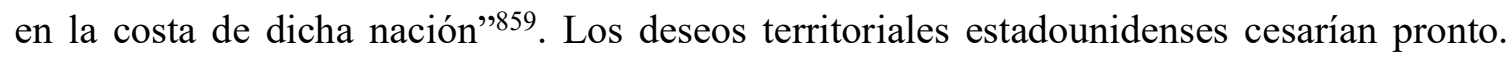
Las conversaciones con Perú se consideraron "fracasadas" 860 en 1911. Sin embargo, la situación entre ambos países no dificultó que se mantuviesen relaciones diplomáticas estables. En un artículo titulado "Propósitos Yanquis" se afirmó que esa amistad se fundamentaba en que Perú "sostiene también cordiales relaciones con la Gran República de Norte América, porque solicita el concurso de ésta contra Chile, en el pleito que sostiene (sic) por incorporarse de nuevo las provincias de Tacna y Arica" ${ }^{\$ 61}$. En Chile, El Mercurio, diario fundado en Santiago en 1900 por Agustín Edwards McClure ${ }^{862}$, había publicado tiempo antes una nota sobre el equilibrio y la justicia de la diplomacia estadounidense en este litigio, elogiando la posición legalista chilena frente al Tratado de Ancón de $1883^{863}$.

\footnotetext{
${ }^{858}$ La situación fronteriza entre Ecuador y Perú no era menos turbulenta que la existente en Tacna y Arica. A comienzos de 1910, por ejemplo, el enrarecimiento de las relaciones ecuatoriano-peruanas permitió que la prensa española informara: "Se asegura en Lima que el Gobierno peruano, para dedicar toda su energía al conflicto de fronteras con el Ecuador, está dispuesto a aceptar las nuevas proposiciones formuladas por el ministro de Negocios Extranjero de Chile para el arreglo definitivo de la cuestión de Tacna y Arica. Comunican desde Washington al Daily Mail que en el Ministerio de Estado inspira serios temores la tirantez de relaciones entre Perú y Ecuador. Se teme que cualquier incidente provoque una conflagración en la América del Sur. Están ya terminados los preparativos guerreros del Perú. En: El Globo, "Perú y el Ecuador", 9 de abril de 1910, p. 1.

${ }^{859}$ La Correspondencia de España, "Propósitos Yanquis", 10 de febrero de 1911, p. 3.

${ }^{860}$ Idem.

${ }^{861}$ Idem.

${ }^{862}$ CORREA SutiL, Sofía, Con las riendas del poder. La derecha chilena en el siglo XX, Santiago, Editorial Sudamericana [Edición digital].

${ }^{863}$ El Heraldo, "Chile y el Perú", 29 de mayo de 1909, p. 4; El Siglo Futuro, “-”, 29 de mayo de 1909, p. 3.
} 
El problema chileno-peruano continuó debatiéndose en las reuniones panamericanas y produciendo noticias. En 1910, con motivo de la IV Conferencia Panamericana en Argentina, el intelectual español Pío Ballesteros Álava ${ }^{864}$ publicó un extenso reportaje sobre su desarrollo, criticando las versiones anteriores del encuentro "orquestado" desde Washington. La formación en derecho e historia de Ballesteros favoreció su interés por la diplomacia americana. En la introducción de su estudio señaló: “es América un continente rico en asuntos de estudio: nacido hace poco tiempo, como quien dice, era natural que sus instituciones del derecho de gentes revistiesen forzosamente caracteres peculiares" ${ }^{\text {865. El }}$ examen de Ballesteros apareció en revistas políticas influyentes en los Estados Unidos como Writings on American History y American Historical Associtation.

La Ilustración Artística también aludía a Estados Unidos y su política internacional “intervencionista” en la Conferencia de Buenos Aires. Allí había corrido el rumor de la intención de algunos países de protestar contra la conducta estadounidense en Nicaragua, días antes de la firma de los "Pactos Dawson"866. Por eso, el Secretario de Estado, Philander Knox, había conminado a sus representantes para "procurar que se sienta lo menos posible la influencia yanqui" ${ }^{867}$.

${ }^{864}$ Escasas referencias sobre la biografía de este escritor se pueden encontrar en PEIRÓ MARTIN, Ignacio, Historiadores en España. Historia de la historia y memoria de la profesión, Zaragoza, Prensas de la Universidad de Zaragoza, 2013, p. 27; PEIRÓ MARTIN, Ignacio y PASAMAR AlzURIA, Gonzalo, Diccionario Akal de Historiadores españoles contemporáneos, Madrid, Ediciones Akal S. A., 2002, p. 101; PASAMAR, Gonzalo, "Las «historias de España» a lo largo del siglo XX: las transformaciones de un género clásico". En GARCÍA CÁRCEL, Ricardo (coord.), La construcción de las historias de España, Madrid, Marcial Pons, Ediciones de Historia S. A., 2004, p. 315. En la Biblioteca Histórica de Santa Cruz de la Universidad de Valladolid se encuentra la tesis doctoral del escritor aludido. Ver: BALLESTEROS, Pío, Origen de la firma de Derecho ante la justicia de Aragón, Madrid, Tip. de la Revista de Archivos, Biblioteca y Museos, 1904.

${ }^{865}$ La España Moderna, "Las Conferencias Panamericanas", febrero de 1911, n. ${ }^{\circ}$ 266, p. 5.

${ }^{866}$ Algunas lecturas que contextualizan el imperialismo estadounidense sobre Nicaragua, por orden de publicación, en: AstiÉ-Burgos, Walter, México y Estados Unidos: entre la cooperación y el desacuerdo, México, Siglo XX Editores, 1998, p. 76; GuTIÉRREZ, Harim, Una alianza fallida: México y Nicaragua contra Estados Unidos, 1909-1910, México, Instituto Mora, 2000; SELSER, Gregorio, Cronología de las intervenciones extranjeras en América Latina: 1899-1945, Tomo III, México, Centro de Investigaciones Interdisciplinarias en Ciencias y Humanidades, Universidad Nacional Autónoma de México, 2001, p. 165; COCKCROFT, James, América Latina y Estados Unidos. Historia politica país por país, México, Siglo XXI Editores, 2001, p. 244; ACOSTA CERÓN, Ramiro, Los nuevos sujetos del derecho internacional, Quito, Ediciones Abya-Yala, 2002, p. 20; LÓPEZ-Álves, Fernando, La formación del Estado y la democracia en América Latina, Bogotá, Editorial Norma, 2003, p. 71; GARDNER MunRO, Dana, Las cinco repúblicas de Centroamérica. Desarrollo político y económico y relaciones con Estados Unidos, Costa Rica, Editorial de la Universidad de Costa Rica, 2003, p. 261-267; GaleanA, Patricia, El Tratado Mc Lane-Ocampo. La comunicación interoceánica y el libre comercio, México, Editorial Porrúa, 2006, p. 20.

${ }^{867}$ La Ilustración Artística, "Revista Hispanoamericana", 29 de agosto de 1910, n. ${ }^{\circ} 1496$, p. 544. 
La revista imaginó prácticas concretas de Knox con sus subalternos quien recomendaba a sus delegados que observasen una actitud que no diera lugar a sospechas de parcialidad en temas "candentes" de la región, aprovechando la Conferencia para influir en casos concretos, "al dar estas instrucciones tuvo Knox seguramente en cuenta la situación creada entre Perú y Chile respecto a Tacna y Arica" ${ }^{968}$.

Ballesteros también cedió a su imaginación. Intuía, temeroso, el avance económico estadounidense en perjuicio del capitalismo europeo. Una vez más, el despliegue neocolonialista de aquel sobre la "América Española" permitió al periodista "hablar", abandonando el hispanismo y abrazando un europeísmo que invitaba a pensar los riesgos asociados al descuido de ese mercado -el "Zollverein americano"- evocando con ese concepto la organización aduanera de la Confederación Germánica ${ }^{869}$.

En Ballesteros apreciamos una vez más el odio hacia Estados Unidos, país que acometía con lentitud la dominación "para no suscitar alarmas ni oposiciones violentas hábil manera de conseguir las cosas,- [...] que el día de mañana acaso deploren

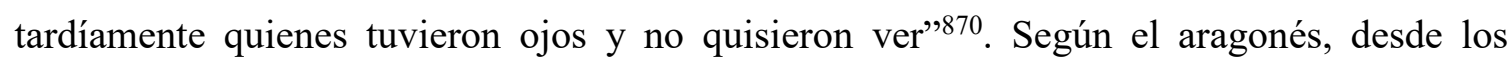
orígenes de las conferencias, los Estados Unidos se habían esmerado por ser su "alma", intentando siempre figurar en primera fila. Ballesteros, como historiador, sabía que la intención de fundar organizaciones americanistas era antigua y que no compartía orígenes con la doctrina internacional estadounidense. Conocía los esfuerzos políticos "estériles" de Bolívar. Lo que favorecía al país del norte -en esto era enfático- era la desorganización política que acompañaba a las repúblicas americanas desde sus independencias. En sus palabras, "las mismas rivalidades entre unas y otras repúblicas latinas, y la falta de prestigio notorio en favor de alguna, impedían que cualquier tomase fructuosamente la iniciativa" ${ }^{871}$.

\footnotetext{
${ }^{868}$ Idem.

${ }^{869}$ La deformación entre el Zollverein original y el concepto creado por la prensa es indesmentible. En el primer caso: "debemos recordar que el 1. ${ }^{\circ}$ de enero de 1834 se creó la Unión Aduanera Alemana (Deutscher Zollverein) -dominada por Prusia y de la que se excluía a la Austria de los Habsburgo-, compuesta por 18 Estados alemanes con una población de 23 millones. Por la importancia económica de Prusia, el thalen prusiano se convirtió en la moneda de uso corriente dentro de la Unión Aduanera, lo que consolidó la unión económica. Esta unión solo fue el primer paso de la unificación política que acabó finalmente imponiéndose". En: Novak Talavera, Fabián, Las relaciones entre el Perú y Alemania, 1828-2003, Lima, Pontificia Universidad Católica del Perú. Instituto de Estudios Internacionales (IDEI). Fondo Editorial, 2004, p. 31.

${ }^{870}$ La España Moderna, "Las Conferencias Panamericanas", febrero de 1911, n. ${ }^{\circ}$ 266, p. 6.

871 Íbidem, p. 7.
} 
Palabras más, palabras menos, las reuniones de Buenos Aires representaban el triunfo moral de los Estados Unidos en América, a pesar de las "mal encubiertas intenciones" $" 872$ de ese país. Para Ballesteros, los resultados de la IV Conferencia se comprendían en primer lugar, por la conversión de las reuniones en una congregación de Estados bajo la voz de mando de los Estados Unidos y, en segundo lugar, por el fracaso del mecanismo arbitral para decidir conflictos entre Estados americanos. Esa reunión dio como resultado también la creación de la Unión Panamericana (UP) comprometida en la planificación de actividades en los ámbitos de la economía y la cultura ${ }^{873}$ y, según un economista sudamericano, marcando el inicio del "panamericanismo" 874.

En gran parte, la oposición a esa postura, defendida por otros países americanos, fue la constante chilena desde la posguerra. Tal posición se presentó en la I Conferencia Panamericana de Washington en 1889 y se extendió durante los encuentros posteriores. En aquel año, señaló Ballesteros, “Chile había indicado ya su opinión contraria a la inclusión de estos asuntos en el programa de la Conferencia, y además no quería poner nuevamente en tela de juicio sus adquisiciones de Tacna y Arica" ${ }^{875}$.

Perú, por el contrario, estimaba otorgar al tratado un efecto retroactivo con el objetivo de recuperar diplomáticamente "lo que años antes había perdido en la guerra, y en vista de tales desavenencias, frustróse (sic) el logro de la sanción más importante adoptada en aquella Conferencia" ${ }^{" 876}$. Los Estados Unidos, forzando la situación para que no fracasara su gestión, ratificaron el mecanismo arbitral, sólo para "hacer valer su autoridad moral, que hubiera salido no poco quebrantada si en aquella Conferencia, de que habían sido alma directora, ninguno de los acuerdos hubiese conseguido ratificación, a lo menos, de una Potencia". 877

\footnotetext{
872 Íbidem, p. 15.

873 Álvarez Londoño, Luis Fernando, Historia del derecho internacional público, Bogotá, Pontificia Universidad Javeriana. Facultad de ciencias jurídicas, 2006, p. 124.

${ }^{874}$ VIEIRA POSADA, Edgar, La formación de espacios regionales en la integración de América Latina, Bogotá, Convenio Andrés Bello, 2008, p. 92.

875 Íbidem, p. 10.

${ }^{876}$ La España Moderna, "Las Conferencias Panamericanas", febrero de 1911, n. ${ }^{\circ} 266$, p. 10.

${ }^{877}$ Idem.
} 
La postura antiyanqui de Ballesteros era conocida. En un estudio anterior relacionado con el "Caso Allsop" 878 , empresa estadounidense con inversiones en Bolivia antes de la guerra y beneficiaria de elevadas sumas de dinero que Chile debería -según su visión- saldar, criticó al país del norte. Innumerables alusiones al "espíritu absorbente manifestado por la República angloamericana"; al "inevitable avance de la sombra yankee sobre el suelo latino"; a su hostigamiento hacia "Chile para que sus demandas fueran satisfechas"; o, más poéticamente, refiriéndose al expansionismo de la Casa Blanca, acusando su mezquindad no dejándose "aniquilar por una explosión de nobles y elevados sentimientos; semejantes a viles alimañas [...] manchan y afean el brillo de las flores, empañando envidiosas, su esplendor" ${ }^{879}$, evidenciaban su animadversión.

Otra censura antiestadounidense acusó a los Estados Unidos de "perturbar" la vida de los países americanos, haciendo llegar esa influencia turbadora hasta el extremo sur del continente. Refiriéndose también al sonado "Caso Allsop", criticó la impaciencia y la soberbia del Secretario de Estado de Estados Unidos puesta de manifiesto con la orden dada al embajador estadounidense en Santiago para retirarse de no solucionarse el conflicto en los términos de la Casa Blanca. La publicación anterior, a diferencia de los escritos de Ballesteros, responsabilizaba a Chile de incumplir el Tratado de Ancón y de la inestabilidad del área Tacno-ariqueña, mientras continuaba su vieja política armamentista. Ninguna de ambas naciones, refiriéndose a Chile y Perú, puede titularse soberana de aquellas, puesto que el tratado se había incumplido por culpa chilena, quien en el "Caso Allsop" había "reconocido la deuda" 880 , teniendo que satisfacerla, "sin perjuicio de la compensación que proceda si Tacna y Arica se adjudican definitivamente al Perú" 881.

\footnotetext{
${ }^{878}$ Cuestión explicada en otra revista española del siguiente modo: "Una entidad mercantil, formada por ciudadanos yanquis bajo la razón social de Allsop y Compañía, hizo algunos anticipos en metálico en la época en que Tacna y Arica estaban en poder del Perú. Entablóse después de la reclamación, Chile reconoció la deuda, y cuando fue preciso liquidar la valoró en 335.000 pesos oro, con intereses desde 1903. Los acreedores exigían mucho más y consiguieron que entrara en juego el gobierno de Estados Unidos. Abierta negociaciones, éste pidió para los Allsop un millón de dólares; se resistió Chile y mantuvieron la cifra los yanquis, quienes al fin propusieron que se sometiera el pleito al tribunal internacional de La Haya, pero a condición de que Chile reconociera el derecho de los Estados Unidos a intervenir diplomáticamente y no hiciese valer la circunstancia de ser chilena la casa Allsop, y por tanto, estar sometida a las leyes y los tribunales de la nación". En: La Ilustración Artística, "Revista Hispanoamericana", 14 de febrero de 1910, n. ${ }^{\circ}$ 1468, p. 106.

${ }^{879}$ La España Moderna, "Un conflicto Yankee-chileno", mayo de 1910, n. ${ }^{\circ}$ 257, p. 101.

${ }^{880}$ La Ilustración Artística, "Revista Hispanoamericana", 14 de febrero de 1910, n. ${ }^{\circ}$ 1468, p. 106.

${ }^{881}$ Idem.
} 
Igual de importante fue la distinción efectuada por la prensa entre los países involucrados en el problema fronterizo. Ballesteros fue uno de los pocos escritores españoles “chilenófilos”. Esa adscripción le permitió juzgar severamente a Perú y Bolivia. Para eso, no reparó en recursos tipográficos, ensalzando el comportamiento chileno antes y después de la guerra.

Los años previos, escribió, el país era "pobre" debido a la escasez de recursos naturales y su escasa población que, sin embargo, se caracterizaba por su espíritu trabajador y esforzado. Pese a esa situación el empresariado chileno mantenía un espíritu emprendedor. Su gobierno, amigo de las ciencias (!), había comenzado a analizar cada centímetro del territorio para dar con las riquezas que se le hacían esquivas. Este gobierno, era para Ballesteros, un gobierno marcadamente pacifista. Así lo dieron a entender su tolerancia para coordinar con Bolivia una serie de tratados previos a la guerra con el objeto de reglamentar los ingresos económicos de las riquezas ubicadas en Atacama. Cerraba ese cuadro meritorio el que hecho de que hacia 1910, parte de la prensa chilena, según Ballesteros, consideró "llegado el caso de unirse los Estados de la América Meridional, constituyéndose firme alianza que opusiera un fuerte dique al espíritu invasor del Coloso del Norte" $" 882$.

Para Ballesteros, la situación peruana era diametralmente opuesta a la chilena. Perú, antes de la guerra, se mostraba como un país "militarizado" que alardeaba de su belicismo. Económicamente, iniciaba una política salitrera nacionalista en Tarapacá. Su diplomacia negociaba "oscuramente" alianzas con Bolivia en contra de Chile. Esos hechos perturbaban el juicio histórico y actual de Ballesteros. Cuando en España se publicaron detalles del "Caso Allsop" y del conflicto Chileno-estadounidense derivado, circularon telegramas peruanos aludiendo el agrado experimentado por la prensa limeña al respecto. Ballesteros despreció ese "insensato regocijo" aprovechado para recordar a Chile la opresión ejercida en Tacna y Arica. El escritor lamentó que Perú, en vez de apelar a la solidaridad americana, viera en el "Caso Allsop" la reiteración "de sus mismas acciones al negarse a dar solución definitiva a las cuestiones, todavía pendientes, comprendidas en el Tratado de Ancón ${ }^{883}$.

\footnotetext{
${ }^{882}$ La España Moderna, “Un conflicto Yankee-chileno", mayo de 1910, n. ' 257, p. 102.

${ }^{883}$ Idem.
} 
Bolivia para Ballesteros era deplorable. Desde su origen republicano hasta la guerra, la anarquía militar relacionada a la "desordenada vida política" había producido sólo gobiernos efímeros con líderes ignorantes. El país padecía de una inestabilidad económica, impedimento fundamental para realizar proyectos políticos.

Mientras Chile se ocupaba en reconocer las riquezas naturales, Bolivia las desatendía. Sin embargo, la situación chilena permitió a Bolivia emprender actitudes abiertamente belicistas contra ese país, acorde con su "espíritu inquieto y belicoso" 884 . Responsable principal de la guerra, la Bolivia de Ballesteros cayó tras ésta en una época de revoluciones sedientas de poder, que imposibilitaron a "Chile concertar con Bolivia un Tratado de paz íntegro y definitivo, por impedirlo varias circunstancias, y entre ellas las revoluciones que en este último país se sucedieron a consecuencia del desastre sufrido" ${ }^{885}$. Chile había pactado en 1884, una tregua indefinida, "cuyo término, si alguno de ambos Gobiernos lo deseaba, debía de anunciarlo al otro con un año de antelación, y reservando Chile a Bolivia un 35 por 100 de las entradas percibidas en la Aduana de Arica, para que él dispusiera libremente" $" 886$.

En otro aspecto, la oposición española al dominio estadounidense en América posibilitó que la prensa utilizara publicaciones de escritores latinoamericanos y otros estados europeos poseídas del mismo espíritu "protector". En el primer caso resalta la fuerte crítica realizada por el ecuatoriano Leónidas Pallares Arteta publicada en La Lectura, explicando la necesidad inaplazable y urgente de la unión entre los países latinoamericanos para oponerse a la "hidrópica ambición de los yanquis" "887. El ecuatoriano incitaba a sus hermanos latinoamericanos a dejar de lado las diferencias locales aunando esfuerzos y contrarrestando "el plan del Tío Samuel" 888 de absorber el comercio y la vida económica de las repúblicas. Para Pallares, la Doctrina Monroe no era otra cosa que "la América Latina para provecho de los americanos del Norte" $" 889$.

\footnotetext{
${ }^{884}$ La España Moderna, "Un conflicto Yankee-chileno", mayo de 1910, n. ${ }^{\circ}$ 257, p. 90.

885 Íbidem, p. 95.

${ }^{886}$ Idem.

${ }^{887}$ La Lectura "La revista de América”, enero de 1913, n. ${ }^{\circ} 145$, p. 98.

${ }^{888}$ Idem.

${ }^{889}$ Idem.
} 
En el segundo caso, Inglaterra fue emblemática en esta lucha económico-ideológica sobre América, quien también rivalizó con Estados Unidos. Un artículo titulado "El ideal Latinoamericano", del The Times South American Supplement utilizado por La Lectura opinó sobre la construcción de naciones en América. En uno de sus párrafos expresó: "Estas naciones $[\ldots]$ que siendo como son, pueblos excitables y belicosos $[\ldots]$ son pueblos tan íntimamente unidos por el idioma y por las ideas" ${ }^{890}$. No obstante la contradicción, el articulista explicó que el desarrollo del pacifismo y del arbitraje no había detenido el "instinto" de dominación territorial en comarcas donde imperaba la cultura española. El mejor ejemplo de lo dicho era el diferendo. Así, "La cuestión de Tacna-Arica, [...] es todavía una herida abierta, que el bálsamo ofrecido por Chile no ha curado [...], parte del público peruano ve en los armamentos de Bolivia la amenaza de una invasión" ${ }^{891}$, encaminada a restablecer su soberanía en el Pacífico.

La nota contenía un análisis histórico-psicológico, escrito por Agustín Edwards McClure, ministro chileno en Inglaterra, que comparó la última centuria política de América con la de Europa. Edwards solicitaba la imparcialidad de los lectores al juzgar el pasado de aquella, argumentando la evolución diferente de sus repúblicas, "construidas" en un solo siglo. Eso permitía que las "dolorosas vicisitudes" americanas resonasen "todavía en los oídos del público europeo" 892 logrando que "gran parte de él crea que la turbulencia, la anarquía y la rivalidad personal son los rasgos principales del continente latinoamericano" "893. En su análisis de las diferencias "mentales-raciales" entre chilenos y peruanos -integrando el aporte español- aseguró que estas procedían de una causa indiscutible. Los conquistadores españoles no eran naturales de una misma provincia. Por ejemplo, mientras en Chile "el elemento ibérico que predominó fue de origen vasco; así lo acreditan muchos nombres ilustres, lo mismo que el carácter sereno, reflexivo y enérgico de sus habitantes" 894 ; el Perú "debe a las provincias de Castilla y de Andalucía el mayor número de colonos, y de aquí el carácter despierto, inteligente y soñador de este pueblo" ${ }^{\text {895. }}$.

\footnotetext{
${ }^{890}$ La Lectura " "El ideal Latinoamericano", mayo de 1913, n. ${ }^{\circ} 149$, p. 201.

${ }^{891}$ Idem.

${ }^{892}$ La Lectura, "El ideal Latinoamericano”, mayo de 1913, n. ${ }^{\circ}$ 149, p. 203.

${ }^{893}$ Idem.

894 Íbidem, p. 202.

895 Idem.
} 
Una parte importante del estudio de Edwards tuvo como telón de fondo la influencia estadounidense en América, que favoreció el surgimiento de una "identidad continental" en respuesta a ese imperialismo. Cierta o no, en tal identidad, más importante que la herencia española era "el temor que a todos causa la amenaza del Norte, la sombra que avanza de los Estados Unidos" $" 896$. Una visión más pesimista referida a esa identidad condenó a la región al fracaso político, como consecuencia de una desorganización secular. Ángel Monjas, autor, entre otras obras, de La América española y la guerra europea, echó mano a una tautología y explicó que los países de "la América española estaban condenados a no entenderse, porque, cada vez que habían intentado hacerlo, habían concluido por ir al fracaso" ${ } 897$. Monjas sorprende por su capacidad de vaticinio en las relaciones interestatales americanas. Previó la conformación del "Pacto de no agresión, consulta y arbitraje" entre Argentina, Brasil y Chile de 1915, las naciones "más cultas" 898 de América, la entente de los "principales" $" 899$. La función de esa asociación sería "evitar un choque armado entre Chile y Perú por la vieja y enojosa cuestión de Tacna y Arica"900. Advertía, además, el ascendente que la política internacional de América del Sur adquiría, lo cual interesaba no solo a los "prohombres" de sus países, sino también a la prensa y opinión latinoamericana.

A diferencia de otros escritores españoles, reconocía el poder del "ABC", nombre popular del "Pacto de no agresión, consulta y arbitraje", para hacer frente a los avances ideológicos de Estados Unidos. No obstante, en la visión de Monjas, Chile tenía problemas para legitimar su posición mediadora en conflictos vecinales. Así, en el problema de límites peruano-ecuatoriano, Estados Unidos apoyó a los dos miembros restantes del ABC. Chile no lo suscribió, porque con el Perú "no ha zanjado todavía la [...] eterna cuestión de Tacna y Arica". Tal situación contribuyó, concluía Monjas, a que no faltase en aquel tiempo quien lamentara la intromisión estadounidense y que no fuera "el ABC del Sur quien interpusiera su ascendiente en este asunto, como en todos los que pudieran originarse entre las repúblicas de origen hispano" 901.

\footnotetext{
${ }^{896}$ Íbidem, p. 201.

${ }^{897}$ La Lectura, "Revista de revistas españolas e hispanoamericanas", mayo de 1914, n. ${ }^{\circ} 161$, p. 431.

${ }^{898}$ Idem.

${ }^{899}$ La España Moderna, "La América moderna”, 1 de marzo de 1912, n. ${ }^{\circ}$ 279, p. 157.

${ }^{900}$ Idem.

${ }^{901}$ La Lectura, "Revista de revistas españolas e hispanoamericanas", mayo de 1914, n. ${ }^{\circ}$ 161, p. 431.
} 
Otras noticias continuaron criticando la política exterior de los Estados Unidos y Chile en la cuestión de Tacna y Arica. El paso del tiempo y la situación de soberanía incierta de esa provincia permitieron el surgimiento del "irredentismo", característico de aquellas comunidades nacionales que, como lo explicó en un artículo el prologuista español del internacionalista argentino Villamayor, aspiraban constantemente a emanciparse y restituir la nacionalidad en provincias anexionadas a otro país como consecuencia de una guerra.

El irredentismo, además, ocasionaba un "resentimiento constante de los países seccionados contra el país absorbente" $" 902$. Este era el caso de las anexiones del territorio italiano que había realizado Austria y, también, de la anexión alemana del territorio francés. En América, el mejor ejemplo lo proporcionaba "la anexión de Tacna y Arica, las provincias hermanas, por Chile, después de su última guerra"903. La analogía histórica una vez más se usaba sin el rigor del conocimiento particular de los hechos, para referirse al recrudecimiento irredentista de la Alsacia y Lorena peruana.

¿Cuáles eran las ideas que, al amparo de Villamayor, se publicaron en la prensa española? En primer lugar que la cuestión de Tacna y Arica cobraba relevancia por entorpecer decisivamente la confraternidad americana. La cuestión fronteriza, en los pensamientos del argentino, significaba para los discípulos más conspicuos de Maquiavelo y Metternich una piedra de tope: "el asunto de Tacna y Arica no tiene remedio: no hay caso" 904 . Lo peor del problema era el estado de crisis permanente, que haría estallar en cualquier momento la guerra.

En consecuencia, el fatalismo de Villamayor se reflejó en su certeza de que el finiquito del problema podía caer "en manos del dios Marte"905. La culpa de ese estallido militar la tendría la torpeza chilena en el manejo de su política exterior. Afirmaba que en “este pleito de Tacna y Arica, la que aparece de cuerpo entero, [...] es Chile, obstinado en dar cumplimiento a su vieja leyenda: "por la razón o la fuerza"906.

\footnotetext{
902 La España Moderna, "La América Moderna", 1 de octubre de 1910, n. ${ }^{\circ}$ 262, p. 115.

${ }^{903}$ Idem.

904 Íbidem, p. 116.

905 Idem.

906 Íbidem, p. 117.
} 
Por eso, sugería a Chile centrarse en la trascendencia de su política internacional y no en ganancias mezquinas. Al pueblo proponía no dejarse fascinar por tentaciones de lucro y engrandecimiento, considerando -a la luz de la historia, como escribió- que si durante décadas, "no ha podido afianzar definitivamente la conquista de Tacna y Arica; que lo único que ha conquistado, en definitiva, son inquietudes políticas, económicas y sociales, hoy le será más difícil la incorporación forzada de esas mismas provincias"907. La pregunta de fondo realizada por Villamayor se puede plantear del siguiente modo: ¿Para qué obstinarse en imprimir a la cuestión de Tacna y Arica caracteres de violencia, rapidez y finiquito, artificialmente, y fuera del Tratado de Ancón?

En ese litigio, Villamayor veía una oportunidad moral para solucionar conflictos latinoamericanos excluyendo terceras potencias. El Villamayor "pacifista" y "sentimental" tergiversó la historia. Recordó a Chile la alianza con Perú para combatir contra España en 1865, donde "encabezados por Portales, constituían asociaciones tendientes a solidarizar al pueblo chileno con el peruano"908 en los momentos de la ocupación de las islas Chincha "por la escuadra del Almirante Méndez Núñez, en nombre de España"909. El argentino olvidó que Portales, reconocido por buena parte de la historiografía chilena como el organizador de la nación, había muerto en 1836.

Sin referirse explícitamente a Estados Unidos, pronosticó la ruptura de la fraternidad americana causada por el imperialismo. Así se desprende de su requerimiento a Chile para no dejarse seducir por capitales mercantiles. Escribió sobre la ética de sus gobernantes que, de tener en "concepto merecido a la filosofía de la historia, [...] sabrán cerrar las puertas estrepitosamente a la tentación de los mercaderes"910. El Villamayor espiritual pensó que ese saber vencería a "ese insaciable Satanás, de las talegas de oro, [...]

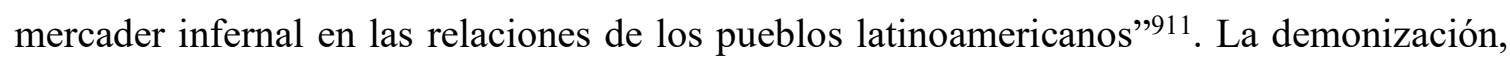
que no se atrevió a identificar, sin embargo, la personificó con exactitud: "Ese Satanás tiene

\footnotetext{
907 Idem.

908 Íbidem, p. 119.

${ }^{909}$ Idem.

910 Íbidem, p. 117.

${ }^{911}$ Idem.
} 
el poder de descubrir dónde y cuándo puede herir la cuerda sensible del patriotismo [...] por medio de una fácil conquista. ${ }^{912}$

Años más tarde, ese Satanás había creado su averno en el Nuevo Mundo. No obstante, la pormenorización de esa obra se excluyó de la prensa, fundamentalmente por el peso informativo de la Gran Guerra. Su duración y brutal excepcionalidad debía modificar, como lo ha sugerido Sánchez, "de modo neto el modo ( sic) de realizar la actividad informativa"913. En efecto, se creó un antagonismo entre prensas aliadófilas y germanófilas ${ }^{914}$. Así, sólo en su fase final reaparecería la litis y su relación con la influencia estadounidense.

En esa etapa constatamos una posición de la prensa "realista" o pragmática frente al imperialismo estadounidense. No se culpaba per se los avances territoriales y la apertura de mercados económicos que aquellos realizaban en América. Surgió, por el contrario, una corriente de opinión menos ingenua que revisaría el funcionamiento de la política económica española con sus antiguos territorios. El papel de la educación española también fue atacado en uno de sus puntos más débiles: el subdesarrollo de la enseñanza técnica orientada a la marina mercante y el comercio. Las escuelas experimentaban a comienzos del siglo pasado "un considerable atraso material y pedagógico en comparación con el resto de países europeos industrializados"915, volviendo su desenvolvimiento, según un historiador, "tortuoso" 916.

\footnotetext{
912 Idem.

913 SÁNCHEZ ARANDA, José J., "Las dificultades de informar en tiempos de guerra. La prensa española durante la I Guerra Mundial”, Communication \& Society, vol. 6 (1 y 2), 1993, p. 173.

914 Ver: EVANS PIM, Joam, "Pro-german Press and Literatura in North-Western Spanish Cultures during the World War I (1914-1918)". En Fatu-Tutoveana, Andrada y Jarazo Álvarez, Rubén (Eds), Press, propaganda and politics. Cultural Periodicals in Francaist Spain and Communist Romania, Newcastle, Cambridge Scholars Publishing, 2013, pp. 96-105; ClemenTe, Josep Carles y PolO, Juan Francisco, La prensa humanitaria en la España Contemporánea (1870-1989), Madrid, Editorial Fundamento, 2003.

915 PericACho GómeZ, Francisco Javier, "Pasado y presente de la renovación pedagógica en España (de finales del Siglo XIX a nuestros días). Un recorrido a través de escuelas emblemáticas”, Revista Complutense de Educación, vol. 25, n. ${ }^{\circ}$ 1, 2014, p. 50.

916 CANO PAVÓN, José Manuel, "La enseñanza técnica en España y en Europa Occidental y el problema del capital humano industrial. Veinticinco años de estudios", ILUIL, vol. 26, 2003, pp. 367-398. Un estudio de historia de la educación técnica comparada entre España y Francia en: DURÁN RODRÍGUEZ, M. Dolores, "La educación técnica popular en Francia y España (1780-1950): algunas consideraciones acerca de las escuelas de artes y oficios en ambos países", Sarmiento, n. ${ }^{\circ} 13,2009$, pp. 69-99.
} 
Exposiciones de ese estilo surgieron en periodistas españoles connotados. Uno de los más enfáticos en acusar las deficiencias económicas fue Salvador de Madariaga Rojo ensayista, diplomático e historiador ${ }^{917}$, radicado en Londres- quien en una visita a Madrid en 1919, expuso una crítica extensa lamentándose de que frente al mercado financiero mundial "España carezca de iniciativa económica suficiente que le permita presentarse ante las naciones con propia y definida personalidad"918. Para Madariaga, esta identidad timorata guardaba relación con el carácter nacional español deformado por su eterna pasividad, confiada siempre en sucesos fortuitos como "la revolución o la lotería"919.

La sensación de despreocupación del gobierno español frente a los problemas marítimos provocó declaraciones del siguiente tono: "de nada servirán las teóricas uniones ibero-americanas ni las fiestas de la raza, ni los discursos y conferencias de aproximación entre la madre patria y sus hijas transatlánticas"920, puesto que se trataba en verdad, según el mismo artículo, de la imposibilidad de competir en baratura con los "productos similares del extranjero, y especialmente de los Estados Unidos, cuya expansión comercial es el más formidable factor para el cumplimiento, a no tardar, de la egoísta Doctrina Monroe"921.

La sensatez del redactor le hacía comprender la esterilidad propagandística conducente a pensar en la confraternidad hispanoamericana, puesto que el rumbo del comercio mundial iba en contra de toda buena intención, privilegiando mercancías y artefactos ofrecidos en condiciones favorables. Más apabullantes fueron las expresiones aparecidas en El Sol sobre la memoria de los trabajos de 1918 publicada por la Unión Hispano-Iberoamericana, institución preocupada por la organización de congresos, publicación de revistas, organización de viajes para intelectuales, que puso de manifiesto "la importancia de la vertiente cultural en la acción exterior española hacia Iberoamérica" $" 922$.

\footnotetext{
917 Ávila LóPEZ, Enrique, Modern Spain. Understanding Modern Nations, United States of America, ABCCLIO, LLC, 2016, p. 142.

${ }^{918}$ El Sol, "Conferencia de Salvador de Madariaga", 23 de enero de 1919, p. 3.

${ }^{919}$ Idem.

${ }^{920}$ Hojas Selectas, "La flota mercante española”, enero de 1918, n. ${ }^{\circ} 193$, p. 38.

${ }^{921}$ Idem.

922 Pereira Castañares, Juan Carlos, "España e Iberoamérica: un siglo de relaciones (1836-1936)", Mélanges de la Casa de Velásquez, tomo 28, n. ${ }^{\circ}$ 3, p. 104.
} 
Burlándose del tamaño de la letra utilizada, "como para alargar el texto de la Memoria"923, el periodista del diario fundado por Nicolás María de Urgoiti criticó la nula actualización en materia económica y diplomática, denunciando las rancias ideas planteadas para establecer relaciones comerciales. El vacío de objetivos prácticos y concretos se llenaba con palabras grandilocuentes. Siguiendo su tradicional concepto publicó El Sol-de que España debe pasarse la vida tirando serpentinas oratorias por encima del Atlántico hasta dar con las tierras de Colón, "la Unión Ibero-Americana, desde el año 1885, en que se fundó, no ha hecho otra cosa que desviar de su verdadero sentido la significación del problema hispanoamericanista"924. Esa desviación había permitido que "hoy existe ya un prejuicio fatal de que las relaciones entre España y América no podrán pasar jamás de un mero floreo literario" ${ }^{925}$.

\section{Imagen n. 39}

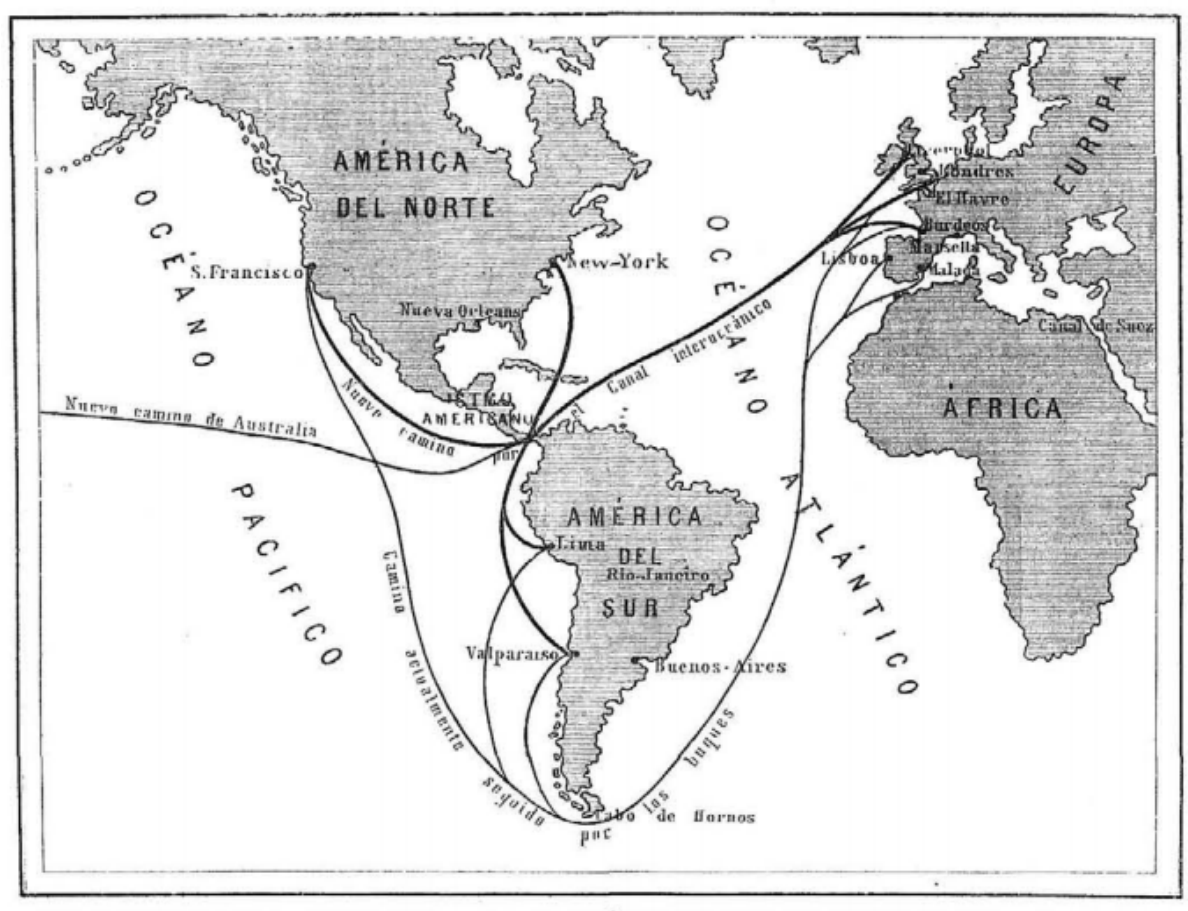

MAPA DEMOSTRATIVO DE LA ABREVIACION DE L.AS RUTAS MARITIMAS POR MEDIO DEL PROYECTADO CANAL. INTEROCEÁNICO del istmo de Panamá.

Fuente: La Ilustración Española y Americana, "El canal interoceánico", 8 de diciembre de 1880, n. $^{\circ} 45$, p. 352.

\footnotetext{
${ }_{923}$ El Sol, "Informaciones de Ibero América", 13 de abril de 1919, p. 29.

${ }^{924}$ Idem.

925 Idem.
} 
La crítica se dirigió también al presidente de la Unión Ibero-Americana, Faustino Rodríguez San Pedro, uno de los "pilares del conservadurismo"926 asturiano, de "notable escasez de imaginación y no poca hostilidad hacia el pensamiento"927. Acusado de ser el político español típico del pasado, ignorante de los sistemas económicos modernos, de privilegiar los aspectos pedagógicos, intelectuales e históricos del hispanoamericanismo, obviando el "intercambio mercantil, económico, financiero, etc. sustentación sólida de toda amistad de pueblos"928. Esa actitud lo llevó al uso exacerbado de lugares comunes, como la "madre España", cuyo deber era "estrechar los lazos", el "viejo solar", el "león ibero" y otras que constituían insustancialmente el ideario del hispanismo.

Los años finales de la Gran Guerra se entendieron en España como un momento favorable para "intensificar" las relaciones con América. Así lo entendió la clase política, quien deseó "fortalecer las relaciones con la América hispana, aprovechando la favorable coyuntura" "929. El ámbito relacional, al contrario del pasado, debía ser económico. El eco de ese anhelo permitió a un escritor de la prensa comprender la importancia de las relaciones hispano-americanas sustentadas en el intercambio de capitales, no siendo tiempo de "lirismos ni de espumas de banquete; el estómago hambriento no es un eterno poeta, ni España ni América se robustecen con glosas más o menos pindáricas, una y otra deben amoldarse a los tiempos dinámicos"930. Tales situaciones dificultaban realizar la mentada unión que, a decir del redactor, "equivale a querer resucitar a un muerto"931. Esta certeza, no impedía trabajar por la inserción española en el mercado económico occidental, conviniendo convertir el país en "cabeza de puente" desde donde "irradien los productos colombinos" $" 932$ en busca de mercados más amplios. El escritor olvidaba, por lo menos en el lenguaje, los floreos discursivos atacados.

\footnotetext{
926 FAEs DíAZ, Enrique, Claudio López Bru, Marqués de Comillas, Madrid, Marcial Pons, Ediciones de Historia, S. A., 2009, p. 146.

927 López SÁnchez, José María, Heterodoxo Españoles. El Centro de Estudios Históricos, 1910-1936, Madrid, Marcial Pons, Ediciones de Historia, S. A., p. 31

928 El Sol, "Informaciones de Ibero América", 13 de abril de 1919, p. 29.

${ }^{929}$ Arenal, Celestino del, Política exterior de España y relaciones con América Latina. Iberoamericanidad, Europeización y Atlantismo en la política exterior española, Madrid, Siglo XXI de España Editores, S. A., 2011, p. 25.

${ }^{930}$ La Ilustración Española y Americana, "España requerida por América”, 22 de junio de 1919, n. ${ }^{\circ}$ 23, p. 367.

931 El Sol, "Informaciones de Ibero América", 13 de abril de 1919, p. 29.

932 Idem.
} 
Desde América del norte, Estados Unidos continuaba fortaleciendo su "monroísmo" con la política ideológica de "expulsar a Europa, y por lo tanto a España, de las costas sudamericanas"933. Así lo demostraba la apertura del Canal de Panamá que permitía una velocidad de comunicaciones interoceánicas desconocida. Contactó, dijo la revista, Colón, Callao, Mollendo, Arica, Iquique, Antofagasta y Coquimbo, agregando con tono profético una situación que sólo décadas después -en 1973 con el apoyo estadounidense a los militares chilenos ${ }^{934}$ - se evidenciaría en toda su magnitud: “toda la república chilena caerá comercialmente bajo la influencia de los Estados Unidos"935.

En 1919, la situación económica estadounidense era privilegiada y, como se sabe, le permitió vivir "los felices años 20, una época de gran prosperidad"936. Un diario apuntó su acelerado crecimiento económico "cuya fuerza expansiva no conoce límites [...] es un peligro para la América española, dada la forma imperialista como se produce su insaciable afán de conquistarlo todo, aun hasta las más apartadas regiones de la América austral"937. Esta nota culminaba su examen aludiendo a la poderosa fuerza expansiva del "capital yanqui" que se mostraba impaciente y, en lugar de adquirir escalonadamente sus zonas de influencia, quería "lanzarse con todos sus ímpetus contra aquellos en quienes quiere hacer presa" 938 .

Las situaciones señaladas daban pie a reflexiones de gran interés que veían, quizás más como anhelo que como hecho, una España requerida por América. Así, se tituló uno de los escritos realizados por el madrileño Javier Fernández Pesquero -representante de la Unión Ibero-Americana en Chile ${ }^{939}$, quien desde allí envió un emotivo texto refiriéndose a la importancia de considerar seriamente un artículo aparecido en El Diario de Buenos Aires, que según Fernández, había producido en toda América una gran sensación por las graves revelaciones que contenía.

\footnotetext{
${ }^{933}$ Hojas Selectas, "La flota mercante española", enero de 1918, n. ${ }^{\circ} 193$, p. 38.

934 PeTRAS, James y VeltMeYer, Henry, Imperio con imperialismo: la dinámica globalizante del capitalismo neoliberal, México, Siglo XXI, 2006, p. 82.

${ }^{935}$ Hojas Selectas, "La flota mercante española", enero de 1918, n. ${ }^{\circ} 193$, p. 38.

${ }^{936}$ SERRANO GARCíA, Juan B., El inversor tranquilo, Madrid, Díaz de Santos, 2013, p. 116.

${ }^{937}$ El Sol, “Aspectos diplomáticos del conflicto yanqui mejicano", 14 de septiembre de 1919, p. 4.

938 Idem.

939 CARRellán Ruiz, Juan Luis, "Javier Fernández Pesquero: un corresponsal español en el fin del mundo". En Márquez Macías, Rosario, Huelva y América. Cien años de Americanismo. Revista "La Rábida” (19111933). De corresponsales y colaboradores, Universidad Internacional de Andalucía, 2014, p. 121.
} 
El editorial trataba sobre la creación de la "Liga Latina" durante la Gran Guerra, organización que reuniría a todos los países latinos, encabezados por España, para mantenerse neutrales a los imperios centrales y contrarios a los aliados "especialmente a los Estados Unidos"940. La idea del editorial era constituir un tercer bloque militar en el mundo. Como en esta alianza la centralidad española era evidente, se debía considerar seriamente en el gobierno, el pueblo y la prensa española. Para Fernández, la "Liga Latina" era un "demostrativo del ansia sentida, ahora más que nunca, en estos países de convivir con la raza en una inteligencia defensiva, en vista del giro peligroso que va tomando, la preponderancia de ciertas razas y sus ambiciones descaradas para el porvenir" ${ }^{\circ 41}$.

Otros acontecimientos, tales como la celebración de un certamen histórico en Chile que depuraría la historia nacional de los errores de contenido relacionados con España o, en el mismo país, el premio del mejor trabajo sobre Hernando de Magallanes, eran manifestaciones que revelaban el interés de los países americanos por España. Sustraerse de aquellas -decía Fernández- "sería un suicidio para España, que puede encontrar en América, cual en otra Covadonga, el centro y eje del resurgimiento de su influencia mundial"942.

Hechos concretos del anhelado hispano-chilenismo pueden fecharse a fines de 1919, cuando el gobierno chileno se dispuso a enviar una misión comercial a España, encabezada por Joaquín Fernández Blanco. La información periodística explicó que el Palacio de La Moneda, entendía la conveniencia del intercambio mercantil y espiritual entre ambos países. El gobierno chileno se ha caracterizado, decía el diario, por la inteligencia y elevada cultura de sus dirigentes, quienes siempre se han caracterizado por sus simpatías a la antigua metrópoli.

La concienciación de que el éxito del imperialismo estadounidense sobre América Latina se debía a la ineptitud de los gobiernos españoles para enfrentar la coyuntura económica mundial llevó, como ha quedado demostrado, a exigir algún tipo de acción concreta, alejada del plano meramente retórico.

${ }^{940}$ La Ilustración Española y Americana, "España requerida por América", 22 de junio de 1919, n. ${ }^{\circ} 23$, p. 367.

${ }_{941}$ Idem.

${ }^{942}$ Idem. 
Para la prensa, en el aspecto diplomático, España debería interesarse por los conflictos de sus antiguos dominios. La cuestión de Tacna y Arica, que una vez concluida la Gran Guerra cobró nuevamente gran dinamismo, presentaba una oportunidad preciosa para el neocolonialismo español. Su larga historia lo transformaba en un referente para realizar analogías con otros conflictos latinoamericanos ${ }^{943}$.

Ante su revitalización un diario publicó: "Surge al fin, con caracteres muy graves, el conflicto peruanochileno, motivado por el viejo pleito de las provincias de Tacna y Arica, que los peruanos llaman "la Alsacia-Lorena" americana"944. La consideración de la noticia permitía prescribir la forma de diplomacia que se debería desarrollar. En efecto, la posición española debía ser aquella "que corresponde al pueblo que dio al mundo la maravilla de América. A fuerza de lirismos inoportunos y excusables, se ha acabado por desacreditar el dictado de «madre patria» que siempre debió ser para España fuente de actividades hispanoamericanas y estímulo de energías y de voluntad"945.

Como lo explicó Sepúlveda, para el nacionalismo español de comienzos del siglo $\mathrm{XX}$, una parte central fue el hispanoamericanismo, entendido como un movimiento articulador de una comunidad "trasnacional" apoyada en una identidad cultural idiomática, religiosa e histórica, "comunidad imaginada que reunía a España con el conjunto de repúblicas americanas, otorgándole a la antigua metrópoli un puesto al menos de primogenitura"946. La palabra clave de la articulación plurinacional debía ser emocional: la "Madre Patria". Sepúlveda la valoró conceptualmente carente de significados concretos y la entendió como un "Tópico de salón, muletilla discursiva, comodín de elogios y baúl de fruslerías". Ante la revitalización peligrosa del conflicto de Tacna y Arica un diario publicó:

Pero, aun con riesgo de caer en el tópico, es necesario decir que nunca como en estos momentos se ofrece a España ocasión de acreditar que lleva dignamente el título glorioso de "madre patria". En política hispanoamericana, como en todo lo demás, han sido tales los desaciertos y tan grande el criminal olvido, que nos encontramos ahora con bien escasas fuerzas para intervenir en los conflictos que se suscitan a través de los intereses de América.

\footnotetext{
${ }^{943}$ El Sol, "Aspectos diplomáticos del conflicto yanqui mejicano”, 14 de septiembre de 1919, p. 4.

${ }^{944}$ El Sol, "Con motivo de un grave conflicto", 28 de noviembre de 1918, p. 1.

945 Idem.

946 SePúlvedA, Isidro, El sueño de la Madre Patria. Hispanoamericanismo y nacionalismo, Madrid, Marcial Pons, Ediciones de Historia S. A., 2005, p. 13.
} 
El intercambio hispanoamericano ha sido simplemente una política de exportación lírica, sin que jamás haya preocupado a nuestros gobernantes el pensamiento de establecer entre aquellos pueblos jóvenes y esta vieja metrópoli una relación más fuerte, política, diplomática, comercial y literaria. Los cónsules que enviábamos a América estaban en sus puestos por vía de aprendizaje. Y mientras los demás pueblos del Occidente de Europa han cuidado la alta política y la gran diplomacia con relación a los pueblos que nacieron de España. [...] Nada se ha hecho en España. Y es triste que por el abandono de nuestros gobernantes, lleguemos a producir en la América del Sur ese lamentable estado de indiferencia, cien veces peor que la hostilidad misma. Con motivo del conflicto chilenoperuano se ofrece ocasión, sino de llevar a cavo un acto político definitivamente eficaz, sí al menos de iniciar la transformación de orientaciones y propósitos: transformación por la que se vea a España comienza a preocuparse de los grandes intereses que tiene más allá de las fronteras, y sobre todo, más allá de los mares ${ }^{947}$.

Importa compartir la cita por un par de aspectos fundamentales, referidos al examen interno y de la proyección internacional del Estado que debían realizar las autoridades españolas. En efecto, sólo comparándose con otras potencias europeas, España entendería que sus procedimientos diplomáticos habían generado una gran lentitud para insertarse dentro del sistema político mundial. Además, como lo propone la nota, la cuestión de Tacna y Arica debía interesar a los gobernantes hispanos pues, de sabe actuar estratégicamente en ese plano internacional, se podría iniciar, mediante los buenos oficios, una transformación positiva en su política exterior.

La nota de ningún modo era excepcional, puesto que existían otros hombres públicos de España que criticaban el encierro español y el poco acierto en sus relaciones con las "repúblicas españolas"948 como insistía cierta prensa en presentar una distinción de éstas elaborada por Kirkpatrick entre repúblicas de la zona tropical y repúblicas de la zona templada. El ya mencionado Salvador de Madariaga, meses después, criticaría el espíritu localista y aislado de España, impedimento para entender a los pueblos americanos ávidos de comunicación con Europa. Madariaga, con tono irónico, decía: "No podemos ir a América como vecinos de Guadalajara, mientras esta vecindad no suponga comercio y compenetración con asuntos internacionales. Últimamente, la ignorancia y la indiferencia con que se ha recibido el problema de Tacna y Arica dicen bastante de esta imposibilidad"949.

\footnotetext{
${ }^{947}$ El Sol, "Con motivo de un grave conflicto", 28 de noviembre de 1918, p. 1.

${ }_{948}$ El Sol, "Panorama de América", 6 de febrero de 1919, p. 8.

${ }^{9}$ El Sol, "Conferencia de Salvador de Madariaga", 23 de enero de 1919, p. 3.
} 
Anhelos a un lado, cuando a comienzos de 1919 el gobierno chileno envío una misión diplomática a Europa con el objetivo de conocer la opinión que diversas cancillerías tenían de la cuestión de Tacna y Arica, España no se incluía en la agenda. Un diario popular publicó que la comisión presidida por el expresidente del Consejo de Ministros, Eliodoro Yáñez, "no vendrá a España [...] es verdad que estos señores tienen por objetivo consultar con las cancillerías de la Entente las probables soluciones que tendría el problema de Tacna y Arica" 950 , no obstando lo anterior para "aprovechando el viaje, hubiese pasado por España dicha Comisión, y dejando aquí la simiente de un tratado de comercio [...] que es lo único serio que vincula a los dos pueblos"951.

Cuatro meses antes, el mismo diario había titulado en letras grandes "Fracasa la intervención americana" refiriéndose a las dificultades que Estados Unidos había tenido para coordinar una solución al problema de Tacna y Arica con apoyo de Argentina que en septiembre de 1919 nuevamente cobraría vigor ${ }^{952}$. La información recibida por radio desde Buenos Aires utilizaba, además, un telegrama enviado desde Londres donde se aseguraba que la Delegación inglesa de la Conferencia de la Paz "no permitirá que se trate en dicha conferencia de la cuestión de Tacna y Arica"953.

Una última innovación del discurso periodístico español frente al avance estadounidense sobre América fue la crítica blanda hacia esos países por el no establecimiento de relaciones comerciales más fluidas. Algunas de estas ideas aparecieron con posterioridad a las conversaciones de paz que finiquitaría la Gran Guerra. En esa época, la doctrina de Wilson permitió a Bolivia iniciar una campaña por la recuperación del litoral perdido en la Guerra del Pacífico en la Sociedad de las Naciones. Ismael Montes, por ejemplo, en nombre de Bolivia exigió la recuperación (?) de “Tacna y Arica [...] protestando por no haberse cumplido el tratado de Ancón con Chile reivindicando los territorios anexionados" $" 954$.

\footnotetext{
${ }^{950}$ El Sol, "Informaciones de Ibero América”, 13 de abril de 1919, p. 29.

951 Idem.

952 España y América, "Desde la Argentina", 30 de septiembre de 1919, p. 128.

${ }^{953} \mathrm{El} \mathrm{Sol,} \mathrm{"Fracasa} \mathrm{la} \mathrm{intervención} \mathrm{americana",} 23$ de diciembre de 1918, p. 5.

${ }^{954}$ La Acción, "La Conferencia de la Paz", 25 de enero de 1919, p. 3.
} 
En efecto, aseguró un diario, América no ha hecho cuanto sabe y puede hacer para que sus relaciones con España traspasen las fronteras de los buenos modales de la diplomacia. Los embajadores americanos "se abandonaron a la fácil cordialidad que les brindaban las sociedades hispano americanistas de España"955. Un caso particular sería la crítica realizada por la prensa sobre el proceder de la cancillería de Perú con España. A diferencia de los primeros tiempos del conflicto chileno-peruano donde la "peruanofilia" de la prensa era la estructura dominante del discurso, a comienzos de los años veinte se visibilizaban algunos cambios de filiación. La prensa, aún en el terreno de las culpas y las emociones escribió: "no es sólo España culpable de la distancia espiritual que la separa de las tierras de Ultramar, sino también ciertos países hispanoamericanos, el Perú entre ellos"956.

\section{Imagen n. ${ }^{\circ} 40$}

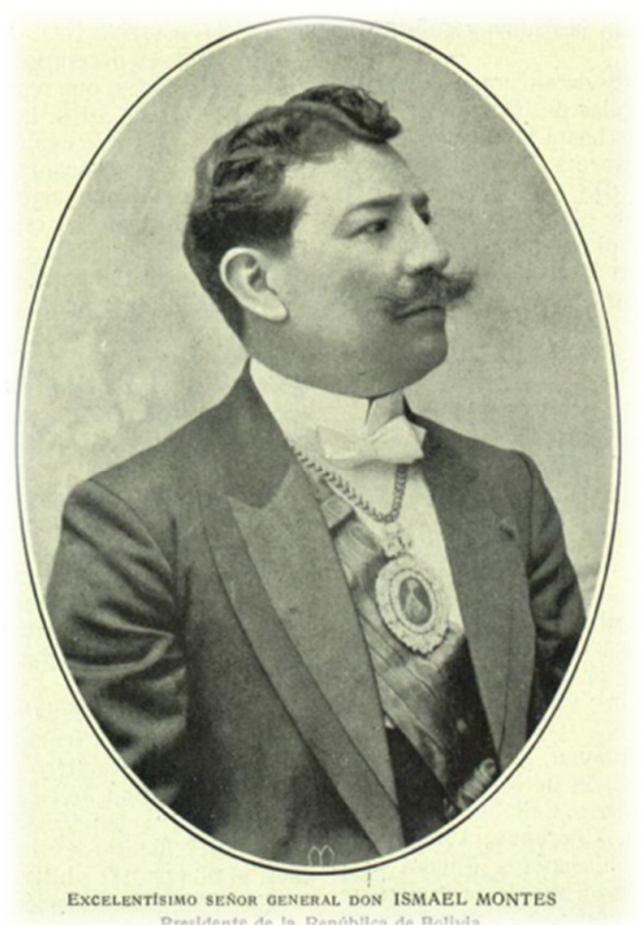

Fuente: Mercurio, "Excelentísimo señor general don Ismael Montes”, 1 de abril de 1915, n. ${ }^{\text {o } 225, ~ p . ~} 99$.

${ }^{955}$ El Sol, "Informaciones de Ibero América", 13 de abril de 1919, p. 29.

${ }^{956}$ El Sol, "La Paz de América en peligro", 14 de septiembre de 1919, p. 4. 
A la par, el Consulado de Bolivia en Madrid abría una práctica que sería recurrente en los próximos años, tendiente a usar la prensa española como plataforma de sus alegatos en contra de Chile, procurando "difundir en el extranjero la justicia de su causa y para tal fin manda emisarios especiales, de gran competencia técnica, a las principales capitales del mundo" 957 . En la nota que nos referimos aquí se pretendió dejar constancia de algunas reflexiones jurídicas elaboradas por el profesor de Derecho Fidel Anzé. Desde la época de la Independencia de los pueblos sudamericanos -leemos- la historia internacional de América no ofrece hecho más capital que el de la Guerra del Pacífico. El luminoso programa pacifista de Wilson, gran apóstol de la democracia, ayudaría a Bolivia para retomar su posición en el mar. El método sería un acuerdo amigable y mutuo con Chile y Perú para otorgarle "las provincias de Tacna y Arica, en el límite de las compensaciones razonables"958. Ismael Montes, por su parte ya había hecho presente un documento ante la Liga de las Naciones donde se establecía que, a propósito de la cuestión chileno peruana "sobre la propiedad de los territorios de Tacna y Arica, [Bolivia] posee derechos superiores sobre estas dos provincias" 959 .

\subsection{Los sacerdotes católicos-peruanos expulsados de Tacna y Arica}

En 1910, Chile y Perú rompieron relaciones diplomáticas una vez más. En esta ocasión, una de las causas de la ruptura fue el artículo tercero del tratado chileno-boliviano donde se estipuló la construcción del ferrocarril de Arica a La Paz. Como lo explicó Bitar ${ }^{960}$, hubo otros hechos que la precipitaron: la Ley de Colonización de Tacna y la expulsión de los sacerdotes peruanos de Tacna y Arica. El impacto del último no dejó indiferente a la prensa española que informó y opinó, reflejando, en suma, una posición hostil hacia los procedimientos "chilenizadores" del país del sur"961.

\footnotetext{
${ }^{957}$ Idem.

${ }^{958}$ La Ilustración Española y Americana, "Bolivia”, 22 de junio de 1919, p. 367.

${ }^{959}$ Idem.

${ }^{960}$ BITAR, Sergio, Un futuro común. Chile, Bolivia, Perú. El norte de Chile en el siglo XXI, Chile, Editorial Aguilar, 2012.

961 Otros episodios de tensión diplomática habían sido reporteados anteriormente por la prensa española. El más significativo fue el de la ruptura de relaciones diplomáticas entre esos países a raíz del ofrecimiento, por parte de Chile, de una corona de bronce para colocar en el mausoleo de los soldados peruanos muertos en la Guerra del Pacífico, que el gobierno peruano entendió como una ofensa. Las noticias publicadas en España en 1909, remarcaron que el motivo de la confrontación guardaba relación con la interpretación peruana de no
} 
El historiador Sergio González ha reflexionado sobre los alcances de esta ruptura entre Chile y Perú. Al respecto ha afirmado que "posiblemente la historia de los curas peruanos expulsados de Tacna y Arica y su reemplazo por capellanes chilenos sea la más emblemática acción chilenizadora [...]"962. En 1909, Máximo Lira, Intendente de la provincia de Tacna, decretó el cierre de todas las iglesias de esa jurisdicción debido a lo que, a su juicio, era "acción proselitista que desde los púlpitos realizaban los sacerdotes peruanos, pues la jurisdicción eclesiástica de esas provincias correspondía a la Arquidiócesis de Arequipa. El conflicto llegó a la Santa Sede.”963. Debió retirarse de Arica el cura párroco Vitaliano Berroa, colaborador del diario nacionalista El Morro de Arica ${ }^{964}$. En efecto, durante el mes de marzo de 1910 se hizo efectivo el decreto de expulsión obra del, por entonces, canciller chileno Agustín Edwards McClure.

aceptar el obsequio chileno mientras Tacna y Arica eran violentamente chilenizadas. Ver, por orden de aparición: El Heraldo, "Chile y el Perú", 22 de enero de 1909, p. 3; El Siglo Futuro, "De Chile", 22 de enero de 1909, p. 3; La Época, "Cosas de América", 22 de enero de 1909, p. 1; El Día, "Chile y el Perú", 23 de enero de 1909, p. 1; La Correspondencia de España, "Ruptura de relaciones", 30 de enero de 1909, p. 3; El Día, "Chile y Perú", 1 de febrero de 1909, p. 2; El Globo, "Perú, Bolivia y Chile", 21 de mayo de 1909, p. 3; El Día, "Perú, Bolivia y Chile", 21 de mayo de 1909, p. 3. Por último, reproducimos la opinión del sacerdote y corresponsal en Lima de la revista España y América sobre la cuestión comentada: "Por mi carta anterior, publicada en el número del 15 de noviembre, tienen ustedes noticias de una suntuosa cripta dedicada por el Perú a los héroes de la guerra del 79. Aquella guerra fue funesta para el Perú, como lo fue para Francia la famosa campaña franco-prusiana del 70; pero algunos hijos del Perú dieron ejemplos altísimos de valor y de civismo, y se ha querido perpetuar su memoria, erigiéndoles un monumento glorioso. Chile quiso también asociarse a esta manifestación, y su representante diplomático se dirigió al Ministro de relaciones exteriores de aquí, ofreciendo una corona. ¡Difícil situación para el gobierno! ¿Cómo podría aceptar él una corona de parte de Chile, estando todavía, por culpa de este país, incumplido el Tratado de Ancón, que fue el término de la espantosa guerra del 79? Por otra parte, un rechazo franco no hubiera sido propio de una cancillería, sobre todo de una cancillería como la del Perú, que, hoy por hoy, frente a Chile, no tiene más fuerza que la del derecho. Se imponía, por consiguiente, una aceptación que fuese, en el fondo, un rechazo diplomático, y, para esto, el Ministro de relaciones exteriores respondió al representante de Chile que el gobierno del Perú agradecía la corona, pero que ya se le señalaría fecha para la colocación de ella en la cripta de los héroes. Decir esto pocos días antes de la inauguración de la famosa cripta, era evidentemente una manera diplomática y delicada de rechazar la corona de Chile. Pero el ministro chileno no lo comprendió o no quiso comprenderlo así, y a los tres o cuatro meses volvió a preguntar a la cancillería peruana que cuando señalaba la fecha para la colocación de la corona. El canciller o ministro de relaciones exteriores respondió que ya se señalaría, pero al mismo tiempo dio a entender que mediaban con Chile negociaciones que afectaban en lo más vivo al honor y dignidad del Perú y que, mientras no se dirimiesen y terminasen mediante un correcto proceder jurídico, era moralmente imposible que el Perú aceptase la corona de Chile." Publicada en: España y América, "Desde el Perú", 1 de abril de 1909, n. ${ }^{\circ}$ 7, p. 139.

962 GonzÁlez, Sergio, La llave y el candado. El conflicto entre Perú y Chile por Tacna y Arica, Chile, LOM Ediciones, 2008, p. 43.

963 GONZÁLEZ, Sergio (2008). La llave..., p. 43.

964 PARDo GómeZ DE BELAÚNDE, Adela, Arequipa, su pasado, presente y futuro, Lima, Imp. Litográfica del Perú, 1967, p. 139. 
En España se acusó el "jacobinismo" 965 de Chile, es decir, el autoritarismo ejercido contra Perú por un Estado fuerte y centralizado. Como en otras ocasiones, la prensa recurrió a ejemplos históricos, dificultando la complejidad local del problema. Ese afán periodístico por afrancesar la situación chileno-peruana también se observó en las innumerables noticias referidas a la "Alsacia y Lorena" de Sudamérica.

Los diarios revisados permiten deducir que el argumento chileno para la expulsión de la curia peruana era el incumplimiento constante de la Constitución por los sacerdotes. El Imparcial y El Día dijeron: "El gobierno de Chile ha acordado expulsar de los territorios de Tacna y Arica a los sacerdotes peruanos, porque se negaban a observar la Constitución"966. Luego de la expulsión de los sacerdotes, las iglesias habían quedado cerradas porque el Obispo de Arequipa se negó a nombrar sustitutos chilenos ${ }^{967}$. Eso permitió que las parroquias fuesen administradas por carmelitas españoles ${ }^{968}$.

Las noticias enfatizaron en las consecuencias de ese "jacobinismo" que había creado el marco para la retirada de la Legación Diplomática de Perú en Chile, que fue entendida por la prensa como un acto de protesta ${ }^{969}$. A la par, los diarios que cubrieron la noticia reprodujeron las expresiones de "sentimentalismo" ofrecidas por el Ministro de Negocios Extranjeros de Chile, quien veía en las acciones chilenizadoras sobre Arica "legítimas medidas adoptadas por Chile" 970 , por lo que las críticas peruanas sólo podían ser entendidas como medidas que tenían "por objeto retrasar la solución del conflicto"971.

\footnotetext{
${ }^{665}$ El Siglo Futuro, "El jacobinismo en Chile", 22 de marzo de 1910, p. 2.

966 El Imparcial, "Sacerdotes expulsados", 7 de marzo de 1910, p. 1; El Día, "Extranjero", 8 de marzo de 1910, p. 2; La Época, "Los sacerdotes del Perú expulsados de Chile”, 6 de marzo de 1910, p. 5.

${ }^{967}$ El Globo, "Extranjero", 8 de marzo de 1910, p. 2.

${ }^{968}$ HuRTADO, Paula, "Sin Dios ni ley. Violencia, incomprensión y desamparo. La situación de Tacna, Arica y Tarapacá tras la Guerra del Pacífico, a la luz del diario El Comercio y la revista Variedades (1910-1912)”, Letras históricas, ${ }^{\circ}{ }^{\circ}$, primavera-verano 2010, p. 145.

${ }^{969}$ El Siglo Futuro, "El jacobinismo en Chile", 22 de marzo de 1910, p. 2; El Imparcial, "Conflicto chilenoperuano", 23 de marzo de 1910, p. 1; El Imparcial, "Chile y Perú", 22 de marzo de 1910, p. 3; El Globo, La protesta de Perú, 23 de marzo de 1910, p. 2; La Correspondencia Militar, "Perú y Chile rompen sus relaciones diplomáticas", 22 de marzo de 1910, p. 1; La Correspondencia de España, "Protesta del Perú", 23 de marzo de 1910, p. 2.

${ }^{970}$ El Imparcial, "Conflicto chileno-peruano", 23 de marzo de 1910, p. 1; La Correspondencia de España, "Chile y Perú", 23 de marzo de 1910, p. 2; El Siglo Futuro, "Del Perú", 22 de marzo de 1910, p. 3; La Correspondencia Militar, "Perú y Chile rompen sus relaciones diplomáticas", 22 de marzo de 1910, p. 1; La Época, "Nuevo conflicto entre Chile y Perú", 23 de marzo de 1910, p. 1.

${ }^{971}$ La Correspondencia de España, "Chile y Perú", 23 de marzo de 1910, p. 2; La Época, "Nuevo conflicto entre Perú y Chile”, 23 de marzo de 1910, p. 1.
} 
Contraria a la dimensión episódica de la expulsión de los sacerdotes peruanos, una revista española aseguró que "Tiempo hace ya que el gobierno chileno intentaba desmembrar de la diócesis de Arequipa la jurisdicción eclesiástica de Tacna y Arica y anexionarla a la de Tarapacá [...]"972. Esa constatación le servía a esa revista como prólogo a su acusación de la ilegalidad chilena, en el marco del derecho internacional, por no haber cumplido los acuerdos firmados en la paz de Ancón de 1883. La ocupación por Chile, afirmó, "es transitoria y sin título jurídico, desde que ha venido el plazo señalado para el plebiscito, al cual la cancillería de Santiago no quiere ir"973.

El autor de esa nota, el geógrafo Ricardo Beltrán, no ocultó su filiación sentimental con Perú. Acusó a Chile de cometer un acto de injusticia al pretender que la jurisdicción eclesiástica de Tacna y Arica se arrancase de Perú poniéndola al servicio de Chile como medio cómodo y eficaz de servir sus intereses en la anexión de esas tierras peruanas, sólo con la razón de la victoria en la guerra, carente de fuerza jurídica "sin más titulo que el del incumplimiento del tratado de 1883 que le dio las riquezas de Tarapacá, pero no el dominio que hoy pretende tener sobre pueblos que son peruanos y cuya condición de anexión no se ha realizado" $" 974$.

Al analizar las consecuencias de la expulsión de los curas peruanos en ese país, comentó que no resultaba difícil comprender la retirada de los diplomáticos en Santiago. Todas sus aseveraciones estaban bien apoyadas por los periódicos limeños que "vienen llenos de artículos, noticias, comentarios y copias de documentos para demostrar la constante mala fe de Chile en este asunto" 975 . En esas publicaciones se reprodujeron las "Actas de las sesiones del Comité chileno nacionalizador de Tacna y Arica", actas secretas que Perú conoció, donde el presidente de Chile, Pedro Montt, se manifestaba dispuesto a romper con el Vaticano si no eran autorizados los curas chilenos para el ejercicio de su sacerdocio. El geógrafo español y miembro de la Real Academia de Historia no consultó, en esta ocasión, prensa chilena.

\footnotetext{
${ }_{972}$ La Ilustración Artística, "Revista Hispanoamericana", 11 de abril de 1910, n. ${ }^{0}$ 1476, p. 234.

973 Idem.

974 Idem.

${ }^{975}$ Idem.
} 
Imagen $n^{\circ} 41$

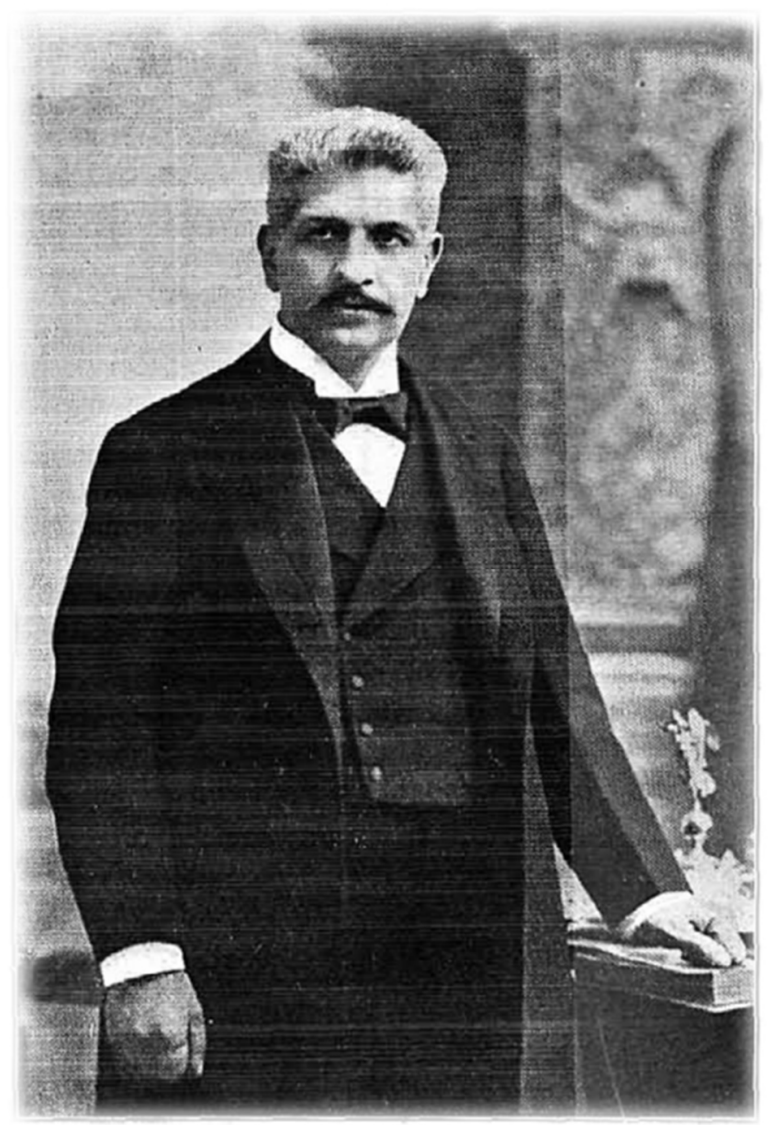

Fuente: La Ilustración Española y Americana, "Dr. D. Pedro Montt", 22 de agosto de 1910, n. ${ }^{\text {o } 31, ~ p . ~} 99$.

Según Beltrán y Rózpide, Chile mantenía negociaciones con las repúblicas vecinas del Perú y les brindaba apoyo en los conflictos que pudiera tener en éste. Esa acusación, por el contrario, no era respaldada documentalmente, y probablemente guardaba relación con su desempeño como miembro de la Comisión de Límites entre Perú y Ecuador en 1905. El interés por el país peruano no finalizaría allí. En 1922 escribió Colección de las Memorias o relaciones que escribieron los virreyes del Perú acerca del estado en que dejaban las cosas generales del reino ${ }^{976}$, análisis histórico que sobrepasa nuestros objetivos.

\footnotetext{
976 Peiró Martín, Ignacio y Gonzalo Pasamar, Alzuria, Diccionario Akal de historiadores españoles contemporáneos, Madrid, Ediciones AKAL S. A., 2002, p. 120; DíAz DíAZ, Gonzalo, Hombres y documentos de la filosofía española, Madrid, Consejo Superior de Investigaciones Científicas, 1980, p. 558.
} 
Pedro Martínez Velez, uno de los más prestigiosos redactores de la revista España y América $^{977}$, cultor de intereses bíblicos-exegéticos ${ }^{978}$, agustino español asentado en Perú, sacrificó la imparcialidad periodística para defender desde la escritura la causa peruana. Según él, la expulsión de los sacerdotes tenía relación con el elevado patriotismo demostrado por ellos en las "cautivas". Por eso "el empeño de la cancillería chilena en que sean chilenos los párrocos y dependan de la jurisdicción también chilena"979.

Paralelamente, reflexionaba sobre los problemas, como éste, derivados del patronato eclesiástico de los Estados. En la carta publicada por la revista España y América, titulada "Desde el Perú", se preguntaba por el futuro de la cuestión religiosa en la frontera. La respuesta previó el éxito de la visita del jurista peruano Alejandro Deustua al Vaticano, de quien esperaba una conducta rigurosamente jurídica $\mathrm{y}$, consecuentemente, el fracaso de los intereses eclesiásticos chilenos.

Deustua ha ido a Roma -relató- como enviado extraordinario del Perú ante la Santa Sede, para defender los derechos peruanos, anticipándose a "cualquier golpe de mano con que pudiera sorprender al Perú la cancillería chilena"980. Deustua tenía las simpatías de los agustinos españoles en Lima, pues era "un cumplido caballero, y para nosotros [...] es persona altamente simpática por su excelente comportamiento y constantes deferencias hacia nosotros" 981 .

La expulsión de los sacerdotes peruanos, así como toda la larga lista de temas que informaba desde el Perú eran, según su parecer, referidos "como quien dice a nuestra casa, a nuestro hogar, a la benéfica expansión de España en América"982. Dos años después, aún desde el Perú, difundía el "activo e ilustrado compañero y hermano P. Martínez Vélez"983, la situación eclesiástica de Tacna y Arica, las provincias "cautivas" dentro del territorio chileno, como le gustaba denominarlas.

\footnotetext{
${ }^{977}$ BotTI, Alfonso, España en la crisis modernista. Cultura, sociedad civil y religiosa entre los siglos XIX y XX, Cuenca, Ediciones de la Universidad de Castilla-La Mancha, 2012, p. 132.

${ }_{978}$ BOTTI, Alfonso, España en la crisis..., p. 133.

${ }^{979}$ España y América, "Desde el Perú", 30 de septiembre de 1909, año VII, tomo III, p. 433.

980 Idem.

${ }^{981}$ Idem.

982 Íbidem, p. 431.

${ }^{983}$ España y América, "Desde el Perú”, septiembre de 1911, año IX, n. ${ }^{\circ}$ 13, p. 478.
} 
En esa ocasión, advertía como el conflicto nuevamente estaba "al rojo vivo". La razón fue la apertura al culto de las iglesias bajo la protección del Vicariato General Castrense de Chile. Una vez más apoyó la causa peruana, que desde su visión estaba estrechada con el derecho. Por esto afirmó que la litis de 1910 era una cuestión delicadísima para la Santa Sede, porque una medida suya menos prudente podría acarrear una verdadera persecución legal religiosa en Perú “donde es tan vivo el sentimiento que tienen de su derecho y de su amor a esas dos provincias cautivas" 984.

Hacia mediados de 1910 se normalizó la situación de las iglesias. El suministro de fe continuó bajo el signo del catolicismo, pero ahora chileno. Todo ello se hizo con la autorización del Vaticano quien "restableció el servicio religioso con sacerdotes chilenos [...] que el obispo peruano de Arequipa había suspendido"985.

Algunas publicaciones optaron por imaginar líneas de acción en el futuro de las relaciones entre chilenos y peruanos. En marzo de 1910 un diario se preguntó “¿Arreglarán, gracias a la intervención de mediadores, sus viejas diferencias, continuamente renovadas?" o “¿confiarán la solución del conflicto al éxito de las armas?”. Proponía, para finiquitar las diferencias, una solución basada en la expresión soberana del voto plebiscitario, enfatizando, eso sí, que "ese plebiscito se ha ido hábilmente retrasado" no conviniéndole esto a Chile "porque el fallo no le sería favorable". Por otro lado, esta trama religiosonacionalista provocó la ironía de El Motín, que desde su rincón anticlerical expresó:

Aquellos chilenos de que nos burlábamos en Los sobrinos del capitán Orant por calmosos y atrasadillos nos dan ahora un bravo ejemplo de entereza y resolución. No sé si tienen o no tienen Concordato para andar con estorbos por su casa; pero han expulsado muy linda y expeditivamente a los sacerdotes peruanos del territorio de Tacna, por negarse éstos a observar la Constitución de Chile. Y van a reemplazarlos con chilenos, lo cual es un mal menor; pero al fin y al cabo es un mal, del que tal vez seamos responsables los españoles; no en vano les transmitimos nuestras costumbres y nuestros frailes durante mucho tiempo. Imitemos ahora su conducta. ¡Fuera todos los sacerdotes que huelan a extranjerismo! Y después... ¡Fuera también los que trasciendan a nacionales! La casa sin cinches; esto es, la felicidad deseada. Me relamo de gusto solo al pensarlo ${ }^{986}$.

\footnotetext{
${ }^{984}$ España y América, “Desde el Perú”, septiembre de 1911, año IX, n. ${ }^{\circ}$ 13, p. 478.

${ }^{985}$ La Época, "El servicio religioso en Chile”, 19 de junio de 1910, p. 1.

${ }^{986}$ El Motín, “¡Fuera parásitos!”, 17 de marzo de 1910, n. ${ }^{\circ} 10$, p. 6.
} 
6.5. ¿Los raíles del progreso? La construcción del ferrocarril Arica-La paz en la prensa

El tratado chileno-boliviano de 1904 obligó al primero de los Estados contratantes a construir un ferrocarril entre Arica y La Paz el cual debía, quince años después de su inauguración, cederse en "dominio y posesión"987 al segundo. La mediterraneidad boliviana, causada por la Guerra del Pacífico y legalizada con el mencionado tratado, favoreció políticas económicas destinadas a la construcción de redes ferroviarias que comunicasen el país con el Pacífico. Los líderes del conservadurismo de finales del siglo XIX y los liberales de comienzos del siglo XX vieron en los ferrocarriles el único medio para dar "salida de los minerales a los puertos" 988.

El Estado boliviano demostraba incapacidad en la gestión de su economía. La recaudación y administración de impuestos, por ejemplo, impedían un uso adecuado de los capitales producidos por la industria del estaño. El país debió recurrir a préstamos internacionales, principalmente de los Estados Unidos ${ }^{989}$, que les permitieron afrontar el pago de intereses de préstamos anteriores y la construcción de ferrocarriles ${ }^{990}$. Bolivia debió asociarse obligatoriamente con el capital extranjero, situación que fue informada fuera del país con tono benevolente: "grandes entidades financieras europeas y americanas se preparan para acometer importantes obras de interés público"991.

En el caso del Ferrocarril de Arica a La Paz, conocido también por el acrónimo FCALP, sus aproximadamente 439 kilómetros ${ }^{992}$ permitieron introducir en Bolivia diversos productos provenientes de, principalmente, Perú, Chile y los Estados Unidos ${ }^{993}$.

\footnotetext{
${ }^{987}$ Madrid Cientifico, "La comunicación de Bolivia con el mar", n. ${ }^{\circ}$ 797, 1913, p. 347.

988 PeÑa HaSBún, Paula, La permanente construcción de lo cruceño: Un estudio sobre la identidad en Santa Cruz de la Sierra, La Paz, Fundación PIEB, 2003, p. 67.

989 BIEBER, León, "Bolivia, 1936-1945. En la encrucijada entre el surgimiento de un nacionalismo militante y la rivalidad germano-norteamericana”. En SALMÓn, Josefa y DELGADO, Guillermo, Identidad, ciudadanía y participación popular desde la Colonia al siglo XX, La Paz, Plural Editores, 2007, p. 173.

990 Halperin Dongui, Tulio, Glade, William, Thorp, Rosemary, BAUER, Arnold, Moreno Fraginals, Manuel, Lewis, Colin M., Bulmer-ThOMAS, Victor, FFrench-DAVIS, Ricardo, MuÑOz, Óscar, PALMA, José Gabriel, Historia Económica de América Latina. Desde la Independencia hasta nuestros días, Barcelona, Crítica, 2002.

${ }^{991}$ La Ilustración Artística, "Revista Hispanoamericana", 24 de julio de 1905, n. ${ }^{\circ} 1230$, p. 474.

992 Alliende E., María Piedad, Historia del ferrocarril en Chile, Santiago, Pehuén Editores, 1993, p. 99.

993 Bradford Burns, E., La pobreza del progreso. América Latina en el siglo XIX, México, Siglo XX Editores, 1990.
} 
En España, Ricardo Beltrán Rózpide situó la construcción del FCALP en el marco de un conjunto de reformas elaboradas por el poder ejecutivo boliviano. En una revista contemporánea a la inauguración del ferrocarril escribió, refiriéndose al tratado de 1904: "En virtud de ese tratado, el Gobierno de Chile, a cambio de la cesión definitiva de la provincia boliviana de Antofagasta, se comprometió a construir por su cuenta el ferrocarril de Arica al Alto de La Paz" ${ }^{994}$.

Según la noción de progreso ofrecida por la modernidad decimonónica, los ferrocarriles encarnaban la mejor demostración del desarrollo material de las naciones. Más que ningún otro proyecto técnico o institución social -ha dicho un historiador- el ferrocarril representó la modernidad ${ }^{995}$. En el caso chileno, este tipo de obras públicas permitidas solamente por capitales privados, favoreció la evaluación positiva de la prensa española quien entregó variados detalles de la construcción ferroviaria. Cronológicamente, dio cuenta de las dificultades financieras iniciales sufridas por Chile en la negociación con diferentes instituciones -Pearson Bank, Deutsche Bank y Sir John Jackson Ltd. ${ }^{996}$ - para reunir los fondos necesarios requeridos por el FCALP.

Si bien las ideas de Chile como un país ambicioso y expansionista permanecían en torno a $19044^{997}$, el ferrocarril demostraba el "desarrollo general del país"998, pues "permitía la continuación del ferrocarril de Tacna-Arica a La Paz, estableciendo así comunicación directa entre la costa de Chile y la capital de Bolivia"999. A la par, se informaban los avances del ferrocarril Trasandino entre Santiago y Buenos Aires y la extensión sobre el suelo chileno de una amplia red de trenes.

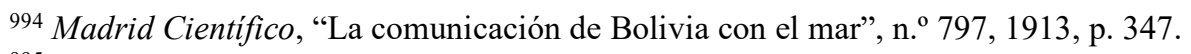

995 JuDT, Tony, Cuando los hechos cambian, Barcelona, Taurus, 2015.

${ }^{996}$ El Siglo Futuro, "Empréstito", 20 de marzo de 1906, p. 3; La Época, "Despachos telegráficos", 20 de marzo de 1906, p. 1; El Liberal, "Situación económica de Chile", 8 de junio de 1906, p. 3; El Siglo Futuro, "Última hora", 23 de noviembre de 1907, p. 7; El Globo, "Los valores chilenos", 24 de noviembre de 1907, p. 1; La Época, "El Ferrocarril de Arica a La Paz. El empréstito chileno", 28 de noviembre de 1907, p. 1; El Siglo Futuro, "Bolsas extranjeras", 28 de noviembre de 1907, p. 3; Gaceta de los Caminos de Hierro, "Ferrocarriles extranjeros", 8 de diciembre de 1907, n. ${ }^{\circ} 2669$, p. 530.

${ }^{997}$ La Ilustración Artística, "Revista Hispanoamericana", 26 de noviembre de 1906, n. ${ }^{\circ} 1300$, p. 762.

998 Industria e Invenciones, "Los mercados neutrales del mundo y sus oportunidades", 2 de julio de 1906, n. ${ }^{\circ} 22$, p. 219.

${ }^{999}$ Idem.
} 
Para Bolivia, la construcción del FCALP significó que la prensa española cambiara la imagen barbárica del país. La modernización que conllevaba la obra le permitió ser presentada como la "Suiza americana"1000, situación que tenía relación también con la legalidad de sus fronteras y el reconocimiento en pleno derecho de éstas en el plano internacional. Así lo daban a entender algunas noticias que comentaban los procesos de “demarcación de la nueva frontera con Chile, de acuerdo al último tratado de paz y amistad"1001 y el trazado de la "frontera con el Brasil, según el tratado de Petrópolis"1002.

Mucho más importantes fueron las ideas de la prensa sobre las riquezas naturales de Bolivia desarrolladas por los ferrocarriles y, por último, la ilusión imaginaria del potencial de progreso de ese país. El tiempo de la visibilidad tenue o de los juicios severos sobre lo boliviano estaba cambiando. Una revista de gran circulación publicó en 1906 que ese año era el del resurgimiento de Bolivia ${ }^{1003}$, a raíz de las obras ferroviarias de Oruro, Viacha, Cochabamba, Potosí, Puerto Sucre, Santa Cruz y La Paz-Arica. En la prensa, la publicación de algunas particularidades geográficas bolivianas favoreció la imaginación de los lectores. Carlos Walker Martínez, político conservador chileno, compartió sus impresiones del área donde se construiría la estación principal del ferrocarril, explicando que esas provincias "no valen la pena de que dos pueblos discutan acerca de su soberanía en ellas [...] su valor económico es escaso" ${ }^{1004}$.

Con un mayor número de detalles, la antropóloga estadounidense Harriet Chalmers Adams, se refirió a los parajes de Bolivia, "comarca olvidada de la América Meridional, que empieza a ser atravesada por ferrocarriles" ${ }^{1005}$. La república de los ermitaños -como la bautizó- había perdido sus puertos marítimos, encaramándose sobre el tejado de Occidente con una ciudad capital "remota e inaccesible" 1006.

\footnotetext{
${ }^{1000}$ Almanaque Bailly-Bailliere, "Un tercer camino desde Bolivia al Pacífico”, Madrid, Casa Editorial BaillyBailliere, 1914, p. 393.

${ }^{1001}$ La Ilustración Artística, "Revista Hispanoamericana”, 26 de noviembre de 1906, n. ${ }^{\circ}$ 1300, p. 762.

${ }^{1002}$ Idem; Gaceta de los Caminos de Hierro, "Ferrocarriles extranjeros", 16 de diciembre de 1910, n. ${ }^{\text {2 2814, }}$ p. 594.

${ }^{1003}$ La Ilustración Artística, "Revista Hispanoamericana", 26 de noviembre de 1906, n. ${ }^{\circ} 1300$, p. 762; Gaceta de los Caminos de Hierro, "Los ferrocarriles y la Bolivia actual", 1 de noviembre de 1907, n. ${ }^{\circ}$ 2664, p. 487.

${ }^{1004}$ La Ilustración Artística, "Revista Hispanoamericana", 7 de septiembre de 1903, p. 586.

${ }^{1005}$ Nuestro Tiempo, "La liberación de Bolivia", marzo de 1913, n. ${ }^{\circ}$ 171, p. 396.

${ }^{1006}$ Idem.
} 
Para la estadounidense, la única forma de vencer ese aislamiento eran los ferrocarriles que activaban la producción de riquezas. En ella, la relación ferrocarrilprogreso era unívoca. En efecto, las ciudades debían unificarse por un sistema ferroviario que "rasgando el silencio del altiplano, vayan a conmover las riquezas dormidas en el seno de las gigantes montañas que rodean el suelo boliviano" 1007 .

Las ideas de Harriet Chalmers aparecieron en la Review of Review de Estados Unidos, donde explicó las transformaciones económicas bolivianas producidas por la política ferroviaria. El estudio fue reproducido por La España Moderna quien añadió un prólogo esperanzador para Bolivia, país que pronto mejoraría su economía y no sería "el pueblo enfermo de que hablaba un ilustre boliviano como Alcides Arguedas"1008. La referencia al intelectual (?) paceño se debía a su obra Pueblo Enfermo. Contribución a la psicología de los pueblos hispanoamericanos. Una causa de esa enfermedad, según Miguel de Unamuno -lector crítico de Pueblo Enfermo...- era el alcoholismo de los "cholos" bolivianos y los "rotos" chilenos, mucho menor "allí donde la sangre blanca entra en mayor proporción" ${ }^{1009}$. Estudios posteriores han acusado esa obra de racismo biológico, pero poco se ha dicho del salmantino que sugirió, en un adagio conocido, curar el racismo viajando.

Otras nociones de Chalmers se referían a las condiciones de vida de los montañeses bolivianos, tan lúgubres como su ambiente. Más rica en detalles fue la reseña de la misma revista española sobre La Paz y sus habitantes: "en las escarpadas calles, los trajes multicolores de las coquetonas cholas y de los vestidos de ópera bufa del cobrizo aymara, dan vida a las escenas que ofrecen encanto y diversidad"1010. Ese retrato social contenía escasos caballeros y damas de la clase alta boliviana, que "con arreglo a la última expresión de la moda, representan minoría [...] parecen extranjeros en este grotesco cuadro". La noción de grotesco, bien puede entenderse aquí representando un estado de cambio, "rompiendo lo que sabemos y mezclándolo con lo desconocido"1011.

\footnotetext{
${ }^{1007}$ La Ilustración Artística, "Revista Hispanoamericana", 26 de noviembre de 1906, n. ${ }^{\circ}$ 1300, p. 762.

${ }^{1008}$ La España Moderna, "La América Moderna", 1 de agosto de 1913, n. . 296, p. 196.

1009 OuIMETTE, Víctor, De patriotismo espiritual. Artículos en "La Nación" de Buenos Aires, 1901-1914, Salamanca, Ediciones Universidad de Salamanca, 1997, p. 154.

${ }^{1010}$ La España Moderna, "La América Moderna", 1 de agosto de 1913, n. ${ }^{2}$ 296, p. 198.

1011 ConNelly, Frances S., Lo grotesco en el arte y la cultura occidentales. La imagen en juego, Madrid, Machado. Grupo de distribución S. L., 2015, p. 32.
} 
Imágenes n. ${ }^{\circ} 42,43,44$ y 45
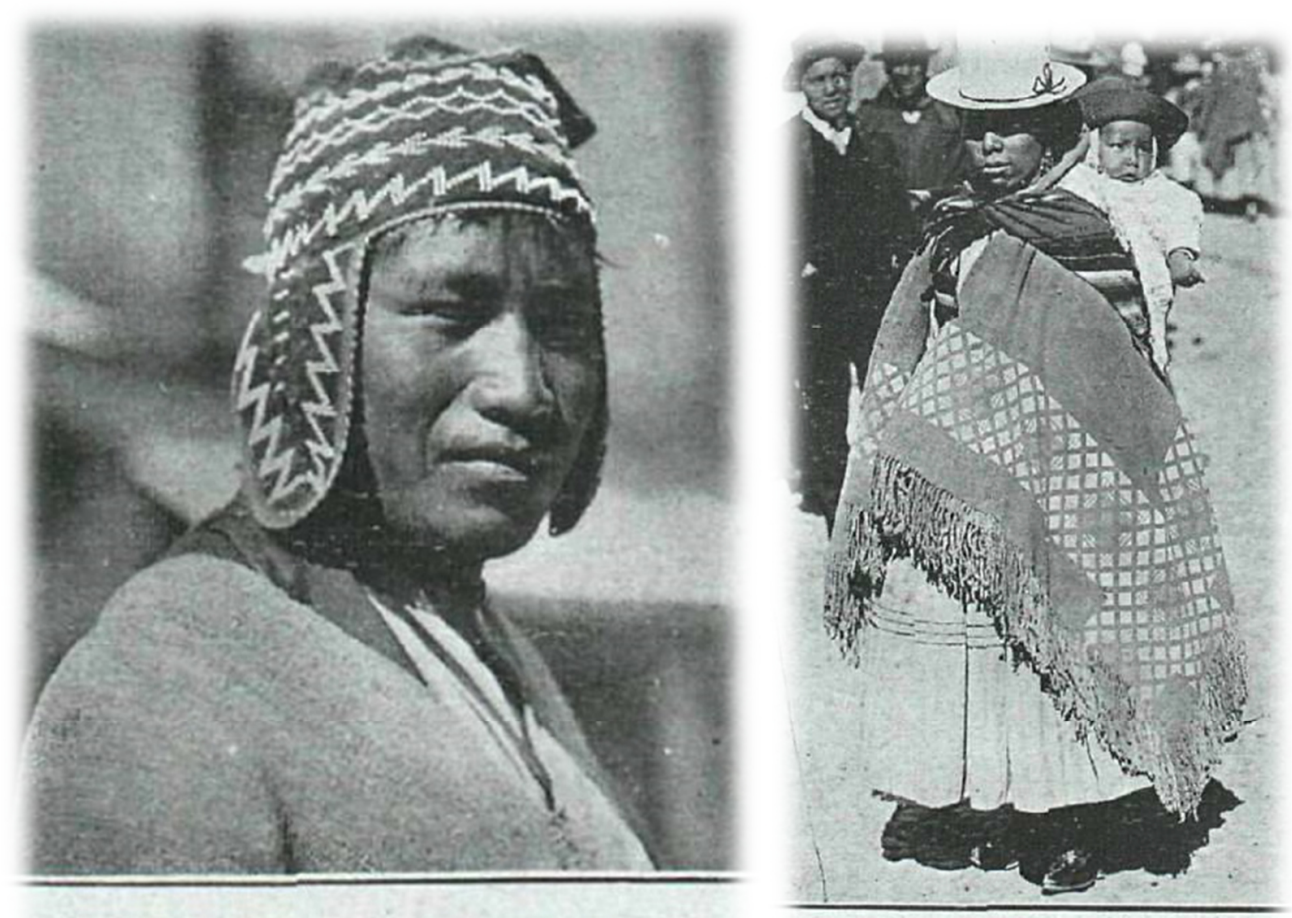

Un aymara, con su dracloso dorro de lana

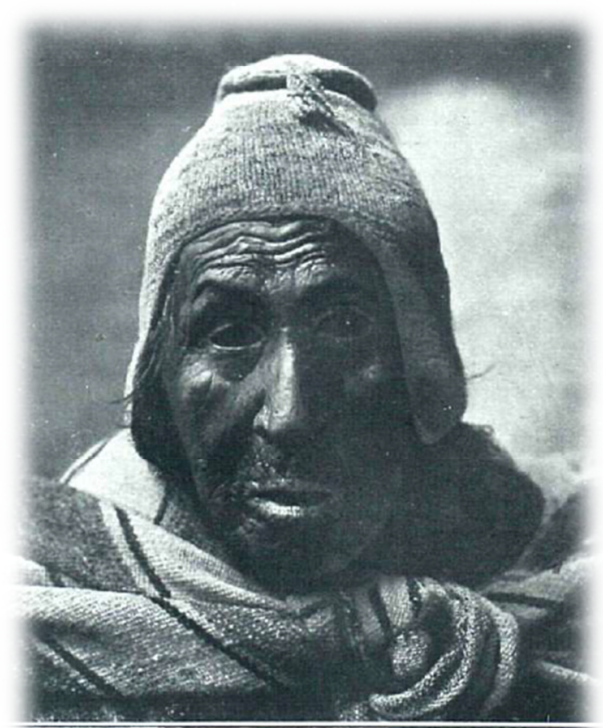

Lo 1 1

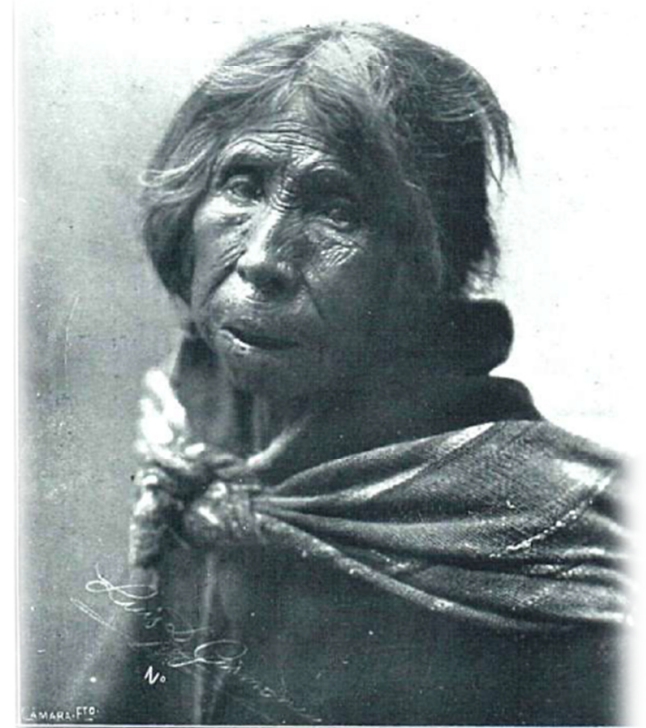

Indla aymarà, de ta Paz (Bolleta)

Fuentes: La Esfera, "Un aymara con su gracioso gorro de lana", 13 de septiembre de 1924, n. ${ }^{\circ} 558$, p. (s/d); La Esfera, "Una madre aymara con su pequeñuelo", 13 de septiembre de 1924, n. ${ }^{\circ}$ 558, p. (s/d); La Esfera, "Indio aymara de ciento veinticinco años", 29 de mayo de 1915, n. ${ }^{\circ}$ 74, p. (s/d); La Esfera, "India aymara de La Paz (Bolivia)", 29 de mayo de 1915, n. ${ }^{\circ}$ 74, p. (s/d). 
Para la prensa, la cualidad de lo moderno llevaba consigo la impronta de lo civilizado. Por eso, no era extraño que el ferrocarril Arica-La Paz permitiera alcanzar a Bolivia esa posición en el concierto de las naciones occidentales. En esta transición el ferrocarril era clave, pues ese transporte movilizaría dentro y fuera del país los "tesoros dormidos en el suelo"1012, permitiendo que la "civilización discurra por sus regiones"1013. Un requisito impostergable prescribía abandonar los medios de comunicación tradicionales - caravanas compuestas de indios y llamas de carga- por ferrocarriles que ofertarían en el mercado global los "innúmeros productos de esta prepotente república interior"1014. Al respecto, otra revista expuso cómo los senderos de mulas con direcciones hacia las costas del Pacífico se cambiaban por ferrocarriles que seguían "las pendientes naturales de la altura de las montañas hasta el nivel del mar, sendas que fueron pisadas por los pueblos incas, siglos antes de que los hombres blancos pusiesen la planta"1015. Las referencias al paisaje se complementaban con características climáticas referidas al mal de montaña o soroche.

Por ejemplo, La Paz, "tiene un clima menos maligno que las otras ciudades [...] a 125.000 (sic) metros sobre el nivel del mar, está sobre el suelo de un estrecho cañón guardado de las heladas ráfagas que soplan sobre el Puna"1016. La relación mediterraneidadcosta pudo producir, como en otras ocasiones, errores de localización, como leemos en otra descripción de la ciudad "caleidoscópica”, "protegida por el Illimani, Dama Blanca, fiel guardián de esta ciudad del Pacífico (sic)"1017.

En la cordillera boliviana los metales preciosos rivalizaban -de acuerdo con las opiniones de la antropóloga- con la abundancia de los productos del bosque. Vida Marítima aludía a los Andes bolivianos como un conjunto de "inmensas cadenas montañosas ricas en minerales"1018 yendo más lejos con su retórica del progreso, pues los ferrocarriles permitirían a Bolivia abrir allí una nueva era industrial en la historia del progreso del mundo.

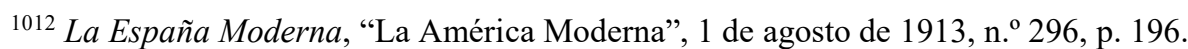

1013 Idem.

${ }^{1014}$ La España Moderna, "La América Moderna”, 1 de agosto de 1913, n. ${ }^{\circ}$ 296, p. 197.

${ }^{1015}$ Nuestro Tiempo, "La liberación de Bolivia", marzo de 1913, n. ${ }^{\circ} 171$, p. 396.

${ }^{1016}$ Idem.

${ }^{1017}$ La España Moderna, "La América Moderna", 1 de agosto de 1913, n. ${ }^{\circ}$ 296, p. 198.

1018 Vida Marítima, "Ferrocarriles en África y Sudamérica", 30 de octubre de 1909, n. ${ }^{\circ} 282$, p. 470. 
En otras palabras, de nada valían las riquezas de las "muchas y muy ricas minas" sin una moderna infraestructura ferroviaria. El conocimiento seguro acerca de las cualidades inequívocas del progreso llevó a asegurar a una revista que Bolivia, por fin, había alcanzado ese estado. En sus palabras, vaticinaba "el momento en que el progreso, filibustero de lo pintoresco, le robará a La Paz su seductora individualidad adquirida durante los muchos años en que permaneció muy apartada de los activos mercados mundiales"1019.

La geomorfología "escabrosa" por donde recorría el FCALP obligó a los ingenieros y trabajadores a abrir senderos a través de las rocas para subir al lado de las montañas. $L a$ Ilustración Artística redactó las complejas labores para "abrir muchos túneles a través de las estribaciones de las montañas y construir numerosos puentes sobre las barrancas y quebradas"1020. La prensa describió la victoria de la ciencia y la ingeniería inglesa sobre la naturaleza ${ }^{1021}$. Una revista comentó el buen comienzo del ferrocarril, a pesar de las dificultades que su construcción presenta a los ingenieros que la acometieron. Superar los condicionantes del relieve escarpado probó "lo que puede el genio británico"1022. Las negociaciones realizadas por Sir John Jackson con el Estado chileno -país que ofrecía un amplio radio de acción a los ingenieros ${ }^{1023}$ - fueron seguidas por la prensa, quien dio cuenta de la satisfacción que dio al inglés saber el avance de los trabajos en la frontera.

Otras publicaciones ofrecían a sus lectores biografías de la Sir John Jackson Limited, marcada por sus triunfos en diferentes lugares del mundo ${ }^{1024}$. En fin, la modernidad del ferrocarril de Arica a La Paz hacía posible la adecuación de los vagones para impedir que la puna o mal de montaña afectase a sus clientes. Ellos ocuparían “departamentos especiales, donde el aire conserva la misma proporción de oxígeno que al nivel del mar"1025.

\footnotetext{
${ }^{1019}$ La España Moderna, "La América Moderna", 1 de agosto de 1913, n. o 296, p. 198.

${ }^{1020}$ La Ilustración Artística, "Expansión ferroviaria en la América del Sur”, 12 de abril de 1915, n. ${ }^{\circ}$ 1737, p. 266.

${ }^{1021}$ Almanaque Bailly-Bailliere, "Un tercer camino desde Bolivia al Pacífico", Madrid, Casa Editorial BaillyBailliere, 1914, p. 394

1022 Vida Marítima, "Ferrocarriles en África y Sudamérica", 30 de octubre de 1909, n. ${ }^{\circ} 282$, p. 470.

1023 Idem.

${ }^{1024}$ Nuevo Mundo, "El nuevo dique Victoria Eugenia", 22 de mayo de 1913, (s/d).

${ }^{1025}$ Gaceta de los Caminos de Hierro, "Ferrocarriles extranjeros", 1 de mayo de 1912, n. . 2880, p. 6.
} 
Todos estos antecedentes le permitían a un almanaque español, en su versión de 1914, asegurar que el FCALP era otro triunfo ferroviario sudamericano; la Revisa Ilustrada de Banca, Ferrocarriles, Industria y Seguros lo valoró como una obra de las más “celebres, grandiosas y admirables construcciones ferroviarias, no sólo de América, sino del mundo" 1026 .

En la región de la triple frontera la mayor dificultad para la firma fue la carencia absoluta de agua ${ }^{1027}$, que debió obtenerse en lugares alejados aumentando su precio. La empresa resolvió el problema construyendo una tubería de 75 millas desde los puntos más altos en el terreno a los lugares bajos de las faenas. Un segundo problema fueron los gastos elevados en el transporte de los materiales, que eran "mayores que el valor de los materiales" 1028 . Por último, las secciones más abruptas debieron ser remontadas utilizando ferrocarriles de cremalleras, un tipo de recurso costoso comenzando a ser utilizado por la ingeniería moderna ${ }^{1029}$.

En otro ámbito, la prensa informó sobre aspectos de la evolución ferroviaria en Bolivia. El comienzo del siglo, con varios proyectos de construcción en diversas regiones del país, dio la impresión de progreso económico, no existente años antes. Un reportaje señaló la inexistencia de trenes en ese país hasta 1855. Algunos magazines discrepaban respecto a cuál había sido el primer ferrocarril boliviano asegurando que era la línea que unía Antofagasta con La Paz ${ }^{1030}$. Tal situación de "atraso" cambiaría por la necesidad de transportar los minerales de Huanchaca hacia Oruro. Una segunda línea conectó el puerto peruano de Mollendo con la región de Puno, otra La Quiaca con Potosí y, por último, Arica con La Paz que estaba llamada a ser “el gran eslabón para la moderna ruta andinotranscontinental" ${ }^{\prime 031}$.

\footnotetext{
${ }^{1026}$ Revista Ilustrada de Banca, Ferrocarriles, Industria y Seguros, "Los ferrocarriles chilenos en 1910", 10 de diciembre de 1910, p. 607.

1027 Madrid Científico, "La comunicación de Bolivia con el mar", n. ${ }^{\circ}$ 797, 1913, p. 347; Almanaque BaillyBailliere, "Un tercer camino desde Bolivia al Pacífico", Madrid, Casa Editorial Bailly-Bailliere, 1914, p. 393. ${ }^{1028}$ Madrid Cientifico, "La comunicación de Bolivia con el mar", n. ${ }^{\circ} 797$, 1913, p. 347.

1029 Almanaque Bailly-Bailliere, "Un tercer camino desde Bolivia al Pacífico", Madrid, Casa Editorial BaillyBailliere, 1914, p. 394.

${ }^{1030}$ La España Moderna, "La América Moderna", 1 de agosto de 1913, n. ${ }^{\circ} 296$, p. 199.

1031 Almanaque Bailly-Bailliere, "Un tercer camino desde Bolivia al Pacífico", Madrid, Casa Editorial BaillyBailliere, 1914, p. 393.
} 


\section{Imagen n. ${ }^{\circ} 46$}

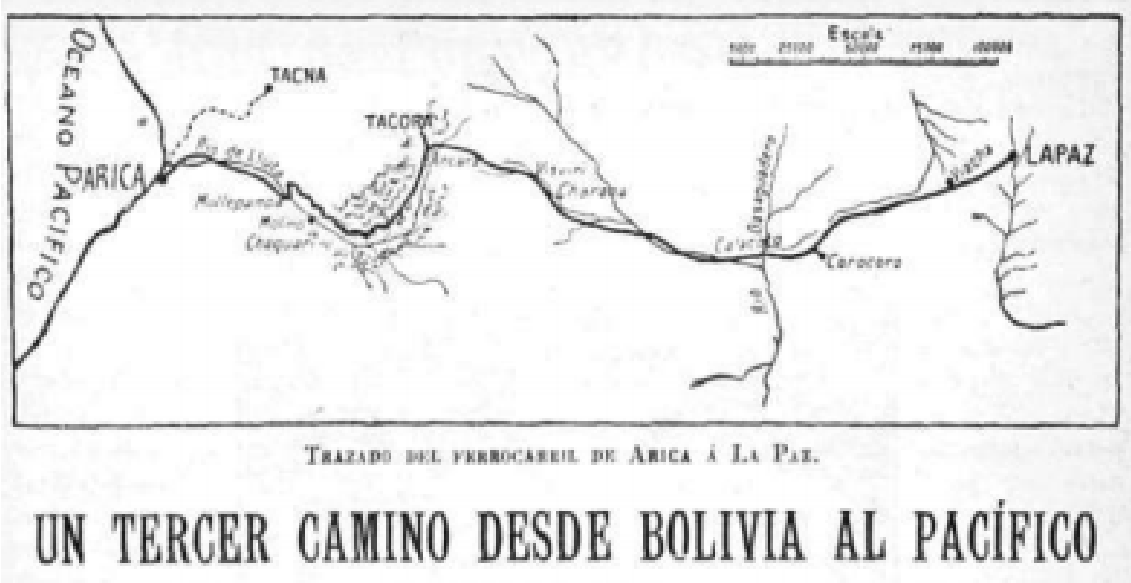

El ferrocarril de Arica á La Paz.

Fuente: Almanaque Bailly-Bailliere, "Un tercer camino desde Bolivia al Pacífico", Madrid, Casa Editorial Bailly-Bailliere, 1914, p. 393.

El 13 de mayo de 1913 se inauguró el ferrocarril de Arica a La Paz, enlazando esa capital con el Océano Pacífico ${ }^{1032}$. Su apertura se había realizado meses antes, en septiembre de 1912, advirtiéndose errores en los datos publicados por la prensa, que también anunció su inauguración en junio y octubre de ese mismo año ${ }^{1033}$, debido a las lluvias excepcionales que habían destruido puentes y terraplenes. Otras informaciones aseguraron que la obra se había proyectado al terminar la Guerra del Pacífico en $1881^{1034}$, pero, a decir verdad, se proyectó con el tratado de 1904 que puso fin a una guerra con Bolivia que había concluido, a su vez, en el campo de batalla en 1880 y con la firma de una tregua en 1884. Discrepancias similares hubo en torno al tiempo de demora entre una ciudad y otra así como con el número exacto de kilómetros del trazado ${ }^{1035}$.

\footnotetext{
1032 Nuestro Tiempo, "La liberación de Bolivia", marzo de 1913, p. 396; La España Moderna, "Codificación del Derecho Internacional americano", 1 de junio de 1913, n 294, p. 108.

1033 ;Adelante!, "De Fuera de España”, 25 de enero de 1912, n. ${ }^{\circ}$ 37, p. 2; ;Adelante!, "De fuera de España”, 15 de marzo de 1912, n. ${ }^{\circ}$ 42, p. 22; Gaceta de los Caminos de Hierro, "Bolivia", 8 de enero de 1912, n. 2865 , p. 19; Gaceta de los Caminos de Hierro, "Bolivia", 1 de marzo de 1912, n. ${ }^{\circ} 2872$, p. 102; Gaceta de los Caminos de Hierro, "Bolivia", 16 de junio de 1912, n. 2886, p. 270; La Época, "Un nuevo ferrocarril en Bolivia", 11 de junio de 1912, p. 4; Gaceta de los Caminos de Hierro, "Ferrocarriles extranjeros", 1 de mayo de 1912 , n. ${ }^{\circ} 2880$, p. 6.

${ }^{1034}$ El Imparcial, "De Arica a La Paz", 29 de mayo de 1912, p. 4; Adelante, "Bolivia", 25 de junio de 1912, n. ${ }^{\circ}$ 55, p, 32; Gaceta de los Caminos de Hierro, "Bolivia", 16 de junio de 1912, n. . 2886, p. 270.

${ }^{1035}$ El Imparcial, "De Arica a La Paz", 29 de mayo de 1912, p. 4; Adelante, "Bolivia", 25 de junio de 1912, n. ${ }^{\circ}$ 55, p, 32; La Época, "Un nuevo ferrocarril en Bolivia", 11 de junio de 1912, p. 4; Gaceta de los Caminos
} 
Las reuniones que sostuvieron los presidentes de Chile y Bolivia en Arica para verificar los avances en los trabajos del ferrocarril fueron también informadas con inexactitud por la prensa. Las noticias referidas a ese acontecimiento se situaron en América Central. Según algunos medios, el presidente electo de Bolivia, Eliodoro Villazón, habría conversado con su homólogo, Pedro Montt sobre "las relaciones que han de existir entre las Repúblicas de América Central"1036.

En esa reunión se trataron diversos temas de interés internacional, centrándose la prensa en las negociaciones que impulsaran con mayor rapidez los trabajos ferroviarios ${ }^{1037}$ y las peticiones de anexión a la soberanía chilena de las provincias de Tacna y Arica realizadas por políticos ariqueños quienes recibieron respuestas "en forma reservada"1038.

Las equivocaciones respecto a la nacionalidad de Tacna y Arica también estuvieron presentes en las noticias referidas a la construcción del ferrocarril. Como en otras ocasiones, Tacna y Arica no pertenecerían, según algunas publicaciones, ni a Chile ni a Perú. Respecto a Perú, se dijo que protestaría "si los bolivianos se obstinan en retener los territorios de Arica y Takna (sic)"1039. Las confusiones de la situación legal llevaron a la prensa a pensar que Tacna y Arica habían pertenecido antes de la guerra a Perú y Bolivia, respectivamente, cuando ambas constituían ciudades del extremo sur peruano antes de $1880^{1040}$.

La lectura de las fuentes demuestra cómo la vinculación entre el progreso y los ferrocarriles era clave en el caso boliviano. En la ausencia de esos transportes, la postergación del ingreso al mundo civilizado era un hecho. Comunicar las riquezas naturales del país con los capitales foráneos, puntualmente de los mercados estadounidense y europeo, era la otra condición. De la fácil salida al mar dependía el porvenir de Bolivia.

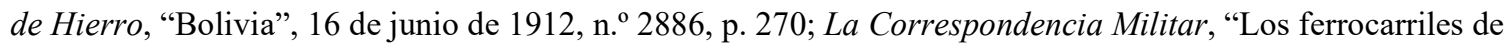
Chile y Bolivia", 7 de marzo de 1912, p. 3.

${ }^{1036}$ El Heraldo, "La América Central", 3 de abril de 1909, p. 1; El Siglo Futuro, "Las repúblicas americanas", 3 de abril de 1909, p. 3; La Correspondencia de España, "Viaje del Presidente", 7 de abril de 1909, p. 3.

${ }^{1037}$ El Siglo Futuro, "Mejoras en Chile", 20 de abril de 1909, p. 3.

${ }^{1038}$ El Siglo Futuro, "El Presidente de Chile", 14 de abril de 1909, p. 2; El Día, "El Presidente de Chile", 16 de abril de 1909, p. 1.

${ }^{1039}$ El Liberal, "Chilenos y peruanos", 27 de febrero de 1905, p. 2; La Correspondencia de España, "Chile y Perú", 26 de febrero de 1905, p. 3.

${ }^{1040}$ El Heraldo, "Perú", 1 de marzo de 1906, p. 4. 
La prensa analizó el atraso económico boliviano en una perspectiva más amplia notando como el atraso de ese país significaba el fracaso económico de Latinoamérica. Bolivia, antes de la fiebre ferroviaria, "languidecía sensiblemente y se retrasaba de sus hermanas del continente suramericano en el camino al progreso"1041. La revista Por esos Mundos vio con claridad la causa de su pobreza: "El gran obstáculo al desarrollo rápido de la industria minera en Bolivia es la falta de vías de comunicación"1042, situación que cambiaría, automáticamente, con la construcción del FCALP. Los trenes, pensó la elite política del país, facilitarían la inmigración blanca y con ésta el progreso ${ }^{1043}$.

En la prensa uno de los aspectos menos tratados fueron los impactos demográficos de la construcción del ferrocarril. La obra trasladó miles de personas hacia la frontera. Desde Japón se movilizaron alrededor de tres mil operarios. Desde Vigo, en el noroeste de España, llegó a Chile "la primera expedición de la emigración libre y gratuita [...] establecida por aquel gobierno mediante un crédito [...] para [...] hacer el ferrocarril de Arica a Paz (sic)". En el plano militar, el desarrollo que traerían a Bolivia los ferrocarriles le permitirían ingresar en la carrera armamentista. La constitución de un Estado Mayor poderoso fue otro signo de su progreso para la prensa. Particularmente, la instrucción militar indígena. Un americanista español la entendió como el fundamento de la "defensa de sus derechos y de su patria" 1044 .

La atmósfera creada por el progreso comunicacional y el despliegue del capitalismo inglés en la frontera cubrió algunos espacios de la sociabilidad burguesa española. Uno de esos, la Casa de América en Barcelona (CA $)^{1045}$, reunió a cónsules de diversos países, así como a delegados de Sociedades Económicas para compartir con Luis Gomes, Jefe de la Armada de Brasil, su intención de comunicar Arica con Recife ferroviariamente. Para la ocasión, el marino expuso el "gran proyecto del ferrocarril [...], que uniría el Atlántico al Pacífico, explicando la trascendencia para el porvenir y para la civilización futura" ${ }^{1046}$.

\footnotetext{
${ }^{1041}$ La Ilustración Artística, "Revista Hispanoamericana”, 26 de noviembre de 1906, nº 1300, p. 762.

${ }^{1042}$ Por Esos Mundos, "El cobre en Bolivia", 1 de julio de 1910, n. ${ }^{\circ}$ 186, p. 141.

${ }^{1043}$ La Ilustración Artística, "Revista Hispanoamericana", 26 de noviembre de 1906, n. ${ }^{\circ}$ 1300, p. 762.

${ }^{1044}$ La Ilustración Artística, "Revista Hispanoamericana", 16 de febrero de 1914, n. ${ }^{\circ}$ 1667, p. 126.

1045 Dalla CORTE, Gabriela, Casa de América en Barcelona (1911-1947), Madrid, LID Editorial, 2005.

${ }^{1046}$ La Época, "Barcelona. En la Casa América", 6 de julio de 1913, p. 2; El Globo, "De Barcelona. Una conferencia", 6 de julio de 1913, p. 1.
} 
Otras publicaciones pronosticaron la pronta construcción de "El gran ferrocarril panamericano" 1047 que permitiría viajar desde Nueva York hasta Valparaíso. La extensión de la línea, de aproximadamente 16800 kilómetros, alucinaba al periodista español Vicente Vera y López, quien ofrecía un conjunto de datos cuantitativos para exclamar que "se podrá ir en tren desde Nueva York a Río de Janeiro jrecorriendo una distancia de cerca de veinte mil kilómetros!”1048. Vera y López quien también practicaba la literatura de ficción era el autor de El periodismo dentro de cien años ${ }^{1049}$.

El ambiente de progreso favorecía la imaginación de acercar localidades distantes. Parte de la prensa se había sumado a la opinión de establecer una línea de navegación entre Cádiz y Pernambuco y entre el Cantábrico y el Amazonas ${ }^{1050}$. El resurgimiento económico de América iba de la mano de las vías férreas y del tejido de comunicaciones que haría entre sus ciudades y Europa. Así se desprende del relato esperanzador de La España Moderna:

Sur-América no es ya "Tierra del mañana", puesto que el dicho de que "el tiempo es dinero" se ha generalizado ya en el país. Sintiendo las treinta o cincuenta horas que dura el viaje al Pacífico, Bolivia ahora vuelve los ojos hacia el seguro puerto de Arica, que sólo dista 260 millas de La Paz. Cuando Chile adquirió el litoral de Bolivia como una indemnización de guerra, también retuvo la provincia peruana de Tacna, en la cual se halla Arica. Y, como una compensación parcial por la pérdida de su litoral, la capital chilena le dio a Bolivia el ferrocarril de Arica a La Paz ${ }^{1051}$.

El resplandor del progreso opacó con notas de este estilo el conflicto limítrofe. Cuantitativamente inferiores fueron las acusaciones peruanas de la ilegalidad del tratado chileno-boliviano en lo relativo a la construcción del ferrocarril. En lenguaje coloquial una noticia acusó a Chile de ser un país que "se desentendió de semejante reclamación y construyó el ferrocarril"1052 dejando en la frontera "la semilla de un conflicto, es decir, que como suele decirse, está aún la pelota en el tejado"1053.

\footnotetext{
${ }^{1047}$ Vida Marítima, "El gran ferrocarril panamericano", 30 de junio de 1911, n. ${ }^{\text {o } 342, ~ p . ~} 278$.

1048 Idem.

1049 LÁZAro, Alberto, H. G. Wells en España: Estudio de los expedientes de censura (1939-1978), Madrid, Editorial Verbum, 2004, p. 59.

${ }^{1050}$ La Época, "Comercio con Brasil", 21 de marzo de 1909, p. 2.

${ }^{1051}$ La España Moderna, "La América Moderna”, 1 de agosto de 1913, n. ${ }^{\circ}$ 296, p. 199.

1052 Madrid Científico, "La comunicación de Bolivia con el mar", 1913, n. ${ }^{\text {o } 979, ~ p . ~} 347$.

1053 Idem.
} 
La idea de Chile como un país incumplidor de sus acuerdos internacionales se reforzaba con noticias publicadas en la prensa española utilizando informaciones del diario chileno nacionalista El Mercurio. Por estos años, el diario dirigido por Agustín Edwards McClure, se refería a las intenciones peruanas que sugerían la entrega de Tacna a Perú y de Arica a Chile acentuando su negativa frente a la propuesta. Los fundamentos de la negación se sostenían en la impopularidad de esa idea en la nación y en el parlamento del país, además de "considerar indiscutibles los derechos de Chile sobre ambas provincias, a las cuales necesita imprescindiblemente para garantir al (sic) seguridad del ferrocarril internacional chileno a Arica y Bolivia"1054.

La prensa española escribiría en vano cómo la inauguración del FCALP abriría una fase de relaciones diplomáticas entre ambos países marcada por la fraternidad. Los años venideros demostrarían que un tendido de hierro era insuficiente para liquidar odios nacionalistas seculares producidos por la guerra.

Con espíritu hispanoamericanista, Ricardo Beltrán juzgaba como razonables y acertadas las declaraciones del vicepresidente boliviano, Eufronio Viscarra, quien creyendo portar el anhelo reivindicacionista de su pueblo aseguraba que "lo que hoy parece imposible, no lo será más tarde" ${ }^{1055}$. En el marco de esas declaraciones la noción militarista de Chile reaparecía en España.

Los comentarios realizados por el senador Bulnes, conocido "bolivianófobo", ayudaban a reproducir tales ideas. Explicando sus puntos de vista con tono ofensivo se preguntaba ¿Por dónde quiere salida al mar Bolivia? y se respondía: "Si es por Chile, no podrá conseguirlo sino empleando la fuerza [...] ¿Por el Perú? pues que sepa Bolivia que su irrupción al Pacífico [...] podría alterar la situación naval, base del predominio chileno" ${ }^{1056}$.

${ }^{1054}$ El Imparcial, "Chile y Perú", 15 de marzo de 1911, p. 1; La Correspondencia de España, "Delimitación de fronteras", 15 de marzo de 1911, p. 2; La Correspondencia Militar, "Sudamérica. Intereses chilenos", 15 de marzo de 1911, p. 2; El Día, "Intereses chilenos", 16 de marzo de 1911, p. 3; El País, "La cuestión de límites", 16 de marzo de 1911, p. 3; El Heraldo Militar, "Delimitación de fronteras", 16 de marzo de 1911, p. 3; El Globo, "Intereses chilenos", 17 de marzo de 1911, p. 3.

${ }^{1055}$ La Ilustración Artística, "Revista Hispanoamericana", 16 de febrero de 1914, n. ${ }^{\circ}$ 1667, p. 126.

${ }^{1056}$ Idem. 
Beltrán Rózpide responsabilizaba a Chile del conflicto fronterizo por no haber concluido nunca de buen modo la desgraciada posguerra. Recurriendo a generalizaciones, tal vez igual de desgraciadas, explicaba que la posición de Bulnes representaba a todos los chilenos. Con reflexiones de ese estilo contradecía los buenos deseos, siempre presentes en sus escritos, hacia la fraternidad latinoamericana, actitud necesaria para "la fortaleza y prosperidad de los pueblos de la América del Sur" ${ }^{1057 .}$

Una actitud antichilena similar tuvo al analizar uno de los discursos del presidente boliviano Ismael Montes en el cual había subrayado "el vivo deseo que tenía Bolivia de adquirir un puerto en el Pacífico"1058. Intuyendo el conocimiento detallado de sus lectores sobre las causas de la Guerra del Pacífico, como del litoral ansiado por las autoridades y pueblo boliviano, aseguró que Chile "por la fuerza de las armas lo hizo suyo"1059.

Al margen de las preferencias nacionales del analista, su capacidad premonitoria respecto a la solución de la litis, así como el papel boliviano en aquella, es sorprendente. Beltrán Rózpide se anticipó en más de una década a la solución ofrecida desde los Estados Unidos por su Secretario General, F. B. Kellogg, quien sugirió - con la negación de Chile y Perú- la cesión de Arica a Bolivia. Con su estilo claro, el español escribió:

La famosa cuestión de Tacna y Arica, que con tanto empeño vienen debatiendo años hace (sic) Chile y Perú, podría resolverse de tal modo que esos territorios no quedasen en poder de Chile ni volvieran al Perú; por lo menos parte de ellos, y especialmente Arica, se entregaría a Bolivia, como prenda de una inteligencia entre las tres repúblicas, de una alianza ofensiva y defensiva dirigida principalmente contra la Argentina y el Brasil. [...] Los bolivianos que la patrocinan hacen notar que a Chile y al Perú les convendría más, mucho más que la posesión de aquellos territorios, de tan escasa importancia y riqueza, y perpetua manzana de discordia entre ambos, una franquicia aduanera que les permitiera introducir en territorio boliviano sus productos libres de derechos, economizando así algunos millones de pesetas al año ${ }^{1060}$.

\footnotetext{
1057 Idem.

${ }^{1058}$ La Ilustración Artística, "Revista Hispanoamericana”, 14 de julio de 1914, n. ${ }^{\circ}$ 1646, p. 458.

1059 Idem.

1060 Idem.
} 
Imágenes n. ${ }^{\circ} 47$ y 48

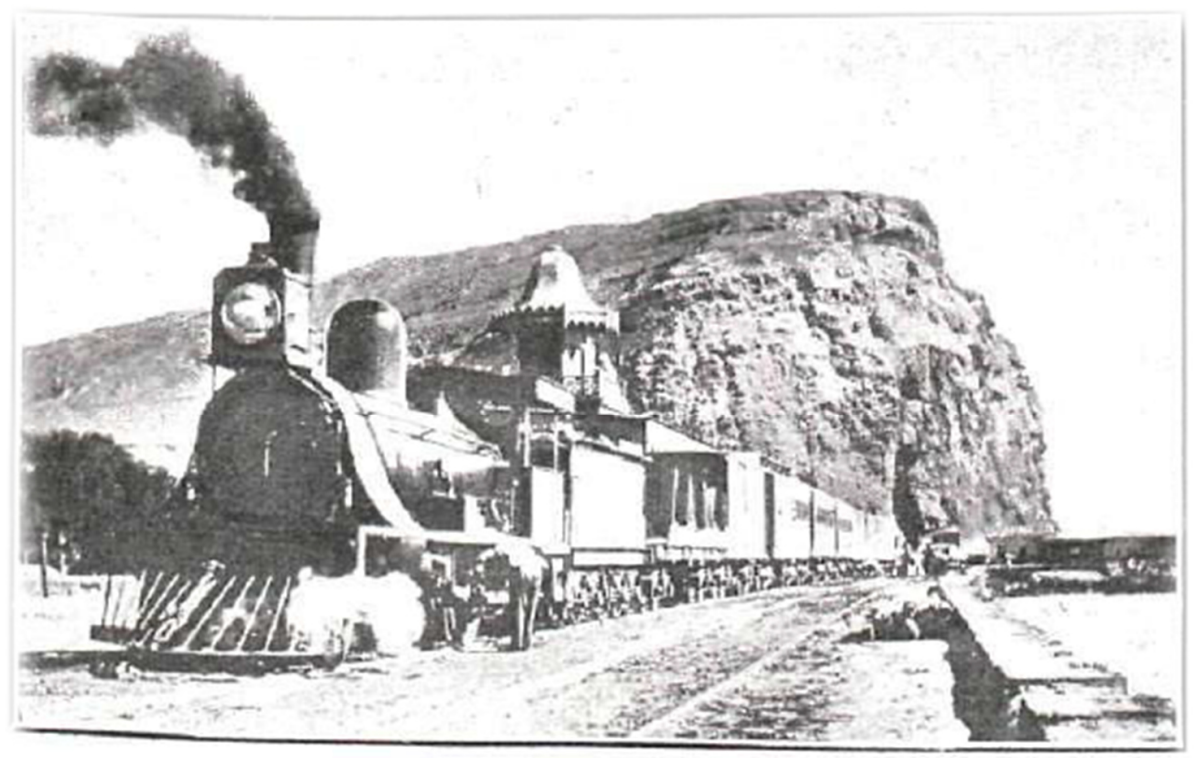

Arica.-Ferrocarril del Morro

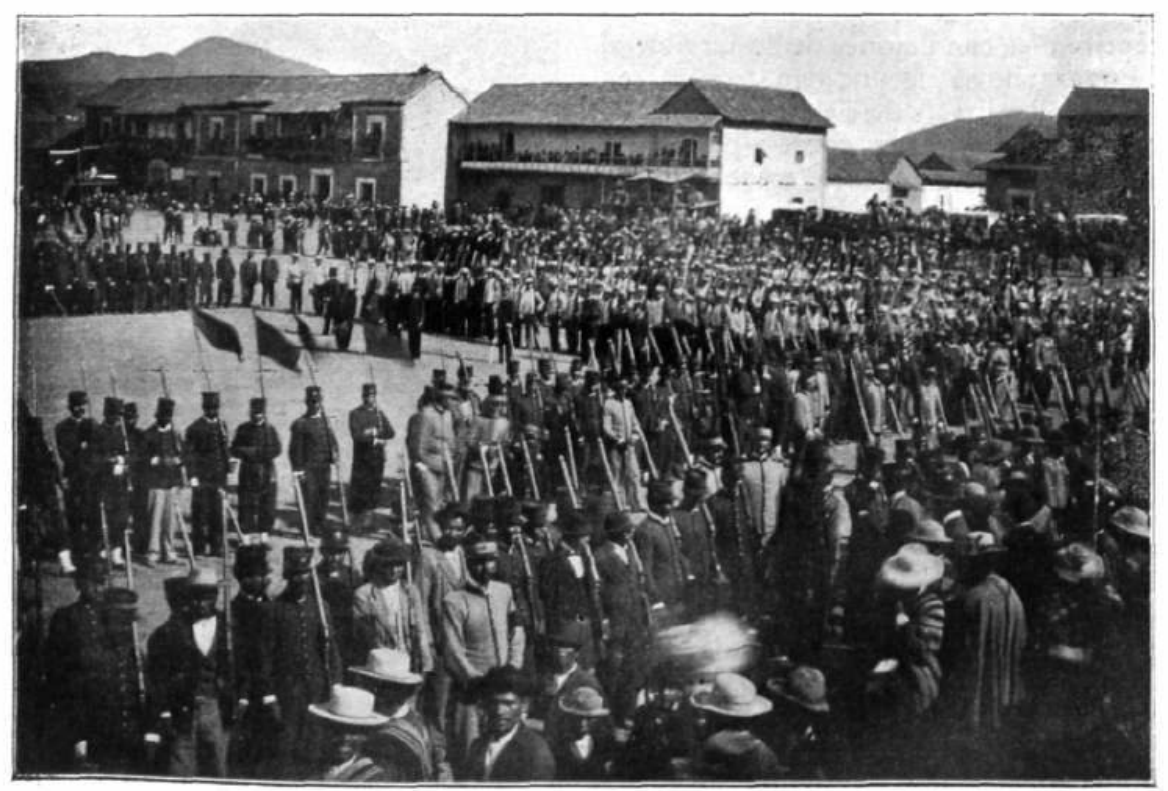

Cuadro completo de los cueppos de la Guabta Nactonal de Cochabamba,

después del despeje efectuado por el tercer batallón regional en un reciet. te ccncurec militar.

Fuentes: La Esfera, "El pleito en que todos tienen razón", 4 de abril de 1925, p. 21; Hojas Selectas, "Bolivia y su organización militar", Barcelona: Establecimiento Tipo-litográfico Editorial de Salvat y C. A., S. en C., 1905, p. 690 . 
Terminada la construcción del ferrocarril de Arica a La Paz en 1913 y concluida la Gran Guerra en 1918, la diplomacia parecía abrir un tiempo nuevo para Bolivia en sus pretensiones de soberanía en el Pacífico. En España se publicaron variadas noticias relacionadas con los trabajos diplomáticos. En Londres, Manuel Ballivián se ocupaba de explicar cómo la integración en Bolivia de Tacna y Arica era el único modo "capaz de restablecer la amistad y paz duradera entre las repúblicas de la costa del Pacífico"1061. En Suiza, el cónsul boliviano M. Fidehoze, publicaba una memoria juzgada como interesante por la prensa solicitando la participación de la Liga de las Naciones en el conflicto ${ }^{1062}$. La neutralidad chilena en la Primera Guerra Mundial y la idea sobre su germanofilia llevó, según El Día, a que "los aliados creen a pie juntillas en que la razón asiste a Bolivia"1063.

El siglo XX testimoniaría la decadencia absoluta del ferrocarril entre Arica y La Paz; la fragilidad del discurso del progreso inventado en la prensa española para explicar el desarrollo de la república altiplánica; y, por último, la energía incombustible de su aparato diplomático para defender sus derechos soberanos sobre territorios chilenos.

\subsection{La presidencia de Guillermo Billinghurst en Perú}

El negociador peruano del protocolo Billinghurst-Latorre asumió el 24 de septiembre de 1912 la presidencia del Perú, elegido por el Congreso con 132 votos a favor y 30 en contra ${ }^{1064}$. Sucedió al deportado Augusto Leguía ${ }^{1065}$. Billinghurst no terminaría su mandato, establecido por ley hasta 1916, debido a la revolución militar de febrero de 1914 encabezada por el coronel Oscar Benavides.

La bibliografía sobre su presidencia es escasa comparándola con la de otros presidentes. La brevedad en el cargo y la poca especialización en esa etapa ${ }^{1066}$, sumadas al

\footnotetext{
${ }^{1061}$ El Día, "Chile", 22 de febrero de 1919, p. 7.

${ }^{1062}$ El Día, "Bolivia reclama una salida al mar", 18 de julio de 1919, p. 7.

${ }^{1063}$ El Día, "Comentario", 22 de febrero de 1919, p. 5.

${ }_{1064}$ BASADRE, Jorge, Historia de la República del Perú, 1822-1933. La República Aristocrática, 1895-1919, Lima, Editorial Universitaria, 1969, p. 216.

1065 SANTOS, Granero y BARCLAY, Federica, La frontera domesticada. Historia económica y social de Loreto, 1850-2000, Fondo Editorial de la Pontificia Universidad Católica del Perú, 2002, p. 192.

1066 GONZÁLEZ, Osmar, El gobierno de Guillermo E. Billinghurst (1912-1914). Los orígenes del populismo en el Perú, Lima, Nuevo Mundo, 2005, p. 24.
} 
"olvido"1067 tejido en torno a él no han impedido producir, por lo menos, dos interpretaciones. La primera construye la idea del líder político, sensibilizado con el proletariado; la segunda acusa al "caudillo" que instrumentalizó las masas con objetivos políticos. La primera enfatiza, sobre todo, los conflictos derivados del aumento del coste de la vida en el pueblo, que sólo él podría solucionar ${ }^{1068}$. Con su presidencia se remarca el cambio en la institucionalidad del país, pues irrumpen los movimientos sociales en el ámbito político ${ }^{1069}$. Su popularidad entre los obreros lo hizo merecedor del apodo "pan grande" 1070 , mote que reflejó el aprecio y grado de aceptación adquirido en esos sectores sociales.

En relación a la política social de Billinghurst un historiador se ha preguntado y respondido al mismo tiempo: ¿¿Qué cosa había sucedido durante el mandato de éste último [...]? Había osado iniciar una política social a favor de las clases populares"1071, y otro ha complementado la cuestión aseverando el control logrado sobre los "movimientos de trabajadores y sindicales"1072. Esas acciones ligadas al carisma del presidente alteraron en el ámbito interno el funcionamiento secular de la República Aristocrática. En el plano externo, las medidas favorables del gobierno hacia los obreros hicieron temer a Inglaterra y Estados Unidos un giro en la política peruana hacia el modelo mexicano, entonces afectado por el campesinado revolucionario ${ }^{1073}$.

1067 GonZÁlez MirandA, Sergio y GonZÁlez Alvarado, Osmar, “Guillermo Billinghurst en Tarapacá: la primavera de un intelectual, el otoño de un presidente”. En GonZÁLEZ MiRANDA, Sergio y PARODI REVOREDO, Daniel, Las historias que nos unen. Episodios positivos en las relaciones peruano-chilenas, siglos XIX y XX, Chile, Universidad Arturo Prat del Estado de Chile; RIL Editores, 2013, p. 154.

1068 Ruiz Zevallos, Augusto, La multitud, las subsistencias y el trabajo, Lima, 1890-1920, Lima, Fondo Editorial de la Pontificia Universidad Católica del Perú, 2001, p. 57.

1069 Blanchard, Peter, The origins of the Peruvian Labor Movement, 1883-1919, United States of America, University of Pittsburg Press, 1982, p. 84.

${ }^{1070}$ Ragas Rojas, José F., "Las urnas temibles. Elecciones, miedo y control en el Perú republicano, 18101931”. En Rosas Lauro, Claudia (Ed.), El miedo en el Perú. Siglos XVI al XX, Perú, Fondo Editorial de la Pontificia Universidad Católica del Perú, 2005, p. 244.

${ }^{1071}$ BRICEÑO BERRÚ, José Enrique, Raíces de la pobreza. Vicisitudes históricas. Ensayo de interpretación de la realidad latinoamericana, Lima, Centro de Producción Fondo Editorial Universidad Mayor de San Marcos, 2006, p. 6.

1072 SÁnchez D., Rubén, Ruiz V., Juan Carlos, LavauX, Stéphanie, Ramos P., Francesca, Bonnet L., Manuel José, Pachón P., Rocío, Rodríguez M., Federmán, Otalvaro H., Andrés, Duarte P., Ivonne, Machuca P., Rubén, SuÁrez I., Carlos, Seguridades en construcción en América Latina, Tomo 1: El círculo de Colombia, Brasil, Ecuador, Panamá, Perú y Venezuela, Bogotá, Centro Editorial Universidad del Rosario, 2005, p. 154.

1073 Arroyo Reyes, Carlos, Nuestros años diez. La Asociación Pro-Indígena, el levantamiento de Rumi Maqui y el incaísmo modernista, LibrosEnRed, 2005, p. 7. 
En el segundo grupo triunfa la idea del Billinghurst "populista"1074 que no desarrolló proyectos acordes al modelo gubernamental clásico del Perú, liderado por las elites político-económicas del país. Raúl Palacios, se refirió a Billinghurst como "un populista, exótico y heterodoxo, rebelde, disidente y divisionista"1075, afirmaciones que se matizarían con el tiempo, pero mantendrían el fondo de su llegada y evolución en el poder. Un aspecto interesante de este grupo es la "espontaneidad" asignada a los movimientos populares peruanos y, por otro lado, su "influencia” decisiva sobre el Congreso. Cuando el gobierno de Billinghurst debió hacer frente a las críticas de la oposición, la "frágil alianza multiclasista empezó a quebrarse y la voz de la tan requerida opinión pública se trastocó en el sonido amenazante de los violentos bombazos callejeros" ${ }^{\prime 1076}$.

La espontaneidad que explica la movilización popular hace lo mismo con la aparición en la escena electoral de Billinghurst. La expresión utilizada que resume lo dicho plantea: "Más un nuevo y amenazante candidato apareció repentinamente en escena, el expierolista Guillermo Billinghurst, que fue ganando el respaldo popular por medio de la demagogia populista [...] asistido por multitudes violentas" ${ }^{1077}$. El clasismo de este tipo de historiografía ha ignorado las particularidades de los sujetos que constituyen lo denominado por ésta plebe, turba o masa, suponiendo que su acción política es desorganizada per se, fundándose "en una limitada perspectiva conductista"1078 de estímulos y respuestas.

¿Qué imagen se propagó por España sobre la presidencia de Billinghurst? La prensa resaltó las cualidades políticas del presidente, subrayando las facetas importantes de su biografía. Billinghurst, nacido en Arica en 1851, realizó sus estudios en Chile y Argentina ingresando posteriormente en la política peruana. En los años de la Guerra del Pacífico, "la figura de Billinghurst descolló entre las de otros peruanos ilustres" ${ }^{1079}$. El capital cultural

\footnotetext{
1074 Henderson, Paul, "The Rise and Fall of Anarcho-Syndicalism in South America, 1880-1930". En Fowler, Will (Ed.), Ideologues and Ideologies in Latin America, London, Greenwood Press, 1997.

1075 GonZÁlez MirandA, Sergio, La llave y el candado. El conflicto entre Perú y Chile por Tacna y Arica, 1883-1929, Santiago, Editorial LOM, 2008, p. 41.

1076 MCEvoy, Carmen, La utopía republicana. Ideales y realidades en la formación de la cultura política peruana (1871-1919), Fondo Editorial de la Pontificia Universidad Católica del Perú, 1997, p. 409.

1077 Quiroz, Alfonso W., Historia de la corrupción en el Perú, Lima, IEP Instituto de Estudios Peruanos, 2013, p. (s/d).

1078 GUHA, Ranahit, Las voces de la historia y otros estudios subalternos, Barcelona, Editorial Crítica S. L., 2002, p. 34.

${ }^{1079}$ Hojas Selectas, "Panorama Universal”, enero de 1912, n. ${ }^{\circ} 121$, p. 1136.
} 
fecundo ${ }^{1080}$ recibido por el ariqueño permitió a la prensa pensar lo acertado que sería su mandato. Un diario publicó: "el gran talento del Sr. Billinghurst hace de él el hombre político peruano mejor preparado para los altos destinos a que lo ha llevado la voluntad de sus conciudadanos" $" 1081$.

Billinghurst -recordemos- intentó solucionar el diferendo en 1898, firmando el protocolo que aprobado por Perú fue rechazado por Chile, "malográndose así una obra que hubiera resuelto una de las cuestiones internacionales más delicadas de la época presente" 1082 . En la cita, la responsabilidad en el fracaso de la paz caía sobre Chile, no impidiendo a la prensa esperar un mejoramiento diplomático chileno-peruano que iría de la mano con la "innegable laboriosidad y cultivada inteligencia" 1083 del peruano.

Imágenes n. ${ }^{\circ} 49,50$ y 51
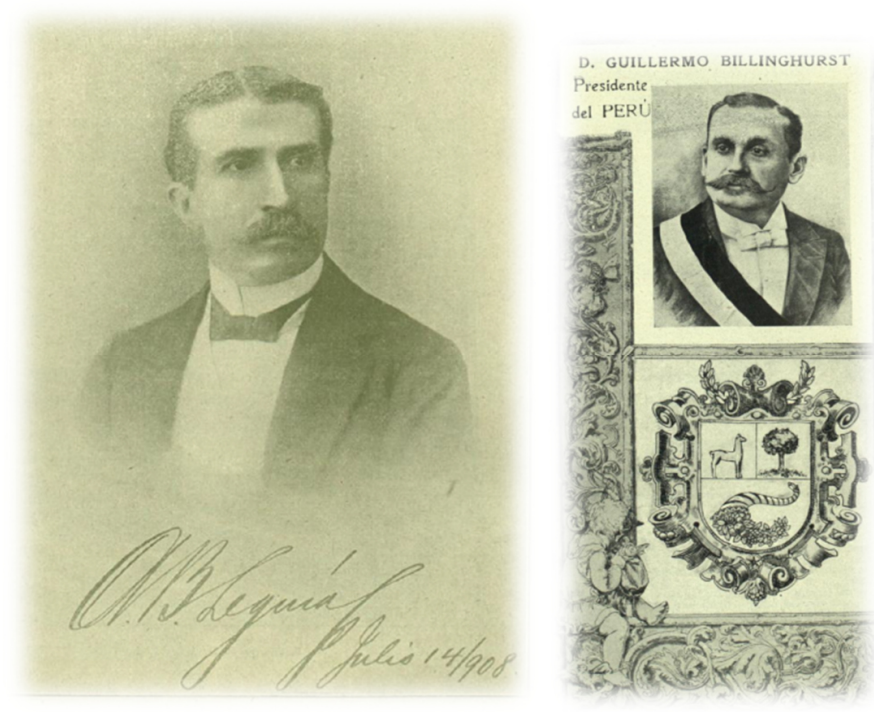

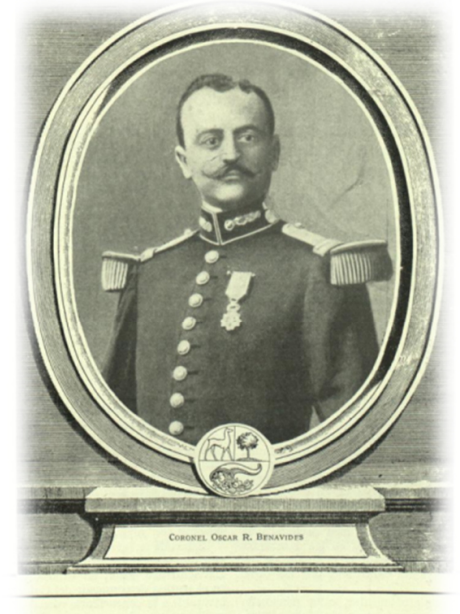

EL PRESIDENTE DEL PERUं

Fuentes: Mercurio, "D. Augusto B. Leguía", 1 de diciembre de 1908, n. ${ }^{\circ} 85$, p. 762; Mercurio, "D. Guillermo Billinghurst. Presidente del Perú", 31 de octubre de 1912, n. ${ }^{\circ} 162$, p. 338; Mercurio, "El presidente del Perú (Óscar Benavides)", 29 de octubre de 1914, n. $^{\circ} 214$, p. 435.

${ }^{1080}$ BouRdiEU, Pierre, Capital cultural, escuela y espacio social, México, Siglo XXI Editores, 2005.

1081 El Heraldo, "El nuevo presidente del Perú", 23 de septiembre de 1912, p. 5; El Nuevo Régimen, "Extranjero", 30 de septiembre de 1912, p. 5.

1082 Hojas Selectas, "Panorama Universal", enero de 1912, n. ${ }^{o} 121$, p. 1137.

${ }^{1083}$ Idem; Mercurio, "D. Guillermo Billinghurst. Presidente del Perú", 31 de octubre de 1912, n. ${ }^{\text {o }}$ 162, p. 338. 
España y América, recordando las negociaciones de 1898, valoró el desempeño del presidente que supo desenvolverse en la capital chilena "tan hábilmente, que negoció con el ministro chileno un protocolo que hubiera zanjado para siempre la cuestión de Tacna y Arica de haber obtenido el pase en el Congreso de Chile"1084. Billinghurst demostró allí "sus cualidades de gran diplomático"1085. Las expectativas de la prensa eran altas. En el plano exterior, vio en Billinghurst al político capaz de negociar con los vecinos del sur; en el plano interior era el indicado para mantener "a raya" el nacionalismo popular.

Beltrán Rózpide, iniciada la presidencia de Billinghurst, realizó un recuento del estado en que quedaba Perú tras la expulsión de Leguía. Una gran parte de su análisis se centró en los problemas fronterizos con Colombia, Ecuador, Brasil, Bolivia y Chile. La situación con el último país fue evaluada particularmente a raíz de las opiniones que el presidente peruano pronunció respecto a la idea de elegir senadores y diputados en Tacna y Arica. Billinghurst, escribió Beltrán, "deplora que los altos poderes de aquella República recomienden la aprobación del proyecto encaminado a conceder representación parlamentaria a las provincias de Tacna y Arica"1086. La intención de legalizar ese proyecto de ley sin la modificación jurídica que las provincias requerían, continuó, "sólo contribuye a enturbiar, sin más resultado, la atmósfera" ${ }^{1087}$.

Otros reportajes sobre diplomáticos americanos, continuaron subrayando el talento diplomático del presidente. Un artículo del poeta y político ecuatoriano, Leónidas Pallares Arteta, comentó las acciones emprendidas por Billinghurst para finalizar el problema chileno-peruano. Pallares, involucrado en las gestiones para fijar las fronteras entre Perú y Ecuador, vio una luz de esperanza en las gestiones del presidente. Se atribuye al gobierno peruano, señaló, la intención de arreglar la cuestión de Tacna y Arica y la de las fronteras ecuatorianas, "Si la primera, que es tan escabrosa, puede arreglarse, la nuestra sería de más fácil solución"1088.

\footnotetext{
${ }^{1084}$ España y América, “Crónica de la quincena”, 1 de octubre de 1912, n. ${ }^{\circ} 19$, p. 382.

${ }^{1085}$ El Heraldo, "El nuevo presidente del Perú", 23 de septiembre de 1912, p. 5; El Nuevo Régimen, "Extranjero", 30 de septiembre de 1912, p. 5.

${ }^{1086}$ La Ilustración Artística, "Revista Hispanoamericana", 23 de septiembre de 1912, n. ${ }^{\circ}$ 1604, p. 622.

1087 Idem.

${ }^{1088}$ La Lectura, "La revista de América", enero de 1913, n. ${ }^{\circ}$ 145, p. 97.
} 
La "revolución en el Perú", como titularon las noticias referidas a la caída del presidente Billinghurst el 4 de febrero de 1914, cambió la visión positiva hacia el mandatario. En Lima, decía una noticia, se encontraron documentos comprometedores relacionados con Billinghurst quien, según el Gobierno Provisional, "se entendía con Chile en las cuestiones de Tacna y Arica de un modo poco conveniente para los intereses del Perú"1089. En medio de la revolución peruana, Billinghurst fue expulsado del Perú hacia Chile en medio de todo tipo de insultos ${ }^{1090}$, donde fallecería un año después provocando tristeza en Perú, preferentemente "entre el elemento obrero y las clases populares en las que tenía hondo arraigo" ${ }^{1091}$. Le sucedería en la conducción del país el coronel Óscar Benavides ${ }^{1092}$ quien intentó restablecer el modelo desgastado de la "maltrecha República Aristocrática"1093.

6.7. El problema chileno-peruano en la I Conferencia Socialista Obrera Panamericana de Argentina

Finalizada la Gran Guerra, la idea de la "autodeterminación de los pueblos" propugnada por el presidente Wilson, fue un punto central en las reuniones que restablecerían la paz. En los círculos diplomáticos, las naciones afectadas por pérdidas de regiones negociaban el restablecimiento territorial como requisito fundamental para la paz. Ésta, en la práctica sería discutida sólo por los vencedores, pues "las grandes decisiones fueron tomadas por el llamado Consejo de los cuatro integrado por Lloyd George por Gran Bretaña, Clemenceau por Francia, Orlando por Italia y Wilson por Estados Unidos"1094.

\footnotetext{
${ }^{1089}$ La Correspondencia de España, "Revolución en el Perú", 9 de febrero de 1914, p. 3.

1090 TAUZIN CASTELlanos, Isabelle, "Manuel González Prada y el poder político (1912-1918)”. En ÁGUILA, Yves, Poder y escrituras en América Latina, vol. 2, Bordeaux, Presses Universitaires de Bordeaux, 2004, p. 46.

${ }^{1091}$ BORRAS, Gérard, Lima, el vals y la canción criolla, 1900-1936, Lima, Institut français d'études andines IFEA; Instituto de Etnomusicología - IDE, 2012, p. (s/d).

1092 Silva-SANTISTEBAN, Ricardo, "La sátira en los cuentos chinos de Abraham Valdelomar". En ÁGUILA, Yves (Comp.), Figuras, géneros y estrategias del humor en España y en América Latina, Bordeaux, Presses Universitaires de Bordeaux, 2007, pp. 93-104; HERRERA CUNTTI, Arístides, Apuntes históricos de una gran ciudad, AHC Ediciones Chincha, Perú, 2006, p. 241.

1093 ARroyo Reyes, Carlos, La Asociación Pro-Indígena, el levantamiento de Rumi Maqui y el incaísmo modernista, LibrosEnRed, 2005, p. 7.

${ }_{1094}$ PERTIERRA DE ROJAS, José Fernando, Las relaciones internacionales durante el periodo de entreguerras, Madrid, Ediciones Akal, 1990, p. 11.
} 
La institucionalización de esos anhelos se efectuó en la Sociedad o Liga de las Naciones, organización que buscó la regulación de los Estados partícipes dentro los marcos del Derecho Internacional ${ }^{1095}$. La neutralidad de España durante el conflicto le permitió formar parte de la Liga. Para ello, Álvaro de Figueroa, conde de Romanones, debió negociar, en una serie de reuniones con Wilson, las condiciones de su incorporación. Uno de los puntos tensos entre ambos guardaba relación con el régimen político antidemocrático español. No obstante, durante el mes de abril de 1919, "Wilson propuso que se admitiera en la Sociedad a España"1096; donde "se pidió a las Cortes la autorización necesaria [...] sancionada por el rey el 14 de agosto de 1919"1097.

Enrique Hernández-Carrillo, colaborador de la revista Cervantes, analizó el papel del socialismo en el restablecimiento de la paz mundial. Para ello se valió de las opiniones del socialista francés Marcel Cachín, quien intuía el sentido práctico de la Liga, creada sólo para "satisfacer los voraces instintos del capitalismo victorioso"1098. Mientras el capitalismo domine -explicaba- "existirá la amenaza de la guerra"1099. Del socialista inglés MacDonald, tomó las declaraciones relativas a la necesidad de la constitución parlamentaria y no gubernamental de la Liga para así conformar una sociedad "esencialmente democrática, no una concepción burguesa, no un instrumento diplomático"1100.

El socialismo latinoamericano también tomó posición política frente a la Liga de las Naciones. Las reuniones parisinas de la organización supranacional estuvieron en el centro del debate realizado por los socialistas latinoamericanos citados en Buenos Aires entre el 20 y 30 de abril de 1919. Convocada por el Partido Socialista Argentino (PSA), la I Conferencia Socialista y Obrera Panamericana no revistió la importancia que sus líderes y simpatizantes esperaban ${ }^{1101}$.

\footnotetext{
${ }^{1095}$ FigueroA Pla, Uldaricio, Organismos internacionales. Tomo I. Teorías y sistemas universales, Santiago, RIL Editores, 2010, p. 177.

${ }^{1096}$ Alguacil CuenCA, Pedro, "España: de la Sociedad de Naciones a Naciones Unidas”, Anales de Derecho. Universidad de Murcia, n. ${ }^{\circ}$ 24, 2006, p. 307.

${ }^{1097}$ Idem.

1098 Cervantes, "El mundo moral", enero de 1919, p. 151.

1099 Idem.

${ }^{1100}$ Idem.

1101 PINTOS, Francisco, Historia del movimiento obrero del Uruguay, Uruguay, Corporación Gráfica, 1960, p. 11 .
} 
Durante las jornadas, el diferendo fue discutido por el proletariado. Sergio Grez al respecto comentó: "Una de las resoluciones aprobadas en esa oportunidad planteaba la necesidad de someter a consideración de la Liga de las Naciones el conflicto limítrofe"1102. Los representantes chilenos, en vez de aceptar esa fórmula presentaron una solución "obrera" consistente en oponerse a tomar las armas "contra sus hermanos del país contrario"1103. Las conferencias, que ayudaban a "saturar la herida aún abierta del 79"1104, convocaron a destacados izquierdistas, entre ellos el peruano José Carlos Mariátegui ${ }^{1105}$.

La prensa se ocupó de las reuniones. El socialismo aún era novedoso en el mundo de las ideas. América ofrecía su "infraestructura" a la ideología europea y pronto varios intelectuales los reformularían de acuerdo a las realidades locales. Consecuentemente, El Sol publicó: "Las nuevas corrientes políticas han encontrado un clima social favorable para su desarrollo en la América latina, y en casi todas las repúblicas de ultramar, los partidos socialistas adquieren grandes proporciones"1106. Otras notas enfatizaron el papel de los socialistas peruanos que sostenían la trascendencia de solucionar el conflicto para el socialismo latinoamericano. La asamblea defendió el arbitraje como mecanismo ante problemas surgidos o que surgiesen entre naciones. Tal posición explicó por qué el representante chileno saludó al peruano, quien había solicitado a la asamblea el sometimiento de la litis a un Tribunal Pacífico de Arbitraje ${ }^{1107}$. Al instante otro delegado peruano "estrechó igualmente la diestra del socialista chileno Hidalgo, al manifestar que los trabajadores chilenos nunca tomarían las armas en contra de un pueblo hermano de América"1108. La distancia entre la teoría y la práctica quedaría de manifiesto al año siguiente cuando en Arica se iniciaron las marchas obrero-nacionalistas chilenas en contra de los trabajadores peruanos ${ }^{1109}$.

\footnotetext{
1102 Grez Toso, Sergio, Historia del comunismo en Chile. La era de Recabarren (1912-1924), Editorial LoM, 2011 , p. 154. VARÓn GABAI, Rafael, El hombre y los Andes. Homenaje a Franklin Pease G. Y., Tomo I, Perú, Fondo Editorial de la Pontificia Universidad Católica del Perú, 2002, p. 144.

${ }^{1105}$ KAPSOLI ESCUdERO, Wilfredo, Mariátegui y los congresos obreros, Perú, Biblioteca Amauta, 1980, p. 58. ${ }^{1106}$ El Sol, "La propaganda socialista en América", 10 de junio de 1919, p. 10.

${ }^{1107}$ El Sol, "Ibero América", 30 de abril de 1919, p. 8; El Sol, "Congreso socialista", 7 de mayo de 1919, p. 9. ${ }^{1108}$ El Sol, "Ibero América", 10 de junio de 1919, p. 10.

${ }^{1109}$ Soto LARA, José Julián, "La Federación Obrera de Chile (FOCH) como movimiento popular nacionalista en Arica (1920)", Tradición y Saber, n. . 2, 2013, pp. 65-84.
} 
La prensa informó en los días posteriores a la clausura de la asamblea sobre la "Resolución relativa a la cuestión de Tacna y Arica"1110, y, como uno de los acuerdos más importantes, la decisión de que la litis sea "sometida a Liga"1111. Esas noticias remarcaban los trabajos conjuntos de los obreros representantes de Chile y Perú. Mereció también atención la participación del obrerismo boliviano quien presentó ante el foro sus aspiraciones de recuperar el litoral perdido en la Guerra del Pacífico ${ }^{1112}$.

Finalmente, la prensa dio cuenta del pacifismo mostrado por los obreros latinoamericanos quienes veían en Tacna y Arica una zona de tensión internacional que podría provocar en cualquier momento una guerra. Esa situación debía reflexionarse para no perturbarla enfatizando "que la cuestión de Tacna y Arica sea sometida al arbitraje de la Liga de las Naciones"1113. A su vez informó del comportamiento de las prensas de algunos de los países participantes. En Perú, por ejemplo, la postura del Congreso Socialista fue bien acogida, comentándose favorablemente los acuerdos relacionados con Tacna y Arica $^{114}$. En Chile, las repercusiones políticas de la reunión no inquietaron a la prensa de la época. Tampoco a los historiadores marxistas de la actualidad.

\subsection{Los buenos oficios de Argentina}

En 1916 la presidencia argentina fue ganada por el candidato radical Hipólito Yrigoyen. La historiografía de ese país dedica extensos análisis al proyecto político de este mandatario que condujo la nación durante años de graves conflictos nacionales e internacionales. En ese plano, durante la Primera Guerra Mundial, la neutralidad argentina fue de suma importancia, pues demostró la resistencia del país a las presiones diplomáticas ejercidas por los Estados Unidos para que declarase la guerra a Alemania. La opresión estadounidense, a quien particularmente le interesaba Argentina, fue insuficiente. El yrigoyenismo demostró que su cancillería mantendría criterios propios ${ }^{1115}$.

\footnotetext{
${ }^{1110}$ El Día, "Resolución relativa a la cuestión de Tacna y Arica”, 2 de mayo de 1919, p. 7.

${ }^{1111}$ El Día, "Acuerdos de la Conferencia panamericana socialista", 4 de mayo de 1919, p. 6.

1112 El Día, "Los trabajos del Congreso socialista panamericano", 3 de junio de 1919, p. 7.

${ }^{1113}$ El Sol, "Se inaugura el Congreso socialista panamericano", 2 de mayo de 1919, p. 6.

${ }^{1114}$ El Día, "La prensa peruana y el asunto de Tacna y Arica", 3 de junio de 1919, p. 7.

1115 SANTORO, Mara, "La democracia incipiente. El radicalismo en el gobierno (1916-1930): Yrigoyen, Alvear, Yrigoyen”. En BARroetaveñA, Mariano, PARSON, Guillermo, Román, Viviana, Rosal, Hernán,
} 
La importancia geopolítica de Argentina y el establecimiento o no de alianzas en época de guerra tenía relación principalmente con su industria alimentaria. Los ganaderos argentinos "vivieron años de enriquecimiento sin precedentes"1116. La conciencia económica y política de su condición "abastecedora" le permitió distanciarse de las poderosas influencias de la cancillería de Washington, asumiendo en América del Sur un papel de mediador en conflictos interestatales, no aspirando, por lo menos de modo formal y explícito, a conseguir allí una posición hegemónica ${ }^{1117}$. Argentina profesaba, ha dicho una historiadora, "el modelo agroexportador como socio comercial de Europa"1118.

En Europa, la prensa española aprobó las gestiones emprendidas por la diplomacia argentina para apoyar en la solución de la cuestión chileno-peruana. La visión benevolente de los diarios y revistas sobre la frontera de ambos países se enmarcaba en las ideas diplomáticas de la época final de la Primera Guerra Mundial, conflicto armado que sensibilizó a la clase política de los Estados enfrentados en la búsqueda de soluciones dialogadas a sus diferendos que construyeron un nuevo orden mundial "incompleto e irreal"1119. En la "América Española", apreció la prensa, se venían desarrollando acercamientos entre las cancillerías de los países que anhelaban concluir definitivamente los problemas fronterizos.

Para los editores de El Sol un buen ejemplo de aquello era la misión diplomática argentina -país animado "siempre por el noble deseo de rivalizar con el de Brasil en iniciativas y proyectos que mantengan permanentemente la paz entre los pueblos hermanos"1120 encabezada por el canciller Honorio Pueyrredón. El objetivo era el ofrecimiento de sus buenos oficios a Chile y Perú para que en conjunto resolvieran el problema de Tacna y Arica. Éste, a juicio del mismo diario, amenazaba constantemente la paz continental. Pueyrredón, por tal razón, recibió el apoyo de otros países sudamericanos, no identificados en el periódico.

SANTORO, Mara, Ideas, politica, economía y sociedad en la Argentina (1880-1955), Buenos Aires, Biblos, 2007.

1116 PUIGgRÓs, Rodolfo, El Yrigoyenismo, Buenos Aires, Galerna, 2006, p. 58.

117 Álvarez Guerrero, Osvaldo, "Hipólito Irigoyen ante la condición humana", Polis. Revista Latinoamericana, n. ${ }^{\circ}$ 13, 2006.

1118 PELOSI, Hebe Carmen, Las relaciones franco-argentinas. Inmigración, comercio y cultura. 1880-1918, Argentina, Librería histórica, 2008, p. 120.

1119 LETTIERI, Alberto. La civilización en debate. La historia contemporánea desde una mirada latinoamericana, Buenos Aires, Prometeo, 2007, p. 313.

${ }^{1120}$ El Sol, "Ibero-América", 4 de abril de 1918, p. 6. 
Como hemos dicho, la fuerza de la cancillería argentina guardaba relación con su administración y economía, situación que le permitió, en estos años, gozar de buena prensa en España. Argentina, remarcó un prestigioso anuario, era regida por una Constitución de corte liberal; y, económicamente, afirmó la misma publicación con un dejo de exageración: "No hay, realmente, en el mundo un país tan rico como la Argentina"1121.

Particularmente, el peso de las consecuencias políticas de la Guerra Mundial hizo reflexionar a los escritores de El Sol sobre la importancia de la paz sudamericana y, también, respecto al papel que en ella tendría el gobierno argentino de Yrigoyen. Un artículo expresó su espera ansiosa de los resultados de la diplomacia argentina, estado de ánimo motivado por los sucesos europeos y las fórmulas discutidas para pactar una paz duradera.

En definitiva, los buenos oficios argentinos eran "de extrema importancia para la tranquilidad de los pueblos sudamericanos, pues todos se hallan interesados en que a la hora que se firme la paz europea se encuentren resueltos todos los problemas internacionales" 1122 .

En otro ámbito, el de las noticias relacionadas al binomio Argentina-Tacna y Arica, se pueden comprender algunos aspectos también sugestivos, tales como la importancia del ideal de la rapidez informativa en la prensa. La noticia del viaje de la embajada argentina hacia Chile motivó el autohalago periodístico, pues se había obtenido esa primicia gracias a un servicio especial. En efecto, los detalles diversos del viaje diplomático llegaron a la redacción del periódico "mucho antes que el telegrama de la Agencia Fabra"1123. La anticipación sobre la agencia rival era prueba de su rápido acceso a la información cablegráfica y, por eso, muestra también de modernidad comunicativa. La anticipación, finalmente, daba a los escritores de la prensa un margen de tiempo para opinar sobre las relaciones chileno-peruanas.

1121 Almanaque Bailly-Bailliere, "La República Argentina", Madrid, Casa Editorial Bailly-Bailliere, 1918, p. 235.

${ }_{1122}$ El Sol, "Ibero-América", 4 de abril de 1918, p. 6.

${ }^{1123}$ El Sol, "Ibero-América", 14 de mayo de 1918, p. 6. 
Los resultados de ese ejercicio intelectual fueron un balance positivo de la aproximación chileno-argentina. Se trataba de países que sufrieron conflictos territoriales y que "en más de una ocasión estuvieron a punto de comprometer la paz continental"1124. Poco importaba, en vista de la trascendencia de los buenos oficios argentinos, la supuesta táctica de su cancillería para contrarrestar la hegemonía brasileña en América ideada por el gobierno de Wenceslau Brás, que meses antes había declarado la guerra a Alemania. La Casa Rosada deseaba solucionar "antiguas cuestiones de límites con los países vecinos"1125.

Las negociaciones chileno-argentinas permiten comprender otras actitudes periodísticas. Por ejemplo, la imaginación privilegiada de ciertos redactores iberoamericanistas. Para ellos, la solución del conflicto de Tacna y Arica era un anhelo sentido por "la mayoría de los pueblos iberoamericanos"1126, parecer loable, pero imposible de demostrar en ausencia de estudios de opinión pública contemporáneos al conflicto. Del mismo modo, es prácticamente imposible conocer cuáles fueron los pueblos que se oponían a la solución de la litis. En sentido similar, una vez más se utilizaba con holgura inexacta, para explicar el diferendo en España, la analogía histórica entre aquellas provincias y Alsacia-Lorena ${ }^{1127}$, sin organizar idea alguna centrada en las diferencias histórico-culturales de Chile, Perú, Alemania y Francia, los países aludidos por la comparación.

A raíz de los buenos oficios argentinos se detecta también una visión prospectiva de la prensa. Tales pensamientos futuristas fueron frecuentes. Por ejemplo, las opiniones alusivas a cómo la política correcta y bien intencionada de las cancillerías de Chile y Perú permitiría acordar una solución satisfactoria, permitiéndoles, estabilizando la frontera en el futuro, alcanzar el desarrollo económico. En palabras de $E l \mathrm{Sol}$-que aprovechando la nota redactó un mandato para sus diplomáticos- Chile y Perú debían entregarse al “desenvolvimiento de sus propias energías y a la fecunda realización de sus destinos que es el único punto de vista que España puede tener en estas delicadas cuestiones" 1128.

\footnotetext{
1124 Idem.

1125 MOTA, Carlos Guilherme y LÓPEZ, Adriana, Historia de Brasil. Una interpretación, Salamanca, Ediciones de la Universidad de Salamanca, 2009, p. 417.

${ }^{1126}$ El Sol, "Ibero-América", 14 de mayo de 1918, p. 6.

${ }^{1127}$ El Sol, "La cuestión de Tacna y Arica", 21 de diciembre de 1917, p. 2.

${ }^{1128}$ El Sol, "Ibero-América", 14 de mayo de 1918, p. 6.
} 
Para la prensa, la importancia de Argentina en el conflicto fronterizo se evidenció en la publicación de reportajes sobre ese país en España. La Emigración Española, por ejemplo, adjuntó la extensa nota de El Diario Español de Buenos Aires que repasaba, brevemente, la historia de la Guerra del Pacífico; las reuniones diplomáticas chilenoargentinas; y, por último, sus visiones sobre el conflicto.

En la versión de El Diario Español la guerra fue provocada por un "desacuerdo de principios e intereses" ${ }^{1129}$ que se mantendría entre los Estados contendientes aun después del Tratado de Ancón. Tal disensión incubó el "viejo y porfiado pleito"1130 de Tacna y Arica. Así mismo, ese impreso comentaba con satisfacción las sesiones del consejo ministerial de Chile que formulaba políticas acordes a los intereses de la nación. Una actitud similar tenía hacia los políticos peruanos quienes debatían en el parlamento varios temas, por mencionar algunos, la importancia de finalizar la litis; el problema de la ayuda "chilenizadora" ofrecida por la masonería Tacno-ariqueña; y, finalmente, el papel de la prensa peruana en la política reivindicacionista de esas provincias.

Creemos que la reproducción del reportaje argentino con sus buenos deseos en la prensa se explica por el llamamiento "unionista" hecho a los latinoamericanos, excluyendo a Estados Unidos, y también por la convocatoria "emancipadora" de las economías de aquellos con respecto de las europeas. En concreto, El Diario Español enfatizó el nuevo escenario diplomático occidental de posguerra que reforzaría puntualmente el "bloque sudamericano para construirlo en una pieza y engranarlo en un acción conjunta de defensa y expansión" ${ }^{1131}$. Sus repúblicas, anotó el diario, después del ingreso de los Estados Unidos en la guerra volvieron la mirada sobre sí, intentando resolver antiguos diferendos. Era preciso que Latinoamérica tratase "como cosa esencial para su vida [...] la emancipación económica $[\ldots]$ "1132, pues el "verdadero ideal patriótico necesario es que vea en favor de su prestigio que ya ha sonado la hora de librar a las naciones de toda situación económica subalterna en que hasta ayer han vivido frente al emporio industrial europeo" 1133 .

\footnotetext{
${ }^{1129}$ La Emigración Española, "Intereses Sudamericanos", 15 de junio de 1918, n. ${ }^{\circ} 11$, p. 87.

${ }^{1130}$ Idem.

${ }^{1131}$ Idem.

1132 Idem.

${ }^{1133}$ Idem.
} 
La relevancia concedida a los buenos oficios argentinos en la cuestión de Tacna y Arica por la prensa española tiene una importancia triple para los efectos de esta investigación. Formó, en primera instancia, algunas ideas relativas a la cordialidad chilenoargentina, favoreciendo así a Chile, país que aún cargaba el signo del autoritarismo diplomático y, en efecto, de la intransigencia política con sus vecinos. Formó, así mismo, imágenes de la funcionalidad que tenía la cuestión de la frontera chileno-peruana en el campo diplomático regional, donde también eran de gran importancia Argentina y Brasil. Por último, las fuentes hemerográficas españolas ocupadas en los buenos oficios de Argentina -aunque escasas- aportan datos de valía en una fase pobremente estudiada de las relaciones chileno-argentinas.

Con todo, la solución de la cuestión de Tacna y Arica debía esperar más de una década. Ortemberg, en una obra reciente, comentó el revés experimentado por la Casa de Pizarro en 1920 cuando Pueyrredón, "representante argentino en la Liga de las Naciones se pronunció en contra de la revisión de pactos constituidos previamente a la constitución de la Liga"1134, dentro de los que, por supuesto, se encontraba el Tratado de Ancón de 1883.

\section{Imágenes $\mathrm{n}^{\mathrm{o}} 52 \mathrm{y} \mathrm{n} .^{\mathrm{o}} 53$}
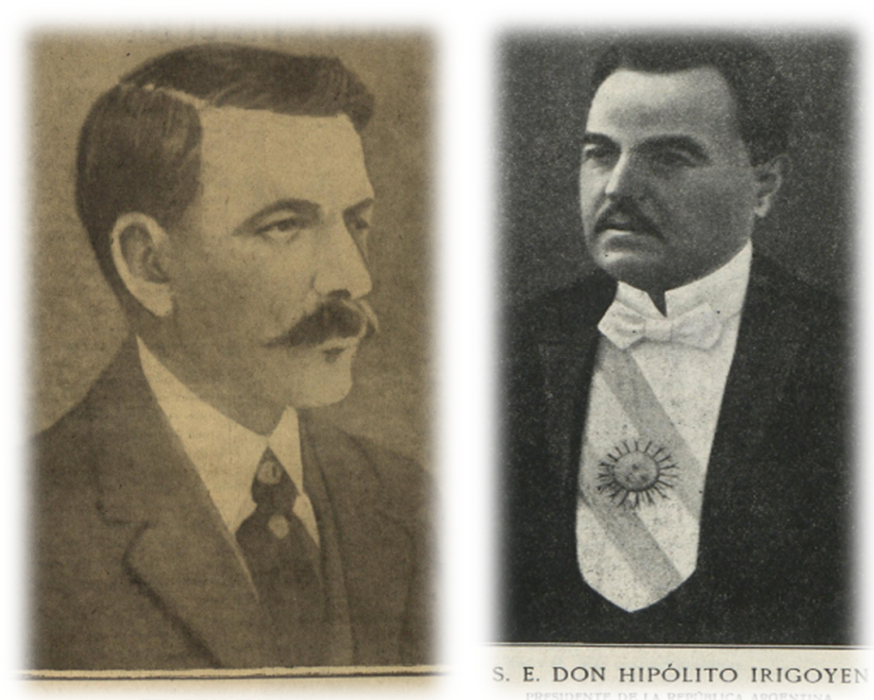

Fuentes: El Figaro, "Wenceslao Braz P. Gomes", n. ${ }^{\circ}$ 101, 23 de noviembre de 1918, p. 43 y Revista de la Real Academia Hispanoamericana de Ciencias y Artes, "S. E. Don Hipólito Irigoyen", n. ${ }^{\text {1 }}$ 1, p. 33.

\footnotetext{
1134 ORTEMBERG, Pablo, "Geopolítica de los monumentos: los próceres en los centenarios de Argentina, Chile
} y Perú (1910-1924)”, Anuario de Estudios Americanos, Vol. 72, n. ${ }^{\circ}$ 1, 2015, p. 335. 
6.9. Ruptura de relaciones consulares entre Chile y Perú

Para Chile y Perú, en el ámbito económico, la consecuencia más grave de la Primera Guerra Mundial fue el descenso brusco de la exportación de salitre tarapaqueño, provincia ubicada en el interior de Iquique, que desencadenó graves crisis económicas en ambos países $^{1135}$. Hacia 1918 la demanda europea del producto disminuyó al extremo de provocar el paro de miles de obreros, principalmente, peruanos y chilenos. El hecho recesivo tuvo dos lecturas, dependiendo de la nacionalidad de los perjudicados. Mientras el Perú acusó a las autoridades chilenas de perseguir a sus ciudadanos y expulsarlos del territorio -aún entendido como parte soberana de la república peruana-, en Chile se negó la tesis peruana explicando la precariedad laboral con argumentos macro-económicos relacionados con la Guerra Mundial.

En un ámbito socio-cultural, en los dos países el nacionalismo estaba bien consolidado determinando gran parte de los comportamientos del proletariado tarapaqueño. Una de sus prácticas recurrentes fue el uso de la violencia físico-simbólica para defender las interpretaciones de la depresión económica, así como de los nacionalismos en tensión. Considerando esos aspectos se comprende la reacción de algunos grupúsculos chilenos en contra del cónsul peruano en Iquique, Santiago Llosa Argüelles. El pueblo chileno de esa ciudad, en el marco de las celebraciones cívicas de la batalla de Pisagua "asaltó su casa, no obstante que la policía trató de protegerla" ${ }^{1136}$, provocando la retirada del cónsul hacia el Perú. Los hechos fueron noticiados, no sólo en los países involucrados, "con ribetes de escándalo"1137. En efecto, el Perú decidió romper relaciones consulares con Chile.

\footnotetext{
1135 AlJovín DE LOSADA, Cristóbal y LÓPEZ, Sinesio, Historia de las elecciones en el Perú: estudios sobre el gobierno representativo, Lima, Instituto de Estudios Peruanos, 2005, p. 98; Bonilla, Heraclio, Gran Bretaña y el Perú (1826-1929): Los mecanismos de un control económico, Lima, Instituto de Estudios Peruanos, 1977, p. 46; GONZÁlEZ, Sergio, La llave y el candado: el conflicto entre Perú y Chile por Tacna y Arica, Santiago, LOM Ediciones, 2008, p. 154; MC EvoY, Carmen, La utopía republicana. Ideales y realidades en la formación de la cultura política peruana (1871-1919), Lima, Pontificia Universidad Católica del Perú, 1997, p. 441; PINTO V., Julio y VALDIVIA O., Verónica, ¿Revolución proletaria o querida chusma? Socialismo y Alessandrismo en la pugna por la politización pampina (1911-1932), Santiago, LOM Ediciones, 2001, p. 51; YÁÑEZ ANDRADE, Juan Carlos, La intervención social en Chile (1907-1932), Santiago, RIL Editores, 2008, p. 165.

${ }^{1136}$ FERNÁNDEZ VALDÉS, Juan José, Chile y Perú. Historia de sus relaciones diplomáticas entre 1879 y 1929 , Santiago: RIL Editores, p. 342.

${ }^{1137}$ Idem.
} 


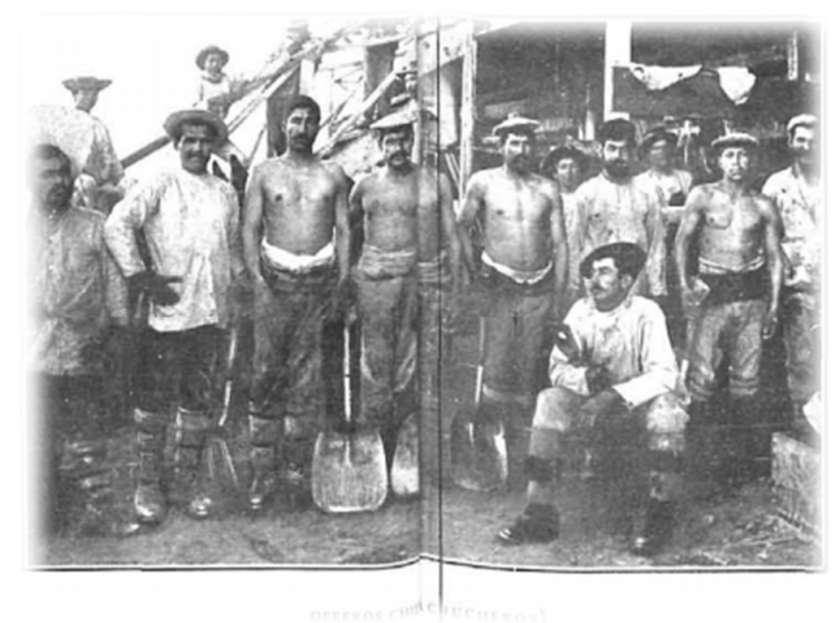

Fuente: La Ilustración Española y Americana, "El salitre y el yodo", 30 de julio de 1915 , n. ${ }^{\circ} 28$, pp. 574-575.

Debido a esos sucesos la ruptura de las relaciones diplomáticas se transformó en una constante política de la posguerra entre ambas cancillerías. Es necesario recordar que años atrás dos excentricidades más de esa relación habían paralizado el diálogo chileno-peruano. En 1908, el gobierno peruano rechazó una corona obsequiada por Chile para colocar en un monumento patrio del país ${ }^{1138}$ provocando un impasse y, posteriormente, en 1910 un decreto del gobierno chileno expulsó a los párrocos peruanos de Tacna y Arica.

La versión chilena oficial de las supuestas agresiones a Llosa fue publicada en la prensa española. Allí se resumían los acontecimientos de Iquique con estas palabras: "El día 2 del presente, aniversario de la batalla de Pisagua [...], celebrose un mitin en Iquique (Chile) en el cual se protestó de la campaña emprendida por una parte de la Prensa peruana" ${ }^{1139}$. Aun cuando esta asamblea se verificó en perfecto orden -continuó el medio periodístico- el gobierno peruano fue informado de sucesos inexistentes. La última parte de ese relato sugiere que el origen de las manifestaciones contra el consulado peruano de Iquique fue, en verdad, una reacción a hechos anteriores:

${ }^{1138}$ El Día, "Perú, Bolivia y Chile", 21 de mayo de 1909, p. 3; El Globo, "Perú, Bolivia y Chile", 21 de mayo de 1909 , p. 3.

${ }^{1139}$ El Sol, "Peligro de guerra en la América española", 28 de noviembre de 1918, p. 1. 
Esa información fue suficiente para que en Paita y Trujillo se organizaran manifestaciones callejeras en contra de Chile y se asaltaran los consulados de esta nación, por lo cual el gobierno peruano dio explicaciones. El gobierno chileno en previsión de mayores dificultades que vivamente desea evitar, autorizó a sus cónsules en el Perú para regresar al país [...] El sábado 23, tuvo lugar otro mitin, también en Iquique; y aunque la energía de las autoridades y jefes militares logró dominar todo el desorden, y la persona del señor cónsul del Perú fue resguardad en todo momento, amigos del cónsul le aconsejaron trasladarse a bordo. [...] En resumen: fueron asaltados los consulados de Chile en Paita y Trujillo, y el Gobierno del Perú dio explicaciones. Estos hechos revelan que por parte de Chile no ha mediado provocación alguna ${ }^{1140}$.

Como en ocasiones pasadas, los errores en las informaciones publicadas en España gozaron de una centralidad indecorosa. La Correspondencia de España publicó:

Anuncian oficialmente de Washington que el Perú ha llamado a sus agentes diplomáticos en Chile, a causa de una manifestación peruana (sic) celebrada en Iquique" ${ }^{\text {"141 }} \mathrm{y}$, días después, aseguró que el plazo de realización del plebiscito por Tacna y Arica, según lo convenido en el tratado de Ancón no había sido una década, sino "veinte años (sic)"1142.

La Nación, por otro lado, aseguró que Colombia "parece solidarizarse con Chile, contra el Perú. En Santa Fe de Bogotá, capital boliviana (sic), más de 5.000 personas, entre ellas numerosos diputados y senadores, se manifestaron ante la Legación de Chile"1143. El Día afirmó sobre los recursos naturales del desierto atacameño, escenario de la nueva disputa, que en "la segunda mitad del siglo pasado (sic) se descubrió en los campos áridos de Arica inmensos yacimientos de salpetrio y guano" 1144 . Hoy se sabe que el guano, usado por poblaciones prehispánicas se explotaba ya en la época española y que su importancia para la economía de la república peruana duró desde, aproximadamente, la década del cuarenta hasta la del setenta del siglo XIX ${ }^{1145}$.

\footnotetext{
1140 Idem.

${ }^{1141}$ La Correspondencia de España, "Las repúblicas americanas", 27 de noviembre de 1918, p. 7.

${ }^{1142}$ El Sol, "Peligro de guerra en la América española", 28 de noviembre de 1918, p. 1; La Correspondencia de España, "Tacna y Arica", 30 de noviembre de 1918, p.1; El Siglo Futuro, "El conflicto entre Chile y Perú", 3 de enero de 1919, p. 3.

1143 La Nación, "Chile y Perú", 8 de diciembre de 1918, p. 7.

${ }^{1144}$ El Día, "El conflicto entre Chile y Perú", 13 de noviembre de 1918, p. 2.

1145 MARiÁtegui, José Carlos, 7 ensayos de interpretación de la realidad peruana, Caracas, Biblioteca Ayacucho, 1979, p. 235; PiZARro, Elías y Soto, José, "Explotación colonial de recursos naturales prehispánicos: el caso del huano de covaderas en el extremo norte de Chile (s. XVI-XVII)". En LEAL, Cristian, CÁCERES, Juan y TOBAR, Leopoldo (Eds.), Lecturas y (re)lecturas en historia colonial II, Chile, Universidad del Bío-Bío, Pontifica Universidad Católica de Valparaíso, Universidad Católica Silva Henríquez, 2014, pp. 239-256.
} 
A la vez, aparecieron titulares que anunciaban y otros que se preguntaban por la nueva guerra chileno-peruana producida, esta vez, por la "gran tirantez entre ambos países"1146 desde la firma del Tratado de Ancón. Otros diarios, con llamativos títulos, advertían del peligro de guerra ${ }^{1147}$ y aportaban datos desconocidos del ataque sufrido por el cónsul peruano quien, opuestamente a lo explicado por Fernández, diplomático e historiador chileno, no recibió "ninguna protección eficaz de la Policía"1148.

Rápidamente las rotativas de varios impresos avisaron el movimiento de tropas ${ }^{1149}$, $\mathrm{y}$, en respuesta, la solidaridad de los socialistas americanos contrarios a la guerra. En otro aspecto, una vez más surgió la iniciativa de políticos peruanos para que los Estados Unidos fijaran las formas de solucionar el diferendo concretándose el plebiscito prometido en Ancón ${ }^{1150}$. En la práctica, el canciller Francisco Tudela y Varela, enemigo del socialismo y "antiindigenista convencido"1151, viajó hacia el norte buscando apoyo para las reivindicaciones territoriales de su país ${ }^{1152}$. Sospechosamente, desde Nueva York se informaba a las centrales telegráficas hispanas el envío de buques de guerra estadounidenses a las costas peruanas.

Ciertos diarios y revistas hicieron estimables esfuerzos analíticos para superar las informaciones básicas de la ruptura consular, aventurándose con interpretaciones históricas. La mayoría de las veces, las fuentes usadas para construir los argumentos de esa hermenéutica no fueron incluidas en las notas. Aún así, es sugestivo el sentimiento provocado en la prensa por la nueva ruptura de relaciones diplomáticas, pues pronto, en nombre del hispanoamericanismo, se rechazó la inminente guerra.

\footnotetext{
${ }^{1146}$ La Correspondencia de España, "Chile y Perú", 28 de noviembre de 1918, p. 7; El Heraldo, "Una nueva guerra", 27 de noviembre de 1918, p. 3; El Sol, "Peligro de guerra en la América española", 28 de noviembre de 1918, p. 1; La Época, "El conflicto entre Chile y Perú", 8 de diciembre de 1918, p. 3.

${ }^{1147}$ El Siglo Futuro, "El conflicto entre Chile y Perú", 3 de enero de 1919, p. 3.

${ }^{1148}$ El Sol, "Peligro de guerra en la América española", 28 de noviembre de 1918, p. 1.

${ }^{1149}$ La Época, "El conflicto entre Chile y Perú", 2 de diciembre de 1918, p. 3; La Época, "El conflicto entre Chile y Perú", 8 de diciembre de 1918, p. 3; La Nación, "Chile y Perú", 8 de diciembre de 1918, p. 7.

${ }^{1150}$ La Época, "El conflicto entre Chile y Perú”, 2 de diciembre de 1918, p. 3; La Acción, “¿La solución?”, 8 de diciembre de 1918, p. 3.

${ }^{1151}$ Ramos NúÑEZ, Carlos, Historia del derecho civil peruano. Siglos XIX y XX, Tomo V, Los signos del cambio, Vol. 2, Las instituciones, Lima, Pontificia Universidad Católica del Perú. Fondo Editorial, 2006, p. 242.

${ }^{1152}$ La Época, "El conflicto entre Chile y Perú", 8 de diciembre de 1918, p. 3; La Nación, "Chile y Perú", 8 de diciembre de 1918, p. 7;
} 
El Día dedicó un interesante reportaje a "nuestros hermanos de raza: los pueblos hispanoamericanos"1153; La Correspondencia ... hizo votos para que "no haya una nueva guerra del Pacífico" ${ }^{1154}$, tildándola de horror absurdo. El Globo prologó uno de sus reportajes señalando los "momentos en que tan fuertes son las corrientes de aproximación hispanoamericana" ${ }^{1155}$, solidaridad internacional que requería conocer a fondo el problema fronterizo, o en sus palabras, "no puede dejar de producir vivo interés en nuestro país el conflicto suscitado entre las dos florecientes Repúblicas del Pacífico"1156.

Las Noticias asumió una posición antichilena y escarmentó a ese país recordándole que los tiempos del imperio de la fuerza formaban parte del pasado, por lo que esperaba el esfuerzo máximo de Chile para "no encender una nueva guerra del Pacífico"1157. Una visión diplomática, pacifista y pragmática tuvo $E l$ Sol, llamando a la concordia chileno-peruana y solicitando la intervención del ministro de Estado español en la disputa, pues "hay en este problema un interés moral para España y una ocasión de recobrar prestigios de orden internacional"1158. El ministro Romanones, quien había "simbolizado durante años y años la decadencia extrema de nuestras costumbres políticas" ${ }^{1159}$, no quebrantó, por el diferendo, su paz.

Parte de una prensa aficionada a la búsqueda de culpables acusó, una vez más, a la política exterior chilena. Sin embargo, a diferencia de los años ochenta del siglo XIX, también juzgó con severidad la participación de peruanos y bolivianos. Los duros soldados chilenos, publicaron diarios matritenses ${ }^{1160}$, compuestos principalmente por mineros $\mathrm{y}$ labradores, vencieron a un ejército peruano-boliviano improvisado que, aunque no carente

\footnotetext{
${ }^{1153}$ El Día, "El conflicto entre Perú y Chile", 13 de noviembre de 1918, p. 2.

${ }^{1154}$ La Correspondencia de España, "Tacna y Arica", 30 de noviembre de 1918, p.1.

${ }^{1155}$ El Globo, "Chile y Perú", 3 de diciembre de 1918, p. 1.

${ }^{1156}$ Idem.

${ }^{1157}$ El Siglo Futuro, "El conflicto entre Chile y Perú", 3 de enero de 1919, p. 3.

${ }_{1158}$ El Sol, "Peligro de guerra en la América española", 28 de noviembre de 1918, p. 1.

1159 CARR, Raymond G., CARR, Stephen, "La crisis del parlamentarismo". En ANDrÉS-GALLEGO, José, Historia general de España y América. Revolución y restauración (1868-1931), Tomo XVI-2, Madrid, Ediciones RIALP, S. A., p. 471.

${ }^{1160}$ La Correspondencia de España, "Tacna y Arica", 30 de noviembre de 1918, p.1; El Siglo Futuro, "El conflicto entre Chile y Perú", 3 de enero de 1919, p. 3
} 
de héroes, sí de "cohesión y eficacia""1161, era producto de una cultura marcada por el desorden crónico ${ }^{1162}$.

Comparado con esos países, el orden administrativo republicano chileno triunfaba. Perú y Bolivia parecían “débiles frente a la fuerte disciplina y excelente organización de los chilenos" $" 1163$. Por otro lado, las consecuencias territoriales de la victoria chilena, conocidas grosso modo en la prensa hispana, se reiteraban: Perú perdió Tacna y Arica en favor de Chile, causa del litigio actual, no conformándose el primero de esos países "con la soberanía que Chile viene ejerciendo en esos territorios, y aspira por todos los medios a recobrar su posesión, alterando el «statu quo» que de hecho existe" ${ }^{1164}$.

Otros diarios se inclinaron hacia una información de carácter cultural. $L a$ Correspondencia ... creía saber de la educación cívica y literaria en el Perú. Aseguró que las nuevas generaciones de peruanos habían sido influidas por la poesía nacionalista, violenta y adicta al orden de Manuel González Prada. Él, crítico de los partidos políticos, acusaba a éstos de ser "fragmentos orgánicos que se agitan y claman por un cerebro [...] pedazos de serpiente que palpitan, saltan y quieren unirse con una cabeza que no existe"1165. Hay cráneos, pero no cerebros - concluía el vate anarquista- afirmando que "Regresar a España para introducir nuevamente su sangre en nuestras venas [...] equivale a retrogradar" ${ }^{\prime 166}$. En ese Perú florecía, más que nunca, un orgullo nacional herido y receloso hacia el recuerdo de Tacna y Arica, provincias sentidas como injurias mortales ${ }^{1167}$. Chile, eludiendo esos sentimientos colectivos e incumpliendo el tratado, mantenía su dominio en las provincias “arrebatadas"1168 al Perú.

Durante la ruptura consular entre La Moneda y la Casa de Pizarro, motivada por los sucesos de Iquique, cobró gran importancia geopolítica la posición tomada por Chile y Perú

\footnotetext{
${ }^{1161}$ La Correspondencia de España, "Tacna y Arica", 30 de noviembre de 1918, p.1.

${ }^{1162}$ El Día, "El conflicto entre Perú y Chile", 13 de noviembre de 1918, p. 2.

1163 Idem.

${ }^{1164}$ El Globo, "Chile y el Perú", 3 de diciembre de 1918, p. 1; La Acción, "Chile y Perú", 4 de diciembre de 1918, p. 2.

${ }^{1165}$ España, "La cuestión de Tacna y Arica", 5 de diciembre de 1918, n. ${ }^{\circ} 191$, p. 8.

1166 GonZÁlez PradA, Manuel, Antología, Barcelona, Red Ediciones S. L., 2016, p. 20.

${ }^{1167}$ La Correspondencia de España, "Tacna y Arica", 30 de noviembre de 1918, p. 1.

${ }^{1168}$ El Día, "El conflicto entre Perú y Chile", 13 de noviembre de 1918, p. 2; La Correspondencia de España, "Tacna y Arica", 30 de noviembre de 1918, p.1; España, "La cuestión de Tacna y Arica", 5 de diciembre de 1918, n. ${ }^{\circ} 191$, p. 8; El Siglo Futuro, "El conflicto entre Chile y Perú", 3 de enero de 1919, p. 3.
} 
en el conflicto mundial. Como se sabe, Chile, al igual que España, mantuvo una postura neutral en la Primera Guerra Mundial.

Chile hizo pública su decisión el 8 de agosto de 1914; España el día anterior ${ }^{1169}$. Perú, por el contario, rompió su neutralidad inicial sumándose a la causa aliada. Esa adhesión, escribió una publicación española, se atribuyó a un propósito peruano secreto para solicitar, oportunamente, la reintegración de Tacna y Arica "como nuevas regiones «irredentas» del suelo americano"1170. Al parecer, la prensa intuía la intención de la cancillería peruana de someter la cuestión territorial a la "futura Conferencia de Paz"1171 con la que se pondría fin a la Gran Guerra.

La neutralidad chilena fue vista como un gesto de cercanía hacia Alemania. El filósofo español Francisco Giner de los Ríos, por ejemplo, aseguraba que "Chile siente simpatías por Alemania, porque su organización, su cultura, su profesorado, son alemanes"1172. Los agustinos encargados de la revista España y América explicaban tal simpatía introduciendo elementos crípticos de esa filiación: "La mayor y más sana parte del país, de la prensa, de sus prohombres, del ejército, del clero, son declaradamente neutrales y, ¿por qué no decirlo?, veladamente, privadamente, germanófilos"1173. Esas y otras publicaciones que de modo explícito se referían al espíritu "alemanesco" de Chile se reforzaban con cientos de notas relativas al posicionamiento chileno en la Guerra Mundial, donde se aseguraba el ingreso del país en el conflicto, la presión estadounidense para declararle la guerra a Alemania, así como de la opinión pública chilena, entre otros temas $^{1174}$.

1169 LLEONART Y AMSELEM, A. J. y CASTIELla y MAIZ, F. M., España y ONU I (1945-1946). La cuestión española. Documentación básica, sistematizada y anotada, Madrid, Consejo Superior de Investigaciones Científicas, 1978, p. 44; CouYOumDJIAN, Juan Ricardo, Chile y Gran Bretaña. Durante la primera guerra mundial y la postguerra, 1914-1921, Santiago, Editorial Andrés Bello, 1986, p. 49.

${ }^{1170}$ El Globo, "Chile y el Perú", 3 de diciembre de 1918, p. 1.

${ }^{1171}$ El Día, "El conflicto entre Perú y Chile", 13 de noviembre de 1918, p. 2. Una interpretación similar en: El

Sol, "Peligro de guerra en la América española", 28 de noviembre de 1918, p. 1.

1172 El Imparcial, "Los jefes de las minorías", 6 de febrero de 1917, pp. 1-2.

${ }^{1173}$ España y América, "La América Española y la guerra europea", 1 de abril de 1918, n. ${ }^{\circ} 10$, p. 194.

${ }^{1174}$ La Acción, "Chile se limitará a formular una enérgica protesta", 10 de febrero de 1917, p. 3; La Nación, "En Chile", 10 de febrero de 1917, p. 4; La Acción, "Chile. Contra los Estados Unidos", 11 de febrero de 1917, p. 3; El Imparcial, "Uruguay y Chile contra el bloqueo", 12 de febrero de 1917, p. 2; La Nación, "El mensaje de Wilson en las repúblicas americanas", 7 de abril de 1917, p. 9; La Nación, "Chile y la guerra germano-americana", 8 de abril de 1917, p. 8; El País, "Chile hacia la guerra", 10 de abril de 1917, p. 2; La 
Chile, llamado desde la época de la Guerra del Pacífico la "Prusia de Sudamérica" 1175 por su organización militar férrea (tabla n. ${ }^{\circ} 10$ ) y conservadurismo político, chocaba así con el Perú en dos planos, uno regional y otro mundial. Su neutralidad "germanófila" aspiraba a la solución del conflicto vecinal con Perú prescindiendo de tribunales internacionales; Perú declaraba solidaridad con la causa de la Entente por “estimarla justa y de acuerdo con el derecho de los pueblos"1176. Esa era una política de previsión, que -esperaban los gobernantes de Lima- daría sus frutos naturales" 1177.

Tabla n. ${ }^{\circ} 10$

Comparación entre los ejércitos de Chile y Perú

\begin{tabular}{|c|c|c|}
\hline \multicolumn{3}{|c|}{ Chile } \\
\hline $\begin{array}{l}\text { Número de habitantes } \\
\text { Servicio Militar }\end{array}$ & $\begin{array}{l}5 \text { millones aprox. } \\
\text { Obligatorio }\end{array}$ & $\begin{array}{l}5 \text { millones aprox. } \\
\text { Obligatorio }\end{array}$ \\
\hline \multicolumn{3}{|l|}{ Ejército } \\
\hline Infantería & 16 batallones & 5 batallones \\
\hline Caballería & 6 regimientos & 6 escuadrones \\
\hline Artillería & $\begin{array}{l}1 \text { regimiento }+4 \text { regimientos } \\
\text { de artillería de montaña }\end{array}$ & 1 regimiento \\
\hline Zapadores & - & 1 regimiento \\
\hline Ingenieros zapadores & 4 secciones & - \\
\hline $\begin{array}{l}\text { Ingenieros de } \\
\text { comunicación }\end{array}$ & 1 sección & - \\
\hline Total de efectivos & Sin dato & 5000 \\
\hline $\begin{array}{l}\text { Efectivos en pie de } \\
\text { guerra }\end{array}$ & 140000 hombres & 120000 hombres \\
\hline
\end{tabular}

Fuente: Elaboración propia a partir de los datos aparecidos en: El Siglo

Futuro, "El conflicto entre Chile y Perú", 3 de enero de 1919, p. 3.

Correspondencia Militar, "Chile a la guerra", 10 de abril de 1917, p. 1; La Época, "La neutralidad de Chile", 13 de abril de 1917, p. 2; El Día, "La cancillería chilena declara su oposición a la guerra", 14 de abril de 1917, p. 1; La Lectura Dominical, "Crónica Semanal", n. ${ }^{\circ} 1$ 215, 14 de abril de 1917, pp. 1-2; La Nación, "La actitud de Chile y Colombia", 17 de abril de 1917, p. 9; La Época, "La neutralidad de Chile", 18 de abril de 1917, p. 2; La Mañana, "Chile permanecerá neutral", 19 de abril de 1917, p. 9; La Acción, "Chile no ha pactado con Alemania", 3 de mayo de 1917, p. 3; La Época, "Chile no ha pactado con Alemania", 3 de mayo de 1917, p. 1; El Liberal, "Chile y Alemania", 4 de mayo de 1917, p. 3; La Nación, "Sobre el supuesto tratado entre Chile y Alemania", 4 de mayo de 1917, p. 7.

${ }^{1175}$ La Correspondencia de España, "Tacna y Arica", 30 de noviembre de 1918, p. 1; España, "La cuestión de Tacna y Arica", 5 de diciembre de 1918, n. ${ }^{\circ}$ 191, p. 8; El Siglo Futuro, "El conflicto entre Chile y Perú", 3 de enero de 1919, p. 3.

${ }^{1176}$ La Correspondencia de España, “Tacna y Arica”, 30 de noviembre de 1918, p.1.

${ }^{1177}$ Idem. 
El episodio escandaloso del consulado peruano en Iquique permitió que un grupo de periodistas españoles se refiriese al ethos de los países comprometidos en el conflicto. Enrique Fajardo, director de $\mathrm{La}$ Voz, utilizando el seudónimo "Fabián Vidal”, ensayó dos definiciones acerca de la identidad nacional de Chile y Perú. Si bien reconocía que ambas naciones eran políticamente conservadoras, sus pueblos tenían profundas diferencias idiosincráticas que permitía al conservadurismo chileno superar el peruano.

Para Vidal, el conservadurismo chileno se caracterizaba por su nacionalismo audaz, expansivo, ordenado y agresivo. No había similitud con el peruano que era, entre otras cosas, blando, muelle, estéril. No servía -aseguraba el sabio Vidal- de aglutinante enérgico, sino que, muy al contrario, corrompía y disociaba. Una parte de la interesante opinión, fortalecedora de las representaciones sociales relativas al militarismo y al esfuerzo laborioso del chileno la introducimos in extenso:

Chile, unido, pobre, acostumbrado a domeñar las estériles asperezas de un suelo ingrato, tendido entre los Andes y el Pacífico, miraba al litoral boliviano y peruano, con las ansias con que un proletario descontento mira los palacios soberbios de los ricos. Tenía, en el roto labrador y minero, una excelentísima materia prima. Los bravos plebeyos de Chile son soldados incomparables. Y al norte, el Perú zumbón y sensual, con exceso de sangre quichúa (sic), dividido en castas enemigas, desmoralizado por una tradición lamentable de corrupción política, tumbábase al sol sin recelo, ignorando a su vecino peligrosísimo... ${ }^{1178}$.

El artículo apologético de Vidal cruzó el Atlántico. En la segunda parte del texto hacía una crítica agria al desenvolvimiento de la política exterior chilena. En los círculos ilustrados de ese país provocó incomodidad. La respuesta elaborada por El Mercurio se publicó, aproximadamente, dos semanas después en importantes diarios españoles. "Las razones de Chile", título de la contra argumentación, acusaba al periodista español de analizar con poca seriedad y ausencia de datos el papel chileno en la guerra y posguerra del Pacífico. El diario chileno dividió el argumento de la contestación en tres puntos, siguiendo el mismo orden temático usado en el reportaje de la revista. De ese modo, criticó las ideas centrales del párrafo citado anteriormente; la afirmación sobre el incumplimiento chileno del artículo tercero del Tratado de Ancón; y, finalmente, el supuesto arraigo peruano hacia ese tratado.

${ }^{1178}$ España, "La cuestión de Tacna y Arica", 5 de diciembre de 1918, n. ${ }^{\circ} 191$, p. 8. 
Sobre el primer punto, El Mercurio acusó a Vidal de olvidar un hito fundamental: antes de la guerra, Chile se preocupó sólo de cimentar la nacionalidad mediante el respeto legalista, apoyándose en el trabajo tesonero del pueblo, procedimientos que le dieron gran prosperidad. El periodista granadino ignoró, igualmente, señalar que Chile cooperó en la independencia peruana, armando la costosa expedición libertadora de 1820.

Posteriormente, Chile ayudó al Perú en la guerra contra España, donde establecieron alianza también con Bolivia y Ecuador ${ }^{1179}$, participación que con posterioridad produjo una crisis económica aguda. En lo relativo al militarismo chileno previo a la guerra, Vidal pasaba por alto que Chile tenía un ejército pobre, inferior a mil hombres mal armados ${ }^{1180}$. Fue la guerra de 1879 una verdadera guerra de defensa nacional -concluye el alegato sobre este punto- ante "el ataque de un enemigo fuerte y artero, que le devolvía de esta manera todos los sacrificios que había hecho ayudándolo en circunstancias críticas"1181.

Sobre el segundo punto, referido al incumplimiento chileno del artículo n. ${ }^{\circ} 3$ del tratado, la defensa chilena fue enérgica. Chile, había escrito Vidal, "no cumplió la cláusula" ${ }^{182}$. El periodista chileno de El Mercurio lamentó la desinformación de su colega español, al que culpó de querer ignorar la verdad histórica, pues intencionalmente ocultaba en su escrito todas las gestiones realizadas por Chile ante Perú para realizar el plebiscito $^{1183}$.

El barrido final de la profesionalidad de Vidal fue provocado por sus declaraciones sobre el conservadurismo político chileno. El escritor de El Mercurio escribió con ironía por la confusión conceptual del español: "Ya se ve que el pendolista español ignora cosas de tanto bulto como las de saber que no hay memoria en América de un triunfo tan grande como el de los partidos liberales en Chile durante las elecciones últimas"1184. En definitiva,

\footnotetext{
${ }^{1179}$ El Siglo Futuro, "El conflicto entre Chile y Perú", 3 de enero de 1919, p. 3.

${ }^{1180}$ De todos modos en Perú y Bolivia era una idea común que Chile se armaba antes de la guerra. Las Noticias de Barcelona también se adhirió a esa tesis: "En 1876 el Perú [...] recurrió a la expropiación de las riquísimas minas de salitre de Tarapacá. Chile se consideró perjudicado con esta medida e hizo los preparativos necesarios para declarar la guerra al Perú". En: El Siglo Futuro, "El conflicto entre Chile y Perú", 3 de enero de 1919, p. 3.

${ }^{1181}$ España, "Crónica Americana", 24 de abril de 1919, n. ${ }^{\circ} 211$, p. 9.

1182 Idem.

1183 Otra publicación que describe la preocupación chilena por realizar el plebiscito: El Día, "Chile y Perú", 4 de enero de 1919, p. 5.

${ }^{1184}$ España , "Crónica Americana", 24 de abril de 1919, n. ${ }^{\circ} 211$, p. 9.
} 
el diario santiaguino, atacó por varios frentes las ideas de Vidal compartidas en "su artículo $\tan$ mal documentado"1185.

\section{Imagen $n .^{\circ} 55$}

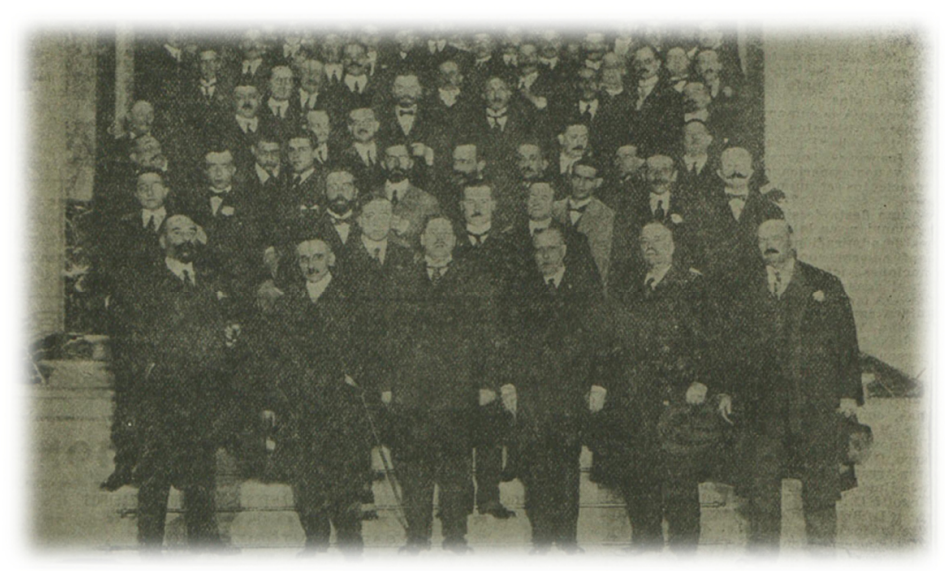

Fuente: La Mañana, "[...] en honor del ilustre redactor de La Correspondencia de España, D. Enrique Fajardo (Fabián Vidal)”, 25 de noviembre de 1918, p. 8.

Sobre el tercer punto, en el cual Vidal afirmó que el Perú anhelaba efectuar el plebiscito del pacto "leonino de Ancón" ${ }^{186}$, El Mercurio apostilló esa afirmación como la más lamentable de todas. En Chile se sabía que Perú, por el contrario, deseaba invalidar completamente el tratado de 1883, aprovechando el contexto diplomático de finales de la guerra mundial. Estas divergencias de criterio hicieron que El Mercurio descalificara al escritor, con tono grosero, imputándolo de mentiroso y lamentándose de que use la España para inventar noticias, pues "hasta ahora" 1187 la revista se caracterizaba por su moralidad pública y rigurosidad. Ante esta polémica, la posición editorial de España fue mesurada, en comparación con la de Vidal y El Mercurio. La revista abogó por un buen periodismo el que, en sus palabras, facilitaba espacio para debates e intercambio de ideas en temas de relevancia social. España comprendía que, metodológicamente, la búsqueda de la verdad histórica implicaba evaluar las verdades parciales para así acercarse a la "verdad verdadera y superior" 1188 .

\footnotetext{
1185 Idem.

1186 Idem.

1187 Idem.

1188 Idem.
} 
No obstante, el carácter temperado de la revista España pronto se desequilibró. La exaltación emergió en defensa del colega nacional, Fabián Vidal. Los juicios chilenos hacia él, acusándolo de mentir en el escrito, sorprendieron por el talante de las palabras y la ignorancia hacia la profesionalidad del fornido periodista. España entonó el mea culpa: "[...] admitimos, a lo sumo, una posibilidad de error"1189. Las diferencias de pareceres provocadas por Vidal y El Mercurio favorecieron un par de reflexiones en torno a la modernidad periodística española. Las equivocaciones, asumió en definitiva la publicación, caracterizaban la industria moderna de la prensa que "sacrifica la calidad -perfección y elegancia- a la cantidad y baratura" ${ }^{\prime 190}$.

La cancillería peruana utilizó la ruptura consular para elaborar una campaña global antichilena, donde la prensa tuvo un lugar privilegiado. La metodología planeada por la diplomacia de Lima consistió, por un lado, en la redacción de notas nacionalistas, altamente emotivas, solicitando el cumplimiento del tratado de 1883. En esos escritos, por otro lado, se entregaban detalles escabrosos de la chilenización que Santiago había implementado en Tacna y Arica. La Legación del Perú en París fue una de las primeras en recibir tales informaciones que, pronto, se reprodujeron en España.

En esas notas se aludió la aceptación del Perú para que el presidente estadounidense Wilson, actuase como árbitro entre ese país y Chile. En España, el cónsul general del Perú en Madrid, José Domingo Cáceres, confirmaba la noticia en "atento besalamano (sic)" "1191. Otro documento inserto en los diarios refirió las manifestaciones antiperuanas ocurridas en todo Chile y, particularmente, en Tacna, Arica y Tarapacá. Las consecuencias sociodemográficas no se demoraron: los peruanos repatriados de Tacna y Arica, según El Sol, alcanzaron los dieciséis mil ${ }^{1192}$. Otro grupo de noticias ofreció mayores detalles sobre la migración peruana. Para elaborar las informaciones se tomaron, principalmente, datos de la prensa limeña.

\footnotetext{
${ }^{1189}$ Idem.

${ }^{1190}$ Idem.

1191 Idem.

1192 La Época, "El conflicto entre Chile y Perú", 18 de diciembre de 1918, p. 3; La Acción, "Chile y Perú", 19 de diciembre de 1918, p. 3; El Siglo Futuro, "Chile y Perú", 19 de diciembre de 1918, p. 1; El Sol, "Sigue la hostilidad entre chilenos y peruanos", 19 de diciembre de 1918, p. 6; La Nación, "Chile y Perú", 19 de diciembre de 1918, p. 5; El Sol, "Perú", 4 de julio de 1919, p. 9.
} 
La prensa española dio a conocer el éxodo inédito de los peruanos avecindados en Chile. Ese proceso incluyó persecuciones y ultrajes. Los principales enclaves peruanos donde llegaron los refugiados fueron los puertos de Mollendo y El Callao; en Bolivia, La Paz acogió a otros fugitivos que utilizaron los ferrocarriles de Antofagasta y Arica.

Estas ideas peruanófilas se robustecieron con la ayuda de otras publicaciones. $E l$ Día, por ejemplo, aseguró que las autoridades chilenas en las "cautivas" presionaban al comercio anglo-estadounidense para expulsar a los trabajadores peruanos. Es más, ciudadanos de esos países abandonaron el territorio demostrando solidaridad con la causa peruana. Las provincias estaban bajo total control chileno y se había ordenado expulsar a todos los peruanos asentados en la pampa salitrera, declaró el mismo diario. Para los analistas peruanos, el conflicto socio-económico sólo era una arista evidente de una conspiración mayor: con la expulsión de los obreros peruanos se pretendía "aumentar la agitación obrera en el Perú, y se cree que una parte del plan chileno consiste en fomentar la revolución y el bolchevismo en el Perú"1193.

Ante los acontecimientos, el cónsul peruano en Madrid entregó una nueva circular de su cancillería a la prensa. El documento explicó la posición peruana frente a la violencia estatal chilena en Tarapacá. Además, condenó la expulsión de Llosa. En otro aspecto, la nota agradeció a Wilson su tono pacificador, en medio del conflicto, aludiendo, paralelamente, la reprobación política mundial de los excesos chilenos. Apelando a la sensibilidad de los lectores, aseguró que los gritos y angustias de los perseguidos llegaban hasta Lima, evadiendo la censura chilena de los medios. El velo impenetrable puesto por las autoridades sobre las coacciones -leemos en la circular- no impedía al mundo conocer la ferocidad de la administración chilena en Tacna-Arica. La circular narró episodios de violencia que no daban márgenes a interpretaciones imparciales o responsabilidades compartidas. El "populacho" chileno, apoyado por miembros del Ejército, participaba en actividades que no eran de su competencia. Las ligas patrióticas, nombre con que se conocieron los grupúsculos xenofóbicos, habían clausurado, conjuntamente, todos los edificios y establecimientos comerciales sometiéndolos después al "peor"1194 de los pillajes.

\footnotetext{
${ }^{1193}$ El Día, "Perú", 26 de enero de 1919, p. 2.

${ }^{1194}$ Idem.
} 
La circular facilitada por Cáceres aseguró que Chile forzaba el retiro de distinguidos conciudadanos Tacno-ariqueños, obligándolos a firmar documentos que reconocían la voluntad del acto. Sus compatriotas eran maltratados con afán de atemorizarlos y expulsarlos limpiando ${ }^{1195}$ el territorio. Así, en el momento del plebiscito en las provincias, existiría un mínimo de electores peruanos. Esas circunstancias forjaron el escepticismo del gobierno del Perú respecto de las medidas adoptadas por Chile después de la ruptura consular. Relacionado con lo anterior, la cancillería de José Pardo rechazó la petición chilena al cónsul francés en Iquique (encargado de "los intereses peruanos en ese puerto" ${ }^{1196}$ ) de enviar embarcaciones para transportar alrededor de dieciocho mil peruanos cesantes de Tarapacá.

La circular sancionó el pecado chileno en la nueva desestabilización socio-política de la frontera. Sirvió también para hacer pública la existencia, inquebrantable, de la peruanidad. Para la cancillería, durante treinta y cinco años de ocupación chilena, ese país no arrancó del corazón de sus habitantes el cariño hacia la patria ausente y el anhelo de reincorporarse a ella. No satisfecho con su dominio ilegal "los expulsa ahora del suelo que es de ellos"1197. Los abusos cometidos por el Estado chileno fueron juzgados en una nota de protesta peruana que demostraba la urgencia del retorno al país de las provincias del desierto. El terrorismo chileno se realizaba, concluía la cancillería, cuando las naciones oprimidas del mundo anhelaban desenvolverse en libertad, amparándose en el derecho, y conscientes de que "la Humanidad condena los abusos de la fuerza"1198.

Al finalizar 1918, la violencia popular empeoró o, por lo menos, así lo entendieron las autoridades peruanas que, en otra circular, sancionaron el vandalismo chileno en Tacna, Arica y Tarapacá. Las predicciones de El Sol acertaban cuando afirmaban el temor causado, entre los habitantes, por esos incidentes, "cuyas consecuencias podrán ser desastrosas"1199.

\footnotetext{
1195 Idem.

${ }^{1196}$ CASTEDO, Leopoldo, Chile: Vida y muerte de la república parlamentaria (de Balmaceda a Alessandri), Santiago, Editorial Sudamericana, 2001, p. 271.

${ }^{1197}$ El Día, "El incidente entre Chile y el Perú", 11 de enero de 1919, p. 5; El País, "El Perú y Chile", 11 de enero de 1919, p. 3; La Acción, "El Perú y Chile", 11 de enero de 1919, p. 5; La Correspondencia Militar, "Chile y el Perú", 11 de enero de 1919, p. 1.

1198 Idem.

${ }^{1199}$ El Sol, "Nuevos incidentes entre Chile y el Perú", 22 de diciembre de 1919, p. 6.
} 
La respuesta chilena, en el debate de notas diplomáticas, no se demoró. La Legación en Madrid envió a la prensa un informe desmintiendo las afirmaciones peruanas. Importantes diarios publicaron el documento que, en líneas generales, evidenciaba el correcto funcionamiento de la administración chilena en Tacna, Arica e Iquique. Las pruebas mostradas eran irrefutables. Los cónsules de diversos países asentados en las dos primeras ciudades firmaron voluntariamente, el 26 de noviembre, un documento testimoniando las garantías y derechos que Chile entregaba a todos los extranjeros.

La circular explicaba que el vicecónsul francés en Iquique, Georges Le Lorrain, informó al intendente chileno Recaredo Amengual que Llosa había escrito a los cónsules extranjeros declarando la razón de su partida. El escrito aludió al hostigamiento de terceros. La circular induce a pensar que Chile contaba con la confianza del representante francés. Le Lorrain demostró al intendente su confianza en que la retirada de Llosa no había sido provocada por chilenos violentos. Amengual tranquilizó al resto de los diplomáticos: "El intendente termina su comunicación al Cuerpo consular manifestando que la autoridad continuará asegurando a todos los habitantes de la provincia, y muy particularmente a los cónsules, el ejercicio de todas las garantías constitucionales y legales"1200. Seguidamente, el canciller chileno, Luis Barros Borgoño, envió a España otra circular enfatizando que las aseveraciones de Llosa estaban desautorizadas por los "cónsules de las demás Naciones extranjeras"1201. En sus palabras, la supuesta gravedad del problema era responsabilidad de su par peruano, deseoso de crear "un ambiente antichileno entre la opinión pública"1202.

Wilson no tardó en atender los disturbios de Iquique. Redactó una carta de marcado paternalismo que, lejos de sugerir soluciones al conflicto, evidenciaba su creencia en las asimetrías político-morales entre las repúblicas, en este caso del norte y sur de América. Una razón de tal diferenciación, es probable, fue el tenaz racismo del “árbitro de la paz” en el campo social y político ${ }^{1203}$.

${ }^{1200}$ El Heraldo, "El incidente chileno-peruano", 30 de noviembre de 1918, p. 2; El Sol, "El conflicto entre Chile y el Perú", 30 de noviembre de 1918, p. 2; La Correspondencia de España, "Incidentes entre Chile y Perú", 1 de diciembre de 1918, p. 5.

${ }^{1201}$ La Época, "El conflicto entre Chile y Perú", 2 de diciembre de 1918, p. 3.

${ }^{1202}$ El Día, "Chile y Perú", 4 de enero de 1919, p. 5.

1203 Palenzuela, Juan Carlos, Prontuario de la Norteamérica racista, Ediciones Centauro, 1976, p. 70; GonzÁlez CASANOva, Pablo y SAXe-FernÁNDez, John, El mundo actual: situación y alternativas, México, 


\section{Imagen n. ${ }^{\circ} 56$}

\section{EL ÁRBITRO DE LA PAZ}

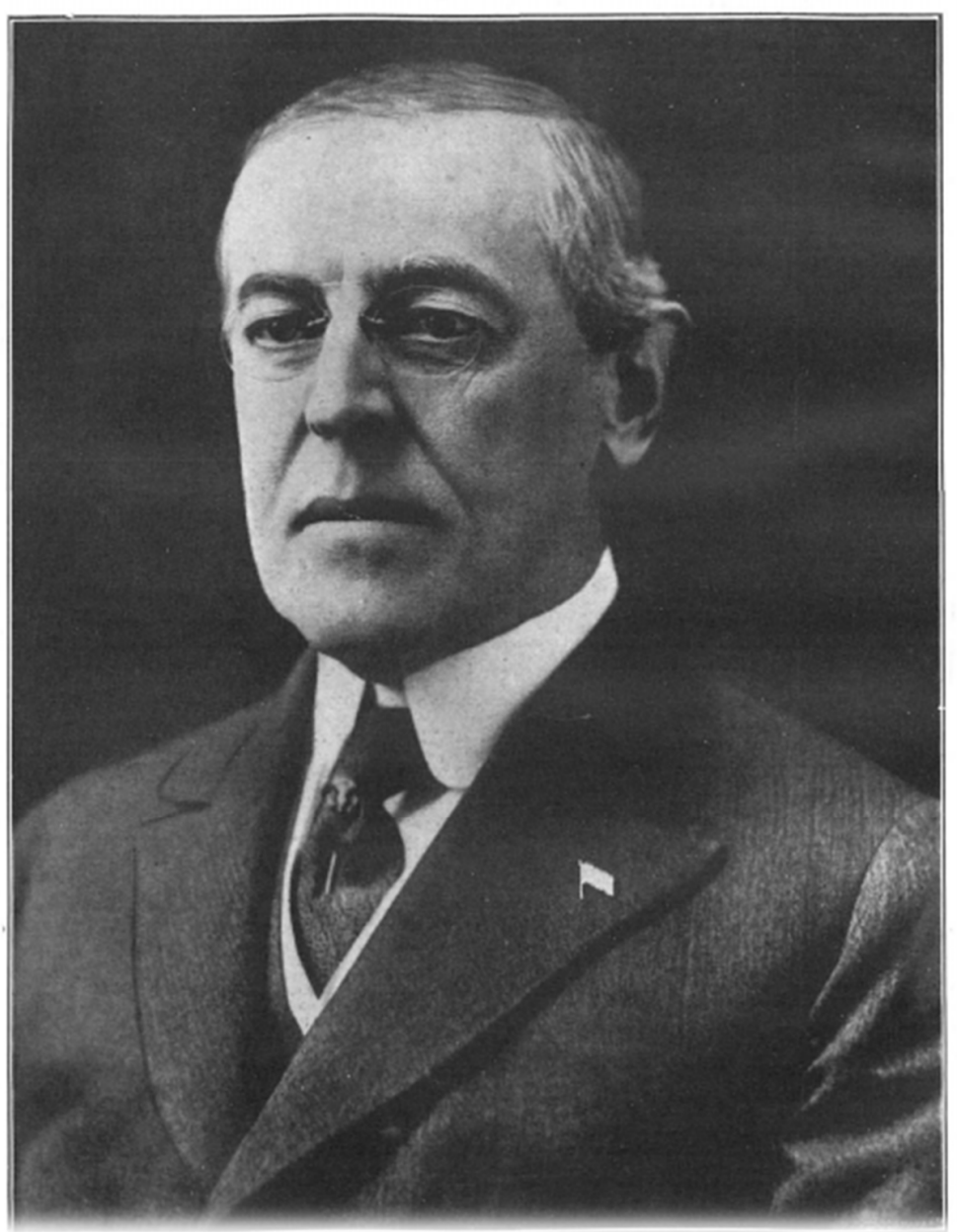

Fuente: Nuevo Murca'o, "El árbitro de la paz”, 18 de octubre de 1918, n. ${ }^{\circ} 1$ 293, p. 18.

Un número importante de diarios españoles reprodujeron la amenazante nota, minimizando las opiniones al respecto o, sólo presentando un resumen del interesante documento. El encabezado decía: "Mensaje del señor presidente Wilson entregado al señor presidente Sanfuentes por el embajador de los Estados Unidos el 6 de diciembre de 1918”:

El presidente de los Estados Unidos desea informar a su excelencia que el Gobierno de los Estados Unidos ha visto con la mayor aprensión varios incidentes que han producido la

Siglo XXI Editores, 2002, p. 37; RosZAK, Theodore, ;Alerta Mundo! El nuevo imperialismo norteamericano, Barcelona, Editorial Kairós, S. A., 2004, p. 176; GEOFFREY, Regan, Guerra, políticos y mentiras. Cómo nos engañan manipulando el pasado y el presente, Barcelona, Crítica, 2006, p. 17. 
suspensión de las relaciones consulares entre las repúblicas de Chile y del Perú. Cualquier agitación que pueda contrariar las perspectivas de paz permanente en el mundo, particularmente en vísperas de la convocación de la Conferencia de la Paz en París, en la cual se espera confiadamente que podrá avanzarse en el sentido de establecer una era de paz definitiva entre los pueblos, sería desastrosa y las personas que la provocaran cargarían ante el mundo con la grave responsabilidad de sus actos. El presidente de los Estados Unidos considera su deber llamar la atención de los Gobiernos del Perú y Chile hacia la gravedad de la actual situación y señalarles la obligación que tienen para con el resto del mundo y de la humanidad en general de tomar medidas inmediatas para reprimir la agitación popular y restablecer relaciones pacíficas. No puede dudarse que se llegará a una solución satisfactoria pacífica de las dificultades producidas entre los dos países y el Gobierno de los Estados Unidos está pronto para ofrecer, solo o conjuntamente con otros países de este hemisferio, toda la asistencia posible para llegar a una solución equitativa de la cuestión ${ }^{1204}$.

Por su parte, con una nota breve, el gobierno chileno comunicó sus puntos de vista a Wilson. La misma semana de su publicación, la prensa española comentó el fracaso de los buenos oficios estadounidenses en el problema chileno-peruano. Se escribió que Chile, unilateralmente, había rechazado la propuesta de la Casa Blanca. La fuente de información era Argentina, país que reconocía también el fracaso de sus ofrecimientos de buenos oficios. La tensión diplomática aumentaba, más aún porque la delegación inglesa de la Conferencia de la Paz declaró no intervenir, de modo alguno, en conflictos de la región sudamericana $^{1205}$. La respuesta chilena, hasta ese momento, de valioso tono soberano, estaba cargada de ironía y artificios:

El presidente ha recibido la amistosa declaración del señor presidente Wilson, que le informa de la aprensión con que ha visto el Gobierno de los Estados Unidos varios incidentes que han producido la suspensión de las relaciones consulares entre las repúblicas de Chile y del Perú. Le corresponde expresar, en respuesta, que dichos incidentes no han alterado en momento alguno la serenidad con que el Gobierno de Chile aprecia los sucesos que, en cualquier forma pueden producir inquietud en sus relaciones internacionales. El señor presidente de los Estados Unidos estima, con fundada razón, que sería desastrosa cualquier agitación que pudiera contrariar la perspectiva de una paz permanente en el mundo, y confiado en que la Conferencia de Paz, próxima a reunirse en París, habrá de avanzar en el sentido de establecer una era de paz definitiva entre todos los pueblos, sería

\footnotetext{
1204 El Sol, "El conflicto peruanochileno", 21 de diciembre de 1918, p. 5; El Día, "La cuestión Chileperuana", 26 de diciembre de 1918, p. 8; El Imparcial, "El incidente entre Chile y el Perú", 26 de diciembre de 1918, p. 3; El Liberal, "El conflicto chileno-peruano", 26 de diciembre de 1918, p. 2; El País, "Las relaciones entre Chile y Perú", 26 de diciembre de 1918, p. 2; El Siglo Futuro, "Chile y Perú", 26 de diciembre de 1918, p. 1; La Acción, "Documentos diplomáticos", 26 de diciembre de 1918, p. 5; La Época, "El conflicto entre Chile y Perú", 26 de diciembre de 1918, p. 3; La Nación, "Documentos diplomáticos", 26 de diciembre de 1918, p. 10.

${ }^{1205}$ La Acción, "Entre Chile y Perú", 23 de diciembre de 1918, p. 3; La Época, "El conflicto entre Chile y el Perú", 23 de diciembre de 1918, p. 1; La Correspondencia de España, "Chile y Perú", 24 de diciembre de 1918, p. 1.
} 
grande la responsabilidad en la que incurrieran ante el mundo los que tal agitación provocasen. El presidente de Chile considera oportuno expresar en esta ocasión que el pueblo chileno, felizmente en paz con todas las naciones desde hace treinta y cinco años, ha contraído todas sus energías a la obra de prosperidad y bienestar, ha sabido resolver con espíritu justiciero todas sus diferencias con sus vecinos y hace los más fervientes votos por la obra de la paz definitiva entre todos los pueblos que haya de plantearse en la Conferencia de París. El señor presidente Wilson llama la atención de los Gobiernos de Chile y del Perú hacia la obligación que tienen para con el resto del mundo y la humanidad en orden al mantenimiento de sus relaciones pacíficas. El presidente de Chile concuerda con tan elevado propósito y puede decir que siempre se ha esmerado su Gobierno en apartar todo incidente que pudiera alterar sin motivo las relaciones que mantiene con todos los pueblos, muy especialmente con diversos países del continente americano. Concluye el presidente de los Estados Unidos afirmando su convicción en la solución pacífica de las diferencias existentes y manifiesta a la vez hallarse pronto para ofrecer, solo o conjuntamente con otros países de este hemisferio, toda inasistencia posible para llegar a una solución equitativa de la cuestión. El presidente de Chile agradece y se complace en tomar nota de los amistosos sentimientos del Gobierno de los Estados Unidos, confiando en que la desinteligencia que Chile tiene pendiente con el Perú, que siempre ha procurado resolver, habrá de encontrar su solución definitiva en conformidad a los preceptos del tratado de Ancón que rige las relaciones de los dos países y a cuyo cumplimiento se halla vinculada la fe de la nación ${ }^{1206}$.

La posición de cancillería chilena debió reafirmarse en una circular posterior publicada a fines de enero de 1919 en España. La dura crítica internacional contra Chile, producida por la exitosa campaña acusatoria del Perú, agilizó la redacción de breves defensas, escritas en formato de notas diplomáticas. En la de enero, por ejemplo, se reafirmó el hecho de que el abandono consular de Llosa fue voluntario y no producto de persecuciones chilenas.

La cancillería chilena negó una segunda acusación peruana sobre actos de violencia sufridos por varias familias peruanas. Sólo reconoció un número mínimo de disturbios callejeros encabezados por chilenos, provocados por el conocimiento de dos ataques sufridos por consulados chilenos en Perú. A la par, la circular tildó de antojadiza la opinión limeña relativa al propósito chileno de expulsar a los peruanos de la zona salitrera y de la provincia de Tacna mediante persecuciones individuales.

\footnotetext{
${ }^{1206}$ El Día, "La cuestión Chile-peruana", 26 de diciembre de 1918, p. 8; El Imparcial, "El incidente entre Chile y el Perú", 26 de diciembre de 1918, p. 3; El Liberal, "El conflicto chileno-peruano", 26 de diciembre de 1918, p. 2; El País, "Las relaciones entre Chile y Perú", 26 de diciembre de 1918, p. 2; El Siglo Futuro, "Chile y Perú", 26 de diciembre de 1918, p. 1; El Sol, "La cuestión chilenoperuana", 26 de diciembre de 1918, p. 3; La Acción, "Documentos diplomáticos", 26 de diciembre de 1918, p. 5; La Época, "El conflicto entre Chile y Perú", 26 de diciembre de 1918, p. 3; La Nación, "Documentos diplomáticos", 26 de diciembre de 1918, p. 10.
} 
En la verdad chilena, la expulsión afectó, exclusivamente, a agitadores peruanos contrarios al orden público. A ellos se les aplicó, en todo momento, la Ley de Residencia. En este punto, la nota chilena jugó, una vez más, con la ironía: recordó al Perú su petición de expulsión de Tacna y Arica, hecha dos años antes, contra Guillermo Billinghurst y Augusto Durand. Al canciller chileno le desagradaba la posición ambivalente de su par peruano.

Así mismo, al político chileno le disgustó la ignorancia con que el político peruano explicaba, desde el nacionalismo y no desde la economía, la expulsión de obreros peruanos. Para demostrar la verdad de su justificación indicó las fluctuaciones del mercado salitrero, desde el comienzo de la guerra hasta aquellos momentos. Ahí se apreció cómo el inicio de la Guerra Mundial provocó en Tarapacá una demanda baja y un éxodo de trabajadores; luego una alta demanda de salitre para elaborar explosivos, retornando los antiguos obreros.

En esos días de bonanza, dijo el canciller, "los obreros chilenos aceptaron como siempre, sin reclamación alguna la competencia del brazo extranjero"1207. La escasez de trabajo volvió durante el armisticio de la guerra. Los siguientes datos demuestran la caída estrepitosa de la exportación de salitre chileno:

Tabla n. ${ }^{\circ} 11$

Exportación de salitre chileno entre 1913 y 1919

\begin{tabular}{|c|c|c|c|}
\hline Año & $\begin{array}{c}\text { Exportación en } \\
\text { toneladas métricas }\end{array}$ & Año & $\begin{array}{c}\text { Exportación en toneladas } \\
\text { métricas }\end{array}$ \\
\hline 1913 & 2738339 & 1917 & 2776365 \\
\hline 1914 & 1846783 & 1918 & 2919177 \\
\hline 1915 & 2023321 & 1919 & 915239 \\
\hline 1916 & 2988369 & 19 & \\
\hline
\end{tabular}

Fuente: Datos publicados por: ORTIZ LETELIER, Fernando, El movimiento obrero en Chile, Santiago, LOM Ediciones, 2005, pp. 38-39.

${ }^{1207}$ El Día, "Entre Chile y Perú", 23 de enero de 1919, p. 7; El Sol, "El conflicto entre Chile y Perú", 23 de enero de 1919, p. 6; La Correspondencia de España, "Chile y Perú", 23 de enero de 1919, p. 4; La Correspondencia Militar, "Entre Chile y el Perú", 23 de enero de 1919, p. 3; La Época, "Chile y Perú", 24 de enero de 1919, p. 4. 
Por último, al canciller le extrañó la forma en que su par peruano homologó las economías de Tarapacá, Tacna y Arica. Las últimas, recordó, no tenían actividad salitrera, sólo industrial y agrícola. Por lo mismo, la calma era completa, pues el pueblo confiaba en la "seriedad de las leyes chilenas y en la ejecución del tratado vigente que prescribe la celebración de un plebiscito" ${ }^{1208}$. La circular remarcó la tesis chilena en la cuestión de Tacna y Arica: la solución estaría ligada al pacto de Ancón, único método de entendimiento.

Las consecuencias políticas de la ruptura consular chileno-peruano fueron analizadas por versados internacionalistas, entre ellos, Adolfo Ortúzar, Alonso de Góngora y Jaime de Zulueta. Los primeros, colaboradores de La Época, el último de El Imparcial. El punto común en los peritos americanistas españoles fue la filiación hacia uno de las naciones contendientes. Mientras Ortúzar y Góngora fueron "chilenófilos”, Zulueta apoyó abiertamente la política exterior de la cancillería peruana.

Adolfo Ortúzar, por ejemplo, criticó el sinnúmero de noticias publicadas en Europa sobre diferendos americanos, por indisponer anímicamente y perturbar el criterio político de los lectores. El espíritu tendencioso de las noticias se debía a que eran producidas por sentimentalismos pasionales ${ }^{1209}$. Centrado en la "vieja cuestión"1210 de Tacna y Arica, vituperó a los creadores de la imagen de Chile como una "Nación de presa"1211 y a quienes compararon la situación fronteriza con la cuestión armenia que había alcanzado triste celebridad luego de la declaración de Turquía para exterminar "hasta el último individuo"1212 de los armenios. Ortúzar sabía los riesgos de publicar injurias en la prensa, pues, pasado el tiempo, las soluciones de los conflictos se separaban de su raíz, debiendo destinarse tiempo diplomático para aclarar acusaciones anteriores que envenenaron "la atmósfera"1213. Por ello intentaba desmontar las responsabilidades chilenas en las expulsiones peruanas. Para el español, del mismo modo que para la cancillería chilena, la salida de los peruanos del desierto se relacionaba con la crisis mundial del salitre.

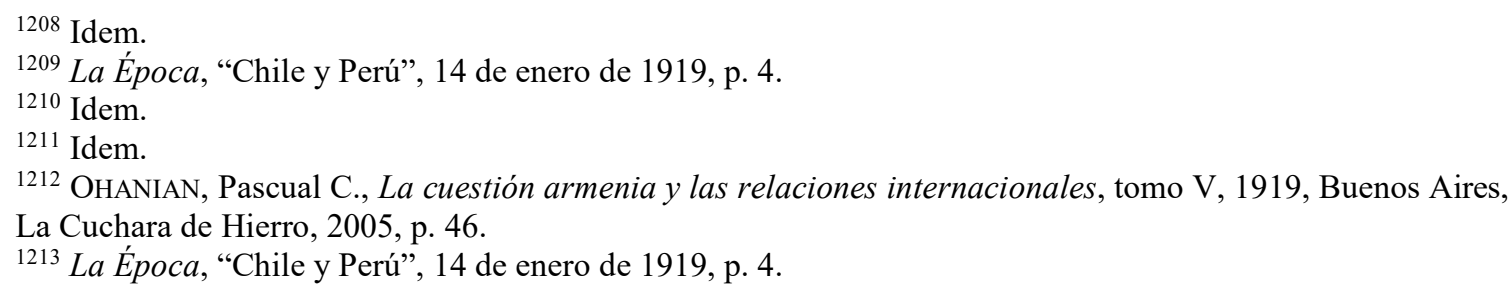


Así mismo, comprendía que los ciclos de depresión y bonanza económica en esa industria eran comunes. Por eso, relativizaba incluso el argumento económico. Si eso fuese cierto, dijo, "no probaría nada: pues sucede a menudo [...] que tan pronto esta industria disminuye por cualquier causa, su producción, los trabajadores, casi automáticamente, se ven obligados a emigrar a las provincias del Sur del país, en busca de otro trabajo" ${ }^{1214}$. Por tal razón, los lectores europeos debían considerar la paralización de la fabricación de explosivos causada por el armisticio. Ellos mismos eran testigos de cómo fue necesario "reconstruir lo devastado por la guerra, convertir la industria bélica en industria de paz y, sobre todo, enfrentar el problema de la desocupación masiva de los excombatientes" 1215 .

El escritor español sostuvo que las acusaciones peruanas del incumplimiento del tratado de 1883 contra Chile eran infundadas. Adujo que, de ser cierta la rebeldía chilena para cumplir los compromisos internacionales, no sería "bien considerado" 1216 ante todos los países. El apologista de Chile apreciaba el constitucionalismo, la gobernabilidad y el ethos laborioso de los chilenos:

Chile es un país que ha desarrollado su existencia a la sombra de la libertad y del derecho; su política ha sido siempre de orden y de buen sentido; su Gobierno estable, y su historia entera, no es más que un capítulo breve, pero intenso, de esfuerzo, de sacrificio, de abnegación en cumplimiento fiel de sus compromisos. De esto nace precisamente el respeto que inspira en el mundo el crédito de Chile $[\ldots]^{1217}$.

El interés de La Época, en esta etapa del conflicto chileno-peruano, se sintetizó en un prólogo al escrito de un corresponsal español en Chile, de seudónimo "Alonso de Góngora", en honor al autor de la Historia de Chile desde su descubrimiento hasta el año $1575^{1218}$. El diario reafirmó su preocupación por establecer relaciones con la América española, máxime en el momento actual, para fortalecer "nuestra política exterior"1219. Un requisito indispensable para esa fortificación diplomática era la información de los países donde la acción del gobierno español debía influir.

${ }^{1214}$ La Época, “Chile y Perú", 14 de enero de 1919, p. 4.

1215 Rossi, Annunziata, Fascismo en Europa, México, Universidad Nacional Autónoma de México, 2006, pp. 29-30.

${ }_{1216}$ La Época, "Chile y Perú", 14 de enero de 1919, p. 4.

1217 Idem.

1218 Góngora Marmolejo, Alonso de, Historia de Chile desde su descubrimiento hasta 1575, Santiago, Editorial Universitaria, 1969.

${ }^{1219}$ La Época, "El conflicto chileno-peruano", 10 de febrero de 1919, p. 3. 
Chile en España, escribió el prologuista, era una de las repúblicas desconocidas y sólo hacía eco su industria salitrera; el país "merecía una atención predilecta"1220. Así, como en años anteriores, las descripciones geográficas del territorio fueron un punto de partida para facilitar a los lectores un cuadro concreto que imaginar. Ahora se comparó la extensión del país con la de España, siendo aquel equivalente a "una España y media"1221. Además de las conocidas salitreras, poseía otras zonas mineras, agrícolas, vinícolas, madereras y carboníferas.

Culturalmente, Chile aprovechó la influencia europea, sin llegar a extranjerizarse, fusionando los aportes de diversos países. La chilenidad, siguiendo a Góngora, podía resumirse así: "De Inglaterra tomó la influencia naval; de Alemania, la militar y el espíritu de organización; de Francia, la industrial y agrícola; de los Estados Unidos, la mercantil; de España, la tradición y el espíritu" ${ }^{1222}$. Sospechosamente, el hispano-chileno evadió las poderosas influencias de los países limítrofes. En escritos posteriores el diario refirió la magnitud de la chilenidad, un sentimiento "vibrante", "poderoso" y "agitado" en los momentos en que Perú quería aprovecharse del momento político internacional ${ }^{1223}$.

Tales manifestaciones de patriotismo, en la interpretación del escritor, sólo ocurrían mezclando un nacionalismo profundo con "la razón"1224. El pueblo chileno tenía la mística de un origen incierto que "no se sabe de dónde se formó, quizás tampoco a donde a va, pero que es firme" 1225 . La elite, por su parte, reflejaba el sentir nacional en libros, discursos y otras manifestaciones de elevada cultura. El "chilenófilo" ensayista, fascinado por el nacionalismo amoroso del país que lo acogió, remarcó la modernidad consolidada de su política y economía. De los problemas sociales y las articulaciones locales de la industrialización, conocidos como la "cuestión social chilena" de la que el proletario tarapaqueño fue arquetipo ${ }^{1226}$, no hacía declaraciones:

\footnotetext{
${ }^{1220}$ Idem.

${ }^{1221}$ Idem.

1222 Idem.

${ }^{1223}$ La Época, "El conflicto chileno-peruano", 20 de mayo de 1919, p. 3.

${ }^{1224}$ La Época, "Chile y el Perú", 18 de agosto de 1919, p. 3.

1225 Idem

1226 GONZÁlez MiRANDA, Sergio, Hombres y mujeres de la pampa. Tarapacá en el ciclo de expansión del salitre, Santiago, LOM Ediciones, 2002, p. 71.
} 
Esto pasa en Chile, porque crean los lectores de La Época, que no es aventurado afirmar que Chile es el país de la América española más consciente de su nacionalidad, de un orgullo patriótico mayor. Se siente en plenitud el progreso; ve la tranquilidad pública asentada sobre bases firmes; el principio de autoridad respetado; el porvenir con un horizonte de amplísimas prosperidades; y todo ello le hace aumentar su patriotismo, porque en los pueblos [...], el vigor -lo mismo cuando se manifiesta en altas espiritualidades que cuando se refleja en riquezas materiales- es cualidad que atrae el amor ${ }^{1227}$.

Los años de la Guerra Mundial y los posteriores vieron aparecer una nueva forma de noticiar la política. Como explicó Clark, las noticias comenzaron a publicarse exacerbando el patriotismo en los asuntos internacionales ${ }^{1228}$. Por ejemplo, en otra opinión de Góngora sobre Chile, referida a las obras públicas en Tacna y Arica -de las que el Perú sólo criticaba- así se demuestra:

Chile, como se ve, es un país que sabe aprovechar su orden, su paz interior, en un progreso incesante que le augura un gran porvenir, un puesto principalísimo en América. ¡Qué grave error y qué tremenda responsabilidad para los directores de la política española el dejar que transcurran días y más días sin que los lazos de filial afecto entre España y Chile se hagan más prácticos, y su intimidad sea algo más que lírica! ${ }^{1229}$ En el plano político, a diferencia del Perú, ha sabido mantener el orden interno. Los pronunciamientos militares, las revoluciones, el caudillismo, etc. no son obstáculos para el normal funcionamiento de la república. Aquellas situaciones de convulsión política más bien "son allí planta exótica"1230.

Alonso de Góngora dedicó íntegramente su artículo de enero a comentar la agudización del conflicto chileno-peruano ocasionado por la ruptura consular. En virtud de la veracidad de su opinión, respaldó su análisis en la obra El conflicto después de la victoria escrita por el diplomático chileno Julio Pérez Canto ${ }^{1231}$. Haciendo una breve biografía del político, repasando su consulado en Londres, la dirección de El Mercurio de Santiago y Valparaíso, y el cometido diplomático en Lima en 1908, reemplazando a José Miguel Echenique Gandarillas ${ }^{1232}$, luego comentó el capítulo "La historia de una República”. Ahí comparó, en detalle, la estabilidad política chilena con la secular anarquía peruana.

${ }^{1227}$ La Época, "Chile y el Perú", 18 de agosto de 1919, p. 3.

1228 CLARK, Toby, Arte y propaganda en el siglo XX. La imagen política en la era de la cultura de masas, Madrid, Ediciones Akal, S. A., 2000, p. 104.

${ }^{1229}$ La Época, "Desde Chile", 24 de octubre de 1919, p. 3.

${ }^{1230}$ Idem.

${ }^{1231}$ PÉREZ CANTO, Julio, El conflicto después de la victoria, Recuerdo e impresiones de un ex-diplomático chileno en el Perú. La última discusión del problema de Tacna y Arica, Santiago, Edición de la empresa ZigZag, 1918.

${ }^{1232}$ Benavides Correa, Alfonso, Una difícil vecindad. Los irrenunciables derechos del Perú en Arica y los recusables acuerdos peruano-chilenos de 1985, Lima, Universidad Nacional Mayor de San Marcos, 1988, p. 57. 
Góngora, con su batería argumental, defendió la posición chilena que negaba la posesión ilegal de Tacna y Arica. Criticaba, por eso, la denominación de aquellas como la "Alsacia y Lorena de América", asegurando que Chile había cumplido siempre el Tratado de Ancón, llevando progreso a esos territorios. En efecto, Chile conquistó Tacna y Arica y “transformó la ocupación militar en ocupación jurídica [...] Chile, en fin, no vaciló en hacer sacrificios de orden cultural y económico en las referidas comarcas, y en cambio el Perú pareció inclinado a no ocuparse más de ellas, según [...] Guillermo Billinghurst”"1233.

Otro escrito de Góngora, refiriéndose nuevamente a la obra de Pérez Canto, se publicó en España. En él insistió sobre la consideración del libro que constituía, a su juicio, un archivo de antecedentes y desarrollo de la litis. En El conflicto después de la victoria..., Pérez Canto argumentó que la retención de Tacna y Arica era estratégica, de amor a la paz sudamericana y de respeto al plebiscito como mecanismo diplomático. En efecto, siendo la rica zona de Tarapacá accesible al Perú por el norte, Chile debió establecer bases militares en Tacna y Arica. Además, la implementación de la soberanía chilena en esas provincias permitía que otros países no desearan su conquista.

En palabras del diplomático, "Tacna y Arica, en poder del Perú sería una presa codiciada por Bolivia. La anexión puede, pues, considerarse como elemento que conservará la paz americana"1234. El problema de Pérez Canto en la explicación del significado del artículo n. ${ }^{\circ} 3$ es que hace suyas las declaraciones realizadas tiempo atrás por Luis Aldunate, canciller chileno en 1883, creador de la tesis de la "cesión encubierta" de Tacna y Arica. De todos modos, para el chileno, el problema era sólo peruano, pues su clase política desatendió el territorio, mirado desde Lima, sureño. Perú -escribió Pérez Canto- debió consignar presupuestariamente la cantidad necesaria para pagar a Chile los diez millones de pesos, si el plebiscito los favorecía; "Piérola gastó los fondos acumulados en combatir la revolución de Vizcarra y Durand, y desde 1886 a 1894 no se consignó nada en el presupuesto peruano para prevenir la contingencia" ${ }^{1235}$. Ante esos hechos, preguntaba ¿No era esto una aquiescencia implícita a la enajenación de la soberanía de Tacna y Arica?

\footnotetext{
${ }^{1233}$ La Época, "El conflicto chileno-peruano", 10 de febrero de 1919, p. 3.

${ }^{1234}$ La Época, "Tacna y Arica”, 2 de marzo de 1919, p. 3.

1235 Idem.
} 
En columnas posteriores, Góngora continuó resumiendo estudios que legalizaban la ocupación chilena en Tacna y Arica. Un ejemplo fue Tacna y Arica después del Tratado de Ancón de Anselmo Blanlot Holley ${ }^{1236}$ y Las causas de las guerras entre Chile y Perú de Gonzalo Bulnes ${ }^{1237}$. Tal cual lo explicó, sus análisis eran benéficos, porque el diferendo para "muchos españoles, y más aún para muchos europeos, se presentará como enmarañada, siendo clara [...]"1238. El problema real, diagnosticado por el letrado Góngora, era la ignorancia de los españoles sobre la historia de América la que "se conoce muy poco" 1239 . Por el contrario, uno de los problemas de este "gongorismo" periodístico era la presentación de ideas, pobremente elaboradas, con estatus de verdad trascendente.

Según Góngora, Blanlot demostraba la victimización peruana, actitud consolidada durante la posguerra. Sin embargo, Chile poseía la documentación probatoria de cómo había sido arrastrado por Perú y Bolivia hacia la guerra. Blanlot, quien durante su estadía en Tacna fue un disciplinado "chilenizador" ${ }^{240}$, ofrecía pruebas. Con décadas de anterioridad, la perfidia peruana se presentó con la deuda impaga de los servicios militares chilenos prestados para independizar el virreinato; luego con la creación de la Confederación Peruano-Boliviana de 1836, proyecto imperialista en detrimento de Chile; por último, con la alianza peruano-boliviana de 1873, países que persuadieron sin éxito a Argentina y por lo cual Chile debió cederle grandes extensiones patagónicas.

Para Góngora y Blanlot la interpretación peruana del tratado era la causa principal del encono nacionalista, lectura que afirmaba la ilegalidad del mismo. Ambos renunciaban al arbitraje de terceros países, potencialmente los que liderasen las Conferencias de la Paz, para resolver la cláusula plebiscitaria. Ambos, también, afirmaban el derecho chileno de coordinar el plebiscito dictando "las condiciones, porque la emisión del sufragio es un acto de ciudadanía, y esta clase de actos los regula quien hace de soberano [...]"1241.

\footnotetext{
1236 Blanlot Holley, Anselmo, Tacna y Arica después del Tratado de Ancón, Santiago, Imprenta Universitaria, 1917.

${ }^{1237}$ BuLnES, Gonzalo, Las causas de la guerra entre Chile y el Perú, Santiago, Sociedad Impr. Litográfica Barcelona, 1918.

${ }^{1238}$ La Época, "El conflicto chileno-peruano", 20 de mayo de 1919, p. 3.

${ }^{1239}$ La Época, "Chile y el Perú", 18 de agosto de 1919, p. 3.

1240 Palacios RodrígueZ, Raúl, La chilenización de Tacna y Arica, Lima, Editorial Arica, 1974, p. 67.

${ }^{1241}$ La Época, "El conflicto chileno-peruano", 20 de mayo de 1919, p. 3.
} 
El escritor del seudónimo vio en el texto de Bulnes virtudes similares que en el de Blanlot. Alabó en Las causas... la buena documentación, serenidad y el interés demostrado hacia antecedentes ignorados por muchos ${ }^{1242}$. Por eso, el libro era crucial para comprender las relaciones chileno-peruanas. Algunos detalles trabajados en la obra fueron la aceptación del principio del uti possidetis, una barrera legal para el res nullius ${ }^{1243}$. Otros fueron las dificultades chileno-bolivianas para delimitar fronteras en Atacama, pues se ignoraba si España confió ese territorio a Charcas o a la Capitanía General de Chile. Descifraron esa incógnita Luis Amunátegui, chileno, y José María Santibáñez, peruano, quienes "registraron los archivos coloniales" ${ }^{1244}$, reuniendo pruebas y contrapruebas.

La propaganda literaria peruana tuvo un impacto similar en España. Entre el Perú y Chile. La cuestión de Tacna y Arica de Enrique Castro y Oyanguren ${ }^{1245}$ y El conflicto entre Perú y Chile (1879-1919), folleto de José Gálvez, fueron anunciadas en diferentes publicaciones ${ }^{1246}$. De particular interés fue la segunda, pues el autor era, además, cónsul en Barcelona. Su estudio evidenció el conocimiento del asunto y un elegante estilo para explicar un pleito similar "al que hasta ayer mismo ha sostenido Francia contra Alemania por la Alsacia y la Lorena"1247. El texto manifestó que la razón en el litigio asistía al Perú, solicitando, por ello, justicia a la Liga de las Naciones. A ésta, Perú se acogía con la abnegación siempre puesta hacia "las grandes causas de la Humanidad"1248. La Revista Hispanoamericana Cervantes patrocinó las ideas de Castro, convencida de que debían terminarse todas las diferencias nacionales para inaugurar una era de solidaridad humana. El ideólogo, detrás de ese anhelo, era Wilson, quien planificó la paz eterna en base "de un cambio completo de la organización internacional" 1249.

\footnotetext{
${ }^{1242}$ La Época, "Chile y el Perú", 18 de agosto de 1919, p. 3.

${ }^{1243}$ En ediciones anteriores algunos diarios comentaron, siguiendo al historiador chileno Diego Barros Arana, las implicancias fronterizas para Chile producidas por su adhesión al principio del uti possidetis de 1810. En: El Día, "Perú, Bolivia y Chile", 21 de mayo de 1909, p. 3; El Globo, "Perú, Bolivia y Chile", 21 de mayo de 1909, p. 3.

${ }^{1244}$ La Época, "Chile y el Perú", 18 de agosto de 1919, p. 3.

1245 CAStro y Oyanguren, Enrique, Entre el Perú y Chile: la cuestión de Tacna y Arica...

${ }^{1246}$ España, "Libros y revistas", 21 de agosto de 1919, n. ${ }^{\circ}$ 212, p. 8; Revista Hispanoamericana Cervantes, "Actualidad Iberoamericana", abril de 1919, (sin dato de número), pp. 151-152.

${ }^{1247}$ Revista Hispanoamericana Cervantes, “Actualidad Iberoamericana”, abril de 1919, (sin dato de número), pp. 151-152.

1248 Íbidem.

1249 PERTIERRA DE ROJAS, José Fernando, Las relaciones internacionales durante el período de entreguerras, Madrid, Ediciones Akal S. A., 1990, p. 19.
} 
Jaime de Zulueta, otro analista internacional, pretendió con un reportaje brevísimo informar de los orígenes y consecuencias de la guerra, así como de la actualidad de la posguerra a raíz del incidente consular ocurrido en Iquique. Los errores históricos básicos sobre el gérmen de la guerra no tardaron en aparecer. Puntualmente, señaló que el incumplimiento de los tratados chileno-bolivianos, previos a la guerra, originó la ruptura de las relaciones entre ambos países -cuando en verdad el decreto de expropiación de la empresa chilena Nitrates and Railway Company of Antofagasta, firmado por el presidente boliviano Hilarión Daza, hizo estallar la guerra- impedía clarificar el inicio del conflicto. Además, el desembarco chileno en Antofagasta, ocurrido el 14 de febrero de 1879, era fechado por Zuleta el "18 de febrero" 1250 .

$\mathrm{Su}$ antichilenismo se manifestó al evaluar positivamente la misión mediadora que Perú, por medio de su ministro "Lavae (sic)"1251, refiriéndose a José Antonio Lavalle, desarrolló en Santiago al desatarse la guerra entre Chile y Bolivia. En Santiago, por el contrario, la visita de Lavalle se consideró una estrategia peruana dilatoria para ganar tiempo en organizar la guerra, pues lo unía con Bolivia el tratado de 1873. El Gobierno chileno -escribió Zulueta- al “devolver al ministro sus pasaportes, le incluía una nota declarando la guerra al Perú [...] fundándose en haber considerado como acto de hostilidad la visita del ministro [...]"1252. En la interpretación del español, Perú evitaba, por todos los medios, la guerra contra Chile, consciente de su desorganización interna e insuficiencia militar, y la aceptó sólo por razones de "honor y decoro patrio"1253. La posición chilena oficial, no exenta de especulaciones ${ }^{1254}$ en este asunto, asegura que Lavalle viajó a Chile para "ganar tiempo y despistar a Chile sobre la existencia del Pacto Secreto"1255. El valedor español de Perú, para explicar la actualidad del conflicto, incluyó sólo un ejemplo de las varias negociaciones entre Chile y Perú para resolver la cuestión de Tacna y Arica.

\footnotetext{
${ }^{1250}$ El Imparcial, "El conflicto chileno-peruano", 15 de enero de 1919, p. 4.

${ }^{1251}$ Idem.

1252 Idem.

1253 Idem.

1254 Villalobos R., Sergio, Chile y Perú. La historia que nos une y nos separa (1535-1883), Santiago, Editorial Universitaria, 2002, p. 143.

1255 Ruiz-Tagle OrRego, Emilio, Bolivia y Chile: el conflicto del Pacifico, Santiago, Editorial Andrés Bello, 1992, p. 153.
} 
Escogió, sin duda, donde resaltara la intención peruana de resolver el diferendo. De tal modo, mencionó las gestiones de 1907, año en que se protestó por el incumplimiento del tratado y cuando, además, la política exterior chilena era más censurable, pues "no sólo no se había hecho, sino que Chile gestionaba anexionarse nuevos territorios y la diócesis de Arequipa" 1256 .

El avasallamiento chileno en Tacna y Arica hizo que Zulueta aprobara la petición de los buenos oficios, realizada por el Perú, a Wilson. Sin considerar la posición de la prensa chilena, Zulueta tomó párrafos de El Comercio, el "órgano más prestigioso de Lima"1257, donde Perú reveló la sumisión de su diplomacia, dependiente de organismos o países no involucrados en el diferendo. El diario limeño, metafóricamente, pidió al Palacio Pizarro tocar las puertas de las cancillerías de las naciones civilizadas, preguntando si el imperio del derecho sólo fue conquistado por "Europa y si, abatido en el viejo continente el régimen de la fuerza, ha de continuar subsistiendo en el hemisferio americano"1258.

El pacificador Zulueta, previendo la posibilidad de una ruptura diplomática, propuso a los líderes políticos chilenos y peruanos efectuar nuevas tácticas para calmar las "bélicas manifestaciones del sentimiento nacional" ${ }^{1259}$. Sugería la intervención de países americanos o llevar al Congreso de la paz las reclamaciones peruanas ${ }^{1260}$. Dos meses después, en la Conferencia de los países neutrales, celebrada en París, Maximiliano Ibáñez -representante en Chile del tradicionalismo y de las prácticas políticas "obsoletas"1261 - aseguró que el diferendo sólo se resolvería de acuerdo con el Tratado de Ancón. El diario que comentó la posición del agente chileno, confundiendo una vez más la economía de la región, señaló que Ibáñez defendía la inviolabilidad del tratado para toda investigación de la Conferencia de la Paz, pues así "las provincias peruanas de Tacna y Arica que constituyen la mayor riqueza salitrera del mundo, continuarán bajo el pabellón de la estrella solitaria, y en América seguiría latente el peligro de una conflagración continental ${ }^{1262}$.

\footnotetext{
${ }^{1256}$ El Imparcial, "El conflicto chileno-peruano", 15 de enero de 1919, p. 4.

1257 Idem.

1258 Idem.

1259 Idem.

1260 Idem.

${ }^{1261}$ IZQUIERDO, Gonzalo, Historia de Chile, tomo III, Santiago, Editorial Andrés Bello, 1990, p. 29.

1262 El Sol, "Chile", 3 de mayo de 1919, p. 4. (Las cursivas son nuestras).
} 
La importancia de la prensa en su papel de crítico del conflicto se notó por la rapidez en que la Legación chilena en Madrid rectificó al periodista. Al día siguiente, además de corregir otros puntos, explicó: "El autor de los comentarios [...] se equivoca también en la importancia que atribuye a la posesión de dichas provincias, o sea en lo que respecta a su riqueza" "263, pues, la industria salitrera no tiene relación "con la posesión de Tacna y Arica, donde no se ha comprobado [...] la existencia de yacimientos de salitre"1264.

Francisco Anaya Ruiz, periodista de Nuevo Mundo, también sintió atracción por Tacna y Arica. Consideraba que era un problema de la "América Hispana" que debía tratarse como español. Por eso, analizaba con patriotismo e imparcialidad. En el historicismo de Anaya, el pasado sudamericano se resumía en las discordias chilenoperuanas por dominar el Pacífico y por el anhelo del último para unirse con Bolivia. Los hechos, aseguraba, demostraron que los chilenos fueron más hábiles y previsores, quienes al comenzar la guerra estaban en condiciones de manifiesta desventaja ${ }^{1265}$ que, valga mencionarlo aquí, no fueron descritas por el español.

Para Anaya, las causas de la guerra eran económicas. Los gravámenes que Bolivia decretó contra las industrias salitreras chilenas, que éstas se negaron a pagar violando "obligaciones contractuales" 1266 - sin mencionar ninguno de los tratados previos que prohibían el incremento de impuestos- produjeron la ocupación chilena de Antofagasta. Chile, además, "calificando de sospechoso"1267 el viaje de Lavalle "le declaró también la guerra"1268 al Perú. Su final, mediante el pacto de Ancón, contempló un plebiscito "desgraciadamente" no realizado" ${ }^{269}$. El análisis del diferendo fue acompañado con una cartografía de los departamentos en litigio y la importancia geopolítica, debido al "acceso [...] sobre el Océano Pacífico"1270, para Chile, Perú y Bolivia.

\footnotetext{
${ }^{1263}$ El Sol, "Informaciones de Ibero América", 5 de mayo de 1919, p. 3.

1264 Idem.

${ }^{1265}$ Nuevo Mundo, "El conflicto entre Perú y Chile", 31 de enero de 1919, n. ${ }^{\circ} 1$ 308, p. 21.

1266 Bustos, Carlos, "Dos siglos de relaciones chileno-bolivianas". En ARTAZA Rouxel, Mario y MiLET GARCÍA, Paz (Editores), Nuestros vecinos, Santiago, RIL Editores, 2007, p. 193.

${ }^{1267}$ Nuevo Mundo, "El conflicto entre Perú y Chile", 31 de enero de 1919, n. ${ }^{\circ} 1$ 308, p. 21.

1268 Idem.

1269 Idem.

1270 SALGAdo Brocal, Juan C. y IzURIETA FERRER, Oscar, Las relaciones bilaterales chileno-peruanas contemporáneas: un enfoque realista, Santiago, Biblioteca Militar, 1992, p. 202.
} 


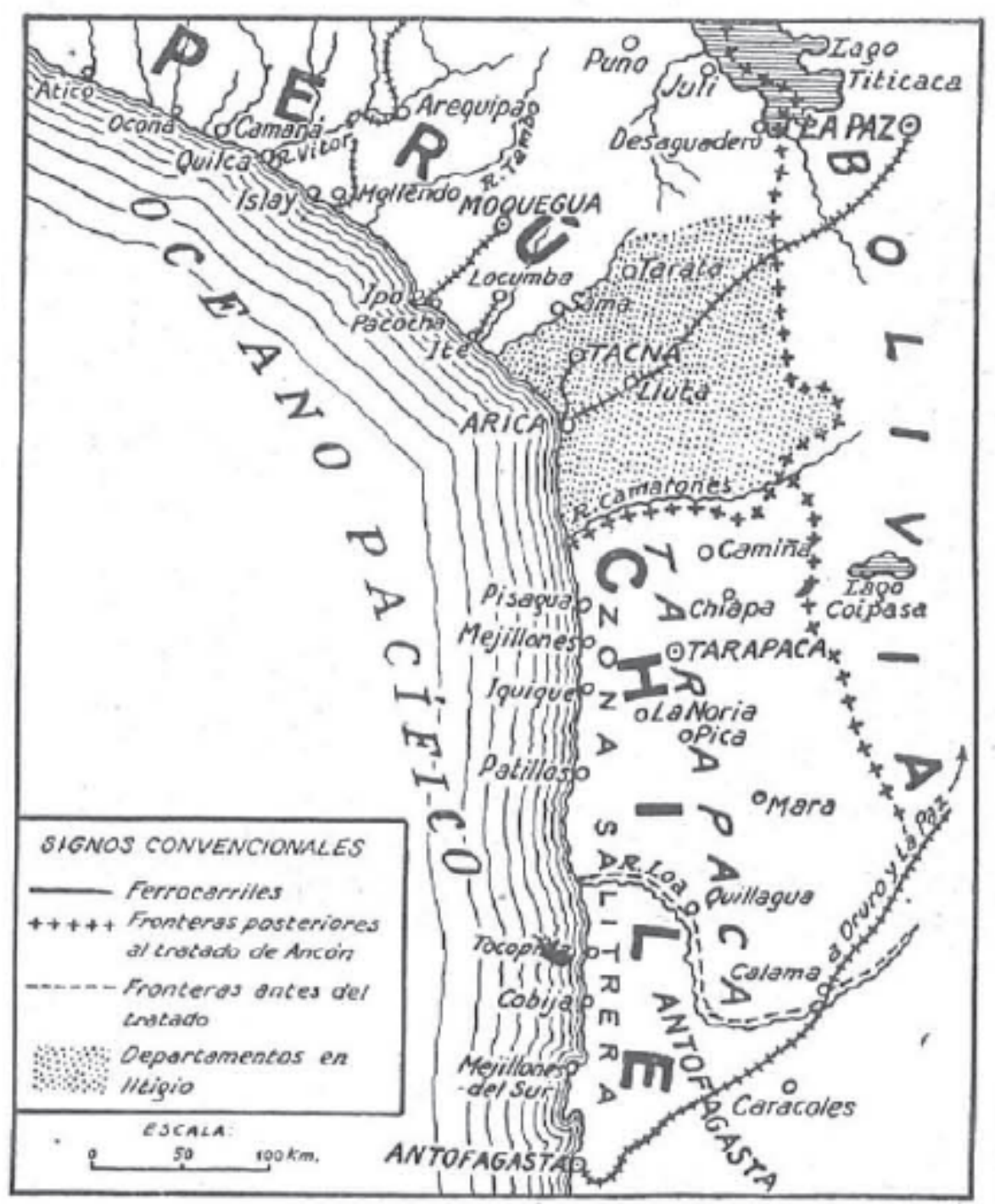

Fuente: Nuevo Mundo, "El conflicto entre Perú y Chile (mapa de la frontera)", 31 de enero de 1919, n. ${ }^{\circ} 1308$, p. 21.

El Perú, aliadófilo durante la guerra mundial, creyó oportuno realizar "manifestaciones reivindicadoras de sus antiguos territorios de Tacna y Arica; manifestaciones $[\ldots]$ contestadas en Chile con otras de sentido contrario"1271. Episodios de violencia, como los sucedidos en Iquique, cercanos al casus belli fueron apaciguados por el presidente Wilson.

${ }^{1271}$ Nuevo Mundo, "El conflicto entre Perú y Chile", 31 de enero de 1919, n. ${ }^{\circ} 1$ 308, p. 21. 
Pareciera que Anaya recuerda al mandatario estadounidense con una intención comparativa, pues consideraba indispensable, para la proyección internacional española, cambiar los "moldes arcaicos" 1272 usados para fomentar un americanismo que por esos años se replegaba sobre sí, siendo más "doméstico"1273 que universal. Así mismo, criticaba las instituciones llamadas ibero o hispanoamericanas, donde sólo se consumían "azucarillos y pesetas"1274 y que incumplían el objetivo de vincularse efectivamente con las repúblicas americanas. Le parecía inadecuada, por último, la flemática diplomacia española, incitando, desde la revista, a sus connotados cófrades para que opinasen sobre los conflictos americanos.

Anaya iba más lejos que los anteriores especuladores, asignando un novedoso papel a los partidos políticos españoles "turnantes (conservador y liberal)"1275, quienes imperativamente debían encargase de los problemas americanos. En sus palabras "Esos partidos políticos que tanto se parecen por las menudencias, egoísmos y cominerías locales, también debieran ampliar sus miras hacia los magníficos horizontes que nos brinda el Nuevo Mundo"1276. El conflicto fronterizo desencadenaba la ira intelectual de Anaya quien criticaba con severidad su gobierno "acostumbrado a vivir al día, marchando a remolque de los acontecimientos (en lugar de anticiparse a ellos)"1277.

Es más, su espíritu justiciero le hizo pensar en la misión filántropa de España, quien debía ofrecer sus buenos oficios apenas surgiesen inconvenientes entre las repúblicas de "raza y lengua españolas"1278. Confiado en su pragmatismo, preveía que esa ayuda sería aceptada y, además, nunca dejaría de agradecerse. Para el caso de Tacna y Arica, Anaya explicaba que el gobierno español aún estaba a tiempo de intervenir como un amigable componedor, prosiguiendo de la siguiente manera:

\footnotetext{
1272 Idem.

1273 VÉLEZ, Palmira, La historiografía americanista en España, 1755-1936, Madrid-Frankfurt, Iberoamericana-Vervuert, 2007, p. 14.

${ }^{1274}$ Nuevo Mundo, "El conflicto entre Perú y Chile", 31 de enero de 1919, n. ${ }^{\circ} 1$ 308, p. 21.

1275 GONZÁlez Portilla, Manuel, "Poder y lobbies económicos en la restauración: La transformación de la clase política”. En Chalmeta, Pedro, Checa Cremades, Fernando, GonzÁlez Portilla, Manuel, et al., Cultura y culturas en la historia, Salamanca, Ediciones Universidad de Salamanca, 1995, p. 119. (119-168)

${ }^{1276}$ Nuevo Mundo, "El conflicto entre Perú y Chile", 31 de enero de 1919, n. 1 308, p. 21.

1277 Idem.

1278 Idem.
} 
Ciñéndonos al caso presente de Perú y Chile, todavía puede estar a tiempo nuestro Gobierno de intervenir como amigable componedor (eludiendo, claro está, la menor rozadura con los Estados Unidos), teniendo en cuenta la estimación y el cariño que se tiene por España en aquellos países. La prueba de lo que decimos es que, en el único protocolo que se ha firmado después del Tratado de Ancón entre Perú y Chile en 1898, llamado Billinghurst-Latorre, se estipuló que las dos Cancillerías someterían al arbitraje de la Reina de España los puntos capitales de la divergencia. Aunque ese convenio sólo fue aprobado por el Gobierno peruano, pues el Congreso chileno no le prestó su asentimiento, siendo ahora mucho más favorables las circunstancias en que se encuentra España con respecto a aquellas repúblicas [...] es lógico pensar que el arbitraje o el consejo del rey Don Alfonso XIII podrá asegurar o facilitar el arreglo ${ }^{1279}$.

La ruptura consular de 1918 entre Chile y Perú, producida por los arrebatos de Iquique, fue protagonizado principalmente por el cónsul peruano en ese puerto salitrero, Santiago Llosa y las autoridades chilenas. Las dimensiones políticas del conflicto, íntimamente relacionadas con la cuestión de Tacna y Arica, produjeron un acentuado interés en la prensa española. Así quedó de manifiesto, por ejemplo, en el alto número de informaciones obtenidas en América, pero también por las extendidas opiniones ensayadas por algunos analistas internacionales quienes asumieron posiciones favorables o contrarias ante la política exterior chilena. El trasfondo económico del rompimiento consular fue puesto en el centro del discurso periodístico. Y, más importante aún, provocó el entusiasmo de escritores hispanoamericanistas, no sólo por conocer el estado de las relaciones chilenoperuanas, sino también por participar activamente en su solución final.

\footnotetext{
${ }^{1279}$ Idem.
} 


\section{AGONÍA DEL HISPANOAMERICANISMO: EL ARBITRAJE DE LOS ESTADOS UNIDOS Y LA SOLUCIÓN DE LA CUESTIÓN DE TACNA Y ARICA (1922-1929)}

Este periodo evidencia los discursos periodísticos españoles elaborados durante la actuación protagónica de los Estados Unidos en el conflicto. Al mismo tiempo, refleja un aumento progresivo de noticias frente al diferendo que, mundialmente, había suscitado gran interés. Desde las Conferencias de Washington (1922), donde Chile y Perú ceden el arbitraje a los Estados Unidos, hasta el Tratado de Lima (1929), la prensa consolidó las representaciones sociales sobre el conflicto y los Estados partícipes, no obstante, las expresiones antichilenas comenzaron a neutralizarse debido, entre otras cosas, al trabajo diplomático que ese país realizaba en Madrid. La solución del diferendo -no alcanzada por el arbitraje- fue apoyada, en todo momento, por la Casa Blanca. Un hispanoamericanismo agónico no criticó esos buenos oficios con la rudeza de los años anteriores; intentó demostrar su poder por medio de la participación de la aviación española en el transporte de los documentos del tratado desde Santiago hacia Lima y con la proposición para adjudicar el premio Nobel de la Paz a los dictadores Carlos Ibáñez y Augusto Leguía, presidentes de Chile y Perú, respectivamente.

\subsection{Las Conferencias de Washington}

La oposición de la cancillería chilena para que una tercera potencia prestara sus buenos oficios en el problema de Tacna y Arica giró inesperadamente. El cambio de gobierno en Chile y, con ello, la presidencia de Arturo Alessandri, dieron un nuevo sello a la política internacional del país. El presidente, tiempo después, recordó: “era menester cambiar el rumbo de nuestra política, y yo había tomado la resolución de hacerlo" 1280 . Luego de varias gestiones con la cancillería peruana, se acordó discutir el problema fronterizo con los Estados Unidos. En efecto, el 15 de mayo de 1922 comenzaron las reuniones diplomáticas entre los representantes de los tres países, encabezadas por el Secretario de Estado, Charles Hughes -autor del triste eslogan "Vivimos bajo una

${ }^{1280}$ AlessandRi PALMA, Arturo, Recuerdos de gobierno, Santiago, Editorial Nascimento, 1967, p. 83. 
Constitución, mas la Constitución es lo que los jueces dicen que es"1281-, conocida como las "Conferencias de Washington" o, con el nombre menos popular, "Conferencias del Pacífico" 1282 .

Alessandri, en la sesión de apertura del Congreso chileno declaró que había aceptado "la intervención amistosa del Presidente Harding [...] dispuesto a no apartarse una línea de la política que se ha trazado en esta cuestión"1283. En Washington, los círculos diplomáticos aseguraban que el Perú había "aceptado sin reservas el proyecto transaccional formulado por el Gobierno de los Estados Unidos"1284. Los sucesos hicieron pensar a la prensa española que los países habían encontrado, por fin, una fórmula de arreglo ${ }^{1285}$.

La buena voluntad de los convocados pronto revelaría resultados positivos para la paz, salvo pequeños inconvenientes ocurridos entre las delegaciones de Chile y Perú, días antes de la firma del acuerdo. El Imparcial afirmó el "fracaso de la Conferencia chilenoperuana"1286. El 20 de julio se acordó que el presidente de los Estados Unidos, Warren Harding, arbitraría el problema del Pacífico. El hecho fue abundantemente noticiado ${ }^{1287}$ así como también la reafirmación de su compromiso ${ }^{1288}$. Un día antes, para matizar la idea que planteaba la buena atmósfera diplomática entre chilenos y peruanos, el mismo diario analizó los comentarios de la prensa peruana relativos al interés chileno por

1281 GonZÁlez Schmal, Raúl, Programa de derecho constitucional, México, Universidad Iberoamericana, 2007, p. 432.

${ }^{1282}$ La Época, "La Conferencia del Pacífico", 17 de mayo de 1922, p. 1.

${ }^{1283}$ La Acción, "La política de los Estados Unidos", 1 de junio de 1922, p. 6.

${ }^{1284}$ La Acción, "El pleito de Tacna y Arica", 5 de julio de 1922, p. 5; La Correspondencia de España, "Chile y Perú", 5 de julio de 1922, p. 3; El Globo, "El conflicto entre Chile y Perú", 6 de julio de 1922, p. 1.

${ }_{1285}$ El Sol, "Extranjero", 5 de julio de 1922, p. 5; La Época, "La cuestión de Tacna y Arica", 7 de julio de 1922, p. 3; La Voz, "Chile ha aceptado el arbitraje que propone el Perú", 10 de julio de 1922, p. 5; El Sol, "Extranjero", 11 de julio de 1922, p. 5; España, "En América: proyecciones imperialistas", 15 de julio de 1922, n. ${ }^{\circ} 329$, p. 7.

${ }^{1286}$ El Imparcial, "Fracaso de la Conferencia chilenoperuana”, 13 de julio de 1922, p. 4.

${ }^{1287}$ El Imparcial, "Ayer fue firmado el acuerdo", 21 de julio de 1922, p. 1; El Sol, "La posesión de Tacna y Arica", 21 de julio de 1922, p. 5; La Acción, "Lo de Tacna y Arica", 21 de julio de 1922, p. 1; La Época, "Solución del conflicto de Tacna y Arica", 21 de julio de 1922, p. 1; El Globo, "Extranjero", 22 de julio de 1922, p. 2; El Heraldo, "Extranjero", 22 de julio de 1922, p. 4.

${ }^{1288}$ La Época, "La cuestión de Tacna y Arica", 24 de enero de 1923, p. 3; La Voz, "La cuestión de Tacna y Arica", 24 de enero de 1923, p. 1; El Siglo Futuro, "La cuestión de Tacna y Arica", 25 de enero de 1923, p. 1; El Sol, "Visita a Harding", 25 de enero de 1923, p. 1; El Sol, "Extranjero", 25 de enero de 1923, p. 5; La Acción, "Lo de Tacna y Arica", 25 de enero de 1923, p. 2; La Correspondencia de España, "Harding, árbitro entre Chile y el Perú", 1 de febrero de 1923, p. 5; La Época, "Lo de Tacna y Arica", 1 de febrero de 1923, p. 1; La Voz, "La cuestión de Tacna y Arica", 1 de febrero de 1923, p. 5; Vida Marítima, "La situación internacional", 15 de febrero de 1923, n. ${ }^{\circ}$ 732, p. 37; La Esfera, "De Norte a Sur", 17 de febrero de 1923, n. ${ }^{\circ} 476$, p. 22. 
hacer fracasar la conferencia. Si se ha llegado a la proposición y aceptación del arbitraje escribían desde Lima- ha sido gracias a la "labor de la Delegación peruana"1289.

No obstante, con meses de anticipación, la prensa sabía el motivo del conflicto entre Chile y Perú: mientras el primero deseaba negociar exclusivamente el artículo n. ${ }^{\circ} 3$ del Tratado de Ancón, el segundo solicitaba la revisión total del documento, divergencia que provocó en Lima varios actos públicos solicitando la militarización y "la declaración de guerra a Chile en el caso de que no se obtengan las concesiones a que se tiene derecho" ${ }^{290}$.

En España la prensa informó, equívocamente, que esta fase de las relaciones chileno-peruanas fue posible gracias a la voluntad del Perú, siendo que, a decir verdad, los Estados Unidos tomaron la iniciativa de ofrecer los buenos oficios ${ }^{1291}$.

El clima diplomático, en esto sí acertó, presentaba un "verdadero empeño de paz y concordia" ${ }^{292}$. Los buenos oficios de los Estados Unidos coincidían con los preparativos generales de la V conferencia Panamericana en Santiago. En esa reunión se discutiría la cuestión de Tacna y Arica y otros asuntos, como la firma de un tratado destinado a prevenir la guerra entre países americanos ${ }^{1293}$. Además, escribió la prensa, se tratará la posibilidad de conceder un puerto en el Pacífico para Bolivia ${ }^{1294}$, país que, junto con México, rechazó la invitación del Estado chileno ${ }^{1295}$. Por su parte, el Director de la Unión Panamericana, Mr. Rowe, comunicaba a la prensa que un tema central del debate serían las relaciones americano-europeas $^{1296}$.

\footnotetext{
${ }^{1289}$ El Imparcial, “Aceptación del arbitraje”, 19 de julio de 1922, p. 4.

${ }^{1290}$ El Imparcial, "La cuestión de Tacna y Arica", 22 de enero de 1922, p. 2; La Libertad, "El pleito chilenoperuano", 22 de enero de 1922, p. 4; El Siglo Futuro, "Chile y Perú", 23 de enero de 1922, p. 4; El Imparcial, "Se confía en una solución amistosa", 23 de marzo de 1922, p. 2.

1291 ÁlveZ Marín, Amaya e IrARRÁZAVAl GomiEn, Andrés, "El plebiscito sobre el destino de Tacna y Arica como solución jurídica a un conflicto bélico. El aporte de Federico Puga-Borne", Revista de Estudios Históricos y Jurídicos, n. ${ }^{\circ}$ 22, 2000, pp. 193-212.

${ }^{1292}$ España y América, "Crónica del extranjero", enero-marzo de 1922, n. ${ }^{\circ}$ 1, p. 80.

1293 Delgado Martín, Jaime, Historia general de España y América, Madrid, RIALP, D. L., 1992, p. 455.

${ }^{1294}$ La Correspondencia de España, "La quinta conferencia panamericana", 18 de enero de 1922, p. 8.

1295 FiguerOA, Uldaricio, La demanda marítima boliviana en los foros internacionales, Santiago, RIL Editores, 2007, p. 63; SAlceda Olivares, Juan Manuel, México y la V conferencia panamericana: un campo de batalla diplomática contra el intervencionismo norteamericano, Tzintzun, n. ${ }^{\circ}$ 50, 2009, pp. 61-104. ${ }^{1296}$ El Imparcial, "La quinta conferencia panamericana", 19 de enero de 1922, p. 4.
} 


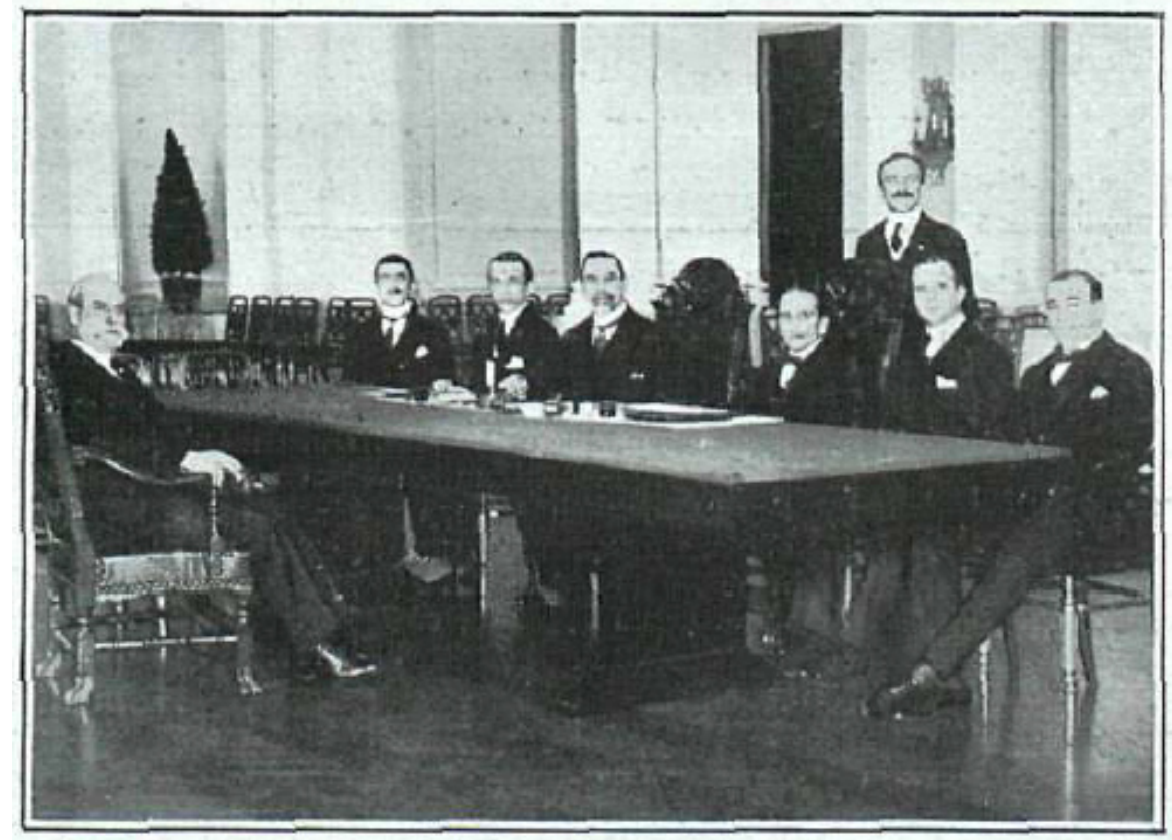

Wasbington.-Insignes diplomátieos americanos que han firmado el tratado eatre Chile y Perú, refereate á la cuestión Tacna-Arica

Fuente: La Esfera, "Insignes diplomáticos americanos que han firmado el tratado entre Chile y Perú referente a la cuestión de TacnaArica”, 17 de febrero de 1923, n. ${ }^{\circ}$ 476, p. 2.

Posteriormente, diarios españoles publicaron noticias relacionadas con el estado de la política peruana interna y con la elección de los delegados que viajarían a Washington. Entre ellos figuraban los reconocidos diplomáticos Melitón Porras y Solón Polo quienes, según la confianza depositada por otras cancillerías, trabajarían para conceder un puerto a Bolivia $^{1297}$. Por parte de Chile lo harían Luis Izquierdo y Carlos Aldunate, políticos moderados en lo relativo al problema fronterizo, decisión que fue valorada por la opinión pública peruana, pues demostraba "cierta tendencia amistosa" 1298 del gobierno chileno.

La antesala de las reuniones, en la interpretación de dos diarios hispanos, mantuvo la expectación en todo el "continente de habla española"1299 en medio de rumores, rápidamente desmentidos, acerca de las negociaciones directas efectuadas entre los

${ }^{1297}$ El Imparcial, "Despachos breves del extranjero", 23 de febrero de 1922, p. 4.

${ }^{1298}$ El Imparcial, "Se confía en una solución amistosa", 23 de marzo de 1922, p. 2.

${ }^{1299}$ El Sol, "La cuestión del Pacífico en Sudamérica", 11 de febrero de 1922, p. 8. 
presidentes de Chile y Perú ${ }^{1300}$. Reportajes extensos del desarrollo de las conferencias se publicaron en diarios y revistas apoyando a Chile, otros al Perú, pero sobre todo realizando críticas durísimas a la acción diplomática española en América. En esas notas no faltó, como había sido costumbre, la fobia contra los Estados Unidos por la hegemonía que intentaban desplegar sobre la región denominada, con ahínco, "América Española". El descontento periodístico era ineficaz: las actas de las Conferencias de Washington estaban en las imprentas ${ }^{1301}$ del gobierno estadounidense ${ }^{1302}$.

Los artículos incluidos en la prensa, favorables a la política exterior chilena, fueron escritos por el diplomático de ese país, Fidel Muñoz Rodríguez y por Jorge Piacentini, periodista argentino del diario bonaerense La Nación. La Esfera se interesó en Muñoz, entre otras cosas, por su participación en la comisión organizadora de la V conferencia panamericana. Además, era uno de los asesores chilenos encargado de la defensa de los intereses soberanos del país en Washington. Tales razones, permiten comprender la retórica usada en su escrito.

Participando del relato oficial sobre las causas de la Guerra del Pacífico, aseguró que Chile fue arrastrado al campo de batalla por Perú y Bolivia, repúblicas aliadas por un pacto militar secreto. Muñoz, ordenando sus ideas, formuló dos preguntas fundamentales para comprender qué se debatía en Washington. Primero escribió, ¿qué derechos adquirió Chile sobre los territorios de Tacna y Arica, en virtud del tratado? y luego ¿qué causas han influido para que este problema no haya podido solucionarse en el espacio de cuarenta años? Las respuestas, de una honradez extraordinaria, se oponían a las visiones duras de los políticos chilenos frente al secesionismo.

A la primera cuestión respondió reconociendo que el tratado sólo otorgó en Tacna y Arica una década de soberanía y que el artículo tercero no llevaba ninguna intención ni cláusula de cesión territorial disimulada como más de algún político chileno lo aseguró y

\footnotetext{
${ }^{1300}$ Idem; El Imparcial, "Despachos breves del extranjero", 2 de abril de 1922, p. 4.

${ }^{1301}$ La Correspondencia de España, "Chile y Perú", 30 de mayo de 1922, p. 1.

1302 LA UNIÓN PANAMERICANA, La sesión de clausura de la conferencia chileno-peruana, Washington, Imprenta del Gobierno, 1922.
} 
que el Perú nunca aprobó ${ }^{1303}$. La mejor prueba de ello eran todas las negociaciones chilenoperuanas para lograr el cumplimiento de esa parte del tratado. En la segunda contestación no culpó a ningún país. Muñoz sabía que el incumplimiento del tratado fue producido por la ausencia de un rumbo constante de la cancillería, causada, a la vez, por la rotativa ministerial; en el Perú, por la instrumentalización política del problema fronterizo, realizada por diversos caudillos quienes no deseaban, en el fondo, solucionar el diferendo.

En el pensamiento de Muñoz el momento actual era determinante para cambiar el rumbo de las relaciones diplomáticas mundiales, en general, y de Chile y Perú, en particular. La guerra europea había concienciado a los líderes de las naciones en resolver pacíficamente las disputas territoriales. Esas naciones, escribió, "ya no se guían con el penacho de los grandes guerreros; buscan su porvenir en sentimientos más humanos, más reales y convenientes para el desarrollo de su propia vida"1304.

Muñoz explicaba la existencia de las conferencias en Washington con dos razones. Por un lado, el peso de la opinión política internacional y, por otro, la espontánea y amistosa intervención de los Estados Unidos.

Causaba admiración en el diplomático que durante la fase deliberativa del problema fronterizo, los pueblos de ambos países habían mantenido la calma, sin grandes estallidos pasionales ni movimientos patrioteros. Sólo la prensa había encauzado la opinión pública. Al parecer de Muñoz, Chile y Perú comprendieron que continuar la litis producía en ambos países "cuantiosos gastos de defensa, de propaganda diplomática y [...] carencia de relaciones políticas y comerciales"1305. Prisionero de su tiempo, no percibía la obcecación de los "representantes" chilenos y peruanos encargados de armonizar la frontera.

Desde ese "locus discursivo" Muñoz afirmó que el árbitro estadounidense sólo debía coordinar el plebiscito. Entendía por éste una práctica democrática y consultiva para saber la voluntad de los tacneños y ariqueños de pertenecer, soberanamente, a Chile o Perú. Por eso, se opuso a la intención peruana de efectuar un plebiscito influido por el Tratado de

${ }^{1303}$ RePÚBLICA DEL Perú, El arbitraje de Tacna y Arica. Actas de la Comisión Plebiscitaria, Lima, Imprenta Torres Aguirre, 1928.

${ }^{1304}$ La Esfera, "El arbitraje en la cuestión de Chile con el Perú", 26 de mayo de 1923, p. 18.

${ }^{1305}$ Idem. 
Versalles, que, en la práctica, sustraería la soberanía chilena de la región para plebiscitarla y neutralizar el territorio.

La nación chilena -escribió dos años antes de los preparativos plebiscitarios en Arica- confía en la imparcialidad y justicia del presidente de los Estados Unidos, quien respetará la noción de equidad y el derecho internacional. Chile, a cambio, garantiza la "seriedad del acto"1306, pero rechaza el desconocimiento de su soberanía. Para Muñoz, la nación, sin duda, era la parte culta del país, la elite dirigente. Por eso, su visión parcial y equívoca sobre ella le haría -ahora en el corto plazo- equivocar su pronóstico. La confianza chilena en el réferi se hundió hasta desestimar el arbitraje estadounidense en 1926.

Permítasenos una última observación hacia los planteamientos del diplomático. La paz, para Muñoz, era el fundamento del capitalismo. De ello se puede desprender que la paz en sí misma carecía de interés para el diplomático, pues lo que realmente importaba, en sus palabras, era el comercio y las industrias, en fin, "la penetración pacífica de los capitales" ${ }^{1307}$.

Jorge Piacentini, enviado a Lima por el "gran diario argentino" 1308 La Nación -que desde su fundación había sido un "intermediario fundamental entre el capital extranjero y los grupos comerciales de Buenos Aires"1309- escribió en favor de Chile, con un marcado tono de alerta, para que considerara la idiosincrasia peruana, forjada durante la cuestión de Tacna y Arica. Sus opiniones eran las de un periodista que de visu había compartido el fervor de la chilenidad y la peruanidad.

Días antes había visitado las capitales de Chile y Perú. Por tal razón, deseaba ofrecer al lector -en sus palabras- un balance de impresiones sobre la cuestión. Su texto, no obstante, rápidamente revela al escritor apasionado que desea conocer culturas de un modo más intuitivo que demostrativo.

\footnotetext{
${ }^{1306}$ Idem.

1307 Idem.

${ }^{1308}$ El Sol, "La cuestión del Pacífico en Sudamérica", 11 de febrero en 1922, p. 8.

${ }_{1309}$ RAMOS, Julio, Desencuentros de la modernidad en América Latina. Literatura y política en el siglo XIX, Santiago, Editorial Cuarto Propio, 2003, p. 134.
} 
Dueño de una seguridad sospechosa, Piacentini realizaba aseveraciones de su experiencia en Lima ampliables al Perú. Sus lectores, de creer lo reporteado, podían hacerse la idea de que todo ese país deseaba una revancha militar con Chile. Poco me ha costado develar el sentir íntimo del pueblo limeño, escribió en un párrafo, que "bien puede aceptarse como índice inequívoco del sentir de la nación entera; y me ha costado poco, porque la ciudad no oculta [...] su ardoroso y patriótico culto hacia la idea del desquite"1310. También notaba que ese sentir surgía de la política interna del Perú, superando diferencias locales, volviéndose un solo cuerpo para recuperar Tacna y Arica. Ahora, la peruanidad era inquebrantable.

Por el contrario, la estadía en Santiago le permitió dar cuenta de un pueblo culto (!), pero también ingenuo. Chile, percibió el fundador de la revista satírica Cascabel, desconocía los verdaderos sentimientos nacionalistas de su vecino pues, mientras confiaba en las Conferencias de Washington, predominaba en el Perú el resarcimiento de la guerra. Nuevamente era cautivo de sus inducciones creando un cuadro completo con sólo retazos de lo visto.

Piacentini marró. Por ejemplo, señalaba que las atmósferas nacionalistas en Lima y Santiago eran muy diferentes debido a la conducción emocional y racional, respectivamente, que hacían las autoridades. Se sabe que en la clase política chilena no existió unanimidad de consenso hacia el arbitraje estadounidense y menos una confianza "ingenua" hacia el Perú. Su "chilenofilia" idealizó la morigerada sociedad chilena. Por eso, estratégicamente, remarcó el odio y deseo vengativo que el Perú sentía hacia Chile. Esos sentimientos se recogen en todas partes, escribió, y "de igual manera se albergan en el corazón del hombre plebeyo que en el del hombre culto; de igual manera en los ojos de las mujeres y lo confiesan los niños. La herida del 79 no está cicatrizada"1311.

La opinión diplomática del político chileno Agustín Ross Edwards, publicada por $E l$ Heraldo, demuestra las equivocaciones de Piacentini. Pero no sólo es importante por eso, sino también porque en medio del arbitraje estadounidense intentó alinear España con Chile y Perú imitando el instrumento diplomático del país norteamericano, pero marginándolo.

${ }^{1310}$ El Sol, "La cuestión del Pacífico en Sudamérica", 11 de febrero en 1922, p. 8.
${ }^{1311}$ Idem. 
Las conferencias de Madrid de 1922, experimento frustrado de la "diplomacia extraoficial" chilena, no superó el proyecto. El “anciano hombre público chileno [...] genuino representante de la antigua escuela de la severidad política internacional"1312 -como lo llamó el bachiller Alcañices ${ }^{1313}$ - creyó que Chile debía anular compromisos con los Estados Unidos para celebrar una conferencia en Madrid, encabezada por el gobierno español de José Sánchez Guerra. La importancia española en la litis tenía una base empírica, pues "facilitará sus archivos, para deducir de ellos la propiedad de la tierra ariqueña"1314.

La idea de Agustín Ross, tío del empresario y político Agustín Edwards McClure, era sencilla. Arica debía entregarse a Bolivia para permitirle una salida al mar, solucionando, de paso, el conflicto chileno-peruano. A decir verdad, sólo en Bolivia sus planteamientos tuvieron aquiescencia.

Tiempo antes, en agosto de 1918, había publicado Tacna y Arica. La solución del problema mediante su transferencia a Bolivia concluyendo "Al redactar el estudio [...] hemos sido guiados por el deseo de servir a nuestro propio país, por espíritu de justicia hacia Bolivia y de equidad hacia el Perú"1315. Allí la idea chocó con Víctor Ayarza quien descartó la mediación hispana. La prensa ironizó con el boicoteador. El Señor Ayarza escribió- defiende la tesis del Perú "y quiere ahorrar a Chile gastos de viaje y revista de archivos hispánicos, pues cree que en el Perú, y en Chile, y en Bolivia hay material histórico bastante para probar los derechos del Perú"1316.

Ross sabía que el conflicto perduraría mientras Tarapacá y su salitre no se devolvieran al Perú. Ese país, por su lado, consideró desatinada la intervención del chileno. En rigor, dijeron los diplomáticos peruanos, era justo que Chile devolviese a Bolivia el litoral antofagastino y no usara Arica como territorio cambiable o de estabilización de

\footnotetext{
${ }_{1312}$ ABC, "ABC en Chile. Alegato Pro Bolivia", 4 de noviembre de 1922, p. 7.

1313 Seudónimo del periodista español Felipe Aparicio según: ARÁngUIZ DONOSO, Horacio, "Una instancia integradora: la inmigración española en Chile, 1850-1900”. En REAL ACADEMIA DE LA HISTORIA, II Congreso de Academias Iberoamericanas de la Historia. Factores de diferenciación e instancias integradoras en la experiencia del mundo iberoamericano. Actas, Madrid, Taravilla, 1994, p. 102.

${ }^{1314}$ El Heraldo, "El conflicto entre Perú y Chile", 10 de noviembre de 1922, p. 2.

1315 Ross EDWARDS, Agustín, Tacna y Arica. La solución del problema mediante su transferencia a Bolivia, La Paz, Litografía e imprenta Moderna, 1918, p. 44.

${ }^{1316}$ El Heraldo, "El conflicto entre Perú y Chile", 10 de noviembre de 1922, p. 2.
} 
relaciones. Ross, intentando polemizar con Ayarza, citó una Real Cédula de 1556 referida a Arica que la habilitó como el puerto comercial de Potosí1317. El $A B C$ publicó los datos históricos que, según Ross, daban a Bolivia el derecho de ejercer soberanía en Arica. El quid de la opinión del diplomático se hallaba en su formación histórica:

Para concluir con este pleito, que es la ruina de Chile y causa de la perpetua intranquilidad en estas riberas del Pacífico, se debe ir a una conferencia en que tomen parte las tres Repúblicas interesadas, celebrándose esa conferencia en Madrid, cerca del Gobierno de España, donde el Gobierno español pueda poner a los litigantes en contacto con los archivos coloniales para extraer de esa documentación allí conservada dignamente la convicción absoluta, incuestionable, indesmentible, de que Bolivia es el territorio de la antigua Audiencia de Charcas, y que a la jurisdicción de esa Audiencia de Charcas estuvieron antaño sometidas las tierras tacneñas y ariqueñas. [...] Los deslindes de la Audiencia de Charcas fueron fijados por la real Cédula de 26 de mayo de 1573 de este modo: "Por el levante y Poniente con los mares del Norte y del Sur y línea de demarcación entre las coronas de Castilla y Portugal". No se dice de dónde partían los términos de la Audiencia en el Mar del Sur (Pacífico); pero conviene hacer constar que Arica fue habilitado por el Rey como puerto comercial de Potosí en 1556. Y algo más todavía: La Audiencia de Charcas formaba parte del Virreinato de Buenos Aires y no del de Lima ${ }^{1318}$.

Los antecedentes expuestos permitieron al diario revelar la importancia de las conferencias de Madrid. Mientras que las de Washington acercaban a chilenos y peruanos, aquellas, ideadas por el vetusto político, incluían a Bolivia. En ese gesto radicaba su significación. El único problema de la alternativa era que Chile y Perú se mostraron abúlicos frente a ella, postura secundada por parte de la prensa española, que vio cómo esa iniciativa ayudaría a España a sentar las bases de futuros arbitrajes en Hispanoamérica.

Los errores periodísticos en puntos delicados del problema se presentaron nuevamente. Esta vez, al intentar sintetizar la apuesta de Ross, concebida en tres fases: Inteligencia chileno-boliviana en torno de Arica; conferencia tripartita en Madrid; y creación del Estado de Tacna-Arica, "proclamada (sic) en plebiscito por los chilenos que en ellas residen (los peruanos fueron expulsados), y, final, anexión a Bolivia ${ }^{1319}$.

La importancia concedida a las Conferencias de Washington por la intelectualidad española fue indudable. Uno de los primeros en estudiarla fue Remigio Gandásegui y Gorrochátegui, arzobispo de Valladolid, hombre caritativo y organizador de "asociaciones

\footnotetext{
${ }^{1317} A B C$, “ABC en Chile. Alegato Pro Bolivia”, 4 de noviembre de 1922, p. 7.

1318 Idem.

${ }^{1319}$ El Heraldo, "El conflicto entre Perú y Chile", 10 de noviembre de 1922, p. 2. (Las cursivas son nuestras).
} 
piadosas y benéficas"1320, quien publicó un análisis prolijo titulado "El acuerdo peruano chileno en la Conferencia de Washington"1321. Para el galdacanés, el objetivo de las conferencias era finalizar el diferendo abierto por la guerra. Esas desavenencias dificultaban, como lo pensaba Muñoz, el intercambio comercial de ambas naciones.

Con espíritu histórico, resumió para los lectores los hechos más importantes de esa guerra. Para ello se refirió, tal cual lo hizo Góngora, al uti possidetis. La importancia de éste fue la seguridad entregada a las constituciones de las repúblicas para ejercer los derechos dentro de un territorio definido. En Chile y Perú, explicó, los límites fueron fijados por Carlos V a doscientas setenta leguas al sur de Lima, modificándose en 1628 y 1778. Ese último año se acordó que el territorio chileno terminaba, por el norte, en Paposo $^{1322}$.

${ }^{1320}$ SÁEZ Y ROMERO, Mariano, Las calles de Segovia, Valladolid, Editorial MAXTOR, 2009, p. 181.

1321 España y América, "El acuerdo peruano chileno en la Conferencia de Washington", n. ${ }^{\circ}$ 13, julioseptiembre de 1922, p. 434-445.

${ }^{1322}$ La ubicación de Paposo, en el desierto de Atacama, motivó y motiva aún una discusión historiográfica entre los historiadores nacionalistas de Chile y Bolivia, principalmente. Los primeros sostienen que durante el dominio español, Paposo marcaba los límites entre el Reino de Chile y el Virreinato del Perú; los segundos argumentan que la Provincia de Charcas ejercía dominio en ese lugar y que, por lo tanto, tenía fronteras con el Reino de Chile. Este diferendo, conocido con el nombre de la "cuestión de Paposo" ha provocado una cuantiosa bibliografía desde el siglo XIX hasta la actualidad. Entre los estudios que tratan la cuestión, por citar tan sólo algunos, ver: BAZÁN DÁVILA, Raúl, El patrimonio territorial que recibimos del Reino de Chile, Santiago, Instituto de Investigaciones del Patrimonio Territorial de Chile. Universidad de Santiago, 1986; BECERRA DE LA ROCA, Rodolfo, Nulidad de una apropiación chilena. Territorio boliviano entre los paralelos 23 y 24, La Paz, Plural Editores, 2006; CERDA SANTANDER, Enrique José, Tratados históricos de los límites internacionales de Chile, C. E. T.- Genchi, 1987, p. 31; COSTA DE LA TORRE, Arturo, Hombres célebres de Bolivia, La Paz, Impr. y librería Renovación, 1970, p. 285; EGAÑA, Rafael, La cuestión de Tacna i Arica. Antecedentes diplomáticos, gestiones diplomáticas, estado actual, Tip. y Encuad. De Muller hnos., 1901, p. 10; Gutiérrez GutiÉrrez, Mario R., Alegato histórico de los derechos de Bolivia al Pacifico, La Paz, Talleres Gráf. Bolivianos, 1962; Instituto De Cultura HispánicA, Archivo Iberoamericano, Madrid, Instituto de Cultura Hispánica. Departamento de Información, 1963, p. 444; LAGOS CARMONA, Guillermo, Historia de las fronteras de Chile. Los tratados de límites con Argentina, Santiago, Editorial Andrés Bello, 1966, p. 29-31; Ministerio DE RELACIONES EXTERIORES DE ChILE, Cuestión chileno-boliviana, Santiago, La Patria, 1879; RepúbliCA DE CHILE, Memoria que el Ministro de Estado en el Departamento de Relaciones Exteriores presenta al congreso nacional de 1862, Santiago, Imprenta Nacional, 1862, p. 81; Ríos GAllardo, Conrado, Chile y Bolivia definen sus fronteras. 1842-1904, Santiago, Editorial Andrés Bello, 1963, p. 25; SANTIVÁÑEZ, José María, Bolivia i Chile. Cuestión de límites, Cochabamba, Imprenta del Siglo, 1863; Silva G., Osvaldo, Atlas de Historia de Chile, Santiago, Editorial Universitaria, 2005, p. 36; SIN AUTOR, Colección de historiadores de Chile y documentos relativos a la historia nacional. Tomo I. Cartas de Pedro de Valdivia al Emperador Carlos V, Santiago, Imprenta de El Ferrocarril, 1861, p. 48; TÉLLEZ L. Eduardo, Historia general de la frontera de Chile con Perú y Bolivia, 1825-1929, Santiago, Universidad de Santiago de Chile, 1989; TORRES, José Antonio, Solución de la cuestión de límites entre Chile i Bolivia, Santiago, Imprenta del Ferrocarril, 1863, p. 29; Trelles, Manuel Ricardo, Cuestión de límites entre la república Argentina y Bolivia, Buenos Aires, Imprenta del Porvenir, 1872, pp. 5-7. 
Después de las independencias, Atacama "pasó temporalmente a Bolivia en 1825 "1323. Desde ese año, afirmó el concitador religioso, Chile "esperaba una oportunidad para agregar a su mapa aquella parte de la costa boliviana"1324. Pero es más, de sus palabras se puede inferir la existencia de un complot chileno para arrebatar a Bolivia el desierto de Atacama. En efecto, aseguró que el gobierno chileno usó en 1842, entre otros, dos pretextos para la anexión: la escasa protección del gobierno boliviano a los habitantes costeños y los abusos de los funcionarios de ese país hacia los empresarios chilenos. En respuesta a esas provocaciones, Chile dictó la ley del 13 de octubre de 1842, declarando que todas las guaneras y riquezas superficiales de Atacama pertenecían al país. Seguidamente, fundó un fuerte militar en Punta Angamos. Bolivia nada pudo hacer. La culpabilidad, para el arzobispo, era del expansionismo chileno, pues Bolivia yacía "sumida en revoluciones y luchas intestinas"1325.

Desde esa disputa los problemas fronterizos entre Chile y Bolivia continuaron hasta 1866, año en que se firmó un tratado limítrofe. Para Gandásegui el tratado "encerraba una gran injusticia" 1326 , porque Chile se hacía propietario de las tierras situadas hasta los $24^{\circ}$ de latitud norte y Bolivia debía ceder a Chile "la mitad de la explotación de los productos naturales, libres de todo impuesto y obligándose a no enajenar jamás su soberanía sin la venia"1327 de ese país. Lamentaba que Chile, a la par de negociar el tratado, comprara buques blindados -armamentismo negado por la historiografía chilena ${ }^{1328}$ - única razón por la cual Bolivia celebró con Perú un tratado secreto defensivo "causa ocasional de la guerra de 1879"1329. El relato eludió los cobros de impuestos, por parte de Bolivia, a la compañía anglo-chilena Edwards-Gibbs, infringiendo el tratado limítrofe chileno-boliviano de 1874. En efecto, "Chile sin previa declaración de ruptura de relaciones, procedió a ocupar militarmente el puerto de Antofagasta" ${ }^{1330 .}$

\footnotetext{
${ }^{1323}$ España y América, "El acuerdo peruano chileno...", n. ${ }^{\circ}$ 13, julio-septiembre de 1922, p. 435.

1324 Íbidem, 435.

1325 Íbidem, p. 436.

${ }^{1326}$ Idem.

${ }^{1327}$ Idem.

1328 GreZ, Carlos, "La supuesta preparación de Chile para la Guerra del Pacífico", Boletín de la Academia Chilena de la Historia, n. ${ }^{\circ}$ 3, 1935, pp. 111-139.

${ }^{1329}$ España y América, "El acuerdo peruano chileno...", n. ${ }^{\circ}$ 13, julio-septiembre de 1922, p. 436.

1330 Íbidem, p. 437.
} 
En ese momento, como vimos, Perú, no obstante el tratado secreto con Bolivia, envió a Chile a la misión Lavalle. Para Gandásegui, Lavalle era un peruano eminente que presentó al gobierno chileno bases excelentes para negociar la paz y que, por culpa de los diplomáticos chilenos, fueron rechazadas. Lavalle fracasó: Chile declaró la guerra al Perú, país militarmente informe.

En medio de su "chilenofobia", la figura de Arturo Prat, capitán de La Esmeralda, inhumado en 1879 por Eduardo Llanos, cónsul español en Iquique, recibió reconocimientos por su heroísmo. El mismo trato se tuvo con Miguel Grau, el "León del Pacífico"1331, capitán peruano del Huáscar. No obstante, para Gandásegui la diferencia radicaba en que después de Angamos Chile quedó dueño del mar, imponiendo "la paz"1332. Sin embargo, su barbarismo le hizo desear la conquista de Lima, "ciudad de las flores y de los perfumes, mansión de opulencia, de la nobleza y del lujo"1333, para allí negociar la paz.

Antes de concretar la paz, los soldados chilenos arrasaron las poblaciones de Tacna y Arica, episodios "de una crueldad trágica"1334. El prelado recordó las matanzas de Arica, citando al historiador chileno Benjamín Vicuña Mackenna, quien narró el momento en que el comandante chileno José de la Cruz Salvo solicitó la rendición al coronel peruano Francisco Bolognesi ${ }^{1335}$. Los arquetipos de ambas personalidades, dependientes de la imaginación de Gandásegui, obedecieron a la adscripción nacional de aquellos. Así, condensó las identidades nacionales de Chile y Perú en Salvo y Bolognesi. El escritor español sentenció:

Son las seis de la mañana. Un pequeño grupo se destaca de las líneas chilenas enarbolando bandera blanca, en dirección al Morro. Es el comandante D. José de la Cruz Salvo, acompañado de un corneta, que trae a Bolognesi, de parte de Baquedano, la propuesta de rendir la plaza, para evitar el derramamiento de nueva sangre, y prometiendo a la guarnición salir de la ciudad a tambor batiente, con todos los honores de la guerra. Salvo es recibido en los puestos de avanzada [...] Se le venda los ojos y se le conduce a la casa que ocupa Bolognesi al pie del Morro. Los dos hombres, Bolognesi, sereno y tranquilo, y Salvo, ceñudo, de mirada fuerte, se contemplan un momento. Le oigo a usted, señor, dice Bolognesi, invitándolo a tomar asiento. Señor, contesta Salvo: El general en Jefe del

\footnotetext{
${ }^{1331}$ Congrains Martin, Eduardo, Miguel Grau: “El León del Pacifico”, Lima, Editorial Ecoma, 1972.

1332 España y América, “El acuerdo peruano chileno...", n. ${ }^{\circ}$ 13, julio-septiembre de 1922, p. 439.

1333 Íbidem, p. 440.

1334 Íbidem, p. 441.

1335 Vicuña MACKENNA, Benjamín, Historia de la campaña de Tacna y Arica, 1879-1880, Santiago, Rafael Jove Editor, 1881.
} 
ejército de Chile, deseoso de evitar un derramamiento inútil de sangre, después de haber vencido en Tacna al grueso del ejército aliado, me envía a pedir la rendición de esta plaza, cuyos recursos en hombres, víveres y municiones conocemos. Al apagarse el eco de la voz incisiva y ruda de Salvo, contestó Bolognesi: tengo deberes sagrados que cumplir, y los cumpliré, quemando el último cartucho ${ }^{1336}$.

Los detalles del movimiento de las tropas y de la mitificación heroica, exclusivamente de los soldados peruanos, satura el relato de la "hecatombe"1337 en el historiador católico. Éste, con grandilocuencia y aludiendo a su deidad, exclamó: “¡Quiera el Señor aceptar el sacrifico de tantas víctimas como un holocausto ofrecido en aras del honor, para la conservación de la unidad nacional!"1338. La lucha entre la fe y la infidelidad en la historia, principio del providencialismo histórico ${ }^{1339}$, en la mentalidad de Gandásegui cristalizó con la antítesis nacionalista del peruanismo antichileno.

En otro aspecto, Bolivia fue minimizada por Gandásegui. Sólo la menciona para criticar el caos y turbación del ejército. El comportamiento de sus soldados reflejó el escaso valor de los hombres bolivianos, recordando las palabras de un historiador quien se refirió a ellos como "Ineptos para ganar ninguna guerra internacional" caracterizados por sus “impulsos primitivos, su ignorancia, y con frecuencia, su cobardía" ${ }^{1340}$. Sospechaba, a la vez, la participación inescrupulosa de agentes chilenos en Bolivia, quienes ofrecían a los políticos del país la entrega de Tacna y Arica. Algunos creyeron en el juego de los “araucanos". En el juicio moral del escritor, ellos fueron los "malos bolivianos que [...] hicieron activa campaña en favor de las proposiciones chilenas" ${ }^{\prime 1341 .}$

Chile, a estas alturas, culpable de toda la trama bélica, rechazó también los buenos oficios estadounidense en 1880, manteniendo sus "exorbitantes demandas"1342 territoriales. La consecuencia de esa decisión fue la campaña de Lima, donde Piérola demostró gran eficacia y "febril actividad"1343 que, sin embargo, fue estéril a causa del tiempo. Además, la artillería chilena superaba a la peruana. Estos aspectos hacían fácil presagiar la victoria

\footnotetext{
${ }^{1336}$ España y América, "El acuerdo peruano chileno...", n. ${ }^{\circ}$ 13, julio-septiembre de 1922, p. 443.

1337 Idem.

${ }^{1338}$ España y América, "El acuerdo peruano chileno...", n. ${ }^{\circ}$ 13, julio-septiembre de 1922, p. 444.

${ }^{1339}$ RIU, Manuel, La alta edad media. Del siglo V al siglo XII, España, Montesinos Editor, 1989, p. 14.

${ }_{1340}$ Ruiz-Tagle OrRego, Emilio, Bolivia y Chile. El conflicto del Pacifico, Santiago, Editorial Andrés Bello, 1992, p. 164.

${ }^{1341}$ España y América, "El acuerdo peruano chileno...", n. ${ }^{\circ}$ 13, julio-septiembre de 1922, p. 445.

${ }^{1342}$ España y América, "El acuerdo peruano chileno...", n. ${ }^{\circ} 14$, octubre-diciembre de 1922, p. 34.

1343 Íbidem, p. 35.
} 
chilena. En Lima, el terror se apoderó de sus habitantes pues se sabía de las "exacciones y atropellos de los ocupantes" 1344 , por tal razón, un gran número de pobladores se refugiaron en asilos, conventos y consulados extranjeros. La gente -escribió una historiadora- al saber la cercanía del enemigo envió "a sus familiares fuera de Lima y para ello no vacila en cerrar casas y trasladar los mismos negocios a provincias o al extranjero"1345.

La descripción de la ocupación chilena de Lima se hizo en términos trágicos. Gandásegui entendió que esa devastación sólo era comparable con otras ocupaciones despiadadas. Dos ejemplos europeos permitían activar en los lectores la imaginación analógica: la invasión alemana al Condestable de Borbón en Roma y la invasión de las huestes napoleónicas de Murat en Madrid. Parece que todo el que se adueña del territorio enemigo -escribió el arzobispo- lleva la misma consigna.

En el caso de Chile, ofreció el testimonio de Patricio Lynch, nuevo gobernador de Lima, quien aseguraba que su país tenía el derecho de apropiarse de los bienes peruanos y, además, percibir todos los productos y valores de los arrendamientos limeños. Bajo ese derecho, Chile transportó a Santiago bibliotecas, gabinetes, cuadros valiosos, imprentas, mobiliario lujoso y un sinfín de otros enseres. Todo lo anterior producido por "los desmanes de la soldadesca y de muchos civiles ambiciosos" ${ }^{\prime 1346}$.

Firmar la paz fue para el Perú igual de trágico que los sucesos anteriores. Sin un estadista visible, una asamblea vecinal nombró presidente provisorio a Francisco García Calderón quien, por diferencias con Lynch "fue hecho prisionero y conducido a Chile"1347. Lo reemplazó Manuel Iglesias, quien acordó, finalmente, con el presidente chileno Domingo Santa María, el Tratado de Ancón.

Remigio Gandásegui sabía que, exceptuando el artículo tercero, el tratado no había causado mayores problemas. El artículo se refería al plebiscito que debía celebrarse en Tacna y Arica que se entendió, señalaba el religioso, de manera diferente en Chile y Perú. Para el primero, el voto debía ser secreto entre tacneños y ariqueños alfabetizados e

\footnotetext{
1344 Íbidem, p. 36.

1345 Guerra MARTinière, Margarita, La ocupación de Lima. Aspectos económicos. 1881-1883, Lima, Fondo Pontificia Universidad Católica del Perú, Fondo Editorial, 1996, p. 27.

${ }^{1346}$ España y América, "El acuerdo peruano chileno...", n. ${ }^{\circ}$ 14, octubre-diciembre de 1922, p. 37.

1347 Íbidem, p. 38.
} 
inscritos en el registro civil. Para Perú el voto debía ser público y excluyendo a los habitantes recién incorporados en ambas ciudades. Además, existía gran desacuerdo respecto a la presidencia de las mesas electorales y mecanismos de escrutinio. Una iniciativa para planificar el plebiscito -recordó Gandásegui- fue el protocolo BillinghurstLatorre de 1898 que "no tuvo la sanción del Congreso chileno"1348.

En la actualidad, explicaba el autor, la opresión practicada por Chile los últimos años se manifestó en la expulsión de "muchos peruanos de abolengo [...] adueñándose de bienes y remates judiciales y otros métodos [...] más o menos violentos"1349. La chilenización forzada de Tacna y Arica convenció al Perú de que el tratado, íntegramente, era inválido.

El escritor percibió que las Conferencias de Washington daban paso a una nueva fase del conflicto. Chile "ya no puede sostener por más tiempo su befaría (sic) actitud"1350 $\mathrm{y}$, por eso, cambió su posición de intransigencia hacia los buenos oficios de terceras potencias. Las razones del cambio fueron las visiones pacíficas producidas por la experiencia de la Primera Guerra Mundial. A éstas se sumaba el problema económico chileno, debido a la crisis salitrera, y, por último, la instrumentalización del problema de Tacna y Arica, con una intención populista, realizada por Arturo Alessandri, "caudillo semirrevolucionario, como proveniente de las masas socialistas" ${ }^{1351}$.

Si bien Gandásegui no criticó los buenos oficios estadounidenses, tampoco criticó a su gobierno, por desestimar la importancia de las relaciones exteriores con América para su construcción nacional. Alejándose de usar adjetivaciones negativas hacia Washington, describió la dinámica de las conferencias lideradas por Charles Hughes, secretario de Estado, con los diplomáticos chilenos y peruanos. El producto de las reuniones, explicó, fue el protocolo del 21 de julio. Chile aceptaba el arbitraje de los Estados Unidos para revisar sólo el artículo tercero del Tratado de Ancón, posición criticada en el Perú y también por el

\footnotetext{
1348 Íbidem, p. 40.

1349 Idem.

${ }^{1350}$ España y América, "El acuerdo peruano chileno...", n. ${ }^{\circ}$ 14, octubre-diciembre de 1922, p. 41.

1351 Íbidem, p. 43.
} 
arzobispo filoperuano pues para ese país "el fin principal de la reunión [...] era la nulidad del tratado de Ancón"1352.

El protocolo constó de tres artículos más un acta complementaria de cinco puntos. Según el documento del sacerdote, el protocolo tenía dos artículos y el acta complementaria cuatro puntos. A continuación, citamos la parte esencial del protocolo:

Artículo primero. - Queda constancia de que las únicas dificultades derivadas del tratado de paz sobre las cuales los dos países no se han puesto de acuerdo son las cuestiones que emanan de las estipulaciones no cumplidas del artículo $3 .^{\circ}$ de dicho tratado.

Artículo segundo. - Las dificultades a que se refiere el artículo anterior serán sometidas al arbitraje del Presidente de los Estados Unidos de América, quien las resolverá sin ulterior recurso, con audiencia de las partes y en vista de las alegaciones y probanzas que éstas presenten. Los plazos y procedimientos serán determinados por el árbitro.

Artículo tercero. - El presente protocolo será sometido a la aprobación de los respectivos gobiernos y las ratificaciones serán canjeadas en Washington, D. C., el 20 de julio de 1922.

En cuanto a las notas que deberán fijar el alcance del arbitraje convenido, se acordó sustituirlas por un Acta Complementaria que se considerará parte integrante del protocolo.

Acta complementaria. - A fin de precisar el alcance del arbitraje estipulado en el artículo segundo del protocolo suscrito en esta fecha, los infrascritos resuelven dejar establecidos los siguientes puntos:

Primero. - Está comprendida en el arbitraje la siguiente cuestión promovida por el Perú en la reunión celebrada por la Conferencia el 27 de mayo último. Con el objeto de determinar la manera en que debe darse cumplimiento a lo estipulado en el artículo tercero del Tratado de Ancón, se somete a arbitraje si procede o no, en las circunstancias actuales, la realización del plebiscito. El gobierno de Chile puede oponer por su parte, ante el árbitro, todas las alegaciones que crea convenientes a su defensa.

Segundo.- En caso que declare la procedencia del plebiscito, el árbitro queda facultado para determinar sus condiciones.

Tercer.- Si el árbitro decidiera la improcedencia del plebiscito, ambas partes, a requerimiento de cualquiera de ellas, discutirán acerca de la situación creada por este fallo. Es entendido, en el interés de la paz y del buen orden, que, en este caso, y mientras esté pendiente un acuerdo acerca de la disposición del territorio, no se perturbará la organización administrativa de las provincias.

Cuarto. - En caso de que no se pusieran de acuerdo los dos gobiernos solicitarán para este efecto los buenos oficios del gobierno de los Estados Unidos de América.

Quinto. - Están igualmente comprendidos en el arbitraje las reclamaciones pendientes sobre Tarata y Chilcaya, según lo determine la suerte definitiva del territorio a que se refiere el artículo 3. ${ }^{\circ}$ de dicho tratado. Esta Acta forma parte integrante del protocolo de su referencia. Firmada y sellada en doble ejemplar en Washington D. C., el 20 de julio de $1922^{1353}$.

El protocolo de arbitraje estadounidense reabrió, en parte de la prensa, las heridas causadas por la marginación española en los diferendos americanos. Las conferencias eran

\footnotetext{
1352 Íbidem, p. 45.

${ }^{1353}$ BARROS, Mario, Historia ... pp. 679-680.
} 
otra prueba de cómo las antiguas colonias no veían en la metrópoli una potencia de gravitación mundial que coordinase la paz. Esa situación fue profundizada por reportajes interesados en Tacna y Arica que, aun firmado el protocolo, continuaron desde las columnas, induciendo al gobierno español para mediar. La autocrítica se hizo más dura.

Siempre ignorante de cuanto pueda interesar de la "América Española" -publicó la revista España - ha dejado nuestra prensa de comentar, con la extensión y cuidado que debiera, lo acontecido recientemente en Washington ${ }^{1354}$. La publicación deseaba comentar, además de los pormenores de las conferencias, las implicaciones de la hegemonía estadounidense sobre la región. En su pensamiento, era un momento más del avance “tutelar"1355 de los Estados Unidos. España debía aprender de ello para salir, de una vez, del embotamiento endémico "de nuestra sensibilidad"1356.

La ausencia de pragmatismo diplomático no era, en la pluma del escritor, sólo patrimonio hispano. Parecía que los países americanos habían heredado tal condición. La mejor demostración de ese legado era el apasionamiento "frente a litigios de orden territorial" ${ }^{1357}$. Por eso interesaba responder si ¿no sería censurable que con nuestra intervención contribuyésemos a exaltar la hiperestesia chileno-peruana? Ese procedimiento hacia las antiguas posesiones sólo demostraba la "atrofiada percepción" 1358 diplomática que no deseaba superar su "neutralidad neutra"1359. La diplomacia española en América tuvo durante los años veinte -escribió un historiador- una deficiente presencia, pues existía "una sola embajada (Buenos Aires) y diez legaciones"1360. Además, los tiempos demostraron que el problema chileno-peruano, en vez de atenuarse, recrudecía, implicando por parte de España el deber de tomar la iniciativa para reactivar una "solidaridad histórica y racial que hace comúnmente insoslayable cuanto acaece en las orillas del Atlántico y del Pacífico"1361.

\footnotetext{
${ }^{1354}$ España, "El litigio chileno-peruano", 5 de agosto de 1922, n. ${ }^{\circ} 332$, p. 4.

1355 Idem.

1356 Idem.

1357 Idem.

${ }^{1358}$ Idem.

1359 Idem.

1360 SePÚlveda MuÑOz, Isidro, "Diplomáticos y cónsules españoles en América, 1892-1936”, Espacio, Tiempo y Forma, tomo V, 1992, p. 400.

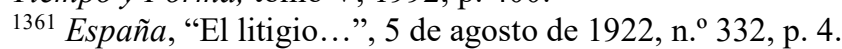


Es interesante notar en este artículo la concepción de objetividad informativa y sobre la "verdad". Si bien sólo con el "criticismo" introductorio al estudio sabemos que se trata de un reportaje evaluativo, que intenta argumentalmente darse a entender, las declaraciones siguientes colisionan con aquella intención. El análisis del problema fronterizo quería realizarse, candorosamente, sin ideas preconcebidas, liberándose de inclinaciones a priori, sólo guiándose por una "objetiva inquietud de justicia [...] de quien persigue derechamente la verdad"1362. En otro aspecto, culpaba, en gran medida, la abstención arbitral de países latinoamericanos en conflictos de la región, actitud que sólo reforzaba el papel tutelar del país norteamericano. Argentina, país que pudo trabajar por la paz, no logró marginar a la potencia del norte. Tiempo antes hubo noticias comentando que el Secretario de Estado estadounidense invitó al gobierno argentino para nombrar "un representante en el Tribunal arbitral"1363. También, elucidando la actitud del canciller peruano, quien propuso un tribunal compuesto por Estados Unidos, Argentina y Brasil ${ }^{1364}$. En conclusión, se manifestó que el árbitro debía poseer más que autoridad moral, es decir, posibilidades coercitivas para hacer cumplir el fallo. Por último, aprovechando el marco analítico de las repúblicas hispanoamericanas, España defendió la demanda marítima boliviana, país que por "justicia internacional" 1365 debía ejercer soberanía en alguna costa del Pacífico.

Las “enseñanzas" deducidas de las relaciones chileno-peruanas en Washington mostraban el avance del panamericanismo, "factura yanqui [...] en el sentido de apartarse del viejo continente y alejar a Europa de toda contienda específicamente americana"1366. Para esta prensa, un panamericanismo sin los Estados Unidos era más respetable, pues las relaciones internacionales se efectuarían entre repúblicas simétricas en poder. De esa forma, los países hispanoamericanos, además, realizarían su desarrollo sin "contactos impuros"1367.

\footnotetext{
1362 Idem.

${ }^{1363}$ El Imparcial, "Despachos breves del extranjero", 4 de junio de 1922, p. 4.

${ }^{1364}$ El Imparcial, "Fracaso de la Conferencia chilenoperuana", 13 de julio de 1922, p. 4.

${ }^{1365}$ España, "El litigio chileno-peruano", 5 de agosto de 1922, n. ${ }^{\circ} 332$, p. 4.

1366 Idem.

1367 Idem.
} 
Así mismo, alertaba benignamente a las antiguas colonias sobre el riesgo contraído al poner sus problemas locales en manos estadounidenses. Como ha precisado un historiador, el americanismo era la unión de América sin los Estados Unidos; el panamericanismo una invención moderna de los Estados Unidos que "nace para contraponerse a la idea racial de acercamiento a España y a la idea latina de acercamiento a la Europa mediterránea"1368.

Si permite que los Estados Unidos sean árbitros de sus contiendas -agoró con precisión- no hay que sorprenderse que luego efectúe sobre la región políticas "reprobables y sojuzgadoras"1369 como las practicadas en México, Haití, República Dominicana y Puerto Rico, que la prensa siguió con interés y tiempo después detalladas obras han dado cuenta $^{1370}$. España se conmovió de la diplomacia americana. Allí:

[...] en un problema que afecta a dos repúblicas hispano-americanas sólo los E.U. actúan, en tanto otras naciones del Nuevo Mundo asisten a la contienda de un modo pasivo, y dejan que sobre América proyecten su sombra exclusiva los hombres de Washington [...] Tal es el estado del problema: los Estados Unidos mediando y arbitrando sin contrapeso. España, ausente e ignorante, y sin embargo, por nuestro desinterés, por el afecto que nos une a aquellas Repúblicas, por el deseo de verlas vivir en paz y armonía, parecería natural que a nuestro país compitiese la alta misión arbitral. Pero ya es tarde; nuestra posible ascendencia moral se desvanece en aquella parte del mundo [...] El monroísmo, con marchamo yanki, progresa. La América latina se transforma progresivamente en una prolongación de los Estados Unidos ${ }^{1371}$.

En otro tema, el de la forma, establecido en el punto primero del Acta suplementaria del protocolo, las cancillerías de Chile y Perú prepararon sus defensas sobre la pertinencia o no del plebiscito. Durante esos meses de trabajo diplomático las noticias disminuyeron considerablemente, reapareciendo en el momento de ratificarse el protocolo en el congreso peruano $^{1372}$ y en la Cámara de diputados chilena ${ }^{1373}$. En ese país, el impulsivo presidente Alessandri hizo declaraciones inconvenientes. Acusando al Perú de realizar una campaña

1368 Blanco Fombona, Rufino, Ensayos Históricos, Caracas, Biblioteca Ayacucho, 1981, p. 355.

${ }^{1369}$ España, "El litigio chileno-peruano", 5 de agosto de 1922, n. ${ }^{\circ} 332$, p. 4.

1370 MORALEs PADRÓn, Francisco, Historia de unas relaciones dificiles (EEUU-América Española), Sevilla, Publicaciones de la Universidad de Sevilla, 1987; SELSER, Gregorio, Cronología de las intervenciones extranjeras en América Latina, tomo III, 1899-1945, México, Centro de Investigaciones Interdisciplinares en Ciencias y Humanidades, Universidad Nacional Autónoma de México, 2001.

${ }^{1371}$ España, "El litigio chileno-peruano", 5 de agosto de 1922, n. ${ }^{\circ} 332$, p. 4.

1372 El Heraldo, "Extranjero", 14 de septiembre de 1922, p. 2; La Voz, "La cuestión de Tacna y Arica", 14 de septiembre de 1922, p. 4; El Imparcial, "Despachos breves del extranjero", 15 de septiembre de 1922, p. 4.

1373 La Época, "Noticias cortas", 30 de noviembre de 1922, p. 1; Vida Marítima, "La situación internacional", 15 de diciembre de 1922, n. $^{\circ} 728$, p. 4. 
publicitaria antichilena, mostró satisfacción de que el árbitro se centrase sólo en el artículo n. ${ }^{\circ}$ 3. La política peruana ha caído y sólo bastó, sentenció el caudillo, "nuestra actitud levantada [...] para que el mundo entero se alce a nuestro favor y para que se nos vea como a un pueblo justiciero que usa la fuerza inmensa que da el respeto al derecho y a la justicia"1374. El trabajo realizado por el equipo jurídico dirigido por el canciller Luis Izquierdo fue enfatizado por la prensa española ${ }^{1375}$.

En Estados Unidos, el ataque cardiaco sufrido por el árbitro el 2 de agosto de 1923, permitió al republicano Calvin Coolidge acceder a la Casa Blanca. El compromiso arbitral asumido por su antecesor fue llevado, ahora, con prolijidad. Sobre su papel en la cuestión de Tacna y Arica la prensa española informó abundantemente sin realizar mayores comentarios $^{1376}$.

El mismo tono utilizó para informar del optimismo con que Chile seguía el estudio de las memorias que las cancillerías de los países enfrentados habían entregado en Washington ${ }^{1377}$. El fallo del árbitro se acercaba. Como en ocasiones anteriores, las centrales telegráficas españolas recibieron noticias falsas sobre las decisiones de la Casa Blanca. Una, publicada en El Sol, aseguró que "Las citadas provincias pasan nuevamente al control del Perú, debiendo pagar Chile 10 millones de dólares en calidad de perjuicios"1378. Al día siguiente no enmendó su error, felicitando la serenidad e imparcialidad de Coolidge ${ }^{1379}$. Otras, más ajustadas a los hechos, dieron cuenta de las coacciones sufridas por los habitantes peruanos de Tacna y Arica en manos de ultranacionalistas chilenos ${ }^{1380}$. Esa

${ }^{1374}$ El Imparcial, "La cuestión de Tacna y Arica", 13 de diciembre de 1922, p. 1.

${ }^{1375}$ La Época, "Nuevo gobierno chileno", 22 de marzo de 1923, p. 1; El Sol, "Tacna y Arica", 11 de mayo de 1923, p. 5; La Voz, "La cuestión de Tacna y Arica", 11 de mayo de 1923, p. 4.

${ }^{1376}$ El Sol, "Extranjero", 15 de abril de 1924, p. 5; La Época, "Noticias cortas", 15 de abril de 1924, p. 1; La Voz, "Coolidge será árbitro en la cuestión de Tacna y Arica", 15 de abril de 1924, p. 5; El Imparcial, "La política de aproximación de los Estados Unidos", 3 de junio de 1924, p. 4; El Imparcial, "El arbitraje yanqui", 29 de julio de 1924, p. 4; El Heraldo, "Coolidge se interesa en el litigio entre Perú y Chile", 27 de agosto de 1924, p. 3; El Imparcial, "El arbitraje de los Estados Unidos", 28 de agosto de 1924, p. 3; El Imparcial, "Noticias de América", 6 de diciembre de 1924, p. 3.

1377 La Libertad, "El pleito chilenoperuano", 5 de abril de 1924, p. 1; La Correspondencia de España, "La cuestión de Tacna y Arica", 16 de abril de 1924, p. 7; La Libertad, "El cuento de la buena pipa", 29 de mayo de 1924, p. 1; El Heraldo, "Informaciones de Chile, Uruguay, Colombia, Brasil y Paraguay", 2 de agosto de 1924, p. 3; El Imparcial, "Optimismo en Chile", 3 de agosto de 1924, p. 4; El Imparcial, "Noticias de América", 29 de agosto de 1924, p. 4.

${ }^{1378}$ El Sol, "La solución del conflicto de Tacna y Arica", 31 de diciembre de 1924, p. 5.

${ }^{1379}$ El Sol, "El pleito chilenoperuano sobre la nacionalidad de Tacna y Arica", 1 de enero de 1925, p. 8.

${ }^{1380}$ El Heraldo, "El Perú quiere anexionarse dos provincias chilenas", 25 de octubre de 1924, p. 3. 
violencia nacionalista sólo sería la antesala de la ejercida durante el proceso plebiscitario que comenzaría en 1925.

\author{
Imagen n. ${ }^{\circ} 59$
}

EN WASHINGTON

\title{
La Conferencia de Tacna y Arica
}

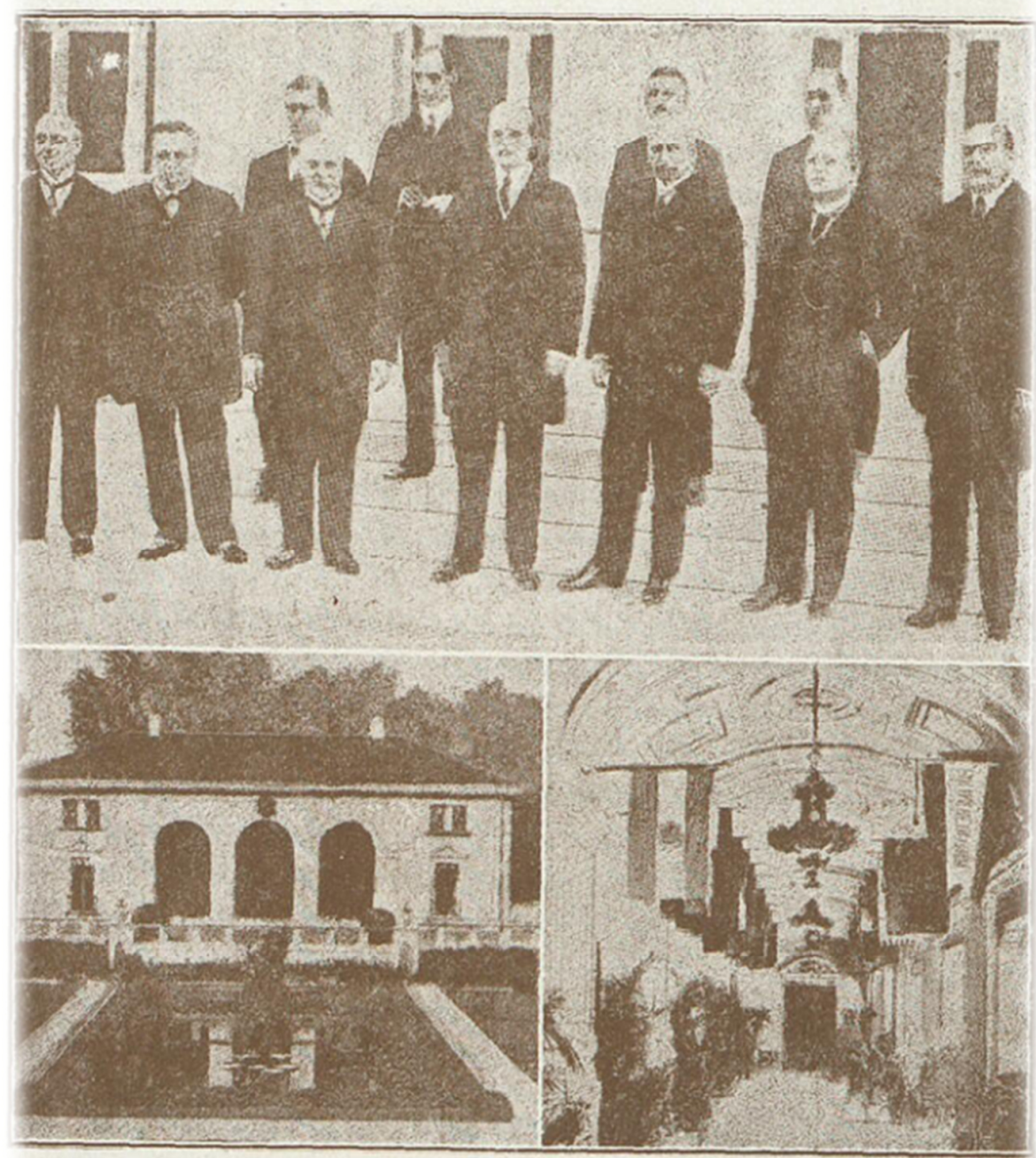

Los delegados de Chile y el Perú con el secretario Higges.-El edificio donde se celebra la Conferencia y el salón de América donde se reúne diariamente.

Revista de la Real Academia Hispano-Americana de Ciencias y Artes, "La Conferencia de Tacna y Arica”, 1922, n. ${ }^{\circ} 15$, p. 6. 
7.2. El fallo del presidente estadounidense

El 4 de marzo de 1925 Calvin Coolidge falló que el plebiscito se realizase. Desde comienzos de ese año, la prensa mostró interés por saber la posición estadounidense. Conjuntamente, noticiaron los desajustes de la política interna chilena. En ese país, una Junta de Gobierno constituida por militares tomó el mando del Estado. Alessandri, de momento, exiliado en la Italia de Mussolini, permitió a un "distinguido diplomático chileno" 1381 , no identificado, presagiar la postergación del fallo estadounidense ${ }^{1382}$. A la vez, la entrega de las memorias finales de Chile y Perú al árbitro, evidenció en los argumentos que la fraternidad mostrada al inicio de las conferencias, se transformó en rivalidad ciega, situación latamente comentada.

El Sol enfatizó que el laudo era menos importante que sus resultados, mostrando escepticismo hacia aquellos. En sus palabras señaló que la decisión de Coolidge ayudaría a mejorar o empeorar las relaciones chileno-peruanas (!). Por esa razón, en otra opinión omitió, a propósito, las cuestiones de derecho internacional vistas como problemas secundarios. La postura jurídica sacrificada fue reemplazada por un hispanoamericanismo delirante que demostró desconocimiento histórico sobre las identidades chilena y peruana.

El periodista, sin perder la cortesía debida en el campo del nacionalismo, expresó: "Con todos los debidos respetos, se nos figura que ésta es una disputa entre hermanos, en vida de los padres, y cuando viven todavía los hermanos en el domicilio paterno. Padre y madre son las razas española y americana"1383. La hermandad, se desprende de la cita, lleva aparejada la condición de minoría de edad y ésta la de inmadurez o, por lo menos, falta de experiencia. Considerar esa condición psicológica en el desarrollo nacional sudamericano interesa, porque, entonces, moralmente debían respeto a los progenitores, pues de allí "han salido chilenos y peruanos"1384.

${ }^{1381}$ El Heraldo, “Planteará otra vez el nuevo estado de cosas el pleito de Tacna y Arica?”, 5 de febrero de 1925, p. 3; La Libertad, "Lo de Tacna y Arica", 5 de febrero de 1925, p. 1.

1382 Idem.

${ }^{1383}$ El Sol, "Tacna y Arica”, 1 de enero de 1925, p. 5.

${ }^{1384}$ Idem. 
La reflexión periodística en torno al origen de Chile y Perú, influida por el "darwinismo social" 1385 , tiene otro aspecto interesante derivado de "biologizar" un asunto político. Cuando el autor aseguró que el padre era España y la madre América, se detecta la intención de "masculinizar" al país europeo que, sin duda, era pensado al otro lado del Atlántico en términos femeninos (madre patria). Los riesgos de los cruces de género ensayados concluyen en el reconocimiento de que Tacna y Arica se ubica en el domicilio paterno $^{1386}$. No considerando un hermafroditismo metafórico nacionalista-que, de todos modos, permite "indagar en el carácter de los sentidos vitales de la lucha política cuando ésta se relaciona con necesidades primordiales" 1387 - usado por el escritor, centrémonos en cómo retoma su interés por reconocer sólo una arista de la poliédrica cuestión. El texto declarativo expresó que:

No queremos saber si Tacna y Arica son chilenas o son peruanas lo que sabemos es que chilenos y peruanos son, esencialmente, una misma cosa, que Chile es una palabra que en el idioma de los incas significa nieve, y que lo mejor sería acabar por medio de algún sistema federativo toda ocasión de disputas territoriales entre los pueblos hispanoamericanos. Harto se nos alcanza que las enormes distancias de América harían ineficaz todo intento de regir países diversos por medio de un Gobierno centralista. Lo que no pudo hacer España no lo podrían hacer tampoco sus hijas ${ }^{1388}$.

El descuido de las aristas jurídicas y culturales en juego en la cuestión de Tacna y Arica intentó suplirse con conocimientos exiguos de analogías históricas, climatología e hispanoamericanismo político. En el primer caso, y como en ocasiones anteriores, la idea era comparar Tacna y Arica con Alsacia y Lorena. A diferencia de los demás usos de la analogía, en El Sol existió la voluntad de derribar ese mito sudamericano, objetivo perseguido años antes por el periodista chileno Ernesto Montenegro en un escrito titulado "Tacna y Arica versus Alsacia y Lorena"1389.

La base de su opinión era la igualdad cultural entre chilenos y peruanos, opuesta totalmente a las diferencias entre alemanes y franceses. No deja de ser atractiva, de la mano

\footnotetext{
${ }^{1385}$ CARreras Ares, Juan José, Razón de historia, Madrid, Marcial Pons. Ediciones de Historia, S. A., 2000, pp. 52-53.

${ }^{1386}$ El Sol, "Tacna y Arica", 1 de enero de 1925, p. 5.

1387 ESTEVA FABREGAT, Claudio, "El bosque hostil o la dialéctica del nacionalismo". En AlCINA FrANCH, José y CALÉS BoURDET, Marisa (Eds.), Hacia una ideología para el siglo XXI. Ante la crisis civilizatoria de nuestro tiempo, Madrid, Ediciones Akal S. A., 2000, p. 67.

${ }^{1388}$ El Sol, "Tacna y Arica”, 1 de enero de 1925, p. 5.

1389 MONTENEGRO, Ernesto, La cuestión chileno-peruana...
} 
de la anterior opinión, la explicación ofrecida para demostrar la similitud cultural de chilenos con peruanos. Ciertamente, sólo el clima de dos pueblos iguales habría trabajado sobre ellos resultados diferentes, pues uno se asentaba sobre zonas tropicales y el otro sobre áreas templadas. Era la época donde la geografía estaba "hechizada por su propio determinismo" 1390 . De todos modos, esas diferencias, otra vez, se invalidaban para comprender a chilenos y peruanos, ya que "ni uno ni otro se previene todo lo debido contra los peligros de cada uno de esos climas" ${ }^{1391}$. El tercer elemento usado por este diario hizo hincapié en algunas ideas compartidas en el párrafo extenso citado referidas al hispanoamericanismo. En la visión de este medio, el diferendo debía superarse para formar una organización política mayor. La conciencia hispanoamericanista, según el periodista, lo empujaba hacia la objetividad en la litis, no sintiendo preferencias hacia Chile o Perú. La verdadera simpatía era hacia la fraternidad con todos los pueblos hispánicos. El objetivo final de esa unión, tema de gran importancia, era ocupar un papel central en el mundo.

Las ensoñaciones milenaristas del español aparecieron en su escrito. Para todos los pueblos ibéricos -afirmó- hay "tarea en América para miles de años"1392. Allí "hay pan para todas las multitudes de la tierra, si se va realizando la obra de sanear aquellos territorios y prepararlos para la explotación" ${ }^{1393}$. Al redactor no sólo le interesaba el aspecto económico de la unión cultural hispanoamericana, ya que era perentorio, por usar un concepto actual, un dinamismo intercultural: "Al mismo tiempo hay que realizar la obra espiritual de irse asimilando y educando las multitudes emigrantes"1394.

La misma publicación trató con detenimiento otra vez la disposición de Coolidge hacia el fallo. En la noticia se detecta una leve chilenofilia. Las valoraciones positivas realizadas hacia la industrialización chilena de Tacna, Arica y Tarapacá, afirmaba, pusieron al Perú "celoso" 1395 de sus territorios perdidos. El Tratado de Ancón se había incumplido por causas ajenas a los deseos de ambos países.

\footnotetext{
1390 SCHAEFER, Fred K., Excepcionalismo en geografia, Barcelona, Publicacions de la Universitat de Barcelona, 1988, p. 82.

${ }^{1391}$ Idem.

1392 Idem.

${ }^{1393}$ Idem.

1394 Idem.

${ }^{1395}$ El Sol, "Tacna y Arica”, 1 de enero de 1925, p. 5.
} 
El juicio para el presidente estadounidense fue severo. Si bien reconocía la labor ardua que significó para el "callado"1396 Coolidge leer la documentación de los "trece grandes volúmenes impresos"1397 y la división del problema fronterizo en tres puntos esenciales (la determinación geográfica del área del conflicto, las informaciones confidenciales de personas que habitaban la región, la importancia de los determinantes históricos, políticos y sociales en el conflicto), el trabajo adolecía de graves faltas.

El Sol sostuvo que quedaron en pie problemas relacionados con los dineros chilenos invertidos en obras públicas en Tacna y Arica. Un punto de los alegatos peruanos solicitó la exención de todo pago si perdía los territorios. Así se detalló en la sexta proposición de la contrarréplica peruana: Cualquier mejora o inversión realizada por Chile en las provincias durante la ocupación indebida "corren de su cuenta y riesgo, puesto que han sido realizadas en propiedad ajena sin consentimiento de su dueño y por ende sin lugar a reclamación"1398. Un mapa incluido en el reportaje carecía, sin embargo, de la simbología pertinente del ferrocarril Arica-La Paz, la obra más costosa acometida por la administración chilena y también la "más política"1399.

\section{Imagen n. 60}

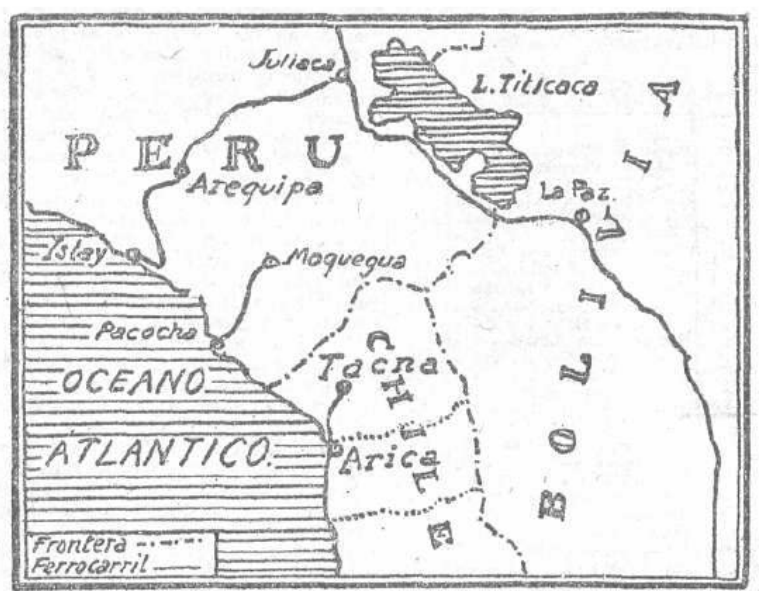

Fuente: El Sol, "El pleito chileno-peruano sobre la nacionalidad de Tacna y Arica", 1 de enero de 1925 , p. 8.

\footnotetext{
${ }^{1396}$ BenNetT, William J., América la última esperanza. Desde el mundo en guerra al triunfo de la libertad, volumen II, Nashville, Grupo Nelson, 2010, p. 88.

${ }^{1397}$ El Sol, "Tacna y Arica", 1 de enero de 1925, p. 5.

${ }^{1398}$ El Sol, "El pleito chilenoperuano sobre la nacionalidad de Tacna y Arica", 1 de enero de 1925, p. 8.

1399 ANGERSTEIN, Dietrich, Historia del ferrocarril en Chile, Santiago, Dirección de Archivos, Bibliotecas y Museos. Centro de Investigaciones Diego Barros Arana, 1997, p. 160.
} 
Las comunicaciones emitidas en Washington acerca del próximo fallo de Coolidge circulaban desde esa ciudad hacia Santiago, Lima y Madrid. Según éstas, gran parte de la labor preliminar estaba resuelta ${ }^{1400}$, informaciones que la prensa chilena publicaba insistentemente ${ }^{1401}$.

En España, la fecha exacta del fallo fue dispar. Las primeras publicaciones sobre el acontecimiento datan del 10 de marzo ${ }^{1402}$. En conjunto, remarcaron la idea de la celebración de un plebiscito en Tacna y Arica que decidiría la soberanía definitiva de las provincias. Una cantidad menor se refirió al impacto de la chilenización de Tacna y Arica que, en aquellos momentos, demostraba que la población era "más chilena que peruana"1403.

El Imparcial comentó esta decisión apelando al humor para criticar la actitud ambivalente del presidente estadounidense. Entre otras estrategias, comparó al presidente yanqui con el creador de la Historia de la vida del Buscón llamado don Pablos y con el dramaturgo vallisoletano José Zorrilla y Moral:

Llamado a dirimir, como árbitro, el conflicto pendiente entre Tacna y Arica, el presidente norteamericano, Coolidge, ha dictado su fallo. Y el fallo falla que falle un plebiscito. Por su parte, el fallador está fallo a fallo. Que se autofallen los interesados. El Sr. Coolidge, que es el más genial de los amigables componedores que se han conocido; ni sube, ni baja, ni se está quedo. Como cuentan de Quevedo, se balancea de un lado a otro. En unos puntos está conforme con los peruanos y en otros con los chilenos. Únicamente consigo mismo no ha podido llegar a un acuerdo franco y decisivo. Por eso, tan sabia y prudentemente como el escultor del Tenorio, exclama, huyendo del conflicto:

$$
\begin{aligned}
& \text { Me voy. No quiero la piel } \\
& \text { dejar aqui entre sus manos, } \\
& \text { que chilenos y peruanos } \\
& \text { se las compongan con él }{ }^{1404} \text {. }
\end{aligned}
$$

El Sol, quizás corrigiendo la despreocupación anterior por los fundamentos jurídicos del fallo arbitral, ofreció posteriormente los detalles del documento entregado por Francisco

${ }^{1400}$ El Imparcial, "Noticias de América", 10 de febrero de 1925, p. 5.

${ }^{1401}$ El Heraldo, "El fallo de la cuestión de Tacna y Arica", 21 de febrero de 1925, p, 3.

${ }^{1402}$ El Imparcial, "Coolidge dicta su fallo", 10 de marzo de 1925, p. 2; El Sol, "Extranjero", 10 de marzo de 1925, p. 5; El Sol, "El conflicto de Tacna y Arica", 10 de marzo de 1925, p. 1; La Libertad, "El litigio entre Tacna y Arica", 10 de marzo de 1925, p. 1; La Lectura Dominical, "Efemérides de la semana", 14 de marzo de 1925 , p. 128.

${ }^{1403}$ La Lectura Dominical, "Tacna y Arica”, 21 de marzo de 1925, p. 141.

${ }^{1404}$ El Imparcial, “Allá ustedes”, 11 de marzo de 1925, p. 1. 
San Cristóbal, Encargado de Negocios de Chile en Madrid. La noticia explicó, en primer lugar, que el árbitro no encontró razones para prescindir del plebiscito. Por lo mismo, el acuerdo de las partes decretó verificar una votación popular en Tacna y Arica, en efecto, el artículo tercero del tratado mantenía su vigencia.

En segundo lugar, se publicaron los requisitos de los votantes, a saber: varones de veintiún años que sepan leer y escribir, nacidos en Tacna y Arica (independientemente de la nacionalidad) y, chilenos y peruanos con más de dos años de residencia. No tenían derecho a voto las mujeres, los analfabetos (salvo que posean algún bien raíz), quienes hayan sido miembros del ejército, la armada, carabineros, policía, servicios secretos, gendarmería (salvo que hayan nacido en el territorio), los sentenciados por delitos infamantes y aquellos con facultades mentales insanas. En tercer lugar, se estipuló que la dirección central del plebiscito la llevaría una comisión plebiscitaria compuesta por tres representantes, uno de Estados Unidos y los otros dos de Chile y Perú.

La recepción del fallo arbitral fue diferente en Chile y Perú. Una revista comentó refiriéndose al último: “A las fiestas en este país celebradas por el resultado del añejo pleito han acompañado los tristes comentarios con que lo han recibido los peruanos"1405. Mientras Chile tomó el fallo como un triunfo diplomático, realizando festejos públicos, desfiles militares y conferencias en escuelas y centros políticos, en el Perú provocó gran desilusión, manifestaciones multitudinarias -algunas compuestas por más de veinte mil mujeres- y sentidos discursos en el parlamento ${ }^{1406}$.

La violencia producida por la frustración de la peruanidad hizo que decenas de manifestantes protestaran frente a la embajada de los Estados Unidos en Lima. El asalto posterior fue también ampliamente noticiado. La policía peruana tuvo que vigilar el edificio de los agentes estadounidenses ${ }^{1407}$. La prensa peruana, por su parte, opinó que el fallo era

\footnotetext{
${ }^{1405}$ La Lectura Dominical, "Tacna y Arica”, 21 de marzo de 1925, p. 141.

${ }^{1406}$ El Sol, "Se somete al plebiscito de los habitantes para que lo resuelvan", 11 de marzo de 1925, p. 1; El Heraldo, "La cuestión de Tacna y Arica", 16 de marzo de 1925, p. 3; El Imparcial, "El fallo de Mr. Coolidge", 17 de marzo de 1925, p. 1; El Heraldo, "Todavía Tacna y Arica", 18 de marzo de 1925, p. 4; El Imparcial, "El Perú, disgustado", 18 de marzo de 1925, p. 5; El Imparcial, "Acuerdos de la Cámara peruana", 19 de marzo de 1925, p. 4; El Imparcial, "Noticias de América", 25 de abril de 1925, p. 5.

${ }^{1407}$ La Voz, "La sentencia arbitral de Coolidge", 19 de marzo de 1925, p. 5; La Voz, "Los peruanos intentan asaltar la Embajada yanqui”, 19 de marzo de 1925, p. 8; El Sol, "Contra la embajada norteamericana en Lima", 20 de marzo de 1925, p. 5; La Época, "Noticias cortas", 20 de marzo de 1925, p. 1.
} 
inadecuado, pues eludía la opresión realizada por Chile contra los peruanos de Tacna y Arica.

El fallo, por ejemplo, publicó El Imparcial de España "es del todo extemporáneo"1408, aludiendo las condiciones de la nacionalidad de los tacneños y ariqueños mutadas después de décadas de chilenización. Aquellas fueron varias veces alertadas por la delegación peruana en Washington, temiendo que el plebiscito bajo las cláusulas "establecidas en el tratado 1904 (sic) resultaría extemporáneo e ineficaz después de la actuación chilena en las provincias en litigio"1409.

En España se aseguró que en el Perú la opinión pública forzó al canciller para realizar declaraciones relativas a las garantías requeridas durante el plebiscito. Por su parte, el delegado peruano en Estados Unidos tuvo que desmentir los rumores que señalaban su renuncia al cargo, mientras que el Washington Post-escribió La Época-aseguraba que el Perú había notificado al presidente Coolidge que el fallo era inaceptable ${ }^{1410}$. Sugería, además, el envío de milicias estadounidenses para neutralizar la región en conflicto o, en su defecto, retirar las tropas chilenas "en las provincias de Tacna y Arica"1411. En suma, la causa de tales decisiones se encontraba en la chilenización acometida por las autoridades quienes "continúan empleando procedimientos ilegales para ejercer influencia en el resultado del plebiscito" 1412 .

En esa atmósfera contaminada por la inflexibilidad de criterios de la chilenidad y la peruanidad, los líderes diplomáticos de ambos países ratificaron su adhesión al fallo. Chile se anticipó en unas semanas al Perú, donde la sensación del fracaso diplomático no se diluía $^{1413}$. Por esos días, los sentimientos hispanoamericanistas estuvieron presentes en la

\footnotetext{
${ }^{1408}$ El Imparcial, "El plebiscito no es solución”, 21 de marzo de 1925, p.2.

${ }^{1409}$ España y América, "Lo de Tacna y Arica", tomo II, abril-junio de 1925, pp. 79-80.

${ }^{1410}$ El Heraldo, "El Perú confía en el resultado del plebiscito", 23 de marzo de 1925, p. 3; El Imparcial, "Perú acepta el plebiscito", 24 de marzo de 1925, p. 1; La Época, "La cuestión de Tacna y Arica", 24 de marzo de 1925 , p. 1.

${ }^{1411}$ El Imparcial, "En vísperas del plebiscito", 14 de mayo de 1925, p. 1.

${ }^{1412}$ La Época, "La cuestión de Tacna y Arica", 1 de abril de 1925, p. 3.

${ }^{1413}$ El Sol, "Chile ha firmado el acuerdo", 20 de mayo de 1925, p. 1; El Sol, "Extranjero", 20 de mayo de 1925, p. 5; El Heraldo, "La cuestión de Tacna y Arica", 20 de mayo de 1925, p. 4; La Correspondencia Militar, "Perú acepta el plebiscito en Tacna y Arica", 10 de junio de 1925, p. 1; La Lectura Dominical, "Efemérides de la semana", 13 de junio de 1925, p. 296; El Imparcial, "Noticias de América", 15 de julio de 1925, p. 3 .
} 
retórica periodística española. Una importante revista aprovechó la coyuntura diplomática para mostrar sus sentimientos:

Para nosotros, los españoles, ofrece la intervención de Estados Unidos tema de justificado sentimiento. No el arbitraje, sino la amigable composición, por tradiciones históricas, igualdad de razas y de costumbres y autoridad irrecusable de la sangre, correspondía a España. Y a los Vistos y Considerandos que contiene el fallo del Presidente yanqui hubieran sustituido con eficacia y amorosa persuasión los razonamientos de justicia y equidad con que resuelven los mayores las querellas de sus hijos; y el Rey de España, como legítimo representante de un pasado común, tenía suprema y paternal autoridad para poner paz y restablecer la cordialidad entre la gran familia hispana ${ }^{1414}$.

\subsection{La comisión plebiscitaria en Arica}

La comisión plebiscitaria fue la institución internacional que, de acuerdo al fallo de Coolidge, debía encargarse de llevar a buen término el plebiscito de Tacna y Arica. Fracasó. Cada uno de los gobiernos participantes en las Conferencias de Washington designó con rapidez sus representantes y, por tal razón, esos nombres circularon prontamente en la prensa española ${ }^{1415}$. La comisión estuvo compuesta por el general John Pershing (Estados Unidos), Agustín Edwards (Chile) y Manuel Freyre (Perú), todos hombres de carrera diplomática, quienes no supieron afianzar la paz en la región.

La prensa vio la necesidad de publicar las biografías de los comisionados. El estilo sobrio de la presentación de Pershing, Edwards y Freyre imposibilita asegurar, en este punto, una tendencia de la prensa hacia alguno de los países. El primero, nacido en 1860 , realizó sus estudios en la Academia Militar de West Point. Participó en la campaña contra los Sioux en Dakota, en la Guerra de Cuba de 1898, en Filipinas, contra los moros de Mindanao, en la Guerra Ruso-Japonesa, en la expedición contra México y en la Gran Guerra. El presidente Roosevelt -señaló un diario con ánimo, quizás, de tiznar el brillante expediente militar de Pershing- "lo pasó de golpe del grado de capitán al de general de brigada, haciéndolo pasar sobre 863 oficiales"1416.

\footnotetext{
${ }^{1414}$ La Lectura Dominical, "Tacna y Arica”, 21 de marzo de 1925, p. 141.

${ }^{1415}$ El Sol, "El plebiscito Tacna-Arica", 30 de marzo de 1925, p. 5; El Heraldo, "La Delegación peruana en el plebiscito sobre Tacna y Arica", 30 de junio de 1925, p. 4; La Voz, "El plebiscito sobre Tacna y Arica", 30 de junio de 1925, p. 3; El Sol, "El plebiscito sobre Tacna y Arica", 1 de julio de 1925, p. 5; La Libertad, "El plebiscito sobre Tacna y Arica", 1 de julio de 1925, p. 3.

${ }^{1416}$ El Sol, "La presidencia del plebiscito", 27 de julio de 1925, p. 8.
} 
Agustín Edwards, uno de los políticos chilenos más poderosos ${ }^{1417}$, nació “en 1876 (sic) en Santiago"1418. Con estudios de derecho y economía ingresó joven en el parlamento, luego en el Ministerio de Relaciones Exteriores, Culto y Colonización y, posteriormente en el de Hacienda. Fue ministro plenipotenciario de Chile en España. De esa experiencia política surgieron dos obras literarias: Lo que vi en España y Las tres fiestas de Sevilla. Fue propietario y director de El Mercurio, el diario más influyente en el país por esos años. El representante chileno, en fin, "es uno de los hombres de mayor figuración e influencia en su país" ${ }^{1419}$.

La comisión chilena que dirigía estaba compuesta, además, por Enrique Chirgwing, Raimundo Ortúzar, Ernesto Barros Jarpa, Manuel Fóster Recabarren, Samuel Claro Lastarria, Manuel Maira, Salvador Allende, Galvarino Gallardo Nieto, Jorge Aldunate, Víctor Robles, Héctor Claro Salas, Guillermo Guerra, Guillermo Garay, Antonio Planet y José Luis Santa María ${ }^{1420}$.

Manuel Freyre, nacido en 1872, era un diplomático de escuela con estudios en Estados Unidos. Desempeñó varios cargos consulares en ese país ascendiendo a secretario de Legación y luego a ministro. Además de Washington, prestó servicios diplomáticos en Tokio, Pekín, Quito, Bogotá y Buenos Aires. El Sol, enfatizando su carrera intachable, dijo de él: "el Gobierno de su país no ha podido encontrar quien mejor asuma la responsabilidad de representarlo en el Alto Tribunal que resolverá para siempre el litigio más grave para su patria"1421.

Freyre, líder de la comisión peruana, era apoyado además por Alberto Salomón, Anselmo Barreto, José María Barreto, Roberto Mac Lean y Oscar Ordóñez ${ }^{1422}$.

\footnotetext{
1417 COUYOUMDJIAN, Juan Ricardo, Chile y Gran Bretaña durante la primera guerra mundial y la posguerra, 1914-1921, Santiago, Editorial Andrés Bello, 1986, p. 29; SALAZAR VERGARA, Gabriel, Mercaderes, empresarios y capitalistas (Chile, siglo XIX), Santiago, Editorial Sudamericana, 2009; VIAL CORREA, Gonzalo, Agustín Edwards Mac Clure: periodista, diplomático y politico: los cuarenta primeros años del siglo XX chileno, Santiago, El Mercurio, 2009.

${ }^{1418}$ El Sol, "La presidencia del plebiscito", 27 de julio de 1925, p. 8. Edwards nació un 17 de junio de 1878.

1419 Idem.

${ }^{1420}$ El Sol, "La Comisión chilena en Arica", 21 de agosto de 1925, p. 5.

${ }^{1421}$ El Sol, "La presidencia del plebiscito", 27 de julio de 1925, p. 8.

${ }^{1422}$ El Sol, "Los trabajos de las Comisiones plebiscitarias", 31 de agosto de 1925, p. 8.
} 
Legalmente, la comisión debía determinar las condiciones y el funcionamiento de las juntas de calificación, oficinas donde se comprobarían los requisitos exigidos a los votantes y planificarían las operaciones plebiscitarias. Además, tenía la potestad de recurrir al presidente Coolidge, en caso de producirse desacuerdos insalvables. La comisión, por último, debía fijar su sede en Arica dentro de los seis meses posteriores a la fecha del fallo, compromiso cumplido y valorado en términos de eficacia por $\mathrm{El} \mathrm{Sol}^{1423}$.

Un resumen de las funciones de la comisión, publicado por diversos órganos periodísticos, señaló que ésta "tendrá el control completo sobre el plebiscito y autoridad para determinar todas las cuestiones relacionadas con la inscripción de votantes, depósito y recuento de votos" ${ }^{1424} \mathrm{y}$, además, "resolver si las personas que solicitan la inscripción se hallan calificadas para ello"1425. En efecto, la convocatoria realizada por Pershing se fechó, según algunos diarios, el 8 de agosto ${ }^{1426}$. Las naves de guerra de los tres países zarparon de sus puertos principales con dirección a Arica ${ }^{1427}$. En aguas del Pacífico navegaban los hombres encargados de tranquilizar las tempestades del patrioterismo chileno-peruano...

La Lectura Dominical publicó un interesante artículo comentando los trabajos de la comisión para reglamentar el derecho a voto. Ese trabajo comprendía un conjunto de disposiciones para fijar juntas de inspección e inscripción, tramitación de denuncias formuladas contra falsos votantes e impresión de las papeletas. En definitiva, escribió La Lectura ... en lenguaje coloquial, la comisión "está adoptando todo género de precauciones contra los pucherazos"1428. Sabía, además, que los requisitos exigidos a los votantes citados en el acápite anterior- limitaba su número, puesto que en Tacna y Arica habían "muchos negros y de éstos son pocos los que saben leer y escribir"1429.

${ }^{1423}$ El Sol, "Las Delegaciones se reunirán el 4 de agosto”, 28 de julio de 1925, p. 2.

${ }^{1424}$ El Heraldo, "La cuestión de Tacna-Arica", 30 de julio de 1925, p. 4; El Imparcial, "Noticias de América", 31 de julio de 1925, p. 4; La Libertad, "El plebiscito sobre Tacna y Arica", 31 de julio de 1925, p. 1.

${ }^{1425}$ El Heraldo, "La cuestión de Tacna-Arica", 30 de julio de 1925, p. 4; El Imparcial, "Noticias de América", 31 de julio de 1925, p. 4; La Libertad, "El plebiscito sobre Tacna y Arica", 31 de julio de 1925, p. 1.

${ }^{1426}$ La Voz, "El plebiscito sobre Tacna y Arica", 8 de julio de 1925, p. 6; El Imparcial, "Preparando el plebiscito", 9 de julio de 1925, p. 2; El Sol, "El plebiscito de Tacna y Arica", 9 de julio de 1925, p. 8; La Época, "Noticias cortas", 9 de julio de 1925, p. 1; La Libertad, "El plebiscito de Tacna y Arica", 9 de julio de 1925, p. 1.

${ }^{1427}$ La Voz, "El plebiscito de Tacna y Arica", 27 de julio de 1925, p. 1; El Sol, "Las delegaciones se reunirán el 4 de agosto", 28 de julio de 1925, p. 2; La Época, "La cuestión de Tacna y Arica”, 28 de julio de 1925, p. 3. ${ }^{1428}$ La Lectura Dominical, "Tacna y Arica", 22 de agosto de 1925, p. 415.

${ }^{1429}$ Idem. 
Arica, luego de décadas formando parte del discurso periodístico mundial a raíz de las desavenencias diplomáticas de Chile y Perú, se convirtió en lugar de los hechos noticiosos. Al igual que en los primeros años de la guerra o durante la construcción del ferrocarril de Arica a La Paz, la prensa española publicó descripciones de la ciudad. Arica, a causa del plebiscito, se convirtió en "el punto de convergencia de toda la América española"1430. Por tal razón, es probable que algunas reseñas del puerto, ofrecidas por prensa española, se publicaran intentando contraponerlas con reseñas de la prensa estadounidense que excluían del relato el pasado hispano de Arica.

Las primeras - españolas- enfatizaban la belleza de una ciudad de no más de cinco mil habitantes (el censo chileno de 1920 informaba una población de 9015 habitantes) ${ }^{1431}$, dotada de un puerto de importancia por donde Bolivia exportaba gran parte de su producción. La noticia suministró datos históricos. Por ejemplo, la conquista de Arica realizada por el "inca Yahuar-Huaca en 1230 (sic)""1432, el origen aymará de su nombre que traducido significaba "abertura nueva"1433, la transformación de su arquitectura y costumbres durante la colonia, la frecuencia de los asaltos de piratas ingleses y holandeses, los terremotos y, por último, los episodios sangrientos de la Guerra del Pacífico. Un plagio fragmentario de este reportaje apareció, aproximadamente, un año después en La Esfera ${ }^{1434}$.

Las segundas -estadounidenses- hacían referencia al desarrollo económico actual, la agricultura y las industrias de "la ciudad del Arco Iris"1435. Ciudad habitada principalmente por chilenos y también por peruanos, indígenas y pobres. Dentro de estos marcos urbanos, proyectados por determinados diarios, se desarrollaba el "más arduo problema que conmueve por (sic) hoy la tranquilidad política de Sur-américa"1436.

Como se dijo, España recibió noticias situadas, puntualmente, en Arica. Éstas dieron cuenta en agosto de la llegada de las tres delegaciones, detallando los recibimientos.

\footnotetext{
${ }^{1430}$ El Sol, "Las Delegaciones se reunirán el 4 de agosto", 28 de julio de 1925, p. 2.

${ }^{1431}$ RePÚBliCA DE CHILE, Censo de población de la República de Chile. Levantado el 15 de diciembre de 1920, Santiago, Soc., Imp. y Litografía Universo, 1925, p. 104.

${ }_{1432}$ El Sol, "Las Delegaciones se reunirán el 4 de agosto", 28 de julio de 1925, p. 2.

1433 Idem.

${ }^{1434}$ La Esfera, "Tacna y Arica, tierra irredenta", 14 de agosto de 1926, n. ${ }^{\circ}$ 658, p. 30.

${ }^{1435}$ El Sol, "Las Delegaciones se reunirán el 4 de agosto", 28 de julio de 1925, p. 2.

${ }^{1436}$ El Sol, "La presidencia del plebiscito", 27 de julio de 1925, p. 8.
} 
La prensa que publicó tales acontecimientos refirió, en el caso chileno, al elevado número de corresponsales acompañantes de la delegación y al desarrollo de la industria periodística, que, por esos días, dobló su producción. Los escasos reportajes gráficos no dieron cuenta de la dinámica social ocasionada por el escenario político $\mathrm{y}$, del modo habitual, retrataron el hito geográfico más simbólico de la frontera: El Morro de Arica.

\section{Imagen $n .^{\circ} 61$}

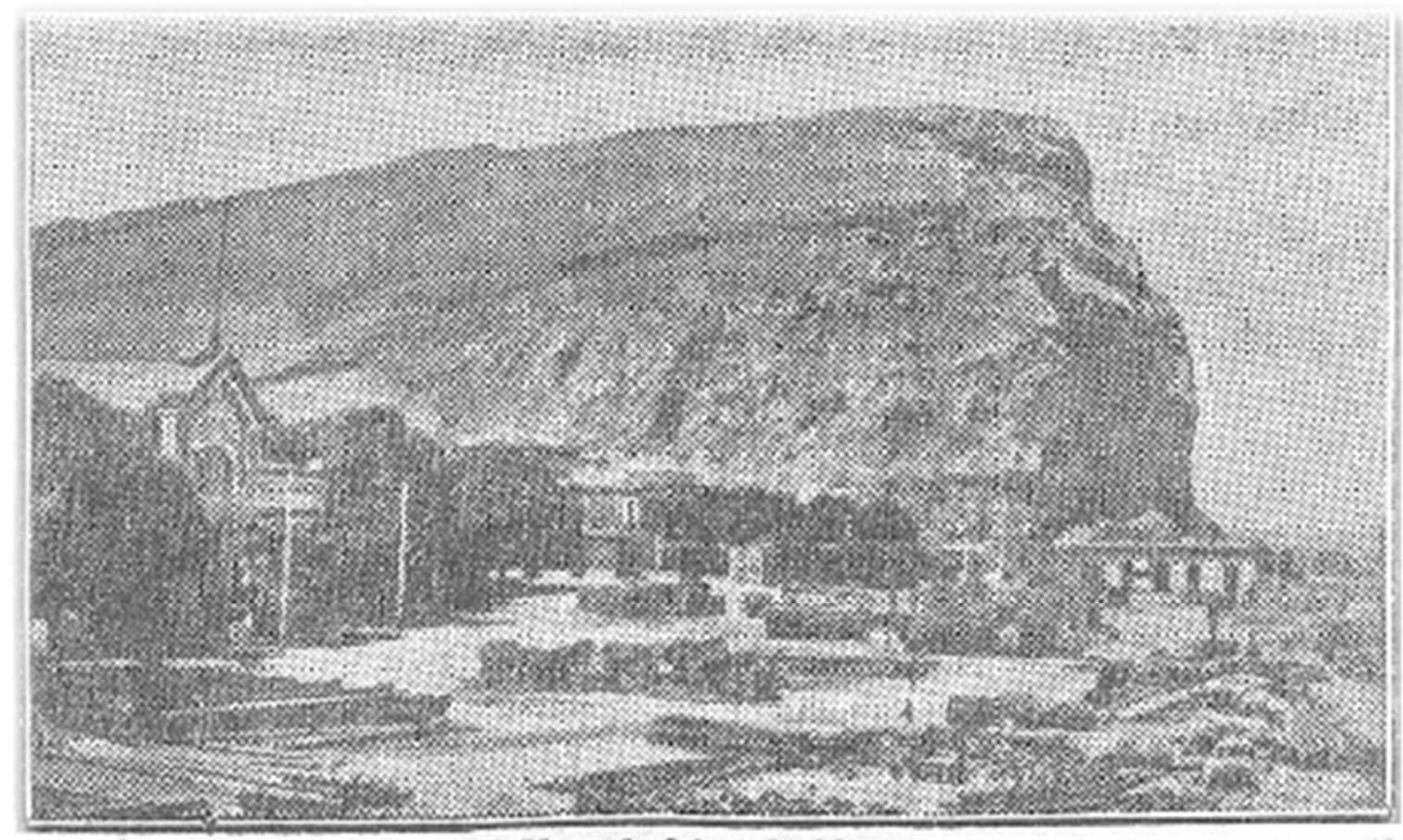

Fet Morno de Artoe $>$ Is Adnnon

Fuente: El Sol, "Los trabajos de las Comisiones plebiscitarias", 31 de agosto de 1925, p. 8.

En el caso peruano, comentó la negación de su delegación para usar los hoteles reservados por Chile, prefiriendo alojarse a bordo del Ucayali ${ }^{1437}$ (denominado equívocamente Ocayali). A la par, en Lima, se hizo frecuente la publicación de noticias que condenaron la chilenización de Tacna y Arica comenzada por el intendente Máximo Lira en 1908.

\footnotetext{
${ }^{1437}$ El Heraldo, "El plebiscito de Tacna y Arica", 1 de agosto de 1925, p. 4; La Voz, "Preparando el plebiscito para la posesión de Tacna y Arica", 1 de agosto de 1925, p. 8; La Libertad, "El plebiscito de Tacna y Arica", 2 de agosto de 1925, p. 1; La Época, "Noticias cortas", 4 de agosto de 1925, p. 1; El Imparcial, "Noticias de América", 5 de agosto de 1925, p. 3; La Lectura Dominical, "Efemérides de la semana", 8 de agosto de 1925, p. 393.
} 
A pesar de esa opresión, La Prensa sacó cuentas alegres, pues los chilenos nacidos en Tacna y Arica "son muy pocos, mientras que los peruanos nacidos en esos territorios capacitados para votar son innumerables. Basta comprobar solamente el número de desterrados de las provincias por negarse a servir al Ejército chileno"1438. Un estudio antiguo, basado en procesos judiciales, rescató las "voces" de los convictos peruanos que rechazaron someterse al servicio militar chileno en Arica ${ }^{1439}$.

Los periodistas de $E l$ Sol reseñaron la intensa propaganda de la prensa peruana que, para avivar el nacionalismo popular, día a día noticiaba contra la administración chilena de Tacna y Arica. La prensa chilena procedía de manera similar. La opinión de El Sol justificaba esas actitudes: "Si de una parte y otra abundan las violencias de concepto -muy disculpables por el ambiente de pasión que el pueblo les refleja-conservase, no obstante, la expresión correcta y serena que conviene al prestigio de la prensa suramericana"1440.

El último en llegar fue el general estadounidense. Sería, casualmente, el primero en retirarse de la cita diplomática.

La primera reunión de la comisión plebiscitaria se realizó el 5 de agosto. Las conversaciones se mantuvieron, de momento, en absoluta reserva. Trascendió a los medios de comunicación, siempre con escaza certeza, la intención de efectuar el plebiscito en un plazo inferior a cuatro meses. Otra vez, pese al rechazo de la idea por parte de Coolidge, Perú insistió con la neutralización de Tacna y Arica durante las jornadas plebiscitarias, único modo de terminar con la privilegiada situación chilena en ese territorio ${ }^{1441}$. Importantes diarios españoles reprodujeron las opiniones de un diario chileno.

${ }^{1438}$ El Imparcial, "Noticias de América", 6 de agosto de 1925, p. 4; La Libertad, "El plebiscito de Tacna y Arica", 6 de agosto de 1925, p. 1.

1439 Soto LARA, José Julián, "Cara y cruz en la militarización de la nueva frontera norte de Chile: el caso de Arica en el inicio del siglo XX”, Actas del I Congreso Internacional de Historia Militar, Madrid, UNED, 2014, pp. 13-44.

${ }^{1440}$ El Sol, "Los trabajos de las Comisiones plebiscitarias", 31 de agosto de 1925, p. 8.

${ }^{1441}$ El Imparcial, "Noticias de América", 22 de agosto de 1925, p. 3; El Heraldo, "La prensa del Perú, descontenta del plebiscito sobre Tacna y Arica", 29 de septiembre de 1925, p. 2; El Imparcial, "Noticias de América", 30 de septiembre de 1925, p. 2; La Época, "La cuestión de Tacna y Arica", 30 de septiembre de 1925, p. 1. 
La República aseguraba que la delegación peruana se había separado de la comisión plebiscitaria a la espera de instrucciones de su Gobierno"1442. Otros aspectos, no menores, fijaron el presupuesto que Chile y Perú debían pagar en los gastos plebiscitarios ${ }^{1443}$ y aceptaron la petición de la delegación peruana para revisar las garantías plebiscitarias causadas por la "mala interpretación del texto"1444.

Reunidos posteriormente los representantes de los países, los inconvenientes reaparecieron. Así lo demostró la prensa al informar de la aceptación, por parte de Pershing, de las garantías exigidas por Perú. Las reacciones del pueblo chileno en Tacna y Arica fueron de violencia desatada. Por tal razón, la cancillería chilena solicitó al militar soluciones efectivas para la consulta electoral, temiendo que "el conflicto llegue a envenenarse, dada la animosidad cada vez mayor" ${ }^{\prime 1445}$.

A la sesión de la comisión donde se discutiría el libre tránsito de peruanos por las provincias el representante chileno se ausentó. La relación Pershing-Edwards se había tornado dificultosa. El primero advertía que existía un protocolo arbitral que Chile prometió cumplir y que contrariándolo violaba las normativas del derecho internacional. El segundo rechazaba las garantías solicitadas por Perú, evaluadas positivamente por Pershing. La comisión plebiscitaria parecía precipitarse al fracaso.

Agustín Edwards, sin embargo, retomó su papel en la comisión, coincidiendo con los días en que Estados Unidos, no se sabe bien por qué, enviaba hacia Arica el acorazado Denver. Por España circulaba en la prensa la posible ruptura entre Chile y Estados Unidos $^{1446}$ y los rumores -desmentidos por Chile- de presentar el problema en la Sociedad

${ }^{1442}$ El Heraldo, "El pleito de Tacna y Arica", 13 de octubre de 1925, p. 5; El Imparcial, "Noticias de América", 14 de octubre de 1925, p. 5; La Libertad, "La cuestión de Tacna y Arica", 14 de octubre de 1925, p. 3.

${ }^{1443}$ El Imparcial, "Noticias de América", 6 de agosto de 1925, p. 4; La Correspondencia Militar, "Se reúne la Comisión Plebiscitaria de Tacna y Arica", 8 de agosto de 1925, p. 2; La Correspondencia Militar, "El plebiscito de Tacna y Arica", 11 de agosto de 1925, p. 5; La Correspondencia Militar, "El plebiscito de Tacna y Arica", 13 de agosto de 1925, p. 5; El Imparcial, "Noticias de América", 14 de agosto de 1925, p. 2; La Libertad, "El plebiscito de Tacna y Arica", 14 de agosto de 1925, p. 1; El Imparcial, "Noticias de América", 16 de agosto de 1925, p. 4.

${ }^{1444}$ El Imparcial, "Noticias de América", 18 de agosto de 1925, p. 3.

${ }^{1445}$ El Heraldo, "Se agrava la cuestión de Tacna y Arica", 26 de noviembre de 1925, p. 2.

${ }^{1446}$ La Libertad, "El plebiscito de Tacna y Arica", 12 de noviembre de 1925, p. 1; La Voz, "Temores de Chile", 26 de noviembre de 1925, p. 5; El Imparcial, "Se agrava la cuestión", 27 de noviembre de 1925, p. 1; El Sol, "un nuevo incidente y un acuerdo", 27 de noviembre de 1925, p. 1; La Libertad, "El plebiscito de 
de las Naciones ${ }^{1447}$. La Libertad, a modo de anécdota, publicó las consecuencias de las pésimas relaciones entre las delegaciones de Chile y los Estados Unidos. En particular, los roces entre Pershing y Alessandri eran "de tal naturaleza que el señor D. Arturo Alessandri, ex presidente de Chile, al embarcarse hoy en este puerto de regreso a Santiago, no se despidió del general Pershing"1448. Más peligrosa para el devenir de la comisión y la solución del conflicto fue, finalmente, la dimisión de Edwards. La historiografía chilena no logra esclarecer sus motivos. Las fuentes hemerográficas consultadas tampoco. Ciertos diarios españoles informaron, brevemente, la "dimisión sensacional"1449 de Edwards contradiciendo las noticias que aseguraban la reanudación de la comisión ${ }^{1450}$.

Parte de la prensa, como se aprecia, a raíz de los sucesos diplomáticos de Arica, saturó de información sus páginas. Con un estado de cosas así, finalizaba el año del plebiscito en medio de deudas, promesas y renuncias. Coolidge notificaba a los gobiernos de Chile y Perú que, por separado, debían con prontitud "depositar 65.000 dólares en un banco de Nueva York" ${ }^{1451}$ para solventar los gastos plebiscitarios. La comisión, por otro lado, fijaba la fecha del plebiscito para el 15 de abril de 1926. John Pershing, representante del árbitro estadounidense en Tacna y Arica, retornaba a su país aquejado por un dolor de muelas. El general -escribió La Época- "regresa enfermo a los Estados Unidos"1452.

Arica", 27 de noviembre de 1925, p. 1; La Voz, "La última complicación en el asunto chileno-peruano", 27 de noviembre de 1925, p. 1; El Sol, "Chile promete asistir a las sesiones", 30 de noviembre de 1925, p. 1; El Sol, "Extranjero", 30 de noviembre de 1925, p. 5; La Voz, "El pleito de Tacna y Arica", 30 de noviembre de 1925, p. 4; El Imparcial, "Noticias de América", 1 de diciembre de 1925, p. 4; El Sol, "La Comisión Plebiscitaria se reúne de nuevo", 1 de diciembre de 1925, p. 1; La Época, "La cuestión de Tacna y Arica. Vuelve a reunirse la comisión", 1 de diciembre de 1925, p. 1; La Libertad, "El plebiscito de Tacna y Arica", 1 de diciembre de 1925, p. 2; La Voz, "El conflicto chileno-peruano", 1 de diciembre de 1925, p. 5; El Sol, "La cuestión de Tacna y Arica", 4 de diciembre de 1925, p. 1; La Voz, "El pleito chileno-peruano", 4 de diciembre de 1925, p. 5; La Época, "La cuestión de Tacna y Arica", 5 de diciembre de 1925, p. 1.

${ }^{1447}$ El Sol, "Se piensa recurrir al a (sic) S. de N.", 2 de diciembre de 1925, p. 8; La Época, "La cuestión de Tacna y Arica", 2 de diciembre de 1925, p. 1; El Imparcial, "Noticias de América", 9 de diciembre de 1925, p. 6; El Imparcial, "Noticias de América", 11 de diciembre de 1925, p. 4.

${ }^{1448}$ La Libertad, "El plebiscito de Tacna y Arica", 5 de diciembre de 1925, p. 4.

${ }^{1449}$ La Libertad, "Dimensión sensacional", 25 de diciembre de 1925, p. 1.

1450 El Heraldo, "Dimite un miembro de la Comisión chilena", 24 de diciembre de 1925, p. 1; La Correspondencia Militar, "El plebiscito de Tacna y Arica. Dimite el delegado chileno", 24 de diciembre de 1925, p. 1; La Época, "La cuestión de Tacna y Arica", 24 de diciembre de 1925, p. 1; La Libertad, "Dimisión sensacional", 25 de diciembre de 1925, p. 1; La Correspondencia Militar, "El plebiscito de Tacna y Arica", 26 de diciembre de 1925, p. 1; La Época, "La cuestión de Tacna y Arica", 26 de diciembre de 1925, p. 3.

${ }^{1451}$ La Voz, "El pleito de Tacna y Arica", 11 de diciembre de 1925, p. 4.

${ }^{1452}$ La Época, "La cuestión de Tacna y Arica", 30 de diciembre de 1925, p. 1. 
7.4. Notas de las Legaciones de Chile, Perú y Bolivia para la prensa de España

Desde que Calvin Coolidge falló en favor del plebiscito hasta el clímax de los achaques dentales de Pershing, causa de su retiro de Arica, los hechos políticos ocurridos allí fueron evaluados opuestamente en Chile y Perú. En las cancillerías, en la prensa y en los pueblos de esos países, desaparecieron las afinidades en torno a la disputa territorial. Los fenómenos derivados del conflicto se polarizaron $\mathrm{y}$, puntualmente, desde un plano moral se continuó la construcción, iniciada durante los años de la guerra, de una otredad que debía enjuiciarse y criminalizarse. Todo "lo peruano" para los chilenos y "lo chileno" para los peruanos - considerando la etérea consistencia de la afirmación- se transformó en un pensamiento enconado dominante en ambos países.

Sus gobiernos sabían que los márgenes de la litis y la solución superaban el plano binacional. Sólo el papel desempeñado por los Estados Unidos demostraba la importancia de reflejar al exterior una política acorde con lo reglamentado por el árbitro. Para las cancillerías de Chile y Perú, Europa también representó un área donde la propaganda configuraba opiniones, favorables o contrarias hacia los procedimientos diplomáticos desarrollados por Tacna y Arica.

La prensa española, en coordinación con las legaciones de Chile y Perú, principales actores del drama del Pacífico, y también Bolivia, quien insistió en su política marítima reivindicativa, facilitó sus imprentas para la defensa de las tesis de esos países. Importaba proyectar imágenes acordes al progreso y respeto del derecho internacional. Por eso, los representantes de las legaciones adjudicaron a la prensa las visiones oficiales del estado de las relaciones diplomáticas. Aun cuando la importancia del conjunto de notas diplomáticas entregadas a las industrias periodísticas fue menor en comparación con los mensajes, interesa señalar la primacía chilena, seguida por los documentos peruanos y bolivianos. Ocasionalmente, la misma circular de un país fue reproducida por diversos medios. Tales circulares fueron mínima o nulamente intervenidas por las editoriales. La siguiente tabla muestra, de izquierda a derecha, el país de la legación emisora de la circular; el autor; el tema principal, el nombre de los diarios que la publicaron y, por último, la fecha de su publicación. 
Tabla n. ${ }^{\circ} 12$

Circulares diplomáticas enviadas por Chile, Perú y Bolivia a la prensa

\begin{tabular}{|c|c|c|c|c|}
\hline País & Autor & Tema & Diarios & Fecha \\
\hline Chile & $\begin{array}{l}\text { Francisco } \\
\text { San } \\
\text { Cristóbal }\end{array}$ & $\begin{array}{l}\text { Desmentir la fecha del fallo } \\
\text { arbitral publicada por la } \\
\text { prensa española }\end{array}$ & $\begin{array}{l}\text { El Sol, El Heraldo, } \\
\text { El Imparcial, La } \\
\text { Voz }\end{array}$ & $06 / 01 / 1925$ \\
\hline Chile & $\begin{array}{l}\text { Francisco } \\
\text { San } \\
\text { Cristóbal }\end{array}$ & $\begin{array}{l}\text { Dar a conocer el fallo } \\
\text { arbitral en España }\end{array}$ & $\begin{array}{l}\text { El Imparcial, } \quad \text { El } \\
\text { Siglo Futuro, La } \\
\text { Libertad }\end{array}$ & $11 / 03 / 1925$ \\
\hline Chile & $\begin{array}{l}\text { Francisco } \\
\text { San } \\
\text { Cristóbal }\end{array}$ & $\begin{array}{l}\text { Demostrar que el fallo } \\
\text { desaprueba la moción } \\
\text { peruana de "neutralizar" } \\
\text { Tacna y Arica }\end{array}$ & El Sol, La Voz & $07 / 05 / 1925$ \\
\hline Chile & $\begin{array}{l}\text { Ernesto } \\
\text { Barros Jarpa }\end{array}$ & $\begin{array}{l}\text { Anuncia la retirada de Chile } \\
\text { la Comisión Plebiscitaria }\end{array}$ & $\begin{array}{l}\text { El Heraldo, El } \\
\text { Imparcial, El Sol, } \\
\text { La Época, La } \\
\text { Libertad, La Voz }\end{array}$ & $26 / 11 / 1925$ \\
\hline Chile & $\begin{array}{l}\text { Emilio } \\
\text { Rodríguez } \\
\text { Mendoza } \\
\end{array}$ & $\begin{array}{l}\text { Presentar en España el } \\
\text { nuevo gobierno chileno }\end{array}$ & El Sol, El Sol & $\begin{array}{l}26 / 12 / 1925 \text { y } \\
28 / 12 / 1925\end{array}$ \\
\hline & & & & Total: 17 \\
\hline Perú & $\begin{array}{l}\text { Eduardo } \\
\text { Leguía }\end{array}$ & $\begin{array}{l}\text { Dar a conocer el fallo } \\
\text { arbitral en España }\end{array}$ & $\begin{array}{l}\text { La Época, El } \\
\text { Imparcial, El Sol }\end{array}$ & $\begin{array}{l}11 / 03 / 1925 \text { y } \\
12 / 03 / 1925\end{array}$ \\
\hline Perú & $\begin{array}{l}\text { Eduardo } \\
\text { Leguía }\end{array}$ & $\begin{array}{l}\text { Solicitud de garantías } \\
\text { plebiscitarias para Perú }\end{array}$ & El Sol & $01 / 05 / 1925$ \\
\hline Perú & $\begin{array}{l}\text { Eduardo } \\
\text { Leguía }\end{array}$ & $\begin{array}{l}\text { Corregir un editorial de } E l \\
\text { Sol }\end{array}$ & El Sol & $12 / 10 / 1925$ \\
\hline Perú & $\begin{array}{l}\text { Eduardo } \\
\text { Leguía }\end{array}$ & $\begin{array}{l}\text { Comunicar la aprobación de } \\
\text { las garantías plebiscitarias } \\
\text { hechas por el Perú a la } \\
\text { comisión plebiscitaria }\end{array}$ & $\begin{array}{l}\text { La Época, La } \mathrm{Voz}, \\
\text { El Heraldo, El } \\
\text { Imparcial, El Sol, } \\
\text { La Libertad }\end{array}$ & $\begin{array}{l}14 / 11 / 1925 \mathrm{y} \\
15 / 11 / 1925\end{array}$ \\
\hline Perú & $\begin{array}{l}\text { Eduardo } \\
\text { Leguía }\end{array}$ & $\begin{array}{l}\text { Desmentir los rumores de } \\
\text { negociación bilateral para } \\
\text { solucionar la litis de Tacna } \\
\text { y Arica }\end{array}$ & $\begin{array}{l}\text { El Imparcial, El } \\
\text { Sol, La Época, La } \\
\text { Libertad, La Voz }\end{array}$ & $\begin{array}{l}07 / 12 / 1925 y \\
08 / 12 / 1925\end{array}$ \\
\hline & & & & Total: 16 \\
\hline Bolivia & Sin dato & $\begin{array}{l}\text { Se sostiene que el fallo no } \\
\text { perjudica los anhelos } \\
\text { marítimos bolivianos }\end{array}$ & $\begin{array}{l}\text { El Imparcial, } \quad \text { El } \\
\text { Siglo Futuro, El } \\
\text { Globo, España y } \\
\text { América }\end{array}$ & $07 / 05 / 1925$ \\
\hline Bolivia & Sin dato & $\begin{array}{l}\text { Solicitar a los Estados } \\
\text { Unidos negociar sobre la } \\
\text { soberanía de Tacna y Arica }\end{array}$ & $\begin{array}{ll}\text { El Imparcial, } & \text { El } \\
\text { Siglo Futuro, } & \text { El } \\
\text { Sol, La Voz } & \\
\end{array}$ & $03 / 07 / 1925$ \\
\hline
\end{tabular}

Total: 8

Fuente: Elaboración propia basada en las fuentes hemerográficas españolas consultadas. 
En el caso de Chile, los cinco temas que interesó dar a conocer en España se relacionaban directamente con el fallo y el reconocimiento del acto plebiscitario. La fascinación por la "verdad" demostrada por ese cuerpo se detecta en la función correctiva asumida.

Por ejemplo, en el momento de publicarse -erróneamente- que los Estados Unidos habían fallado devolver Tacna y Arica al Perú, además del pago de diez millones de dólares, San Cristóbal, replicó el "absurdo" ${ }^{1453}$ y dirigió un comunicado a varios diarios. En esos momentos, la decisión de Coolidge no se había publicado oficialmente y, como se demostraría después, distaba de lo escrito en los diarios españoles.

San Cristóbal, diligente, explicaba que después de la lectura de la prensa consultó cablegráficamente al Ministerio de Relaciones Exteriores donde le explicaron que la información era absolutamente falsa. Aprovechaba la instancia para remarcar el papel del árbitro, quien no estaba facultado para decidir la soberanía de los territorios litigiosos, sino sólo respecto al proceder del plebiscito. El agente chileno atribuyó el error periodístico a la mala traducción de una nota aparecida en la edición parisina del The New York Times.

Sin duda, el interés demostrado por la prensa hacia las informaciones de la legación chilena guardó relación con la noción de ser aquella una fuente primaria de información. En el momento de las graves tensiones diplomáticas entre Chile y Perú, donde una gran cantidad de información era tomada de otros periódicos, la valoración de las circulares aumentó considerablemente.

Por tal razón fue conveniente para la prensa ampliar las noticias recibidas sobre el fallo de Coolidge. En esta ocasión, San Cristóbal presentó los resúmenes del laudo arbitral que, en otras palabras, delimitaba el objetivo del plebiscito, su organización y los requisitos para quienes desearan votar. La legación peruana, por su parte, envió un documento de cuatro puntos que contenía información despachada desde Lima. En éste se afirmaba la celebración de un plebiscito presidido por los Estados Unidos, además de nuevas demarcaciones territoriales en la frontera.

${ }^{1453}$ El Heraldo, "El pleito de Tacna y Arica aún no ha sido resuelto", 6 de enero de 1925, p. 5. 
Después del fallo la tranquilidad diplomática deseable para la preparación de los trabajos plebiscitarios se esfumó. Las acusaciones de la chilenización sufrida por tacneños y ariqueños, hizo desconfiar al gobierno peruano del ambiente que se formaría durante el plebiscito. Por eso, la política exterior peruana, inmediatamente posterior al laudo, consistió en solicitar al árbitro seis garantías. El Sol, uno de los diarios que mayor importancia dio al litigio y a las informaciones de las legaciones de Chile y Perú, las publicó íntegramente.

Éstas, en resumen, solicitaban: a) Desocupación de los territorios de Tacna y Arica por autoridades y fuerzas armadas chilenas reemplazadas por autoridades estadounidenses, b) Que se adelante la instalación y el funcionamiento de la comisión plebiscitaria, a efectos de evitar la coacción de las autoridades chilenas hacia los peruanos, c) Que el plazo para la votación comience a contarse después de la salida de las autoridades chilenas, d) Que se declare la permanencia de la calidad de residencia para los peruanos residentes cinco años en Tacna y Arica que fueron expulsados por las autoridades chilenas, e) Que los chilenos de Tacna y Arica comprueben su ocupación para evitar fraudes electorales, y f) Que se tenga presente que la inhabilidad del voto, de quienes hayan sufrido prisión por sentencia judicial, medida que favorecía a Chile, quien administraba la justicia en las provincias pudiendo usarla arbitrariamente. San Cristóbal debió enviar a la prensa las declaraciones realizadas por Coolidge frente a las demandas peruanas, todas rechazadas, en ese momento, por el presidente estadounidense.

El diplomático chileno solicitó la publicación de un desmentido sobre la fecha del fallo. Eduardo Leguía -el "más destacado"1454 de los Leguía que ocuparon cargos diplomáticos en España-, hermano del presidente, corrigió, en plena organización de la votación, un editorial de El Sol. En carta enviada al director Félix Lorenzo, quien analizó el "razonamiento chileno" 1455 , basándose en la llamada de Leguía a incumplir el plebiscito, escribió con el objetivo de desmentir terminantemente "las declaraciones [...] que el editorialista recoge sin pronunciarse sobre su autenticidad y alcances" 1456 .

1454 MARTínez RiAZA, Ascensión, "Las relaciones el Perú España 1919-1939. Temas clave y líneas de trabajo". En SeVIlla Soler, Rosario, Consolidación republicana en América Latina, Sevilla, Consejo Superior de Investigaciones Científicas, 1999, p. 207.

${ }^{1455}$ El Sol, "Una carta del Ministro del Perú", 12 de octubre de 1925, p. 2.

1456 Íbid. 
Aun cuando los problemas de fondo en la acusación aludían a la ética periodística del editor sobre la apreciada "verdad" de los hechos, su leguaje correcto agradeció la hospitalidad hacia las líneas redactadas, reiterando los sentimientos de "consideración y amistad"1457. No sería la última nota que El Sol publicó del pariente de Leguía.

Ese y otros diarios informaron de la aprobación de las garantías solicitadas por Perú realizada por Pershing. Contrariamente a lo establecido por Coolidge, el militar estableció en la reunión de la comisión del 2 de noviembre una serie de medidas cercanas a la neutralización. En rigor, entregó al representante chileno un listado encabezado por el gobernador y otros once funcionarios de alta jerarquía ordenando su inmediata destitución. La razón: "haber usado de su autoridad para impedir la legítima expresión de opiniones sobre materias que resolverá el plebiscito"1458.

Ahora, el gobierno chileno saboreaba el trago amargo de la derrota. Las decisiones de Pershing, contrarias a los intereses chilenos, provocaron la retirada temporal de sus representantes. La decisión, según lo expresa la circular diplomática, era una medida de presión para que se dictasen con rapidez los artículos del reglamento electoral. Los contratiempos para las pretensiones chilenas sobre Tacna y Arica continuarían.

Finalizando el año, como vimos, Edwards renunció a la delegación chilena. En Santiago, la presidencia del país había sido asumida por Emiliano Figueroa Larraín, dejando atrás, por poco tiempo, la inestabilidad provocada por el entremetimiento de los militares en la política. Su ministro de defensa, Carlos Ibáñez del Campo actuaba en la sombra $^{1459}$. Emilio Rodríguez Mendoza, autor de Los Estados Unidos de Sudamérica ${ }^{1460}$, reemplazante de San Cristóbal y de buenas amistades en los círculos políticos españoles, comentaría:

${ }^{1457}$ El Sol, "Una carta del Ministro del Perú", 12 de octubre de 1925, p. 2.

${ }^{1458}$ El Heraldo, "La cuestión de Tacna y Arica", 14 de noviembre de 1925, p. 4; El Imparcial, "Una nota de la Legación del Perú", 14 de noviembre de 1925, p. 1; El Sol, "El plebiscito de Tacna y Arica", 14 de noviembre de 1925, p. 4; La Época, "La cuestión de Tacna y Arica", 14 de noviembre de 1925, p. 3; La Voz, "La cuestión de Tacna y Arica", 14 de noviembre de 1925, p. 5; La Libertad, "El pleito de Tacna y Arica", 15 de noviembre de 1925 , p. 6.

${ }^{1459}$ Herrero A., Víctor, Agustín Edwards Eastman: Una biografía desclasificada del dueño de El Mercurio, Santiago, Debate, 2014.

${ }^{1460}$ MendozA RodrígueZ, Emilio, Los Estados Desunidos de Sudamérica, Valladolid, Talleres Tipográficos Cuesta, 1927. 
La Administración Figueroa Larraín reanuda pues, la vida constitucional chilena [...] Chile entra así en una era de paz y de trabajo eminentemente nacional y en cuanto a la cuestión palpitante en estos momentos, la de Tacna y Arica, el país entero sin una sola excepción anhela un término definitivo pacífico y en todo de acuerdo con el Protocolo de Washington $^{1461}$.

Los deseos de Rodríguez, forjados al otro lado del Atlántico, naufragaron. La comisión plebiscitaria se hundía, cada día más, a causa del desentendimiento torpe del triángulo diplomático. La violencia discursiva, dentro de la sesiones de la comisión, pronto inundó a los pueblos chileno y peruano quienes, a su modo, la transfiguraron en violencia física. Los sacrificios de sangre, por las calles de la ciudad, ahogaron tanto a las mareas de nacionalistas reunidos en Arica como al mismo plebiscito.

\subsection{Editar la violencia}

Desde el establecimiento de la comisión plebiscitaria, los desacuerdos en temas fundamentales de la organización del referéndum provocaron gran tensión entre sus miembros. Pershing, Edwards y Freire a lo largo de las reuniones demostraron una grave incapacidad diplomática para coordinar la fase final del laudo arbitral estipulado por los Estados Unidos. A pesar de la reserva informativa autoimpuesta por la comisión para evitar la violencia de dos pueblos que experimentaban el clímax de sus identidades nacionales, la prensa publicó noticias dando la impresión de un conflicto insalvable. Peticiones de neutralización, de garantías plebiscitarias, de apresurar la fecha de la votación, de ausencia de una atmósfera plebiscitaria, etc., empantanaron la institución creada por Coolidge para solucionar el conflicto secular.

En Tacna y Arica los habitantes comunes y corrientes experimentaron el auge de la violencia. Los grupos más radicales de chilenos y peruanos, organizados en agrupaciones ultranacionalistas, tiñeron la ciudad de sangre en defensa de sus banderas ${ }^{1462}$. El escándalo se hizo mundial.

${ }^{1461} \mathrm{El} \mathrm{Sol,} \mathrm{"El} \mathrm{nuevo} \mathrm{gobierno} \mathrm{de} \mathrm{Chile",} 28$ de diciembre de 1925, p. 2.

1462 SOTO LARA, José Julián, La cruz de alquitrán: historia de la vida cotidiana y de la sociabilidad entre chilenos y peruanos en Arica (1920-1929), tesis para optar al grado de magíster en historia, Santiago, Universidad de Chile, 2014. 
La prensa de España no fue ajena al problema. A las noticias políticas referidas al plebiscito de Tacna y Arica, sumó un conjunto importante de noticias que dieron cuenta, en la península, de las consecuencias sociales del litigio. En su mayoría estas aparecen comenzando 1926, si bien los episodios alentados por esos nacionalismos carniceros -la chilenidad y la peruanidad- venían desarrollándose meses atrás.

La prensa española continuó publicando noticias estadounidenses y comprando, en efecto, la información mediante sus agencias telegráficas. Desde Washington, por ejemplo, comentaron el 7 de enero los grandes disturbios chileno-peruanos de Tacna y Arica, hechos que no tuvieron "gravedad". Esas situaciones se complementaban con telegramas que referían los ataques perpetrados por pandillas peruanas contra plebiscitarios chilenos recién llegados. En esta información la valoración de la "gravedad" parece vincularse con la muerte. Es decir, la "gravedad" era mayor cuando los patrioteros mataban al enemigo y menor cuando, a pesar de las lesiones, continúa con vida. En los episodios comentados aquí "resultaron algunos heridos; pero no se registró ningún muerto"1463.

La noticia elaboró una explicación de la violencia, ensayando un argumento "totalitario". El móvil de aquella era el nacionalismo. Así, la oposición de las identidades sociales de chilenos y peruanos producidas por la guerra, durante la posguerra y en los momentos plebiscitarios, afinaba los sentimientos de discordia. En palabras de la prensa: "Todos estos incidentes son debidos al sentimiento de hostilidad que reina entre chilenos y peruanos con motivo del pleito existente acerca de las ciudades de Tacna y Arica"1464. Como consecuencia de esa violencia, de vuelta brevemente al plano político, la comisión debió ocupar tiempo en analizar ese fenómeno y no, estrictamente, en la organización de las elecciones. El objetivo de la comisión se trocó hacia el mantenimiento del “orden" 1465.

\footnotetext{
${ }^{1463}$ El Imparcial, "Choque entre chilenos y peruanos", 8 de enero de 1926, p. 3; El Sol, "Varios incidentes entre chilenos y peruanos", 8 de enero de 1926, p. 1; El Sol, "Extranjero", 8 de enero de 1926, p. 5; La Época, "La cuestión de Tacna y Arica", 8 de enero de 1926, p. 3; La Libertad, "Colisiones en Tacna y Arica", 8 de enero de 1926, p. 1; La Voz, "En Arica se pegan chilenos y peruanos", 8 de enero de 1926, p. 5.

${ }^{1464}$ El Imparcial, "Choque entre chilenos y peruanos", 8 de enero de 1926, p. 3; El Sol, "Varios incidentes entre chilenos y peruanos", 8 de enero de 1926, p. 1; El Sol, "Extranjero", 8 de enero de 1926, p. 5; La Época, "La cuestión de Tacna y Arica", 8 de enero de 1926, p. 3; La Libertad, "Colisiones en Tacna y Arica", 8 de enero de 1926, p. 1; La Voz, "En Arica se pegan chilenos y peruanos", 8 de enero de 1926, p. 5.

${ }^{1465}$ La Voz, "Tacna y Arica", 14 de enero de 1926, p. 6; El Heraldo, "La Comisión plebiscitaria adopta medidas para mantener el orden", 19 de enero de 1926, p. 4.
} 
Por esa razón se hizo prioritario buscar responsables del desorden plebiscitario. La comisión estableció que en los incidentes antes expuestos los ciudadanos violentados fueron peruanos y no chilenos. Además, se desmentía el rumor, no mencionado en aquellas noticias, de las órdenes dictadas por José Pizarro O'Phelan, Director de la Oficina de Propaganda del Perú en Tacna y Arica, para abrir fuego contra los chilenos.

Estas nuevas informaciones contradecían el elevado número de noticias referidas a los acontecimientos del 7 de enero y, mientras aquellas fueron adquiridas en Washington, estas otras en París. Le Matin en esa ocasión agregó que, producto de estos hechos, la delegación chilena había presentado sus "excusas"1466.

Por otro lado, la prensa española, al igual que en los años de la Guerra del Pacífico, no demostró interés por la situación de los súbditos residentes en la zona del conflicto. La inexistencia de reportajes referidos a su adscripción, durante la época plebiscitaria, sólo refuerza la idea del interés político (informando, como dijo Aguirre, sólo datos de grandes personajes) ${ }^{1467}$ que el problema suscitó en las imprentas españolas. Si bien la prensa chilena, en varias ocasiones, se refería a las naciones amigas, es decir a los colonos de otros países proclives a Chile en la época electiva, en España sólo pudimos analizar una nota relacionada con lo dicho.

La colonia española existente hacia la década del veinte en Chile y Perú derivó hacia formas distintas de apoyo nacionalista. Como resultó lógico los residentes en el primer país se volvieron "chilenófilos", cuando no "peruanófobos"; en el segundo "peruanófilos" y "chilenófobos". Esta distinción, claro está, admite posiciones medias e identidades nacionales menos duras. Un buen ejemplo de la afiliación nacionalista, prácticamente obligada de estos años, lo ofrece el conflicto entre los españoles en El Callao, agrupados en la "Sociedad de beneficencia española" y el "representante de la colonia española de Tacna y Arica"1468.

${ }^{1466}$ La Voz, "El pleito de Tacna y Arica", 15 de enero de 1926, p. 8; El Imparcial, "Incidente resuelto", 16 de enero de 1926, p. 2; El Sol, "El nuevo presidente de la Comisión plebiscitaria", 16 de enero de 1926, p. 1.

1467 Aguirre Rojas, Carlos Antonio, Antimanual del mal historiador, México, La Vasija, 2002.

${ }^{1468}$ La Libertad, "El plebiscito de Tacna y Arica", 4 de febrero de 1926, p. 3. 
La disconformidad del primero tenía motivos nacionalistas. El presidente de la Sociedad escribió desde El Callao a Sáenz la penosa impresión provocada allí por la actitud de los españoles en Tacna y Arica. Continuaba su censura en los siguientes términos, manifestando una opinión relativa al buen trato del "leguismo" hacia sus paisanos: "Esta actitud hostil contrasta con la simpatía del Gobierno y pueblo peruanos en estos momentos en que se va a levantar en Lima un monumento que perpetúe la gloria de los soldados españoles muertos en la guerra de la Independencia"1469 apoyado entusiastamente por el “Casino Español de Lima”1470.

Los choques entre chilenos y peruanos se recrudecieron. A pesar de las precauciones tomadas por la comisión plebiscitaria, los discursos nacionalistas de airados defensores de la "razón nacional" impulsaron a jóvenes y adultos hacia la aniquilación del antagonista.

El "placebo" de la historia oficial -chilena o peruana-, publicada por prensas instaladas ad hoc ultrapolitizadas y recitadas de memoria por las plazas de la frontera, racionalizó la violencia. La conciencia de grupo se fortalecía aún más con la llegada de decenas de presuntos electores ariqueños y tacneños ${ }^{1471}$.

La prensa de España, nuevamente publicó las noticias que demostraban la dinámica viciosa en que devino el plebiscito. En Madrid recibían notas de Arica sobre los nuevos incidentes entre chilenos y peruanos que dejaban de saldo varios heridos. Algunos titulares fueron impresionantes: "Nuevo choque entre chilenos y peruanos", "Un choque sangriento en Arica entre chilenos y peruanos". Ahora, a diferencia de los encuentros de enero, la Policía y el Ejército debieron restablecer el "orden"1472. Los pleitos, en definitiva, tenían todos los rasgos de la violencia desatada durante la estadía de Pershing ${ }^{1473}$.

\footnotetext{
${ }^{1469}$ Idem.

1470 MARTínez RiAzA, Ascensión, “A pesar del gobierno”. Españoles en el Perú, 1879-1939, Madrid, Consejo Superior de Investigaciones Científicas. Instituto de Historia, 2006, p. 313.

${ }^{1471}$ La Correspondencia Militar, "Propaganda peruana en Arica", 2 de marzo de 1926, p. 1.

1472 El Sol, "Nuevo choque entre chilenos y peruanos", 8 de marzo de 1926, p. 1; La Correspondencia Militar, "En Arica se registran incidentes entre chilenos y peruanos", 8 de marzo de 1926, p. 5; La Voz, "Un choque sangriento en Arica entre chilenos y peruanos", 8 de marzo de 1926, p. 5.

${ }^{1473}$ El Heraldo, "Tacna y Arica", 17 de marzo de 1926, p. 3.
} 
España y América, fue una de las pocas revistas que opinó sobre la violencia plebiscitaria. Si bien su reportaje no fue un análisis de las causas y desarrollo de aquella, facilitó la comprensión de las repercusiones emotivas entre sus redactores. Agustinos, la mayoría, se distancian de adherirse a Chile o Perú. Consecuentemente, en el escrito publicado en la sección "América Española”, titulado "Chile-Perú-Bolivia", prevalece la tristeza provocada por el conflicto. Por eso, los sacerdotes anhelan un acercamiento "justiciero" 1474 entre las repúblicas "hermanas"1475 para que se reconozcan como tal y olviden viejas rencillas. Los religiosos sabían de los últimos acontecimientos "infaustos"1476: el asesinato de dos soldados peruanos en la frontera con Bolivia; el apedreamiento de la legación del Perú en La Paz" ${ }^{1477}$; por último y no menos "alarmante"1478 y causante de "poner el ánimo en tensión"1479, la creación de la República de Tacna y Arica, idea elaborada por Coolidge. La revista conoció esos hechos gracias al envío de informaciones anónimas desde el Perú que incluían prensa limeña subrayada y anotada. Esos diarios titulaban sus noticias con grandilocuencia: "Serenos y firmes", "Un grupo de peruanos insultados y atacados a tiros", "Nuevos crímenes y atropellos en Tacna y Arica", "La amoralidad", etc. Por esos días El Mercurio acusaba la amenaza peruana de quebrar la paz continental si perdía Tacna y Arica ${ }^{1480}$.

De todos modos, la mesura de los escritores y el distanciamiento hacia los bandos en conflicto, les permitió realizar una interesante declaración metodológica. No insertarían ninguna afirmación creada "al ardor del patriotismo"1481, como apodíctica, mientras no la compararan con prensa chilena.

\footnotetext{
${ }^{1474}$ España y América, "Crónica general española y americana”, 1 de abril de 1926, n. ㄱ 7, p. 75.

1475 Idem.

${ }^{1476}$ Idem

${ }^{1477}$ Las noticias referidas al apedreamiento de la Legación peruana en La Paz por una agrupación de más de mil quinientas personas fue publicada también en otros diarios. Ver: El Heraldo, "La Legación del Perú en Bolivia apedreada por la multitud", 19 de abril de 1926, p. 3; La Voz, "Dos soldados peruanos muertos en la frontera de Bolivia", 19 de abril de 1926, p. 4; El Sol, "Incidentes entre peruanos y bolivianos", 20 de abril de 1920, p. 5; La Libertad, "Se agrava el conflicto de Tacna y Arica", 20 de abril de 1926, p. 1; La Voz, "Incidente entre el Perú y Bolivia", 20 de abril de 1026, p. 5; El Sol, "Nota oficial sobre un incidente", 23 de abril de 1926, p. 1.

${ }^{1478}$ España y América, “Crónica general española y americana”, 1 de abril de 1926, n. ${ }^{\circ}$ 7, p. 75.

1479 Idem.

${ }^{1480}$ El Heraldo, "Tacna y Arica", 10 de abril de 1926, p. 2; La Correspondencia Militar, "La actitud de la prensa peruana en lo de Tacna y Arica", 12 de abril de 1926, p. 1.

${ }^{1481}$ España y América, "Crónica general española y americana", 1 de abril de 1926, n. ${ }^{\text { }}$ 7, p. 75.
} 
En ese país, a juzgar por la ausencia de reportajes en la España y América, se ausentaron recolectores anónimos de prensa, acusadores de los rumbos del diferendo fronterizo ante el tribunal de la prensa internacional.

La selección de noticias hecha por la prensa sugería a los lectores las ideas que podían pensarse. Excluyendo cualquier tipo de conductismo en la transmisión de los mensajes, parece aconsejable concebir que si la prensa consultada era peruana los terroristas eran chilenos; si reproducía informaciones chilenas, los terroristas eran peruanos. A esto puede agregarse la intención de forzar la "realidad" para afirmar la inexistencia de violencia peruana ${ }^{1482}$. De todos modos, parecen tener mayor consistencia dos hechos: la violencia nacionalista de chilenos y peruanos y la particular bestialidad de los primeros.

Las comunicaciones recibidas en Lima desde Tacna y Arica, reproducidas en España, señalaban la frecuencia de las "agresiones contra súbditos peruanos"1483, las golpizas recibidas por los vendedores de periódicos antichilenos ${ }^{1484} \mathrm{y}$ la suspensión de $E l$ Corvo, diario "peruanófobo"1485. El área de la violencia se extendió, por el norte, hasta Lima, donde se organizaron represalias "contra chilenos residentes en esa población"1486. Hacia el oriente, en La Paz, las riñas entre chilenos y peruanos, fueron reprimidas por la autoridad. Así, se hizo imposible organizar el plebiscito. Las cúpulas nacionales representadas por Lassiter, Claro Lastarria (quien reemplazó a Edwards) y Freyre, no conciliaron el acto en medio de la violencia. Los chilenos, enardecidos por ello, aumentaban su cólera. In extremis rodearon la residencia de Lassiter criticando su liderazgo, hecho publicado por varios diarios españoles. La democracia representativa había triunfado: Mientras el pueblo solicitaba la votación, la comisión cancelaba el plebiscito $^{1487}$.

1482 El Heraldo, "El Senado chileno se pronuncia por el plebiscito", 30 de abril de 1926, p. 3; La Correspondencia Militar, "Manifestación de protesta", 3 de mayo de 1926, p. 1.

1483 El Imparcial, "Incidentes entre Chile y Perú", 16 de junio de 1926, p. 1.

${ }^{1484}$ El Siglo Futuro, "La cuestión de Tacna y Arica", 14 de junio de 1926, p. 3; La Correspondencia Militar, "Agresiones en Tacna", 15 de junio de 1926, p. 3.

${ }^{1485}$ La Correspondencia Militar, "Suspensión de un periódico en Arica", 22 de julio de 1926, p. 3.

${ }^{1486}$ El Imparcial, "Noticias de América", 17 de junio de 1926, p. 4; La Correspondencia Militar, "Incidentes en Arica", 17 de junio de 1926, p. 3.

1487 El Heraldo, "Tacna y Arica", 18 de junio de 1926, p. 3; La Voz, "La cuestión de Tacna y Arica", 18 de junio de 1926, p. 8; El Imparcial, "El litigio de Tacna y Arica", 19 de junio de 1926, p. 3; La Correspondencia Militar, "El litigio de Tacna y Arica", 19 de junio de 1926, p. 5; El Sol, "Extranjero", 24 de 


\subsection{Tacna y Arica para Bolivia: La propuesta de Frank Kellogg}

La frustración del plebiscito fue noticia en España. Si bien durante todo 1926 circularon rumores sobre las dificultades para efectuarlo, fue la violencia popular la que, en última instancia, determinó su caída. A finales de marzo -aún constituida la comisión plebiscitaria- y hasta el mes de octubre, se publicaron noticias referidas a la mediación de los Estados Unidos ${ }^{1488}$, buenos oficios que no incluirían, en esta ocasión, un representante del árbitro en la zona litigiosa. Esta nueva fase estuvo caracterizada por una "anarquía informativa", reflejo de los hechos diplomáticos ocurridos entre los países contendientes.

Muerto el plebiscito, las soluciones previstas fueron variadas y no siempre ajustadas con las posiciones oficiales de esos Estados. Un conjunto no menor de propuestas prácticas resolutivas del "viejo y eterno"1489 litigio de Tacna y Arica aparecieron en la prensa. Ninguna de ellas se materializó. Por nombrar algunas: Venta de Tacna y Arica a Bolivia por diez millones de dólares ${ }^{1490}$; reparto de Tacna y Arica entre Chile, Perú y Bolivia ${ }^{1491}$, propuesta rebatida por Chile ${ }^{1492}$; división de Tacna y Arica entre Perú y Chile ${ }^{1493}$, respectivamente, obteniendo Perú la menor parte ${ }^{1494} \sin$ intentar los chilenos recuperar Tarata $^{1495}$; ocupación militar transitoria de Tacna y Arica por Chile ${ }^{1496}$; efectuar el

junio de 1926, p. 5; La Época, "Noticias cortas", 24 de junio de 1926, p. 1; El Heraldo, "En Tacna reina gran efervescencia", 12 de julio de 1926, p. 3; El Siglo Futuro, "El pleito de Tacna-Arica", 12 de julio de 1926, p. 1; La Correspondencia Militar, "Protestas contra la suspensión del plebiscito de Tacna y Arica", 12 de julio de 1926, p. 6; El Sol, "Siguen los ánimos exaltados", 13 de julio de 1926, p. 5; La Voz, "Chilenos y peruanos", 13 de julio de 1926, p. 5; La Correspondencia Militar, "Nuevo conflicto entre chilenos y peruanos", 24 de agosto de 1926, p. 4.

${ }^{1488}$ El Sol, "Extranjero", 27 de marzo de 1926, p. 5; La Voz, "La mediación yanqui la aceptan Chile y Perú", 27 de marzo de 1926, p. 5; El Sol, "Tacna y Arica", 31 de mayo de 1925, p. 5; La Correspondencia Militar, "El litigio de Tacna y Arica", 19 de junio de 1926, p. 5.

${ }^{1489}$ El Sol, "Los errores de un plebiscito", 18 de enero de 1926, p. 1.

${ }^{1490}$ La Voz, "Una posible solución para lo de Tacna y Arica", 30 de marzo de 1926, p. 5.

${ }^{1491}$ La Voz, "La cuestión de Tacna y Arica", 20 de mayo de 1926, p. 1; El Sol, "Una nueva fórmula de concordia", 21 de mayo de 1926, p. 5; La Voz, "La cuestión de Tacna y Arica", 21 de mayo de 1926, p. 8; El Sol, "Tacna y Arica", 22 de mayo de 1926, p. 5; La Voz, "El pleito de Tacna y Arica", 12 de junio de 1926, p. 5; El Sol, "Tacna y Arica", 30 de julio de 1926, p. 1; El Sol, "Tacna y Arica", 11 de octubre de 1926, p. 5; La Voz, "La cuestión de Tacna y Arica", 30 de octubre de 1926, p. 5.

1492 El Sol, "Tacna y Arica", 3 de junio de 1926, p. 5; La Correspondencia Militar, "Chile no aceptará la propuesta de Kellogg sobre Tacna y Arica", 3 de junio de 1926, p. 6; La Época, "Noticias cortas", 3 de junio de 1926, p. 3; La Voz, "El pleito de Tacna y Arica", 3 de junio de 1926, p. 5;

${ }^{1493}$ El Imparcial, "Noticias de América", 13 de junio de 1926, p. 4.

${ }^{1494}$ España y América, "Perú y Chile", 1 de julio de 1926, n. ${ }^{\circ} 13$, p. 61.

${ }^{1495}$ El Heraldo, "El pleito chilenoperuano", 2 de julio de 1926, p. 3; La Correspondencia Militar, "El eterno problema de Tacna y Arica", 2 de julio de 1926, p. 4. 
plebiscito $^{1497}$; que Tacna pase al Perú y Arica a Chile ${ }^{1498}$; creación de un Estado neutral o protectorado $^{1499}$, y por último, el arbitraje del Rey Alfonso XIII.

La prensa española prestó escasa importancia a la última noticia, al parecer porque sólo había sido un rumor oído en los Estados Unidos. Supuestamente, Chile y Perú acordaron desplazar al árbitro actual del diferendo para "ofrecer al Rey de España don Alfonso XIII, el arbitraje de la cuestión de Tacna y Arica, con la condición previa de cortar el fallo. Hasta ahora ningún despacho de las naciones litigantes ha comprobado la noticia" ${ }^{1500}$. El rey había estado días antes en Gran Bretaña entrevistándose con el Secretario del Foreign Office para "tratar la cuestión de la Sociedad de las Naciones"1501.

El restablecimiento del orden diplomático intentó ser impuesto, otra vez, por la inteligencia estadounidense. El Secretario de Estado, Frank Kellogg, con quien el intervencionismo en América "tuvo un nuevo repunte" ${ }^{1502}$, planteó la tesis -recibida sin alegría entre los litigantes- de ceder Tacna y Arica a Bolivia. La iniciativa de Kellogg, sin duda, guardaba relación con las declaraciones de Coolidge sobre la "imposible solución"1503 de la cuestión chileno-peruana. Pero, también, con la insistencia de Bolivia para acceder al mar, petición primero rechazada por Coolidge en misiva al presidente boliviano Hernando Siles ${ }^{1504}$ que luego sería aceptada por él.

El gobierno chileno no aceptó la participación boliviana en las negociaciones diplomáticas y, menos, la posibilidad de que ese país obtuviese soberanía territorial en las regiones disputadas.

\footnotetext{
${ }^{1496}$ El Imparcial, "Tacna y Arica", 17 de junio de 1926, p. 3; La Voz, "El pleito de Tacna y Arica", 17 de junio de 1926, p. 5.

${ }^{1497}$ La Correspondencia Militar, "Tres fórmulas para solucionar el pleito de Tacna y Arica", 15 de junio de 1926, p. 3.

1498 Idem.

${ }^{1499}$ El Globo, "Juicios de la prensa de los Estados Unidos", 6 de agosto de 1926, p. 3.

${ }^{1500}$ El Siglo Futuro, “¿El Rey de España, árbitro en el pleito de Tacna y Arica?”, 8 de julio de 1926, p. 2.

1501 TuSELl, Javier y GARCía QuEIPO DE LlANO, Genoveva, El dictador y el mediador. España y Gran Bretaña, 1923-1930, Madrid, C.S.I.C. Centro de estudios históricos, 1986, p. 56.

1502 RAYMONT, Henry, Vecinos en conflicto. La historia de las relaciones entre Estados Unidos y Latinoamérica desde Franklin Delano Roosevelt hasta nuestros días, México, Siglo XXI, 2007, p. 36.

${ }^{1503}$ El Heraldo, "El conflicto de Tacna y Arica parece insoluble", 29 de abril de 1926, p. 3.

${ }^{1504} \mathrm{El} \mathrm{Sol,} \mathrm{"Una} \mathrm{nueva} \mathrm{fórmula} \mathrm{de} \mathrm{concordia",} 21$ de mayo de 1926, p. 5.
} 
La prensa española, a pesar de las dificultades para obtener informaciones fidedignas sobre el curso de los hechos, aseguró la férrea oposición de Chile a Bolivia y el carácter categórico de una nota enviada por Kellogg a Santiago, supuestamente concebida en términos de ultimátum ${ }^{1505}$. En Bolivia, por el contrario, la idea de Kellogg agradó en los círculos políticos y populares. El Partido Nacionalista acordó felicitarlo y “emprender una activa campaña de propaganda para conseguir la reivindicación de los derechos de Bolivia"1506. En esos días, informaciones obtenidas por la Agencia Fabra en Washington culparon a Chile del fracaso plebiscitario y su intransigencia con las garantías solicitadas por el Perú ${ }^{1507}$. Por último, siempre como rumor, comunicaron la intención chilena de dividir el territorio entre Chile y Perú, cediendo a éste la parte menor ${ }^{1508}$.

\section{Imagen $n .^{\circ} 62$}

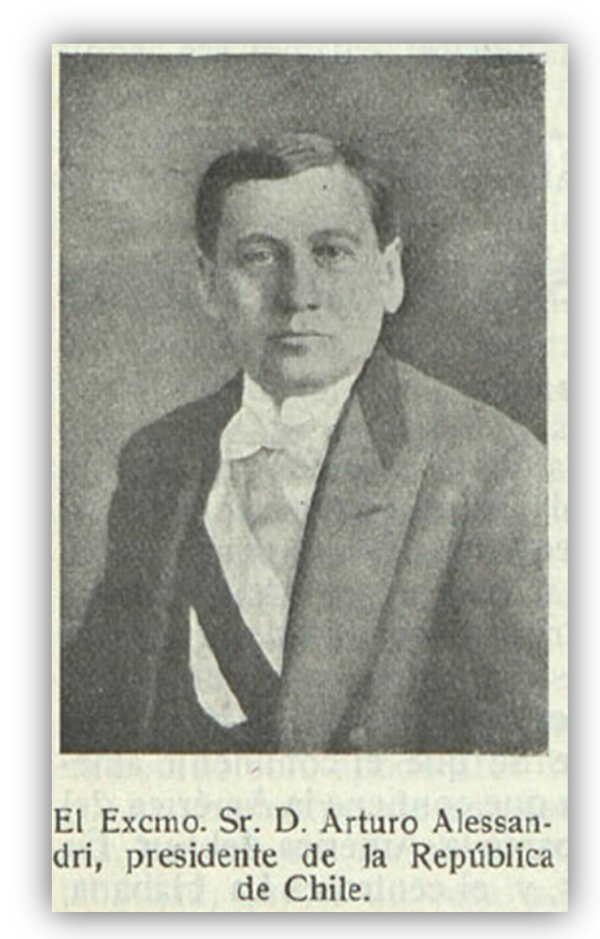

Fuente: Revista Hispanoamericana de Ciencias, Letras y Artes, "Vuelve a Chile el presidente Alessandri", marzo de 1925, n. ${ }^{\circ}$ 23, p. 117.

\footnotetext{
${ }^{1505}$ La Correspondencia Militar, "Sigue el conflicto de Tacna y Arica", 7 de junio de 1926, p. 6.

${ }^{1506}$ El Globo, "El conflicto de Tacna y Arica", 7 de junio de 1926, p. 2.

${ }^{1507}$ La Voz, "El pleito de Tacna y Arica", 12 de junio de 1926, p. 5.

${ }^{1508}$ La Época, "La cuestión de Tacna y Arica", 14 de junio de 1926, p. 1; La Correspondencia Militar, "El pleito de Tacna y Arica", 14 de junio de 1926, p. 5; La Voz, "El pleito de Tacna y Arica", 14 de junio de 1926, p. 1; El Sol, "El conflicto de Tacna y Arica", 15 de junio de 1926, p. 5.
} 
Todos esos conflictos tuvieron su punto álgido con los ácidos discursos de Alessandri, contra Estados Unidos, "pueblo de gigantes gobernado por enanos"1509, quien tuvo que ser defendido ante Kellogg por la embajada chilena en Washington. En esa reunión Kellogg recibió la noticia que Chile daba por finalizados los buenos oficios estadounidenses $^{1510}$. El Secretario de Estado, días después, manifestó la intención de publicar la correspondencia oficial para demostrar al verdadero responsable del fracaso ${ }^{1511}$.

Superadas esas dificultades, en agosto de 1926, se reanudaron las conversaciones entre Kellogg, Velarde (Perú) y Cruchaga (Chile). Perú se oponía a que Bolivia o Chile ejercieran soberanía en Tacna y Arica. El rumor que Bolivia compraría la frontera, concienció a la prensa de la precariedad económica del país, carente de capital necesario para adquirirla y, ni siquiera, para contratar un empréstito estadounidense ${ }^{1512}$ debido al subdesarrollo de su economía y la ineficiente planificación política ${ }^{1513}$.

La prensa estadounidense atendió profusamente el diferendo. La española, por su parte, realizó importantes análisis del tratamiento del conflicto en la imprenta estadounidense, valiéndose del The New York Times, The World y "un centenar de otros periódicos"1514. Al primero desagradó la posición de Chile y Perú ante las propuestas de Kellogg. Si continúa esa oposición, escribió, "sólo quedan dos caminos: o se crea un estado neutral análogo a los que, con fines semejantes, se formarán en Europa [...] o se transfiere dicho territorio a Bolivia"1515. De negarse también a esas propuestas, amenazó con espíritu "wilsoniano", el "mundo hará responsable de las consecuencias de este gravísimo paso a la nación que así proceda"1516.

${ }^{1509}$ SOTO LARA, José Julián, La cruz de alquitrán..., p. 144.

${ }^{1510}$ La Correspondencia Militar, "La cuestión de Tacna y Arica", 19 de junio de 1926, p. 2; El Sol, "Tacna y Arica", 21 de junio de 1926, p. 5.

${ }^{1511}$ El Sol, "El conflicto de Tacna y Arica", 24 de junio de 1926, p. 5; La Correspondencia Militar, "El fracaso del plebiscito sobre Tacna y Arica", 24 de junio de 1926, p. 2.

${ }^{1512}$ La Época, "Se reanudan las negociaciones sobre Tacna y Arica", 12 de agosto de 1926, p. 1; La Época, "La cuestión de Tacna y Arica", 12 de octubre de 1926, p. 3; La Voz, "La cuestión de Tacna y Arica", 12 de octubre de 1926, p. 5; La Correspondencia Militar, "Informaciones hispanoamericanas", 9 de noviembre de 1926, p. 4.

${ }^{1513}$ Soliz V., Edgar, Bolivia, subdesarrollo económico y poder político en el marco de la independencia postcolonial, La Paz, Universidad Mayor de San Andrés, 1980.

${ }^{1514}$ El Globo, "Juicios de la prensa de los Estados Unidos", 6 de agosto de 1926, p. 3.

1515 Idem.

${ }^{1516}$ Idem. 
The World desconfiaba de la creación del Estado neutral. Tacna y Arica, con una superficie de nueve mil millas y una población de cuarenta mil habitantes, sin patriotismo local, sin fuentes fiscales, etc. serían "un campo de maquinaciones internacionales"1517. Otros diarios estadounidenses superaron la idea de la cesión territorial porcentual a Bolivia prefiriendo la cesión total.

Ésta, geopolíticamente, crearía una barrera entre Chile y Perú, impidiendo el surgimiento de diferendos. Bolivia obtendría su anhelada salida al mar. Desde el imperio, como suele pensarse al actuar en conflictos internacionales, el espíritu justiciero es también capitalista: "Así se habrá hecho un acto de justicia no entre dos, sino tres países, y, bajo tan favorables auspicios, la parte occidental de Sudamérica, en la cual se han invertido cuantiosos capitales norteamericanos, entraría en un periodo de progreso, libre de trabas internacionales" $" 1518$.

Así, la idea primaria de Kellogg -entrega de un porcentaje de Tacna y Arica a Bolivia- devino en la propuesta final: las provincias debían cederse completamente, a cambio de compensaciones económicas repartidas de igual forma entre Chile y Perú ${ }^{1519}$. La prensa española se abstuvo de realizar juicios al respecto. Actitud mantenida al informar sobre la buena recepción que la propuesta de Kellogg tuvo en los círculos diplomáticos americanos, exceptuando los directamente involucrados ${ }^{1520}$. Las diversas fuentes de prensa utilizadas por importantes diarios españoles -El Heraldo, El Siglo Futuro, La Época, La $V o z-$ señalaron la aceptación chilena de la propuesta de Kellogg ${ }^{1521}$.

\footnotetext{
${ }^{1517}$ El Globo, "Juicios de la prensa de los Estados Unidos", 6 de agosto de 1926, p. 3. 1518 Idem.

1519 El Heraldo, "Tacna y Arica", 1 de diciembre de 1926, p. 3; El Siglo Futuro, "La cuestión de Tacna y Arica", 1 de diciembre de 1926, p. 3; La Época, "La cuestión de Tacna y Arica", 1 de diciembre de 1926, p. 2; La Voz, "La cuestión de Tacna y Arica", 1 de diciembre de 1926, p. 8; El Sol, "Tacna y Arica", 2 de diciembre de 1926, p. 5; La Correspondencia Militar, "El pleito entre Chile y Perú", 2 de diciembre de 1926, p. 4.

${ }^{1520}$ El Heraldo, "El pleito de Tacna y Arica", 2 de diciembre de 1926, p. 3; La Época, "El problema de Tacna y Arica", 3 de diciembre de 1926, p. 1; La Voz, "La cuestión de Tacna y Arica", 3 de diciembre de 1926, p. 6. ${ }^{1521}$ El Siglo Futuro, "El conflicto de Tacna y Arica", 6 de diciembre de 1926, p. 3; La Época, "La cuestión de Tacna y Arica", 6 de diciembre de 1926, p. 3; La Voz, "La cuestión de Tacna y Arica", 6 de diciembre de 1926, p. 8; El Heraldo, "Tacna y Arica", 7 de diciembre de 1926, p. 3; El Sol, "América", 7 de diciembre de 1926, p. 5; La Libertad, "El conflicto de Tacna y Arica", 7 de diciembre de 1926, p. 1; La Voz, "El pleito de Tacna y Arica", 7 de diciembre de 1926, p. 8.
} 
Los días permitieron relativizar en la prensa tal beneplácito. En Tacna y Arica, el pueblo aún sobreexcitado por la época plebiscitaria, no tenía proyectado entregarlas a Bolivia. Los diarios chilenos dieron cuenta de esa posición, a la vez que otros políticos de Santiago se distanciaron más de los Estados Unidos, criticando la solución de Kellogg.

En su opinión, la "enajenación"1522 de Tacna y Arica era imposible, a sabiendas de que esa propuesta era "la última tentativa del Gobierno norteamericano para el arreglo del litigio chilenoperuano"1523. También en el Perú, Kellogg comenzaba su descenso. La inquietud más acuciante de la cancillería era qué papel tendría el pueblo en la entrega regional a Bolivia. El cambio abrupto de la nacionalidad de miles de habitantes fue visto en términos de mayor complejidad en el gobierno peruano que en el estadounidense. La Casa Blanca poco dijo al respecto. De tal forma, el diálogo en torno a Kellogg entraba en un impasse. Varios diarios españoles publicaban la respuesta peruana al Secretario de Estado: Perú solicitaba la posesión íntegra de Tacna y Arica, comprometiéndose a ceder a Bolivia el puerto de Vítor. La propuesta de Kellogg, tal como el plebiscito, fracasaba ${ }^{1524}$.

\subsection{La firma del Tratado de Lima}

A comienzos de 1929, aparecieron en la prensa las primeras noticias del tratado que puso fin a la litis. En éstas se mencionaban las conferencias desarrolladas en Santiago entre el canciller chileno, Conrado Ríos, y el primer embajador peruano en ese país, César Elguera. El eje de las reuniones fue el problema de las concesiones y las aspiraciones máximas y mínimas de cada país en la frontera. Al parecer, hacia finales de enero, aquellas estarían concretadas para transformarlas en los documentos de la paz. El rumor de que Arica pasaría a soberanía chilena y Tacna a peruana adquiría gran fuerza ${ }^{1525}$.

\footnotetext{
${ }^{1522}$ El Sol, "Desconfianza sobre la conducta de Bolivia", 10 de diciembre de 1926, p. 5; La Correspondencia Militar, "La cuestión de Tacna y Arica", 10 de diciembre de 1926, p. 2; La Voz, "El pleito de Tacna y Arica", 10 de diciembre de 1926, p. 1; La Correspondencia Militar, "Proposición del Secretario Mr. Kellogg", 11 de diciembre de 1926, p. 1.

${ }^{1523}$ El Sol, "Sobre Tacna y Arica", 13 de diciembre de 1926, p. 5.

${ }^{1524}$ El Sol, "El Perú y la proposición de Míster Kellogg", 15 de diciembre de 1926, p. 5; La Voz, "La cuestión de Tacna y Arica", 15 de diciembre de 1926, p. 2; El Imparcial, "El Perú contesta a Norteamérica", 23 de diciembre de 1926, p. 8; La Época, "La cuestión de Tacna y Arica", 23 de diciembre de 1926, p. 1.

${ }^{1525}$ El Sol, "La cuestión de Tacna y Arica", 5 de enero de 1929, p. 5; La Voz, "El asunto de Tacna y Arica", 5 de enero de 1929 , p. 1.
} 
Llegado ese plazo la paz no se alcanzó. En Lima, los intensos trabajos de la embajada chilena y en Santiago de la peruana no daban tregua. Los diplomáticos, debido a la marcha enérgica de las negociaciones para estabilizar la frontera, suspendieron "sus vacaciones en sus respectivos países" ${ }^{1526}$. Más aún, pese a las diversas informaciones que señalaban la prórroga de las discusiones acerca del arreglo, ahora para mediados de abril, y las afirmaciones realizadas por la Agencia Americana sobre la inexistencia real de una fórmula de arreglo ${ }^{1527}$, los principales diarios anunciaron la solución del conflicto ${ }^{1528}$.

La equivocación se mantuvo. Era el riesgo de conocer, mediante telegramas, los acontecimientos diplomáticos de Santiago y Lima que, además, se desarrollaban con reserva, discreción y ritmos más lentos para las decisiones. En aquel contexto confuso $E l$ Heraldo escribió un extenso reportaje titulado "Se ha resuelto la cuestión de Tacna y Arica”, fundado sólo en cablegramas. La noticia reforzaba la idea sobre su larga duración, bastante particular, en el ámbito internacional. Desde el origen de la litis -afirmó el diario dirigido por Manuel Fontdevila Cruixent- "Tacna y Arica era una rúbrica casi diaria en la información periodística. Negociaciones, arbitrajes, plebiscitos: todo fracasaba. [...] sonaban en Lima o en Santiago palabras amenazadoras"1529.

Ese temor hizo que las cancillerías de Chile y Perú buscasen la asistencia de los Estados Unidos, quienes desde junio de 1928 apoyaban la búsqueda de la solución final del diferendo. Ella sólo llegó cuando esos gobiernos decidieron romper la unidad del territorio. Esa ruptura regional, que provocó serias repercusiones en el plano social para los habitantes tacno-ariqueños, no obstante, fue valorada por la prensa.

\footnotetext{
${ }^{1526}$ El Sol, "Las relaciones con el Perú y el pleito de Tacna y Arica", 19 de enero de 1929, p. 5; La Voz, "La cuestión de Tacna y Arica", 19 de enero de 1929, p. 5.

${ }^{1527}$ El Heraldo, "Todavía Tacna y Arica", 16 de febrero de 1929, p. 3; El Sol, "La cuestión de Tacna y Arica", 16 de febrero de 1929, p. 1; La Época, "La cuestión de Tacna y Arica", 16 de febrero de 1929, p. 1; La Voz, "La cuestión de Tacna y Arica", 16 de febrero de 1929, p. 8.

${ }^{1528}$ El Heraldo, “Se ha resuelto, por fin, el conflicto de Tacna y Arica?”, 21 de febrero de 1929, p. 3; El Siglo Futuro, "Parece que al fin se ha resuelto la cuestión de Tacna y Arica", 21 de febrero de 1929, p. 6; La Época, "Solución del pleito de Tacna y Arica", 21 de febrero de 1929, p. 1; La Voz, "Ya está resuelta la cuestión de Tacna y Arica", 21 de febrero de 1929, p. 1; El Imparcial, "Ha quedado resuelto el problema de Tacna y Arica", 22 de febrero de 1929, p. 1; La Libertad, "Se llega a un acuerdo en lo de Tacna y Arica", 22 de febrero de 1929 , p. 4.

${ }^{1529}$ El Heraldo, "Se ha resuelto la cuestión de Tacna y Arica", 22 de febrero de 1929, p. 1.
} 
Nuevamente El Heraldo comentó la felicidad sentida al finalizar una discordia cincuentenaria. La función internacional de Tacna y Arica, desde ahora, sería demostrar los métodos diplomáticos para arreglar cuestiones fronterizas pendientes en América. Menos fallido en sus impresiones, vaticinó con exactitud el problema que, en el futuro, ocasionará el tratado limítrofe para Bolivia. El único punto oscuro del convenio era la situación de ese país que "gracias a él, se ve definitivamente privada de salida al mar que justamente apetece" 1530 . Varios telegramas chilenos recibidos en España marcaban la nueva frontera al norte de la línea ferroviaria de Arica a La Paz ${ }^{1531}$.

Tal felicidad, causada por el término del conflicto, fue fugaz. Al día siguiente, por lo menos, cinco diarios de alta circulación, incluyendo El Heraldo, publicaron lo opuesto. La cuestión de Tacna y Arica no estaba resuelta, “¿Era demasiado pronto!”1532, se dijo con ironía. Esos periódicos, para enunciar el nuevo rumbo del conflicto, se valieron de cablegramas londinenses que aseguraban el desmentido oficial del gobierno peruano y chileno sobre la supuesta solución. Además, la opinión del embajador estadounidense en Lima aún demostraba su anhelo por la paz. En un cable, el diplomático declaró: “quisiera que fueran ciertas las noticias de estos días" ${ }^{1533}$. Con anterioridad, de regreso de sus vacaciones en los Estados Unidos, comentó a la cancillería peruana el disgusto producido en su país al enterarse del atraso de las negociaciones chileno-peruanas. Aprovechó esa reunión para comunicar que, de persistir el atraso, "los Estados Unidos favorecerían la cesión a Bolivia de los territorios disputados"1534.

El trabajo de la prensa era incesante. En España se recibían notas desde Santiago parafraseando las palabras del presidente chileno Carlos Ibáñez al parlamento elogiando el espíritu conciliatorio de las conversaciones chileno-peruanas.

\footnotetext{
${ }^{1530}$ El Heraldo, "Se ha resuelto la cuestión de Tacna y Arica", 22 de febrero de 1929, p. 1.

${ }^{1531}$ El Heraldo, "Se ha resuelto la cuestión de Tacna y Arica", 22 de febrero de 1929, p. 1; El Sol, "Ha quedado resuelta la cuestión de Tacna y Arica", 22 de febrero de 1929, p. 5; La Época, "Solución del pleito de Tacna y Arica", 22 de febrero de 1929, p. 1; La Correspondencia Militar, "Por fin se ha resuelto el problema de Tacna y Arica", 23 de febrero de 1929, p. 1; El Siglo Futuro, "De la solución del pleito de Tacna y Arica", 3 de mayo de 1929, p. 5; La Correspondencia Militar, "Las bases para el pleito de Tacna y Arica", 3 de mayo de 1929, p. 4; La Correspondencia Militar, "La solución del pleito de Tacna y Arica", 19 de mayo de 1929, p. 2; La Época, "El acuerdo sobre Tacna y Arica", 20 de mayo de 1929, p. 5. 1532 La Libertad, "Lo de Tacna y Arica seguirá en litigio", 23 de febrero de 1929, p. 3.

${ }^{1533}$ El Sol, "La cuestión de Tacna y Arica", 23 de febrero de 1929, p. 1; La Época, "La cuestión de Tacna y Arica", 23 de febrero de 1929, p. 4; La Voz, "La cuestión de Tacna y Arica", 23 de febrero de 1929, p. 3. 1534 Idem.
} 
Las noticias recibidas desde Lima eran menos halagüeñas. Afirmaban unas, desmentían otras, el estallido de una revolución culminada con el magnicidio de Leguía, motivado por el acuerdo con Chile. El representante peruano en Madrid, Eduardo Leguía, apresuradamente desmintió ambas. Por otro lado, desde los Estados Unidos enfatizaban la importancia de sus buenos oficios, mencionando las trabas suscitadas en los acuerdos de paz, debido a los intereses de una empresa de ese país que construiría un puerto en el sur peruano. En Sudamérica, diarios paceños hacían campaña para la cesión de Arica a Bolivia. En Uruguay, el Consejo Nacional de la Administración celebraba la solución del conflicto chileno-peruano ${ }^{1535}$.

\section{Imagen $n .^{\circ} 63$}

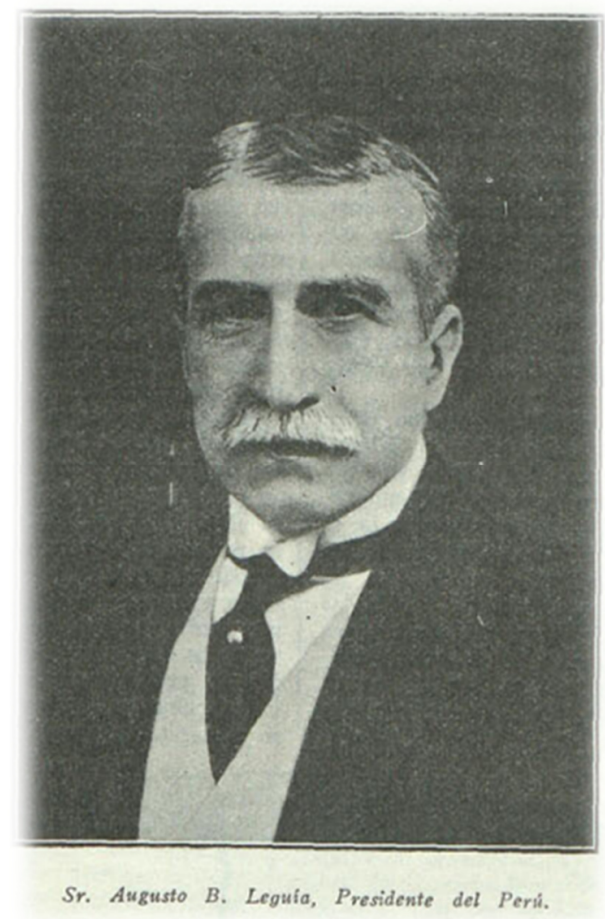

Fuente: Unión Patriótica, "Sr. Augusto B. Leguía. Presidente del Perú", 1 de abril de 1930, n. $^{\circ} 84$ y 85 , p. 25.

${ }^{1535} \mathrm{El} \mathrm{Sol,} \mathrm{"El} \mathrm{mensaje} \mathrm{del} \mathrm{Presidente,} \mathrm{general} \mathrm{Ibáñez",} 24$ de febrero de 1929, p. 7; El Sol, "Tacna y Arica", 24 de febrero de 1929, p. 7; El Sol, "Rumores no confirmados de graves desórdenes en el Perú", 24 de febrero de 1929, p. 7; La Voz, "La cuestión de Tacna y Arica", 25 de febrero de 1929, p. 5; El Heraldo, “¿No estaba resuelto ya el pleito de Tacna y Arica?", 1 de marzo de 1929, p. 2; Gutiérrez, Sin título, 2 de marzo de 1929, n. ${ }^{\circ}$ 91, p. 19; La Lectura Dominical, "Efemérides de la semana", 2 de marzo de 1929, n. ${ }^{\circ} 1$ 385, p. 151; El Sol, "La cuestión de Tacna y Arica", 24 de abril de 1929, p. 5. 
El acopio de noticias contradictorias de la frontera dificultó la comprensión del proceso. Para sumar equivocaciones, la prensa publicó las siguientes palabras de Ibáñez: "Espero que dentro de muy poco tiempo podré anunciar a mi país que se ha resuelto definitivamente la cuestión de Tacna y Arica, pendientes desde hace cincuenta años"1536. Aseguraba que esa declaración "es la primera relacionada con el antiguo litigio que hace el presidente Ibáñez"1537.

Durante abril y mayo la prensa, basándose en agencias, continuó afirmando la finalización del conflicto ${ }^{1538}$. Las excepciones fueron sólo dos "encuadres" noticiosos relativos al papel de España en el diferendo. En aquellos se recordó el resultado lamentable del protocolo de 1898 en donde España actuaba como árbitro. Se recordó, también, que ese arbitraje fracasó por culpa de los diputados chilenos.

Los recuerdos de esa irreverencia hacia España se devaluaron. Casi tres décadas después ambos países acordaron dar espectacularidad al cierre del problema. Los documentos que sellarían la paz fueron confiados para su transporte a los aviadores españoles del Jesús del Gran Poder. La Correspondencia Militar elogió a Ibáñez por la iniciativa de que España los portara. Nunca con más razón, profundizó, puede decirse que España es madre de pueblos y "nunca el hispanoamericanismo ha tenido más bella manifestación que en ésta" ${ }^{1539}$. España, finalizó el diario, sobre las alas del Jesús del Gran Poder "lleva la paz... He aquí la madre, la gran madre de los pueblos de América"1540.

\footnotetext{
${ }^{1536}$ El Heraldo, "El presidente de Chile anuncia la pronta solución del asunto de Tacna y Arica", 17 de abril de 1929, p. 3; El Siglo Futuro, "La cuestión de Tacna y Arica a punto de resolverse", 17 de abril de 1929, p. 6; La Voz, "La cuestión de Tacna y Arica", 17 de abril de 1929, p. 5; El Imparcial, "Chile", 18 de abril de 1929, p. 5; El Sol, "La solución del conflicto de Tacna y Arica", 18 de abril de 1929, p. 1; La Libertad, "La solución del conflicto de Tacna y Arica”, 18 de abril de 1929, p. 2.

${ }^{1537}$ Idem.

${ }^{1538}$ La Época, "La cuestión de Tacna y Arica", 22 de abril de 1929, p. 6; La Voz, "La cuestión de Tacna y Arica resuelta", 22 de abril de 1929, p. 1; El Sol, "La cuestión de Tacna y Arica", 23 de abril de 1929, p. 7; El Heraldo, "La nueva frontera entre Chile y el Perú", 25 de abril de 1929, p. 3; El Sol, "La cuestión de Tacna y Arica", 25 de abril de 1929, p. 5; El Imparcial, "Chile", 25 de abril de 1929, p. 5; La Correspondencia Militar, "Hoy se firmará en Lima el acuerdo sobre el pleito de Tacna y Arica", 25 de abril de 1929, p. 3; La Libertad, "Hoy se firmará el arreglo del pleito de Tacna y Arica", 25 de abril de 1929, p. 2; La Voz, "La cuestión de Tacna y Arica", 25 de abril de 1929, p. 2; La Correspondencia Militar, "La solución del problema de Tacna y Arica", 1 de mayo de 1929, p. 3; La Época, "La solución del pleito de Tacna y Arica", 3 de mayo de 1929, p. 1; La Libertad, "La solución del pleito de Tacna y Arica", 3 de mayo de 1929, p. 1.

${ }^{1539}$ La Correspondencia Militar, "El histórico proceso de Tacna y Arica", 19 de abril de 1929, p. 1.

1540 Idem.
} 
En el segundo "encuadre", los editores vieron la necesidad de explicar el origen de la cuestión de Tacna y Arica por su gran importancia para la política internacional suramericana. A diferencia de la posición general, opuesta a los buenos oficios de Estados Unidos, El Sol favoreció la atención dedicada por ese país a Perú y Chile. Este último, señaló el diario, sorprendió después del fracaso plebiscitario y de las propuestas del Secretario de Estado, Frank Kellogg, con la intención de nacionalizar las provincias de Tacna y Arica. La región fronteriza se mostraba contraria al movimiento diplomático de toda América, donde se establecía "cada día más sólidamente la base del pacifismo y obliga a la conciencia continental a buscar arreglos amistosos en todo género de litigios. El de Tacna y Arica parecía quedar al margen como una amenaza irremediable"1541. Esa, entre otras razones, permitía evaluar la solución del problema chileno-peruano en términos positivos catalogándolo como un éxito de la democracia.

Hasta ese momento las cancillerías de Chile y Perú habían acordado: a) La retirada de Chile de Tacna 30 días después de ratificado el tratado, b) El trazado de la frontera se situará diez kilómetros al norte del Río Lluta, paralela a la línea del ferrocarril de Arica a La Paz, c) Creación del puerto libre de Arica, d) Chile construirá en Arica un puerto y un muelle destinado al comercio peruano, con edificio de Aduana y estación terminal del ferrocarril Arica-Tacna, e) Pago de Chile al Perú de una indemnización de seis millones de dólares, f) Ambos gobiernos demarcarán las fronteras asesorados por técnicos. De existir divergencias las resolverá una comisión neutral, g) Los derechos legales de peruanos y chilenos en los respectivos territorios no serán discutidos. Los niños chilenos de Tacna y los peruanos de Arica mantendrían sus nacionalidades hasta los veintiún años en que optarán por una u otra, h) El Morro se desmilitarizará y se erigirá un monumento que simbolice la paz entre ambos países ${ }^{1542}$. Aún no se redactaba el artículo que prohibía a Chile y Perú ceder territorios de Tacna y Arica a Bolivia.

${ }^{1541}$ El Sol, "Tacna y Arica”, 26 de abril de 1929, p. 1.

${ }^{1542}$ El Heraldo, "El pleito de Tacna y Arica está a punto de quedar definitivamente resuelto", 3 de mayo de 1929, p. 3; El Siglo Futuro, "El pacto decisivo de la cuestión chileno-peruana", 3 de mayo de 1929, p. 4; El Siglo Futuro, "De la situación del pleito de Tacna y Arica", 3 de mayo de 1929, p. 5; El Sol, "La solución del pleito de Tacna y Arica", 3 de mayo de 1929, p. 5; La Correspondencia Militar, "Las bases para el pleito de Tacna y Arica", 3 de mayo de 1929, p. 4; La Voz, "La cuestión de Tacna y Arica", 3 de mayo de 1929, p. 5; La Correspondencia Militar, "Las cláusulas del Tratado de Tacna y Arica", 9 de mayo de 1929, p. 4; La Época, "El acuerdo sobre Tacna y Arica", 18 de mayo de 1929, p. 4; El Heraldo, "Los términos en que está 
Desde Washington se informaba a España la exitosa recepción del tratado en las embajadas de Chile y Perú. Los representantes diplomáticos de esos países realizarían la entrega del documento al presidente Hoover quien había declarado "que podía darse por terminado definitivamente este asunto, que ha permanecido en pie durante cuarenta y seis años, y ha dado lugar en el transcurso de ellos a situaciones difíciles"1543. En el Departamento de Estado comenzaba el estudio de cada una de las cláusulas del tratado con el objeto de anunciar, lo más pronto posible y de manera oficial, el acuerdo ${ }^{1544}$. Sin embargo, la firma del tratado se demoró más de lo previsto.

La prensa española había anunciado, de acuerdo con informaciones recibidas por la Associated Press, el día 17 de mayo como fecha de la firma ${ }^{1545}$. A las 16:00 horas del día siguiente Hoover notificó el acuerdo, acontecimiento que tuvo impresiones favorables en Washington, Lima y Santiago. La Nación de Buenos Aires, dejándose llevar por la apoteosis fraternidad internacionalista, aseguró que el acuerdo había sido una obra "duradera" de pacificación entre los pueblos firmantes ${ }^{1546}$. El tiempo demostraría la paradojal brevedad de esa duración.

redactado el acuerdo entre Chile y el Perú", 18 de mayo de 1929, p. 3; El Sol, "El Presidente Hoover notifica la solución del pleito Tacna y Arica", 18 de mayo de 1929, p. 5; La Correspondencia Militar, "La solución del pleito de Tacna y Arica", 19 de mayo de 1929, p. 2; La Libertad, "El pleito de Tacna y Arica, resuelto definitivamente", 18 de mayo de 1929, p. 1; La Voz, "Hoover ratifica el acuerdo a que han llegado Chile y el Perú", 18 de mayo de 1929 , p. 5.

${ }^{1543}$ La Voz, "La cuestión de Tacna y Arica", 3 de mayo de 1929, p. 5; El Imparcial, "La cuestión de Tacna y Arica", 4 de mayo de 1929, p. 1; La Correspondencia Militar, "La política extranjera", 4 de mayo de 1929, p. 5; La Voz, "El pleito de Tacna y Arica", 4 de mayo de 1929, p. 6.

${ }^{1544}$ El Sol, "La cuestión de Tacna y Arica", 14 de mayo de 1929, p. 8; La Época, "En Washington se sigue estudiando el acuerdo sobre Tacna y Arica", 14 de mayo de 1929, p. 1; La Voz, "La cuestión de Tacna y Arica", 14 de mayo de 1929, p. 1.

${ }^{1545}$ El Heraldo, "Mañana se verificará el cambio de firmas entre los representantes de Chile y Perú", 16 de mayo de 1929, p. 11; La Voz, "La cuestión de Tacna y Arica", 16 de mayo de 1929, p. 5; El Sol, "El acuerdo de Tacna y Arica se comunicará hoy oficialmente", 17 de mayo de 1929, p. 5; La Libertad, "La solución del conflicto de Tacna y Arica", 17 de mayo de 1929, p. 6.

${ }^{1546}$ La Correspondencia Militar, "Noticia oficial del arreglo del pleito de Tacna y Arica", 18 de mayo de 1929, p. 5; La Voz, "Hoover notifica el acuerdo a que han llegado Chile y el Perú", 18 de mayo de 1929, p. 5; El Sol, "La cuestión de Tacna y Arica", 19 de mayo de 1929, p. 7; La Libertad, "El viejo pleito de Tacna y Arica", 19 de mayo de 1929, p. 1; La Correspondencia Militar, "Celebrando el acuerdo", 19 de mayo de 1929, p. 2; La Libertad, "El viejo pleito de Tacna y Arica", 19 de mayo de 1929, p. 1; El Sol, "La cuestión de Tacna y Arica", 19 de mayo de 1929, p. 7; El Imparcial, "El pleito de Tacna y Arica", 19 de mayo de 1929, p. 5. 
Comentando el anuncio de Hoover, El Sol acertó en las dificultades derivadas del acuerdo -publicado íntegramente en los diarios ${ }^{1547}$ - por excluir la petición marítima boliviana. Sin tener en cuenta el anhelo costero de ese país, aseguraba el diario, la solución era "a medias"1548. Sólo el día que ese acuerdo tome forma, escribía con tono profético, "habrá quedado absoluta y totalmente zanjada la vieja cuestión"1549. Los afectos hacia las pretensiones bolivianas cambiaban drásticamente para referirse a la diplomacia estadounidense. Aunque $\mathrm{El} \mathrm{Sol}$ declaró no interesarse por las intervenciones, tácticas y fracasos anteriores de la Casa Blanca para lograr la paz en la frontera chileno-peruana no desestimó recursos literarios para concluir la extensa columna de opinión con las ideas señaladas.

El papel de los buenos oficios de los Estados Unidos era subvalorado. La paz lograda por dos pueblos "hispánicos"1550 era, sin duda, "más que un éxito de la diplomacia norteamericana $[\ldots]$ una consecuencia del espíritu de concordia existente entre los dos países y del tradicional sentido democrático de la política americana"1551. El tiempo, nuevamente, contradeciría la mentada tradición demócrata en ambos países.

Perú, más pronto de lo esperado, serviría de ejemplo. En Lima, los estudiantes organizados realizaron manifestaciones hostiles hacia el acuerdo anunciado por Hoover ${ }^{1552}$. La imprenta del Diario Oficial fue coincidiendo con la circulación, otra vez, del rumor del asesinato del presidente Leguía. Los reporteros de El Heraldo debieron comunicarse con su hermano, representante diplomático de Perú en España, quien aseguró no tener noticias del movimiento social. Eduardo Leguía aprovechó esa entrevista para reforzar la idea de que en el Perú el tratado había sido recibido con satisfacción.

${ }^{1547}$ El Sol, "Texto oficial del convenio chilenoperuano", 19 de mayo de 1929, p. 6; La Época, "El acuerdo sobre Tacna y Arica", 20 de mayo de 1929, p. 5; La Voz, "La cuestión de Tacna y Arica", 20 de mayo de 1929, p. 7; La Correspondencia Militar, "La solución del problema de Tacna y Arica", 21 de mayo de 1929, p. 4.

${ }_{1548}$ El Sol, "El pleito chilenoperuano, resuelto", 19 de mayo de 1929, p. 1.

1549 Idem.

${ }^{1550}$ Idem.

${ }^{1551}$ Idem

1552 El Heraldo, "Contra la solución del pleito de Tacna y Arica", 22 de mayo de 1929, p. 1; La Voz, "Manifestación en Lima", 22 de mayo de 1929, p. 5; El Imparcial, "Perú", 23 de mayo de 1929, p. 5; La Correspondencia Militar, "No ha habido revolución en Lima", 23 de mayo de 1929, p. 4; La Voz, "En el Perú no se ha alterado el orden público", 23 de mayo de 1929, p. 3; La Libertad, "El pleito de Tacna y Arica", 25 de mayo de 1929, p. 5; La Libertad, "El pleito de Tacna y Arica", 26 de mayo de 1929, p. 8. 
En esos días se recibieron en España algunos cablegramas que anunciaban una nueva revolución en Perú, desmentida mediante una circular facilitada por Eduardo Leguía a El Sol. En ella se establecía la tranquilidad política en el país, interrumpida sólo por manifestaciones contra el tratado ${ }^{1553}$. Meses después sería remplazado por Gonzalo Aramburú $^{1554}$. La agitación peruana hizo pensar a un redactor español lo injusto de los buenos oficios de Hoover. Para él, los Estados Unidos eran los responsables de la convulsión política peruana. La crítica se realizó en términos místicos, eurocéntricos y alarmistas:

El Destino (sic) quiere, por lo visto, que no se resuelva nunca definitivamente el famoso pleito de Tacna y Arica, que desde hace un sinnúmero de años mantiene en tensión constante a Chile y al Perú y constituye una amenaza perpetua para la paz en Suramérica, ya que si se llegase a un conflicto sería difícil limitarlo a las dos naciones directamente interesadas. Lo remoto del problema y el sinnúmero de fases por que ha pasado ha hecho que la opinión europea se desentendiese de él o no lo tomara al menos muy en serio; pero no por ello deja de ser una cuestión vital de cuya solución depende en gran parte el mantenimiento de la paz en la América del Sur. [...] Como se sabe, la cuestión parecía haberse resuelto al fin. Estos días se ha hecho pública la resolución del presidente de los Estados Unidos, cuyo laudo habían aceptado los dos países interesados. A simple vista la solución que atribuye al Perú una de las provincias discutidas y la otra a Chile parece bastante razonable; pero el hecho es que mientras en Chile no ha provocado, que se sepa, protestas ostensibles, en el Perú ha producido un serio disgusto exteriorizado en disturbios. El laudo de Mr. Hoover no ha logrado, por tanto, satisfacer a las dos partes. Hubiera tenido mayor fortuna la Sociedad de Naciones, cuya intervención se reclamaba, y que por hallarse más alejada podía ofrecer mayores garantías de imparcialidad. No hay que olvidar que la Sociedad de Naciones ha tenido que entender en cuestiones más difíciles y complicadas aún. Se suponía, en el caso de que el movimiento peruano de protesta triunfe o impida la aceptación del acuerdo, la cuestión de Tacna y Arica no sólo no se habría resuelto, sino que entraría en una fase peligrosísima ${ }^{1555}$.

El Tratado de Lima que puso fin al problema de Tacna y Arica se firmó el 3 de junio de 1929. De este modo se anulaba el Tratado de Ancón de 1883. Diversos diarios españoles publicaron los sucesos, intentando apegarse al hecho no realizando evaluaciones ${ }^{1556}$. Restaba sólo la aprobación de los parlamentos de Chile y Perú. En Chile, pronosticaba la prensa, se realizaría el 18 de junio y en Perú el 17 del mismo mes ${ }^{1557}$.

${ }^{1553}$ El Sol, "Los supuestos disturbios en el Perú", 26 de mayo de 1929, p. 7.

${ }^{1554}$ El Sol, "Nuevo Secretario de la Legación del Perú", 3 de julio de 1929, p. 2.

${ }^{1555}$ El Heraldo, "El pleito de Tacna y Arica", 23 de mayo de 1929, p. 1.

${ }^{1556}$ El Heraldo, "Ha sido firmado, por fin, el Tratado sobre Tacna y Arica", 4 de junio de 1929, p. 3; La Época, "El conflicto de Tacna y Arica", 4 de junio de 1929, p. 2; La Libertad, "El abrazo de Lima", 4 de junio de 1929, p. 6; La Voz, "Firma del acuerdo sobre Tacna y Arica", 4 de junio de 1929, p. 5; El Imparcial, 
En Europa, con anterioridad, en el consejo de la Sociedad de las Naciones asentado en Madrid y presidido por el barón de Adatci, el delegado chileno se refirió a la solución del conflicto chileno-peruano. Enrique Villegas, acudiendo a la retórica pacifista, dijo sobre el tratado: "creemos que aquel elimina toda posibilidad de futuros conflictos entre pueblos unidos por un común deseo de progreso y de engrandecimiento, a la sombra de la paz" ${ }^{1558}$. A su intervención agregó el papel elevado de los aviadores españoles Jiménez e Iglesias quienes “encontrándose en Chile durante las negociaciones, cumplieron la noble y alta misión de llevar desde Santiago a Lima por la vía aérea y bajo el pabellón de España los documentos que han servido de base al feliz acuerdo con el Perú"1559. En la sesión, el embajador de España en París, Quiñones de León, reflexionó: “Queda así unido el nombre de España a la solución de un conflicto que ha mantenido separados durante largos años a dos pueblos de nuestra raza" 1560 .

El día después El Heraldo analizó la importancia del discurso para la paz en la “América Española", sin mencionar, en ningún momento, la activa participación de los Estados Unidos. Los celos periodísticos eran difíciles de controlar. Suavizaban esa actitud las palabras del nuncio Pacelli, publicadas en diversos órganos de la prensa española. Durante un banquete celebrado en Berlín con motivo de la solución de la cuestión de Tacna y Arica, el decano del cuerpo diplomático resaltó en los representantes de Chile y Perú "los supremos valores religiosos y morales que conserva la vieja tradición católica en los países americanos como herencia de la gloriosa nación española" ${ }^{1561}$.

\footnotetext{
"América, satisfecha de la solución del conflicto", 5 de junio de 1929, p. 1; La Emigración Española, "Chile y Perú han llegado a un acuerdo", 5 de junio de 1929, p. 3; La Libertad, "El Tratado sobre Tacna y Arica", 5 de junio de 1929, p. 5; La Libertad, "El arreglo de lo de Tacna y Arica", 12 de junio de 1929, p. 1.

${ }^{1557}$ La Libertad, "El arreglo de lo de Tacna y Arica", 12 de junio de 1929, p. 1; El Heraldo, "El Tratado de Tacna y Arica", 13 de junio de 1929, p, 16; El Sol, "El Congreso y el acuerdo con Chile", 14 de junio de 1929, p. 1.

${ }^{1558}$ El Heraldo, "Una comunicación del señor Villegas sobre la solución del pleito de Tacna y Arica", 13 de junio de 1929, p. 1; El Siglo Futuro, "El pleito de Tacna y Arica", 13 de junio de 1929, p. 6; El Imparcial, "Sesión pública", 14 de junio de 1929, p. 8.

${ }^{1559}$ La Época, "Hoy se ha tratado de la importante cuestión de las minorías", 13 de junio de 1929, p. 1.

${ }^{1560}$ La Época, "Hoy se ha tratado de la importante cuestión de las minorías", 13 de junio de 1929, p. 1; La Correspondencia Militar, "En la sesión de ayer de la Sociedad de Naciones quedó aprobado el informe de las minorías", 14 de junio de 1929, p. 1.

${ }^{1561}$ El Imparcial, "La solución del pleito Tacna-Arica", 20 de junio de 1929, p. 1; La Voz, "La solución del pleito sobre Tacna y Arica", 20 de junio de 1929, p. 1; La Época, "Para festejar la solución del pleito de Tacna y Arica", 20 de junio de 1929, p. 2; La Correspondencia Militar, "Banquete hispanoamericano para festejar la solución de la cuestión de Tacna y Arica”, 21 de junio de 1929, p. 4.
} 
El embajador español, Espinosa de los Monteros también hizo uso de la palabra celebrando el acuerdo fraterno de dos pueblos que formaban parte de una "familia bien avenida e inveteradamente enlazados a España" ${ }^{1562}$. Como anécdota, otro diario publicó parte del discurso pronunciado por Villegas, asegurando que era el "representante" de Tacna y Arica.

El Sol, diario que siguió de cerca el proceso final del conflicto llamó la atención de su colega. La columna, con tintes de amonestación, tenía como finalidad moral "evitar que algunos periodistas madrileños, en vena de improvisar Estados, se hagan demasiadas ilusiones". La meticulosidad del correcto escritor en el campo diplomático alertaba al empleado de La Correspondencia Militar sobre el cuidado que exigen las relaciones internacional y puntualmente las sudamericanas para evitar "sembrar recelos entre Chile y Perú"1563.

Los hechos posteriores que la prensa transformó en noticia trataron de la aprobación del tratado por los parlamentos de Chile y Perú. En Santiago, las gestiones del canciller Ríos lograron una rápida aprobación del Senado. Los pasos siguientes eran la presentación del tratado en la Cámara de diputados para que luego retornase al Senado y se firmase su aprobación definitiva ${ }^{1564}$. Ibáñez, durante las celebraciones de la firma del tratado comentó, entre otros aspectos, la importancia de las soluciones directas entre países enfrentados ${ }^{1565}$.

${ }^{1562}$ El Imparcial, "La solución del pleito Tacna-Arica", 20 de junio de 1929, p. 1; La Voz, "La solución del pleito sobre Tacna y Arica", 20 de junio de 1929, p. 1; La Época, "Para festejar la solución del pleito de Tacna y Arica", 20 de junio de 1929, p. 2; La Correspondencia Militar, "Banquete hispanoamericano para festejar la solución de la cuestión de Tacna y Arica", 21 de junio de 1929, p. 4.

${ }^{1563}$ El Sol, "No hay que abusar", 14 de junio de 1929, p. 1.

${ }^{1564}$ La Correspondencia Militar, "Un mensaje por la solución de Tacna y Arica”, 21 de junio de 1929, p. 4; La Libertad, "El tratado sobre lo de Tacna y Arica", 23 de junio de 1929, p. 1; El Siglo Futuro, "El acuerdo sobre Tacna y Arica", 2 de julio de 1929, p. 3; El Heraldo, "El Senado chileno ratifica el pacto de Tacna y Arica", 2 de julio de 1929, p. 3; La Libertad, "El Senado aprueba el tratado", 3 de julio de 1929, p. 5; La Correspondencia Militar, "La rectificación del tratado de Tacna y Arica", 4 de julio de 1929, p. 4; El Sol, "El Congreso trata del acuerdo de Tacna y Arica", 5 de julio de 1929, p. 5; El Imparcial, "Todavía tienen que ocuparse de Tacna y Arica", 5 de julio de 1929, p. 5; La Libertad, "Lo de Tacna y Arica", 6 de julio de 1929, p. 1; La Época, "Fin del conflicto de Tacna y Arica", 6 de julio de 1929, p. 6; La Época, "La solución del pleito de Tacna y Arica", 8 de julio de 1929, p. 6; El Siglo Futuro, "Chile", 8 de julio de 1929, p. 2.

${ }^{1565}$ El Siglo Futuro, "Discurso del presidente Ibáñez acerca de la solución del pleito de Tacna y Arica", 11 de julio de 1929, p. 6; La Correspondencia Militar, "Manifestaciones del general Ibáñez”, 11 de julio de 1929, p. 3; El Heraldo, "Un discurso del presidente de Chile", 10 de julio de 1929, p. 15. 


\section{Imagen n. ${ }^{\circ} 64$}

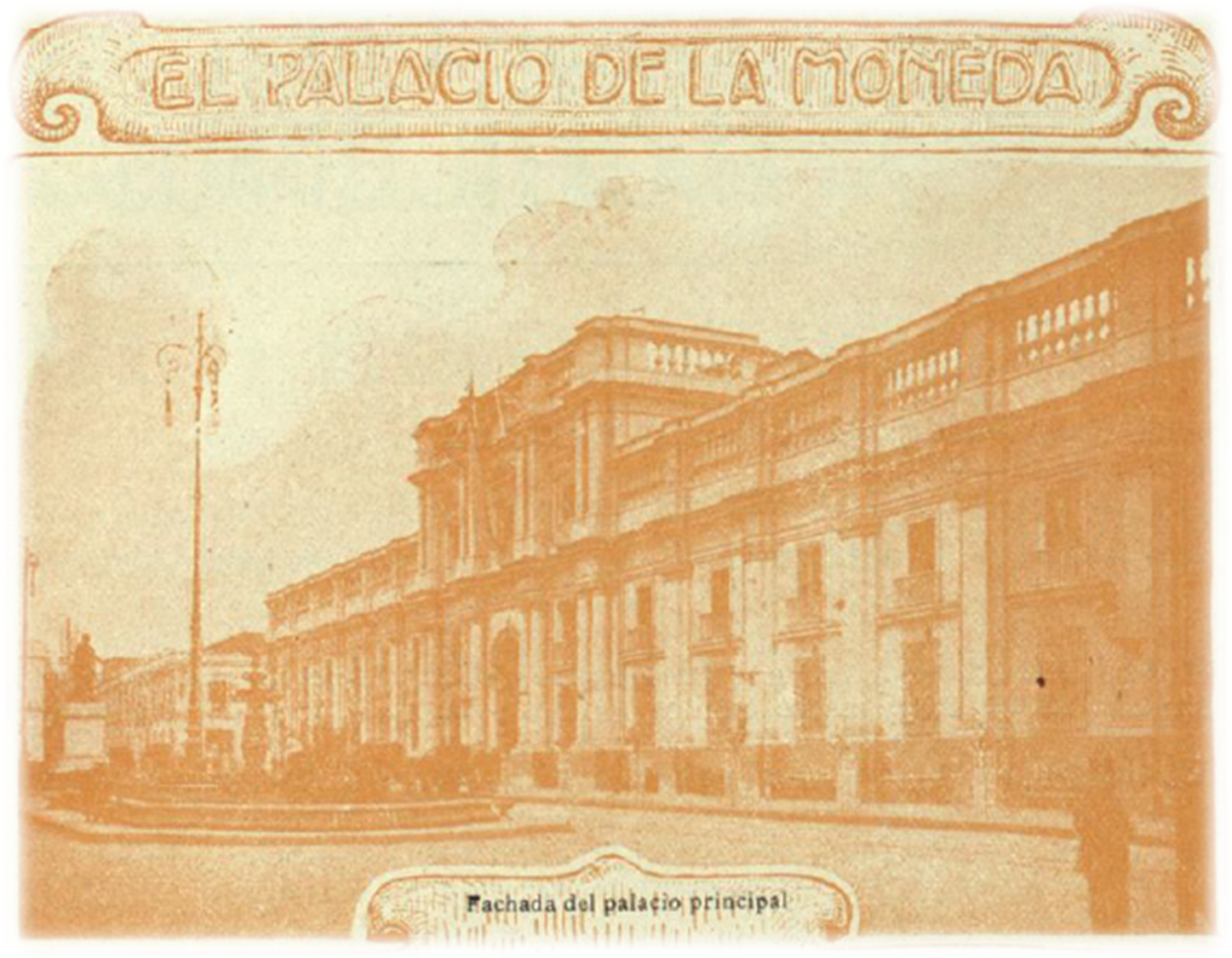

Fuente: Mercurio, "El Palacio de La Moneda”, 20 de octubre de 1910, n. ${ }^{\circ}$ 109, p. 399.

Allí remarcó, como lo hizo en el mensaje de apertura del Congreso, el espíritu de conciliación y amistad hacia el Perú1566. En Lima, el presidente Leguía sugirió la ratificación del tratado en la ceremonia de inauguración del Congreso, asumiendo su total responsabilidad en sus consecuencias. Luego de una breve discusión parlamentaria -que incluyó un duelo entre dos parlamentarios ${ }^{1567}$ - se aprobó el acuerdo chileno-peruano ${ }^{1568}$.

\footnotetext{
${ }^{1566}$ El Siglo Futuro, "El mensaje del Presidente al Parlamento", 23 de mayo de 1929, p. 3; La Época, "La apertura del Parlamento chileno", 23 de mayo de 1929, p. 2.

${ }^{1567}$ El Heraldo, "Un duelo entre dos políticos peruanos", 8 de julio de 1929, p. 3.

${ }^{1568}$ El Heraldo, "La apertura del parlamento peruano", 27 de junio de 1929, p. 3; El Sol, "Perú", 28 de junio de 1929, p. 5; La Correspondencia Militar, "Solemne sesión en el Parlamento por la solución de Tacna y Arica", 28 de junio de 1929, p. 6; La Libertad, "La ratificación del tratado sobre Tacna y Arica", 28 de junio de 1929, p. 6; El Sol, "Perú", 30 de junio de 1929, p. 7; El Sol, "El discurso del Presidente", 1 de julio de 1929, p. 5; El Heraldo, "El Congreso del Perú ratifica el acuerdo", 3 de julio de 1929, p. 2; La Época, "Noticias cortas", 3 de julio de 1929, p. 4; La Voz, "Noticias breves del extranjero", 3 de julio de 1929, p. 8; El Imparcial, "El Congreso peruano ratifica el acuerdo", 4 de julio de 1929, p. 5; El Sol, "El Congreso ratifica
} 
Por su simbolismo, el día de la independencia del Perú, 28 de julio, se utilizó para la firma de la ratificación de los gobiernos de Chile y Perú en la ciudad de Santiago ${ }^{1569}$. Algunos diarios ofrecieron detalles de la ceremonia posterior celebrada en el salón de recepciones del Palacio de La Moneda, donde el canciller chileno entregó al embajador peruano un "cheque de seis millones de dólares, según está estipulado en el Acuerdo"1570.

En Ginebra, informó la prensa española, los delegados de Chile y Perú entregaron a la Sociedad de las Naciones ${ }^{1571}$ el tratado de paz que bloqueó a Bolivia el acceso al mar. Aquel 28 de julio se había publicado en los diarios oficiales de los países firmantes el protocolo complementario del tratado prohibiendo "la posibilidad de la venta de Tacna o Arica a Bolivia" 1572 contradiciendo, de derecho, los rumores recibidos de Washington que aseguraban una concesión costera para ese país ${ }^{1573}$. Semanas antes, las legaciones bolivianas en Europa habían facilitado circulares a los principales diarios de las capitales señalando:

Esta prohibición tendía a frustrar las aspiraciones bolivianas de una salida al mar en compensación por la pérdida de su costa en la guerra del 79. Y esto es más sorprendente porque cuando esta cuestión fue llevada a Ginebra en 1921, el delegado chileno prometió formalmente que si Bolivia retiraba su solicitud para que la Liga de Naciones abriera una información al respecto, el Gobierno chileno entablaría negociaciones directas con el boliviano con el propósito de revisar la situación creada por el Tratado de 1904 y la pérdida de la provincia marítima de Antofagasta. No sólo se ha olvidado de esa promesa, sino que el Gobierno chileno aparece ahora tomando medidas para impedir la realización del deseo de Bolivia de procurarse una salida al mar por medio de negociaciones diplomáticas ${ }^{1574}$.

el Tratado de Tacna y Arica", 4 de julio de 1929, p. 5; La Libertad, "Ratificación del acuerdo sobre Tacna y Arica", 4 de julio de 1929, p. 5.

${ }^{1569}$ El Heraldo, "La solución del pleito de Tacna y Arica" 13 de julio de 1929, p. 3; La Voz, "El Tratado sobre Tacna y Arica", 13 de julio de 1929, p. 4; El Imparcial, "Perú", 14 de julio de 1929, p. 5; El Sol, "La ratificación del Tratado con Chile", 14 de julio de 1929, p. 7; La Libertad, "El Tratado entre Chile y Perú", 14 de julio de 1929, p. 5; La Época, "La ratificación del Tratado sobre Tacna y Arica", 15 de julio de 1929, p. 4.

${ }^{1570}$ La Libertad, "Cambio de ratificaciones entre Chile y Perú", 30 de julio de 1929, p. 7; La Correspondencia Militar, "Cambio de ratificaciones entre Chile y Perú", 31 de julio de 1929, p. 4.

${ }^{1571}$ La Libertad, "El Tratado de Tacna y Arica", 2 de agosto de 1929, p. 1; El Imparcial, "El Tratado de Tacna y Arica", 4 de agosto de 1929, p. 5; La Correspondencia Militar, "El Tratado de Tacna y Arica y la Liga de las Naciones", 4 de agosto de 1929, p. 1; El Imparcial, "Entrega del Tratado sobre Tacna-Arica", 26 de septiembre de 1929, p. 5; El Sol, "Ayer se declaró clausurada la décima Asamblea", 26 de septiembre de 1929 , p. 5.

${ }^{1572}$ La Voz, "La solución del pleito de Tacna y Arica", 29 de julio de 1929, p. 8; El Imparcial, "Ayer fue firmado el protocolo entre Chile y Perú", 30 de julio de 1929, p. 1; El Sol, "Chile", 30 de julio de 1929, p. 7; La Libertad, "El tratado entre el Perú y Chile", 30 de julio de 1929, p. 7.

${ }^{1573}$ La Voz, "El acuerdo sobre Tacna y Arica", 4 de julio de 1929, p. 2.

${ }^{1574}$ La Voz, "Manifestación en Lima", 22 de mayo de 1929, p. 5. 
La solución del conflicto limítrofe permitió que el gobierno chileno aprovechase la coyuntura diplomática para anunciar, con gran pompa, una serie de obras públicas en Arica. La primera consistió en declarar al aeródromo de la ciudad aeropuerto internacional ${ }^{1575}$ permitiéndole unir Arica con Miami ${ }^{1576}$. La segunda "faraónica" empresa, pretendía construir un nuevo puerto en la ciudad. La intención era instalar dos muelles de protección en la bahía sobre una zona portuaria superior a los 25000 metros $^{1577}$.

La estadía de Ibáñez en Arica tuvo la finalidad de ver sobre el terreno la planificación y avances de las obras ${ }^{1578}$. Por último, en el Morro se erigiría un monumento a la paz. A los pocos días de iniciada la campaña bancaria para reunir los fondos la suma ascendió a 25000 pesos chilenos ${ }^{1579}$. El fervor inicial no bastaría. El Cristo de la Paz, nombre que recibió la imagen situada en la cima de la roca sacra se instaló en 1999; el bronce se había fundido en Madrid doce años antes.

\subsection{Ruegos estériles: El Nobel de la Paz para Leguía e Ibáñez}

Casi medio siglo demoró Chile y Perú en solucionar el diferendo. Desde la matanza de Arica, que la prensa, pese a las dificultades técnicas de la época, informó detalladamente, hasta la firma del Tratado de Lima, todos los esfuerzos para alcanzar la paz fueron infructuosos. Los archivos de las cancillerías de Chile y Perú guardan en sus anaqueles miles de documentos como pruebas indesmentibles de las dificultades que sus gobiernos tuvieron para acordar, con justicia, la solución de la litis. Ésta sólo llegaría en

${ }^{1575}$ El Heraldo, "Doce aeropuertos en Chile", 25 de julio de 1929, p. 3; La Época, "Doce aeropuertos en Chile", 25 de julio de 1929, p. 2; La Correspondencia Militar, "Nuevos puertos aéreos", 8 de agosto de 1929, p. 2.

${ }^{1576}$ El Siglo Futuro, "Nueva línea aérea", 26 de noviembre de 1929, p. 6; La Correspondencia Militar, "Nueva línea aérea", 27 de noviembre de 1929, p. 2.

${ }^{1577}$ El Heraldo, "Se va a engrandecer y embellecer la capital y a construir el puerto de Arica", 24 de julio de 1929, p. 11; La Época, "El puerto de Arica", 24 de julio de 1929, p. 4; La Voz, "El puerto de Arica", 24 de julio de 1929, p. 1; El Imparcial, "Chile", 25 de julio de 1929, p. 5; La Correspondencia Militar, "El puerto de Arica”, 25 de julio de 1929, p. 1.

${ }^{1578}$ El Sol, "El Presidente Ibáñez en Arica", 4 de agosto de 1929, p. 7; La Correspondencia Militar, "El Presidente Ibáñez desembarca en Arica", 4 de agosto de 1929, p. 1; La Libertad, "El presidente de Chile desembarca en Arica", 4 de agosto de 1929, p. 6.

${ }^{1579}$ El Heraldo, "Se va a erigir un monumento a la paz en Arica", 20 de julio de 1929, p. 7. 
1929, siendo los presidentes de Chile, Carlos Ibáñez del Campo, y del Perú, Augusto Leguía ${ }^{1580}$ quienes apoyados en sus equipos jurídicos la alcanzaron.

La prensa española, interesada en la finalización de la cuestión de Tacna y Arica y en las personalidades de los presidentes de Chile y Perú, vio con buenos ojos los rumores que en Lima y Santiago comenzaron a circular sobre la posible postulación de ambos políticos al premio Nobel de la Paz. En particular, Augusto Leguía había recibido a comienzos de 1929 el gran collar de la Orden Militar del Cristo, concedida por el Papa ${ }^{1581}$. Para la ocasión, Emilio Lissón, en representación del Sumo Pontífice, arzobispo de Lima y amigo cercano del presidente, dirigió el acto de condecoración. Lissón, testigo de las deportaciones políticas efectuadas por Leguía "mantuvo un silencio discreto frente a estas y otras acciones arbitrarias"1582. De todos modos, en esa capital -publicaron El Sol y El Imparcial- se comenzaban a organizar agrupaciones para trabajar en la recomendación de Leguía como "merecedor del Premio Nobel de la Paz por sus esfuerzos realizados a favor de la paz entre naciones americanas que han sido culminados con franco éxito en el Tratado de Tacna y Arica, recientemente firmado en la República de Chile"1583.

Poco tiempo después, sin embargo, en la prensa desaparecieron las informaciones referidas a la concesión del galardón para los presidentes americanos. Durante un par de meses predominó el silencio periodístico que sólo acabaría con la reactivación de la iniciativa presentada desde España, gracias a la actividad de la Unión Iberoamericana.

\footnotetext{
${ }^{1580}$ Las escasas obras que refieren brevemente a la candidatura de Leguía para Premio Nobel de la Paz han tenido un juicio dispar. Mientras algunas aceptan la nominación, otras realizan críticas duras debido a la política interna represiva que tuvo los últimos años de su mandato. Para más información ver: UNIVERSIDAD Central Del Ecuador, Anales de la Universidad Central del Ecuador, Quito, Imp. de la Universidad Central, 1933, p. 531; BARRós, Oscar, Por la justicia y por la patria, Lima, Tall. De Linotipia, 1940, p. 78; ORTIZ, Delio, Amazonas abajo; biografía de una infamia, Quito, Editora Quito, 1955, p. 188; ZÁRATE LezCANo, José, Perú y Brasil: relaciones y límites, antecedentes históricos de la Amazonía, Lima, Ministerio de Guerra, Servicio de Prensa, Propaganda y Publicaciones Militares, 1957; Ovando SANZ, Guillermo y VÁsqueZ, Alberto M., Obras completas de Humberto Vásquez Machicado y José Vásquez Machicado, La Paz, Don Bosco, 1988; Encuentro InTernacional De Peruanistas, Estado de los estudios históricosociales sobre el Perú a fines del siglo XX, Lima, UNESCO, Universidad de Lima, Fondo de Cultura Económica, 1996, p. 451; SELSER, Gregorio, Cronología de las intervenciones extranjeras en América Latina, 1899-1945, tomo III, México, Centro de investigaciones interdisciplinarias en ciencias y humanidades, Universidad Nacional Autónoma de México, 2001, p. 535.

${ }^{1581}$ El Sol, "Perú", 19 de febrero de 1929, p. 7.

1582 KLAIBER, Jeffrey, "Iglesia Católica y poder político en el siglo XX”. En MARZAL, Manuel M., RoMERO, Catalina y SÁnchez, José, La religión en el Perú al filo del milenio, Lima, Fondo Editorial de la Pontificia Universidad Católica del Perú, 2002, p. 88.

${ }^{1583}$ El Imparcial, "Perú", 26 de julio de 1929, p. 5; El Sol, "Perú", 26 de julio de 1929, p. 5.
} 
Esta institución, según José Prat, tenía por objetivo fortalecer las relaciones colaborativas entre las repúblicas hispanoamericanas y de lengua portuguesa. El centro de estudios de la Unión contaba con una importante hemeroteca con publicaciones de la región ${ }^{1584}$. Desde allí se elaboró una intensa campaña para postular a los presidentes Ibáñez y Leguía al premio Nobel de la Paz. Por razones simbólicas, su directiva esperó hasta el 12 de octubre para enviar una solicitud de adhesión a todos los presidentes de los países americanos. Jacobo Fitz-James Stuart y Falcó, firmante del documento, expresó:

Excelentísimo señor presidente de la República: Recabamos el 12 de octubre, Fiesta de la Raza, valioso voto de vuecencia para nuestro proyecto, con anuencia del Gobierno español, de solicitar premio Nobel pro Paz para presidentes Chile Perú, que resolvieron amistosamente asunto Tacna y Arica ${ }^{1585}$.

Por otro lado, en Chile, la colonia sueca realizó una serie de reuniones acordando solicitar al Parlamento de su país, por medio de la representación diplomática en esa capital, la concesión del Premio Nobel de la Paz a los presidentes de Chile y Perú ${ }^{1586}$. Sólo uno de los diarios que reprodujo ese anhelo arriesgó un título que dispersó en los lectores el trasfondo nefasto de la nominación: la concesión del Premio Nobel de la Paz a dos dictadores. En Lima, mientras tanto, la comunidad sueca emprendió actividades similares. Discutida la resolución, enviaron un cable al Rector de la Universidad de Upsala solicitando la concesión del Nobel de la Paz al presidente Leguía ${ }^{1587}$. Otras publicaciones, quizás sumándose a la propuesta de la Unión Iberoamericana, en grandes letras titularon "El premio Nobel para los presidentes de Perú y Chile"1588.

\footnotetext{
1584 GonZÁlez, Pilar, “José Prat: Recuerdos de Colombia”. En Abellán, José Luis y MonClús, Antonio (Coords.), El pensamiento español contemporáneo y la idea de América. El pensamiento en el exilio, Barcelona, Editorial Anthropos, 1989, p. 298.

${ }^{1585}$ El Siglo, "El Premio Nobel de la Paz para los presidentes de Chile y Perú". 12 de octubre de 1929, p. 6; El Sol, "Se pide el Premio Nobel para los Presidentes de Chile y Perú", 12 de octubre de 1929, p. 8; La Época, "Se pide el Premio Nobel de la Paz para los Presidentes de Chile y Perú", 12 de octubre de 1929, p. 4; La Voz, "Un cable a los presidentes", 12 de octubre de 1929, p. 3; El Imparcial, "La Unión Iberoamericana", 13 de octubre de 1929, p. 2; El Sol, "Se pide el Premio Nobel de la Paz para los Presidentes de Chile y Perú", 13 de octubre de 1929, p. 6; La Correspondencia Militar, "El Premio Nobel de la Paz para los Presidentes de Chile y Perú", 13 de octubre de 1929, p. 4; La Libertad, "Se pide el premio Nobel de la Paz para los Presidentes de Chile y Perú", 13 de octubre de 1929, p. 7. Las cursivas en la cita son nuestras.

1586 El Heraldo, "Se pide el premio de la paz para dos dictadores", 19 de octubre de 1929, p. 3; La Correspondencia Militar, "El Premio Nobel de la Paz", 19 de octubre de 1929, p. 4.

${ }^{1587}$ El Imparcial, "La colonia sueca en Lima pide el premio Nobel para Leguía", 12 de noviembre de 1929, p. 5.

${ }^{1588}$ La Libertad, "E1 Premio Nobel para los presidentes de Perú y Chile", 20 de octubre de 1929, p. 4.
} 
En efecto, la propuesta del grupo "iberoamericanista" tuvo muy buena acogida, sobre todo en los presidentes de los Estados caribeños y centroamericanos. En menos de un mes, los gobiernos de República Dominicana, Cuba, Costa Rica, Guatemala, Honduras y Panamá se adhirieron a la sugerencia del duque de Alba. Posteriormente, lo hizo, representando a Sudamérica, Ecuador y Paraguay. De acuerdo a las impresiones de la prensa española que se ocupó de la iniciativa, todos ellos habían respondido con gran “efusión” a la proposición ${ }^{1589}$.

Hacia fines de 1929, tal como se publicó en la prensa, la incertidumbre de los gobiernos de México, Venezuela y El Salvador no impidió que la iniciativa, popular a estas alturas, prosperara ahora en los Estados Unidos. Allí, la figura de Leguía cobró gran realce entre la diplomacia que valoró su política exterior pacifista en el conflicto de Tacna y Arica $\mathrm{y}$, además, en los acuerdos fronterizos con Bolivia, Brasil y Colombia ${ }^{1590}$.

En el país del norte, el dictador peruano gozaba de amplias simpatías. Durante los más de diez años que lideró el país, su proyecto económico se apoyó en el capitalismo estadounidense. El Perú - como lo ha sugerido un historiador- se transformó en un “enclave" porque los recursos obtenidos allí no completaban el proceso capitalista ${ }^{1591}$. Su figura cobró resonancia opacando la candidatura de Ibáñez.

El Sol, según su costumbre, ofreció algunas opiniones, después de varios días de informar "objetivamente" los hechos relativos a la nominación para el Nobel. Analizó el significado de lo "iberoamericano", identidad autoasignada por la institución promotora de otorgar el Nobel a los dictadores. Con espíritu sociolingüístico aseguró la necesidad de modificar el concepto para hacerlo entendible a la comunidad.

${ }^{1589}$ El Imparcial, "El Premio Nobel para los presidentes de Chile y Perú,, 30 de octubre de 1929, p. 1; El Sol, "El Premio Nóbel (sic) de la Paz", 30 de octubre de 1929, p. 3; El Imparcial, "El premio Nobel para los presidentes de Chile y Perú", 1 de noviembre de 1929, p. 2; El Sol, "El Premio Nobel para los presidentes de Chile y el Perú", 1 de noviembre de 1929, p. 3; La Época, "La petición del (sic) de la Paz para los Presidentes de Chile y Perú", 1 de noviembre de 1929, p. 2; El Imparcial, "El Premio Nobel para los presidentes de Chile y Perú", 6 de noviembre de 1929, p. 3; El Sol, "El Premio Nobel para los presidentes de Chile y Perú", 7 de noviembre de 1929, p.8.

${ }^{1590}$ El Imparcial, "El premio Nóbel (sic) para Leguía”, 28 de noviembre de 1929, p. 5.

1591 CotLer, Julio, "De Velasco a Belaúnde: el problema de la construcción nacional y la democracia en Perú”. En González CaSAnova, Pablo (Coord.), El Estado en América Latina. Teoría y práctica, México, Universidad de Las Naciones Unidas, Siglo XXI Editores S. A., 2003, p. 351. 
La meticulosidad del redactor le permitió comprender el poder constructivo que tienen las palabras, sobre todo tratándose de una directamente relacionada con los intereses del Estado español. Nos hemos permitido -escribió- modificar los textos enviados por la Unión Iberoamericana, para unificar en lo posible el lenguaje y ponerlo en armonía con las aspiraciones de "los muchos que, como nosotros, creen que este detalle encierra cierta importancia" 1592 . Y continuaba:

Por eso hemos corregido en el texto, siempre que ha sido posible, iberoamericano y latinoamericano, escribiendo en su lugar hispanoamericano. Respetamos, naturalmente, el nombre que la entidad ha creído indispensable conservar, si bien lamentaremos siempre el confusionismo que con tal sencillo detalle se fomenta ${ }^{1593}$.

Lamentablemente, desconocemos las reflexiones del duque del Alba en torno a la triada conceptual Hispanoamérica, Iberoamérica, Latinoamérica, bastante compleja, sobre todo por referirse a cuestiones de identidad supranacional. Por el contrario, conocemos mejor el interés central de algunos políticos e intelectuales hispanistas por liderar, aunque sea espiritualmente, cualquier proyecto macro-regional que incluyese ese país con las antiguas colonias americanas. De ningún modo, por último, creemos equívoca la sensata petición de la Unión Iberoamericana para conceder el premio Nobel a Leguía e Ibáñez, ambos representantes de autoritarismo político. Aquel anhelo provenía, también, de un contexto político autoritario en picado: los últimos meses de la dictadura de un diabético y "aletargado" 1594 Primo de Rivera. Al fin de cuentas, la dulce victoria de las candidaturas presentadas por la Unión fracasaría. Sumaría amargura, para sorpresa española, la concesión del Nobel de la Paz de 1929 a Frank Kellogg, negociador en la cuestión de Tacna y Arica y reconocido panamericanista, distinción recibida el 27 de noviembre de 1930.

Parte de la prensa española se interesó por el resultado del Nobel. Por ejemplo, el Heraldo de Madrid, quien insertó equívocamente una fotografía de Calvin Coolidge para graficar el rostro de Frank Kellogg ${ }^{1595}$.

\footnotetext{
${ }^{1592}$ El Sol, "El Premio Nobel para los presidentes de Chile y Perú", 7 de noviembre de 1929, p. 8.

1593 Idem.

1594 PAYNE, Stanley G., La primera democracia española. La segunda república, 1931-1936, Barcelona, Ediciones Paidós Ibérica S. A., 1995, p. 37.

${ }^{1595}$ Heraldo de Madrid, "Los Premios Nobel de la Paz 1929 y 1930”, 28 de noviembre de 1930, p. 1.
} 
Por su lado, Ernesto Dethorey, corresponsal español en Suecia, con tono envidioso por el resultado de la elección, reporteó para la sección "Cartas de Suecia" un artículo titulado "El Premio Nobel de la Paz" enfatizando, sobre todo, el desbarajuste en el año de la entrega del galardón, por lo que inició su crítica como sigue:

De este año. Porque del premio del año pasado, que le ha correspondido a Kellogg, no he de hablar ahora. Es un premio que se da con retraso. Un premio fiambre. Todo lo que se puede decir sobre el pacto Kellogg, que es lo que ha motivado el premio, ya se ha dicho. Ya se sabía el año pasado como este año. Yo no comprendo cómo no se lo dieron en su día. El Premio Nobel de la Paz es para premiar toda una vida dedicada al pacifismo, o una obra o un simple hecho pacifista. Esto era el caso de Kellogg: un hecho pacifista. El pacto Kellogg. Reconocido el hecho debía haber sido premiado en su tiempo. No esperar un año ${ }^{1596}$.

Imagen n. ${ }^{\circ} 65$

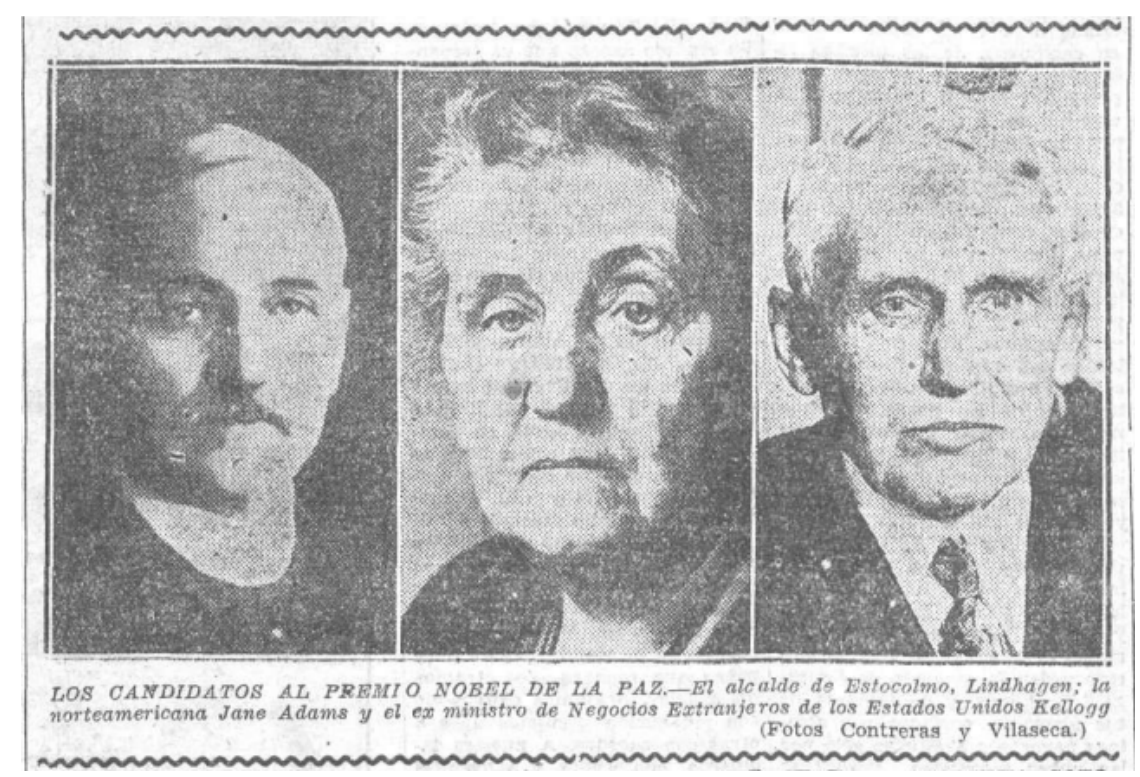

Fuente: La Voz, "Los candidatos al Premio Nobel de la Paz" (hacia la derecha de la página, Frank Kellogg), 15 de septiembre de 1930, p. 3.

Los ruegos estériles de la Unión Panamericana y de la colonia sueca en Chile y Perú para otorgar el Nobel de la Paz a Ibáñez y Leguía, sólo sepultó la participación del país nórdico en la trama del Pacífico. De todos modos, parece difícil encontrar respaldo documental o empírico sobre el interés diplomático de Suecia en la solución del diferendo chileno-peruano.

${ }^{1596}$ La Libertad, "El Premio Nobel de la Paz", 16 de diciembre de 1930, p. 4. 
Todo lo contrario sucede con España al revisar los periódicos más importantes en el cambio de siglo XIX al XX. En su caso, el fantasma del hispanoamericanismo rondó las imprentas que publicaron centenares de noticias respecto al papel "primordial" de España en la finalización del conflicto entre Chile y Perú. La ratificación del acuerdo de paz firmado en Santiago, como hemos señalado, fue encargada al Jesús del Gran Poder, avión español que simbolizó, como veremos más adelante, el padre omnisciente que dona la paz.

\subsection{El Jesús del Gran Poder: Mensajero de Paz}

La finalización jurídica del conflicto de Tacna y Arica reservó a la aviación española el honor de transportar los documentos del Tratado, desde Santiago hasta Lima, aprovechando la ruta del Jesús del Gran Poder. El avión, pilotado por los aviadores Ignacio Jiménez y Francisco Iglesias, despegó de Sevilla el 24 de marzo aterrizando en Cassamary (Brasil) el 26 de ese mes. Luego de atravesar la cordillera de Los Andes, el biplano llegó a Santiago.

La travesía, de gran riesgo y en un momento experimental de la aviación mundial, sumada a la misión diplomática encomendada, provocó en la prensa hispana gran algarabía. Centenares de noticias dedicadas al viaje, grandilocuencia por la misión de paz, fotografías y un hispanoamericanismo entusiasta, caracterizaron la producción periodística durante abril de 1929.

Diarios y revistas celebraron la perfección del vuelo y los recibimientos triunfales en todas las ciudades visitadas. En Chile -escribió Aérea- además de los homenajes personales, les fue solicitada una atención de alto valor espiritual, "pues pusieron en sus manos el protocolo que pone fin al casi secular pleito de Tacna y Arica entre ella y su vecino el Perú" ${ }^{1597}$. Ese gesto, explicó otra publicación, representaba un homenaje y un acto de confianza para los aviadores españoles, haciéndoles portadores de los documentos diplomáticos que finalizarían la debatida cuestión ${ }^{1598}$.

\footnotetext{
${ }^{1597}$ Aérea, "Continuación del viaje del Jesús del Gran Poder", abril de 1929, n. o 69, p. 3.

${ }^{1598}$ El Siglo Futuro, "Acuerdos del Consejo de Ministros celebrados anoche”, 18 de abril de 1929, p. 2.
} 
Nuevo Mundo, por su lado, también remarcó el significado espiritual y simbólico de ese encargo, pues los aviadores transportaban "la documentación que contiene la demarcación de la futura frontera entre Chile y Perú [...] Jiménez e Iglesias eran portadores de paz y cordialidad"1599. La trascendencia de la tarea fue remachada por el aviador Alfredo Kindelán, fundador del Ejército del Aire de España, quien, entre otras cosas, se mostró satisfecho por la honrosa misión ${ }^{1600}$.

\section{Imagen n. ${ }^{\circ} 66$}

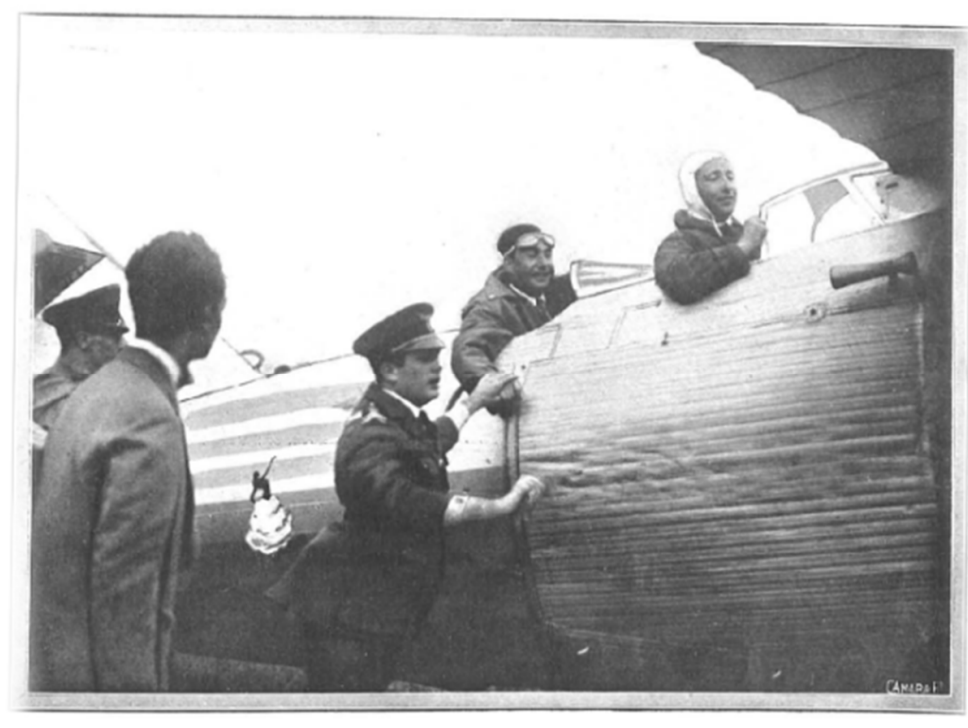

Fuente: Nuevo Mundo, “El vuelo triunfal de los aviadores Jiménez e Iglesias”, 26 de abril de 1929, p. 23.

Como en el pasado, los impresos recurrieron a la geografía de Chile y Perú para situar el itinerario del Jesús del Gran Poder. Uno de éstos mencionó sus similitudes geológicas y de asentamiento de la población sobre las vertientes andinas. Así mismo, los fondos marinos poseían acentuadas pendientes (3000, 4000 y 6000 metros), profundidades relacionadas con la gran actividad sísmica de la región. Ambos países estaban influidos por corrientes marinas frías que refrescaban el ambiente. La minería era otro punto en común. En el caso chileno, salitre, cobre, hierro, oro y plata; los dos últimos también en el caso peruano, donde además se encontraban metales raros de alto precio, como el vanadio y el tungsteno.

\footnotetext{
${ }^{1599}$ Nuevo Mundo, "El vuelo triunfal de los aviadores Jiménez e Iglesias", 26 de abril de 1929, p. 23. ${ }^{1600}$ La Libertad, "El viaje de Jiménez e Iglesias", 19 de abril de 1929, p. 5.
} 
La estrategia geográfica se acompañó, tal cual se realizaba desde los orígenes del conflicto, con las descripciones "culturales" de los países. Los viejos tópicos de la modernidad y progreso chileno, así como también de su militarismo, ausentes en el Perú se mantuvieron. Santiago, por ejemplo, con medio millón de habitantes, era un importante centro cultural y artístico sudamericano, en "la Universidad y otros centros científicos y en la organización militar hay huellas de la influencia alemana. Chile se considera como la nación más progresiva y adelantada de Suramérica"1601.

La antigua capital virreinal, en la descripción periodística, no brillaba por su modernidad ni militarismo prusiano: "La capital, Lima, tiene 200.000 habitantes, y es una de las ciudades americanas en que se conserva más puro el espíritu español que la creó"1602.

Los medios anunciaron que el Jesús del Gran Poder sobrevolaría la línea de costa, en medio de Los Andes y el Pacífico. Ese trayecto tendría una importancia fundamental para la memoria histórica española, ya que Jiménez e Iglesias divisarían, desde los cielos, “tierras llenas de trágicas reliquias de españoles, de los que las conquistaron y de los que alzaron aquellas libres repúblicas"1603. La Voz recordó la bravura de los conquistadores extremeños Francisco Pizarro, Diego de Almagro y Pedro de Valdivia, pero también la de aquellos héroes anónimos que, con abnegación y astucia, "clavaron en aquellas tierras las indestructibles raíces del alma hispana, que aun conservan, y que ahora se emociona al contacto de estos aéreos emisarios del saludo de España"1604. En esa misma tesitura, posteriormente $L a$ Voz reseñó el tramo final del viaje ${ }^{1605}$.

En los periódicos existe disparidad respecto al artífice de la peculiar misión diplomática. Una excepción, pareciera que erróneamente, asignó al gobierno de España la autoría de tan "gallardo gesto"1606.

\footnotetext{
${ }^{1601}$ La Voz, "De Santiago de Chile a Lima del Perú", 18 de abril de 1929, p. 2.

1602 Idem.

1603 Idem.

1604 Idem.

${ }^{1605}$ La Voz, "Perú, Ecuador, Colombia y Panamá", 30 de abril de 1929, p. 2.

${ }^{1606}$ La Época, "Gran entusiasmo por la misión diplomática conferida a Jiménez e Iglesias", 19 de abril de 1929, p. 2.
} 
Ese periódico afirmó, sin dar nombres, que las autoridades políticas españolas ofrecieron a Chile y Perú el Jesús del Gran Poder como "paloma mensajera de paz [...] para aquella misión diplomática e histórica" ${ }^{1607}$, siendo por eso muy elogiados ${ }^{1608}$.

El articulista de La Lectura Dominical, Mínimo, se opuso a esa interpretación, agradeciéndoles a Ibáñez y Leguía la designación de Jiménez e Iglesias para participar en nombre "de la Madre Patria, como mensajeros de paz"1609. El gesto delicado satisfizo el "patriotismo"1610 de Mínimo.

Otro impreso, disidente de las anteriores opiniones, felicitó sólo al presidente chileno por el mandato diplomático ${ }^{1611}$. En fin, conocido el desenlace del conflicto en la Sociedad de las Naciones, el embajador español, José María Quiñones de León, explicó: "Por una feliz coincidencia ha querido la suerte que la llegada a Chile de dos aviadores españoles [...] permitiese que bajo el pabellón español, y por la vía aérea, haya sido enviado de Santiago a Lima el documento estableciendo el acuerdo tan esperado ${ }^{1612}$.

El azar, auténtico artífice de la misión, quedó sintetizado en el vibrante escrito "Ofrenda suprema": "Por una inexplicada, acaso por ser inexplicable, asociación de ideas, fueron nuestros recuerdos a dar con aquella hermosa, suprema misión, que fue honra y galardón de confianza, que les otorgó el Gobierno de Chile, haciéndoles portavoces del Tratado $[\ldots]^{1613}$.

En Chile y Perú los aviadores tuvieron una actividad social intensa. Sobre la estadía en Santiago, la prensa española ofreció varios detalles de las celebraciones realizadas en su honor. Jiménez e Iglesias también fueron entrevistados por los principales diarios chilenos, donde comentaron los momentos más importantes de la travesía. La prensa chilena dejó innumerables testimonios fotográficos de los españoles.

\footnotetext{
1607 Idem.

${ }^{1608}$ El Imparcial, "El Jesús del Gran Poder, mensajero de paz”, 19 de abril de 1929, p. 5.

${ }^{1609}$ La Lectura Dominical, "Crónica semanal”, 27 de abril de 1929, n. ${ }^{\text {o }} 1$ 843, p. 276.

1610 Idem.

${ }^{1611}$ El Imparcial, "Tacna y Arica”, 3 de mayo de 1929, p. 5.

${ }^{1612}$ La Época, "Hoy se ha tratado de la importante cuestión de las minorías", 13 de junio de 1929, p. 1.

${ }^{1613}$ La Libertad, "Ofrenda suprema”, 13 de junio de 1929, p. 3.
} 
La Iglesia Católica, por su parte, se hizo presente en las ovaciones. Monseñor Errázuriz, arzobispo de Santiago, al finalizar la visita pactada con los aviadores, expresó: "Espero de Dios que cumplirán con éxito todo el raid para la gloria de España y de su Ejército"1614.

Así mismo, en el Casino de Oficiales del Aeródromo Militar "El Bosque", la colonia española, encabezada por el marqués de Berna, representante diplomático en Chile -quien apoyara, en más de una ocasión, a los inmigrantes españoles infaustos ${ }^{1615}$ - les entregó unas insignias de la Aviación Española con la corona real de brillantes. Luego de la ceremonia, una numerosa comitiva los acompañó hasta el Estadio Italiano donde presenciaron un partido de fútbol entre un equipo español y el club deportivo "Santiago".

Jiménez e Iglesias, posteriormente, recibieron los documentos diplomáticos del diferendo Tacno-ariqueño que transportarían hasta Lima. En los diarios se escribió: "Afirmase que un funcionario de la Cancillería ha entregado al ministro de España, señor marqués de Berna, un abultado sobre que contiene los documentos por los que se soluciona el pleito de Tacna y Arica"1616. Las primeras horas de la mañana del 22 de abril despegaron rumbo a Lima. Las descripciones de la prensa española enfatizaron el entusiasmo provocado por la llegada del Jesús del Gran Poder a la frontera. Un numeroso grupo de personas, aposentado en el aeródromo, esperaba la llegada de los aviadores. La Municipalidad había publicado en la prensa el horario de aterrizaje previsto, por lo que al comenzar el descenso fue recibido por cientos de ariqueños con "estentóreos vivas a España"1617.

${ }^{1614}$ El Heraldo, "De Santiago de Chile a Arica", 22 de abril de 1929, p. 11; El Siglo Futuro, "Los aviadores del Jesús del Gran Poder salieron hoy para Arica", 22 de abril de 1929, p. 6; El Imparcial, "El Jesús del Gran Poder en Arica", 23 de abril de 1929, p. 5.

${ }^{1615}$ ESTRADA, Baldomero, "La historia infausta de la inmigración española en Chile a través de los conflictos comerciales y políticos", Historia, vol. 35, 2002, pp. 63-89.

${ }^{1616}$ El Heraldo, "De Santiago de Chile a Arica", 22 de abril de 1929, p. 11; El Siglo Futuro, "Los aviadores del Jesús del Gran Poder salieron hoy para Arica", 22 de abril de 1929, p. 6; La Voz, "Esta mañana salió para Arica", 22 de abril de 1929, p. 12; El Sol, "Jiménez e Iglesias salieron de Santiago de Chile y aterrizaron en Arica", 23 de abril de 1929, p. 7.

${ }^{1617}$ El Imparcial, "El Jesús del Gran Poder en Arica", 23 de abril de 1929, p. 5; El Sol, "Jiménez e Iglesias salieron de Santiago de Chile y aterrizaron en Arica", 23 de abril de 1929, p. 7; La Correspondencia Militar, "El Jesús del Gran Poder ha llegado a Arica", 23 de abril de 1929, p. 6; La Época, "Jiménez e Iglesias parten para Lima", 23 de abril de 1929, p. 4; La Libertad, "Jiménez e Iglesias hacen una nueva etapa", 23 de abril de 
Allí les esperaban el representante de España en el Perú, el cónsul español en Arica y numerosos miembros de la "colonia española, que abrazaron entusiasmados a Jiménez e Iglesias"1618. Los niños de las escuelas agitaban banderas españolas y chilenas, aclamando a los mensajeros de paz. Según El Siglo..., los capitanes Jiménez e Iglesias fueron conducidos, en hombros, por la multitud hasta el Casino Oficial donde se les obsequió con champagne ${ }^{1619}$.

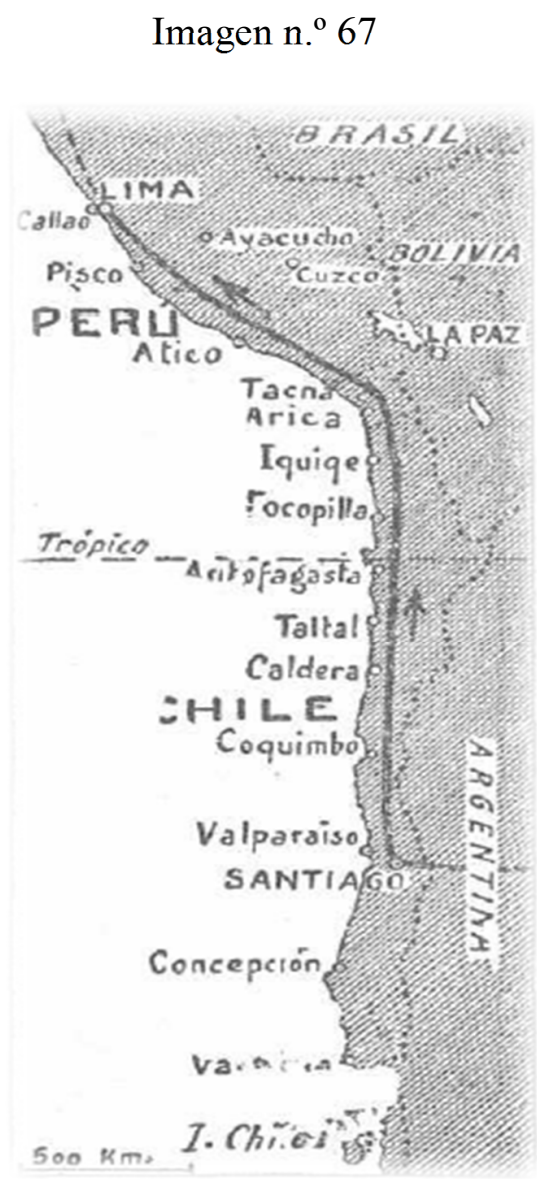

Fuente: La Voz, "De Santiago de Chile a Lima del Perú", 18 de abril de 1929, p. 2.

1929, p. 2; El Sol, "Jiménez e Iglesias aterrizaron ayer felizmente en Lima, donde han sido objeto de emocionante recibimiento", 24 de abril de 1929, p. 1.

${ }^{1618}$ El Heraldo, "El avión español llega a Arica", 23 de abril de 1929, p. 2; El Siglo Futuro, "El Jesús del Gran Poder aterrizó en Arica", 23 de abril de 1929, p. 2; El Sol, "Jiménez e Iglesias salieron de Santiago de Chile y aterrizaron en Arica", 23 de abril de 1929, p. 7; La Correspondencia Militar, "El Jesús del Gran Poder ha llegado a Arica", 23 de abril de 1929, p. 6; La Época, "Jiménez e Iglesias parten para Lima”, 23 de abril de 1929, p. 4; La Libertad, "Jiménez e Iglesias hacen una nueva etapa", 23 de abril de 1929, p. 2.

${ }^{1619}$ El Siglo Futuro, "El Jesús del Gran Poder aterrizó en Arica", 23 de abril de 1929, p. 2; El Imparcial, "Ayer llegaron los aviadores a Lima", 24 de abril de 1929, p. 8; La Correspondencia Militar, "El Jesús del Gran Poder llega a Lima", 24 de abril de 1929, p. 4; La Libertad, "Jiménez e Iglesias volaron ayer desde Arica hasta Lima", 24 de abril de 1929, p. 5. 
La despedida de Arica fue similar al recibimiento ${ }^{1620}$. En el aeródromo se congregó la muchedumbre, encabezada por las autoridades locales y españolas, quienes despidieron a los aviadores aclamando "sin cesar a [...] la madre patria hasta que el avión se perdió en el horizonte"1621. El Siglo... reprodujo los agradecimientos de los aviadores, reforzando las ideas de Chile como un país recio y amante de España: "Llevamos un recuerdo imborrable de Chile. Diremos a nuestro Monarca que en el pueblo del último rincón de la América Española vive una nación progresista y viril que ama grandemente a su madre España"1622.

La prensa limeña, narró la española, anunció el 23 de abril la llegada del Jesús del Gran Poder. La ciudad mostró una actividad fuera de lo normal ${ }^{1623}$. El comercio español cerró más temprano de lo habitual, dirigiéndose sus empleados al aeródromo donde se reunieron más de 40000 personas. Los edificios públicos y particulares izaron banderas españolas y peruanas. El alcalde dedicó emotivas palabras a España. Tal sentimiento no menguó en los relatos impresos en ese país:

A las 14.45 dibujase en el espacio un punto apenas visible. Un sordo murmullo de la muchedumbre acogió la aparición de los españoles, mensajeros del presidente de Chile. A medida que el aparato se aproximaba iba en aumento la expectación, y cuando apareció sobre el aeródromo estalló una ovación inmensa. Los vivas a la madre España, a los aviadores españoles y al rey Alfonso se sucedían sin interrupción. A las 14.25 en punto (hora local), después de volar sobre la ciudad y el aeródromo, tomó tierra el Jesús del Gran Poder, en medio de un entusiasmo que rayó en verdadera locura. La masa arroyó a las fuerzas que la contenía y rodeó a los aviadores sin dejarlos apenas saltar del avión. Después de ser saludados los capitanes Jiménez e Iglesias por el Gobierno y el Alcalde, quienes les dieron la bienvenida y los declararon huéspedes oficiales y predilectos, el ministro de España y el cónsul les dieron un abrazo. En estos momentos en un automóvil con el Alcalde, dispónense (sic) los aviadores a partir para la población. Los vivas son incesantes. Muchas mujeres lloran de emoción ${ }^{1624}$.

\footnotetext{
${ }^{1620}$ La Voz, "El Jesús del Gran Poder", 23 de abril de 1929, p. 3.

${ }^{1621}$ El Heraldo, "El avión español llega a Arica", 23 de abril de 1929, p. 2.

${ }^{1622}$ El Siglo Futuro, "Entusiasta recibimiento en Lima a los aviadores del Jesús del Gran Poder", 24 de abril de 1929 , p. 2.

${ }^{1623}$ LÓPEZ MARTíneZ, Héctor, El siglo XX en el Perú a través de El Comercio, Lima, Ediciones El Comercio, 1994 , p. 330.

${ }^{1624}$ El Imparcial, “Ayer llegaron los aviadores a Lima”, 24 de abril de 1929, p. 8; El Siglo Futuro, "Entusiasta recibimiento en Lima a los aviadores del Jesús del Gran Poder", 24 de abril de 1929, p. 2; El Sol, "Jiménez e Iglesias aterrizaron ayer felizmente en Lima, donde han sido objeto de emocionante recibimiento", 24 de abril de 1929, p. 1; La Correspondencia Militar, "El Jesús del Gran Poder llega a Lima", 24 de abril de 1929, p. 4; La Libertad, "Jiménez e Iglesias volaron ayer desde Arica hasta Lima", 24 de abril de 1929, p. 5; La Voz, "Los aviadores españoles han aterrizado felizmente en Lima", 24 de abril de 1929, p. 3.
} 
El sentimiento popular hacia España era compartido por el "prosopopéyico"1625 Augusto Leguía ${ }^{1626}$. Según El Heraldo, éste tenía el tratado en sus manos, información contradicha por el mismo diario al día siguiente ${ }^{1627}$. Leguía recibió a los aviadores en la Casa de Pizarro, felicitándolos por la proeza realizada en honor de España.

Durante el diálogo, el presidente se refirió a la hermandad que debe existir entre Chile y Perú "hijas de la madre España"1628. Palabras similares tuvo el plenipotenciario chileno en Lima, Emiliano Figueroa Larraín, quien les expresó “cuanto era su agrado de que fueran manos españolas las portadoras de los documentos que representan una gestión fecunda para la unión de Chile y Perú"1629.

Las celebraciones limeñas fueron similares a las santiaguinas. La prensa comentó cada uno de los movimientos, desde las visitas al Country Club, Círculo Militar y Catedral de San Pedro, donde los jesuitas, en su mayoría españoles ${ }^{1630}$, celebraron misa compartiendo un "vino español"1631. Los religiosos habían fundado en esa ciudad, entre otras instituciones, un centro de empleadas domésticas, un pensionado, un colegio diurno y una escuela nocturna ${ }^{1632}$. Aérea aseguró que en Lima, ciudad similar a "Córdoba o Sevilla,

\footnotetext{
1625 GUERRERo BARÓN, Javier, El proceso político de las derechas en Colombia y los imaginarios sobre las guerras internacionales 1930-1945. La guerra con el Perú, la guerra civil española y la Segunda Guerra Mundial, el ascenso del fascismo y la construcción del discurso del odio, Tunja, Editorial UPTC, 2014, p. 90. ${ }^{1626}$ Para revisar interesantes estudios sobre las relaciones estatales entre España y Perú durante el gobierno de Augusto Leguía ver: MARTíNEZ RIAZA, Ascensión, "Las buenas relaciones de dos regímenes autoritarios. El Perú y España durante el Oncenio (1919-1930)". En GARCÍA JORDÁn, P., IZARD, M. y LAVIÑA, J. (coords.), Memoria, Creación e Historia: luchar contra el olvido, Barcelona, Publicacions Universitat Barcelona, 1994a, pp. 273-291; MARTíNEZ RiAZA, Ascensión, "El Perú y España durante el Oncenio. El hispanismo en el discurso oficial y las manifestaciones simbólicas (1919-1930)", Histórica, A. XVIII, 2, 1994b, pp. 335-363; MARTínez RiAZA, Ascensión, En el Perú y al servicio de España. La trayectoria del cónsul Antonio Pinilla Rambaud 1918-1939, Lima, Instituto Riva Agüero, 2008.

${ }^{1627}$ El Heraldo, "La entrega del protocolo de Tacna y Arica", 24 de abril de 1929, p. 11; El Heraldo, "El punto terminal del crucero aéreo será La Habana", 25 de abril de 1929, p. 11; El Imparcial, "Los aviadores españoles en Lima", 25 de abril de 1929, p. 8; La Libertad, "La entrega de los documentos de Tacna y Arica", 26 de abril de 1929, p. 6; La Correspondencia Militar, "El vuelo del Jesús del Gran Poder", 26 de abril de 1929 , p. 2.

${ }^{1628}$ El Siglo Futuro, "Entusiasta recibimiento en Lima a los aviadores del Jesús del Gran Poder", 24 de abril de 1929, p. 2.

${ }^{1629}$ El Heraldo, "El punto terminal del crucero aéreo será La Habana", 25 de abril de 1929, p.11; La Libertad, "La entrega de los documentos de Tacna y Arica", 26 de abril de 1929, p. 6.

${ }^{1630}$ El Imparcial, "Los aviadores españoles en Lima”, 26 de abril de 1929, p. 5.

${ }^{1631}$ Idem; La Correspondencia Militar, "El vuelo del Jesús del Gran Poder", 26 de abril de 1929, p. 2.

1632 KlAiber, Jeffrey, La Iglesia en el Perú. Su historia social desde la independencia, Lima, Pontificia Universidad Católica del Perú. Fondo Editorial, 1996, p. 186.
} 
donde las mujeres llevan la clásica mantilla prendida con la gracia y gentileza de una macarena" 1633 se llegó "al sumun, a lo apoteósico"1634 del recorrido.

Jiménez e Iglesias retornaron a España por mar. El crucero Almirante Cervera ancló en Cádiz el 7 de junio de $1929^{1635}$. Los aviadores fueron recibidos como héroes. Diarios y revistas tipografiaron ese sentir ${ }^{1636}$. En las primeras entrevistas comentaron la satisfacción producida al portar el tratado chileno-peruano. Algunas publicaciones mencionaban la hazaña que supuso recorrer 18285 kilómetros sin que las ruedas del avión necesitasen más aire que el inyectado en Sevilla ${ }^{1637}$. Al aeródromo de esa ciudad concurrieron más de ocho mil personas, de acuerdo a $\mathrm{El} \mathrm{Sol}$, ovacionando a los aviadores que, como en Arica y otras ciudades americanas, fueron paseados a hombros. Días después, los "héroes"1638 recibieron la Medalla Aérea de una ceremonia oficiada en el Paseo de Coches del Retiro ${ }^{1639}$ y participaron de una cena organizada por el ministro chileno en España, Emilio Rodríguez Mendoza, para celebrar la finalización del conflicto chileno-peruano ${ }^{1640}$. En esa ocasión, el general Primo de Rivera enfatizó la importancia de que el Jesús del Gran Poder "haya sido portador de preciosos documentos que han contribuido a la firma del acuerdo"1641, palabras que repitió al mes siguiente cuando en la embajada chilena recibiera la insignia de la Gran Cruz del Mérito ${ }^{1642}$.

Heroísmos aparte, una sección pragmática de la prensa hispanoamericanista reflexionó sobre las enseñanzas adquiridas luego del vuelo americano del biplano. La más importante, sin duda, era concienciar a la diplomacia española de su papel mediador entre

1633 Aérea, "El vuelo triunfal del Jesús del Gran Poder sobre el Atlántico y las repúblicas hispanoamericanas", julio de 1929, n. $^{\circ} 72$, p. 8.

${ }^{1634}$ Idem.

${ }^{1635}$ SALAS, Nicolás, Sevilla, Anales del siglo XX, tomo I, Sevilla, Editorial Castillejo, 1999, p. 356.

${ }^{1636}$ La Voz, "Jiménez e Iglesias han llegado esta mañana a Sevilla", 8 de junio de 1929, p. 3; El Sol, "Los tripulantes pasaron el día de ayer en Sevilla y hoy llegarán a Madrid”, 9 de junio de 1929, p. 6; La Correspondencia Militar, "El Jesús del Gran Poder que fue ayer en vuelo de Cádiz a Sevilla, llegará hoy a Madrid", 9 de junio de 1929, p. 4.

${ }^{1637}$ La Libertad, "Sevilla dispensa un entusiasta recibimiento a los tripulantes del Jesús del gran Poder", 9 de junio de 1929, p. 6.

${ }^{1638}$ La Lectura Dominical, "Crónica semanal”, 26 de junio de 1929, n. ${ }^{\circ} 1$ 848, p. 3.

${ }^{1639}$ El Imparcial, “Cómo ganó la laureada el Sargento García”, 14 de junio de 1929, p. 1.

${ }^{1640}$ El Sol, "En Madrid”, 18 de junio de 1929, p. 7.

${ }^{1641}$ La Correspondencia Militar, "Terminada la reunión de la Sociedad de Naciones en Madrid, regresan a sus países los delegados", 18 de junio de 1929, p. 1.

${ }^{1642}$ El Imparcial, "Imposición de insignias al Marqués de Estella”, 16 de julio de 1929, p. 8; El Siglo Futuro, "Imposición de insignias al Marqués de Estella", 16 de julio de 1929, p. 2; La Época, "Imposición de una condecoración al presidente del Consejo", 16 de julio de 1929, p. 2. 
repúblicas con diferendos vigentes en la "América Española". A pesar de esa elite hispanoamericanista o, puntualmente, de los críticos hacia los métodos de acercamiento entre "madre" e "hijas", el pragmatismo racional se desvanecía en palabras emocionantes y metafóricas infravaloradas en los liquidadores del diferendo chileno-peruano.

Una revista extractó el principal saber que dejaba para España los vuelos del Jesús del Gran Poder:

Pero lo más trascendental de la visita de nuestros compatriotas a Chile, lo que debe señalar con el refulgente hito el rumbo de nuestras relaciones con las Repúblicas americanas de nuestra raza, es el hecho honroso de haber depositado en sus manos viriles los documentos diplomáticos que contienen la solución del enojoso y antiguo pleito sobre la posesión de Tacna y Arica entre Chile y Perú. [...] El Jesús del Gran Poder no ha tenido durante su ruta momentos de más gloria que aquellos en que, alzando el vuelo en Chile, tendió majestuoso un puente de amor entre esta nación y Perú, la España andaluza, rediviva y nostálgica, que en tierras americanas aún recuerda y mantiene la tradición del viejo solar ${ }^{1643}$.

1643 Aérea, "El vuelo triunfal del Jesús del Gran Poder sobre el Atlántico y las repúblicas hispanoamericanas", julio de 1929, n. ${ }^{\text {7 } 72, ~ p . ~} 8$. 


\section{CONCLUSIONES}

Entre 1880 y 1929 Chile y Perú vivieron el proceso y los traumas posteriores derivados de la Guerra del Pacífico, uno de los episodios bélicos más importantes de la historia contemporánea de América. Sin lugar a dudas, el nacionalismo de ambos países estuvo determinado por esa etapa histórica donde el fundamento de la discordia se centró en el conflicto de Tacna y Arica, que interesó a gran parte de Occidente. En España, la guerra y la posguerra se conocieron gracias a la prensa, que tuvo una posición discursivamente activa en un diferendo entre Estados que, a su juicio, compartían vínculos culturales poderosos con la "Madre patria". Chile y Perú experimentaban, desde sus ethos, el acoplamiento a la "era de los nacionalismos".

En esos países, el peso ideológico de los nacionalismos quedó demostrado en nuestro intento de contextualización de la litis. Tal constatación nos hizo cuestionar el uso sencillo que actualmente se viene realizando en la historiografía del "contexto histórico". Antes de presenciar su desaparición de la constelación que constituye el lenguaje formal de nuestra disciplina, propusimos, aún cuando no era el objetivo del estudio, repensar su uso y modelar alguna forma escrita para situar el(los) hecho(s) investigado(s). Para ello nos valimos de la excelsa producción chilena y peruana que, desde 1880 hasta la actualidad, se ha referido al diferendo, valiéndose -no podía ser de otro modo- de una mirada maniquea, moralista e intolerante hacia las "razones" histórico-sociológicas de sus contrarios. Autores chilenos y peruanos, por igual, continuaron la guerra disparando palabras desde sus burós.

La consistencia de los nacionalismos chileno-peruano durante el cambio del siglo XIX al XX hizo pertinente plantearnos como objetivo general de la investigación el análisis de las representaciones sociales elaboradas, impresas y socializadas por la prensa española durante el periodo 1880-1929 respecto al conflicto de Tacna y Arica, como también hacia los Estados involucrados, directa e indirectamente en él. El número de países que rotaron como satélites en torno al diferendo territorial no fue menor: Chile, Perú, Bolivia, Argentina, Estados Unidos y España. Si bien otros Estados tuvieron una participación importante, tal es el caso de Inglaterra o Brasil, en la prensa española analizada, sólo los señalados tuvieron un papel vigoroso y destacado por ese medio. 
Preguntarse por las representaciones sociales fabricadas por la prensa española nos llevó, en primer lugar, a delimitar desde qué campo de esta ciencia se desarrollaría la investigación. Como se apuntó en el apartado teórico, la historia cultural y sus planteamientos conceptuales, elaborados por los seguidores críticos de Peter Burke, ocupados por comprender qué, cómo y por qué una comunidad piensa su entorno físico o social de tal modo y no de otro, desplazó a otras líneas desde donde también se pudo partir. Las concepciones guías de la historia política, social o económica, se centrarían en otras dimensiones de la prensa, tales como los grupos de poder político presentes en sus páginas; las condiciones laborales de los operarios de las empresas periodísticas; las inversiones, ganancias o pérdidas de esas mismas, por mencionar algunas posibilidades.

Las representaciones sociales, abstracción teórica fundamental para acceder a las formas de pensamiento social, han intentado ser definidas de variadas maneras. No se debe olvidar que desde los estudios pioneros de Moscovici hasta la actualidad el aparato crítico aportado por especialistas de diversas áreas de las ciencias sociales ha aumentado. Sin embargo, superaba los límites de nuestra investigación realizar aportes teóricos desde, por ejemplo, la historia teórica o la historia conceptual. Para salvar esa dificultad, no obstante, seleccionamos cinco definiciones de representaciones sociales que poseen gran aceptación en los staff de investigadores y que desde ellas analizan la realidad (construida) que los rodea, desde el presente, o influye desde el pasado.

Los capítulos que contienen los argumentos históricos, así como las pruebas hemerográficas que demuestran la trama de la construcción de representaciones sobre el conflicto en España, son compatibles con las definiciones mencionadas. Veamos una por una. Parece difícil no estar de acuerdo con Jodelet y Guerrero en que las informaciones y opiniones publicadas por la prensa parten de una "percepción" del conflicto, que son “construidas" en las industrias periodísticas y que, en conjunto, facilitan al público una "teoría ingenua” o sencilla para leer la realidad local o extranjera. Así mismo las evidencias presentadas demuestran que la larga duración del diferendo y su cobertura noticiosa hicieron posible en los editores y probablemente en los lectores una "interpretación del curso de los acontecimientos". 
Más claramente, continuando con ambos teóricos, la investigación desarrollada deja establecido cómo la prensa española planteó un tipo de relación con las repúblicas enfrentadas en el diferendo. Esa tensión de identidades nacionales, donde la tradición y la ética estatal tuvieron gran relevancia, puede comprenderse como una expresión de la relación entre "grupos" distantes puestos en comunicación por sus culturas diferentes o, en última instancia, por su "otredad". Sin duda, esa comunicación, por los condicionantes tecnológicos del tiempo estudiado, difícilmente hubieses tenido otra forma de poner en contacto a emisores y receptores. En efecto, fueron los discursos periodísticos circulantes por el "espacio público", inscritos en el lenguaje y los símbolos, los que codificaron y categorizaron esa parcela mínima de lo que Jodelet y Guerrero llamaron "universo de la vida".

Comprender en España la posguerra chileno-peruana provocada, principalmente por la indefinición de la frontera entre esos países, pudo ser complicado. Los escasos kilómetros compartidos, de este a oeste, en ese confín no tienen punto de comparación con las, seguramente, mayores longitudes de papel gastado para opinar y defender las causas nacionalistas de La Moneda y la Casa de Pizarro. Los argumentos, como suele ocurrir en el nacionalismo, fueron más emotivos que científicos. Por ello, como apuntó Abric, las representaciones sociales insertas en la comunicación deben tener una "visión funcional", entendiendo por esta última palabra lo útil, cómodo y de fácil acceso. Pues sólo en esa sencillez explicativa pueden otorgar a los sujetos un sentido y entendimiento de la "realidad" por medio de un "sistema referencial". Es altamente probable que éste se basara en la diferenciación, distancia y negación, por parte de la prensa, de los procedimientos diplomáticos entre Chile y Perú. Las semejanzas de las culturas políticas de esos países con España debían minimizarse. No eran modelos adecuados de organización estatal.

Cobra sentido, entonces, el reforzamiento de la diferenciación elaborado por la prensa, fabricando un "sistema cognitivo", en palabras de Araya, compuesto por estereotipos (Chile bárbaro, Perú exótico, Latinoamérica incivilizada), por opiniones (las de Pío Ballesteros, Camilo Barcia, Ricardo Beltrán y Fabián Vidal, por ejemplo), por valores y normas. Esas estrategias periodísticas, una vez activadas tuvieron efectos en la propia prensa que miró la litis orientándose hacia un plano moral binario: positivo o negativo. 
La obra realizada por la prensa española, presentada como un cuadro compuesto por trazos gruesos de representaciones sociales referidas al conflicto, no se hizo de la noche a la mañana. Desde 1880 hasta 1929 trascurrió cerca de medio siglo, tiempo suficiente para que las representaciones madurasen desde su nacimiento sangriento, como ideas superficiales y pasajeras, hacia imágenes mentales de mayor peso y trascendencia. La reiteración mensual, o incluso anual de comunicados en torno al conflicto de Tacna y Arica, permitió lo que Wagner y Hayes denominaron "estructuración" de la imagen. Creemos que, con esa concepción, lo que quieren expresar es una diferencia con los pensamientos sencillos, carentes de afectos, evolución, metáforas e iconos, estas últimas, por el contrario, características constitutivas de las representaciones sociales provocadas por "fenómenos socialmente relevantes".

No es aventurado asegurar que la Guerra del Pacífico suscitó gran atracción en la prensa española. Las razones se encontraron en su interés por el devenir político de los antiguos territorios ultramarinos; en el ideal burgués constructor del hombre político informado y culto, no sólo de lo ocurrido dentro los márgenes estrechos del Estado; en la alta demanda de noticias por parte de los españoles con familiares en los territorios de la guerra; o, por último, en el propio espíritu de la prensa española de esos años que iniciaba el difícil camino de retratar los hechos exteriores desde los parámetros objetivistas de la "verdad". La relevancia de la guerra, sin duda, tuvo su continuidad durante la posguerra, cuando el riesgo de un nuevo enfrentamiento, como un cáncer nacionalista, se expandió entre los Estados partícipes. Cada traspié en la cura era detenidamente diagnosticado desde Madrid y Barcelona. También se profetizó el futuro, a corto y lejano plazo, de la enfermedad.

Banchs, Agudo y Astorga, por último, han demostrado cómo las representaciones sociales se ubican entre la dimensión psicológica y la dimensión social. Esta aseveración es de suma importancia para comprender la producción de representaciones relativas al conflicto. Al comenzar la guerra, es probable que la telegrafía recibida en los diarios y revistas haya formado en los escritores una opinión sobre los contendientes. Su papel fue fundamental en la masificación de sus interpretaciones por España y posteriormente sirvió de base a las futuras generaciones de redactores. 
El ejemplo sirve para comprender la ubicación de las representaciones sociales que hemos estudiado. El esquema no es mecánico, es decir, no concluye la dimensión psicológica en el momento en que otros escritores toman las ideas, más o menos originales, de los autores primarios. En el largo desarrollo del conflicto aparecieron otros escritores que renovaron algunas miradas hacia los países deliberantes. No se debe olvidar el paso lento, pero evidente, del prejuicio del barbarismo chileno, en los años ochenta, hacia la representación del mismo como un Estado moderno que destacó entre los vecinos de Sudamérica. La conexión psicológica-social, por último, se puede hacer más compleja, puesto que en la elaboración de las representaciones sociales de nuestro interés el papel de acontecimientos fronterizos o diplomáticos de otros lugares del mundo pudieran ejercer una influencia en la concepción que se tenía del primero.

Lo que parece seguro, siguiendo a Banchs, Agudo y Astorga, es que las representaciones tienen un papel significativo en la construcción de la realidad. Esa construcción es "social", puesto que, por el contrario, un pensamiento complejo estéticamente que habita una sola mente, alejado de todo contacto con el exterior, es estéril en la práctica social y no rompe los límites de su biología. Nuevamente la larga duración del conflicto permite comprender como funcionó en el discurso periodístico español la construcción de, en rigor, seis realidades de identidad. Esas realidades -la "identidad" del conflicto más las identidades nacionales de los países involucrados en el diferendo- fueron, poco a poco, asumiendo un carácter "naturalizado", es decir, asumiendo como infalibles y veraces las características esenciales que, no obstante, había fabricado la prensa. Este hecho puede comprenderse mejor al analizar la construcción de representaciones y naturalizaciones del conflicto con metodologías de historia comparada. Los resultados de un estudio de prensa española, chilena y peruana, por ejemplo, demostrarían cuan poderoso es el papel periodístico en la sustentación del nacionalismo y la creación de la alteridad.

Si construir un segmento de la "realidad" por medio de representaciones, teniendo, además, el favor del tiempo, conlleva la naturalización de éstas, es lógico que el criticismo ausente las transforme en una "epistemología del sentido común". A diferencia de una epistemología filosófica, el conocimiento de sentido común no se preguntaría por el aparato teórico, conceptual, formal, ni metodológico que produjo ese saber. 
Es por ese motivo que nuestra investigación se separó de una historia cultural enfocada en la "alta cultura". De no hacerlo, nuestro interés hubiese estado en el análisis del discurso de los periodistas e intelectuales españoles que dedicaron reflexiones al devenir del conflicto chileno-peruano. Al mismo tiempo, hubiésemos desechado centenares de noticias sin autoría que aparecieron, constantemente, en la prensa con un carácter breve y con un mínimum de opiniones. No obstante, convencidos de que la búsqueda de representaciones sociales, por la amplitud del concepto, debe rastrearse por diversos aparatos de lenguaje, comprendimos que las noticias "objetivistas" tenían una importancia modeladora al constituir los datos sólidos del conflicto. Nos referimos a los lugares del conflicto (Tacna, Arica, Tarapacá, Santiago, Lima, Washington, etc.), al tiempo (cada fecha asignada a las noticias), a los sujetos (Nicolás de Piérola, Manuel Baquedano, Guillermo Billinghurst, Arturo Alessandri, Augusto Leguía, etc.) y a los Estados en conflicto (Chile, Perú, Bolivia, etc.). Sin esa triangulación espacial-temporal-humana, los hechos del problema del Pacífico quedaban sujetos a una libertad de existencia no buscada, creemos, por quienes trabajaron para informar de América en España.

Por otro lado, los seis objetivos específicos de la investigación intentaron alcanzarse, con exactitud desde el capítulo tercero. Allí se explicó, en los apartados "consideraciones heurísticas", "fuentes", "muestra" y "análisis de contenido", las principales características de los documentos históricos que sustentaron los argumentos para validar la hipótesis. El primer objetivo, de carácter "selectivo", se materializó con la búsqueda, extracción y clasificación de las noticias relacionadas con el conflicto y con las identidades nacionales de los países implicados. El proceso de clasificación intentó demostrar la separación superficial entre noticias informativas y de opinión, pues, como apuntamos anteriormente, ambas formas de producir el texto, ayudaron en la construcción de representaciones periodísticas. El proceso comentado permitió, además, demostrar la validez del uso de noticias extranjeras en investigaciones histórico-culturales interesadas en descubrir las formas de producción de alteridades de orden nacional.

Nuestro segundo objetivo pretendía la "individualización” del discurso periodístico español sobre Tacna y Arica. Para ello debía ceñirse con rigor a las noticias publicadas por la prensa para comunicar la guerra y la posguerra. 
La especificidad del discurso periodístico favoreció la elaboración de todos los acontecimientos considerados en los capítulos cuatro a siete. En ellos se demostró, nuevamente, el gran interés que produjo el conflicto en la industria de la prensa, pero también la fortaleza que cada uno de esos acontecimientos tuvo para consolidar la atención que tendrían los sucesivos. El proceso de individualización o especificidad del discurso de la prensa requiere una aclaración más. Su continuidad y profundidad, en vez de ser matizado con otros eventos políticos o, en vez de desaparecer, se extendió temporalmente y cavó en las páginas periodísticas. De hecho, al revisar las fuentes constatamos que "Tacna y Arica" surge como un conflicto titulado por los diarios con referencias a Chile, Perú o América. Sin embargo, el paso del siglo XIX al XX testimonió el nacimiento de una entidad propia y bien diferenciada ("Tacna y Arica"), independiente de otras denominaciones.

La intuición a priori de aquello exigía establecer un tercer objetivo "comparativo". Su planteamiento se debió a nuestras sospechas iniciales sobre una posible heterogeneidad de miradas mantenida por la prensa al publicar noticias de la frontera. Tal sospecha nos permitió dudar de la efectividad lingüística que tendría señalar el estudio de la "prensa", en singular, y no de las "prensas" en plural. Estábamos convencidos de la importancia que tuvo el conflicto en España, pero parecía lógico que su existencia y ubicación lejana no provocaría un debate "nacional".

Los escritores españoles ocupados del diferendo no lograron diversificar las opiniones sobre la litis y los países contendientes y, en consecuencia, la mayoría de las publicaciones mantuvo una posición unánime que dinamizó un grupo consistente de representaciones sociales. Las repercusiones políticas que la disputa entre Chile y el Perú podían tener en España, salvo las derivadas de la firma de protocolo Billinghurst-Latorre en 1898, eran mínimas.

Esto hizo que las etapas anteriores y posteriores a ese momento diplomático propusieran, con tibieza, una mayor injerencia de la debilitada diplomacia española y que el retorno de la influencia política y económica quedase más bien en el plano de las ideas. La era de las naciones, referida al principio, filtraba en la prensa con meridiana claridad cuáles eran los hechos que requerían de acción política o de mayor locuacidad. 
Es decir, las comparaciones de las noticias que forman los capítulos históricos de la investigación al no sugerir distintos ángulos del conflicto, reforzaron las nociones estereotipadas del mismo. Por usar un lenguaje actual, el "pluralismo" de opiniones sobre los hechos de la frontera chileno-peruana, fue prácticamente inexistente. El ejercicio comparativo en vez de ofrecer antítesis o terceras vías para entender la guerra y posguerra, otorgó más solidez a las ideas publicadas por la prensa al comienzo del conflicto.

Por esta razón estructuramos las pruebas documentales en etapas representacionales. El objetivo cuarto, de corte "sustancial", marcó cuatro fases con fechas relevantes en la historia del conflicto (la guerra, el arbitraje español, su caída y el Tratado de Lima). Esa decisión permitió comprender la visión periodística más bien uniforme hacia el diferendo, puesto que de otro modo la estructura argumental hubiese considerado sólo los contrastes interpretativos periodísticos. El primer mecanismo triunfó frente al segundo, porque, además, los hechos históricos escogidos intensificaron la producción noticiosa.

El punto interpretativo constituyó el objetivo quinto. Las ideas surgidas de la lectura de prensa, así como de la misma explicación escrita del porqué de la inclinación de la prensa hacia el diferendo y su función constructiva de identidades alógenas, maduró debido al peso cuantitativo (cantidad de unidades de análisis) y cualitativo (discurso) de la muestra. Cabe señalar que la hermenéutica histórica no se efectuó desde el aislamiento de las fuentes, sino más bien desde el apoyo crítico en la literatura científica, principalmente española, centrada en aspectos eludidos por nosotros. Ese saber evidenció un abandono, comprensible, del papel de la prensa como constructor de la nación española por alteridad.

Los objetivos específicos, desde el primero hasta el último, tuvieron la intención de contrarrestar los escollos teóricos de las representaciones sociales instituyendo imágenes mentales limitadas, pero de gran definición y potencial histórico explicativo. En consecuencia, el objetivo específico sexto se propuso definir, primero, las características propias o singularidades del conflicto de Tacna y Arica y, segundo, las identidades nacionales fabricadas por la prensa de los Estados comprometidos en aquel. A continuación explicaremos esos aspectos centrales, comenzando por los siete atributos que singularizaron, en nuestra opinión, el conflicto chileno-peruano: alógeno, económico, de espejo, desestabilizador, hermético, estatista y laberíntico. 
Atributo "alógeno": Para la prensa el conflicto ocurría, como era lógico, en un espacio "extranjero", allende de sus fronteras nacionales. Eso no imposibilitó, sin embargo, su consideración por él, produciendo conocimientos respecto a los rumbos diplomáticos que tomaba. Comenzando el siglo pasado ese atributo adquirió mayor importancia, porque el diferendo provocaba gran interés en los Estados Unidos, potencia que anhelaba una hegemonía político-económica en la "América Hispana".

Atributo "económico": La prensa entendió que la cuestión fronteriza era un conflicto político, interestatal y diplomático, pero de base esencialmente económica. No se equivocó. La guerra tuvo causas económicas (recursos naturales: salitre, guano y otros minerales), donde las riquezas del Atacama boliviano y el Tarapacá peruano fueron conquistadas por Chile, por las armas y luego con tratados de paz en 1883 con Perú y 1904 con Bolivia.

Atributo del "espejo" (de la desinteligencia de los litigantes): El largo diferendo reflejó la necedad de los diplomáticos chilenos y peruanos encargados de su solución. Ambos países, con otros problemas internos -la guerra civil de 1891 o el golpe de Estado de 1924 en Chile; el golpe de Estado de 1914 o las purgas del "leguiísmo" durante los años veinte, por nombrar cuatro de los funestos episodios políticos de esos países- evidenciaban el cretinismo de sus conductores republicanos y la "infancia" de sus modelos de gobernanza. De La Moneda y la Casa de Pizarro se alejaban las fórmulas políticas adecuadas para pasar del caos a la modernidad. Los esfuerzos de las clases dirigentes chocaban contra las bases humanas, étnica, lingüística e históricamente heterogéneas. Centrándonos en la provincia de Tacna y Arica, después de 1880 y durante su chilenización, la población estuvo conformada por grupos étnicos variados (aymaras, afrodescendientes, mestizos y blancos); la lengua española para comunicarse y comprender el mundo se usaba mayormente por las dos últimas categorías. Cada grupo, unos con más claridad que otros, sabía del pasado remoto y reciente por medio de la oralidad o la historia oficial. Estas particularidades fueron obviadas por aquellos gobiernos que, obsesionados por sus intenciones de nacionalizar o recuperar el territorio, nublaron el diálogo escogiendo un vocabulario propio del paradigma del Estado-Nación decimonónico. Los resultados de esa praxis fueron las noticias que la telegrafía española recibió de Chile y el Perú. 
Atributo "desestabilizador": Para los diarios y revistas, las provincias de Tacna y Arica constituyeron, después de la guerra, un hot spot bélico en América. Las desinteligencias diplomáticas aludidas tenían una consecuencia lógica: la probabilidad de una nueva guerra chileno-peruano-boliviana. De ocurrir, obstaculizaría el paso cansino de esas naciones hacia el progreso que, como se vio, se militarizaban con el aplauso de sus líderes políticos y pueblos, a expensas de otras áreas de "engrandecimiento nacional". Un problema derivado de la situación anterior era que las alianzas militares ahora convocarían a la mayoría de los Estados sudamericanos. Eso ayuda a comprender la preocupación demostrada por la prensa cuando se activaron, en variadas oportunidades, las alarmas de guerra al otro lado del Atlántico.

Atributo "hermético": Vista desde España, la localización en terra incognita de Tacna y Arica, región por la cual Chile y Perú desde 1880 iniciaron sus diferencias, había tenido gran importancia y menos hermetismo en la época española. La centralidad de Arica en los tiempos áureos de Potosí no era más que pasado. Por eso, siglos después, iniciada la Guerra del Pacífico, fue prioritario describir periodísticamente los rasgos fundamentales del territorio litigioso. Así dieron cuenta varias noticias publicadas en España que pusieron en manos de los lectores, mediante palabras, imágenes de grabados o fotografías, el territorio donde se sustentó el conflicto. Montañas, desiertos, escasez de agua, altas temperaturas, ausencia de vegetación, entre otras características, definieron un paisaje natural árido que servía como telón de fondo al conflicto diplomático.

Atributo "estatista" (en la conducción del conflicto): Desde la participación de Tacna y Arica en la guerra, pasando por las Conferencias de Arica y el establecimiento de la comisión plebiscitaria, hasta el Tratado de Lima, la prensa consideró preferentemente a los hombres de Estado. Generales, coroneles, capitanes, presidentes, cancilleres y diplomáticos sirvieron para explicar el conflicto. La soldadesca fue olvidada por las agencias telegráficas, pero también por las empresas periodísticas que infravaloraron su importancia. Las bajas mortales fueron, a lo sumo, mencionadas en cifras. Ese desprecio demuestra una vocación "estatista" de la prensa y, en consecuencia, una tendencia “antipopular", es decir, el desinterés por la gente común y corriente que participó en la guerra y la posguerra. 
Personalidades como Baquedano, Thompson y Lynch, Montt, Alessandri e Ibáñez, por mencionar algunos nombres chilenos; Bolognesi, Piérola, Montero, Bermúdez, Ordoñez y Leguía, entre los personajes públicos peruanos, "humanizaron" la pugna. La prensa olvidó que en los casos de Chile y Perú la construcción nacional, si bien había sido una obra de las elites políticas "encapsuladas", había triunfado debido a la participación activa de la plebe. Los contingentes consumidores de las ideologías elaboradas "desde arriba" hicieron posible los fenómenos sociales de la "chilenidad" o la "peruanidad". Tal cuestión careció de importancia para una prensa, en general, burguesa que veía en los grandes hombres los artífices de la historia.

Atributo "laberíntico": Un conflicto que bordeó el medio siglo no podía carecer de complejidad y aumento de las variables explicativas para comprender su origen, desarrollo y devenir. La prensa fue consciente de ese rasgo. En el origen, la imagen de la litis pudo tener mínimas incorrecciones, pues se trataba de una disputa regional entre dos Estados. Uno con mayor interés geopolítico, Chile, y otro con un interés económico-sentimental, Perú. Sin embargo, ese "mecanicismo" explicativo daría paso a otra etapa que derribaba el simplismo de las causas y efectos producidos por los estímulos diplomáticos. Denominamos este atributo "laberíntico", porque al adjetivarlo así queremos subrayar la dificultad creciente, finalizada la guerra, para comprenderlo. Ello guardó relación con el hecho de que las negociaciones para solucionarlo estuvieran en las cancillerías de Chile y Perú, pero también en las de terceras potencias. La prensa publicó informaciones sugestivas al cumplirse una década de la administración chilena, comentando las razones que permitieron posponer el plebiscito. A ello se sumó, con posterioridad, el arbitraje español y el tratado chileno-boliviano, entre otros acaecimientos. Las relaciones chileno-peruanas, en paralelo, experimentaban tensiones y distensiones, apareciendo actores nuevos, resultando de todo lo anterior un cuadro deforme y anárquico donde parecía difícil dar con la salida.

La conjunción de esos atributos modeló las representaciones sociales que la prensa construyó hacia las identidades nacionales de los Estados Unidos, España, Bolivia, Perú y Chile y que, en el mismo orden, definimos a continuación. Interesa recordar que cada rasgo de esas identidades es producido por su relación directa con la cuestión de Tacna y Arica. 
a) Representaciones sobre los Estados Unidos. País que desde las Conferencias de Arica, realizadas durante la Guerra del Pacífico, tuvo una participación diplomática relevante en las relaciones chileno-peruanas. Por entonces, sus "buenos oficios" no causaron sospechas de una conducta imperialista, pues se prefirió su mediación antes que el aumento de la influencia militar chilena en Sudamérica. No obstante, una parte de la prensa alertó de las intenciones encubiertas de la Doctrina Monroe. Esta última imagen experimentó, a partir de los años noventa, una definición debido al supuesto anhelo de ese país por conseguir beneficios territoriales de los países litigantes y, también, por el comportamiento "antiespañol" de la prensa estadounidense que deseaba eliminar cualquier rastro de influencias hispanas de América.

La distancia ética de la prensa confluyó con la derrota militar española de 1898 y ésta con el surgimiento de un hispanoamericanismo enemigo de cualquier tipo de vínculo de Washington con las "repúblicas latinas". Cada una de las conferencias panamericanas (México 1901, Río de Janeiro 1906, Buenos Aires 1910, Santiago 1923 y La Habana 1928), mostraban a la prensa las intenciones estadounidenses de liderar la economía y la política de la macrorregión, sospechando de sus tácticas desestabilizadoras de las relaciones entre los países de habla hispana para luego recurrir como componedores moralmente superiores. Los achares hispanos tenían, además, otra razón: Estados Unidos coordinó una política exitosa de acercamiento con el Perú para resolver el problema de las "cautivas".

El panamericanismo estadounidense hizo desconfiar a una parte de la intelectualidad española que criticó, con agudeza, las estrategias de la Secretaria de Estado. De todos modos, el triunfalismo que acompañó a ese país después de la Gran Guerra, así como la confianza de Chile y Perú para resolver la litis mediante las Conferencias de Washington, no "ensuciaron" más la imagen que los Estados Unidos tuvo en la prensa española. La política desarrollada por Wilson, Harding, Coolidge y Hoover sobre Tacna y Arica recibió menos reprobaciones que las actitudes políticas de las dos primeras décadas del siglo XX, donde el campo de dominio (conflicto de Tacna y Arica, principalmente) no poseía el liderazgo consolidado de los Estados Unidos. Por el contrario, la evidencia del poder diplomático de la Casa Blanca en la década del veinte, hizo disminuir de modo considerable la crítica del periodismo español hacia su, a esas alturas, rival imaginario. 
b) Representaciones sobre España: El seguimiento del problema de Tacna y Arica permitió a la prensa realizar un conjunto de aclaraciones donde reveló detalles mínimos (debido al impacto moderado de la cuestión de Tacna y Arica en la vida política de España), pero de suma importancia -enclavados en diarios y revistas- sobre su identidad nacional. Desde el comienzo hasta el final del diferendo se constató una vocación de la prensa española "pacifista", por lo menos, hacia el exterior americano. Comprendía que para sus antiguas colonias la guerra desfavorecía la superación de las condicionantes y determinantes del atraso.

Pese a su pacifismo, parte de la prensa valoró el liderazgo militarista de Nicolás de Piérola, caudillo que dirigió al país después que el presidente Prado saliera del Perú con dirección a Europa para, supuestamente, coordinar el abastecimiento de armas de potencias europeas. Cabe señalar que la postura de paz de la prensa no le impidió demostrar gran desprecio por las actitudes de Chile en la guerra y la posguerra -la "chilenofobia"- que sólo matizó hacia el final de la controversia fronteriza. Ello hizo, en consecuencia, inclinar sus posiciones nacionalistas-sentimentales hacia el Perú -la "peruanofilia"- que, a pesar de los contactos cada vez más intensos entre la Casa de Pizarro y "Yanquilandia", como en algún momento denominó a Estados Unidos, no le hicieron cambiar su filiación inicial. En otro aspecto, por esos años tomó forma la conciencia del atraso de la industria periodística española que impedía obtener informaciones de calidad sobre lo que acontecía en el otrora virreinato limeño.

El pacifismo de la prensa continuó durante los años del protocolo, pero con un matiz que la marcó hasta 1929. La paz fue un vértice importante del hispanoamericanismo que, poco a poco, dirigió su objetivo hacia la crítica de la hegemonía estadounidense sobre América. Esa situación puede comprenderse, de manera absoluta, con motivo de la guerra del 98, donde la antipatía hacia los "yanquis" se consolidó en la prensa. Uno de los objetivos del Congreso Social y Económico Hispanoamericano, muy noticiado en los medios de comunicación, fue la discusión en torno a los arbitrajes entre los países de la “América Hispana”. Esa reunión señaló la fundación informal de lo que fue la faceta más bombástica del hispanoamericanismo de comienzos del siglo veinte. 
El lenguaje periodístico altisonante de los triunfos del escultor Agustín Querol, la posibilidad realista del establecimiento de relaciones político-económicas con las repúblicas "hijas" de la "madre" patria y un alto grado de conciencia sobre las formas de realizarlo dan cuenta de una España interesada en resolver con éxito su vinculación con una región concebida como lugar de influencias naturales. Luego de largos años de "floreos" literarios hacia América, el término de la Primera Guerra Mundial construyó un escenario adecuado para arremeter ideológicamente en esos países. Sin embargo, era demasiado tarde. El puesto había sido ocupado, en gran medida, por los Estados Unidos quienes lograron convocar en Washington a los representantes diplomáticos de Chile y Perú para solucionar la cuestión de Tacna y Arica.

Los recelos y las inquietudes hacia los Estados Unidos no cesaron. Sin embargo, a decir verdad, no se vislumbraron críticas consistentes hacia ellos por su actuación en el fallo y, luego, en los intentos de plebiscito realizados en Tacna y Arica durante 1925 y 1926. La prensa española entonces invirtió la forma de reflejar su nacionalismo apelando sólo a la alteridad con los Estados Unidos y comenzó, antes de solucionarse definitivamente el diferendo, una introspección no carente de cuantioso amor propio. El peso de las informaciones que tuvo el transporte de documentos diplomáticos desde Santiago hacia Lima en 1929 fue excepcional en comparación con los más de cuarenta años anteriores de análisis hemerográfico. Los mensajeros de la paz, los portadores de la paz, los pacificadores, etc., quisieron tener parte estelar en un conflicto diplomático, donde ésta se les había negado, por colocar una fecha, ya en 1901, cuando la Cámara de diputados chilena consensuó prescindir del arbitraje de la reina regente.

Quizás en el conocimiento de esa "realidad" la prensa se esmeró por comentar con gran prolijidad y anécdotas las demostraciones de afecto realizadas por los habitantes de Santiago, Arica y Lima hacia los aviadores españoles del Jesús del Gran Poder. Esa misma incorrección de las percepciones nacionales dio a luz la campaña, coordinada desde España, para reconocer con el Premio Nobel de la Paz a los líderes de los gobiernos autoritarios de Chile (Carlos Ibáñez del Campo) y Perú (Augusto Leguía), propuesta desestimada por los jueces de tan alta distinción. 
c) Representaciones sobre Bolivia: La representación periodística socializada de Bolivia, a pesar de su tercería infatigable en la cuestión de Tacna y Arica fue funesta. Sin duda, tal apreciación estuvo determinada por su papel modesto en los orígenes del conflicto, es decir, en su desempeño militar durante la Guerra del Pacífico. Un ejército indígena, mayormente no profesional, y la descoordinación entre los altos mandos y la tropa, puso en evidencia la debilidad que acompañó en la guerra y la posguerra al Estado boliviano. Luego de la batalla de Tacna, la retirada de sus tropas hacia las alturas cordilleranas puso en evidencia la desorganización político-militar del país. La destitución del presidente que condujo a Bolivia hacia la guerra, Hilarión Daza, ocupado en la "politiquilla doméstica", las revoluciones por la toma del poder, el ascenso del general Narciso Campero, su derrocamiento, sumado a la ruina económica del país hicieron de Bolivia, en la percepción española, el ejemplo del país anárquico e "infante" en su organización republicana.

La imagen del país altiplánico tuvo un retoque novedoso tras un leve momento de armamentismo, extrañamente valorado por la prensa española que sentía mayor apego hacia la paz (lo cual no excluía que admirara la profesionalización de las fuerzas armadas). El segundo momento, a nuestro juicio, sitúa a Bolivia en el espacio periodístico español como un país de grandes recursos económicas, quizás uno de los países más ricos del mundo en minerales, pero con un atraso que bordeaba los valores antitéticos del progreso y la modernización. Paradojalmente, con el tratado de paz firmado con Bolivia en 1904, Chile marcó uno de los momentos más espectaculares del desarrollo boliviano al tender una línea de tren desde Arica hasta La Paz. Según la prensa, la explotación mineral, el intercambio de capitales, la movilización de mano de obra, el triunfo de la ciencia ante la naturaleza, etc., harían que Bolivia no sólo ingresara en una nueva etapa de su historia, iniciando con su economía un cambio global.

Aún cuando la coyuntura de su representación negativa señaló el cambio de siglo, varios escritores españoles, al referirse a la cuestión de Tacna y Arica, retomaron con mayor detalle lo que ya había pasado a ser parte de la historia de ese país: su desgraciado pasado y porvenir producido por su enfrentamiento con Chile, la pérdida de su litoral y la estéril voz que sus demandas internacionales tenían en la escena política occidental. 
d) Representaciones sobre Perú: El fracaso en la Guerra del Pacífico también sirvió para construir las imágenes periodísticas básicas del Perú en España. País de un militarismo insuficiente para enfrentar con éxito a Chile, debido a su papel inferior en los campos de batalla, fue creando héroes a un ritmo más acelerado que el de Chile. Gozó, por esta razón, del afecto humanitario de la prensa. La lógica de la protección al más débil, en este caso se cumplió a cabalidad. La valentía de sus soldados pronto se transformó en orgullo admirable, pues ponía freno a todas las propuestas de paz elaboradas por un Chile que deseaba quebrar su unidad soberana y territorial. Similar al caso boliviano, la política peruana estuvo caracterizada por la inconsistencia de sus líderes y la debilidad constitucional, quebrada por la guerra, pero continuada después por los pasos fugaces y erróneos del mismo Prado, Piérola, García Calderón, Montero, Iglesias, etc. La cadena de presidentes que veían sus proyectos políticos truncados por las revoluciones no paró en la posguerra. Recordemos la fase final del gobierno de Bermúdez, el nuevo gobierno de Piérola y así, hasta los mismos años del oncenio de Leguía que terminarían, en una nueva revuelta política.

La debilidad política peruana determinó la ineficacia del país para oponerse a Chile y obligarle a cumplir el Tratado de Ancón. Tiempo después no tuvo la fuerza interna para oponerse a la chilenización de Tacna y Arica. Esa endeblez, encontró un respaldo moral en la prensa española. A la par, la imagen positiva del país "vencido" adquirió un mayor valoración debido a la elección del artista español Agustín Querol, realizada por la municipalidad de Lima, para que esculpiese un monumento al héroe peruano Francisco Bolognesi. El círculo virtuoso de la imagen peruana se nutrió de los relatos que recordaron, a propósito de Querol, los hechos del Asalto y Toma del Morro de 1880. El Perú pensaba en España y encendía la llama del hispanoamericanismo o, por lo menos de la fraternidad hispano-peruana. El Perú fue visto, al mismo tiempo, como un país que progresaba en su armamentismo, legitimado en parte por sus múltiples conflictos limítrofes con todos sus países vecinos. Entre ellos, el caso de Tacna y Arica era el más emblemático. Por eso es que, consciente de su incapacidad diplomática buscó amistad con los Estados Unidos, relación que no provocó un juicio severo de la prensa, sino más bien fue comprendido por escritores de importancia en el periodismo peninsular, baste recordar los casos de Martínez Velez, Zulueta o Beltrán y Rózpide. 
Sólo críticas marginales hacia el país comentaron su ethos "zambón y sensual" como una forma de contraponerlo a la blancura y seriedad chilena. Por otro lado, terminada la Primera Guerra Mundial, reapareció la cuestión chileno-peruana. La perversión chilena ahora había expulsado de Iquique al cónsul peruano, provocando en la cancillería de ese país una intensa propaganda antichilena que consideró a España como un punto clave de esa estrategia. Los años finales, pese a la inteligencia de su gobierno por finalizar el problema de Tacna y Arica mediante el Tratado de Lima reflejaron, una vez más, la inestabilidad política de una nación que agredía, tras el fallo de Coolidge, la embajada de los Estados Unidos en Lima, que intercambiaba golpes con grupos nacionalistas chilenos en la época plebiscitaria y que, por último, no quedaba del todo conforme con la solución final de 1929 movilizando grupos de ciudadanos por las principales vías limeñas.

e) Representaciones sobre Chile: La representación construida por la prensa de este país presentó, en comparación con la de los anteriores, un mayor dinamismo. En los orígenes, fue aciaga como la de la república boliviana, pero por razones diametralmente opuestas. El ejército chileno hacia 1880 ya había conquistado todo el litoral boliviano y gran parte del Tarapacá peruano. Esas "victorias", con todo el desgaste que significaron en términos humanos, fomentaron la idea de la barbaridad chilena, de su comportamiento bestial en las batallas, de su militarismo y armamentismo sin par, todos conceptos que se desarrollaron con mayor detalle durante la campaña de Tacna y Arica y posteriormente en la campaña de Lima. El bombardeo "por entretenimiento" de innumerables caletas peruanas con población civil provocó la censura de esa práctica en la prensa que no dudó, salvo pequeñas excepciones, en asumir una profunda "chilenofobia".

El vandalismo mostrado por Chile en la guerra derivó hacia un vandalismo formal o, por lo menos, sin armas, en el plano diplomático. Todo mecanismo legal para alcanzar la paz con Perú y Bolivia era caracterizado por la negación al diálogo, bajo los puntos de vista e intereses de La Moneda. La imposición de la inestabilidad y el daño que la "Prusia de América del Sur" -país ambicioso, violento, ladrón e irrespetuoso del derecho de genteshacía al continente, conformaba una representación absolutamente negativa, salvo excepciones que valoraron su constitucionalismo y solvencia económica. Sin embargo, el paso de los años sumó otro argumento al “jacobinismo" chileno. 
La dura chilenización que el gobierno efectuó sobre Tacna y Arica demostró que las valoraciones adversas hacia el país tenían un correlato con los hechos. Una pausa en medio de esta terrible fabricación representacional fue la firma del protocolo Billinghurst-Latorre, coyuntura que no bastaría por lo breve de su duración, para romper las vigas que sostenían el anterior modo de pensar a Chile. Aún más, como se dijo en la prensa, gran parte de la culpa del fracaso del arbitraje español la había tenido la Cámara de diputados chilena, con lo cual se depositó una nueva capa fóbica sobre el país. La buena prensa que gozó el presidente chileno Federico Errázuriz tampoco fue suficiente.

Las conferencias panamericanas, por el contrario, donde Chile una y otra vez defendió su posición antiarbitraje "retroactivo" para los conflictos limítrofes de las repúblicas americanas serían el mejor argumento para quienes proponían que el Estado no cedía en asuntos importantes para la paz del continente. Por otro lado, el destello de humanitarismo chileno que representó el tratado con Bolivia en 1904 al día siguiente quedaría al descubierto: lo que en verdad hacía Chile era legalizar su dominio sobre el antiguo litoral boliviano. Su imagen de país astuto, falaz y engañoso no terminaría con ello. Ahora eran la firma del Tratado de Ancón con el Perú y el Tratado de Paz, Amistad y Comercio con Bolivia los acontecimientos que mostraban la ilegalidad chilena y, en efecto, la poca seriedad con que tomaba a los Estados con quienes los suscribía.

En el caso de su relación con Bolivia, la prensa supo ver aspectos de modernidad en el establecimiento de rutas ferroviarias que desarrollarían la economía regional, sin embargo, el peso de la tradición chilenofóbica era mayor. Chile imponía sus puntos de vista en la cuestión de Tacna y Arica actuando tal cual rezaba en el lema de su escudo nacional: "Por la razón o la fuerza". Salvo defensas periodísticas muy apegadas a los estereotipos vigentes a comienzos de siglo sobre la pugna entre la civilización y la barbarie en las sociedades modernas (recordemos los elogios prochilenos de Ortúzar, Góngora o Piacentini) durante la última década del problema, el discurso periodístico sobre Chile tuvo una raíz histórica difícil de modificar. Se sabía del "pasado" de Chile en la guerra y la posguerra y aun cuando la imagen de solidez constitucional fue, en parte dañada por desordenes políticos en medio de la clase dirigente, hubo orgullo porque el país logró concretar el Tratado de Lima y finalizar un conflicto que ya se sentía antiguo e infinito. 
La minimización de la representación social sobre Chile como un país bárbaro llegó, no obstante, en el último año del conflicto. La cesión de la documentación del tratado a los aviadores españoles del Jesús del Gran Poder adormeció la crítica periodística e hizo creer en la revitalización de los lazos hispano-chilenos los que abrirían una época de mutua cooperación económica. El poder del vaticinio de la prensa, tantas veces triunfante durante su cobertura a la cuestión de Tacna y Arica, ahora se extraviaría. Pronto Chile y España "hija" y "madre"- conocerían senderos políticos inexplorados hasta ese entonces, cubiertos de sangre e incomprensión. La barbarie abandonaba por un tiempo a Chile presentando, a la vez, sus credenciales despreciables para morar España.

Todas las constataciones históricas anteriores, resultado del diálogo entre el pensamiento teórico-metodológico social y las fuentes hemerográficas analizadas en detalle permiten sostener, con bajo riesgo de error, la consistencia de la hipótesis presentada en la introducción de nuestra investigación. Las particularidades del conflicto fronterizo, así como las representaciones sociales construidas por una prensa española interesada en él permiten sostener la validez de las ideas centrales incluidas en aquella.

No obstante, la producción de conocimiento histórico del conflicto debe resolverse con estudios futuros que definan aspectos soslayados por nosotros, verbi gratia, un análisis de la "totalidad" de la prensa española sobre el diferendo; la construcción de representaciones del conflicto en las prensas de los países involucrados estableciendo una comparación entre aquellas; la fabricación de imágenes de esos países antes de 1880; el mismo aspecto, pero considerando los años posterior a 1929; las visiones construidas por las prensas de Chile, Perú, Bolivia y Estados Unidos acerca de la España política del cambio de siglo pasado; la utilización de fuentes diplomáticas españolas y americanas que permitan elaborar nuevas interrogantes de la relación entre esos Estados; repensar, por lo anterior, la metodología histórica con el objetivo de proponer a la comunidad historiográfica modos de construcción de saberes; y, por último, plantear un modelo de análisis que incluya a los lectores de la prensa para descentrar científicamente la exclusividad de la faceta escrita del medio de comunicación. Da la sensación, antes de pasar página, que sólo esos esfuerzos permitirán, con nuevos aportes, un conocimiento social concluyente y justiciero de las Naciones de Papel aquí presentadas. 



\section{FUENTES}

a) Fuentes hemerográficas de la Hemeroteca Digital de la Biblioteca Nacional de España.

1. ¡Adelante!, "Bolivia", 25 de junio de 1912, año II, n. ${ }^{\circ}$ 55, p. 32.

2. iAdelante!, "De fuera de España", 15 de marzo de 1912, año II, n. ${ }^{\circ}$ 42, p. 22.

3. iAdelante!, "De fuera de España", 25 de enero de 1912, año II, n. ${ }^{\circ}$ 37, p. 2.

4. Actualidades, "Guerra en el Pacífico", 18 de mayo de 1910, ( $\sin$ dato de año), n. ${ }^{\circ}$ 118, p. 3.

5. Aérea, "Continuación de viaje del «Jesús del Gran Poder»", abril de 1929, año VII, n. ${ }^{\circ} 69$, p. 3

6. Aérea, "El vuelo trinfal del Jesús del Gran Poder sobre el Atlántico y las repúblicas hispanoamericanas", julio de 1929 , n. ${ }^{\circ} 72$, año VII, p. 8.

7. Aérea, "Otro excelente vuelo de 4.200 kilómetros", octubre de 1927, p. 36.

8. Almanaque Bailly Bailliere, "El año artístico y literario. 1903", 1904, s/d. p. 233.

9. Almanaque Bailly-Bailliere, "Bolivia", 1908, p. 298.

10. Almanaque Bailly-Bailliere, "El año filatélico", 1928, p. 192.

11. Almanaque Bailly-Bailliere, "Un tercer camino desde Bolivia al Pacífico", 1914, Madrid: Casa Editorial Bailly-Bailliere, p. 393.

12. Alrededor del Mundo, "Contestaciones recibidas", 24 de abril de 1903, p. 272.

13. Alrededor del Mundo, "Las olas gigantes que siguen a los terremotos", 10 de febrero de 1909, n. $^{\circ} 506$, p. 90.

14. Anuario del Comercio, de la Industria, de la Magistratura y de la Administración, "Chile", Año 1899, p. 3061.

15. Anuario del Comercio, de la Industria, de la Magistratura y de la Administración, "Cuerpo diplomático y consular", 1896, p. 8 [i?]

16. Archivo Diplomático de España, "Sueltos", 21 de enero de 1884, p. 22.

17. Archivo Diplomático y Consular de España, "Cuestiones Internacionales: Tacna y Arica", 16 de septiembre de 1892, p. 1681.

18. Archivo Diplomático y Consular de España, "De Chile", 30 de mayo de 1890, p. 833.

19. Archivo Diplomático y Consular de España, "El nuevo Presidente del Perú", 17 de septiembre de 1890, p. 945.

20. Archivo Diplomático y Consular de España, "La Conferencia Internacional Americana", 17 de septiembre de 1890, año VIII, n. ${ }^{\circ}$ 326, p. 941.

21. Archivo Diplomático y Consular de España, "La República del Perú", 16 de enero de 1887 , p. 2278.

22. Archivo Diplomático y Consular de España, "Semana Política", 16 de abril de 1891, año IX, n. ${ }^{\text {354, p. }} 1156$.

23. Archivo Diplomático-Político de España, "Noticias del Pacífico", 29 de diciembre de 1883, año I, n. ${ }^{\circ} 35$, p. 562. 
24. Arquitectura y Construcción, Bellas Artes, Decoración, Industria, Arte Moderno, Revista Mensual, "Concursos", enero de 1902, año VI, n. ${ }^{\circ} 114$, p. 16.

25. Buen Humor, "Charlas dominicales", n. ${ }^{\circ}$ 339, año VII, 27 de mayo de 1928, p. 1.

26. Cosmópolis, "El Perú y su cuestión del Pacífico", agosto de 1921, n. ㅇ 32, p. 637.

27. Cosmópolis, "Nuevas fases de la política chilena", octubre de 1921, n. o 34, p. 314.

28. Diario Oficial de Avisos de Madrid, "Chile", 26 de julio de 1884, p. 3.

29. Diario Oficial de Avisos de Madrid, "Correspondencia de España”, 11 de febrero de 1880, p. 3.

30. Diario Oficial de Avisos de Madrid, "Despachos telegráficos", 11 de junio de 1880, p. 3.

31. Diario Oficial de Avisos de Madrid, "Despachos telegráficos", 11 de enero de 1883, p. 3.

32. Diario Oficial de Avisos de Madrid, "Despachos telegráficos", 13 de noviembre de 1882, p. 3.

33. Diario Oficial de Avisos de Madrid, "Despachos telegráficos", 20 de mayo de 1882, p. 2.

34. Diario Oficial de Avisos de Madrid, "En la América del Sur", 3 de marzo de 1900, p. 2.

35. Diario Oficial de Avisos de Madrid, "Extranjero", 21 de junio de 1898. p. 1.

36. Diario Oficial de Avisos de Madrid, "La población de Chile", 26 de octubre de 1886, p. 2.

37. Diario Oficial de Avisos de Madrid, "Noticias extranjeras", 28 de mayo de 1883, p. 3.

38. Diario Oficial de Avisos de Madrid, "Noticias", 5 de agosto de 1898, p. 2.

39. El Álbum Ibero Americano, "Crónica española y americana", 30 de junio de 1895, p. 278.

40. El Álbum Ibero Americano, "Doctor Roque Sáenz Peña, diplomático argentino", 30 de septiembre de 1892, n. ${ }^{\circ} 12$, p. 142.

41. El Álbum Ibero Americano, "Nuestros grabados. Excmo. Sr. D. Federico Errázuriz, Presidente de la República de Chile”, 22 de abril de 1901, n ${ }^{\circ} 15$, p. 179.

42. El Álbum Ibero Americano, "Crónica española y americana. Chile y Perú", 14 de mayo de 1901, p. 2.

43. El Álbum Ibero Americano, "Crónica española y americana. Chile, Perú y Bolivia", 30 de noviembre de 1900, p. 518.

44. El Álbum Ibero Americano, "Crónica española y americana", 30 de abril de 1905, n. ${ }^{\circ} 16$, p. 182.

45. El Álbum Ibero Americano, "Crónica española y americana", 7 de junio de 1900, p. 242.

46. El Álbum Ibero Americano, "Crónica europea y americana", 22 de enero de 1905, n. ${ }^{\circ} 3$, p. 26. 
47. El Álbum Ibero Americano, "Crónica europea y americana", 7 de agosto de 1908, año XXVI, n. ${ }^{\circ} 29$, p. 2.

48. El Álbum Ibero Americano, "España y Perú", 7 de noviembre de 1900, p. 484.

49. El Arte del Teatro, "La primera ópera en Lima", 1 de junio de 1907, año II, n. ${ }^{\circ} 29$, p. 1.

50. El Correo Militar, “HHabrá guerra?”, 4 de septiembre de 1889, p. 3.

51. El Correo Militar, “¿Otra guerra?”, 28 de marzo de 1884, p. 3.

52. El Correo Militar, “Asuntos extranjeros”, 28 de mayo de 1883, p. 3.

53. El Correo Militar, "Chile", 6 de junio de 1890, p. 2.

54. El Correo Militar, "Del extranjero", 17 de mayo de 1883, p. 2.

55. El Correo Militar, "El país chileno", 14 de diciembre de 1900, p. 2.

56. El Correo Militar, "La cuestión del Pacífico", 12 de febrero de 1883, p. 2.

57. El Correo Militar, "La insurrección chilena", 21 de abril de 1891, p. 1.

58. El Correo Militar, "La perla de Lima", 1 de octubre de 1890, p. 4.

59. El Correo Militar, "Noticias varias", 13 de abril de 1891, p. 2.

60. El Correo Militar, "Perú", 28 de abril de 1890, p. 2.

61. El Correo Militar, "Repúblicas del Pacífico", 14 de marzo de 1883, p. 2.

62. El Correo Militar, "Última hora", 10 de enero de 1883, p. 2.

63. El Día, "Acuerdos de la Conferencia Panamericana Socialista", 4 de mayo de 1919, p. 6.

64. El Día, "América Española", 11 de febrero de 1884, p. 1.

65. El Día, "América Española", 15 de febrero de 1882, p. 2.

66. El Día, "América Española", 18 de junio de 1882, p. 1.

67. El Día, "América española", 22 de enero de 1884, p. 1.

68. El Día, "América española", 23 de febrero de 1882, p. 1.

69. El Día, "América Española", 24 de noviembre de 1882, p. 2.

70. El Día, "América española", 25 de agosto de 1882, p. 2.

71. El Día, "Apertura del Congreso brasileño", 30 de julio de 1910, p. 3.

72. El Día, "Bolivia reclama una salida al mar", 18 de julio de 1919, p. 7.

73. El Día, "Bolivia", 2 de abril de 1909, p. 2.

74. El Día, "Chile y el Perú", 23 de enero de 1909, p. 1.

75. El Día, "Chile y el Perú", 28 de enero de 1909, p. 1.

76. El Día, "Chile y Perú", 1 de febrero de 1909, p. 2.

77. El Día, "Chile y Perú", 1 de junio de 1882, p. 1.

78. El Día, "Chile y Perú", 3 de febrero de 1909, p. 1.

79. El Día, "Chile y Perú", 4 de enero de 1919, p. 5.

80. El Día, "Chile", 2 de mayo de 1894, p. 2.

81. El Día, "Chile", 22 de febrero de 1919, p. 7.

82. El Día, "Chile", 7 de mayo de 1913, p. 2.

83. El Día, "Comentario", 22 de febrero de 1919, p. 5.

84. El Día, "Cosmorama", 10 de febrero de 1893, p. 3. 
85. El Día, "Cosmorama", 7 de septiembre de 1892, p. 3.

86. El Día, "De ayer a hoy", 17 de septiembre de 1898, p. 1.

87. El Día, "El arreglo de las diferencias entre Perú y Chile", 5 de mayo de 1919, p. 8.

88. El Día, "El conflicto chileno-peruano", 4 de noviembre de 1911, p. 2.

89. El Día, "El Conflicto entre Perú y Chile", 13 de noviembre de 1918, p. 2.

90. El Día, "El Congreso Socialista Panamericano", 2 de mayo de 1919, p. 7.

91. El Día, "El incidente entre Chile y el Perú", 11 de enero de 1919, p. 5.

92. El Día, "El presidente de Chile", 16 de abril de 1909, p. 1.

93. El Día, "Entre Chile y Perú", 23 de enero de 1919, p. 7.

94. El Día, "Extranjero", 8 de marzo de 1910, p. 2.

95. El Día, "Guerra inminente", 8 de abril de 1910, p. 1.

96. El Día, "Intereses chilenos", 16 de marzo de 1911, p. 3.

97. El Día, "La Cuestión Chile-peruana", 26 de diciembre de 1918, p. 8.

98. El Día, "La Guerra entre Chile y el Perú", 17 de noviembre de 1908, p. 2.

99. El Día, "La insurrección de Chile", 12 de abril de 1891, p. 2

100. El Día, "La insurrección de Chile", 21 de febrero de 1891, p. 2.

101. El Día, "La insurrección de Chile", 25 de febrero de 1891, p. 2.

102. El Día, "La paz chileno-peruana", 30 de enero de 1884, p. 1.

103. El Día, "La Polonia de América", 21 de diciembre de 1883, p. 1.

104. El Día, "La prensa peruana y el asunto de Tacna y Arica", 3 de junio de 1919, p. 7.

105. El Día, "Los trabajos del Congreso Socialista Panamericano", 3 de junio de 1919,

p. 7.

106. El Día, "Noticias varias", 3 de abril de 1883, p. 1.

107. El Día, "Noticias varias", 9 de agosto de 1887, p. 3.

108. El Día, "Perú, Bolivia y Chile", 21 de mayo de 1909, p. 3.

109. El Día, "Perú", 26 de enero de 1919, p. 2.

110. El Día, "Telegramas (Agencia Fabra)", 16 de mayo de 1883, p. 1.

111. El Día, "Telegramas Agencia Fabra", 10 de enero de 1883, p. 1.

112. El Día, "Telegramas Agencia Fabra", 14 de febrero de 1882, p. 2.

113. El Día, "Telegramas", 27 de mayo de 1883, p. 1.

114. El Día, "Terremoto en América", 31 de marzo de 1892, p. 2.

115. El Día, "Tradiciones peruanas", 28 de mayo de 1883, p. 6.

116. El Día, "Tradiciones peruanas", 30 de diciembre de 1883, p. 4.

117. El Día, "Últimos telegramas. De la Agencia Fabra. Pago de una indemnización", 31 de julio de 1898, p. 3.

118. El Día, "Un plebiscito", 1 de mayo de 1898, p. 1.

119. El Estudiante, "Lugones y el Presidente Leguía", junio de 1925, n. ${ }^{\circ}$ 7, (sin numeración).

120. El Globo, “¿Graves desórdenes en Chile?”, 14 de octubre de 1920, p. 3.

121. El Globo, "Bolivia y el Perú", 24 de marzo de 1920, p. 1.

122. El Globo, "Bolivia, el Perú y Chile", 10 de marzo de 1920, p. 2. 
123. El Globo, "Chile desea renovar sus buques de guerra", 10 de julio de 1926, p. 1.

124. El Globo, "Chile y el Perú", 24 de marzo de 1910, p. 3.

125. El Globo, "Chile y el Perú", 3 de diciembre de 1918, p. 1.

126. El Globo, "Comentarios sobre el estado del conflicto chilenoperuano por la posesión de Tacna y Arica", 13 de agosto de 1926, p. 2.

127. El Globo, "Conferencia del señor Francos Rodríguez", 14 de abril de 1921, p. 1.

128. El Globo, "Conflicto entre Chile y Perú", 28 de octubre de 1911, p. 2.

129. El Globo, "De América", 13 de octubre de 1925, p. 1.

130. El Globo, "De América", 14 de mayo de 1925, p. 1.

131. El Globo, "De Barcelona. Una conferencia", 6 de julio de 1913, p. 1.

132. El Globo, "De la Agencia", 13 de noviembre de 1882, p. 2.

133. El Globo, "Del extranjero", 4 de junio de 1921, p. 3.

134. El Globo, "El Arbitraje de España entre Chile y el Perú", 1 de agosto de 1898, p. 2.

135. El Globo, "El Arbitraje de España entre Chile y Perú", 24 de agosto de 1898, p. 2.

136. El Globo, "El conflicto de Tacna y Arica", 7 de junio de 1926, p. 2.

137. El Globo, "El conflicto entre Chile y Perú", 6 de julio de 1922, p. 1.

138. El Globo, "El nuevo ministro plenipotenciario de Chile", 26 de enero de 1910, p. 1.

139. El Globo, "El pleito de Tacna y Arica", 26 de mayo de 1926, p. 1.

140. El Globo, "Estado", 10 de noviembre de 1920, p. 1.

141. El Globo, "Extranjero. Perú y el Ecuador", 9 de abril de 1910, p. 1.

142. El Globo, "Extranjero", 15 de febrero de 1882, p. 2.

143. El Globo, "Extranjero", 22 de julio de 1922, p. 2.

144. El Globo, "Extranjero", 29 de diciembre de 1921, p. 3.

145. El Globo, "Extranjero", 8 de marzo de 1910, p. 2.

146. El Globo, "Información americana", 20 de enero de 1926, p. 3.

147. El Globo, "Informaciones del Extranjero", 25 de enero de 1922, p. 2.

148. El Globo, "Informes de Chile", 13 de marzo de 1920, p. 1.

149. El Globo, "Intereses chilenos", 17 de marzo de 1911, p. 3.

150. El Globo, "Juicios de la prensa de los Estados Unidos", 6 de agosto de 1926, p. 3.

151. El Globo, "La cuestión de Tacna y Arica", 10 de agosto de 1925, p. 1.

152. El Globo, "La cuestión de Tacna y Arica", 23 de abril de 1926, p. 2.

153. El Globo, "La cuestión de Tacna y Arica", 23 de enero de 1922, p. 2.

154. El Globo, "La cuestión del Pacífico", 10 de julio de 1926, p. 1.

155. El Globo, "La cuestión del Pacífico", 7 de mayo de 1925, p. 1.

156. El Globo, "La Misión Española", 10 de diciembre de 1920, p. 2.

157. El Globo, "La Misión española", 22 de noviembre de 1920, p. 2.

158. El Globo, "La protesta de Perú", 23 de marzo de 1910, p. 2.

159. El Globo, "La situación en Chile", 10 de agosto de 1920, p. 2.

160. El Globo, "Los valores chilenos", 24 de noviembre de 1907, p. 1. 
161. El Globo, "No se arregla lo de Arica", 5 de mayo de 1926, p. 3.

162. El Globo, "Noticias generales", 10 de marzo de 1880, p. 3.

163. El Globo, "Noticias generales", 18 de junio de 1883, p. 2.

164. El Globo, "Perú, Bolivia y Chile", 21 de mayo de 1909, p. 3.

165. El Globo, "Perú", 27 de marzo de 1880, p. 3.

166. El Globo, "Política de concordia", 11 de junio de 1920, p. 2.

167. El Globo, "Presidencia", 19 de noviembre de 1920, p. 1.

168. El Globo, "Revista Extranjera", 10 de enero de 1880, p. 2.

169. El Globo, "Revista Extranjera", 6 de enero de 1880, p. 2.

170. El Globo, "Tacna y Arica", 25 de febrero de 1926, p. 2.

171. El Globo, "Tacna y Arica", 7 de abril de 1926, p. 2.

172. El Globo, "Telegramas de la Agencia Fabra", 15 de junio de 1880, p. 3.

173. El Globo, "Telegramas de la Agencia Fabra", 29 de enero de 1881, p. 3.

174. El Globo, "Telegramas de la Agencia Fabra", 31 de mayo de 1880, p. 3.

175. El Globo, "Telegramas", 11 de enero de 1883, p. 3.

176. El Globo, "Telegramas", 20 de mayo de 1882, p. 2.

177. El Globo, "Telegramas", 28 de mayo de 1883, p. 2.

178. El Globo, "Temblores marinos", 21 de agosto de 1883, p. 1.

179. El Globo, "Un collar de ojos humanos", 9 de noviembre de 1885. p. 3.

180. El Globo, "Un plebiscito", 1 de mayo de 1898, p. [i?]

181. El Heraldo de Madrid, "Perú", 1 de marzo de 1906, p. 4.

182. El Heraldo Militar, "Chile y Perú", 4 de noviembre de 1911, p. 1.

183. El Heraldo Militar, "Chile y Perú", 4 de noviembre de 1911, p. 1.

184. El Heraldo Militar, "Delimitación de fronteras", 16 de marzo de 1911, p. 3.

185. El Heraldo Militar, "El ferrocarril chileno-boliviano", 16 de mayo de 1913, p.2.

186. El Heraldo, “AAcepta Chile el reparto propuesto?”, 12 de junio de 1926, p. 5.

187. El Heraldo, “¿No estaba resuelto ya el pleito de Tacna y Arica?”, 1 de marzo de 1929, p. 2.

188. El Heraldo, “¿Planteará otra vez el nuevo estado de cosas el pleito de Tacna y Arica?", 5 de febrero de 1925, p. 3.

189. El Heraldo, “Se ha resuelto, por fin, el conflicto de Tacna y Arica?”, 21 de febrero de 1929, p. 3.

190. El Heraldo, “Se intensifica la eficacia militar peruana?”, 17 de diciembre de 1925, p. 2.

191. El Heraldo, "América del Sur", 22 de abril de 1925, p. 3.

192. El Heraldo, "América del Sur", 4 de julio de 1925, p. 3.

193. El Heraldo, "Chile sólo tiene intenciones pacifistas respecto al Perú", 28 de agosto de 1924, p. 3.

194. El Heraldo, "Chile y el Perú", 22 de enero de 1909, p. 3.

195. El Heraldo, "Chile y el Perú", 29 de mayo de 1909, p. 4. 
196. El Heraldo, "Chile y Perú están dispuestos a reanudar sus relaciones diplomáticas interrumpidas hace veinte años", 14 de julio de 1928, p. 3.

197. El Heraldo, "Chile, Perú y Bolivia", 23 de marzo de 1920, p. 2.

198. El Heraldo, "Chile", 19 de febrero de 1906, p. 1.

199. El Heraldo, "Chile", 2 de marzo de 1906, p. 1.

200. El Heraldo, "Chilenos y argentinos", 10 de marzo de 1902, p. 1.

201. El Heraldo, "Conmemorando un triunfo", 3 de julio de 1902, p. 2.

202. El Heraldo, "Contra la solución del pleito de Tacna y Arica", 22 de mayo de 1929, p. 1.

203. El Heraldo, "Coolidge se interesa en el litigio entre Perú y Chile", 27 de agosto de 1924, p. 3.

204. El Heraldo, "Crónicas americanas", 31 de mayo de 1920, p. 3.

205. El Heraldo, "Cuadro de la vida americana", 5 de junio de 1920, p. 5.

206. El Heraldo, "De Santiago de Chile a Arica", 22 de abril de 1929, p. 1.

207. El Heraldo, "De Santiago de Chile a Arica", 22 de abril de 1929, p. 11.

208. El Heraldo, "De todas partes", 16 de abril de 1891, p. 1.

209. El Heraldo, "De todas partes", 29 de agosto de 1892, p. 1.

210. El Heraldo, "Desde México", 16 de diciembre de 1901, p. 2.

211. El Heraldo, "Dimite un miembro de la Comisión chilena", 24 de diciembre de 1925, p. 1.

212. El Heraldo, "Doce aeropuertos para Chile", 25 de julio de 1929, p. 3.

213. El Heraldo, "Durante el plebiscito sobre Tacna y Arica", 13 de agosto de 1925, p. 1.

214. El Heraldo, "El avión español llega a Arica", 23 de abril de 1929, p. 2.

215. El Heraldo, "El centenario de Magallanes", 23 de septiembre de 1920, p. 5.

216. El Heraldo, "El conflicto de Tacna y Arica parece insoluble", 29 de abril de 1926, p. 3.

217. El Heraldo, "El conflicto de Tacna y Arica y la opinión del Perú", 12 de agosto de 1926, p. 2.

218. El Heraldo, "El conflicto entre Perú y Chile", 10 de noviembre de 1922, p. 2.

219. El Heraldo, "El Congreso del Perú ratifica el acuerdo", 3 de julio de 1929, p. 2.

220. El Heraldo, "El Congreso Panamericano", 7 de noviembre de 1901. p. 1.

221. El Heraldo, "El consejo de la S.D.N.", 14 de junio de 1929, p. 1.

222. El Heraldo, "El día 15 se verificará el plebiscito sobre el pleito de Tacna y Arica", 10 de diciembre de 1925, p. 4.

223. El Heraldo, "El divorcio entre América del Norte y América del Sur", 29 de diciembre de 1927, p. 1.

224. El Heraldo, "El fallo de la cuestión de Tacna y Arica", 21 de febrero de 1925, p. 3.

225. El Heraldo, "El General Pershing disgustado del plebiscito de Tacna y Arica", 3 de noviembre de 1925, p. 2. 
226. El Heraldo, "El general Pershing está cansado de Perú y de Chile por su desidia en el pleito de Tacna y Arica”, 10 de noviembre de 1925, p. 1.

227. El Heraldo, "El General Pershing tiene plenos poderes en el pleito de Tacna y Arica", 22 de septiembre de 1925, p. 2.

228. El Heraldo, "El gobierno peruano prepara una importante decisión en el pleito de Tacna y Arica", 5 de mayo de 1925, p. 4.

229. El Heraldo, "El incidente chileno-peruano", 30 de noviembre de 1918, p. 2.

230. El Heraldo, "El laudo de Míster Coolidge sobre Tacna y Arica", 12 de marzo de 1925, p. 4.

231. El Heraldo, "El monumento a Bolognesi", 12 de diciembre de 1902, p. 3.

232. El Heraldo, "El nuevo presidente del Perú", 23 de septiembre de 1912, p. 5.

233. El Heraldo, "El Perú confía en el resultado del plebiscito", 23 de marzo de 1925, p. 3.

234. El Heraldo, "El Perú cree que el plebiscito sobre Tacna y Arica le será favorable", 8 de agosto de 1925, p. 4.

235. El Heraldo, "El Perú quiere anexionarse dos provincias chilenas", 25 de octubre de 1924, p. 3.

236. El Heraldo, "El plebiscito de Tacna y Arica", 1 de agosto de 1925, p. 4.

237. El Heraldo, "El plebiscito de Tacna y Arica", 25 de julio de 1925, p. 3.

238. El Heraldo, "El plebiscito de Tacna y Arica", 3 de agosto de 1925, p. 1.

239. El Heraldo, "El plebiscito sobre Tacna y Arica", 6 de agosto de 1925, p. 2.

240. El Heraldo, "El pleito chilenoperuano", 2 de julio de 1926, p. 3.

241. El Heraldo, "El pleito de Tacna y Arica aún no ha sido resuelto", 6 de enero de 1925, p. 5.

242. El Heraldo, "El pleito de Tacna y Arica está a punto de quedar definitivamente resuelto", 3 de mayo de 1929, p. 3.

243. El Heraldo, "El pleito de Tacna y Arica no está en vías de resolverse", 1 de octubre de 1925, p. 4.

244. El Heraldo, "El pleito de Tacna y Arica", 13 de octubre de 1925, p. 5.

245. El Heraldo, "El pleito de Tacna y Arica", 2 de diciembre de 1926, p. 3.

246. El Heraldo, "El pleito de Tacna y Arica", 2 de enero de 1926, p. 3.

247. El Heraldo, "El pleito de Tacna y Arica", 23 de mayo de 1929, p. 1.

248. El Heraldo, "El pleito de Tacna y Arica", 25 de abril de 1925, p. 3.

249. El Heraldo, "El pleito de Tacna y Arica", 26 de diciembre de 1925, p. 3.

250. El Heraldo, "El pleito de Tacna y Arica", 7 de julio de 1928, p. 3.

251. El Heraldo, "El presidente de Chile anuncia la pronta resolución del asunto de Tacna y Arica", 17 de abril de 1929, p. 3.

252. El Heraldo, "El presidente del Perú despide a los ciudadanos que marchan a votar por la patria", 1 de marzo de 1926, p. 3.

253. El Heraldo, "El punto terminal del crucero aéreo será La Habana", 25 de abril de 1929, p. 11. 
254. El Heraldo, "El Senado chileno ratifica el pacto de Tacna y Arica", 2 de julio de 1929 , p. 3.

255. El Heraldo, "El Senado chileno se pronuncia por el plebiscito", 30 de abril de 1926, p. 3.

256. El Heraldo, "El Tratado de Tacna y Arica", 13 de junio de 1929, p. 16.

257. El Heraldo, "El viejo pleito de Tacna y Arica", 11 de marzo de 1925, p. 2.

258. El Heraldo, "En el estudio de Querol", 13 de mayo de 1904, p. 1.

259. El Heraldo, "En la Económica Matritense", 8 de mayo de 1926, p. 5.

260. El Heraldo, "En Tacna reina gran efervescencia", 12 de julio de 1926, p. 3.

261. El Heraldo, "España y América. Chile", 11 de abril de 1913, p. 1.

262. El Heraldo, "Extranjero", 14 de septiembre de 1922, p. 2.

263. El Heraldo, "Extranjero", 22 de julio de 1922, p. 4.

264. El Heraldo, "Graves sucesos en el Perú", 24 de julio de 1920, p. 4.

265. El Heraldo, "Ha sido firmado, por fin, el Tratado sobre Tacna y Arica", 4 de junio de 1929 , p. 3.

266. El Heraldo, "Ha surgido un grave desacuerdo entre el representante de Chile y el general Pershing", 4 de diciembre de 1925, p. 2.

267. El Heraldo, "Halagos de Bolivia a Chile para obtener un puerto en el Pacífico", 20 de agosto de 1925, p. 4.

268. El Heraldo, "Información de Chile, Uruguay, Colombia, Brasil y Paraguay", 2 de agosto de 1924, p. 3.

269. El Heraldo, "La Alsacia y la Lorena de Sud América", 23 de abril de 1894, p. 1.

270. El Heraldo, "La América Central", 3 de abril de 1909, p. 1.

271. El Heraldo, "La apertura del parlamento peruano", 27 de junio de 1929, p. 3.

272. El Heraldo, "La busca de un tesoro", 14 de abril de 1928, p. 14.

273. El Heraldo, "La Comisión Plebiscitaria adopta medidas para mantener el orden", 19 de enero de 1926, p. 4.

274. El Heraldo, "La cuestión de Tacna y Arica", 14 de noviembre de 1925, p. 4.

275. El Heraldo, "La cuestión de Tacna y Arica", 16 de marzo de 1925, p. 3.

276. El Heraldo, "La cuestión de Tacna y Arica", 20 de mayo de 1925, p. 4.

277. El Heraldo, "La cuestión de Tacna y Arica", 28 de abril de 1928, p. 3.

278. El Heraldo, "La cuestión de Tacna-Arica", 30 de julio de 1925, p. 4.

279. El Heraldo, "La delegación peruana en el plebiscito de Tacna y Arica", 30 de junio de 1925, p. 4.

280. El Heraldo, "La entrega del protocolo de Tacna y Arica", 24 de abril de 1929, p. 11.

281. El Heraldo, "La Legación del Perú en Bolivia apedreada por la multitud", 19 de abril de 1926, p. 3.

282. El Heraldo, "La línea española del Pacífico", 2 de octubre de 1928, p. 12.

283. El Heraldo, "La nueva frontera entre Chile y el Perú", 25 de abril de 1929, p. 3. 
284. El Heraldo, "La prensa del Perú descontenta del plebiscito sobre Tacna y Arica", 29 de septiembre de 1925, p. 2.

285. El Heraldo, "La situación política en Bolivia se complica", 7 de octubre de 1929, p. 1.

286. El Heraldo, "La solución del conflicto de Tacna y Arica", 16 de mayo de 1929, p. 11.

287. El Heraldo, "La solución del pleito de Tacna y Arica", 13 de julio de 1929, p. 3.

288. El Heraldo, "La vieja querella entre Perú y Chile", 13 de marzo de 1925, p. 1.

289. El Heraldo, "Las Cámaras de Chile quieren una solución digna", 18 de septiembre de 1926, p. 2.

290. El Heraldo, "Las fuerzas chilenas se retiran de Tacna y Arica", 25 de febrero de 1926, p. 3.

291. El Heraldo, "Las inquietudes sudamericanas. Santiago de Chile.", 28 de octubre de 1924, p. 3.

292. El Heraldo, "Las medidas propuestas ahora por Chile son las que en un principio proponía el Perú", 1 de abril de 1926, p. 2.

293. El Heraldo, "Las relaciones entre Perú y Bolivia", 7 de julio de 1920, p. 4.

294. El Heraldo, "Las tropas derrotadas", 12 de abril de 1891, p. 2.

295. El Heraldo, "Los rotarios argentinos celebran la solución del pleito de Tacna y Arica", 9 de julio de 1929, p. 16.

296. El Heraldo, "Los términos en que está redactado el acuerdo entre Chile y Perú",

18 de mayo de 1929, p. 3.

297. El Heraldo, "Ninguna parcela de los territorios correspondientes a Chile y el Perú podrá ser cedida a un tercero", 4 de mayo de 1919, p. 3.

298. El Heraldo, "Notas americanas", 12 de enero de 1926, p. 4.

299. El Heraldo, "Noticias de América", 10 de julio de 1927, p. 8.

300. El Heraldo, "Noticias de América", 12 de enero de 1927, p. 1.

301. El Heraldo, "Noticias de América", 13 de julio de 1927, p. 6.

302. El Heraldo, "Noticias de América", 18 de mayo de 1927, p. 4.

303. El Heraldo, "Noticias de América", 2 de marzo de 1927, p. 6.

304. El Heraldo, "Noticias de América", 22 de junio de 1927, p. 5.

305. El Heraldo, "Noticias de América", 27 de abril de 1927, p. 5.

306. El Heraldo, "Noticias de América", 27 de diciembre de 1921, p. 5.

307. El Heraldo, "Noticias de América", 31 de julio de 1927, p. 2.

308. El Heraldo, "Noticias de América", 5 de enero de 1927, p. 3.

309. El Heraldo, "Noticias de América", 6 de abril de 1927, p. 5.

310. El Heraldo, "Noticias generales", 11 de enero de 1902, p. 6.

311. El Heraldo, "Otros acontecimientos", 1 de enero de 1927, p. 3.

312. El Heraldo, "Parece que Chile renuncia a Arica en favor del Perú", 19 de mayo de 1926, p. 3. 
313. El Heraldo, "Parece que se recrudece el viejo conflicto entre Tacna y Arica", 10 de diciembre de 1927, p. 3.

314. El Heraldo, "Perú celebrará su independencia con la entrada en posesión de la ciudad de Tacna", 18 de junio de 1929, p. 16.

315. El Heraldo, "Perú contesta a las proposiciones yanquis", 18 de enero de 1927, p. 3 .

316. El Heraldo, "Por la hegemonía del Sur del Pacífico", 30 de diciembre de 1921, p. 3.

317. El Heraldo, "Presidencia", 19 de noviembre de 1920, p. 3.

318. El Heraldo, "Puga Bornes", 26 de enero de 1910, p. 2.

319. El Heraldo, "Querol en América", 9 de junio de 1902, p. 1.

320. El Heraldo, "Real Sociedad Económica Matritense", 6 de mayo de 1925, p. 5.

321. El Heraldo, "Recelos del Perú por los preparativos bélicos de Chile", 6 de julio de 1926, p. 3.

322. El Heraldo, "Sáenz Peña, según Blasco Ibáñez", 25 de junio de 1910, p. 1.

323. El Heraldo, "Se agrava la cuestión de Tacna y Arica", 26 de noviembre de 1925, p. 2.

324. El Heraldo, "Se anuncian acontecimientos de importancia", 26 de marzo de 1927, p. 3.

325. El Heraldo, "Se asegura oficialmente que la cuestión de Tacna y Arica no está definitivamente resuelta", 23 de febrero de 1929, p. 3.

326. El Heraldo, "Se ha resuelto la cuestión de Tacna y Arica", 22 de febrero de 1929, p. 1.

327. El Heraldo, "Se pide el premio de la paz para dos dictadores", 19 de octubre de 1929 , p. 3.

328. El Heraldo, "Se prorroga el plazo de inscripción plebiscitaria", 4 de mayo de 1926, p. 1.

329. El Heraldo, "Se teme que la intervención de Bolivia dificulte el pleito", 21 de mayo de 1929, p. 3.

330. El Heraldo, "Se va a engrandecer y embellecer la capital y a construir el puerto de Arica", 24 de julio de 1929, p. 11.

331. El Heraldo, "Se va a erigir un monumento a la paz en Arica", 20 de julio de 1929, p. 7.

332. El Heraldo, "Según el Times la situación política y económica chilena es bastante difícil", 14 de abril de 1927, p. 3.

333. El Heraldo, "Según La Nación chilena, el momento no es el más propicio para reunirse en buena paz", 22 de noviembre de 1927, p. 3.

334. El Heraldo, "Tacna y Arica esperan el laudo de Míster Coolidge", 5 de marzo de 1925, p. 1.

335. El Heraldo, "Tacna y Arica", 18 de junio de 1926, p. 3.

336. El Heraldo, "Tacna y Arica", 1 de diciembre de 1926, p. 3. 
337. El Heraldo, "Tacna y Arica", 10 de abril de 1926, p. 2.

338. El Heraldo, "Tacna y Arica", 14 de enero de 1926, p. 6.

339. El Heraldo, "Tacna y Arica", 17 de marzo de 1926, p. 3.

340. El Heraldo, "Tacna y Arica", 2 de febrero de 1926, p. 2.

341. El Heraldo, "Tacna y Arica", 3 de julio de 1926, p. 2.

342. El Heraldo, "Tacna y Arica", 6 de febrero de 1926, p. 5.

343. El Heraldo, "Tacna y Arica", 7 de diciembre de 1926, p. 3.

344. El Heraldo, "Terminantes declaraciones del ex presidente Alessandri", 21 de agosto de 1926, p. 3.

345. El Heraldo, "Todavía Tacna y Arica", 16 de febrero de 1929, p. 3.

346. El Heraldo, "Todavía Tacna y Arica", 18 de marzo de 1925, p. 4.

347. El Heraldo, "Trabajos de la Comisión Plebiscitaria sobre Tacna y Arica", 11 de agosto de 1925, p. 4.

348. El Heraldo, "Un discurso del presidente de Chile", 10 de julio de 1929, p. 15.

349. El Heraldo, "Un duelo entre dos políticos peruanos", 8 de julio de 1929, p. 3.

350. El Heraldo, "Una carta de la Legación del Perú", 28 de octubre de 1924, p. 5.

351. El Heraldo, "Una comunicación del señor Villegas sobre la solución del pleito de Tacna y Arica", 13 de junio de 1929, p. 1.

352. El Heraldo, "Una explicación de la Legación de Bolivia sobre el reciente complot", 15 de octubre de 1929, p. 2.

353. El Heraldo, "Una nueva guerra", 27 de noviembre de 1918, p. 3.

354. El Heraldo, "Unión Iberoamericana", 17 de diciembre de 1926, p. 5.

355. El Heraldo, "Ya está abierto el censo plebiscitario", 30 de marzo de 1926, p. 2.

356. El Heraldo, "Ya se compran hasta los votos en el plebiscito sobre Tacna y Arica",

27 de agosto de 1925, p. 6.

357. El Imparcial, "(Por correo)", 10 de mayo de 1891, p. 2.

358. El Imparcial, "Aceptación del arbitraje”, 19 de julio de 1922, p. 4.

359. El Imparcial, "Actitud del Gobierno de Chile", 7 de enero de 1922, p. 2.

360. El Imparcial, “Acuerdos de la Cámara peruana”, 19 de marzo de 1925, p. 4.

361. El Imparcial, "Agencia Fabra", 12 de octubre de 1880, p. 2.

362. El Imparcial, "Agencia Fabra”, 13 de junio de 1880, p. 3.

363. El Imparcial, "Agencia Fabra", 2 de diciembre de 1880, p. 2.

364. El Imparcial, "Alessandri, en funciones”, 26 de marzo de 1925, p. 1.

365. El Imparcial, "Allá ustedes", 11 de marzo de 1925, p. 1.

366. El Imparcial, "Alrededor del mundo", 9 de noviembre de 1885, p. 2.

367. El Imparcial, "América, satisfecha de la solución del conflicto", 5 de junio de 1929, p. 1.

368. El Imparcial, "Arbitraje por España", 1 de mayo de 1898. p. 3.

369. El Imparcial, "Ayer fue firmado el acuerdo", 21 de julio de 1922, p. 1.

370. El Imparcial, "Ayer fue firmado el protocolo entre Chile y Perú", 30 de julio de 1929, p. 1. 
371. El Imparcial, "Ayer llegaron los aviadores a Lima”, 24 de abril de 1929, p. 8.

372. El Imparcial, "Ayer llegó a Madrid el ex presidente D. Bautista Saavedra”, 13 de marzo de 1929, p. 3.

373. El Imparcial, "Bolivia quiere participar en las negociaciones", 27 de enero de 1922, p. 3.

374. El Imparcial, "Bolivia solicitó ser admitida en las negociaciones de Washington", 24 de enero de 1922, p. 3.

375. El Imparcial, "Bolivia y Paraguay tratarán directamente", 17 de septiembre de 1929 , p. 1.

376. El Imparcial, "Bolivia", de octubre de 1929, p. 5.

377. El Imparcial, "Brillante recibimiento de la misión española en Chile", 21 de noviembre de 1920, p. 1.

378. El Imparcial, "Carta del Pacífico", 10 de febrero de 1880, p. 2.

379. El Imparcial, "Chile rechaza el arbitraje de Inglaterra", 5 de julio de 1921, p. 3

380. El Imparcial, "Chile y el Perú. Arbitraje de la Reina Regente de España", 8 de julio de 1898, p. 2.

381. El Imparcial, "Chile y el Perú", 27 de enero de 1909, p. 1.

382. El Imparcial, "Chile y el Perú", 7 de agosto de 1920, p. 1.

383. El Imparcial, "Chile y Perú", 15 de marzo de 1911, p. 1.

384. El Imparcial, "Chile y Perú", 22 de marzo de 1910, p. 3.

385. El Imparcial, "Chile", 18 de abril de 1929, p. 5.

386. El Imparcial, "Chile”, 18 de mayo de 1929, p. 5.

387. El Imparcial, "Chile", 21 de julio de 1929, p. 5.

388. El Imparcial, "Chile", 25 de abril de 1929, p. 5.

389. El Imparcial, "Chile", 25 de julio de 1929, p. 5.

390. El Imparcial, "Chilenos y peruanos", 25 de abril de 1910, p. 1.

391. El Imparcial, "Choques entre chilenos y peruanos", 8 de enero de 1926, p. 3.

392. El Imparcial, "Combates en la frontera”, 18 de diciembre de 1928, p. 1.

393. El Imparcial, "Cómo ganó la laureada el Sargento García”, 14 de junio de 1929, p. 1.

394. El Imparcial, "Conferencias de ayer", 17 de diciembre de 1926, p. 5.

395. El Imparcial, "Conflicto chileno-peruano", 23 de marzo de 1910, p. 1.

396. El Imparcial, "Coolidge dicta su fallo", 10 de marzo de 1925, p. 2.

397. El Imparcial, "Despachos breves del extranjero", 1 de abril de 1922, p. 2.

398. El Imparcial, "Despachos breves del extranjero", 11 de marzo de 1922, p. 4.

399. El Imparcial, "Despachos breves del extranjero", 15 de septiembre de 1922, p. 4.

400. El Imparcial, "Despachos breves del extranjero", 2 de abril de 1922, p. 4.

401. El Imparcial, "Despachos breves del extranjero", 23 de febrero de 1922, p. 4.

402. El Imparcial, "Despachos breves del extranjero", 28 de diciembre de 1921, p. 2.

403. El Imparcial, "Despachos breves del extranjero", 4 de junio de 1922, p. 4.

404. El Imparcial, "Despachos telegráficos. Agencia Fabra", 11 de junio de 1880, p. 3. 
405. El Imparcial, "Despachos telegráficos. Agencia Fabra", 31 de mayo de 1880, p. 1.

406. El Imparcial, "Dice la Legación de Chile", 26 de noviembre de 1925, p. 5.

407. El Imparcial, "El arbitraje de los Estados Unidos", 28 de agosto de 1924, p. 3.

408. El Imparcial, "El arbitraje yanqui", 29 de julio de 1924, p. 4.

409. El Imparcial, "El conflicto chileno-peruano", 15 de enero de 1919, p. 4.

410. El Imparcial, "El conflicto entre Perú y Chile", 21 de diciembre de 1921, p. 1.

411. El Imparcial, "El congreso peruano ratifica el acuerdo", 4 de julio de 1929, p. 5.

412. El Imparcial, "El fallo de Míster Coolidge", 17 de marzo de 1925, p. 1.

413. El Imparcial, "El ferrocarril chileno-boliviano", 15 de mayo de 1913, p. 4.

414. El Imparcial, "El Gobierno presenta un proyecto de defensa nacional", 17 de agosto de 1920, p. 2.

415. El Imparcial, "El incidente entre Chile y el Perú", 26 de diciembre de 1918, p. 3.

416. El Imparcial, "El Jesús del Gran Poder en Arica", 23 de abril de 1929, p. 5.

417. El Imparcial, "El Jesús del Gran Poder, mensajero de paz”, 19 de abril de 1929,

p. 5 .

418. El Imparcial, "El litigio de Tacna y Arica", 19 de junio de 1926, p. 3.

419. El Imparcial, "El noble gesto de caridad de Brasil", 20 de noviembre de 1929, p. 4.

420. El Imparcial, "El Perú contesta a Norteamérica", 23 de diciembre de 126, p. 8.

421. El Imparcial, "El Perú, disgustado", 18 de marzo de 1925, p. 5.

422. El Imparcial, "El plebiscito no es solución", 21 de marzo de 1925, p. 2.

423. El Imparcial, "El pleito de Tacna y Arica lleva visos de terminarse", 3 de enero de 1922, p. 3.

424. El Imparcial, "El pleito de Tacna y Arica no está resuelto", 21 de febrero de 1929, p. 3.

425. El Imparcial, "El pleito de Tacna y Arica", 18 de julio de 1924, p. 4.

426. El Imparcial, "El pleito de Tacna y Arica", 19 de mayo de 1929, p. 5.

427. El Imparcial, "El pleito de Tacna y Arica", 21 de junio de 1924, p. 4.

428. El Imparcial, "El pleito de Tacna y Arica", 6 de febrero de 1924, p. 2.

429. El Imparcial, "El pleito de Tacna y Arica", 8 de diciembre de 1925, p. 5.

430. El Imparcial, "El pleito entre Bolivia y el Perú", 20 de marzo de 1920, p. 3.

431. El Imparcial, "El pleito entre Bolivia y el Perú", 23 de marzo de 1920, p.1.

432. El Imparcial, "El pleito interminable", 9 de septiembre de 1926, p. 5.

433. El Imparcial, "El premio Nobel para Leguía", 28 de noviembre de 1929, p. 5.

434. El Imparcial, "El premio Nobel para los presidentes de Chile y Perú", 1 de noviembre de 1929, p. 2.

435. El Imparcial, "El premio Nobel para los presidentes de Chile y Perú", 6 de noviembre de 1929 , p. 3.

436. El Imparcial, "El premio Nobel para los presidentes de Chile y Perú", 30 de octubre de 1929, p. 1.

437. El Imparcial, "El problema del Pacífico", 6 de octubre de 1928, p. 10. 
438. El Imparcial, "El reingreso del Perú", 28 de julio de 1928, p. 9.

439. El Imparcial, "El Tratado de Tacna y Arica", 4 de agosto de 1929, p. 5.

440. El Imparcial, "En Chile se juzga un triunfo", 12 de marzo de 1925, p. 3.

441. El Imparcial, "En el centenario de Ayacucho", 10 de diciembre de 1924, p. 1.

442. El Imparcial, "En la Academia de Jurisprudencia", 28 de mayo de 1929, p. 3.

443. El Imparcial, "En vísperas del plebiscito", 14 de mayo de 1925, p. 1.

444. El Imparcial, "Entrega del Tratado sobre Tacna-Arica", 26 de septiembre de 1929,

p. 5.

445. El Imparcial, "Entrega oficial de Arica", 5 de septiembre de 1929, p. 3.

446. El Imparcial, "Epistolario hispanoamericano", 24 de octubre de 1928, p. 10.

447. El Imparcial, "Españas y las repúblicas hispanoamericanas”, 31 de julio de 1925,

p. 1 .

448. El Imparcial, "Ferrocarril Americano", 29 de mayo de 1912, p. 4.

449. El Imparcial, "Fracaso de la Conferencia chilenoperuana", 13 de julio de 1922, p. 4.

450. El Imparcial, "Graves desórdenes en Chile", 25 de julio de 1920, p. 1.

451. El Imparcial, "Ha quedado resuelto el problema de Tacna y Arica", 22 de febrero de 1929, p. 1.

452. El Imparcial, "Hoy hace sesenta años", 15 de septiembre de 1928, p. 3.

453. El Imparcial, "Imposición de insignias al Marqués de Estella", 16 de julio de 1929, p. 8.

454. El Imparcial, "Incidente resuelto", 16 de enero de 1926, p. 2.

455. El Imparcial, "Incidentes entre Chile y el Perú", 16 de junio de 1926, p. 1.

456. El Imparcial, "Información cablegráfica de América", 12 de noviembre de 1921, p. 3.

457. El Imparcial, "Información cablegráfica de América", 27 de agosto de 1922, p. 5.

458. El Imparcial, "Información cablegráfica de América", 7 de noviembre de 1920, p. 3.

459. El Imparcial, "Información cablegráfica. De la Agencia Americana", 13 de agosto de 1922, p. 4.

460. El Imparcial, "Inocencia", 11 de abril de 1928, p. 2.

461. El Imparcial, "La América del Sur”, 22 de octubre de 1881, p. 2.

462. El Imparcial, "La colonia Sueca en Lima pide el premio Nobel para Leguía", 12 de noviembre de 1929, p. 5.

463. El Imparcial, "La cuestión chileno peruana", 31 de agosto de 1898, p. 1.

464. El Imparcial, "La cuestión de Tacna y Arica", 10 de enero de 1922, p. 1.

465. El Imparcial, "La cuestión de Tacna y Arica", 11 de enero de 1922, p. 2.

466. El Imparcial, "La cuestión de Tacna y Arica", 13 de diciembre de 1922, p. 1.

467. El Imparcial, "La cuestión de Tacna y Arica", 15 de julio de 1922, p. 2.

468. El Imparcial, "La cuestión de Tacna y Arica", 22 de enero de 1922, p. 2.

469. El Imparcial, "La cuestión de Tacna y Arica", 4 de mayo de 1929, p. 1. 
470. El Imparcial, "La cuestión del Pacífico", 3 de julio de 1925, p. 4.

471. El Imparcial, "La cuestión del Pacífico", 6 de mayo de 1925, p. 2.

472. El Imparcial, "La dulce paz de la aldea...", 11 de julio de 1928, p. 4.

473. El Imparcial, "La Embajada española en Chile", 23 de noviembre de 1920, p. 2.

474. El Imparcial, "La entrega de Tacna", 29 de agosto, p. 3.

475. El Imparcial, "La fecha del plebiscito", 11 de diciembre de 1925, p. 2.

476. El Imparcial, "La misión española a Chile", 11 de noviembre de 1920, p. 2.

477. El Imparcial, "La Misión española llega a Arica", 20 de noviembre de 1920, p. 1.

478. El Imparcial, "La política de aproximación de los Estados Unidos", 3 de junio de

1924, p. 4.

479. El Imparcial, "La quinta Conferencia panamericana", 19 de enero de 1922, p. 4.

480. El Imparcial, "La reelección el presidente señor Leguía", 15 de octubre de 1929,

p. 5.

481. El Imparcial, "La revolución chilena", 17 de febrero de 1891, p. 1.

482. El Imparcial, "La revolución de Bolivia", 18 de julio de 1920, p. 1.

483. El Imparcial, "La solución del pleito Tacna-Arica", 20 de junio de 1929, p. 1.

484. El Imparcial, "La sustitución de Pershing", 14 de enero de 1926, p. 6.

485. El Imparcial, "La Unión Iberoamericana", 13 de octubre de 1929, p. 2.

486. El Imparcial, "Las comunicaciones de España con las repúblicas del Pacífico", 2

de octubre de 1928, p. 10.

487. El Imparcial, "Las conferencias de ayer", 8 de mayo de 1926, p. 5.

488. El Imparcial, "Las relaciones entre Bolivia y el Perú", 9 de mayo de 1920, p. 1.

489. El Imparcial, "Líneas de vapores chilenos a Europa", 13 de julio de 1928, p. 13.

490. El Imparcial, "Llegada del general Pershing", 4 de agosto de 1925, p. 2.

491. El Imparcial, "Los aviadores españoles en Lima", 25 de abril de 1929, p. 8.

492. El Imparcial, "Los aviadores españoles en Lima”, 26 de abril de 1929, p. 5.

493. El Imparcial, "Los españoles en América", 11 de abril de 1902, p. 2.

494. El Imparcial, "Los ingleses en el Pacífico", 4 de febrero de 1881, p. 1.

495. El Imparcial, "Los triunfos de Querol”, 10 de junio de 1902, p. 1.

496. El Imparcial, "Manifestaciones en favor de Alessandri”, 28 de enero de 1925, p. 4.

497. El Imparcial, "No hubo movimiento revolucionario", 8 de octubre de 1929, p. 5.

498. El Imparcial, "Noticas de América", 9 de junio de 1928, p. 5.

499. El Imparcial, "Noticias de América", 1 de diciembre de 1925, p. 4.

500. El Imparcial, "Noticias de América", 10 de febrero de 1925, p. 5.

501. El Imparcial, "Noticias de América", 10 de septiembre de 1926, p. 3.

502. El Imparcial, "Noticias de América", 11 de diciembre de 1925, p. 4.

503. El Imparcial, "Noticias de América", 11 de febrero de 1926, p. 5.

504. El Imparcial, "Noticias de América", 11 de noviembre de 1925, p. 5.

505. El Imparcial, "Noticias de América", 13 de agosto de 1926, p. 7.

506. El Imparcial, "Noticias de América", 13 de enero de 1926, p. 5.

507. El Imparcial, "Noticias de América", 13 de junio de 1926, p. 4. 
508. El Imparcial, "Noticias de América", 13 de noviembre de 1925, p. 5.

509. El Imparcial, "Noticias de América", 14 de agosto de 1925, p. 2.

510. El Imparcial, "Noticias de América", 14 de octubre de 1925, p. 5.

511. El Imparcial, "Noticias de América", 15 de julio de 1925, p. 3.

512. El Imparcial, "Noticias de América", 16 de agosto de 1925, p. 4.

513. El Imparcial, "Noticias de América", 17 de junio de 1926, p. 4.

514. El Imparcial, "Noticias de América", 18 de agosto de 1925, p. 3.

515. El Imparcial, "Noticias de América", 18 de julio de 1925, p. 5.

516. El Imparcial, "Noticias de América", 18 de marzo de 1926, p. 3.

517. El Imparcial, "Noticias de América", 18 de mayo de 1926, p. 2.

518. El Imparcial, "Noticias de América", 19 de enero de 1928, p. 3.

519. El Imparcial, "Noticias de América", 2 de abril de 1926, p. 2.

520. El Imparcial, "Noticias de América", 20 de agosto de 1926, p. 7.

521. El Imparcial, "Noticias de América", 20 de marzo de 1926, p. 2.

522. El Imparcial, "Noticias de América", 22 de agosto de 1925, p. 3.

523. El Imparcial, "Noticias de América", 22 de octubre de 1926, p. 2.

524. El Imparcial, "Noticias de América", 22 de septiembre de 1925, p. 3.

525. El Imparcial, "Noticias de América", 22 de septiembre de 1926, p. 5.

526. El Imparcial, "Noticias de América", 24 de abril de 1925, p. 5.

527. El Imparcial, "Noticias de América", 25 de abril de 1925, p. 5.

528. El Imparcial, "Noticias de América", 25 de junio de 1924, p. 4.

529. El Imparcial, "Noticias de América", 25 de junio de 1926, p. 2.

530. El Imparcial, "Noticias de América", 27 de junio de 1925, p. 4.

531. El Imparcial, "Noticias de América", 29 de agosto de 1924, p. 4.

532. El Imparcial, "Noticias de América", 29 de junio de 1924, p. 4.

533. El Imparcial, "Noticias de América", 29 de junio de 1926, p. 2.

534. El Imparcial, "Noticias de América", 29 de mayo de 1926, p. 2.

535. El Imparcial, "Noticias de América", 3 de febrero de 1926, p. 6.

536. El Imparcial, "Noticias de América", 30 de julio de 1925, p. 2.

537. El Imparcial, "Noticias de América", 30 de septiembre de 1925, p. 2.

538. El Imparcial, "Noticias de América", 31 de julio de 1925, p. 4.

539. El Imparcial, "Noticias de América", 4 de junio de 1926, p. 7.

540. El Imparcial, "Noticias de América", 4 de noviembre de 1925, p. 6.

541. El Imparcial, "Noticias de América", 5 de agosto de 1925, p. 3.

542. El Imparcial, "Noticias de América", 5 de diciembre de 1925, p. 2.

543. El Imparcial, "Noticias de América", 5 de febrero de 1925, p. 5.

544. El Imparcial, "Noticias de América", 5 de junio de 1926, p. 5.

545. El Imparcial, "Noticias de América", 5 de noviembre de 1926, p. 5.

546. El Imparcial, "Noticias de América", 6 de agosto de 1925, p. 4.

547. El Imparcial, "Noticias de América", 6 de diciembre de 1924, p. 3.

548. El Imparcial, "Noticias de América", 6 de octubre de 1925, p. 5. 
549. El Imparcial, "Noticias de América", 7 de diciembre de 1924, p. 4.

550. El Imparcial, "Noticias de América", 8 de julio de 1925, p. 4.

551. El Imparcial, "Noticias de América", 9 de agosto de 1925, p. 1.

552. El Imparcial, "Noticias de América", 9 de diciembre de 1925, p. 6.

553. El Imparcial, "Noticias de Sud-América", 14 de junio de 1881, p. 3.

554. El Imparcial, "Optimismo en Chile", 3 de agosto de 1924, p. 4.

555. El Imparcial, "Parece ser que Perú acepta la proposición chilena", 20 de marzo de 1929, p. 1.

556. El Imparcial, "Pershing, inspector del plebiscito", 28 de marzo de 1925, p. 4.

557. El Imparcial, "Perú acepta el plebiscito", 24 de marzo de 1925, p. 1.

558. El Imparcial, "Perú", 14 de julio de 1929, p. 5.

559. El Imparcial, "Perú", 22 de mayo de 1929, p. 5.

560. El Imparcial, "Perú", 23 de mayo de 1929, p. 5.

561. El Imparcial, "Perú", 26 de julio de 1929, p. 5.

562. El Imparcial, "Perú", 3 de octubre de 1929, p. 5.

563. El Imparcial, "Política de concordia entre Chile y Bolivia", 10 de junio de 1920, p. 3.

564. El Imparcial, "Preparando el plebiscito", 5 de julio de 1925, p. 3.

565. El Imparcial, "Preparando el plebiscito", 9 de julio de 1925, p. 2.

566. El Imparcial, "Preparativos para el plebiscito", 10 de abril de 1925, p. 5.

567. El Imparcial, "Prosiguen los comentarios", 13 de marzo de 1925, p. 1.

568. El Imparcial, "Reglamento de Policía fronteriza entre Chile y Perú", 15 de agosto de 1929 , p. 5.

569. El Imparcial, "Relato e impresiones de un viaje", 12 de abril de 1921, p. 3.

570. El Imparcial, "Resolución definitiva del pleito", 19 de mayo de 1929, p. 1.

571. El Imparcial, "Reuniones y Sociedades", 6 de mayo de 1926, p. 6.

572. El Imparcial, "Sacerdotes expulsados", 7 de marzo de 1910, p. 1.

573. El Imparcial, "Satisfacción en Chile", 11 de marzo de 1925, p. 3.

574. El Imparcial, "Se agrava la cuestión”, 27 de noviembre de 1925, p. 1.

575. El Imparcial, "Se confía en una solución amistosa", 23 de marzo de 1922, p. 2.

576. El Imparcial, "Se conjura un movimiento revolucionario", 11 de agosto de 1920, p. 2.

577. El Imparcial, "Se cree inminente la guerra entre Bolivia y Perú", 19 de marzo de 1920, p. 1.

578. El Imparcial, "Se inaugura en la exposición la semana chilena", 22 de octubre de 1929, p. 4.

579. El Imparcial, "Se pide la militarización del Perú", 2 de marzo de 1922, p. 1.

580. El Imparcial, "Se teme al arbitraje de Norte América", 11 de marzo de 1922, p. 2.

581. El Imparcial, "Sección de Noticias", 11 de marzo de 1880, p. 3.

582. El Imparcial, "Sección de noticias", 13 de diciembre 1888, p. 6.

583. El Imparcial, "Sección de noticias", 13 de noviembre de 1882, p. 1. 
584. El Imparcial, "Sección de noticias", 13 de noviembre de 1888, p. 6.

585. El Imparcial, "Sección de Noticias", 19 de enero de 1880, p. 1.

586. El Imparcial, "Sección de noticias", 22 de mayo de 1883, p. 3.

587. El Imparcial, "Sección de noticias", 28 de marzo de 1884, p. 3.

588. El Imparcial, "Sección de noticias", 31 de marzo de 1892, p. 3.

589. El Imparcial, "Sección de noticias", 7 de julio de 1882, p. 2.

590. El Imparcial, "Sección de noticias", 7 de marzo de 1885, p. 2.

591. El Imparcial, "Sección de noticias", 8 de noviembre de 1882, p. 3.

592. El Imparcial, "Sesión pública", 14 de junio de 1929, p. 8.

593. El Imparcial, "Sobre el liquidado pleito de Tacna y Arica", 18 de octubre de 1928,

p. 10.

594. El Imparcial, "Solución del problema", 20 de mayo de 1926, p. 3.

595. El Imparcial, "Subsiste la disparidad de criterios", 30 de diciembre de 1921, p. 1.

596. El Imparcial, "Tacna y Arica”, 17 de junio de 1926, p. 3.

597. El Imparcial, "Tacna y Arica", 3 de mayo de 1929, p. 5.

598. El Imparcial, "Tacna y Arica”, 6 de enero de 1925, p. 3.

599. El Imparcial, “Tarapacá será del Perú”, 2 de septiembre de 1925, p. 4.

600. El Imparcial, "Telegramas (de la Agencia Fabra)", 28 de mayo de 1883, p. 1.

601. El Imparcial, "Todavía tienen que ocuparse de Tacna y Arica”, 5 de julio de 1929,

p. 5.

602. El Imparcial, "Un arbitraje de España", 20 de septiembre de 1898, p. 3.

603. El Imparcial, "Una nota de la legación del Perú", 14 de noviembre de 1925, p. 1.

604. El Imparcial, "Una nota del gobierno a la Cancillería boliviana", 3 de marzo de 1920, p. 4.

605. El Imparcial, "Una obra de Querol”, 26 de enero de 1903, p. 3.

606. El Imparcial, "Varias noticias", 26 de enero de 1910, p. 2.

607. El Liberal, "Argentinos y chilenos", 30 de diciembre de 1901, p. 1.

608. El Liberal, "Barco de emigrantes", 3 de abril de 1907, p. 2.

609. El Liberal, "Chile y España", 9 de septiembre de 1882, p. 1.

610. El Liberal, "Chile", 13 de abril de 1891, p. 2.

611. El Liberal, "Chilenos y peruanos", 27 de febrero de 1905, p. 2.

612. El Liberal, "Después del Congreso", 4 de septiembre de 1906, p. 1.

613. El Liberal, "El conflicto chileno-peruano", 26 de diciembre de 1918, p. 2.

614. El Liberal, "El monumento a Bolognesi", 26 de enero de 1903, p. 3.

615. El Liberal, "El Telégrafo. Agencia Fabra", 12 de octubre de 1880, p. 3.

616. El Liberal, "El Telégrafo. Agencia Fabra", 13 de junio de 1880, p. 4.

617. El Liberal, "El Telégrafo. Agencia Fabra", 29 de enero de 1881, p. 3.

618. El Liberal, "El Telégrafo. Agencia Fabra", 31 de mayo de 1880, p. 3.

619. El Liberal, "El Telégrafo. Perú”, 31 de marzo de 1892, p. 2.

620. El Liberal, "El Telégrafo", 11 de junio de 1880, p. 3.

621. El Liberal, "El telégrafo", 13 de noviembre de 1882, p. 1. 
622. El Liberal, "El Telégrafo", 20 de mayo de 1882, p. 2.

623. El Liberal, "En Tacna y Arica", 31 de agosto de 1906, p. 2.

624. El Liberal, "Extranjero. Chile y Perú", 14 de julio de 1880, p. 1.

625. El Liberal, "Extranjero. El Telégrafo", 28 de mayo de 1883, p. 1.

626. El Liberal, "Extranjero", 10 de enero de 1881, p. 1.

627. El Liberal, "Extranjero", 30 de abril de 1880, p. 1.

628. El Liberal, "Extranjero", 5 de abril de 1880, p. 1.

629. El Liberal, "La deuda de Chile", 6 de mayo de 1907, p. 3.

630. El Liberal, "Situación económica de Chile", 8 de junio de 1906, p. 3.

631. El Mentidero, "Dos puntos filipinos", n. ${ }^{\circ}$ 470, 4 de marzo de 1922, p. 3.

632. El Mentidero, "El estómago de Francos", 22 de enero de 1921, p. 6.

633. El Mentidero, "Que les den Antofagasta", 27 de marzo de 1920, p. 14.

634. El Mundo de los Niños, "De Barcelona a Manila", 10 de julio de 1888, p. 6.

635. El Mundo Ilustrado, "Historia Natural del Hombre", n. ${ }^{\circ}$ 147, Año 1883, p. 76.

636. El Mundo Ilustrado, "Las fuerzas terrestres y marítimas de Chile, Perú y Bolivia en la guerra actual”, año 1880 , n. ${ }^{\circ} 39$, pp. 470-471.

637. El Mundo Naval Ilustrado, "Tacna y Arica”, 1 de septiembre de 1898, p. 18.

638. El Nuevo Régimen, "América”, 23 de noviembre de 1895, p. [i?]

639. El Nuevo Régimen, "Chile y Buenos Aires", 27 de marzo de 1897, p. 1.

640. El Nuevo Régimen, "Chile y el Perú”, 13 de mayo de 1899, p. 1.

641. El Nuevo Régimen, "Chile", 9 de junio de 1894, p. 4.

642. El Nuevo Régimen, "El Congreso del Haya", 12 de agosto de 1899, p. 1.

643. El Nuevo Régimen, "Extranjero. Chile", 12 de febrero 1898, p. 2.

644. El Nuevo Régimen, "Extranjero. Chile”, 19 de mayo de 1894, p. 3.

645. El Nuevo Régimen, "Extranjero", 30 de septiembre de 1912, p. 5.

646. El Nuevo Régimen, "Las Alianzas", 17 de noviembre de 1900, p. 1.

647. El Nuevo Régimen, "Las Repúblicas Meridionales de América", 17 de diciembre de 1898 , p. 2.

648. El Nuevo Régimen, "Revista de la semana", 13 de junio de 1891, p. 7.

649. El Nuevo Régimen, "Tacna y Arica”, 13 de octubre de 1900, p. 1.

650. El País, "Chile y Perú", 25 de julio de 1920, p. 2.

651. El País, "D. Mariano José Madueño", 5 de mayo de 1908, p. 5.

652. El País, "De Arte", 9 de diciembre de 1901, p. 2.

653. El País, "Desórdenes políticos en Chile", 13 de octubre de 1920, p. 3.

654. El País, "El nuevo presidente de la República Doctor Roque Sáenz Peña", 12 de octubre de 1910, p. 19.

655. El País, "El Perú y Chile. Una circular telegráfica", 11 de enero de 1919, p. 3.

656. El Pais, "Extranjero (de la Agencia Fabra). Congreso de Chile", 3 de junio de 1896, p. 3.

657. El País, "Inundaciones", 17 de febrero de 1911, p. 2.

658. El País, "La cuestión de los límites", 16 de marzo de 1911, p. 3. 
659. El País, "La revolución de Chile (por telégrafo)", 22 de febrero de 1891, p. 3.

660. El País, "Las relaciones entre Chile y Perú", 26 de diciembre de 1918, p. 2.

661. El País, "Los puertos de Chile", 11 de marzo de 1911, p. 2.

662. El País, "Mensaje presidencial", 14 de agosto de 1897, p. 2.

663. El País, "Negociaciones de paz", 23 de julio de 1898, p. 2.

664. El País, "Servicio telegráfico. Insurrecciones chilenas", 12 de abril de 1891, p. 6.

665. El País, "Terremoto", 31 de marzo de 1892, p. 2.

666. El Siglo Futuro, "El conflicto entre Chile y Perú", 3 de enero de 1919, p. 3.

667. El Siglo Futuro, (sin título), 29 de mayo de 1909, p. 3.

668. El Siglo Futuro, “¿El Rey de España, árbitro en el pleito de Tacna-Arica?”, 8 de julio de1926, p. 2.

669. El Siglo Futuro, “QQué ocurre en Valparaíso?”, 13 de octubre de 1920, p. 2.

670. El Siglo Futuro, "Acuerdos del Consejo de Ministros celebrados anoche", 18 de abril de 1929, p. 2.

671. El Siglo Futuro, "América del Sud", 3 de abril de 1880, p. 2.

672. El Siglo Futuro, “América del Sur”, 16 de febrero de 1882, p. 3.

673. El Siglo Futuro, “América del Sur”, 28 de junio de 1880, p. 2.

674. El Siglo Futuro, "América del Sur", 9 de marzo de 1880, p. 3.

675. El Siglo Futuro, “América Ecuatorial”, 16 de febrero de 1880, p. 3.

676. El Siglo Futuro, “América”, 2 de octubre de 1880, p. 3.

677. El Siglo Futuro, "América", 23 de febrero de 1880, p. 3.

678. El Siglo Futuro, “Arbitraje de España entre Chile y el Perú”, 5 de julio de 1898, p. 1.

679. El Siglo Futuro, "Bolsas extranjeras", 28 de noviembre de 1907, p. 3.

680. El Siglo Futuro, "Cambio Diplomático", 18 de agosto de 1928, p. 6.

681. El Siglo Futuro, "Chile acepta el arbitraje”, 22 de diciembre de 1921, p. 2.

682. El Siglo Futuro, "Chile y el Perú", 13 de diciembre de 1918, p. 1.

683. El Siglo Futuro, "Chile y Perú", 19 de diciembre de 1918, p. 1.

684. El Siglo Futuro, "Chile y Perú", 2 de noviembre de 1911, p. 3.

685. El Siglo Futuro, "Chile y Perú", 23 de enero de 1922, p. 4.

686. El Siglo Futuro, "Chile y Perú", 26 de diciembre de 1918, p. 1.

687. El Siglo Futuro, "Chile y Perú", 27 de enero de 1909, pp. 2-3.

688. El Siglo Futuro, "Chile", 10 de marzo de 1880, p. 3.

689. El Siglo Futuro, "Chile”, 8 de julio de 1929, p. 2.

690. El Siglo Futuro, "Condecoraciones chilenas a Millán Astray, Jiménez e Iglesias”,

8 de octubre de 1929, p. 2.

691. El Siglo Futuro, "Conflicto entre el Ecuador y el Perú”, 28 de junio de 1884, p. 3.

692. El Siglo Futuro, "De Chile", 22 de enero de 1909, p. 3.

693. El Siglo Futuro, "De la situación del pleito de Tacna y Arica", 3 de mayo de 1929, p. 5.

694. El Siglo Futuro, "Del extranjero", 1 de diciembre de 1926, p. 3. 
695. El Siglo Futuro, "Del Perú”, 22 de marzo de 1910, p. 3.

696. El Siglo Futuro, "Detalles del último golpe de Estado", 16 de julio de 1920, p. 1.

697. El Siglo Futuro, "Discurso del presidente Ibáñez acerca de la solución del pleito de

Tacna y Arica", 11 de julio de 1929, p. 6.

698. El Siglo Futuro, "El acuerdo sobre Tacna y Arica", 2 de julio de 1929, p. 3.

699. El Siglo Futuro, "El conflicto chileno-peruano", 12 de agosto de 1926, p. 2.

700. El Siglo Futuro, "El conflicto chilenoperuano", 16 de diciembre de 1921, p. 1.

701. El Siglo Futuro, "El conflicto de Tacna y Arica", 6 de diciembre de 1926, p. 3.

702. El Siglo Futuro, "El conflicto entre Bolivia y Perú resuelto", 23 de marzo de 1920, p. 1.

703. El Siglo Futuro, "El general revolucionario Ismael Montes", 15 de octubre de 1929, p. 6.

704. El Siglo Futuro, "El jacobinismo en Chile", 22 de marzo de 1910, p. 2.

705. El Siglo Futuro, "El Jesús del Gran Poder aterrizó en Arica", 23 de abril de 1929, p. 2.

706. El Siglo Futuro, "El mensaje del Presidente al Parlamento", 23 de mayo de 1929, p. 3.

707. El Siglo Futuro, "El mensaje presidencial a la Cámara chilena", 2 de junio de 1921, p. 1.

708. El Siglo Futuro, "El pacto decisivo de la cuestión chileno-peruano", 3 de mayo de 1929 , p. 4.

709. El Siglo Futuro, "El Perú", 9 de noviembre de 1880, p. 3.

710. El Siglo Futuro, "El pleito de Tacna y Arica resuelto", 19 de mayo de 1926, p. 1.

711. El Siglo Futuro, "El pleito de Tacna y Arica", 13 de junio de 1929, p. 6.

712. El Siglo Futuro, "El pleito de Tacna-Arica”, 12 de julio de 1926, p. 1.

713. El Siglo Futuro, "El premio Nobel de la paz para los presidentes de Chile y Perú", 12 de octubre de 1929, p. 6.

714. El Siglo Futuro, "El Presidente de Chile", 14 de abril de 1909, p. 2.

715. El Siglo Futuro, "El viaje de Don Carlos", 8 de agosto de 1887, p. 1.

716. El Siglo Futuro, "Empréstito", 20 de marzo de 1906, p. 3.

717. El Siglo Futuro, "En las elecciones triunfan dos candidatos republicanos", 6 de mayo de 1925, p. 3.

718. El Siglo Futuro, "En Sevilla se inauguró ayer la semana chilena", 21 de octubre de 1929, p. 6.

719. El Siglo Futuro, "Entre Chile y Perú", 25 de marzo de 1920, p. 1.

720. El Siglo Futuro, "Entusiasta recibimiento en Lima a los aviadores de «Jesús del

Gran Poder»", 24 de abril de 1929, p. 2.

721. El Siglo Futuro, "Estados Unidos", 1 de febrero de 1882, p. 3.

722. El Siglo Futuro, "Extranjero", 25 de abril de 1894, p. 3.

723. El Siglo Futuro, "Extranjero", 26 de mayo de 1926, p. 3.

724. El Siglo Futuro, "Extranjero", 8 de enero de 1908, p. 1 
725. El Siglo Futuro, "Ferrocarril chileno", 30 de junio de 1909, p. 3.

726. El Siglo Futuro, "Fortificación de puertos", 11 de marzo de 1911, p. 3.

727. El Siglo Futuro, "Guerra del Pacífico", 1 de diciembre de 1880, p. 3.

728. El Siglo Futuro, "Guerra del Pacífico", 16 de junio de 1880, p. 3.

729. El Siglo Futuro, “Guerra en el Pacífico", 11 de junio de 1880, p. 2.

730. El Siglo Futuro, "Guerra en la América del Sur”, 8 de abril de 1880, p. 3.

731. El Siglo Futuro, "Imposición de insignias al Marqués de Estella", 16 de julio de 1929, p. 2.

732. El Siglo Futuro, "Información Iberoamericana", 10 de septiembre de 1926, p. 3.

733. El Siglo Futuro, "Información Iberoamericana", 22 de septiembre de 1926, p. 4.

734. El Siglo Futuro, "La cuestión de Tacna y Arica a punto de resolverse", 17 de abril de 1929, p. 6.

735. El Siglo Futuro, "La cuestión de Tacna y Arica", 14 de junio de 1926, p. 3.

736. El Siglo Futuro, "La cuestión de Tacna y Arica", 3 de julio de 1925, p. 4.

737. El Siglo Futuro, "La cuestión Tacna y Arica", 25 de enero de 1923, p. 1.

738. El Siglo Futuro, "La Guerra del Pacífico", 31 de enero de 1883, p. 2.

739. El Siglo Futuro, "La Guerra en el Pacífico", 19 de agosto de 1880, p. 3.

740. El Siglo Futuro, "La guerra en el Pacífico", 9 de agosto de 1880, p. 2.

741. El Siglo Futuro, "La mañana de hoy", 25 de noviembre de 1926, p. 2.

742. El Siglo Futuro, "La Misión a Chile", 10 de noviembre de 1920, p. 2.

743. El Siglo Futuro, "La revolución de Nicaragua y el pleito de Tacna y Arica", 5 de enero de 1927, p. 3.

744. El Siglo Futuro, "Las repúblicas americanas", 3 de abril de 1909, p. 3.

745. El Siglo Futuro, "Las Repúblicas Hispanoamericanas", 7 de agosto de 1926, p. 3.

746. El Siglo Futuro, "Llegada a Arica de la misión española que va a Chile", 20 de noviembre de 1920, p. 1.

747. El Siglo Futuro, "Lo de Tacna y Arica", 15 de junio de 1926, p. 3.

748. El Siglo Futuro, "Lo de Tacna y Arica", 17 de enero de 1927, p. 1.

749. El Siglo Futuro, "Los aviadores del Jesús del Gran Poder salieron hoy para Arica", 22 de abril de 1929, p. 6.

750. El Siglo Futuro, "Mejoras en Chile", 20 de abril de 1909, p. 3.

751. El Siglo Futuro, "Mensaje presidencial", 14 de agosto de 1897, p. 3.

752. El Siglo Futuro, "Miscelánea extranjera", 10 de diciembre de 1925, p. 3.

753. El Siglo Futuro, "Miscelánea extranjera", 19 de junio de 1926, p. 3.

754. El Siglo Futuro, "Noticias de Chile", 25 de marzo de 1891, p. 1.

755. El Siglo Futuro, "Noticias recientes del Pacífico", 4 de julio de 1884, p. 2.

756. El Siglo Futuro, "Nueva línea aérea", 26 de noviembre de 1929, p. 6.

757. El Siglo Futuro, "Parece que al fin se ha resuelto la cuestión de Tacna y Arica", 21 de febrero de 1929 , p. 6.

758. El Siglo Futuro, "Parece que el pleito se resolverá satisfactoriamente", 3 de enero de 1922, p. 1. 
759. El Siglo Futuro, "Patriotismo peruano", 24 de septiembre de 1886, p. 3.

760. El Siglo Futuro, "Perú y el Ecuador", 7 de abril de 1910, p. 2.

761. El Siglo Futuro, "Perú y el Ecuador", 9 de abril de 1910, p. 2.

762. El Siglo Futuro, "Pésimos signos en Sud-América", 5 de noviembre de 1886, p. 2.

763. El Siglo Futuro, "República de Bolivia y Chile", 7 de febrero de 1884, p. 2.

764. El Siglo Futuro, "República de Bolivia", 11 de mayo de 1885, p. 3.

765. El Siglo Futuro, "República peruana", 15 de diciembre de 1880, p. 3.

766. El Siglo Futuro, "República peruana", 29 de diciembre de 1880, p. 3.

767. El Siglo Futuro, "Repúblicas del Pacífico", 26 de octubre de 1880, p. 3.

768. El Siglo Futuro, "Repúblicas del Pacífico", 4 de noviembre de 1880, p. 2.

769. El Siglo Futuro, "Repúblicas Sudamericanas", 2 de junio de 1880, p. 3.

770. El Siglo Futuro, "Revista Extranjera", 5 de abril de 1884, p. 3.

771. El Siglo Futuro, "Se comenta la movilización de Chile", 19 de julio de 1920, p. 1.

772. El Siglo Futuro, "Se pide la militarización del Perú", 2 de marzo de 1922, p. 2.

773. El Siglo Futuro, "Sentencia arbitral del presidente de los Estados Unidos", 11 de marzo de 1925, p. 3.

774. El Siglo Futuro, "Servicio Telegráfico. Última hora”, 22 de enero de 1908, p. 3.

775. El Siglo Futuro, "Servicio Telegráfico. Última hora", 23 de noviembre de 1907, p. 3.

776. El Siglo Futuro, "Subsisten las discrepancias entre Chile y Perú", 30 de diciembre de 1921, p. 2.

777. El Siglo Futuro, "Telegrama. Mensaje del presidente de Chile", 2 de junio de 1894, p. 3.

778. El Siglo Futuro, "Telegramas [...] Recibidos a última hora”, 16 de mayo de 1883, p. 3.

779. El Siglo Futuro, "Telegramas Agencia Fabra", 15 de junio de 1880, p. 3.

780. El Siglo Futuro, "Telegramas Agencia Fabra”, 12 de junio de 1880, p. 3.

781. El Siglo Futuro, "Telegramas Agencia Fabra”, 12 de octubre de 1880, p. 3.

782. El Siglo Futuro, "Telegramas Agencia Fabra”, 14 de febrero de 1882, p. 4.

783. El Siglo Futuro, "Telegramas Agencia Fabra”, 19 de mayo de 1882, p. 3.

784. El Siglo Futuro, “Telegramas de la Agencia Fabra”, 31 de julio de 1898, p. 2.

785. El Siglo Futuro, "Telegramas. Agencia Fabra”, 10 de enero de 1883. p. 3.

786. El Siglo Futuro, "Telegramas. Agencia Fabra", 31 de mayo de 1880, p. 3.

787. El Siglo Futuro, “Telegramas. Terremoto”, 31 de marzo de 1892, p. 3.

788. El Siglo Futuro, "Terremoto", 27 de diciembre de 1906, p. 3.

789. El Siglo Futuro, "Una nota chilena", 25 de marzo de 1920, p. 1.

790. El Siglo Futuro, "Viaje de Don Carlos", 22 de agosto de 1887, p. 1.

791. El Sol, "A América por Europa", 23 de agosto de 1926, p. 1.

792. El Sol, "Actualidad diplomática hispanoamericana", 29 de enero de 1929, p. 2.

793. El Sol, "América", 7 de diciembre de 1926, p. 5.

794. El Sol, "Apreciaciones de un senador chileno", 27 de enero de 1927, p. 8. 
795. El Sol, "Arte militar", 25 de mayo de 1926, p. 2.

796. El Sol, "Aspectos diplomáticos del conflicto yanqui mejicano", 14 de septiembre de 1919, p. 4.

797. El Sol, "Ateneo. La Liga de las Naciones en su aspecto español. Conferencia de Salvador de Madariaga", 23 de enero de 1919, p. 3.

798. El Sol, "Aún queda justicia en el mundo", 27 de enero de 1926, p. 4.

799. El Sol, "Ayer se declaró clausurada la décima Asamblea", 26 de septiembre de 1929 , p. 5.

800. El Sol, "Banquete diplomático", 16 de febrero de 1928, p. 7.

801. El Sol, "Bolivia y el Perú", 29 de febrero de 1920, p. 7.

802. El Sol, "Bolivia y la solución de Tacna y Arica", 5 de mayo de 1929, p. 1.

803. El Sol, "Bolivia", 1 de marzo de 1929, p. 5.

804. El Sol, "Bolivia", 14 de enero de 1927, p. 5

805. El Sol, "Bolivia", 26 de enero de 1927, p. 5.

806. El Sol, "Bolivia", 5 de enero de 1927, p. 5.

807. El Sol, "Bolivia", 6 de abril de 1927, p. 5.

808. El Sol, "Chile ha firmado el acuerdo", 20 de mayo de 1925, p. 1.

809. El Sol, "Chile promete asistir a las sesiones", 30 de noviembre de 1925, p. 1.

810. El Sol, "Chile y la Liga de las Naciones", 22 de febrero de 1920, p. 7.

811. El Sol, "Chile, Perú y la Liga de las Naciones", 22 de julio de 1928, p. 7.

812. El Sol, "Chile", 11 de septiembre de 1927, p. 7.

813. El Sol, "Chile", 13 de diciembre de 1926, p. 5.

814. El Sol, "Chile", 13 de enero de 1927, p. 8.

815. El Sol, "Chile", 13 de julio de 1927, p. 5.

816. El Sol, "Chile", 15 de abril de 1927, p. 5.

817. El Sol, "Chile", 17 de junio de 1927, p. 5.

818. El Sol, "Chile", 18 de mayo de 1927, p. 5.

819. El Sol, "Chile", 2 de marzo de 1927, p. 5.

820. El Sol, "Chile", 20 de diciembre de 1926, p. 5.

821. El Sol, "Chile", 20 de junio de 1927, p. 5.

822. El Sol, "Chile", 20 de octubre de 1927, p. 7.

823. El Sol, "Chile", 24 de enero de 1927, p. 5.

824. El Sol, "Chile", 24 de febrero de 1924, p. 5.

825. El Sol, "Chile", 25 de mayo de 1927, p. 5.

826. El Sol, "Chile", 29 de mayo de 1929, p. 5.

827. El Sol, "Chile", 3 de enero de 1927, p. 5.

828. El Sol, "Chile", 3 de mayo de 1919, p. 4.

829. El Sol, "Chile", 30 de julio de 1929, p. 7.

830. El Sol, "Con motivo de un grave conflicto", 28 de noviembre de 1918, p. 1.

831. El Sol, "Conferencia del Ministro de Chile", 23 de febrero de 1927, p. 8.

832. El Sol, "Conflicto entre Chile y Perú", 15 de diciembre de 1921, p. 1. 
833. El Sol, "Conflicto entre Chile y Perú", 16 de diciembre de 1921, p. 5.

834. El Sol, "Conflicto entre Chile y Perú", 21 de diciembre de 1921, p. 5.

835. El Sol, "Contestación del Perú a la nota chilena", 30 de diciembre de 1921, p. 5.

836. El Sol, "Contra el capitalismo anglosajón”, 8 de febrero de 1927, p. 5.

837. El Sol, "Contra la embajada norteamericana en Lima”, 20 de marzo de 1925, p. 5.

838. El Sol, "Costes y Le Brix a Bolivia", 21 de diciembre de 1927, p. 5.

839. El Sol, "Declaraciones del ministro de Estado chileno", 15 de julio de 1926, p. 5.

840. El Sol, "Declaraciones del Ministro de Estado del Perú", 16 de julio de 1926, p. 5.

841. El Sol, "Declaraciones del Presidente Ibáñez", 24 de julio de 1928, p. 5.

842. El Sol, "Declaraciones del representante de Chile, sobre Tacna y Arica, en la

Sociedad de Naciones", 11 de diciembre de 1926, p. 7.

843. El Sol, "Desconfianza sobre la conducta de Bolivia", 10 de diciembre de 1926,

p. 5.

844. El Sol, "Desde Chile", 25 de julio de 1924, p. 4.

845. El Sol, "Desde el Perú", 14 de enero de 1926, p. 1.

846. El Sol, "Desde el Perú", 9 de octubre de 1925, p. 5.

847. El Sol, "Después del fallo de Mr. Coolidge", 1 de mayo de 1925, p. 2.

848. El Sol, "Documentos oficiales. La cuestión chilenoperuana", 26 de diciembre de 1918, p. 3.

849. El Sol, "Dos cartas que acaban de explicar el suceso", 2 de enero de 1926, p. 8.

850. El Sol, "Dos éxitos de la diplomacia americana a juicio del Presidente Coolidge",

15 de julio de 1928, p. 7.

851. El Sol, "El 15 de abril será el plebiscito", 17 de diciembre de 1925, p. 1.

852. El Sol, "El acuerdo de Tacna y Arica se comunicará hoy oficialmente", 17 de mayo de 1929, p. 5.

853. El Sol, "El aniversario de Washington se celebra también en París", 23 de febrero de 1926, p. 5.

854. El Sol, "El conflicto de Tacna y Arica", 15 de junio de 1926, p. 5.

855. El Sol, "El conflicto de Tacna y Arica", 10 de marzo de 1925, p. 1.

856. El Sol, "El conflicto de Tacna y Arica", 12 de marzo de 1925, p. 8.

857. El Sol, "El conflicto de Tacna y Arica", 16 de junio de 1926, p. 5.

858. El Sol, "El conflicto de Tacna y Arica", 17 de junio de 1926, p. 5.

859. El Sol, "El conflicto de Tacna y Arica", 19 de junio de 1926, p. 5.

860. El Sol, "El conflicto de Tacna y Arica", 24 de junio de 1926, p. 5.

861. El Sol, "El conflicto entre Chile y el Perú", 30 de noviembre de 1918, p. 6.

862. El Sol, "El conflicto entre Chile y Perú", 17 de diciembre de 1921, p. 5.

863. El Sol, "El conflicto entre Chile y Perú", 20 de diciembre de 1921, p. 1.

864. El Sol, "El conflicto entre Chile y Perú", 22 de diciembre de 1921, p. 5.

865. El Sol, "El conflicto entre Chile y Perú", 23 de enero de 1919, p. 6.

866. El Sol, "El conflicto entre Chile y Perú", 24 de diciembre de 1921, p. 5.

867. El Sol, "El conflicto entre Chile y Perú", 28 de diciembre de 1921, p. 5. 
868. El Sol, "El conflicto entre Perú y Bolivia", 23 de marzo de 1920, p. 8.

869. El Sol, "El conflicto peruanochileno", 21 de diciembre de 1918, p. 5.

870. El Sol, "El Congreso ratifica el Tratado de Tacna y Arica", 4 de julio de 1929, p. 5.

871. El Sol, "El Congreso trata del acuerdo de Tacna y Arica", 5 de julio de 1929, p. 5.

872. El Sol, "El Congreso y el acuerdo con Chile", 14 de junio de 1929, p. 1.

873. El Sol, "El Coronel Ibáñez y el pleito de Tacna y Arica", 26 de marzo de 1927,

p. 7.

874. El Sol, "El discurso del Presidente", 1 de julio de 1929, p. 5.

875. El Sol, "El ex presidente de Bolivia, señor Saavedra", 13 de marzo de 1929, p. 3.

876. El Sol, "El fallo del Presidente Coolidge", 4 de mayo de 1926, p. 1.

877. El Sol, "El General Lassiter toma la posesión de la presidencia", 8 de febrero de 1926, p. 5.

878. El Sol, "El general Pershing regresa a los Estados Unidos", 31 de diciembre de 1925, p. 8.

879. El Sol, "El Gobierno chileno no acepta el arbitraje", 18 de diciembre de 1921, p. 5.

880. El Sol, "El mensaje del presidente, General Ibáñez”, 24 de febrero de 1929, p. 7.

881. El Sol, "El nuevo gobierno de Chile", 26 de diciembre de 1925, p. 1.

882. El Sol, "El nuevo gobierno de Chile", 28 de diciembre de 1925, p. 2.

883. El Sol, "El nuevo presidente de la Comisión Plebiscitaria", 16 de enero de 1926, p. 1.

884. El Sol, "El Perú y el Ecuador", 25 de agosto de 1929, p. 1.

885. El Sol, "El Perú y la cuestión de Tacna y Arica en Ginebra", 23 de septiembre de 1927, p. 5.

886. El Sol, "El Perú y la cuestión de Tacna y Arica", 15 de septiembre de 1928, p. 4.

887. El Sol, "El Perú y la proposición de Míster Kellogg”, 15 de diciembre de 1926, p. 5.

888. El Sol, "El plebiscito de Tacna y Arica", 1 de septiembre de 1925, p. 5.

889. El Sol, "El plebiscito de Tacna y Arica", 14 de noviembre de 1925, p. 4.

890. El Sol, "El plebiscito de Tacna y Arica", 27 de marzo de 1926, p. 1.

891. El Sol, "El plebiscito de Tacna y Arica", 5 de agosto de 1925, p. 1.

892. El Sol, "El plebiscito de Tacna y Arica", 9 de julio de 1925, p. 8.

893. El Sol, "El plebiscito sobre Tacna y Arica", 1 de julio de 1925, p. 5.

894. El Sol, "El plebiscito sobre Tacna y Arica", 11 de diciembre de 1925, p. 5.

895. El Sol, "El plebiscito Tacna-Arica", 30 de marzo de 1925, p. 5.

896. El Sol, "El pleito chilenoperuano resuelto", 19 de mayo de 1929, p. 1.

897. El Sol, "El pleito chilenoperuano sobre la nacionalidad de Tacna y Arica", 1 de enero de 1925 , p. 8.

898. El Sol, "El pleito chileno-peruano", 6 de enero de 1925, p. 5.

899. El Sol, "El pleito de Tacna y Arica", 12 de junio de 1926, p. 5.

900. El Sol, "El pobre Panamá", 14 de abril de 1926, p. 1.

901. El Sol, "El poder espiritual de España", 2 de febrero de 1928, p. 9. 
902. El Sol, "El premio Nobel de la Paz", 30 de octubre de 1929, p. 3.

903. El Sol, "El Premio Nobel para los presidentes de Chile y el Perú", 1 de noviembre de 1929 , p. 3.

904. El Sol, "El Premio Nobel para los presidentes de Chile y Perú", 7 de noviembre de 1929, p. 8.

905. El Sol, "El Presidente Hoover notifica la solución del pleito Tacna Arica", 18 de mayo de 1929, p. 5.

906. El Sol, "E1 Presidente Ibáñez en Arica", 4 de agosto de 1929, p. 7.

907. El Sol, "El primer embajador peruano en Chile", 4 de octubre de 1928, p. 8.

908. El Sol, "El problema de Bolivia y la prensa", 25 de septiembre de 1925, p. 6.

909. El Sol, "El salvador de Sáenz Peña ha muerto", 5 de abril de 1929, p. 5.

910. El Sol, "El Sr. Ríos Gallardo llega a España", 29 de septiembre de 1929, p. 12.

911. El Sol, "El trágico fin de Edwin Elmore", 2 de diciembre de 1925, p. 1.

912. El Sol, "El viaje de Míster Coolidge y la Conferencia de La Habana", 29 de diciembre de 1927, p. 1.

913. El Sol, "En Bolivia", 6 de octubre de 1929, p. 7.

914. El Sol, "En el Ateneo. Conferencia del señor Ayarza", 16 de mayo de 1923, p. 4.

915. El Sol, "En la Sociedad Económica Matritense", 8 de mayo de 1926, p. 2.

916. El Sol, "En la Unión Iberoamericana", 17 de diciembre de 1926, p. 4.

917. El Sol, "En Madrid", 18 de junio de 1929, p. 7.

918. El Sol, "En Washington se teme que las reclamaciones de Bolivia dificulten la ratificación del Tratado", 21 de mayo de 1929, p. 12.

919. El Sol, "España y el litigio paraguayo boliviano", 3 de septiembre de 1927, p. 2.

920. El Sol, "Extranjero", 10 de marzo de 1925, p. 5.

921. El Sol, "Extranjero", 11 de julio de 1922, p. 5.

922. El Sol, "Extranjero", 11 de marzo de 1926, p. 5.

923. El Sol, "Extranjero", 15 de abril de 1924, p. 5.

924. El Sol, "Extranjero", 16 de junio de 1926, p. 5.

925. El Sol, "Extranjero", 20 de mayo de 1925, p. 5.

926. El Sol, "Extranjero", 24 de junio de 1926, p. 5.

927. El Sol, "Extranjero", 25 de enero de 1923, p. 5.

928. El Sol, "Extranjero", 27 de marzo de 1926, p. 5.

929. El Sol, "Extranjero", 30 de noviembre de 1925, p. 5.

930. El Sol, "Extranjero", 5 de julio de 1922, p. 5.

931. El Sol, "Extranjero", 8 de enero de 1926, p. 5.

932. El Sol, "Fallecimiento del señor Lansing", 31 de octubre de 1928, p. 5.

933. El Sol, "Fantasmas de ahora", 7 de mayo de 1927, p. 8.

934. El Sol, "Fracasa la intervención americana", 23 de diciembre de 1918, p. 5.

935. El Sol, "Franco se propone atravesar los Andes y regresar a España por Cuba y los

Estados Unidos", 2 de febrero de 1926, p. 2. 
936. El Sol, "Ha muerto el Ministro de Relaciones Exteriores", 5 de noviembre de 1927, p. 5.

937. El Sol, "Ha quedado resuelta la cuestión de Tacna y Arica", 22 de febrero de 1929, p. 5.

938. El Sol, "Hablando con el ministro plenipotenciario del Perú", 28 de mayo de 1924, p. 2.

939. El Sol, "Homenaje de los marinos chilenos a un héroe peruano", 20 de noviembre de 1929 , p. 5.

940. El Sol, "Ibero América", 10 de junio de 1919, p. 10.

941. El Sol, "Ibero América", 30 de abril de 1919, p. 8.

942. El Sol, "Ibero América", 7 de mayo de 1919, p. 9.

943. El Sol, "Ibero-América", 14 de mayo de 1918, p. 6.

944. El Sol, "Ibero-América", 4 de abril de 1918, p. 6.

945. El Sol, "Impresión favorable en los Estados Unidos", 26 de junio de 1926, p. 1.

946. El Sol, "Incidentes entre peruanos y bolivianos", 20 de abril de 1926, p. 5.

947. El Sol, "Influencia extranjera", 24 de julio de 1925, p. 1.

948. El Sol, "Informaciones de Ibero América", 13 de abril de 1919, p. 29.

949. El Sol, "Informaciones de Ibero América", 5 de mayo de 1919, p. 3.

950. El Sol, "Jiménez e Iglesias aterrizaron ayer felizmente en Lima, donde han sido objeto de emocionante recibimiento", 24 de septiembre de 1929, p. 1.

951. El Sol, "Jiménez e Iglesias salieron de Santiago de Chile y aterrizaron en Arica", 23 de abril de 1929, p. 7.

952. El Sol, "La actualidad peruana", 7 de enero de 1927, p. 4.

953. El Sol, "La Asamblea Hispánica de Panamá", 4 de junio de 1926, p. 5.

954. El Sol, "La comisión chilena en Arica", 21 de agosto de 1925, p. 5.

955. El Sol, "La comisión plebiscitaria se reúne de nuevo", 1 de diciembre de 1925, p. 1.

956. El Sol, "La Conferencia Panamericana de La Habana", 23 de noviembre de 1927, p. 5.

957. El Sol, "La crisis de la industria textil", 16 de abril de 1927, p. 5.

958. El Sol, "La cuestión boliviano-paraguaya", 17 de septiembre de 1929, p. 5.

959. El Sol, "La cuestión de Tacna y Arica", 11 de diciembre de 1927, p. 7.

960. El Sol, "La cuestión de Tacna y Arica", 11 de julio de 1928, p. 5.

961. El Sol, "La cuestión de Tacna y Arica", 11 de marzo de 1920, p. 7.

962. El Sol, "La cuestión de Tacna y Arica", 11 de octubre de 1928, p. 8.

963. El Sol, "La cuestión de Tacna y Arica", 11 de septiembre de 1926, p. 1.

964. El Sol, "La cuestión de Tacna y Arica", 12 de abril de 1929, p. 5.

965. El Sol, "La cuestión de Tacna y Arica", 12 de marzo de 1920, p. 1.

966. El Sol, "La cuestión de Tacna y Arica", 13 de octubre de 1928, p. 5.

967. El Sol, "La cuestión de Tacna y Arica", 14 de abril de 1929, p. 7.

968. El Sol, "La cuestión de Tacna y Arica", 14 de mayo de 1929, p. 8. 
969. El Sol, "La cuestión de Tacna y Arica", 16 de febrero de 1929, p. 1.

970. El Sol, "La cuestión de Tacna y Arica", 19 de febrero de 1929, p. 7.

971. El Sol, "La cuestión de Tacna y Arica", 19 de mayo de 1929, p. 7.

972. El Sol, "La cuestión de Tacna y Arica", 2 de octubre de 1926, p. 8.

973. El Sol, "La cuestión de Tacna y Arica", 20 de junio de 1925, p. 2.

974. El Sol, "La cuestión de Tacna y Arica", 21 de diciembre de 1917, p. 2.

975. El Sol, "La cuestión de Tacna y Arica", 21 de septiembre de 1926, p. 5.

976. El Sol, "La cuestión de Tacna y Arica", 22 de septiembre de 1926, p. 8.

977. El Sol, "La cuestión de Tacna y Arica", 23 de abril de 1929, p. 7.

978. El Sol, "La cuestión de Tacna y Arica", 23 de febrero de 1929, p. 1.

979. El Sol, "La cuestión de Tacna y Arica", 24 de abril de 1929, p. 5.

980. El Sol, "La cuestión de Tacna y Arica", 25 de abril de 1929, p. 5.

981. El Sol, "La cuestión de Tacna y Arica", 26 de junio de 1926, p. 5.

982. El Sol, "La cuestión de Tacna y Arica", 29 de mayo de 1924, p. 1.

983. El Sol, "La cuestión de Tacna y Arica", 4 de diciembre de 1925, p. 1.

984. El Sol, "La cuestión de Tacna y Arica", 5 de enero de 1929, p. 5.

985. El Sol, "La cuestión de Tacna y Arica", 6 de marzo de 1920, p. 7.

986. El Sol, "La cuestión del Pacífico en Sudamérica", 11 de febrero de 1922, p. 8.

987. El Sol, "La delegación chilena se retira de la Comisión Plebiscitaria", 26 de noviembre de 1925, p. 2.

988. El Sol, "La devolución de un ferrocarril a Bolivia", 3 de febrero de 1928, p. 5.

989. El Sol, "La elección presidencial", 7 de abril de 1925, p. 8.

990. El Sol, "La función moderadora de España", 3 de abril de 1920, p. 7.

991. El Sol, "La función moderadora de España", 3 de abril de 1920, p. 7.

992. El Sol, "La guerra en Suramérica", 18 de diciembre de 1928, p. 1.

993. El Sol, "La huelga general en Lima", 21 de enero de 1919, p. 5.

994. El Sol, "La isla del doctor Moreau", 4 de abril de 1924, p. 8.

995. El Sol, "La isla del doctor Moreau", 6 de abril de 1924, p. 8.

996. El Sol, "La mujer limeña", 24 de mayo de 1926, p. 5.

997. El Sol, "La opinión chilena y el pleito de Tacna y Arica", 8 de julio de 1928, p. 7.

998. El Sol, "La paz de América en peligro", 14 de septiembre de 1919, p. 4.

999. El Sol, "La Paz Stimson", 27 de mayo de 1928, p. 3.

1000. El Sol, "La política intervencionista juzgada por un norteamericano", 30 de enero

de 1929, p. 1.

1001. El Sol, "La popularidad de los extranjeros", 6 de octubre de 1926, p. 1.

1002. El Sol, "La posesión de Tacna y Arica", 21 de julio de 1922, p. 5.

1003. El Sol, "La prensa y el discurso de Míster Coolidge”, 30 de abril de 1927, p. 7.

1004. El Sol, "La presidencia de Chile", 23 de mayo de 1927, p. 1.

1005. El Sol, "La presidencia del plebiscito", 27 de julio de 1925, p. 8.

1006. El Sol, "La ratificación del Tratado con Chile", 14 de julio de 1929, p. 7.

1007. El Sol, "La salida al mar", 8 de mayo de 1929, p. 5. 
1008. El Sol, "La salud de Pershing", 12 de marzo de 1926, p. 5.

1009. El Sol, "La situación, aunque grave, tiende a la solución pacífica", 13 de diciembre de 1928, p. 1.

1010. El Sol, "La solución del conflicto de Tacna y Arica", 18 de abril de 1929, p. 1.

1011. El Sol, "La solución del conflicto de Tacna y Arica", 31 de diciembre de 1924, p. 5.

1012. El Sol, "La solución del pleito de Tacna y Arica", 3 de mayo de 1929, p. 5.

1013. El Sol, "La travesía aérea de los Andes", 28 de octubre de 1925, p. 1.

1014. El Sol, "Las delegaciones se reunirán el 4 de agosto", 28 de julio de 1925, p. 2.

1015. El Sol, "Las enseñanzas comerciales en Chile", 29 de mayo de 1929, p. 7.

1016. El Sol, "Las fronteras con el Perú", 29 de abril de 1928, p. 7.

1017. El Sol, "Las fronteras de Guatemala y Honduras", 24 de abril de 1928, p. 5.

1018. El Sol, "Las relaciones chileno-peruanas mejoran", 9 de junio de 1928, p. 5.

1019. El Sol, "Las relaciones chileno-peruanas", 18 de octubre de 1928, p. 7.

1020. El Sol, "Las relaciones con el Perú y el pleito de Tacna y Arica", 19 de enero de 1929 , p. 5.

1021. El Sol, "Las relaciones entre Chile y Perú", 15 de julio de 1928, p. 1.

1022. El Sol, "Llega a Arica la Comisión Peruana", 29 de agosto de 1929, p. 5.

1023. El Sol, "Llega el general Lassiter a su destino", 21 de enero de 1926, p. 5.

1024. El Sol, "Lo que hemos querido", 8 de marzo de 1928, p. 4.

1025. El Sol, "Los errores de un plebiscito", 18 de enero de 1926, p. 1.

1026. El Sol, "Los estudiantes en Hispanoamérica", 4 de octubre de 1924, p. 6.

1027. El Sol, "Los gastos de representación en el pleito de Tacna y Arica", 15 de octubre de 1927, p. 5.

1028. El Sol, "Los miembros hispanoamericanos del Consejo", 10 de febrero de 1927, p. 8.

1029. El Sol, "Los nuevos servicios trasatlánticos", 12 de junio de 1926, p. 7.

1030. El Sol, "Los rotarios argentinos celebran el acuerdo de Tacna y Arica", 10 de julio de 1929, p. 1.

1031. El Sol, "Los salvadores de Sáenz Peña", 11 de abril de 1929, p. 5.

1032. El Sol, "Los supuestos disturbios en el Perú", 26 de mayo de 1929, p. 7.

1033. El Sol, "Los trabajos de las comisiones plebiscitarias", 31 de agosto de 1925, p. 8.

1034. El Sol, "Los tripulantes pasaron el día de ayer en Sevilla y hoy llegarán a Madrid", 9 de junio de 1929, p. 6.

1035. El Sol, "Más sobre Tacna y Arica", 16 de diciembre de 1925, p. 5.

1036. El Sol, "Misión militar disuelta", 3 de octubre de 1929, p. 5.

1037. El Sol, "No hay que abusar", 14 de junio de 1929, p. 1.

1038. El Sol, "Nota oficial sobre un incidente", 23 de abril de 1926, p. 1.

1039. El Sol, "Nota oficiosa del Consulado de Bolivia", 20 de marzo de 1920, p. 3.

1040. El Sol, "Nota oficiosa peruana", 19 de marzo de 1920, p. 1. 
1041. El Sol, "Notas hispanoamericanas", 3 de julio de 1925, p. 5.

1042. El Sol, "Nuevo choque entre chilenos y peruanos", 8 de marzo de 1926, p. 1.

1043. El Sol, "Nuevo Ministro de Perú en Londres", 22 de julio de 1926, p. 1.

1044. El Sol, "Nuevo Secretario de la Legación del Perú", 3 de julio de 1929, p. 2.

1045. El Sol, "Nuevos incidentes entre Chile y Perú", 22 de diciembre de 1919, p. 6.

1046. El Sol, "Once estudiantes muertos y numerosos heridos", 31 de mayo de 1923, p. 1.

1047. El Sol, "Otra opinión favorable a la neutralización de Tacna y Arica", 6 de diciembre de 1926, p. 5.

1048. El Sol, "Página Iberoamericana", 17 de diciembre de 1921, p. 8

1049. El Sol, "Panorama de América", 6 de febrero de 1919, p. 8.

1050. El Sol, "Para conmemorar una fecha histórica", 20 de septiembre de 1929, p. 5.

1051. El Sol, "Peligro de guerra en la América española", 28 de noviembre de 1918,

p. 1.

1052. El Sol, "Perú se retira de la conferencia de Tacna y Arica", 2 de octubre de 1925,

p. 5.

1053. El Sol, "Perú y Bolivia", 4 de marzo de 1920, p. 3.

1054. El Sol, "Perú y Bolivia", 9 de marzo de 1920, p. 9.

1055. El Sol, "Perú", 10 de julio de 1927, p. 7.

1056. El Sol, "Perú", 11 de mayo de 1927, p. 5.

1057. El Sol, "Perú", 13 de junio de 1927, p. 5.

1058. El Sol, "Perú", 18 de enero de 1927, p. 5.

1059. El Sol, "Perú", 19 de marzo de 1927, p. 7.

1060. El Sol, "Perú", 26 de julio de 1929, p. 5.

1061. El Sol, "Perú", 28 de junio de 1929, p. 5.

1062. El Sol, "Perú", 30 de junio de 1929, p. 7.

1063. El Sol, "Perú", 4 de julio de 1919, p. 9.

1064. El Sol, "Perú", 6 de enero de 1927, p. 7.

1065. El Sol, "Por qué mató Santos Chocano", 18 de noviembre de 1925, p. 1.

1066. El Sol, "Prensa inglesa", 7 de mayo de 1929, p. 7.

1067. El Sol, "Prensa madrileña", 9 de diciembre de 1926, p. 6.

1068. El Sol, "Reclamación atendida", 6 de julio de 1926, p. 5.

1069. El Sol, "Respuesta de Coolidge a la nota peruana", 7 de mayo de 1925, p. 2.

1070. El Sol, "Restablecimiento de relaciones", 16 de agosto de 1928, p. 3.

1071. El Sol, "Revista de Libros", 1 de enero de 1925, p. 2.

1072. El Sol, "Rumores no confirmados de graves desórdenes en el Perú", 24 de febrero de 1929 , p. 7.

1073. El Sol, "Se inaugura el Congreso Socialista Panamericano", 2 de mayo de 1919, p. 6.

1074. El Sol, "Se pide el premio de Nobel para los Presidentes de Chile y Perú", 12 de octubre de 1929, p. 8. 
1075. El Sol, "Se pide el premio Nobel de la paz para los presidentes de Chile y Perú",

13 de octubre de 1929, p. 6.

1076. El Sol, "Se piensa en recurrir al a S. de N.", 2 de diciembre de 1925, p. 8.

1077. El Sol, "Se somete al plebiscito de los habitantes para que lo resuelvan", 11 de marzo de 1925, p. 1.

1078. El Sol, "Se tienen impresiones optimistas", 3 de enero de 1922, p. 5.

1079. El Sol, "Sigue la hostilidad entre chilenos y peruanos", 19 de diciembre de 1918,

p. 6.

1080. El Sol, "Siguen los ánimos exaltados", 13 de julio de 1926, p. 5.

1081. El Sol, "Siguen los augurios desfavorables", 20 de enero de 1928, p. 5.

1082. El Sol, "Tacna y Arica", 1 de enero de 1925, p. 5.

1083. El Sol, "Tacna y Arica", 11 de mayo de 1923, p. 5.

1084. El Sol, "Tacna y Arica", 11 de octubre de 1926, p. 5.

1085. El Sol, "Tacna y Arica", 12 de abril de 1926, p. 5.

1086. El Sol, "Tacna y Arica”, 13 de agosto de 1926, p. 1.

1087. El Sol, "Tacna y Arica", 14 de octubre de 1926, p. 5.

1088. El Sol, "Tacna y Arica", 19 de julio de 1926, p. 5.

1089. El Sol, "Tacna y Arica", 2 de diciembre de 1926, p. 5.

1090. El Sol, "Tacna y Arica", 2 de junio de 1926, p. 5.

1091. El Sol, "Tacna y Arica", 2 de marzo de 1926, p. 1.

1092. El Sol, "Tacna y Arica", 20 de agosto de 1926, p. 5.

1093. El Sol, "Tacna y Arica", 21 de junio de 1926, p. 5.

1094. El Sol, "Tacna y Arica", 22 de mayo de 1926, p. 5.

1095. El Sol, "Tacna y Arica”, 23 de agosto de 1926, p. 5.

1096. El Sol, "Tacna y Arica”, 24 de febrero de 1929, p. 7.

1097. El Sol, "Tacna y Arica”, 26 de abril de 1929, p. 1.

1098. El Sol, "Tacna y Arica", 27 de febrero de 1926, p. 1.

1099. El Sol, "Tacna y Arica", 29 de abril de 1926, p. 1.

1100. El Sol, "Tacna y Arica", 29 de mayo de 1926, p. 5

1101. El Sol, "Tacna y Arica", 3 de febrero de 1923, p. 1.

1102. El Sol, "Tacna y Arica", 3 de junio de 1926, p. 5.

1103. El Sol, "Tacna y Arica", 30 de julio de 1926, p. 1.

1104. El Sol, "Tacna y Arica", 30 de noviembre de 1925, p. 5.

1105. El Sol, "Tacna y Arica”, 30 de noviembre de 1926, p. 5.

1106. El Sol, "Tacna y Arica", 31 de mayo de 1925, p. 5.

1107. El Sol, "Tacna y Arica", 4 de enero de 1926, p. 5.

1108. El Sol, "Tacna y Arica", 5 de enero de 1926, p. 1.

1109. El Sol, "Tacna y Arica", 5 de noviembre de 1926, p. 5.

1110. El Sol, "Tacna y Arica", 7 de agosto de 1925, p. 5.

1111. El Sol, "Tacna y Arica", 7 de agosto de 1925, p. 5.

1112. El Sol, "Tacna y Arica", 8 de julio de 1926, p. 5. 
1113. El Sol, "Tacna y Arica", 9 de octubre de 1925, p. 5.

1114. El Sol, "Texto oficial del convenio chilenoperuano", 19 de mayo de 1929, p. 6.

1115. El Sol, "Un comunicado de la Legación de Bolivia en Londres", 22 de mayo de 1929 , p. 5.

1116. El Sol, "Un nuevo incidente y un acuerdo", 27 de noviembre de 1925, p. 1.

1117. El Sol, "Un reglamento de policía entre Chile y Perú", 15 de agosto de 1929, p. 5.

1118. El Sol, "Una carta de la Legación de Chile", 15 de enero de 1926, p. 1.

1119. El Sol, "Una carta de la Legación del Perú", 16 de enero de 1926, p. 1.

1120. El Sol, "Una carta del Ministro del Perú", 12 de octubre de 1925, p. 2.

1121. El Sol, "Una carta del ministro del Perú", 30 de mayo de 1924, p. 1.

1122. El Sol, "Una fórmula inesperada", 31 de marzo de 1926, p. 5.

1123. El Sol, "Una nota chilena", 24 de marzo de 1920, p. 7.

1124. El Sol, "Una nota de la Legación del Perú", 8 de diciembre de 1925, p. 5.

1125. El Sol, "Una nota del Ministro de Relaciones Exteriores del Perú", 7 de septiembre de 1926, p. 6.

1126. El Sol, "Una nueva fórmula de concordia", 21 de mayo de 1926, p. 5.

1127. El Sol, "Una proposición sobre Tacna y Arica", 28 de mayo de 1925, p. 5.

1128. El Sol, "Una réplica de la Legación de Chile", 9 de septiembre de 1926, p. 2.

1129. El Sol, "Varios incidentes entre chilenos y peruanos", 8 de enero de 1926, p. 1.

1130. El Sol, "Versión oficial de los últimos sucesos políticos", 9 de octubre de 1929, p. 5.

1131. El Sol, "Viajeros de ambos mundos", 11 de mayo de 1927, p. 5.

1132. El Sol, "Visita a Harding", 25 de enero de 1923, p. 1.

1133. España y América de Madrid, "Perú", septiembre de 1911, año IX, n. ${ }^{\circ} 13$, p. 478.

1134. España y América, "Chile", 30 de septiembre de 1910, año VIII, n. ${ }^{\circ} 13$, p. 474.

1135. España y América, "Correspondencias extranjeras. Desde el Perú", 30 de septiembre de 1909, año VII, tomo III, p. 433.

1136. España y América, "Crisis del régimen parlamentario en Chile", 1 de octubre de 1912, año X, n. ${ }^{\circ}$ 19, p. 100.

1137. España y América, "Crónica de la quincena", 1 de octubre de 1912, año X, n. ${ }^{\circ}$ 19, p. 382.

1138. España y América, "Crónica del extranjero", año XX, (datos no disponibles), p. 80.

1139. España y América, "Crónica del extranjero", 1921, (datos no disponibles), p. 80.

1140. España y América, "Crónica general española y americana", 1 de abril de 1926, año XXIV, n. ${ }^{\circ}$ 7, pp. 68-76.

1141. España y América, "Crónica general española y americana", 1 de enero de 1926, año XXIV, n. ${ }^{\circ}$ 1, pp. 67-80.

1142. España y América, "Crónica general española y americana", 1 de julio de 1926, año XXIV, n. ${ }^{\circ} 13$, pp. 57-63. 
1143. España y América, "Desde el Perú. Por el P.M. Gorrochátegui”, n. ${ }^{\circ}$ 13, año XIX, 1 de julio de 1921, p. 36.

1144. España y América, "Desde el Perú", 1 de octubre de 1926, año XXIV, n. ${ }^{\circ} 19$, pp. 132-133.

1145. España y América, "Desde la Argentina”, 30 de septiembre de 1919, p. 128.

1146. España y América, "El A.B.C. Suramericano", 1 de julio de 1912, año X, n. ${ }^{\circ} 13$, p. 396.

1147. España y América, "El A.B.C. Suramericano”, 1 de julio de 1912, año X, n. ${ }^{\circ} 13$, p. 395.

1148. España y América, "El acuerdo peruano chileno en la Conferencia de Washington", año XX, 1 de julio de 1922, n. ${ }^{\circ} 13$, p. 434-445.

1149. España y América, "El acuerdo peruano chileno en la Conferencia de

Washington", año XX, tomo IV, octubre, noviembre y diciembre de 1922, p. 34-46.

1150. España y América, "El centenario de Chile", 30 de septiembre de 1910, año VIII, n. ${ }^{\circ} 13$, p. 494.

1151. España y América, "El Perú hacia el progreso", 1 de octubre de 1926, año XXIV, n. ${ }^{\circ} 19$, p. 237.

1152. España y América, "España y la exposición argentina", 30 de junio de 1910, año VIII, n. ${ }^{\circ}$ 7, p. 131.

1153. España y América, "Extranjero. La eterna cuestión del Pacífico: Circular del Ministerio Negocios Extranjeros de Bolivia", año XXIII, n. ${ }^{\circ} 13,1$ de julio de 1925, p. $155-156$.

1154. España y América, "Extranjero. Lo de Tacna y Arica", año XXXII, tomo II, abril, mayo y junio de 1925, p. 79-80.

1155. España y América, "Extranjero", 1 de noviembre de 1906, año IV, n. ${ }^{\circ}$ 21, p. 396.

1156. España y América, "Extranjero", año XXIII, n. ${ }^{\circ}$ 19, 1 de octubre de 1925, pp. 7778.

1157. España y América, "La cuestión de Tacna y Arica", 1 de abril de 1922, año XX, n. ${ }^{\circ}$, p. 80 .

1158. España y América, "La literatura en Chile en 1922", 1 de julio de 1923, año XXI, n. ${ }^{\circ} 13$, p. 46.

1159. España y América, "Nuestros grabados", 1 de enero de 1906, n. ${ }^{\circ} 1$, p. 80.

1160. España, "Actualidad" (poema), n. ${ }^{\circ}$ 410, 23 de febrero de 1924, p. 7.

1161. España, "Amistad sintomática”, 14 de agosto de 1920, n. ${ }^{\circ}$ 276, p. 10.

1162. España, "Consultorio grafológico", 23 de septiembre de 1922, n. ${ }^{\circ} 336$, p. 6.

1163. España, "Crónica americana", 24 de abril de 1919, n. ${ }^{\circ} 211$, p. 9.

1164. España, "Crónica Americana", 31 de julio de 1920, n. ${ }^{\circ} 274$, p. 8.

1165. España, "Crónica Americana", 31 de julio de 1920, n. ${ }^{\circ} 274$, p. 9.

1166. España, "El conflicto entre Perú y Bolivia”, 20 de marzo de 1920, n. ${ }^{\text {o } 255, ~ p . ~} 13$.

1167. España, "El litigio chileno-peruano", 5 de agosto de 1922, n. ${ }^{\circ} 332$, p. 4.

1168. España, "El premio del mucho hablar", 5 de enero de 1924, año X, n. ${ }^{\circ}$ 403, p. 5. 
1169. España, "En América: Proyecciones imperialistas", 15 de julio de 1922, n. ${ }^{\circ} 329$,

p. 7.

1170. España, "La cuestión de Tacna y Arica", 5 de diciembre de 1918, n. ${ }^{\circ} 191$, p. 8.

1171. España, "Las huelgas peruanas", 23 de enero de 1919, n. ${ }^{\circ} 198$, p. 10.

1172. España, "Libros y revistas", 21 de agosto de 1919, n. ${ }^{\circ} 212$, p. 8.

1173. España, "Otra Conferencia, hija de la Conferencia del Desarme", 25 de febrero de 1922, n. ${ }^{\circ} 309$, p. 11.

1174. España, "Puntos de vista", 14 de agosto de 1920, n. ${ }^{\circ}$ 276, p. 11.

1175. España, "Vaivenes de la aspiración boliviana", 14 de agosto de 1920, n. ${ }^{\circ} 276$, p. 10.

1176. Faro, "Chile", 7 de febrero de 1909, año II, n. ${ }^{\circ}$ 51, p. 4.

1177. Fernando Soldevilla, El Año Político. 1925, "La cuestión de Tacna y Arica", año

XXXI, Madrid, Imprenta y Encuadernación de Julio Cosano, 1925, p. 112

1178. Gaceta de los Caminos de hierro, "Bolivia", 1 de marzo de 1912, año LVII, n. ${ }^{\circ}$ 2872, p. 102.

1179. Gaceta de los Caminos de Hierro, "Bolivia", 16 de junio de 1912, año LVII, 2886, p. 270.

1180. Gaceta de los Caminos de Hierro, "Bolivia", 8 de enero de 1912, año LVII, n. ${ }^{\circ}$ 2865, p. 19.

1181. Gaceta de los Caminos de Hierro, "Ferrocarriles extranjeros", 1 de mayo de 1912, año LVII, n. ${ }^{\circ} 2880$, p. 6.

1182. Gaceta de los Caminos de Hierro, "Ferrocarriles extranjeros", 16 de diciembre de 1910, año LV, n. ${ }^{\circ}$ 2814, p. 594.

1183. Gaceta de los Caminos de Hierro, "Ferrocarriles extranjeros", 20 de octubre de 1922, año LXVII, n. ${ }^{\circ} 3348$, p. 4.

1184. Gaceta de los Caminos de Hierro, "Ferrocarriles extranjeros", 8 de diciembre de 1907, año LII, n. ${ }^{\circ} 2.669$, p. 530.

1185. Gaceta de los Caminos de Hierro, "Los ferrocarriles en la República de Bolivia", 1 de diciembre de 1927, p. 399.

1186. Gaceta de los Caminos de Hierro, "Los ferrocarriles y la Bolivia actual", 1 de noviembre de 1907, año LII, n. ${ }^{\circ} 2.664$, p. 487.

1187. Guía Oficial de España, "Consulados españoles", 1898, p. 94.

1188. Guía Oficial de España, "Consulados españoles”, 1928, Madrid, Sucesores de Rivadeneira, p. 174.

1189. Gutiérrez, "(Sin título)", 2 de marzo de 1929, (sin datos de la revista), p. 19.

1190. Hojas Selectas, "Crónica internacional", enero de 1906, n. o 49, p. 933.

1191. Hojas Selectas, "Excmo. Sr. General Leónidas Plaza G.”, enero de 1902, p. 898.

1192. Hojas Selectas, "La flota mercante española", enero de 1918, n. ${ }^{\circ} 193$, p. 38.

1193. Hojas Selectas, "Panorama Universal", enero de 1912, año XI, n. ${ }^{\circ}$ 121, p. 1137.

1194. Hojas Selectas, "Panorama Universal”, enero de 1912, año XI, n. ${ }^{\circ}$ 121, p. 1136.

1195. Ilustración Artística, "Bolivia", 20 de junio de 1887, p. 207. 
1196. Ilustración Artística, "Juan Guillermo Moor", 23 de junio de 1890, año IX, n. ${ }^{\circ}$ 443, p. 645-646.

1197. Ilustración Artística, "Libros enviados a esta redacción por autores o editores", 18 de marzo de 1901, p. 200.

1198. Ilustración Artística, "Revista Hispano americana", 1 de septiembre de 1902, n. ${ }^{\circ}$ 1079, p. 570.

1199. Ilustración Artística, "Revista Hispano-Americana", 15 de julio de 1901, p. 2.

1200. Ilustración Católica de España, "Historia al día", 15 de mayo de 1898, n. 9 , p. 14.

1201. Industria e Invenciones, "Los mercados neutrales del mundo y sus

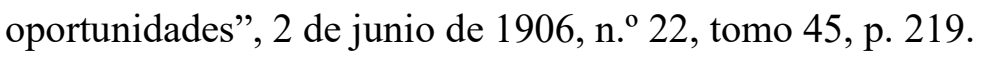

1202. Industria e Invenciones, "Movimientos actuales de la corteza terrestre", 7 de marzo de 1885 , tomo III, n. ${ }^{\circ} 62$, p. 2.

1203. Industria e Invenciones, "Revista de la Electricidad", 15 de abril de 1911, tomo 55-127, n. ${ }^{\circ} 15$, p. 130.

1204. La Acción, “La solución?”, 8 de diciembre de 1918, p. 3.

1205. La Acción, "Boletín de política extranjera", 2 de junio de 1921, p. 1.

1206. La Acción, "Chile y el Perú", 15 de diciembre de 1921, p. 2.

1207. La Acción, "Chile y el Perú", 4 de diciembre de 1918, p. 2.

1208. La Acción, “Chile y el Tratado de Ancón”, 14 de junio de 1922, p. 2.

1209. La Acción, "Documentos diplomáticos. La cuestión chileno-peruana", 26 de diciembre de 1918, p. 5.

1210. La Acción, "El incidente de Arica", 15 de diciembre de 1920, p. 1.

1211. La Acción, "El Perú y Chile", 11 de enero de 1919, p. 5.

1212. La Acción, "El pleito de Tacna y Arica", 5 de julio de 1922, p. 5.

1213. La Acción, "En Marina", 25 de septiembre de 1920, p. 6.

1214. La Acción, "Entre Chile y Perú", 23 de diciembre de 1918, p. 3.

1215. La Acción, "Impresiones de un viaje por América", 12 de abril de 1921, p. 2.

1216. La Acción, "La Conferencia de la Paz", 25 de enero de 1919, p. 3.

1217. La Acción, "La cuestión de Tacna y Arica", 20 de diciembre de 1921, p. 6.

1218. La Acción, "La Misión española en Chile", 20 de noviembre de 1920, p. 6.

1219. La Acción, "La Misión española", 11 de diciembre de 1920, p. 3.

1220. La Acción, "La política de los Estados Unidos", 1 de junio de 1922, p. 6.

1221. La Acción, "Lo de Tacna y Arica", 10 de marzo de 1924, p. 2.

1222. La Acción, "Lo de Tacna y Arica", 16 de agosto de 1922, p. 2.

1223. La Acción, "Lo de Tacna y Arica", 21 de julio de 1922, p. 1.

1224. La Acción, "Lo de Tacna y Arica", 25 de enero de 1923, p. 2.

1225. La Acción, "Personalidades españolas", 20 de noviembre de 1920, p. 1.

1226. La Acción, "Política y politiqueo", 19 de noviembre de 1920, p. 6.

1227. La Acción, "Sigue la hostilidad. Chile y Perú", 19 de diciembre de 1918, p. 3. 1228. La Acción, "Una invitación que causa asombro", 15 de diciembre de 1921, p. 4. 
1229. La América, "Europa y el Tratado de Paz chileno peruano", 15 de abril de 1884, p. 5.

1230. La América, "La América Latina", 8 de abril de 1882, p. 6.

1231. La América, "La Guerra del Pacífico", 8 de abril de 1880, p. 12.

1232. La América, "La isla de Cuba y las repúblicas hispano-americanas", 28 de julio de 1882 , p. 6.

1233. La América, "La paz en el Pacífico", 28 de julio de 1880, p. 12.

1234. La América, "Perú", 18 de enero de 1886, año XXVII, n. ${ }^{\circ} 1$, p. 14.

1235. La Ciudad Lineal, "La Ciudad Lineal en Chile", 20 de octubre de 1912, año XVII, n. ${ }^{\circ}$ 500, p. 369.

1236. La Ciudad Lineal, "La colaboración del poder. Don Luis Schmidt", 10 de octubre de 1929, año XXXIII, n. ${ }^{\circ}$ 817, p. 389.

1237. La Correspondencia de España, "Agustín Querol", 11 de junio de 1902, p. 1

1238. La Correspondencia de España, "América Latina”, 9 de mayo de 1909, p. 2.

1239. La Correspondencia de España, "Arbitraje combatido", 10 de enero de 1911, p. 1.

1240. La Correspondencia de España, "Chile ambicioso", 10 de diciembre de 1903, p. 1.

1241. La Correspondencia de España, "Chile y Bolivia", 10 de junio de 1920, p. 2.

1242. La Correspondencia de España, "Chile y el Perú", 24 de marzo de 1920, p. 2.

1243. La Correspondencia de España, "Chile y Perú. El arbitraje de los Estados

Unidos", 5 de julio de 1922, p. 3.

1244. La Correspondencia de España, "Chile y Perú", 1 de febrero de 1929, p. 7.

1245. La Correspondencia de España, "Chile y Perú", 15 de diciembre de 1921, p. 3.

1246. La Correspondencia de España, "Chile y Perú", 23 de enero de 1919, p. 4.

1247. La Correspondencia de España, "Chile y Perú", 23 de marzo de 1910, p. 2.

1248. La Correspondencia de España, "Chile y Perú", 24 de diciembre de 1918, p. 1.

1249. La Correspondencia de España, "Chile y Perú", 28 de diciembre de 1921, p. 3.

1250. La Correspondencia de España, "Chile y Perú", 28 de noviembre de 1918, p. 7.

1251. La Correspondencia de España, "Chile y Perú", 30 de mayo de 1922, p. 1.

1252. La Correspondencia de España, "Conflicto americano", 27 de marzo de 1910, p. 1.

1253. La Correspondencia de España, "Correspondencia de España", 11 de febrero de 1880, p. 3.

1254. La Correspondencia de España, "De la Agencia Fabra", 3 de junio de 1894, p. 2.

1255. La Correspondencia de España, "Delimitación de fronteras", 15 de marzo de 1911, p. 2.

1256. La Correspondencia de España, "Despachos telegráficos", 13 de noviembre de 1882 , p. 3.

1257. La Correspondencia de España, "Despachos telegráficos", 15 de febrero de 1882, p. 1. 
1258. La Correspondencia de España, "Despachos telegráficos", 20 de mayo de 1882, p. 1.

1259. La Correspondencia de España, "Despachos telegráficos", 28 de mayo de 1883, p. 1.

1260. La Correspondencia de España, "El arbitraje de los Estados Unidos sobre Tacna y Arica", 2 de diciembre de 1922, p. 5.

1261. La Correspondencia de España, "El conflicto chilenoperuano", 13 de junio de 1922, p. 6.

1262. La Correspondencia de España, "El pleito de Tacna y Arica", 6 de febrero de 1924, p. 2.

1263. La Correspondencia de España, "En cuatro líneas”, 26 de noviembre de 1920, p. 2.

1264. La Correspondencia de España, "En cuatro líneas", 5 de julio de 1921, p. 2.

1265. La Correspondencia de España, "En el estudio de Querol", 1 de febrero de 1903, p. 2.

1266. La Correspondencia de España, "Hablando con el Presidente", 27 de noviembre de 1920 , p. 6.

1267. La Correspondencia de España, "Hablando con el señor Dato", 19 de noviembre de 1920 , p. 5.

1268. La Correspondencia de España, "Harding, árbitro entre Chile y el Perú", 1 de febrero de 1923, p. 5.

1269. La Correspondencia de España, "Incidente entre Chile y Perú", 1 de diciembre de 1918, p. 5.

1270. La Correspondencia de España, "La cuestión Chile-Perú", 21 de diciembre de 1921, p. 3.

1271. La Correspondencia de España, "La cuestión de Tacna y Arica", 13 de diciembre de 1921, p. 3.

1272. La Correspondencia de España, "La cuestión de Tacna y Arica", 16 de abril de 1924, p. 7.

1273. La Correspondencia de España, "La cuestión de Tacna y Arica", 2 de julio de 1924, p. 8.

1274. La Correspondencia de España, "La cuestión del Pacífico", 24 de julio de 1920, p. 7.

1275. La Correspondencia de España, "La joven América. Varios conflictos", 27 de octubre de 1911, p. 2.

1276. La Correspondencia de España, "La Misión española", 10 de diciembre de 1920, p. 6.

1277. La Correspondencia de España, "La Misión española", 22 de noviembre de 1920, p. 2.

1278. La Correspondencia de España, "La obra de Querol. Primer premio del Museo Internacional", 5 de mayo de 1902, p. 2. 
1279. La Correspondencia de España, "La quinta conferencia panamericana", 18 de enero de 1922, p. 8.

1280. La Correspondencia de España, "La Revolución en Bolivia", 15 de julio de 1920, p. 2.

1281. La Correspondencia de España, "Las repúblicas americanas", 27 de noviembre de 1918, p. 7.

1282. La Correspondencia de España, "Las tropas peruanas han atravesado la frontera chilena", 14 de diciembre de 1921, p. 1.

1283. La Correspondencia de España, "Lo que dice el Ministro de Estado", 27 de septiembre de 1920, p. 3.

1284. La Correspondencia de España "Los sucesos de Bolivia provocan inquietud", 19 de julio de 1920, p. 2.

1285. La Correspondencia de España, "Mensaje presidencial", 30 de julio de 1910, p. 3.

1286. La Correspondencia de España, "No hay arreglo. Han terminado las negociaciones", 3 de enero de 1922, p. 2.

1287. La Correspondencia de España, "Noticias de Chile", 14 de agosto de 1922, p. 3.

1288. La Correspondencia de España, "Perú y Bolivia", 23 de marzo de 1920, p. 2.

1289. La Correspondencia de España, "Perú y el Ecuador", 8 de abril de 1910, p. 1.

1290. La Correspondencia de España, "Política de Chile", 2 de junio de 1921, p. 1.

1291. La Correspondencia de España, "Protesta contra un tratado", 26 de febrero de 1905 , p. 3.

1292. La Correspondencia de España, "Protesta del Perú", 23 de marzo de 1910, p. 2.

1293. La Correspondencia de España, "Recelos del Ecuador", 10 de abril de 1910, p. 2.

1294. La Correspondencia de España, "Revolución en el Perú", 9 de febrero de 1914, p. 3.

1295. La Correspondencia de España, "Ruptura de relaciones", 30 de enero de 1909, p. 3.

1296. La Correspondencia de España, "Tacna y Arica", 21 de diciembre de 1921, p. 7.

1297. La Correspondencia de España, "Tacna y Arica", 30 de noviembre de 1918, p. 1.

1298. La Correspondencia de España, "Telegramas. De la Agencia Fabra”, 3 de junio de 1896, p. 3.

1299. La Correspondencia de España, "Telegramas", 29 de enero de 1881, p. 2.

1300. La Correspondencia de España, "Un triunfo de Querol”, 11 de abril de 1902, p. 2.

1301. La Correspondencia de España, "Viaje del Presidente", 7 de abril de 1909, p. 3.

1302. La Correspondencia de España. "Propósitos yanquis", 10 de febrero de 1911, p. 3.

1303. La Correspondencia de España. "Relaciones Internacionales", 3 de noviembre de 1911, p. 2. 
1304. La Correspondencia Militar, “El arbitraje de Tacna y Arica será ofrecido al Rey de España?", 8 de julio de 1926, p. 6.

1305. La Correspondencia Militar, "', 16 de marzo de 1926, p. 4.

1306. La Correspondencia Militar, "Agitación política en La Paz", 6 de octubre de 1929, p. 2.

1307. La Correspondencia Militar, "Agresiones en Tacna", 15 de junio de 1926, p. 3.

1308. La Correspondencia Militar, "Agustín Querol", 11 de abril de 1902, p. 2.

1309. La Correspondencia Militar, "Banquete hispanoamericano para festejar la solución de la cuestión de Tacna y Arica", 21 de junio de 1929, p. 4.

1310. La Correspondencia Militar, "Bolivia y el Perú", 24 de marzo de 1920, p. 3.

1311. La Correspondencia Militar, "Cambio de ratificaciones entre Chile y Perú", 31 de julio de 1929, p. 4.

1312. La Correspondencia Militar, "Celebrando el acuerdo", 19 de mayo de 1929, p. 2.

1313. La Correspondencia Militar, "Chile está decidido a que se lleve a cabo el plebiscito", 20 de abril de 1926, p. 4.

1314. La Correspondencia Militar, "Chile no aceptará la propuesta de Kellogg sobre Tacna y Arica", 3 de junio de 1926, p. 6.

1315. La Correspondencia Militar, "Chile y el Perú", 11 de enero de 1919, p. 1.

1316. La Correspondencia Militar, "Chile y la Legación de España", 1 de enero de 1927, p. 1.

1317. La Correspondencia Militar, "Chile", 6 de mayo de 1913, p. 2.

1318. La Correspondencia Militar, "Chile", 7 de agosto de 1920, p. 3.

1319. La Correspondencia Militar, "Conflicto entre Chile y Perú", 26 de octubre de 1911, p. 3.

1320. La Correspondencia Militar, "Crónica. América", 13 de septiembre de 1906, p. 2.

1321. La Correspondencia Militar, "Declaraciones de un diplomático", 21 de junio de 1924, p. 4.

1322. La Correspondencia Militar, "Del presidente. Nuestro barcos", 27 de noviembre de 1920 , p. 3.

1323. La Correspondencia Militar, "Dificultades en el plebiscito de Tacna y Arica", 17 de marzo de 1926, p. 1.

1324. La Correspondencia Militar, "Dimisión del primer ministro peruano", 18 de diciembre de 1926, p. 4.

1325. La Correspondencia Militar, "Discrepancias entre chilenos y peruanos", $10 \mathrm{de}$ febrero de 1926, p. 6.

1326. La Correspondencia Militar, "El aniversario del Gobierno de Ibáñez”, 24 de julio de 1928, p. 4.

1327. La Correspondencia Militar, "El antiguo litigio de Tacna y Arica", 18 de octubre de 1928, p. 3. 
1328. La Correspondencia Militar, "El asunto de Tacna y Arica", 10 de abril de 1926, p. 3.

1329. La Correspondencia Militar, "El asunto de Tacna y Arica", 18 de marzo de 1926, p. 1.

1330. La Correspondencia Militar, "El conflicto chileno-peruano", 18 de julio de 1924, p. 4.

1331. La Correspondencia Militar, "El conflicto entre Chile y Perú", 15 de diciembre de 1921, p. 1.

1332. La Correspondencia Militar, "El conflicto entre Chile y Perú", 19 de diciembre de 1921, p. 3.

1333. La Correspondencia Militar, "El conflicto entre Chile y Perú", 30 de diciembre de 1921, p. 2.

1334. La Correspondencia Militar, "El derecho de Chile en el plebiscito", 6 de abril de 1926, p. 3.

1335. La Correspondencia Militar, "El eterno plebiscito", 24 de febrero de 1926, p. 6.

1336. La Correspondencia Militar, "El eterno pleito de Tacna y Arica", 18 de noviembre de 1926, p. 5.

1337. La Correspondencia Militar, "El eterno pleito", 13 de agosto de 1926, p. 1.

1338. La Correspondencia Militar, "El eterno pleito", 21 de septiembre de 1926, p. 4.

1339. La Correspondencia Militar, "El eterno pleito", 25 de febrero de 1926, p. 2.

1340. La Correspondencia Militar, "El eterno pleito", 7 de agosto de 1926, p. 1.

1341. La Correspondencia Militar, "El eterno problema de Tacna y Arica", 2 de julio de 1926, p. 4.

1342. La Correspondencia Militar, "El ex presidente Alessandri se revuelve contra los Estados Unidos de Norteamérica", 19 de junio de 1926, p. 2.

1343. La Correspondencia Militar, "El fracaso del plebiscito sobre Tacna y Arica", 24 de junio de 1926, p. 2.

1344. La Correspondencia Militar, "El General Pershing sustituido", 9 de enero de 1926, p. 3.

1345. La Correspondencia Militar, "El histórico proceso de Tacna y Arica", 19 de abril de 1929, p. 1.

1346. La Correspondencia Militar, "El Jesús del Gran Poder ha llegado a Arica", 23 de abril de 1929, p. 6.

1347. La Correspondencia Militar, "El Jesús del Gran Poder llega a Lima”, 24 de abril de 1929, p. 4.

1348. La Correspondencia Militar, "El Jesús del Gran Poder que fue ayer en vuelo de Cádiz a Sevilla, llegará hoy Madrid", 9 de junio de 1929, p. 4.

1349. La Correspondencia Militar, "El litigio de Tacna y Arica", 19 de junio de 1926, p. 5.

1350. La Correspondencia Militar, "El litigio de Tacna y Arica", 9 de junio de 1928, p. 2. 
1351. La Correspondencia Militar, "El nuevo presidente de la Comisión Plebiscitaria de Tacna y Arica", 13 de enero de 1926, p. 1.

1352. La Correspondencia Militar, "El nuevo puerto de Arica", 20 de marzo de 1929, p. 4.

1353. La Correspondencia Militar, "El plebiscito de Tacna y Arica. Dimite el delegado chileno", 24 de diciembre de 1925, p. 1.

1354. La Correspondencia Militar, "El plebiscito de Tacna y Arica", 11 de agosto de 1925 , p. 5.

1355. La Correspondencia Militar, "El plebiscito de Tacna y Arica", 13 de agosto de 1925 , p. 5.

1356. La Correspondencia Militar, "El plebiscito de Tacna y Arica", 14 de abril de 1926, p. 1.

1357. La Correspondencia Militar, "El plebiscito de Tacna y Arica", 19 de marzo de 1926, p. 5.

1358. La Correspondencia Militar, "El plebiscito de Tacna y Arica", 26 de diciembre de 1925, p. 1.

1359. La Correspondencia Militar, "El plebiscito de Tacna y Arica", 27 de febrero de 1926, p. 2.

1360. La Correspondencia Militar, "El plebiscito de Tacna y Arica", 28 de diciembre de 1926, p. 1.

1361. La Correspondencia Militar, "El plebiscito de Tacna y Arica", 4 de julio de 1925, p. 3.

1362. La Correspondencia Militar, "El plebiscito de Tacna y Arica", 4 de mayo de 1926, p. 6.

1363. La Correspondencia Militar, "El pleito de Tacna y Arica", 10 de septiembre de 1926, p, 2.

1364. La Correspondencia Militar, "El pleito de Tacna y Arica", 12 de abril de 1926, p. 2.

1365. La Correspondencia Militar, "El pleito de Tacna y Arica", 14 de julio de 1926, p. 5.

1366. La Correspondencia Militar, "El pleito de Tacna y Arica", 2 de junio de 1929, p. 4.

1367. La Correspondencia Militar, "El pleito de Tacna y Arica", 2 de mayo de 1929, p. 4.

1368. La Correspondencia Militar, "El pleito de Tacna y Arica", 21 de julio de 1926, p. 2.

1369. La Correspondencia Militar, "El pleito de Tacna y Arica", 21 de julio de 1926, p. 2.

1370. La Correspondencia Militar, "El pleito de Tacna y Arica", 25 de enero de 1927, p. 1. 
1371. La Correspondencia Militar, "El pleito de Tacna y Arica", 29 de junio de 1926, p. 5.

1372. La Correspondencia Militar, "El pleito de Tacna y Arica", 3 de febrero de 1927, p. 3.

1373. La Correspondencia Militar, "El pleito de Tacna y Arica", 8 de enero de 1926, p. 5.

1374. La Correspondencia Militar, "El pleito de Tacna y Arica", 8 de septiembre de 1926, p. 3.

1375. La Correspondencia Militar, "El pleito de Tacna-Arica", 17 de noviembre de 1926, p. 1.

1376. La Correspondencia Militar, "El pleito entre Chile y el Perú", 2 de diciembre de 1926, p. 4.

1377. La Correspondencia Militar, "El premio Nobel de la Paz para los presidentes de Chile y Perú", 13 de octubre de 1929, p. 4.

1378. La Correspondencia Militar, "El premio Nobel de la Paz", 19 de octubre de 1929, p. 4.

1379. La Correspondencia Militar, "El presidente Coolidge mantiene contra Chile y Perú, el acuerdo de la Comisión del Plebiscito", 28 de enero de 1926, p. 5.

1380. La Correspondencia Militar, "El Presidente Ibáñez desembarca en Arica", 4 de agosto de 1929, p. 1.

1381. La Correspondencia Militar, "El puerto de Arica", 25 de julio de 1929, p. 1.

1382. La Correspondencia Militar, "El Tratado de Tacna y Arica y la Liga de las Naciones", 4 de agosto de 1929, p. 1

1383. La Correspondencia Militar, "El viaje de la Misión española", 20 de noviembre de 1920 , p. 1.

1384. La Correspondencia Militar, "El vuelo del Jesús del Gran Poder", 26 de abril de 1929, p. 2.

1385. La Correspondencia Militar, "En Arica se registran incidentes entre chilenos y peruanos", 8 de marzo de 1926, p. 5 .

1386. La Correspondencia Militar, "En Chile se comentan los preparativos bélicos del Perú", 27 de enero de 1927, p. 4.

1387. La Correspondencia Militar, "En la sesión de ayer de la Sociedad de Naciones quedó aprobado el informe de las minorías", 14 de junio de 1929, p. 1.

1388. La Correspondencia Militar, "Entre Chile y el Perú", 23 de enero de 1919, p. 3.

1389. La Correspondencia Militar, "Guerra próxima", 8 de abril de 1910, p. 1.

1390. La Correspondencia Militar, "Hacia la emancipación de la influencia norteamericana", 2 de marzo de 1926, p. 1.

1391. La Correspondencia Militar, "Hoy se firmará en Lima el acuerdo sobre el pleito de Tacna y Arica", 25 de abril de 1929, p. 3.

1392. La Correspondencia Militar, "Incidentes en Arica", 17 de junio de 1926, p. 3. 
1393. La Correspondencia Militar, "Informaciones hispanoamericanas", 10 de septiembre de 1926, p. 4.

1394. La Correspondencia Militar, "Informaciones hispanoamericanas", 9 de noviembre de 1926, p. 4.

1395. La Correspondencia Militar, "Intervendrán otros países en el plebiscito", 22 de julio de 1926, p. 3.

1396. La Correspondencia Militar, "La actitud de Chile en la cuestión de Tacna y Arica", 30 de marzo de 1926, p. 1.

1397. La Correspondencia Militar, "La actitud de la prensa peruana en lo de Tacna y Arica", 12 de abril de 1926, p. 1.

1398. La Correspondencia Militar, "La cuestión chilenoperuana", 17 de agosto de 1920, p. 2.

1399. La Correspondencia Militar, "La cuestión de Tacna y Arica", 10 de diciembre de 1926, p. 2.

1400. La Correspondencia Militar, "La cuestión de Tacna y Arica", 13 de abril de 1929, p. 4.

1401. La Correspondencia Militar, "La cuestión de Tacna y Arica", 14 de septiembre de 1925, p. 6.

1402. La Correspondencia Militar, "La cuestión de Tacna y Arica", 19 de junio de 1926, p. 2.

1403. La Correspondencia Militar, "La cuestión de Tacna y Arica", 2 de marzo de 1929, p. 1.

1404. La Correspondencia Militar, "La cuestión de Tacna y Arica", 20 de septiembre de 1926, p. 4.

1405. La Correspondencia Militar, "La cuestión de Tacna y Arica", 22 de septiembre de 1925 , p. 5.

1406. La Correspondencia Militar, "La cuestión de Tacna y Arica", 24 de junio de 1926, p. 1.

1407. La Correspondencia Militar, "La cuestión de Tacna y Arica", 25 de junio de 1926, p. 6.

1408. La Correspondencia Militar, "La cuestión de Tacna y Arica", 9 de enero de 1926, p. 3.

1409. La Correspondencia Militar, "La cuestión del Pacífico. De la Agencia Americana", 22 de febrero de 1926, p. 2.

1410. La Correspondencia Militar, "La cuestión del Pacífico", 10 de julio de 1926, p. 3.

1411. La Correspondencia Militar, "La cuestión del Pacífico", 16 de octubre de 1926, p. 1.

1412. La Correspondencia Militar, "La cuestión del Pacífico", 21 de agosto de 1926, p. 4. 
1413. La Correspondencia Militar, "La designación del General Lassiter", 20 de enero de 1926, p. 1.

1414. La Correspondencia Militar, "La devolución de Tacna", 29 de agosto de 1929, p. 4.

1415. La Correspondencia Militar, "La eterna cuestión de Tacna y Arica", 1 de agosto de 1927, p. 2.

1416. La Correspondencia Militar, "La familia Real visita el pabellón chileno y el colombiano", 24 de octubre de 1929, pp. 1

1417. La Correspondencia Militar, "La fiesta nacional chilena", 29 de mayo de 1929, p. 3.

1418. La Correspondencia Militar, "La intervención americana en Nicaragua", 3 de enero de 1927, p. 1.

1419. La Correspondencia Militar, "La intervención de Norteamérica en Nicaragua y la actitud de Chile", 25 de enero de 1927, p. 1.

1420. La Correspondencia Militar, "La Misión española en Chile", 8 de diciembre de 1920, p. 1.

1421. La Correspondencia Militar, "La política extranjera", 4 de mayo de 1929, p. 5.

1422. La Correspondencia Militar, "La política peruana", 18 de marzo de 1927, p. 4.

1423. La Correspondencia Militar, "La presidencia de la Comisión plebiscitaria", 18 de febrero de 1926, p. 2.

1424. La Correspondencia Militar, "La rectificación del tratado de Tacna y Arica", 4 de julio de 1929, p. 4.

1425. La Correspondencia Militar, "La renovación de la delegación chilena", 22 de julio de 1926, p. 3.

1426. La Correspondencia Militar, "La Revolución en Bolivia", 16 de julio de 1920, p. 3.

1427. La Correspondencia Militar, "La situación internacional de América", 30 de abril de 1927, p. 2.

1428. La Correspondencia Militar, "La solución de Tacna y Arica", 14 de abril de 1929 , p. 3.

1429. La Correspondencia Militar, "La solución del pleito de Tacna y Arica", 18 de mayo de 1929, p. 5.

1430. La Correspondencia Militar, "La solución del pleito de Tacna y Arica", 19 de mayo de 1929 , p. 2

1431. La Correspondencia Militar, "La solución del problema de Tacna y Arica", 1 de mayo de 1929, p. 3.

1432. La Correspondencia Militar, "La solución del problema de Tacna y Arica", 21 de mayo de 1929, p. 4.

1433. La Correspondencia Militar, "Las bases para el pleito de Tacna y Arica", 3 de mayo de 1929, p. 4. 
1434. La Correspondencia Militar, "Las cláusulas del Tratado de Tacna y Arica", 9 de mayo de 1929, p. 4.

1435. La Correspondencia Militar, "Las cuestiones de límites", 25 de abril de 1910, p. 2.

1436. La Correspondencia Militar, "Las tramitaciones para el plebiscito de Tacna y Arica", 15 de mayo de 1926, p. 3.

1437. La Correspondencia Militar, "Las tropas chilenas vuelven a ocupar Tacna y Arica", 31 de marzo de 1926, p. 3.

1438. La Correspondencia Militar, "Los delegados americanos de la Comisión plebiscitaria mantienen sus puntos de vista", 18 de junio de 1926, p. 2.

1439. La Correspondencia Militar, "Los ferrocarriles de Chile y Bolivia", 7 de marzo de 1912 , p. 3

1440. La Correspondencia Militar, "Los preparativos del Perú", 9 de abril de 1910, p. 1.

1441. La Correspondencia Militar, "Manifestación de protesta", 3 de mayo de 1926, p. 1.

1442. La Correspondencia Militar, "Manifestaciones del General Ibáñez", 11 de julio de 1929 , p. 3.

1443. La Correspondencia Militar, "Medidas de la Comisión del Plebiscito", 20 de enero de 1926, p. 1.

1444. La Correspondencia Militar, "Ni cambia ni termina", 28 de marzo de 1927, p. 4.

1445. La Correspondencia Militar, "No ha habido revolución en Lima", 23 de mayo de 1929, p. 4.

1446. La Correspondencia Militar, "Nombramiento diplomático", 24 de febrero de 1926, p. 6.

1447. La Correspondencia Militar, "Noticia oficial del arreglo del pleito de Tacna y Arica", 18 de mayo de 1929, p. 5.

1448. La Correspondencia Militar, "Noticias de provincias", 9 de octubre de 1929, p. 4.

1449. La Correspondencia Militar, "Nueva línea aérea", 27 de noviembre de 1929, p. 2. 1450. La Correspondencia Militar, "Nuevo conflicto entre chilenos y peruanos", 24 de agosto de 1926, p. 4.

1451. La Correspondencia Militar, "Nuevos puertos aéreos", 8 de agosto de 1929, p. 2.

1452. La Correspondencia Militar, "Perú acepta el plebiscito en Tacna y Arica", 10 de junio de 1925, p. 1.

1453. La Correspondencia Militar, "Perú propone nuevo arreglo de la cuestión Tacna y Arica", 29 de marzo de 1926, p. 2.

1454. La Correspondencia Militar, "Perú rechaza la proposición norteamericana sobre Tacna y Arica", 5 de enero de 1927, p. 4.

1455. La Correspondencia Militar, "Perú y Chile rompen sus relaciones diplomáticas", 22 de marzo de 1910, p. 1. 
1456. La Correspondencia Militar, "Por fin se ha resuelto el problema de Tacna y Arica", 23 de febrero de 1929, p. 1.

1457. La Correspondencia Militar, "Propaganda peruana en Arica", 2 de marzo de 1926, p. 1.

1458. La Correspondencia Militar, "Proposición del Secretario Mr. Kellogg", 11 de diciembre de 1926, p. 1.

1459. La Correspondencia Militar, "Protesta del gobierno boliviano", 9 de mayo de 1929, p. 4.

1460. La Correspondencia Militar, "Protestas contra la suspensión del plebiscito de Tacna y Arica", 12 de julio de 1926, p. 6.

1461. La Correspondencia Militar, "Puerto Fortificado", 11 de marzo de 1911, p. 2.

1462. La Correspondencia Militar, "Raid Lima Santiago de Chile Buenos Aires", 18 de septiembre de 1929, p. 1.

1463. La Correspondencia Militar, "Rechazando las acusaciones peruanas", 20 de enero de 1926, p. 1.

1464. La Correspondencia Militar, "Rumores de crisis", 25 de junio de 1924, p. 4.

1465. La Correspondencia Militar, "Se confirma que van muy adelantadas las gestiones para una solución del pleito de Tacna y Arica", 12 de junio de 1926, p. 6.

1466. La Correspondencia Militar, "Se considera factible la solución del pleito de Tacna y Arica", 30 de junio de 1926, p. 5.

1467. La Correspondencia Militar, "Se reúne la Comisión Plebiscitaria de Tacna y Arica", 8 de agosto de 1925, p. 2.

1468. La Correspondencia Militar, "Se reúne la Comisión Plebiscitaria", 31 de marzo de 1926, p. 3.

1469. La Correspondencia Militar, "Sigue el conflicto de Tacna y Arica", 7 de junio de 1926, p. 6.

1470. La Correspondencia Militar, "Solemne sesión en el Parlamento por la solución de Tacna y Arica", 28 de junio de 1929, p. 6.

1471. La Correspondencia Militar, "Sudamérica. Intereses chilenos", 15 de marzo de 1911, p. 2.

1472. La Correspondencia Militar, "Suspensión de un periódico en Arica", 22 de julio de 1926, p. 3.

1473. La Correspondencia Militar, "Terminada la reunión de la Sociedad de Naciones en Madrid, regresan a sus países los delegados", 18 de junio de 1929, p. 1.

1474. La Correspondencia Militar, "Tres fórmulas para solucionar el pleito de Tacna y Arica", 15 de junio de 1926, p. 3.

1475. La Correspondencia Militar, "Un banquete", 15 de mayo de 1913, p. 2.

1476. La Correspondencia Militar, "Un mensaje por la solución de Tacna y Arica", 21 de junio de 1929, p. 4.

1477. La Correspondencia Militar, "Un nuevo reglamento electoral", 24 de junio de 1926, p. 1. 
1478. La Correspondencia Militar, "Una campaña nacional", 10 de julio de 1926, p. 3. 1479. La Correspondencia Militar, "Una nota de la Cancillería", 20 de abril de 1926, p. 5.

1480. La Correspondencia Militar, "Una rectificación", 28 de diciembre de 1926, p. 1. 1481. La Correspondencia, "El Presidente Errázuriz", 18 de julio de 1901, p. 3.

1482. La Dinastía, "Las diferencias entre Chile y Bolivia", 22 de mayo de 1903, p. 3. 1483. La Dinastía, "Noticias extranjeras", 23 de febrero de 1891, p. 3.

1484. La Dinastía, "Telegramas. Del extranjero", 1 de abril de 1892, p. 3.

1485. La Dinastía, "Tratado de paz y amistad con el Perú", 2 de agosto de 1898. p. 1. 1486. La Dinastía, "Varias noticias", 13 de abril de 1891, p. 3.

1487. La Discusión, “-”, 20 de mayo de 1882, p. 3.

1488. La Discusión, "Chile", 28 de diciembre de 1880, p. 2.

1489. La Discusión, "Despachos telegráficos", 11 de enero de 1883, p. 2.

1490. La Discusión, "Despachos telegráficos", 11 de junio de 1880, p. 2.

1491. La Discusión, "Despachos telegráficos", 13 de junio de 1880, p. 2.

1492. La Discusión, "Extranjero", 11 de agosto de 1880, p. 2.

1493. La Discusión, "Extranjero", 12 de febrero de 1884, p. 2.

1494. La Discusión, "Extranjero", 29 de marzo de 1884, p. 1.

1495. La Discusión, "Extranjero", 29 de mayo de 1883, p. 2.

1496. La Discusión, "Extranjero", 3 de abril de 1883, p. 2.

1497. La Discusión, "Extranjero", 3 de diciembre de 1882. p. 2.

1498. La Discusión, "Extranjero", 5 de enero de 1884, p. 2.

1499. La Discusión, "Noticias generales", 15 de febrero de 1882, p. 3.

1500. La Discusión, "Noticias", 22 de enero de 1880, p. 2.

1501. La Emigración Española, "Chile y Perú han llegado a un acuerdo", 5 de junio de 1929, p. 3.

1502. La Emigración Española, "Intereses sudamericanos", 15 de junio de 1918, p. 87. 1503. La Emigración Española, "República de Cuba", 20 de noviembre de 1927, p. 7.

1504. La Emigración Española, "República del Perú", n. ${ }^{\circ} 1,5$ de enero de 1926, p. 5.

1505. La Época, “¿Otra S.D.N.?”, 5 de julio de 1926, p. 1.

1506. La Época, “-”, 12 de abril de 1880, p. 1.

1507. La Época, “-”, 13 de febrero de 1880, p. 2.

1508. La Época, “-”, 16 de mayo de 1883, p. 3.

1509. La Época, “-”, 16 de noviembre de 1880, p. 3.

1510. La Época, “-”, 27 de diciembre de 1880, p. 1.

1511. La Época, "Apertura del Parlamento del Perú. Mensaje presidencial”, 29 de julio de 1910, p. 3.

1512. La Época, “Arbitraje de España entre el Perú y Chile”, 20 de septiembre de 1898, p. 1.

1513. La Época, “Arbitraje de Norteamérica en la cuestión chileno-peruana”, 24 de diciembre de 1921, p. 2. 
1514. La Época, "Barcelona. En la Casa América”, 6 de julio de 1913, p. 2.

1515. La Época, "Bolivia contra el Perú", 19 de marzo de 1920, p. 3.

1516. La Época, "Bolivia quiere intervenir en las negociaciones chileno-peruanas", 23 de enero de 1922, p. 4.

1517. La Época, "Carta de Chile", 3 de septiembre de 1890, p. 2.

1518. La Época, "Carta del Perú", 23 de septiembre de 1898, p. 2.

1519. La Época, "Cartas peruanas", 13 de abril de 1882, p. 4.

1520. La Época, "Chile acepta el arbitraje", 21 de diciembre de 1921, p. 2.

1521. La Época, "Chile y el Perú", 18 de agosto de 1919, p. 3.

1522. La Época, "Chile y la Argentina", 9 de septiembre de 1898, p. 1.

1523. La Época, "Chile y Perú", 14 de enero de 1919, p. 4.

1524. La Época, "Chile y Perú", 15 de marzo de 1911, p. 1.

1525. La Época, "Chile y Perú", 24 de enero de 1919, p. 4.

1526. La Época, "Chile y su política exterior", 9 de agosto de 1920, p. 3.

1527. La Época, "Chile y su progreso", 16 de agosto de 1920, p. 1.

1528. La Época, "Chile", 20 de febrero de 1911, p. 3.

1529. La Época, "Comercio con Brasil”, 21 de marzo de 1909, p. 2.

1530. La Época, "Conferencia del señor Révesz en la Unión Iberoamericana”, 17 de diciembre de 1926, p. 4.

1531. La Época, "Cosas de América", 22 de enero de 1909, p. 1.

1532. La Época, "D. Carlos en el Perú", 9 de agosto de 1887, p. 2.

1533. La Época, "De la Agencia Fabra. Terremoto", 31 de marzo de 1892, p. 1.

1534. La Época, "De la Agencia Mencheta. Perú y Chile", 31 de julio de 1898. p. 3.

1535. La Época, "Desde Chile", 24 de octubre de 1919, p. 3.

1536. La Época, "Desórdenes en Lima. Once estudiantes muertos", 31 de mayo de 1923, p. 1.

1537. La Época, "Despachos telegráficos", 1 de diciembre de 1880, p. 2.

1538. La Época, "Despachos telegráficos", 12 de junio de 1880, p. 3.

1539. La Época, "Despachos telegráficos", 12 de octubre de 1880, p. 3.

1540. La Época, "Despachos telegráficos", 15 de junio de 1880, p. 5.

1541. La Época, "Despachos telegráficos", 20 de marzo de 1906, p. 1.

1542. La Época, "Despachos telegráficos", 31 de mayo de 1880, p. 1

1543. La Época, "Doce aeropuertos en Chile", 25 de julio de 1929, p. 2.

1544. La Época, "Don Andrés Révesz en la Sociedad Económica Matritense", 28 de enero de 1929, p. 2.

1545. La Época, "Ecos del día", 26 de febrero de 1884, p. 1.

1546. La Época, "Ecos del día", 9 de noviembre de 1882, p. 2.

1547. La Época, "El acuerdo sobre Tacna y Arica", 18 de mayo de 1929, p. 4.

1548. La Época, "El acuerdo sobre Tacna y Arica", 20 de mayo de 1929, p. 5.

1549. La Época, "El Arbitraje de España entre Chile y el Perú", 23 de agosto de 1898, p. 3. 
1550. La Época, "El arbitraje de España sobre Tacna y Arica", 2 de septiembre de 1898, p. 1.

1551. La Época, "El arbitraje de España sobre Tacna y Arica", 4 de octubre de 1898, p. 1.

1552. La Época, "El aviador Hillcot atraviesa los Andes", 2 de enero de 1925, p. 3.

1553. La Época, "El centenario de Magallanes", 2 de agosto de 1920, p. 1.

1554. La Época, "El conflicto chileno-peruano", 10 de febrero de 1919, p. 3.

1555. La Época, "El conflicto chileno-peruano", 20 de mayo de 1919, p. 3.

1556. La Época, "El conflicto de Tacna y Arica", 4 de junio de 1929, p. 2.

1557. La Época, "El conflicto entre Chile y el Perú", 18 de diciembre de 1918, p. 3.

1558. La Época, "El conflicto entre Chile y Perú", 2 de diciembre de 1918, p. 3.

1559. La Época, "El conflicto entre Chile y Perú", 23 de diciembre de 1918, p. 1.

1560. La Época, "El conflicto entre Chile y Perú", 26 de diciembre de 1918, p. 3.

1561. La Época, "El conflicto entre Chile y Perú", 8 de diciembre de 1918, p. 3.

1562. La Época, "El Consejo de la S.D.N.", 14 de junio de 1929, p. 1.

1563. La Época, "El ferrocarril chileno-boliviano", 14 de mayo de 1913, p. 3.

1564. La Época, "El Ferrocarril de Arica a La Paz. El empréstito chileno", 28 de noviembre de 1907, p. 1.

1565. La Época, "El Ferrocarril de Arica a La Paz. Un banquete", 15 de mayo de 1913, p. 3.

1566. La Época, "El Ferrocarril de Arica a La Paz", 30 de junio de 1909, p. 3.

1567. La Época, "El Ferrocarril de Bolivia", 23 de enero de 1908, p. 2.

1568. La Época, "El fracaso de la política de Coolidge", 24 de marzo de 1926, p. 1.

1569. La Época, "El Instituto de Derecho Internacional", 15 de octubre de 1929, p. 1.

1570. La Época, "El mensaje del presidente Hoover al Congreso", 4 de diciembre de 1929 , p. 4.

1571. La Época, "El mensaje presidencial", 2 de junio de 1921, p. 1.

1572. La Época, "El Ministro de España en la Argentina”, 22 de agosto de 1898, p. 4.

1573. La Época, "El nuevo Gobierno de Chile", 12 de febrero de 1927, p. 1.

1574. La Época, "El nuevo ministro de Chile", 26 de enero de 1910, p. 1.

1575. La Época, "El parlamento chileno.- Discurso presidencial.- Las relaciones con

Bolivia", 2 de junio de 1922, p. 1.

1576. La Época, "El Perú y Chile", 7 de abril de 1910, p. 2.

1577. La Época, "El plebiscito de Tacna y Arica", 2 de enero de 1926, p. 3.

1578. La Época, "El plebiscito sobre Tacna y Arica", 17 de diciembre de 1925, p. 1.

1579. La Época, "El plebiscito sobre Tacna y Arica", 26 de noviembre de 1925, p. 3.

1580. La Época, "El plebiscito sobre Tacna y Arica", 6 de julio de 1925, p. 1.

1581. La Época, "El pleito de Tacna y Arica", 20 de agosto de 1926, p. 1.

1582. La Época, "El pleito de Tacna y Arica", 6 de abril de 1927, p. 1.

1583. La Época, "El problema de Tacna y Arica", 3 de diciembre de 1926, p. 1. 
1584. La Época, "El problema del Pacífico en la América del Sur", 9 de octubre de 1900, p. 3.

1585. La Época, "El problema internacional entre Chile y Perú", 9 de octubre de 1920, p. 1.

1586. La Época, "El próximo Congreso Panamericano", 29 de septiembre de 1901, p. 1.

1587. La Época, "El proyecto de un aviador colombiano", 16 de marzo de 1929, p. 1.

1588. La Época, "El puerto de Arica", 24 de julio de 1929, p. 4.

1589. La Época, "El señor Révesz en la Real Academia de Ciencias Morales y Políticas", 10 de mayo de 1926, p. 6.

1590. La Época, "El servicio religioso en Chile", 19 de junio de 1910, p. 1.

1591. La Época, "El taller de noticias falsas", 4 de julio de 1898, p. 2.

1592. La Época, "El viaje de Don Carlos por América", 17 de agosto de 1887, p. 4.

1593. La Época, "Elecciones presidenciales", 3 de septiembre de 1898, p 3.

1594. La Época, "Embajadas chilenas. Fortificaciones", 11 de marzo de 1911, p. 1.

1595. La Época, "Emigrantes a Chile", 3 de abril de 1907, p. 2.

1596. La Época, "En el estudio de Querol", 26 de enero de 1903, p. 1.

1597. La Época, "En Estado", 10 de noviembre de 1920, p. 1.

1598. La Época, "En honor del delegado de Chile en la Sociedad de Naciones", 17 de junio de 1929, p. 1.

1599. La Época, "En la América Latina", 28 de mayo de 1901, p. 1.

1600. La Época "En Washington se sigue estudiando el acuerdo sobre Tacna y Arica", 14 de mayo de 1929, p. 1.

1601. La Época, "España en América", 24 de agosto de 1900, p. 3.

1602. La Época, "Fallecimiento del ex secretario de Estado Lansing", 31 de octubre de 1928, p. 1.

1603. La Época, "Fianza para resolver el pleito de Tacna y Arica", 11 de diciembre de 1925, p. 3.

1604. La Época, "Fin del conflicto de Tacna y Arica", 6 de julio de 1929, p. 6.

1605. La Época, "Gran entusiasmo por la misión diplomática conferida a Jiménez e Iglesias", 19 de abril de 1929, p. 2.

1606. La Época, "Hispanoamérica en la política internacional", 7 de marzo de 1928, p. 1.

1607. La Época, "Hoy se ha tratado de la importante cuestión de las minorías", 13 de junio de 1929, p. 1.

1608. La Época, "Huellas españolas. Un libro de Francos Rodríguez", 19 de agosto de 1922, p. 6.

1609. La Época, "Imposición de una condecoración al presidente del Consejo", 16 de julio de 1929, p. 2.

1610. La Época, "Inundaciones en Chile", 17 de febrero de 1911, p. 1.

1611. La Época, “Jiménez e Iglesias parten para Lima”, 23 de abril de 1929, p. 4. 
1612. La Época, "La apertura del parlamento chileno", 23 de mayo de 1929, p. 2.

1613. La Época, "La conferencia del Pacífico", 17 de mayo de 1922, p. 1.

1614. La Época, "La cuestión chileno-peruana", 16 de diciembre de 1921, p. 1.

1615. La Época, "La cuestión chileno-peruana", 19 de diciembre de 1921, p. 4.

1616. La Época, "La cuestión chilenoperuana", 3 de enero de 1922, p. 1.

1617. La Época, "La cuestión chilenoperuana", 30 de diciembre de 1921, p. 4.

1618. La Época, "La cuestión de Tacna y Arica en Ginebra y una nota del gobierno del

Perú", 23 de septiembre de 1927, p. 2.

1619. La Época, "La cuestión de Tacna y Arica resuelta", 22 de abril de 1929, p. 6.

1620. La Época, "La cuestión de Tacna y Arica se agrava", 26 de noviembre de 1925,

p. 1.

1621. La Época, "La cuestión de Tacna y Arica. Chile quiere el plebiscito", 14 de abril de 1926, p. 1.

1622. La Época, "La cuestión de Tacna y Arica. Vuelve a reunirse la comisión", 1 de diciembre de 1925, p. 1.

1623. La Época, "La cuestión de Tacna y Arica", 1 de abril de 1925, p. 3.

1624. La Época, "La cuestión de Tacna y Arica", 1 de diciembre de 1926, p. 2.

1625. La Época, "La cuestión de Tacna y Arica", 1 de septiembre de 1925, p. 3.

1626. La Época, "La cuestión de Tacna y Arica", 10 de marzo de 1925, p. 1.

1627. La Época, "La cuestión de Tacna y Arica”, 10 de septiembre de 1926, p. 3.

1628. La Época, "La cuestión de Tacna y Arica", 11 de diciembre de 1925, p. 1.

1629. La Época, "La cuestión de Tacna y Arica", 11 de marzo de 1925, p. 3.

1630. La Época, "La cuestión de Tacna y Arica", 12 de octubre de 1926, p. 3.

1631. La Época, "La cuestión de Tacna y Arica", 13 de diciembre de 1922, p. 1.

1632. La Época, "La cuestión de Tacna y Arica", 14 de junio de 1926, p. 1.

1633. La Época, "La cuestión de Tacna y Arica”, 14 de noviembre de 1925, p. 3.

1634. La Época, "La cuestión de Tacna y Arica", 16 de enero de 1926, p. 1.

1635. La Época, "La cuestión de Tacna y Arica", 16 de febrero de 1929, p. 1.

1636. La Época, "La cuestión de Tacna y Arica", 18 de enero de 1927, p. 4.

1637. La Época, "La cuestión de Tacna y Arica", 18 de marzo de 1926, p. 1.

1638. La Época, "La cuestión de Tacna y Arica", 19 de junio de 1926, p. 1.

1639. La Época, "La cuestión de Tacna y Arica", 19 de mayo de 1926, p. 2.

1640. La Época, "La cuestión de Tacna y Arica", 2 de diciembre de 1925, p. 1.

1641. La Época, "la cuestión de Tacna y Arica", 20 de julio de 1926, p.3.

1642. La Época, "La cuestión de Tacna y Arica", 20 de junio de 1925, p. 1.

1643. La Época, "La cuestión de Tacna y Arica", 23 de diciembre de 1926, p. 1.

1644. La Época, "La cuestión de Tacna y Arica", 23 de febrero de 1929, p. 4.

1645. La Época, "La cuestión de Tacna y Arica", 24 de diciembre de 1925, p. 1.

1646. La Época, "La cuestión de Tacna y Arica", 24 de enero de 1923, p. 1

1647. La Época, "La cuestión de Tacna y Arica", 24 de enero de 1923, p. 3.

1648. La Época, "La cuestión de Tacna y Arica", 24 de marzo de 1925, p. 1. 
1649. La Época, "La cuestión de Tacna y Arica", 26 de diciembre de 1925, p. 3.

1650. La Época, "La cuestión de Tacna y Arica", 26 de enero de 1927, p. 1.

1651. La Época, "La cuestión de Tacna y Arica", 28 de julio de 1925, p. 3.

1652. La Época, "La cuestión de Tacna y Arica", 29 de agosto de 1921, p. 1.

1653. La Época, "La cuestión de Tacna y Arica", 30 de diciembre de 1925, p. 1.

1654. La Época, "La cuestión de Tacna y Arica", 30 de marzo de 1926, p. 1.

1655. La Época, "La cuestión de Tacna y Arica", 30 de septiembre de 1925, p. 1.

1656. La Época, "La cuestión de Tacna y Arica", 5 de diciembre de 1925, p. 1.

1657. La Época, "La cuestión de Tacna y Arica", 6 de diciembre de 1926, p. 3.

1658. La Época, "La cuestión de Tacna y Arica", 7 de julio de 1922, p. 3.

1659. La Época, "La cuestión de Tacna y Arica", 7 de julio de 1928, p. 4.

1660. La Época, "La cuestión de Tacna y Arica", 8 de agosto de 1925, p. 3.

1661. La Época, "La cuestión de Tacna y Arica", 8 de diciembre de 1925, p. 3.

1662. La Época, "La cuestión de Tacna y Arica", 8 de enero de 1926, p. 3.

1663. La Época, "La cuestión de Tacna y Arica", 9 de enero de 1926, p. 3.

1664. La Época, "La cuestión del Pacífico", 1 de octubre de 1926, p. 7.

1665. La Época, "La entrega del protocolo de Tacna y Arica", 25 de septiembre de 1929, p. 2.

1666. La Época, "La insurrección de Chile", 21 de febrero de 1891, p. 3.

1667. La Época, "La Misión española a Chile”, 20 de noviembre de 1920, p. 1.

1668. La Época, "La misión española a Chile", 27 de septiembre de 1920, p. 3.

1669. La Época, "La Misión española a Chile", 6 de noviembre de 1920, p. 6.

1670. La Época, "La Misión española en Chile", 23 de noviembre de 1920, p. 3.

1671. La Época, "La Misión española y el alma chilena", 10 de diciembre de 1920, p. 1.

1672. La Época, "La petición del de la Paz para los presidentes de Chile y Perú", 1 de noviembre de 1929, p. 2.

1673. La Época, "La ratificación del tratado sobre Tacna y Arica", 15 de julio de 1929, p. 4.

1674. La Época, "La renovación de poderes al Señor Leguía", 15 de octubre de 1929,

p. 1.

1675. La Época, "La revolución de Chile", 12 de abril de 1891, p. 1.

1676. La Época, "La revolución en Chile", 20 de abril de 1891, p. 2.

1677. La Época, "La situación en Bolivia", 15 de octubre de 1929, p. 4.

1678. La Época, "La Sociedad de Naciones", 21 de julio de 1928, p. 3.

1679. La Época, "La solución del pleito de Tacna y Arica", 3 de mayo de 1929, p. 1.

1680. La Época, "La solución del pleito de Tacna y Arica", 8 de julio de 1929, p. 6.

1681. La Época, "Las aspiraciones de Bolivia y el Perú sobre Arica", 11 de marzo de 1920, p. 3.

1682. La Época, "Las cuestiones territoriales en las repúblicas sudamericanas", 14 de octubre de 1900, p. 2. 
1683. La Época, "Las cuestiones territoriales en las repúblicas sudamericanas", 15 de octubre de 1900, p. 1.

1684. La Época, "Las diferencias entre Chile y Bolivia", 17 de mayo de 1903, p. 2.

1685. La Época, "Las negociaciones sobre la paz", 22 de julio de 1898, p. 1.

1686. La Época, "Las relaciones con Perú y Bolivia", 3 de septiembre de 1920, p. 1.

1687. La Época, "Las relaciones entre Chile y Bolivia", 27 de agosto de 1926, p. 1.

1688. La Época, "Lo de Tacna y Arica", 1 de febrero de 1923, p. 1.

1689. La Época, "Lo que dice el presidente", 25 de septiembre de 1920, p. 1.

1690. La Época, "Los actos de la semana chilena", 21 de octubre de 1929, p. 2.

1691. La Época, "Los ferrocarriles de Chile", 9 de mayo de 1913, p. 1.

1692. La Época, "Los sacerdotes del Perú expulsados de Chile", 6 de marzo de 1910, p. 5.

1693. La Época, "Manifestaciones del presidente", 19 de noviembre de 1920, p. 1.

1694. La Época, "Manifestaciones del presidente", 19 de noviembre de 1920, p. 1.

1695. La Época, "Manifestaciones del presidente", 27 de noviembre de 1920, p. 1.

1696. La Época, "Manifestaciones del señor Francos Rodríguez, explicando un incidente", 11 de diciembre de 1920, p. 1.

1697. La Época, "Moratoria para el tránsito comercial en Tacna y Arica", 2 de septiembre de 1920, p. 3.

1698. La Época, "Movimiento revolucionario en Bolivia", 15 de julio de 1920, p. 1.

1699. La Época, "No hay Tratado secreto entre Perú y Chile", 7 de enero de 1908, p. 3.

1700. La Época, "Notas de última hora", 30 de agosto de 1898, p. 3.

1701. La Época, "Noticas Generales", 11 de enero de1902, p. 3.

1702. La Época, "Noticias cortas", 1 de marzo de 1920, p. 1.

1703. La Época, "Noticias cortas", 15 de abril de 1924, p. 1.

1704. La Época, "Noticias cortas", 16 de noviembre de 1922, p. 1.

1705. La Época, "Noticias cortas", 20 de marzo de 1925, p. 1.

1706. La Época, "Noticias cortas", 20 de mayo de 1925, p. 1.

1707. La Época, "Noticias cortas", 21 de enero de 1926, p. 1.

1708. La Época, "Noticias cortas", 24 de junio de 1926, p. 1.

1709. La Época, "Noticias cortas", 3 de julio de 1929, p. 4.

1710. La Época, "Noticias cortas", 3 de junio de 1926, p. 3.

1711. La Época, "Noticias cortas", 30 de noviembre de 1922, p. 1.

1712. La Época, "Noticias cortas", 4 de agosto de 1925, p. 1.

1713. La Época, "Noticias cortas", 4 de junio de 1929, p. 1.

1714. La Época, "Noticias cortas", 8 de abril de 1925, p. 1.

1715. La Época, "Noticias cortas", 9 de julio de 1925, p. 1.

1716. La Época, "Noticias de Chile", 27 de septiembre de 1898, p. 3.

1717. La Época, "Noticias de Estado", 25 de septiembre de 1920, p. 3.

1718. La Época, "Noticias de la Guerra chileno-peruana", 22 de julio de 1880, p. 1.

1719. La Época, "Noticias de los Estados Unidos", 2 de abril de 1892, p. 2. 
1720. La Época, "Nuestra Misión extraordinaria en Chile", 25 de enero de 1921, p. 1.

1721. La Época, "Nuestros telegramas", 13 de noviembre de 1882, p. 3.

1722. La Época, "Nuestros Telegramas", 14 de febrero de 1882, p. 3.

1723. La Época, "Nuestros telegramas", 19 de mayo de 1882, p. 2.

1724. La Época, "Nuevo conflicto entre Perú y Chile", 23 de marzo de 1910, p. 1.

1725. La Época, "Nuevo Gobierno chileno", 22 de marzo de 1923, p. 1.

1726. La Época, "Nuevo presidente de la Comisión Plebiscitaria de Tacna y Arica", 13

de enero de 1926, p. 1.

1727. La Época, "Otras notas", 14 de junio de 1929, p. 2.

1728. La Época, "Para festejar la solución del pleito de Tacna y Arica", 20 de junio de 1929, p. 2.

1729. La Época, "Prensa extranjera", 14 de octubre de 1880, p. 3.

1730. La Época, "Prensa extranjera", 18 de agosto de 1880, p. 2.

1731. La Época, "Prensa extranjera", 28 de marzo de 1880, p. 1

1732. La Época, "Prensa extranjera", 4 de abril de 1880, p. 3.

1733. La Época, "Próximas declaraciones del ministro de Estado chileno", 30 de junio de 1928, p. 4.

1734. La Época, "Quejas del Perú sobre Tacna y Arica”, 1 de agosto de 1927, p. 1.

1735. La Época, "Relaciones Hispano-Americanas", 3 de julio de 1901, p. 1.

1736. La Época, "Relato e impresiones de un viaje a América", 12 de abril de 1921, p. 1.

1737. La Época, "Respuesta de Chile al Gobierno peruano", 27 de diciembre de 1921, p. 3.

1738. La Época, "Revista extranjera", 17 de febrero de 1882, p. 2.

1739. La Época, "Se confirma el aplazamiento del plebiscito de Tacna y Arica", 27 de marzo de 1926, p. 1.

1740. La Época, "Se confirma la elección del Coronel Ibáñez para la presidencia de Chile", 25 de mayo de 1927.

1741. La Época, "Se pide el premio Nobel de la Paz para los presidentes de Chile y Perú", 12 de octubre de 1929, p. 4.

1742. La Época, "Se reanudan las negociaciones sobre Tacna y Arica", 12 de agosto de 1926, p, 1.

1743. La Época, "Sevilla", 8 de octubre de 1929, p. 2.

1744. La Época, "Solución del conflicto de Tacna y Arica", 21 de julio de 1922, p. 1.

1745. La Época, "Solución del pleito de Tacna y Arica", 21 de febrero de 1929, p. 1.

1746. La Época, "Solución del pleito de Tacna y Arica", 22 de febrero de 1929, p. 1.

1747. La Época, "Tacna y Arica", 2 de marzo de 1919, p. 3.

1748. La Época, “Tratado de Paz y Amistad con el Perú", 30 de julio de 1898, p. 2.

1749. La Época, "Últimos telegramas. Apertura del Congreso chileno", 2 de junio de 1896, p. 3.

1750. La Época, "Un bohemio parisiense", 17 de octubre de 1880, p. 1. 
1751. La Época, "Un bohemio parisiense", 2 de noviembre de 1880, p. 1.

1752. La Época, "Un bohemio parisiense", 28 de septiembre de 1880, p. 1.

1753. La Época, "Un bohemio parisiense", 29 de septiembre de 1880, p. 1.

1754. La Época, "Un nuevo ferrocarril en Bolivia", 11 de junio de 1912, p. 4.

1755. La Época, "Una nota de la Legación de Chile", 24 de marzo de 1920, p. 1.

1756. La Época, "Varias noticias", 23 de enero de 1913, p. 1.

1757. La Época, "Visita a los pabellones de Chile y Colombia", 23 de octubre de 1929,

p. 4.

1758. La Época, "Vuelven a suspenderse las negociaciones sobre Tacna y Arica", 8 de noviembre de 1926, p.1.

1759. La Esfera, "De Norte a Sur" (fotografía), 17 de febrero de 1923, p. 22.

1760. La Esfera, "El arbitraje en la cuestión de Chile con el Perú", 26 de mayo de 1923,

p. 18.

1761. La Esfera, "El pleito en el que todos tienen razón", 4 de abril de 1925, p. 21.

1762. La Esfera, "El pleito en el que todos tienen razón", 4 de abril de 1925, p. 22.

1763. La Esfera, "Emoción de cumbres", 15 de diciembre de 1928, p. 34.

1764. La Esfera, "Tacna y Arica, tierra irredenta", 14 de agosto de 1926, año XIII, n. ${ }^{\circ}$ 658, p. 30.

1765. La Esfera, "Vistas y aspectos de Lima", 3 de agosto de 1929, año XVI, n. ${ }^{\circ} 813$, p. 22.

1766. La España Moderna, "Chilenización de Tacna y Arica", 1 de marzo de 1901, p. 148.

1767. La España Moderna, "Codificación del derecho internacional americano", 1 de junio de 1913, año XXV, n. ${ }^{\circ}$ 294, p. 108.

1768. La España Moderna, "El arbitraje hispanoamericano", noviembre de 1903, año $\mathrm{XV}, \mathrm{n}^{\circ}{ }^{\mathrm{o}} 179, \mathrm{p}$.

1769. La España Moderna, "La América moderna", 1 de abril de 1913, año XXV, n. ${ }^{\circ}$ 292, p. 149.

1770. La España Moderna, "La América moderna", 1 de agosto de 1913, año XXV, n. ${ }^{\circ}$ 296, p. 196.

1771. La España Moderna, "La América moderna", 1 de enero de 1912, año XXIV, Tomo 277, p. 151.

1772. La España Moderna, "La América moderna", 1 de marzo de 1912, año XXIV, Tomo 279, p. 157.

1773. La España Moderna, "La América Moderna", 1 de octubre de 1910, año XXII, n. ${ }^{\circ} 262$, p. 115.

1774. La España Moderna, "Las Conferencias Panamericanas", febrero de 1911, año XXIII, n. ${ }^{\circ}$ 266, pp. 5-22.

1775. La España Moderna, "Las nuevas confederaciones", 1 de noviembre de 1898, p. 102. 
1776. La España Moderna, "Los himnos nacionales de la América Española", 1903, año XV, n. ${ }^{\circ} 169$, p. 116.

1777. La España Moderna, "Revista Hispanoamericana", 1 de agosto de 1899, año XI, n. ${ }^{\circ} 128$, p. 186.

1778. La España Moderna, "Revista Hispanoamericana", 1 de agosto de 1900, p. 147.

1779. La España Moderna, "Revista Hispanoamericana", 1 de diciembre de 1899, año XI, n. ${ }^{\circ} 132$, p. 191.

1780. La España Moderna, "Revista Hispanoamericana", 1 de diciembre de 1900, año XII, n. ${ }^{\circ} 144$, p. 157.

1781. La España Moderna, "Revista Hispanoamericana", 1 de enero de 1899, año XI, n. ${ }^{\circ} 121$, pp. 130, 131, 132.

1782. La España Moderna, "Revista Hispanoamericana", 1 de febrero de 1899, año XI, n. ${ }^{\circ} 122$, p. 164.

1783. La España Moderna, "Revista Hispanoamericana", 1 de julio de 1900, año XII, n. ${ }^{\circ} 139$, p. 126.

1784. La España Moderna, "Revista Hispanoamericana", 1 de junio de 1900, año XII, n. ${ }^{\circ} 138$, pp. $146-147$.

1785. La España Moderna, "Revista Hispanoamericana", 1 de marzo de 1899, año XI, n. ${ }^{\circ} 123$, p. 199.

1786. La España Moderna, "Revista Hispanoamericana", 1 de marzo de 1900, año XII, n. ${ }^{\mathrm{o}} 135$, p. 150.

1787. La España Moderna, "Revista Hispanoamericana", 1 de mayo de 1900, año XII, n. ${ }^{\circ} 137$, p. 192.

1788. La España Moderna, "Revista Hispanoamericana", 1 de noviembre de 1899, año XI, n. ${ }^{\circ} 131$, p. 157.

1789. La España Moderna, "Revista Hispanoamericana", 1 de noviembre de 1900, p. 169.

1790. La España Moderna, "Revista Hispanoamericana", 1 de octubre de 1900, pp. 128-129.

1791. La España Moderna, "Revista Hispanoamericana", 1 de septiembre de 1899, año XI, n. ${ }^{\circ} 129$, p. 163.

1792. La España Moderna, "Revista Hispanoamericana", 1 de septiembre de 1901, año XIII, n. ${ }^{\circ} 153$, pp. 158-159.

1793. La España Moderna, "Revista Hispanoamericana", 11 de diciembre de 1898, año X, n. ${ }^{\circ} 120$, p. 169.

1794. La España Moderna, "Revista ultramarina", 1 de noviembre de 1890, año II, n. ${ }^{\circ}$ XXIII, pp. 216-217.

1795. La España Moderna, "Un conflicto Yankee-chileno. La cuestión Allsop", mayo 1910, año XXII, n. ${ }^{\circ} 257,89-102$.

1796. La Fiesta Brava, "Y dale con Cagancho", n. ${ }^{\circ}$ 22, 16 de septiembre de 1926, p. 6. 
1797. La Gaceta de los Caminos de Hierro, "Chile", 20 de septiembre de 1921, año LXVI, n. ${ }^{\circ} 3309$, p. 318.

1798. La Gaceta Literaria, "El pleito del Pacífico", 1 de enero de 1927, p. 2.

1799. La Gaceta Literaria, "El pleito del Pacífico", 15 de enero de 1927, p. 6.

1800. La Gaceta Literaria, "Joaquín Edwards Bello: Tacna y Arica. (Madrid, 1927)",

15 de julio de 1927, p. 4.

1801. La Iberia, “-" 3 de diciembre de 1882, p. 3.

1802. La Iberia, "América del Sur", 1 de enero de 1880, p. 2.

1803. La Iberia, "América del Sur", 11 de marzo de 1880, pp. 1-2.

1804. La Iberia, "América del Sur", 12 de marzo de 1880, p. 2.

1805. La Iberia, "América del Sur", 14 de enero de 1881, p. 2.

1806. La Iberia, "América del Sur", 17 de enero de 1880, p. 2.

1807. La Iberia, “América del Sur", 19 de noviembre de 1880, p. 2.

1808. La Iberia, "América del Sur", 2 de diciembre de 1880, p. 2.

1809. La Iberia, "América del Sur", 21 de noviembre de 1880, p. 2.

1810. La Iberia, "América del Sur", 25 de febrero de 1880, p. 2.

1811. La Iberia, "América del Sur", 27 de diciembre de 1880, p. 2.

1812. La Iberia, "América del Sur", 29 de enero de 1880, pp. 1-2

1813. La Iberia, "América", 11 de mayo de 1881, p. 2.

1814. La Iberia, "América”, 12 de febrero de 1881, pp. 2-3.

1815. La Iberia, "América", 19 de mayo de 1882, p. 2.

1816. La Iberia, "América", 2 de diciembre de 1882. p. 1.

1817. La Iberia, "América", 20 de octubre de 1881, p. 3.

1818. La Iberia, "América", 21 de octubre de 1882, p. 2.

1819. La Iberia, "América", 26 de agosto de 1881, p. 2.

1820. La Iberia, "América", 30 de enero de 1882, p. 2.

1821. La Iberia, "América", 8 de junio de 1883, p. 2.

1822. La Iberia, "Bolsín", 13 de marzo de 1882, p. 3.

1823. La Iberia, "Buenos Aires", 14 de junio de 1881, p. 2.

1824. La Iberia, "Chile", 18 de abril de 1880, p. 2.

1825. La Iberia, "Chile", 5 de junio de 1884, p. 2.

1826. La Iberia, "Correo de América", 16 de febrero de 1882, p. 2.

1827. La Iberia, "Despachos telegráficos de la Agencia Fabra", 12 de octubre de 1880,

p. 2.

1828. La Iberia, "Despachos telegráficos de la Agencia Fabra", 15 de junio de 1880, p. 1.

1829. La Iberia, "Despachos telegráficos de la Agencia Fabra", 29 de enero de 1881, p. 2.

1830. La Iberia, "El Tratado de paz chileno peruano", 31 de enero de 1884, p. 2.

1831. La Iberia, "Extranjero", 18 de febrero de 1881, p. 3.

1832. La Iberia, "Extranjero", 19 de agosto de 1880, p. 2. 
1833. La Iberia, "La insurrección chilena", 12 de abril de 1891, p. 1.

1834. La Iberia, "Paz con honra", 23 de septiembre de 1881, p. 2.

1835. La Iberia, "Santiago de Chile", 2 de junio de 1894, p. 1.

1836. La Iberia, "Telegramas de la Agencia Fabra", 11 de enero de 1883, p. 2.

1837. La Iberia, "Telegramas de la Agencia Fabra", 13 de noviembre de 1882, p. 2.

1838. La Iberia, "Telegramas de la Agencia Fabra", 15 de febrero de 1882, p. 2.

1839. La Iberia, "Telegramas de la Agencia Fabra", 20 de mayo de 1882, p. 3.

1840. La Iberia, "Telegramas", 17 de mayo de 1883, p. 2.

1841. La Ilustració Catalana, "Crónica general”, 30 de diciembre de 1880, tomo I, p. 138.

1842. La Ilustración Artística, "Expansión ferroviaria en la América del Sur", 12 de abril de 1915, año XXXIV, n. ${ }^{\circ}$ 1737, p. 266.

1843. La Ilustración Artística, "Monumento a Bolognesi", 19 de mayo de 1902, n. ${ }^{\circ}$ 1064, p. 338.

1844. La Ilustración Artística, "Noticias geográficas", 4 de junio de 1883, p. 8.

1845. La Ilustración Artística, "Revista Hispanoamericana", 1 de mayo de 1905, n. ${ }^{\circ}$ 1218, p. 282.

1846. La Ilustración Artística, "Revista Hispanoamericana", 11 de abril de 1910, n. ${ }^{\circ}$ 1476, p. 234.

1847. La Ilustración Artística, "Revista Hispanoamericana", 11 de marzo de 1912, año XXXI, n. ${ }^{\circ} 1576$, p. 174.

1848. La Ilustración Artística, "Revista Hispanoamericana", 14 de febrero de 1910, n. ${ }^{\circ}$ 1468, p. 106.

1849. La Ilustración Artística, "Revista Hispanoamericana", 15 de abril de 1907, n. ${ }^{\circ}$ 1320, p. 250.

1850. La Ilustración Artística, "Revista Hispanoamericana", 18 de diciembre de 1912, Año XXX, n. ${ }^{\circ} 1564$, p. 814.

1851. La Ilustración Artística, "Revista Hispanoamericana", 23 de septiembre de 1912, año XXXI, n. ${ }^{\circ} 1604$, p. 622.

1852. La Ilustración Artística, "Revista Hispanoamericana", 24 de julio de 1905, n. ${ }^{\circ}$ 1230, p. 474.

1853. La Ilustración Artística, "Revista Hispanoamericana", 25 de septiembre de 1911, año XXX, n. ${ }^{\circ} 1552$, p. 622.

1854. La Ilustración Artística, "Revista Hispanoamericana", 26 de noviembre de 1906, año XXV, n. ${ }^{\circ} 1300$, p. 762.

1855. La Ilustración Artística, "Revista Hispanoamericana", 27 de octubre de 1902, año XXI, n. ${ }^{\circ} 1087$, p. 698.

1856. La Ilustración Artística, "Revista Hispanoamericana", 29 de agosto de 1910, año XXIX, n. ${ }^{\circ} 1496$, p. 544.

1857. La Ilustración Artística, "Revista Hispanoamericana", 30 de noviembre de 1908, año XXVII, n. ${ }^{\circ} 1405$, p. 778. 
1858. La Ilustración Artística, "Revista Hispanoamericana", 30 de septiembre de 1907, n. ${ }^{\circ} 1344$, p. 634.

1859. La Ilustración Artística, "Revista Hispanoamericana", 5 de febrero de 1912, año XXXI, n. ${ }^{\circ} 1571$, p. 94.

1860. La Ilustración Artística, "Revista Hispanoamericana", 7 de septiembre de 1903, p. 586.

1861. La Ilustración Artística, "Revista Hispanoamericana", 8 de marzo de 1909, año XXVIII, n. ${ }^{\circ} 1419$, p. 170.

1862. La Ilustración Artística, "Revista Hispanoamericana", 9 de mayo de 1904, año XXIII, n. ${ }^{\circ} 1167$, p. 314.

1863. La Ilustración Artística, "Revista Hispanoamericana", año XXIII, n. ${ }^{\circ} 1195$, p. 762.

1864. La Ilustración Artística, "Revista Hispanoamericana", año XXIII, n. ${ }^{\circ} 1195$, p. 762.

1865. La Ilustración Artística, "Revista Hispanoamericana", año XXV, 14 de mayo de 1906, n. ${ }^{\circ} 1272$, p. 314.

1866. La Ilustración Artística, "Revista Hispanoamericana", año XXV, 9 de julio de 1906, n. ${ }^{\circ} 1280$, p. 442.

1867. La Ilustración Artística, "Revista Hispanoamericana", año XXV, n. ${ }^{\circ} 1.292,1$ de octubre de 1906, p. 634.

1868. La Ilustración Artística, "Revista Hispanoamericana", n ${ }^{\circ}$ 1646, 14 de julio de 1913, año XXXII, p. 458.

1869. La Ilustración Artística, "Revista Hispanoamericana", año XXIII, n. ${ }^{0}$ 1677, p. 126.

1870. La Ilustración Católica, "Chile", 21 de noviembre, n. ${ }^{\circ}$ 19, p. 152.

1871. La Ilustración Española y Americana, "Conflicto entre Chile y Perú", 30 de diciembre de 1921, p. 509.

1872. La Ilustración Española y Americana, "Crónica americana”, 30 de junio de 1880, p. 427.

1873. La Ilustración Española y Americana, "Crónica General", 15 de agosto de 1882, p. 82.

1874. La Ilustración Española y Americana, "Don Benjamín Vicuña Mackenna", 8 de septiembre de 1886, p. 103-131.

1875. La Ilustración española y americana, "Don Manuel Baquedano", 8 de diciembre de 1880 , p. 338.

1876. La Ilustración Española y Americana, "El conflicto del Pacífico y su resolución violenta", 30 de abril de 1920, n 16, p. 243.

1877. La Ilustración Española y Americana, "El Contraalmirante D. Lisardo Montero", 30 de agosto de 1882 , p. 3.

1878. La Ilustración Española y Americana, "El problema de nuestras fronteras del Norte (Tacna y Arica)", 22 de febrero de 1901, p. 124. 
1879. La Ilustración Española y Americana, "El salitre y el yodo", 30 de julio de 1915, año XXXIII, n. ${ }^{\circ} 1677$, p. 573.

1880. La Ilustración Española y Americana, "España requerida por América", 22 de junio de 1919, n. $^{\circ} 23$, p. 367.

1881. La Ilustración Española y Americana, "Guerra del Pacífico", 15 de junio de 1880, p. 379.

1882. La Ilustración Española y Americana, "Guerra del Pacífico", 22 de abril de 1881, p. 251.

1883. La Ilustración Española y Americana, "Guerra del Pacífico", 28 de febrero de 1881. p. 123.

1884. La Ilustración Española y Americana, "Inglaterra y nuestro americanismo", 22 de septiembre de 1920, n. ${ }^{\circ} 35$, p. 513.

1885. La Ilustración Española y Americana, "Junta del Congreso Provisional de Chile", 22 de septiembre de 1891, p. 3.

1886. La Ilustración Española y Americana, "La Guerra del Pacífico", 8 de enero de 1880, p. 10.

1887. La Ilustración Española y Americana, "La política internacional del Perú", 15 de diciembre de 1920, n. ${ }^{\circ}$ 46, p. 607.

1888. La Ilustración Española y Americana, "Libros presentados a esta redacción por autores o editores", 30 de mayo de 1881, p. 363.

1889. La Ilustración Española y Americana, "Monumento a Bolognesi", 30 de junio de 1902, n. ${ }^{\circ} 24$, p. 399.

1890. La Ilustración Española y Americana, "Monumento a la marina nacional de Chile", 30 de julio de 1886, p. 2.

1891. La Ilustración Española y Americana, "Nuestros grabados", 8 de enero de 1902, n. ${ }^{\mathrm{o}} 1, \mathrm{p} .3$.

1892. La Ilustración Española y Americana, "Perú: vista del puerto de Mollendo", 8 de abril de 1880, p. 222.

1893. La Ilustración Española y Americana, "Por ambos mundos", 30 de octubre de 1892, p. 299-302.

1894. La Ilustración Española y Americana, "Por ambos mundos", 8 de julio de 1891, n. ${ }^{\circ} 25$, p. $14-15$.

1895. La Ilustración Española y Americana, "Revista Americana", 30 de enero de 1881, p. 63.

1896. La Ilustración Española y Americana, "Sucesos de América", 8 de mayo de 1880, pp. 291, 292, 293.

1897. La Ilustración Española y Americana, "Sucesos de Chile", 15 de febrero de 1891, p. 91.

1898. La Ilustración Española y Americana, "Vida americana", 30 de abril de 1920, n. ${ }^{\circ}$ 16, p. 252. 
1899. La Ilustración Española y Americana, "Vida americana", 8 de agosto de 1920, n. 29, p. 425.

1900. La Ilustración Financiera, "Ante un plebiscito", 20 de mayo de 1925, p. 1.

1901. La Ilustración Financiera, "Caja de depósitos y consignaciones (Perú)", 4 de noviembre de 1925 , p. s/n.

1902. La Ilustración Financiera, "El patriotismo peruano", año XIX, n. ${ }^{\circ}$ 798, 3 de febrero de 1926, p. 2.

1903. La Ilustración Financiera, "Las ciudades modernas", n. ${ }^{\circ} 842,22$ de diciembre de 1926, p.

1904. La Ilustración Financiera, "Sin título", 20 de mayo de 1925, p. s/p.

1905. La Ilustración Ibérica, “A América”, 22 de noviembre de 1898, p. 4.

1906. La Ilustración Ibérica, "Cerámica peruana: Lago de Titicaca y sus cercanías", 7 de junio de 1890, pp. 13-14.

1907. La Ilustración Ibérica, "La revolución de Chile", 14 de marzo 1891, p. 174.

1908. La Ilustración Ibérica, "Museo Peabody”, 25 de abril de 1891, p. 267.

1909. La Ilustración Militar, "Tarata y Moquegua", 30 de enero de 1910, año VI, n. ${ }^{\circ}$ 122 , p. 26.

1910. La Ilustración, "Chile", 23 de febrero de 1890, p. 14.

1911. La Ilustración, "De los terremotos", 1 de mayo de 1887, n. ${ }^{\circ} 339$, p. 297.

1912. La Ilustración, "Viaje al (sic) través de los Andes", 18 de enero de 1885, p. 11.

1913. La Lectura Dominical, "Chile y su nueva Constitución”, 5 de marzo de 1927, p. 11.

1914. La Lectura Dominical, "Crónica del extranjero", n. ${ }^{\circ} 1.751$, año XXXIV, 23 de julio de 1927, p. 601.

1915. La Lectura Dominical, "Crónica semanal”, 26 de junio de 1929, año XXXVI, n. ${ }^{\circ}$ 1.848 , p. 3.

1916. La Lectura Dominical, "Crónica semanal", 27 de abril de 1929, año XXXVI, n. ${ }^{\circ}$ 1.843, p. 276.

1917. La Lectura Dominical, "Efemérides de la semana", 11 de mayo de 1929, año XXXVI, n. ${ }^{\circ} 1.845$, p. 317.

1918. La Lectura Dominical, "Efemérides de la semana", 11 de noviembre de 1925, p. 344.

1919. La Lectura Dominical, "Efemérides de la semana", 13 de junio de 1925, p. 296.

1920. La Lectura Dominical, "Efemérides de la semana", 14 de marzo de 1925, p. 128.

1921. La Lectura Dominical, "Efemérides de la semana", 19 de diciembre de 1925, p. 620 .

1922. La Lectura Dominical, "Efemérides de la semana", 2 de marzo de 1929, año XXXVI, n. ${ }^{\circ} 1.835$, p. 151.

1923. La Lectura Dominical, "Efemérides de la semana", 22 de junio de 1929, año XXXVI, n. ${ }^{\circ} 1.851$, p. 420. 
1924. La Lectura Dominical, "Efemérides de la semana", 23 de enero de 1926, año XXIII, n. ${ }^{\circ} 1.673$, p. 8.

1925. La Lectura Dominical, "Efemérides de la semana", 27 de abril de 1929, año XXXVI, n. ${ }^{\circ} 1843$, p. 13.

1926. La Lectura Dominical, "Efemérides de la semana", 3 de abril de 1926, año XXIII, n. ${ }^{\circ} 1.683$, p. 168.

1927. La Lectura Dominical, "Efemérides de la semana", 8 de agosto de 1925, p. 393.

1928. La Lectura Dominical, "El mal de América", 5 de febrero de 1927, p. 1.

1929. La Lectura Dominical, "Folletón de la Lectura Dominical Emigración, novela de

P. Alberto Risco, S. J.”, 13 de octubre de 1928, p. 725.

1930. La Lectura Dominical, "Otro diálogo sobre el patriotismo", 22 de junio de 1929, año XXXVI, n. ${ }^{\circ} 1.851$, p. 6.

1931. La Lectura Dominical, "Tacna y Arica”, 21 de marzo de 1925, p. 141.

1932. La Lectura Dominical, "Tacna y Arica”, 22 de agosto de 1925, p. 415.

1933. La Lectura, "La revista de América", enero de 1913, año XIII, n. ${ }^{\circ} 145$, p. 97.

1934. La Lectura, "Mercurio peruano", mayo de 1920, año XX, n. ${ }^{\circ} 233$, p. 90.

1935. La Lectura, "Prensa", mayo de 1913, año XIII, n. ${ }^{\circ}$ 149, p. 201.

1936. La Lectura "Revista de Revistas españolas e hispanoamericanas", mayo de 1914, año XIV, n. ${ }^{\circ} 161$, p. 431.

1937. La Lectura, "Revista de revistas", enero de 1907, año VII, n. ${ }^{\circ} 73$, p. 186.

1938. La Lectura. Revista de Ciencias y de Artes, "Querol, por José R. Melida", mayo de 1902, año II, n. ${ }^{\circ} 17$, p. 78.

1939. La Libertad, “'Tendrá Bolivia una salida al mar?”, 30 de octubre de 1926, p. 1.

1940. La Libertad, "Agitación política en Bolivia”, 6 de octubre de 1929, p. 1.

1941. La Libertad, “Ayer llegó el doctor Stresemann”, 9 de junio de 1929, p. 5.

1942. La Libertad, "Cambio de ratificaciones entre Chile y el Perú", 30 de julio de 1929 , p. 7.

1943. La Libertad, "Camilo Barcia en el Ateneo", 18 de noviembre de 1921, p. 5.

1944. La Libertad, "Camino de una solución definitiva", 11 de octubre de 1928, p. 4.

1945. La Libertad, "Chile respetará el fallo sobre Tacna y Arica", 4 de enero de 1925,

p. 1.

1946. La Libertad, "Chile y Bolivia", 27 de agosto de 1926, p. 5.

1947. La Libertad, "Chile y el Perú", 25 de marzo de 1920, p. 4.

1948. La Libertad, "Chile y el Perú", 28 de diciembre de 1921, p. 1.

1949. La Libertad, "Chile y Perú", 2 de septiembre de 1925, p. 1.

1950. La Libertad, "Chile y Perú", 21 de diciembre de 1921, p. 1.

1951. La Libertad, "Chile", 9 de enero de 1927, p. 7.

1952. La Libertad, "Chocano homicida", 14 de septiembre de 1926, p. 1.

1953. La Libertad, "Colisiones en Tacna y Arica", 8 de enero de 1926, p. 1.

1954. La Libertad, "Colombia y los Estados Unidos", 7 de octubre de 1928, p. 1.

1955. La Libertad, "Colombia y los Estados Unidos", 7 de octubre de 1928, p. 1. 
1956. La Libertad, "Coplas del día", 7 de diciembre de 1926, p. 1.

1957. La Libertad, "Crítica literaria”, 3 de noviembre de 1929, p. 4.

1958. La Libertad, "Después de la solución del pleito Tacna-Arica", 4 de octubre de 1929 , p. 2.

1959. La Libertad, "Dice el Ministro de Estado", 26 de septiembre de 1920, p. 4.

1960. La Libertad, "Dimisión sensacional", 25 de diciembre de 1925, p. 1.

1961. La Libertad, "El abrazo de Lima", 4 de junio de 1929, p. 6.

1962. La Libertad, "El aplazamiento de la Conferencia Panamericana", 23 de noviembre de 1927 , p. 7.

1963. La Libertad, "El arreglo de lo de Tacna y Arica", 12 de junio de 1929, p. 1.

1964. La Libertad, "El caso de Guatemala", 28 de abril de 1920, p. 4.

1965. La Libertad, "El conflicto chilenoperuano", 13 de marzo de 1924, p. 1.

1966. La Libertad, "El conflicto de Tacna y Arica", 3 de mayo de 1929, p. 1.

1967. La Libertad, "El conflicto de Tacna y Arica", 7 de diciembre de 1926, p. 1.

1968. La Libertad, "El cuento de la buena pipa", 29 de mayo de 1924, p. 1.

1969. La Libertad, "El Infante don Fernando en Chile", 20 de noviembre de 1920, p. 2.

1970. La Libertad, "El litigio de Tacna y Arica", 21 de junio de 1924, p. 1.

1971. La Libertad, "El litigio entre Tacna y Arica", 10 de marzo de 1925, p. 1.

1972. La Libertad, "El litigio entre Tacna y Arica", 27 de noviembre de 1924, p. 1.

1973. La Libertad, "E1 Perú contra Chile", 14 de diciembre de 1921, p. 1.

1974. La Libertad, "El Perú contra Chile", 16 de diciembre de 1921, p. 1.

1975. La Libertad, "El Perú contra Chile", 17 de diciembre de 1921, p. 1.

1976. La Libertad, "El plebiscito de Arica", 27 de noviembre de 1925, p. 1.

1977. La Libertad, "El plebiscito de Tacna y Arica", 1 de diciembre de 1925, p. 2.

1978. La Libertad, "El plebiscito de Tacna y Arica", 11 de marzo de 1925, p. 1.

1979. La Libertad, "El plebiscito de Tacna y Arica", 12 de noviembre de 1925, p. 1.

1980. La Libertad, "El plebiscito de Tacna y Arica", 14 de agosto de 1925, p. 1.

1981. La Libertad, "El plebiscito de Tacna y Arica", 2 de agosto de 1925, p. 1.

1982. La Libertad, "El plebiscito de Tacna y Arica", 2 de marzo de 1926, p. 1.

1983. La Libertad, "El plebiscito de Tacna y Arica", 26 de noviembre de 1925, p. 4.

1984. La Libertad, "El plebiscito de Tacna y Arica", 4 de febrero de 1926, p. 3.

1985. La Libertad, "El plebiscito de Tacna y Arica", 5 de julio de 1925, p. 1.

1986. La Libertad, "El plebiscito de Tacna y Arica", 5 de julio de 1925, p. 4.

1987. La Libertad, "El plebiscito de Tacna y Arica", 6 de agosto de 1925, p. 1.

1988. La Libertad, "El plebiscito de Tacna y Arica", 9 de julio de 1925, p. 1.

1989. La Libertad, "El plebiscito sobre Tacna y Arica", 1 de julio de 1925, p. 3.

1990. La Libertad, "El plebiscito sobre Tacna y Arica", 31 de julio de 1925, p. 1.

1991. La Libertad, "El pleito chilenoperuano", 22 de enero de 1922, p. 4.

1992. La Libertad, "El pleito chilenoperuano", 5 de abril de 1924, p. 1.

1993. La Libertad, "El pleito de Tacna y Arica resuelto definitivamente", 18 de mayo de 1929, p.1. 
1994. La Libertad, "El pleito de Tacna y Arica", 15 de noviembre de 1925, p. 6.

1995. La Libertad, "El pleito de Tacna y Arica", 21 de mayo de 1926, p. 1.

1996. La Libertad, "El pleito de Tacna y Arica", 25 de mayo de 1929, p. 5.

1997. La Libertad, "El pleito de Tacna y Arica", 26 de mayo de 1929, p. 8.

1998. La Libertad, "El premio Nobel para los presidentes de Perú y Chile", 20 de octubre de 1929, p. 4.

1999. La Libertad, "El presidente de Chile desembarca en Arica", 4 de agosto de 1929,

p. 6.

2000. La Libertad, "El problema de Tacna y Arica", 8 de diciembre de 1925, p. 3.

2001. La Libertad, "El problema del Pacífico", 14 de junio de 1924, p. 1.

2002. La Libertad, "El rumbo de Norteamérica", 15 de noviembre de 1924, p. 1.

2003. La Libertad, "El Senado chileno aprueba el tratado", 3 de julio de 1929, p. 5.

2004. La Libertad, "El Tratado de Tacna y Arica", 2 de agosto de 1929, p. 1.

2005. La Libertad, "El Tratado de Tacna y Arica", 26 de septiembre de 1929, p. 5.

2006. La Libertad, "El Tratado entre Chile y Perú", 14 de julio de 1929, p. 5.

2007. La Libertad, "El tratado entre el Perú y Chile", 30 de julio de 1929, p. 7.

2008. La Libertad, "El tratado sobre lo de Tacna y Arica", 23 de junio de 1929, p. 1.

2009. La Libertad, "El Tratado sobre Tacna y Arica", 5 de junio de 1929, p. 5.

2010. La Libertad, "El viaje de Jiménez e Iglesias", 19 de abril de 1929, p. 5.

2011. La Libertad, "El viejo pleito de Tacna y Arica", 19 de mayo de 1929, p. 1.

2012. La Libertad, "El viejo pleito entre Tacna y Arica", 22 de mayo de 1929, p. 5.

2013. La Libertad, "Elogio del continentalismo", 9 de abril de 1927, p. 1.

2014. La Libertad, "Ha sido aprobada la ponencia del Comité de los Tres sobre las minorías", 14 de junio de 1929, p. 5.

2015. La Libertad, "Hoy se firmará el arreglo del pleito de Tacna y Arica", 25 de abril de 1929, p. 2.

2016. La Libertad, "Jiménez e Iglesias hacen una nueva etapa", 23 de abril de 1929, p. 2.

2017. La Libertad, "Jiménez e Iglesias volaron ayer desde Arica hasta Lima", 24 de abril de 1929, p. 5.

2018. La Libertad, "La acción chilena en Tacna y Arica", 13 de abril de 1924, p. 1.

2019. La Libertad, "La Conferencia de La Habana", 18 de febrero de 1928, p. 4.

2020. La Libertad, "La crucificada", 29 de octubre de 1926, p. 3.

2021. La Libertad, "La cuestión de Tacna y Arica no se arregla", 27 de noviembre de 1925, p. 2.

2022. La Libertad, "La cuestión de Tacna y Arica" (continuación), 2 de octubre de 1925, p. 6.

2023. La Libertad, "La cuestión de Tacna y Arica", 14 de octubre de 1925, p. 3.

2024. La Libertad, "La cuestión de Tacna y Arica", 16 de junio de 1926, p. 1.

2025. La Libertad, "La cuestión de Tacna y Arica", 2 de octubre de 1925, p. 5.

2026. La Libertad, "La cuestión de Tacna y Arica", 2 de octubre de 1926, p. 5. 
2027. La Libertad, "La cuestión de Tacna y Arica", 29 de abril de 1928, p. 4.

2028. La Libertad, "La cuestión del Pacífico", 20 de agosto de 1926, p. 1.

2029. La Libertad, "La entrega de los documentos de Tacna y Arica", 26 de abril de 1929, p. 6.

2030. La Libertad, "La entrega de Tacna al Perú", 29 de agosto de 1929, p. 1.

2031. La Libertad, "La entrega de Tacna", 5 de septiembre de 1929, p. 1.

2032. La Libertad, "La Escuela Francisco de Vitoria", 19 de octubre de 1926, p. 1.

2033. La Libertad, "La mañana del presidente", 10 de noviembre de 1920, p. 6.

2034. La Libertad, "La mediación de Calvin Coolidge", 7 de enero de 1925, p. 1.

2035. La Libertad, "La Misión a Chile", 11 de noviembre de 1920, p. 6.

2036. La Libertad, "La Misión española en Chile", 21 de noviembre, p. 1.

2037. La Libertad, "La nueva frontera entre Tacna y Arica", 1 de octubre de 1929, p. 1.

2038. La Libertad, "La política en Chile", 8 de agosto de 1920, p. 4.

2039. La Libertad, "La preocupación pantográfica", 30 de mayo de 1926, p. 1.

2040. La Libertad, "La presidencia del Perú", 15 de octubre de 1929, p. 1.

2041. La Libertad, "La ratificación del tratado sobre Tacna y Arica", 28 de junio de 1929 , p. 6.

2042. La Libertad, "La solución del conflicto de Tacna y Arica", 17 de mayo de 1929,

p. 6.

2043. La Libertad, "La solución del conflicto de Tacna y Arica", 18 de abril de 1929,

p. 2.

2044. La Libertad, "La viruela y la difteria", 28 de noviembre de 1926, p. 6.

2045. La Libertad, "Las conferencias de ayer", 8 de mayo de 1926, p. 5.

2046. La Libertad, "Las relaciones entre Chile y el Perú", 11 de julio de 1928, p. 4.

2047. La Libertad, "Lo de Tacna y Arica seguirá en litigio", 23 de febrero de 1929,

p. 3.

2048. La Libertad, "Lo de Tacna y Arica", 11 de diciembre de 1925, p. 2.

2049. La Libertad, "Lo de Tacna y Arica", 5 de febrero de 1925, p. 1.

2050. La Libertad, "Lo de Tacna y Arica", 5 de mayo de 1929, p. 4.

2051. La Libertad, "Lo de Tacna y Arica", 6 de julio de 1929, p. 1.

2052. La Libertad, "Lo que dice la prensa", 29 de agosto de 1926, p. 1.

2053. La Libertad, "Los parlamentarios chilenos", 24 de febrero de 1924, p. 1.

2054. La Libertad, "Ofrenda suprema", 13 de junio de 1929, p. 3.

2055. La Libertad, "Pésame parlamentario", 19 de marzo de 1925, p. 3.

2056. La Libertad, "Ratificación del acuerdo sobre Tacna y Arica", 4 de julio de 1929,

p. 5.

2057. La Libertad, "Se agrava el conflicto de Tacna y Arica", 20 de abril de 1926, p. 1.

2058. La Libertad, "Se llega a un acuerdo en lo de Tacna y Arica", 22 de febrero de 1929, p. 4.

2059. La Libertad, "Se pide el premio Nobel de la Paz para los presidentes de Chile y

Perú", 13 de octubre de 1929, p. 7. 
2060. La Libertad, "Sevilla dispensa un entusiasta recibimiento a los tripulantes del Jesús del Gran Poder", 9 de junio de 1929, p. 6.

2061. La Libertad, "Sociedad Económica Matritense", 6 de mayo de 1926, p. 7.

2062. La Libertad, "Un buen escritor y un buen diplomático", 18 de noviembre 1926,

p. 3.

2063. La Libertad, "Un cablegrama al Ministro de Chile", 15 de diciembre de 1921, p. 1.

2064. La Libertad, "Un discurso de Coolidge", 30 de abril de 1927, p. 4.

2065. La Libertad, "Un discurso, una escisión y algunos comentarios", 17 de diciembre de 1920, p. 1.

2066. La Libertad, "Una lección de continentalismo", 8 de enero de 1929, p. 1.

2067. La Libertad, "Una petición de Bolivia", 28 de enero de 1928, p. 1.

2068. La Libertad, "Vapores correos para América", 1 de febrero de 1920, p. 2.

2069. La Monarquía, "Extranjero", 16 de diciembre de 1888, p. 3.

2070. La Nación Militar, "Ecos Militares de América. Chile”, 3 de junio de 1900,

p. 600 .

2071. La Nación Militar, "Ecos militares de América", 15 de julio de 1900, p. 3.

2072. La Nación Militar, "Los militares de América", 8 de abril de 1900, pp. 538-539.

2073. La Nación, "Chile y el Perú", 8 de diciembre de 1918, p. 7.

2074. La Nación, “Chile y Perú”, 19 de diciembre de 1918, p. 5.

2075. La Nación, "Documentos diplomáticos. La cuestión entre Chile y el Perú", 26 de

diciembre de 1918, p. 10.

2076. La República, "América", 22 de febrero de 1891, p. 2.

2077. La Unión Católica, "Extranjero", 31 de marzo de 1892, p. 3.

2078. La Unión Católica, "Mensaje presidencial”, 14 de agosto de 1897. p. 3.

2079. La Unión Católica, "Por telégrafo. Mensaje presidencial", 2 de junio de 1894,

p. 2.

2080. La Unión Ilustrada, "En el pabellón de Chile de la exposición", 20 de octubre de 1929, p. 26.

2081. La Unión, “-”, 9 de agosto de 1887, p. 1.

2082. La Unión, "Boletín telegráfico", 10 de enero de 1883, p. 4.

2083. La Unión, "Boletín telegráfico", 13 de noviembre de 1882, p. 4.

2084. La Unión, "Boletín telegráfico", 19 de mayo de 1882, p. 4.

2085. La Unión, "Chile y el Perú", 25 de junio de 1883, p. 2.

2086. La Unión, "Correo de Ultramar", 1 de julio de 1880, p. 1.

2087. La Unión, "Correo extranjero", 15 de octubre de 1880, p. 1.

2088. La Unión, "Correo extranjero", 3 de junio de 1880, p. 1.

2089. La Unión, "Correo extranjero", 7 de agosto de 1880, p. 1.

2090. La Unión, "Fenómenos volcánicos y terremotos en 1878”, 12 de julio de 1880,

p. 3.

2091. La Unión, “Graves noticias del Pacífico", 31 de julio de 1882, p. 2. 
2092. La Unión, "La paz en el Pacífico", 26 de julio de 1883, p. 3.

2093. La Unión, "La paz entre Chile y Bolivia", 27 de noviembre de 1883, pp. 2-3.

2094. La Unión, "La paz entre Chile y Perú", 4 de agosto de 1883, p. 2.

2095. La Unión, "La paz entre Chile y Perú", 8 de diciembre de 1883, p. 2.

2096. La Unión, "La situación en Bolivia”, 12 de abril de 1884, p. 2.

2097. La Unión, "Noticias de América", 6 de septiembre de 1880, p. 2.

2098. La Unión, “Telegramas de la Agencia Fabra”, 15 de junio de 1880, p. 1.

2099. La Unión, "Telegramas", 14 de febrero de 1882, p. 3.

2100. La Unión, "TELEGRAMAS", 17 de junio de 1880, p. 1.

2101. La Unión, “Telegramas”, 17 de enero de 1880, p. 2.

2102. La Voz (de Las Palmas), "La cajetilla de cigarros", 7 de diciembre de 1927, p. 1.

2103. La Voz, “QQué ha pasado en Valparaíso?”, 12 de octubre de 1920, p. 2.

2104. La Voz, "Acorazados y submarinos", 6 de enero de 1921, p. 1.

2105. La Voz, "Actitud de los chilenos", 11 de diciembre de 1926, p. 5.

2106. La Voz, "Alessandri”, 27 de diciembre de 1921, p. 4.

2107. La Voz, “Aprobación”, 27 de diciembre de 1921, p. 8.

2108. La Voz, "Ayer siguieron los trabajos de las comisiones", 23 de septiembre de 1927, p. 5.

2109. La Voz, "Bolivia la olvidada", 23 de mayo de 1929, p. 1.

2110. La Voz, "Bolivia la olvidada", 25 de mayo de 1929, p. 6.

2111. La Voz, "Bolivia sigue insistiendo en que se le conceda una salida al mar", 21 de mayo de 1929, p. 5.

2112. La Voz, "Chile acepta el arbitraje propuesto por el Perú", 21 de diciembre de 1921, p. 5.

2113. La Voz, "Chile ha aceptado el arbitraje que propone el Perú", 10 de julio de 1922 , p. 5.

2114. La Voz, "Chile se retira de la Comisión Plebiscitaria", 26 de noviembre de 1925, p. 5.

2115. La Voz, "Chile y Perú", 16 de septiembre de 1920, p. 3.

2116. La Voz, "Chile, Perú y la S. de N.", 23 de julio de 1928, p. 5.

2117. La Voz, "Chilenos y peruanos", 13 de julio de 1926, p. 5.

2118. La Voz, "Chilenos y peruanos", 25 de diciembre de 1926, p. 5.

2119. La Voz, "Coolidge será árbitro en la cuestión de Tacna y Arica", 15 de abril de 1924, p. 5.

2120. La Voz, "De como don Eduardo Dato es un lobo de mar", 11 de enero de 1921, p. 4.

2121. La Voz, "De Santiago de Chile a Lima del Perú", 18 de abril de 1929, p. 2.

2122. La Voz, "Declaraciones de Coolidge", 14 de julio de 1928, p. 5.

2123. La Voz, "Declaraciones de Leguía", 18 de enero de 1927, p. 5.

2124. La Voz, "Dimisión del Gobierno", 25 de mayo de 1927, p. 5. 
2125. La Voz, "Dos soldados peruanos muertos en la frontera de Bolivia", 19 de abril de 1926, p. 4.

2126. La Voz, "El acuerdo sobre Tacna y Arica", 4 de julio de 1929, p. 2.

2127. La Voz, "El aniversario de Washington", 23 de febrero de 1926, p. 5.

2128. La Voz, "El asunto de Tacna y Arica", 5 de enero de 1929, p. 1.

2129. La Voz, "El centenario de Magallanes", 19 de noviembre de 1920, p. 5.

2130. La Voz, "El chileno en Madrid", 1 de octubre de 1928, p. 1.

2131. La Voz, "El conflicto americano", 13 de diciembre de 1928, p. 1.

2132. La Voz, "El conflicto chileno-peruano", 1 de diciembre de 1925, p. 5.

2133. La Voz, "El culto de la disciplina", 28 de agosto de 1922, p. 1.

2134. La Voz, "El desdoblamiento de la Sociedad de Naciones", 7 de abril de 1926, p. 3.

2135. La Voz, "El discurso de Coolidge", 29 de abril de 1927, p. 5.

2136. La Voz, "El España", 19 de noviembre de 1920, p. 3.

2137. La Voz, "El Ferrocarril La Paz-Arica", 16 de mayo de 1928, p. 5.

2138. La Voz, "El informe del Perú agrada a los amigos de Coolidge", 28 de enero de 1928 , p. 5.

2139. La Voz, "El Jesús del Gran Poder", 23 de abril de 1929, p. 3.

2140. La Voz, "El movimiento revolucionario de Bolivia", 15 de julio de 1920, p. 5.

2141. La Voz, "El Paraguay pide a la Sociedad de Naciones que intervenga en el conflicto", 13 de diciembre de 1928, p. 2.

2142. La Voz, "El Perú acepta el plebiscito en la cuestión de Tacna y Arica", 9 de junio de 1925 , p. 3.

2143. La Voz, "El plebiscito de Tacna y Arica", 27 de julio de 1925, p. 1.

2144. La Voz, "El plebiscito de Tacna y Arica", 9 de febrero de 1926, p. 1.

2145. La Voz, "El plebiscito sobre Tacna y Arica", 30 de junio de 1925, p. 3.

2146. La Voz, "El plebiscito sobre Tacna y Arica", 8 de julio de 1925, p. 6.

2147. La Voz, "El pleito acerca de Tacna y Arica", 10 de marzo de 1925, p. 1.

2148. La Voz, "El pleito chileno-peruano", 26 de marzo de 1926, p. 4.

2149. La Voz, "El pleito chileno-peruano", 27 de febrero de 1926, p. 5.

2150. La Voz, "El pleito chileno-peruano", 27 de febrero de 1926, p. 5.

2151. La Voz, "El pleito chileno-peruano", 4 de diciembre de 1925, p. 5.

2152. La Voz, "El pleito de Tacna y Arica", 1 de abril de 1925, p. 8.

2153. La Voz, "El pleito de Tacna y Arica", 1 de agosto de 1927, p. 11.

2154. La Voz, "El pleito de Tacna y Arica", 10 de diciembre de 1926, p. 1.

2155. La Voz, "El pleito de Tacna y Arica", 11 de diciembre de 1925, p. 4.

2156. La Voz, "El pleito de Tacna y Arica", 11 de marzo de 1925, p. 5.

2157. La Voz, "El pleito de Tacna y Arica", 12 de abril de 1926, p. 5.

2158. La Voz, "El pleito de Tacna y Arica", 12 de junio de 1926, p. 5.

2159. La Voz, "El pleito de Tacna y Arica", 14 de junio de 1926, p. 1.

2160. La Voz, "El pleito de Tacna y Arica", 15 de enero de 1926, p. 8. 
2161. La Voz, "El pleito de Tacna y Arica", 17 de junio de 1926, p. 5. 2162. La Voz, "El pleito de Tacna y Arica", 17 de mayo de 1927, p. 5. 2163. La Voz, "El pleito de Tacna y Arica", 2 de junio de 1926, p. 8. 2164. La Voz, "El pleito de Tacna y Arica", 25 de enero de 1927, p. 5. 2165. La Voz, "El pleito de Tacna y Arica", 25 de junio de 1926, p. 5. 2166. La Voz, "El pleito de Tacna y Arica", 28 de enero de 1927, p. 4. 2167. La Voz, "El pleito de Tacna y Arica", 29 de marzo de 1926, p. 5. 2168. La Voz, "El pleito de Tacna y Arica", 3 de junio de 1926, p. 5. 2169. La Voz, "El pleito de Tacna y Arica", 30 de julio de 1926, p. 5. 2170. La Voz, "El pleito de Tacna y Arica", 30 de julio de 1927, p. 7. 2171. La Voz, "El pleito de Tacna y Arica", 30 de noviembre de 1925, p. 4. 2172. La Voz, "El pleito de Tacna y Arica", 4 de mayo de 1929, p. 6. 2173. La Voz, "El pleito de Tacna y Arica", 5 de abril de 1927, p. 4.

2174. La Voz, "El pleito de Tacna y Arica", 6 de febrero de 1926, p. 8. 2175. La Voz, "El pleito de Tacna y Arica", 6 de mayo de 1929, p. 12. 2176. La Voz, "El pleito de Tacna y Arica", 7 de diciembre de 1925, p. 8. 2177. La Voz, "El pleito de Tacna y Arica", 7 de diciembre de 1926, p. 8. 2178. La Voz, "El pleito de Tacna y Arica", 8 de junio de 1928, p. 3.

2179. La Voz, "El pleito de Tacna y Arica", 8 de septiembre de 1926, p. 3.

2180. La Voz, "El problema de Tacna y Arica", 3 de julio de 1925, p. 5.

2181. La Voz, "El problema de Tacna y Arica", 5 de enero de 1926, p. 5.

2182. La Voz, "El puerto de Arica", 22 de junio de 1927, p. 5.

2183. La Voz, "El puerto de Arica", 24 de julio de 1929, p. 1.

2184. La Voz, "El Tratado sobre Tacna y Arica", 13 de julio de 1929, p. 4.

2185. La Voz, "El viaje fracasado del señor Montejo", 23 de septiembre de 1922, p. 2.

2186. La Voz, "En Arica se pegan chilenos y peruanos", 8 de enero de 1926, p. 5.

2187. La Voz, "En Bolivia se descubre una contrarrevolución", 10 de agosto de 1920, p. 8 .

2188. La Voz, "En el Perú no se ha alterado el orden público", 23 de mayo de 1929, p. 3.

2189. La Voz, "Entre Chile y el Perú", 7 de mayo de 1925, p. 5.

2190. La Voz, "Esta mañana salió para Arica", 22 de abril de 1929, p. 12.

2191. La Voz, "Firma del acuerdo sobre Tacna y Arica", 4 de junio de 1929, p. 5.

2192. La Voz, "Francos Rodríguez explica sus frases", 10 de diciembre de 1920, p. 8.

2193. La Voz, "Gravísimos desórdenes en Chile", 24 de julio de 1920, p. 1.

2194. La Voz, "Hoover notifica el acuerdo a que han llegado Chile y el Perú", 18 de mayo de 1929, p. 5.

2195. La Voz, "Incidente entre el Perú y Bolivia", 20 de abril de 1926, p. 5.

2196. La Voz, "Jiménez e Iglesias han llegado esta mañana a Sevilla", 8 de junio de 1929, p. 3.

2197. La Voz, "La actitud de Bolivia", 23 de mayo de 1929, p. 5. 
2198. La Voz, "La Conferencia Panamericana", 23 de noviembre de 1927, p. 5. 2199. La Voz, "La Conferencia Panamericana", 24 de enero de 1928, p. 5. 2200. La Voz, "La cuestión de Nicaragua", 20 de enero de 1928, p. 5. 2201. La Voz, "La cuestión de Tacna y Arica resuelta", 22 de abril de 1929, p. 1. 2202. La Voz, "La cuestión de Tacna y Arica", 1 de diciembre de 1926, p. 8. 2203. La Voz, "La cuestión de Tacna y Arica", 1 de febrero de 1923, p. 5. 2204. La Voz, "La cuestión de Tacna y Arica", 1 de noviembre de 1926, p. 5. 2205. La Voz, "La cuestión de Tacna y Arica", 10 de diciembre de 1927, p. 1. 2206. La Voz, "La cuestión de Tacna y Arica", 10 de julio de 1928, p. 5. 2207. La Voz, "La cuestión de Tacna y Arica", 11 de julio de 1927, p. 10. 2208. La Voz, "La cuestión de Tacna y Arica", 11 de mayo de 1923, p. 4. 2209. La Voz, "La cuestión de Tacna y Arica", 11 de octubre de 1926, p. 5. 2210. La Voz, "La cuestión de Tacna y Arica", 11 de octubre de 1928, p. 3. 2211. La Voz, "La cuestión de Tacna y Arica", 12 de julio de 1927, p. 2. 2212. La Voz, "La cuestión de Tacna y Arica", 12 de octubre de 1926, p. 5. 2213. La Voz, "La cuestión de Tacna y Arica", 14 de abril de 1926, p. 3. 2214. La Voz, "La cuestión de Tacna y Arica", 14 de junio de 1929, p. 2. 2215. La Voz, "La cuestión de Tacna y Arica", 14 de mayo de 1929, p. 1. 2216. La Voz, "La cuestión de Tacna y Arica", 14 de noviembre de 1925, p. 5. 2217. La Voz, "La cuestión de Tacna y Arica", 14 de octubre de 1926, p. 5. 2218. La Voz, "La cuestión de Tacna y Arica", 14 de septiembre de 1922, p. 4. 2219. La Voz, "La cuestión de Tacna y Arica", 15 de diciembre de 1926, p. 2. 2220. La Voz, "La cuestión de Tacna y Arica", 15 de julio de 1926, p. 5. 2221. La Voz, "La cuestión de Tacna y Arica", 15 de octubre de 1927, p. 5. 2222. La Voz, "La cuestión de Tacna y Arica", 16 de febrero de 1929, p. 8. 2223. La Voz, "La cuestión de Tacna y Arica", 16 de julio de 1926, p. 5. 2224. La Voz, "La cuestión de Tacna y Arica", 16 de mayo de 1929, p. 5. 2225. La Voz, "La cuestión de Tacna y Arica", 17 de abril de 1929, p. 5. 2226. La Voz, "La cuestión de Tacna y Arica", 17 de diciembre de 1925, p. 3. 2227. La Voz, "La cuestión de Tacna y Arica", 17 de julio de 1926, p. 5. 2228. La Voz, "La cuestión de Tacna y Arica", 17 de junio de 1927, p. 5. 2229. La Voz, "La cuestión de Tacna y Arica", 18 de enero de 1928, p. 6. 2230. La Voz, "La cuestión de Tacna y Arica", 18 de junio de 1926, p. 8. 2231. La Voz, "La cuestión de Tacna y Arica", 19 de enero de 1929, p. 5. 2232. La Voz, "La cuestión de Tacna y Arica", 19 de febrero de 1929, p. 5. 2233. La Voz, "La cuestión de Tacna y Arica", 2 de enero de 1926, p. 4. 2234. La Voz, "La cuestión de Tacna y Arica", 20 de mayo de 1926, p. 1. 2235. La Voz, "La cuestión de Tacna y Arica", 20 de mayo de 1929, p. 7. 2236. La Voz, "La cuestión de Tacna y Arica", 21 de mayo de 1926, p. 8. 2237. La Voz, "La cuestión de Tacna y Arica", 21 de septiembre de 1926, p. 7. 2238. La Voz, "La cuestión de Tacna y Arica", 22 de febrero de 1929, p. 1. 
2239. La Voz, "La cuestión de Tacna y Arica", 22 de febrero de 1929, p. 8.

2240. La Voz, "La cuestión de Tacna y Arica", 22 de septiembre de 1926, p. 5.

2241. La Voz, "La cuestión de Tacna y Arica", 24 de agosto de 1926, p. 5.

2242. La Voz, "La cuestión de Tacna y Arica", 24 de enero de 1923, p. 1.

2243. La Voz, "La cuestión de Tacna y Arica", 25 de abril de 1929, p. 2.

2244. La Voz, "La cuestión de Tacna y Arica", 25 de febrero de 1929, p. 5.

2245. La Voz, "La cuestión de Tacna y Arica", 28 de marzo de 1927, p. 10.

2246. La Voz, "La cuestión de Tacna y Arica", 3 de diciembre de 1926, p. 6.

2247. La Voz, "La cuestión de Tacna y Arica", 3 de mayo de 1929, p. 5.

2248. La Voz, "La cuestión de Tacna y Arica", 30 de noviembre de 1926, p. 2.

2249. La Voz, "La cuestión de Tacna y Arica", 30 de octubre de 1926, p. 5.

2250. La Voz, "La cuestión de Tacna y Arica", 4 de enero de 1927, p. 7.

2251. La Voz, "La cuestión de Tacna y Arica", 4 de julio de 1921, p. 1.

2252. La Voz, "La cuestión de Tacna y Arica", 5 de enero de 1927, p. 5.

2253. La Voz, "La cuestión de Tacna y Arica", 6 de diciembre de 1926, p. 8.

2254. La Voz, "La cuestión de Tacna y Arica", 6 de enero de 1925, p. 5.

2255. La Voz, "La cuestión de Tacna y Arica", 8 de julio de 1926, p. 5.

2256. La Voz, "La cuestión de Tacna y Arica", 8 de mayo de 1929, p. 1.

2257. La Voz, "La cuestión del Pacífico", 2 de octubre de 1926, p. 5.

2258. La Voz, "La cuestión Tacna Arica", 15 de diciembre de 1921, p. 2.

2259. La Voz, "La entrega de Tacna al Perú", 28 de agosto de 1929, p. 6.

2260. La Voz, "La España tocará en Iquique", 10 de noviembre de 1920, p. 3.

2261. La Voz, "La mediación yanqui la aceptan Chile y el Perú", 27 de marzo de 1926,

p. 5.

2262. La Voz, "La Misión que irá a Chile", 25 de septiembre de 1920, p. 2.

2263. La Voz, "La Policía mata a tiros a once estudiantes y hiere a muchos", $31 \mathrm{de}$ mayo de 1923, p. 5.

2264. La Voz, "La política chilena", 29 de marzo de 1927, p. 5.

2265. La Voz, "La política exterior de Chile", 3 de enero de 1927, p. 3.

2266. La Voz, "La provincia de Tarapacá será peruana", 1 de septiembre de 1925, p. 8.

2267. La Voz, "La reelección del presidente Leguía", 14 de octubre de 1929, p. 7.

2268. La Voz, "La sentencia arbitral de Coolidge", 19 de marzo de 1925, p. 5.

2269. La Voz, "La situación política en Bolivia", 14 de octubre de 1929, p. 7.

2270. La Voz, "La situación política en Chile", 14 de abril de 1927, p. 2.

2271. La Voz, "La situación se normaliza después de las últimas deportaciones", 7 de octubre de 1929, p. 7.

2272. La Voz, "La Sociedad de Naciones en Madrid", 13 de junio de 1929, p. 2.

2273. La Voz, "La Sociedad de Naciones en Madrid", 17 de junio de 1929, p. 2.

2274. La Voz, "La Sociedad de Naciones", 26 de septiembre de 1929, p. 5.

2275. La Voz, "La solución del pleito de Tacna y Arica", 29 de julio de 1929, p. 8.

2276. La Voz, "La solución del pleito sobre Tacna y Arica", 20 de junio de 1929, p. 4. 
2277. La Voz, "La substitución de Pershing", 13 de enero de 1926, p. 7.

2278. La Voz, "La última complicación en el asunto chileno-peruano", 27 de noviembre de 1925, p. 1.

2279. La Voz, "Las diferencias entre Chile y Perú", 2 de diciembre de 1925, p. 5.

2280. La Voz, "Las negociaciones van por buen camino", 27 de diciembre de 1921, p. 8.

2281. La Voz, "Lo de Tacna y Arica", 23 de agosto de 1926, p. 5.

2282. La Voz, "Lo que ignoraba Francos", 11 de diciembre de 1920, p. 5.

2283. La Voz, "Los aviadores españoles han aterrizado felizmente en Lima", 24 de abril de 1929 , p. 3.

2284. La Voz, "Los buenos deseos del Gobierno peruano", 29 de diciembre de 1921, p. 8.

2285. La Voz, "Los países hispanoamericanos, contra el capitalismo yanqui", 8 de febrero de 1927, p. 5.

2286. La Voz, "Los peruanos intentan asaltar la Embajada Yanqui", 19 de marzo de 1925, p. 8.

2287. La Voz, "Los peruanos y Francos Rodríguez”, 7 de diciembre de 1920, p. 8.

2288. La Voz, "Manifestación en Lima", 22 de mayo de 1929, p. 5.

2289. La Voz, "No es una simple cuestión de amor propio", 9 de diciembre de 1920,

p. 5.

2290. La Voz, "No está aún resuelta la cuestión de Tacna y Arica", 23 de febrero de 1929, p. 3.

2291. La Voz, "No ha habido ningún encuentro en la frontera chilenoperuana", 16 y 17 de diciembre de 1921, p. 8.

2292. La Voz, "Noticias breves del extranjero", 2 de febrero de 1928, p. 6.

2293. La Voz, "Noticias breves del extranjero", 25 de mayo de 1929, p. 3.

2294. La Voz, "Noticias breves del extranjero", 3 de julio de 1929, p. 8.

2295. La Voz, "Noticias breves del extranjero", 3 de octubre de 1929, p. 6.

2296. La Voz, "Noticias breves del extranjero", 5 de abril de 1929, p. 8.

2297. La Voz, "Nuestro Peñaflorida", 25 de septiembre de 1929, p. 1.

2298. La Voz, "Perú, Ecuador, Colombia y Panamá", 30 de abril de 1929, p. 2.

2299. La Voz, "Por qué mató Santos Chocano a Edwin Elmore", 18 de noviembre de 1925, p. 4.

2300. La Voz, "Preparando el plebiscito para la posesión de Tacna y Arica", 1 de agosto de 1925 , p. 8.

2301. La Voz, "Protestas", 27 de diciembre de 1921, p. 8.

2302. La Voz, "Se consolida la situación en Bolivia", 19 de julio de 1920, p. 5.

2303. La Voz, "Tacna y Arica", 16 de enero de 1926, p. 5.

2304. La Voz, "Tacna y Arica", 20 de junio de 1925, p. 1.

2305. La Voz, "Tacna y Arica", 8 de marzo de 1926, p. 5.

2306. La Voz, "Un cable a los presidentes", 12 de octubre de 1929, p. 3. 
2307. La Voz, "Un complot contra Leguía", 23 de diciembre de 1926, p. 5.

2308. La Voz, "Un reglamento de Policía entre Chile y Perú", 15 de agosto de 1929, p. 1.

2309. La Voz, "Una nota del Gobierno peruano", 23 de agosto de 1920, p. 3.

2310. La Voz, "Una posible solución para lo de Tacna y Arica", 30 de marzo de 1926, p. 5.

2311. La Voz, "Varias conferencias", 23 de febrero de 1927, p. 2.

2312. La Voz, "Ya está resuelta la cuestión de Tacna y Arica", 21 de febrero de 1929, p. 1.

2313. Las Dominicales del Libre Pensamiento, "El Coronel Bolognesi”, 18 de abril de 1902, p. 1.

2314. Las Dominicales del Libre Pensamiento, "En el día de la Patria", 20 de octubre de 1898, p. 4.

2315. Las Dominicales del Libre Pensamiento, "Flagelación en el Perú", 24 de noviembre de 1898, p. 2.

2316. Las Dominicales del Libre Pensamiento, "La Guerra del Perú", 26 de abril de 1895, p. 4.

2317. Las Dominicales del Libre Pensamiento, "Perú", 17 de marzo de 1893, p. 4.

2318. Madrid Científico, "Evocación de la química", $1^{a}$ quincena de enero de 1929, año XXXVI, n. ${ }^{\circ} 1.225$, p. 11.

2319. Madrid Científico, "La comunicación de Bolivia con el mar", 1913, año XX, n. ${ }^{\circ}$ 797, p. 347.

2320. Muchas Gracias, "Cara Millo", año II, n. ${ }^{\circ} 67,9$ de mayo de 1925, p. 1.

2321. Mundial Magazine, "El yermo fecundo", junio de 1913, año III, vol. V, n. ${ }^{\circ}$ 26, p. 168.

2322. Mundo Gráfico, "El pabellón de Chile en la exposición Iberoamericana", 4 de diciembre de 1929, año XIX, n. ${ }^{\circ}$ 944, s.p.

2323. Nuestro Tiempo, "El arbitraje", junio de 1925, año XXV, n. ${ }^{\circ}$ 318, p. 277.

2324. Nuestro Tiempo, "El arreglo radical del pleito peruanochilenoboliviano", año XXIII, n. ${ }^{\circ} 293$, p. 234-236.

2325. Nuestro Tiempo, "La cuestión de límites en la América Española", septiembre de 1902, año II, n. ${ }^{\circ} 21$, p. 365.

2326. Nuestro Tiempo, "La cuestión de límites en la América Española", septiembre de 1902, n. $^{\circ} 21$, p. 370.

2327. Nuestro tiempo, "La liberación de Bolivia", marzo de 1913, año XIII, n. ${ }^{\circ} 171$, p. 396.

2328. Nuestro Tiempo, "Revista Bibliográfica", noviembre de 1919, año XIX, n. ${ }^{\circ} 251$, p. 236.

2329. Nuestro Tiempo, "Solidaridad espiritual hispano-americano", marzo de 1924, año XXIV, n. ${ }^{\circ}$ 303, p. 300. 
2330. Nuevo Mundo, "Bolivia y Paraguay ante la conferencia Panamericana de conciliación", 11 de enero de 1929, año XXXVI, n. ${ }^{\circ} 1.825$, p. 13.

2331. Nuevo Mundo, "El Conflicto entre Perú y Chile", 31 de enero de 1919, año XXVI, n. ${ }^{\circ} 1.308$, p. 21.

2332. Nuevo Mundo, "El faro de los muertos", 9 de noviembre de 1928, año XXXV, n. ${ }^{\circ}$ 1.816, p. 8.

2333. Nuevo Mundo, "El nuevo dique Victoria Eugenia", 22 de mayo de 1913, p. ¿?

2334. Nuevo Mundo, "El vuelo triunfal de los aviadores Jiménez e Iglesias", 26 de abril de 1929, año XXXVI, n. ${ }^{\circ} 1.840$, p. 23.

2335. Nuevo Mundo, "La diplomacia y el cheque", 30 de abril de 1926, año XXIII, n. ${ }^{\circ}$ 1.684, p. 3.

2336. Nuevo Mundo, "La República de Chile", 8 de enero de 1902, año IX, n. ${ }^{\circ} 418$, pp. 3-4.

2337. Nuevo Mundo, "Madrid en la geografía y en la historia", 12 de octubre de 1928, año XXXV, n. ${ }^{\circ} 1.812$, p. 52.

2338. Oro de ley, "El desierto de Arica”, 15 de octubre de 1926, p. 324.

2339. Panorama, "D. Agustín Vélez Ocampo", n. ${ }^{\circ}$ 40, 22 de agosto de 1927, p. 14.

2340. Panorama, "D. Alberto A. Giesecke", 15 de enero de 1928, año VI, n. ${ }^{\circ}$ 46, p. 2.

2341. Panorama, "D. Fermín Eizaguirre", n. ' 38, 25 de junio de 1927, p. 31.

2342. Panorama, "D. Julio Fuenzalida R.”, 18 de marzo de 1925, año III, n. ${ }^{\circ}$ 25, p. 14.

2343. Panorama, "D. Oscar M. Barrios M.”, n. ' 40, 22 de agosto de 1927, p. 3.

2344. Panorama, "Don E. M. Patroni”, 10 de agosto de 1925, año III, p. 30.

2345. Panorama, "Padre D. José Vitaliano Berroa", n. ${ }^{\circ}$ 39, 29 de julio de 1927, p. 6.

2346. Por Esos Mundos, “¿Rendirá el mundo las armas?”, n. ${ }^{\circ} 12,21$ de marzo de 1926, s.p.

2347. Por Esos Mundos, "El cobre en Bolivia", 1 de julio de 1910, año XI, n. ${ }^{\circ} 186$, p. 141.

2348. Por Esos Mundos, "La obra de Querol", 1 de enero de 1910, n. ${ }^{\circ}$ 180, año XI, vol. XX, p. 39.

2349. Revista Contemporánea de Madrid, "Revista extranjera", noviembre de 1883, n. $^{\circ}$ 48, p. 377.

2350. Revista Contemporánea, "Relación que hizo de su viaje por España la señora condesa D'Aulnof en 1697”, octubre, año XVI, n. . 80, año de 1890, p. 383.

2351. Revista de Archivos, Bibliotecas y Museos (Historia y ciencias auxiliares),

"Variedades", 1 de abril de 1902, año VI, n. 4 y 5, p. 409.

2352. Revista de Archivos, Bibliotecas y Museos, "Descubrimientos prehistóricos", números 7-9, año XXX, p. 322.

2353. Revista de Ciencias Eclesiásticas, "Perú”, Año 1901, p. 620.

2354. Revista de España, "Bolivia", enero, n. ${ }^{\circ}$ 125, año 1889, p. 509.

2355. Revista de España, “Crónica política exterior”, enero, año 1887, n. 114, p. 306. 
2356. Revista de España, "Crónica política", tomo LXXXIX, noviembre de 1882, pp. 286-287.

2357. Revista de España, "Estudios precolumbinos (sic)", julio, n. ${ }^{\circ}$ 141, año 1892, p. 176.

2358. Revista de España, "Méjico", noviembre, tomo CXXIV, n. ${ }^{\circ} 124$, año 1888,

p. 197.

2359. Revista de España, "Religiones del Perú", julio, n. ${ }^{\circ} 135$, año de 1891, p. 487.

2360. Revista de Geografía Comercial, “América”, 1 de mayo de 1896, año XII, n. ${ }^{\circ}$ 153-154, p. 7.

2361. Revista de Geografia Comercial, "Chile. Comercio con España”, 1 de diciembre de 1889, año IV, n. ${ }^{\circ} 76$, p. 335.

2362. Revista de Geografia Comercial, "La Cerne, de Hannon, no es la islete Herne", 1 de julio de 1886, año II, p. 31.

2363. Revista General Internacional, "Crónica internacional”, 22 de noviembre de 1900, año II, n. ${ }^{\circ} 77$, p. 674.

2364. Revista General Internacional, "Crónica internacional”, 30 de septiembre de 1900, año II, n. ${ }^{\circ} 70$, p. 565.

2365. Revista Hispanoamericana Cervantes, "Actualidad iberoamericana", abril de 1919, (sin datos de año y n. ${ }^{\circ}$ ), pp. 151-152.

2366. Revista Iberoamericana de Ciencias Eclesiásticas, "Chile”, Año I, Tomo II. año 1901, p. 233.

2367. Revista Iberoamericana de Ciencias Eclesiásticas, "La cuestión chilenoperuana", 1902, año II, tomo III, p. 108.

2368. Revista Iberoamericana de Ciencias Eclesiásticas, "Revista Ibero-Americana", Año I, tomo I. Año 1901. p. 744.

2369. Revista Iberoamericana de Ciencias Eclesiásticas., "Chile”, Año I, tomo I. año 1901, p. 489.

2370. Revista Ilustrada de Banca, Ferrocarriles, Industria y Seguros, "Los ferrocarriles chilenos en 1910", 10 de diciembre de 1910, (sin datos de año y número), p. 607.

2371. Revista Ilustrada de Banca, Ferrocarriles, Industria y Seguros, "Banco Mercantil", 25 de febrero de 1913, (sin datos), p. 109.

2372. Revista Ilustrada de Banca, Ferrocarriles, Industria y Seguros, "Los ferrocarriles en la República de Bolivia", 25 de noviembre de 1927, p. 8.

2373. Vida Marítima, "Desinfección de buques en Chile", 20 de junio de 1908, año VII, n. ${ }^{\circ} 233$, p. 269.

2374. Vida Marítima, "El gran ferrocarril Panamericano", 30 de junio de 1911, año X, n. ${ }^{\circ} 342$, p. 278.

2375. Vida Marítima, "Ferrocarriles en África y Sudamérica", 30 de octubre de 1909, año VIII, n. ${ }^{\circ} 282$, p. 470.

2376. Vida Marítima, "Inmigración japonesa en la América del Sud", 10 de noviembre de 1907, año VI, n. ${ }^{\circ}$ 211, p. 492. 
2377. Vida Marítima, "La situación internacional", 15 de diciembre de 1922, año XXI, n. ${ }^{\text {7 }} 728$, p. 4.

2378. Vida Marítima, "La situación internacional”, 15 de febrero de 1923, año XXII, n. ${ }^{\circ} 732$, p. 37.

2379. Vida Marítima, "Recuerdos del viaje del España al Pacífico", 15 de septiembre de 1922, año XXI, n. ${ }^{\circ} 722$, p. 8. 
b) Fuentes hemerográficas de la Biblioteca Virtual de Prensa Histórica del Ministerio de Educación, Cultura y Deporte del Gobierno de España.

1. Boletín de la Sociedad Geográfica de Madrid, "El camino de Bolivia al Atlántico", tomo IX, septiembre de 1880, p. 173.

2. Boletín de la Sociedad Geográfica de Madrid, "El camino de Bolivia al Atlántico", tomo IX, septiembre de 1880, p. 174.

3. Diari Catalá, "Extracte de telegramas de la prempsa local", 1 de junio de 1880, p. 8.

4. Diari Catalá, "Extracte de telegramas de la prempsa local", 17 de julio de 1880, p. 8.

5. Diari Catalá, "Guerra entre Xile y Perú", 14 de junio de 1880, p. 4.

6. Diari Catalá, "Telégramas de la prempsa extranjera", 18 de enero de 1880, p. 8.

7. Diari Catalá, "Telégramas de la prempsa extranjera", 19 de enero de 1880, p. 4.

8. Diari Catalá, "Telégramas de la prempsa extranjera", 19 de enero de 1880, p. 4.

9. Diari Catalá, "Telégramas particulars", 15 de junio de 1880, p. 8.

10. Diario de Córdoba, "América", 18 de mayo de 1880, p. 1.

11. Diario de Córdoba, "Estranjeras (sic)", 2 de junio de 1880, p. 2.

12. Diario de Córdoba, "Estranjeras (sic)", 2 de junio de 1880, p. 2.

13. Diario de Córdoba, "Estranjeras (sic)", 3 de diciembre de 1880, p. 2.

14. El Amigo, "Revista de los principales sucesos de la semana", 13 de junio de 1880, p. 4.

15. El Amigo, "Revista de los principales sucesos de la semana", 14 de marzo de 1880, p. 3.

16. El Amigo, "Revista de los principales sucesos de la semana", 6 de junio de 1880, p. 3.

17. El Áncora, "Partes Telegráficos", 2 de diciembre de 1880, p. 4.

18. El Áncora, "Partes Telegráficos", 3 de junio de 1880, p. 3.

19. El Áncora, "Sección Extranjera", 19 de noviembre de 1880, p. 3.

20. El Áncora, "Sección Extranjera", 21 de abril de 1880, p. 3

21. El Áncora, "Sección Extranjera", 21 de abril de 1880, p. 3.

22. El Áncora, "Sección Extranjera", 5 de julio de 1880, p. 3.

23. El Áncora, "Sección Extranjera", 5 de julio de 1880, p. 3.

24. El Bien Público, [s. t.], 6 de marzo de 1880, p. 2.

25. El Bien Público, [s. t.], 6 de marzo de 1880, p. 2.

26. El Bien Público, [s. t.], 6 de marzo de 1880, p. 2.

27. El Bien Público, "América del Sur", 17 de marzo de 1880, p. 2.

28. El Bien Público, “América del Sur”, 29 de noviembre de 1880, p. 2.

29. El Bien Público, “América del Sur”, 29 de noviembre de 1880, p. 2.

30. El Bien Público, "América del Sur”, 3 de abril de 1880, p. 2.

31. El Bien Público, "Carta del Perú", 2 de junio de 1880, p. 2.

32. El Bien Público, "Cartas Sud Americanas", 12 de abril de 1880, p. 1.

33. El Bien Público, "Cartas Sud Americanas", 12 de julio de 1880, p. 1.

34. El Bien Público, "Cartas Sud Americanas", 14 de octubre de 1880, p. 1.

35. El Bien Público, "Cartas Sud Americanas", 21 de agosto de 1880, p. 1.

36. El Bien Público, "Cartas Sud Americanas", 22 de julio de 1880, p. 1. 
37. El Bien Público, "Cartas Sud Americanas", 9 de septiembre de 1880, p. 1.

38. El Bien Público, "Cartas Sud-Americanas", 21 de agosto de 1880, p. 1.

39. El Bien Público, "Chile y Perú", 3 de enero de 1880, p. 1.

40. El Bien Público, "Chile y Perú", 3 de enero de 1880, p. 2.

41. El Bien Público, "La Batalla de Tacna", 17 de julio de 1880, p. 1.

42. El Bien Público, "La Guerra del Pacífico", 22 de abril de 1880, p. 3.

43. El Bien Público, "Telegramas particulares", 15 de junio de 1880, p. 3.

44. El Bien Público, "Telegramas particulares", 20 de enero de 1880, p. 2.

45. El Comercio, [s. t.], 20 de febrero de 1880, p. 1.

46. El Comercio, "Cómo se gobiernan las repúblicas", 30 de diciembre de 1880, p. 1.

47. El Comercio, "Cómo se gobiernan las repúblicas", 30 de diciembre de 1880, p. 2.

48. El Comercio, "Correo de anoche", 2 de junio de 1880, p. 2.

49. El Comercio, "Correo de anoche", 3 de diciembre de 1880, p. 2.

50. El Comercio, "Gacetillas", 13 de marzo de 1880, p. 3.

51. El Comercio, "Partes telegráficos", 3 de diciembre de 1880, p. 3.

52. El Comercio, "Revista extranjera de El Comercio", 4 de abril de 1880, p. 1.

53. El Constitucional, "Despachos telegráficos", 3 de diciembre de 1880, p. 3.

54. El Eco de Santiago, "De todas partes", 27 de agosto de 1898, p. 4.

55. El Graduador, "Despachos telegráficos", 18 de junio de 1880, p. 2.

56. El Graduador, "Despachos telegráficos", 3 de diciembre de 1880, p. 2.

57. El Pabellón Nacional, "Inglaterra", 5 de febrero de 1881, p. 3.

58. El Timón, "Guerra chileno-peruana", 29 de octubre de 1880, p. 2.

59. Heraldo de Zamora, "Telegramas del extranjero", 1 de agosto de 1898, p. 2.

60. La Crónica Meridional, "Noticias generales", 3 de junio de 1880, p. 3.

61. La Crónica Meridional, "Telegramas", 5 de diciembre de 1880, p. 2.

62. La Ilustració Catalana, "Crónica General", n. ${ }^{\circ}$ 18, 30 de diciembre de 1880, p. 2.

63. La Mañana, "Noticias", 21 de enero de 1880, p. 3.

64. La Opinión, "Correo", 2 de diciembre de 1880, p. 3.

65. La Opinión, "Partes telegráficos", 19 de enero de 1880, p. 3.

66. Mercurio, "Chile y España", 20 de octubre de 1910, n. ${ }^{\circ}$ 109, p. 418.

67. Mercurio, "El monumento a Bolognesi”, 1 de septiembre de 1904, n. ${ }^{\circ}$ 34, año IV, p. 12.

68. Mercurio, "Excelentísimo señor general don Ismael Montes", 1 de abril de 1915, n. ${ }^{\circ} 225$, p. 99. 


\section{BIBLIOGRAFÍA}

ABric, Jean-Claude, Prácticas sociales y representaciones, México, Ediciones Coyoacán, 2001.

ABRISKETA, Joana, "El derecho a la asistencia humanitaria: fundamentación y límites", Los desafios de la acción humanitaria: Un balance. En ROBERTS, Adam, ABrisKeTA, Joana, EtXeberría, Xavier, Rey, Francisco, Sogge, David, Raisin, Joanne, RAmsbotham, Alexander, Aguirre, Mariano, MÉdicos SIN Fronteras, Barcelona, Icaria Editorial S. A., 1999, pp. 77-78.

ACEREDA, Alberto, “La hispanidad amenazada: Rubén Darío y la guerra del 98”, Bolingual Review/La revista bilingüe, vol. 25, n. ${ }^{\circ} 1$, pp. 99-110.

ACOSTA CERÓn, Ramiro, Los nuevos sujetos del derecho internacional, Quito, Ediciones Abya-Yala, 2002.

Aguirre Rojas, Carlos Antonio, Antimanual del mal historiador, México, La Vasija, 2002.

AIme, Marco, Cultura, Buenos Aires, Adriana Hidalgo editora, 2015.

AkmaJian, Adrian, Demers, Richard A. y ARnish., Robert M., Lingüistica: una introducción al lenguaje y la comunicación, Madrid, Alianza Editorial S. A., 1987.

Alessandri Palma, Arturo, Recuerdos de gobierno, Santiago, Editorial Nascimento, 1967.

Alguacil CuencA, Pedro, "España: de la Sociedad de Naciones a Naciones Unidas", Anales de Derecho. Universidad de Murcia, n. ${ }^{\circ}$ 24, 2006, pp. 303-318.

Alía Miranda, Francisco, Técnicas de investigación para historiadores, Madrid, Editorial Síntesis, 2005.

Aljovín DE LOSADA, Cristóbal y CAVIERES F., EdUARDO, "Reflexiones para un análisis histórico de Chile-Perú en el siglo XIX y la Guerra del Pacífico”. En CAVIERES F., Eduardo y Aljovín DE LosadA, Cristóbal (Comps.), Chile-Perú; Perú-Chile en el siglo XIX. La formación del Estado, la economía y la sociedad, Valparaíso, Ediciones Universitarias de Valparaíso, Pontificia Universidad Católica de Valparaíso, 2005, pp. 11-24.

Aljovín de Losada, Cristóbal y LóPez, Sinesio, Historia de las elecciones en el Perú: estudios sobre el gobierno representativo, Lima, Instituto de Estudios Peruanos, 2005. 
Alliende E., María Piedad, Historia del ferrocarril en Chile, Santiago, Pehuén Editores, 1993.

Alonso, Sonia, Volkens, Andrés y Gómez, Braulio, Análisis de contenidos de texto políticos. Un enfoque cuantitativo, Madrid, Centro de Investigaciones Sociológicas, 2012.

Álvarez García, Marcos, Líderes políticos del siglo XX en América Latina, Santiago, LOM Ediciones, 2007.

Álvarez Guerrero, Osvaldo, "Hipólito Irigoyen ante la condición humana", Polis. Revista Latinoamericana, . $^{\circ} 13,2006$, Disponible en:

$<$ https://polis.revues.org/5437\#authors $>$ [consultado el 25/10/2014].

Álvarez Londoño, Luis Fernando, Historia del derecho internacional público, Bogotá, Pontificia Universidad Javeriana. Facultad de ciencias jurídicas, 2006.

Álvarez, Juan, "Investigación cuantitativa/investigación cualitativa ¿Una falsa disyuntiva?”. En CoOK, T. D. y ReIChARDT, Ch. S., Métodos cualitativos y cuantitativos en investigación evaluativa, Madrid, Ediciones Morata, S. L., 2005, pp. 9-24.

Álvez Marín, Amaya e Irarrázaval Gomien, Andrés, "El plebiscito sobre el destino de Tacna y Arica como solución jurídica a un conflicto bélico. El aporte de Federico Puga-Borne", Revista de Estudios Históricos y Jurídicos, n. ${ }^{\circ}$ 22, 2000, pp. 193-212.

AlzAmorA, Isaac, La cuestión peruano-chilena, París, Petite collection américaine, 1919.

AMODIO, Emanuele, Cultura, comunicación, lenguaje, Caracas, IESALC UNESCO, 2010.

ANDERSON, Benedict, Comunidades imaginadas. Reflexiones sobre el origen y la difusión del nacionalismo, México, FCE, 1993.

Angerstein, Dietrich, Historia del ferrocarril en Chile, Santiago, Dirección de Archivos, Bibliotecas y Museos. Centro de Investigaciones Diego Barros Arana, 1997.

ApARICI, Roberto, "La construcción de la realidad". En APARICI, Roberto (Coord.), La construcción de la realidad en los medios de comunicación, Madrid, Universidad Nacional de Educación a Distancia, 2010, pp. 11-22.

ArAngo, Manuel Antonio, "Aspectos sociales en tres poemas de Cantos de vida y esperanza, de Rubén Darío: «Salutación del optimista», «Los cisnes», n. ${ }^{\circ} 1$, y «A Roosevelt»", Anales de Literatura Hispanoamericana, vol. 6, 1977, pp. 279-289. 
ARÁNGUIZ DonOSO, Horacio, "Una instancia integradora: la inmigración española en Chile, 1850-1900". En ReAl ACAdemia DE la Historia, II Congreso de Academias Iberoamericanas de la Historia. Factores de diferenciación e instancias integradoras en la experiencia del mundo iberoamericano. Actas, Madrid, Taravilla, 1994, pp. 95-104.

Araya Pinochet, Carlos, Historia de América en perspectiva latinoamericana, San José, EUNED, 2006.

ARAYA, Sandra, "Las representaciones sociales: ejes teóricos para su discusión", Cuadernos de ciencias sociales, n. $^{\circ}$ 127, 2002, pp. 1-83.

Arenal, Celestino del, Política exterior de España y relaciones con América Latina. Iberoamericanidad, Europeización y Atlantismo en la política exterior española, Madrid, Siglo XXI de España Editores, S. A., 2011.

Arias Serrano, Laura, Las fuentes de la historia del arte en la época contemporánea, Barcelona, Ediciones del Serbal, 2012.

Arroyo Cabello, María, "La prensa murciana en el desastre del 98", Historia y Comunicación Social, n. ${ }^{\circ}$ 3, 1998, pp. 15-25.

Arroyo Reyes, Carlos, Nuestros años diez. La Asociación Pro-Indígena, el levantamiento de Rumi Maqui y el incaísmo modernista, LibrosEnRed, 2005.

Arteaga Alemparte, El Problema del Pacifico. Artículos publicados en "O Paiz" de Río de Janeiro, sobre la cuestión de Tacna y Arica por “Arteaga Alemparte”, Santiago, Imprenta Universitaria, 1919.

AstiÉ-Burgos, Walter, México y Estados Unidos: entre la cooperación y el desacuerdo, México, Siglo XX Editores, 1998.

Aurell, Jaume, La escritura de la memoria. De los positivismo a los postmodernismos, Valencia, Universitat de València, 2005.

Austin, J. L., Cómo hacer cosas con palabras, Santiago, Escuela de Filosofía Universidad ARCIS, Edición electrónica, Disponible en:

$<$ http://revistaliterariakatharsis.org/Como_hacer_cosas_con_palabras.pdf $>$ [consultado el: 17/01/2016].

Ávila LóPeZ, Enrique, Modern Spain. Understanding Modern Nations, United States of America, ABC-CLIO, LLC, 2016, p. 142.

Ballesteros, Pío, Origen de la firma de Derecho ante la justicia de Aragón, Madrid, Tip. de la Revista de Archivos, Biblioteca y Museos, 1904. 
BAnchs, María, Agudo, Álvaro y AstorgA, Lislie, "Imaginarios, representaciones y memoria social”. En ARRUdA, Ángela y DE AlBA, Martha, Espacios imaginarios y representaciones sociales. Aportes desde Latinoamérica, Barcelona, Anthropos Editorial, 2007, pp. 47-95.

BARDIN, Laurence, Análisis de contenido, Madrid, Akal S. A., 2002.

Barona, Josep Lluís, Ciencia e Historia, Debates y tendencias en la historiografía de la ciencia, Godella, Seminari d'Estudis sobre la Ciència, 1994.

BARRERA LunA, Raúl, "El concepto de cultura, definiciones, debates y usos sociales". Revista de Claseshistoria, febrero de 2013, p. (s/d), Disponible en:

$<$ http://www.claseshistoria.com/revista/index.html> [consultado el: 28/08/2015].

BARRETO, José María, El problema peruano-chileno (1883-1911), Lima, Imprenta Americana, 1919.

BARreto, José María, Sin réplica. Cartas diplomáticas, Bolivia, Imprenta Velarde, 1919.

BArros Borgoño, Luis, Los tratados con Bolivia de 1895, La Paz, Imp. Moderna, 1918.

BARros JARPA, Ernesto, Hacia la solución. Apuntaciones al margen de la negociación chileno-peruana de 1921, Santiago, Imprenta Universitaria, 1922.

BArros, Mario, Historia diplomática de Chile (1541-1938), Barcelona, Ediciones Ariel, 1970.

BARRÓs, Oscar, Por la justicia y por la patria, Lima, Tall. De Linotipia, 1940.

BASADRE, Jorge, Historia de la República del Perú 1822-1833, tomo XII, Lima, Editorial Universitaria, 1969.

BASADRE, Jorge, Historia de la República del Perú 1822-1833, tomo XIII, Lima, Editorial Universitaria, 1968.

BASADre, Jorge, Historia de la República del Perú, Lima, Tall. Graf. P. L. Villanueva, 1968.

BAUD, Michiel, "Fronteras y la construcción del Estado en América Latina". En TORRES Cisneros, Gustavo, Van Dijck, Pitou, Baud, Michiel, Hogenboom, Barbara, Zoomers, Annelies, YpeiJ, Annelou y Ouweneel, Arij, Cruzando fronteras. Reflexiones sobre la relevancia de fronteras históricas, simbólicas y casi desaparecidas en América Latina, Quito, Ediciones Abya-Yala, 2004.

BAUER, Wilhelm, La opinión pública y sus bases históricas, Santander, Publicaciones de la Universidad de Cantabria, 2009. 
BAZÁN DÁvILA, Raúl, El patrimonio territorial que recibimos del Reino de Chile, Santiago, Instituto de Investigaciones del Patrimonio Territorial de Chile. Universidad de Santiago, 1986.

BECERRA DE LA RoCA, Rodolfo, Nulidad de una apropiación chilena. Territorio boliviano entre los paralelos 23 y 24, La Paz, Plural Editores, 2006.

Bello Codecido, Emilio, Anotaciones para la historia de las negociaciones diplomáticas con el Perú y Bolivia (1900-1904), Chile, Imprenta La Ilustración, 1919.

BELTRÁn RózPIDE, Ricardo, Los pueblos hispanoamericanos en el siglo XX, Madrid, Imprenta de Administración Militar, 1904.

Benavides Correa, Alfonso, Una difícil vecindad. Los irrenunciables derechos del Perú en Arica y los recusables acuerdos peruano-chilenos de 1985, Lima, Universidad Nacional Mayor de San Marcos, 1988.

BennetT, William J., América la última esperanza. Desde el mundo en guerra al triunfo de la libertad, volumen II, Nashville, Grupo Nelson, 2010.

BERENSON, Edward, "La historia cultural americana. La historia cultural de Francia vista desde América”. En POIRRIER, Philip, La historia cultural ¿Un giro historiográfico mundial?, Valencia, Publicacions de la Universitat de Valencia, 2012.

Berger, Peter y Luckmann, Thomas, La construcción social de la realidad, Buenos Aires, Talleres Gráficos Color EFE, 2003.

Bernal Rodríguez, Manuel, "La construcción social de la realidad en los titulares de prensa (Los sucesos de Casa Viejas de 1933 en ABC)". En Herrero Aguado, Carmen, Israel Garzón, Estrella, Espejo Cala, Carmen, Bernal Rodríguez, Manuel, García Gordillo, María del Mar, GonzÁlez Galiana, Rafael, MÉndeZ García de PARedes, Elena, Andalucía como ámbito de interés periodístico, Sevilla, Padilla Libros editores \& libreros, 1998, pp. 71-93.

Bernales Ballesteros, Jorge, Estabridis CÁrdenas, Ricardo, Gisbert, Teresa, Mesa, José de, LÁmbarri Bracesco, Jesús, TORD, Luis Enrique, CASTRILlón, Alfonso, Escultura en el Perú, Lima, Banco de Crédito del Perú, 1999.

Bernardi, Alberto de y Guarracino, Scipione, Dizionario di Storia, Milano, Edizioni Scolastiche Bruno Mondadori, 1993.

BIEBER, León, "Bolivia, 1936-1945. En la encrucijada entre el surgimiento de un nacionalismo militante y la rivalidad germano-norteamericana". En SALMÓN, Josefa y Delgado, Guillermo, Identidad, ciudadanía y participación popular desde la Colonia al siglo XX, La Paz, Plural Editores, 2007, pp. 171-180. 
BITAR, Sergio, Un futuro común. Chile, Bolivia, Perú. El norte de Chile en el siglo XXI. Chile, Editorial Aguilar, 2012.

Blanchard, Peter, The origins of the Peruvian Labor Movement, 1883-1919, United States of America, University of Pittsburg Press, 1982.

Blanco Fombona, Rufino, Ensayos Históricos, Caracas, Biblioteca Ayacucho, 1981.

Blanlot Holley, Anselmo, Tacna y Arica después del Tratado de Ancón, Santiago, Imprenta Universitaria, 1917.

Bobbio, Norberto, Matteucci, Nicola y PAsquino, Gianfranco, Diccionario de Política, México, Siglo XXI Editores, 2005.

BONED CólerA, Ana, "La vertiente popular de El Resumen y su inserción en la prensa de masas", Historia y Comunicación Social, n. ${ }^{\circ}$ 2, 1997, pp. 113-123.

Boni, Federico, Teoría de los medios de comunicación, Barcelona, Universitat Autònoma de Barcelona. Servei de Publicacions; Castelló de la Plana, Publicaciones de la Universitat Jaume I; Barcelona, Universitat Pompeu Fabra; València, Publicacions de la Universitat de València, 2008.

Bonilla, Heraclio, Gran Bretaña y el Perú (1826-1929): Los mecanismos de un control económico, Lima, Instituto de Estudios Peruanos, 1977.

Bonsignore CARo, Federico, Atlántida. Historia, imágenes y personalidades, a cien años de su creación, Montevideo, Trilce, 2011.

BORRAS, Gérard, Lima, el vals y la canción criolla, 1900-1936, Lima, Institut français d'études andines - IFEA; Instituto de Etnomusicología - IDE, 2012, p. (s/d).

Borrat, Héctor, "El periódico. Actor del sistema político”, Anàlisi, n. ${ }^{\circ}$ 12, 1989, pp. 6780.

BotTI, Alfonso, España en la crisis modernista. Cultura, sociedad civil y religiosa entre los siglos $X I X$ y $X X$, Cuenca, Ediciones de la Universidad de Castilla-La Mancha, 2012.

BourdÉ, Guy y MARTin, Hervé, Las escuelas históricas, Madrid, Akal S. A., 2004.

Bourdieu, Pierre, ¿Qué significa hablar?, Madrid, Akal D. L., 1985.

Bourdieu, Pierre, Capital cultura, escuela y espacio social, México, Siglo XXI Editores, 2005. 
Bradford Burns, E., La pobreza del progreso. América Latina en el siglo XIX, México, Siglo XX Editores, 1990.

Briceño Berrú, José Enrique, Raíces de la pobreza. Vicisitudes históricas. Ensayo de interpretación de la realidad latinoamericana, Lima, Centro de Producción Fondo Editorial Universidad Mayor de San Marcos, 2006.

Bulnes, Gonzalo, Las causas de la guerra entre Chile y el Perú, Santiago, Sociedad Impr. Litográfica Barcelona, 1918.

Burguière, André, Diccionario Akal de ciencias históricas, Madrid, Ediciones Akal, S. A., 1991.

Burguiere, André, Dictionnaire des Sciences Historiques, París, Presses Universitaries de France, 1986.

BuRKe, Peter, ¿Qué es historia cultural?, Barcelona, Paidós, 2005.

BuRKE, Peter, "Obertura: la nueva historia, su pasado y su futuro". En BuRKE, Peter, Formas de hacer historia, Madrid, Alianza Editorial, 1996, pp. 11-37.

BuRKE, Peter, Formas de historia cultural, Madrid, Alianza Editorial, 2006.

Burke, Peter, Funciones sociales del lenguaje a través de la historia, Madrid, Alianza Editorial, 1996.

Burke, Peter, "Historia cultural de las prácticas intelectuales". En FERnández SeBASTián, Javier, CAPellán de Miguel, Gonzalo, Conceptos politicos, tiempo e historia. Nuevos enfoques en historia conceptual, Madrid, McGraw-Hill Interamericana de España, pp. 115-138.

Burke, Peter, Historia social del conocimiento. De la Enciclopedia a la Wikipedia, volumen II, Barcelona, Paidós orígenes, 2012.

Bustos, Carlos, "Dos siglos de relaciones chileno-bolivianas". En ARTAZA RouXel, Mario y Milet García, Paz (Editores), Nuestros vecinos, Santiago, RIL Editores, 2007.

CABrera, Miguel, Historia, lenguaje y teoría de la sociedad, España, Ediciones Cátedra, 2001.

CaIvano, Thomas, Historia de la Guerra de América entre Chile, Perú y Bolivia, Iquique, Librería Italiana Baghetti Hermanos, 1904.

CAL, Rosa, "Las presiones del poder sobre los medios de comunicación social", Historia y comunicación social, vol. 7, 2002, pp. 11-30. 
CAlderón, Pedro José, "Nueva circular del gobierno peruano sobre las conferencias de Arica”. En Editorial Andrés Bello, Boletín de la Guerra del Pacífico, 18791881, Santiago, Editorial Andrés Bello, 1979.

CAmpo Rodríguez, Juan del, Batallas legendarias del Perú y del mundo: episodios y anécdotas, Lima, Fondo Editorial Fundación Academia Diplomática del Perú, 2002.

CAmpo Tejedor, Alberto del, Historia cultural del flamenco: el barbero y la guitarra, Córdoba, Almuzara, 2013.

CANO PAVÓN, José Manuel, "La enseñanza técnica en España y en Europa Occidental y el problema del capital humano industrial. Veinticinco años de estudios", ILUIL, vol. 26, 2003, pp. 367-398.

Cardemil Herrara, Alberto, El camino de la utopía. Alessandri, Frei, Allende. Pensamiento y obra, Santiago, Editorial Andrés Bello, 1997.

CARR, Raymond G., CARR, Stephen, "La crisis del parlamentarismo". En ANDrÉSGALlEGO, José, Historia general de España y América. Revolución y restauración (1868-1931), Tomo XVI-2, Madrid, Ediciones RIALP, S. A., pp. 465-522.

Carreras Ares, Juan José, Razón de historia, Madrid, Marcial Pons. Ediciones de Historia, S. A., 2000.

CASTEDO, Leopoldo, Chile: Vida y muerte de la república parlamentaria (de Balmaceda a Alessandri), Santiago, Editorial Sudamericana, 2001.

CAstorina, José y BARreiro, Alicia, "Las representaciones sociales y su horizonte ideológico: Una relación problemática”, Boletín de psicología, n. ${ }^{\circ} 86,2006$, pp. 726.

Castro Nogueira, Luis, CAstro Nogueira, Miguel Ángel y Morales Navarro, Julián, Metodología de las ciencias sociales. Una introducción crítica, Madrid, Tecnos, 2008.

Castro PeÑA, Yeni, El mito Roosevelt para América Latina (1901-1909), Quito, Universidad Andina Simón Bolívar, Abya Yala, Corporación Editora Nacional, 2007.

Castro y Oyanguren, Enrique, Entre el Perú y Chile: la cuestión de Tacna y Arica. Páginas de divulgación histórica, Perú, Imprenta del Estado, 1919.

Cavallo, Guglielmo y Chartier, Roger, Historia de la lectura en el mundo occidental, Madrid, Taurus, 2001. 
CEA, María, Fundamentos y aplicaciones en metodología cuantitativa, España, Síntesis, 2012.

Cegarra, José, "Fundamentos teórico epistemológicos de los imaginarios sociales". Cinta de Moebio. Revista de epistemología de ciencias sociales, n. $^{\circ}$ 43, 2012, pp. 1-13.

Cerda Santander, Enrique José, Tratados históricos de los límites internacionales de Chile, C. E. T.- Genchi, 1987.

Charadeau, Patrick, El discurso de la información. La construcción del espejo social, Barcelona, Gedisa Editores, 2007.

CHARTIER, Roger, El mundo como representación. Estudios sobre historia cultural, Barcelona, Gedisa, 1999.

Chaunu, Pierre, Historia cuantitativa, historia serial, México, Fondo de Cultura Económica, 1987.

Chomsky, Noam y Ramonet, Ignacio, Cómo nos venden la moto, Barcelona, Icaria, 2010.

ChORDÁ, Frederic, MARTín, Teodoro y RIVERo, Isabel, Diccionario de términos históricos $y$ afines, Madrid, Ediciones Istmo, 1983.

CID, Gabriel, "De guerras, ritos y conquistas: Conmemoraciones bélicas y nacionalismo chileno en el "norte grande", 1879-1910". En CAVIERES FIGUEROA, Eduardo y CHAUPIS TORRES, José, La guerra del Pacifico en perspectiva histórica. Reflexiones $y$ proyecciones en pasado y presente, Arica, Universidad de Tarapacá, 2015, pp. 185-202.

CLARK, Toby, Arte y propaganda en el siglo XX. La imagen política en la era de la cultura de masas, Madrid, Ediciones Akal, S. A., 2000.

Clemente, Josep Carles y Polo, Juan Francisco, La prensa humanitaria en la España Contemporánea (1870-1989), Madrid, Editorial Fundamento, 2003.

Cockcroft, James, América Latina y Estados Unidos. Historia política país por país, México, Siglo XXI Editores, 2001.

COLLE, Raymond, El análisis de contenido de las comunicaciones. 2. Técnicas de análisis, Tenerife, Sociedad Latina de Comunicación Social, 2011.

Colom Cañellas, Antoni J., Alzina Seguí, Pere, "La historia de 1'educació a Menorca. Análisi bibliográfica", Educació y Cultura. Revista Mallorquina de Pedagogía, n. ${ }^{\circ}$ 18, 2005, pp. 7-22. 
CONCHA, José Miguel, Iniciativas chilenas para una alianza estratégica con Bolivia (18791899), La Paz, Plural Editores, 2011.

Congrains Martin, Eduardo, Miguel Grau: "El León del Pacífico", Lima, Editorial Ecoma, 1972.

ConNelly, Frances S., Lo grotesco en el arte y la cultura occidentales. La imagen en juego, Madrid, Machado. Grupo de distribución S. L., 2015.

CORREA, Loreto, "Del poder a los tratados: desarrollo y ferrocarriles en Bolivia, 18701904". Historia, vol. 46, n. ${ }^{\circ}$ 2, 2013, Disponible en: http://www.scielo.cl/scielo.php?pid=S0717-

$71942013000200001 \&$ script $=$ sci_arttext

Correa SutiL, Sofía, Con las riendas del poder. La derecha chilena en el siglo XX, Santiago, Editorial Sudamericana [Edición digital].

Corvalán, Facundo, "50 años de representaciones sociales y psicología: campo Psy, bifurcaciones y desafíos", ECOS Estudos contemporaneos da subjetividade, n. ${ }^{\circ} 1$, 2013, pp. 115-127.

Costa de la Torre, Arturo, Hombres célebres de Bolivia, La Paz, Impr. y Librería Renovación, 1970.

Cotler, Julio, "De Velasco a Belaúnde: el problema de la construcción nacional y la democracia en Perú". En González Casanova, Pablo (Coord.), El Estado en América Latina. Teoría y práctica, México, Universidad de Las Naciones Unidas, Siglo XXI Editores S. A., 2003, pp. 349-366.

COUYOUMdian, Juan Ricardo, Chile y Gran Bretaña durante la primera guerra mundial y la posguerra, 1914-1921, Santiago, Editorial Andrés Bello, 1986.

Couyoumdian, Juan Ricardo, Chile y Gran Bretaña. Durante la primera guerra mundial y la postguerra, 1914-1921, Santiago, Editorial Andrés Bello, 1986.

Dalla Corte, Gabriela, Casa de América en Barcelona (1911-1947), Madrid, LID Editorial, 2005.

DARnton, Robert, "Historia de la lectura". En BurKe, Peter (Ed.), Formas de hacer historia, Madrid, Alianza Editorial, 1993, pp. 177-208.

DÁvalos y Lissón, Pedro, Tacna y Tarapacá peruanos. Artículos publicados en "El Comercio" de Lima, en el mes de diciembre de 1918, [s. d.], [s. d.], 1918. 
De Fleur, Melvin y Ball-Rokeach, Sandra, Teorías de la comunicación de masas, Barcelona, Ediciones Paidós Ibérica, S. A. 1993.

Delgado IdARretA, José Miguel, "La prensa: fuente historiográfica". En Instituto DE ESTUDIOS RIOJANOS (Editores), Investigación humanística y científica en La Rioja. Homenaje a Julio Luis Fernández Sevilla y Mayela Balmaseda Aróspide, La Rioja, Instituto de Estudios riojanos, 2000, pp. 245-256.

Delgado Martín, Jaime, Historia general de España y América, Madrid, RIALP, D. L., 1992.

DetiEnNe, Marcel, L'identité nationale, une énigme, París, Éditions Gallimard, 2010.

DíAz Aguad, Alfonso, "La violencia del discurso. La problemática política y social de Tacna y Arica a través de la prensa local, 1918-1926”. En DíAZ ARAYA, Alberto, Ruz Zagal, Rodrigo y Galdames Rosas, Luis (Compiladores), Tiempos violentos. Fragmentos de historia social en Arica, Arica, Ediciones Universidad de Tarapacá, 2014, pp. 75-84.

Díaz Aguad, Alfonso y Pizarro Pizarro, Elías, "Tacna y Arica en tiempos del centenario", Diálogo Andino, n. . 24, 2004.

Díaz Araya, Alberto; Ruz Zagal, Rodrigo; Galdames Rosas, Luis y TAPIA TOSETTI, Alejandro, "El Arica peruano de ayer. Siglo XIX", Revista Atenea n. . 505, 2012, pp. 159-184.

DíAz DíAz, Gonzalo, Hombres y documentos de la filosofia española, Madrid, Consejo Superior de Investigaciones Científicas, 1980.

DiCCIONARIO RAE, <http://dle.rae.es/?id=Kz0Vifv> [consultado el: 30/01/2016].

DüMMER ScheEl, Sylvia, Sin tropicalismos ni exageraciones. La construcción de la imagen de Chile para la exposición Iberoamericana de Sevilla en 1929, Santiago, RIL Editores, 2012.

DunKerley, James, Orígenes del poder militar. Bolivia 1879-1935, La Paz, Plural Editores, 2006.

DurÁN Rodríguez, M. Dolores, "La educación técnica popular en Francia y España (1780-1950): algunas consideraciones acerca de las escuelas de artes y oficios en ambos países", Sarmiento, n. ${ }^{\circ}$ 13, 2009, pp. 69-99.

Eckholt Ithurralde, Edgard, Chile y Perú 1994-2009: Realismo en la frontera, Santiago, Magíster en Política Exterior, IDEA-ACADE, Universidad de Santiago de Chile, 2012. 
Egaña, Rafael, La cuestión de Tacna i Arica. Antecedentes diplomáticos, gestiones diplomáticas, estado actual, Tip. y Encuad. De Müller hnos., 1901.

El Mercurio, "Carlos Vicuña Fuentes”, 16 de agosto de 1931, p. 5.

Encuentro Internacional De Peruanistas, Estado de los estudios histórico-sociales sobre el Perú a fines del siglo XX, Lima, UnESCO, Universidad de Lima, Fondo de Cultura Económica, 1996.

Escagedo Salmón, Mateo, Solares montañeses: viejos linajes de la provincia de Santander, vol. 8, Santander, Wilsen Editorial, 1991.

EsPeChe, Carlos Ernesto, "Periodismo objetivo o subjetivo, una falsa dicotomía", Congreso de Periodismo y medios de comunicación, 2012, pp. 1-20.

Esteva Fabregat, Claudio, "El bosque hostil o la dialéctica del nacionalismo". En Alcina FrAnCH, José y CALÉs Bourdet, Marisa (Eds.), Hacia una ideología para el siglo XXI. Ante la crisis civilizatoria de nuestro tiempo, Madrid, Ediciones Akal S. A., 2000, pp. 59-101.

Estrada TURRO, Baldomero, Desarrollo empresarial urbano e inmigración europea: españoles en Valparaíso (1880-1940), Memoria para optar al grado de Doctor, Facultad de Geografía e Historia, Universidad Complutense de Madrid, 2012.

ESTRADA, Baldomero, "La historia infausta de la inmigración española en Chile a través de los conflictos comerciales y políticos”, Historia, vol. 35, 2002, pp. 63-89.

EtCheberry, Alfredo, Conceptos generales y bosquejo histórico del Derecho Penal Internacional, 2006, p. 3, Disponible en:

$<$ https://webcache.googleusercontent.com/search?q=cache:mlCu_WtBBLgJ:https:// www.ucursos.cl/derecho/2012/1/D125C0729/6/material_docente/bajar\%3Fid_material\%3 $\mathrm{D} 419022+\& \mathrm{~cd}=1 \& \mathrm{hl}=\mathrm{es} \& \mathrm{ct}=\mathrm{clnk} \& \mathrm{gl}=\mathrm{es}>$ [consultado el: $25 / 12 / 2015]$.

EtXeberría, Xavier, Rey, Francisco, Sogge, David, Raisin, Joanne, Ramsbotham, Alexander, AGUiRRE, Mariano, MÉDICOS SIN FRONTERAs, Barcelona, Icaria Editorial S. A., 1999, pp. 77-78.

Evans PIM, Joam, "Pro-german Press and Literatura in North-Western Spanish Cultures during the World War I (1914-1918)". En FAtU-Tutoveana, Andrada y JARAzO Álvarez, Rubén (Eds), Press, propaganda and politics. Cultural Periodicals in Francaist Spain and Communist Romania, Newcastle, Cambridge Scholars Publishing, 2013, pp. 96-105. 
Faes DíAz, Enrique, Claudio López Bru, Marqués de Comillas, Madrid, Marcial Pons, Ediciones de Historia, S. A., 2009.

FELIZ, Tiberio, "Análisis de contenido de la comunicación asíncrona en la formación universitaria", Revista de Educación, n. ${ }^{\circ}$ 358, mayo-agosto 2012, Disponible en: $<$ http://www.revistaeducacion.mec.es/doi/358_079.pdf $>$ [consultado el: 05/12/2014].

Fermandois, Joaquín, PARodi, Daniel, ZaPata, Antonio y GonZÁlez, Sergio, Generación de diálogo. Chile-Perú, Perú-Chile. Documento 2. Aspectos históricos, Lima, Equis Equis S. A., 2011.

Fernández VAldés, Juan José, Chile y Perú. Historia de sus relaciones diplomáticas entre 1879 y 1929, Santiago, RIL editores, 2004.

Ferrater Mora, José, Diccionario de Filosofia, Madrid, Alianza, 1986, p. 675.

Figueroa Pla, Uldaricio, Organismos internacionales. Tomo I. Teorías y sistemas universales, Santiago, RIL Editores, 2010.

FIGUEROA, Uldaricio, La demanda marítima boliviana en los foros internacionales, Santiago, RIL Editores, 2007.

FLoud, Roderick, Métodos cuantitativos para historiadores, España, Alianza Editorial, 1979.

Fundación Astur, Ciclo de conferencias. Pensando el futuro, Ediciones Trilce, Montevideo, 2012.

FusI, Juan Pablo, Historia mínima de España, Madrid, Turner Publicaciones S. L., 2012.

Galeana, Patricia, El Tratado Mc Lane-Ocampo. La comunicación interoceánica y el libre comercio, México, Editorial Porrúa, 2006.

GANDARIlla SAlgado, José Guadalupe, Globalización, totalidad e historia. Ensayos de interpretación crítica, Buenos Aires, Ediciones Herramienta, 2003.

García Belaúnde, Víctor Andrés, El expediente Prado, Lima, Universidad San Martín de Porres, 2014.

GARcía GonZÁlez, Gloria M., Anotaciones para una reflexión sobre la historia de la prensa y de la comunicación en España, Studia Zamorensia n. ${ }^{\circ}$ 2, 1995, p. 183-194.

GarcíA-SAYÁn, Diego, Vidas paralelas. Región andina, desafios y respuestas, Bogotá, Tercer Mundo Editores, 1999. 
Gardner Munro, Dana, Las cinco repúblicas de Centroamérica. Desarrollo político y económico y relaciones con Estados Unidos, Costa Rica, Editorial de la Universidad de Costa Rica, 2003.

Gargurevich, Juan, A golpe de titular: CIA y periodismo en América Latina, Praga, Videopress, 1981.

Gargurevich, Juan, Prensa, radio y TV. Historia crítica, Lima, Editorial Horizonte, 1987.

Garland, Alejandro, El problema de Tacna y Arica. Confidencial, Lima, Imprenta La Industria, 1900.

GeErTz, Clifford, Conocimiento local. Ensayo sobre la interpretación de las culturas, Barcelona, Paidós, S. A., 1994.

GEERTZ, Clifford, La interpretación de las culturas, Barcelona, Editorial Gedisa, S. A., 1997.

GELLNER, Ernest, Naciones y nacionalismo, España, Alianza Editorial, 2001.

GEOFFrey, Regan, Guerra, políticos y mentiras. Cómo nos engañan manipulando el pasado y el presente, Barcelona, Crítica, 2006.

GIL, Rodolfo, Agustín Querol, Madrid, Saenz de Jubera, 1910.

Giral Quintana, Eugenio, La radiodifusión en Andorra. Política, economía y espacio comunicacional en un país dependiente, Barcelona, Universitat de Barcelona, 1988, p. 30, Disponible en:

$<$ http://www.tesisenred.net/bitstream/handle/10803/22682/01.EGQ_1de10.pdf?sequ ence $=1>$ [consultado el: 25/12/2015].

Góngora Marmolejo, Alonso de, Historia de Chile desde su descubrimiento hasta 1575, Santiago, Editorial Universitaria, 1969.

GonzÁlez Río, María José, Metodología de la investigación social. Técnicas de recolección de datos, Alicante, Editorial AguACLARA, 1997.

GonzÁlez Casanova, Pablo y SaXe-Fernández, John, El mundo actual: situación y alternativas, México, Siglo XXI Editores, 2002.

GonzÁlez Miranda, Sergio y GonzÁlez Alvarado, Osmar, "Guillermo Billinghurst en Tarapacá: la primavera de un intelectual, el otoño de un presidente”. En GoNZÁLEZ Miranda, Sergio y PAROdi Revoredo, Daniel, Las historias que nos unen. Episodios positivos en las relaciones peruano-chilenas, siglos XIX y XX, Chile, Universidad Arturo Prat del Estado de Chile; RIL Editores, 2013, pp. 151-176. 
GonzÁlez Miranda, Sergio, El dios cautivo: Las ligas patrióticas en la chilenización compulsiva de Tarapacá (1910-1922), Santiago, LOM Ediciones, 2004.

GonzÁlez Miranda, Sergio, Hombres y mujeres de la pampa. Tarapacá en el ciclo de expansión del salitre, Santiago, LOM Ediciones, 2002.

GonzÁlez Miranda, Sergio, La llave y el candado. El conflicto entre Perú y Chile por Tacna y Arica, 1883-1929, Santiago, Editorial LOM, 2008.

GonzÁlez Portilla, Manuel, "Poder y lobbies económicos en la restauración: La transformación de la clase política". En Chalmeta, Pedro, Checa Cremades, Fernando, GonzÁlez PorTilla, Manuel, et al., Cultura y culturas en la historia, Salamanca, Ediciones Universidad de Salamanca, 1995, pp. 119-168.

GonZÁlez PradA, Manuel, Antología, Barcelona, Red Ediciones S. L., 2016.

GonzÁlez Schmal, Raúl, Programa de derecho constitucional, México, Universidad Iberoamericana, 2007.

GONZÁLEZ, Osmar, El gobierno de Guillermo E. Billinghurst (1912-1914). Los orígenes del populismo en el Perú, Lima, Nuevo Mundo, 2005.

GonzÁlez, Pilar, "José Prat: Recuerdos de Colombia". En ABellán, José Luis y Monclús, Antonio (Coords.), El pensamiento español contemporáneo y la idea de América. El pensamiento en el exilio, Barcelona, Editorial Anthropos, 1989, pp. 277-384.

GonzÁlez, Sergio, La llave y el candado. El conflicto entre Perú y Chile por Tacna y Arica, Chile, LOM Ediciones, 2008.

GonZÁlez, Sergio, La llave y el candado: el conflicto entre Perú y Chile por Tacna y Arica, Santiago, LOM Ediciones, 2008.

GRACIA, Juan, "Historia de la comunicación: perspectivas metodológicas y teórico historiográficas desde la historia cultural”, Historia Contemporánea, n. ${ }^{\circ} 45,2013$, pp. 639-688.

Granados LouredA, Juan Antonio, Breve historia de los Borbones españoles, España, Ediciones Nowtilus, S. L., 2010.

Grez Toso, Sergio, Historia del comunismo en Chile. La era de Recabarren (1912-1924), Editorial LOM, 2011.

Grez, Carlos, La supuesta preparación de Chile para la Guerra del Pacifico, Boletín de la Academia Chilena de la Historia, n. ${ }^{\circ}$ 3, 1935, pp. 111-139. 
GüELl, Pedro, “¿Qué se dice cuándo se dice cultura? Notas sobre el nombre de un

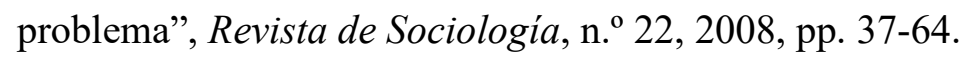

Guerrero BARÓN, Javier, El proceso político de las derechas en Colombia y los imaginarios sobre las guerras internacionales 1930-1945. La guerra con el Perú, la guerra civil española y la Segunda Guerra Mundial, el ascenso del fascismo y la construcción del discurso del odio, Tunja, Editorial UPTC, 2014.

Guerra MARTINiÈRe, Margarita, La ocupación de Lima. Aspectos económicos. 1881-1883, Lima, Fondo Pontificia Universidad Católica del Perú, Fondo Editorial, 1996.

Guevara Torres, José Guillermo, Tacna: la chilenización imposible. Visión del proceso de chilenización de Tacna y Arica (1880-1929), 2012, p. 21, $<$ http://myslide.es/documents/tacna-la-chilenizacion-imposible.html $>$ [consultado el: 20/03/2014].

GuHA, Ranahit, Las voces de la historia y otros estudios subalternos, Barcelona, Crítica, 2002 .

GuHA, Ranahit, Las voces de la historia y otros estudios subalternos, Barcelona, Editorial Crítica S. L., 2002.

Gutiérrez Gutiérrez, Mario R., Alegato histórico de los derechos de Bolivia al Pacífico, La Paz, Talleres Gráf. Bolivianos, 1962.

GUTIÉRREZ ViÑUALES, Rodrigo, "Monumentos conmemorativos de escultores españoles en Iberoamérica (1897-1926)". En CABAÑAS BRAVO, Miguel (Coord.), El arte español fuera de España, España, CYAN, Proyectos y Producciones editoriales, S. A., 2003, pp. 355-366.

GutiÉRrez, Harim, Una alianza fallida: México y Nicaragua contra Estados Unidos, 1909-1910, México, Instituto Mora, 2000.

Halperin Dongui, Tulio, Glade, William, Thorp, Rosemary, Bauer, Arnold, Moreno Fraginals, Manuel, Lewis, Colin M., Bulmer-Thomas, Victor, Ffrench-Davis, Ricardo, MuÑoz, Óscar, Palma, José Gabriel, Historia Económica de América Latina. Desde la Independencia hasta nuestros días, Barcelona, Crítica, 2002.

HeInEMANN, Klaus, Introducción a la metodología de la investigación empírica, Barcelona, Editorial Paidotribo, 2003.

Henderson, Paul, "The Rise and Fall of Anarcho-Syndicalism in South America, 18801930”. En Fowler, Will (Ed.), Ideologues and Ideologies in Latin America, London, Greenwood Press, 1997. 
HenKel, Andrea, "Rubén Darío y la cultura norteamericana: A Roosevelt", Seminario El Mediterráneo en la poesía del Modernismo y del 27', Universität zu Köln Fachbereich Romanistik Wintersemester 2009/2010. [En línea] disponible en: http://lateinamerika.phil-fak.uni-

koeln.de/fileadmin/sites/aspla/bilder/ip_2010/Andrea_Henkel_RubenDario_.pdf [consultado el: 05/02/2015].

HERNÁNDEZ SANDOICA, Elena, Tendencias historiográficas actuales. Escribir historia hoy, Madrid, Akal, 2004.

Herrera CuntTI, Arístides, Apuntes históricos de una gran ciudad, AHC Ediciones Chincha, Perú, 2006.

Herrero A., Víctor, Agustín Edwards Eastman: Una biografía desclasificada del dueño de El Mercurio, Santiago, Debate, 2014.

Herrero Cecilia, Juan, Teorías de pragmática, de lingüística textual y de análisis del discurso, Cuenca, Ediciones de la Universidad de Castilla-La Mancha, 2006.

Hobsbawm, Eric, Naciones y nacionalismos desde 1780, Barcelona, Crítica, 1998.

HuERTAS, Rafael, Historia cultural de la psiquiatría, Madrid, Catarata, 2012.

Hurtado, Paula, "Sin Dios ni ley. Violencia, incomprensión y desamparo. La situación de Tacna, Arica y Tarapacá tras la Guerra del Pacífico, a la luz del diario El Comercio y la revista Variedades (1910-1912)", Letras históricas, n. ${ }^{\circ}$ 2, primavera-verano 2010, pp. 133-153.

Instituto De Cultura HispániCA, Archivo Iberoamericano, Madrid, Instituto de Cultura Hispánica. Departamento de Información, 1963.

Itroiz, Josefina, Trupa, Noelia y VACCA, Laura Celina, "Discutiendo el concepto de cultura", Acta académica de la VI Jornadas de Sociología de la Universidad Nacional de la Plata. [En línea] disponible en: http://www.aacademica.org/000027/749.pdf

IzQuiERdo, Gonzalo, Historia de Chile, tomo III, Santiago, Editorial Andrés Bello, 1990.

Jodelet, Denis y Guerrero, Alfredo, Develando la cultura. Estudios en representaciones sociales, México, Universidad Nacional Autónoma de México, 2000.

JudT, Tony, Cuando los hechos cambian, Barcelona, Taurus, 2015.

Julià I SEguí, Gabriel, Un menorquín para Uruguay: Orestes Araujo, Sicoa, Ciutadella de Menorca, 1993. 
KAPSOli Escudero, Wilfredo, Mariátegui y los congresos obreros, Perú, Biblioteca Amauta, 1980.

KIRCHER, Mirta, "La prensa escrita. Actor social y político, espacio de producción cultural y fuente de información histórica", Revista de Historia, n. ${ }^{\circ}$ 19, 2005, pp. 115-122.

Klaiber S. J., Jeffrey, La Iglesia Católica en el Perú, Lima, Pontificia Universidad Católica del Perú. Fondo Editorial, 1996.

Klaiber, Jeffrey, "Iglesia Católica y poder político en el siglo XX". En MarZaL, Manuel M., Romero, Catalina y SÁnchez, José, La religión en el Perú al filo del milenio, Lima, Fondo Editorial de la Pontificia Universidad Católica del Perú, 2002, pp. 87108.

Klaiber, Jeffrey, La Iglesia en el Perú. Su historia social desde la independencia, Lima, Pontificia Universidad Católica del Perú. Fondo Editorial, 1996.

KRIPPENDORFF, Klaus, Metodología de análisis de contenido. Teoría y práctica, Barcelona, Ediciones Paidós, 1990.

LA UNIÓN PANAMERICANA, La sesión de clausura de la conferencia chileno-peruana, Washington, Imprenta del Gobierno, 1922.

Lagos Carmona, Guillermo, Historia de las Fronteras de Chile. Los tratados de límites con Perú, Santiago, Editorial Andrés Bello, 1981.

Lagos Carmona, Guillermo, Historia de las fronteras de Chile. Los tratados de límites con Argentina, Santiago, Editorial Andrés Bello, 1966.

Landes, David, LinZ, Juan, Tilly, Louise, Tilly, Charles y otros, Las dimensiones del pasado. Estudios de historia cuantitativa, España, Alianza Editorial, 1974.

Langlois, Charles-V. y SeIgnobos, Charles, Introducción a los estudios históricos. En Sevillano Calero, Francisco, Salamanca, Universidad de Alicante, 2003.

LÁzAro, Alberto, H. G. Wells en España: Estudio de los expedientes de censura (19391978), Madrid, Editorial Verbum, 2004.

Lemogodeuc, Jean-Marie, América Hispánica en el siglo XX: identidades, culturas y sociedades, Caracas, Universidad Católica Andrés Bello, 2002.

LETTIERI, Alberto, La civilización en debate. La historia contemporánea desde una mirada latinoamericana, Buenos Aires, Prometeo, 2007. 
Llanos SIERRA, Nelson, El reino chileno del terror: la prensa estadounidense y la controversia de Tacna y Arica, 1925-1926, Estudios hemisféricos y polares, vol. 2, n. ${ }^{\text {o } 2, ~ 2011, ~ p p . ~ 45-69 . ~}$

Lleonart y Amselem, A. J. y CAstiella y Maiz, F. M., España y ONU I (1945-1946). La cuestión española. Documentación básica, sistematizada y anotada, Madrid, Consejo Superior de Investigaciones Científicas, 1978.

LÓPEZ Lita, Rafael, Fernández Beltrán, Francisco y DurÁn MaÑÉs, Ángeles (eds.), La prensa local y la prensa gratuita, Castelló de la Plana, Publicacions de la Universitat Jaume I, 2002.

LÓPeZ MartíneZ, Héctor, El siglo XX en el Perú a través de El Comercio, Lima, Editorial El Comercio, 1994.

LóPez SÁnchez, José María, Heterodoxo Españoles. El Centro de Estudios Históricos, 1910-1936, Madrid, Marcial Pons, Ediciones de Historia, S. A.

LÓPez Urrutia, Carlos, Guerra del Pacífico, Madrid, El Ciprés Editores, 2008.

López UrRutia, Carlos, Historia de la Marina de Chile, Santiago, Editorial Andrés Bello, 1968.

LÓPEZ, Javier, Breve historia cultural de los nacionalismos europeos, Madrid, Catarata, 2013.

LÓPEZ-Álves, Fernando, La formación del Estado y la democracia en América Latina, Bogotá, Editorial Norma, 2003.

Lull, James, Medios, comunicación, cultura. Aproximación global, Buenos Aires, Amorrortu Editores, 2007.

Maldonado, Carlos Eduardo, "Heurística y producción de conocimiento nuevo en la perspectiva CTS”. En HERNÁNDEZ GARCÍA, Iliana (Compiladora), Estética, ciencia y tecnología. Creaciones electrónicas y numéricas, Colombia, Editorial Pontificia Universidad Javeriana, 2005, pp. 101-107.

MARIÁtegui, José Carlos, 7 ensayos de interpretación de la realidad peruana, Caracas, Biblioteca Ayacucho, 1979.

MArín GonzÁlez, Gelu, Atlas de Europa. La Europa de las lenguas, la Europa de las naciones, Madrid, Ediciones Istmo S. A., 2000. 
MARTíNez RiAZA, Ascensión, “«A pesar del gobierno». Españoles en el Perú, 1879-1939”, Madrid, Consejo Superior de Investigaciones Científicas. Instituto de Historia, 2006.

MARTínez RiaZA, Ascensión, “El Perú y España durante el Oncenio. El hispanismo en el discurso oficial y las manifestaciones simbólicas (1919-1930)", Histórica, A. XVIII, 2, 1994b, pp. 335-363.

MARTíneZ RiAZA, Ascensión, "Estado y territorio en Iberoamérica. Conflictos interregionales. Un modelo analítico: la Guerra del Pacífico, 1879-1883”, Revista Complutense de Historia de América, n. ${ }^{\circ}$ 20, 1994, pp. 181-206.

MARTíneZ RiAZA, Ascensión, "Las buenas relaciones de dos regímenes autoritarios. El Perú y España durante el Oncenio (1919-1930)”. En GARcía JordÁn, P., IZARD, M. y Laviña, J. (coords.), Memoria, Creación e Historia: luchar contra el olvido, Barcelona, Publicacions Universitat Barcelona, 1994a, pp. 273-291.

MARTínez RiaZA, Ascensión, "Las relaciones el Perú España 1919-1939. Temas clave y líneas de trabajo". En SEvilla Soler, Rosario, Consolidación republicana en América Latina, Sevilla, Consejo Superior de Investigaciones Científicas, 1999, pp. 201-230.

MARTíneZ RiAZA, Ascensión, "Las relaciones entre el Perú y España 1880-1930”. En UnESCO, Estado de los estudios histórico-sociales sobre el Perú a finales del siglo $X X$, Lima, Lima UNESCO- Universidad de Lima-Fondo de Cultura Económica, 1998, pp. 439-466.

MARTíneZ RiaZA, Ascensión, "Por daños y perjuicios: reclamaciones de españoles en el Perú, siglos XIX y XX”, Anuario de Estudios Americanos, n. ${ }^{\circ}$ 66, enero-junio, 2009, pp. 135-170.

MARTínez RiAzA, Ascensión, En el Perú y al servicio de España. La trayectoria del cónsul Antonio Pinilla Rambaud 1918-1939, Lima, Instituto Riva Agüero, 2008.

MAtuTE, Álvaro, Heurística e historia, México, Centro de Investigaciones Interdisciplinarias en Ciencias y Humanidades, 1999.

MC CAllister, Rick, "Esquizofrenia e imperialismo en Rubén Darío", Revista Cátedra, Universidad de Managua, n. ${ }^{\circ}$ 14, julio-diciembre 2010, pp. 29-38. 
Mc Evoy, Carmen, La utopía republicana. Ideales y realidades en la formación de la cultura política peruana (1871-1919), Lima, Pontificia Universidad Católica del Perú, 1997.

McEvoy, Carmen, "Civilización, masculinidad y superioridad racial: Una aproximación al discurso republicano chileno durante la Guerra del Pacífico (1879-1884)", Revista de Sociología e Política, vol. 20, n. ${ }^{\circ}$ 42, 2012, pp. 73-92.

MCKernan, James, Investigación-acción y currículum. Métodos y recursos para profesionales reflexivos, Madrid, Ediciones Morata S. L, 2001.

Mendiola, Alfonso y ZermeÑo, Guillermo, "Hacia una metodología del discurso histórico". En GALINDO CÁCERES, Luis Jesús (Coordinador), Técnicas de investigación en sociedad, cultura y comunicación, México, Addison Wesley Longman, 1998, pp. 165-206.

Mendoza Rodríguez, Emilio, Los Estados Desunidos de Sudamérica, Valladolid, Talleres Tipográficos Cuesta, 1927.

Ministerio de Relaciones Exteriores de Chile, Cuestión chileno-boliviana, Santiago, La Patria, 1879.

Ministerio de Relaciones Exteriores de Chile, Las Conferencias de Arica, Santiago, Imprenta Nacional, 1880.

Ministerio de Relaciones Exteriores de Chile, Las Conferencias de Washington. Antecedentes reunidos por orden del Ministro de Relaciones Exteriores, don Ernesto Barros Jarpa, Santiago, La Ilustración, 1922.

Ministerio de Relaciones Exteriores del Perú, Circulares diplomáticas, Lima, Imp. Americana, 1919.

Ministerio de Relaciones Exteriores del Perú, En la Cámara de Diputados. El Ministro de Relaciones Exteriores Dr. Alberto Salomón refuta al canciller chileno Sr. Barros Jarpa, Lima, Imp. Torres Aguirre, 1921.

Ministerio de Relaciones EXTERIORES Del Perú, Exposición documentada sobre el estado actual del problema del Pacífico, Perú, Imprenta Torres Aguirre, 1921.

Mirkine-GuetzÉVItch, Boris, Derecho constitucional internacional, Madrid, Editorial Reus S. A., 2009.

Montenegro, Ernesto, La cuestión chileno-peruana, Santiago, La Penitenciaría, 1919.

Moragas, Miquel de, Interpretar la comunicación. Estudios sobre medios en América y Europa, Barcelona, Gedisa S. A., 2011. 
Moral Ruíz, Joaquín del, Historia y ciencias humanas. Sobre metodología y didáctica, Madrid, Huerga y Fierro Editores, S. L., 1999.

Morales PADRÓn, Francisco, Historia de unas relaciones dificiles (EEUU-América Española), Sevilla, Publicaciones de la Universidad de Sevilla, 1987.

Moreno, Amparo, Rovetto, Florencia y Buitrago, Alfonso, ¿De quién hablan las noticias? Guía para humanizar la información, Barcelona, Icaria editorial S. A., 2007.

Moreno, Francisco, "Prólogo. Historia, sociedad y lengua". En BARrigA, Rebeca y Martín, Pedro (Dir.), Historia sociolingüistica de México, Volumen I, México D. F, El Colegio de México, Centro de Estudios Lingüísticos y Literarios, 2010, p. $(\mathrm{s} / \mathrm{d})$

$<$ https://books.google.es/books?id=wXJdCQAAQBAJ\&printsec=frontcover\&dq=hi storia + sociolinguistica + de + M\%C3\%A9xico\&hl=es\&sa=X\&ved=0ahUKEwiH0tb9 79HKAhXCuRQKHdxYCIIQ6AEIJTAB\#v=onepage\&q\&f=false $>$ [consultado el: 15/09/2014].

Morong ReYes, Germán y TÉllez LugARO, Eduardo, "De escrituras globales a proyectos locales: La historiografía nacional en el contexto de la chilenización de Tarapacá”, Universum, Vol. 30, n. ${ }^{\circ}$ 2, 2015, pp. 197-217.

Moscoso, Javier, Historia cultural del dolor, Madrid, Taurus, 2011.

Moscovici, Serge, “Prefacio”. En ArrudA, Ángel y AlbA, María del (Coords.), Espacios imaginarios y representaciones sociales. Aportes desde Latinoamérica, Barcelona, Anthropos, 2007, pp. 7-13.

MotA, Carlos Guilherme y LóPez, Adriana, Historia de Brasil. Una interpretación, Salamanca, Ediciones de la Universidad de Salamanca, 2009.

Moyssén, Xavier, La crítica de arte en México, 1896-1921, Estudios y documentos I (1896-1913), Tomo I, México, Universidad Nacional Autónoma de México. Instituto de Investigaciones Estéticas, 1999.

NANDY, Achis, Imágenes del Estado. Cultura, violencia y desarrollo, México, FCE, 2011.

NAVArRo, Francesc (Director), Historia Universal. Diccionario de términos históricos, España, Editorial Salvat, S. L., 2004.

NousCHI, Marc, Historia del siglo XX. Todos los mundos. El mundo, Madrid, Ediciones Cátedra, S. A., 1996. 
Novak Talavera, Fabián, Las relaciones entre el Perú y Alemania, 1828-2003, Lima, Pontificia Universidad Católica del Perú. Instituto de Estudios Internacionales (IDEI). Fondo Editorial, 2004.

Novak Talavera, Fabián, Las relaciones entre el Perú y Francia (1827-2004), Lima, Fondo Editorial de la Pontificia Universidad Católica del Perú, 2005.

NúÑEZ P., Jorge, 1891. Crónica de la Guerra Civil, Santiago, LOM Ediciones, 2003.

OHANIAN, Pascual C., La cuestión armenia y las relaciones internacionales, tomo V, 1919, Buenos Aires, La Cuchara de Hierro, 2005.

Orrego Luco, Augusto, La cuestión del Pacífico. Tacna y Arica, Santiago, Soc. ImprentaLitografía Barcelona, 1919.

OrRegO, Juan Luis, Lima 1. El corazón de la ciudad, Lima, Santillana S. A. 2013.

OrTega, Julio y RiVERo, Isabel, Diccionario de términos y acontecimientos históricos, Madrid, Ediciones Globo, 2002.

Ortemberg, Pablo, "Geopolítica de los monumentos: los próceres en los centenarios de Argentina, Chile y Perú (1910-1924)”, Anuario de Estudios Americanos, vol. 72, n. ${ }^{\circ} 1,2015$, pp. 321-350.

ORTIZ, Delio, Amazonas abajo; biografía de una infamia, Quito, Editora Quito, 1955.

OsSio SANJINÉS, Luís, Introducción a la teoría de la historia, La Paz, Librería Editorial Juventud, 1981.

Ouimette, Víctor, De patriotismo espiritual. Artículos en "La Nación" de Buenos Aires, 1901-1914, Salamanca, Ediciones Universidad de Salamanca, 1997.

Ovando SAnZ, Guillermo y VÁsquez, Alberto M., Obras completas de Humberto Vásquez Machicado y José Vásquez Machicado, La Paz, Don Bosco, 1988.

Palacios Rodríguez, Raúl, La chilenización de Tacna y Arica, Lima, Editorial Arica, 1974.

Palenzuela, Juan Carlos, Prontuario de la Norteamérica racista, Ediciones Centauro, 1976.

Paniagua Santamaría, Pedro, Información e interpretación en periodismo. Hacia una nueva teoría de los géneros, Barcelona, Carrera Edició, 2009.

Pardo Gómez de Belaúnde, Adela, Arequipa, su pasado, presente y futuro, Lima, Imp. Litográfica del Perú, 1967, p. 139. 
PASAMAR, Gonzalo, "Las «historias de España» a lo largo del siglo XX: las transformaciones de un género clásico”. En GARCÍA CÁRCEL, Ricardo (coord.), La construcción de las historias de España, Madrid, Marcial Pons, Ediciones de Historia S. A., 2004.

Patiño Franco, José Uriel, La Iglesia en América Latina. Una mirada histórica al proceso evangelizador eclesial en el continente de la esperanza. Siglos $X V-X X$, Bogotá, Sociedad San Pablo, 2002.

PAYNE, Stanley G., La primera democracia española. La segunda república, 1931-1936, Barcelona, Ediciones Paidós Ibérica S. A., 1995.

PeAse G. Y., Franklin, Perú. Hombre e Historia. La República. III, Lima, EDUBANCO, 1993.

Peiró Martín, Ignacio y Gonzalo Pasamar, Alzuria, Diccionario Akal de historiadores españoles contemporáneos, Madrid, Ediciones AKAL S. A., 2002.

Peiró Martin, Ignacio y Pasamar Alzuria, Gonzalo, Diccionario Akal de Historiadores españoles contemporáneos, Madrid, Ediciones Akal S. A., 2002.

Peiró MARTin, Ignacio, Historiadores en España. Historia de la historia y memoria de la profesión, Zaragoza, Prensas de la Universidad de Zaragoza, 2013.

Pelosi, Hebe Carmen, Las relaciones franco-argentinas. Inmigración, comercio y cultura. 1880-1918, Argentina, Librería histórica, 2008.

PEÑA Hasbún, Paula, La permanente construcción de lo cruceño: Un estudio sobre la identidad en Santa Cruz de la Sierra, La Paz, Fundación PIEB, 2003.

Pereira CASTAÑARes, Juan Carlos, "España e Iberoamérica: un siglo de relaciones (18361936)", Mélanges de la Casa de Velásquez, tomo 28, n. ${ }^{\circ}$ 3, p. 104.

Pereira-Muro, Género, Nación y Literatura. Emilia Pardo Bazán en la literatura gallega y española, Estados Unidos, Purdue University Press, 2013.

Pereyra Plasencia, Hugo, "La negociación diplomática del Tratado de Ancón", Histórica, XXXIX.2, 2015, pp. 153-170.

PÉREZ CANTO, Julio, El conflicto después de la victoria, Recuerdo e impresiones de un exdiplomático chileno en el Perú. La última discusión del problema de Tacna y Arica, Santiago, Edición de la empresa Zig-Zag, 1918. 
PÉREZ RoldÁn, Carmen, "La prensa republicana madrileña durante el siglo XIX: La Igualdad y El Combate como ejemplos de periódicos republicanos", Historia y Comunicación Social, n. ${ }^{\circ}$ 4, 1999, pp. 317-339.

PÉREZ SERRANO, Gloria, Investigación cualitativa. Retos e investigaciones. II Técnicas y análisis de datos, Madrid, Editorial La Muralla, S. A., 1994.

Pericacho Gómez, Francisco Javier, "Pasado y presente de la renovación pedagógica en España (de finales del Siglo XIX a nuestros días). Un recorrido a través de escuelas emblemáticas", Revista Complutense de Educación, vol. 25, n. 1, 2014, pp. 47-67.

PERTIERRA DE ROJAS, José Fernando, Las relaciones internacionales durante el periodo de entreguerras, Madrid, Ediciones Akal S. A., 1990.

PESCE, Fernando, "Sentidos políticos, finalidades formativas y enfoques disciplinares en la Geografía como materia escolar en la Enseñanza Secundaria uruguaya. (19351963)", Tesis doctoral, pp. 77-84, Disponible en:

http://repositorio.flacsoandes.edu.ec/bitstream/10469/6660/2/TFLACSO-

2014LFPG.pdf [consultado el: 25/12/2015].

Petras, James y VeltMeyer, Henry, Imperio con imperialismo: la dinámica globalizante del capitalismo neoliberal, México, Siglo XXI, 2006.

Pierrotti, Nelson, "La educación colonial en Montevideo y la banda oriental ¿Quién enseñaba, cómo y para qué? (1726-1814)”, Estudios Históricos, n. ${ }^{\circ}$ 14, 2015, < http://www.estudioshistoricos.org/14/eh1403.pdf> [consultado el: 25/12/2015];

PINTO V., Julio y VALDIVIA O., Verónica, ¿Revolución proletaria o querida chusma? Socialismo y Alessandrismo en la pugna por la politización pampina (1911-1932), Santiago, LOM Ediciones, 2001.

PinTos, Francisco, Historia del movimiento obrero del Uruguay, Uruguay, Corporación Gráfica, 1960.

PiZARro, Elías y Soto, José, "Explotación colonial de recursos naturales prehispánicos: el caso del huano de covaderas en el extremo norte de Chile (s. XVI-XVII)". En LEAL, Cristian, CÁCERES, Juan y TOBAR, Leopoldo (Eds.), Lecturas y (re)lecturas en historia colonial II, Chile, Universidad del Bío-Bío, Pontifica Universidad Católica de Valparaíso, Universidad Católica Silva Henríquez, 2014, pp. 239-256.

Pizarroso, Alejandro, Historia de la prensa, Madrid, Centro de Estudios Ramón Areces, 1994.

Pomian, K. Sobre la historia, Madrid, Cátedra, 1999. 
POnS, Anaclet y SERnA, Justo, "Variaciones sobre la historia cultural en España". En Philip Poirrier, La historia cultural ¿Un giro historiográfico mundial?, Valencia, Publicaciones de la Universitat de Valencia, 2012, pp. 187-199.

Porras Barrenechea, Raúl, Historia de los límites del Perú: texto dictado a los alumnos del Colegio Anglo-Peruano de Lima, conforme al programa oficial, Perú, Librería francesa científica y casa editorial E. Rosay, F. y E. Rosay, 1930.

Portal EsPinOSA, Ismael, Chile ante el árbitro: su conducta desde 1820, Perú, Librería e Imprenta Gil, 1924.

PotTER, Jonathan, La representación de la realidad: discurso, retórica y construcción social, Barcelona: PAIDÓS, 1998.

PRIORA, Juan Carlos, "La arqueología como ciencia que confiere veracidad a un documento histórico". En Galleti, Amelia, Hablemos de historia. Cuestiones teóricas y metodológicas de la historia, Paraná, Editorial de Entre Ríos, 2006, pp. 83-94.

Puiggrós, Rodolfo, El Yrigoyenismo, Buenos Aires, Galerna, 2006.

QUiNTERO L., Gilberto R., "Los fundamentos de la historia como disciplina científica”. En LÓPEZ BOHÓRQUEZ, Alí Enrique (Coordinador), En búsqueda de la historia. Memorias de las Iras Jornadas de Investigación de Escuela de Historia. Homenaje al Dr. Eduardo Arcila Farías, Venezuela, Consejo de Publicaciones de la Universidad de los Andes, 1998, pp. 59-64.

Quiroz, Alfonso W., Corrupt Circles. A History of unbound graft in Peru, Washington D. C., The Johns Hopkins University Press, 2008.

Quiroz, Alfonso W., Historia de la corrupción en el Perú, Lima, IEP Instituto de Estudios Peruanos, 2013.

Ragas Rojas, José F., "Las urnas temibles. Elecciones, miedo y control en el Perú republicano, 1810-1931". En Rosas LaUro, Claudia (Ed.), El miedo en el Perú. Siglos XVI al XX, Perú, Fondo Editorial de la Pontificia Universidad Católica del Perú, 2005.

RAMíREZ, Mario Teodoro, De la razón a la praxis. Vías hermenéuticas, Morelia, Siglo XXI Editores, 2003.

Ramos NúÑEZ, Carlos, Historia del derecho civil peruano. Siglos XIX y XX, Tomo V, Los signos del cambio, vol. 2, Las instituciones, Lima, Pontificia Universidad Católica del Perú. Fondo Editorial, 2006. 
Ramos Santana, Alberto, "La vida cotidiana en el Cádiz de las Cortes. El recurso a la prensa como fuente para su estudio". En CANTOS CASENAVE, Marieta, DuRÁN LóPeZ, Fernando, Romero Ferrero, Alberto (Eds.), La Guerra de pluma. Estudios sobre la prensa de Cádiz en el tiempo de las cortes (1810-1814). Tomo III. Sociedad, consumo y vida cotidiana, España, Universidad de Cádiz-Servicio de Publicaciones, 2008, pp. 21-102.

Ramos, Julio, Desencuentros de la modernidad en América Latina. Literatura y política en el siglo XIX, Santiago, Editorial Cuarto Propio, 2003.

RAYMONT, Henry, Vecinos en conflicto. La historia de las relaciones entre Estados Unidos y Latinoamérica desde Franklin Delano Roosevelt hasta nuestros días, México, Siglo XXI, 2007.

Real Academia de la Historia, II Congreso de Academias Iberoamericanas de la Historia. Factores de diferenciación e instancias integradoras en la experiencia del mundo iberoamericano. Actas, Madrid, Taravilla, 1994, pp. 95-104.

REALI, María Laura, "El conflicto regional visto desde Uruguay y la construcción de un relato revisionista". En CRESPO, Horacio, PALACIO, Juan Manuel y PALACIOS, Guillermo (Coordinadores), La guerra del Paraguay. Historiografías. Representaciones. Contextos, México, El Colegio de México, 2013, edición electrónica sin número de página.

REICHARDT, Charles y COOK, Thomas, "Hacia una superación del enfrentamiento entre los métodos cuantitativos y cualitativos". En CoOK, T. D. y REICHARDT, Ch. S., Métodos cualitativos y cuantitativos en investigación evaluativa, Madrid, Ediciones Morata, S. L., 2005, pp. 25-58.

RÉNIQue, José Luis, "De literati a socialista: el caso de Juan Croniqueur". En FloreS EsPinOzA, Javier y VARÓN GABAI, Rafael, El hombre y los Andes. Homenaje a Franklin Pease G. Y., Tomo I, Perú, Fondo Editorial de la Pontificia Universidad Católica del Perú, 2002.

RenOuvin, Pierre, La crisis europea y la I a Guerra Mundial (1904-1918), Madrid, Ediciones Akal S. A., 1990.

República de Bolivia, Conferencias diplomáticas de Arica entre los plenipotenciarios de Bolivia, Chile y el Perú con motivo de la mediación de Estados Unidos, La Paz, Imprenta de la Unión Americana, 1880, p. 3.

RePÚBliCA DE ChILE, Vocación de paz: La política exterior de Chile, Chile, Dirección Nacional de Fronteras y Límites del Estado, 2016. 
República de Chile, Censo de población de la República de Chile. Levantado el 15 de diciembre de 1920, Santiago, Soc., Imp. y Litografía Universo, 1925.

RepúblicA De Chile, Memoria que el Ministro de Estado en el Departamento de Relaciones Exteriores presenta al congreso nacional de 1862, Santiago, Imprenta Nacional, 1862.

RePÚBlica del Perú, Memoria del Gobierno del Perú. Controversia Marítima (Perúv. Chile). Volumen I. (Traducción no oficial), 2009. [En línea], disponible en: http://www.rree.gob.pe/noticias/Documents/Memoria\%20del\%20Gobierno\%20del $\% 20$ Per\%C3\%BA.pdf.

República de Perú. Arbitraje entre el Perú y Chile: réplica del Perú en el litigio que, emanado de la Cuestión del Pacifico, se sigue ante el presidente de los Estados Unidos de América como Árbitro, Perú, Editorial T. Scheuch, 1924.

República del Perú, Arbitraje entre el Perú y Chile. Réplica del Perú en el litigio que, emanado de la cuestión del Pacífico, se sigue ante el Presidente de los Estados Unidos de América como Árbitro, Washington D. C., [s. d.], 1924.

RepúBliCA Del Perú, El arbitraje de Tacna y Arica. Actas de la Comisión Plebiscitaria, Lima, Imprenta Torres Aguirre, 1928.

República del Perú, En la Cámara de Diputados. El Ministro de Relaciones Exteriores Dr. Alberto Salomón refuta al canciller chileno Sr. Barros Jarpa, Lima, Imp. Torres Aguirre, 1921.

Requeijo Rey, Paula, Sanz GonzÁlez, Carlos y Valle, Carlos del, "Propaganda norteamericana en la Primera Guerra Mundial: simplificación y deformación a través del cartel", Historia y comunicación social, vol. 18, 2013, pp. 31-42.

Revista Claridad, 1921, Santiago de Chile, Vol. I, n. ${ }^{\circ}$ 33, s/p.

RICOUER, Paul, Historia y Verdad, Madrid, Encuentro, 1990.

Ríos Gallardo, Conrado, Chile y Bolivia definen sus fronteras. 1842-1904, Santiago, Editorial Andrés Bello, 1963.

RIU, Manuel, La alta edad media. Del siglo V al siglo XII, España, Montesinos Editor, 1989.

Riva-AgüERo, José de la, Estudios de historia peruana. La emancipación y la república. VII, Lima, Pontificia Universidad Católica del Perú, 1971. 
RIVAS, Fernando, "La prensa escrita como documento histórico: cuidado, prevenciones y consideraciones", En SANTANDER Molina, Pedro (Editor), Analizando los medios y la comunicación. Teoría y métodos, Chile, Pontificia Universidad Católica de Valparaíso, 2009, pp. 51-64.

Robles MendozA, Román, Legislación peruana sobre comunidades campesinas, Lima, Fondo Editorial de la Facultad de Ciencias Sociales Universidad Nacional Mayor de San Marcos, 2002.

Robles MuÑoz, Cristóbal, 1898: Diplomacia y opinión, Madrid, Consejo Superior de Investigaciones Científicas, 1991.

RodríGuez Murillo, Marco Antonio, "Modernismo y sociedad en la obra poética de Rubén Darío", Temas antropológicos, Revista científica de investigaciones regionales, vol. 35, n. ${ }^{\circ}$ 1, 2012-2013, Universidad Autónoma de Yucatán, pp. 81107.

RoJAS, Rolando, "La guerra inacabable. Itinerario de los problemas sin resolver que dejó la Guerra del Pacífico", Revista Argumentos, n. ${ }^{\circ} 3,2013$, pp. 24-29.

RomÁn, Mercedes, "Aspectos metodológicos de la historia de la comunicación". Latina. Revista Latina de comunicación social, n. ${ }^{0}$ 43, 2001, $<$ http://www.ull.es/publicaciones/latina/2001/latina43julio/38roman.htm> [consultado el: 12/07/2015].

Romo Feito, Fernando, "Escucho con mis ojos a los muertos". La odisea de la interpretación literaria, Madrid, Consejo Superior de Investigaciones Científicas. Instituto de Lengua, Literatura, Antropología, 2008.

Ross EDWARDS, Agustín, Tacna y Arica. La solución del problema mediante su transferencia a Bolivia, La Paz, Litografía e imprenta Moderna, 1918.

Rossi, Annunziata, Fascismo en Europa, México, Universidad Nacional Autónoma de México, 2006.

RoszaK, Theodore, iAlerta Mundo! El nuevo imperialismo norteamericano, Barcelona, Editorial Kairós, S. A., 2004.

RUbÉn DARÍo, Antología poética, Madrid: Editorial EDAF, S. L., 1998.

Rubilar Luengo, Mauricio E., La política exterior de Chile durante la guerra y postguerra del Pacífico (1879-1891): Las relaciones con Estados Unidos y Colombia. Diplomacia, opinión pública y poder naval. Tesis para optar al grado de doctor en Europa y el Mundo Atlántico: poder, cultura y sociedad, Valladolid, Universidad de Valladolid, 2012. [Inédita]. 
Ruiz Zevallos, Augusto, La multitud, las subsistencias y el trabajo, Lima, 1890-1920, Lima, Fondo Editorial de la Pontificia Universidad Católica del Perú, 2001.

RuIZ, Nicolás, "La prensa nacionalista en Vizcaya durante la Restauración: el espejo de una comunidad en construcción”, El Argonauta español, n. ${ }^{\circ}$ 5, 2008, pp. 1-14.

Ruiz-Tagle Orrego, Emilio, Bolivia y Chile. El conflicto del Pacifico, Santiago, Editorial Andrés Bello, 1992.

Ruiz-Tagle Orrego, Emilio, Bolivia y Chile: el conflicto del Pacifico, Santiago, Editorial Andrés Bello, 1992.

SOCIEDAD URUGUAYA DE HISTORIA DE LA EDUCACIÓn, "Breve reseña de la creación de la SUHE (Sociedad Uruguaya de Historia de la Educación)", Historia de la Educación. Anuario, vol. 11, 2010, < http://www.scielo.org.ar/scielo.php?script=sci_arttext\&pid=S231392772010000100022> [consultado el: 25/12/2015]

SÁEZ y Romero, Mariano, Las calles de Segovia, Valladolid, Editorial MAXTOR, 2009.

SÁIZ, María Dolores, "La prensa madrileña en torno a 1898", Historia y Comunicación Social, n. ${ }^{\circ}$ 3, 1998, pp. 195-200.

SALAS, Nicolás, Sevilla, Anales del siglo XX, tomo I, Sevilla, Editorial Castillejo, 1999.

Salazar Vergara, Gabriel, Mercaderes, empresarios y capitalistas (Chile, siglo XIX), Santiago, Editorial Sudamericana, 2009.

SAlCeda Olivares, Juan Manuel, "México y la V conferencia panamericana: un campo de batalla diplomática contra el intervencionismo norteamericano", Tzintzun, n. ${ }^{\circ}$ 50, 2009, pp. 61-104.

SAlgado Brocal, Juan C. y IzURIETA FERRER, Oscar, Las relaciones bilaterales chilenoperuanas contemporáneas: un enfoque realista, Santiago, Biblioteca Militar, 1992.

Salinas, Raquel, Agencias transnacionales de información y el Tercer Mundo, Ecuador, Quito Times, 1984. LóPez Valle, Diana, Zamorano Silva, Osvaldo, Periodismo libre en patrias libres, Checoslovaquia, Federación Latinoamericana de Periodistas, 1985.

SÁnCHEZ ARANDA, José J., "Las dificultades de informar en tiempos de guerra. La prensa española durante la I Guerra Mundial", Communication \& Society, vol. 6 (1 y 2), 1993, pp. 173-187. 
Sánchez D., Rubén, Ruiz V., Juan Carlos, Lavaux, Stéphanie, Ramos P., Francesca, Bonnet L., Manuel José, Pachón P., Rocío, Rodríguez M., Federmán, Otalvaro H., Andrés, Duarte P., Ivonne, Machuca P., Rubén, SuÁrez I., Carlos, Seguridades en construcción en América Latina, Tomo 1: El círculo de Colombia, Brasil, Ecuador, Panamá, Perú y Venezuela, Bogotá, Centro Editorial Universidad del Rosario, 2005.

SÁnchez de Madariaga, Elena, Conceptos fundamentales de Historia, Madrid, Alianza Editorial, 2007.

SÁnchez GarcíA, Francisco José, Pragmática de los titulares políticos. Las estrategias implícitas de persuasión ideológica, Madrid, Visor Libros S. L., 2010.

SÁnChEz GómEz, Gonzalo, "El acto social de investigar". En TORRES CARRILlO, Alfonso y JIMÉNEZ BECERRA, Absalón, (Compiladores), La práctica investigativa en ciencias sociales, Bogotá, Universidad Nacional Pedagógica, 2006, pp. 154-158.

SÁNCHEZ GómEZ, Julio, Hermana mayor o enemiga. Latinoamérica frente a Estados Unidos en el cambio de siglo (1898-1906). En EsteBAn DE VEGA, Mariano, LuiS Martín, Francisco de, Morales Moya, Antonio, Jirones de Hispanidad: España, Cuba, Puerto Rico y Filipinas en la perspectiva de dos cambios de siglo, Salamanca, Universidad de Salamanca, 2004, pp. 173-215.

SANSÓn CORBO, Tomás David, "La contribución de intelectuales extranjeros en la configuración de la historiografía uruguaya”, Revista Expedições. Teoría de História \& Historiografía, vol. 5, n. ${ }^{\circ}$ 1, 2014.

SANTivÁÑEZ, José María, Bolivia i Chile. Cuestión de límites, Cochabamba, Imprenta del Siglo, 1863.

SANTORO, Mara, "La democracia incipiente. El radicalismo en el gobierno (1916-1930): Yrigoyen, Alvear, Yrigoyen”. En Barroetaveña, Mariano, PARson, Guillermo, Román, Viviana, Rosal, Hernán, SANTORO, Mara, Ideas, política, economía y sociedad en la Argentina (1880-1955), Buenos Aires, Biblos, 2007.

SAntos, Granero y BARClay, Federica, La frontera domesticada. Historia económica y social de Loreto, 1850-2000, Fondo Editorial de la Pontificia Universidad Católica del Perú, 2002.

SANZANA InSUNZA, Isaac, "Consideraciones sobre el cosmopolitismo en Rubén Darío", Revista Borradores, Vol. X-XI, año 2009-2010, Universidad Nacional de Río Cuarto, pp. 1-10. 
SchAEFER, Fred K., Excepcionalismo en geografia, Barcelona, Publicacions de la Universitat de Barcelona, 1988.

Schiffman, Leon G. y KanuK, Leslie Lazar, Comportamiento del consumidor, México, Pearson Educación, 2005.

SCHUlze SCHNEIDER, Ingrid, "Los medios de comunicación en la Gran Guerra, Todo por la Patria”, Historia y comunicación social, vol. 18, 2013, pp. 15-30.

SElSER, Gregorio, Cronología de las intervenciones extranjeras en América Latina: 18991945, Tomo III, México, Centro de Investigaciones Interdisciplinarias en Ciencias y Humanidades, Universidad Nacional Autónoma de México, 2001.

SEOANE, María Cruz, Historia del periodismo en España, 2. El siglo XIX, Madrid, Alianza Editorial, 1996.

SEPÚlVEdA MuÑoz, Isidro, "Diplomáticos y cónsules españoles en América, 1892-1936", Espacio, Tiempo y Forma, tomo V, 1992, pp. 397-412.

SepúlvedA, Isidro, El sueño de la Madre Patria. Hispanoamericanismo y nacionalismo, Madrid, Marcial Pons, Ediciones de Historia S. A., 2005.

SERnA, Justo y Pons, Anaclet, La historia cultural. Autores, obras y lugares, Madrid, Ediciones Akal S. A., 2005.

Serrano García, Juan B., El inversor tranquilo, Madrid, Díaz de Santos, 2013.

Silva G., Osvaldo, Atlas de Historia de Chile, Santiago, Editorial Universitaria, 2005.

Silva-SANTiSTEBAN, Ricardo, "La sátira en los cuentos chinos de Abraham Valdelomar". En ÁGuILA, Yves (Comp.), Figuras, géneros y estrategias del humor en España y en América Latina, Bordeaux, Presses Universitaires de Bordeaux, 2007, pp. 93104.

SiLverstone, Roger, ¿Por qué estudiar los medios? Buenos Aires, Talleres gráficos EFE, 2004.

SIN AUTOR, Colección de historiadores de Chile y documentos relativos a la historia nacional. Tomo I. Cartas de Pedro de Valdivia al Emperador Carlos V, Santiago, Imprenta de El Ferrocarril, 1861.

SMITH, Anthony, “¿Gastronomía o geología? El rol del nacionalismo en la reconstrucción de las naciones”. En Fernández Bravo, Álvaro (Comp.), La invención de la nación. Lectura de la identidad de Herder a Homi Bhabha, Buenos Aires, Manantial, 2000, pp. 185-210. 
SMiTH, Anthony, Nacionalismo y modernidad, España, Istmo, 2000.

Smith, Anthony D., Nacionalismo. Teoría, ideología, historia, Madrid, Alianza Editorial, 2001 .

SoHr, Raúl, Historia y poder de la prensa, Santiago, Editorial Andrés Bello, 1998.

SOlAR, David, "Una guerra por encima de las posibilidades españolas", Historia y comunicación social, n. ${ }^{\circ}$ 3, 1998, pp. 239-259.

Soliz V., Edgar, Bolivia, subdesarrollo económico y poder político en el marco de la independencia post-colonial, La Paz, Universidad Mayor de San Andrés, 1980.

Soriano Llobera, Juan M., Prensa económica ¿Ángel o demonio? De la democracia a la actualidad, Huelva, Servicio de publicaciones Fundación para la Investigación Juan Manuel Flores Jimeno, 2012.

Soto LARA, José Julián, "Cara y cruz en la militarización de la nueva frontera norte de Chile: el caso de Arica en el inicio del siglo XX", Actas del I Congreso Internacional de Historia Militar, Madrid, UNED, 2014, pp. 13-44.

Soto LARA, José Julián, "El arbitraje de España de 1898 en la cuestión de Tacna y Arica: estado del arte y perspectivas heurísticas, Realidades y perspectivas de jóvenes investigadores. Nuevas fronteras de investigación. Actas Coloquios EChF, n. ${ }^{0}$ 7, París, Ediciones EChF, 2015, pp. 145-172.

Soto LaRA, José Julián, "El conflicto de Tacna y Arica entre Chile y Perú: La visión de la prensa española (1880-1929)". En Hernández RodrígueZ, Paula, HernándeZ SÁnchez, Gustavo, Juanes Cortés, Antonio, Píriz GonzÁlez, Carlos, PovedA ARIAS, Pablo, RodríGUez Escobar, Moisés, Las violencias y la historia. Colección temas y perspectivas de la historia, n. ${ }^{\circ}$, Salamanca, Ergar Ediciones Antema, 2016, pp. 145-165.

Soto LARA, José Julián, "La Federación Obrera de Chile (FOCH) como movimiento popular nacionalista en Arica (1920)", Tradición y Saber, n. . 2, 2013, pp. 65-84.

Soto LARA, José Julián, “La guerra y posguerra del Pacífico en la prensa de España: Desde las Conferencias de Arica hasta el arbitraje de la Reina María Cristina (18801901)”. En Giménez Chornet, Vicent y Colomer Viadel, Antonio, I Congreso Internacional América-Europa, Europa-América, Valencia, Editorial Universitat Politècnica de Valéncia, 2015, pp. 249-270.

Soto LARA, José Julián, "La prensa española como fuente histórica para el problema de Tacna y Arica (1880-1901): heurística y método", TRIM Tordesillas Revista de Investigación Multidisciplinar, n. ${ }^{\circ}$ 7, 2014, pp. 25-42. 
SoTO LARA, José Julián, "La prensa española como fuente histórica para el problema de Tacna y Arica (1880-1901): heurística y método", Tordesillas Revista de Investigación Multidisciplinar, n. ${ }^{\circ}$ 7, 2014, pp. 25-42.

Soto LARA, José Julián, La cruz de alquitrán: historia de la vida cotidiana y de la sociabilidad entre chilenos y peruanos en Arica (1920-1929), tesis para optar al grado de magíster en historia, Santiago, Universidad de Chile, 2014. [Inédita].

Stuven, Ana María, Chile disperso. El país en fragmentos, Santiago, Editorial Cuarto Propio, 2007.

TABANERA García, Nuria, "Una crisis nacional en la distancia. El 98 español visto desde Argentina”. En Saz Campos, Ismael, y Archilés i Cardona, Ferran, Estudios sobre nacionalismo y nación en la España Contemporánea, Zaragoza, Prensa Universitarias de Zaragoza, 2011.

Tauzin Castellanos, Isabelle, "Manuel González Prada y el poder político (1912-1918)". En ÁGuila, Yves, Poder y escrituras en América Latina, vol. 2, Bordeaux, Presses Universitaires de Bordeaux, 2004.

TÉLlez L. Eduardo, Historia general de la frontera de Chile con Perú y Bolivia, 1825 1929, Santiago, Universidad de Santiago de Chile, 1989.

TÉLlez, Carlos, La cuestión de Tacna y Arica, Perú, Editorial Cervantes, 1925, p. 213.

THINÈs, Georges y Lempereur, Agnès, Diccionario general de Ciencias Humanas, Madrid, Ediciones Cátedra, S. A., 1978.

Todorov, Tzvetan, La conquista de América. El problema del otro, México D. F., Siglo XXI Editores.

Torres, José Antonio, Solución de la cuestión de límites entre Chile i Bolivia, Santiago, Imprenta del Ferrocarril, 1863.

Trelles, Manuel Ricardo, Cuestión de límites entre la república Argentina y Bolivia, Buenos Aires, Imprenta del Porvenir, 1872.

Tunnermann Berheim, Carlos, "El pensamiento político de Rubén Darío", UPOLI CIELAC, Documento de trabajo, n. ${ }^{\circ}$ 3. [En línea] disponible en: http://biblioteca.clacso.edu.ar/Nicaragua/cielac-upoli/20100709040155/C4.pdf

TuSEll, Javier y GARCía QueIPO DE LlANO, Genoveva, El dictador y el mediador. España y Gran Bretaña, 1923-1930, Madrid, C.S.I.C. Centro de estudios históricos, 1986. 
UgAlde, Luis, El Gomecismo y la política panamericana de Estados Unidos, Caracas, Universidad Católica Andrés Bello, 2005.

UlloA, Alberto. El fallo arbitral del Presidente de Estados Unidos de América en la cuestión de Tacna y Arica, Perú, Seminario y Cía., 1925.

UnAmuno, Miguel de, Epistolario inédito 2, 1915-1936, Madrid, Espasa Calpe, 1991.

United States. President (1923-1929: Coolidge), Tacna-Arica: fallo arbitral, Chile, Imprenta Chile, 1925, s/p.

Universidad Central del Ecuador, Anales de la Universidad Central del Ecuador, Quito, Imp. de la Universidad Central, 1933.

VAN DiJk, Teun, Discurso y poder, Barcelona, Editorial Gedisa S. A., 2009.

VAN DiJK, Teun, Ideología y discurso. Una introducción multidisciplinaria, Barcelona, Editorial Ariel S. A., $2^{\mathrm{a}}$ edición, 2008.

Vargas Ugarte, Rubén, Historia General del Perú, Barcelona, Carlos Milla Batres, 1984.

Velasco GómeZ, Ambrosio, "Introducción: perspectivas y horizontes de la heurística en las ciencias y las humanidades". En Velasco Gómez, Ambrosio (Coord.), El concepto de heurística en las ciencias y las humanidades, México, Siglo XXI Editores, 2000, pp. 1-12.

VÉLEZ, Palmira, La historiografia americanista en España, 1755-1936, Madrid-Frankfurt, Iberoamericana-Vervuert, 2007.

Vera Noriega, José Ángel, Rodríguez Carvajal, Claudia Karina y Grubits, Sonia, "La psicología social y el concepto de cultura", Psicología \& Sociedade, volumen 21, n. ${ }^{\circ} 1,2009$, pp. 100-107.

Vial Correa, Gonzalo, Agustín Edwards Mac Clure: periodista, diplomático y político: los cuarenta primeros años del siglo XX chileno, Santiago, El Mercurio, 2009.

VIal Solar, Javier, "Reminiscencias diplomáticas", La Revista Nueva, tomo II, 1900, p. 383, pp. 376-390.

Vicuña Mackenna, Benjamín, Historia de la campaña de Tacna y Arica, 1879-1880, Santiago, Rafael Jove Editor, 1881.

Vicuña Mackenna, Benjamín, La revolución de la Independencia del Perú. Desde 1809 a 1819, Lima, Imprenta del Comercio por J. M. Monterola, 1860. 
VICUÑA, Carlos, La libertad de opinar y el problema de Tacna y Arica, Santiago, Imprenta, Litografía y Encuadernación Selecta, 1921.

VIEIRA PoSADA, Edgar, La formación de espacios regionales en la integración de América Latina, Bogotá, Convenio Andrés Bello, 2008.

Villalobos R., Sergio, Chile y Perú. La historia que nos une y nos separa (1535-1883), Santiago, Editorial Universitaria, 2002.

Villares, Ramón y BAHAMONDE, Ángel, El mundo contemporáneo del siglo XIX al XX, [edición digital].

Villegas Torres, Fernando, "Vínculos artísticos entre España y Perú (1892-1929): Elementos para la construcción del imaginario peruano", Memoria presentada para optar al grado de Doctor, Madrid, Universidad Complutense de Madrid, Facultad de Geografía e Historia, Departamento de Historia del Arte III, 2013.

Villegas Torres, Fernando, El Perú a través de la pintura y crítica de Teófilo Castillo (1857-1922): nacionalismo, modernización y nostalgia en la Lima del 900, Lima, ANR, 2006.

VIÑAO, Antonio, "Historia de la educación e historia cultural: posibilidades, problemas, cuestiones". Revista de Educación, n. ${ }^{\circ}$ 306, 1995, pp. 245-269.

WAGNER, Wolfgang y HAYES, Nicky, El discurso de lo cotidiano y el sentido común. La teoria de las representaciones sociales, Barcelona, Anthropos Editorial, 2011.

WeBER, David, Bárbaros. Los españoles y sus salvajes en la era de la Ilustración, Barcelona, Editorial Crítica, 2007.

WERNER, Florian, La materia oscura: historia cultural de la mierda, Barcelona, Tusquets, 2013.

WIEsse, Carlos, El asunto de Tacna y Arica, Lima, Emp. Tip. Lártiga, 1917, p. 32.

WiEsse, Carlos, Resumen de historia del Perú, Perú, Librería francesa científica Galland, 1908.

YANES, Julio, Metodología de la historia de la comunicación social en Canarias. La prensa y las fuentes hemerográficas, Tenerife, Ediciones de baile de Sol, 2005.

YÁÑEZ ANDRADE, Juan Carlos, La intervención social en Chile (1907-1932), Santiago, RIL Editores, 2008.

YARLEQUÉ, Manuel, Artículos internacionales sobre Tarapacá, Tacna y Arica, Lima, Imp. y Librería de San Pedro, 1917. 
Zallo, Ramón, Estructuras de la comunicación y cultura. Políticas para la era digital, Barcelona, Editorial Gedisa S. A., 2011.

ZÁrate LezCAno, José, Perú y Brasil: relaciones y límites, antecedentes históricos de la Amazonía, Lima, Ministerio de Guerra, Servicio de Prensa, Propaganda y Publicaciones Militares, 1957.

ZIMMERMANN, Eduardo, "Transformaciones del Estado". En AyAla MorA, Enrique (Director) y POSADA CARBÓ, Eduardo (Coordinador), Los proyectos nacionales latinoamericanos: sus instrumentos y articulación, 1870-1930, España, Ediciones UNESCO, 2008.

ZuleTA, Ignacio, La polémica modernista: el modernismo de mar a mar, 1898-1907, Bogotá, Instituto Caro y Cuervo, 1988. 



\section{ÍNDICE DE IMÁGENES, GRÁFICOS Y TABLAS}

Imágenes

Imagen n. ${ }^{\circ}$ 1: Perú.- Vista de Arica, Plaza fuerte sobre la costa.

Imagen n. ${ }^{\circ}$ 2: La corbeta «Unión» fuerza el bloqueo del puerto, el 17 de marzo último

Imagen n. ${ }^{\circ}$ 3: Mapa de una parte de la República boliviana

Imagen n. ${ }^{\circ}$ 4: El general Campero

Imagen n. ${ }^{\circ}$ 5: El general D. Hilarión Daza

Imagen n. ${ }^{\circ}$ 6: El coronel D. Nicolás de Piérola

Imagen n. ${ }^{\circ}$ 7: El general D. Mariano I. Prado

Imagen n. ${ }^{\circ}$ 8: Arica (Perú). Combate sostenido el 27 de febrero, por el monitor peruano «Manco Capac» contra los buques chilenos «Huáscar»y «Magallanes»

Imagen n. ${ }^{\circ}$ 9: Don Manuel Thompson, comandante del monitor chileno Huáscar

Imagen n. ${ }^{\circ}$ 10: D. Manuel Baquedano 155

Imagen n. ${ }^{\circ}$ 11: D. Orestes Araujo 166

$\begin{array}{ll}\text { Imagen n. } & \text { 12: Emilio Castelar } \\ & 173\end{array}$

Imagen n. ${ }^{\circ}$ 13: Excmo. Señor D. Cristino Martos 173

$\begin{array}{ll}\text { Imagen n. } & { }^{\circ} \text { 14: Monroe } \\ & 173\end{array}$

Imagen n. ${ }^{\circ}$ 15: Vista panorámica de la bahía y puerto de Arica al embarcarse la tercera expedición chilena el 15 de diciembre

Imagen n. $^{\circ}$ 16: Soldados peruanos, bolivianos y chilenos 180

Imagen n. ${ }^{\circ}$ 17: Callao de Lima. Evacuación de la ciudad por los súbditos extranjeros, a la aproximación de la escuadra chilena

Imagen . $^{\circ}$ 18: Un vivac chileno cerca de Chorrillos, después de la batalla librada el 13 de enero último 
Imagen n..$^{\circ}$ 20: Vista general de Lima desde el Fuerte de San Cristóbal, ocupado por las tropas chilenas el 18 de enero último

Imagen n. ${ }^{\circ}$ 21: D. Francisco García Calderón 186

Imagen n. ${ }^{\circ}$ 22: Santiago de Chile. Interior del Senado Nacional 192

Imagen n. ${ }^{\circ}$ 23: S. M. la Reina Regente de España 199

Imagen n. ${ }^{\circ}$ 24: Las Cortes actuales (Mateo Sagasta) 201

Imagen n. ${ }^{\circ}$ 25: Excmo. Sr. D. Eduardo L. de Romaña 213

Imagen n. ${ }^{\circ}$ 26: Recepción celebrada en el Palacio Real en honor de los congresistas 217

Imagen n. ${ }^{\circ}$ 27: Preparación para la celebración del Congreso HispanoAmericano

Imagen n. ${ }^{\circ}$ 28: Los congresistas en la presidencia del Congreso de Ministros 217

Imagen n. ${ }^{\circ}$ 29: La Conferencia internacional americana de México 220

Imagen n. ${ }^{\circ}$ 30: La República de Chile 222

Imagen n. ${ }^{\circ}$ 31: La República de Chile 222

Imagen n. ${ }^{\circ}$ 32: Raza chilena 222

Imagen n. ${ }^{\circ} 33$ : Indio chileno 222

Imagen n. ${ }^{\circ}$ 34: Mujer indígena araucana $\quad 222$

Imagen n. ${ }^{\circ}$ 35: Chile y España 223

$\begin{array}{ll}\text { Imagen n. }{ }^{\circ} \text { 36: Agustín Querol } & 228\end{array}$

Imagen n. ${ }^{\circ}$ 37: Agustín Querol.- Monumento a Bolognesi 233

Imagen n. ${ }^{\circ}$ 38: D. Ricardo Beltrán y Rózpide 243

Imagen n. ${ }^{\circ}$ 39: El canal interoceánico 261

Imagen n. ${ }^{\circ}$ 40: Excelentísimo señor general don Ismael Montes 268

Imagen n. ${ }^{\circ}$ 41: Dr. D. Pedro Montt 273

Imagen n. ${ }^{\circ}$ 42: Un aymara con su gracioso gorro de lana 280 
Imagen $n .^{\circ} 43$ : Una madre aymara con su pequeñuelo

Imagen $n .^{\circ} 44$ : Indio aymara de ciento veinticinco años

Imagen n. ${ }^{\circ} 45$ : India aymara de La Paz (Bolivia)

280

Imagen n. ${ }^{\circ}$ 46: Un tercer camino desde Bolivia al Pacífico

284

Imagen n. ${ }^{\circ}$ 47: Arica.- Ferrocarril del Morro

290

Imagen . $^{\circ}$ 48: Bolivia y su organización militar

290

Imagen n. ${ }^{\circ}$ 49: D. Augusto B. Leguía

294

Imagen n. ${ }^{\circ}$ 50: D. Guillermo Billinghurst. Presidente del Perú

294

Imagen n. ${ }^{\circ}$ 51: El presidente del Perú

294

Imagen n. ${ }^{\circ}$ 52: Wenceslao Braz P. Gomes

304

Imagen n. ${ }^{\circ}$ 53: S. E. Don Hipólito Irigoyen

304

Imagen n. ${ }^{\circ}$ 54: El salitre y el yodo

306

Imagen n. ${ }^{\circ}$ 55: En honor del ilustre redactor de La Correspondencia de España, D. Enrique Fajardo (Fabián Vidal)

Imagen n. ${ }^{\circ}$ 56: Woodrow Wilson

Imagen n. ${ }^{\circ}$ 57: El conflicto entre Perú y Chile

Imagen $n .^{\circ}$ 58: Insignes diplomáticos americanos que han afirmado el tratado entre Chile y Perú referente a la cuestión de Tacna-Arica

Imagen n. ${ }^{\circ}$ 59: La Conferencia de Tacna y Arica

Imagen n. ${ }^{\circ}$ 60: El pleito chileno-peruano sobre la nacionalidad de Tacna y Arica

Imagen n. ${ }^{\circ}$ 61: Los trabajos de las Comisiones plebiscitarias

Imagen n. ${ }^{\circ}$ 62: Vuelve a Chile el presidente Alessandri

Imagen n. ${ }^{\circ}$ 63: Sr. Augusto B. Leguía

Imagen n. ${ }^{\circ}$ 64: El Palacio de la Moneda

Imagen n. ${ }^{\circ}$ 65: Los convenios al Premio Nobel de la Paz

408

Imagen n. ${ }^{\circ}$ 66: El vuelo triunfal de los aviadores Jiménez e Iglesias 


\section{Gráficos}

Gráfico n. ${ }^{\circ}$ 1: Lugar de producción de la prensa $\quad 91$

Gráfico n. ${ }^{\circ}$ 2: Número de noticias sobre Tacna y Arica (1880-1929) 92

Gráfico n. ${ }^{\circ}$ 3: Comparación entre cantidad de títulos de revistas y diarios 99

Gráfico n. ${ }^{\circ}$ 4: Aporte de UABNG por revistas y diarios $\quad 100$

Gráfico n. ${ }^{\circ}$ 5: Género de las publicaciones 101

Gráfico n. ${ }^{\circ}$ 6: Número de noticias por publicación 104

$\begin{array}{ll}\text { Gráfico n. }^{\circ} \text { 7: Agencias de prensa } & 106\end{array}$

Gráfico n. ${ }^{\circ}$ 8: Texto de relieve (información) y texto de detalle (opinión) 110

Gráfico n. ${ }^{\circ}$ 9: Publicaciones de Chile, Perú, Bolivia y Argentina más utilizadas $\quad 114$

Gráfico n. ${ }^{\circ}$ 10: Publicaciones extranjeras más utilizadas por la prensa 116

Gráfico n. ${ }^{\circ}$ 11: Procedencia de las noticias de referencia por países para informar de la litis 119

Gráfico n. ${ }^{\circ}$ 12: Utilización de Arica en la prensa para referirse al conflicto $\quad 119$

Tablas

Tabla n. ${ }^{\circ}$ 1: Títulos de las publicaciones y periodicidad 98

Tabla n. ${ }^{\circ}$ 2: Nombre de los diarios 99

Tabla n. ${ }^{\circ}$ 3: Autores de noticias referidas a la cuestión de Tacna y Arica 108

Tabla n. ${ }^{\circ}$ 4: Publicaciones americanas utilizadas como fuentes de información por la prensa española

Tabla n. ${ }^{\circ}$ 5: Publicaciones extranjeras utilizadas como fuentes por la prensa española

Tabla n. ${ }^{\circ}$ 6: Ciudades de referencia usadas por la prensa para informar del conflicto 
Tabla n. ${ }^{\circ}$ 10: Comparación entre los ejércitos de Chile y Perú

Tabla n. ${ }^{\circ} 11$ : Exportación de salitre chileno entre 1913 y 1919

Tabla n. ${ }^{\circ}$ 12: Circulares diplomáticas enviadas por Chile, Perú y Bolivia a la prensa 